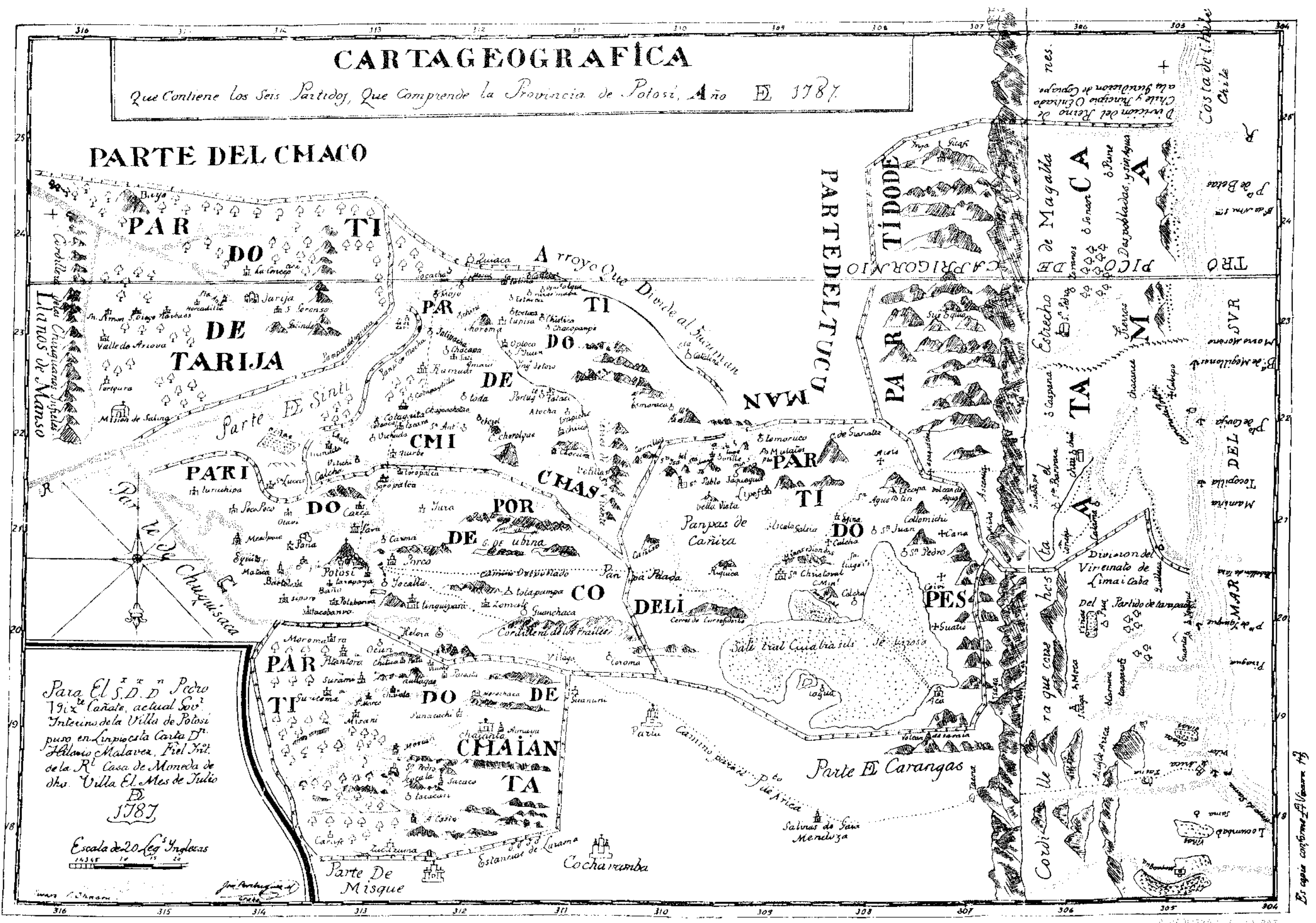




$$
\begin{aligned}
& \text { C } \text { O L L E E C C I. O N } \\
& \text { C U L T U R A } \\
& \text { 'Dirigiida por } \\
& \text { Armando Alba }
\end{aligned}
$$

Este libro

se imprimió bajo la dirección de Armando Alba, con el siguiente personal: Secretario corrector Marjano Subieta, Contador Luis Zárate Araujo, Prensista Pablo Zambrana G., Linógrafo Jorge Martínez Tovar, empastador y cosedor Julio Calvo. Ayudantes Rauil A. Salinas, Wálter Avendaño y Jorge Pareja.

Los grabados se hicieron en la Editorial "Ultima Hora" de La Paz; la Carta Geográfica y la sobretapa en "La Papelera S. A." de la misma ciudad. 


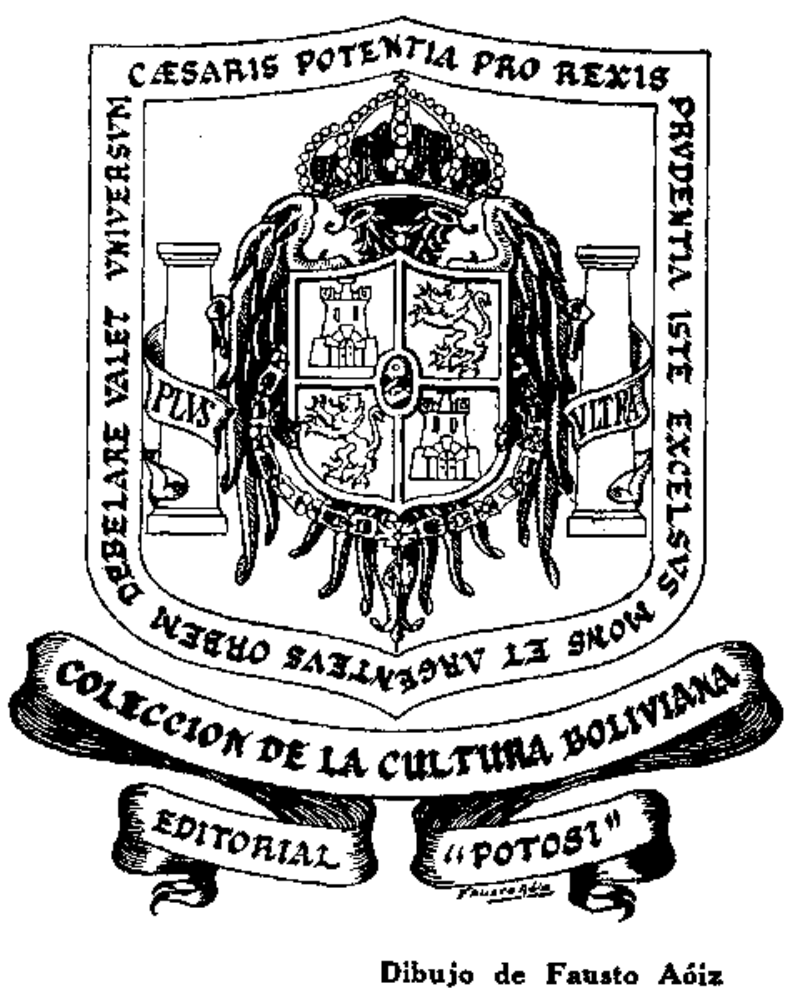


Colección Primera: Los escritores de la Colonia. N $N^{9} 1$.

\author{
Vol. I.
}

(No. general).

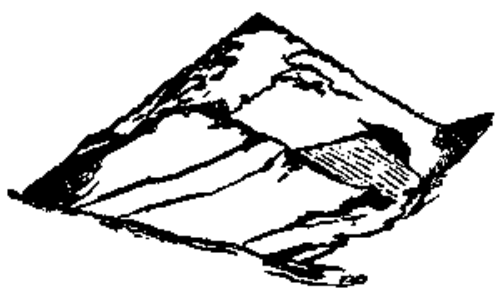

La presente edición fue hecha en los talleres de la Editorial "POTOSI", dependiente de la Sociedad Geográfica y de Historia, en la Casa Real de Moneda. Se concluyó la impresión el día 10 de Noviembre de 1952 años.

Copyright by Editorial "Potosê". Printed and made in Potosi, B o livia. 


\section{G U I A}

HISTORICA, GEOGRAFICA, FISICA, POLITICA, GIVIL Y LEGAL DEL GOBIERNO E IN. TENDENCIA DE LA PROVINGIA DE POTOSI 



\title{
G U I A
}

\section{histórica, geográfica, física, política, civil y legal del Gobierno e Intendencia de la Provincia de Potosí}

\section{DIVIDIDA EN DOS PARTES}

En las cuales, con distinción de Capítulos y Noticias, se describe la villa de POTOSI, su Cerro Rico, y los seis Partidos de: Porco, Chichas, Lipez, Chayanta, Tarixa, y Atacama; con la Historia del descubrimiento de este mineral imponderable, de sus inmensos productos; de las Minas principales de plata, oro y otros metales de todo el distrito de Charcas, y del método de su beneficio; con las demás producciones maravillosas, que ilustran la Historia Natural del reino mineral.

\section{SE EXPLICA}

La nueva Ordenanza de Intendentes, por las cuatro causas de Justicia, Policía, Hacienda y Guerra, con proyectos más útiles para promover la Agricultura, Comercio, Industría y Economía Civil, Eclesiástica y Militar en estos paises, a beneficio del Rey y de los Indios.

\section{SE TRATA}

Del establecimiento y servicio de la Mita, de los Azogues; de las Cajas Reales; de Ia Casa Real de Monediz; del Banco de Rescates, y del Nuevo Reglamento de Minas, deslindando los casos y jurisdicciones sobre cada tuno de estos objetos; y se hacen varios discursos juridicos acerca de las Leyes y Ordenanzas de su manejo, con un comentario claro y específico de las respectivas a Minexía.

\author{
ESCRITA Y DEDICADA POR
}

\section{PEDRO VICENTE CAÑETE Y DOMINGUEZ,}

Doctor on Sagrada Teología y ambos Derechos, Asesor General que fué del Virreinato de Buenos Aires, de la Capitanía General del Paraguay, y actual Teniente Letrado del Gobierno de Potosí.

\section{AL EXCMO. SEÑOR}

D. NICOLAS DEL CAMPO, Primer Marqués de Loreto, Brigadier de log Reales

Ejércitos de S. M. Católica; Virrey y Capitán General de las Provincias del Río de La Plata.

\section{AÑO M. DCC. XCI}


Reservados todos los derechos de edición de acuerdo a ley. 


\section{$I N T R E O D E C A C I O N$}



SI publicar un libro en este ambiente es labor ingrata por las dificultades materiales a vencer y por la indiferencia de mu chas gentes hacia tales esfuerzos, editar una serie de obras cimeras del fondo bibliográfico del país, resulta indudablemente un quehacer afanoso y complejo, susceptible de convertirse en dolorosa lid, en un pueblo por condición específica y desarrollado sen. tido materialista. esencialmente minero.

$Y$, sin embargo, hemos puesto voluntad y celo apasiona. do para dar comienzo a la COLECCION DE LA CULTURA BOLIVIANA, con riguroso criterio selectivo, amplio en sus proyecciones y solvente en la valoración de nuestros mejores escritores, como no se hizo antes de ahora; ésto, sin menoscabo de in tentos aislados como el plan de publicaciones antológicas y frag. mentarias que dirigió en 1939 el inteligente y entusiasta Gustavo Adolfo Otero, o el aporte de libros bolivianos, impresos en la Ar. gentina, en forma esporádica, por la Fundación "Patiño".

Dotar a la nación de un conjunto de libros cuidadosamen. te clasificados en tres series: de memorialistas e historiadores de la época colonial, de nuestros escritores en ciencias y arte que corresponden al siglo XIX, y de los contemporáneos consagrados por el juicio crítico o que sobresalgan en los concursos a convocarse, no es una idea peregrina o un optimista impulso personal. Trátase de la realización de un viejo anhelo del grupo "Gesta Bár. 
bara", que hace más de veinte años aspiró a que Potosí -en función rectora de ciudad madre de la República - diera no sólo el estaño del Cerro Rico extraído cotidianamente por miles de trabajadores de las minas, sino la paciente producción de esos otros veneros del pensamiento boliviano, puros e invalorables en contenido espiritual, cuya existencia ignora la gran masa ciudadana o la connce de segunda mano; riqueza no trascendida al mundo exterior, donde el hombre de la calle sabe - si es que sabe - que Bolivia es un país perdido en el corazón del Continente, con muchos metales que exporta a Estados Unidos de Norte América e Inglaterra, y primero en la nómina de los pueblos afectados de trepidante "volcanismo" político.

Ese grupo de escritores a que se refería Carlos Medinaceli como la "generación heroica" por la batalla intelectual librada en un medio no evolucionado y suspicaz, ha dado la pauta a la Sociedad Geográfica y de Historia "Potosi", para llevar a buen término la trascendente misión de hacer cultura auténtica y perdurable. Puestas en vigor las leyes que crean los recursos necesarios -en la jurisdicción departamental - para adquirir la imprenta y materiales, ha sido posible su compra e instalación, como un complemento vivo del Museo Nacional de la Casa de Moneda, con el objeto de. terminado de que en ella se editen los documentos históricos de la Sección de Archivos Coloniales y de la República, además de libros y revistas.

Por consiguiente, si la perseverancia — que no el azar- ha puesto en nuestras manos el vasto proyecto y el instrumento para realizarlo, nos sentimos ufanos de emprender la tarea, conscientes de contribuir con nuestro trabajo a que el pueblo conozca la jerar. quía espiritual y el austero saber de nuestros hombres de letras. Medio seguro por el que se alcanzará el ancho camino para la solución del problema cultural de Bolivia, igual o más intrincado que el de su economía.

Hacer llegar el libro, escogido y provechoso, hasta las grandes mayorías nacionales, será nuestra actitud preferente; y después, interesar al elemento foráneo - investigador, universitario, periodista o simple lector de cosas de Bolivia - para que mediante las publicaciones difundidas, nos conozca, comprenda y respete. 
Nada más lógico que el hecho de iniciar nuestras publicaciones con la historia de la ciudad que, en el período de la Colonia, preponderó entre todas por el auge de la minería, el crecimiento súbito de la población y el fausto de su vida; de la ciudad cabecera que impuso su influencia decisiva en toda la zona altoperuana, y por el volumen cuantioso de metal argentífero exportado al viejo mundo, conmovió los sistemas económicos imperantes en Europa, comenzando por "romper la estable relación bimetálica" como enuncia $\mathrm{E}$. I. Hamilton, en uno de los ensayos más perspicaces sobre los tesoros de A'mérica.

Pues bien, por su importancia dio motivo a que informantes oficiales, cronistas espontíureos y escritores de diferente condición, dedicaran sus trabajos - unas veces cumpliendo obligaciones buro. cráticas y otras por el interés subyugante del tema- al acontecer potosino, fabuloso y munífico. De aquí, los muchísimos documentos en su mayor parte inéditos catalogados en los archivos de América y Europa; las extensas referencias y alusiones en libros considerados clásicos, descle los que tratan de geografía universal como el ya añejo Atlas de Bertius, de.jurisprudencia y colonización como el de Solórzano, hasta los monográficos como los de Acosta, Garcilaso, Ulloa y muchos más; las crónicas y leyendas escritas por autores oriundos de la Villa, que recogieron emocionados, los episodios de la tradición familiar, que han servido a una literatura evocado$\mathrm{ra}$, añorante, de matices románticos. No es extraño, pues, que existiera en el abundante acervo documental, más de una obra de extraordinaria importancia.

Este es el caso del presente libro que con la "Historia de la Villa Imperial" de Orsua y Vela, parcialmente conocida por resúmenes que quedaron en el país, del manuscrito completo que se guarda en la Biblioteca del Palacio Real de Madrid, tiene máxima validez por ser fuente de información directa de la historia de un pueblo e indice superior de la literatura de su tiempo.

Hasta hoy se conservó inédito el texto íntegro. Publicóse en la "Biblioteca Boliviana", fragmentos de tres capítulos de la parte primera. Y no es que se ignorase, antes de ahora, el manuscrito de Potosí. A más de la familia que cuidó los dos gruesos volúmenes 
con solícito esmero, digno de agradecer públicamente, fue conocido en el siglo pasado por eminentes conductores de la opinión local. Empero, creemos que no le dieron importancia, y artillados de prejuicios contra todo lo hispano, conociendo algunos pasajes de la vida del intransigente Cañete - no olvidamos que en esos tiempos se sentía aún el estremecimiento del derrumbe de la dominación española- cerraron el libro con estudiada displicencia y quizá con manifiesta animadversión.

En la bibliografía potosina, si la GUIA del Asesor de Paula Sanz, es un escrito notable, en la dispersa producción del autor califícase como su mejor obra, la más extensa y la que refleja con. exactitud las ideas, erudición y sutileza que consagran la fama del combatido funcionario virreinal.

Ningún género literario como el de la GUIA, pudo estar a mejor tono con las calidades intelectuales de Cañete, para que luciera sus conocimientos sobre materias las más diversas; se sirviera de los documentos revisados con paciente desvelo; divagara en el terreno de las doctrinas más paradójicas; y también, para que no se sujetase en forma rígida a método alguno en la composición del libro, como requieren los que tratan temas especializados, que no admiten digresiones ni desvios.

Escribiendo una densa obra jurídica nos habría dado un fruto maduro de su excepcional conocimiento de la ciencia del Derecho; en historiador puro, es presumible que nos abrumara, sobre todo, por su empeño en la enumeración de datos, cifras, nombres y estadísticas. Mas, no habría sido posible percibir con claridad, como ahora lo hacemos a través del espíritu proteico, escurridizo, zigzagueante del autor, las formas y costumbres de la vida de Potosí. En la arbitraria disposición de los capítulos y noticias, Cañete y Domínguez, sin artificios, estampa sus impresiones, proporciona nuevos elementos de juicio y anota personales puntos de vista sobre el suceso histórico de la Villa, como si escribiese al acaso, sin cánones ni limitaciones, con la misma llaneza con que solia ambular en las tardes, cuando vecino, por las calles retorcidas y estrechas del poblado. Por ésto, la GUIA es libro sugestivo; a la vez docto y humano, minucioso y contradictorio, en el que abundan el detalle y la cita, 
y no está exento de la sensibilidad intuitiva del escritor finesecular.

Prieto compendio de dos siglos de vida sobrecargada en cuestiones públicas de distinta clase, nos revela una historia apenas presentida, que no conocíamos, porque estuvo pospuesta por pintorescos escritos que eran lo periférico de ese tremendo fenómeno económico-social que se desarrolló dentro y en las faldas del Cerro Rico. Desigual en su estilo, con páginas en las que el idioma deja fluír su castizo donaire y cae, inesperadamente, en obscuridad y pesadez, denuncia su lenta elaboración, en que el autor reflejó entre líneas, sus cambiantes estados de ánimo y sus preferencias o desafectos por ciertos tópicos que herían su formación mental de hombre de lucha, de experto abogado, de magistrado conocedor de todos los cabildeos of icinescos, de mundano señor que ridiculiza con severo análisis la postura provinciana de sus coetáneos.

Quien recorra sus páginas, ha de encontrar un escrito que escapa a la gárrula literatura a que se nos ha acostumbrado. Las muchas noticias acerca de la vida administrativa, de la industria minera, del régimen interno de la Casa de Moneda, Banco de Rescates de San Carlos y Cajas Reales, et estudio de las técnicas del trabajo y de la producción, las características de la convivencia vecinal, las reformas de las leyes, lo estatuído en el servieio del culto $\mathrm{y}$ las orientaciones sobre urbanismo e higiene, le hacen un texto de consulta y de información imprescindible, especialmente para todos aquellos que creían que la villa potosina fue algo así como una tierra de Canaán, buena para acumular riquezas y ventura con facilidad y sin medida; y para los otros, que confinaron el sentido histó. rico de la ciudad a solamente la visión dantesca del mitayo sufriendo el vejamen del colonizador ambicioso e inhumano. Páginas que son ancho campo en el que se transparentan los conflictos de hace doscientos años, muchos de ellos no solucionados hasta el presente, pareciéndonos novísimos casos emergentes de nuestros actuales modos de vivir.

Estas son eh síntesis, las características de la obra de Cañete, que presentamos al juicio del lector y a la meditación de las personas cultivadas. Fue escrita en muchas horas de diario trabajo, en una habitación de la Casa Real de Moneda, que sirvió de morada 
al autor. La hemos impreso en el mismo histórico y bello edificio, mediados ciento sesenta y cinco años. Al anotar el detalle coincidente, queremos destacar su valor intrínseco, que no desmedra a pesar del tiempo transcurrido. Muestra su lozanía, y es fruto sazona do, el mejor que podía dejar de herencia a estas tierras - que amó como suyas- el ilustre paraguayo, que, a más de escritor y humanista, teólogo y abogado, poseyó innegables condiciones de político vivaz y de hombre de Estado - superior en mucho a otros de su época- que no aleanzó a una posesión directiva alta cual lo merecía, porque la Corona de España se mostró cicatera para entregar el mando de estas provincias importantes a manos americanas, por hábiles que fuesen.

Nuestros historiadores, por razones obvias se han dedicado a los estudiós brográficos de los personajes del albor republicanō, dejando en la sombra las figuras estelares del mundo de la Colonia, que por sus vidas y actuacion en elevados cargos administrâtivos o por sus trabajos en la industria minera y el comercio, son hitos indispensables de conocer para un enjuiciamiento certero del cuadro social de aquellos tiempos, con sus perfiles propios y su justa perspectiva. Poco se sabe en Potosí del antiguo gobernador vasco Esquivel, muerto una noche por el bando español de los "Vicuñas"; del borrascoso Egas de Guzmán; de Ventura Santelices y Venero, estimulador brillante de la minería y reorganizador de los servicios fiscales; de Juan del Pino Manrique, funcionario de honrosa tradi. ción en varias provincias; de Joseph de Lizarazu y Bahamonde, Director de la Ceca potosina y vecino prominente por su abolengo y su influencia; de Domingo Bolívar, Tomás Camberos, Hilario Ma' laver, que ocuparon altas situaciones en la misma repartición que el anterior; de mineros afortunados como los descubridores del Cero y los que les siguieron hasta el Ilustre Gremio de Azogueros, dirigido por verdaderos expertos y técnicos como Neish, Bravo de 
Bobadilla, Antonio López de Quiroga,el Marqués de Aro, entre otros; de Inspectores virreinales de amplios conocimientos como Torre Tagle, que sabía de asuntos contables como de estilos arquitectónicos; de juristas famosos como el Fiscal Victorián de Villava, venido desde España a la Audiencia de Charcas, para no citar sino a los que recordamos de momento. Idéntica suerte cupo al autor de este libro, con ser representante notorio del dominio español en los últimos tiempos: mereció alguna referencia breve en la reseñia. de los acontecimientos de 1810, junto a Francisco de Paula Sanz, a quién don Modesto Omiste califica de buen administrador y pacífico, aunque la verdad sea otra.

Felizmente, la trayectoria de Cañete y Domínguez está identificadi en su línea principal, a estas horas, por los datos de investigadores extranjeros y por la documentación complementaria inserta en páginas siguientes. Muy joven emigra de su tierra de origen - la capital del Paraguay - hasta Santiago de Chile, para estudiar teolo. gía y derecho. Por sus aptitudes y conocimientos se traslada a Buenos Aires, en el espectable cargo de Asesor del Virrey Zeballos. Sustituído éste por Juan José Vertiz en 1792, regresa a Asunción en igual empleo dependiente de la Capitanía General. Cosecha la simpatía y el respeto del pueblo por su conducta austera, su trabajo eficaz y su extraordinaria ilustración. Nuevamente destinado a Buenos Aires y Santiago de Chile, pasa a Consejero de Francisco de Paula Sanz, Gobernador de la pródiga provincia de Potosí. Su estancia en la Villa, será por mucho tiempo. Vale decir, del resto de sus años, sin tomar en cuenta breves ausencias a Chuquisaca o La Paz. En el alto estrado roqueño de Potosí, ante la mirada benévola de los partidarios y desafiando la rencorosa protesta de los enemigos, Cañete dará vibración y colorido a su vida de labor infatigable y de dolorosas experiencias. Diestro en el manejo de la cosa pública, mundano y distinguido, culto y fino observador, domina el ambiente, subyuga a la sociedad, crea en torno suyo afectos sinceros y suscita también odios subterráneos, envidias que han de crecer en la sombra, para volcarse sobre sus hombros, ante el pasmo de la población indo-hispana. Como la selva añorada, misteriosa y atrayente, será para Cañete la sierra desnuda y grandiosa del Potosí el arpón 
que detenga y arraigue su existencia, y cumplida ésta, guarde por siempre sus cenizas, con el arrebatado celo de la mujer amante que perpetúa su pasión en la vida y en la muerte.

Su diligencia se multiplica: reajusta la administración pública, estudia los asuntos de la minería y colabora con el Gremio de Azogueros, fomenta el urbanismo, investiga los problemas regionales de la provincia, redacta las notas e informes que firma Paula Sanz,para ante las autoridades superiores del reino; y a poco tiempo, riñe con los mineros encumbrados, con los vecinos principales, con la clerecía y con el propio Gobernador, a quien ha servido con ardo. rosa voluntad. Es trasladado a Chuquisaca, nombrado Secretario del Presidente de la Audiencia de Charcas, García Pizarro, y tiene el título real de Ministro Honorario de la corporación. Más tarde cumplirá obligaciones de Fiscal interino, y en los escarceos de la guerra de la Independencia, asumirá por breve tiempo, el Rectorado de la Universidad Carolina. Su vida en Chuquisaca, es episodio de tormenta. Don Gabriel René Moreno, nos ha dejado una donosa página de comentario. Cañete, en la ciudad audiencial, como en Potosi, convence, triunfa al pronto. Reacciona violentamente ante la pasividad inveterada de su jefe. Arguye, intriga, pelea. Tras los pasos del ya conocido Consejero y Secretario, se levanta una enor. me tolvanera de escándolo, propicio alimento de ese mundillo veleidoso y acartonado de Oidores, de chantres acorchetados al Palacio Arzobispal, de bulliciosos mozalbetes universitarios y de gentes de la sociedad que encuentran embeleso en agitarse con los aires de to. da pendencia. No pocas de las actitudes de Cañete, estimulan al rojo vivo la combustión del espiritu revolucionario predominante en la ciudad letrada. Después, en horas de infortunio y desbordado en su pasión de venganza, saldrá de allí, como huído, para allegarse en el norte a Goyeneche y contribuír a la organización de los Comités de Pacificación, tan crueles para con los patriotas.

Recorre la región del Lago Sagrado, temeroso de persecucio. nes y castigo. Retorna a Potosí, buscando alivio y sedante en el hogar abandonado. Las contingencias de la guerra de emancipación alcanzan hasta su casa, que es saqueada y destruída por soldados del ejército auxiliar. El docto Oidor se siente envejecido de años y de 
penas. El nuevo orden ha barrido con todo: han desaparecido los pocos y buenos amigos; lejos están los compañeros y colegas de trabajo; perdidos para siempre los soldados de la causa. Sería completa soledad, si al lado suyo no estuviese firme, resuelta a conllevar todo sufrimiento, su segunda esposa doña Melchora Pérez. Prudencio, y rodeándole su hija "fatua" y unos parientes. El corazón fatigado estallarí súbito. Muchos desconsuelos acumulados contribuyen a acortar una vida activa, intensa, trashumante. Repentinamente falleció en uno de los últimos días de enero de 1816. No tuvo tiempo para dictar sus disposiciones postreras. Parecía de sesenta años de edad, reza el certificado de defunción. La viuda quedó en espantosa miseria.

Tres rasgos distinguen la personalidad de Cañete: sabe mu. cho porque es excepcional observador del contorno, asiduo visitante de todas la bibliotecas de los Conventos y, buen latinista, no des perdicia minuto, toda vez que trata de estudiar a un buen filósofo, un literato, un jurisconsulto, un científico, un cronista de viajes. Mantiene autoridad en la administración pública, porque pocos pueden rivalizar con él en capacidad de trabajo; no sólo atiende su despacho ordinario sino que fiscaliza oficinas, interroga a los empleados, compulsa expedientes y verifica informaciones con desconcertante entusiasmo. Es apasionado porque su temperamento obedece quién sabe a qué herencras irrehuíbles; leal a la causa del Rey, se constituye en el afiliado vehemente y fanático. Ningún "español de América" más convencido que él, para defender la monarquía como sistema de gobierno y el mando de la autoridad peninsular en esta parte del mundo. Vida, en suma, de creación y de angustia; de beligerancia y de amargura; errante vida por muchos caminos, bajo el signo de Némesis. Las alas del viento de la tragedia baten incansables en el espíxitu de este hermano menor de Antonio Pérez, aquel dignatario sibarita, señor de horca y cuchillo, gran político y eminente Ministro del poderoso Felipe II, que después, caído en desgracia, fue juzgado como sangriento instigador de crímenes, perseguido obsesionante y abominable proscrito.

Nuestro autor trae a la vida una malhadada estrella como compensación a sus excepcionales dotes de talento y listeza. Desde 
su juventud los acontecimientos lo arrastran al palenque de la dis" puta. Por donde dirige el timón de su barco hay "mar de fondo". Todo se le torna agresivo y su existencia es desesperada peripecia. Los adversarios apuntan sus dardos para herirle y humillarle; sus jefes se sirven de él en horas de dificultad y lo abandonan cuando el barro del descrédito mancha su prestigio de famoso legista, de funcionario cumplido, de hábil escritor, a quien se considera en el choque de las pasiones en juego, sórdido abogado, intrigante "cara" millero", venal defensor de la institueión de la Mita, realista traidor a los esfuerzos de la -liberación americana.

Escribe el gran don Gabriel René Moreno, que de haber dado Cañete el salto a la otra orilla, desde su posición de servidor de la política española, distinta habría sido la ejemplar y fulgurante hazaña del 25 de mayo de 1809 en Chuquisaca; porque pudo haber tenido el impulso definido y abierto que luego magnificaría el he' cho trascendental de La Paz, con Murillo, en julio del mismo año. Es posible que así hubiese ocurrido y, ahora, en nuestra historia es. taría inscrito en página de honor el nombre del "egregio" paraguayo, junto al del brillante y "meteórico" Monteagudo: Mas, Cañete, no alcanzará esa gloria, porque soldado consecuente con una causa perdida, concitó para sí, irremediablemente, la condenación y el olvido. Don León M. Loza, en el estudio insertado en este libro, juzga que en Cañete obró su premiosa condición económica de ingrediente decisivo para que continuase inflexible abanderado del "realismo"en tierras insurgentes del Alto Perú. Pensamos que otras causas superiores determinaron su obstinada conducta. Entre ellas, su gratitud a la Corona que lo distinguió con designaciones impor. tantes en la administración en Buenos Aires, Santiago, Asunción y Charcas; saberse un "hombre de derecho" incapaz de admitir como lícitos los intentos de mudanza política por los medios violentos de la rebelión armada; poseer un temperamento heredado de la sangre de Ruy Diaz de Guzmán, enteramente español y, por último, la espectable situación alcanzada, que no le permitía desviar el camino. Linaje, educación, carácter, pesaban demasiado sobre él, para que se considerase en todo momento un auténtico "realista", en una at" mósfera que imitaba, pálidamente, el señorial recinto de las Cortes 
de la Villa del Oso y del Madroño.

Cuántas veces, en hora de meditación íntima, a solas consigo mismo, debió pensar que su actitud en defensa del régimen, excedía el límite de sus propias obligaciones y las de muchos otros ciudadanos nacidos en la distante Iberia, que hacían fortuna, vivían a satisfacción y usufructuaban honores y privilegios, con haber instalado sus tiendas de aventureros sobre el lomo de los Andes. Y si nunca lo hizo, sus implacables émulos se encargarían de lanzarle, en voz alta, el duro reproche lapidario. Uno de ellos, irreductible en el odio, sensible a las reacciones de su amor propio - la "negra honrilla" española-, peligroso en grado sumo por su reconocida autoridad intelectual, se constituiría en adalid: don Victorián de Villava, aragonés, catedrático de la Universidad de Huesca, traductor de las "Lecciones de Comercio" del abate Antonio Genovesi, desig. nado Fiscal de la Audiencia de Charcas, Protector de Naturales y -a su paso por Buenos Aires- Juez Residenciador del ex-Virrey, Marqués de Loreto.

Dura, acre batalla de siete años se libró entre los dos togados, con la intervención circunstancial del Gobernador Paula Sanz, del Gremio de Azogueros y de algunos curas doctrineros de Chayanta. Reto a muerte de dos súbditos del Rey, que ocupaban posiciones irreconciliables, perfectamente definidas por una realidad histórica fundamental que ya había divorciado a América de España -la ins. titución de la Mita - con mayor gravitación que las mismas ideas contenidas en libros de los Enciclopedistas de Prancia. Dos contrafiguras, representativas de dos corrientes de opinión, en el inmenso escenario social y político: Cañete, partidario de la continuación de la servidumbre de los indios en las minas del Potosí, por ser irremplazable sistema de trabajo para que la importantísima Villa Imperial, cabeza de Partidos y Meca de las riquezas del Virreinato, no desaperezca ni sufran merma la economía del Estado y de los particulares; y Villava, "luchador inconmovible por un ideal de justicia" que replica que "poco importa que los hombres se llamen gobernadores, subdelegados, asesores o corregidores... ello es cierto que la suerte del indio no se ha mejorado con el nuevo Código de Intendentes", La resistencia a remitir nuevos mitayos desde Cha- 
yanta a los trabajos mineros del Coronel español Nicolás Urzainqui y consocios vascos Jáuregui y Orueta, pone mayor encono en la contensión, que degenera en desbordado e injurioso personalismo.

Como en las típicas comedias de equivocaciones, los papeles estuvieron trastrocados: el americano que esgrime las armas de su ingenio y de su erudición de jurista para justificar el opresor sistema de España en sus colonias; el español pertinaz, como buen hijo de Aragón, que reclama con talento y razones incontrovertibles, la redención del indio, hasta parecer "precursor y profeta de la independencia de América Hispana" al decir de don Ricardo Levene. Tal la sensacional controversia en la que no escasean los "discursos" y las "réplicas" en profusa circulación en pequeños folletos impresos o en copias manuscritas. Cañete, en forma directa o escribiendo para el Gobernador Paula Sanz, aboga por una causa exe' crada enfáticamente por el juicio público continental; Villava, ataca y condena la institución de la Miti, convirtiéndose en paladín de una naciente emoción social, que no tardará en imponerse en el nuevo mundo.

En el teatro de la Historia de aquellos días ya convulsiona. dos y febriles, sobre el pretil del escenario, Cañete y Villava, frente a frente, irrumpen con las notas graves, apasionadas del preludio de esa sinfonía heroica que fue el proceso de la emancipación.

\section{Armando ALBA}

Nota. - Nos hemos informado en el áltimo tiempo, de un dato aclaratorio que explica por qué no se imprimió esta GUIA a fines del siglo XVIII, en la capital de España, con el dinero proveniente del aporte 
que hicieron los Azogueros de Potosí, como consta del documento inédito que se publica en el libro.

Habría ocurrido que don Vicente Cañete, escribió su obra en un borrador extenso (que nos ha servido como la más importante fuente para esta edición) en la que mús de una vez censura o critica ciertos procedimientos de los dueños de minas en el Cerro de Potosí, en el trato con los trabajadores indios, en el incumplimiento de las leyes impositivas y otras. El señor Cañete, al dedicar su obra al Gremio de Azogueros, habría hecho reproducir copias de su trabajo, con muchas supresiones, reformas y aderezos; copias que fueron conocidas de los mineros y enviadas al Consejo de Indias, a la Audiencia de Charcas, etc. Los Azogueros mandaron entregar en manos de don Inclalecio Genzález Socasa, la suma de tres mil pesos para la impresión de la obra en Madrid. Pero, ocurrió que don Victorián de Villava, alcanzó a conocer el manuscrito original, y en el calor de la polémica, eñ uno de sus "discursos" de recriminación al Asesor de la Intendencia de Potosí, denunció la doble conducta de Cañete con relación a los mineros: por una parte, dedicándoles su libro, expurgado de toda censura a ellos; por otra, haberles atacado en los papeles originales, en forma clara e intergiversable. Aquella revelación alcanzó su objetivo: el "Ilustre Gremio de Azogueros" - cuán presuntuosos fueron estos azogueros enriquecidos del Potosí — se dio por ofendido y retiró su ayuda material a Cañete La GUIA no fue impresa, por este incidente. Queda explicada, también, la razón de la enorme diferencia de las dos versiones hasta hoy oonservadas: del manuscrito de Potosí y la copia catalogada en el Archivo General de Indias.- $\boldsymbol{A} . \boldsymbol{A}$. 
Difficile æstimamus, quæ in terra sunt; et quæ in prospectu sunt, invenimus cum labore.

Sapient, cap. 9. $v, 16$.

* Con dificultad llegamos a alcanzar lo que hay en la tierra; y hallamos con trabajo lo que tenemos delante.

(La Sabiduria. Salomón). 


\section{DEDICATORIAS}



Al Excmo. Sr. Dn. Antonio Porlier, del Consejo de Estado y primer Secretario del Despacho Universal de Gracia $y$ Justicia de Indias.

\section{Señor:}

En lugar de gratitud hallaria la más rigida censura en el público de Potosí, si no viera colocado el muy esclarecido nombre de V.E. al frente de un Libro, que trata las materias geográficas, históricas, físicas y politicas de esta Imperial Villa y de su imponderable Cerro; porque so daría por agraviado en no darle por Protector un personaje que honró a este vecindario con su amor, con sus aprecios y con su presencia por tiempo dilatado; y yo también debería temer con razón los justos enojos de $V$. E., violándole los derechos que tiene a la tutela de una obra, que debe ser suya por justicia siendo su asunto el gran Potosí. Por todos estos motivos unidos al de mi obligación y respeto a su Excma. persona, resolvi ofrecer a $V$. E. este corto obsequio, bien asegurado que aunque por ser trabajio mío no sea digno de la protección de V. E., lo aceptará por otra parte muy gustoso, dirigiéndose todo él a dar al mundo una idea que hasta ahora no se la ha presentado tan cumplida de las grandezas de esta Provincia.

Confieso a V. E. que mi corazón ha querido arrebatar mi pluma más de una vez, para llenar esta Dedicatoria con elogios de. 
sus ilustres virtudes y méritos, a imitación de Ovidio y de Virgilio; pero al cabo de muchos combates he logrado forzar estos impulsos en honor de V. E. mismo, porque ni mis talentos alcanzan a decir dignamente todo cuanto merece $V$. $E$., ni es decente a un personaje enriquecido de tan grande cumulo de prendas, ponerme yo a querer sumar sus virtudes. Sin embargo, no omitiré publicar al tiempo de poner a los pies de V. E. esta ofrenda de mi afecto, que a nadie como a V. E. se adapta tan maravillosamente aquel célebre encomio repetido del poeta Claudiano al Cónsul Stilicón:

\author{
Sparguntur in omnes \\ in te mixta fluunt, et quae \\ divisa beatos \\ efficiunt, collecta tenes.
}

Soy de V. E. el más humilde, afectísimo y reconocido servidor.- Potosi, diciembre 6 de 1789.-Pedro Vicente Cañete.

\title{
Al muy Ilustre Gremio de Azogueros de Potosí:
}

El deseo de servir mejor al Rey y de poder complacer más cumplidamente a V.S. en el despacho interesante y crítico de sus graves negocios me obligó a desentrañar todos los Archivos copiosos de esa Imperial Villa, para poder ser más útil a su vecindario, cuanto fuese mayor mi conocimiento sobre todos los grandes objetos de su gobierno.

Su población ilustre compuesta de ciento cincuenta mil almas; su Cabildo respetable por el carácter de unos Regidores todos ellos Caballeros de las Ordenes Militares de Castilla; su Ribera poderosa en corrientes de plata más que de agua; su Azoguería admirable por la reunión de tantos Señores distinguidos por su nacimiento ilustre, por las Cruces de sus Pechos, por los Títulos de sus Casas, por la aplicación de su industria, por el exceso de sus gastos, por la generosidad de sus dádivas, por la humani- 


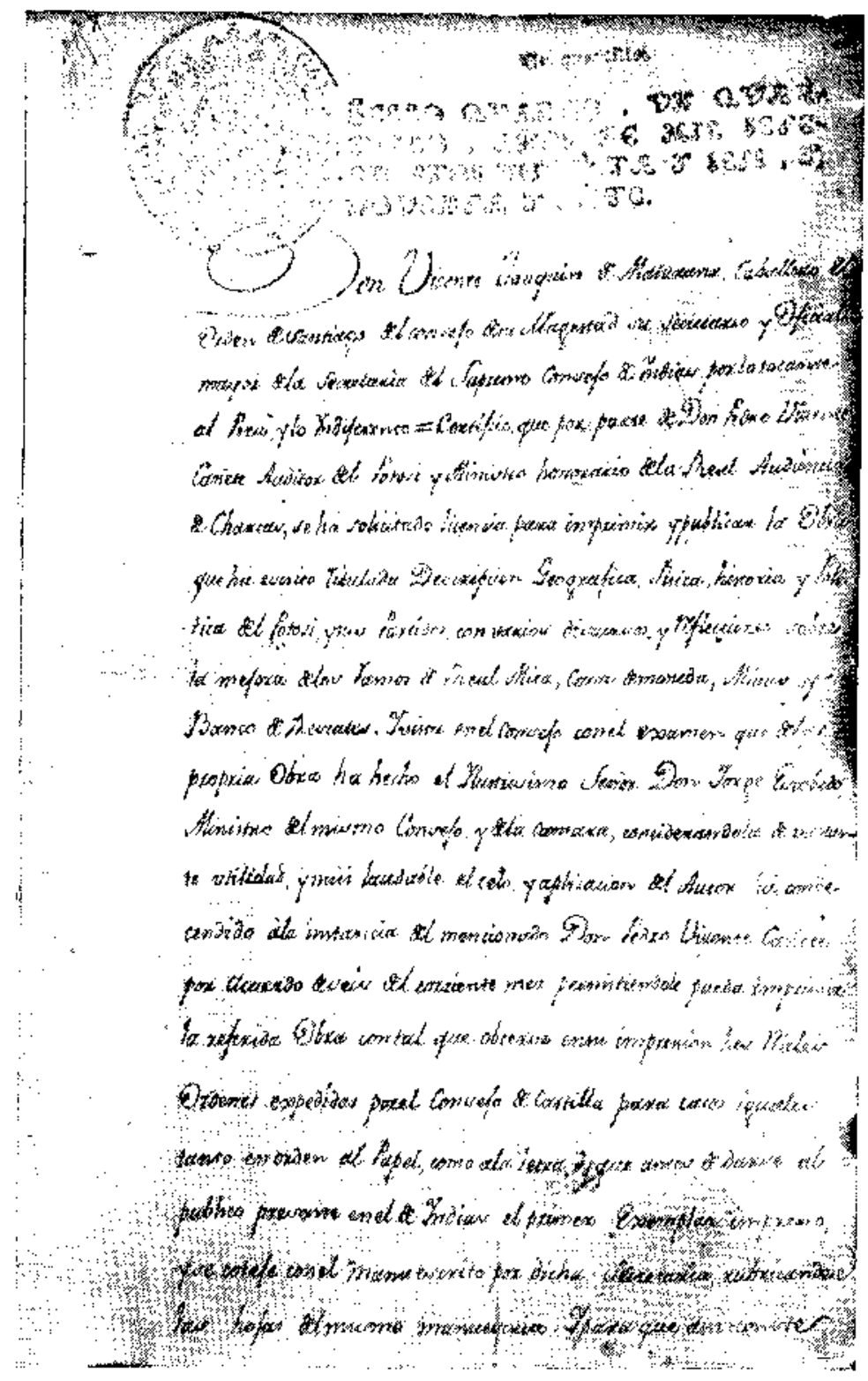

Testimonio del certificado de la solicitud de Don Pedro Vicente Cañete y Dominguez, para "imprimir y publicar" su obra.

(Reproducción del texto en la pág. 7). 


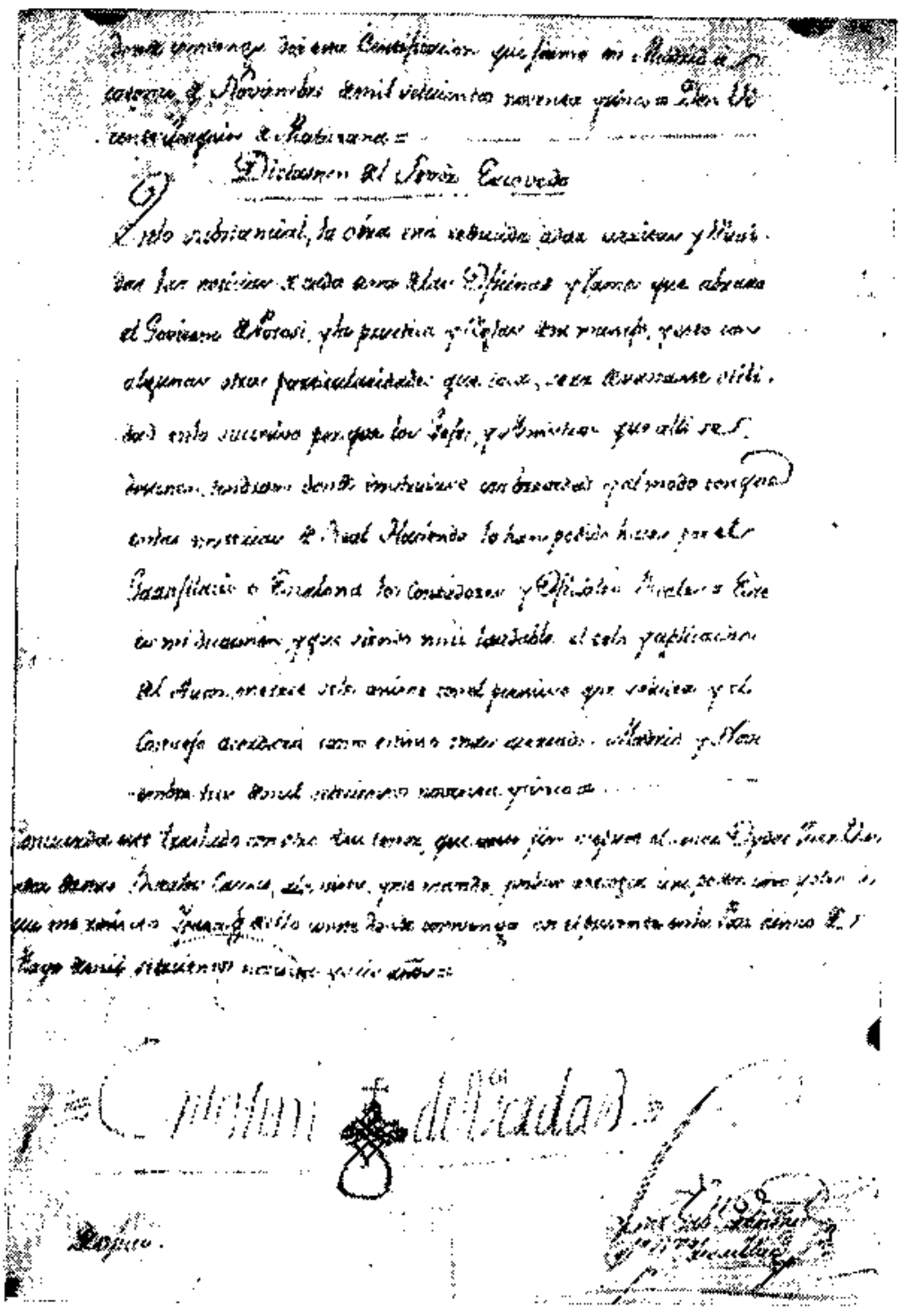

Dictamen de Don Jorge Escovedo y Alarcón opinando porque se concela permiso para la publicación de la obra.

(Reproducción del texto en la páp. 8). 


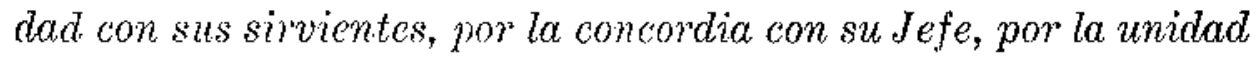
de sus proyectos, por la unión pacifica de sus intereses y últimamente por su amor y lealtad incomparable al Rey y a la Patria; movieron mi admiración y mi estudio desde que entré a servir la. Asesoría de esa Intendencia para dar al Mundo una Historia Fisica y Política de las grandezas de Potosí, y de los justos motivos con que su nombre se ha hecho tan universal como la luz del sol por' todos los paises de la Tiema.

Su Casa de Moneda, el servicio de la Mita, la riqueza de sus minas, los destinos del Real Banco y la extensa jurisdicción de los seis Partidos que componen su Provincia, comprenden tanta multitud de materias complicadas, de reglas obscurecidas y de intereses tan dignos que apesar del celo de muchos excelentes Magistrados que han gobcrnado a esa Villa, no han podido conseguir todos los adelantamientos que promete el País, porque de ordinario se han relevado de los mandos al empezar a conocer los objetos acreedores de sus cuidados.

Por justa correspondencia pues, al amor que he merecido del vecindario de Potosi, y especialmente a su Ilustre Azoguería sacrifiqué mi descanso por escribir esta obra aprobada ya por el Supremo Consejo de las Indias, con dictamen del Ilustrísimo Sr. Dn. Jorge de Escovedo, uno de los más sabios y celosos Gobernadores de Potosí.

Este Sr. Ministro recomienda la utilidad de mi trabajo para beneficio del público y para pronta dirección de los jefes. $Y$ Yo lo escribi con la ambición de eternizar mi gratitud a V. S. y mi amor a un Pais, donde el destino de la Providencia separó de mi lado a la compañera más amada de mi corazón. Y por esto uniéndose también en mis afectos el interés de no separarme jamás de esa Villa, por los recuerdos de mi Libro; todo ello junto me ha obligado a dedicarlo a V. S. para que viendo el Reyno del Perit consagrado mi nombre al respeto y al honor del Gremio más antiguo, más llustre y más útil de sus Provincias, sirva por testigo inmortal de que yo he sido el más amante celador de las glorias y de los derechos del gran Potosí. 
Acepte V. S. este fruto de mis desvelos, así como yo acepté con tan buena gana, los cuidados de su felicidad, y dígnese dar testimonio, en esto mismo de que yo no he anhelado jamás el oro y la plata de sus Minas, sino ínicamente el bien universal de sus dignos habitantes.

Ntro. Señor guarde a V. S. muchos años.-Paz, junio 20 de 1796.- Pedro Vicente Cañete. *

* La dedicatoria al Excmo. Sr. Porlier, encuéntrase en el Libro original manuscrito que se conserva en el Archivo de Indias on Selilla, estante 121, cajón $7^{\circ}$. El Sr. Porlier, Marqués de Bajamar, nació en Laguna de Tenerife en 1722 y falleció el año 1790. Sobresaliente jurisconsulto, desempeñó altas y delicadas funciones administrativas en América $y$ en el Consejo de Indias en Madrid.

El distinguido investigador don Luis Subieta Sagimaga, ha facilitado el original de la dedicatoria al llustre Gremio do Azofueros. Se publicó por vez primera en el segundo número de la "Reisista del Circulo de Bellas Artes", año 1982, bajo mi dirección. Al mismo fondo documental inédito, corresponden las notts del Ilustre Gremio de Arogueros que resolvió costear la edición en España y la suscrita por el apoderado del Sr. Cañete, don Indalecio Gonzulez de Socasa; asi como la certificación de haber solicitado el autor licencia para publicar el libro y el consiguiente dictamen del Señor de Escovedo. Por causas ignoradas hasta hoy, no se editó la obra en aquella ocasión. El texto de los documentos es el siguiente:

"Potosí, julio 20 de 1796.- Habiéndose tisto en Junta General de Azogueros, presente el Señor Gobcrnador Intendonte de csta Provincia, el oficio del Señor Oidor Honorario de la Real Audiencia de Charcas, Teniente Asesor de este Gobierno Intendencia, residente en La Paz, su fecha en esta ciudad, 20 de Junio, con el dorumento que acompaña, acordaron: que por los señores Diputados del Grentio se conteste al Sr. Don Pedro Vicente Cañete a nombre suyo, manifestándole el aprecio que a este Ilustre Cuerpo merece la distinción con que $S u$ Señoría lo prefiere en la dedicación de su digna obra, fruto de sus incesantes tareas de que son testigos todos los individuos de csta Junta y aun todo este público, como igualmente de sus singulares esmeros en beneficio y para fomento de esta Azogueria. Y para comprobar de algún modo su gratitud a dicho Sr. Ministro, resuelven suplicarle se sirva dejar al cargo de este llustre Cuerpo la impresión de su obra para que se haga a su costa, sacándose su importe según el valor que se conceptúa del Ramo de Academia, que como subsistente, aunque se halle con aloún empeño se irá sucesivamente reintegrando. $Y$ los Señores $D i$ - 
putados procederún a mandar se verifique la impresión con arreglo a las disposiciones que dicho Sr. Ministro tenga a bien dictarles para que todo se haga a su mayor satisfacción completamente $y$ lo firman de que doy fe, previniendo se tome razón de esta Junta en el Real Banco. Francisco de Paula Sanz,-- Pedro Samudio,- Pedro Antonio de Azcárate, - Luis de Orueta, - El Conde de Casa Real de Moneda,-Fermin Prudencio Pérez,- José de Quesada, - Doctor Juan José Vargas,José de Oña,-Juan de Dios Mora y Pimentel,-Mariano Prudencio Pérez,- Manuel de Jinregui,-Gregorio de Barragán,-Joaquín Prudencio,- Mariano Torre,-Juan Rudesindo Zilveti,-- Pedro de Arrieta.- Ante mí: Manuel de Aguirre, Escribano de S. M. R.-Tomóse razón de la Junta antectente a fojas 29 vuelta del Libro de Provisiones de la Contaduría del Real Banco de San Carlos de Potosí. Julio 21 de 1796.- Por enfermedad del Contador, Esteban Caballero, Ofl. Mayor."

"He recibilo de los Señores Diputados del Ilustre Gremio de AzoIneros de esta Riber'a, la cantidad de Tres Mil pesos en plata doble de rostro, de los cuales me hago cargo de orden y cuenta del Sr. Dr. Don Pedro Vicente Cañete, Oidor Honorario de la Real Audiencia de lo Plata y Asesor de este Gobierno Intendencia, arreglado a su carta de 16 de septiembre último, escrila desde su actual residencia, de la ciudad de La Paz, y para despachar por el presente Situado del Comercio, a entregar en la ciudad de Inenos Aires a Don Anselmo Saenz Baliente, ausente a su poder, y de la misma cuenta, con orden que de la propia haga el regislro de dicho importe en el primer Barco de Guerra, Aviso o Mercante, en que vayan caudales de aquel comercio, y en líquido deducidos los derechos de conducción y demás hasta puestos a bordo, con dirección a entregar en Madrid, en primer lugar a Don Franciseo Suárez Baldés, apoderado de dicho Sr. Cañete, y en segundo a Don Francisco Jiménez Sarmiento, que lo es del referido Ilustre Gremio. Todo lo que (en cuanto a la remisión) acreditare al indicado Sr. Dr. Don Pedro, con los Conocimientos de estilo. Declarando: que la nominada cantidad me expresan dichos Señores Diputados se la suplen al Sr. interesado para la impresión de cierta obra que escribió y dedicó al mismo Ilustre Gremio; a conformidad de lo que este resolvió sobre la materia, en Junta que para el efecto celebró en fecha 20 de Julio de este presente año. Potosí, octubre 13 de 1796 años.- Son 3.000 pesos.- Indalecio González de Socasa."

"CERTIFICADO. - Don Vicente Joaquin de Maturana, Caballero del Orden de Santiago, del Consejo de Su Majestad, su Secretario y Oficial mayor de la Secretaría del Supremo Consejo de Indias por lo tocante al Perú y lo Indiferente - Certifico, que por parte de Don Pedro Vicente Cañete, Auditor del Potosí y Ministro honorario de la Real Audiencia de Charcas, se ha solicitado licencia para imprimir $y$ publicar la Obra que ha escrito titulada Descripción Geográfica, Física, Histórica y Política del Potosi y sus Partidos, con varios discursos y reflexiones sobre la mejora de los Ramos de Real Mita, Casa de Moneda, Minas y Banco de Rescates. Y vista en el Consejo, con el exámen que de la propia obra ha hecho el Ilustrisimo Señor Don Jorge Escovedo, Ministro del mismo Consejo y de la Cámara, considerándola de bastante utilidad y muy laudable el celo y aplicacion del autor ha condes- 
cendido a la instancia del mencionado Don Pedro Vicente Cañete por. acuerdo de seis del corriente mes, permitiéndole pueda imprimir la referida obra con tal que observe en su impresión las Reales Ordenes expedidas por el Consejo de Castilla para casos iguales, tanto en orden al papel como a la letra, $y$ que antes de darse al público presente en el de Indias el primer ejemplar impreso, y se coteje con el manuscrito por dicha Secretaria, rubricándose las hojas del mismo manuscrito. $Y$ para que asi conste donde convenga doy esta Certificación que firmo en Madrid a catorce de Noviembre de mil setecientos noventa y cinco.Don Vicente Joaquin de Maturona.- DICTAMEN ULL SENOR ESCOVEDO. - En lo sustancial, la obra está reducida a dar escritas y reunidas las noticias de cada una de las Oficinas y Ramos que abraza el Gobierno de Potosí, y la práctica y reglas de su monejo, y esta con algunas otras particularidades que toca, será de bastante utilidad en lo sucesivo porque los Jefes y Minislros que alli se destinen, tendrán donde instruirse con brevedad $y$ al modo con que en las materias de Real Hacienda lo han podido hacer por el Gazofilacio o Escalona los Contadores y Oficiales Reales. Este es mi dictamen y que siendo muy laudable el celo y aplicación del Autor, merece se le anime con el permiso que solicita, y el Consejo acordará como estime más acertado.Madrid y Noviembre tres de mil setecientos noventa $y$ cinco.- Concuerda este traslado con otro de su tenor, que a este fin me puso el señor Oidor, Iuez Visitador de estas Reales Cajas, a la vista y me mandó y volvió a recoger a su poder uno y otro, a que me remito. Y para que de ello conste donde convenga, doy el presente en La Paz, a cinco de Mayo de mil setecientos noventa y seis años.- En testimonio de verdad.-De oficio. Antonio Gabriel Quiñones, Eseribano de Su Majestad." Nota de A. Alba. 
PROSPECTO 



\begin{abstract}
A hora aimaños, que entré a servir la Asesoría de esta Provincia, fue mi primer cuidado imponerme en las materias más esenciales a que debe contraerse la atención del Gobierno de Potosí; con las noticias que pedi a unos y a otros del estado geográfico y físico de los cinco Partidos agregados a esta Intendencia, yo creí encontrar desde luego, cuando no en todos, siquiera en los empleados $y$ en los escribanos la instrucción que necesitaba al menos para un conocimiento por mayor del origen, reglas y método con que se habia regido este Gremio de Azogueros desde su establecimiento, de la economía de las cuatro Superintendencias de Minas, Mita, Banco y Casa de Moneda, y por último de aquellas cosas más generales tocantes a la situación de los Partidos, a su población, a sus producciones, con lo demás relativo a los dos ramos de Policia y Hacienda, que son los móviles principales de la felicidad pública de todos los Estados.
\end{abstract}

Los escribanos se contentaban con satisfacerme en las más cosas de que eran preguntados, ser práctica inmemorial en Potosí, sin saber dar razón de las providencias que habian motivado algunos entables de importancia, $y$ otros a mi juicio muy abusivos, que se estaban abservando. Los demás, aunque respondían, lo ejecutaban con ciertas generalidades y de una manera tan inverosimil, que me hicieron dudar de la puntualidad de sus noticias. En efecto, muy poco satisfecho yo, traté de averiguar el fundamento de las relaciones que les oía, y al cabo vine a descubrir que casi todos hablaban por una tradición falsa o equivocada de una historieta de cuentos impertinentes, que aqui llaman "anales de Potosí".

En cuanto a los Partidos, era todavia mayor la obsouridad, porque algunos pocos que daban razón de ellos, habian viajado sin reflexión; $y$ así, apenas podhan decir ciertas cosas comunes de ninguna importancia; 
de suerte que los que tenemos influjo en el Gobierno no podíamos formar concepto de estos territorios, ni de las causas del atraso de la agricultura $y$ de las minas, en medio de palparse la decadencia de uno y otro ramo; sin hallar recurso para los conocimientos precisos ni en las geografias del Reino, ni en nuestro viajero Ulloa, ni en los cronistas Mendoza y Calancha; porque en las geografías apenas se encuentra razón muy diminuta y general de los Desiertos de Atacama, por incidencia de la descripción del Reino de Chile, con tal o cual noticia del Puerto de Cobija en orden únicamente a su altura del Polo. En Ulloa, con ser el más exacto observador de esta parte de América, no pasa de diez líneas lo que habla de Atacama, Porco y Lípez, dejando en silencio los dos Partidos más ricos de Chayanta y Chichas. Finalmente, en los cronistas no se lee una palabra acerca de nuestros Partidos campestres, contrayendo su descripción a sólo la Villa de Potosí; pero ninguno de ellos puede dar idea bastante para comprender cabalmente el estado de estas poblaciones en lo geográfico, físico $y$ político.

Sobre rescates de platas, anteriores a los mercaderes primitivos de este nombre, no hallé ni tradición. Tampoco pude encontrar siquiera un sujeto que me informase del origen de una clase de ladrones, conocidos con el nombre de Ckacchas, que aqui están tolerados de que roben en el Cerro, desde la tarde del sábado hasta la madrugada del lunes siguiente; ni era menor la incertidumbre acerca del tiempo y número de los Repartimientos generales de la Real Mita, y mucho más en orden a los motivos que obligaron para construir ingenios en esta Ribera, con la historia concerniente al manejo y distribución de los azogues y a la cronología de sus precios desde que se inventó la amalgamación hasta el presente, con las demás novedades acaecidas en orden a la composición de las deudas atrasadas de este ramo con los dueños de los ingenios.

Conociendo la importancia de estas materias, me empeñé a desenterrar sus preciosas noticias, registrando más de doscientos volúmenes del Archivo de la Casa Real y del Cabildo, sin perdonar los fragmentos más obscuros que fuí solicitando por toda la Villa, por entonces únicamente para mi instrucción pxivada. Después que ya tuve acopiadas las memorias suficientes que me sacaron de dudas, juzgué de la obligación de un buen patricio hacer de todas ellas una colección metódica para el gobierno de los empleados en esta Villa, y para ilustración de todos sus vecinos; pero habiendo reflexionado posteriormente que estas anécdotas eran dignas de comunicarse al público, no solamente por lo mucho que podian importar a los Superiores Magistrados y Tribunales del Reino para el acierto de sus providencias, sino también para que se haga notorio a todos, dentro y fuera de América y España, la sabia economía con que se han reglado estos objetos, $y$ al mismo tiempo las admirables instituciones dictadas en todos los tiempos para fomento y prosperidad de los establecimientos de Policía y de industria más interesantes y opulentos que tiene el Rey en estos dominios: al cabo me resolví a formalizar esta des- 


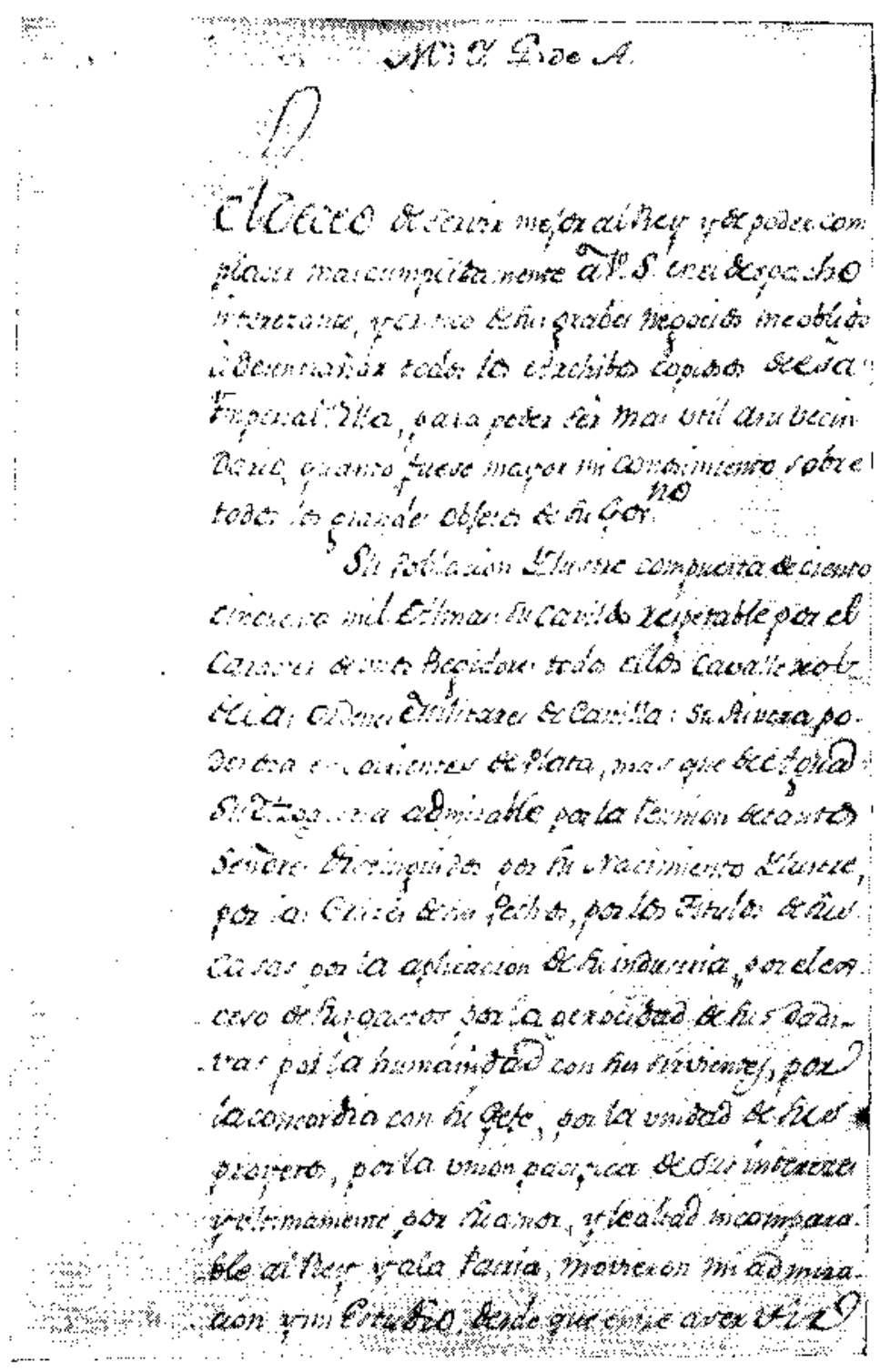

Primera parte de la dedicatoria al Muy Ilustre Gremio de Azogueros de Potosí.

(Reproducción del texto en las págs. 4 y 5 ). 


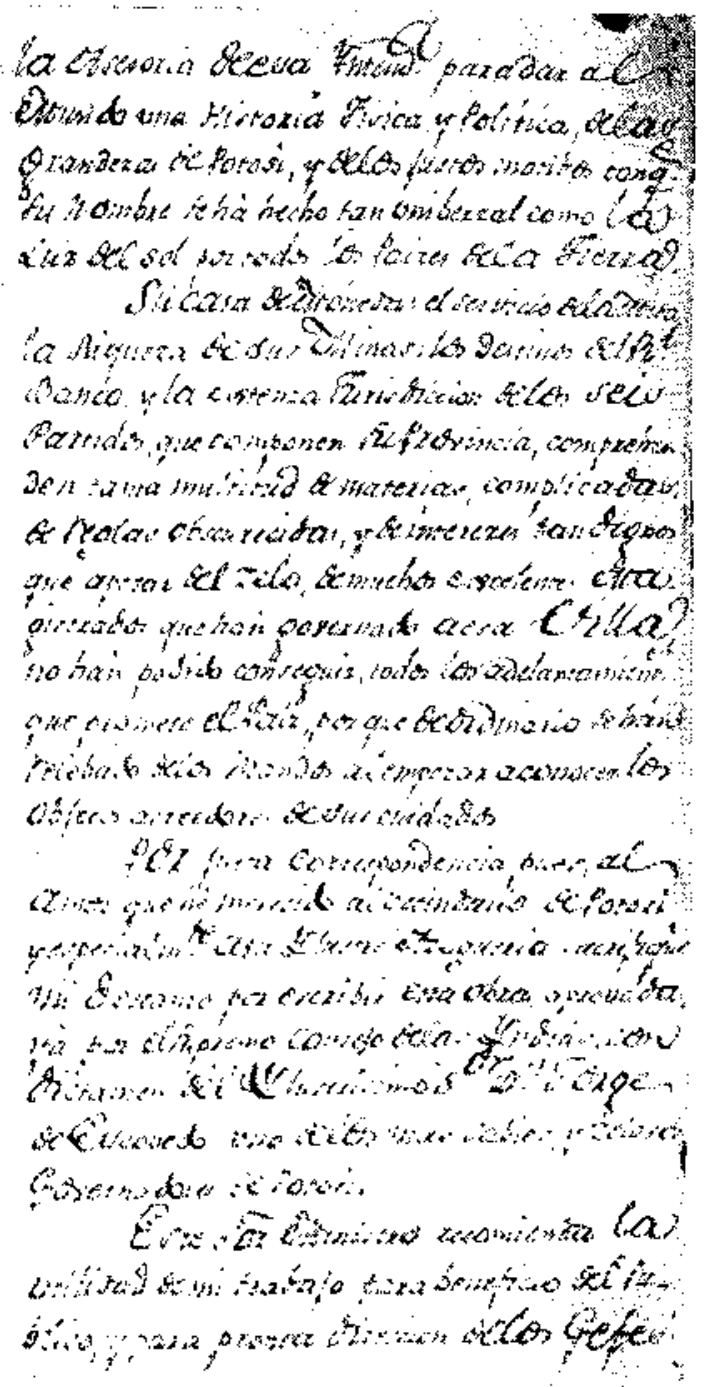

Segunia parte de la dedicatoria al Muy Ilustre Gremio de Azogueros de Potosí.

(Reproducción del texto en la pág. 5). 


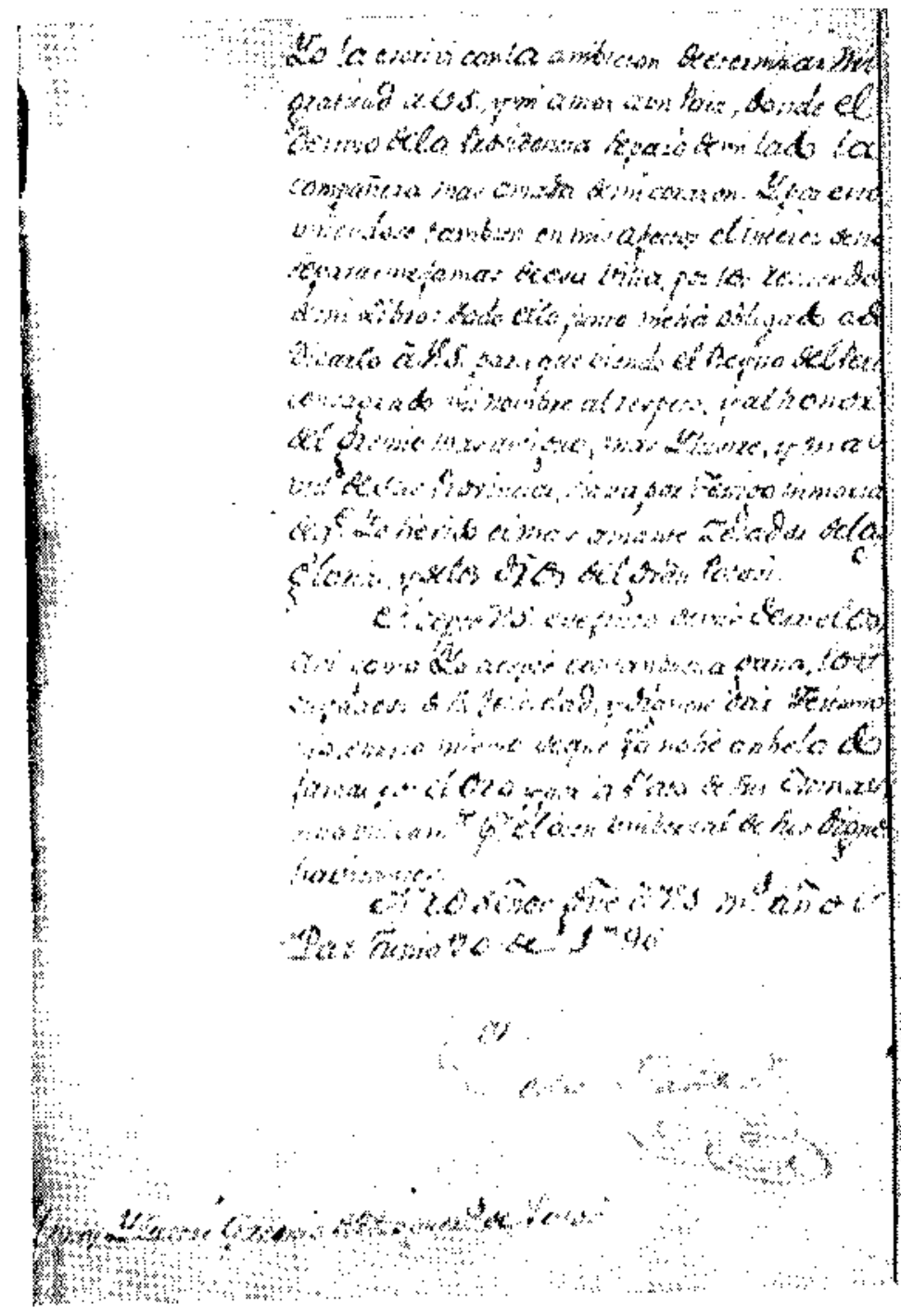

Tercera parte de la dedicatoria al Muy Ilustre Gremio de Azogneros de Potosí, con la firma autógrafa.

(Reproducción del texto en las págs. 5 y 6). 


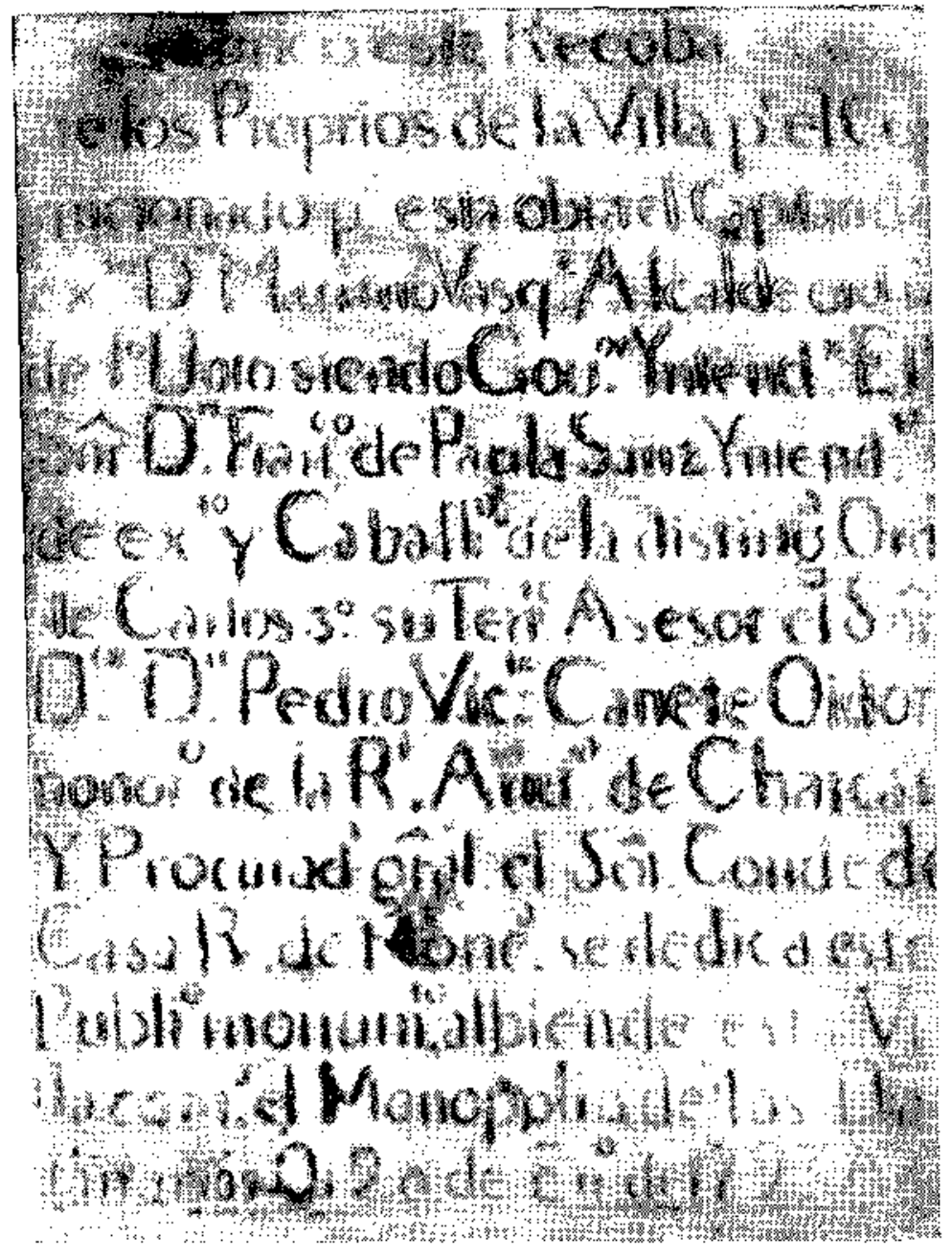

Lápida colocada en el Mercado de Abastos de Potosí.

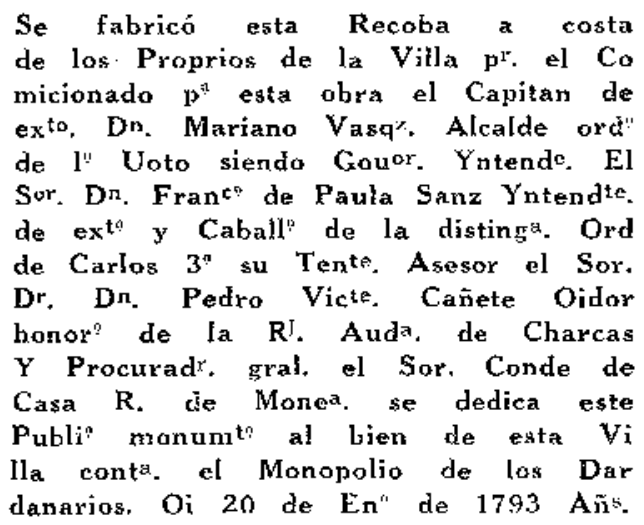


cripción geográfica, histórica, fisica y política de la Provincia de Potosí, a pesar de los poderosos obstáculos que ofrecian las tareas del oficio, aunque muy a costa mía por los quebrantos de mi salud y de mi descanso.

Sin interrumpir la corrección de las materias he interpolado varios discursos, avisos y reflexiones políticas que me han parecido conducentes, agregando al fin de la obra diferentes estados del producto de las oficinas de esta Villa, del número de los Curatos de toda la Provincia, con sus respectivos sinodos y mesadas, del número total de los pobladores, con un mapa topográfico comprensivo de todos los pueblos, y demás circunstancias que hasta ahora no se han explicado con tanta puntualidad en ningún plano.

Si el público hallare alguna cosa apreciable en este trabajo, tendré yo la mayor complacencia por haber acertado con su gusto; pero no debiendo lisonjearme de no haber incurrido en muchos defectos, pido que me los dispense porque mi situación entre el ruido de tantos negocios no permite todos los esmeros que hubiera querido emplear en esta obra; por lo mismo, no me avergüenzo de confesar las faltas, cuando Marcial confesó ingenuamente las de sus Epigramas, con ser uno de los poetas más excelentes de su siglo. - Vale.*

\footnotetext{
* Este "Prospecto" precede al "Discurso Preliminar" en el manuscrito catalogado en el Archivo de Sevilla. No aparece en los originales de Potosí que su autor -a juicio mío- escribió inicialmente, insertando el "Prólogo y Argumento de la Obra", de donde resumió después muchos conceptos y repitió datos en su "Prospecto", como podrá verificar el lector al hacer comparación de los documentos de ambas fuentes - Archivo de Sevilla y manuscrito de Potosi- que se registran en esta edición completa.

Adquixí el libro original existente en Patosi, en sus dos gruesos volúmenes, el año 1928, de manos del ilustrado hombre de letras don Luis Serrudo Vargas, con destino a la "Biblioteca Municipal" y el propósito de que fuese editado por cuenta del Honorable Ayuntamiento, en editoriales de Madrid o Buenos Aires. A gestión posterior -año 1941- recogí el libro para la "Sección de Archivos Coloniales" del "Museo Nacional de la Casa de Moneda", que me cupo organizar.

El cotejo de dicho manuscrito con las fotocopias obtenidas en el Archivo de Sevilla $-y$ con una reproduccion hecha por amanuense del mismo documento cuidado en España, que ha puesto en mis manos el historiador don León M. Loza,- me lleva al convencimiento de que el libro original es el que posee actualmente el Archivo del Museo de la Moneda, y el ejemplar de Sevilla es copia corregida y considerablemente resumida en su segunda parte, por convenir asf al Sr. Cañete, para facilitar su aprobación por eî Consejo de lndias y simplifiear su edición.

Por curioso dato marginal del autor en el documento de Sevilla, dispone la presentación de seis ejemplares manuscritos de su obra: uno para el Sr. Gobernador de Potosí; tres para las Salas del Consejo de Indias en Madrid; uno para el Archivo Secreto y otro para acompañar al expediente de solicitud aprobatoria y de licencia para la publicación. Para Don Jorge de Escovedo, Censor de la obra, recomienda un ejemplar de los más cuidadosamente escritos.- Nota de A. Alba.
} 
PROLOGO Y ARGUMENTO DE LA OBRA 
$+$ 
$\boldsymbol{U}_{N A}$ NA dilatada experiencia de Abogado en el reino de Chile y en la capital de Buenos Aires; la practica continua de Asesor en el Virreinato del Rio de la Plata y en la Capitanía General del Paraguay, por muchos años; el mancjo reflexivo de toda clase de negocios, los más graves, y el conocimiento de las materias del Reino, principalmente sobre los indios, que es el asinnto más frecuente del Paraguay, me habia persuadido, cuando entré a servir la Tenencia del Gobierno de Potosí, que a pocos pasos llegaria a adquirir cuanto necesitase saber para el cabal desempeño de mi oficio. Metí el hombro al peso de muchos negocios que abarcan las cuatro Superintendencias anexas a la Intendencia, y comencé a conocer que la complicación de circunstancias requería un estudio mucho más extenso del que crế necesario. Quise excusarlo informándome de los escribanos de Minas y Mita, sobre lo más esencial de estas dependencias, y de otras personas al parecer practicas en todas las cosas de Potosi; pero en breve tiempo toqué mil desengaños de mi primer concepto.

Conocí que todos hablaban por una tradición falsa o equivocada, por una historieta de cuentos impertinentes que aquí llaman "anales de Potosi", haciéndose creer sobre su palabra, en la confianza de no encontrarse papeles en los archivos; $y$ por consiguiente, que si yo no examinase de propósito los documentos hasta salir de dudas, me sucedería acabar el servicio en el mismo estado de inocencia en que han salido muchos de los que han gobernado esta Villa.

Al cabo de pocas tareas fui descubriendo varias noticias auténticas, con las que despejé las primeras obscuridades y me prometí salir de dudas si me aplicaba al registro prolijo de los grandes protocolos de las Cajas, del Cabildo y denás oficinas, despreciando ya enteramente la alucinación en que estaban casi todos, de no encontrarse papeles.

Entonces resolvi también hacer fructuoso mi trabajo a los que hubiesen de mandar esta Villa, tanto más importante que antes, por los ricos y extensos Partidos agregados a su Provincia, El título de la obra in- 
dica mi pensamiento, $y$ las graves materias que incluye califican el estudio impendido para llenar su idea.

En efecto, he registrado más de doscientos volumenes de libros de Acuerdos, Provisiones antiguas, procesos y Cédulas arrinconados siglos enteros en los estantes y escaparates de las oficinas, bebiendo en las mismas fuentes noticias que por acá estaban sepultadas en el olvido o confundidas con una tradición equivocada.

En esta operación observé que habiéndose pedido informe más de una vez sobre asuntos muy interesantes, pero más antiguos de un siglo, se atribuía todo a la costumbre, sin atinar con el origen, teniéndolo en las mismas oficinas, por varias provisiones o Cédulas reales.

Citaré ejemplar porque no se acuse de arbitraria mi relación. El Excmo. Sr. Virrey de Lima, mandó a estos oficiales reales que informasen sobre la práctica de rematar en lotosí los oficios concejiles de la wrovincia del Tucumán: ellos lo ejecutaron en veintiocho de mayo de mil setecientos cuarentiocho, certificando la constancia de los remates hechos por más de un siglo atrás, y añadieron que no parecia la cédula que lo habiese prevenido. Después encontré yo, que habia tenido principio de una provisión del Sr. Marqués de Montesclaros, fecha en Lima, a veintitrés de agosto de mil seiscientos nueve, mandada guardar por ofra del Sr. Marqués de Guadalcázar, de veintinueve de fobrero de mil seiscientos veinticuatro, a pedimento del Fiscal Don Luis Enríquez, con lo prevención de que nunca se alterase el orden dispuesto por el Gobierno para los remates de oficios.

Omito decir sobre los rescates de plata, establecimiento de mita $y$ el número de los repartimientos generales, como sobre la Casa de Moneda; porque exceptuando lo más vulgar que por frocuente en la práctica se conservaba en la memoria de los vecinos, en lo demás guardaban inviolable secreto, $y$ lo peor es las suposiciones falsas de muchas cosas que nunca han sucedido, como la ereción de Casa de Moneda en Porco, que muchos afirman, no habiendo sido así jamás, como después se han convencido.

Sirva por última prueba, que el Corregidor de Porco intentó incluír en su jurisdicción el Baño, llamado de "Don Diego" (que es una casería con manantial de aguas termales, a distancia de Potosi cerca de cineo leguas); formó competencia y después de haber apurado a este Gobierno, vino a quedar el negocio sin decisión porque no encontraran, ni aun sabian fijamente de la Cédula de limites de esta Villa. Todos hablaban de ella a bulto, pero lo cierto es que no pareció; con la diligencia la encontré yo después, en un libro de los del Cabildo, que comenzó el año de 1701,y han salido de una duda, que en realidad era muy nociva al interés público de las jurisdicciones.

En cuanto a los Partidos, era todavía mayor la obscuridad; porque algunos pocos, que daban razón de ellos, habian viajado sin reflexión, $y$ asi apenas podian decir ciertas cosas comunes, de ninguna importancia. $Y$ fuera de aquí nadie podia formar concepto de estos territorios, pues, nuestro viajero Ulloa, con ser el más exacto observador de esta parte dé América, no pasa de diez líneas lo que habla de Atacama, Porco y Lípez, dejando en silencio las dos Provincias más ricas de Chayanta y Chichas.

Para que un Gobernador pudiese instruirse perfectamente de toda su Provincia, necesitaba mucha aplicación, con la fatiga de examinar 
cada una de por si las materias dignas de providencia; y como esto requiere tiempo, sucedería cumplirse el quinquenio y cesar en el mando en aquel preciso periodo que podia ser útil por la práctica que ya hubiese adquirido; de suerte que sucediéndose unos a otros los hombres de más celo, quedaria la Provincia sin adelantamientos.

No es menester más prueba, que no haberse podido levantar hasta hoy el mapa topográfico que previene la Ordenanza de Intendentes, en el artículo 53, pero ni aun se han evacuado las relaciones históricas de cada Partido, segín lo dispuesto en el artículo 54, porque los mismos Subdelegados ignoran las particularidades de sus Partidos y mucho más los objetos que se deben promover en ellos para mejorarlos. He visto algunas relaciones; pero tan insubstanciales y frías, que solo contienen cuentos de la cigüeña.

Conocen muy bien la miseria en que se hallan los pueblos, el atraso de la agricultura, la decadencia de las minas, el poco aprovechamiento de los indios en la doctrina evangélica, $y$ el desorden en general de las Provincias. Todo les consta prácticamente, $y$ no vemos, a ninguno, que proponga algún proyecto para reparar tanta lástima. Cada Subdelegado tira a pasar su tiempo y aprovechar lo que puede.

$L a$ administración de Justicia y la Policia, tan encargadas por la Ordenanza, van abriendo brechas para nuevos desórdenes o para mantener los antiguos. Cuando los atacan, responden que no son letrados y que no entienden la Ordenanza.

Desiniés de haber palpado todos estos obstáculos de nuestra felicidad, confieso que muchas veces me ha arrebatado el celo por el Rey $y$ por la Palrit. Mi autoridad no es bastante para poner el remedio que necesitan los males políticos del país, ni se puede lograr a tan poco tiempo, cuando cste uerpo apenas va convaleciendo de las antiguas enfermedades que eran más graves.

Nuestro sabio Gobierno ha dictado las mejores reglas para vivificar todos sus miembros adormecidos: lo que falta es aplicarlas en la práctica con inteligeneia y con sagacidad.

El amor por la causa del Rey (a quién todo lo debo) me arrebató al pensamiento atrevido de escribir una GUIA que pudiese ilustrar a los Gobernadores Intendentes, con especialidad a los de Potosi, para adelantar estos Estados y hacerlos útiles a la Corona, remediando los muchos ineonvenientes que impiden su prosperidad.

Para conseguirlo he sacrificado mi salud, mi reposo y mi poco dinero, porque sólo a esta costa podia yo. lograr el fin que me habia propuesto.

En esta obra verón un mapa exactisimo de la Provincia de Potosi, con distinción de sus Partidos, Doctrinas, pueblos, ríos, Minerales y montes; de suerte que a golpe de ojo se instruirá un Intendente én el mismo dia que fuese provisto.

$Y_{0}$ he asalariado persona inteligente que viajase la Provincia con reflexión, para describirla según arte: ya se ve, para estos costos ha sido menester quitarme el pan de la boca; pero estoy muy contento con mi pobreza, a trueque de que florezca el Reino y adelante el erario de mi amado Soberano. 
He doblado mis tareas para ilustrar unos escritos nuevos sobre materias de tanta gravedad; pues aunque al Gazofilacio escribió do Real Hacienda, fue en el sistema antiguo del Gobiemo de este Reino. He combinado todos los asuntos al tono de la Ordenanza: explico y cito las Leyes Reales recopiladas y facilito por un método claro el conocimiento, manejo $y$ despacho de los ramos fiscales que se administran en estas Cajas Reales.

Hago un comentario prolijo de las Ordenanzas de minas, materia que nadie ha tratado por lo perteneciente al Perü; y no omito proyecto conveniente a la industria y economia de estos paises.

Desde luego, creo que esta empresa es muy superior a mis fuerzas y a mis talentos; pero es mucho menor a mis deseos por el acierto $y$ por el bien del Estado. Cualquier lector discreto que se haga cargo de la multitud de asuntos, de su gravedad y principalmente de su novedad, me disculpará los errores, pues anstoso de dar testimonio de mi aplicación y lealtad a la confianza del Rey, en el puesto que se ha dignado darme su piedad, junto con otro motivo que no me interesa menos, me ha apresurado a concluir la obra sin tener tiempo siquiera para castigarla de primera mano. Virgilio y otros élebres escritores se sabe el tiempo dilatado que impendieron en sus escritos y la prolijidad con que los enmendaron y corrigieron. Horacio lo aconseja encarecidamente, y todos asi lo observan para evitar la censura pública.

Nadie como yo debia practicar estos preceplos, na tanto por mi insuficiencia como por la mezcla de materias politicas, económicas, juridicas, históricas $y$ fisicas que me he visto precisado a tocar en esta obra. El Indice no descubre el pormenor de ellas, porque no puede abarcar la multitud de cuestiones, advertencias $y$ observaciones que contiene cada capitulo; ni he tenido tiempo para formar el de cada punto por alfabeto; por lo que habrás de tomarte el trabajo de leerlo todo para que sea cabal tu juicio.

Pero será menester emplear también tu paciencia para dispensar los innumerables defectos que encontrares. No me avergüenzo de confesarlos, cuando Marcial confesó ingenuamente los de sus epigramas, con ser uno de los poetas más excelentes de su siglo.

Lo que más particularmente te ruego, amado lector, es, que si fueres eclesiástico o por otro título te tocasen mis escritos, no los interpretes siniestramente; porque mi intento no ha sido dar materia a la detracción, sino hacer conocer las dolencias, para que se pueda atinar con el remedio. Protesto de buena fe, como San Jerónimo en caso semejante, que la utilidad publica es todo el fin que me mueve a proponer el mal estado dé muchas cosas reparables en esta Provincia: cada uno meta la manoren su pecho $y$ alégrese en hallándose inculpado, o busque la enmienda si conociese sus faltas.

No por eso discurro que sólo el aire de mi pluma podrá asegurar el partido que voy buscando: por el contrario, me temo que salga algún Lacilo a satirizar mi estilo, mi talento, mi método o mi doctrina; pero sépase que nunca será capaz de acusarme de poco fiel a la verdad, y yo lo miraré como Athenas a Diógenes, queviendo censurarlo todo desde una cuba donde apenas se descubre una vara de cielo: empeño verdaderamente ridiculo, cuando se critica lo que no se entiende ni se ha visto.

Desde luego desconfío conseguir los efectos de mi asunto: con to- 


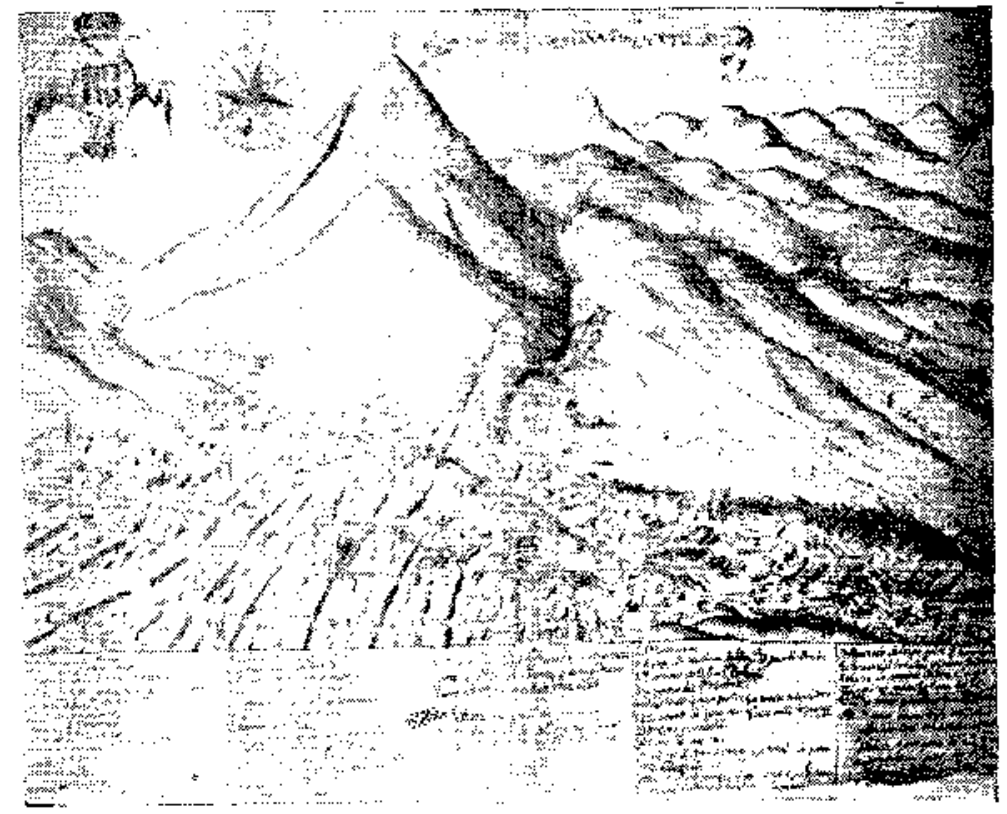

Plano del Cerro de Potosi y parte de la Villa, por Don Joaquín Antonio de Guendica, Marqués de Aro, minero y duer̃o de ingenios.

(Sección docunentos históricos del Musen Nl. de la Casa de Moneda). 1758 


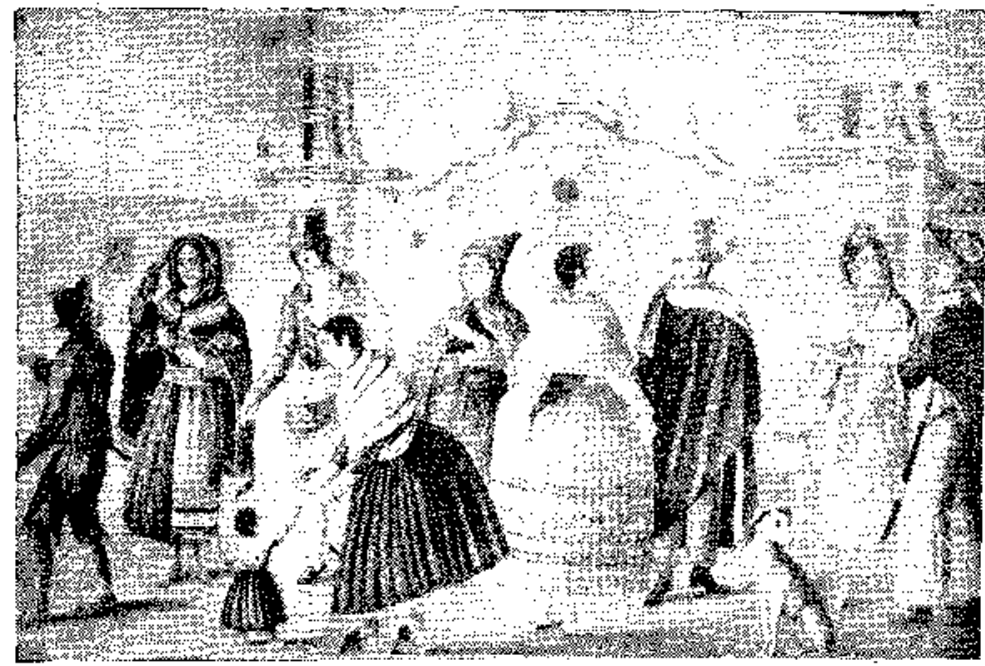

En la plaza principal o de "El Regocijo" de Potosí: en el primer plano, figuras y trajes característicos le la época. Al fondo, las líneas de la Iglesia Matriz.

(Dibujo de la obra "Travels in various parts of Perú", de Mr. Edmound Temple. 1830). 
do, no ho de suspender mi pluma; porque estoy seguro de que entendida la razón yl la causa de él, se despertarán espiritus generosos, que sostengan los justos derechos de la felicidad pública y del bien del Estado a que unicamente aspiro.-Vale.*

* El "Prólogo" que antecede ha sido tomado de la copia manuscrita que está en poder de Ia Sociedad Geográfica y de Historia "Potosí", a que he hecho referencia anteriomente. Nota de A. Alba. 
- 
PROYECTO PREVIO PARA LA ANEXION DEL

PARTIDO DE TARAPACA AL VIRREINATO DE BUENOS AIRES 

PROYECTO PREVIO EN QUE SE DEMUESTRA LA CONVENIENCIA QUE DFBE ESPERARSE A BENEFICIO DEL REY Y DEL ESTADO, SI SE AGREGA AL VIRREYNATO DE BUENOS AIRES EL PARTIDO DE TARAPACA, CON EL CERRO RICO DE GUANTAJAIA Y SU TERRITORIO, TIRANDO LA LINEA DE DEMARCACION POR LA QUEBRADA DE CAMARONES.

$\mathbf{L}$ $\triangle$ A materia de confines, ha sido siempre ocasión fecunda de graves discordias entre Reinos y Provincias vecinas, y también entre particulares. La prueba está clara en aquellas ruidosas contestaciones que tuvieron las dos Coronas de Castilla y Portugal, sobre la línea de demarcación señalada en la Bula de Alejandro VI, para decidir los dominios de ambas conquistas en el Nuevo Mundo Americano, I sin haberse podido terminar las diferencias de límites por espacio de cerca de tres siglos, hasta el último tratado preliminar de 1777 .

El mismo principio tuvieron los funestos encuentros de Francisco Pizarro y Diego de Almagro; y al cabo fue la ruina de los dos la emulación nacida entre ellos, de la codicia de incluír la ciudad del Cuzco en el término de sus gobernaciones. ${ }^{2}$

Conociendo estos inconvenientes, deslindaron nuestras leyes los territorios de las Audiencias, Gobiernos y Corregimientos, demarcando linderos específicos y permanentes, para evitar toda confusión y desavenencia entre las jurisdicciones.

En la Ley 9, Tit. 15, Libro $2^{\circ}$ de la Recopilación de Indias, se distingue puntualmente el distrito de la Real Audiencia de Charcas, señalando los límites por donde se divide de las Audiencias de Lima y Chile. La línea divisoria es conocida por todos y por lo mismo no se especificó en la Real Cédula fecha en San Ildefonso a $1^{\circ}$ de agosto de 1776, sobre la erección del Virreinato de Buenos Aires y se tuvo por bastante señalarle por territorio todo el perteneciente a la Real Audiencia de La Plata, con 
las ciudades de Mendoza y San Juan del Pico, de la Gobernación de Chile.

Según estos deslindes, sirve de límite entre los dos Virreinatos, el río de Loa sobre la costa del mar del Sur, a los $20^{\circ}$ y $30^{\prime}$ de latitud, y al mismo tiempo confina los Partidos de Atacama y de Pica ; el primero perteneciente a esta Provincia, y el otro al de Arequipa, de la jurisdicción de Lima.

La línea que corta las pertenencias desde la desembocadura del río de Loa, remata sobre la guan cordilera de los Lípez, con el encuentro de otra línea, que demarca la doctrina de Llica y divide a este mismo Partido del de Tarapacá; de sucrte que abandonando nuestra jurisdicción sobre la serranía, treinta leguas más que sobre la costa, viene a formar en los altos una figura de martillo, que desde la derecera del Loa se prolonga hasta el mar, quedando en el vacío inferior a Lípez el Partido de Tarapacá con sus respectivos pueblos.

Midiendo la distancia desde el ángulo donde termina el territorio de Lípez, que cabalmente corresponde a la quebrada cle Camarones, en 19", se encuentran, por la costa, treinta leguas hasta el Loa por la longitud del terreno, y por el ancho diez leguas tirando de mar a cordillera hasta donde confina con Lípez.

Esta manga de tierra está muy bien deslindada hacia el costado occidental por el mar; hacia el Norte por Camarones, y hacia el Sur por el Loa; pero en la parte oriental no hay más linderos fijos que la serranía.

Por esta falta de claridad se han ocasionado algunas desaveniencias de los tarapaqueños con el Cura de Llica y Tahua, del Partido de Iipez, sobre límites; y según me acuerdo, hará como un año que cl Intondente de Arequipa pasó exhorto a este Gobierno, acusando de exceso al citado Cura de Llica, por haber proluibido varias funciones eclesiásticas a otros Párrocos de aquella Provincia, en la suposición de hallarse construída la Capilla dentro de su territorio. Este acto prueba muy bien que los deslindes por este lado no son bastante específicos, y también hace recelar que en creciendo nuestras poblaciones se fomentarán discordias muy graves y ruidosas entre ambas vecindades.

Pero aun cuando fuesen claros y visibles los hinderos: esto mismo contribuiría al daño del Rey y de los indios, como en el día está sucediendo. Los pobladores de Pica y Tarapacá, que por lo regular son españoles, cholos o mestizos, se pasan a Atacama con mercaderías de la tierra, como son la coca, bayeta de la tierra, algunas cintas, cuentas y otras frioleras, para cambiarlas por trigo y maíz y también para el rescate de oro y plata; ellos vagan por todo el distrito engañando a los infelices indios, que por no conocer el interés sólido y verdadero, compran lo que no han menester, y si acaso se les vende cosa que necesitan, son tan excesivos los precios que salen perjudicados en más de la mitad de lo justo.

De aquí resulta que los vecinos arrastran a sus países hasta los alimentos precisos, con todo el oro y plata que pueden adquirir, en la confianza que pisando la raya de aquelia jurisdicción, ya están libres de ser demandados, así por los compradores, como por Ministros encargados de la cobranza de Alcabalas, defraudándole al Rey estos derechos, no menos que los quintos de la plata y oro que extravían. Ya se ve que el Subdelegado y un Receptor sólo, no son capaces de celar los fraudes que se cometen en lugares tan distantes y extensos; y aun cuando se llegaran a conocer, ya no admiten remedio, porque los agresores se ausentan a sus domi- 
cilios donde son excusadas diligencias, porque todo lo embrollan con el favor o con la intriga.

Desde luego no scría así, si ambos Partidos estuviesen sujetos a una misma autoridad, porque averiguado el delito en uno de ellos, tendrían fuerza las órdenes para perseguir a los reos y castigarlos en el otro.

fos mismos indios conocen muy bien los efectos de esta independencia de jurisdicciones, $y$ fácilmente se trasladan para verse libres de pagax el tributo. La proporeión es muy oportuna, por el contínuo trajín que tienen hacia Tarapać́ los de Lípez, a vender la pólvora y los carneros de la tierra en aquel distrito. Muchos de estos se quedan por allí, abrigados del minero o de otro que los necesita para su servicio, perdjendo el Fey sus tributos. Ni se puede atribuir a otro principio la poca población de nuestros Partidos, en medio de ser tan fértil el de Atacama.

Si no hubicra esta división de mandos, pasarían nuestros comisionados a registi'ar aquellas poblaciones $\mathrm{y}$ alli mismo empadronarían a los desertores, y los reducirían a sus domicilios; cuando ahora, por la razćn contraria, no puedon hacerlo ni aun sus propios Caciques (como lo ejecutan hacia la parte del Tucumán), temerosos do volver cargados de agravios en vez de tributos.

Todos estos desórdenes van debilitando nuestras poblaciones, y es de temer que a más años quedarán hechos esqueletos junto a la ruina de su corta agricultura; pues no encontrando fomento real en el cambio de los fi'utos después de extraerse fuera de los pueblos, en trueque de las frioleras, cl poco dinero que granjean en las minas o en la pesca, no tendrán impulso el comercio ni la labranza, por falta de la substancia numeraria que es la que vivifica todos los cucrpos políticos.

No es menos scnsible el atraso del Partido de Tarapacá por la misma causa, en medio de haber depositado allí la naturaleza el mayor tesoro dei mundo en el cerro de Guantajaia, $y$ en las demás serranías de la comarca. Los más sc contentan con admirar las riquezas que oyen contar de Guantajaia; otros atribuyen las relaciones a ponderación; pero ninguno hace un estudio práctico de las grandes ventajas que debe esperar el Estado del fomento de este mineral.

Se acredita por la Historia que en el descubrimiento de Potosí, se exitó on un grado imponderable, no solamente la ambición de los particulares para adquirir sus grandes riquezas, sino también la del Gobierno en dictar reglas inteligentes para su régimen, y en contribuír auxilios generosos para su fomento y subsistencia. El Cerro se hallaba entonces en un país desierto, árido $\mathrm{y}$ distante nueve leguas de la población de Porco: no había agua, ni leña, bajo de un clima tan rigido que ne era habitado ni aun de vicuñas, y huían de él las gentes como de su sepulcro.

Es verdad que eran grandes sus riquezas y varias las vetas caudalosas; pero en su mayor auge, jamás pudo rendir arriba de medio quintal de plata por cada quintal de metal. Con todo, arrastró desde su solio a un Virey tan respetable como el Excmo. Sr. Dn. Francisco de Toledo, y venciendo la providencia humana todos los obstáculos de la naturaleza, se pobló al cabo de pocos años con número crecido de gentes por medio de la Mita señalada para su servicio; tuvo surtimiento de aguas con el arbitrio de las Lagunas, $y$ por último vino a sobrarle todo por consecuencia natural de la población, sin estorbar a estos admirables progresos el no hallarse en sus inmediaciones otro mineral de codicia ni de metal más precioso 
que la plata; cuando al mismo tiempo se iba adquiriendo con el tribajo una experiencia funesta de que a la mayor hondura se mostraba cada vez nás mezquina la naturaleza en la pobreza de los metales, con el justo temor de quedar inutilizadas a largo tiempo las grandes cmpresas que fuo preciso costear al principio.

Después que se divulgó esta fama y provino la admiración de todo el mundo, de ser Potosí, el cerro más rico de todos los Fstados, se hizo el descubrimiento del mineral de Guantajaia, superior verdaderamente en las riquezas, pero menos dichoso en la opinión. Diré algo sobre sus cualidades, para que se comprenda mejor la importancia del Proyecto.

Este es un cerro tan poderoso, que cuando se trabaja en barra, pinde veinticuatro libras de plata cada arroba de metal: riqueza que jamás tuvo Potosí. Son innumerables sus vetas caudalosas, y todo el terreno de su comarca tán fértil de metales, que no se echa menos ninguna especie, sin excepción del oro.

En lo trabajado hasta aquí, se reconoce que allí no ha transtornado la naturaleza cl método regular en que se crían los metales; porque se aumentan las riquezas en la profundidad, al contrario de lo que sucede en Potosí. Por esto, aungue suban los costos de la labor, ciece con exceso la ley del metal para alentar el empeño de los mineros, con la particularidad que hasta el dia sólo ha dado en agua una mina (nombrada del Cura), a más de doscientas yardas de hondura.

Muchos se han empleado en sus labores y después de emriquecidos se han jdo a ser dichosos a otras partes; pero habiéndose ahondado las minas dentro de unas cajas durisimas de piedra de ala de mosca, causa muy proporcionada de la superior ley de sus metales, no pueden ya los mineros por sí solos hacer grandes progresos, por falta de gente para el trabajo; por el grande costo con que se conducen todos los bastimentos, hasta el agua, a unos precios excesivos; y finalmente, por cl crecido flete del acarreo de los metales hasta Tarapacá, a distancia de dieciocho a veinte leguas.

Como allí apenas hay agua para beber, sufren los mineros el perjuicio de no poder llevar gruesa en las moliendas, respecto de hacerlas en quimbaletes, que son instrumentos formados de unas grandes piedras esféricas que moviéndose de un lado y otzo sobre soleras también de piedra, sacan al cabo del día una tarea muy corta, que no podría costear el trabajo si los minerales no fuesen de tanta ley.

Por esta causa se ven abandonados por desmontes del cerro unos metales de más de catorce marcos de ley, que bastarían para enriquecernos en Potosí. Según su abundancia, me aseguran que si se beneficiasen producirian más de un millón de pesos.

Ya quisieran los extranjeros estos desperdicios para hacer felices sus Estados. ¿Y es posible que nosotros nos mostremos tan insensibles a nuestra felicidad? En realidad que así hemos vivido hasta ahora; pero viéndose ya ilustrado nuestro país, con un sistema de minería más sabio y más benéfico que el antiguo, debemos esperar que con la soberana protección del Rey, tome nuevo aliento el espíritu decadente de los mineros de Guantajaia; que si estos emprenden trabajos de importancia, aquél mineral sólo, es capaz de enriquecer el reino; porque si ahora, sin fomento, produce medio millón de pesos al año, después que reciba el impulso 
de mejores auxilios, es seguro que su corriente anual haya de exceder de doscientos cincuenta mil marcos.

Lo que hay es que estos dichosos efectos sólo se pueden lograr con la agregación de aquel territorio al Virreinato de Buenos Aires. Escúchese de buena fe esta proposición y no se podrá contradecir.

Dos cosas son indispensables para dar impulso a los trabajos de minas el Guantajaia: la primera, es surtir de agua aquel país, y la segunda, facilitar los rescates. Aunque no hay ríos inmediatos por allí ni llueve jamás, pero hay grandes lhuvias en las cabeceras de la serranía, cuyas vertientes llegan hasta Tarapacá en los tiempos respectivos y corren por el valle de su nombre, hasta un cordón de sierras que corta la campaña de Norte a Sur, impidicndo la dirección del estero, de suerte que este embarazo tuezce su curso hacia la parte de Pica, aunque las aguas se consumen en los arenales a pocas leguas.

Sirve de canal una quebrada de más de doce leguas, que se va angostando hasta un pasaje lamado Guaviña, donde se puede formar muy fácilmente una represa con tres o más paredes de cal y canto, con sus compuertas, para recoger las aguas que ahora se desperdician.

Cada depósito sería una Laguma, * y por el orden que se fuesen llenanclo las primeras, vaciarán en las sucesivas el agua sobrante, hasta quedar todas bien surtidas, para contribuir por todo el año un brazo mediano de agua con qué hacer las moliendas en ingenios grandes como los de Potosí.

Con cuatro Lagunas de buen porte, puede moler por todo el año una ribera de cien ingenios. En Potosí no hubo en la antigüedad más Laguna que la de Tabacoñuño, y era suliciente para igual número de ingenios, despnés de surtir las pilas del pueblo. Aunque en años escasos de lluvias, fuesen también cortas las vertientes, siempre alcanzarian para llonar una o dos Lagunas, que siendo de gran buque, no habría falta de agua para llevar una corriente regular, alternando por días o por semanas.

Con estas mismas aguas se pudiera regar todo el valle de Tarapacá, fértil por su naturaleza, cuando en medio de tanta sequedad produce unos grandes árboles llamados Tamarugales, ** muy a propósito para varias obras de importancia. Se poblaria entonces el terreno por innumerables labradores, que a porfía lo complarían al Rey; $y$ con el cultivo se abastecería aquel lugar de todo género de fiutos y vendrían a costar las subsistencias de los mineros una mitad monos de lo que actualmente salen; resultando dos ventajas muy considerables, la una en el fomento de las minas, y la otra en el empleo de la agricuItura.

Si ahora rinde cada quimbalete cincuenta marcos a la semana, después sc cuadruplicaría la partide por la mayor gruesa de harinas, que semanalmente producen los ingenios de agua; y por más que fuesen grandes los costos de la saca de metales y de su acarreo, siempre se costearía el trabajo con la gruesa de la molienda, como sucede en Potosí, donde en liegando los metales a cuatro marcos, ya es conveniencia para el azoguero, por lo que avanza en el beneficio de las platas a correspondencia de las porciones que se muelen.

Yo computo que cada represa no puede costar arriba de 15.000 pesos, esto es formando las paredes de cal y canto, con sus contramurallas y terraplenes, como están en Potosí de manera que si se construyesen por primera vez cinco Lagunas, vendrán a gastarse 75.000 pesos. Pero 
como esta agua no alcanza hasta el Mineral, es menester ahorrar el costo de su acarreo haciendo en la inmediación a la mar (que sólo dista dos leguas) seis u ocho grandes pozos, de donde se puedan proveer los mineros. Esta es una empresa que se pucde intentar sin nota de capricho, porque según buena física, deben extenderse por todos aquellos contornos las filtraciones del mar. Torlos lo tienen por exporiencia en Montcvideo, en cuyas playas hay pozas de agua riquísima con que se surte el pueblo; y en la misma capital de Buenos Aires, cada casa tiene su pozo, con todo de hallarse el pueblo tan superiok al nivel del río y de ser por su naturaleza seco aquel terreno.

Para estas obras calculo otros 25.000 pesos, que con los setenta $y$ cinco mil de las lagunas, suben a ciell mil. Debemos suponer que los mineros no tienen de donde contribuírlos. La Real Hacienda tampoco está en estado de anticipar estos suplementos; ni Lima tiene arbitrios para hacerlos, hallándose alcanzados todos sus ramos de más pensiopes que productos: con que, mientras Guantajaia quedare dentro de su jurisdicción, es preciso que vaya a menos cada día, y después se prive el Éstado de las inmensas riquezas que encicrra su suelo.

Aun entre particulares, cuando se teme que una heredad se ha de menoscabar partiéndose entre muchos, se manda adjudicaly a uno solo que las pueda mantener y adelantar; luego, con mayor lazón se debe tomar el mismo temperamento con Guantajaia, agregándolo al Virleinato de Tiuenos Ajres, porque solamente de aquí puede sel fomentado en utilidad del Rey y de la causa pública.

Véase el cómo: Potosí tiene un Banco opulento, que cada vez irá a más con los nuevos fondos que deben entral con los descuentos de un real en marco do todas las platas del Virreinato. El fin es fomentar la minería, principalmente en lo general de una Provincia, y más cuando de una operación han de salir bencficiados innumerables mineros particulares: luego no pudiéndose imaginar ninguna cmpresa más útil ni más conducente a conseguir este fin, por consecuencia de su mismo establecimiento se debe emplear su fondo en el romento de Guantajaia, con preferencia a las demás habilitaciones.

El reintegro es seguro y se puede lograr on corto plazo, sin gravamen de aquellos mineros, con el arbitrio suave de ir descontándoles, sobre el real de Ordenanza, $1 / 2$ real mis de cada marco, hasta cubrir el suplemento. Yo aseguro que estableciendo los ingenios y fomentando el Mineral por los medios referidos, subirian los productos anuales a doscientos cincuenta mil marcos, que son dos millenes de pesos, pues si ahora rinde 500.000 pesos, forzosamente se cuadruplicaría csta cantidad con la gruesa del trabajo.

Bien pudiera pagarse el suplemento dentro de un año, aplicando a este destino los pallacus del cerro, nero adoptando el temperamento de sacar $1 / 2$ real por marco, importa el descuento 15.625 pesos al año, con los cuales se cubren con desahogo los 100.000 pesos en seis años, quedando a beneficio de aquellos mineros esta importantísima obra. Con todo, en breve se inutilizaría la empresa, si para su permanencia no se asignase una dotación compctente a costa de todos los participes del beneficio. El arbitrio podía ser un impuesto moderado de sisa en los abastos, carnes y llcores, o en otro ramo que discurriese el Gobierno.

Sería consiguiente a la agregación el feliz expediente de los ros- 
cates, guc ahora son muy difíciles en gravísimo perjuicio del Mineral. Lima está dos tantos más distante que Potosí; las demoras y los fletes son mucho mayores e inevitables los riesgos de ríos, robos y demás contingencias del camino. El mincro necesita prontamente su dinero para jornales y otros avíos, $y$ no puede sufrir sin quiebra una dilatación extraordinaria en el cambio de las barras. En Potosí lo encuentran todo en el día, con la proporción de conseguir los retornos en el mismo tiempo que se necesita para principar la expedición en I.ima.

Por csta causa envían las pastas a esta Casa de Moneda, sin embargo de no ser de su jurisdicción, y ticnen aquí más correspondencias que en Jima, por la mayor facilidad de ariarse al contado o a plazo.

Fl nucro Tribunal de Hinería que debe resider en Potosí, dictaría también los medios oportunos para adelantar los trabajos y empresas del mineral; y el Superintendente de este Departamento, como más inmediato podría contribuix a los auxilios con más prontitud que desde Iima, por consiguiente con más provecho.

A este propúsito, se pudiera entablar un correo periódico de encomiendas para conducir las barras y su retorno en moneda o materiales, con una utilidad imponderable para el Rey. Supongamos que sólo importasen millón y medio de posos las barras que se fundicran en la callana de Tarapacá; era forzoso que el retomo subiese a otro tanto; con lo que se venían a componer tres millones. Conducidas estas cantidades por el coreo con el premio de mo por ciento, debia percibir el Rey 30.000 pesos do este ramo, y el público quedaria bien servido con la prontitud y con la seguridad que nunca, $y$ alu también con la equidad del acarreo, por costarle mucho más en el día.

Sobre toro, un miembro tan lejano de su corazón (que es Iima), jamás podr recibir todo el impulso que necosita para ser fomentado. Fi Tybunal de aquella capital y el Sumerintendente nada pueden obrar que no sea por relaciones, ni es posible que celen siquiera la observancia de las Ordenanzas. Al contrario, en Potosí, por las circunstancias de vecindar y demás proporciones explicadas; luego, si deseamos su adelantamiento es preciso que procuremos su incorporación. Entonces se meditaría sobre la asignacjón de Mita que clesde luego conviene hacerla, cuando vemos quo se concedio en el siglo pasado a Bcrengucla de Pacajes, Oruro y Garcimendoza, con no haber llegado jamás al caudal de Guantajaia.

En conclusión, este mineral depende de la provincia de Potosí. De Lípez Ilevan Ia pólvora y los carneros; de Atacama mucha parte de los granos; y de esta Villa el dinero y muchos otros avíos. Aquí es donde ocurren en todas sus necesidades y no hay otro pueblo más proporcionado a remediarlas con mayor oportunidad.

Sin Potosí casi no pudicra subsistir, y sin él es imposible que se adclante, ni el Rey puede mejorkl su IIacienda en muchísimas entradas de que ahora carece por el atraso del mineral; luego, si hay tan fundadas esperanzas de crecidos adelantamientos en caso de agregarse a este Virreinato, no se puede negar que conviene hacerlo para beneficio del Rey $y$ del Estado. Desde luego me atrevo a decir que si yo tuviera la dicha de ser crédo, cn pocos años fuera el reino más feliz de lo que hoy se halla.

1. - Fn J3adajoz sc juntaron de parte de ambas Coronas muchos Ministros letrados, que despućs de varias conferencias, alzaron la Junta más desavenidos que nun- 
ca.- Sandoval, en la Historia de Carlos V. - Lib. 11, \& 24, tomo $1 \%$, fol. 422 .

2.- Sandoval: Lib. $13, \S 30$, tomo $1^{\circ}$, fol, 515 .

* En la Segunda parte, Cap. $8^{\circ}$, Notjcia $7^{\circ}$, \& $1^{\circ}$, se propone tambićn el arbitrio de conducir por acequias el agua de un río que corre en las cabeceras de la sierra; pero esta empresa es muy costosa respecto del de las Lagunas; y asi considero mejor construírlas, porque importaria la primera obra cerca de 500.000 pesos.

** Son unos árboles de buen tamaño, para ejes de los ingenios, y para otros utensilios de estas máquinas. 
PARTE PRIMERA 



\title{
CAPITULO PRIMERO
}

\section{De la Fundación de la Villa Imperial de Potosí}

Se describe su situación, planta y allura del Polo.- Su antigua magnificencia.- El número de sus pobladores, iglesias y oficinas.- La calidad de su temperamento; al aspecto y naturaleza de su terreno, y de las aguos minerales de su territorio.

NOTIOIA PRIMERA

\begin{abstract}
De la fundación de la Villa con todo lo tocante a la descripción de su casco.
\end{abstract}

A

A UNQUE la fundación de la Villa Imperial de Potosi, fue posterior al descubrimiento de su Cerro, el más rico manantial de plata de todo el mundo, trataremos primero de su población, altura, vecindario y demás circunstancias.

Esta Villa se halla situada en la falda del Cerro, a la parte del Nor-

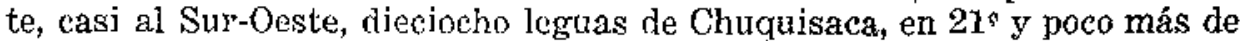
$20^{\prime}$ de altura, según los PP. Cronistas Mendoza y Calancha. ${ }^{1}$ El Geógrafo Murillo ${ }^{2}$ conviene en la distancia, menos en la altura, y le asigna $20^{\circ} \mathrm{y}$ $30^{\prime}$ y medio de latitud meridional, y 31,3 de Iongitud. Nuestro viajero americano Dn. Antonio de Ulloa, ${ }^{3}$ sin afirmar grados de latitud, asigna la distancia de veinte a veinticinco leguas hasta Chuquisaca. Esto es Io más verosímil, y todavía se estienden los prácticos hasta veintiocho leguas. El año 1545 se pobló este asiento por muchos vecinos de Porco, Chuquisaca y de otros lugares del Perí, que allí acudieron con la codicia de la plata. ${ }^{4}$

I.a sucesiva congregación de todo género de gentes, aumentó tanto la población, que llegó a extender su circunferencia hasta dos leguas ${ }^{5}$, habiendo en este distrito, entre familias nobilísimas, indios y españoles de 
todos sexos, más de 150.000 aimas, que se numeraron el año de 1611 , por orden del Licenciado Bejarano, Oidor Decano y Presidente de Charcas. El P. Mendoza asegura que ${ }^{7}$ tendría 50.000 indios de ordinario asistentes y trajinantes; y más de 1.500 casas de españoles; Murillo conviene en el número de indios. ${ }^{8}$ Pero, en cuanto a las casas de españoles, mercaderes y mineros, las limita a sólo el número de 500 ; bien que puede componerse este cómputo, haciendo la regulación en los ticmpos de Murillo, que son muy posteriores a los de Mendoza. (a)

Tiene iglesia Matriz en la Plaza Mayor, llamada del Regocijo desde la antiguiedad. Conventos de N.P. Santo Dommgo, तe N.P. Sn. Francisco, fundado el año de (1547), a instancia del Corregidor Pedro de HinoJosa; đe Na $S^{n}$ de las Mercedes; de San Agustín, fundado el año de 1584 ; un Hospital de San Juan de Dios y otro de la Yilla, fundado el año de 1555, que corre a cargo de los Religiosos de Belén desde el año de 1700. Un Monasterio de Monjas ermitañas de San Agustín, conocidas por" "las Mókicas". Otro de Carmelitas Descatzas, fuñado el año de 1685, por la Venerable M. Josefa de Stá. María, a expensas de Dn. Lorenzo de Nariondo y Oquendo, con la dotación de cerca de millón y medio en plata, joyas y perlas. Una casa de mujeres recogidas, una cuadra de la Plaza al poniente, fundada por María Suarez, $\mathrm{x}$ costa de "su confesor, el Licenciado Manuel de Salvanes, con ayuda de las limosnas de la Vilia, " que ahora se halla trasladada en el Colegio que fue de los ex-Jesuítas, calle de por medio del recogimiento antiguo en la citada calle y rumbo.

Aunque Calancha ${ }^{\text {to }}$ afirma que tuvo catorce Parroquias sin la iglesia Mayor, se engaña, y sólo fueron trece como refiere Mendoza ${ }^{11}$ y se comprueba por una Provisión de 25 de abril te 1574, en que el Virrey Dn. Francisco de Toledo, hace relación que el año de 1572, mandó erigir en Potosí trece Parroquias, seis nuevas y siete antiguas, señalando a cada una el sínodo de 800 pesos ensayados. La minoración de los indios, cl atraso de las minas y el excesivo costo de los sínođos, obligó después a suprimir, a mediados de este siglo, los seis Curatos nucvos que erigió el Sr. Toledo, dejando solamente los siete antiguos que ahora subsisten fuera de la iglesia Matriz y de la Misericordia, nombrado Curato de Piezas, para enterratorio de esclavos, zambos y mulatos. La Matriz era antes servida de tres Curas; pero el Rey ha mandado suprimir el uno, para que de los dos que quedan, resida el uno en la iglesia de las Recogidas, con la misma jurisdicción, que se extiende por toda la Villa sobre todos los españoles, sin determinado territorio. En la Plaza Mayor, hacia el Oeste, está la Casa Pretorial donde vive el Gobernador, accesoria al Ayuntamiento y Cárcel. Ambas muy bien fabricadas, de altos y balcones, aunque muy antiguos. La Sala Capitular es magnífica, con sillería dorada y cubierta de terciopelo carmesí, de que están entapizadas la paredes, con rica flecadura de seda al canto.

La Caja_Realestá al Sur en la Plaza. La Casa de Moneda al Norte, haciendo esquina en la primera cuadra de la Plaza. Ei Reai Banco está al Sur, media cuadra de la Plaza; es casa arrendada, por no tenerla propia esta oficina. Tiene la Villa dos Administraciones principales: la una de la Real Aduana, y otra de Tabaco y Naipes, de que trataremos separadamente; fuera de la de Correos, que-está sujeta a la Presidencia de Charcas, en quien tiene subdelegada su jurisdicción el Sr. Virrey.

Este Cabildo era en lo antiguo dependiente del de Chuquísaca, y a principio de cada año venían de allí dos Regidores para hacer la elección 
de Alcaldes. Después hizo la Villa al Rey un crecido servicio pecuniario en oro, para que se le eximiera de aquella jurisdicción, $y$ en efecto lo consiguió, quedando libre de ella en todos sus_actos, como se refiere en una Real

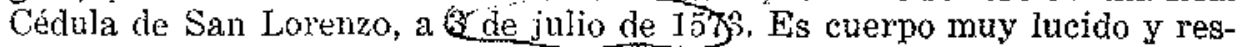
petable; de los cargos concejiles solo Taitan el de Alférez Real y Alguacil Mayor, que estân vącos muchos años ha.

Los Alcaldos han sido siempre muy autorizados y gastan demasiado el año de su vara; porque además de las opulentas mesas, refrescos y fiestas que hacen on sus recibimientos, trae cada uno dos, tres y aun cuatro Pajes, vestidos de paño con galones, con el título de Ministros, que sirven para las prisiones y demás diligencias de justicia.

Los Alcaldos de Ja_Santa Hermandad gastan también demasiado fausto, aunque no tanto tren; pero se sabe que en los tiempos que estaba en boya el Cerro, consumía un Alcalde rumboso 14 o 15.000 pesos en un sólo año. Scgún su Ordenanza, es secreta la votación de todos Ios oficios concejiles, y así no puede elegirse uno a sí mismo, aunque lo pueda hacer en las elecciones públicas. ${ }^{12}$ El Cabildo tiene el privilegio de sentarse dentro del presbiterio en la Matriz, por cierta limosna que contribuyó para su fábrica. El Sr. Argandoña intentó embarazarlo, pero se le amparó por el Rey en la posesión del asiento.

Este pueblo era en lo antiguo tan opulento y xico, y tan espléndido en sus funciones, que en la coronación del Serentsimo Emperador Carlos $V$, se gastaron ocho millones; en las exequias del Sr. Dn. Felipe III, seis millones; y así con los demás Reyes de Castilla. Todo esto salía del vecindario que contribuía según sus facultades por derrama repartida por las Justicias. Compruébase esto mistno por las excesivas dotes que muchos caballeros dieron a sus hijas. El General Pereyra casó a su hija Dña. Plácida Eustaquia, año de 1579 , dándole de dote dos millones y trescientos mil pesos; el General Mejía dotó a la suya en un millón, año de 1612; Dña. Catalina Argandoña llevó oehocientos mil pesos, fuera de unas haciendas de viñas, cuando casó con Dn. Luis de Esquivel. Dña. Ursula Obando otra igual cantidad, año de 1629; y por último, hasta el año 1647, se cuentan más de ocho dotes que el menor pasaba de doscientos mil pesos; al contrario se experimenta ahora, que no se encuentra una dote de cincuenta mil pesos saneados.

No es menor prueba de la antigna magnificencia, los excesivos ser vicios que en dinero y en soldados ha hecho al Rey esta Villa, pues, desde cl año de 1560 hasta 1670 , consta haber dado de donativo en varias ocasiones, dicz millones en plata; y desde 1598 hasta el citado de 1670, se computa haber salido de Potosí más de ocho mil criollos voluntarios, a servir al Rey en diferentes sucesos y lugares del Reino.

Esta su nativa lealtad y amor al Rey, ha calificado hasta el último grado en la sublevación general de los indios, en el año de 1780 Casi no quedó pueblo que no negase la obediencia al trono o no se conmoviese con escándalo a vista de tan universal mal ejemplo, solicitando sacudir, cuando no el vasallaje, al menos el yugo de las principales leyes tributarias del Reino,

Con residir la Real Audiencia en Chuquisaca, allí fue donde más se declaró la insolencia, con muertes, robos, insultos y criminales escándalos, sin contener a los insurgentes la viva imagen de la Soberanía que repre- 
sentaba aquél regio Tribunal, ni los castigos ejemplares que se ejecutaron en muchos de ellos.

Sólo Potosí se libertó de este contagio, manteniéndose siempre fiel al Rey; y correspondiendo la elevación de los ánimos de sus moradores, a la eminencia de su situación, pasaron vergonzosas por sus piés las nubes del tumulto y libertinaje, sin obscurecer jamás la claridad de sus acreditadas lealtades. En cuyo testimonio la honyó ol Rey con el título de "Fidelisima Villa", en oprobio de las otras desleales; $y$ en los venideros siglos será el padrón de la fidelidad y en su nombre sólo tracrá la califieación de sus lealtades.

El tiempo quc cón sus vicisitudes ha tenido poder para consumir los Imperios y Monarớas más florecientes, ha tenido tambićn para empobrecer el mayor tesoro de riqueza que ha conocido el mundo. Todo ha ido a menos en Potosí. Las minas, los caudales, la Mita y la población. De cinco mil bocaminas que tuvo el Cerro en labor corriente, no llegarán en el dia a cien. De millones que los vecinos tenían de sobra para dotax a sus hijas, no hay quien pueda dar ahora cineuenta nil posos. De cinco mil indios que

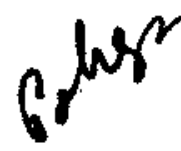
Tenían de Mita, no llegan a tres mil. De mil quinientas casas de españoles, apenas habrá la décima parte; $y$ de ciento cincuenta mil moradores, a lo sumo alcanzará el número de veinticuatro mil quiniontos, que se empadronaron los años de 1778 y 1779, de orden del Sr. Dn. Jorge Escovedo, Gobernador de Potosí, en cumplimiento de Real Orden de 10 de noviembre de 1776 ; aunque en el día pasarán de treinta mil, por el mucho concurso de comerciantes y forasteros.

Es una compasión mirar los aliededores de esta magnífica Villa. Se ve con dolor inmenso el pueblo destruído, y pasando la ribera de los molinos e ingenios hacia la parte del Cerro, no descubre la vista sino paredes yermas, sin techos, cuyas ruinas dan a conocer la extensión primitiva de esta Villa, y que si se poblara sería bastante para fundal un pueblo me. diano.

Lo mismo se observa por cuantas partes se investigue la Villa; siendo la principal prueba de su decadencia el lallarse todavía en lo nás interior de ella, muchas casas techadas de paja; bien que con cl buen gusto que se va introduciendo (aunque insensiblemente), se ve mejorada la fábrica de los edificios, y se irán edificando obras nuevas, que hermosearán la Villa en pocos años.

El pueblo se edificó tumultuariamente por los que vinieron arrastrados de la codicia de la plata, al descubrimiento de su rico Cerro. Todos creyeron que sus riquezas, como las de otuas minas, no fuesen permanentes; por cuyo motivo de nada cuidaron monos que do la población. Cada uno se situó donde quiso, de manera que fucron formando unas calles demasiado angostas y largas, para asegurar el tráfico y abrigarse de los vientos fríos de la sierra.

En este estado la encontró el Sr. Toledo, quinto Virrey del Perú, cuando vino a Potosí el año de 1572. Deseoso de mejorarla, mandó abrir calles y la redujo en la forma de población que hoy conserva. Son empedradas todas sus calles; pero con desigualdad y sin arte. La piedraes de figura de huevo, con las puntas hacia fueva que hace demasiado molestoso el piso, en especial a los forasteros. Tienc sieto pilas de donde se surte el pueblo de agua, siendo las principales en su fábrica, las de la Moneda y San Roque. También las tienen a su costa algunas casas particulares; pero la gente de 
alguna forma no bebe esta agua sino la de San Rocue o San Martín; y los de mejor gusto mandan traev de otios manantiates mís inmediatos a las Lagunas, cuya agua aunque llovediza, como no se corrompe port los fríos, filtrándose por algunos ojos de la tierra, sale riquísima al gusto y es saludable.

Junto a San Martín, ocho cuadras de la Plaza, está la Toma Principal de donde se distribuye el agua a la Villa y sus pilas, por acequias que coI'ren subterineas dentro de unos conductos de barro cocido. Los que trabajaron esta obra se conoce no tuvieron el mejor arte, porque la madre de las acequias apenas profundiza una cuarta o una tercia del piso de la calle, por cuya causa hay continuos derrames de las cañerias, que frecuentemente se romper con cualquicr peso quc cargue sobre ellas.

Convenclía ahondarlas más de una vara, como están las cañerías de Chile, pero lá Villa no tiene propios para esta gran obra, ni el vecindario arbitrios; que a tonerlos, seria mejor formarlas de plomo, que es muy barato y sucle venderse el quintal por 20 reales. Serían mucho más durables y mejor el agua, porgue no recibiría afecto del barro ni se consumiría la mucha que ahora se extravía por las porosidarles y malas junturas de los caños.

Como hay tanto inckio en Ia Villa, que no tiene más habitación que las calles y plazas, son puerquísimos estos lugares; y tanto, que una calle traviesa, muy angosta y lärga, llamada "de lus Siete Vueltas", cuatro cuadras de la Plaza, es intransitable para gentes decentes, por estar siempre innundada de inmundicia. Fs preciso que el Gobierno se mantenga con inexorablo fortaleza para hacer efectivas las providencias de Policía, que sólo asj podrán irse acostumbrando a la limpieza y se hará practicable el aseo al cabo de algunos años. Aun las iglesias, que son de bella fábrica de piedua, están tan sucias, que yo vi en San Juan, en un día de sus festividades, montones de basura dentro del templo, que era preciso huír para no emporcar la medias y 'apatos.

Admira la suma incrible de plata que ha consumido el lujo en fiestas, regalos y otros festejos profanos; y que no se haya empleado siquieFa una vigésima parte en el culto de Dios. Las iglesias más bien aperadas, apenas tienen los más precisos utengTios de plata. Las demás usan las vinajeras de estaño, barro viclriado u hoja de lata, pudiéndolas tener de vidrio muy ascado, que se fabrica en Cochabamba. Se disculpan con los inevitables robos de toda alhaja rica; pero lo cierto es que el desaseo de los templos, así en su piso como en los paños de altares, acusa el poco cuidado que se tiene de estas cosas sagradas.

No digo que sea culpa de los Curas; pero, ello es constante que la Matriz tiene para tos, otros equivalentes, y cada Curato los pongos y sacristanes, que no deben ocuparse en otros cuidados. Lo que se ve en las iglesias, son muchos cuadros viejos, de pinturas antiguas, que cubren las paredes; y sólo en las festividades se adornan muy decentemente con espejos, flores y otros homenajes prestados. Abundan, si, muchas trompetas, flautas, tambores y cohetes; indios bailarines, con plumajes en la cabeza, vestidos a la heroica de los Incas, con espaldones y brazaletes de plata, de modo que cada indio llevará más de veinte marcos de metal labrado; muchos arcos por delante, entretejidos de mancerinas, (b) azafates y otras piezas de plata, cuyo valor puede subir, en las funciones de más fuste, a cuatro o cinco mil pesos. 
Como es tan crecida la entrada de burros con motales y abastos, la de carneros de la tierra (llamas) con sal, carbon y leña; la de mulas con cargazones de comercio; fuera de las muchas bestias que mantiene la Vi.

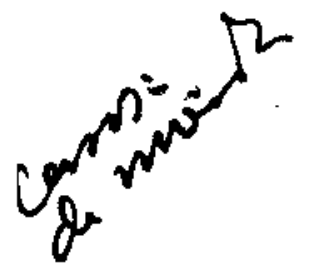
lla, para las panaderías y remonta de regalo, es inmensa la baspra que se recoge; y con la que han ido arrojando a los extremos del pubblo, se han formado unos cerros que casi igualan los edificios más altos de la Villa.

Cuatro cuadras de la Plaza, junto a San Lorenzo, al Norte, hay un basural que casi tapa el mojinete del templo; en San Martín, San Francisco y otras partes, se encuentran otros tantos montones tan crecidos que parecen cerros. Si el temperamento no fuera tan contrario a la corrupción, serían inextinguibles las epidemias cada año; principalmente hallándose colocados los dos hospitales tan en lo interior, que el de Belén sólo dista menos de media cuadra de la Plaza, y el de San Juan de Dios tres.

No puede alcanzarse el motivo de estas fundaciones tan contra toda policía y buen gobierno, pudiendo haberlas fabricado a distancia competente y al rumbo del viento dominante del país, para que arrastrase en todos tiempos los efluvios morbosos de la Villa, por ser el único asilo de los males epidémicos la separación de los primeros contagiados en ermitas o casas distantes de los pueblos y de caminos pasajeros, lo menos un cuarto de legua, según lo califica el modemo cirujano Don Francisco Gil, ${ }^{13}$ con excelentes ejemplos de historia; y por más cuidado que se tenga en ticmpo de peste, nunca podrá el Magistrado evitar el contagio, ya del aire, que ha de ventilar de los aposentos enfermizos sobre todo el pucblo; ya de los médicos, sirvientes, religiosos y criados que viven en el comercio general de la Villa; y yà finalmente de aquellos primeros convalecientes que salicren del hospital con su pobre ropa penetrada de toda la infección pestilencial.

El remedio era trasladar ustas casas al campo; pero es un imposible político, porque no hay fondos con qué hacerlo. De aquí procede que por el hospital pasan, accesorias una a otra, dos cañerías que surten de agua aquella casa y a la de Moneda. Como son de barro cocido los caños, se filtran recíprocamente las aguas, de unos a otros, y es necesario que las aguas puercas con que se han purificado los paños de la enfermería, si no se extravían por algún conducto separado, que no le hay, infecten las demás aguas con que se mezclan causando, cuando no sea enfermedad, un notable asco al vecindario.

Aunque la Villa según la altura del Folo, está dentro del trópico en la zona tórrida, es tan alta y encumbrada su situación, que bañándola todo el año los aires destemplados de las cordilleras nevadas, es demasiade frío y molesto su temperamento, por las continuas lluvias que se experimenta desde noviembre hasta marzo; granizos, hielos, nevadas y furiosos vientos desde mayo hasta septiembre, siendo el menos saludable y más impetuoso el Norte o Tomahavi (que así se llaman en estas regiones los vientos australes), asegurando el P. Calancha ${ }^{14}$ que uma tarde vió en Potosí tan enojado este viento, que levantando techos, se pensó que perecía toda la Villa.

Este autor y el Cronista Mendoza, ${ }^{15}$ con cuantos han escrito o hablado de Potosí, ponderan por tan extremoso el frio de su temperamento, que aseguran no producir fruto algurio, grano ni semilla, flores ni yerbas, si no es alguna cebada en hoja en los abrigos de las quebradas; añadiendo ${ }^{16}$ que en cincuenta años desde la población de Potosí, no logró la vida nin- 
gún niño nacido de padres españoles, porque el demasiado frío y los aires helados los mataban, o al nacer o antes de los quince días de nacidos; por lo que se salían las madres a parir en los valles convecinos, y no volvían a la Villa hasta que cumpliese un año el niño.

Con esto comprueba Calancha por milagro de San Nicolás Tolentino, el que, habiendo nacido en Potosí, año de 1098, Dn. Nicolás Flores, hijo de Dn. Francisco Flores, hubicse logrado la vida en premio de la confianza santa de sus devotos padres, ascgurando haber sido el primer criollo español de l'otosí.

No debo oponcme a la devoción de este religioso, ni a la poderosa protección del Santo a favor de cuantos de velas le invocan; pero, sí, me insta la reflexión de que, si en Potosí ningún niño español pudo vivir, hasta que lo consiguiú Nicolás Flores por milagro; cs preciso decir que: o se ha mudado ol clina y el antiguo exagerado rigor de sus fríos, o que se están ejceutando repetidos milagros gratuitos en cuantos partos felicísimos se ven todos los años, de señoras españolas que paren en Potosí y logran sus hijos vivos sin invocar al Santo y aun sin saber de este suceso.

Ningún sensato puede admitir mudanza del clima, a menos que demuestre que Potosí no mantiene su primitiva situación. Menos purde confesar estos multiplicados milagros, porque la Iglesia ha puesto freno a la facilidad supersticiosa de vanas creencias, estableciendo reglas para que sin su canónica declaración, no se crea como milagros los efectos naturales.

Pasemos pues a buscar el verdadero principio de aquellas desgracias, dejando a San Nicolás el honor que le es debido en la protección del primer criollo potosino. Un pueblo formado tumultuariamente a impulsos de la codicia y con poca esperanza de su duración, por cl temor muy probable de la pérdida de sus riquezas; por unos vecinos que corrían tras de la plata, sin traer de sus domiciios más comodidad que la confianza de encontrarla en estos mincrales; es forzoso que sus edificios fuesen los menos costosos, sin abrigos de vidrieras, retretes ni gabinetes, y sin aquellos precisos reparos que inventa el hombre ya sosegado en la posesión de stis haberes para disfrutarlos con gusto.

Am ahora se ven pocas casas con estas circunstancias y no son muchas las que tienen vidricras, contentándose las más con bastidores de lienzos, papel o encerado en las ventanas, y antes, los más ricos tenían por gala una claraloya con piedras transparentes de berenguela.

De aquí se infiere que el frío obraría con toda su actividad en aquellos tiernos euerpecillos recién nacidos; y el destemple de los hielos, aguas y vientos, necesariamente había de causar su ruina, principalmente sofocando los aposentos y viviendas los malignos efluvios del carbón encendido de los braseros, de que usaban para el abrigo. Cualquier médico dirá que si ahora, en Potosí, y lo mismo digo de Arequipa o del mejor país del mundo, se practicara un método tan opuesto a la salud, morirían como antes todos los recién nacidos, cuando aun de los adultos han perecido muchísimos en Potosí, de que yo soy testigo, por la poca cautela en el uso de los braseros. Con que debemos concluír que el principio de la vida de los muchachos pendió de las comodidades en la habitación y preservativos que comenzaron a usar estos vecinos con la experiencia de lo útil y danoso en este temperamento.

Este discurso se funda en la razón física, que no puede este frío embarazar la vida de los recién nacidos, cuando no impide la vegetación 


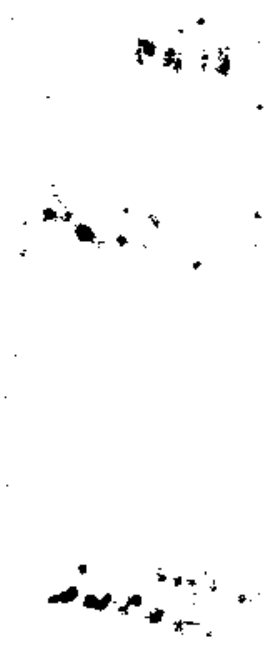

de las plantas, flores, arbustos, hortalizas y yerbas que ahora vemos criar, granar y vegetar en los jardines de Ios patios de muchas casas curiosas de la Villa: pues, no es menos robusto el mecanismo vegetal de un niño que de una flor.

Ya se ve que para esto tienen el cuidado de cubrir las plantas en la noche para preservarlas del hielo; y el no haberse visto igual prodigio en los primeros siglos de Potosí, consistía en que sus habitadores sólo acudían al cultivo de las minas y querian, no como ahora flores, sino piñas de plata en sus casas.

En cualquiera parte de la Villa y en sus alrededores se cria cebada y otras yerbas, que están falsificando la vulgar opinixin del frio intolerable. Es verdad que nunca hace calor para vestilse de tafetán; pero, como el sol es tan fuerte por la situación natural del Polo, se sucla, aunque con algún trabajo, como sucede en mí y en otros muchos que veo correrles el sudor por la cara en haciendo un ejercicio algo extadordinazio; y lo único cierto es que lo que más incomodat es no conocerse aquí sino una sola estación en todo el año, y nuestrá naturaleza solamente gusta de la variedad.

Algunos creen, y es opinión vulgar en la Villa, que ahora es me-

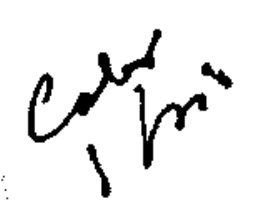
nos el frío por la copiosa exhalación del immenso fuego que encienden las chicheras y panaderos, para el beneficio de aquella bebida $y$ del pan. Todos se engañan: porque antiguamente, cuando la población se componía de 150.000 almas, era mucho mayor el movimicnto de chicherías $y$ banaderías, agregándose más de 6.000 guaijas, esto es, hornillos corrientes en el Cerro para fundir Ios metales, como anotan Acosta y Garcilaso, ${ }^{17} \mathrm{y}$ entonces naturalmente estas evaporaciones de fuego y humo habían de templar el frío y crudeza de los aires de la atnósfera con que se mezclaban; y por el mismo argumento físico, debió ser menor el trío, pues ayudaban no poco dos tantos o tres más de los efluvios que perdían los muchísimos trabajadores y pobladores que tenía esta opulenta Villa.

Su jurisdicción comprende siete pueblecitos, nombrados: Tarapaya, Santa Lucia, Chulchucani, Manquiri, Guariguari, Salinas y Urmiri, con la extensión que le concedió el Sr. Don Francisco de Toledo, hallándose en Potosi este gran Virrey.

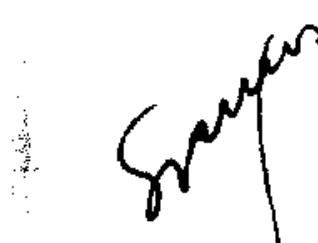

Dentro de la misma Villa residen los gremios siguientes: Ponaderos, Pulperos, Pintores, Barberos, Teiedores, Carpinteros, Matanceros, Cancheros, Trapicheros, Silleros, Guitareros, Cereros, Thadores, Plateros, Sastres, Zapateros, Ollewos, Albañiles, Chicheros, Coheteros, Herreros, Ojoteros y Sombrereros. Estos oficios no tienen la menor formalidad, porque no se examinan, no hay Matestro Mayor, no tienen Ordenanzas ni la Justicia interviene para cosa alguna en sus exámenes, aprobación de su pericia y demás circunstancias con que se manejan cstos cuerpos de industria en otras partes.

Por csto, rarisimo oficial se encuentra que entienda su arte, y lo que todos saben es mentir, $y$ entrampar cuantas obras se les encomiendan, viéndose casi todos los años maestros plateros quebrados en crecidas cantidades del oro y plata que han disipado en borrachewas y otros vicios, a que son naturaimente inclinados; de suerte que rarísimo artesano es el que se ve andar vestido decentemente, porque la mayor parte de los demás andan cargados de andrajos y parecen más mendigos que oficiales: a causa del inevitable desorden de consumir en borrachera el domingo y lanes, 
cuanto han ganado entre semana, por cuya razón llaman aquí por chiste: "San Lunes") Pero en medio de esta miseria se hallan los gremios sobremanera gravados con fiestas del Corpus, toros, faenas y otras contribuciones forzosas, que sirven no poco para empeorar su infeliz fortuna.

Nace de esta unirersal disipación y poco interés aun de su propio sudor, el increíble consumo que tiene la Villa de aguardiente, chicha, vino, dulces y todo cuanto insinúa el gusto y lisonjea el regalo. He visto un cómpulo seguro que en años pasados se gastaron en sólo uno, treinta mil botijas de agnardiente; sé pos otro comerciante, que solamente de su tienda compran dos mujei'es confiteras, el importe de 14 a 15.000 pesos de azúcar al año, para dulces de confitería, que se consumen todos, con dos tantos más que venden otras de este oficio, en conservas de miel para indios y demás gente ordinaria. De manera que sin exror se puede calcular el consumo anual de más de un millón en estas cspecies, entrando también el trigo y harina de maíz.

Como nadie ignora el regalo de este país, concurren todos a su plaza, de los parajes más remotos, con cuanta fruta, hortalizas y carne producen estos territorios, pasando con ellos por medio de la plaza de Chuquisaca, sin querer venderlos alli, por el ventajoso precio en que aquí lo ejecutan, y porque saben que un dorado (pez) vale de diez hasta veinticinco pesos, según los tiempos, y que eñ años pasados costó un pescado de esta clase cinco mil pesos, precio inciéble, por cierto, a que lo hizo subir la imprudente competencia de los mayordomos de dos casas ricas'de esta Villa, llegando a tal exireno la vanidad, que la que perdió el regalo de este rico bocado, despidió al Mayordomo en pena de su cobardía, debiendo premiar su moderación.

La aprehonsión de semejantes locuras ha hecho de este país el más abundante $y$ provisto de toda la sierra. Todo se encientran aundue caro, y con ser Chuquisaca la corte de este distrito, vienen de allí regularmente a buscar los vinos, accites y pescado seco, para los principales vecinos. Los indios son los que surten de abastos; pero, como se hospedan en las Canchas, que son unas casas distantes cuatro cuadras de la Plaza, les compran los cancheros sus efectos por poco menos que nada, y ellos después ganan un $25 \%$ en el regateo; siendo lo más gravoso a los infelices indios, que salen los enviados de las canchas por los cantos (extramuros) y allí les quitan los abastos al precio que quieren, y esto llaman aquí "arcar"; (c) abuso que no ha podido extinguir el Gobierno, por mucho cuidado que haya dedicado a este objeto.

La abundancia consiste principalmente en la mucha plata que corre de los rescates semanales, que suben a 35.000 y más pesos en el Reaì Banco, de sólo el cerro de Potosí. Aunque los azogueros pereiben estas sumas, sc distribuyen casi todas en jornales y avíos, que forzosamente circulan en todas las tiendas y canchas del pueblo; y por eso se ve de las entradas del año de 1785, que la Alcabala de efectos de Cessilla internados a la Villa, subió a 130.000 pesos.

Ei Patrón titular de esta Villa es ell Santo Santiago, y de su rico Cerro, San Agustín. A este gran Padrc lo puso Ta Vifta principio de su fundación, por haber salido en suerte tres veces repetidas, en ocasión de solicitar sodorros del cielo, por aguas de que se carecía en todo un año, con innumerables muertes de hombres y ganados; y en correspondencia

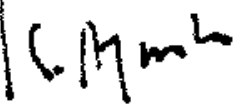


del notorio y pronto favor del Santo quedó votado Patrón, y lo pintan como tal junto al Cerro y la Villa. ${ }^{8}$

\section{NOTI I A S E G U N D A} Del aspecto y naturaleza
del terreno de Potosí.
L za la vista todos lomas cemos hondomados chestas y quebradas, y aunque no se perciben bien mirando el país horizontaimente, se reconoce la notable degradación del terreno, estando cerca o paseándolo.

Por todas partes descubre la vista un cordónde.cerros altísimos. Al Este, los que con sus quebradas forman el depósito de las Lagunas, que surten de agua la Ribera de los ingenios de moler metales y las pilas de la Villa. Al Poniente, otros que formando una cadena de sexranisas, se extienden hasta las costas de la mar. Al Norte, los que se trasmontan para ir a Chuquisaca, por un camino que llaman de "Laderillas", a causa ke llevar su giro angosto y escabroso por la falda de la montena, a distancia

- de una legua, hasta llegar a una pampita $\Omega$ escampado llamado "el Tambi llo". Al Sur está situdo- fameso_cerco de Potosí, sirviendo como de co-

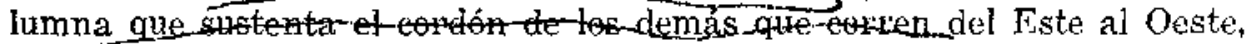
mediando una espaciosa quebrada entre él y los cerros de las Lagunas, por donde viene el camino de Buenos Aires, arrimado a su falda. Cireen muchos, por lo que han dicho los autores, que es el cerro más alto de estas comarcas; pero se ha falsificado esta opinión con las últimas observaciones que se han practicado en la mensura del Cerro Rico, y cualquiera, sin ser matemático, palpará esta antigua preocupación, viendo que al entrarse el sol, cuando ya todo es sombra en el Cerro Rico, todavía se divisan sus luces en las cumbres de uno u otro cerro oriental hacia la parte de las Lagunas.

La colina intermedia sobre que está situada la Villa, se cxtiende como media legua con algún declive hacia el Poniente, y allí forma a manera de campo algo ondeado el que llaman de "San Clemente". Todo él está cubierto de piedras sueltas, entre giandes y pequeñas. Esta observación convence que son restos de las peñas grandes que hubo por allí antiguamente y se deshicieron con el ticmpo. Con la sucesión de los años, debe creerse que el todo o la mayor parte de esta colina se corroerá, y formarán en ella considerables barrancos, lomas y arroyadas ya la degradación imperceptible de las peñas, ya la resistencia accidental de las tierras, ya la rapidez de los torrentes, ya las aguas de las lluvias recias, que acarrean y arrebatan las tierras, ya las fuentes internas y subterráneas que abundan aquí, han de minar el terreno, y en fin, aun las lluvias oxdinarias y suaves, con el largo tiempo, como dice Dn. Guillermo Fowles 19 Solo el Gobierno puede embarazar esta mutación tan perjudicial y aun hacer fructífero el terreno ahora inútil, por medio de providencias económicas, ordenando que las innumerables tropas de mulas, burros y carneros de la tierra que salen de vacío, trasladen de los basurales de la Villa, tres o cuatro arrobas de tierra a otro campo. Así quedaría el pueblo purgado de esta 
inmunda vecindad y el campo mantendría inalterable su superficie, lográndose además un gran espacio de terreno que podría venderse o repartirse para sementeras de cebada y de otras yerbas útiles al comercio y provisión de la Villa.

Todias las serranias que hacen el recinto de esta comarca, son estériles y peladas, eubiertas de piedras sueltas, de arena y de tierra. No por eso se encuentran minas en todas ellas, pucs, aunque sea opinión de muchos, " que los minerales sólo se hallan en las montañar ostériles, na-

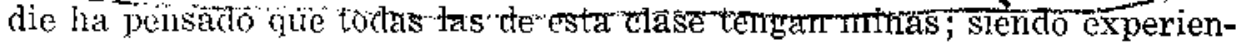
cia constante que hay muchos cerros riquísimos de minexales que se ven cubiertus de plantas. En el Almadén, en el propio cercado donde estân los hornos, nacen más de cuarenta especies de plantas entre los vapores sulfúreos; del mismo modo, están pobladas de encinas, pinos y otros árboles frutales y yerbas las minas de Santa María en Francia, las de Clausthal en Hartz, Hannover; La Dorotea, la Carolina y la de Freiberg en Sajonia, cubiertas de cebada en el mes de Junio, según nos cuenta el naturalista Bowles. 21

Así pues, la causa de la esterilidad de estos cerros, no es otra que la descomposición diaria de las peñas, para suplir la tierra que las aguas y los vientos arrebatan con la mayor facilidad, por ser tan escarpadas las montañas. Por lo mismo, debe esperarse que llegará tiempo en que conl la humedad y rajees podridas de moho o musgo que ella produce, se formarâ una capa de tierra vegetal donde se crie tanta yerba que cubra todo el cerro, como están los demás de que acabamos de hablar, según opina el célebre Bowles, 22 tratando de la montaña de Ramelsberg, que es tan peladia como la de Potosi, y hace más de novecientos años que viven del producto de su mina los habitantes de lá ciuclad Imperial de Gozlar, situada al pié de clla.

Esta esterilidad sin duda debe atribuírse a singular provideneia de Dios; porque así descubiertos a la vista los anizos de los cerros, caracterizó con sus colores el depósito de las riquezas de las minas, para que en medio de la poca inteligencia que hay, en estos países, de la mineralogía o metalurgia, se hallasen los minerales para uso y comodidad de los hombres. Y siendo constante que por acá se guían de las señas exteriores para buscar y beneficiar las minas, como lo practicaban los romanos, seguramente estarían intactas hasta ahora muchas de las más ricas minas que se ha trabajado, si no hubieran visto los colores que tienen de manifiesto sus cerros : así como dejaron de trabajar los romanos, la célebre mina de la Platilla, por estar poblada de prados y yerbas, no vieron los colores fer

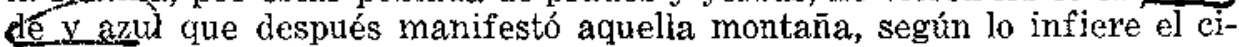
tado Bowles. ${ }^{23}$

NOTICIA T E R C E A

De las aguas minerales del $\begin{aligned} & \text { ThES leguas de la Villa, según el cronista } \\ & \text { territorio de Potosi }\end{aligned}$
ma de un cerrillo con su desaguadero, que tendrá de box y en contorno
maguna de agua caliente de Tarapaya, enci- 
cuatro cuadras, según el primero, y doce según cl otro de los dos historiadores citados. Es muy hondable y sus aguas son termas saludables, que sirven de baños. En medio está el manantial que sale a borbollones, con su desagüe a un lado, por donde se tumplan otros baños de agua más caliente, cuatro cuadras bajo de la Laguna. Calancha le atribuye la propiedad de que tira hacia sí a quien entra dentro, llevando para abajo al que nada en ella, a cuya causa se ahogan muchos. ${ }^{26}$ Esta relación es parecida a la que hace Heródoto, ${ }^{2 \top}$ de una fuente quo había en la Etiopía, do aguas tan ligeras que su superficie no podía sostener cterpo alguno por delgado que él fuese, y que cuantos allí se bariaban cran como untados de aceite y sentian la violencia; y si cl P. Calancha añadiera que todos los cuerpos, aunque sean muy porosos y ligeros, van al fondo como arrastrados de una oculta fuerza del agua, sin sobrenadar cosa alguna en ella, como asegura Diodoro de Sicilia 28 del Sila, aquel río del Asia, que atraviesa la Circacia, se haría tan sospechosa de cyédito la noticia de nuestro eronista, como lo fue la de Diodoro para Demócrito y Aristóteles, según Fstrabón. 2" Yo me persuado que los que alli se han ahogado no sabrían nadar, como sucede en casi todos los de estos paises fríos de la sierra, y en cualquier rio hubieran tenido la misma suerte; y cuando sea cierta la atracción referida, es efecto de los remolinos que forma el borbollón que arroja la Laguna, cuyos turbillones giran su curso de la circunferencia hacia el centro, y de aquí viene, arrastrar para abajo al gue entra dentro con ayuda de Ia fuerza centrífuga del agua.

La cualidad cierta que tienen aquellas aguas, es la de ser minerales, calientes y saludables. Aquí hay que examinar dos puntos muy esenciales e importantes. El primero, en qué consista la virtud curativa de aquellas aguas, no dependiendo de las materias, que descubren las análisis químicas que se han hecho en otros minerales de igual naturaleza. ${ }^{30}$ El otro es, cual sea la causa de la igualdad, constancia y permanencia del calor de las aguas termales, por tantos siglos. Ello no puede ser el fuego subterráneo ni el calor que podrán comunicar los volcanes a las aguas, porque no se sabe el lugar de este fuego ni cómo se alimente tan metódicamente que nunca sean más ni menos el fuego, ni el calor. 'Tampoco puede explicarse el por qué, observándose en los voleanes tanta diferencia en los tiempos de erupción, por la copia de materias inflamadas que arrojan entonces, nunca se conoce mutación en las aguas minelates, que siempre y en todos tiempos, por siglos y siglos, mantienen el mismo i«lóntico grado cle calor. Con estas sabias reflexiones impugna el citaro A\%ara, en el lugar ya referido, la opinión que asigna el fuego subter'ánco por causa del calor de las aguas, pero, sin abrir su dictamen, reserva ambos reparos a la reflexión de los sabios. Fl Iltmo. Feijoó, en su "Teatro Crítico", 31 atribuye a varios hálitos nitrosos, sulfúreos, vitriólicos y otros con que corren mezcladas las aguas de semejantes manantiales. M. Baumé, gran químico parisiense, afirma que las piritas (que son un género de minerales metálicos, compuestos de substancias o sulfúreas o salinas), descomponiéndose en lo interior de la tierra, dan las materias salinas de que el agua se carga al pasar por ellas, y que estas son las causas primeras de todas las aguas minerales. Otro físico que toque de propósito estos reparos, puede examinar las varias complicaciones quc causan efectos tan admirables, que para mi instituto basta promover la aplicación de los naturalistas. 
1.- Mendoza: Crónica de San Francisco; Lib. 19, Cap. 4\%, fol. 29.- Calancha: Lib. $3^{\circ}$, Cap. 40 , Nos. 4 y 5 , fols. 747 y 748 : tomo $1^{4}$.

2.- Murillo: Geografía ; Lib. 9*, Cap. 17, tomo 9 , fol. 288.

3.- Ulloa: Resumen histórico de los Incas: tomo $2^{*}$, fol. $68, \mathrm{~N}^{*} 110$, y tomo $3^{\circ}$, Lib. $1 \%$, Cap. 13, N" 340 , fol. 196.

4.-Calancha: Lib. 3" ${ }_{4}$ Cap. $40, N^{v} 3$, lol. 746, tono 1."- Murillo: Geografia; Lib. 9", Cap. 17.

5.- Ulloa: Joco citato.

6.-- Calancha: Lib. 3", Cap. 40, N"3, fol. 746, tomo 1".- Murillo: Geografía; Lib. 9 , Cap. 17.

7.- P. Mendoza: Lib. 1", Cap. 4", fol. 31.

8.- Murillo: I,ib. $9^{\circ}$, Cap. 17, toino $9^{\circ}$, fol. 288.

(a) El Diccionatio de Lorenzo Echard, traducido del inglés al francés por M. Wosgien y correrido por 13 . Antonio Montpalau, tomo $1^{\prime \prime}$, letra A, pone a Atacama en $22^{\circ} 30^{\prime}$ de latitud meridional, fol. 101. En el tomo $3 \%$, letra P. fol. 63, pone a I'otosí en 20" 40'. Juan de Irat, en la descripción de las Indias Occidentales, siguiendo al $\mathrm{F}$. Acosta, con la expresión de ser autor exacto, dice en el Lib. $2^{\circ}$, Cap. $\left.8^{\circ}, f^{\circ} 0\right], 463$, que T'otosi tiene de latitud $21^{\circ} 40^{\prime}$.

9.-P. Mendoza: Lib. "3", Cab. 40, 101. 567.

10.-Calancha: Lib. 3", Cap. 4", N"3.

11.- Mendoza: Lib. 1", Cap. 6\%, fol. 31 .

12. - Ley 7, Tít. 15, Parte Primera, Acevedo y otros que cita Bolaños. Philípyca, $1^{*}$ parte, $\$ 2, N^{*} 32$, fol. 14.- Fermosino: tratado $1^{\circ}$, de Cap. Sede vacante $9,8$. $\mathrm{N}^{\prime} 10$, tomo 9, pág. 84. - Scarfantoni: Lib. 4, Lucubr. Tít. 6, a $\mathrm{N}^{\circ} 22$, fol. 117.

(b) Mancerinas: platos medianos con abrazadera circular en el centro, para sujetar la jicara en que se sirve el chocolate. Tomó nombre del Marqués de Mancera, Virrey del Perú, desde 1639 a 1648 . (N. de E.).

13.- Gil: 'Tratado de la preservación de viruclas; $\mathrm{N}^{4} 64$, fol. 50.

14.-Calancha: Lib. $3^{\circ}$, Cup. 40, fol. $743, \mathrm{~N}^{\circ} 1$, tomo $1{ }^{\circ}$.

15.- Calancha: loco citato.- Mendoza: Crónica de Sian Francisco de Charcas, Lib. 1\%, Cap. $4^{\circ}$, tomo $1^{\circ}$, fol. 31 , Col. 2.

16.- Calancha: Lib. $3 \%$, Cap. 41, fol. 750.

17,- Acosta: Historia de Tndias; Lib. $4^{\circ}$, Catp. $9^{\circ},-$ Garcilaso: l'rimera parte Lib. $8^{\circ}$, Cap. 25, Comentarios Reales.

(c) "Jarkear", es la verdadera palabra quichua, que significa: detener, atajar. (N. de E.).

18. - Calancha: Jib. $3^{*}$, Cap. $40, N^{*} 5$, fol. 747 .

19.- Bowles: Historia Natural de Tspaña; fol. 545.

20.- Bowles: Historiu Natural de España; pág. 143.

21.-- Bowles: Historia Natural, citida; págs. 142 hasta 145.

22.- Bowles: Historia Natural ; fol. 145.

23.-- Bowles: Historia Naiural ; pág. 141.

24.- Mendoza: Crónica de San Francisco de Charcas; Lib. $1^{\circ}$, Cap. $4^{\circ}$, fol. 31.

25.-Calancha: Crónica de Sun Agustín; Lib. $3^{\circ}$, Cap. 40, $\mathrm{N}^{\circ} 1$, fol. 743.

26. - Calancha: loco citato.

27.- Heródoto: thal.

28.- Diodoro de Sicilia: Lib. $2^{\circ}$.

29.-. Demócrito y Aristóteles. apud, Strabón: Lib. 15.

30.- Bowles: Fistoria Natural de Fispaña, fol. 559 , y su adicionador D. José Nicolás de Azara, en la Nota $N^{\circ} 1$.

31.- Feijoó: Teatro Crítico, tomo $2^{\circ}$, Discurso $1^{\circ}$, Nos. 12, 13 y 14, fol. 264. 
, 


\title{
CAPITULO SEGUNDO \\ Del Rico Mineral de Potosí
}

\author{
De su descubrimiento y riquezas.- De las minas del Cerro Rico $y$ de \\ otras de sus contornos.
}

\author{
NOT I C I A PRI M R A
}

$\begin{gathered}\text { Descubrimiento y riạuezas del } \\ \text { Cerro de Potosi, }\end{gathered}$
mable ni más célebre por sus riquezas, que
elde-Potosí. Así, pues, merece que tratemos de él con la mayor prolijidad. Está situado este promontorio de nlata al I Sur de la Villa, en el cantón mís eminente de las tierras de estas comarcas. Fs el primer corlo gue se mira a la falda del camino de Buenos Aires, al Poniente; porque mediando entre ól y los que al Este forman las Lägunas una quebrada por donde viene el camino real, es como la pirámide en que se sostiene el cordón de las serranías que corren al Oeste. Está como dominando a los demás, así por ser el único, que con alguna separación descubre su clevada cumbre y la mitad de su cuerpo, como por servirle de cimiekto una alta colina que siendo el mismo piso de la Villa, lo suspende sobre las otras montaña a los ojos que To miran. Esta caúsa falaz de la vista ha hecho decir a muchos ' $y$ vulgarmente a todos, que señorea a los demás cerros como gigante en la altura, aumentándole la ponderación todo lo que ahora engaña como cierto a quien no lo observa con inteligencia.

El cronista Mendoza ${ }^{2}$ le da al Cerro cuatro leguas en redondo, y de la raíz a la cumbre una legua castellana. El P. Calancha, ${ }^{3}$ exagerando su altura y la extensión de sus faldas, dice que éstas rodean más de una legua, y la cumbre media, pequeña, aunque para subirlc ha de andarse más de una legua. El Geógrafo Murillo, ${ }^{4}$ conformándose más con este último, 
asegura que bojea una legua y que desde la cumbre al suclo tendrá un cuarto de legua en derechur'a.

Estos dos últimos se acercan más a la verdad, porque habiéndose mensurado el Cerro por tu Geónetra, gobernalido esta Villa su actual Intendente Don Francisco de Paula Sanz y Soler, (a) se hallo que de la cima a lo más humilde de su falda, tenía el Cer'o 629 varas de perpendicular, que componen medio cuarto cscaso de legua, (b) bien que la subida, por los rodeos de laderas y labor'es, tendrá una legua escasa. Entonces so observó con el nivel y demás instrumentos dol arte, que hacia la parte del Este, había otro cerio más alto y que cualquier curioso lo advertirá notando, al entrar el sol, que todavía se ve luz en aquellas cumbles, cuanuo ya es toda sombra nuestro Cerro.

Su figura es como de un pall de azuicar que lo distingue a la prir mera vista, de todos los demás. Tis raso, seco, pelado y sctéril, frío, destemplado y ávide. 5 Anque ahora no produce fruta ni yerba, como dice Murillo, no fue así en los principios de su descubrimicnto, porque consta ${ }^{7}$ que todo él estaba cubierto de una paja larga, que llaman "hicho" los indios, (c) que Ios españoles consumieron despues en la fiudición de los metales, con el uso de más de 6.000 guairas fabricadas en cl Cerio para este efecto; y como es tan continno y general el trajín del Cerro con burros y carneros, y casi todo esté compuesto de catas, desmontes y arroyadas pequeñas, se ha impedido la nueva vegetacion de estas yertós; pero el tiempo hará, como en otros minerales, que vuelva a vestirse de sus antiguos prados. Con todo, se ve en cl día, en los sitios poco cursados, manchones de pasto, que aquí llaman "cebaglilla", indicando la antigua fertilidad de aquella tierra.

El Señor Virrey Marqués de Montesclaros, haciendo descripción del Cerro, en un capítulo de la Instrucción que dejó a su sucesor, refie. re ${ }^{8}$ sobre las cualidades que dejamos expuestas, que remata ariba en punta y en ella hay una plaza llana de buen tamaño, casi en forma circular. Arrmado y atyo inconporäo por ta banda det Norte, tiene otro cerro más pequeño respecto del primero y tan semejante a él, que decían los indios era su hijo, y asi le llaman hoy: "Guayna Potosi", whe en sul lengua dice: "Potosí el Mozo". Ambos cer'os tienen el color entre brimgjosy

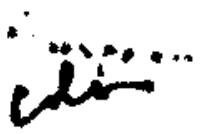

- pando o rojo oscuyo según Calancha y Murillo, o como dice Barba 10 son rubios de color de trigo, como son los más de los minerales o cerros de plata de estas provincias. La tierra, por lo general, es guijarreña peñascosa, arenisca y compuesta en parte de lajas amoladeras.1J

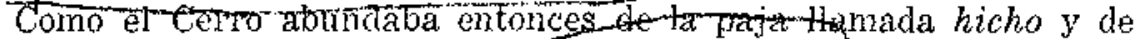
atros matorrales 12 que cubrían el cotor do sus panizos única señal por donde se guiaban los indios para el trăbajo de los minerares, a la manera de los romanos, nunca llegaron a conocer este manantial de riquezas, sin embargo de las experiencias que tenian de minas en esta Provincia, con el trabajo de las del asiento de Pqrco, que ya labraban los indios, cuando los españoles ganaron la Provincial de los Charcas, el año de 1538, como lo anotan Garcilaso y Acosta; ${ }^{13}$ y así se mantuvo oculto este tesoro, hasta el año 1545, en que se hizo su descubrimiento por una casualidad.

El Cronista Antonionde Herrera, ${ }^{14}$ refiere que este portentoso haIlazgo se hizo por un indio llamado Gualca denación Cliumbibilca, provincia cercana al Cuzcor que corxiendo tras de unos carneros de la tierra que guardaba a un soldado llamado Villanroel, del asiento de Porco; con Ia

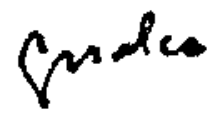


ocasión que habiéndose arrancado una mata de paja en que se asió por no caer al subir al ceryo en st ateance, se manifestó la veta rica, que conoclo ê îndio por la noticia que tenía de minas. Calancha ${ }^{15}$ afirma como más conforme a la tradición de los antiguos, que el descubrimiento de la veta sucedió que pasando este indio la noche en el Cerro, con los carneros amaryados en las matas de paja, las arrancaron al tiempo de cargarlos, desmoronando los cóspedes y ticrua, donde divisó los metales. Men-l dora 15 cuenta el caso que, cogiéndole la noche a Gualea en lo alto del Cerro, hizo fuego con las pajas y a poca llama comenzo a derretirse la plata.

Io que hay de cierto es que, notank otro indio, su compañero, natulal de Jauja, Jlamado Huanca, la repentina riqueza de Gualca, y negándole éste a artel"d modo "de beneficiar los metales, que, a fuerza de porfía, le confesó levaba de este Cerro, se clesavinieron ambos y fue la causa de manifestar of secreto a su amo Villarroel, el cual, certificado de la riqueza, registró la veta on 21 de abril de 1545 , conservando hasta ahora el título de "Descubridora" Tr y por otiro nombre el de "Centeno"; 18 a que se sjguio dentro de pocos días di hallazgo de otras vetas no menos ricas, nombradas: la del Estañto, la Fita y la de Mendieta, que son las cuatro vetas principales de nuestro famoso Cer'o, fuera de innumerable multitud de otras menores que tuvo y tiene hasta ahora, ${ }^{19}$ contándose, no sin admiración, que sólo en este famoso Cerro hay más de cincumithocaminas abiertas, de cuyas labores se ha extraido, hasta el año de 1783, la increíble suma de 820.513 .893 pesus 6 reales, fucrtes de a ocho, según las partidas de los I ibros Reales a que se refiere una razón certificada que remitió al Rey, el actual Tesorero de estas Cajas, Dn. Lamberto de Sierra, en 16 de jumio de 1784, en que se refiere que los Reales Deyechos del quinto y dieamo cobrados en sus respectivos tiempos, suben a 151.722 .647 pesos $1 \% \mathrm{~m} / 4$ rextes, a los cuales corresponden los 820.000 .000 referidos, por la gruesa del caudal sacado y fundido en barras en esta Real Callana; esto es sin incluirse lo presentado al quinto en los once años primeros desde 1545, en que fue descubierto ol mineral, hasta 1556; porque de los Libros Reules solo consta desde este tiempo la satisfacción de este Real Derecho; aunque haciendo cómputo del caudal que afirma Calancha, 20 (tal vez yor noticias extrajudiciales), haberse quintado desde el deseubrimiento hasta el año de 1574, deben agregarse $25 \mathrm{mi}$. llones más a la gruesa de los 820.000 .000 referidos.

Con el irrefragable comprobante de estos testimonios se hace creible lo que asegura Murillo, ${ }^{21}$ citando a Herrera y al P. Claudio Clemente, que cada día se sacaba 30.000 pesos, sölo de lo que se marcaba y quintaba, que no llegando ni aun a la tercera parte de los frutos del mineral, tocaba al Rey millón y ruedio de ruintos al año.

Todos aseguran ${ }^{22}$ que no siendo mayor era igual a lo quintado, la cantidad que dejaba de quintarse, ya por desperdicio de los indios, ya por la ocultación, gasto y consumo de los mineros y contratantes en piñas, planchas, plata labrada y en otros varios menesteres; cuyas sumas, si llegald a cateylarse, montan sin la menor duda, otro tanto o algo más que los 845.000 .000 que ha producido este portentoso Cerro. Con razón, pues, exclama Escalona: " $\mathrm{j}$ "Oh, Dios! ¿ đónde estaban escondidos tantos millones y estas increíbles montañas de plata?". 
De otras minas de sus contornos, y permanencia de las del Cerro.
D EL mismo Cerro repartió la naturaleza, como ramas de sus increibles riquezas, otras minas en todo el contorno de la primitiva jurisdicción de la Villa. I as de $A$ ndacaba, asegura Barba; ${ }^{24}$ que afianza en su abundancia por muchos siglos, metales de plata, y que sólo en su saca pueden ocupar'se todos Ios indios de Mita de este Reino. Y aunque en el día se halla desierto este mineral, en el concepto de disfrutado, puede creerse efecto más bien de ignorancia en buscar sus vetas perdidas, que de escasez de plata; y tal vez el tiempo abri rá nuevos caminos para su hallazgo. También las hay en Tabacoñuño, (d) Guariguari, Karikarj, Piquisa, La Veracruz, Siporo, fuera de otras mu chas más que, por poco estimables, no las menciona nitestro Barba; ${ }^{25}$ pero no debemos omitir la de Chaquí, cuatro leguas de Potosí, que el mismo Barba (B) celebra como una de las más famosas en toda esta tierra, pox la relación de sus incomparables riquezas, aunque se ignora dónde esté, sin embargo que su busca ha costado muchas vidas de indios que se han muerto con sus propias manos por no descubriria.

En esto se ve haber andado tan pródiga la mano de Dios, en la plantación de estos inmensos tesoros pará magnificencia de nuestros Católicos Reyes, que sólo Potosí y sus contornos, y mucho más incluyendo los Partidos que se han agregado, puede competir con las riquezas del reino más opulento del mundo, $y$ puede asegurarse sin arrojo que a todos ellos juntos excede el nuevo Imperio de ambas Américas, auncue no se crea los cnearecimientos que cor Simón Mayolo hace el Sr. Solórzano, 26 de pescarse en los ríos, con redes como pescados, el oro; pues, está visto, según lo demuestra Dn. José Llano y Zapata en sus Memorias Históricas, ${ }^{27}$ que Mayolo copió cstas noticias de Pedro Mexía, éste del Bachiller Enciso, y que habiéndolos autorizado el cronista Herrera, incurrió en la misma credulidad nuestro sabio Solólzano.

Así pues, por más que no juzguemos exclusivo el privilegio de la abundancia del oro y plata en los ríos de Africa, del Brasil, de Chile, de México y del Perú, atendiendo a las muchas riquezas que pondera Plinio ${ }^{2:}$ en su Historia Natural de las preciosas arenas del rio Tajo en España, y a lo que exageran las opulentas minas de nuestra península, Diodoro Sículo, ${ }^{29}$ Strabón, M. Haustín de Villars ${ }^{30} \mathrm{y}$, por lo respectivo a Francia, el P. Daniel y el Barón de Beau Solleil, :1 con todo, comparando los frutos de nuestros minerales, son incomparablemente excesivos.

Es verdad que Don Francisco Xavier de Garma y Salcedo, 32 prueba con bastantes testimonios de historiadores antiguos, la prodigiosa fecundidad de España en oro y plata, y las inmensas sumas que de estos metales sacaron de ella los griegos, cartagineses y romanos, llegando a tanto el exceso, que se fabricaban de plata los pescbres, y que hubo cerca de Cartagena un pozo llamado. Rebelo que tributaba cada día a Nival, hasta tres mit ducados de las moneda de nuestros tiempos, y se dice hay 
escritor espuñol que afirma se beneficiaron en España más de quinientas minas, que cl ocio de los naturales y el decurso de los tiempos ha dejado perdor, como concluye el diario de los literatos de España. ${ }^{33}$

Strabon asegura que on su tiempo tenían los romanos más de cuarenta mil hombres ocupados en las minas de las inmediaciones de Cartagena, que fructificaban diariamente al pueblo romano, veinticinco mil dracmas libres, que ascionden a cinchenta mil reales de vellón, que son 2.500 pesos fuertes.

Don Guillermo Bowles, 3 citando el testimonio de Alonso Carranza, afirma gue una scmana con otra se sacaban de el Guadalcanal (que ha sido el mâs famoso mineral de España), sesenta mil ducados; y concluye con la listoria de la Casa de Frasti, como por gran ponderación, que esta mina babía producidn 8.000 .000 de pesetas, cuya suma se emplé, con otras, en la fábrica del Fscorial.

Tolo esto junto cor la observación de Diodoro Sículo, ${ }^{36}$ sobre que Ir plata que se llevaba en barras a Judea, bajo el reinado de Salomón, y que se supone tan común allí como las piedras, era también sacada de España, "ir nada compone en comparación de los tesoros de América, y aun tal vez de sólo F'otosí.

Hemos visto que eru sílo su Cerro Rico se ven abiertas más de cinco mil ninas, fuera de las muchas de sus contornos; de cllas se sacaban diariamente 30.000 pesos, que se supone la tercera parte de sus frutos, por lo mucho que so ocultaba sin quintar; y ajustado el cálculo de las gruesas de plata cxtraida le sus entrañas, sube al increíble monto de 1.690.000.000. Agréguesc ahora que sólo de una mina de México, lamada Lr: Foludorte de que hace mención Bowles, 38 consta por la relación del Cura icl lugay rue allí se fundó, baber recibido 50.000 pesos que habia prolucido la mina para el Santo de su iglesia, el día que trabajó por su cuenta. Fste mismo autor asegura que cl metal más rico daba cincuen. ta $y$ dos libras de plata por quintal; el mediano, veinticinco, y el más pobre de las tasas, ocho. Acosta y Garcilaso ${ }^{39}$ afirman que en aqueilos tiempos fuc tan rico el metal de Potosí, que de un quintal se sacaba medio guintal de plata; de suctte que si en la Judea andaba tan conún como las piedras la plata llevada de España, en Potosí, las mismas piedras eran plata, pudiendo afimarso desde luego, que las viqueras de América no tiencn cotejo con todas las minas del mundo, y sólo Potosí, equivale a un reino entero, sicndo el bienaventurado de los Reyes nuestro Católico Monarca, en haberlo dotado Dios con los países más ricos y preciosos del Universo, en la opulencia de Ias infinitas minas que tienen estos Dominios, según la rolación de D. Alonso Barba ${ }^{40} \mathrm{y}$ de Don Antonio de Ulloa en su viaje a la América Meridional.

Lo más aclmirable en las minas de Potosí es Ja permanencia de sus riguezas Acosta ${ }^{4} 1$ nota que en muchos años fueron tan preciosos los metales, que de un quintal se sacaba, de ordinario, 40 y 50 pesos ensayados, por fundicion. Desde el año de 1545 en que se descubrió el Cerro, hasta 1566, que son 21 años, duró esta inaudita opulencia, hasta que se perdió en este mismo tiempo ol metal rico que llanan tacana en Potosí, euya naturalcza, propiedades y diferencias explica nuestro Barba, concluyendo, ${ }^{12}$ para mayor conocimiento y aprecio de su especie, que "la tacana es plata debajo de color negro abasado sin resplandor ninguno".

En todos aquellos felices tiempos se desechaban por desmontes 
los demás metales que rendían 4 ó 6 pesos ensayados, por quintal porque no se podian beneficiar con fuego, como reliere Acosta; ${ }^{3}$ pero, puesto en uso en Potosí, el ventajoso beneficio por azogue, siguieron los mineros trabajondo con provecho todos los desmontes quc antes habían despreciado, porque siempre eran de más de 406 pesos ensayados, por quintal, sin otro costo que su acarreo a los ingenios y el salario do beneficiaclores, según el citado Acosta."

En once años, desde el de 1571 hista de 1582 , se consumicron todos los desmontes antiguos, y siendo pieciso contiruar el trabajo de las minas en labores formales, con excesivos costos y pérdidas, ya por el azogue consumido, asi como polque estando ya rotis las cajas, no podía un indio sólo sacar en una semana lo que antes sacaba en un dia; ya finalmente por la pobreza de los metales, que apenas producían 5 ó 6 pesos por quintal, tí casi abandonaron la población para irse a buscar otros minerales, principalmente después do los años de 1594 y 1595, en que habiendo comenzado a dar cll agua estas minas, como lo anota Acosta, ${ }^{\prime 6}$ faltó el metal negrillo que antes se sacaba de las minas aguadas y servía por material conducentísimo al pronto y monos costoso benoficio de las platas; pero los contuvo sin duda on la continuacion de estos penosos trabajos, las merceles de la benignidad del Rey y la esporanza de mejoray' su fortuna, viendo que siempre sacaban plata; aumque, stanko al parecer de Acosta, 47 a más trabajo debían esperar menos, porque scgún la experiencia con que atestigua su opinión este autor, mientras más se ahondan las minas en Polosí, es más pobre ol metal que so saca.

Esta esperanza de futuras felicidades, contra tan repetidos testimonios de la experiencia, no pudo tener más que dos apoyos: el primero es que dándose varios socavones al Cerro, se descubrirían labores de mejor ley, como se representó al St: Virrey Conde de Chinchón, en ol año de 1631; y se expresó este misno motivo en primero de Julio de 1634 por: estos Oficiales Reales, alcgando que por estar muy buscada y sin ley la labor de medio arriba, que es donde se trabajaba, se habían disminnído los quintos del año 1633 en 20.376 pesos ensayados; y anque no se pemitió por entonees un Socavón Real, por: no aventurar unos gastos tan erecidos como ciertos y anticipados, en busca de un lucro puramente contingente y futuro; con todo, concedió el Conde de Chinchón, que el Corregidor de esta Villa depositase los indios vacos en los mincros más necesitados, para emprender sacavones en sus labores; y se sabe que tuvieron buen suceso algunas de estas operaciones, principalmente en la labor que llaman de Cotamito; pero siendo cicrto lo que afirma Acosta, de encontrarse metal cada vez más pobre cuanto más se ahondan las minás en Potosí, que es prueba evidente de ser sus venas trastornadas, esto es, más ricas en la superficie que en lo profundo, ${ }^{4}$ parece excusada diligencia la de agujerear el Cerro con socavones, porque este arbitrio sólo es bueno para descubrir con el corte la veta rica que de repente se le perdió al minero o se le aguó; y siempre que procediere, como aquí, el atraso de la minería por estar consumidas las vetas ricas y aun sus cajas, y todas sus labores reducidas a unos metales de bajísima ley, sólo se descubrirá pobrèza y lástima, cuanto más adelantare el socavón y, lo que es peor, no podrán correr las aguas de tal cual mina rica innundada, si acaso sus planes están inferiores a los del socavón contra las reglas que prescribe la Geometría y apunta el sabio naturalista Bowles, 49 porque 
siendo contra lo natural el ascenso libre del agua venciendo su propio peso, es preciso que las aguas de Ia mina de Arenas, pongo por ejemplo, que se supone la més rica y es la inmediata al campichuelo o valle que hace su dechive hacia el Poniente, queden enteramente estancadas si el socatón viene superior a ellas y no corre por debajo de los chiles o planes. (e)

SII.

De la reproducción de los me- $\mathrm{W}_{\text {L }}$ otro apoyo pudo scr la creencia en que tales del Cerro rle Potosí viven todos de ser criadero de plata el rico Corro de Potosí; parece que lo testifica la experiencia $y$ "po" lo menos vemos todos - dijo Don Alonso Barba, 50 el año de 1637, en su Arte de Metales, - que las piedras dejadas años antes dentro de las minas, porque no tenian plata, se sacan después con ella, tan continua $y$ abundantemento que no se puede atribuir sino al perpetuo engendradero de plata."

EIT. CaTancha asegura" que "cl metal contado de la peña en Po-
tosi, si esto año no as de ley, dentro de autro crece y tiene todos los quilates."

No hay duda que muchos hombres sabios se han pcrsuadido firmomente de la vegetación de los metales y aun Aristóteles ${ }^{52}$ observa que en Chipre hay una copecie de cobre que los labradores cortan en menudos podazos y siembran on la tierra como grano; y que en Hiberia, provincia antigita del Asia, llamada ahora Georgia, los pastotes queman las selvas para aumentar el calor y la fecundidad de la tierra y haciendo aberturas en ella, derraman la plata fundida que despućs crece allí y se multiplica mucho. También se cuenta i: que en Bohemia se encontraron hongos o morillas que eran difíciles de cortar; porque sus fibras estaban llenas de ramos a venas de plata; fuera de muchos otros cjemplares que pudieran citarse sobre muy clásicas autoridades, acerca de haberse encontrado finísimo oro en varias laíces y hojas de las viñas de Alemania, según Gonston y Alcjandro.

Esta líltima noticia se ha comprobado después con otras modernas observaciones, experimentos y ensayes, por donde se califica que las plantas conticnen real y esencialmente oro, que preexiste ya formado en. ellas; concluyondo de aquí Monsieur Sage ${ }^{5}$ con muchos célebres quími$\mathrm{cos}$, que el oro entra como principio en la composición de los vegetales, tan efectivamente como el hierro, cuya existencia en las mismas plantas no hay ya nadis quien la impugne.

La Ley 27, Título 11, Partida 4", parece que confirma la opinión de Barba y Calancha, contando entro los verdaderos frutos los minerales y canteras que renacen; con lo que se persuade que las piedras y las rocas vegetan como las plantas; esto es, que al modo que la nutrición de las plantas slipone necesariamente una distribución do la savia filtrada por muchos canales, casi es menester convenir que la formación de los metales y sobre todo su vegetación provienen de que las sustancias metấlicas cstán también lienas de canales imperceptibles que filtran y distribuyen en ellas los jugos de la tierra; y al paso que el movimiento, el

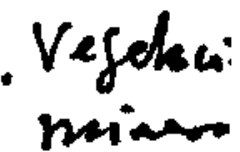


calor, una circulación continuada y una especie de fermentación insensible, se cree que forman las minas en lo interior de la tierra, así también su vegetación reproduce lo que se ha sacado de ellas mismas.

Io contrario parece que convence la división de clases en que los químicos y naturalistas distribuyen, de un acuerdo, todos los cuerpos naturales, llamándolos reinos, que son: el mincral, el vegetal y el animal. Los objetos del reino minedal (según la explicación de M. Baumé, célebre químico), son todos aquellos cuerjos que la naturaleza produce y encierra en el seno de la tierra, que no teniendo principio alguno de vida ni de vegetación, están absolutamente privados de toda facultad reproductiva y sólo tienen por la mayor parte una cierta suerte de coordinación simétrica o de cristalización. Al contrario, los vegetales como cucrpos organizados, poseen partes muy a propósito para su generación y se reproducen por medio de las semillas; y en esto es en lo que se diferencian de los cutrpos del reino mineral, concluye el citado químico; y en efecto, si hubiéramos de atribuír a los minerales las mismas facultades de reproducirse que poseen las plantas y otros vegetales, sin duda pertenecería al reino vegetal cualquier ente mineral y sería preciso redueir a uno los dos reinos, mineral y vegetal.

Así pues, sólo gue avancemos con el sistema de Mr. Homberg, hasta la conjetura de que las picdras se forman de verdadera somilla, como las plantas, podría llamarse vegetación propiamente tal la que se les quiere atribuír; o que siguiendo el común modo de filosofar, digamos que la lisiacencia o regoneración de los motales, procede del jugo o esp.ritu metalico que reside en determinadas matrices o mineras. Pero esta es una expresión tan ambigua que nada explica, según el Iltmo. Feijoó, " i ni la conjetura de las semillas de las plantas se ha esforzado suficientemente como lo pondera el citado autor.

Por todos estos principios juzgo falaz la experiencia que alegan nuestro Barba y Calancha, en cuanto a la keprodtuccion de los metales de nuestro Cerro, y que su engaño plocede de hariación en el trabajo de los mineros. Ello consta de lo cxpuesto, que conforme fué empobreciendo el Cerro, fucron aprovechándose los mineros de los desmontes y de otros antiguos desperdicios, que los primeros trabajadores desecharon por la pobreza de Ios metales. Como en los años más inmediatos al descubrimiento, eran incomparablemente más caros y escasos los mantenimientos, ropas, avios, utensilios y materiales necesarios para el trabajo de las minas por consecuencia de sus mismas riquezas, claro está que no todo metal podía costear al minero, y éste, forzosamente, había de arrojar como desperdicio el metal que no superaba las expensas en cuya comparación se llamaba entonces pobre.

Con la decadencia sucesiva, volvieron a los empleos de la agricultura y del comercio innumerables gentes que, con la sed de la plata, estaban como estancadas en esta Villa. Se minoró la primitiva abundancia del dinero, creció la circulación de los efectos, y decayendo consiguientemente su precio, ya exan menores los costos de la minería, y por una combinación necesaria de todas estas circunstancias, venía a ser rico el metal que antes se desmontó en la reputación de pobre. Así pues, como todos veían que con el decurso de los años se trabajaba una clase de metales que antes se dejó de beneficiar por pobres, es fácil conjeturar que atribuyesen a una portentosa regeneración lo que era pura consecuencia 
de las circunstancias del tiempo. Ni puedo persuadirme a otra cosa, a menos que se calificara esta noticia ensayando metales, reputados pobres, los cuales se dejaran en las mismas minas, hasta cinco o seis años, y que al cabo de este tiempo se reensayasen y beneficiasen, para ver si realmente se reprodujo la plata que allí no existía.

Tenemos la prueba más decisiva de este discurso, en lo que actualmente se ve en los trabajos de los antiguos desmontes y de labores despobladas. Ya se ha referido que cuando el quintal de metal le producía al minero 5 ó 6 pesos, no le hacía cuenta su beneficio, porque eran mayores los costos. Ahora el metal de los desmontes, que aquí llaman pallaeus, (f) apenas rinde cinco mareos por cajón -que son $50 \mathrm{qq}-\mathrm{y}$ la labor más rica no pasa de ocho marcos o nueve por cajón de metal barreteado; de suerte que los pallacus del día no pasan del rendimiento de cinco reales por quintal, y el metal barreteado, siendo rico, no llega a mueve reales. Discírrase como se quiera: al cabo se ha de llegar a concluír que costearse los presentes mineros con la sexta parte menos de los aprovechamientos que recogian los antiguos, no puede consistir en otru principio que en la considerable baja de los precios de los víveres y utensilios, bien sea por haber crecido su abundancia por la mayor aplicación a la industria, o porque habiendo disminuído la población de esta Villa a 25.000 personas, de 150.000 que antes residian en ella, ha resultado que sobrando ahora de qué sustentarse, ha decaído la estimación de lo superfluo, cuanto antes por ser todo necesario y algo más, subía su valor con la misma carestía, como en cfecto sabemos que ma gallina valía ocho reales en la antigiiedad, un huevo dos reales, una libra de cera de Castilla diez pesos, y así lo demás.

Si verdaderamente se reprodujera la plata en este Mineral, no podía menos de encontrarse notable aumento de riqueza en los metales de las matrices o labores antiquísimas despobladas, que después se han adjudicado en estos últimos tiempos, por el derecho de limpia. Por cierto que los mineros sólo han tocado desengaños en estos costosos trabajos. Nada más adelantan que descubrir profundísimas cavernas donde los primeros mineros sepultaron todos sus caudales y con ellos la felicidad de sus familias; y si alguna vez aclaman hallazgo de riqueza, nada más es, en realidad, que el trabajo de algunos cortos ramillos de metal estrellado o el disfrute de los antiguos puentes, los cuales como construídos con metales de buena cualidad, tienen con qué cebar por algún tiempo la avaricia de los mincros: luego, es evidente la falsedad de la regeneración de la plata, pues, a ser cierta, al cabo de cuarenta o cincuenta años se encontraría metal en abundancia dentro de las minas despobladas.

Esta constante experiencia de sacarse menos provecho cuanto más se ahonda el trabajo de estas minas, acredita en mi concepto, casi hasta la evidencia, el juicioso dictamen que ya hemos citado del historiador Acosta. No debemos pues esperar ( $g$ ) que encontraremos los manantiales de plata que algunos ereen hallarse todavía escondidos en las entràñas del Cerro; porque si los hubiera, ya habrían aparecido algunas muestras a setecientas y más varas de profundidad que se han ahondado las labores de la mina llamada de Arenas. El Cerro todo está horadado como un cascabel y las labores antiguas y modernas son tantas, que se cruzan por lo interior de sus entrañas como los vacíos de una esponja. No sólo los mineros trajinan incesantemente estos lugares, sino principal- 
mente Ios Cacchas (Ckacchas), que siendo unos ladrones en cierta manera tolerados por el gobierno, penetran con su codicia los abismos más insondables del Cerro. Con todo, ni estos ni aquellos han encontrado rastros de la riqueza que sc imagina, sin embargo de lievar todos ellos un trabajo trastornado por la ambición, sin abstenerse de derribar puent tes y de incurrir contra todas las precauciones que estableció la Ordenan za para la conservación de las minas y para evitar el riesgo de los indios.

De esto proceden grandes y contínuos aisamientos, derrumbes y hundimientos en las minas, con inevitables muertes de los indios; y aunque deba creerse demasiadamente exagerado el cómputo que forma Calancha, $>7$ asegurando que por cada peso que se acuña, mueren dioz in $f$ dios, lo cierto es que si las minas en geneial se contemptañ unas Caribdes espantosas, que sorben y devoran a cuantos en ellas se fatigan, éstas de Potosí son unos verdaderos abismos de la humanidad, según el juif cio de muchos.

El desorden en el trabajo ha introducido tal confusión en las pertenencias de los mineros, que cada uno trabaja donde puede, siguiendo la labor đonde se metió sin saber de quién es ni dónde se hảlla. Todos convienen en este usufructo, porque esperan que la industria laboriosa de los otros vencerá la dureza en que corre la veta o encontrará la riqueza que él no puede buscar; y en cualquiera de los dos casos, bion sea de fa- cilitarle la saca de los metales por haber dado en blandura, o de mejorar de fortuna en alguna razonable boya de metales : entonces son los pleitos y las discordias. Lo peor es que seyún el estado de estas minas, difícilmente podrá evacuarse una medida justa y acertada por el mejor gcómetra. Sólo el Gobierno puede poner remedio, poniendo en la posibic observancia las Ordenanzas, en que se vuelvan a construír los puentes y woteen los caminos y socavones, para que no llegue el infausto día de sumergirse el Cerro desapareciendo a nuestra vista este noble patrimonio del Estado, con todos los que trabajan sus minas. (h)

En medio de los atrasos que se han referido, debemos tener la fundada esperanza que la duraeión de estas minas será la misma del Cerro. Aunque sabemos por relaciones verídicas de mineros hábiles, que han ahondado hasta los planes, que en ellos no hay mayor riqueza de la que ahora se disfruta, convienen todos que se encuentran los mismos metales (bien que en mayor dureza). Todo el Cerro está compuesto de metales, unos más pobres que otros, y es preciso que mientras él subsista se saque siempre la plata, tal vez en considerable abundancia si se logra desaguar la mina de Arenas, la de Encinas y algunas más en que se considera riqueza; puesto que, según Barba, 58 los ojos o manantiales de agua que se ven en los aerros, no son pequeños indicios de la cercanía de las vetas, respecto de correr por éstas el agua que por aquellos sale. Pero debemos temer al mismo tiempo, que después de un coste inmenso en desaguarlas, corramos el riesgo de no hallar las vetas o de hallarlas exhaustas, como pronosticó el mineralogista Bowles 59 de la mina de Guadalcanal; $y$ en efecto, se consumieron inútimente capitales muy cuantiosos en desaguar los pozos, sin que hasta ahora se haya podido dar con la veta, según la nota de su ilustrador Azara. ${ }^{60}$ 


\section{\& III.}

De las diversas clases de metales del Cerro y dirección de sus vetas.
$\mathbf{P}$ ASEMOS ahora a describir las-clases de metales que se cncuentran en nuestro Cerro y la dirección de sus vetas, para mayor ilustración de su historia. Como las sustancias metálicas sox de tan grande utilidad cn las artes, en la química, en la medicina $y$ en los usos ordinarios de la vida, se ha examinado con la mayor: prolijidad las clases que forman estos cucrpos, las propiedades más generales comunes a las materias metálicas y las que son absolutamente particulares a carla una de ellas. Sin embargo de estas investigaciones, no se conocen más que catorce sustancias metálicas, que según la diferencia de sus particulares propiedades, que hacen las unas dúctiles, otras maleables, otras fijas en el fuego, se dividen en tres clases, a saber:

Primera: los metales perfectos, cue son el oro, la platina y la patas

Segunda: los metales imperfectos, que son el cobre, el estaño, el plomo y el hierro.

Tercora: los semi-metales, que son el régulo de antimonio, el bisnuuto, el zinc, el régulo de cobalto, el régulo de arsénico, el nikel y el mer-* c⿲îto onazogte.

De todas estas clases sólo se encuentian en nuestro Cerro y a sus alrodedores, el plomo ustaño y plata. Testifica Barba, que hacia el sornbrío, en el paraje que llaman de Cívicos, hay muchas vetas de plomo. ${ }^{61}$ Que una de las cuatro vetas principales del Cerro, fue tan abundante de estaño, que se llamó de este nombre, y en la profundidad dio en plata; añadiendo que, un cuatro de legua de San Bernardo, hay otro mineral de estaño, ${ }^{62}$ el cual no es ahora conocido.

La plata se encuentra en el día sólo en tres suertes de metales, que llaman zacos, mulatos y nequillos: en lengua general de los indios sc llama pacolel metal docolor hermejo, más o menos encendido, pero en estas promfictas llaman pacos a los de cualquier color, aunque sean verdes cobrizos, ahiguerados, amarillos o azufrados, a diferencia de los acerados o espejados y otros que llaman negrillos.

Metal $2 u$ latd es un medio entre pacos y negritlos; se cría entre estos dos y tiene el color bayo, y él por sí mismo se da a conocer. Este metal abunda menos qux los otros dos géneros antecedentes; no se encuentra en vetas formales on el día, sino en ramificadas por hilos delgados, que regularmente ticne mucha riqueza por lo que se acerca al rosicler y cochizo, según lo explica el célebr'c Barba, ${ }^{63}$ para dar conocimiento de estos metales. (i)

Las vetas más comunes del Cerro son las que en el uso de los mineros se llaman "profundas" y son las que por lo regular van de arriba abajo o derechas de la superficie hacia lo hondo, o con alguna declinación de la pcrpendicular a la oblicua, aunque también hay algunas que se extienden y alargan hacia los lados sin decaída considerable hacia el centro de la tierra, que es lo que llaman "mantos". Todas las vetas principales corren de Norte a Sur, y las cuatro más famosas, que son: la Rica, la de Centeno, la del Estaño y la de Thendieta, tienen de ancho, por donde
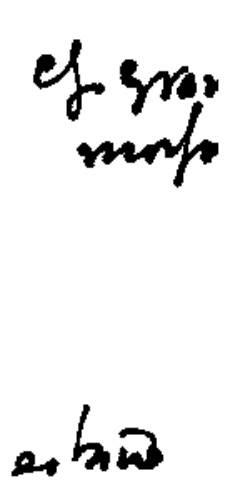
más, seis pies, y por donde menos, un palmo, llevando su cur'so de Norte a Sux como queda dicho, con pequeña declinación hacia el Poniente. ${ }^{61}$ En esto se ve que aunque algunos antiguos daban el primer lugar de excelencia a las vetas que corren del Este al Oeste, 6.5 to contrario enseña la experiencia en las minas més riecis del mundo. Ln la de Guadalcanal, que era tan rica en plata como lo es ahora cualquiera de América, ${ }^{66}$ asegura Bowles, ${ }^{67}$ que la gran veta corre de Norte a Sur, segun se descubre por más de doscientos pasos en la superficic. (j)

'También hay otras vetas menores que corren mas de Levante y otras de Poniente, que cruzando el Cerio vienen a juntarse con las grandes vetas principales en la cumbre. Algunos antiguos aseguran 68 que el Cérro tiene toda su riqueza por la parte que le amanece el sol y que por la parte del sombrío no es de ley el metal. Calancha "9 afirma, por el contrario, de ser la plata de hacia el Poniente la más rica, cuya diferencia de ambos historiadores consiste sin duda en las contrarias relaciones con que fueron persuadidos.

En el mismo Cerro hay un sitio llamado "Eslabonera", donde se encuentra en el haz de la tiex'a piedras riquísinas, pero tan duras, que destruyen las almadanetas de los ingenios, y sólo calciníndose se ve el provecho, pero es tan exorbitante sil costo que impicie totalmente su beneficio; de que se dio cuenta al Rey, por el Sr. Visitador D. Jusé Antonio Areche, y el Sr. D. Jorge Escovedo, siendo Gobcrnador de Potosí, en el año de 1781, para que llevándose este metal a España, se ensayase por prácticos mineralogistas $y$ se indagase el verdadero modo de beneficiarlo con utilidad.

Los gabinetes de Historia Natural conticnen una multitud de muestras de minas, infinitamente diversas, io pero todas se reducen a las catorce especies de sustancias metálicas que hemos referido. Dl arte de conocer y preparar las minas, es muy extenso y exige una aplicación particular, mucho estudio y mayor práctica; por lo que dice el célcbre Bowles; ${ }^{11}$ sirve de poco lo que se lee si no ra unido con la experiencia, y un sobrestante de minas, sin saber leet', entenderá más de su trabajo que quien haya escrito 40 libros. Muchos autores han tratado de esta materia: entre los españoles son los más célebres, D. Alonso de Barba, Cura que fue de la Parroquia de San Bernardo de Potosí "Dr Euis Berrio de Montalvo, Alcalde de Crimen, de Méjico; D. Juan Orđóñez Montalvo; D. Bernardo Pérez de Vargas; D. Juan de Sosa; D. Juan de Alfé, (k) y otros varios como D. Juan Fernández del Castillo y el P. Acosta, que han tocado varios puntos sobre minas. De los extranjeros hay muchos y célebres escritores, tales son: Agrícola (De re-metálica), sobre minas de Alemania; el P. Kircher, en su "Mundo Subterráneo"; Felipe Krebs, "De ligno et lapide, de metalibus et mineralibus", del Estado de Hassia; Christóbal Schluter, "De la Fuente de Minus", traducido por Helot en París, año de 1750; Granger, Madama de Beau Soleill, las observaciones de la Academia Real de las Ciencias, Noticias del Diario Económico; y por último el célebre químico M. Baumé, (1) que aunque no escribió un tratado íntegro de Mineralogía, señaló los caracteres principales por donde pueden reconocerse las materias metálicas; designó las minas por las señales y caracteres que les son propios; indicó los métodos que se practican para descubrirlas y reconocer la dirección de las vetas, los medios que se emplean para extraer los minerales de las entrañas de la tierra y las pre- 
cauciones que se toman contra las inundaciones y ruinas, para penetrar sin riesgo en el laboratorio subterráneo de la naturaleza; añadiendo un artículo muy útil para poner'se a cubierto de las exhalaciones subterráneas y rapores minerales flogísticos que exhalan las minas en distintos grados y ocasionałn la muerte a Jos trabajadores. $\mathrm{Mi}$ árimo no es entrometerme en retalles sobre este particular, porque siendo el estudio de las minas un arte que forma ciencia y profesión separada, que para ser provechosa requiere que se hermanen una experiencia adquirida desde la juventud y la piáctica de los principios del arte por todo el curso de la vida; so deb remitir estos cuiclados a otros que tengan los precisos conocimientos. A este fin, el sabio y celoso Ministerio de Indias, ha formado nuevas Ordenanzas de Minas, en el año pasado de 1785, mandando establecer on esta lilla lin Senado o Consejo que cuide de su inspección, (ll) acreditando con esta nueva politica económica, de que hasta ahora hemos carecido, la atuncion cue le reroce la minería, como ramo el más interesante de comercio y objeto principal cle Hacienda.

\footnotetext{
1.- Gazofilatcio: Lib. $1^{\circ}$, Cap. $45, \mathrm{~N}^{4} 55$, fol. 189

2.- Mendoza: Lib. $1^{\circ}$, Cap. $4^{\circ}$, 1'ol. 30.

3.-Calancha: Lib. 3", Cap. 40, $\mathrm{N}^{\mathrm{N}} 1$, fol. 743 .

4.- Murillo: tomo 9, Lib. 9", Cap. 17, fol. 288 .
}

(a) Én la copia del archivo de la Moneda, se cita a Pino Manrique. (N. de E.).

(b) Fr la copia manuserita del archivo de Sevilla, dice: "958 varas de perpendicular que componian un quinto escaso de legua." ( $N$. de E.).

5.- Calancha y Mendoza, ja citados.

6.- Murillo, ya referido.

7.-Calancha, Id. jd.

(c) "Hichu", en quichua: paja. (N. de E.).

8.- Gizzofilacio reproduce a la letra este capítulo: Lib. $1^{\circ}$, Cap. 45, N" 56 , fol. 189.

9.- Calancha: Lib. $3^{\circ}$, Cap. 40, $\mathrm{N}^{\circ} 1$, fol. 743 - Murillo: tomo 9, Cap. 17, fol. 291.

10. - Barba: Arte de los Metales, Lib. 1", Cap. 24, 10l. 24.

11.- Mendoza: Lib. 1", Cap. 4\%, fol. 32.

12. - Calancha: Ioco citato.- Mendoza: Ibídem, fol. 30.

13. - Garcilaso: Parte segunda, Historia del P'erú, J,ib. $3^{9}$, Cap. $2^{9}$.- Acosta: Lib. $4^{9}$, Historia Indiana, Cap. $6^{*}$.

14.....-Herrera: Década octava, Lib. 11.

15.-Calancha: 10 co citato.

16.- Mendoza: en el lugar referido.

17 . Ulloa: tomo $3^{\circ}$, de su Viaje; Liis. $1^{\circ}$, Cap. $13, N^{\circ} 339$, fol. 195.

18.- Barba: Lib. $1^{\circ}$, Cap. $25, N^{\circ} 25$.

19. - Ulloa y Barba, en los lugares citados.

20.- Calancha: Lib. $3^{\circ}$, Cap. $40, \mathrm{~N}^{\circ} 1, \mathrm{f}^{\prime} \mathrm{OH} .744$.

21.- Murilo: Lib. $9^{\circ}$, Cap. 17, fol, $288 .-$ Uiloa: tomo $3^{\circ}$, fol. $197, \mathrm{~N}^{\circ} 341$.

22,- Calancha: Lib. $3^{\circ}$, Cap. 40, $\mathrm{N}^{\circ} 1$, 10l. 745. - Gazofilacio: Lib. 1" Cap. 45, $\mathrm{N}^{\circ} 59$.

23.- Escalona: en su Gazofilacio loco citato.

24.- Barba: Lib. 1\%, Cap. 27, fol. 28.

(d) Tahuako-ñuñu, voz aimara que significa "pecho de doncella". (N. de E.).

25.-. Barba: Lib. 1", Cap. 27.- (B) Barba: Lib. 1\%, Cap. 28, fol. 29.

26. - Solórzano: en su "Politica", Lib. 6", Cap. 1", $\mathbf{N}^{\circ} 5$, tomo $2^{\circ}$, fol. 424.

27.-. José Llano y Zapata: Memorias Históricas. Tomo $1^{\circ}$, fol. 1.

28.- Plinio: Lib. $3^{\circ}$, Cap. 34 .

29.-Diodoro Sículo: Lib. $5^{\circ}$ - Strabón: Lib. $3^{\circ}$, citados por M. Rollin, Historia Antigua, tomo $2^{\circ}$, Parte primera, Cap. $1^{\circ}, \S 5^{\circ}$, fol. 271.

30.- Haustin de Villars, en su tratado nuevo del Arte Metálico.

31.- P. Daniel: Historia de Francia, tomo $3^{*}$, en folio, pág. 1918.- El Barón de Beau Solleil, en su tratado dedicado al Cardenal Richelieu, bajo el título de "Restitución de Plutón, etc.", de donáe sacó el catálogo de todas las minas de Francia.- Valemont, en su Física Oculta.

32.- Tratado Universal de España, \& 18, tomo $1^{\circ}$. 
33.-. Diario de los Literatos, tomo $6^{\circ}$, Art. $7^{\circ}$, fol. 266.

34.- Strabón: Lib. 3, pág. 147, citado por Rollin, tomo 2", fol. 252.

35.-.- Bowles: Historia Natural, fol, 67.

36.- Diodoro Sículo: Lib. $5^{\circ}$.

37.- Jeremías: Cap. 20, versículo $6^{\circ}$.

38. - Bowles: Historia Natural, folios 25 y 26.

39.- Acosta: Lib. $4^{\circ}$, Historia Indiana, Cap. $6^{\circ}$ - Garcilaso: $2^{\natural}$ parte, Lib. 30, Cap. $2^{\circ}$.

40.- Barba: Lib. 1\%, hasta el Cap. 34.

41.- Acosta: Lib. 4", Historia Indiarta, Cap. 9".

42.- Barba: Lib. $2^{\circ}$ del Arte de los Metales, Cap, $3 "$.

43.- Acosta: Lib. $4^{\circ}$, Historia Indiana, Cap. $9^{\circ}$.

44.- Acosta: Lib. $4^{\circ}$, Cap. 11.

45.- De todo esto se hace relación en la Real Cédula de Madrid, a 26 de febrero de 1628 , como hecho positivo, veinte años atrús.

46.- Acosta: Lib. $4^{\circ}$, Cap. $7^{\circ}$.

47. - Acosta: Lib. $4^{\circ}$, Cap. $8^{\circ}$ - La descripción de las minas de Potosí, libro 11, Cap. $3^{4}$.

48.- Bowles: Historia Natural, fol. 68.

49.- Bowles: fols. 34 y 35 .

(e) Se trata este punto difusamente en otra obra sobre minas dedicada al Sr. Dr. Fr. Antonio Valdés. (Nota del manuscrito del Archivo General de Indias en Sevilla).

50.- Barba: Lib. 1\%, Cap. 18, fol. 17 vta. Sr. Dr. Fr. Antonio Valdes. (Nota de la copia del original de Sevilla).

51.- Calancha: Lib. $3^{\circ}$, Cap. 40, fol, 745.- Mr. Tresier en su "Viaje de la Mar del Sur desde el año de 1712 hasta 1714 ", fol, 146, también cree en la reproducción de los metales en el Cerro de Potosí.

52.-. Aristóteles: De mirabilia auscultatione.

53.- El Diario de los Sabios de Sumden, ciudad de Suecia, del 17 de mayo de 1683.

54.- Gonston: Clase 4", Cap. 26.- Alejandro: Lib. 4", Dierum genialiurr, Cap. $9^{\circ}$.

55.-M. Sage: Profesor Real de Mineralogía y Docinástica, en la Real Casa de Mo. neda de París: en su arte de ensayar oro y plata, traducido por Casimiro Gómez de Ortega, Boticario Mayor Honorario del Rey.

56.-Feijoó: Teatro Crítico ; tomo 5". Discurso 15, § 16, No 51.

(f) Metales recogidos de ertre desperdicios. (N. de E.)

(g) Véase en la obra dedicada al Excmo. Señor Valdés, con título de "Errores de la Minería del Perú". (Nota del Ms. del A. G. I.).

57. C Calancha: Cap. 40, Lib. $3^{\circ}, N^{\circ} 1$ al fin, fol. 745 .

(h) Tambićn se encuentran otros metales de ley superior a los más antiguos, como puede verse en la obra citada en la apostilla (g). (Nota del Ms. del A. G. I.).

58.- Barba: Libro $1^{\circ}$, Cap. 24, fol. 24.

59.- Bowles: fol. 67 .

60.- Axara: Ibid. N 1 , fol. 67.

61. - Barba: Lib. 19, Cap. 31.

62. - Barba: Lib. 1\%, Cap. 32 .

63.- Barba: Lib. $2^{\circ}$, Cap. $3^{\circ}$.

(i) La descripción científica de los metales se puede ver en la obra intitulada "Errores de la Minería del Perú". (Nota del Ms. del A. G. I.).

64.-Barba: Lib. 14, Cap. 25, fol. 25.- Murillo: Lib. 9, de su Geografía Histórica, Cap. 14, fol. 234.

65. - Barba: Lib. $1^{\circ}$, Cap. 25.

66.- Bowles: en el Discurso P'reliminar de la Historia Natural de España, fol. 34.

67.- Historia Natural, fol. 64.

(j) "De Nordeste a Sudeste". (En la copia de Sevilla).

68.-. Mendoza: Crónica de San Francisco. Lib. 1․, Cap. 4\%, fol. 30.

69.- Calancha: Lib. $3^{\circ}$, Cap. $40, N^{\circ} 1$, fol. 745.

70.- Véase "Fl Espectáculo de la Naturaleza". Tomo 3". Entretenimiento 8\%, donde se halla un inventario razonable de todas las produciones de las minas.

71.- Discurso Preliminar, fol. 28.

(k) "Azfe", en la copia de Sevilla.

(1) Los autores más célebres se verán citados en la obra "Frrores de la Minería del Perú". (Nota del Ms. del A. G. I.).

(l) No se ha establecido todavía por los motivos referidos en el Discursio Preliminar de la obra citada en la anterior apostilla (I). (Nota del Ms. del A. G. I.). 


\title{
CAPITULO TERCERO \\ Beneficio de metales y uso del azogue.

\author{
Del beneficio de las minas de Palosí y de la variedad que en esto
} ha hubido.
}

\author{
NOTICIA PRI M E A
}

\begin{abstract}
De las diferentes maneras de beneficios que se han practicado hasta ahora en las muchas clases de metales de este Cerro, $y$ en las escorias $y$ tierras.
\end{abstract}

E manda fundar el Rey en esta Villa, se ensenará la Química, la Mineralogía y la Metalurgia, como en el célebre Seminario Patrióm tico de Vergara, para que aprendiendo a distinguir el carácter de los metales, su naturaleza y ley, se emprenda el trabajo de las minas, con esperanza, cuandio no cierta, probable, de sus productos y utilidad. Al cabo llegará el feliz día en que a los trabajos en grande sobre las minas, precedan aqucllas precisas operaciones en pequeño, destinadas para ensayar las minas y llegar por este medio al importante conocimiento tesuley y natualeza Ese trabajo en pequeño, que es a lo que se llama Locimasia o Arte de Ensayes se ha practicado en Potosí con el mayor abandono, por unos hombres jgnorantes que llaman "benefi-X ciadores", sin más pruebas de suficiencia que haber alegado tres o cuatro años de práctica en la carrera de minero, ocasionando a los dueños de minas, al Estado y a la Real Hacienda tan notable pérdida de caudales, que puede asegurarse sin temeridad, no haberse aprovechado por falta de conocimiento del verdadero método del beneficio, una tercia o cuarta parte menos de las riquezas que ha rendido el Cerro de Potosí. 
Así exclama nuestro célebre Barba, ${ }^{1}$ que, sin exageración se han perdido muchos millones en los desperdicios que ha habido en el beneficio de los metales de plata, así en la ley que no han dado, por no ser entendidas sus naturalezas y diferencias, como en las descompasadas pérdidas de azogue. No atribuye a otra causa estas infaustísimas quicbras, sino a que el magisterio del beneficio de metales lo ha tratado quien no lo entiende, sin preceder examen y licencia de la autoridad pública. No basta que tenga procedimientos honrados y cristianos; porque la concurrencia de estas prendas solamente servirá para contenerle los crecidos y continuos robos que comunmentc ejecutan otros de menos probidach, teniendo la ocasión en las manos. Debe saber conocer los metales, sis calidades, naturalezas y diferencias, para que entienda cuáles son propios para azogue, cuáles para fundición. No deben ignorar las mozclas que los acompañan para separarlas, los accidentes del azoguo $y$ el estilo ordinario de beneficiar por menor y por mayor; y antes que en un examen riguroso haga constar que sabe hacer bien por lo menos un ensaye por menor de toda harina, antes de incorporar al cajón, para enterarse de la plata que tiene y el producto que ha de sacax: ninguno debe ser adritido por beneficiador.

La inobservancia de este importante aviso ha costado al Estado innumerables millones. A este propósito, refiere con demasiado dolor suyo nuestro Barba, ${ }^{2}$ dos casos muy remarcables, acaecidos con él mismo en la Provincia de los lípez, y se reduce el uno a que de una mina que otro desamparó porque de cada quintal de metal no le acudía a más de cuatro o cinco pesos por el modo ordinario del azogue, sacó él novecientos pesos por quintal, beneficiándoln por fuego. Cuenta que allí se levantó un ingenio, $\mathrm{y}$ de aquella veta nombiada "N. S. de Begoña" y de otras muchas, se sacaron grandes sumas de plata.

Remediado este mal que, sin duda, es la raíz de los atrasos de Potosí, forzosamente florecerá la minería y convaleciendo de su antigua decadencia, rendirá mayores frutos de los que podían esperarse, annque no tantos como hubiera producido siendo más anticipada la cura.

Todos estos desperdicios se verán paipables con la historia siguiente del beneficio.

Como los indios no alcanzaron otro modo de beneficiar los metales de plata, que fundiéndolos_con plomo, según lo anotan Acosta y Gareilaso, ${ }^{3}$ continuaron los españoles el mismo método de fundición en esta forma. Construyeron en e] Cerro más de seis mil hornillos, que liamaban "guairas"; " echaban alí los minerales de plata, sin mezcla de otro alguno, siendo dóciles, corrientes y de toda ley, y daban fuego hasta derretir la plata quedando aparte la escoria. Los metales que no tenían corriente, mezclaban con otro más bajo, muy cargado de plomo, que llaman "soroche", (a) que en lengua de indio quiere decir "cosa que hace derretir" o deslizar", " y uniendo ambas materias con cuenta y razón, daban fuego a los hornillos hasta derretirse y sacar la plata pura, como antes se dijo. ${ }^{6}$

Usaron de este beneficio mientras duró la "tacana", metal riquísimo del Cerro, por espacio de veintiún años, desde 1545 que se descubrió, hasta 1566. En este tiempo quiso Dios mejorar la suerte de estos mineros con la invención del beneficio por azogue, por medio de Pedro Fernández 
de Velasco que lo enscino en el Pexú, año de 1571, gobernando D. Francisco de Toledo, quinto Virrey de Lima. ${ }^{7}$

El metal molido y cernido en unos cedazos de telas de alambre, lo echaban en unos cajones que tenían la medida de cincuenta quintales de metal cada uno. Preparaban esta harina con cinco quintales de sal y el azogue necesario para rue se pudiera amasar e incorporar una con otra. Dábanle por debajo fuego lento, con liania de unas pajas (llamadas hicho) de que abundaba el Cerro y sus contomos; con lo cual se lograba la incorporación del azogue con el metal, dentro cle cinco o seis días. Lavaban después esta masa on unas tincts grandes o pozas de agua, y quedaba en las bateas el azogue y la plata; y exprimiendo fuertemente todo este cuerpo en un lienzo, quedaba dentro de él la pella de plata, saliéndose el azogue a otras bateas, en donde se recogía. Luego amoldaban estas pellas dentro de unos vasos de barro en figura de panes de azúcar a que llaman piñas, y dándole fuego on unos hornos, para que exhalase el humo del azogue que habiá quedado en la pella, quedaba la plata pura y acendrada, on cstado de reducipla a barras ${ }^{8}$ que llevaban los interesados a las Cajas Reales para su ensaye y quinto.

Despucis de once años que se practicó este método de beneficio, a saber, descie 1571 hasta 1582 , se vio la azoguería nuevamente afligida por el mucho costo rlel azogue que se perdía y por la pobreza de los metales, que así por su poca ley como por el trabajo y gasto que se causaba en sacarlos de tanta profundidad y dureza, apenas rendía cinco o seis pesos cada cuintal, cuando en los primeros veinte años el metal menos rico daba cuarenta o cincuenta pesos ensayados, por fundición. Fué creciendo la miseria hasta el estado de reducirse el rendimiento a doce onzas por quintal, consumiendo siempre casi el mismo azogue que antes; lo que puso a los más en la desesperación de desamparar la Villa y su Cerro. Sucedió entonces que, por fin del ano de 1586, Carlos Corso de Leca descubrió el bencficio del hierro en esta forma: Deshacían el hierroen piedras grandes de amolar, y el agua tel trieryo deshecho se echaba en los cajones de metal con cl azogue y sal; resultando de esta operación tan buen cfecto, que si antes se perdian diez libras de azogue, se consiguió cl no perderse más que una. Animados con esto los azogueros volvieron a proseguir sus labores, entablaron otras nuevas, engrosaron el beneficio y sc reparó una gran despoblación; pero viendo el Sr. Virrey Conde del Villardompardo, el poco consumo de azogue, envió provisión para que no se usase el beneficio del hier'’o, según refiere Escalona. ' Con todo, se experimentó el mismo alivio con la invención de que en cada cajón se echasen dos o tres quintales de metal negrillo bien quemado, porque ayudaba el beneficio y suplía la concurrencia del hierro para que no fuese tan grancle la pérdida del azogue; pero habiendo dado en agua, por los años de 1594 y 95 , las minas de donde se sacaba metal negrillo, ${ }^{10}$ como también porque si se descubría alguna de esta clase, era tan dura que no se podía trabajar, cesó este provechiosísimo benefioio. Faltó también el hicho que se recogía en este Cerro y en otros circunvecinos; de que resultó que los cajones que con el fomento del fuego lograban antes la incorporación del azogue con el metal dentro de cinco o seis días, se tardaba después más de veinticinco o treinta, porque los dejaban solamente al sol y al aire para que se vayan curando, añadiendo el imponderable costo y trabajo de amasar los cuerpos con los pies, todos los dias, hasta que se incorpore per- 
fectamente el azogue con el metal. Al mismo tiempo se cosimieron todos los metales de fundición y fue preciso derribar y destruír las guairas y homillos del Cerro, quedando la azoguería apurada en tanto extremo, que sc hubiera despoblado la Villa, a no laberse inventado agregar el cobre, plomo, estaño y cal en las cantidades oportunas, sobre las mezclas de la sal, hierro y azogue, por haber sido el único medio de mejorar el beneficio, que hasta ahora se practica on la forma siguiente:

Puestas las harinas del metal bien molido y cernido en los buitrones (que son unos patiecitos empcitrados y cercados), divididas en dos cuerpos o medios cajones, se le echa a cada cuerpo diez o docc arrobas de sal, y al cajón veinte o veinticuatro arrobas, y echáncole agua los deshacen y amasan como barro. La sal hace el oficio de descngiasar y diluír, esponjando los sólidos, y con la ayuda del repaso, que es el diario amasijo que hacen los indios con los pies en aquellos cucrpos; se limpian las partículas de plata para que el azogue las recoja; $y$ por lo mismo de considerarse la sal como principal vehículo para que el metal dé toda su ley, creen estos mineros que nunca daña la abundancia y por el contrario es muy perjudicial su falta. Según la clase y naturaleza de los metales, es necesario prepararlos con otrus matcrias y magistrales. Si es paco mulato, como este metal abuuda de alcaparrosa se preparan primero con cal antes de azogar las harinas, y cuando ya queda ésta amortiguada y destruídas sus grasas, se le echa el azogue puro según conjetura de la ley del metal: por lo regular, siendo de seis marcos por cajón, se le pone doce libras de azogue, y a cada cuerpo o medio cajón seis libras, echándolo bien espartamado para que con el repaso se incorpore pronto. Si el metal es quinto, abunda de bronce y algún arsénico: es frío, y necesita ayudarle con caparrosa, porque ésta destruye y aniquila cicrto toque que tiene el azogue del mismo bronce, que parece una tela gruesa dorada, que impide el beneficio: así, se le pone azogue puro.

Si son vilasiquis, panizos y todo metal de plomería, así llamado por hallarse la plata visible en partículas menudas envueltas en ciertas grasas o sucos grasientos casi petrificados, de color plomo o de otros colores: se le acompaña bastante caparrosa $y$ se hace el beneficio con el azogue mezclado con plomo material, el cual comunicando cierta humedad a los acompañados, da consistencia al azogue, para resistir a lo mordicante y ácido de la caparrosa, y ayuda a absorber otras malezas, quedando por último el plomo reducido a partes térreas. Si todavía se mantiene la masa con alguna caparrosa que liaman calor, la temperan con la cal, en calma; y si cstá fría con algún toque de bronce o de otro extraño, la calientan con copagira, que es la caparrosa; de suerte que todo lo frío y cálido consiste en mezclar a lo ácido, lo alcalino, y al contrario, los beneficiadores llaman cálicio, cuando las grasas procedicas de la caparrosa, arsénico u otros sucos oleaginosos dominan al azogue impidiendo que obre en la plata. En este caso se corta lo ácido y punzante con la sal alcalina que contiene la cal; porque destruyendo las telas o películas grasientas, queda limpio el azogue y obra con facilidad. Por el contrario, cuando reconocen algún toque frío, gue procede de otras especies de grasas astringentes y del escarche que causa la demasiada cal, 'se aniquilan y limpian aquellas malignas mezclas con sus contrarios, que son el agua o tierra de caparrosa, y a esto Ilaman temperar o calentar.

Viendo el beneficiador sus lavas limpias y purificadas de todos 
sus contrarios, sigue dándole todos los días los correspondientes repasos $\mathrm{y}$ añadiendo el azogue que se nocesitare, después de cuatro semanas de esta maniobra desde que los incorporó, los limpia con la cal y los abandera cchándoles más azogue que los pone casi en caldo, y lo regular es que siendo de cinco marcos, lleva cada cajón veinte a veintidos libras de azogue. Inmediatamente se transporta aquelia masa desde el buitrón a un po\% grande, que llaman encha de lacar, donde echando por un canalito agua a la masa, la menean con azadones enturbiandola cuanto pueden, y saliendo así por un aguicro o conducto, cae sobre cierta porción de atogue que se impregna con la plata y el azogue de la lava. Concluído esto, se exprime ei azogue quedando separada la plata que llaman pella, de la que se forma la piña en moldes de madera, y se requema para que haciendo exhalive el fuego el resto cicl azogue, quede acendrada la plata, como antes se dijo. (b)

Los morales neyrillos se bonefician por fuego, preparándolos con la guena, paia dar por azogle la plata. "Según la graduación de las quemas y ensayes por menol, se hace ol beneficio por mayor, añadiéndole siempre los bnefieiadores prácticos del día, otra especie cle metal pobre, a que llitman en uso vulgar': chacurrusear.

'or el mucho costo de este beneficio; por la escasez de metales negrillos; y principalmente por falta de inteligencia, son muy pocos los que en esto se emplean, pero me persuarlo que sienpre sacaron algún provecho de su trabajo.

Pocos son, así mismo, los que se ocupan en el beneficio de los relaves de los trapiches, $y$ he vido decir a Don Joaquin Bravo de Bobadilla, Aleulde provincial de esta Villa y el más inteligente azoguero de la Ribura, que su padre fuc el primero que comenzó a beneficiar los relaves, ahora treinta o cuarenta años. Fn el país llaman relaves, aquellas tierras o escorias que se tiran sin mas que el primer beneficio por azogue. Los trapicheros hacen el comercio de esta especie de tierras con los azogueros principales.

Estas tierras o escorias proceden de aquellos metales que sacan los clacechas. Estos van a los trapiches, donde a pocas horas sacan la plata con auxilios del trapichcro. Alli muelen el metal y repasándolo con copagira luego le echan el azogue tocado con estaño o plomo, y a pocas horas io limpian y lavan, quedando toda aquella tierra que llaman relave en una cocha para el trapichero, que hace después venta de ella, a ocho y hasta doce pesos el cajón, scgín se reconocen más o menos apurados. Aun cuando el trapichero compra los metales siempre llevan mal beneficio, porque saliendo la harina demasiado gruesa, el azogue no puede atraer la plata que estuviere on lo interior del cuerpo del relave, respecto de incorporar en sí sola la plata que inmediatamente toca. ${ }^{12}$

I tos azogueros queman estos relaves y echándoles al principio cal y sal, sacan siete u ocho marcos poi cajón. Aunque es constante que en los ingenios grandes se lavan de tres y medio hasta cuatro marcos por cajón de pallacus, y del metal barreteado hasta ocho o nueve, que es muy raro, no debe extrinnarse que de aquejlas tierras ya beneficiadas en los trapiches se saque de siete a ocho marcos por cajón, porque los cleacchas extraen el metal más florido de las vetas a puchos o en poquedades, sin perdonar mina ni labor que según sus conocimientos pteda dejarles utilidad. Por lo mismo de ser metal el más rico del Cerro, sacan ellas el pro- 
vecho que al azoguero no pucde rendirle su trabajo, bien quc, según ostoy bicn informado, los pallacus que producen tres $\mathrm{y}$ medio a cuatro marcos por cajón, y cl metal barretearo de cinco para arriba, ya costean el trabajo del azoguero; falsificándose con esto la relación de Mr. Fresier en su viaje, ${ }^{13}$ de que en Potosí cs menester que el cajón de motal rinda diez marcos de plata para costear el trabajo o pagar los gastos, porcuc, en efecto, si esto fuera así ya se hubiera extinguido la azoguería, por no haber en el día azogucro que lave con esta ley en todà la Ribera.

Este método de beneficio es conforme, en lo más esencial, a los principios que dicta el celebrado "Arte de Mctales" de nuestro Burba; 14 pero, ya sea por falta de beneficiadores inteligentes que practiquen sus avisos, o ya por no habersc procurado remediar los daños que previno el mismo autor, han sidio $y$ son tan notables las cuantiosas sumas de plata que se han perdido y se pierden nasta el dia, que clebe sorgrender sólo este cuidado a un gobierno vigilante y celoso de los intereses del Fstado $\mathrm{y}$ bien de la Patria-

Esto se convence evidentemento con las reflexiones siguientes. E] azogue atrae e incorpora on sí, solo la plata que inmediatamente toca. Como esto no sucede con la que estuviere on lo interior del cuerpo del relave, es menester que se pierda tanto más o menos cuanto el metal fuere más rico y la harina más o menos gruesa. Acabamos de referir cl imperfecto modo de beneficiar en los trapiches, porque allí sólo se lira a sacar en pocas horas la plata según se putede. Estas máquinas según e] mecanismo de su construcción, no pueden sutilizar perfectamente las harinas. Sale por consiguiente gruesa un tanto más que en los ingenios grandes. Así es forzoso que el azogue recoja y se amalgame con los átomos imperceptibles de la plata que se sueltan del cuerpo on que estaban con la sutileza de la harina, quedando la más gruesa sin beneficio y perdida enteramento la plata que en clla se encerpaba; y habićndose oído ya que el metal robado por los ckacchas es el más rico del Cerro, debomos concluir que es y ha sido immensa la cantidad de plata que se ha perdido en esta Villa.

Graduando los relaves de los trapiches por el mismo cálculo que los de ingenios grandes, chseña ma reiterada experiencia, testificada por Barba, ${ }^{15}$ que por lo meros queda en ellos tanto como la sexta parte de lo que se sacó del cajón. Supóngase ahora que los chacchas numca hayan rescatado más de mil marcos semanales, que son los mismos que vendían en el gobiemo del Sr. Santelices (que no es así; porque en los tiempos de riqueza sacarían elios por lo menos un duplo más). Por esta cuerta se deduce que por doscientos años en que se arrojaban los relaves al rio, se perdió en cada uno de ellos 55,944 pesos, que es la sexta parte de los mil marcos semanales, computando el valor de cada uno por 7 pesos corrientes, ascendiendo el total de estas pérdidas, a 11.188.800 pesos co rrientes, en perjuicio ixreparable del Estado y de la Patria.

Todavía es más infausto y espantoso cl desperdicio en los relaves de los ingenios grandes. Ciento noventa años ha que se hace uso de estas máquinas desde que se consumió el metal de fundición; en todo este tiempo no ha podido remediarse el dañosísimo defecto que se nota en la molienda de los metales. I.as almadanetas nunca han podido ni podrán sutilizarlos como convendría, porque en la harina que mueJen no encuentran sujeto o cuerpo bastante en qué puedan hacer toda su ejecución los 
golpes, como lo anota Barba. ${ }^{16}$ Los mazos que obran en aire libre dentro de los morterados, levantan tanto polvo con el impulso, que no podrá sufrirlo quien no esté acostumbrado a respirar dentro de estas oficinas. Con lo más sutil de la harina que se reparte con los golpes, se levanta también una porción considerable de átomos imperceptibles de plata, que se asientan después con el polvo, por su peso natural, en el suelo de las piezas, sin lo que se pega en las paredes y techos. Toda la plata que se evapora en polvo al tiempo de moler y cernir las harinas con la que se pierde en los relaves, calcúlese solamente por una sexta parte de lo que se saca por cajón, según el cómputo de Barba. ${ }^{17}$ Supóngase también que la gruesa de la Ribera sólo ha lendido de parte de los ingenios grandes, 1.500 .000 pesos, que ahora produce al año en su mayor pobreza. Computando pucs la pérdida de la sexta parte de esta suma, salen perdidos 250.000 pesos al año, y llega su total en ciento noventa años, a la increíble suma de 17.500 .000 pesos.

Véase aquí todo lo que se ha llevado ol río de la Ribera de Potosí, sin dejarnos más fruto qưe la confusión de nuestra: indolencia en la aplicación de lo más importante a nuestra felicidad.

\section{NOTICIA SEG U N D A}

Del desperdicio de azogre. $\mathbf{N}$ es menor la pérdida de azogue, que ha procedido de la falta de inteligencia de estos mineros. Es relación generalmente testificada por los autores mâs fidedignos del reino, is que el más práctico beneficiador consume tanto peso de azogue como lo que saca de plata y rara es la vez que no se pierde más. Por lo que supone el célebre mineralogista Bowles, ${ }^{19}$ que es lo más probable que se pierden tantas onzas de azogue como onzas de plata se sacan; conformándose este cómputo a la relación que dejó el Sr. Príncipe de Esquilache, 20 en que asegura "ser" necesario consumit cada año en el beneficio de los metales, mús de seis mil quintales de azogue, porque otros tantos se sacan de plata"; on cuya cuenta fundó su cálculo Don José de Escals, Marqués de Torreverona, 21 para regular quintal por quintal de pérdida.

Tampoco ha habido desquite de la pérdida de azogue en la desazogadora; tanto, que nuestro Barba ${ }^{22}$ llegó a afirmar que en su tiempo, con estar tan bajo el bereficio de los metales en la Villa, importaba sólo en ella, el año que menos, más de treinta mil pesos.

Todos convienen que estas pérdidas consisten en haberse cuidado poco de la materia de que se hacen los cañones y caperuzas para desazogar, y de la poca curiosidad de taparlos por donde se juntan. Formándose estos vasos de barros esponjosos y llenos de poros, se exhala por ellos mismos el vapor del azogue sutilizado con la violencia del fuego; y aun ahora, que por la pobreza de los metales se pone más cuidado en el beneficio de la plata, se experimenta siempre alguna pérdida en la requemadora, que regularmente son dos o tres libras en cada piña. En mucha par- 
te estaría ya remediado este daño, si los cañones y caperuzas de desazogar se hubieran formado del barro de que se hacen los crisoles con las precauciones que aconseja Barba. ${ }^{23}$ Sería tambićn infinitamente menor el consumo del azogue, si antes de incorporar el cajón y proceder a su lava, se practicaran por lo menos dos ensayes por fundición y otro por azogue, en la forma que tan sabiamente previenc el arte ${ }^{2.4}$ y sc atendieran los circunstanciados avisos para cortocer el tiempo y sazón en que se deben lavar los cajones, combinando la estación o temple del tiempo y el temperamento interiox del cobre o caparrosa con los repasos, ${ }^{25}$ porque si se ejecuta la lava sin haber llegado los cajones a este punto (que no es fácil conocerse), se pierde la plata que aun no ha recogillo el azogue, $\mathrm{y}^{\prime}$ si se pasa, se remuele, " 6 quedando sin duda en las lamas y relaves y dentro de los pozos de los buitrones, el azogue que falta en los beneficios, con abundancia de plata; "iT y así se ve hasta el día, que hay muchos con el nombre de caguachiris, que con notorio provecho suyo compran y benefician los relaves y lamas 28 que ha acarreado el agua a su salida de los ingenios. A más de la experiencia con que esto se comprueba en cl hallazgo de azogue trasminado en los buitrones y del que recogen los caguachiris, sirve de eficacísima prueba el desigual consumo del azogue, porque los hábiles beneficiadores pierden menos y otros más, según el grado de su impericia.

\author{
NOTICIA TER C E A
}

Del correspondido de azogutes. $\boldsymbol{D}_{\mathbb{E} \text { esto procede que nunca se ha podido ni }}$ azogue con los marcos de plata beneficiados. En concepto de la importancia de este ramo, se mandó en Real Orden de 2 de sejptiembre de 1784, que en el reparto y distribución del azogue, se guardase aquí la práctica observada en Nueva España, en cuanto a formalizar la cuenta del consumo de este ingrediente, con- respecto a la plata beneficiada. Esto no obstante, informaron los Ministros del Real Banco de San Carlos de esta Villa, en 23 de febrero del año 85 , que ese punto nunea podía afijarse con certeza en estas partes, así porgue los metales son de diversa naturaleza que los de México, como por la impericia que se cxperimenta en la mayor parte de los beneficiadores. A este efecto, hacen relación de varios experimentos que el Sr. Don Jorge Escovedo, siendo Gobernador, mandó hacer en tres ingenios, el año de 1780, para el arreglo de esta correspondencia; y aunque resultó que 292 libvas de azogue consumidas rindieron 398 mareos cinco onzas de plata, en piñas, que viene a corlesponder a cada 100 libras de este ingrediente, 136 y medio marcos en pina; con todo, formando sus cálculos según sus fundadas experiencias, opinaron que 100 libras de azogue rendirán como 120 o 130 marcos de plata.

Todo esto convence que ahora se pierde más azogue que antes, y que en México se consume menos que aquí, porque según el testimonio 
de Barba, 29 antes sc consumía tanto peso de azogue como lo que se sacaba de plata; y por lo que testifica Bowles, ${ }^{30}$ en México se pierden tantas onzas de azogue como onzas de plata se sacan, y por consiguiente, 100 libras de azogue dan el correspondido de 200 marcos de plata, para igualar un peso con otro.

Estat materia, por lo gue hemos visto, es de las más inciertas de la metalurgia de Eotosí. De aquí proviene tanta variedad en el cómputo de la correspondencia y no es capaz de formar juicio seguro por lo que diecn los autores, ni es absolutamente cierto lo que añade Valenzuela, 3 sobre que se benefician 150 marcos de plata con cada quintal de azogue, que son 100 libras.

Como on al Banco se reparte el auxilio de azogues según la correspondencia de las platas que se han rescatado, piensan muchos que es sobrecargar la azoguería con una providoncia infructuosa, suponiendo que su único objeto es preceaver en las fuentes el extravio de la plata sin quintar; pero siendo cierto que la eenomía del Gobierno debe cuidar el adelantamjento de la mincría, como ramo del comercio y objeto de la Hacienda, son justisimas lodas estas prevenciones para que ahorrándose en lo posible las pérdidas, esa plata más circule en cl Estado, para vivificar el comercio y la industria.

\author{
NOTICIA C UA R T A
}

Arbitrios para mejorar el be-
neficio y evitar el despexdicio
de azogue.

$\mathbf{E}$ STOS nobles objetos, a mi juicio, pueden conseguirse sin mucho retardo, celando el Gobierno que no sean admitidos por beneficiadores hombres imperitos sin examen y sin liecencia de la autoridad pública, para que entrando con conocimiento de sus obligaciones, impida los notables desperdicios de azogue que causan las lavas do los cajones sin tiempo ni razón, y el desazogamiento de las piñas. No se evitarían pocos daños si el Cobiemo, al tiempo de la visita de los ingenios, hiciese un reconocimiento prolijo de las retortas o vasos de clesazogar, multando al azoguero quo no los tuviese de la materia más propia pảra el efecto, según el consejo del práctico Barba. Ni sería menos conveniente que los buitrones se formasen de piedras euadradas bien unidas y argamasadas sus junturas, para impedir la trasminación del azogue; pites, siendo el empedrado de los más como el de las calles, formado de unas piedras de figura oval, fácilmente sc introduce el azogue por Ios espacios o huecos que median entre las piedras. Cuidado en realidad no impertinente, cuando para estorbar los desperdicios del mosto, vemos que donde hay cultura y aplicación a la industria, se forman los lagares con toda esta prolijidad.

Debe aplicarse este mismo celo reconociendo, al visitar los ingenios, si las telas de los cedazos de cernir están demasiado ralas, prohibiendo enteramente su uso, porque aquella harina gruesa o relave que sale por ellas, es un conocido desperdicio de lá plata que encierra en su 
interior y que el azogue no puede atraer no tocándole inmediatamente. Así mismo podrá remediarse mucho cubriendo las soleras con cajones de madera o cueros, a manera de pabellones que suban dos varas para arriba, con sus agujeros por donde se pueda mover el brazo de la almadaneta, para que el inmenso polvo que se levanta con los golpes, quede allí encerrado sin evaporarse como ahora sucede, y cuando esto no se ejecute, a lo menos se cuide cada año que del piso de las piezas donde se muele, se excave una cuarta de tierra $y$ barran bien los techos y paredes, y se mande beneficiar estas barreduras no ropasadas en el mismo método que ahora se benefician las tierras de la Casa de Moneda, con tanta utilidad por medio de los ingenios por sutil, que ya hay algunos en la libera.

Con esta diligencia y con celar vigilantemente que no se muelan metales mojados, por ser los que más resisten at reducirse en harina sutil, que es de donde se saca el provecho, estoy scguro que al cabo del año, se sacaría una sexta o séptima parte mx́s de plata que ahora se pierde sin provecho, porque juntos estos muchos poquitos que nos parecen de ninguna consideración, harian al cabo del año una gruesa grande de caudal. La misma naturaleza nos enseña esta economia, formando a nutestra vista grandes ríos de pequeños i imperceptibles vapores que se han exhalado de la tierra, y debemos creer que los infinitos átomos de plata que se han desprendido en los pisos de los ingenios con la exhalación del polvo más sutil, habrén formado todos sus stielos de plata; y yo me contentaría para ser rico con que me cediesen aquellas tierras o barreduras.

Es digno de remedio otro daño, no pequeño, que se experimenta en la ley de las platas, porque deshaciénclose en menudísimas partículas el cobre y estaño de que son hechas las almadanetas, se incorporan con la demás harina y amalgamándose todo junto con cl azogue, hace bajar la ley de las platas, de suerte que habiendo sido las de mejor y subida ley estas de nuestro Cerro, apenas llegan en el día a la ley de once dineros y veinte granos, cuando antes elan de veintidos; y lo pcor es que estando dispuestos que por cada grano que baje de los veinte, se cobre al azoguero $8 \mathrm{y} 1 / 4$ maravedises, siente la azoguería este perjuicio que ella misma se lo causa. De esta mezcla procede la dificultad y gastos de afinaciones en la Casa de Moneda; y para evitarlo, no debería permitirse que ninguno hiciese uso de almadanetas que no estuviesen bien reconocidas por dos prácticos ensayadores, cl uno de la Caja Real y otro de la Moneda, para que se prohibiese enteramente cl trabajo con las que tuviusen mucha mezcla y saturación de plomo o estaño, que aumentándose para ser más dúctil el cobrc, se le quita mucha parte de su consistencia y empeora la plata para la afinación.

1.-- Barba: Lib. 2", Cap. 1".

2.- Barba: Lib. $2^{\circ}$, Caj. $2^{\circ}$.

3.- Acosta: IJistoria Indiana, Lib. 4" Cap. 1".- Garcilaso: Primera Parte. I.ib. 5", Cap. $7^{\circ}$; y Seg'unda Parte. Lib. $8^{\circ}$, Cap. 25.

4.- Acosta: Lib. 4\%, Cap. 9"; y Garcilaso: Primera Parte. Lit.. 8", Cap. 25.

(a) En quichua: suruchij, que hiace chorrear. (N. de E.).

5.- Garcilaso: Primera Parte. Jib. $8^{\circ}$, Cap. 24.

6.- Acosta: Lib. $4^{\circ}$, Cap. $5^{\circ}$ y $6^{\circ}$.- Garcilaso: Primera Parte. Lib. $8^{\circ}$, Cap. 24.-Gazofilacio: Lib. 1\%, Cap. 45, $N^{\circ} 3$, fol, 169.

7.- Garcilaso: Primera Paxte. Lib. 8, Cap. 25.- Acosta: Lib. $4^{\circ}$, Cap. 11.

8.- Acosta: Lib. 4", Cap. 12.- El Sr. Solórzano, en su "Politica". Tom. 2", Lib. 6", 
Cap. $2^{\circ}, \mathrm{N}^{\circ} 18$, fol. 433 , refiere el mismo método de beneficio que queda dicho, citando al mencionado historiador Acosta.

9.- Escalona: en su Gazofilacio. Lib. $1^{\circ}$, Cap. 45, $\mathrm{N}^{\mathrm{a}} 29$, fol. 177.

10,-Acosta: Lib. $4^{\circ}$, Cap. $7^{\circ}$.

(b) Este es el método que practican los bencficiadores del paf́s. (Nota de la com pia de Sevilla).

11. - Barba: Lib. $2^{\circ}$, Cap. $4 \%$, al fin.

12.-Barba: Lib. 2\%, Cap. 6\%, fol. 42.

13. - M. Fresier: Relación del Viaje de la Mar del Sur; fol. 141; en el Cap. "Del Modo de hacer las pinas".

14.- Barba: Lib. $2^{\circ}$, por todo ćl.

15. - Barba: Lib. $2^{\circ}$, Cap. $6^{\circ}$.

16.- Barba: Lib. 2", Cap. $6^{\circ}$.

17.-.m Ibidem.

18.- Barba: Lib. 1", Cap. 33; Lib. 2", Cap. 21.- Ulloa, en su "Viaje"; Lib. 1", Cap. 13. Tom, 3", fol. 197, N". 341 .

19.- Bowles: IListoria Natural de España, fol. 25.

20.- Esta relación se cita por Escalona en el Gazofilacio; Lib. 19, Cap. 14, N $^{\circ} 7$.

21. - Marqués de Torreveroma, en papel que imprimió el año de 1700.

22.-Barba: Lib. 2\%, Cap. 23.

23.--- Ibidem.

24.- Barba: Lib. $2^{\circ}$, Cap. 12 y 20.

25.- Barba: I.ib. 20 , Cap. 20.

26. - Ibidem.

27.- Barba: I,ib. 2", Cap. 21.

28.- Loco citato.

29.- Barba: Lib. 1", Cap, 33, y Lib. 2", Cap. 21.

30.- Bowles: fol. 25.

31. - En la adición al Sr. Solórzano; Lib. $6^{\circ}$, Cap. $2^{\circ}, \mathrm{N}^{\circ} 45$ del sumario. 



\title{
CAPITULO CUARTO
}

\author{
Minerales de Azogue y su Comercio \\ Del azogue, de la diversidad de sus precios, y de la mano y método de \\ su distribución.
}

\author{
NOTICIA PRIMERA
}

$\begin{array}{cl}\text { De la invención del beneficio } & \text { TABIENDOSE apuntado el beneficio de } \\ \text { por azogue. } & \text { la plata por amalgame con el azogue, no se- } \\ \text { rá inconducente referir el tiempo de su des- }\end{array}$ cubrimiento y el autor de esta feliz invención.

Segưn el célebro mineralogista Bowles, 1 es preciso confesar que los españoles han sido los inventores de esta especie de beneficio. E1 Sr. Solórzano y el viajero D. Antonio Uhoa, "2 citan por autor a Pedra.Fernándoz de $\mathrm{Velasco}$, quien habiendo aprendido este beneficio en Nueva España, donde se practicaba ya por enseñanza de ta misma naturaleza, ${ }^{3}$ vino a lima el año de 1569 , siendo Virrey D. Francisco de Toledo, y prometió cnseñar este beneficio y hecha la prueba con buen suceso el año de 1571 en Potosí, se comenzó este beneficio con azogues traíclos de Huancavelica. Yo me persuado que hay alguna equivocación en cuanto al tiempo en que vino a Lima Pedro Frernández de Velasco, porque en Cédula de Madrid, a 28 de dicicmbre de 1568, consta haberse ordenado en ella al Sr, Virrey Toledo, que mandase repetir las experiencias sobre el beneficio de la plata por azogue; con cuya providencia se acredita que por lo menos dos años antes del de 1569, se había tratado este asunto, y es regular cque la propuesta se hubiese hecho desde entonces por el citado Velasco, una vez que éste fue quien enseñó el nuevo beneficio y quien se lle- 
vó el premio de 400.000 pesos que por ello se le dieron, mitad de la Real Hacienda y la otra mitad del caudal de los azogueros.

\section{NOT I C I A SEG UN D A} Descubrimiento de las minas
de Huancavelica.
Tista invención tuvo su mayor fomento con las célebres minas de azogue que descubrió un portugués llamado Enrique Garcés $(C$

gobernando el Perú el Licenciado López García de Castro, que son lís que llaman de Palcas, en términos de la ciudad de Guamanga, según el Sr." Solórzano; 4 aunque Ulloa 5 supone hecho en Patas, que es Corregimiento del Obispado de Trujillo. Poco después un indio de Amador Cabrera, llamado Navincopar del pueblo de Acoria, descubrió allí cerca las que hoy llaman de Huancavelica; ${ }^{6}$ para cuya labov' se asignaron 620 indios de Mita en nueve provincias de las más cercanas, según el ilustrador Valenzuela. 7

NOTICIA TER C E R A

Minerales que han proveído de azogue a Potosí.
D ESDE aqual tiempo se comenzó a proveer el asiento de Potosí de azogues conducidos de las minas de Huancavelica, y de ellas

mismas se surtieron todos los minerales del Perú, por más de dos siglos, en una cantidad prodigiosa de azogue, hasta que habiendo comenzado a decaer el año de 1752, en adelante se transportaron también al Perú los azogues de el Almadén, que antiguamente surtían sólo a las de Mćxico con cinco o seis mil quintales al año, desde cuyo ticmpo se aumentó la saca hasta 18.000 quintales anuales. ${ }^{8}$

Pero siendo las minas del Almadén de tanta antigüedad, que ya hablan de ella muchos autores ${ }^{3}$ de los que vivieron trescientos años antes de Jesucristo, llegó a tan notable decadencia en el curso de los siglos, que el año de 1645, abandonaron esta célebre mina aquellos dos famosos alemanes Ilamados Marco y Cristóbal Fuggan, por no haber podido cumplir la capitulación que hicieron de dar al Rey, al año, 4.500 quintales de mercurio. Desde entonces la mandó el Rey administrar por su cuenta, destinando más de 45.000 árboles para sostener las galerías de la mina, y mediante los hornos de reverbero que estableció D. Juan Alonso Bustamante, Director de esta grande obra. se lograron después los rendimientos que nunca pudieron sacar los alemanes con las retortas de que siempre usaban.

Con todo, no habiendo bastado las cacas de una y otra mina para surtir a ambos reinos del Perú y México, ha contratado nuestra Corte con la Cámara Imperial, para que anualmente nos pongan en Cádiz, cantidad de azogues para proveer los Reales Almacenes de estos Reinos, con los precisos repuestos de este ingrediente. (a)

Con esto se ha verificado el sabio pronóstico del mineralogista 
Bowles, ${ }^{10}$ sobre que legaría caso de escasear notablemente así las minas del Almadén cono las de Huancavelica, aconsejando que convendría mucho buscar con tiempo otras minas de qué surtirnos, supuesto que en todo el mundo no se conoceu más minas de azogue que las de Carinthia en Alemania, de Huancavelica en el Perú, del Almadén en España ${ }^{11}$ y de Triulí en Hungria ${ }^{12}$ fuera de la Hydria que es la principal.

Del mismo modo se ve fallida la conjetura que hizo el $\mathrm{Sr}$. Solórzano, ${ }^{13}$ de que llevándose buena cuenta con las de Huancavelica, podía dar azogues a todas las lndias, pues, por fundado que fuese su cálculo en aquellos tiempos, ya en estos últimos se ha conocido la decadencia de aquel mineral, hastn obligarmos a traer azogues de Alemania, según se na dicho, como of mismo Sr. Solomano ${ }^{14}$ testifica haberse practicado otras veces.

\section{NOTIOIA OUARTA}

De varios minerales de azo- $\mathbf{W}$ STA escasez se experimenta, no porque gue en el Perú. carezcamos de ricas minas de azogue ell nuestra América, sino por haber'se mandado cerrar algunas de bastante abundancia, con el objeto que no quedando otras en estos kcinos que los de Huancavelica, se evitara por este medio el fraude que se reconocía en los quintos.

Por esta razón se mandó cerrar un mineral xico de azogue, en el Corregimiento de Cuenca, jurjsolicción del reino de Quito, asegurando nuestro viajero Ullou, ${ }^{3 i}$ que en tiempos pasados se sacaba de él mucho azogue para el beneficio de aquellas minas; y si bien se logró cortar el fraude con cerrarlas, añade que esta misma providencia contribuyó en parte a la notable decadencia que se ha experimentado en las labores de minas de plata en toda la provincia de Quito.

Gamboa ${ }^{16}$ refiere muy por monor otras muchas minas de azogue descubiertas en Chilapo, Cerros del Carro, Picacho y otros lugares de México citando diferentes juntas celebradas para el trabajo de ellas y experimentos de su calidad.

Nuestro Barba 17 testifica haber minas de azogue en Challactiri, cuatro leguas de esta Villa; y que habiéndose traído de Huarina y Moromoro jicas piedras de azogue, no se logró su beneficio, por la muerte violenta y sospechosa de quien trataba de descubrir la mina que ha quedado oculta hasta hoy, y yo he visto una real provisión de 27 de junio de 1595 en que la Audiencia de Charcas mandó a los Oficiales Reales de Potosí, a pedimento del Fiscal, que por sí, o por apoderado tomasen posesión de las minas de azogue, (excepto la Descubridora) que Juan de Aguilar había registrado ante el Presidente Don Juan López de Zepeda, en el pucblo de San Marcos de Miraflores, Partido de Chayanta, suponiéndose de mucha riqueza.

Si torlas las minas referidas, sc buscaran, descubrieran y beneficiaran, según el permiso de las leyes y órdenes del Reino ${ }^{18}$ no tendríamos necesidad de ocurrir por este ingrediente a reinos extranjeros, $y$ como dice Ulloa ${ }^{19}$ entrando en examen del inconveniente de los fraudes, sería fácil encontrar remedio para aprovecharse de sus riquezas, sin el 
temor que obliga expedir aquella providencia. Abtudaria en nuestros países la plata, a proporción del azogue y resucitaría en nuestro siglo aquella feliz abundancia que hizo envidiable nuestra fortuna a todas las naciones dol mundo: Entonces florecería igualmente la azoguería, vendiéndose el azogue, por sólo una cuarta o quinta parte de lo que hoy le cues-

- ta. Por lo tocante a México, calcula Gamboa ${ }^{20}$ que trabajándose aquellas Minas, podría venderse cada quintal de azogue a trece o quince pesos, ahorrándose el exceso, que va hasta ochenta y dos pesos, cinco tomines $y$ nueve granos del cuño mexicano, que es el precio que para allí tasa y prefine la ley ${ }^{21}$ como correspondiente a los sesenta ducados, que con su valor principal, fletes y otros gastos, montaba el quintal de azogue del Almadén. 22

\section{NOTICIA Q U I N T A}

Se refiere históricamente los
diversos precios del azogue, y
otras graves contestaciones so-
bre este asunto.

$\mathbf{E}$ $\mathrm{N}$ el Perí, nunca se ha prefinido precio cierto a los azogues por las loyes. Pero el Senor Virrey Toledo, al principio del descubrimiento del nuevo bonelicio por amalgame mancló vender cada quintal de azogue, a ochenta y cuatro pesos dos tomines ensayados, que hacen corrientes, ciento treinta y dos pesos medio real. En otra provisión del mismo señor, de 15 de janio de 1598, he visto que ordenó, bajo la pena de perdimiento de bienes y destierro, que ninguno vendiese àogues a más precio de ochenta y cinco pesos ensayados, ni se permijtiesen levendedores en esta especie. $Y$ es el caso que en aquellos primeros tievupos, los particulares conducían azogues de su cuenta con licencias, fuera de las cantidades, a que estaban obligados por sus arrendamientos, bajo la calidad de cobrárscles el dos y medio por ciento de la entradá en el puerto de Pisco, y cl cinco en esta Villa, como se previene en provisión dada en Lima a 18 de mayo de 1576, por el citado Scñor Virrey, y por usto sc los tasó el precio a que debían venderlos, prohibiéndose las reventas, por segunda o tercera mano.

Ultimamente por varias cédulas, despachadas desde 1601 y recopiladas en la ley $3^{a}$ tít $15 \mathrm{Lib}^{\prime} 6$ de Indias, se mandó dar el azogue, que se vendiere por cuenta del Rey, a los mineros, al precio y costo, que tuviere cada quintal, puesto en Potosi, y demás asientos de minas, librándose para esta Villa cédula particular, su fecha en Alanjuez a 26 de mayo de 1609, archivada en la olicina de Real Hacionda en que se renovó la disposición que queda citada.

En consecuencia de ella solicitó esta Azoguería la correspondiente liquidación, que se hizo por el tribunal de chentas de Lima de mandato del Señor Virrey Conde de Chinchón, saliendo el precio de cada quintal, puesto en Potosí, con su costo, y costos, a sesenta y cuatro pesos ensayados en barra, que hacen ciento cinco pesos, siete reales corrientes, a cuyo precio se mandó vender, desde 7 de febrero de 1631 pagándolo de contado: en que se les hizo la rebaja de seis pesos que van hasta setenta pesos ensayados, que por entonces valía cada quintal.

Gobernando el Señor Virrey Marqués de Mancera, se adicionó por los azogueros esta liquidación, y en otra nueva que se hizo por el mismo tribunal de orden del citado Señor Virrey, pareció que el precio de cada 
quintal, puesto en los almacones de esta Villa con su costo, y costas, era el de cincuenta $y$ ocho pesos, cinco tomines y ocho granos ensayados en barra; de cuatrocientos cincuenta maravedies que hacen noventa y siete pesos un leal corrientos, a cuyo cómputo se hizo su expendio, desde fin de diciembir de 3645 , hasta nueve de abril de 1655 .

Conseguida esta rebaja protendieron los azogueros, que al respecto de clla se les debia cargar el precio del azogue desde el 26 de mayo de 1609 , en que S. M. les hizo la merced, y que se les volviese el exceso que habiar pagado de más, o por lo menos se les compensase en lo que debían al Rey, de resto de los azogues que se les fíc hasta fin del año de 1630; en efecto se suspendio la cobranza de estos restos, mientras S. M. a quien se dio cuenta, ordenaso otra cosa. Sucesivamente se despacharon varias Cédulas 2: a los Señores Virreyes, Conde de Salvatierra, Alba de Liste, Santi-Lstcban y Duque de la Palata, con más otra ${ }^{24}$ a don Francisco Nestares Marín, Presidente y Visitador de la Real Audiencia de Charcas, Cajas Reales y Casa de Moneda de esta Villa, concediendo a la azogueria esperas limitadas de los débitos de azogues fiados; hasta que por otra Códula posterior ${ }^{25}$ se cometió el ajustamiento y conclusión de este negocio a don Pedro Luis Enríquez, Conde de Canillas, que entonces era Corregidor de esta Villa y Visitador de sus Reales Cajas.

Para afinar el exceso en el precio de los azogues, se formó nuevo ajuste, que salicndo en torlo arreglado a la segunda liquidación del Tribunal de Cuentas, en que se estimó por legítimo y justo el precio de 97 pesos 1 real corvientes, se abonó a los azogueros todo el exceso que se les había cargado de más. Con lo que salicron alcanzando a la Real Hacienda muchos de los azogueros, otros con restos cortísimos, y utilizado el fisco con la remisión gratuita que algunos de ellos le hicieron de sus a!cances.

No obstante de haberse jecutoriado este precio en el expresado ajustamiento final, advirtiendo el Conde de Canillas, que el Visitador D. Francisco Nestares había subido el precio de los azogues en el año de 1655, de 97 pesos 1 real, hasta 102 pesos 5 reales, corrichtes, para asegurar con los 5 pesos 4 reales, que van de exceso cualquiera deuda que contrajese el gremio con la Real Hacienda en lo futuro, por la necesidad que había de fiarle mucha parte de azogues, sin más seguro que la mancomunidad del Gremio, (b) se conformó desto luego el citado Conde de Canillas con este arbitrio, tomando igual determinación, annque para clla no tuvo orden especial ni otro motivo más que una Cédula despachada a don Diego Portugal, siendo Prosidente de Charcas, ${ }^{26}$ donde S. M. aprobó por más a propósito para cobrar con suavidad los reagros de azogues, el medio de acrocentar sobre el precio corriente de cada quintal, algún exceso más que también se pagase de contado.

El débito de 118.095 pesos 1 ral que rosultó de estas liquidaciones, contra los ingenios que tenín repartimiento de indios, se transigió con los azogueros por el Conde, en que lo pagasen en diez años, la décima en cada uno; con cuyo arbitrio aprobado por el Sr. Virrey, se habían pagado dos décimas partcs hasta d año de 1695 , como se reficre en RcaJ Cédula de Mradrid, a 31 de diciembre de 1704, cometiéndose por ella misma a Dr. Clemente Durana, y por su defecto a Dn. Diego Hidalgo, oidores de Charcas, la facultad de hacer iguales transacciones. Así lo verifico, remitiendo y condonando creciclos alcances que se habian deduei- 
do contra varios ingenios, que por no haberles cabido repartimiento de indios de Mita se mandaron arruinar y demoles.

Posteriormente, representó ei Gremio de Azogueros sus considerables atrasos por la disininución de la Mita en la peste grande del año de 1721, y por las ruinas de los ingenios, solicitando el abono del exceso que se les había llevado en el precio de los azogues. El Rey les mandó admitir en cuenta de pago el exceso que justificase el Gromio con intervención del Fiscal de Charcas, despachando a este efecto para dicho Tribunal y para el Sr. Virrey del Perú, Cédula Real con fecha en Al'anjuez a 13 de junio de 1724 ; cuyas diligencias no se han solemnizado hasta ahora, sin embargo que a otra nueva instancia de la Azoguería proveyó el Tribunal de Cuentas de Lima, en 14 de diciembre de 1763, que usase de su derecho con arreglo a la citada Real Cédula.

Por estas causas corrió siempr'c el precio del azogue a los 102 pesos 5 reales susodichos, hasta el día 20 de agosto de 1744 , en que se publicó la rebaja a 99 pesos 1 real, en conformidad del concierto que hizo con el asentista de Huancavelica, el Sr. Dri. Jeiónimo de Sola, Gobernador de aquella Villa y Superintendente Gencral del Rarno de Azogues; cuyo Auto proveído en 27 de mayo de 1744, es como sigue: "Habiendo visto los Informes antecedentes, mando que los Oficiales Reales de la Real Caja de Potosí, que ahora y en el ínterin no haya novedad en el asiento del trajín de azogues, vendan a los azogneros de aquella Ribera y a los demás mineros de su jurjsdicción, el quintal de azogue a 99 pesos 1 real, respecto de que además de los azogues que se expresan en el Informe antecedente, hay la especial de no poderse dar punto fijo en la rebaja de Badanas y Cordeles, pues estos mudan de precios con continuación, cuyo establecimiento empezará a correr desde el dia que se haga saber a los dichos azogueros la resolución de S. M., y este Auto se emprotocolará para que siempre conste la determinación, ctc.".

A este precio corrieron loa azogies hasta el mes de noviembre de 1779 , en que se comenzaron a vender a 73 pesos 3 reales, en virtud de superior orden del Sr. Visitador General D. José Antonio Areche, su fecha en Lima, a 17 de septiembre del citado año 79, por la que al mismo tiempo abolió la injusta gratificación de 2 reales por quintal que pagaban tos azogueros, con título de emolumentos, al Oficial Mayor Balanzario y Portero mayor de las Cajas; y duró el expendio en este pic hasta enero de $\mathbf{1 7 8 3 .}$

Desde enero de 1783 hasta abril de 1784 , a 99 pesos 6 reales, en virtud de orden del Sr. Visitador General D. Jorge Escovedo, su fecha en Lima, 25 de noviembre de 1782 , con motivo de la ruina padecida en las minas de Huancavelica.

Desde abril de 1784 hasta junjo de 1787, a 60 pesos, en virtud de Real Orden de 10 de noviembre de 1783 indistintamente, sean los azogues del Almadén que vienen por la vía de Buenos Aires, o de Huancavelica por la de Lima.

De junío deI 87 en adelante, a 71 pesos cada quintal. Pues, aunque por Real Orden de 24 de agosto de 1786 , se mandó que los azogues de Alemania se vendan a 80 pesos y los demás a 60 como antes, se ha tenido por. conveniente prorratear los valores y reducirlos al precio fijo y común de 71 pesos, para evitar confusiones y todo desorden, en virtud de Providencia del Superintendente General Subdelegado de Buenos Aires. 


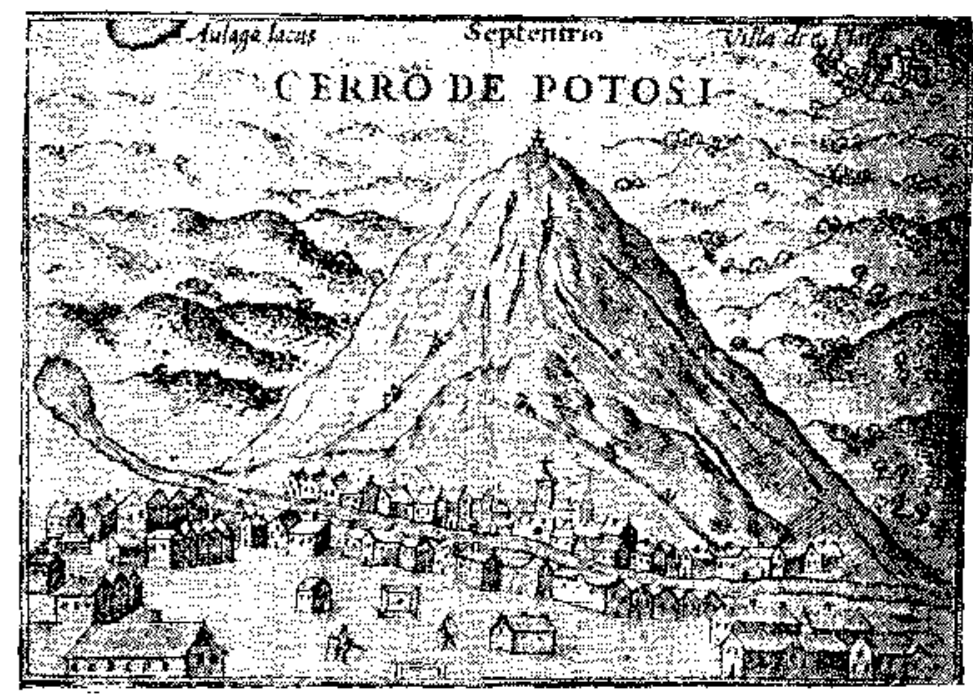

Plano del Cerro de Potosí y de las primeras edificaciones te Ia futura Villa Imperial. Grabado de Jodocus Hondius (15631611) que se publicó por primera vez en el famoso ATLAS de Pedro Bertius (1565-1629). 


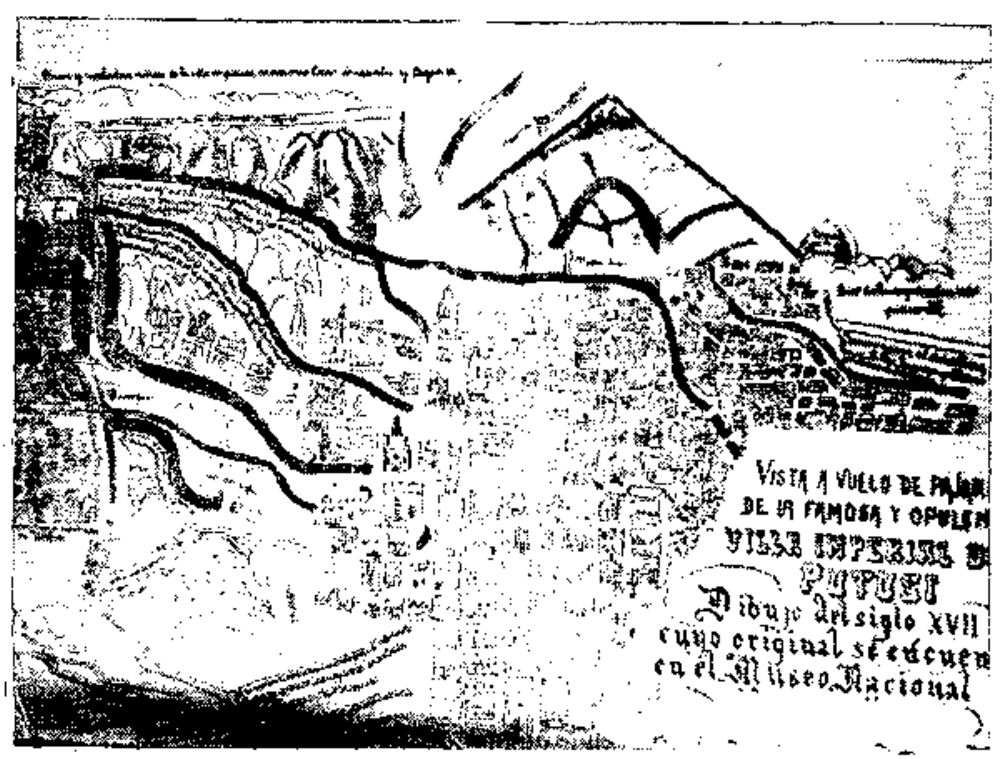

"Breve y verdadero retrato de la Villa Imperial de este rico Cerro, Arrabales y Lagunas".

(Dibujo del siglo XVII). 


\section{NOTICIA SEXTA}

De las diversas manos que han
administrado los azogues. disposición do lns leyes del a tonio Areche, encargó este tos, fesce el mes de noviombre de 1779 , Ministros del Banco de Resca 17 de septiembre del mismo; y aunque el Art. 136 de la Real Ordenanza de Interdontes, del año de 1782, mandó guardar las leyes que confiaron a los Oficiales Reales el cuidado de esteramo, se revocó después por la adición 12 do la misma Orclenanza, manteniendo a los Ministros del Banco, en là Acministración que ya tenítn de los azogues.

Con esta mudanza de manos se ha variado también demasiado el antigio método do su administración. Nuestro célebre Escalona $2 \%$ refiere gue la voluntaria, incauta $y$ tumultuaria distribución que hacían del azogue al fiado los Oficiales Reales, hizo subir cl alcance de las deudas de este genero, hasta $\mathrm{el}$ año de 1629 , a 1.811 .459 pcsos, 5 tomines y 2 granos cnsayados, sin probable csperanza de recupcración. De este abuso pro cedieron muchas oficacos y reiteradas providencias, para que las ventas se hicieran al contado, sin embargo de la contraria costumbre que alegó la Azoguería, por los sólidos y justos motivos que representó al Sr. Virrey Concle de Chinchón, el Sr. D. Juan de Carvajal y Sande, Visitador Goneral do la R. A. de Charcas, on un circunstanciado informe, donde hace la historia, bien que concisa, muy prolija y puntual de este negocio. ${ }^{29}$

Sin embargo de estas órdenes y diferentes Cédulas Reales despachadas 30 para que el azogue se vandiese de contado, permitió el Sr. Virrey Conde de Chinchón, a los Oficiales Reales de Potosí, que pudieran distribuír anualmente, al fiado bajo de idóneas fianzas, dos mil quintales de azoguc; y aunque al año siguiente se repitió la prohibición, tomó por mejor partido el Sr. Presidente Don Juan de Lizarazu, de descerrajar las Cajas Reales y distribuír a los mineros mil quintales al fiado, con tan buen suceso, que se cubrió todo el crédito fiscal, sin quiebra de medio reat.

El Rey, atendiendo a la imposibilidad de hacerse al contado todas las ventas, permitió por dos Leyes Reales, ${ }^{31}$ que en el Perú se dé la mitad del azogue al contado y la otra al fiado, con los plazos más breves y con buenas fianzas.

Consecuentes a esto se libraron varias provisiones por los Sres. Virreyes Marqués de Guadalcázar y Conde de Chinchón, 32 previniendo que el azogue que se vendiere a los arrendarlores de minas e ingenios, sea pagando a S. M. el tercio de su valor al contado, en lugar de la mitad; y que en cuanto a los azogueros y mineros propietarios, que no tienen arrendadas sus haciendas y benefician por sus personas las minas e ingenios, se procure que del primer azogue que se les repartiere después del despacho de armada de cada año, esté cobrado para el segundo repartimiento, conforme a la obligación que hacen cuando lo reciben.

No es así ahora, porque el plazo de un año que se daba en tiempo de los Oficiales Reales a los azogueros de esta Villa y a los de afuera, a 
pagar por Cartas Cuentas, esto es, en los ticmpos más antiguos, desde abril a abril, y en los últimos, desde enero a nnero, mandó el señor Visitador General Areche, fisese de seis meses. Conforme a esta orden y a las Ordenareas del Panco, so auxilia por lo regular con mil libras de azogue por cada cabeza de ingenio, con cargo de presentar otros tantos marcos de plata en piña.

Los de Potosí, a excejción de pocos, pagan por sumanas, de las mismas piñas que rescatan, hipotecunclo para seguridad del débito, los enseres de los ingenios que poseen en propiedad o ch arrendamiento; y los de afuera, satisfacen cumplido el piazo, asegurando el auxilio con un fiador mancomunado, a satisfacción de los itinistros de Banco.

Con este método ya no se experimentan las crecidas sumas de rezagos que antiguamente causaban las deudas de azogues, porque repartiéndose a los azogueros las cantidades correspondientes al rescate cle sus platas, no tienen lugar a revender al fiado, cono antes lo hacían, con la ambición de pagar su costo con la ganancia del fiado, quedándoles libre su valor principal sin aplicar su industria, ni otro trabajo alguno; y sucedia perderlo todo, recargándose a más tiempo de más deudas, en su perjuicio y del Rey. Así se ve que desde el año do $169 \gamma^{\prime}$ hasta 1705, estaban debiendo los ingenios, por razón de azogues, 242.882 pesos; 33 y en el mes de diciembre de $\mathrm{1762}$, habiéndose liquidado todas las deudas antiguas, causadas desde las resultas del Concle de Canillas en el año de 1686, hasta 1720, quedaron on 255.588 pesos; y desde 1747 hasta 1761 , por deudas modernas, 34.668 pesos, 34 cuyos débitos antiguos quedaron reducidos en fin de diciembre de 1774 , en la cantidad de 110.111 pesos 4 y $1 / 2$ reales; y los modernos en 2.297 pesos 4 y $1 / 2$ reales, 35 a cuya cuenta es muy poco o nada lo que se debe en el día.

\section{NOTICIA SEPTI M A}

\section{Del Asiento, del Trájín y con- ducción de azogues.}

$\mathbf{N}$ los precios y condiciones con que se remataba el Asiento y Real Trajín de azogucs, y el estado en que hoy se halla esta materia, con algunas reflexiones sobre el modo más conveniente y útil a la Real Hacienda, en que puede verificarse la conducción de este efecto.

En el siglo pasado, regularmente se hacían estos remates entre los Oficiales Reales de Potosí, con aprobación del Sr. Virrey, por ser estas las Cajas donde debían conducirse, y porque aquí mismo era donde debía formarse el cargo a los azogueros fiadores del conductor, en caso de no cumplír su contrata, que es lo mismo que se practica hasta ahora con los oficios, rematándose en el lugar donde se han de servir, con aprobación del Sr. Virrey o de la Junta Superior de Hacienda, según la nueva Ordenanza de Intendentes. Pero hallándose ejemplares antiguos de haberse rematado en Lima estos Trajines o A sientos, ell los años de 1616 y 1756, se ejecutó lo mismo en el primer Asiento de la conducción de azogues y caudales del Virreinato del Río de la Plata, subastándose en Bucnos Aires, a 11 de agosto de 1779 , con la calidad de pagársele ocho pesos por cada quintal hasta Potosî, siendo de su cuenta los retobos y la conducción de caudales de Potosí a Buenos Aircs, con el premio del 1\%. De Chuquisaca 
y Oruro a Potosí, de 1 y $1 / 2$ roales \%. Kos de Cochabamba, Carangas, Ia Paz, y Chucuito y los de Carabaya, por $7 \mathrm{y} 1 / 2$ reales $\%$, bajo las fianzas de 200.000 pesos, a satisfacción de los Oficiales Reales de Potosí. Después, en 6 de junio de 1783 , se aumenti el flete de 8 pesos hasta 14 por quintal, con el $2 \%$ r de rofacción a su favor, con motivo de un ajustamiento provisional cue se hizo con el Asmontista, para la conducción de azogues desde esta Villa a las Cajas de Oruro, Carangas, Ia $\mathrm{Pa}$ y Chueuito.

El Excmo. S1. Gálvez, como Simperintendente General de este ramo, declaró en providentéta dada en San Jorenzo, a 16 de octubre de 1784 , que las contratas otorgadas por a asentista Romero, on 11 de agosto de 1779 y 6 de junio de $178 \%$, diesen principio en $1^{\circ}$ de enero de 1784 , y dulasen cinco años átiles, conforme lo tenía resuelto en 18 de agosto del 84 , poro con la calidad precisa que se conduzean de Buenos Aires a Potosí los azogues por 11 pesos cada quintal y sin innovar el precio de la conduceion de caudales del situado ni el asiento provisional para transportar los azogues desde Potusí a Chucuito, La Paz, Carangas y Oruro; par ra lo cual nombró el Asentista General un apoderado en Potosí, que ejeculase estas conducciones a dichas Cajas, con aprobación de la Superintendencia de Buenos Aires en julio del 85 bajo de fianzas que debían recibir a su satisfacción estos Ministros principales de Real Hacienda.

Esta contrata, aunque no sea demasiado lucrativa al Rcy, es más ventajosa que otras en cuanto a los fletes; porque la que se celebró en Lima, a 29 de mayo de 1756 , por die\% años, bajo la fianza de sólo 20.000 pesos, señalaba por flete de cada quintal de azogue en bruto, 17 pesos con dos quintos fo refacción descle Huncavelica a Potosí, mediando sólo la distancia de 336 leguas; con que, hallándose más de 500 esta Villa de buenos Aires, es re mayor conveniencia este Asiento por la rebaja de 6 pesos de flete en carla quintal.

Aun es más notable la mejora respecto de los tiempos más antiguos. He visto que a 20 de septiembre de 1616 , se remató en Lima, por orden del Sr. Príncipe de Esunilache, el Trajín de azogues desde el puerto de Arica a Potosí, por el flete de 7 posos 4 reales ensayados, que son 11 pesos 5 reales $y$ $2 / 1$ corrientes; $y$ hasta Oruro por 6 pesos 6 reales también ensayados, que hacen corrientes 9 pesos 6 reales. En otro remate hecho en Potosí, a 9 de marzo de 1624, con aprobación del Sr. Marqués de Guartalcázar, se estipuló pagar 8 pcsos ensayados, que son 12 pesos 4 reales corrientes, bajo la fianza de 20.000 , por el quintal conducido a Potosí desde Arica; y de allí a Oruro, 7 pesos 9 granos y medio ensayados, que hacen 10 pesos 7 y $1 / 2$ reales corrientes, con todo que Arica sólo dista de Potosi 120 leguas, y de Orwro 68 por unos caminos llanos, sim riesgos ni ríos que son los que aumental el trabajo, los cuidados y los costos del Trajín de Buenos Aires hasta esta Villa. (c)

\section{N O T I C I A O C T A V A}

Medios de mejorar el Trajín $\mathbf{P}_{\text {ERO aun así le hacía mucha cuenta al }}$ de los azogues. Rey y al público, por las ventajosas condiciones de los remates. Que es lo que debe atenderse más principalmente que los fletes. Los trajineros estaban obigados entonces a sacar de Arica cada partida de 2.000 quintales, pasados 
setenta y cinco días del recibo de la primera, y de ahí abajo, cada cuarenta días. Debían entregar en Potosí dentro de treinta y cuatro días, y en Oruro dentro de veinticuatro, desde el otorgamiento de la Carta Cuenta y recibo de la partida de azoguc, toda lá gruesa recibida en Arica, sin falta alguna; bajo la pena que pasados tres días más, serían de su cuenta y riesgo los costos, fletes y salarios de los que fuesen enviados por lus Oficiales Reales para aviar las partidas, y de pagar al contado las fallas de azogue que no excedieren de 10 quintales en cada partida, al precio de 70 pesos ensayados, a como los vendía el Rey en aquel tiempo, y de ahí arriba, 200 pesos ensayados, sin perjuicio del castigo que mereciesen los trajineros o sus criados, por el delito de extravio o robo que se Ies justificase. Era tambicn condición el recibir en Aricu los azogues dentro de quince días como surgiese el navio que los condujere, y sacarlos de allí a los cuatro días de su recibo, corriendo desde entonces todos los riesgos el ascntista, aun después de entregados en los Reales Almacenes de Potosí, hasta su total distribución a los azogueros, excepto los casos fortuitos de incendio, ruina, etc.

Los motivos de estas sabias condiciones son bicn notorios, como precisos al buen orden y seguridad de este efecto. Porque estando expuesto a derramarse el azogue rompiéndose las badanas con la humedad de los almacenes, convenía señalar plazo perentorio ell que los trajincros se hiciesen cargo de él, y lo condujesen cuanto antes, corriendo ellos cl riesgo desde el término asignado a su saljda, si era culpable la demora.

Precisados, por otra parte, los trajineros a sacar las partidas de a 2.000 quintales dentro de setenta y cinco días del recibo de la primera, y de ahí abajo, cada cuarenta días, no podían menos que comprar recuas de mulas propias en qué hacer estas conduccioncs, por no ser tácil encontrar siempre a estos plazos arrieros que fletar; $y$ de aquí resultaban dos grandes conveniencias: una al Rey, en la oportuna distribución del azogue, con aumento de los Reales Derechos que causa la abundancia de platas que con él se beneficia, sin el riesgo de derrames dentro de los almacenes con la demora: otra al comercio, porque no teniendo el asentista necesidad de echar mano a las recuas que ocupa el comercio en sus trajines, nunca subirían los fletes con la escasez de arrieros, ni se retardarían las cargazones en los caminos por falta de los avios precisos.

Así mismo, se podía contar siempre de fijo, para tiempo determinado, con toda la partida de azogues que había salido por aquella vez y saliese sucesivamente del puerto de Arica a csta Administración de Potosí, sin que el ramo tuviese que lastrar costo alguno en un caso extraordinario de demorarse los Tuajineros, más tiempo del plazo señalado, porque debían ser de cuenta de éstos los costos de los comisionados, los fletes y avíos de su traída.

No era menos conducente para evitar extravíos $\mathrm{y}$ mala versación de los azogues, el que se entregasen las partidas completas como se habían recibido en Arica, bajo la pena de pagar las fallas que pasasen de diez quintales, al exhorbitante precio de 200 pesos ensayados, porque con esta cautela se aseguraba que el asentista no vendiese azogues en los caminos a los mineros necesitados, o a otros particulares que los negocian para extraviar las platas que sacan defraudando los diezmos y otros Derechos Reales; pues no pudiendo hacerle cuenta al asentista ni al comprador, pagar este efecto a tan subido costo, llegaría intacto a estos Almacenes Reales. Al contrario, si el asentista no tuviese la obligación de en- 
tregar las partidas que recibió por entero, y sólo pagarse las fallas al precio corriente, como vende el Rey, tendría muchas ocasiones de enriquecer, y perjudicar al Rey en la minería con la escasez de este ingrediente; porque valiendo siempre los azogues en los asientos de minas de afuera, utıa mitad o un torcio más que en Potosí, lucraría esta ganancia el trajinero, descargándose de la venta con el pretexto de fallas; y lo peor es que no entregando las partidas integras como hubiese recibido, iría enterando las fallas de la primera con la segunda y cuando llegasen a conocerse, que sólo sería al fin del Asiento, tratarían de cubrixlas con el $2 \%$ de refacción, quedándole de este modo libre una excesiva ganancia, y sin castigo un delito tan grave como es el de comerciar azogues contra el tenor expreso de las leyes del r'cino; ${ }^{36}$ y durante cl tiempo del trajín tendría franca la excusa de no haber encontrado avios suficientes para hacer su oportuna conducción, en gravísimo perjuicio de la minería y del Rey.

Pero no siendo fácil evitar todos estos inconvenientes, ni encontrar quien se obligue a las condiciones que dejamos referidas, dicta la actual constitución de las cosas, otro arbitrio que es el único a que se puede recurrir para conseguir un manejo fiel, cauto $y$ diligente en semejante trajín.

Ya vemos felizmente establecido desde el día 30 de cnero del presente año del 86, el Correo de encomiendas de csta Villa a Buenos Aires; cuya erección se avisó al público en 6 de octubre de 1785. Se va cumpliendo, como se prometió, continuar las salidas cada dos meses sucesivamente, es a saber, en 30 de marzo, 30 de mayo, 30 de julio, 30 de septiembre, y 30 de noviembre, sin falta ni retardación, obligándose la Renta de Correos a verificar las conducciones a cargo de los del número de la Administración principal de Buenos Aires, en los plazos siguientes: los que salgan de la Villa en 30 de encro, 30 de maxzo, y 30 de noviembre, han de llegar a Buenos Aires en cincuenta $y$ dos días; los de 30 de julio y 30 de septiembre, on cincuenta $y$ cuatro; y el de 30 de mayo, en cuarenta y ocho; bajo la obligación de responder al público de todo evento y contingencia, por culpa, fraude o negligencia de sus dependientes, a excepción de los casus puramen. te fortuitos, como se publicó en Buenos Aires, a 16 de febrero del 86 . (d)

Los mismos asentistas que ha contratado la Renta, para proveer a sus conductores de recuas y carruajes, pueden con oportunidad y conveniencia suya, retornar los corrcos desde Buenos Aires a esta Villa, dentro de ura tercera parte más de los plazos señalados, que vendría a subir el más largo a setenta y dos dias. Bajo de este pie podría hacerse cargo la Renta de la conducción de los azogues y del retorno de su producto, y situados tal vez por sólo 8 pesos de flete por quintal, y por un $2 \%$ en las platas, que aunque sca una mitad más de lo que tira el actual asentista, siempre queda beneficiado el Rey, haciéndose este pago a sus propias rentas. Entonces no se perjudica el comercio, porque teniendo asentistas no se ocuparían las recuas del trajín común de los mercaderes. No subirían los fletes por esta causa, ni la Administración de azogues de esta Villa sufriría las grandes demoras que sufre en perjuicio de la minería y del Rey, en la lentitud de sus conducciones, y lo que es mayor ventaja, podría contar en un plazo fijo con todas las partidas por entero, como se hubiesen recibido en Buenos Aires.

También se puede hacer la conducción de azogues, en alguno de los navios o fragatas del cargo del Comandante del Río de la Plata, para re- 
tornar en ellos mismos los caudales de este Reino, por el Pucrto de Atacama, como se propone en otro lugar (Parte 2", Cap. $5^{\prime \prime}$ al fin) más extensamente. Pero se debe tener particular cuidado en proveer cautelas muy inteligentes para evitar el contrabando que pueden hacer con este motivo, por lo fácil que sería a los macstres o comandantes de tales ravios, extraviar piñas del Perú, y arribar fraudulentamente en los pucrtos de Portugal, a la vuelta o a la renida, para hacer su comercio chancestino, y después trasponer los efectos de contrabando en alguna isla inmediata a Buenos Aires.

1.- Bowles: Discurso preliminar de la Historia Natural de Fispaña, fol. 23.

2.-- Solórzano, en su "Folítica"; Lib. 6", Cap. 2", N" 17. Tono 2", fol. 433.... Ulloa: Tomo 3", de su "Viaje"; Lib, 1", Cap. 12, $\mathrm{N}^{\circ} 289$, fol, 167.

3.-Gamboa: en su "Comentario de las Ordenanzas de Minas"; Cap. 22, $\$$ 9, $\mathrm{N}^{\circ} 31$, fol. 406 .

4.- Solórzano: en su "Política", Lib. 6", Cap. 2", $\mathrm{N}^{\circ}$ 12. T'omo 2", fol, 432.

5.-Ulloa: en su "Viaje", Lib. 1", Cap. 12. Tomo 3", $\mathrm{N}^{\circ} 289$, fol, 160, y Tomo 4", $N^{\circ} 165$, fol. 110 .

6.-- Solórzano: en su lugar citado._ Murillo: Geografía Histórica, Lib. 9, Cap. 14, fol. 239 .

7.- Ramiro Valenzuela a Solórzano, Lib. 1", de la "Política", Cap. 1S, N" 134.

8.- Bowles: Historia Natural de España, fol. 17.

9.- Theofrasto y Vitruvio, citados por Bowles en la obra referida, $N^{\prime \prime} G$.

(a) Cuesta cada quintal puesto en Cádiz 90 florines que son 49 pesos fuertes, al paso que el Emperador vende a sus vasallos cada quintal a 190 florines que son 79 pesos fuertes, lo que prueba la equidad de nuestro Soberuno. (Nota del manuscrito de Sevilla).

10.- Bowles: fol. 22, y en el Discurso prelininar, fol. 18.

11.- Solórzano: en su "Política", Lib. $6^{\circ}$, Cap. $2^{\circ}, \mathrm{N}^{\circ} 10$ y 11 , fol, 432 . Tomo $2^{\text {p }}$.

12.- Bowles: Discurso preliminar, fol. 16 y en el cuerpo de la obra, fol. 22.

13.- Solórzano: en su "Política", Lib. 6", Cap. 2", N" 33, fol. 435.

14.- - Solórzano: Lib. $6^{\circ}$, Cap. $2^{\circ}, \mathrm{N}^{\circ} 23$.

15,- Ulloa: Tomo $2^{9}$, Parte Primera, Lib. $6^{n}$, Cap. 10, No 1085, fol. 613.

16. - Gamboa: en su Comentario, Tít. $2^{\circ}$, $\$ 2$, fol. 31 , № 53 hasta 64 .

17. - Barba: Lib. $1^{4}$, Cap. 83.

18,-- Libro $4^{\circ}$, Tít. 19, Lib. $4^{\circ}$, Lib. 21, Tít. 15, Lib. $6^{\circ}$, de Indias. Ordenanzas 17 , Tít. $1^{\circ}$, Lib. 3, de las Generales del Perí, permiten estos descubrimientos concediendo a los descubridores de minas de azogue las nismas varadas que las de plata, con el goce de ellas por treinta años.

19.-Ulloa: Tomo $2^{\circ}$, Parte Primera, Lib. $6^{\circ}$, Cap. 1', $\mathrm{N}^{\circ} 103 \overline{1}$, fol. 613.

20.-Gamboa: Cap. $2^{\circ}, \mathrm{N}^{2} 63$, fol, 43.

21.- Ley 8, Tít. 23, Lib. 8, de Indlas. Al fin de este título y libro se pone una nota en que se revocan varias Cédulas, en que se trataha: la rebaja de este precio.

22.- Gamboa: Cap. 291, $\mathrm{N}^{\circ} 44$

23.- Cédulas Reales de 28 de abril de $1650 ; 9$ de abril de $1655 ; 13$ de abril de 1665 , y 5 de junio de 1681 .

24.- Cédula Real de 9 de abril de 1655 .

25 - - Cédula Real de 24 de noviembre de 1682 .

(b) Por Real Cédula de Aranjuez, a $1 \pm$ de mayo de 1654, se mandó que los azogueros sean admilidos por fiadores, unos por otros, para facilitar el cobro de los azogues; y por Auto acordado de Lima, su fecha 6 de enero de 1724, se permitió esta fianza de mancomunidad, con apercibimiento de quitarles los indios y repartirlos a los mineros que pagasen al plazo. En otro Auto acordado, de 27 de junio de 1753 , se permitió lo mismo para los trapicheros y dueños de ingenios, menos a los piqueros.

26.- Cédzla Real de Madrid, a 27 de septiembre de 1614, citada por Escalona en su Gazofilacio, Lib. $1^{\circ}$, Cap. $45, \mathrm{~N}^{\circ} 62$, fol. 194.

27.- Leyes $2,3,5,7$. Tít. 23 , Lib. 8 de Indias.- En lo primitivo corrían los azogues en Potosí a cargo de un Factor, que los administraba con 800 pesos en- 
yados de salario al año, y un Oficial con 300 . El Príncipe de Esquilache abolió este oficio en J'iovisión de 28 de junio de 1619, enacargando esta Admimistración al euidado del Factor Oficial Real, y de su Oficial con la ayuda de costa de 300 pesos ensayados, bajo la mancomunidad de los tres Oficiales Reales como en los denás ramos de la Real Hacienda.

28.-Escalona: en su Gazotilacio, Lib. 1", Cap. 45, N" 7, fol. 171.

29. - Todo esto se refiere a la letra en al Gazofilacio, $\mathrm{I}_{\mathrm{ib}} 1^{\circ}$, Cap. $45, \mathrm{~N}^{\circ} 20$ y 25 , desde el fol. 176.

30..... Cédulas Reales de 27 de septiembre de $1614 ; 15$ de febrero; 31 de marzo y 19) de abril de 16.33 , ref'eridas por Escalona, Lib. 1", Cap. 45, N* 1.5 .

31.- Leyes 10 y 11, Tít. 23, Lib. 8 de Indias.

32 - Provisiones Resles de 30 de septiembre de $1620 ; 1^{\circ}$ de abril de $1627 ; 30$ de abril y 2 de octubre de 1625 , juc corren desde fojas 31.7 de las Ordenanzas Generales del Perú.

33.- Este alcance se refiere en la Real Cédula despuchada de Madrid en 18 de noviemble de 1703 , dando comisión para componer deudas atrasadas de este género al ojdor Du, Clemente Durana.

34.-... Consti. do cortilicaciones del 'Tesor'ero Oficial Teal Dn. Antonio Asín, su feaha 4 de diciembre de 1.762 .

35.- Asi lo refiere el Tribunal de Cuentas de Lima, on un Informe de 19 de septiembre de 1777 .

(c) Ia diferencia de un peso ensayado a um peso corriente es de 4 y $1 / 2$ reales, de manera que el peso ensayado vale 12 y $1 / 2$ reales del actúado.

36.- Ley Primera, Tít. 23, Lib. 8 de Indias.

(d) En este año se suspendió el correo de Encomiendas, porque el comercio con cuyas remesas se hacía este trajín, nombró conductor para sus expediciones con el premio de $1 \%$, pero puede continuar con el Asiento de azogues. 
. 


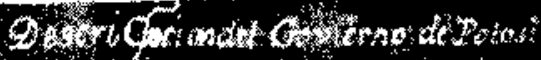

3

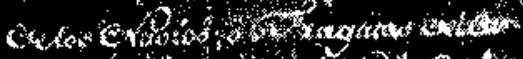

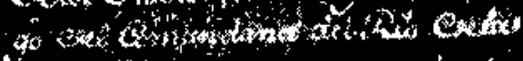

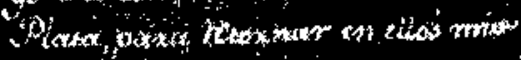

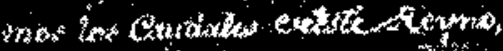

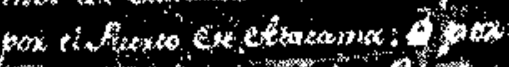

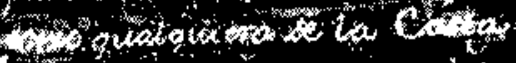

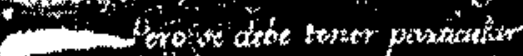

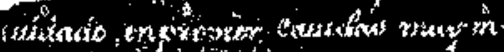

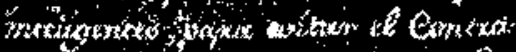

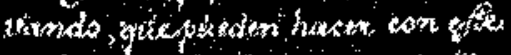

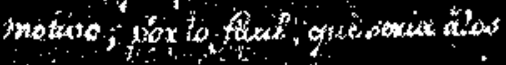

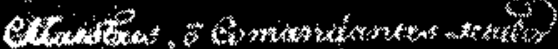

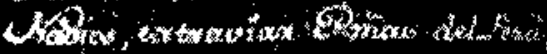

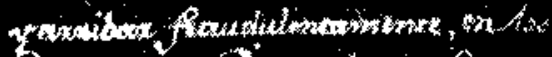

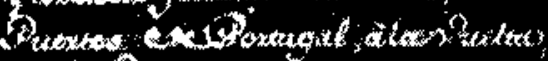

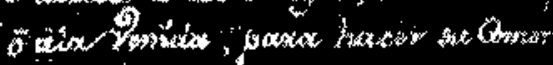

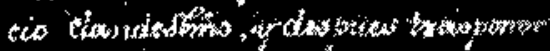

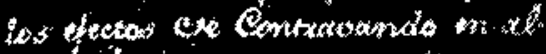

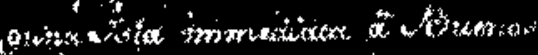
eftates? ,

\section{GAITULO QUINTO}

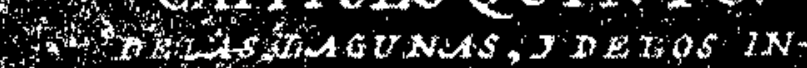

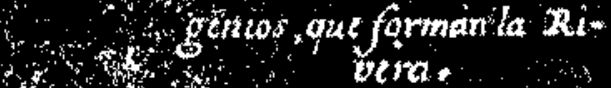

WhotClat

Q Atorwos powighe fabritaran

Ingenios o torghias ingurosi.

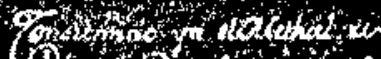

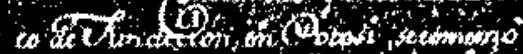

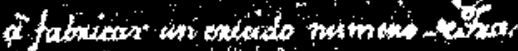

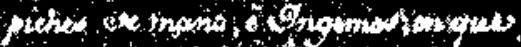

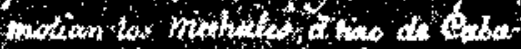

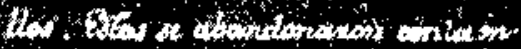

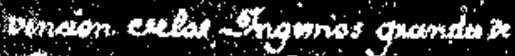

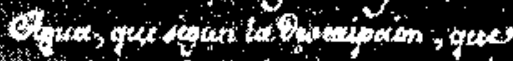

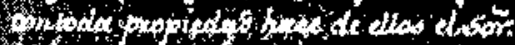

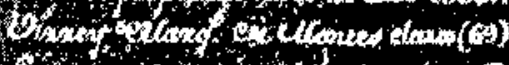

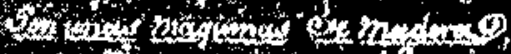

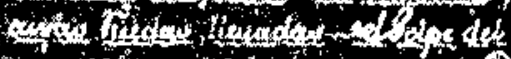

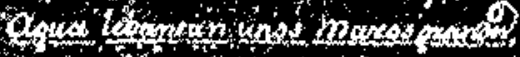

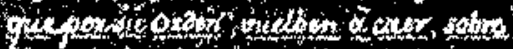

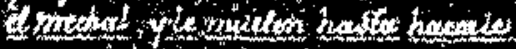

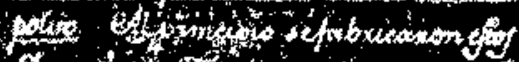

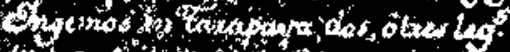

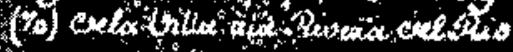

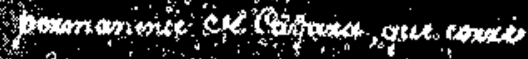

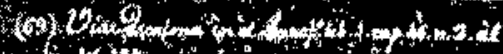
$\therefore$, n s

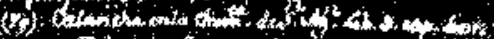

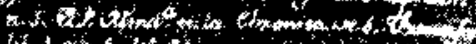

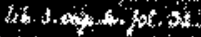

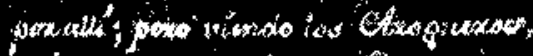

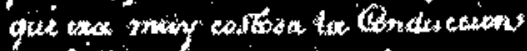

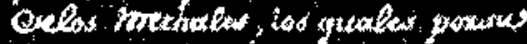

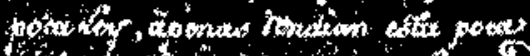

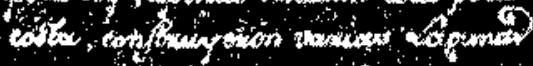

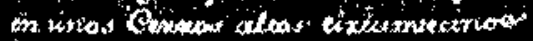

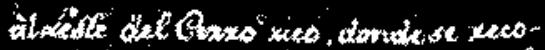

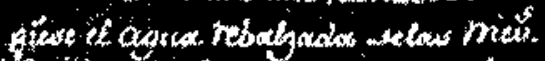

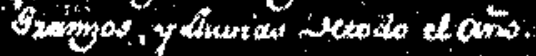

\section{NOTICLA.I}

- Hôntio antigkio de Tragunas.

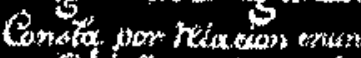

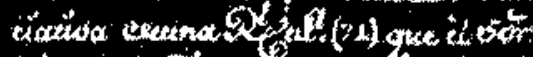

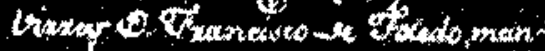

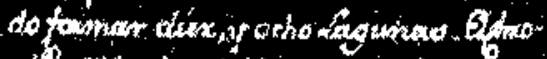

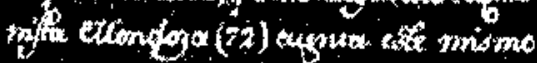

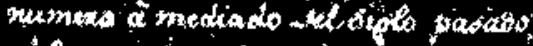

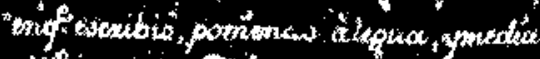

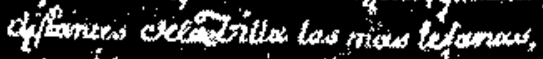

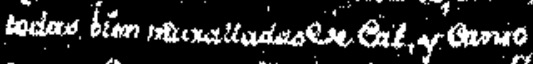

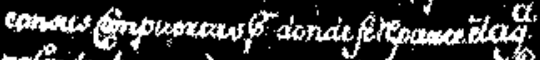

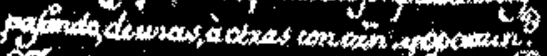

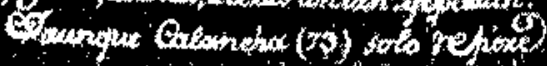

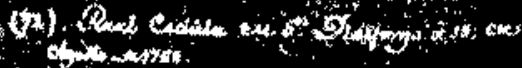

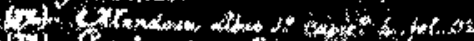

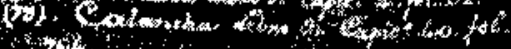

Fotoenpia de una página del Manuscrito de esta obra, que se conserva en al Archivo General de Indias.

(Corresponde el texto a las páfs. 89 y 90 ). 


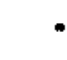




\title{
CAPITULO QUINTO \\ Lagunas e Ingenios de Potosí. \\ De las Lagunas y de los Ingenios que forman la Ribera. \\ NOTICIA PRI M E R A
}

\begin{abstract}
Motivos por qué se fabricaron Ingenios y Lagunas en Potosí.

C ONSUMIDO ya el metal rico de fundjción en Potosí, se comenzó a fabricar un crecido numero de Trapiches de mano e ingenios, en que molíay los metales a tiro de caballos. Estos se abandonaron con la invención de los ingenios grandes de agua, que según la descripción que con toda propiedad hace de ellos el Sr. Virrey, Marqués de Montesclaros, ${ }^{1}$ son unas máquinas de madera, cuyas ruedas llevadas del golpe del agua, levantan unos mazos grandes, que por su orden vuelven a caer sobre el metal y le muelen hasta hacerle polvo. Al principio se fabricaron estos ingenios en Tarapaya, dos o tres leguas ${ }^{2}$ de la Villa, a la Ribera del rio permanente de Cayara que corre por allí; pero viendo los azogueros que era muy costosa la conducción de los metales, los cuales, por su poca ley, apenas rendían esta poca costa, construyeron varias Lagunas en unos cerros altos, circunvecinos al Este del Cerro Rico, donde se recogiese al agua rebalsada de las nieves, granizos y lluvias de todo el año.
\end{abstract}

\section{NOTICIA SEGU N D A}

Número antiguo de Lagunas. CoNSTA por relación enunciativa de una Real Cédula, ${ }^{3}$ que el Sr. Virrey D. Francisco de Toledo mandó formar dieciocho Lagunas. El cronista Mendoza cuen- 
ta ${ }^{4}$ este mismo número a mediados del siglo pasado on que escribió, poniendo a legua y media distantes de la Villa las más lejanas, todas bien muradas de cal y canto, con sus compuertas por donde se reparte el agua, pasando de unas a otras con orden y oportunidad. Y aunque Calancha ${ }^{5}$ sólo refiere cinco Lagunas, que son: Tabacoñuño (conocida hoy por Chalviri), Kari-kari, San I ázaro, San Sebastián, y San Salvador, debe creerse que cuando escribió este antor, estuviesen arruinadis las que después se restablecieron.

\author{
N O T I C I A T E R C E R A
}

Número actual de Lagunas. Afrora tenemos veinte I agunas, a saber: San Buenaventura, San José, Santa Lucía, San Joaquin, Providencia, Estanque y Atocha, esta última distante tres leguas de la Villa, y todas hacia la parte del baño, (a) con incinación al Norte. Siguen: la de Chalviri, muy celebrada por su tamaño y capacidad, distante tres leguas de Potosî, que por caer sobre Tabacoñuîn, so llamó del mismo nombre en la antigijedad; la Redondilla, Lobatona, Olestía, Patos, San Ildefonso. San I'ablo, San Fernando, Mazos, San Juan de Muñza, Santa Bárbara, San Sebastian. Fuera de estas hay otras dos, la una nombrada las Cruces, arriba de San Juan de Muñiza, que en cl cía está perdida y sin compuerta; la otra llaman el Lstanquillo Nuevo, que no debe contarse entre las Iagunas por ser una cspecic de quebrada, a manera de estanque, clonde se recogen las aguas que se conducer a San lldefonso.

\title{
NOTI C I A C U A R T A
}

Distribución de la Ribera de Antrguamente comenzaba la Ribera Potosí, de los ingenios, de la Laguna de San Sebastián. "Después, el Gobcrnador D. Ventura Santelices, mandó formar junto al primer ingenio, llamado Agua de Castilla, distante un cuarto de legua de la población, otra Laguna que sc nombró el Estanquillo, con paredes de cal y canto, para recoger las aguas que se desperdician de la acequia, y medir desde alli las necesarias para el abasto de la Ribera y de la Villa. Fstá descompuesta, y su mismo destino persuade la necesidad de su refacción.

Las aguas que se sueltan de las Lagunas forman el arroyo de esta Ribera, que corre de Este a Oeste por una acequia de más de vara $y$ tercia de ancho, construída de cal y canto, partiendo la población por dos cuadras de la Plaza.

A mediados del siglo pasado, corrió la longitud de la Ribera de Trapiches e ingenios, inclusos los de Tarapaya, cerca de cuatro leguas; ${ }^{8}$ pero ahora tendrá como legua y media escasa, principiando por el ingenio de Agua de Castilla hasta Cantumarca y de ahí más abrjo, comprendiendo cinco ingenios por sutil nuevamente edificados. 


\section{NOTICIA Q U I N T A}

Custodia y reparo de las $\mathbf{P}$ ARA el reparo, custodia y buena cuenta Lagunas. de las Lagunas y para la oportuna distribución de sus aguas, se asignaron varios indios

de mita, y un lagunero ${ }^{9}$ dotado con mil pesos; habiendose gastado del cauclal propio de los azogueros, más de 2.000 .000 y medio de pesos ensayados, en estas magnilicas obras, sin computar las ingentes sumas que sucesivamente se han consumido en eI reparo de las Lagunas, de sus murallas y compuertas, $y$ de los arcaduces por donde corre el arroyo hacia el centro de una quebrada inmediata a la falda septentrional del Cerro Rico.

\section{N O T I C I A S E X T A}

Número de Ingenios y el tiem- $\boldsymbol{W}_{\mathrm{N}}$ este estado comenzó a correr la Ribepo que comenzaron a moler. ra por el mes de marzo de 1577 , moliendo ciento cincuenta cabezas de ingenios que se habían constyuido por disposición y señalamiento privativo del Sr. Virrey, D. Francisco de Toledo. ${ }^{10}$ Con el tiempo se fueron disminuyendo, de manera que en los repartimientos de la Mita, en los años de 1624 y 1633, sólo se encontraron ciento veintidos cabezas, contando los ingenios de esta Ribera con los de Tarapaya.

\section{N O T I C I A S E P T I M A}

Ruina de la Ribera por la reventazón de una Laguna.
$\mathrm{C}$ ASI la mitad de estos ingenios se arruinaron coll la infausta y formidable inundación de la Laguna de Caricari (Kari-kari), que experimentó esta Villa el día 15 de marzo de 1626 (fol. 373 del libro que compuso en 19 de marzo de 1626 , hasta el 5 de diciembre de 1628 , el Procurador Gencral Cristóbal de Salto) por culpa del Corregidor Bartolomé de Astete; porque no habicndo convenido a las instancias del Lagunero, en mandar dar algún desaguie a la Laguna rebalsada entonces de agua con las abundantes lluvias de aquel año, dio lugar a que agitada la Iaguna con el violento impulso de los vientos de estas regiones, desportillase el vallado hacia la parte que mira a la Villa, cosa de tres cuartas a pique; y no encontrando resistencia en los tajamaves, que eran, como en todas las demás Lagunas, unas paredes de céspedes, barro y piedras, rompió el agua con tanta precipitación, que arrastrando la tierra y piedras que arrancaba, se sorbió todos los ingenios que caen sobre el pueblo y casi los restantes de la Ribera, haciendo pedazos las ruedas, volcando los mazos y ejes, derribando las paredes, anegando las casas y arrebatando cuanto encontró en ellas, con imponderable estruendo y confusión por espacio de dos horas que duró la inundación, desde la una del día hasta más de las tres de la tarde; quedaron ahogadas más de dos mil personas y se perdieron muchos millones en metales, azogues, barras, piñas, moneda, alhajas y joyas. ${ }^{11}$ 


\author{
NOTIOIA OOTA VA
}

Nueva forma en que se repararon las Lagunas; impuestos establecidos para este fin $y$ premios concedidos para la reedificación de los Ingenios.
E tó luego del reparo conveniente a tan considerable daño, mandando murar las I agunas de cal $\mathrm{y}$ canto, con profundos cimientos de dos varas de grueso y con sus compuertas fuertes y seguras; con que se aquietó el recelo (que antes era continuo) de otra reventazón; haciéndose cspecial desagüe por dónde poderlas sangrar cuando parezca conveniente en tiempo de abundancia de aguas. ${ }^{12}$

Con este motivo el Sr. Virrey, Marqués de Guadalcázar, ${ }^{13}$ mandó continuar el impuesto que se había cargarlo en el vino, para reparar fuentes y caminos y traer el agua a la Plaza; estableciendo de nuevo para el reparo y fortificación de las Lagunas, sus compuertas y marcos y para la canal principal: la sisa de un real ch cada carnero de Castilla de los que se gastaren en la Villa, y cuatro reales en cada vaca, buey, toro o novillo, que sale a real en cada cuarto de dichas reses. Concedió asimismo a los azogueros perjudicados en la inundación, el indulto de fírseles el azogue por tres años, al precio de 60 pesos ensayados; $y$ a los demás que no recibieron daño, que se les vendiese a 66 pesos quintal, pagando de contado todo el exceso y el residuo de su valot hasta los 60 , fiado por algunos meses; añadiendo el premio de mil pesos al primero que recdificase los ingenios arruinados: seiscientos al segundo y cuatrocientos al tercero, con más que se repartiesen 160 indios por un año, de los señalados a las minas de Porco, a los que tratasen de reedificar las casas y tiendas cercanas a las cuadras de la Ribera, comisionando para este prorrateo y demás providencias, a Dn. Alonso Pérez de Salazar, Oidor de Charcas.

\title{
NOTIOIA NOVE N A
}

\begin{abstract}
Producto de la sisa para reparos de Lagunas; $y$ nombramiento del Lagunero.

$\mathbf{E}$ $\mathrm{N}$ aquel mismo año consta 14 haberse hecho postura a esto nuevo impucsto de sisa, en 26.000 pesos; pero, las soluciones y fraudes en la administración de este ramo, lo hicieron bajar hasta 4.000 pesos el año de 1750 , en que entró a gobernar esta Villa D. Ventura Santelices; y aunque puesto en Administración creció de 10.000 a 11.000 pesos, ${ }^{15}$ en el día sólo rinde 7.000 pesos en arrendamiento. De sus productos se manticne un Lagunero con 800 pesos, nombrado por el Gobernador de Potosí, como Superintendente de la Mita, y su Ayudante con 500, según lo tiene declarado S. M., en cierta competencia con el Sr. Virrey de Lima, sobre astos nombramientos, por Real Cédula de Sn. Ildefonso, a 19 de agosto de 1768.
\end{abstract}




\section{NOT I C I A D E C I M A}

Sueldo del Lagunero Mayor. A QUI me parece digno de advertir que aunque por Auto acordado del superior Gobierno, con voto consultivo de la R. A. de Lima, a 27 de marzo de 1751 , se aumentó af lagunero hasta 800 pesos, el sueldo anual que por otro Auto de 8 de febrero de 1748 , se rebajó a 600 pesos, de los mil pesos que le estaban antes asignados; fue hecho este señalamiento provisionalmente, con la calidad de por ahora y sin ejemplar, por indulto particular de D. Juan Antonio Aldao, Lagunero Mayor, por quién entonces se hizo la consulta; y aunque en la citada Real Cédula de 1768, se hace mención del sueldo de 800 pesos, sólo fue entunciativamentc, con referencia a lo informado sobre este punto, sin que recayese la decisión más que sobre la materia del nomblamiento de Jatgunero, acerca de quién debía serlo; ni sería injusto roducir esta dotación a los citados 600 pesos, según las atenciones a que vemos contraerse los I aguneros, que todo lo descargan en sus Tenientes, y cuando quiera mantenérseles en el goce actual, se debería formar una Ordenanza eserita por donde reconociesen obligaciones indefectibles, so la pena de pexder el suekdo.

\section{N O TIOIA U N D E C I M A}

Restablecimiento de la Ribera. WoLVAMOS ya a los ingenios. Las providencias expresadas, del Sr. Marqués de Guadalcázatr, fucron tau oportmas en los avíos, auxilios y premios con que alentó la azoguería, ghe se vio el año 1633, completo el mismo númcro de ciento veinticlós caberas que existían el año de 1624, dos años anterior a la inundación, llegando por estos medios, no sólo a restablecerse la Ribera, sino también à acrecentarise el número de los ingenios. Nuestro Alonso Barba, ${ }^{16}$ hablando de la Laguna de Tabacoñuñu, el año de 1637 en que escribió su célebre obra, dice "que se recogía sólo en ella, agua bastante para hacer correr un rio todo un año entero, con que muelen de dia y de noche más de cien ingenios". Más adelante, por el año de 1663, refieren los cuonistas, Mendoza y Calancha, 'i que molían en la Ribera de Potosí más de ciento treinta cabezas de ingenios, a cuyo número ya habían llegado estas máquinas el año de 1646, en que escribió nuestro Escalona; ${ }^{18}$ pero a poco tiempo después, llegó a tal disminución, que en el repartimiento general hecho por el Sr. Virrey Conde de la Monclova, a 8 de mayo de 1692, sólo se encontraron cincuenta y siete cabezas; y de estas mismas, mandó arruinar y demoler muchas el Conde de Canillas, Dn. Pedro Ruíz Enríquez, Corregidor de esta Villa, el año siguiente de 1693, por no haber alcanzado la asignación de Mita sino para treinta y cuatro cabezas. ${ }^{19}$

\section{NOTIOIA D U O D E C I M A}

Demolición de algunos ir- $\begin{aligned} & \text { Yo me persuado que el Conde de Canillas } \\ & \text { genios. }\end{aligned}$
mandó ejecutar esta demolición, arreglado a
la Ordenanza 15 del Sr. Virrey Marqués de Cañete, recopilada en la 22, Tit. 11, Lib. $3^{\circ}$, de las Generales del Perú; 
pues, debiéndose presumir, según el estado decadente do las minas en aquella ocasión, que las treinta y cuatio cabezas con repartimiento de $\mathrm{Mi}$ ta, eran bastantes para la molienda y consumo de los metales que se sacaban del Cerro; es regular hubiese meditado impedir los abusos que forzosamente resultan de haber más ingenios de los que son necesarios para moler los metales: y son el repartir los indios a los ingenios sus mismos dueños, dejando de ocuparlos en las minas; y no teriendo qué moler en ellos, es consiguiente hacer ventas de los indios, paliándolas con color de arrendamientos de los ingenios.

\section{NOTICIA DECIMATERCERA}

Número de ingenios que se- $\mathbf{P}$.OR esta causa señaló el Sr. Virrey Dn. ñaló el Señor Toledo y el Señor Francisco de Toledo, el número de ingenios Velasco. que computó suficientes para el consumo de los metales que se sacaban de las minas de Potosí en su tiempo; y fundado en esto misno, prohibió el Sr. Dn. Garća Hurtado de Mendoza, Marqués de Cañete, por los años de 1589, que ninguno hiciese de nuevo ningún ingenio demás de los que estaban edjficados y acabados al tiempo de la publicación de las Ordenanzas del Si. Toledo. 20

El Sr. D. Luis Velasco mandó guardar la Ordenanza quince referida del Sr. Marqués de Cañete, en carta de 6 de marzo de 1598, ordenando que no se permitiesc hacer ingenios de nuevo, ni reparar el que estuviese despoblado o caído; en cuya conformidad así lo mandó el Idiccnciado Dn. Juan Díaz de Lupidana, en la adición número 8, Tít. 14, Lib. 3ُ de las Ordenanzas del Perú, dando por motivo de esta prohibieión: para que no tengan ocasión los dueños de pedir se les rephrtan indios.

Con todo, nuestro 1 . Gaspar Escalona, ${ }^{21}$ refiriendo difcientes causas de las prohibiciones expresadas, concluye, ${ }^{22}$ que nor su consojo, jamás embarazaría edificar nuevos ingenios, con tal que se asignase cierta cantidad para el Rey, por vía de servicio pecuniario de cada licencia, como se ejecuta en las que se conceden para molinos de trigo y otras mercedes. Funda su opinión en que aumentándose la molienda, crecerá también la saca de plata; pero no obstante esta conveniencia, juzga deberse observar las prohibiciones de repartir indios a los ingevios que se labrasen de nuevo.

A mi parecer, se engaña; porgue no pudiéndose moler más metales de los que se sacan, nunea se aumentará la molienda aunque haya un crecido número de ingenios, ni la saca podrá crecer sino a proporción de los metales que se extraen de las minas, que siempre ha de tener correspondencia con los indios de repartimiento; siendo lo principal que con el acrecentamiento de los ingcnios, resucitarán fouzosamente los abusos que trató de cxtinguir la reiterada prohibición de los Srs. Virreyes. 
NOTICIA DEC I MACUARTA

Providencia moderna sobre fá- $\mathbf{P}$ oR todas estas consideraciones, auuque frica de ingenios. posteriormente ha permitido el Rey, por Real Cédula fecha en Buen Retiro, a $\mathbf{1 5}$ de julio de 1750 , Cap. 2", dirigida al Gobernador de Potosi, que se aumenten las cabezts de ingenios, hace alli mismo una admirable limitación, ordenando que este aumento sea hasta donde alcance ol número do indios mitayos que hoy hay destinados, reducido el numevo de cuarenta a sólo veinte; con cuya dicción: "hasta", que es limitativa, quiso excluir al Rey, para lo sucesivo, la fabrica de ingenios que no tuvieion repartimiento de indios, conformándose en todo al espíritu de la Ordenanza del Sr. D. Francisco de Toledo, mandada guardar por las de los Srs. Marqués de Cañete y D. Luis de Velasco, pal'a que no se edifiquen más ingenios de los que señaló el Sr. Toledo, respecto a que los que excediesen de esta tasa no debían tener asignación de Mita, y sólo servirían para dar ocasión a los mineros rrogligentes, para vender sus indios a los dueños de ingenios, sin aprovechar'se de su trabajo en la labor de sus minas; de que resulta que en el clía no debe permitirse más número de cabezas de ingenios, que hasta donde alcancen Ios indios mitayos reclucidos al número de veinte por cabeza.

Hasta el dia no ha tenido efecto esta justísima providencia, por ignorarse el número fijo de la Mita, ni éste podrá sabarse con certeza mien. tras no se actúe la revisital de todas las Provincias afectas al servicio de ella y se forme nuovo repartimiento general; porque siguièndose en el dia el último que practicó el Sr. Conde de la Monclova, en 8 de mayo de 1692, se experimenta unit notable dismintucion en los 4.101 indios que distribuyó para el trabajo de las minas e ingenios de la Ribera de Potosí, así a causa de lat formidable peste gue, en los 19 y 21, casi exterminó la Amćrica, como porque habiéndose numerado últimamente los forasteros junto con los originarios, es tan iricierto el númelo como es contingente la residencia de los primeros; $y$ asi se ve gue el Oidor D. Pedro Vásquez de Velasco, Superintendente de la Mita en Potosí, representó al Sr. Virrey Marqués de Castelfuerte, el ano de 1783, que estando destinados en el repartimiento del Sr. Monclova, mil trescientos indios con sus dos remudas, que llegan a cuatro mil trescientos sesenta y siete indios, del total de los que pagan mita al cabo del año, sólo residían cxistentes de efectivo trabajo en Potosí, seiscientos cincuenta indios, y cuyo número, aunque corto, ha sido siempre a menos más adelante, pues, el total de la Mita que efectivamente viene a esta Villa, por todo el año, apenas llega a dos mil ochocientos setenta y nueve indios, según la razón circunstanciada que se formó el año de 1780, por orden del Sr. Dn. Jorge Escovedo.

A causa de esta incertidumbre no puede arreglarse por ahora el número de ingenios. Así se han fabricado algunos más, de pocos años a esta parte, con licencias de este Gobierno y con aprobación del Sr. Virrey, bajo la calidad de pagar la media anata reducida a 17 pesos 5 y 1/2 reales, con más 50 pesos por vía de servicio pecuniario por cada cabeza. Con lo que se hallan en esta Ribera, hasta la fecha, sesenta y siete cabezas de ingenios grandes de agua, fuera de algunos trapiches de fábrica 
antigua y cinco ingenios por sutil, que también muelen con agua y son de la misma figura que dibuja M. Fresier, en su viaje a la mar del Sur, 23 los cuales se comenzaron a usar en esta Ribera desde el año de 1780 , pero mucho antes se trabajaba ya con ellos en todo Chucuito y Guarachuri, de donde sin duda sacó el modelo el citado viajero.

\section{NOTICIA D E C I M A Q U I N T A}

Arbitrio para conservar las
Lagunas surtidas de agua en
tiempo de seca.

$\mathbf{T}$ Jen con aguas advenedizas de lluvias, nieves y granizos que recogen las Lagunas de que hemos hecho mención. Las ag'las regularmente comienzan por octubre y acaban en marzo. El año que son escasas, se padece muchos trabajos, porque parando la molienda cesa la saca de platas $y$ viene a perderse cada semana de veintiocho mil a treinta mil pesos, que es lo correspondiente a doscientos mil marcos, más o menos, que se rescatan todos los años de los productos de este Cerro Rico. Ya sc ve el daño que se sigue a la Real Haciencla y al comercio.

Por lo mismo, es de los puntos más esenciales de este Golierno, la conservación de las aguas; que todo ello pende, en parte, de economía en su consumo, y en parte, del cuidado de reparar las Lagunas. Regularmente se ve, aun en los años estériles, que corre el agua por la Ribera los domingos, en que no hay molienda; y por las pilas y cañerías de la Villa, dia y noche por todo el año, desperdiciándose ese precioso agente de la felicidad de toda la población, sin necesjdad; porque suspendiondo el curso del agua por las noches, quedaría toda la que se va cconomizando para surtir la Ribera uno o dos meses, de los úitimos del año, para suplix de este modo la falta de las lluvias si acaso se atrasasen; sin que el Gobierno tenga que recelar algún caso de incendio, porque las más casas de la Villa, tienen sus pozos y aljibes con qué reparar estos sueesos.

El remedio más permanente es limpiar las Lagunas de las muchas arenas que arrastran las aguas y tienen lieno, inutilmente, el lugar que debían ocupar éstas; a este fin está destinado el ramo de sisa, y para el mismo suelen obligarse todos los gremios junto con los indios de Mita, los de las Parroquias y yanaconas, por faenas, contribuyendo en dinero al arbitrio del Gobiemo cuando quieren eximirse del trabajo; en el cual, conforme un Auto acordado del Superior Gobierno, con voto consultivo de la Real Audiencia de Lima, su fecha 8 de febrero de 1748, se mandó guałdar el orden siguiente: que el martes concurriesen en fajina los descansos de Mita; el miércoles los mestizos, los mulatos y los oficiales de los gremios, sirviendo de mayordomos los maestros, para que los hagan trabajar; el jueves u otro día, la gente de los Curatos, con asistencia de sus Párrocos o Ayudantes, de los Alcaldes veedores del Cerro, Capitán de la Mita y Protector, turnando además por días o semanas, un Regidor con un azoguero y dueño de ingenios; y para que nunca se dude cuales sean los gremios, véase la lista siguiente: Panaderos, pulperos, pintores, barberos, tejedores, carpinteros, matanceros, cancheros, trapicheros, silleros, guitarreros, cereros, tiradores, plateros, sastres, zapateros, olleros, alba- 
ñiles, chicheros, coheteros, herreros, ojoteros, sombrereros, montereros.

Poro segín la opinión de los prácticos, no convienen estas limpias, porque autuella arena fangosa que sirve como de álveo o fondo a las Lagunas, cría en la superficie una especie de lama que impide la trasminación del agua por infinitas cangrejeras que hay abiertas en aquellos sitios. To otro, porque las mismas arenas conglutinadas al pie de los cimientos, impiden que las aguas se resuman por allí, haciendo forzoso, en quitándolas, arrimarles una muralla al pie, por la parte de adentro. Finalmente, porque limpiándolas quedan las compuertas muy superiores al piso de las Iagunas, $y$ es preciso cortar las murallas o no aprovechar toda la porción de agua que quedase estancada sin salida.

Así parece más conveniente suspender las murallas dos o tres varas hacia arriba, para aumentar la capacidad de los vasos y embarazar el continuo desperdicio de las aguas, que en tiempo abundante de lluvias, rebalsan y se derraman, sin provecho, por dos o tres meses continuos al año. Si bien rue para esta obra son menestex dos cosas: la primera, cantidad considerable de plata, que sin embargo de no haberla en el ramo de sisa, pudiera suplirse de la Real Hacienda, con cargo de reintegro, como otras veces se ha hecho. La segunda, que el Director fuese un hidrostático hábil, para que haciéndose cargo que un pie cúbico de agua dulce común pesa cerca de 70 libras, (b) supicra graduar el espesor de las murallas y las demás medidas que las mantuviesen sin riesgo, a proporción del mayor peso que acrecentase ol aumento de las aguas, porque sin estas precisas cautelas, tal vez experimentariamos en nuestros días iguales desdichas a las del infeliz suceso de la inumlación de Caricari (Kari-kari).

Sin embargo, considerando los inconvenientes propuestos en otro Jugar ${ }^{24}$ contra el proyecto de levantar las paredes de las Lagunas, juzgo más conveniente limpiarlas, como se hace en Huesca, pues las dificultados de cangrejeras y compuertas se pueden vencer muy bien con los arbitrios de la Policía.

1.-Vide Escalona, en Gazophi]. Lib. 1", Cap. 40, $\mathrm{N}^{*} 2$ al fin, fol. 198.

2.-Calancha: en la Crónica de Sar Agustín, Lib. 3, Cap, 40, $\mathrm{N}^{*} 1 .-$ El P. Mendoza: en la Crónica de San Francisco, Lib. 1", Cap. 4\%, fol. 31.

3.- Real Códula de San Ilde fonso, a 19 de agosto de 1768.

4.- Mendoza: IJib. $1^{\circ}$, Cap. $4^{\circ}$, fol, 31.

5.-Calancha: J.ib. $3^{\circ}$, Cap. 40, fol. 744.

(a) Ajude sin duda el autor al "Baño de Don Diego". (N. de E.).

6.- Escalona admira csta Laguna: Lib. 1"., Cap. 45, $\mathrm{N}^{\circ}$ 2, fol. 169.

7.- Mendoza: I,ib. 1", Cap. 4", fol. 31 .

8.- Así refiere Mendoza, I,ib. $1^{\circ}$, Cap. $4^{\circ}$, fol. 31.

9.- Mendoza: T.ib. 1", Cap. 23, fol. 128.

10.- En Real Cédula de Buen Retiro, a 15 de julio de 1750 , Cap. 2 , se refiere que el citado Sr. Virrey señaló y tasó este número de ingenios. En repartimiento del Sr. Margués de Guadalcázar, del año de 1624 , se repartió Mita a 95 cabe. zas de esta libera $y$ a 27 de Taxapaya; y en otro reparlimiento hecho por el Sr. D. Juan de Carvajal y Sande, el año de 1633 , de orden del Sr. Virrey, Conde de Chinchón, se numerazon en esta Ribera 106 cabezas, y en Tarapaya 16.

11.- Mendoza: refiere muy por menoi este lastimoso suceso, en su Crónica, Lib. $1^{\circ}$, Cap. 23, fol. 127.- Calancha lo apunta, Lib. $3{ }^{\circ}$, Cap. 40 , fol. 744.

12.-Mendoza: J.ib. $1^{\circ}$, Cap. 23 , fol. 131.

13.- Todo esto se refiere en una Provisión de 30 de mayo de 1626.

14.- Así consta en el citado Supremo Despacho de 30 de mayo de 1626 .

15.- 'Todo esto so refiere en lieal Cédula de San Lorenzo, a 21 de julio de 1766.

16.-- Barba: Lib. 1". Cap. 27, fol, 23. 
17.- Mendoza: Lib. $1^{\circ}$, Cap. $4^{\circ}$, fol. 31.- Calancha: Lib. 3, Cap. 40, fol. 744.

18. - Escalona: Lib. $1^{\circ}$, Cap. $45, \mathrm{~N}^{\circ} 2$, fol. 169 .

19.-- Así lo refiere el Licenciado D. Matías Lagunes, Fiscal de la Audiencia de Lima, en una vista de 5 de abril de 1693 .

20.- Esta publicación se hizo en Lima, a 6 de noviembre de 1575 , según se refiere en el Auto que da principio al Lib. $2^{v}$ de las Ordenanzas, fol. 12 t. $^{\circ}$

21.- Escalona: en su Gazofilacio, Lib. $1^{\circ}$, Cap. 46, $N^{\circ} 30$, fol. 198.

22.-Escalona: Lib. 1\%, Cap. 46, No 40 al fín.

23.- M. Fresier: Plancha 22, pág. 138.

(b) Las aguas como todos los flúidos, guardan un equilibrio admirable causado por la presión reciproca de sus partículas, y asi hacen poca fuerza contra las murallas, cuando no tienen corriente.

24.- Párrafo $2^{\circ}$, Cap. 6, Noticia 5, artículo 2". 


\section{1}

\section{CAPITULO SEXTO}

\section{De la Mita}

Se refiere el origen, progresos, novedades y actual estado de la Mita, con los empadronamientos hechos desde el año de 1578 hasta 1690.

\section{$\S \mathbf{I}$.}

\footnotetext{
A

J. tiempo de conquistarse las Américas por la Corona de Castilla, se tuvo muy a la vista el porleroso ejemplo de los atenienses, macedonios y otras naciones cultas, principalmente de los romanos, que según testifica Strabón, 1 tenían en su tiempo ocupados hasta cuarenta mil hombres en el trabajo de las minas de las inmediaciones de Cartagena. Los mismos In-u cas y Moctezumas que señoredron a Nueva España y el Perú, tenían por costumbre ocupar en la labor de los mincrales de oro y ptata y del cina-6 brio, sólo para pintarse con su bermellón, infinitos millares de indios, con tan absoluta sujeción y dominio como si fuesen esclavos, según los historiadores que cita el sapientísimo $\mathrm{Sx}$. Solórzano. ${ }^{2}$

No obstante estos autorizados hechos de las primeras naciones del mundo y hallarse cjecutoriados con ellos mismos los justísimos títulos ale-

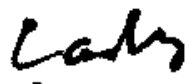
rewn

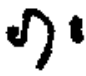
gados por el Sr. Solórzano y el llmo. Montenegro, ${ }^{3}$ para que los Príncipes Soberanos puedan ocupar lícitamente a sus vasallos en cualquier género de trabajo, obligándolos a la labor de las minas y a otros servicios fuertes y forzados; miraron siempre nuestros Reves con tanto escrúpulo esta materia, que al mismo tiempo que encargaron la buena cuenta con el beneficio y labor de las minas descubiertas, y el cuidado de buscar y labrar otras de nuevo, jamás permitieron echar indios por fuerza a minas para sacar oro ni plata; antes por el contrario, prohibio este punto con tanto rigor el Sr. Emperador Carlos V. en el año de 1529, ${ }^{4}$ que a los con-
} 
traventores se les impuso la pena de perdimiento de la Encomienda y más cien mil maravedies, aplicados a la Real Cámara, Juez y denunciador; ${ }^{5}$ extendiendo otra Ley ${ }^{6}$ esta prohibición aun para llevar los indios cargados con vitualla u otras cosas a los Reales Asjentos de minas, bajo de gravísimas penas. Todos estos procedimientos hacen tanto más admirable la conducta de nuestros Católicos Reyes, cuanto acreditaron más su moderación, amox-y benignidad hacia Tós Tndiôs, pier iriendo estos objetos a la conveniencia del Estado, en uñus tieñipes euando los más doctos espahroles, como Quevedo y Sepúlvefa pretendían que los indios cran por naturaleza esclavos, ho con servidumbre rigurosa de propiedad, sino con esclavitud política, civil y regia, en el sentido que escribió Aristóteles ${ }^{\overline{ }}$ de aquel género de gentes que siendo tardos y estúpidos de ingenio, pero robustos y fuertes de cuerpo, parece que la natuturateża los subordinó económica y politicamente $a$ otros hombres más llustrados, para que viviesen amparados bajo de su protección.

En breve tiempo fundaron los indios una experiencia bien acreditada de que no era posible lievar adelante, ni aun conservar, la labor y beneficio de la mina, si se dejaba a su arbitrio el trabajar o no en ellas. Su abatimiento en la ociosidad, su repugnancia a todo servicio, por la costumbre en que nacieron y se criaron de andar errantes, sin propiedad, y vivir de la escasa cosecha de sus casas silvestres; su ninguna policía y peor educación, los arrastraba sensiblemente a los vicios connaturales de la embriaguez, de la idolatría y del adulterio, separándolos de todo cjercicio lucrativo y honesto. Así fue preciso variar el antiguo sistema de gobierno, para que el Estado no careciese del todo del fruto de los minerales, por no haberse conocido entonces otro medio de conscrvarlo que el cultivo de las minas, tanto por su gran provecho, como por la esterilidad de la tierra y falta de cultivadores.

A este fin se despacharon diferentes Cédulas, ${ }^{8}$ por lo respectivo al Perú, al Sr. Virey D. Francisco de Toledo, ordenándele que a los españoles se les repartiesen indios para las minas, como se reparten para labores de campos y otras obras públicas a que ellos, desde su infidelidad, estaban obligados y acudían siempre por sus llamamientos. Este gran Virrey, de cuya elección dice Araciel, " que la Santidad de Pío V., le dio al Rey las gracias por ello, añadiendo que a su prudencia se debió el feliz estado del Reino del Perú, por su eonocimiento en las materias de Gobicrno, que parece haber sido ilustrado para ellas; formó luego las Ordenanzas y repartimientos que le parecieron convenientes, así para las minas de plata de Potosí, como para las de azogue de Huancavelica, y otras de este Reino, ${ }^{10}$ que son el mineral de Berengueja de Pacajes, que aun antes que Potosí tuvo indios de "cédula", 11 Porco y Zaruma. ${ }^{12}$

El Rey, a quien se dio cuenta de todo lo proveído, no sólo se lo aprobó sino también mandó ampliar y extender a las demás que de nuevo se fuesen descubriendo, por un capítulo de carta de 20 de enero de 1589 , escrita al Sr. D. Fernando de Torres y Portugal, Conde de Villardompardo, $7^{\circ}$ Virrey del Perú, con las mismas condiciones que están prevenidas en la Ley 19. Tit. 15, Libro $6^{\circ}$ de la Recopilación de Indias; con lo que se formalizó el asunto de la Mita.

El P. Agia (a) citado por el Sr. Solórzano, ${ }^{13}$ dice que en su tiempo, los que se repartían de Mita para el Cerro de Potosí, eran trece mil y cuarenta (13.040), y que otros tantos y aun más se exponian para mingarse. (b) 
Nuestro Escalona 14 afirma que el Sr. Dn. Francisco de Toledo distribuyó para la labor de las minas de Potosí, trece mil quinientos indios, repartidos en Provincies distantes hasta ciento cincuenta leguas.

Ramiro Valenzticla ${ }^{15}$ refiere que el Sr. Virrey Toledo, por los años de 1575, asignó noventa y cinco mil indios en diez y siete Provincias, para el beneficio del Cerro de Potosí, acordando que de estos saliese, al principio del año, la séptima parte, y habiendo asistido a las minas un año, volviescn a sus países, libres de Mita por seis años, y saliese al trabajo otra sćptima parte, de suerte que en esta forma trabajaban todos los días cuatro mil quinientos indios y descansaban novecientos o se alquilaban voluntariamente. El Sr. Don Felipe III., en una Cédula despachada al Sr. D. Luis de Vclissco, ${ }^{16}$ hace relación de que siempre se habian repartido para el bencficio y labor de las minas de Potosí, quince mil indios, llevándose por sus mitas cinco mil de ellos cada cuatro meses. En la Ordenanza 9, 'Tit. 13, Libro 3 " del Perú, se previene por el Sr. Virrey D. Luis de Velasco, que se repartan cuatro mil seiscientos treinta y cuatro indios de Mita.

Esta diferencia sin duda procede de la variedad que tuvo en sus principios el asunto de la Mita, o que gobernándose por relaciones los citados autores, no pudieron acordar en unas mismas noticias. Lo que consta do los Libros Reales y otros documentos que he registrado, es que el Sr. Virrey Dn. Francisco de Tolcdo, por el mes de agosto de 1578, hizo en Lima el repartimiento de los indios de Mita para Potosí, en catorce mil closcientos cuarenta y ocho indios, cuya Mita ordinaria era de cuatro mil setecientos veinticuatro mitarios por cada tercio del año o cada cuatro moses; $y$ anncue consta haber hecho otro repartimiento a 20 de diciembre de 1580, no resultal que hubiese hecho la menor novedad.

\section{$\$$ II.}

Fundación del Hospital para Como el IIospital se fundó en el año de indios mitarios. 15525- trató al mismo tiempo de formalizar la Mita, expedir providencias para curación y socorro de los indios; a este respecto les impuso el gravamen de pagar al año en el Hospital un tomin o medio peso ensayado, en lugar de lo que antes pagaban de doetriha, ${ }^{17}$ aplicendo este ramo para el sustento de los pobres, indios y españoles, del IIospital de esta Villa, bajo el cargo de un Administrador que debía correr con su cobranza, con facultades de pedir libramientos contra el Mayordomo del Hospital, para el pago de los salarios situados en esta consignación.

\section{$\S$ III.}

Dotación del Hospital. $\quad$ UNDO también, por provisión fecha en Potosí, a 18 de enero de 1575 , la Caja de Granos, 18 bajo el manejo de Contadores y Liaveros, para su debida cuenta y razón, estableciendo que los indios de la Mita ordinaria paguen $1 / 2 \mathrm{real}$ cada semana, en consideración de haberles acrecentado los salarios, co- 
mo se expresa en un Despacho dado en Tiaguanaco, a 10 de julio de 1575, dando en él comisión al Sr. Presidente y un Oirlor de Charcas, para que tomasen ctientas a los Oficiales Reales de la Caja de Granos.

Consignó en el ramo del tomín, a más del sustento y curación de los indios y españoles pobres, el salario de los indios Fiscales de las Parroquias, destinados par'a traer de ellas al IIospital los indios enfermos, con más 100 pesos ensayados al Vicario de la Villa, por Capellán de la Cárcel. En la Caja de Granos se situaicu los salarios ciel Corregidor, por Visitador del Cerro, Alcalde de Minas, Protector, Capellán de la Cấccol, Administrador, al Contador, ocho indios Capitanes, ocho Guatamayos o Alguaciles, Catedrático de lengua, fundado en la Compañía con mil pesos; de los barberos destinados para curarlos en las rancherias; y para gastos de papel; que todo venía a sumar cer'ca de 11.000 pesos ensayados; pero como estas dotaciones excedian por lo regular el producto de los granos en que se habian situado, se mandó suplir del tomín lo que faltase, y así venía a ser siempre variable la situación de dicho rano del tomín.

Establecida la Mita por el Sr. Toledo bajo de estas Ordenanzas, continuaron los demás Sres. Virveyes los t'epartimientos bajo del mismo pie. Así ejecutó el suyo el Sr. Martín Enriquez, a principio de 1583, asignando trece mil indios, con la Mita ordinaria de cuatro mil cuatrocientos cincuenta y tres, cuyo número se redujo el año de 1585, por Provisión de la R. A. de Charcas, a cuatro mil tiescientos cuarenta y seis, en cousideración a las fallas que se averiguaron.

E) Sr. Conde del Villardompardo, por repartimiento hecho en la Magdalena, a 11 de dieiembre de 1588 , scrialó trece mil trescientos diez y seis, cuya mita ordinaria cran cuatro mil cuatrucientos trece indios.

En las Ordenanzas formadas para la Caja de Granos y Tomines de Potosí, por el Sr. D. Gaspar de Escalona y Agücro, su fecha en esta Villa a 29 de marzo de 1601, se iefiere que, rebajados los indios del último repartimiento general y los que dejabal de venir; quedaron en doce mil seiscientos treinta mitarios, con la mita ordinaria de cuatro mil doscientos diez.

El Sr. Marqués de Montesclacos, repartió en el mes de junio de 1602, cuatro mil cuatrocientos veinticuatro indios de Mita ordinaria.

El Sr. Príncipe de Esquilache, en 28 de octubre de 1618, asignó cuatro mil doscientos noventa y cuatro indios de Mita ordinaria, entre soldados, socavones, y azogueros, reduciéndose a tres mil ochocientos sesenta y un indios los repartidos a las minas y ciento veinticuatro cabezas de ingenios que tenía esta Ribera.

En este mismo tiempo reclamaron los indios contra la Caja de Gramos y Tomines que establcció el Sx. Toledo. Se reflexionó muy bien el notable sentimiento que les cansaba la rebaja de sus jornales, para el entero de estas consignaciones, y lo justo que era sosegar sus clamores aboliendo tal establecimiento, a cuyo fin se despachó Real Cédula, por el Sr. Don Felipe III, su fecha en Madrid a 10 de diciembre de 1618 , sometida al Sr. Príncipe de Esquilache, para que cesase enteramente y para siempre esta contribución, ordenando que los salarios de Alcalde de minas, Veedores y demás Ministros, se situasen en algunas Encomiendas vacas y que en el Hospital de Potosí se curase a los indios enfermos, con toda caridad y regalo, sin pagar cosa alguna.

Con todo, siguieron pagando como antes los pobres indios el im- 
puesto del tomín, en todo el gobierno del Sr. Marqués de Guadalcázar. Este Sr. Virrey, por Despacho en Santa, (c) a 16. de junio de 1622, dio comisión al Sr. Diego de Portugal, Presidente de Charcas, para efectuar el repartimiento gencral de la Mita; y por cl que se publicó en 15 de novicmbre de 1621 , consta que el total de la asignación subió a cuatro mil doscicntos sesenta $y$ cinco indios, señalando tres mil novecientos ochenta $y$ dos para las minas y ciento veinticuatio cabezas de ingenios de esta Ribera y del valle de Tarapaya, y los restantes, para soldados y socavones.

\section{$\$ I V$.} Exención del derecho de
Granos, que pagaban al Hos-
pital los indios mitarios.
$\mathbf{L}$ Chinchón, muy feliz para Ios indios, porque este Virrey, conformandose en todo a la Real detcrminación expresada, dio por extinguidas lats anteriores contribuciones en Auto de 18 de mayo de 1632 , y resolvió que, en consideración de no haber repartimientos vacos, se situase la quinta parte de los salarios en la Real Hacienda; que cesara la situación que en los Granos tenían los Corregidores de Potosí, como Visitadores del Cerro; que no se cobrase más el tomin del Hospital, y que los interesados propusiesen arbitios para complemento de sus dotaciones; sometiéndose este asuuto, en acuerdo general de Hacienda que para este fin se celebró, al Sr. Don Juan de Carvajal y Sancle, del Consejo de S. M. en el Supremo de Indias, Prosidente y Visitador de la $R$. A. de Charcas y Cajas de Potosí.

Se reiteró está provideneja en Auto de 24 de mayo del mismo año, imponiendo a falta de repartimientos vacos, en cada barra de ciento veinto marcos, 10 reales en plata, con cargo de llevar los Oficiales Reales, cuenta aparte dol producto de este ramo, y de añadir o quitar, según el más - menos peso de las barras; cliyo impuesto, porque todavía no alcanzaba para el entero de los salarios, se aumentó con dos reales más sobre los diez dichos en cada ciento veinte marcos de plata; quedando de esta suerte totalmente abolida una imposición en extremo gravosa para los indios mitarios de Potosí, cuyo alivio ya scrá perpetuo en esta parte, habiéndose canonizado las citadas providencias por la Icy 14, Tit. 15 , Libro $6^{\circ}$ de Indias, en que se recopiló la referida Cédula de 1618 .

En el año de 1633, hizo otro repartimiento el Sr. Juan de Carvajal, por orden y comisión del susodicho Sr. Virrey, señalando cuatro mil ciento veintinueve indios, ocho tercios a las minas e ingenios de Potosí y del valle de Tarapaya; cuya asignación sólo alcanzó a noventa y cuatro cabezas de los primeros y siete de los segundos, quedando sin ella doce cabezas en esta Villa y nucve en Tarapaya.

$$
\begin{gathered}
\text { Continuación del asunto } \\
\text { de la Mita. }
\end{gathered}
$$


mil cuatrocientos veintitrés indios el Sr. Duqque de la Pàlata, el año de 1688, en la numeración general que hizo on las Provincias asignadas y en otras que de nuevo asignó, destinando cincuenta inclios para cada una de las cincuenta y cinco cabezas de minas que estimó por útiles; pero ejecutó la extraña novedad de incluir: juntamente a los indios, forastelos Yanaconas, y mandó que el indio que salía de Mita no pagase tributo al año siguiente; todo ello contra el tenor de la Ley 14, Tít. 5", Libro 6" de Indias.

tos Corregidores, Prelados y Curas (d) de las diez y seis Parroquias afectas a la Mita de Potosí, representaron muchas causas dificultando cumplir las órdenes que expidió el Sr. Duque de la Palata, para que los forasteros que se hallaron y empadronaron en ellas al tiempo de la numeración general, quedasen con la misma obligación de Tasa y Mita que Ios originarios; cuya tributación aquietó el Sr. Conde de la Honclova, por Despacho de 27 de abril de 1692, mandando que corriesc por cntonces el cargo de tributos y Mita de los indios originarios, suspendiéndose por lo tocante a los forasteros empadronados en dicha numeración, por haberse hecho con errores.

Luego mandó hacer otro repartimiento general, en 8 de mayo deI mismo año de 1692, señalando para cl trabajo de las minas e ingenios de la Ribera de Potosí, cuatro mil ciento un indios que se hallaron de séptima en los originarios, según la numeración general del Sa. Ducue de la Palata; y por más que se estrechó el cómputo y numexación que antes tenjan los ingenios, no alcanzó este número de séptima más que para treinta y cuatro cabezas de a cuarenta indios por cada ma, quedando sin repartimiento veintitrés cabezas de ellos.

Sobre las providencias que dio el Conde de la Monclova, unas muevas y otras contrarias a las dadas por el Sr: Duque de la Palata, se suscitaron muy serias y prolijas contestaciones, que habiéndose agitado por muchos años, según relación de Ramiro Valenzuela, ${ }^{2 "}$ sc despacharon finalmente en 18 de febrero de 1697, varias Cédulas para el Sr. Virrey y Audiencia de Lima y Corregidor de Potosí, con dicz artículos que recopila el Adicionador de la Política India, ${ }^{21}$ donde se resolvieron los puntos principales de las anteriores diferencias; pero llevado el negocio al aclerdo para resolver otras graves controversias que de nuevo se originaron con los Informes del Corregidor, Real Audiencia, y Oficiales Reales de Potosí: se resolvió suspender la Real Cédula y dar cuenta a S. M. aunque se aventurase quitar la Mita en el todo. En efecto, la parte del Fisco insistió en esto último, y aunque se consultó a S. M. (añade el citado Adicionador), no se tomó más resolución que se formase una Junta en el Perú, de que no se sabe qué ha resultado. ${ }^{22}$

Esto era así por los años de 1730, en que escribió Valenzuela; pero habiéndose remitido últimamente los votos 'originales que, de orden del Rey, dieron Ios Ministros de las Audiencias de Lima y Chareas, con Informe del Sr. Virrey del Perú, se despachó Real Cédula, por consulta del Consejo, su fecha en Sevilla; a 22 de octubre de 1732, comprendiendo doce puntos muy esenciales, que han puesto este grave negocio en estado de perfecta serenidad. Se declaró, pues, en ella, entre otras cosas, que no se haga novedad en la continuación de las Mitas, corriendo estas, no en las demás Provincias que después se agregaron por el Duque de la Palata, y sí, precisa y únicamente, en las que antes estaban sujetas al repartimiento, que son las diez y seis siguientes: Pacajes, Omasuyos, Paria, Cocha- 
bamba, Poreo, Chayanta. Tarita, Carangas, Chucuito, Paucarcolla, Lampa, Azángaro, Conde, Changras, y Quispicanchi, 23

Se añadió la calidad precisa qle el repartimiento se verifique solamente al respecto de la séptima parte, según está prevenido en Leyes y Ordenanzas, " corriendo estu misma regla en los indios forasteros que se hallen en dichas 16 Provincias, por no deber gozar mayor privilegio que los naturales, sólo por haber desamparado sus tierras; con lo que vino a decidirse la gran controversia de contrariedad de votos, que obligaron al $\mathrm{Sr}$. Conde de la Monclova para relevar del servicio de la Mita a los forasteros que comprendió el Duque de la Palata.

Dedúcese de esto mismo, que verificado el servicio de la Mita en la séptima, cl indio que asistiere un año en Potosí, ha de tener seis de descanso en su pueblo, sin que pueda ser nuevamente molestado hasta que se haya cumplido este término.

Se declaró también ${ }^{2 . \lambda}$ que la Mita debía venir con dos descansos o remudas, como estableció Don Francisco de Toledo, para que el indio que trabajare una semana en las minas e ingenios de Potosí, descanse las dos siguientes; por: haberse reconocido serles de perjuicio la forma que dio el Duque de la Palata, de que la Mita se llevase con sola una remuda para. que trabajando una semana descansase ot ra. ${ }^{26}$

\section{$\S$ VI.}

De los leguajes que se de- $\mathbf{N}_{0}$ siendo justo que los indios mitarios ben pagar a los mitarios. costeen sus largos viajes, se halla prevenido en diferentes Cédulas antiguas, Leyes y Ordenanzas, ${ }^{27}$ que se les pague el camino de ida y vuelta, disponiendo ${ }^{28}$ que cl leguaje sea de $1 / 2$ real por legua, pero sin computar número fijo de leguas por el camino de cada día. El Sr. Conde de la Monclova ${ }^{29}$ mandó computar a razón de cinco leguas por día y que el jornal fuese de 5 reales diarios. En otra Cédula posterior sil ya se estableció punto fijo ordenando que en la ida y vuelta de los indios mitarios se hayan de regular por cuatro leguas al día, pagándoseles en cada uno la mitad del jornal que gozaren cuando trabajan en las minas. Sobre cuyo punto se resolvió novísimamente 31 que el jornal sea el de 4 reales de plata por cada día que trabajan en las minas y su mitad por el leguaje, que vienen a componer 2 reales diarios o 1/2 real de plata por cada legua; añadiéndose ${ }^{32}$ en alivio de los miserables indios, que, antes de salir las Mitas de los lagares donde están repartidas, se les pague por los Capitanes de ellas, la mitad del jornal que pudiere importar el viaje hasta llegar a la mina, para que deje algún socorro a sus familias si se hallare con ella, y de no, vayan gustosos con esta paga antiripada; y que los dueños de minas tomando seguridad de los Capitanes, estén obligados a darles los medios nenesarios para que hagan estos socorros, sin que se pueda obligar a los indios a que salgan sin ellos.

A consecuencia de estas Reales disposiciones, se ordenó por un auto acordado del Supcrior Gobicrno de Lima, fecha 26 de marzo de 1754, que guardándose otro Decreto de 9 de octubre de 1753 , adclantasen los mineros y azogueros el leguaje a los indios de Mita, remitiéndolo a los Corregidores, para que éstos les entreguen con intervención del Cura dol lugar 
de donde saliere la Mita, haciéndolo constal pol cortíicación que debe dirigirse al Gobierno de Potosí.

Esto no obstante, nunea se ha vcrifieado la paga del leguaje de venida, con fl pretexto de compensurse con la falla co intios de Mita que siempre se experimenta, ${ }^{2}$ exceptuando una u otra coasion que so anticiparon los leguajes a los indios de Chucuito por mano kle aquel Gobernador, como se colige do dos cartas del S1. Virrog D. Mannel Amat, ${ }^{31}$ cn qùe se ordenó que en adelante se entrecrue en mano propia lo respectivo a cada indio; y aunque por Auto definitivo de 17 de septiembre de 1771, declaró este justo derecho a favor do los indios do Chucuito, en contradictorio juicio del Superintendente de la Mita, Dn, Pedro Tagle, Oidor de Charcas, mandando formar margesí de las distancias de cada Provincia, no tuvo su debido cumplimiento, por haberse mandaco al mismo tiempo que no se hiciera novedad por entones sul cuanto a los leguajes de la venida, por haberse contentado los querellantes con los de la vuelta, quedando el negocio en su antiguo estado por fulta de estiverzo por parte de los indios, siendo contra lo natural que unos inlelices, sobre ser gravados en el trabajo de salir de sus Provincias a cumplir con su Mita, sean también pensionados a costear de su mismo sudor tan largos viajes.

Lo más estraño es que en margesí formado por cł Capitán de la Mita, en consorcio del Protector, a 25 de septiombre de 1771 , se supme que la Mita para salir a Potosí, se congrega en un detaiminado pueblo de las provincias afectas al repartimiento, que siempre es de los más cercanos a la Villa, para defrauklar ocho, diez, cuinec o más leguas que camina desde la parcialidad de donde sale, hasta llegar al punto puesto de reunión, como se demostró en la descripción de la Provincia de Chichas; pero como está en actual observancia, se pone para gobierno la tabla siguiente:

Provincia de Chucuito. - La Mita salte del paraje nombrado El Desaguadero, distante de csta Villa ciento treinta leguas, que a $1 / 2$ real cada una, hacen ocho pesos un real de leguaje $\ldots \ldots \ldots \ldots \ldots \ldots \ldots$

" Paria. - Del pueblo de San José de Poopó, donde se junta la Mita, dista cuarenta y ocho leguas, que a $1 / 2$ real importa tres pesos ..............

" $\quad$ Chayanta. - El pueblo y asiento de San Pedro de Macha, dista treinta leguas, que hacen a $1 / 2 \mathrm{rcal}$,

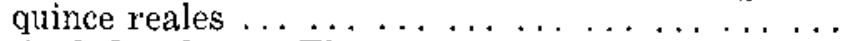

" "Cochabamba. - Ei pueblo Real de San Pablo de Capinota, de donde sale la Mita, dista sesenta leguas, que a $1 / 2$ real hacen $\ldots \ldots \ldots \ldots \ldots \ldots$

" "Porco. - El pueblo de Santiago de Chaquí, donde se congrega la Mita, dista siete leguas, que a $1 / 2$ real hacen $\ldots \ldots \ldots \ldots \ldots \ldots \ldots \ldots \ldots$

" Carangas. - EI pueblo de San Juan de Corque Marca, dista noventa leguas, que a $1 / 2$ real hacen.

" Pacajes. - El asiento de San Diego de Topoco, dista ciento treinta leguas, que a $1 / 2$ real hacen .....

"Quispicanchi. - El pueblo de Pomacanche (Puma-

08.1 cancha), dista ciento ochenta leguas, que a $1 / 2$ real 


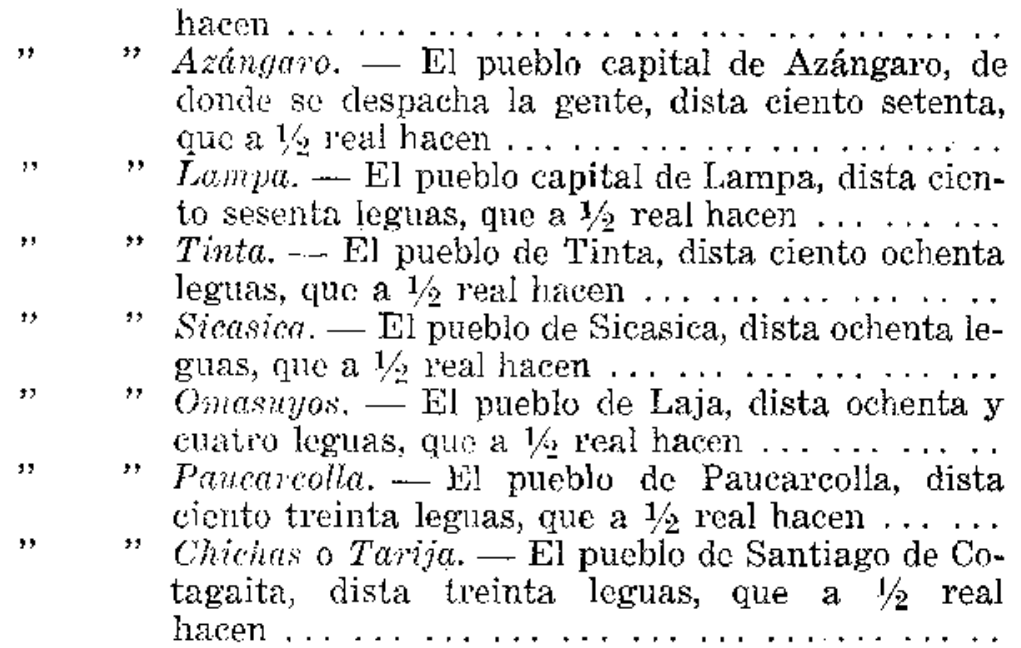

Conforme a esto margesí se les paga el camino de la vuelta, por lo regular sin fraude ni menuscabo, que jamás debería ni aun temerse que sucediese, si estos pagamentos sc hiciesen indispensablemente en mano propia del indio, en presencia del Cobernador, con asistencia del Escribano de Minas para dar fe de ello, y uno de los Oficiales Reales para formar las respectivas relaciones con qué dar cuenta al Consejo, según está ordenado por Rcal Coduia de Madrid, a 18 de febrero de 1697, Cap. $7^{\circ}$, y por otra posterior de Sicvilla a 22 de octubre de 1732, Cap. 6, debiéndose abolir en virtud de estas Reales determinaciones, la práctica de pagárseles este leguaje solamente ante el Capitán mayor de la Mita y Protector de Naturales, porque computándose entre los jornales, debe observarse en el modo y forma de su satisfacción una misma solemnidad. Sólo en cuanto al lugar nada se dispuso en las Cédulas referidas; pero hallándose resuelto por el Sr. Conde de la Monclova, en Despacho de 27 de abril de 1692, que estas pagas se ejecutan en el oficio de Cabildo (que ahora sc entiende con el de Minas, estando ya scparadas estas Escribanías que antes estaban unitlas), debe guardaise esta disposición como no revocada por ninguna posterior; y sería éste el único medio de no excusarse los citados Ministros, con la ocasión de hallarse esta oficina en la Plaza.

Con todo esto, no logran los infelices indios el alivio que el Rey les desca en el socorro de leguajes para costear con ellos sus viajes, porque durante el tiempo de la Mita consumen en el sustento de sus personas y familias, que regularmente traen consigo, mucho más de lo que ganan. Por consiguiente, contraen empeños y a su despedida es preciso pagarlos, quedando tanto o más insolventes que antes; de suerte que se ven precisados de hacer su peregrinación mendigando y robando en los caminos, o de quedarse ocultos en la Villa, para exponerse al conchavo o min$g a$, hasta poder habilitar su marcha; y como la inclinación dominante del indio es la liber'tad, jamás vielve a buscar su domicilio, ni tiene con qué hacerlo, porque todo lo que granjea lo disipa en sus vicios y borracheras.

Aun todavía trae peores consecuencias el no pagarles los leguajes de la venida, porque en rigor de justicia no se puede obligar a los indios a salir de sus tierras sin estos anticipados socorros. Muchos Corregido- 
res antes de abolirse el sistema de este Gobierno, se escudaban con ello para no despachar el entero de las Mitas, a fin de cobrar sus repartos con más facilidad teniendo a la mano los indios; y aun ahora que se ha extinguido este tropiezo, no se ha remediado todo el mal, porque los Subdelegados cơn tal de hacer expedita la cobranza de tributos de su cargo con la presencia del indio, no se cansan demasiado en procurar su remisión a la Mita.

Lo peor es que, obligados a salix de sus tietras por fuerza, se les suple parte del viático con los frutos de las tierras de Conunidad, en perjuicio de la primitiva institución de este ramo; y al resto lo costean estos infelices del producto de sus pobres cosechas en ver de vestirse con él, extendiéndose el perjuicio a todá la parcialidad, auncue sea a quien no toca la Mita, por la reprensible corruptela que tienen los Gobernadores indios, de repartir entre todos la carne, gallinas y demás efectos que acostumbran traer, con título de regalos, llamados ricuchicos, para obsequio del Capitán mayor de la Mita, y Alcaldes Vcedores del Cerro.

Pero cllo es cierto que aunque tengan viva su acción para demandar la paga anticipada de los lcguajes de venida, no pueden resistivse a ejecutarla con la libertad que les concedió la Real Cédula de 18 de fobrero de 1697 , Cap. 6\%, porque habiéndose suspendido su ejecucion, según se ha dicho, se despachó posteriormente, con mejor conociniento, la de 22 de octubre de 1732, ordenando en el Capítulo 4", la anticipación de estos mismos socorros, con supresión de la cláusula que, en la anterjor Cédula citada, disponía no poderse obligar al indjo a salir de sus tierras sin esta paga; que fue lo mismo que revocarla.

\section{$\S$ VII.}

Formalidades que se deben observar en el envío y recibo de la Mita, $\mathrm{g}$ facultades del Superintendente para verificar su entero.

A SI pues, los Corregidores antes, y ahora los respectivos Subdelegados de las Intendencias nuevamente erigidas, estaban y están perpetuamente obligados al despacho de las Mitas y lo ejecutan en esta forma. Remiten, con oficio al Gobernador de Potosí, la lista y numeración de los indios a quienes toca el repartimiento, con expresión de su número, de los pueblos de donde son y de los Capitanes enteradores de cada Aylin. Este documento se remite con decreto al Capitán mayor de la Mita, para que pase muestra de todos ellos y dé cuenta si está conforme a la numeración referida; a cuyo fin se congregan los indios en la Plaza, en las puertas del oficio de minas, en presencia del Capitán mayor y Alcaldes Veedores, quienes lamándolos por la lista, pasan la muestra y previenen a los Capitanes enteradores concurran al servicio de las minas e ingenios de sus respectivos repartimientos. (e)

Antiguamente, después de recibida la Mita, daba cada pueblo sus fianzas ante el Escribano de ella, en presencia deI Snperintendente y Capitán mayor, con asistencia de los interesados o de sus Mayordomos, para que tomándose razón de los fiadores, quedasen éstos responsables a reponer el indio "cédula" que faltase. Ahora no se observà esta formalidad, pero el azoguero tiene buen euidado de hacer cargo al Capitán enterador de los rezagos que ocasiona el indio que le falta después de pasada 
la lista; de donde procede que los entoradores no se detienen en arbitrios reprobados, para tener siempie sobrantes con qué enterar los rezagos.

Si la falta está de parte de los Corregidores o Subdelegados, por omisión en el despacho de la Mita, tiene el Gobernador de Potosí facultad para proceder contra cllos, hasta suspenderios de sus oficios y nombrar personas que administren justicia y recauden los Reales tributos por cuenta de ellos mismos y de sus tiadores, interin se da cuenta al Superior Gobierno, según lo prevenido por el Sr. Virrcy Marqués de Villagarcía, con voto consultivo del Real Acuerdo de Lima, cn Auto de 13 de scptiembre

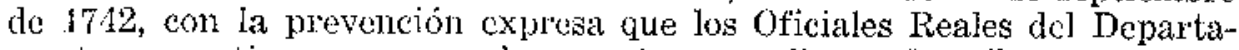
mento respectivo, no pasen las cuentas que dieren de tributos, sin que también las don de los enteros de Mitas de sus Provincias, a proporción de sus repartimientos, con recibo de los azogueros o con otros instrumentos jurídicos equivalentes, quedando responsables los Corregidores o Subdelegados a los rezagos de Mitas que se causaren por su omisión; y ya que deben rendir ahora los Subdelegados sus cuentas ante los Intendentes, debe entender'se con éstos lo dispuesto con los Oficiales Reales.

Para averigular la falla y despacharse por el entero a costa de los Corregidores o Subdelègados, dispone la Ordenanza 35, Tit. 10, Libro $3^{\circ}$ de] Perú, que cada cuatro meses, los Capitanes hagan alarde $\mathbf{y}$ reseña de Ios indios de sus parcialidades, para ver si está completo el repartimiento.

\section{$\S$ VIII.}

Del trucque del servicio personal, en plata, $\mathbf{y}$ sus penas.

D E esta diligencia puede resultar la falta, no de parte de los Subdelegados, sino del indio particular que se redimió del trabajo con dinero, o de los Capitanes enteradores y azogueros, que haciendo granjería del sudor de los miserables indios, se dan por entregados de los que verdaderamente no han recibido, como sucede no pocas veces, cambiando su servicio en plata, para dejarlos ir por aquella Mita. Este abuso que ha sido muy antiguo en Potosí, lo cortó en parte el Sr. Conde de la Monclova, en Provisión de 27 de abril de 1692, ordenando que los enteros en plata, on trueque del servicio personal, se hicieran a razón de tres pesos únicamente, y de ningún modo a los nucve y medio, ni a siete, ni aun a los cuatro pesos y medio que antes se acostumbraba; pero subsistiendo todavía el daño que resultaba a la causa pública, de no destinarse los indios al trabajo de las minas, se despacharon dos Reales Cédulas ${ }^{35}$ ordem nando que los mitarios no se piedan rescatar por dinero y sólo se les permita dando en su lugar otros indios que sean útiles para el trabajo de las minas; sin que se admita dispensación en este punto, por graves inconvenientes que se han experimentado en lo contrario; confirmándose en estas novísimas Reales disposiciones, la justísima resolución de muchas Leyes y Ordenanzas recopiladas 36 que han prohibido rigurosamente que se vendan, truequen, cobren y reciban en plata o cualquier otra especie el trabajo de los indios que les estén señalados, por sí o por interpósita persona, bajo la pena de 150 pesos ensayados por cada indio de quien recibiere plata el señor de la hacienda, aplicados por tercias partes, Cáma$x a$, Juez y denunciador; en la que igualmente incurre el minero que lo recibiese, y más cuatro meses de destierro preciso del Cerro, por la prime- 
ra vez; ${ }^{37}$ por la segunda, perdimiento peryetuo de los indios repartidos y privación de podérseles volver en adelante, y más, pagucn de pena 300 pesos de oro, aplicados por tercias partes; $y$ el minero que to hizo o consintió, caiga en pena de vergüura pública y dos años de destiemo de la Villa y Cerro, y más 300 pesos de olo, aplicados on la forma dicha; ${ }^{3:} \mathrm{y}$ aunque cl Sr. Virrey D. Luis de Velasco, aumento la pena pecuniaria hasta 2.000 pesos ensayados, en la Ordenanza 1", Tit. 13, Libro $3^{\circ}$ del Perú, (la que parece habex altexado o colvegido las anteriores, como posterior en el orden) nada más hizo que reaglavar la pena por la tercerł vez que se contraviniese a las citadas prohibiciones.

Esta pena, que por' haberse tasado en las Ordenanzas, fue entonces ordinaria, se hizo arbitraria después que por Real Códula de 1620, recopilada en la Ley 7, Tit. 15, Libro 6" de Indlials, se mantó proceder contra los que en esto delinquieren, no sólo en ser privados de los indios, sino condenados en las penas corporales y poculiarias que prociere justo; con lo que pueden los jueces que conocieven de semojantos dolitos, acrecentar o moderar las penas que quedan roferidas; pero nada se ha innovado en cuanto al fuero de cste crimen $\mathrm{y}$ el modo de su procedimiento; es decir, que así el Corregidor o Gobernador do la Villa, y las demás justicias ordinarias de ella, a prevención, puteden proceder contia los infractores, por un conocimiento breve y sumarjo, de suerte que constando el hecho con sola la declaración de cuatro indios, sin necesidad de otra averiguación ni más formalidades, deben ejccutar el castigo, según lo prevenido en la Ordenanza 1", T'́t. 11, y Ordeuanza 1:, al fir, del Tit. 13, Libro $3^{\circ}$ del Per'ti.

Así pues, la disposición del Sr. Monclova, sólo rige hasta el día, en el caso de formarse cargo a los Subdelegados por los rezagos de Mitas que se causaron por su omisión, porque nada más deben pagar que tres pesos semanales por carla indio de falla, quo viene a salir a cuatro reales por cada día de los seis que componen la semana, conforme se declaró en la Real Cédula de 22 de octubre de 1782, Cap. $5^{\circ}$.

$$
\S \text { IX. }
$$

Ingar destinado para la pa- $\mathbf{A}_{\text {los indios que trabajaban efectivamen- }}$ ga semanal de jornales, $y$ te en sus respectivos repartimientos, se papersonas que deben concurrir gaban antes sus jornalcs los domingos de caa este acto. da mes, con las solemnidades y en el lugar que disponen las Ordenanzas 19, 20, y 21, Tít. 10, Libio 3o del Pcrú. Ahora está en todo variado este método, porque las pagas se hacen los lumes de cada semana, en una casería llamada Guayna, situada al pie del Cerro, a la izquierda del camino real viniendo a la Villa. Deben concurrir el Gobernador, Escribano de Minas, y uno de los Oficiales Reales, para que se formen relaciones de estas pagas por este último, para remitirlas al Consejo, y dé fe el Escribano haberse verificado en mano propia de los indios mitayos. ${ }^{3: 1}$ Asisten también a esta operación, el Capitán mayor, Alcaldes Veedores y los azogueros que tienen repartimiento o sus apoderados, bajo la pena de 10 pesos ensayados a estos últimos, por la primera vez que faltaren; por la segunda 20 pesos, y por la terccra 50 de la misma plata, a más de la suspensión del reparti- 
miento por cierto nimoro de semanas, según lo dispuesto en las Ordenanzas 20 y '21, 'Tít. 10, Libro 3" del Per't.

Esta concu'rencia debe sẹ' de las más indispensables operaciones de la Superintendencia, por sel un equivalente juicio de visita para oír agravios a los indios, como también a los azogueros en cuanto al servicio de los primeros. A uste fin dispone la Ordenanzat ${ }^{\prime \prime}$ que se pregunte en goncral a todos y a cada uno en particular, en su lengua, qué dís o noches han trabajado y si les dieron tareas y en qué forma, y si para cumplirlas han doblad el tiompo y trabajo: si les han dado velas suficientes o si ellos han presto alonnus, de sus casus, y qué daños, agravios o malos tratemicntos se les ha hecho contia Ordencha, para que justificada la culpa sumariamente allí mismo, se proceda contra los culpados, castigando a vista de todos al Capitán mayor, on un carnero de la tierra, al indio que se le convenciese de no häbel cumplido con su obligación.

Cuando todavía existiail los dieciséis iridios Alcaldes Cañars, uno por cada l'rovincia de todas las ajectas a Mita, sc hacia esta convocatoria con milha solemnidad, saliendo los lunes a Jas dos y tres de la mañana, cuatro Alcaldes con clatín y caja por todas las rancherias, avisando a los Capitanes enteradojes, que acudiesen a Guayna con los indios "cédulas" que hubjesen trabajado la semana anterior, para ser pagados y desagraviacios. Aumque ya no se ejecuta esta convocatoria desae que se abolieron los Alcaldes Cañaris, se practica sieripre el concur'so a Guayna todos los lunes, pero no asiste ninguno de lus Oliciales Reales, sin duda por puro efecto dol disimulo y tolerancia do Gobernarlor, no obstante habérseles ordenado en repetidas providencias por los Señores Virreyes, ${ }^{41}$ que indispensablemente presencien las pagas, aunque no se hagan de la Real Hacienda ni ellos tengan jurisdicción alguna, más que una intervención material.

Muchas veces no concurre el Superintendente y suple sus veces el Capitán mayor debicndo hacterlo el Teniente de la Villa, conforme a Ordenanza ${ }^{42}$ y al nuevo sistema de lntendentes, para que așí por su mayor instrucción en el derecho como por autoridad de sl empleo, desagravie con més seriedad cualesquier excesos, sin disimular que un acto tan esencial al buen gobierno, sea todo aparato y ceremonia.

\section{$\S \mathrm{X}$.}

Abusos introducidos en per-
juicio de la Mita. Sr. Dn. Francisco de Toledo, 13 cuya Ordenanza se mandó guardar después por el Sr. Marqués de Cañete, "A prohibió rigurosamente señalar tareas a los indios barreteros, que son los que quicbran el metal, y principalmente a los apiris, que son los que lo sacan de lo interior de la mina, fuera de ella, a un lugar que llaman cancha, considerando imposible cumplirlas o a lo menos de insoportable trabajo por la hondura de las minas y gran distancia que hay desde el centro y chiles a la superficie donde to sacan; y ordenaron que cada indio saque aquello que buenamente pudiore en las horas que le están asignadas para trajoja " no más, sin que les puedan dar más trabajo, ni quitarles cosa alguna de sus jornales, so 
pena, por la primera vez, de diez pesos ensayados, por cada indio, por la segunda la pena doblada, y por la tercera, de doscientos pesos con más privación de los indios; ampliando otra Ordenanza ${ }^{46}$ a tales términos el favor de los indios, que aunque no trabajen mancla pagárseles su jomal, con la absoluta prohibición de castigar esta culpa otros que no sean los Alcaldes Veedores del Cerro, procediendo antes que éstos entren primero en la mina para juzgar, viéndola, si merece o no castigo. ${ }^{\text {is }}$

Nada de esto se observa, en gravísimo perjuicio del miscrable indio; y para que se conozca el insufrible trabajo a que se ha reducido el servicio de esta gente, nótese que, recibida la Mita, sube al Cerro la primera punta con sus botas para sacar el metal, que son unos costales de cuero, de tres cuartas de largo y media vara do ancho; llevar la hervamienta pesaria pólvora y velas, cn compañía del Cu*aca a. Sogunda; hacen su trabajo por la noche en sacar metal, pox ser lo más penoso en el servicio de las minas.

El barretero, que siempre es mingado y trabaja en compañía de otro de la misma clase, hace su tarea alternativamente, esto es, mientras el uno da un tiro o barreno o gasta un espacio semejante, el otro descansa durmiendo o acullicando (gue así llaman el mascar la coca); alternando así entre los dos, deben rendir en cada noche cuatro tiros, y ganan en cada noche seis reales.

El metal que desgaja el barretero lo recoge el "cédula" o mitariouy lo lleva a la broceana, que es un Tugar distante donde se escoge y reduce a pedazos menores por otros indios mingas, llamados brociris, que ganan cada noche cinco reales; en este trabajo octupa toda la noche el infeliz mitario, entrando y saliendo de la mina, cargado del costal lieno de cuatro o más arrobas de metal, arrastrándose con ese peso por los suelos, pasando estrechas angosturas y grandes precipicios, hasta enterar veinticineo costales al amanecer, que es lo que llamar una palla, sin ganar más salario que cuatro reales por excesiva tarea, y una vcla que se le da para cada hoche; ${ }^{48}$ de suerte que, por ciento veinticinco botas de metal que entregan en cinco pallas o en otras tantas noches que trabajan en la semana, vienen a ganar estos infelices apenas veinte reales, que cuando más les alcanza paragastarlos en chicha et do mingo

Una sola mala noche sabemos cuanto quebranta al hombre más robusto y bien alimentado. Para estos infelices todas las noches son malísimas. Ellos suben y bajan sobrecargados con cuatro arrobas de peso, por unas cavernas llenas de horror y riesgo, que parecen habitaciones de demonios. Los hálitos minerales los quebrantan de tal manera, que así por el cansancio de estas penosas tareas, como por el copioso sudor que brotan con el calor subterráneo, y excesiva frialdad que reciben al salir de las minas, amanecen tan lánguidos r mortalos owe parecen cadáveres; y el descanso de la mañana es chasquear' (f) lo que ha sacado de la mina por' la noche, que se reduce a enterar la tarea de veinte a treinta, más o menos, botas de metal con peso de cuatro ar'robas, poco más o menos, cada una. Así pues, puede decirse con verdad que el abuso ha constituído estos hombres en la clase de los más infelices del mundo, debiéndose reptltar más dichosos aquellos facincrosos reos que se envían forzados a trabajar las minas de azogue, pues, por más de haberse creído intolerable esta pena y poco menos terrible que la muerte, Io cielto es que cada forzado apenas trabaja lijeramente tres horas al día, cada uno le cuesta al 
Rey ocho reales diarios, se regalan $y$ comen mejor que ningún labradór, venden la mitad de su ración y gozan de robustísima salud, como lo testifica el naturalista Bowles. ${ }^{19}$

Con todo de parecer, como es verdaderanente, imposible el cumplimiento de unas tareas que no podrían llenarlas ni aun los brutos, se ve que estos infelices satisfacen, ya que no pueden por sí solos, costeando de su escaso salario otro compañero que les ayude (que llaman Yanapacus), (g) y tal vez hacen ellos mismos el gasto de las velas que les faltan para el trabajo de las cinco noches de la semana, por no ser posible que las cinco velas que los dan para dichas cinco noches hayan de durarles por toda la semana, siendo natural que en las subidas, bajadas, entradas y salidas de la minza, con el calor subterráneo y con el aire que reciben las candulas en este continuo trajín, se gasten al doble de lo que consumen en una piezal, doncle se experimenta que una vela no alçanza para toda la noche.

En esto se les causa una grande injusticia contra la Oxdenanza que manda ill rlarlos dos velas por cada noche, quedando responsable a la restitución el azogucro, que con el sudor de los miserables indios costea estos criminales ahorros, sin considerar que, si el miscrable mitario deja de comel pan por comprar velas para hacer su trabajo, es porque teme que de sus jornales se le descuente lo que ha faltado en las tareas, como regularmente sucede, haciendo el cómputo de cada día de servicio por veinticinco botas, de a cuatro arrobas de metal cada una; de manera que si cn las cinco noches del trabajo semanal sólo sc han enterado cien botas, que componen cuatro pallas, no les pagan más que dos pesos, rebajándoles cuatro reales por la quinta palla que falta, y esto es después de haberse propasado tal vez a castigarlos de su autoridad propia, sin guardar la justifieación que tanto encarga la Ordenanzé 4", Tít. 10, y la Ordenanza $6^{n}$, Tít. 11, Libro $3^{n}$ del l'erú, ni dejarles la libertad de no trabajar los días de fiesta que guardan los españoles, según lo dispuso el Sr. Marqués de Cañete, en su Ordenanza 49, recopilada después en la $5^{n}$, Tít. 10, Libro $3^{\circ}$ del Perú, conformándose a los Cánones del Concilio Provincial Limense y Mexicano. 51

\section{$\S \mathrm{XI}$.}

Dias de fiesta de guarda $\mathbf{Y}$ A que ha incidido este punto, que es de para los indios. los de mayor escrúpulo como tocante a la santificación de las fiestas, será justo detenerme algún tanto on su examen. Aunque los días de fiesta de guarda para los indios, están reducidos por Breve Apostólico de Paulo III, solamente a todos los domingos, las cuatro Pascuas en los primeros dias, la Circuncisión, Ascensión, Corpus-Cristi, la Natividad de N. S., Anunciación Purificación y Asunción y el día de San Pedro y San Pablo, ${ }^{52}$ así en estos como en los demás días festivos que guardan los españoles, no deben ser compelidos a trabajar contra su voluntad, quedando libres para alquilarse con quien les pareciere, por sus justos jornales, según está declarado en los Concilios Provinciales Jimense y Mexicano ${ }^{53}$ y en diferentes ordenanzas y leyes recopiladas del Reino. ${ }^{54}$ 
Sobre todas estas Canónicas y Reales decisiones resuelve el salpientísimo Sr. Solórzano, ${ }^{55}$ que no es licito forzarlos a trabajar en las demás fiestas del año que guardan los españoles, si ellos dijesen que tam. bién las quieren guardar; aunque sea con el fin de aumontal la saca y beneficio de metales, para la mayor prospcridad del Reino; añadiendo 50 que en varias consultas que se lo hicieron por los Sres. Virreyes de lima, siendo él Oidor de aquella Audiencia, siempre fue de parecer que las fiestas debían guardarse con preferencia a todo otro objeto por favorable que parezca, excepto el caso $"{ }^{\prime}$ de amenazar ruina las minas o de otra causa repentina y precisa, en que no acudicndo a gozar de la ocasión resultarían de la tardanza daños irreparables; de cuyo mismo scntir son otros autores regnícolas de la mejor nota, como Dn. Franciseo Carrasco y Fr. Juan Focher. "5s

Pero, porque esta doctrina puede causal notables escrúpulos e inquietudes en los superiores que permiten la violación de tales festividades, debo hacer presente que el Ilmo. Sr. Montenegro, Prelado prudentísimo y muy sabio de las materias de indios, resuclve sin la monor perplejidad: ${ }^{5}$ que no pecan los que obligan a los indios a trabugar los dias de fiesta que ellos no tienen obligacion a guardar; lo primero, porque los Concilios Provinciales citados, no dicen más de que no sean compelidos, cuyas palabras no ponen precepto que obliga a pecado mortal; lo segundo, porque los indios regulamente quieren guardar las fiestas por beber y no por devoción; y así, hacerles trabajar, más es estorbar la ociosidad y embriaguez que atajarles la devoción. Esta doctrina me parece muy sana y más conveniente al estado de la presente necosidad del Reino pır la escasez de las minas de este Cerro y notorios atrasos del Gremio y Azogueros, porque la Iglesia jamás ha pretendido obligax a este ocio en daño público del Estado o república, como lo declara un Capítulo canónjeo, 6 y en su conformidad lo resuelve Suárc, ti aconsejando que para mayor seguridad y para evitar el escándalo, se pida siempre licencia al ordinario en estos casos.

Yo, desde luego, me persuado que haya precedirlo el permiso de los Iimos. Sres. Arzobispos para el trabajo de los indios en los días festivos, que son para ellos de voluntaria observancia, pues, aun en el caso que quisiesen trabajar voluntariamente, dispone un Concilio Provincial $\mathrm{Me}-$ xicano, ${ }^{62}$ que no lo ejecuten sin licencia del Ordinario, para evitar por este medio que los españoles tomen la misma ocasión de hacer obras serviles en tales festividades; por lo que es regular que para obligarlos se haya interpuesto con mayor razón la autoridad eclesiástica. Aun en otros casos menos precisos y urgentes vemos aquí dispensados los domingos y demás días festivos, vendiendo en ellos públicamente bayetas y otros géneros de la tierra, una clase de indios e indias que llaman gateras, (h) bajo el gravamen de cierta limosna que contribuyen para la Iglesia, con todo que para esta dispensación no se alega más motivo que el de socorrer a los indios mitarios que bajan del Cerro únicamente en aquellos días; sobre lo que es digno de advertencia que aunque sea facultativo al Ordinario, imponer ciertas limosnas en las dispensaciones de días festivos, por vía de conmutación y no de multa (que sólo al Sumo Pontífice es facultativa), no es de precepto su contribución y sí, solamente de consejo, como resuelve sabiamente con muchos Doctores el Ittmo. Fermosino; is y así debe reputarse por agravio el apremio con que son forzados los in- 
felices indios a contribur estas limosnas a los que mantienen su administración por via de negociación cuestionaria y lucrativa.

Sin embargo que no se quebrante Ley alguná Eclesiástica ni se peque haciendo trabajar a los indios en los días privilegiados para ellos, scguin la doctina citadi, se les agrava la nolestia de su penoso servicio, con quitarles muchos más dias de descanso de los que gozan los españolns $y$ demás gentes teniendo menos trabajo. Las mismas leyes 61 tienen consideración de lo mucho que conviene que los indios se huelguen y descansolr. A este fin se establecicron los días festivos, interponiendo a los trabajos al descanso, como un temperamento necesario a la vida, según decia Sincea; porque siendo continua la fatiga del cuerpo, desmayan las fuerzas y no pueden recobrarse sij deleitar ánimo con el descanso y la alegría, como Io explica el insigne Arraya. ${ }^{65}$

\section{$\$$ X.II.}

\begin{abstract}
La decadencia de la Mita $y$ otras fatales consecuencias que han procedido de los abusos tolerados contra ella.
\end{abstract}

d

E STOS injustos apremios y las cruelísimas continuas muertes que recibian los indios de Mita en el Cerro de Potosí, fi los llegaron a hol'rorizar tanto, que huyendo de estos pueblos que les fundó el Inca y el Virrey Dn. Francisco de Toledo, 't para reducirlos a vida política y recogertos de los campos donde vivían como fieras salvajes, 68 se fueron a buscar los valles más remotos y escondidos, dónde vivir libres de las extorsiones y molestias ${ }^{69}$ de este penoso servicio. Allí los cubrió el favor de los mismos hacendados, interesatios en su permanencia para la labor de los campos y cultivo de las chacras; de suerte que ha sido inútil toda diligencia en buscarlos para volver sus personas y familias a los pueblos de su origen.

Con el trato libre que en estos parajes tenían con los españoles, negros y mulatos, pasaron a las clases de mestizos y otras, transformándose ya en otro género de gentes exentas del gravamen de la Mita. En estos sitios desamparados de todo alixilio racional, obraron con mayor fuerza sus estragos las timelas, que repetidas cada siete años, con otras malignas epidemi is de garrotillo y exisipela, io llegaron a exterminar en tales términos la casta de los indios, que, entre otras causas, se atribuyó principalmente a estas pestes la notable disminución de indios, averiguada en los años de 1607, gobernando el Sr. Marqués de Montesclaros; ${ }^{71}$ y por áltimo, el horroroso azote de aquel contagio mortífero que inficionó todo el Reino, el año de 1719 , acabó de an'uinar los pueblos, sin dejar casi una familia a quien no arrebatase la mayor parte de sus individuos.

Estas son las verdaderas y principales causas de la decadencia a que ha llegado la Mita de Potosí, y no aquella formidable mortandad que pondera Calancha, i2 tocando el extremo de la exageración en asegurar que cada peso que se acuña en Potosí, cuesta diez indios muertos en las cavernas de las minas; a cuyo principio atribuyen también los modernos historiacleres Raynal y Robertson, ${ }^{73}$ la rápida destrucción de la casta de indios en los Estados de América donde se trabajan minas; porque si fuera cierto el cómputo de Calancha, sería preciso convenir que habían pe- 
recido en este Cerro más de ochocientos mil millones de indios, que son los correspondientes a más de ochocientos miliones re pesos que se han acuñado; jo cual no sólo es inverosímil sino ridículo.

ES verdad que Don Fernancio Carrillo y Altamirano, hablando con el Rey Católico, y el Capitín Juan González de Acevedo con Felipe III, en otro memorial que le presentó el año de 1602, afirman que en todo el distrito del Perú donde los indlos son precisados a trabajar en las minas, su número se habia reducido a la mitad, y en algunos lugares al tercio, del que habia en el Virreynato de D. Francisco de Toledo, por los años de $1581 ;{ }^{74}$ con cuyo testimonio comprueban los citarlos historiadores, que fas minas aniquilan el género humano y que su trabajo ha destruído la.mayor parte de los indios.

Por muy respetables que sean estos autores españoles, hemos visto en el principio de este parágrafo, que el año de 1601, rebajadas las fallas de todos los anteriores repartimientos, qucdaron roce mil sciscientos treinta mitarios; cuyo número cotejado al de catorce mil doscientos cuarentiocho indios que repartió el Sr. Don Francisco de Tolcdo, por el mes de agosto de 1578 y en 20 de diciembre de 1580 , resulta la falla de un tiempo a otro, no de la tcrcer'a parte y menos de la mitad, como afirma el referido González de Acevedo, sino apenas de mil seisciontos dieciocho indios, que viene a corresponder a poco más do una décima parte; y siendo verosímil que esta cantidad se hubiese disminuído por la deserción de los indios a Io interior de los valles y por las pestes y epidemias, más bien que por la mortandad en las minas, será justo preferir la primera conjetura como más conforme a la experiencia y a la naturaleza del indio.

Después acá, según los años, se ha ido disminuyendo la Mita, como por grados, sin duda por el mayor influjo de las causas expresadas y por la desolación que causaron aquellas grandes epidemias de erisipela y garrotillo el año de 1614, a más de la peste grande deł año de 1719. Así se ve que el año de 1692, se repartieron por el Sr. Conde de la Monclova, cuatro mil ciento un inclios solamente, de los cuales, debiendo residir en Potosí existentes de efectivo trabajo mil trescientos, con sus dos remudas, apenas concurrían seiscientos cincuenta el año de 1733, como lo representó el Superintendente de la Mita Dn. Pedro Vásquez de Velasco, Oidor de Charcas.

\section{§ XIII.}

Estado actual de la Mita. WI. Sr. Virrey 75 Marqués de Castelfuerte, mandó que por el tenor de las últimas Visitas aprobadas por el Gobierno, certificase el Contador de Retasas, el número de indios de cada Provincia de las Mitarias, y la séptima de cada una, para que conforme a ellas mandase hacer el entero el Gobernador de Potosí, como comisionado para este negocio; y en nueve Provincias que se numeraron, se hallaron dos mil trescientos quince indios, a saber: mil setecientos cuarenta de gruesa de séptima y seiscientos uno de contínuo trabajo con dos descansos; pero decayendo cada vez más este asunto por omisión de los Corregidores, parte por resistencla de los indios, que repugnan trabajar en minas pobres donde no tienen qué robar, y tam- 
bién por la ignorancia en que han vivido y viven estos azogueros de sus respectivas asignaciones, sin cncontrarse dos que tengan instrumento que acredite su repartiniento, legó al cabo la Mita a tal confusión y decadencia, que en el año de 1780 fue necesario formar una razón casi arbitraria de las Provincias mitarias y de los indios que vienen de ellas; y aunque resultó que el total de la Mita debía llegar a tres mil trescientos vcintiséis, se vio que sólo enteraban dos mil ochocientos setenta y nueve, cuyo número no se ha completario después, observándose, con demasiado detrimento del público, en las Visitas subsiguientes de minas e ingenios, que entre todos los indios reparidos, componen solamente mil novecientos cincuenta y cinco, a saber: ochocientos cincuenta y uno a los ingenios, y mil ciento cuatro a las minas.

De esto procede que algunas parcialidades trabajan en dos puntas y poquísimas cn tres, como era debido para que tuviesen dos descansos; y lo peor es que debicndo remudarse la Mita cada cuatro meses, según su establecimiento, vienen los más de los indios por un año, otros por menos y algunos por dos, perjudicando sobremanera la salud de los indios y el buell servicio de las minas en un trabajo tan penoso sin interrupción. Así sucede que o se mueren, o crían males habituales que los imposibilitan, o se quedan bien hallados en la Villa, sin pensar en volver a sus domiciljos.

En este conflicto no se presenta otro remedio a nuestra primera vista, que el de no sujetar el repartimiento de la Mita a la séptima parte, como previene la Ley 21 , Tít. 12 , Libro $6^{\circ}$ de Indias, ${ }^{76}$ y ya parece conveniente aumentar a cada vecindad el número necesario para el repartimiento de todas las minas e ingenios de Potosí, conforme a la prevención de dicha Ley, teniendo tan oportuno ejemplar en la Ley 22 del mismo Título y Libro, que extiende al $4 \%$ cl repartimiento de la Mita en Nueva España.

Pero es demasiado duro y cxtraordinario este remedio para que nos avancemos a él, antes de tentar primero otros recursos menos repugnantes a la decisión terminante de la citada ley.

\section{\$ XIV.}

Necesidad de hacer nuevo
repartiniento general y me-
dios para verificarlo.

E puto de los indios puros deI Perú, a quienes se cobran tributos, concede el número de casi dos millones y medio, ni es dudable que así sea, reconociéndose, por lo común, aumento de tributarios en las numeraciones y Revisitas que se han hecho en este Reino. ${ }^{8}$ Porque como en estos empadronamientos generales se alistan todas las Provincias, los indios que faltan en una, salen forzosamente on las otras, y esto sucede principalmente en las no afectas a la Mita, por retirarse a ellas, como a pueblos de refugio donde se libertan de venir a Potosí a los tiempos de su repartimiento. Con que, si pudiera averiguarse el domicilio y naturaleza de estos indios forasteros, que son unos desertores fugitivos de las tierras donde nacieron, por defraudar el servicio de su destino, fácilmente podrían ser restituídos para completar la Mita.

El trabajo es, que en la Revisita general que se está practicando, 
en virtud de las instrucciones formadas por el Sr. Dn. Jorge Escovedo, Visitador General que fue del Perú, a $1^{\circ}$ de julio rle 1871, en 54 artículos, con arreglo al 120 y 121 de la nueva Ordenanza de Intendentes, sal* duá desde Iuego el aumento que se desea, como ha sucedido en Chichas y sucederá en otros Partidos donde asistan comisionados de honor y probidad, que no quieran concertar'se con los Subdelegados a la ocultación de la mitad o de alguna gran parte de los tributarios cue habiten en los Partidos fuera de los Padroncillos que actualmente rigen, (cuyos tributos recaudan para su particular provecho, como compensativo de las fallas de los empadronados antes de ahora) ; pero siendo casi imposible que todos los Subdelegados y Apoderados Fiscales que entienden en esta importantísima operación, sean de iguales medidas en su conducta, cristiandad y amor al Rey, debe temerse justamente que en muchas Provincias se ocultará un gran número de indios (como se ha hecho etras veces), defraudándose al Rey sus tributos y a la minería el servicio de la Mita.

Es muy notorio que en un solo Partido, de los cinco que comprende la Provincia de Potosí, hubo Corregidor que recogía 15.000 pesos de tributos, fuera de Ios enteros que haoía en las Cajas Reales conforme a los Padroncillos corrientes; y el Subdelegaro que le sucedió, se sabe que después de haber alegado gran servicio por haber acrecentade la masa de tributos en otra tanta cantidad, todavía le quedaron de ganancia de 5 a 6.000 pesos anuales, en un ramo de indios tributarios lamados Yanaconas.

No es menester ponderar cuán dulce es la lisonja del interés, cuando no necesita de mano ajena para negociarse, ni se ha dudado jamás de aquella fuerza invencible, aunque oculta, de Ia ambición del oro y de la plata, que siendo amada de todos, en sentencia de la Escritura, ${ }^{79}$ conduce al hombre hasta el extremo de los vicios, pervirtiendo el juicio más sano la vil esperanza de la retribución, como se expresa en el Deuteronomio; ${ }^{80}$ y así, se deja sentir con anticipación el recelo de que en vez de conseguirse el descubrimiento de los indios ocultos en las haciendas, estancias, chacras y casas de campo, comprendidas en el distrito de cada cabecera, con la práctica de difigencias que previene el Art. 15 de la Instrucción de Revisitas, para averiguar los tributarios y sirvientes de ellas, sus calidades de originarios o forasteros $y$ el lugar de donde fuerch estos, procurarán los dueños, poseedores o administradores de las haclendas, que los Jueces no hagan diligencias para buscarlos; y si éstos no son tales que no dediquen todo el estudio de su esperanza a recibir la recompensa sólo de Dios y del Príncipe, según expresión del Fmperador Justiniano en una célebre Auténtica, sl en lugar de sacar los indios que hubiere, harán información que no los hay.

Ya se ve que cumpliéndose exactamente las justas prevenciones de los artjeulos 22 y 23 de la Instrucción de Revisitas, deberá constar en los Padrones la clase de forasteros con la expresión de su nombre, de su patria, de su estado, de sus hijos, de su edad, con la circunstancia de poseer o no tierras en aquel pueblo, ayliu o lugar donde se hallare viviendo; y será fácil por esta guía conocer si corresponde a cualquiera de las Provincias afectas a Mita, y de consiguiente, si es fugitivo de su naturaleza contra el tenor de la Ley 18 , Tít. $3^{\circ}$, Libro $6^{\circ}$ de la Recopilación de Indias; y como por otra parte, ordena el artículo 22 de la citada Instrucción de Revisitas, que la calidad de tributario o mitario se haya de notar en la Partida 
del indio o del ayllu al tiempo de su matrícula, esclarecerán los mismos Padiones con tanta puntualidad este asunto, que servirán de competente justificación para averiguar los mitarios fugitivos a otras provincias exentas de Mita.

Para cue la Revisita produjera, además de la averiguación de tributarios para la paga de tasas, (en que se interesa la Real Hacienda), el impritante efecto de descubrir los mitarios faltos, hubiera sido conveniente practicase con citación del Gremio de azogueros, para que nombrando éstos una persona que concurriese a su actuación con los comisionados Reales cn cada Partido, no quedase por hacer después otra diligencia alguna; y aunque el Exemo. Sr. Vir'rey Dn. Hanuel Amat, determinó esta solemnidad, con voto consultivo del Real Acuerdo, a 12 de enero de 1764, sólo para el distrito de las Provincias afectus a la Mita de Potosí, con el fin de evitar en ellas la ocultacion de mitarios por los Corregidores u otros interesados en los indios, debía haberse practicado lo mismo en el presente caso de la actual Revisita general dentro del Reino, para que nunca se presuma menos exactitud en el descubrimiento de los forasteros, en que la Azogucría de Potosí tiene su interés, precediendo para ello Providencia circulir de los dos Señores Vir'eyes, de Lima y Buenos Aires, paIa el distrito de ambos Reinos; por cuyo defecto, si ahora se pretendiese examinar este negocio, ser'a necesario ocurrir al Sr. Virrey del Río de La Plata por parte de la Azogueria, para que les mandase dar vista de todos los Padrones, para el preciso fin de deducir su derecho de las anotaciones de las matrículas soble el entero de la Mita, como punto de puro gobienno; a cuyo fin pediría su Excclencia copias autenticas de los Padrones (i) a la Superintendeneia General de Hacienda, por donde ha corrido la Revisita, por tratarse del ajustamiento de las tasas, en que nadie interesa sino el Rey.

Es consiguiente a cste recurso: lo primero, restituír a sus domicilios o Provincias mitarias todos los indios solteros, pues, aunque por la Ley 12, Título $1^{\circ}$ y Ley 12, Tít. 3\%, Libro $6^{\circ}$ de Indias, les está permitido mudarse de unos lugares a otros y quedarse en las chacras donde hubieren habitado, esto se entiende no resultando agravio a los Encomenderos, Caciques $\mathrm{u}$ otros legítimos interesados (como los azogueros de Potosí), con estas separaciones, según se halla declarado por la Ley 7, Tít. 7 y Lcy 28 , Tít. 8, Lib. $6^{\circ}$ citado. Lo segundo, que la vuelta a incorporarse en sus pueblos y reducciones, debe verificarse igualmente con los casados, por hallarse dispuesto en la Ley 7 y 10, Tít. 19, Lib. 6", que las indias casadas y sus hijos sean del pucblo del marido; con lo que se logrará insensiblemente reemplazar las considerables fallas que ahora se nota en las Provincias mitarias, y cuando más no se pueda, a lo menos se completará el número que asignó el Sr. Conde de la Monclova en el último repartimiento, que hasta ahora rige para el servicio de las minas e ingenios de Potosí; proculándose precaver en adelante semejantes deserciones, con renovar bajo de graves penas el Capítulo $4^{\circ}$ de la Real Cédula de 1609,82 en que se prohibió con rigor a los Caciques, que no admitan en sus pueblos los indios naturales o forasteros que se hubieren avecindado en las poblaciones afectas a repartimiento; que llevándose a tesón su cumplimiento, se logrará en lo succsivo, cuando no el remedio total de los actuales daños, siquiera que éstos sean menores, a beneficio del Rey y de la causa pública. 
Y cuando nada favorable resultare de estas diligencias, deberá practicarse Io resuelto en el Cap. $5^{\circ}$ de la citada Real Cédula de 1609 y en la Ley 21, Tít. 12, Lib. 6" de Indias; esto es, que no alcanzando la séptima parte de los vecinos que hubiere en cada pucblo, y parccicre necesario cargar a cada vecindario más número de indios, se suspenda el efecto y dé cuenta el Virrey con su Informe al Consejo, para la determinación. Este remedio es el más conforme al espiritu de nuestra legislación, por no juzgarse conveniente extender la Mita a otras Provincias más de las que señaló el Virrey Don Francisco de Toledo; porque este sabio Gobernador graduó con la mayor prudencia y discernimicnto las distancias y los temples, al tiempo que hizo su Repartimiento general, eligiendo a los más cercanos a las minas y labores, y de los temples menos contrarios al temperamento del sitio donde habían de trabajar, para que la diferencia de climas, que siempre es nociva a la salud y vida de los indios, no destruyese el servicio que se intentaba entablar, y en efecto, siendo esta disposición tan prudente, equitativa y consonante a las piadosas intenciones del Rey, se confirmó en la Luy 13 y 14, Tit. 1', y Ley 29, Tít. 12, Li. bro 6 de Indias, ordenando rigurosamente que los indios de tieria fría no sean sacados a la caliente ni a otros temples notoriamente contrarios, ni sean de provincias distantes los que se repartiesen para las minas.

\section{$\$ \mathrm{XV}$.}

La grande importancia de poblar los Asientos de minas, para la conservación de la Mita.
A AL efecto pues de arreglar este importantísimo asunto, de que, sin duda, pende la subsistencia de las minas de Potosí, $y$ de consiguiente la felieidad de este Reino y tal vez su conservación en toda la comprensión de lo que se llama Sierra en el Perú, es indispensable que los Sres. Virreyus de Buenos Aires, hagan imevo Repartimiento general de indios para Potosí, con la igualdad, proporción, circunstancias y consideraciones que dictan la J ey 8 y 16, Tút. 15, Lib. $6^{\circ}$ de Indias, mandando revivir la disposición de la I cy 17 del citado Tít. y Libro, en cuanto a que en la comarca de Potosí se hagan poblaciones de indios para el servicio de las minas, como antes hubieron, scgún se reconoce en inmensas ruinas que se descubren en los alrededores de la Villa y en los cantones inmediatos a ella.

Esta providencia que surtió los més inzpartantes efectos en aquellos primeros tiempos, sirve ahora solamente para intrincadísimos pleitos entre españoles e indios, porque aqnellos, como más dedicados a la labranza y otro género de industria para felicidad de la población, han ocupado muchas tierras desiertas de las que antes se reparticion a los indios que ya no vienen a trabajar en estas minas o tal vez se han poblado en aquella parte que ha abandonado la disminución de la Parcialidad o Ayllu que todavía vienc, pero en tan corto número, que_necesita de mucho menos terreno. Aquí son las discordias; y lo peor es que en atención a su miseria, objeto principal de sus privilegios, se piensa siempre en su amparo, en perjuicio notable de la población.

Los indios jamás han tenido propiedad absolutab pues, los historiadores Acosta y Garcilaso, ${ }^{\circ 3}$ nos cuentan que en aquellos pocos pueblos que fundaron los Reyes Incas para deducir los indios, les repartían las 
tierras en tres partes. La una para sustento de los Ministros y Sacerdotes del Sol y de otros ídolos que adoraban; la otra para el Inea; y la 3 ir para los mismos indios, graduando simpre la distribucion, de sterte que nunca les faltase, antes bien, les sobrasc; y cuando crecía la población, cercenaban a la parte del Sol y del Inca, lo suficiente para los nuevos vasallos.

Al principio de la pacificación y muchos años después, en que el Sr. Toledo hizo visita general en el Reino del Perú, sc formaron pueblos, abolicron idolatrías $y$, conservando a los indios en su antigua costumbre, señaló dicho Virrey a cada población las tierras competentes para sus chacras $y$ sementoras it (que ahora llaman de Comunidad); pero como poco a poco se han ido despoblando, guedando vacantes, baldios y desiertos aqueJlos terrenos, ha dispuesto $S$. M. de ellos, concediéndolos en su Real nombre a los españoles que entraron a ocuparjos, otros señores Virreyes sucesores del Sr. Toledo.

Fn la citada Ley 17, Tít. 15, Lib. 6", se prohibe a los indios vender - arrendar Ias tierras que se les repartioron en la comarca de Potosí, expresando que sólo fue para que las bereficion y labren; que es lo mismo que haberles concedido únicamente el usufructo, reservada su propiedad en la Corona. Así, para que puedan poblarse con estancias para ganados de la tierra, con trapiches y con chacras de labranza, seria conveniente publicar bando llamando a los primeros dueños, para que dentro de tres meses rolvieren a poblar estas tierras, bajo la pena de arjudicarse a quien las pidiese, conforme a la teey 11, Tít. 12, Tib. 4" de Indias; y cuando por este legal arbitrio no se lograse incitar la codicia de los indios, al menos se restablecería la población de mejores vecinos, purgándose la Villa y sus contornos de tan asquerosas ruinas que afean en extremo el público aspecto.

Es indubitable que las más parcialidades (sino son todas) de las que tienen tiemas en esta comarca, con el fin de pastear sus carneros en ellas, abusan criminalmente del inclulto de la Ley arrendándolas a espanoles o a indios, en particular provecho del Curaca del Aylh; y es la causa (de ello) los muchos sobrantes que tienen por la disminución de mitarios con cuyo respecto graduó el Si: Toledo estos Repartimientos. Los $\mathrm{Cu}$ racas roban a su salvo con esta administración y tienen mano para enterar en plata los indios que faltan para el servicio, por concierto con ellos mismos, siempre con lucro de aquellos. El único remedio será visitar las tierras, ceñirlas a lo suficiente para los actuales mitarios, y repartir el resto a los españoles como antes lo hacían los lincas, en cuyos derechos han. sucedido nuestros Teyes Catohcos segim dectaiación de la Ley 14 , títula 12, Libro 4t te- nndias; además que no parece justo que andan vacantes come advenedizos los españoles mismos que ouparon, paciflcaron $\mathrm{V}$ blaron estos países con stu sangre y con slis ammes.

1.- Strabón: citado por R. Rollin, en el Torno $2^{\circ}$ de la Historia Antigua, Cap. $1^{\circ}$, Parte Primera, \& $5^{\circ}$, fol. 251.

2.- Solórzano: en su "Política", Lib. 2\%, Cap. 15, N" 28, Tomo 1", fol. 126.

3.- Solórzano: en su "Política", Lib. 2", Cap. 15, 7, 16, 17 y 18.- Montenegro, en su Itinerario de parrocos, Lib. $2^{\circ}$,Tratado 11 , Sección I'rimera, fol. 251 .

4.- Solórzano: cita esta Real Provisión en su "Política", Cap. 16, Lib. 20, N" 72 y 73, Tomo $1^{\circ}$, fol. 136 . 
5.- Ley 22, Tít. 9, Lib. $6^{\circ}$ de la Recopilación de Indins.

6.- Ley 8, Tít. 12 , Lib. $6^{\circ}$, de la misma Recopilación.

7.- Aristóteles: Lib. 1", Polít., Cap. 3 y 4.

8.- Véase en Solórzano, Lib. 2" de su "Política", Cap. 15, N" 37 y siguientes.

9.- Gazci Pérez de Araciel: en su Menoria o Alegación, $\mathbb{N}^{\prime \prime} 32$, versículo particularmente citado por el Sr. Abrev, en el Tratado de Vacantes, Parte Segunda, $\$ 3 \%, N^{\circ} 407$, Let. y marginal, fol. 205 .

10.- Solórzano: Lib. 2 de su "Política", Cap 15, $\mathrm{N}^{\vee} 39$.

11. - Dn. Alonso Barba: en su Arte de los Metales, Cap. 2", fol. 3.

12.- Ley 18 y siguientes, Tít. 15, Lib. $6^{\circ}$ de Indias.-Ordenanza 36, Tít. 10, Lib. 3 de las del Perú.

(a) Miguel de Agia, de la Oł'den de San Flancisco, nació en Valencia en el siglo XVI y enseñó Filosofía. Pasó a Nveva España en 1563 para hacerse cargo de la Cátedra de Teología en el Convento de Guatemala. Ẽr 1600 publicó, durante su estancia en Madrid, el Tratado "Dc exlibendis auxilits". Como Secretario del Comisario General de la Orden, visitó las provincius y custodias de Perú y Tierra Firme. Se cercioró mediante informes y relaciones de diverso origen sobre los trabajos en las minas de Potosí. Avecindado en Lima hasta sus últimos días, publicó en 1604 su célebre obra "Tres pareceres sobre las servidumbres personales de los indios", con motivo de la consulta que a personajes doctos y sobresulientes hizo el Virrey sobre la nejor aplicación que debía dase a la Real Cédula de 24 de noviombre de 1601 , fechada en Valladolid, por la que el Rey Don Felipe "establecía nomas radicales para suprimir los abusos que en materia de servidumbres personales -especialmente en el trabajo de minas- se cometian por parte de los enconienderos".

For dato de] investigador peruano don Guillermo Lohmann Villena, se sábe que según la "Relación del Ldo. Miguel de Angulo de las razones y pareceres que se han dado sobre que se quite y cese la mita forzada de indios para la mina del Cerro de Potosi, Sección Audiencia de Chareas, legajo 268 del Archivo General de Indias", Fray Miguel de Agia se retractó en cláusula testamentaria de algunas de sus opiniones luego rue "reconoció por vista de ojos el quebrantamiento de la libertai natural juzgando por ilícita esta ocupación".

La reedición de los I'areceres de Agia se ha hecho con el titulo de "Servidumbres personales de indios", con un estudio preliminar de F. Javier de Ayala, por cuenta del Conscjo Superioz de Investigaciones Científicas, Escuela de Estudios Hispano-Americanos, eil Sevilla, el año 1946.- Nota de A. Alba.

13.- Solórzano: Lib. $2^{\circ}$ de su "Política", Cap. 17, $\mathrm{N}^{\circ} 26$.

(b) "Mingarse", voz quichua que significa: alquilar sus servicios en reemplazo de otro. (N. de E.).

14.- Escalona: in Gazophil. Lib. $1^{\circ}$, Cap. 16, Caso 13, $\mathrm{N}^{\circ} 4$, fol. 60.

15.- Valenzuela: en su "Ilustración al Sr. Solórzano", Lib. 20, Cap. 18, No 61. y 62, fol. 148 , Tomo $1^{\circ}$.

16.- Cédula de 24 de noviembre de 1601, recopilada en el Tít. 18, Lib. $2^{\circ}$ de las Ordenanzas del Perú, fol. 203, Cap. 12 .

17. - Todo esto se refiere en las Ordenanzas de la Caja de Granos y Tomines, formadas por el Dr. Escalona, en 29 de marzo de 1601.

18. - Llamábase "Granos" esta contribución, porque no habiendo entonces moneda, en granos de plata, compensó dicho Sr. Virrey Toledo, en $1 / 2$ real cada semana.

(c) Provincia del Departamento Ancachs del Perú. (N. de E.).

19.- Valenxuela: en la Adición al Sr. Solórzano, Lib. 2" de su "Política", Cap. 18, $\mathrm{N}^{9} 65$, Tomo $1^{\circ}$, fol. 148 .

(d) Todo este suceso se refiere en una certificación de D. Antonio Iturricarral, Contador de Retasas, su fecha en Lima, a 19 de julio de 1692 .

20.-Valenzuela: Lib. $2^{9}$ de la "Política" del Sx. Solárzano, Cap. 18, desde el No 68 hasta 133 .

21.-. Solórzano: Lib. y Cap. citados, $N^{\circ} 91$.

22.- Valenzuela: en el lugar citado.

23.-Vide la Adición al Sr. Solórzano, Lib. 2॰, Cap. 18, ํ 116, pág. 150.

24. - Real Cédula de Aranjuez, a 26 de mayo de 1609 , que corre al fol. 211, Cap. $5^{\circ}$ del Tít. 18, Lib. $2 *$ de las Ordenanzas del Perú, Leyes 21, 23, 25, 27, 31, Tít. 12, Lib. $6^{\circ}$ de Indias. 
25.-- Real Cédula citada de 22 de octubre de 1732 , Cap. $3^{\circ}$.

26. - Este perjuício lo terjía abolido ya el Sr. Conde de Ia Monclova, en Provisión de 27 de abril de 1692

27.- Real Cédula de 1601, N' 14 al fol, 208 del Tit. 18, Lib. $2^{\circ}$ de las Ordenanzas del Perú. - lieal Cédula de 1609, Cap, 9, fol, 211, Tít. y Lib. citado dej Perú.Carta del Sr. Virrey Conde de Chinchón, fecha 3 de jumio de 1634 , escrita al Sr. Visitador D. Juan de Carvajal, previene la pluntual paga de leguajes. Ordenanza 23, Tít. 10 y Ordenanza 13, T'ít. 13, Lib. $3^{\circ}$ del Perú.- Ley $3^{*}$, Tít. 12,

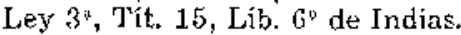

28. - Ordenanza 16, 'Tít, 13, Lib. $3^{\circ}$ del Perí,

29.- l'rov. del Sr. Conde de la Monciova, su lecha 27 de abril de 1692.

30.- Real Cédula de Madrid a 18 de febrero de 1697, Cap. 4\%, dirigida al Gobernador de I'otosí.

31. - Real Cédula de Sevilla, a 22 de octubre de 1732, Cap. 4 , dirigida a los Oficiales Reales de Potosí.

32.-- Reales Cédulas citadas de 1697, Cap. 5" y $6^{\circ}$, y la de 1732, Cap. 4\%.

33.- Este pretexto es muy antiguo, como refiere Ramiro Valenzuela en la Adición al Sr. Solórtano: Lib. $2^{\circ}$ de su "Política", Cap. 18, N" 81.

$34 .-$ Cartas de 4 de diciembre de $1762 \mathrm{y} 1^{*}$ de febrero de 1763.

(e) Fil repartimiento y entrega de los indios señaludos toca hacer al Superintendente de la Mita después que el arrendatario haya dado fianzas de dejar las minas limpias y según la Ordenanza 7 al fin y Ordenanza 10, Tít. 13, Lib. 3 del Perú, adición de Lupidana, Tít. 14, Lib. 3, $N^{\circ}$ 2, 6. Solórzano "Política", Lib. 2, Cap. 18, N 29, T'omo I., fol. 146.

35. - Real Cédula de Madrid a 18 de febrero de 1697, Cap. 30, Real Cédula de Sevilla a 22 de octubre de 1732 , Cap. 10.

36. - Ordenanze $1^{n}$ y $2^{\circ}$, Tit, 11, Tib. $\hat{\gamma}^{\prime \prime}$ y Ordenanzas $1^{\natural}, 2^{n}, 3^{n}, 11^{\circ}$, Tít. 13, Lib. $3^{\circ}$, del Perú, formadas por los Sres. Virreyes Marqués de Cañete y $D$. Luis de Velasco.- Ley 30, Tít. 12, Libro 18, 'ít. 13, Ley $5^{n}$, y niás expresiva la 7", Tít. 15, Lib. $6^{*}$ de Indias, en lo que sobre ellas nota el Sr. Solórzano, Lib. $2^{\circ}$ de su "Política", Cap. 18, N" 9, Tomo t", fol. 144.

37.- Ordenanza 9, del Sr. D. Luis de Velasco, recopilada en la Ordenanza 2*, Tít. 11, Lib. 3" del Perú.

38.- Ordenanza 25, del Sr. Marqués de Cañete, recopilada en la I", Tit. 11 , Lib. $3^{\circ}$ del l’erú y mandada guardar por el Sr. D. Lais de Velasco, en la $2^{2}$ del Tít. 11 , Lib. $3^{\circ}$ citado.

39. - Real Cédula de Sevilla, a 22 de octubre de 1732 , Cap. $6^{\circ}$.

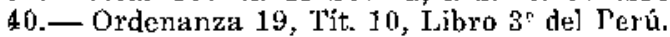

41. - En Auto acordado de 28 de febrero 11 y 20 de agosto de 1755, se mandó guardar la Real Cédula de 1732 , en cuanto a la asistencia de uno de los Oficiales Reales en el sitio de Guayna, $y$ en otro de 17 de agosto de 1756 , se declaró que su asistencia era puramente materinl, sin jurisdicción alguna.

42. - Ordenanza 19, 20,21, Tít. 10, Lib. $3^{\circ}$, del Perú.

43.- Ordenanza 10, Tít. 10, Lib. $3^{\circ}$ del Peri.

44.- Ordenanza 11, Tít. 10, Lib. 3 citado.

45... Ordenanza 3 y $4^{4}$ Tít, 10, Lib. $3^{\prime}$.

46. - Ordenanza $4^{4}$, Tit. 10 , Jib. $3^{4}$ citado.

47.- Ordenanza $4^{4}$, Tít. 10.-- Ordenanza $6^{\circ}$, Tít. 11 , Lib. $3^{\circ}$ citado.

48. - A los apiris debe darse dos velas para cada noche, según la Adición de Lupidana, 'Tít. 14, N 19, que amplió la Ordenanza 24, Tít. 10, Jib. $3^{\circ}$ del Perú.

(f) "Chasquear", roz y medismo quichua, que significa destrozar a golpes de piedra u otro instrumento. (Nota de E.).

49.- Bowles: Historia Natural de Esprāia, en la descripción de las minas de cinabrio de Almadén, fol. 9 .

(g) "Yanapacus", en quichua: "ayuchantes" o "auxiliares".

50. Adición de Lupidana, Tít. 14, No 19 , que amplió a dos velas por cada noche en número tasado en la Ordenanza 24 , Tit. 10, Lib. $33^{\circ}$.

51. - Concilio Limense primero Provincial, acción $4^{*}$, Cap. 9, referido por el Cardenal de Aguirre en el Tomo $6^{\circ}$ de su colccción, fol. 45.- Concilio $2^{\circ}$ Provincial Limense, Cap. 38, citado por Aguirre en el Tomo expresado, fol. 415.Concilio Provincial Mexicano, celebrado el año de 1585 , Lib. 2^, Tít. $3^{*}$, párrafo 9 , al fol. 107 del Tomo $6^{\circ}$ de la colección de Aguirre.

52.- Este Calendario está inserto en los Concilios Limerse y Mexicano, en los lu- 
gares que arriba se citan, y en las obras del Sr. Solólzano: Lib. 2 " de la "Política", Cap. 29, N*11.- Carrasco:

53,- Ad legem. 4", Tít, 1*, Lib. $1^{*}$ de Indias, Cap. $2^{*}$ de feries, $N^{*} 34 .-$ Montenegro: Itinerario pare Párrocos, Lib, $4^{\circ}$, 'Trat. $2{ }^{\circ}, \mathrm{N}^{*} 6$ del l'rólogo, fol, 411.

54.- Vide $N^{\prime \prime} 42$ - Ordenanza 5", Tít, 1". Ordenanza $7^{\wedge}$, Tíl. 11, Lib. $3^{\circ}$ del I'erú, Ley 17 , Tít. $1^{\circ}$, Lib. $1^{\circ}$. Ley 21 , Tít. 13 . Ley 22 y 60 , Tit. 16 , Lib. $6^{\circ}$ de Indias.Ley 14, Tít. $1^{\circ}$, Lib. $1^{*}$

55.- Sr. Solórzano: "Política", Lib. 2", Cap. 29, $\mathrm{N}^{\star} 13$ hasta 18 de Jure Indiarum, Lib, 1", Cap. $27, \mathrm{~N}^{\circ} 95$

56.- Sr. Solorzano: en el lugar citado de su "Potítica", N" 19 y en el Jure Indiarum, N०98.

57.- Sr. Solórzano: en su "Politica", Lib. 2", Cap. 29, N'21, y en el Jure Indiarum, Lib. 1*, Cap. 27, $\mathrm{N}^{\circ} 102$.

58.- Carrasco: sobre ly Ley 4", Tít. 1", Lib. $1^{\circ}$ de lndias, Cap. $2^{\prime}$ de feries, $N^{*} 34$. Focher: en la explicación de la Bula de Paulo III.

59.- S. Montenegro: en su Itinerario para I'árrocos de Indios, Lib. 4\%, 'I'rat. 2", Sec$1^{\circ}, \mathrm{N}^{4} 411$.

60.— Cap. licet de feries.

61.- Suárez: De Religiones, Lib. $2^{\circ}$, Cap. 32, No5, Tomo 12, fol. 112.

62.- Concilio Prov, Mexicano del año de $158 \tilde{0}$, Lib. $2^{\circ}$, Tit. $3^{\circ}, \mathrm{N}^{\circ} 9$, referido por Cardenal de Aguirre en el Tomo $6^{\circ}$ de su colección, fol, 107-108.

(h) "Kcateras", voz quichua que proviene de "kcatu", puesto o sitio donde expende sus mercaderias el indio. (Nota de E.).

63.- Fermosino, in Cap. licet tertio De Feriis, Cuest. $4^{*}$, No 7 hasta 10, tomo 5\%, 64.- Ley 9, Tít. 15, Lib. 6 .

65.- Arraya: Lib. $3^{\circ}$ Observatiorum, Cap. $5^{\circ}, \mathrm{N}^{*} 65$.

66.- P. Calancha: Lib. $3^{\circ}$, Cap. 40 , fol. 745 , asegura que cada peso que se acuña euesta diez indios muertos en las cntrañas del Gerro.

67.- Como lo nota Garcilazo: Primera I'arte de la Historia Indiana, Lib. 1*, Cap. 12.

68.- - Sr. Solórzano: Lib. '20 de Jure Indiarum, Cap. $7^{\circ}, \mathrm{N}^{\circ} 29$. cribió del modo que se podía tener en la reducción de los indios, y el $P$. Fr.

69.- Licenciado Dn. Juan de Aguila, Arcediano de Arequipa, en un Trat, que esBuenaventura de Salinas, Discurso $3^{\circ}$, Historia Novi Orbis, Cap. $2^{\circ}$ y $3^{\circ}$.

70. Calancha: Lib. 2", Cap. 37, $\mathrm{N}^{\circ} 6$, fol. 502, y Lib. 4", Cap. 17, $\mathrm{N}^{\circ}$ 6, fol. 888, asegura que era común en estas Provincias el farrotillo y erisipelia, de que moría mucha gente india.

71. - Dn. Dionisio de Aliedo: en su aviso histórico.

72.-Calancha: en el lugar próximo citado.

73.- El Abate Nuix, en sus reflexiones imparciales sobre la humaridad de los españoles en las Indias, los cita e impugna.

74.- Estos testimonios se citan por el Abate Nuix, en el tomo de sus reflexiones imparciules, reflexión $1^{\circ}, \mathrm{N}^{\circ} 6^{\circ}$, fol. 57 .

75. - Precedió voto consultivo del acuerdo, su fecha 8 de junio de 1733 .

76.- Real Cédula de Felipe Ill en Aranjuez, a 26 de mayo de 1609 , Cap. $5^{\circ}$, al fol. 212 vuelta del Tit. $18, \mathrm{~J}$ ib. $2^{\circ}$ de las Ordenarzas del Perú.

77.- Robertson, citado por el Abate Nuix en sus Ref'lexiones Imparciales, Reflexión $1^{4}, \mathrm{~N}^{\circ}$ 14, fol. 130 .

78. - Dn. Pedro Varela y Ulloa en las notas a las citadas Reflexiories, en Reflexión $1^{\natural}, N^{\circ} 6^{\circ}$, Letra " $A$ " marginal, fol. 58 .

79.- Esdras, Cap. $1^{\circ}$

80.- Deuteronomio, Cap. 16.

81. - Autentica ut judices: sine quo sufragio \& Eos auten in fine.

(i) A la Contaduria General de Retasas, para que haga el ajustamiento de la séptima por los Padrones de las Provincias Mitarias. - (Según la copia del original existente en el Archivo de Indias en Sevilla).

82.- Real Cédula de Felipe III, dada en Aranjuez, a 26 de mayo de 1609 , dirigida al Marqués de Montes Claros y recopilada a fol. 211 de las Ordenanzas del Perú, Tít. 18, Lib. $2^{\circ}$.

83.- Acosta: Lib. 6\%, Historia Indiana, Cap. 15, Garcilaso: Parte Primera, Historia, Lib. 5?, Cap. 1\%.

84.- Así lo nota D. Juan de Aguila en un papel que escribió y queda arriba citado. 


\title{
CAPITULO SEPTIMO
}

\section{Del Real Banco de Rescates}

\author{
Del Real Banco de San Carlos de la Villa de Potosi; su establecimiento, \\ progresos y demás insidencias.
}

NOTIOIA PRIMERA

Del origen y motivos de los rescates de platas en Potosi y la forma en que se hacían antiguamente.
$\mathrm{N}$ vamos a hablar aquí de aquellas $\mathrm{Ca}$ jas Generales establecidas sobre el crédito público de toda una Nación, bajo la autoridad del Soberano que representa a todo el Estado y la ganancia de todos los ciudadanos reunidos, que es lo que los políticos llaman Banco para el pago de mercaderias, de las Letras de cambio y para otros objetos demasiado interesantes a los seguros y a la libertad del comercio. Sólo intento tratar de un Depósito abierto para subsidio de la minería, bajo de ciertas Ordenanzas y Regiamentos que cautelando su administración, influye indirectamente en todas las operaciones relativas a aumentar la opulencia del Estado.

Ningún lugar del Reino necesitaba tanto como Potosí, el establecimiento de un fondo público, para prosperidad del paîs, para conveniencia de los mineros y para ventaja de la Real Hacienda; porque sólo por este medio podría lograrse que se aumentase la masa circulante de los valores efectivos y numerarios, con los que, además de vivificar el comercio y socorrer la industria de la minería, se hace de presente y sin fralde el pago de los Reales Derechos.

Nadie ignora que aun después de establecida esta Casa de Moneda, era tan poca la que en ella se labraba, que sobre no alcanzar su giro 
para las contrataciones y negocios del Reino, todavia escaseaba para el pago de los jomales y mantenimientos; motivo que, por su gravedad obligó al Sr. Don Francisco de Toledo, a despachar dos provisiones, fechas en Potosí, a 9 de cnero y 23 de lebrero de 1575 , para qie de todas las barras ensayadas y fundidas, despues de pagado el quinto y demás derechos, entregasen los Oficiales Reales la cuarta parte de ellas al Tesorero de la Moneda, para labrarse en reales entregándose las restantes a los ducños a quienes perteneciesen; por haberse reconocido entonces que aun no había alcanzado a proveer de bastante remedio sobre estos públicos objetos, otro anterior Despacho suyo, de 26 de junio de 1574 , en que previno a los Oficiales Reales, era orden de S. M. que de su cuenta se labrase diez mil marcos, y que en caso de no meter los particulares plata suficiente, pasasen a la Casa seis mil marcos en rieles, para que se beneficiasen de cuenta del Rey y a su costa, para que $m$ parasen las laboves ni llegase a escasear en el Reino la moneda.

Cualquiera que se detenga en rellexionar con algún juicio sobre las causas de esta increible escasez de moneda, si al mismo tiempo considera que sucedía esto cuando en todo el Reino del Períi era única la Casa de Moneda de Potosí, en medio de ser tanta la abundancia de plata, que cada día se deducía cnantiosas sumas de miles por razón de quintos y demás Derechos Reales, de las barras fundidas en la Real Callana; no podría menos de atribuírla a la falta de rescates y a la demora que se padecía en la labor y beneficio de las platas en las tres hornazas de que se componía la Casa de Moneda en su pximer establecimiento.

Así pues, para remedio de estos daños se remató por asiento público el Rescate de Platas, en 14 de abril de 1575, por disposición del Sr. Toledo, cuya prudencia tan sólida y reflexionada en este negocio, como en todos los demás tocantes al gobierno de estas Provincias, parece que con una admirable ilustración planteó desde entonces una figura del Banco que después se fundó con tan dichosos progresos.

El remate fue por tres años, con la obligación de meter en la $\mathrm{Ca}-$ sa de Moneda, en cada uno de ellos, 60.000 marcos de plata ensayada y marcada, de ley de 11 dineros y 4 granos, para que de ellos se hicieran reales, en cada cuatro meses 20.000 marcos, dándole al subastador Juan del Castillo, para ayuda, 4.000 pesos dentro de ocho días, y 8.000 más al cabo de tres meses, con el cargo de restitúr los curnolido el tiempo de su contrata. Se le dejaron dos hornazas de las tres que por entonces había en la Moneda, y la una para el común, con la condición que no ocupándola los particulares o edificándose otra hornaza más de las susodichas, pudiese labrar en todas ellas cuantos marcos quisiese fuera de los 60.000 de su convenio.

Para facilitar este cambio, se le permitió pener tienda pública, así él como cualquier otro con su poder, en la plaza o calle que le pareciese en esta Villa, en Chuquisaca, La Paz, y en todos los demás lugares del Distrito de la Real Audiencia de Charcas, señalándosele el precio del rescate por cada peso de plata ensayada y marcada redućida a 450 maravedís, cada peso 12 reales y medio, y el corriente a 9 reales, a vista del Ensayador, con el privilegio exclusivo de que ninguna otra persona pudiese hacer estos trueques, bajo la pena de perder todos los reales trocados, a beneficio del asentista y más mil pesos para la Cámara, permitiéndose a les demás particulares la distribución de reales para sólo el caso de ajustar sus 
pagas en Ias compras, ventas y contrataciones, jornales y mantenimientos, $\mathrm{y}$ de ningún modo para negociar el rescate de barras con la moneda que de su cuenta se trabajase en la Casa.

Conformándose a este modelo, se siguieron en los años posteriores otros rescatadores que negociaban el trueque y cambio de las barras, con el título de Mercaderes de Plata. Estos ejercían el rescate bajo fianzas y ciertas precauciones que servían como de reglamentos. Tenía cada Mercader un libro ribricado por los Oficiales Reales, donde se sentaban con claridad, diaria y monsualmente, los marcos rescatados y los nombres de los sujetos. En cada correo daban certificación de lo rescatado en el intermedio, para averiguar si los marcos que el azoguero dio a quintos correspondian al azogue que sacó o si vendió parte de él o no trabajó con empeño; y la misma correspondencia de los líbros de Quintos, servía para justificar si el Mercader de Plata fundió todos los marcos de piña que rescató, o extravió parte de ellos en frausle de los Reales Dercchos.

El negocio no sólo era lucrativo sino también vastísimo, porque a más de las piñas que rescataban a los mineros, compraban al Rey, en precios moderados, las barras sobrantes de lo mandado labrar de cuenta de S. M., que según se ve en una Piovisión del Sr. Marqués de Guadalcázar, su fecha en Lima, a 14 de febrero de 1629, estaba ordenado antes de ese tiempo, que se sellasen hasta 500.000 pesos, y de ahí en adelante otros tantos más, de suerte que llegase a un millón de a 8 reales por cuenta de $\mathrm{S}$. M., respecto a que no alcanzaba la primera cantidad para la gente de mar y guerra, situado de Chile y Mita de Huancavelica; pero con todo, no consiguiéndose el fin de aumentar la circulación de la masa numeraria, porque los rescates no se hacían todos en moneda, sino la mayor parte en pago de las habilitaciones anticipadas o en azogues y cn otros efectos, ordenaron los Sres. Virreyes, Príncipe de San Bono en el año de 1718, y el Sr. Castelfuerte, en los de 1724 y 1731, que los Oficiales Reales de Potosí, remitiesen a los de Chucuito, cada año, 50.000 pesos para rescate de barras, y al Corregidor de Lípez bajo de fianzas, hasta 16.000 pesos para el mismo fin, tasánclose a 143 maravedís el ensayado; y llegó a extenderse tanto esta negociación, que en los años siguientes se suplía de las Cajas Reales a la Tesorería de la Moneda, el dinero para el rescate de barras en la Villa de Oruro, de cuenta de S. M., con conocido aumento suyo, porque comprándose allí las platas a 143 y \%/l. el ensayado, se abonaba aquí a 146 .

$$
\text { NOTICIA SEGUNDA }
$$

$\S \mathrm{I}$.

Establecimiento de la Companía de Azogueros de Potosí para avíos de sus Minas. Se refiere el número de acciones y capitales con cune comenzó. taciones de azogues, cobres, hierro, acero, maderas y sebos para el corriente de los ingenios y minas; y en efecto, formalizado este proyecto en 12 de enero de 1747, por el Sr. Don José de Herboso, Contador Mayor del Tri- 
bunal de Cuentas de Lima, y Visitador de estas Reales Cajas y Casa de Moneda, otorgaron la cscritura pública de Compañía en 15 de enero citado, ante el Escribano Antonio Martínez Moreira, en virtud de Junta que precedió el 14 del mismo, obligándose a dejar en poder do los Mercaderes de Plata, el pico de 2 y $3 / 4$, reales, de los 7 pesos y 2 y $3 / 1$, reales en que se estimaba entonces cada marco de plata en piña de Azoguero, percibiendo cada uno 7 pesos efectivos.

El Sr. Virrey, Conde de Superunda, aprobó este proyecto, por Auto acordado en Junta de Hacienda, a 17 de abril del 47, librando en su conformidad el Despacho correspondiente; y en su virtud vendieron los Azogueros a los Mercaderes de Plata, desde 1" de marzo de 1747, hasta 20 de febrero del 51, 484.287 marcos una onza, dejando cn poder de ellos los 2 y $3 / 4$ reales estipulados.

Aunque estos productos se encerraban en una Caja de dos llaves, manejadas por dos Azogueros nombrados por el Cuerpo y el Protector de la Compañía, se experimentó, en el corto espacio de cuatro años, una crecida y lastimosa quiebra; pues debiendo existir en arcas 164.794 pesos $3 / 4$ reales, de principal por cuenta de la Compañía, por febrero de 1751 en que Dn. Ventura Santelices se hizo cargo de su protección, se hallaron solamente 13 pesos 6 reales, a causa de haberse entregado por el Sr. Dn. José Herboso, y Llaveros a los tres Mercaderes de Plata que había entonces, el principal expresado, bajo de ciertos intereses que asccndían a 10.426 pesos 6 reales; de suerte que añadiendo esta suma al principal susodicho, subió la quiebra a $175.207,3 / 1$ reales, sin más recurso que perseguir con ejecuciones de difícil éxito à los Mercaderes, sus bienes y fiadores.

Continuó esta exacción de los 2 y $\%$ reales en marco de piña, algún tiempo más adelante en el Gobierno del Sr. Santelices; pero, mal avenido este celoso Ministro con las contingencias y riesgos del anterior manejo, trató de establecer un Banco de cuenta de la Compañía, bajo de Reglamentos que asegurasen su fiel y exacta administración.

$\S 11$.

Esstablecimiento del Banco por Los Azogueros promovieron este utilísilos Azogueros. mo establecimiento en Junta general de 18 de enero de 1752 , y fue aprobado en 7 de febrero por el Sr. Santelices, y por S. M. en Cédula de 12 de junio del mismo año, con la calidad de que la Compañía fundamentase el pie en que había de caminar, sus fines y demás objetos. Para ello fue comisionado D. Miguel Antonio Escurruchea, en 12 de diciembre de dicho año, y sin embargo de haber aceptado esta comisión, nunca parecicron tales Ordenanzas.

$\S$ III.

Empezó el Rescate del Banco, por establecimiento de los Azogueros, por el año de 1752 .

$\mathrm{N}$ O obstante haberse encontrado en arcas por cuenta de la R. Compañía, 57.800 pesos, procedidos, parte, de los rescates anteriores a la erección del Banco, y de algunas cobranzas de lo adeudado por los Mercaderes de Plata fallidos, fue preciso aumen- 
tar este fondo cuando se principió a rescatar por cuenta del Banco, en 8 de febreto de 1752, supliendo de la Real Hacienda 10.000 pesos, y dos mil más de los salarios dol Sr. Santelices; extendiendose a tanto cl celo de este Ministro, que para proseguir el grueso rescate que se presentaba, solicitó con nobles insinuaciones a las personas de su mayor confianza, para que supliesen de su peculio algunas cantidades, por cuyo medio se facilitara este pingüe negocio; de suerto que no existiendo documentos con qué esclarecer las pertenencias de este fondo, tal vez por haberse confundido o substraído en tiempo que fuese sindicado el Administrador que manejó los caudales del Banco, desde el año de 1752 hasta el de 1754, to único que se sabe de cierto es que los rescates se hicieron entonces, no solamente con dinero de la Compañía, sino con el de S. M., salario del Sr. Santelices y suplementos de particulares.

La falta de ordenanzas peculiares no cmbarazó el ventajoso progreso de estc floreciente proyecto, así en cuanto a las notorias y crecidas utilidades, como en los auxilios y habjlitaciones de la minería, para alivio de los azogueros y felicidad del Estado; pues, se ve que de su infatigablo aplicación en presenciar todas las funciones del giro del Banco, se evitaron en las fundiciones de piñas a barras, en la Real Caja, las considerables mermas que antes sufrían los mercaderes particulares. El dispuso que so encerraser en arcas, semanalmente, las utilidades del rescate, las cobranzas de auxilios dados a los azogueros, en plata y azogues, junto con el importe de las ventas de once mil y más quintales de fierro, que comprados en Buenos Aires al costo de 20 pesos quintal, se vendió la mayor parte a 30 y 35 pesos, con ganancia de muchos miles, sin permitir que corriese en poder de los Administradores más caudal que el preciso para la compra de marcos, pero sin perjuicio de los auxilios que siempre suministró con conocimiento de causa a los Azogueros de esta Villa, para compra de ejes, ruedas, sal, pagamento de leguajes de indios de Mita, y carta-cuentas de azogue en la Real Caja, cuidando con admirable prevención el exacto reintegro de los fondos del Banco, unas veces con un peso de cada marco de los que presentaban al rescate, y otras con semanas de 25 y 50 pesos.

Con esta imponderable economía llegó a tal aumento el fondo del Banco, que a principios de febrero de 1762 , ascendía a 817.141 pesos 3 reales; a saber: 371.055 pesos 1 real, en barras diezmadas, plata sellada, ramalatos (que es la moneda mal sellada), bocados de plata de Callana y olo; 341.052 pesos 7 y $1 / 2$ reales, en 11.185 quintales 87 libras de hierro de Vizcaya, inclusive 2.996 quintales 40 libras que se entregaron después de concluídos los inventarios, a principios de febrero de 1762 , y en 105.033 pesos 2 y $1 / 2$ xeales en deudas procedidas en la mayor parte de auxilios contribuídos a la Azoguería, de suerte que rebajados de esta cantidad 112.799 pesos 1 real, satisfechos a la Real Hacienda por 40.000 pesos que se debían de suplementos por los 2.000 pesos del salario del señor Santelices y por 70.799 pesos 1 real, como importe de fletamentos de fierro, importaron las existencias que entregó por inventario el Sr. Dn. Ventura Santelices, 704.342 pesos 2 reales, líquidos y efectivos. 


\author{
$\S \quad$ IV.
}

Epoca en que se empezó a pagar al azoguero a 7 y 32 pessos el marco de piña, en lugar de 7 pesos que antes se le pagaba.
$\mathbf{E}$ to que se dio al valor de las platas, pues, siendo el precio antiguo de 7 pessos 2 y $3 / 4$ reales, cuyo pico se siguió cobrando desde 8 de febrero de 1752 (en que se estableció el Banco) hasta 16 de septiembre de 1753 , percibiendo el azoguero únicamente 7 pesos efectivos por marco de plata en piña, hizo Dn. Ventura Santelices, que cada marco se pagase a la Azogucría de Potosí, a 7 pesos 4 reales, (como se observa hasta ahora) quedando a su bencficio 1 y $1 / 1$, reales en marco, más que antes. A los mineros de fuera sc tomaron sus platas de la piña más acendrada, a 7 pesos 2 y $1 / 2$ reales; a los trapicheros de la Vilia, a 7 pesos, y a los ekacchas a 6 pesos 6 reales. El Gobernador Santelices igualó los valores de las platas de la Villa y de los azogueros de afuera, siendo acendrada la piña, y de no serlo, a proporción de su ley y merma; a los trapicheros fijó el precio de 7 pesos 1 real y a los ckacchas el de 7 pesos; de modo que desdo su tiempo perciben los azogueros de fuera uno y medio reales más que antes; los trapicheros un real y los ckacchas dos reales; resultando de esta ventaja de la minería, otra no menos considerable al Estado y a la Real Hacienda, respecto que aumentada la masa de los rescates en el Banco, y la venta de barras en la Casa de Moneda, de cuyos valores debía deducirse el derecho de cobos, los Reales Diezmos y el subsidio de la Compañía de Azogueros; de consiguiente creció la labor de la Moneda con las mayores porciones de plata que se beneliciaba a proporción de los auxilios; el comercio se vivificó tambićn con la circulación de mayor masa numeraria, difundiéndose a todos los ramos del Estado este beneficio, y por áltimo, la Real Hacienda se engrosó considerablemente con las nuevas entradas, según cl crecimiento de las matexias causantes del crédito fiscal.

\section{NOFIOIA TER C R A}

Quiebra del Banco de Potosí, $\boldsymbol{E}_{\mathrm{N}}$ este admirable estado se recibió del sus causas $y$ resultas. Banco el nuevo Gobernador Don Jaime San Just, a principios de febrero de 1762 . Su extremada bondad abrió margen a les abusos del Administrador. Las ingentes cantidades que entraron en poder de éste, se disiparon con la libertad de su manejo arbitrario. No se cuidó de recaudar las deudas a su tiempo ni de reservar en arcas las utilidades de los rescates, quedando todo el tesoro a la voluntad de los administradores, cuando no debían tener en su mano más que la precisa cantidad para el giro de los cambios semanales de las pinas; $\mathbf{y}$ de este desorden resultó que el Superior Gobierno de Lima, dio comisión al Oidor Don Pedro Tagle, para la inquisición de estos excesos, por Auto del Real Acuerdo de 29 de agosto de 1766. En efecto, se averiguó otra segunda quiebra, sin comparación más sensible, por 
el mejor pic en gue se hallaba el Banco; y por las diligencias actuadas por abri] de 1767 , subió la falla a 353.226 pesos 2 y $1 / 4$ reales; entrando en esta suma 63.022 pesos que se habían consumido por el Secretario y Mayordomo del Gobernador, a la sombra de las inocentes condescendencias de éste, $y$ de las abusivas liberalidades del Administrador; de suerte que debiendo existir en Arcas más de un millón de pesos, por los procedidos

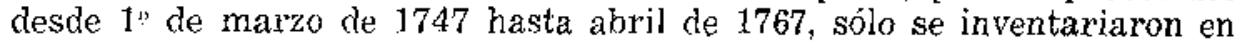
esta pesquisa 113.582 pesos 2 reales, en plata y hierro.

Suspendido el Gobernador por esta causa, entró Dn. Pedro de Tagle a ejercer su comisión y en virtud de las facuitades a que se le extendió, removió al Administrador y Contador, subrogando otros Ministros más fieles, exactos y celosos. Formó tambićn, a fines de 1770, un Reglamonto provisional del Banco, por cuyo medio y el de sus efícaces esfuerzos en hacerlo guardar puntualmente en cuanto a la paga semanal efectiva de los Reales Derechos de cobos y diezmos; en no retardar las cobranzas do azogue y demás auxilios; en custodiar estrechamente dentro de Arcas las utilidades del cambio, y en mantener en inalterable concierto el manejo y giro de los caudales del Banco, se logró tan feliz reposición, que a principios de agosto de 1773, entvegó al Fiscal $D_{n}$. Tomás Alvarez de Acevedo, su sucesor, 778.272 pesos 4 y $1 / 2$ reales, en dinero, hierro, muebles, utensilios y deudas, según el balance de su respectivo inventario.

Este Ministro gobernó hasta últimos de mayo de 1775 , y entregó a Dn. Francisco Gúúmez, que le succdió, 833.809 pesos 1/2 real; a saber: 453.106 pesos 5 y $1 / 2$ reales en plata, y 380.702 pesos 3 reales en existencias y deudas, cuya cantidad, puesta en cotcjo con la recibida del Sr. Tagle, resulta con cl aumento de 55.536 pesos 4 reales.

Fenecido este Gobierno a principios de junio de 1776, se entregaron al sucesor, Conde de San Antonio, 864.623 pesos 7 y $1 / 2$ reales; a saber: 532.063 pesos en dinero, 332.560 pesos 1 real en existencias y deudas, aumentando el fondo anterior, en 30.814 pesos 7 reales.

El Conde gobernó hasta 12 de noviembre de 1777, y entregó a Dn. Jorge de Escovedo y Alarcón, Visitador General del Reino y actual Superintendente Subdelegado en Jima, 915.461 pesos 5 reales, dando de aumento 50.835 pesos 5 y $1 / 2$ reales.

Este sabio y celoso Ministro, todo entregado a los afanes del Gobierno público, no se embarazó en sus tareas para entrar a un serio examen del origen del Banco, de sus progresos alternados con sus quiebras y de los medios más sólidos de mejorar su manejo y deslindar los derechos de su establecimiento. Elevó sus nobles ideas con mucha preferencia sobre el proyecto de Dn. Ventura Santelices, que se habia hecho hasta entonces inimitable; porque Don Ventura se contrajo únicamente a destruír el nombre de la Compañía con que nació este negocio de cambios en el año 47, y le subrogó el de "Banco de Azogueros", metodizando su giro por providencias puramente económicas, no escritas ni perpetuas, sin Ordenanzas y sin otra Ley que su arbitrio, aunque en todo prudentísimo, legal y equitativo.

Entró pues el Sr. Don Jorge en conocimiento universal de estas materias. Descubrió luego que el rescate de cuenta de la Real Compañía de Azogueros, tuvo principio en el establecimiento del Banco con un fondo compuesto, en parte, de caudales de la Azoguería, y lo demás, de suplementos particulares y hechos por la Real Hacienda a quien, por esta 
causa y otras de igual privilegio, se debian 40.000 pesos al acabar su gobierno Dn. Ventura Santelices.

Descubrió quc, a los principios, no tuvo consumado efecto aquella universal y recíproca estipulación que se propusieron todos los Azogueros de esta Villa, de dejar en poder del Mercader de Platas el pico de 2 y $3 / 4$, reales de los 7 pesos 2 y $3 / 4$ reales en cue se estimaba entonces cada marco de plata en piña. Aunque por esta razón unos tenían más derecho que otros, se disputaba po. todos un mismo dominio. El Gobernador no mantenía sino un mero fucro de protecetón sobre este cuerpo. Los individuos se reputaban dueños privativos de todo el fondo $\mathrm{y}$ pretendian tener en él, cuando no un manejo arbitiario, al menos un Gobierno exclusivo de toda otra autoridad. Los Llaveros y demás dependientes de este interesantísimo manejo, eran nombrados por elección de la Azoguería.

Como la multitud dificilmente conciexta sus pareceres en un objeto útil y justo, de aquí nacían las intrigas, sobomos, colusiones y desasosiegos públicos. Los clectos, unos poco empeñados en cumplir sus deberes con honra y con justicia, otros por gratos a quien los elevó a este lucrativo ministerio, distribuian los caudales públicos sin justa proporción y tal vez sin legalidad. El Jefe era mirado como un personaje respetable, pero sin autoridad decisiva sobre el Cuerpo. Nunca se contaba con el Rey ni era reputado acreedor a estos intereses, sicndo constante que lo eran los Azogueros, sin otra razón que haber puesto la pazte del fondo con menos gravamen que la Real Hacienda, que de un golpe sólo desembolsó más que todos juntos en medio año.

\section{N O T I C I A C U A R T A}

\section{Incorporación del Banco de Potosí a la Real Corona, con el titulo de "San Carlos".}

Se pone un estado de los fondos entregados $\mathrm{y}$ perdidos al tiempo de la incorporación.
$\mathbf{T}$ ODO esto, junto con el mal uso experimentado por reiteradas sensibles ocasiones en esta pública administración, de que pendía el interés de los Azogueros, el de la Real Hacienda y el del Estado, obligó el celo del Sr. Don Jorge a proponer la incorporación del Banco a la Real Corona, bajo de unas medidas tan justas, que dejando al Rey el dominio, quedase franco el favor de los antiguos auxilios y socorros a la Azoguería. En efecto, jdeado este proyecto en 16 de abril de 1779 , se vio en dos juntas consccutivas, celebradas en los meses de abril y junio, interviniendo en ellas el Procurador General de Ia Villa, por parte de los interesados ausentes y muertos. También se tuvo presente un grueso volumen de documentos y razones mandadas dar al Contador del Banco, con una lista de repartición y nómina de interesados, así presentes, como incógnitos y ausentes, precediendo citación personal a los primeros, y por carta a los últimos de residencia conocida.

Con la libertad que a todos se dejó para abrir su dictamen, no solamente cedieron al arbitrio de este sabio Magistrado el modo de repartición que les propuso, sino también renunciaron ante S. M., perpetuamen- 
te, por tostimoniu de su fidelidad y amor, cuantos derechos pudieran tocarles a pretender ellos por sus respectivas acciones. De todo se dió cuenta, con testimonio, al Visitador General del Reino, Dn. José Antonio de Areche, en el mismo año, quién con el Informe del Tribunal de Cuentas y vista de los Fiscales de la Real Audiencia, aprobó la incorporación en Decreto de 21 de junio de 1779.

Consccutivamente se mandó citar a nueva Junta, y por habersc respondido de comín acuerdo en la que se celcbró a 9 de agosto, que nada les ocuryía que representar, ni añadir a lo tratado en la de 27 de abril de 1779, se pasó a extender en efecto la escritura de cesión, a 9 de agosto citado, ante el. Fsscribano Francisco Plácido de Molina. El mismo día tomó posesión del Bánco el Sr. Escovedo, a nombre de S. M.; y de esta fecha corre de cuenta de su Real Hacienda, con el título de: "Real Banco de San Carlos".

Corridas estas diligencias, se ordenó en Auto de 11 de agosto, que desde el siguiente día ocurriesen los intercsados al Tesorero del Banco, a recibir las hijuelas respectivas a sus capitales; y el día 17 del mismo. a la Plaza pública, a percibir las que les cupiese en suerte, según la distribución formada contra el fondo del Banco, cuya suma en dinero subía, por thia parte, a 268.851 pesos 4 reales efectivos en arcas; y por otra, 400.000 pesos suplidos al Rey, para las urgencias de la expedición que vino a la América meridional el año de 1776, al mando del Capitán General Dn. Pedro Antonio de Cevallos; que juntas estas partidas al importe de muebles, utensilios, deudas y auxilios, componían el capital de 1.070 .846 pesos 7 reales, los mismos que se distribuyeron con arreglo al proyecto, en la forma siguiente:

Fondo entregado a los interesados:

En plata sellada . . . . . . . . . . . . . . . . . . \$ 153.211

En dependencias causadas con palos ejes conducidos del Tucumán, per-

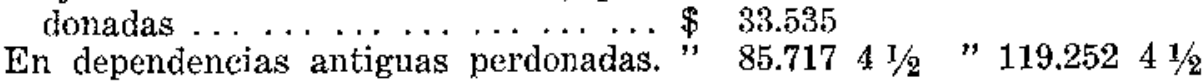

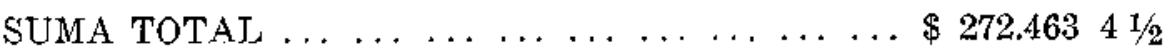

Fondo útil a javor de S. M.

Remitidos para las urgencias de Buenos

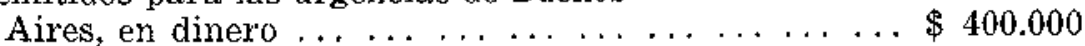

En dinero efectivo $\ldots \ldots \ldots \ldots \ldots \ldots \$ 119.59011 / 2$

En dependencias de palos ejes, después de las perdonadas ............

En cinco palos ejes existentes ......."

En hierro existente $\ldots \ldots \ldots \ldots \ldots$

En el vendido a D. Tomás Romero ....."

En azadas existentes ............"

En auxilios dados en azogue ........" 14.7195

En lo dado en almadanetas ......... 


\begin{tabular}{|c|c|c|c|}
\hline $\begin{array}{l}\text { En Io suplido para almadanetas } \ldots \ldots \\
\text { En auxilios dados para el socavón } \ldots \ldots\end{array}$ & $\begin{array}{ll}" & 4.467 \\
& 2.000\end{array}$ & & \\
\hline En muebles de las of icinas $\ldots \ldots \ldots$ & 2.887 & $1 / 2$ & $" 247.19561 / 2$ \\
\hline
\end{tabular}

Fondo perdido por la imposibilidad de su cobranza:

Importa la memoria de insolventes, finados, ausentes, no confesados, en di-

ligencias, etc. etc. . . . . . . . . $\$ 151.0542$

En monedas defectuosas, remitidas a la

Real Audiencia ............" $1326 \quad \$ \quad 151.1868$

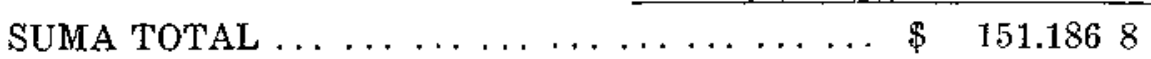

Resúmen de esta repartición

A beneficio de los Azogueros . . . . . . . . . . . . \$ $272.46341 \%$

Al de la Real Hacienda ... . . . . . . . . . . . . . . . . " $247.19561 / 2$

En el fondo perdido . . . . . . . . . . . . . . . . ..." 151.1868

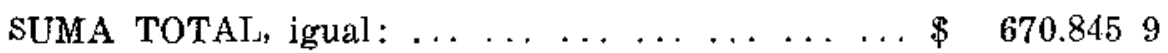

Utilidades del Banco en un $\mathbf{E}_{\mathrm{N}}$ la cuenta general ajustada en 2 de quinquenio siguiente a la in- enero de 1780 , correspondiente desde la incorporación, y gastos que su. corporación del Banco, hasta fines de 1779, fre su fondo. Se pone al fin de importó el fondo (excluídos los 400.000 peeste capítulo un estado com- sos remitidos a Buenos Aires, de que nunca prensivo hasta fin del año se ha hecho mención en las posteriores) 1786. 256.938 pesos 3 reales; a saber: 164.913 pesos 2 y $1 / 2$ reales, en dinero y 92.025 pesos $1 / 2$ real, en dependencias y existencias; y ascendiendo el que le cupo en la repartición a 247.196 pesos 2 y $1 / 2$ reales, resultaron de aumento 9.742 pesos, independientes de 7.696 pesos 4 reales, gastados en la obra del Socavón; de modo que el giro dio de aumento en estas dos partidas, 17.438 pe$\operatorname{sos} 4$ y $1 / 2$ reales.

En los cinco años postcriores, desde 1780 hasta 1784 , se ha girado con el mismo fondo de los referidos 256.938 pesos 3 reales, costeando de las utilidades los gastos del Socavón hasta 20.000 pesos, ' Tesorería principal de la Real Hacienda, el resto de las ganancias líquidas, ${ }^{2}$ cuya demostración es como sigue: 


\begin{tabular}{|c|c|c|c|c|}
\hline & $\begin{array}{l}\text { Ganancias del } \\
\text { giro }\end{array}$ & & $\begin{array}{l}\text { Sastos del } \\
\text { Socavón }\end{array}$ & $\begin{array}{l}\text { Entregados en } \\
\text { las Rls. Cajas }\end{array}$ \\
\hline Año de 1780 & $\$ \quad 42.929 .5$ & $\$$ & 19.384 .3 & $\$ \quad 23.545 .2$ \\
\hline$" \quad " 1781$ & $" \quad 28.904$ & $"$ & 17.808. & $" \quad 11.095 .1$ \\
\hline$" 1782$ & $" \quad 23.526 .3$ & $"$ & 1).146.2 & $" \quad 8.308 .1$ \\
\hline$" 1783$ & " $\quad 33.811 .1$ & $"$ & 18.879 .4 & " 14.931 .5 \\
\hline$" \quad " 1784$ & " $\quad 29.935 .7$ & $"$ & 17.078 .8 & $" \quad 12.862 .4$ \\
\hline Totales: & $\$ 159.106 .6$ & $\$$ & 88.292 .2 & $\$ 70.742 .3$ \\
\hline
\end{tabular}

R E S U M E N

Gastos en el socavón . . . . . . . . . . . . . . . . . \$ 88.292 .2

Entregados en la Real Caja ... . . ........." $\ldots$ " 70.742 .3

$\$ 159.034 .5$

NOTA. - Que la extraña cortedad de utilidades demostrada en la partida del año de 1782, procede de haberse deducido de las correspondientes al mismo año, 5.118 pesos 7 y $1 / 2$ reales; entregados en 12 de diciembie del mismo a Dn. Claudio Rospigliosi, en virtud del Supremo Despacho del Gobierno de Buenos Aires, su fecha 29 de julio, para reintegrarle otra tanta cantidad que se habia cobrado de los arrendamientos de sus ingenios y casas embargados por resultas de los cargos que le formó Dn. Ventura Santelices, por el tiempo que fue Administrador de la Compañía intitulada después Banco; advirtiéndose de esto, que agregada la partida, suman las ganancias de 1.782, a 28.645 pesos 2 y $1 / 2$ reales.

En esta prolija serie de acontecimientos del Banco, se reconoce la distinción de épocas en que está distribuída su Historia. La primera comienza el año de 1747, en que el Contador Mayor Dn. José Herbozo proyectó y estableció la Compañía de Azogueros, para la compra y rescate de platas; y en este círculo de años se sintió aquella lastimosa quiebra de más de 170.000, que dejamos referido, en poder de los Mercaderes de Plata. La segunda época sigue desde el año do 1752 , en que Dn. Ventura Santelices mejoró esta negociación, erigiendo un Banco de cuenta de la misma Compañía, bajo de las reglas y método que hemos visto. En este tiempo no fue rnenor ni de mejor aspecto aquel sensible suceso de la falencia de 300.000 y más pesos, gobernando Dn. Jaime San Just, con todos los acontecimientos referidos durante su mando. La tercera feliz época principia en el año de 1779, en que se verificó la incorporación del Banco a la Real Corona, por virtud del imponderable celo del Sr. Escovedo. (a)

Esta obra sola, mejor diré sola su idea, bastaba para elevar su mérito y hacer inmortal su nombre en Potosí. Hacían quince años que este pueblo se había goberìado por diferentes Jefes en sus distintas oficinas; aun el gobierno político tuvo sus alteraciones bicn notables con la suspensión de su Jefe natural en el mando. Siendo difícil conducirse por un mismo espíritu de equidad y primor, un cuerpo dirigido por diversas ca- 
bezas, se hallaba esta república llena de incrcia on sus miembros, por la debilidad con que estuvo manejada. No faltaban parcialidades, y todas las oficinas necesitaban de espuela para vivificar sus operaciones, y de una autoridad revestida de tesón y grandes conocimientos, para mejorar su disciplina.

\section{N O T I I A S E X T A}

Formación del Reglamento a- ENTRo, desde luego, luchando con todos probado por el Rey, para el estos tropiezos, en medio del inmenso trabagobierno del Banco. jo de atender a los graves objetos que habían ocupado antes un hombre para cada uno, siendo él solo para todos juntos, por la reunión de las Superintendencias al Gobierno. Le sobrecargaron las prolijas comisiones de la visita general en la Subdelegación que obtuvo para esta Villa. Cumplió con exactitud todos sus deberes en las Cajas Reales y Casa de Moneda. Erigió con igual acierto la Real Aduana, formalizando su oficina, economía y método de gobierno. Por último, formó a principjos del año de 1780, con admirable pulso y prevención, un circunstanciado reglamento ${ }^{3}$ para la dirección y manejo del Banco, distinguiendo los casos, los empleos y sus respectivas obligaciones, en términos de asegurar para lo sucesivo el más fiel : exacto manejo de esta importante oficina, que ahora se maneja por él, desde su publicación, y está mandado guardar provisionalmznite, cor Real Ordenanza de San 1ldefonso, a 24 de agosto de 1782 .

\section{N O T I C I A S E P TI I A}

$\S I$.

Economia del Banco en los 10 más esencial de este Reglamento viene principales empleos de su a compendiarse en las obligaciones del Admanejo. ministrador, Tesorero y Contador, por cuyas manos corre toda la economía del manejo. Aunque ello sea bien perceptible en las Ordenanzas, no será justo que siendo esta obra Gría para los Gobernadores, se omita aquí la relación de todo el mecanismo de la oficina, para ahorrarles el tiempo en experiencias, que son el único camino por donde se llega a estos conocimientos.

\section{$\S$ II.}

I. Administrador del Banco. ToDAS las platas que traen al rescate los azogueros, trapicheros y chacchas de esta Villa, y los mineros de las Provincias de afuera, se compran por el Administrador en cualquier día de la semana; pero el más ocupado es siempre el domingo, porque en él hacen los azogueros de la Villa toda o la principal gruesa de los cambios, por ser el más inmediato a los días jue- 
ves, viernes y sábado en que practican las lavas y sacan las pellas y piñas de plata.

Como este giro no exceptua piñones, planchas y cualesquiera otras piczas de plata chafalonía (que en la vajilla) por pequeñas que ellas sean, 4 no se prucba su ley por ensaye para el ajustamiento de los valores; porque con estas menudas operaciones, además de entorpecer el mancjo de la oficina, se causilían notables costos a las partes, en requemar cada picza de por sí y ensayarla, cargando a cada interesado el carbón y otros gastos menores; y en los mismos libros bancarios resultaria una confusión inavcriguable de esta infinidad ridícula de partidas.

El Administrador, que siempre es o debe ser una persona muy experta en conocer las leyes y accidentes de las platas, sólo por la vista o por el sonido del metal calcula prudencialmente la ley correspondiente a cada pieza, y conforme a este computo que es decisivo, se ajusta el valor y se paga al interesado, "si fuere azoguero, al precio de 7 pesos 4 reales siendo de ley de 11 dineros 20 granos, hasta 11 dincros 22 granos, y por cada grano que haya de baja de los 20,8 y $1 / 4$ marcos, hasta los 22 granos. " La misma regla rige en las compras de piñas a los mineros de afuera; con la diferencia que sus platas no deben bajar de 11,21; pero las planchas de Porco, por su mala calidad, tienen fijado el precio de 6 pesos 6 reales, ${ }^{7}$ y las demás piezas, como son piñones y barretones, se pagan a proporción de su ley y merma, pasando la piña de 12 marcos; 8 sin alterar para con los trapicheros y ckacchas el precio de 7 pesos 1 real para los primeros, y el de 7 pesos para los últimos, no desmereciéndolo sus platas por el mal beneficio. La chafalonía o vajilla se paga a 6 pesos 4 reales, " sin embargo que por lo regular pierde en ella el Banco uno o dos reales, por cl mucho cobre con que la ligan estos plateros, atendiendo a que fundida y diezmada en la Real Caja, rinde a la Real Hacienda como 7 reales en marco, por los derechos de 1 y $1 / 2 \%$ de cobos y diezmo.

Aunque las platas de 11 dineros 20 granos, se pagan en el Banco a 7 pcsos 4 reales, siendo su valor el de 8 pesos 4 reales, 31 maravedíes, en cuyo exceso parece que se usurpa al azogucro 8 reales 31 maravedíes, es bien manifiesto el beneficio que le resulta en estos cambios, porque recibe su importe libre de cargo y responsabilidad de derechos, quedando obligado el Banco a satisfacerlos en las Reales Cajas. Ajustada la cuenta por menor de los gastos que se impenden hasta dejar exequible cada bawra de 180 marcos, resulta que de 11 dineros 20 granos cuesta 7 reales, 28 maravedies por cl 1 y $1 / 2 \%$ de cobos y Real Derecho de diczmo, con más 17 maravedícs y 16-31 avos, por gastos de fundición y ensaye, quedándole al Banco, de ganancia líquida, 29 y $1 / 2$ maravedíes, y a este respecto lo equivalente en las demés platas, según sus leyes y mermas; pero en compensación de este pequeño lucro que deja de percibir el azoguero, por interesarlo el Rey, se le cranquea el favor de continuos auxilios en plata, azogues, palos-ejes y otros utensilios que de continuo necesita para llevar corriente su giro, sobrecargándose el Rey con estas pensiones que ningún otro particular podría sostener.

De este principio procede el no observarse con el azoguero, aun después de haberse reducido la ley de la moneda a 11 dineros justos, la disposición de que al ducño de la plata se abone el exceso de granos o se le rebaje los que tenga de menos, de 11 para abajo, a razón de 8 y 1/4 mar- 
cos porque siendo de cuenta del Banco la satisfacción de los Derechos Roales,exige sobre la ley justa los 20 granos de exceso, para responder a este cargo en lugar del azoguero que si hubiera de satisfacerlo apenas adelantaría los 29 y $1 / 2$ marcos refericlos, lespecto a menstrarse el valor por la ley, después de satisfechos los indispensables derechos pertenecientes al Rey.

Las platas compradas desde el miércoles hasta d martes siguiente, se pasan este dáa, en costales arreglados, a la Real Caja, donde después de fundidas y marcadas las bar'ras, se deducen el miêrcoles por los Oficiales Reales, el 1 y $1 / 2 \%$ de cobos y el diezmo, junto con los gastos de fundidor y ensayador o hechura de barras, al respecto de cinco pesos por cada una de 180 marcos.

En el mismo día se pasan a la Real Casa de Moneda las barras ya diezmadas de sli cuenta (menos las que se dejaron on las Cajas Reales, en satisfacción de los derechos referidos). Allí se reensayan por sus ensayadores, y después que se pesa y ajusta por la Contaduría y Tesorería, expide la Superintendencia el libramiento respectivo a favor del Tesorero del Banco, que regularmente recibe el dinero el sábato de aquella semana.

En todo se procede con la más exacta prolijidad, para impedir los fraudes y malversaciones que antes se habian experimentado. Por libre que parezca el manejo del Administrador, corre tan ceñido a las indispensables reglas de la Ordenanza, que no le queda margen para cxeesos. Por su autoridad nada puede librar contra el fondo enceryado en $\mathrm{Ar}$ cas, ni aún contra los 70.000 pesos del giro semanal existerte en poder del Tesorero, si no es para compra de marcos y gastos anexos a ello. $\mathrm{Pa}-$ ra su satisfacción expide el Administrador, cada semana, los Cargaremes o Libranzas, en mayor número de 300, con fecha, sujeto vendedor, marcos, precio y valor, en que, después de satisfecho, pone el Contador el "Tómese razón", y lleva cuenta en un Libro diario o manual, en que también constan las cobranzas verificadas (que entran en porler del Tesorero) porr cuenta de auxilios dados a los azogueros en dinero, palos-ejes, almadanetas y otros utensilios. Lo mismo ejecuta en los honorarios semanales del Superintendente, sueldos de empleados, y como cincuenta a setenta pesos de jornales de indios requemadores, despachando el domingo las correspondientes Libranzas para su pago y para el del carbón consumido en las requemaderas, y otros gastos menores.

Todo lo extraordinario que se expende en los mil pesos que se dan de auxilios, a principios del año, por cada cabeza de ingenio, a pagar por semanas para mediados de diciembre, fiados de azogues, leguajes, composición de ruedas, aisamiento de minas, ejes y demás avíos que debe contribuir el Banco, sólo el Superintendente puede mandarlo pagar con conocimiento de causa, y todo elío montará poco más de 60.000 pesos, pero el giro con todas sus entradas y salidas, asciende a más de tres y medio millones anuales.

\section{Tesorero.}

El Tesorero recibe semanalmente en la Casa de Moneda, el procedido de las barras, y en el Banco el de todas las cobranzas, formándosele por el Contador, cada domingo, los respectivos cargos $y$ datas; debiendo prevenirse que aunque no debe existir en su poder más cantidad de 70.000 pesos, 10 se- 
gún se ha dicho, se le auxilia del dinero encerrado en Arcas, cuando el del giro no haya alcanzado para el rescate semanal por opulento y crectido.

III. Contador. Como el Contador es Fiscal del Administrador y Tesorero, toma semanalmente cuenta, al piimero, de los marcos comprados en la semana, con distinción de precios, y al segundo, de los 70.000 pesos existentes en su poder para el giro, y demás partidas percibidas por cobranzas. Recibe en data al Administrador, los marcos presentados en la fundición de la Real Caja, totos los martes, y al Tesorelo los pagamentos legítimos en virtud de las Libranzas del Administrador o Superintendente, el dinero existente del giro semanal, el entregado para eneerrar en Arcas de tres laves los domingos, ya sea jor ganancias o por cobranzas de auxilios, $y$ todos los demás procedidos líquidos, sacándole el cargo de los 70.000 pesos que siempre giran en su poder para compra de marcos.

Sobre todos estos docurnentos forma el Contador 52 liquidaciones semanales, $y$ al fin de año una general con los estractos mensuales deducidos del Libl't Diarin o manual, de el de cuentas semanales, de el de gastos del Socavón, de el de deudores por auxilios y de el de Caja o de encerramiento en Arcas de todo procedido. (b)

EI Contador no tiene llaves, ${ }^{11}$ porque las tres del Arca paran en poder del Superintendente, Administrador $y$ Tesorero; ${ }^{12}$ por esta razón tampoco da fianzas, al paso que el Administrador y Tesorero las dieron en cantidad de $\mathbf{1 5 . 0 0 0}$ pesos al tiempo de la incorporación del Banco a la Real Corona; y aunque antes no las daban, se ordena en el Reglamento del año de 1780, que los sucesores en estos empleos afiancen hasta 20.000 pesos, ${ }^{13}$ como los Oficjales Reales de estas Cajas.

IV. Sueldos. Por demasiado prolija que parezca esta ocupación, se compensa muy bien con los competentes salarios en que están dotadas todas las plazas, principalmente en el día, mejorados en mucho los sueldos que antes percibían, como se ve en la planilla siguiente:

Sueldos semanales en el Gobierno de Dn. Ventura Santelices:

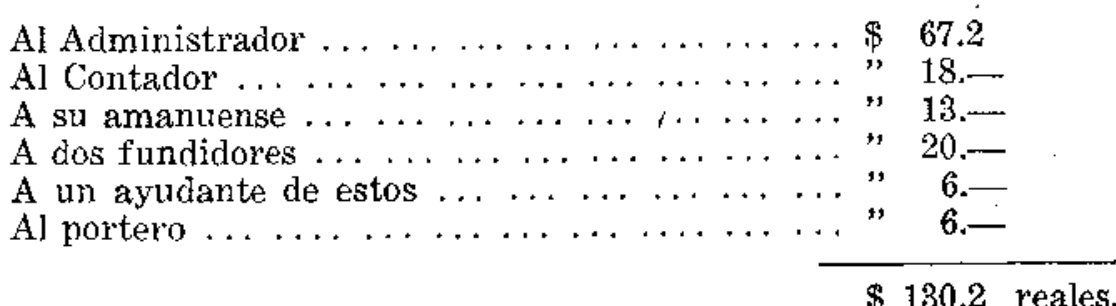

NOTA. - Teniendo el año no bisiesto 52 semanas y un día, corresponden al respecto de 130 pesos 2 reales semanales, 6.791 pesos 4 y $1 / 2$ reales al año. 
Sueldos semanales en el Gobierno de Don Jaime San Just.

Al Sr. San Just, por asignación del Gremio de Azogueros ... .................

Al Administrador y sus Oficiales ... . . . . . " 164._

Al Asesor . . . . . . . . . . . . . . . . . . " 12.

$\$ 252.71 / 2$ reales.

Los 252 pesos 7 1/2 reales semanales, corresponden anuales a pesos 13.494 .

Sueldos anuales que hoy satisface el Real Banco 14

Al Superintendente, 12 pesos diarios, desde la comisión del Sr. Tagle, que en el año no bisiesto importan: (c) $\ldots \ldots \ldots \ldots \ldots$

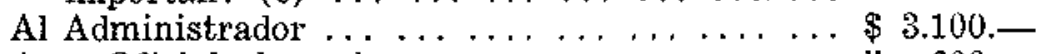

A su Oficial plumario $\ldots \ldots \ldots \ldots \ldots$

A dos fundidores, a 520 pesos cada uno ......

Al ayudante de la fundición .............

Al Contador

"600.-

$\$ 4.388 .-$

A su Oficial primeiro $\cdots$

Al segundo

Al tercero $\ldots \ldots \ldots \ldots$

Al Tesorero . ... . . . . . . . . . . . . . " $\overline{2.500 .-}$

A un Oficial suyo, a quien deben ayudar los fundidores de la dotación del Administrador, en el pagamento de las platas que se compran y demás ocurrencias $\ldots . \ldots, \ldots, \ldots, \ldots \ldots$

Al Portero, $\ldots \ldots \ldots \ldots \ldots \ldots \ldots$

Al Defensor de la Real Hacienda ...................

Al Escribano de la Real Hacienda, que actúa en las incidencias del ramo de azogue . . . . . . . . .

Al Escribano del Banco ................

TOTAL: ..................

1.040

"312.— " 5.052.-

2.000.-

$800 .-1$

600.

500. - 3.900

312.

100.

" $\quad 50 .-$.

NOTA. - No debe juzgarse extraño este acrecentamiento de sueldos, porque ahola es, sin comparación, mayor el trabajo y prolijidad con que se llevan los Libros y la exactitud de infinitos abonos semanales en el expendio del azogue, cuyos pagamentos se hacían por cartas-cuentas, solamente, cuando corrían a cargo de los Oficiales Reales.

En lo expuesto se ve que la incorporación del Banco a la Real Corona, en nada ha variado los fines de su nativo establecimiento, porque continuando en fomentar la minería con auxilios abundantes y oportu- 
nos, 1.j sólo trata el nucvo Reglamento de metodizar su justa distribución, cvitando quicbras y asegurando los sobrantes a favor del Rey, para que la opulencia del fondo que sin este noble destino sería un caudal muerto, inmóvil e infecundo, circule con los expendios de la Real Hacienda, para prosperidad del Estado. Y sin tropezar en que la Azoguería de Potosí, debía ser el único acrecdor a los socorros, por ser su gremio quien estableció esta Compañía o Banco, para fomento de sus individuos, sufriendo, desde su erección, sucesivos descuentos en los valores de sus platas; se extendió también a los minerales de otras Provincias el bencficio de los auxilios, así en plata como en azogues, ${ }^{16}$ bien que limitando la primera especie a 1.000 pesos solamente, bajo de dos fianzas de crédito y conocido abono, de mancomún con personas que no scan mineros, con total igualdad a los Azogueros de Potosí, en lo respectivo a plazos, y demás circunstancias prevenidas en el Reglamento para con ellos; y en chanto a los azog:ıes, bajo de fianzas o prentlas, a satisfacción del Administrador y Tesorero, a pagar dentro de seis meses, haciendo antes constar el interesado, por certificación del Corregidor de su Partido y kel Contador del Banco, ser de cjereicio minero y haber traído en otras ocasiones al rescate, lo menos 500 marcos de plata. ${ }^{17}$

$$
\text { N O T I C I A O O T A V A }
$$

\section{Banco general de Avios para todas las Minas del Virreinato.}

\section{$\S \mathrm{I}$.}

se propone los medios más. WSTE favor extensivo del nuevo Reglaproporcionados a su conservación y alivio de los Mineros. mento del Banco de Potosi, sirve como de base para ampliar sus Leyes a beneficio de toda la minería de este Virreinato, haciendo universal para todo el distrito, un depósito de caudales públicos destinados en su primera constitución, para fomento del Gremio de Azogueros de esta Villa.

En México sc ha crigido un Banco general de avíos de minas, para fondo dotal de las de aquel reino. El título 16 de su Ordenanza de 22 de mayo de 1783, trata de su establecimiento, administrativo, cobro y custodia, de sus fondos y pensiones con que se han gravado Nada especial previene que no se halle plenamente proveído en los 14 Títulos del Reglamento de nuestro Banco, aventajándole éste en la decisión menuda y circunstanciada de innumerables casos particulares y cn una infinidad de cautelas admirables para el buen uso de los auxilios y estrecha administración, así del caudal puesto en giro, como del fondo encerrado en Arcas; de suerte que a primera vista puede considerarse demasiado fácil fomentar toda la minería del Virreinato con los avíos de este mismo Banco, bajo las reglas que hoy rigen su manejo.

Pero no es tan llano como parece ni puede subsistir una extensión tan universal, sir variar en alguna parte su actual constitución. Por la Ordenanza 1a. Tít. 7 del Banco de Potosí, están señalados para fondo 200.000 pesos, atendiendo a que el giro semanal del rescate, regularmente no excede de 70.000 pesos; y aunque los auxilios anuales ordina- 
rios y extraordinarios no pasan de 100.000 , no suben a más de los 80.000 restantes los otros avios menores y ocurencias de los cambios. En efecto, así sucede en el día por contraerse los avíos a la Azoguería de Potosí, siendo raro o ninguno de los mineros de otras provincias, que soliciten de su fondo el auxilio de 1.000 pesos, ya por demasiado corto, $y$ principalmente por la dificultad de fiadores que abonen su crédito; $y$ solamente vemos que ocurren pol azogues, de los minerales de Chichas, Lípez y Aullagas, donde no hay Cajas Reales, porque los demás, del distrito de Guantajaia, Iampa, Oruro, Carabaya y Chucuito, sacan cste ingrediente de sus respectivas Cajas, donde corre su administración $y$ expendio.

De esto resulta que son raros los que traen a l'otosí barras de Guantajaia, fundidas y quintadas en Oruro, y las más que se funden en las callanas de su respectivo territorio, se encaminan para Lima, bien sea para labrar en aquella Casa de Moneda, o para llevarlas en pasta a los Reinos de España; por lo que el todo o el principal giro del rescate de nuestro Banco, viene a reducirse a las platas de este Cerro Rico, de Chichas, Lípez, Aullagas, de Porco, de Ubina, de Siporo y de otros Asientos menos considerables situados en varios cantones do su comarca.

Todos estos, que conducen sus platas a Potosí, suf ren el descuen. to señalado para el fondo en las Ordenanzas $5^{\prime}, 6^{\circ}$ y $7^{\prime \prime}$, del Tít. $2^{\prime \prime}$, fuera de la pérdida de los picos, que no llegando a onza no se pagan a los Azogueros de Potosí; y a los demás, en pasando de 12 marcos, se los satisface solamente hasta la media onza, y en partidas menor'es hasta la cuarta, 18 con la circunstancia de prohibírseles 19 la facultad de fundir por su cuenta las platas, como reservada al Banco, para evitar las dilaciones y perjuicios que sufrirían en los ensayes, paga de derechos y otras precisas estaciones hasta cobrar su valor.

Como estos mineros están acostumbrados a traer sus platas al rescate y no tienen otra oficina donde despacharlas con más brevedad, ni hay otros rescatadores que puedan cambiar toda la gruesa por estas inmediaciones, tampoco tienen inconveniente on que corran los cambios en el pie que ahora se hace.

Pero siendo forzoso en este nuevo sistema, incorporar a la Azoguería de Potosí todos los demás mineros de este Vil'reinato, para que formando un solo cuerpo, se aliente $y$ vivifique por igual, también era preciso que perciban unos mismos auxilios, asegurándoles con prendas superabundantes o fianzas abonadas, a pagar dentro de cuatro meses de la fecha del avio; ${ }^{20}$ y siempre que no lo ejecuten en este término, que puede imponerse por plazo para verificar las remesas, proceder a las ejecuciones $y$ ventas de alhajas, en la forma dispuesta por la Ordenanza 21, Tit. 6 del Reglamento.

Aunque todos hayan de tener una misma opción a los auxilios concedidos por el Reglamento en las Ordenanzas $1^{a}, 6^{\mathrm{a}}$ y $8^{\mathrm{n}}$, del Tít. $6^{\circ}$, es menester variar la forma prescripta para su distribución, ${ }^{21}$ porque habiéndose reservado al Gremio de Azogueros de Potosí, la facultad privativa para determinar el destino del dinero de auxilios, en la Junta Gencral que celebran todos los años el día 17 de enelo o siguiente, si fuese feriado, 22 en que no entran ni tienen voz los demás mineros, debe habilitárseles a estos el arbitrio de disponer la parte que les corresponde, pexmitiendo a cada uno el representar a la Dirección General que aquí se establecie- 
re, cuanto hallare conveniente para la felicidad de su trabajo, pidiendo avios y lo demás que neccsite; que siendo urgente el caso y la ocasión repertina y ejecutiva, cono de aisamiento de minas, quiebra de ruedas $u$ otra descompostura que, sin pronto remedio, haya de hacel parar la labor, podrá conferenciarse la instancia en Junta de los Diputados generales, pasándola a la Superintendencia, con el Informe respectivo, para el despacho de las Libranzas.

\$II.

Cautelas para prosperar el $\mathbf{P}$ ERO si la necesilad procediere del orden trabajo de minería y evitar general que se observa en casi todas las mifraudes. nas del Reino, cada minero hará una relación circunstanciada de lá suya, expresando las causas del atraso y medios cie repararlo, y la remitirá al fin de año, con las boletas de rotos, al Superintendente y Junta de la Dirección, para que confrontadas estas lelaciones con los Informes instructivos que todos los años deben hacer los Jueces o Alcaldes de Minas, sobre los registros, labores corrientes, despobladas y nuevamente descubiertas, mojones y todo lo demás perteneciente al estado de las minas y sus dependencias, por reconocimientos y visitas que están obligados a practicar cada año por Ia Ordenanza, "2: se determine el destino más útil de los auxilios, según las necesidades de cada mina, librándose a favor del interesado o de quien tenga su poder bastante, la cantidad destinada en la lista que se formare con arreglo a la Ordenanza 8", Tít. $6^{\circ}$ del Banco, pasando aviso Ia Dirección al Juez del respectivo Asiento, para que esté a la mira de la inversion útil y oportuna del auxilio, con el cargo de dar cuenta de sus efectos, en el Informe del año siguiente.

Para afianzar sobre mejores y más seguros conocimientos las providencias económicas en materia de minas, sin aventurar los auxilios del Banco, empleándose en las de ningún provecho, serả conveniente que el Juez del mineral acompañe sus informes con una averiguación de la ley de los metales y de la costa del beneficio, así en jornales y materiales, como en pérdida de azogue, teniendo a la vista los Libros de los beneficios que los dueños tuvieren, para examinando el punto de decadencia (si lo hubiere) por los peritos facultativos, se promuevan los medios de su adelantamiento. $\mathrm{Y}$ cuando no, se lograse siquiera arreglar los costos a la ley del metal; debiendo entonces presumirse que el minero recomienda fraudulentamente su trabajo, por d interés de los avíos de plata y azogues, para otros fines ajenos a su constitución; en este caso puede arbitrarse sin dilación lo que más convenga al particular y al Estado, sobre la continuación o abandono del trabajo, después de la inspección de la mina, medidas y domás diligencias preventivas en el Art. 18, Tít. 9, de la Ordenanza de México.

Con estas cautelas, es muy probable que nunca hayan quiebras ni se falte al plazo con la correspondencia de los fiados de avios. Se asegura también que alguno, para prolongar la esperanza de sus acreedores, o por otros fines menos rectos, no se entretenga en el trabajo infructuoso de una mina perdida. $Y$ porque puede suceder (como está sucediendo) que para cubrir la quiebra de la mina, rescate platas con la de 
los auxilios, porque el Banco siga dándoselos, debe cuidarse que los ducños de minas lleven libros de cuenta y razón, en que conste con toda claridad las piñas que sacaren, plata y oro que beneficiaren, así de su cuenta como de encomicnda y fletadores, y cualesquicra personas que las sacaren de los ingenios o minerales, tengan obligación de tomar certificación de los Ministros del Banco, del importe de los rescates, para remitirlas todos los años al Superintendonte y Junta de la Djuección, con carta-cuenta de las piñas que por su libro pareciere haber beneficiado, y razón de las personas a quicnes las vendieron o entrogaron; practicándose lo mismo con los Mercaderes aviadores que negocian en los minerales de afvera con el rescate de piñas, en cuanto a estar obligaclos de asontar en su Libro y poner razón de la plata que recibieron de cualquiera cluoño de minas e ingenios; para que llevéndola a lundiz y cambiar al Banco, manifiesten la razón de las piñas que son de cuenta de los ducños del ingenio donde se beneficiaron, o de la silya, dejando la misma en los Libros de los dueños de ingenios de donde salieren, firmado de la persona que extrajere aquellas piñas o pasta. Así constará muy por monor y circunstanciadamente los productos de carla mincral y la condición do los que vienen al Banco a rescatar piñas, csto es, si son mineros o meros aviadores, y sobre todo se evitará el riesgo de extraviarse las platas de los Partidos, de esta Provincia y de otras dol Virreinato, en fraude de los Reales derechos; respecto de sor esta seguridad una consconencia forzosa de la obligación en que están los mineros, los mercaderes o compradores de platas, de encaminarlas en derechura a la Real Callana del distrito, y manifestarlas dentro de segundo día como hubieren llegado, bajo la pena de comiso, según do dispuso el Sr. Virrcy Dnque de la Palata, para este Reino del Perú, en Providencia de 13 de mayo de 1682, y para el do México su novísima Ordenanza de 1783, en el Art. 10 del Tít. 15.

Aunque hayan de observarse las mismas regtas y cautelas en los minerales del distrito de las demás Calas Reales dẹ Virreinato, como son Oruro, Carangas, Carabaya, Chucuito, La Paz y Chuquisaca, debe variarse el modo de distribuir los avios, atondiendo a la distancia de los lugares. Para con los tres Partidos que son Chayanta, Chichas y Lípez, donde no hay callana y por esto viencn todos sus mineros a la capital de Potosí, para fundir y quintar sus platas, no tiene embarazo el que reciban en el mismo Banco los azogues y demás avíos en plata. Pero es impracticable para los mineros de otras Provincias, respecto de tener la fundición y diezmo en sus respectivas Cajas, de donde para venir a Potosí por auxilios, impenderian muchos costos, largo tiempo y, lo que es más, una morosa ausencia de sus trabajos y negocios.

$$
\S 111 \text {. }
$$

Método, lugar y forma de
repartir los auxilios en plata
y azogues a Ios mineros de
fuera de esta Provincia de
Potosí.
P OR csto convendria distribuir en las Ca-
jas a los Minerales del respectivo departa-
mento, los auxilios en plata, así como ahora
se reparten los azogues, graduando bno y
otro a proporción del fuste de los mincrales
y del eorriente de su labor; de suerte que a
en ingenios propios o arrendados, se les so- 
corra con los mil pesos anuales y cantidad de azogues que dispone la Ordenanza 28, Tít. 6, y la Ordenanza $7^{\text {n }}$ con la 8*, Tít. 8 del Reglamento del Banco, por considerárseles en la misma clase con los azogueros de Potosí, según el cspíritu de la Ordenanza 2", Tít. 8 de dicho Reglamento, referente a la 7 del Tít. $6^{\circ}$; entendiéndose con los trapicheros de afuera el socorro de 200 pesos, bajo las seguridades, abonos y plazo que previene la Ordenanza 22 del Tít. $6^{\text {" }}$; y en cuanto a los azogues, el avío de 300 libras solamente, con las cautelas de la Ordenanza 59, Tít. 8, a fin de no aventurar su cobranza.

Los demás mineros que no trabajan en ingenios grandes o chicos ni trapiches, $y$ no llevan corriente formal aunque estén estacados con registro, hacen más dificultosa la contribución de allxilios, por el notorio riesgo a que se expone su cobranza, careciendo de crédito y posesiones para el seguro de sus resultas. No obstante, como todos exntribuyen poco o mucho a la prosperidad del Estado, también se hacen acreedores a ser socorridos en los fondos del Banco, a ejemplo de lo que se practlea en Potosí, acudiendo con azogue a los clacchas y otras personas que io solicitan, hasta 100 libras a dinero de contado o prendas equivalentes, ${ }^{24}$ a sabiendas de que estas gentes no tienen mina propia y de ser robadas de ajenas pertenencias la menudencia de pastas que presentan al rescate, si bien que será preciso mosurar todo género de avíos con que estas gentes fuesen socorridas, a las cantidades que en los Libros que ellos lievaren o los Mcrcaderes aviadores, constase haber beneficiado en el año anterior, cohibiendo a los Ministros que hubicsen de manejar estos giros toda facultad para alongamiento de plazos, dispensación de seguridades y acrecentamiento de la cantidad señalada para auxilios. .

$$
\text { \& IV. }
$$

Aviadores particulares de mi- Los que diere el Ranco han de ser sin pernas. Se refieren varios in- juicio de los Aviadores particulares, que por convenientes y los medios de interesarse en los rescates de platas y de evitarlos. otros metales, socorren al fiado, por lo regular con géneros y efectos, en todos los minerales de fuera; pues, además de no ser justo hacer exclusivo el negocio de avíos, por las consideraciones que apunta todo el Título 15 de la Ordenanza de México, es conveniente a la mayor seguridad del Banco, que sea acumulativo con los Mercaderes de platas; porque estos, como intcresados, bicn sea por la utilidad que perciben en aquél algo menos del precio legal y justo de la plata con que son pagados, o por otros contratos que celebran con los mineros, están prontos a ser sus fiadores en la Caja, para los fiados de azogues y otros auxilios, como destinados a fomentar la mina de que ellos esperan el lucro.

Pcro si la negociación de avíos particulares se quisiere ceñir a la calidad de hacerse en reales de contado o en Letras pagables sin premio ni pérdida, y en géneros y efectos, al mismo precio que se compran con dinero en mano en el lugar de donde los hubiere sacado el aviador, como dispone por indispensable condición la Ordenanza $4^{2}$, del Tít. de la Mi- 
nería de México, no sé encontrará en todo d L'erú un Mercader aviador, porque exceptuando tal cual que auxilia en grancle algún minero poderoso en frutos o fundadas esperanzas de la mina, los más son mos Mercadeles de poco crédito y giro, que sacan fiados los gencios jara llevar a los minerales; allí los vuelven a 1ijar con concepto al tionpo del plazo, que es parte de precio según la ley, ${ }^{25}$ y tambich con colsideración a los lletes y alcabalas que pagaron y a los riesgos del camino; y como todas estas circunstancias juntas hacen subju los valores, es inverificable la venta de los efectos en el mismo precio que se hubieran comprado con dinero de contado, y de consiguiente, quedaría inhabilitado el negocio de avios particulares siempre que se intentase la obscrvancia cle aquellas calidades. No será poco en que los Jueces de los respectivos asientos, celen que no se excedan los precios corrientes de aquel ligar, ni se concieften los pactos usurarios que facilita la misma necesidad de los mineros. $\mathrm{Ni}$ es justo ni conforme al dictamen de equidad, que al vendedor se le prive de aquella regular ventaja que debe justamente prometcrse de su comereio.

También debe cortarse otro abuso demasiado perjudicial: de venderse azogues en feales de contado o bajo de fianzas, a personas que no son de ejercicio mincros. En el Ranco de Potosí se halla esto prohibido estrechamente, en la Ordenanza 8*, Tít. 8 de su Reglamento, así para cvitar fraudes en las rentas " come para formalizar la razón de correspondidos y ajustár las reglas más oportunas a esta cuenta que tanto importa para los fines que explica el Reglamento de este Banco. ${ }^{27}$

De no observarse esta precaución, vendiéndose azogues a cualquiera persona, sin examen de su ejercicio, se sigue que comprándolos on la Caja a 60 pesos quintal (que es el áltimo precio fijado en Real Ordenanza de 10 de noviembre de 1783), se vende luego por los Mercaderes, en calidad de avíos a los mineros de fuera, a un $50 \%$ más, por lo menos, y no pocas veces a un $100 \%$, eontraviniendo a las Leyes que prohiben el comercio de un género de Estanco, y perjudicando sobre manera al infeliz minero, en doblarle el precio de este ingrediente, pues ha de pagar lo equivalente a otro tanto más de lo que no se ha aprovechado para la saca y beneficio de las platas.

Pero siendo difícil y talvez impracticable a un minero pobre, ocurir a la Caja de su Depertamento en busca de azogues, sin tener prendas, crédito ni fiadores con que asegurarlo, no conviene negarlos en el todo a los Mercaderes aviadores ; porque afianzando, a más de su precio, dos cosas, la primera: haber de presentar a la fundición y diezmo, otros tantos marcos de plata como sacó de azogue; ${ }^{28}$ la segunda, no haberlo de vender a más precio del que el Rey ha señalado, se cumple con todos los fines a que aspiran las Leyes; bien que al mismo tiempo de celarse por los respectivos Jueces el cumplimiento de estas obligaciones, es justo que ellos mismos, al tiempo de recibir las Guías del azogue, ajusten a favor del Mercader aquel tanto por ciento más que debiere acrecentar al precio señalado, por razón de los fletes. 
$\S V$.

Ganancias del Banco en las denlás Provincias del Virreinato.

OHIO el único compensativo de estas franquicias, auxilios y socurros, es el descuento que se hal de haccr en todas las platas, a benoficio del fondo det Banco general que conviene establecer en torio al distrito de nuestro Virreinato, ocurren sobre este sistema algunas dificultades. Ia primera, el cómputo de la ganancia bancaria, para arreglar a lina ley justa los descuentos. La segunda, si deba extenderse a los aviadoies, no habiendo recibido estos el favor de los socorros. La tercera, si la utilidad del Banco deba descontarse aun en el caso que desplés de fundida y diezmada la plata, no consienta el Mercader en su rescate. La cuarta, cómo doban gobernarse los Oficiales Reales residentes en los mismos Asientos de minas, en los rescates de plata por partidas menores, de diforcntes lcyes, para no exponer a pérdida el interés del Banco ni el del mincro, por error en el cómputo.

La resolución de estos puntos servíá como regla para el establecimiento propuesto. Cuando se trate de las ganancias del Banco, debe tenerse consideración, 110 solamente al valor intrínseco que tiere el marco de plata, así un maravedícs como reducido a pesos corrientes de a ocho, sino tambien al extrinseco que haya establecido en cada mineral el comercio de las barras o pastas. Las platas de Oruro tienen por lo regular 11 dineros 22 granos de ley, $y$ las de Carangas 11-21. Reduciendo estas leyes a 11 dincros justos, corresponde a cada marco de Oruro el vaJor intrínseco de 8 pesos 5 reales 3 y $1 / 2$ maravedies, y al de Carangas, 8 pesos 5 reales, 5 y $1 / 1$ maravedies. Cuando estas platas se compran en piña, le cuesta al Mcrcader 6 pesos y medio cada marco en Carangas, y 7 pesos en Oruro; de suerte que no subiendo de diez reales el costo de cada marco, en lo que pagó por el $1 \mathrm{y}^{1 / 2} \%$ de cobos, Real Derecho de diezmo, gastos de fundición, ensaye y fletes de su conducción a la Casa de Moneda de Potosí, queda en cada marco de las platas de Carangas, la ganancia libre de 7 y $1 / 2$ a 8 reales, y en las de Oruro, de 4 a 5.

\section{$\S$ VI.}

Descuentos del valor de las platas.
S nor dificultad para el arreglo de los descuentos. En el Reglamento de este Banco tenemos una pauta muy justa y equitativa. Previcne la Ordenanza 1", del Tít. $5^{\circ}$, que para guardarse con el püblico la buena fe que corresponde y atemperar a lo justo las ganancias del Banco, nunca hayan de pasar estas (siendo líquidas) de un real en marco ni bajar de medio en todas las partidas que lleguen a mil marcos. Siendo pues conveniente uniformar el giro de las Cajas subaltornas del Banco con la principal de Potosí, no hay por qué cansarnos en buscar otros modelos, teniendo ya declarada una re- 
gla fija en punto a ganancias; y así, deberá roducirse el descuento a un real por marco, y esta será la ganancia bancaria líquida, en que no puede alegar perjuicio el Mercader, quedándole siempre tan considerable utilidad como la que sc ha visto.

En las partidas menores que no llegando a mil marcos no quisiere fundir el dueño de su cuenta, porque solicita su rescate, parece también justo que el Banco le satisfaga dos reales más en mai'co, sobre el precio corriente del mineral, en consideración a la crecida ganancia que va a percibir y a lo que conviene fomentar la nuineria; debiendo esperarse que al ver sus platas mejor pagadas en el Banco que por los Mercaderes, le darán preferencia en los rescates, y lo que habia de ganar cl aviador, lucrará entonces este fondo público. Infinitamente mejorar'á el estado de la minería con este aumento de precios y en el círculo de pocos años vendría a colmarse de una inmensidad de rentas, principalmente si sobre el descuento expresado, se agrega la ganancia de los picos corridos y quebrados, en la forma dispuesta por el Reglamento.

Con respecto a las muchas utilidades cue se considera haber de quedar siempre a favor del aviador o Mercader de plata, sin embargo del desczento de un real, es de presumir que haciendo la fiundición de su cuenta, lleve de la misma sus barras a cualquicra de las dos Casas de Moneda, de Lima o de Potosí, como tiene libertad de hacer cualquiera vasallo del Rey, habiendo pagado todos los derechos correspondientes; pues, aunque el primer Virrey de Buenos Aires, el Excmo. Sr. Don Pedro Cevallos, en Superior Despacho dado en la Colonia del Sacramento a 8 de julio de 1777, prohibió, bajo la pena de comiso, extraer para Lima del distrito de este Virreinato oro y plata en pasta, tejos y polvo, permitiéndolo para Buenos Aires solamente estando diezmada; y la Real Audiencia de Charcas, en Real Provisión circular de 20 de agosto del mismo año, mandó guardar esta prohibición; (d) en el día no se observa, cn consideración de que una barra diczmada y makcada, es comerciable en todo el Reino y es una moneda equivalcnte.

Sobre este supuesto y de ser conforme a lo que dispuso el A $z^{2 t} 1^{\text {s }}$ del Tít. 16 de la Ordenanza de Minería de México, que todas las platas que entraren en cualọicra de las Casa Reales de Moneda del Reino, o que se remitieran en pasta a las de España, por cuenta de sus dueños particulares, hayan de contribuír el real de su dcscuento para fondo dotal de la propia minería; deberá ser uno de los principales encargos de los Oriciales Reales de cada Departamento, la cobranza de esta contribución al tiempo de ajustar la cuenta de los derechos, después de fundidas las barras, ordenando sus ajustamientos y los Libros de este rano, al método escrupuloso que dispone todo el Título 9 del Reglamento de Potosí, variando algunas circumstancias en cuanto a la distinción de ministerios que allí se hace respecto a que ambos Ministros han de hacer unas mismas funciones sobre el seguro de los conocimientos del Finsayador en cuanto a la ley de las platas, quedando responsable por esta intervención, en los términos que disponen las Ordenanzas del Perú y las Leyes del Reino. ${ }^{30}$

Pero atendiendo el perjntcio que resultaría contra el comercio, dejando de reducir a moneda las barras, y también a la Real Ilacienda por' la privación de las utilidades que proceden de la labor en reales, y que tal vez por la granjería de que se las pagan mejor los extranjeros reci- 
biéndolas en pasta, procurarian llevarlas en este estado a Europa, deben provenir'se las cautelas oportunas contra este desorden.

\section{$\S$ VII.}

\begin{abstract}
Precaución para amonedar las barras que no se rescataren.
\end{abstract}

$\mathbf{L}$ A Ley a , Tit. 13 de Indias, presenta una precaución de las más próbidas y bien meditadas: se reduce a que los Mercaderes de plata que no quisieren rescatarla, hagan obligación de labrarla dentro del término de 6 meses, en una de las Casas de Moneda de este Rcino (e) o de embarcarlas cn el mismo término para España, y a que en el primer caso presentarán testimonio del Escribano de la Casa donde se hubiere hecho la labor, de haberlo ejecutado; $y$ en el segundo, la partida de registro del navio donde se hizo el envío, bajo la pena de 500 pesos ensayados, a menos de justificarse por documento de igual fe, que on aquel plazo no hubo salida de embarcaciones, o que no se pudo verificar la rondición de la moneda.

No debe dudarse que por este medio se logrará considerable crecimiento en la labor de la Moneda, se aumentará la masa numeraria, abundarán on el Reiro los valores efectivos, florecerá el comercio y refluirá este beneficio en los demás ramos del Estado.

Con esto quedan sólidamente desvanecidas las cuatro dificultades que se propusieron, porque ya se ha dicho que las ganancias del Banco se han de reducir a un real en ciertos casos, y en otros en algo más, según las circunstancias del dueño; que esta contribución debe extenderse a los aviadores como a los mineros, por las utilidades y franquezas que también participan los primeros, aun cuando no quieran rescatar las barras; $y$ en cuanto a la cuarta y última, puede encargarse el Ensayador de las funciones que ejerce el Administrador en el Banco de Potosí, por la pericia y grandes conocimientos que debe poseer de los accidentes y calidades de las platas, que así correrá menos riesgo el interés particular y el público del Banco, en el cómputo de las leyes y ajustamiento de valores; sin que los Oficiales Reales tengan por esto algún derecho para pretender ayudas de costa o aumento de salarios, porque esta administración viene a ser una consecuencia insidente del manejo de los azogues, que se ha considerado como una anexidad del Ministerio de Hacienda. Pero para que este giro corra uniforme y bajo de una misma cuenta, deberá arreglarse en el pie de la Administración general de la Real Aduana de Buenos Aires, para que del mismo modo que remiten a ella Jas cuentas respectivas a derechos de Aduana los Oficiales Reales delVirreinato que tienen este cargo, así también remitan a la Contaduría general de el Banco de Potosí las correspondientes a rescates, azogues y auxilios de sus Departamentos, para que todas vayan en una cuerda al Tribunal de. Cuentas de Buenos Aires, en los tiempos, forma y método prescritos en el Reglamento de este Banco. 
Fondo quo se computa para $\$$ STE gran sistema, figurando segun la el Banco de Avíos Genera- planta propuesta, no puede subsistir con el les, para la Mineria del Vi- fiturio de los 200.000 pesos solamente que le rreinato. estín señalados. Este deposito, incliso el caudal de giro, se considero bastante con respecto a la Minería de Potosí, que se miró como el único o principal objeto del fomento, y ya que se va cxtender a todo "i Virreinato, debe también aumentarse el fondo a proporción de los mayotes auxilios y rescates. Para millón y mertio de pesos, con diferencia dé poco más o menos, que produce el Cerro de Potosí, puede surtir el giro de 70.000 pesos, por los continuos y sucesivos repuestos de este mismo dinero; y el resto de 130.000 pesos pueden alcanzar también, aumque con escasez, pal'a los auxilios ordinarios y extraordinarios de esta Azoguería y sus fincas. Para en adelante debe proporcionarse un fondo que equivalga por lo menos a la gruesa de cuatro y medio o cinco millones de pesos, que se labran en esta Casa de Moneda, deI procedido de las minas del Virreinato; con cuyo respecto $y$ al de los auxilios, juzgo que el fondo no dobe apear de un millón de pesos. Al principio puede suplirse del ramo de Reales Diezmos, (f) aunque bien mirado, puede colmarse esta Caja en breve tiempo, de las utilidades del mismo Banco; y cuando para uno u otro bubieren inconvenientes, parece no sería difícil juntar las cantidades necesarias para hacer los principales rescates en las Cajas del Virreinato, tomándolas de Ios hombres de negocios, con el abono de un medio por ciento de interés al mes, en el corto tiempo que puede mediar entre el desembolso en Chucuito, Carangas y otras partes y el reintegro en Potosí, por la mucha conveniencia que reporta la Real Hacienda y el Estado de proporcionarse estos trueques que nunca se podrán lograr sin unos repuestos considerables y efectivos. ${ }^{31}$

\title{
$\S 1 X$.
}

\begin{abstract}
Superintendente. Su res- \$STA importante Administración debe ponsabilidad; jurisdicción, callsas a que se extiende, $y$ sus facultades.

quedar sujeta a la Dirección y mano de un Superintendente, que debe ser el mismo de Potosí, para que a todo el cuerpo se inspire un propio espíritu en la unidad de la cabeza. El Intendente de la Provincia lo es ahora de las demás dependencias de esta Villa, por la reunión de todas las Superintendencias a este empleo, desde la publicación de la Ordenanza de 28 de enero de $1783 ;^{32}$ y aunque por el Tít. 10 del Reglamento del Banco, están asignados solamente dos mil pesos de sueldo a esta Superintendencia, con concepto del que debe gozar por la Moneda, perejben en el día 4.380.- al año, al respecto de 12 pesos diarios, desde la comisión de Dn. Pedro Tagle, sin pa-
\end{abstract}


gar media anata ni montepío, por considerarse como ayuda de costa o sobresucldo; y es regulir que esto cese luego que se le asigne la dotación correspondicute, reservada hasta ahora a la soberana voluntad, por el A.t. 273 de la citata instructión de 28 de enero.

Como tenedor de una de las tres llaves del Arca del Tesoro, es responsable a que los encerramientos semanalos se hagan en el día y modo establecido, $3: 3$ y a todos los caudales de que hubicra dispuesto excediendo el tenor de la Ordenanza 34 alterando el método del rescate. ${ }^{35}$ Debe asistir a las juntas mensuales y a otros actos que dispone el Reglamento, ${ }^{36}$ procedicnrlo siempre ar'reglarlo a él. is

Ex todo lo gubernativo, económico y judicial, tiene el Superintendente jurisdicción privativa, con inhibición de los demás Tribunales, y las apelaciones debe otorgarlas a la Intendencia General de Buenos Aires, en lo gubernativo, directivo y económico del Banco y de sus caudales; 38 pero en el día $: 4$ reben dirigirso los recursos a la Junta Superior de Buchos Aires, en las causas de Hacienda, ya sean de Gobierno o de Justicia. En lo demás, que no toque directa ni indirectamente a las obligacionos de los Ministros y Dependientes del Banco, como son las causas civiles y criminales que no proceden de sus oficios o por motivo de ellos; a saber: los delitos comunes, juicios de inventarios, sucesiones hereditarias, compañas universales, concurso de acreedołes o cesión de bienes, providencias de l'olicía y buen gobierno, tratos y negocios particulares de los reforidos Ministros y subalternos, quodan sujetos a la jurisdiccion Resl ordinaria, con stiboroinación a la Real Audiencia, para donde rleben otorgause a las partes sus apelaciones, ${ }^{40}$ y aunque Ia Ordenanza 7 , Tít. 10 del Reglamento previene que en este género de causas, que pasen de mil pesos o que merezcan prisión, embargo de bienes o ejecución, se pase anticipado aviso de oficio al Siperintendente, para que poniéndose otro sujeto en su lugar, no se exponga el Real servicio en los caudales y papeles que tuvieren a su cargo; con todo, siendo los casos criminales ejecutivos in fraganti, u otros actos judiciales en que precediendo el oficio referido, se aventure por ello tal vez la administración de justicia, declara el Art. 85 de la instrucción de Intendentes, que en semejantes circunstaneias se debe diferir el aviso hasta después de evacuadas las diligencias que pidan o recomienden el secreto.

\section{$\S X$.}

Provisión de los empleos A consecnencia de esta jurisdicción concedel Banco. de el Reglamento ${ }^{41}$ al Superintendente la facultad de proveer en vacante los empleos de los tres Ministros del Banco, a saber: Administrador, Contador y Tesorero, ascondiendo siempre el Ministro más inmediato a la plaza superior que haya vacado, sin poder alterar este orden sino cuando faltaren o no quisieren admitir los Ministros siguientes al que hubiese faltado por privación, muerte o renuncia; en cuyo caso deben ocupar la resulta los tres Oficiales primcros de la Administración, Contaduría y Tesorería, con tal que lleven cuando menos dos años de servicio, participan- 
do los nombramientos a la Intendencia Gencral de Buenos Aires y al Ministerio de Indias, con testimonio de las fianzas para el despacho de la Real confirmación, con areglo a la Ordenanza $7^{\natural}$, T'ít. $1^{\mathrm{n}}$ del Reglamento; $(\mathrm{g})$ y cuando por ineptitud de los empleados o por otra justa y probada causa, fuese preciso variar cl orden de estas provisiones nombrando otro sujeto de fuera, debe oírse al interesado cxcluído, si lo pidiere, dando cuenta de todo al Ministerio de Indias; pero en ningún caso puede clegir para las plazas principales a ningún pariente ni doméstico suyo, ${ }^{12}$ para evitarse de este modo toda ocasión de disimulo, decidia, fraude o colusión; con cuyo objcto se prohibió anteriormente, en Real Cédula de EI Pardo, a 20 de enero de 1775 , que on las Cajas ni en oficina alguna de Real Hacienda, sirviesen a un mismo tiempo padres, hijos, yernos, tíos, sobrinos o hermanos y cuñados, ni parientes dentro de los grados expresados; $y$ esto, aunque antes de la citada Real Cédula, estuvieren proveídos, porque en el tal caso deberían colocarse en otros destinos; de lo cual se deduce por una extensión muy justa y legal, que entrando un Superinf tendente pariente de alguno de los Ministros, debe ser colocado inmediatamente en otro destino, o darse cuenta al Rey, para que resuelva lo más conveniente a su servicio.

Todos los demás Oficiales de las tres oficinas del Banco, son a nominación libre de sus respectivos Jefes y amovibles por' estos; con precedente noticia del Superintendente, sin necesidad de confirmación, ni descuento de media anata y montepío. ${ }^{43}$

\section{$\S \mathrm{XI}$.}

Indultos de los empleádos $\mathbf{E}_{\mathrm{STE} \text { indulto de exceptuar de Real Con- }}$ en el Banco. firmación a los referidos oficiales, es demasiado estimable; hallándose dispuesto en Real Orden de 20 de febrero de 1774 , que la soliciten todos los Dependientes cuyas dotaciones lleguen a 400 pesos, sean de la clase y condición que fuesen, respecto de haber resuelto S. M. que en lo sucesivo sean todos estos destinos de su absoluta nominación, como los Oficiales Reales. Gozan también la gracia de percibir semanalmente los sueldos, para no entorpecer los ajustamientos semanales, ${ }^{44}$ por una excepción especial de la Ley 1" Tít. 26, Libro de Indias, que manda absolutamente pagar los salarios por los tercios del año y no antes, bajo la pena de no recibirse en cuenta dispensándoscles csta prohibición más francamente que a los Ministros, Oficiales y Dependientes de la Casa de Moneda, donde se pagan mensualmente por nóminas interinarias, con el cargo de despachar al último de cada tercio del año, libramientos separados, intervenidos por la Contaduría; ${ }^{45}$ y sólo están equiparados en que los Ministros de una y otra dependencia, reciben en el entretanto de la Real Confirmación, las dos tercias partes de sus sueldos; 16 sin embargo de que por las Leyes de Indias ${ }^{47}$ se pcrmite el goce de la mitad del salario solamente.

No es menor la regalía del Superintendente para poder proveer 
por si mismo las tres plazas principales del Banco, porque según el orden general de las Leyes, 48 toca a los Sres. Virreyes la provisión de todos oficios, y con ser uno mismo el cargo de Superintendente de la Casa de Moneda, no le está permitido provcer Ios empleos, y si, solamente, proponer para cada uno tres sujetos de satisfacción y mérito, ${ }^{49}$ todo Io que hace conocer el particular favor que el Banco ha merecido a las soberanas atenciones de S. M. y por lo mismo, la obligación estrechísima en que están cuantos le manejan, de ser fieles, exactos y diligentes en desempeñar con vigilancia y pureza el servicio de sus ministerios.

\section{$\$$ XII.}

Advertencia muy importantie.
$\mathbf{N}_{0}$ caso -...en mi concepto-_ de atrasarse mucho la Administración que vemos florecer ahora

con tan felices progresos; porque si los empleos han de alternar por grados según vacaren, al cabo de años habré de entrar de Administrador el Contador o Tesorero. El primero no tiene obligación de saber otra cosa más que llevar la buena cuenta y razón de los libros y formar los balances bien ajustactos; el segundo, por razón de su ejercicio y obligaciones, cumple anivelando su conducta sobre una exacta probidad de pureza. Ninguno de los dos puede adquirir los conocimientos que debe poseer un Ad̉ministrador hábil del Banco, por muchos años que hayan servido sus oficinas con el más loable desempeño, porque esto que es conocer a la vista los accidentes $\mathrm{y}$ leyes de las platas y ajustar sus valores por un cómputo que raras veces diste de la verdad, no puede aprenderse jamás llevando libros ni con entregar moneda, sino viviendo mucho tiempo sobre el mismo campo donde se trata este género de negocio. El método arbicrario y puramente confidencial de comprarse las platas en piña o pella, por el precio que a ojo se calcula, por no permitir el ensaye por fuego y copclla el grueso y diario rcscate del Banco, multitud de sus partidas y dueños, costos y dilaciones que a esto se seguirían, ${ }^{50}$ exige en el Administrador una experiencia adquirida desde la juventud y perfeccionada casi en todo el curso de la vida. Faltando en los demás Ministros estas indispensables dotes, por la desproporción de sus manejos, claro está el irreparable perjuicio que resultaría al particular y a la Real Hacienda, ascendiendo de improviso un Ministro imperito, a una plaza que recomienda tantos requisitos. $Y$ así, sexá menos mal negar este grado al recurso de sus méritos, que exponer al Banco a unos partidos tan funestos, pudiendo colocarse en otros destinos donde sean premiados con provecho del ministerio, los que hubiesen servido con desempeño $y$ exactitud.

Si se ha de seguir el método del Reglamento, como parece preciciso según las circunstancias con que se hacen los rescates, no encuentro otro medio para arriesgar lo menos que sea posible la administración, com. mo ascender a este empleo los Ensayadores más hábiles, acreditados y expertos del Virreinato; en defecto de estos los Fundidores, y por el de ambos, algún Azoguero antiguo y de conocida experiencia de la avalua- 
ción de las platas; porque sólo éstos habráll de posecr los conocimientos y experiencia que pide una ocupación de esta clase.

Los Superintendentes deben tener muy a la vista esta advertencia, para que se modifique la Ordenanza del Banco en esta parte; pues, aunque al tiempo de su formación fue muy justo prevenirse el ascenso de los Ministros, por sus grados, atendiendo a que servía entonces la Contaduría un sujeto de los más bien dotados de todas las calidades de un buen Administrador, es muy dif́igil encontrarse después y siempre otro de sus mismas medidas.

1.- Ordenanza 26, Tít. 6 del Banco.

2.- Ordenanza 7 y 8 , Tít. 7 del Banco.

(a) En el año de 1742 se estableció la Compañía de Azogueros para el rescate de pastas, y tuvo de quiebra 170.000 pesos; en 1752 se estableció el Banco por cuenta de los azogucros y tuvieron de quiebra 300.000 pesos. (Nota del Ms. del A. G. I.).

3.- El Reglamento consta de 14 T'́tulos, muy reflexivos y próbidos.

4.-- Ordenanza 1", Tít. 2 del Real Banco.

5.-Ordenanza 2, Tít. 2, del Real Banco.

6.--Ordenanza 3, Tít. 2, citado.

7.- Ordenanza 6, Tít. 2, citado.

8.- Ordenanza 4, Tít, 2 , referido.

9.- Ordenanza 13, del Tít. 2.

10.- Ordenanza 19, del Tit. 2, del Banco.

(b) El modo de instruír las cuentas y llevar los Libros, se expresa yor menor en todo el Título 9 del Reglamento del Banco.

11. - Ordenanza 5, Tít. 12.

12.- Ordenanza 2, Tit. 10. Orderanza 7, Tit. 11. Ordenarza 3, Tít. 13.

13.-. Ordenanza 2, Tít. 11 y 13 del Banco.

14.- La dotación de los empleos, consta de la Ordenanza 9, Tít. 11. Ordenanza 8, Tít. 12. Ordenanza 6, Tít. 13. Ordenanza 1, Tít. 10, del Banco.

(c) Al Superintendente actual Dn. Francisco de Paula Sanz, no se le paga esle sobresueldo y sólo goza el salaxio de 9.000 pesos que tenía en Buenos Aires como Intendente General.

15.- Ordenanza 1, Tit. 6.

16.-Ordenanza 23 , Tít. 6. Ordenanza 7, Tít. 8.

17.- Ordenanza 24, Tít. 6. Ordenanza 8, Tít. 8 del Banco.

18.- Ordenanza 5 , del Tit. 5 .

19. - Ordenanza 8 del Tít. 3.

20. - Ordenanza 20, Tít. 6. El plazo conveniente para fomentar a estos mineros, no debe bajar de un año.

21. - Ordenanzas $2^{4}, 3^{\natural}$, y $5^{\ominus}$, del Tít. $6^{\circ}$.

22. - Ordenanzas $2^{4}, 3^{4}$ y $5^{4}$, del Tít. $6^{4}$ citado.

23.- Ordenanza $1^{*}$, Tít. 9. Ordenanza $3^{*}$, Tít. 3. Ordenanza $1^{*}$, Tít. 5*, Lib. $3^{\circ}$ del l'erú.

24.-. Ordenanza $6^{\circ}$, Tít. 8 del Banco.

25.-. Ley 15, Tít. 8, Libro $8^{\circ}$ de Inds. "Ibid", cuyo beneficio consiste en el tiempo que es parte de precio.

26.- Ordenanza 9, Tít. 8.

27.- Ordenanzas $3^{*}$ y $4^{4}$, Tít. 8.

28.- El Sr. Virrey Conde de Chinchon, en Despacho de 30 de abril de 1629 , impuso a todas las personas que comprasen azogue, la obligación de quintar la plata, con arreglo al Cap. 87 de las Ordenanzas por el Sr. Dn. Francisco de Toledo a los Oficiales Reales.

29.- Véase la Ordenanza $3^{*}$ y siguientes hasta la 12 del Tít. $5^{\circ}$ del Reglamento del Banco.

(d) El Sr. D. Bartolomé González de Poveda, Presidente de Charcas, con arreglo a una Real Cédula de 26 de febrero de 1684 , mandó que en las Castus de Moneda de Lima y Potosi, se labrara toda la plata que en ellas hubiere aplicando a cada una el mineral que le tocare y según los parajes en que estuvieren; en cuya conformidad no parece violenta la orden del Sr. Virrey Cevallos; antes 
bich conveniente para aumentar la labor y beneficio de la moneda.

30.- Véase el Tít. 17, Lib. $3^{*}$ de las Ordenanzas Generales del Perú y el Tít. 22, Lib. 4 "de las Leyes de Indias.

(e) Sesún las Leyes y práctica establecida, dice Ustaris, en su Teórica y Práctica del Comercio, Cap. 104, fol. 376, pérrafo útimo, que se puede apremiar a los particulares a que lieven a Jabrar en las Casas de Moneda todas las platas en pasta, conto piñas, barras, etc.

(f) El Art. 194 de la Oxdenanza de Intendencias, previene que en las Tesorerias principales, foráneas y menores de las provincias que tuvierar minas en co-

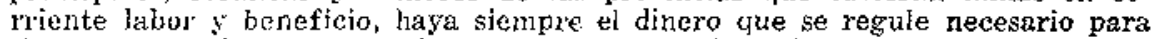
e] rescate $y$ efectivo pago del oro y plata que los mineros llevaren a vender. Aquí no sejala el fondo para estos suplementos: pero como habla del Banco, como incorporado a la Corona, es claro que siendo para la Real Hacienda las utilidades, scan tambiẹn de su cuenta estas habilitaciones.

31.- Ustaris: ell su Teórica y Práctica del Comercio, Cap. 104, fol. 376.

32.- Vide el Art. $1^{\circ}$ de dicha Ordenanza.

33.- Ordenanza 2, T'ít. 11 .

34 - Ordenanza 3 , Tit. 10.

35 - - Ordenanza 4:, Tít. 10.

36.- Ordenanza 9, Tít. 10.

37.- Ordenariza 10, Tit. 10.

38.- Ordenanza 7, Tit. 10.

39.- Artículos: 5,74 y 84 de la Ordenana de Intendentes.

40.- Ordenanza 7, Tit. 10 del Reglamento.- Art. 84 de Ia Ordenanza de Intendentes.

41.- Ordenanza $6^{\circ}$, Tít. 10 .

(g) Ahora se debe participar al Sr. Virrey como Superintendente de Real Hacienda por haber variado el sistema en que habla la Ordenanza del Banco.

42. - Ordenanza 6 eitada del Tít. 10.

43.- Ordenanza 7 y 8 , Tít. 1\%. Ordenanza 6, Tít. 10 al fin.

44.- Ordenanza 9, Tit. 1".

45.- Ordenanza 22. Párrafo 6 de la Casa de Moneda.

46.- Ordenanza $\tau^{n}$, Tít. $1^{\circ}$ del Banco; y Ordenanza 40 de la de Moneda.

47.- Ley 51, Tít. 2, Lib. 30.

48. - Leyes $1^{*}$ y $3^{n}$, Tít. 2.

49. - Ordenanza $22, \$ 22^{\circ}$ de la Casa de Moneda.

50. - Así lo dispone expresamente la Ordenanza $2^{*}$, Tít. $2^{\circ}$ del Reglamento del Banco. 


\title{
CAPITULO OCTAVO
}

\section{De la Real Casa de Moneda de Potosí}

Se refiere el tiempo y motivos de su Fundación, el método antiguo y moderno de su labor; las quiebras que antes sufrió, y lo demás tocante a sus oficinas.

C

UMO en las Américas se hacía todo el comercio por cambio y permutación de unas cosas con otras, se adoptó por una convención universal en el Perú, el hacer uso de la coca para los tratos y contratos como otras naciones de la moneda; ' en Nueva España, del cacao; ${ }^{2}$ en Verapaz, de las plumas ricas; ${ }^{3}$ y en otras partes, de unas planchuelas delgadas, de tres o cuatro dedos más o menos, de cobre, plata y oro. ${ }^{4}$ Después de la conquista se introdujo contratar con barras de plata, tejuelos de oro y también en polvo.

\author{
NOTIGIA PRIMERA
}

De los metales considerados co- WSTOS metales en pastas sólo eran conmo mercalieria. siderados como mercaderías que entraban en las permutas entre las demás cosas. Su valor era puramente respectivo y subía o bajaba según la opinión del pueblo. Cuando estaban en bruto o tales como la naturaleza los ofrece, tenían

- un valor; después de afinados o purificados otro; y por fin adquirían el último cuando el trabajo y el arte los había reducido a vasos y uten- 
silios de todas especies y crecía este último valor a proporción del gusto del comprador, de la bella idea de la obra, y de la más o menos concurrencia de los operarios; de suerte que los metales considerados como materia prima, tenían un valor, y contemplados como materia trabajada otro; porque en el primer caso se estimiba el metal sólo, y en el segundo, el metal y el trabajo.

Este valor reconocido en los metales, obligó a partirlos en pedazos, para dar en cambio de lo que se compraba, y según este uso llegaron a ser la medida común de toctos los valores, pero sin determinarsc más que a ojo por el bulto y a mano por el peso. Esta regla poco segura ocasionó perjuicios y quejas y muy grandes fraudes, principalmente con los indios, que no sabiendo distinguir a ticnto el peso y pureza de los metales, eran más fáciles de engariarse, porque sólo atendían a trocar uno por otro. Aun en el caso de convenirse el comprador y el verdedor a pesar el oro o la plata, como se usa en la China, para prevenir engaños, era demasiado embarazoso recurriy continuamente a las medidas y muy difícil asegurarse del grado de pureza de los metales, cuyo grado muda su valor.

NOTICIA S E G U N D A

$\begin{array}{ll}\text { De los metales contemplados } & \text { WNTONCES acudió la autoridad pública } \\ \text { como moneda. } & \text { al socorro del comercio, haciendo ensayar el } \\ \text { minando lo que se llama sil título, esto es, su grado de pureza. Después } & \text { oro y la plata que tenían corriente }\end{array}$ los dividió en diferentes frdectones, con un cierto peso cada una, e imprimió sobre ellas una señal que atestiguase el título y el peso. Esta es, pues, la moneda, cuyo valor se conoce con sólo mirarla, y la que evita los fraudes, manteniendo más confianza en el comercio, y de consiguiente también le facilita.

En América era todavía más urgente esta providencia, porque a más de ser preciso evitar las dificultades del bałancín, perjuicios, fraudes y quejas, convenía detener los grandes inconvenientes y alborotos que podian temerse y más de una vez resultaron de la tardanza de los situados para pagar la gente de guerra, salatios y demás mantenimientos que se socoren y cubren con dinero.

Por estos justos motivos, mandó batir la primera moneda en Nueva España, Don Antonio de Mendoza, primer Virrey de aquel reino, ${ }^{5}$ y segundo del Perú, haciéndola dividir en reales de a cuatro, de a tres, de a dos, sencillos y medios y por úitimo hasta cuartillos de plata, (a) después que los indios, mal contentos con la moneda de cobre que comenzó a correr en Nueva España, y particularmente en la Isla de Santo Domingo, arrojaron a la Laguna los cuartos que recibían, en más de doscientos mils pesos de valor. ${ }^{6} \mathrm{La}$ escasez de dinero y la consideración de los males que produce en la sociedad, obligó también al Rey Jorge de Inglaterra, a mandar que se hiciese moneda de cobre en Boston, ciudad de Nueva Inglaterra. 7 


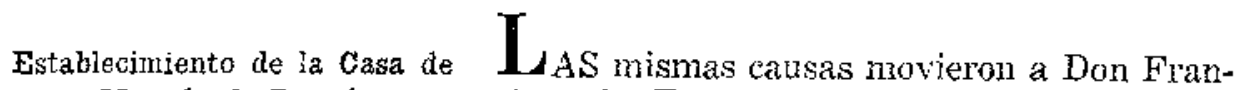
Moneda de Potosí. cisco de Toledo, mandar construir en la Villa Imperial de Potosi, una Casa de Moneda donde pudiera labiarse la inmensa cantidad de plata que se extraía de este riquisimo Cerro, para el giro de las contrataciones $y$ negocios del Rivino, y para el pago de jornales y mantenimientos.

Fue nombrado obrero de su fábrica Jerónimo Leto, vecino de Potosí, a quien, por una Provisión dada en Arequipa, a 27 de septiembre de $157 \overline{5}$, consta habérsele mandado pagar 8.231 pesos un tomin 13 granos de plata corriente, como costo total del edificio que se comenzó a construír el año de 1572 , cuando el citado Sx. Virrey vino a practicar su visita general cn esta Villa.

Aunque estas noticias se consideren poco conducentes para ilustrar la forma y origen del establecimiento de la Casa de Moneda de esta Villa, importa siempre extender su historia a todas las antigiedades, como decía Séneca, 8 para que nada se ignore de lo acaecido en los primeros siglos de nuestra población." Así pues, voy a referir todo lo que acerca de este punto he podido encontrar en medio de la confusión de los archivos, para que todos sepan lo que ahora todos ignoran, sin más conocimiento que el que les ministra una tradición imperita.

\section{NOTICI A C UAR TA}

Historia circunstanciada del origen de la Casa de Moneda de Potosí; de su costo y de la fábrica de las cuatro hornazas antiguas.
$\mathbf{E}$ se establecieron tres hornazas para la fundición de metales y corte de las monedas, con destino do las mismas operaciones que hoy se practican en la oficina de Fielatura. A cada una se le asignó cuatro esclayos con las

herramientas necesarias, al cargo de un capatáz que corriere con el manejo de ellas como Jefe, concediéndoles el ventajoso arbitrio de poder pagar el valor de estas oficinas, con la mitad o el tercio del derecho de braceaje que fuesen devengando, hasta hacersc dueños en propiedad de las hornazas, luego que las acabasen de pagar. Se reconocí que las tres solas no podían cortar toda la moneda necesaria para el giro del Reino, y entonces mandó el Sr. Toledo, en Provisión dada en Arequipa, a 30 de agosto de 1575, que se trabajase otra, con el mismo señalamiento de herramientas y esclavos, a costa de la Real Hacienda, no obstante que había dado ya cuenta al Rey, de haber costado Ia Casa con sus tres hornazas, once mil pesos consignados on el Cuzco, sobre lo concertado con los herederos de Tomás Vásquez. 
Cantiriades de labor en Ia Casa de Moneda, de cuenta del Rey $\mathrm{y}$ de los partidarios, en la proporción de diez mil marcos.

A TENDLENDO al beneficio miversal del comercio, tenía prevenido a los Oficiales Reales de Potosí, en otro anterior despacho, de 26 de junio de 1574 , era orden de S. M. que de su cuenta se labrasen diez mil marcos; y que, en el caso de no meter los particulares plata suficiente, pasen a la Casa seis mil marcos en ricles, para que se beneficien de cuenta y costo de la Real Hacienda, a fin de que no parasen las labores ni liegase a escasear la moneda. $Y$ porque estas providencias no bastaron para el crecimiento de la labor de la moneda, dispuso en dos Provisiones dadas en Potosí, a 9 de encro y 23 de febrero de 1575 , que de todas las barras ensayadas y fundidas en las Cajas Reales, después de pagado el quinto $\mathrm{y}$ demás derechos, se rescrvase a los dıeños la cuarta parte, con orden a los Oficiales Reales de pasarla al Tesoro de la Casa de Moneda, para reducirla en reales, y en esta forma devolver su portonencia a cada interesado, en consideración de que por su escasoz no quelabau bien pagados Ios indios de la Mita y otros sirviontes do la Casa.

\section{$\$$ II.}

Se remata la amonedación de la plata, en 27 de abril de 1575 años, para facilitar la circulación en Potosí.

$\mathrm{S}$ DIN embargo de estas prudentes prevenciones, no siendo todavía bastante la moneda que se labraba, para extender su giro a todo el Reino y pagar los jornales y precios de los negocios y contrataciones; después que se mandó consumir la plata meruda que corría en el Reino, por su poca ley, so remató por Asiento público el rescate de platas, en Juan del Castillo, a 27 de abril de 1575, aprobado por el Si. Virrey Toledo, en su decreto dado en La Paz, a 27 de mayo del mismo año, obligándose a meter en la Casa de Moneda, on cada uno de los tres años dol remate, sesenta mil marcos de plata ensayada y marcada, de la ley de 11 dineros y 4 granos, para que de cllos se hicieran reales, en cada cuatro meses los veinte mil marcos; para cuyo efecto le cedieron dos hornazas, reservardo la tercera para el común; de suerte que ajustada la cuenta de 67 reales por cada marco, correspondía al año la rendición total de 502.500 pesos, que juntos con la labor de la tercera hornaza reservada para el común, que cuando más cortaría una cuarta o quinta parte del remate de Juan del Castilio, subiría el todo a 600 pesos, poco o más o menos, de lo perteneciente a particulares.

De cuenta del Rey se labraban 500.000 pesos, y por no alcanzar esta cantidad para la gente de mar y guerra, situado de Chile y Mita de Huancavelica, mandó el Sr. Marqués de Guadalcázar, en Provisión de 14 
de febrero de 1629, que los Oficiales Reales mandasen sellar, a más de los referidos 500.000 pesos, otros tantos, de suerte que llegase a un millón de a 8 reales, remitiendo a Castilla las barras sobrantes, para evitar las pérdidas que se seguian de venderlas aquí a precios moderados.

\section{NOTICIA SEX TA}

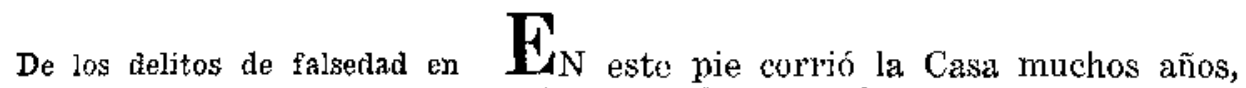
la fábrica de moneda, en esta bajo las Ordenanzas formadas para su buen Casa de Potosí. manejo y dirección, por el Sr. Toledo, el año de 1575, que existen manuscritas en la Contaduría; pero como su gobierno estaba a cargo del Presidente de Charcas, en calidad de Superintendente, y las visitas ordinarias de las oficinas se hacian por dos Diputados del Cabildo, no fue difícil a los Mercaderes de platas, por la mucha mano que tenian en estos negocios, el corromper a los Ensayadores y demás Oficiales de la Casa, para alterar la ley de la moneda, en perjuicio de la confianza pública; de suerte que este exceso, entre otros muchos que se hacían en la Villa, obligó que se promoviese mudar esta Casa a otro palaje del Reino.

\section{NOTI I A S E P T I M A}

Reos convictos de falsedad, y $\mathbf{P}$ ARA la averiguación, castigo y remedio la pena que se les impuso. de estos daños, fue nombrado por Visitador y Presidente de Charcas, Don Francisco Nestares Marín, el año de 1649, comenzó luego a practicar su comisión; y habiendo resultado culpados muchos oficiales que gobernaban cargos y rentas en la Casa de Moneda, y entre ellos, convencidos reos principales de falsedad de clla, Francisco Gómez de la Rocha, Mercader de plata, y Felipe Ramíxez de Arellano, Ensayador de la Casa, los condenó a pcna capital y perdimiento de bienes, multando a los demás en cantidades tan erecidas, que llegaron las multas hasta doscientos mil pesos; y lo que más asombra es que hubo acuñador que salió condenado en veinte mil. Prueba esa, incontestable, de las inmensas riquezas de esta Villa y de los muchos millares que habían robado en la Casa, falseando la ley de la moneda con la excesiva liga de cobre.

$$
\text { NOT I C I A O C T A V A }
$$

$\begin{array}{cl}\text { Propuesta para la trasiación } & \text { WL Rey aprobó esta sentencia, en Real Cé- } \\ \text { de esta casa de Moneda de } & \begin{array}{l}\text { dula de Madrid, a } 17 \text { de abril de 1651, y man- } \\ \text { dó pedir informes al Virrey y Audiencias de }\end{array} \\ \text { Potosí. } & \text { Lima y Charcas, sobre la traslación de esta }\end{array}$ Casa a otra parte, ordenando que on este negocio sc acordase también 
con el Presidente Nestares; y de este modo quedó suspensa la resolución hasta el año de 1684, como lo vercmos después.

\section{NOTIOIA NOVENA}

Falta de ley en la moneda, y $\mathbf{H}$ Nhet otras cosas, se previno también al los medios de abouarla en su entera pureza.

Presidente, que se pusiese de acuerdo con ol Virrey, el Sr. Conde de Salvatierra, para que en la Casa de Moneda de Potosí, se labrase la necesaria, de toda bondad, peso y ley, purgándola de los cinco y hasta seis granos no cumplidos más de liga, con que había corrido hasta entonces, para que así se ajustase a la ley precisa de las Casas de Castilla. En efecto, produjo su informe circunstanciado, on un Auto que proveyó en 4 de febrero de 1652 , reduciendo a tres calisas principales la alteración de la ley de la moneda. I a primera, quintarse en Potosí, 3 reales de cada marco labrado, para los derechos cle señoreaje y braccaje, dejando al interesado 64 reafes solamente, cuturlo en Castilla se les descontaba únicamente un real, percibiendo 66 reales el dueño de la plata. La segunda, que corriendo las piñas al interés de un $5 \%$, era preciso restaurarlo en la labor de Ia moneda. La tercera, porque los Mercaderes de Platas, por cuyas manos corría el negocio, trataban siempre de hacer su granjería en los aumentos de la liga.

En consecuencia, propuso sacar la restauración de estos mismos principios, sin perjuicio de los avíos de la Villa, Cerro, Kibera y minerales, indios y comercio de la Provincia, Real Hacienda $y$ terceros, arbitrando que de los 5 reales de señoreaje y braceaje, y de los derechos pertenecientes a los Oficiales de la Casa de Moneda, se quitase cierta cantidad de granos, para abonar la ley que le faltaba hasta los $49 \mathrm{y} 1 / 2$ mavavedíes que importaban los seis granos de la liga, conforme a la distribución de la planilla siguiente:

\section{Granos, a 8 maravedies $y$ 1/1 cada grano, son: 49 y $1 / 2$ maravedíes}

\begin{tabular}{|c|c|c|}
\hline En las piñas & $17 .-$ & maravedies \\
\hline En el real de señoreaje $\ldots \ldots \ldots \ldots$ & 8.25 & centavos \\
\hline En derechos del Tesorero . . . . . . . . . . & 8.74 & $"$ \\
\hline En derechos del Ensayador $\ldots \ldots \ldots \ldots$ & 8.25 & " \\
\hline 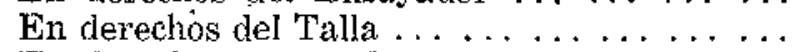 & 1.44 & $"$ \\
\hline En derechos de los dos Guardas ......... & 0.88 & $"$ \\
\hline En derechos del Escribano ............ & 0.44 & $"$ \\
\hline En derechos del Balanzario $\ldots \ldots \ldots \ldots$ & 0.50 & $"$ \\
\hline En derechos de braceaje de los Capataces ... & 3.00 & $"$ \\
\hline En el braceaje de los acuñadores ... ..... & 1.00 & $"$ \\
\hline
\end{tabular}

Total: 49 maravedies 50 centavos.

En el interin venía la resolución del Superior Gobiexno, mandó en Auto de 6 de julio de 1652, que se labrase la moneda de toda ley y peso de 11 dineros y 4 granos, con la nueva forma de dos columnas, con arre- 
glo a la citada Real Cédula de 7 de abril de 1651; en cuya conformidad se labraron las primeras partidas con estas calidades, en el mismo año de 1652, supliéndose para el ajuste y entero de la ley, los 6 granos de la sisa de la Villa; y continuando la labor, se acuñaron 16 partidas más, desde 4 de abril hasta 3 de julio, supliendo los 4 granos en el señoleaje y derechos de Oficiales, y los dos granos restantes, de las condenaciones de visita.

Con fecha 30 de julio de 1652, libró su Provisión el Sr. Conde de Salvatierra, y por lo dispuesto en ella ordenó el Presidente Nestares, en Auto de 28 de agosto siguiente, que para el ajustamiento de la ley de la moneda, se supliesen los 6 gianos referidos, de la imposición del deretho de cobos y de la que cstaba situada sobre carla barra (que eran 12 reales), palta salarios do los Alcaldes Vecdores; prohibiendo a los Oficiales Reales la cobranza de ambas inmosiciones, para que con el valor de ellas, que importaban $\$ 1$ maravedies y 91 centaros on cada marco, pudiesen los dueños de las barras suplir la ley de la moneda.

Además, cargó sobre los derechos del Tesorero, 7 mavavedíes en cada marco:

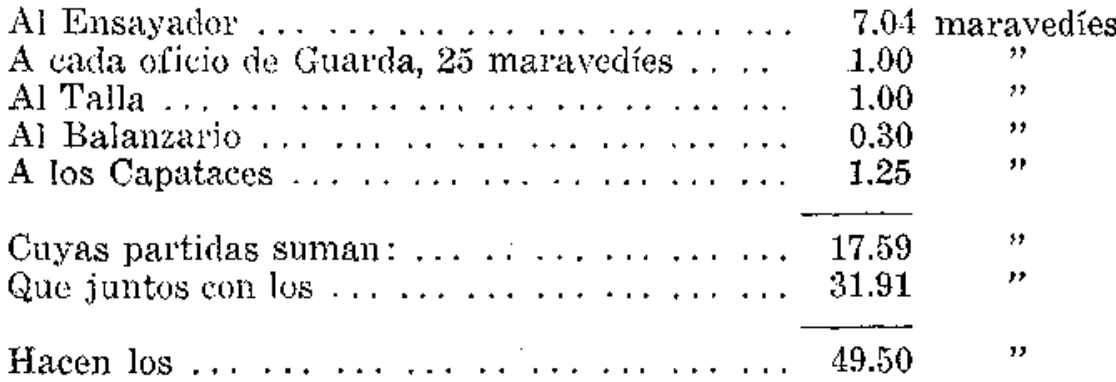

que faltaban para enterar la justa ley de la moneda.

Y por conformarse más ajustadamente con la Real Cédula de 17 de abril de 1651, en que S. M. resolvió no se labrasen el Potosí los cinco millones que propuso Nestal's, sino limitadamente la cantidad precisa y necesaria para el comercio del Reino, enviándose a España toda la demás plata en barras, $y$ no en moneda; ordenó dicho Presidente, en el citado Auto de 4 de febrero de 1652, que la labor no pase de 40.000 pesos cada semana, en dos partidas de a 20.000 cada una, bajo pena de la vida y perdimiento de bienes; cuyas cantidades, al respecto de cincuenta y dos sumanas, componian 248.358 marcos, que a razón de 67 reales cada uno, debían valer 2.080 .000 .02 pesos 3 reales. Luego después, extendió la labor a 50.000 pesos semanales, que vendrian a montar al año 2.700 barras, según al peso en que debian fundirse en aquellos tiempos.

Sobre las otras 1.300 barras que se computaba quedaría de las cuatro mil que solín quintarse en cada año, mandó cargar la imposición de los doce reales para salulio de los Veedores, agregándoles cuatro indios de mita, que antes se les había quitado, para completar sus respectivas dotacionesc con el valor y fruto de lo que trabajasen estos mitarios.

La tasa mencionada que se puso a la labor de la Moneda por el Presidente Nestares, la alzó êl mismo, en Auto de 6 de julio de 1652, respecto de haber permitido el Sr. Virrey Conde de Salvatierra, que se la- 
brara cuanta moneda se pudiese; cuya Providencia se confirmó con la Orden de S. M., del año de 1682, para que se labrase toda la plata del Rey y particulares, sin pasar pasta a España, con el fin de evitar su extracción fuera del Reino sin pagar los quintos y demás Reales Derechos.

\section{NOT I C I A D E C I M A}

Fundación de Casa de Moneda en las ciudades de Lima y del Cuzco; la primera para labor de plata, y la segunda para oro,

$\mathbf{P}$

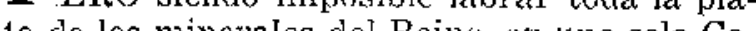
ta de los minerales del Reino, en una sola $\mathrm{Ca}$ sa de Moneda, y de consiguiente haber de perjudicarse cl giro del comercio, en la que quedaba sin cuño, se despachó Cédula de $\mathrm{Ma}$ drid, a 26 de Febrero de 1684, para el Presidente de Charcas, Don Bartolomé González de Poveda, refiriendo lo que se había prevenido en otro Despacho de 6 de enero de 1683, al Sr. Virrey Duque de la Palata, sobre In erección de Casa de Moneda, para la labor de la plata, en la ciudad de lima, y otia para ta dedolo, en la del Cuzco; y concluye ordenando que hubiese desde Ilogo en Iima Casa de Moneda, conservando la de Potosí, y que se aplicase a cada una el mineral que le tocare, según los parajes en que estuvieren.

En efecto, se verificó la fundación de la Casa de Lima, y se confirmó para sicmpre el establecimiento de la de Potosí, con la ordeu de su conservación, denegándose justamente las instancias que se habian promovido para trasladarla a otra parte, como lo dejamos dicho. Tambión se fundó en el Cuzco, la que se destinó para la labor del oro en el Real Despacho de 1683 , según se convence por varias monedas de oro que han corrido de aquel cuño, asegurándome Dn. Francisco Cevallos, Contador actual de esta Casa de Potosí, que tuvo en su poder como seis de ellas, habidas del difunto Conde de Casa Real de Moneda. Puro ya no subsiste en el Cuzco semejante Casa ni aun se conserva, entre los más, memoria de que la hubo.

\section{NOTIOIA DECIMAPRIMERA}

Privación de las hornazas, de $\mathbf{P}$. OR apéndice de la Visita del Presidente resultas de la Visita deI Sr. Nestares debe notarse, que de resulta de vaNestares. rios cargos, se les quitó las hornazas a los Capataces o ducños de ellas y se remataron en varias personas, de cuenta de $\mathrm{S}$. M., en 24.000 pesos cada una, asignándoles por razón de emolumentos, 26 maravedies por marco de los que rendían. Después se les rebajó de esta asignación 2 maravedies en marco, y por esta causa se devolvió a los interesados 7.500 pesos, quedando reducido el principal de cada hornaza a 16.500 pesos, los cuales arregló el Visitador Nestares a un $15 \%$ : el cinco, por réditos del citado principal, y el diez, por la responsabilidad y trabajo de los hornaceros, a cuyo res- 
pecto vino a quedar la asignación de cmolumentos, en 24 maravedíes en marco, por ser los mismos que Ics correspondía al cómputo de un $\mathbf{1 5} \%$, según la cuenta que se tiró de los marcos que habían rendido en los dos años anterior'es; pero siendo falible esta cuenta, por la variedad de los años subsiguientes, se añadió a los 24 maravedies, 75 centavos más, por vía de recompensa, los mismos que ganaron en cada marco que rendian deste aquél tiempo hasta 16 de agosto de $17 \overline{2} 8$. De cuya sucesiva innovación hablaremos cuando se tratare de los acaccimientos posteriores de este siglo.

\section{NOTIOIA D UODECI MA}

Reintegración del Real Dere-
cho de cobos. tal Casa de Moneda, colrieron algunos años, hasta el de 1684, en que siendo Presidente de Charcas, cl Licenciado Don Bartolomé González de Poveda, mandó por Auto de 19 de mayo, que se reintegrará el derecho de cobos, a razón de $1 \%$, cuya cobranza se había suspendido desde el año de 1652, por orden de Nestares, para suplir con su importe el abono que faltaba en la moneda para su entera ley. Como el $1 \%$ de cobos importaba 23 maravedíes, 60 centavos, y los 21 maravedíes concedidos por el gremio de Azoguelos y Mercaderes de Platas, no alcanzaban al entero de esta cantidad, cedieron los Oficiales de la Moneda 2 maravedíes y 60 centavos de sus derechos, para cumplimiento de los 23 maravedíes, 60 centavos del $1 \%$ de cobos, repartiendose entre los dichos Oficiales, sueldo por libra, la referida rebaja.

Posteriormente ordenó el Sr. Virey Duque de la Palata, por Auto acordado en Junta de Hacienda, a 6 de julio de 1684, que se reintegrase el quinto del derecho de cobos, que hasta entonces sólo se había pagado a razón del $1 \%$, cargando los cuatro maravedíes setenta y dos centavos de su importe, en el real de señoreaje. En su conformidad, proveyó Auto en 5 de agosto del mismo año el Presidente Poveda, para que los Oficiales Reales cobrasen, desde luego, de todas las barras que se llevasen a quintar para fundir en la Casa de Moneda, el derecho de cobos por entero, como lo habían hecho del $1 \%$, desde el día 20 de mayo; y en atención a lo mandado de que los 4 maravedies, 72 centavos que importa el quinto del derecho de cobos, se supliese del procedido del señoreaje, ordenó que sacando el Tesorero de la Moneda dicho suplemento, enterase en la Caja Real, por razón de señorcaje, los 29 maravedíes, 28 centavos restantes, de los 34 que importa el real de señoreaje.

Agregando a estos 4 maravedíes, 72 centavos, los 17 maravedíes que el Gremio de Azogueros concedió de baja en el precio de sus piñas el año de $1653 ; 4$ los mercaderes de piata; 2 y 60 centavos que los Oficiales de la Casa of recicion cobrar de menos en sus derechos; 3 y 40 centavos remitidos por S. M., hacen 31 maravedíes y 72 centavos, con los que quedó corrichte la cobranza del derecho de cobos por entero, y satisfecho el costo de la labor de la Casa. 
Establecidas ya con estas Providencias todas las cosas de la Casa de Moneda, se continuó labrando toda la de su giro con la ley justa de 11 dineros, 4 granos, conforme a las Leyes y Ordenanzas del Reino. ${ }^{16}$ Ultimamente, para igaalar la moneda de España $y$ de estos Reinos, con la que corría y corrc entre las naciones extranjeras, se mando, por la Ordenanza de 9 de junio de 1728 (que tatat de la ley, peso y estampa de la moneda), que se labrase de 11 dineros justos.

Este nuevo Reglamento, compuesto de 39 Capítulos, se remitió acompañado de una Real Orden, de 30 del mismo meś, ordenćndose a más de lo expresado acerca de la ley, que se sacase de cada marco de plata amonedada, 68 reales eri lugar de los 67 que antes prodicía, ${ }^{11}$ guardándose el real de aumento a disposición del Rey; que en las monedas se pusiera con claridad el año en que se hubiere labrado, el nombre de la Casa y el de los Ensayadores; que éstos pusiesen en las barras la ley que hallaren, señalándola por dineros y granos y no por maravedies como antes, y que las volvieran a ensayar, respondicndo por las fallas los de las Cajas.

\section{NOTIOIA DECI M T E EOERA}

Primeras rendiciones con la $A$ consecuencia de estas ómdenes, se labró reducción de la ley a 11 dine- y rindió la primera partida en esta Real Caros justos. sa, a 8 de octubre de 1729 ; pero como el importe de los 4 granos de menos ley en que se había labrado la moneda, fueron guardando en Caja separada, hicieron instancia los Mercaderes de Plata, para que se les aplicase este producto. El Virrey les mandó acudiesen a S. M. y entre tanto, que se depositara el aumento tomándose razón de las labores y fundiciones que fuesen haciendo cle su cuenta.

\section{NOTI I I D E C I M A C U A R T A}

Aplicación de los cuatro granos de baja en la ley, a favor de los dueños de los metales.

$\mathbf{E}_{\mathrm{L}}$ de Comercio y de Moneda. Allí se tuvo presente, lo $1 \%$ : que por el Capitulo 20 de la Ordenanza de 9 de junio, no se reservó S. $\mathrm{M}$. en las labozes de la Moneda más aprovechamiento que el delecho de señoreaje en un real, el cle braceaje para los Ministros, ei real de aumento en peso, y el feble para la fábrica de la Casa de Moneda; declarando era el ánimo del Rey, estimular con la utilidad a los particulares, para que llevasen más platas; lo $2^{\circ}$, que siendo el intrínseco valor del marco, de 11 dineros 64 reales de plata, perdería el Mercader un real, 6 maravedíes y 4 quintos en cada marco, fuera de las costas de ligas, jornales de afinación, primera fundición, portes y acarreos, si no se le aplicase el importe de los 4 granos. Véase aquí demostáado: 
De los 68 reales que debe rendir cada marco, se le descontaba al Mercader': el real de aumento en peso, el de señoreaje, dos de braceaje, 6 maravedíes y $4 / 5$ de ensayes, y otro real más de plata que producen los cuatro granos de baja en la ley; quedandole solamente 62 reales 27 maravedies y $1 / 5$ de la plata, con pérdida de 1 real, 6 maravedíes y $4 / 5$ en cada marco.

Lo tercero, que hallándose dispuesto en el Cap. $7^{\circ}$ de las Ordenanzas de 16 de julio de 1730, que todas las labores de Moneda se hagan de euenta dol Rey, y se paguen las platas de 11 dineros a 80 reales Provinciales, que antes ara el precio cle las de 11 dineros, 4 granos; y a proporción se arregle el precio, segín la subida o bajal de ley; es consiguiente, siendo uno mismo el valor de los 11 dineros, 4 gimos antes, con el de 11 dineros justos ahora, que el exceso de los cuatro granos sea a bencficio del Mercader labrante, en acriel mayor valor que tomaron las platas por la reducción de su ley, en esjecial considerándose que al Mercader, como dueño del metal, le toca todo el valor de él, y como a labrante de su cuenta, todo el de la moneda, sin más cargo que pagar los derechos establecidos, reducida que sea la moneda a su verdadero peso y ley. Lo $4^{\circ}$, que así como reglada en lo antiguo la moneda a los 11. dineros, 4 granos, todo el exceso hasta 12 dineros, que es la ley superior de la plata, era del dueño; del mismo modo, bajada ahora a la ley de 11 dineros justos, deben quedar a su beneficio los 4 granos de baja; porque siendo dueño del metal el que lo labra de su cuenta, lo es también de cuanto produce la labor; sobre cuyos fundamentos se tiró la última vesolución en Real Cédula de El Pardo, a 26 de febrero de 1735, ordenando que se les restituyese y reintegrase a todos los Mercaderes de plata el importe de los cuatro granos que se les había retenido; y así lo mandó cumplir el Sr. Virrey Marqués de Castelfuerte, en Despacho de 28 de junio de 1738.

\section{NOTICIA DECIMAQUINTA}

Nueva Ordenanza para labrar DESPUES de algunos años, pareció convemoneda de cordoncillo. niente alterar el antiguo régimen y gobierno de esta Casa de Moneda, reuniendo en el Corregidor de la Villa la Superintendencia de ella, para que mirándola más de cerca, con autoridad en su manejo, pudiese remediar cualquier exceso y mantener en buen orden todas suis oficinas. A este fin fue nombrado Corregidor y Superintendente, Don Ventura Santelices y Venero, Oidor de la Contratación de Cádiz, con varias instrucciones y despachos, para que arreglándose a ellos y a la Ordenanza expedida para el gobierno de la Casa de Moneda de México, en lo que fuese adaptable, y se conformase con las instrucciones referidas, estableciese ésta de Potosí, en otro nuevo pie y mejor método que antes; cuyo tenor de la Real Cédula es el siguiente:

"EL REY: Por cuanto habiendo tenido por conveniente expedir "nueva Ordenanza para el mejor régimen y gobierno de la Casa de Mo"neda de México y pudiendo conducir que para el establecimiento de ésa "tengáis presente su contexto, he resuelto se acompañe a ésta el ejem- 
"plar adjunto impreso y firmado por Dn. Juan Antonio Valenciano, mi "Secretario, que lo es en mi Consejo de las Indias por lo correspondicn"te a la parte de Nueva España, a fin de que teniéndola presente y usan"do de ella, en todo se conforme $y$ adapte con la Instrucción, Cédulas $y$ "demás papeles que han formado por" la Secretaría de Estado y del Des"pacho universal de Indias, para el ar'reglo de ésa; lo pongádis en prác"tica, sin hacer, en los casos que se oponga o se varie substancialmente, "de ellos uso alguno, porque siempre deberéis estar" a lo que estuviere pre"venido y se contenga en los mencionados Despachos. Por tanto, os man"do que usando de la Instrucción, Papeles y demás Despachos que han "formado por la expiesada Secretaría de Fistado y del Despacho de In"dias que se os remiten en esta ocasión, y a que declaréis sin alteración "ni variedad, tengáis presente la referida Ordenanza y la pongáis en prác"tica en todo cuanto sea adaptable y pueda convinarse con ellas, ya por"que declare alguno o algunos de sus Capítulos, ya porque contenga o "adelante lo que no pudo prevenirse, o quedó sin explicarse en ellos, pucs "siempre que varie, diliculte o pueda impedir" su contexto, ha de quedar "sin la menor validación en la parte que se oponga o diferoncie, porque "así es mi voluntad. Dada en B. Retiro, a tres de octubre de mil setecien"tos y cincuenta".

Estas mismas Ordenanzas formadas de orden del Fiey, por Dn. Gabriel Fernández de Molinillo, Superintendente de la Casa de Moneda de México, estaban mandadas observar en aquel Reino por Real Cédula de $1^{\circ}$ de agosto de $1750 \mathrm{y}$ por otra de 12 de noviembre de $1751^{1:}$ se remitieron al Virrey de Lima, Conde de Superunda, para que haciéndolas obsexvar en lo que fuesen adaptables, avisase la novedad quo fuese preciso hacer en ellas, a fin de formar, en vista de todo, un Reglamento General para todas las Casas del Reino.

Para producir su informe con seguro conocimiento, el Virrey pidió el suyo al Superintendente de la Casa de Lima, y con lo que éste expuso en cuanto a las Ordenanzas puestas en práctica y lo que en alguna había parecido conveniente variar, se despachó Cédula del Buen Retiro, a 11 de noviembre de 1755 , para que se observasen con las calidades propuestas por el Virrey, variando según las circunstancias de la ciudad de Lima: la primera y la cuarenta su incidente; la $5^{4}, 6^{\text {n }}, 8^{n}, 10^{4}, 2^{\text {n }}$, $21^{a}, 25^{a}$ y $27^{\text {a }}$, sobre las cuales se hicieron las oportunas declaraciones por vía de adición a la margen del respectivo capítulo, de los 10 que componen el Reglamento, que en compendio viene a establecer lo siguiente.

\section{N O T I C I A D E G I M A S E X TA}

Número de empleos $\mathrm{y}$ sus dotaciones, con arreglo al Cap. 1" y 40 de la Ordenanza $y$ de un Auto acordado del Superior Gobierno. AL número de los Ministros, Oficiales y
operarios de la Casa, con Ios sueldos que
señala el Cap. 40, con variedad de la de Mé-
xico, el Sr. Virrey Dn. Manuel Amat hizo
otro señalamiento de sueldos y empleos pa-
ra esta Casa de Potosí, en Auto acordado de

2 de mayo de 1775 , variando las dotaciones de la Ordenanza, en algunos 
do los empleos de ella, como se ve de la planilla que va puesta a continuación; pero, labiendo representado al Superintendente, Conde de San Antonio, los oficiales perjudicados, como fueron el primero y tercero de la Contaduría, el Fiel, el Herrero y el Talla Mayor con sus dos oficiales, que no podían contimas' el ejercicio de sus empleos sin disfrutar el sueldo entero que antes habian percibido, fueron mantenidos en su antiguo goce, por Auto del Supcrintendente, de 27 de septicmbre de 1776, sobre que dio cuenta al Superior Gobierno. fos posteriores Superintendentes y Visitadores do la Casa, tampoco han ctuerido hacer novedad, atendiendo al mayor trabajo cue les resulta a estos empleados con la nueva labor del oro; cuyo punto, consultado por Dn. Jorge Escovedo al Visitador General Dn. Jose Antonio Areche, su antecesor, y a la Intendencia General de Buenos Aires, se aprobó el goce de dichos sueldos. Los demás aumentos que se notan en el peón libre, soldados de la puerta y guardas de noche, $y$ en las plazas creadas de nuevo, como el Teniente de Fiel, el Afinador y su ayudante, Beneficiador de ticrras, Proveedor, Maestro de Molinos y un oficial más de la Taila, proceden todos de varias Providencias de los Superintendentes de la Casa; debiendo prevenirse que los demás que se ocupan en la Real Casa y no van puestos en la planilia, son peones libies, jornaleros que sólo trabajan en ocasión de labor, unos más que otros, según sus destinos, y vendrá a ascender el total de sus jornales a 160 posos sobre poco más o menos.

$$
\text { P L A N I L L A D E S L E L D O S }
$$

\section{De los empleos de la Real Casa de Moneda de Potosí.}

Empleos

Superintendente .........

Contador ... ...........

Oficial $1^{\circ}$ de la Contaduría ...

Idem $z^{\prime} . \ldots \ldots \ldots \ldots$

Idem $3^{\circ}, \ldots \ldots \ldots \ldots$

Tesorero $\ldots \ldots \ldots \ldots \ldots$

Fara tres oficiales de la Tesorería $\ldots \ldots \ldots \ldots \ldots$

Ensayador $1^{\circ} \ldots \ldots \ldots \ldots$

Ensayador $2^{\prime} \ldots \ldots \ldots$

Balanzario ............

Teniente de Balanzario .....

Fiel ...............

Fundidor de cizallas .......

Teniente de Fundidor de ciza-

llas ... ............

Teniente de Guarda-cunos ....

Cuatro Guarda-ristas, a 400 ..

Tres Acunadores, a 500 .. ..

Ferrero $\ldots \ldots \ldots, \ldots, \ldots$

Cerrajero ... . . . . . . .

Fundidor ... . . . . . . .

Cuatro Guarda-vistas ... ....

Guarda-cuños ... . . ... ...

Talle Mayor ... ... . . . .

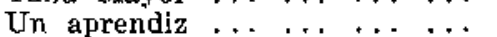

\section{Sueldos se- gún la Orde. nanza}

$\$$
$"$
$"$
$"$

$6.000 .-$
$4.200--$
$1.200 .-$
$500 .-$
$500 .-$
$5.000 .-$
$1.800 .-$
$3.000 .-$
$1.500 .-$
$1.400 .-$
$800 .-$
$2.000 .-$
$800 .-$
$400 .-$
$600 .--$
$1.600--$
$1.500 .-$
$0.000--$
$0.000 .-$
$3.000 .-$
$4.000--$
$1.400 .--$
$1.800 .-$
$91-$

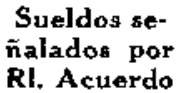

Sueldos al presente
$\$ 0.000$. $3.500 .-$ $500 .-$ $500 .-2$ 3.500. 1.000 . 1.800 $1.400 .-$ 0.000. 800 . $2.000 .-$ 700 .400 $600 .-$ 1.600. $1.300 .-2$ 800 $0.000 .-$ $1.733 .2 \quad 3 / 2$

" 3.200.

" $1.400 .-$

" $1.800 .-2$ 
A un Oficial de la Talla .......

A otro Oficial de dicha Talla ..

A otro Oficial mayor, puesto por el Sr: Tagle ... ... .

Dos Cortadores de moneda ...

l'ortero Marcador .........

Al Portero de la calle y Alguacíl Merino $\ldots, \ldots \ldots \ldots$

Al Escribano ...........

Asesor ... . . . . . . . .

Dos Guardas de noche .......

Cuatro soldados de la puerta ..

Un peón libre ...........

Afinador $1.000, y$ su Ayudante $300, \ldots \ldots \ldots \ldots$

Beneficiador de tierras ......

Ayudante del Fiel ... ... ...

Proveedor ... .........

Muestro de Molinos ... ... .

Totales:.......

\begin{tabular}{|c|c|}
\hline$\$$ & $\begin{array}{l}400 .- \\
000 .-\end{array}$ \\
\hline$"$ & 000. \\
\hline$"$ & $1.0000 .-\cdots$ \\
\hline$"$ & $35,1, \ldots$ \\
\hline , & 800. \\
\hline$"$ & $1.000 .-$ \\
\hline$"$ & 200.0 \\
\hline$"$ & $408 .-1 \% 1$, \\
\hline$"$ & $000,-$ \\
\hline ", & $144 .-$ \\
\hline " & $000 .--$ \\
\hline$"$ & $000 .-$ \\
\hline$"$ & $000 .-$ \\
\hline " & 0000 \\
\hline$"$ & $000 .--$ \\
\hline
\end{tabular}

$\$$

$400 . \cdots$

$2010 .-.$.

$\$ 450$.

"4 400.

(1) (6)

1.000

$360 .-0$

"600.-

"1.000.-..

$11 \quad 360$.

" $500 .-$

5110,

Sul1.....

$100,--$

$204 . \cdots-$ P. 2,

$$
000 \text {... }
$$

144 .

$809 .-$

(1)

720.

1. $920 .-2$

184.-.

$\begin{array}{ll}" & 000 .- \\ " & 000 . \ldots \\ " & 000 .- \\ " & 000 .- \\ & 000 .-\end{array}$

\$ 39.888.-

$$
\begin{aligned}
& 1.300 .- \\
& 500 .- \\
& 800 . \\
& 300 \text {. } \\
& 624, \ldots \\
& \text { \$ } 40.311 .2 \quad 1 / 2
\end{aligned}
$$

Consecutivamente trata la Ordenaria 39, Cap. 29 de la formalidad para el juramento y posesión de los Ministros, Oficiales y Dependientes de la Casa; de la jurisdicción de los Srs. Secrctarios del Despacho Universal de las Indias; ${ }^{33}$ de la de los Sr's. Virreyes; ${ }^{4}$ y de los Stzperintendentes. ${ }^{15}$

I a disposición del reglamento acerca de los Superintendentes en ninguna otra cosa se alteró por la Ordenanza de Intendentes, sino en haberse reunido por el artículo $1^{\circ}$ en el Gobernador de Potosí, esta comisión con las demás respectivas a Banco, Minas y Mita que antes corrían separadas al cargo de distintos jefes, como queda dicho en el Discurso Preliminar.

Toda la novedad recayó en los Exemos. Señores Virreyes en virtud del Art. $2^{\circ}$ de la citada Ordenanza, pues por ella quedaron enteramente inhibidos del cuidado, dirección, arreglo y manejo de todos los ramos y productos de la Real Ilacienda, y consiguientemente de la autoridad que siempre tuvieron sobre los ministros, oficiales y operarios de la Casa en todo lo civil tocante a sus oficios, o procedente por motivo de ellos; sin poder ya entender en ninguna de estas materias como reservadas al conocimiento privativo de la Junta Superior que se mandó erigir en Buenos Aires por los artículos $3^{\circ}$ y $5^{n}$ de la nueva Ordenanza, y a la autoridad de la Intendencia General establecida anteriormente en dicha capital por Real Cédula dada en El Pardo a 21 de marzo de 1778. Pero habiéndoseles vuelto después por Real Orden del año próximo pasado de 788 todas las facultades antiguas con reunión al Virreinato de la Superintendencia General de Hacienda que se les habia quitado, han reasumido nuevamente el despacho de todos los negocios con la superioridad absoluta en todos los empleados del Reino, sin más excepciones que aquellas que se hallan puestas y declaradas por las leyes generales de la recopilación y demás ordenanzas aprobadas por el Supremo Consejo de las Indias.

En cuanto a los demás empleos de la Casa manifiesta la misma tabla las cortas innovaciones que han sufrido mucho antes de la Ordenanza de Intendentes. En el año 78 la había hecho ya Don Jorge Escovedo, dividiendo el empleo de proveedor del Guardamateriales, bajo de un re- 
glamento que formó en 6 rie agosto del mismo año para gobiemo del último, el cual fue aprobado por S. M., en Real Orden de San ]ldefonso a $2: 3$ de agosto de 1782 . Y para facilitar el ingreso a este destino rebajó a 2.000 pesos la tianza de 4.000, tasada por la Ordenanza de la Casa, 16 mandáncole abontar por lazón de notmas $1 \%$ en el carbón, medio en la leña y cuatro en la cebada. Is Gobernador, Don Juan del Pino, mantuvo cstos oficios en la misma scparación por algún tiempo, hasta que muerto el proveedor, los volvió a unir en el Gualdamateriales, don Ignacio P'rieto, por ser asi conforme a ordonanza, y últimamente arreglado a ella el actual Superintenclente, don Francisco de Paula Sanz, proveyó los dos juntos en Don Mariano de Arroyo, por mucrte de Prieto.

\section{N O T I C I A D E C I M A S E T I M A}

Juristicción de los sres. vi- $\mathbb{N}_{\mathrm{N}}$ medio de todas las variaciones explirreyes on lo criminal de las calas, conservaron siempre los Señores Vicausas de la Moneda. rueyes la jurisdicción criminal para resolver los recursos y consultas de las sentencias capitales del Superintendente, con voto de Real acuerdo, ${ }^{17} \mathrm{Y}$ por esto será bien que tratomos este purto con la distinción con que antes se miraba, para no confundir las materias tocantes al gobierno con las respectivas a la Superintendencia Gencral; en tiempo que corrían separados estos dos glaves uncargos se hallaban destinadas también las funciones esenciaIos de todos ellos par'a evitar competencias, pues se guardó la regla de todos los asuntos que se comunicasen de la Corte, por la vía y mano a quien correspondian, de manera que sólo con ver la dirección por donde venían se sabía ya la naturaleza del negocio y el juzgado a quien tocaba su conocimiento.

Sobre este principio munca se dudó, que sin embargo de lo dispuesto en el artículo $2 "$ de la nueva Ordenanza, debían continuar conociendo los Señores Virreyes sobre asuntos criminales de la moneda, por el mismo hecho de haberse comunicado yor su mano entre otros Reales Despachos la Real Cédula dada en Él Pardo, a 22 de marzo de 1786, sobre la pena capital, que en ella se manda imponer con precedente consulta del Virrey, a los que saquean y roban oro y plata de las Casas de Moneda, pues en caso contrario se hubiera dirigido a la Intendencia General, como se ejecutaba con todo lo civil en las Casas de Moneda.

NOTA. - Los tres ultimos parágrafos de la Noticia Décimasexta, y los dos primeros de la Décimaséptima, han sido tomados del manuscrito de Sevilla, y sustituyen al texto del libro existente en Potosi, que dice:

(FINAL DE LA NOTIOIA DECIMASEXTA:)

"La disposicion dol Reglamento se halla bastante variada en cucuto a la jurisdicción de los Sres. Virreyes, $y$ lo que corresponde a los Superintendentes necesita alounas declaraciones, para que esta autoridad no tropicce con los demós Jueces en los casos dependientes de la jurisdicción ordinaria. Por al Art. $2^{n}$ de la Real Ordenanza de Inten- 
dentes, de 28 de enero de 1782, se dejan al cuidado, dirección y manejo de la Intendencia General de Buenos Aires y a la Junta Superior erigida en aquella capital, (Awt. 5" de la Ordenanza de Intendentes) todos los ramos y productos de la Real Hacienda, separámalos del conocimiento de los Sres. Virtieyes.

"Los cuantiosos caudales de las Casas ale Moneda, componen uno de los ramos más pingücs de la Real Hacienda y es preciso que su manejo se mida por las reglas de la Nueva Ordenanza, con inhibición de la Superior autoridad de los Sres. Virreyes, ententitíndose sólo con la Intendencia General la jurisdicción que les atriluze el reglamento sobre los Ministros, Oficiales y Operarios de la Cast, en todo lo civit tocante a sus oficios o procedente por motivo de ellos".

\section{(COMIENZO DE LA NOTICIA DEOIMASEPTIMA:)}

"Pero en cuanto a lo criminal, juzgo que se les debe conservar. la jurisdicción, para resolver los recursos de la sentencia del Superintendente, con voto consultivo del Acuerdo; (Capítulo s" de la Ordenanza de Moneda.) porque habiéndose deslindalo entre el Señor Virrey y la Intendencia General las respectivas jurisdiceiones de una y otra autoridad, dirigiendo las materias de sus dependencias por la vía y mano a quien corresponden, para que no se confundar las irtenes achmulando su ejecución a dos polestades diferentes, es forzoso deilucir que las causas criminales pertenecientes a la misma Casa, competen a la jurisdicción del Señor Virrey de Buenos Aires, una vez que por su mano se han comunicado, entre otros Reales Despachos, la Cédula dada en E' Pardo, a 22 de marzo de 1786, sobre la pena capital que en ella se manda imponer, con precedente consulta del Virrey, a los que saguean y roban oro y plata de las Casas de Moneda; porque a no ser así, se hubiera dirigido a la Intendencia General, como ejecuta con todo lo civil de las Casas de Moneda".-. (Nota de A. Alba).

El asunto debe compararse con lo establecido entre el Consulado y la Sala del Crimen, según las circunstancias expresadas. El Consulado procede contra los Mercaderes que defraudan la hacienda ajena, $y$ puede condenarlos y remitix el fraude, dolo o delito cometido en lo tocante a la mercancía y su arte y negociación y contra el estatuto de ella, así en falsificar las mercaderías y suponer las malas por buenas, como en su contratación y ejercicio, hasta imponerles cualquiera pena civil o pecuniaria $;^{18}$ pero en todo lo que es delito tocante a 10 eriminal, se debe remitir a la Justicia $;^{19}$ así también debe conocer la Intendencia General de todas las causas civiles pertenecientes a la Casa de Moneda, y el Sr. Virrey, de las criminales.

$$
\text { NOTI I A D E C I M A C T A V A }
$$

La vía donde se deben propo-
ner los empleos de la Moneda.
Real Orden de 7 de octubre de 1778, que la
Intendencia General de Buenos Aires debe 
to, deben dirigirse alli y no al Virrey las propuestas que antes se le hacían en las vacantes de los empleos, por el Superintendente o por su mano por el Contador, Juez de Balanza, Ficl y Fundidor Mayor, en los casos de la Ordenanza $22,23,27$ y 28 de la Moneda; y así lo tiene ordenado el Visitaror General del Reino, Don Josć Antonio Areche, con fecha de 13 de abrit do 1779. (b) Pero debe advertirse que, aungue por Real Orden de 20 de encro de 1761. se mandó para la Casa de Moneda de México, que precisanente se propongan sujetos de los que sirven en la propia Casa para las vacantes, salvo cl caso de ser todos indignos e insuficientes, no se ha extendido al perí esta resolnción en los términos que se anota, y sólo se previne, en el nímero penítimo, Cap. 23 de la Ordenanza, que las propuestas se hagan atendieinlo a los que sirvon en la Casa; que no es más que una recomendación, sin precepto.

\section{NOTICIA D E C I M A O V E A} Fmpleos que necesitan Real
confirmación.
D ministros: el Contador, Tesorero, los dos

Ensayadores, el Juez de Balanza y el Ficl de Moncda, y los cinco Oficiales Mayores que numel'a ol Cap. 1" rle la Ordenauza, a saber: el Fundidor, Grarda-cuños, Giardamaterialts, Tallidor y Primer Oficial de la Contaduría. En liss vacuntes do estos oficios debe el Superintendente proponer a ln Superintenciencia Gencral, para cada empleo tres sujetos idóneos y bencméritos, pirra que de los propuestos nombre interinamente uno, el cual ha do ocmrir con su nombramiento al Real Consejo de Indias, a impetrar la confirmación y título de propiedad; ${ }^{20}$ y en el entretanto, deben gozar las dos tercias partes de su sueldo; y presentado el Real T'ítulo de confirmación, les corre integramente desde el día de la poscsión. ${ }^{21}$

Los oficiales subalternos del Contador, Juez de Balanza, Fiel de Moneda y Fundidor Mayor, y los demás dependientes de la Casa de Moneda de Potosí, se deben nombrar por la Intendencia Ceneral, a propuesta del Superintendente, conformo a la Ordenanza 22 y al Auto acordado por el Superior Gobierno de Tima en 2 de mayo de 1775 , debiendo gozar \{́tegramente el sieldo desde el dia de su posesión, respecto que no necesitan de Real confirmación, "Sólo sc exceptúan de propuesta los tres Oficiales o Cajeros que debe tener el Tesorero conforme a la Ordenanza 1", mediante no necesitar demás aprobación y título que la elección y nombramiento verbal del mismo Tesorero, con facultad de recibirlos y despedirlos a su arbitrio, cuando y como le convenga. ${ }^{23}$

\section{NOTICIA VIGEST M A}

sueldos de los interinos. CUANDO en el referido Auto acordado de 2 de mayo de $\mathbf{1 7 7 5}$, formalizó el Superior

Gobierno de Lima la asignación de salarios y nombramiento de Ministros, se extrañó que estos hubiesen percibido el sueldo por entero, debiendo gozar solamente las dos tercias partes, como interinos; y consultado el asun- 
to por Dn. Jorge Escovedo, Superintendente "le I'otosi, en 2 de octubre de 1779, al Visitador General del Reino, Dn. Nosé Antonio de Aleche, resolvió éstc, en 8 de octubre de 1780 , la continuación del pago íntegro de sueldos a los interinos, con calidad de aprobarse por la Intendencia General de Buenos Aires, como lo rutiticó er 16 ste marzo de 1781, en consideración de haber pagado la media anata por entero, y se declaró que para en adelante se guardase la Ordernanza.

\section{NOTICIA VIGESI M P RI H E R A}

Montepio y media anata. DE todos los Ministros expresados, están comprendidos en el Reglamento del Montepío solamente el Superintendente, Contador y Tesorero, como se declaró por Real Orden de Aranjuez, a 16 de agosto de 1779; pero en cuanto a la media anata, deben yagarla todos los empleados que para ejercer su oficio necesitan Cédula o Despacho del Rey o de los Sr's. Virreyes, Capitanes Generales y otros Ministros, según la ley 4: Cap. 10 y 2", Tít. 19, Libro $8^{\circ}$ de Indias; por cuya regla quedan exceptualos de pagar este derecho solamente los Cajeros de la T'esol'ería, que son a clcción abitraria de sus Jefes y amovibles por ellos, sin necesidad de otra superior aprobación y título.

Todos los obligados a este derecho, deben pagallo antes de tomar posesión, en lo que les tocare de la primera paga, asegurando la segunda a satisfacción de los Oficiales Reales; "a y si tomarla la posesión no pagaren dentro de quince dias, como se les intime o requiera o haga notorio que lo deben, incurren en la pena de pagar doblado este derecho por todo rigor de ejecución. ${ }^{25}$ Lo cual debe obselvarse en lo que no se hubiere innovado por la Real Cédula de 26 de mayo de 1774 , donde se prescribieron nuevas reglas para el pago y seguridad de la media anata.

En conclusión, me parece digno do advertir que el mal servicio que se nota en muchos de los Oficiales menores de la Casa de Moneda, procede de la facultad libre con que los Superintendentes los reciben y despiden, sin atender que no tocándoles más que proponerlos, sólo el que los nombró es quien puede removerlos; y cuando por la distancia de la Superioridad fuese prceiso acudir con prontitud a remediar el daño que resulte o se recele de la ineptitud o mala versación del empleado, es conforme a justicia que se le haga sumaria, para dar cuenta con ella a la autoridad que hizo el nombramiento, suspendiéndole entre tanto del ajercicio del empleo. (c)

\section{NOTI I A VI G E I I A S E G U N D A}

\section{Medios políticos de mejorar el servicio de los Empleados.}

$\mathbf{E}_{\mathrm{N}}$ mente destine para superintendente, provisionalmente destine para su recmplazo el oficio que se le siga, según su grado, colocando en la última resulta a quien le pareciere más a propósito, por vía de interina providencia, para que no se perjudique el servicio mientras se hacen las propuestas conforme a Ordenanza; pues, de ejecutarse 
lo contrario, sucede que ningín Oficial se empeña a sobresalir en su ministcrio, por la poca esperanza de ascender, experimentándose de continuo que, vacando un empleo, lo confierc el Superintendente a quien mejor le parece y después da cuenta con el nombramiento, que siempre se confirna, quedando los demás en sus antiguos destinos, sin mejorar de premio. Lo mejor scría que fuesen de la absoluta nominación del Rey (como son los Oficiales Reales) todos los empleos cuyas dotaciones lleguen a 400 pesos, segín está prevenide en Real Orden de 20 de febrero de 1774, porque asegurados entonces en la Real confinmación, mirarian con más amor sus destinos $y$ se empeñarian en mejorarlos por el camino del mérito.

NOTICIA VI GESI MA TERCERA

Cierta declaración en cuanto a la excepción de los Dependientes de la Moneda, de la jurisdicción ordinaria.
A tagunos superintendentes han querido adaptarse la declaración de la Ordenanza 5:, pretendierdo que en los casos de que pueden conocer las Justicias Reales, contra los Finistros, oficiales y Dependientes de la Casa, no se ejecuten los mandamientos de prisión y embargo de bienes que libraren sin darles antes cuenta, como está prevenido para con el ViProy; y de resultas de una competencia que se tuvo en esta Villa, declayo el Sr. Virrey, Confle rle Superunda, con voto consultivo dol Real Acuerdo, en 13 de juhio do 1752 , que los Alcaldes ordinarios tienen jurisdicción contia los Olicialus telineuntes de lo Casa de Moneda, en los delitos que no tocaten a sus respectiros ejercicios, como igualmente contra los mineros y dependicntes de Minas y Mita en sus causas civiles y criminales, a excepcion de las que fucsen propias y particulares de su ejercieio; y del mismo modo, para castigo de los indios clackhas; y que en todos estos casos en que los Jueces ordinarios ordenarcn prisión y embargo, debe recibirlos en la Carcel el Alguacil Mayor, sin necesidad de dar antes cuenta al Suporintendente, $y$ sí, sulamente, después de ejecutada la prisión, cuando ésta se actuare en algún dopartamento de la Moneda o de otro ejercicio público, para que subrogue en su lugar a otro. El Rey aprobó este Auto acordado, declarando en Real Cédula de Aranjuez, a 26 de abril de 1761, deber quedar en su fuerza y vigor para los casos que ocurran las reglas que en íste se contienen; pero cuando se juzgare innovada esta disposición, por la unión de todas las Superintendenctas de esta Villa al Intendente de ella, 26 nunce sería preciso anticiparle este aviso, si por ello se aventurase la administración de Justicia; y sí, solamente, después de evacuadas las diligencias que pidan o recomienden el secreto, según se dispone en los Artículos 85 y 86 de la Ordenanza de Intendentes.

NOTI I A VIGESIMA C UAR T A

A
$\begin{gathered}\text { Apelaciones en causas crimi- } \\ \text { nales de la Moneda. } \\ \text { za ju, de la Moneda, deben admitirse para el }\end{gathered}$
nales, ordenó el Conde de Superunda, que en los casos de moneda falsa 
dentro de la misma Casa, se admitan para la Real Audiencia de Charcas, a fin de evitar la fuga de los reos con la dilacion del recurso; a cuya resolución deben arreglarse los Superintendentes, para no quedar responsables ci lix ocasiones de fuga. Ningún otro Juez putede conocer del delito de falsedad de moneda, sin embargo de extendeise a las Justicias ordinarias por la Ordenanza 22, Tít. '2", Libro $1 "$ de jas Gencrales del Pe-

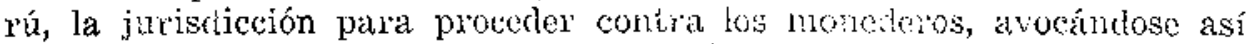
las causas de falsedad, aunque sea cometida dentro de la Casa de Moneda, porque esta Providencia quedô rovocala en el Nizcro Reglamento, 27 en que se inhibió privativamente de la Audiencia y domás Tribunales al Superintendente, concedicudole a d sólo la juxisdiécicia para tocio lo gubernativo, económico, directivo y providencial de la Casi.

\section{NOTICIA VIGESIMAQUINTA}

\section{Explicación de varias Reales Ordenes acerca de la pena contra ladrones.}

Y autoridad, en las causas criminales de robos, que son frecuentes en la Casa, puede ocinrir la duda acerca de la pena on cue loben sor condenados los ladrones, y en cuanto a las formalidades de su ejecucion, debo prevenir que, a consulta del Superintendente Dn. Jorge Escovedo, se declaró en Real Orden, fecha en Ël Parko a 29 de enero de 1782 , que contra los ladrones se imponga la pena de doscientos azotes y socavón; $y$ si los robos fueren grandes, que se les ahorque, formándoles causas breves y sumarias, como corresponde a la estiecha y privilegiada naturaleza de ellas cuando los ladrones fueren aplehondidos infraganti o con cl hurto en las manos.

Aquí no se exceptúan calidades, que no es difícil encontra'se en los ladrones; no se determina cantidad para constitury en la clase de grandes los robos, ni se declara el tiempo de la condenación de los reos en el socavón. Todos los cuales puntos no son de pequeña consideración para el acierto del Superintendente; pero habiéndose dispuesto en la Ordenanza 8i, Tít. 10 del Reglamento del Banco, que se imponga la pena de azotes y socavón según la calidad de la persona, debe entenderse en este mismo sentido la última resolución de S. M., por ser regular que las Leyes y Providencias se expliquen, distingan, limiten y declaren unas por otras.

En cuanto a la cantidad del robo para que se llame grande, es aun más difícil su computación, porque unos 28 la dejan al arbitrio del Juez, otros dicen que no se debe atender la cantidad sino la iniquidad, ${ }^{29}$ y otros ${ }^{30}$ que se debe considerax principalmonte la cualidad del lugar, como si fuese el Palacio del Príncipe u otro lugav de esta clase, que agrava el delito según sus circunstancias. Así se ve, que por consideración del lugar se impone pena de muerte, pasando el ladrón de 17 años, y de azotes y galeras al que excediese de 15, por todo hurto ejecutado en la Corte y cinco leguas en contorno, en poca o mucha cantidad, por la Real Pragmática sanción del año 1734, recopilada en los Autos 19 y 21, Tít. 11, Libro $8^{\circ}$ de los acordados de Castilla.

No obstante, distinguiéndose en la Real Orden de 1782, los hurtos 
grandes de los pequerios, para pena de muerte o de azotes, se debe atendor siempre, un incstro caso, la cantidad del robo, teniéndose por hurto pequeño el qua no pase de 20 pesos, respecto de estimarse de poco valor todas las causas de cste gónero " y como tales, estar prohibido por la Ley 1", Tít. 10, Lib, 5" de Inclias, que se formen procesos sobre ellas.

Aunque el ladrón do cantidad pequeña, cogido infraganti, niegue cl delito, basta para el castigo que sca convenido por los testigos que lo

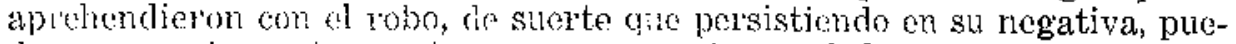
de ser pnosto on tormento, no para areriguar el delito, sino para sabor de sus chalidades y cómplices, entendiendose bastantemente probado el hurto, por "un solo testigo idónco, alméte sea el cómplice confeso de sí y su infamia pitrgetda, y añadiendo dos indicirs o argumentos graves que conspiren al mismo fin y persuadan a la prudente racional credulidad de ser el clelincuente, "3: sin que en estos casos sea preciso formar proceso ni consultar la ejecución a la heal Audiencia; porque en cuanto a lo primero, aprobó el Iey la consulta dol Superintendente, sobre la imposición de pena de azotes sin proceso; y en cuanto a lo segundo, eximió de este recuisito al Supetintendente la Ordenanza 8, Tít. 10 del Reglamento del Banco, conforme on lo sustancial a la Ordenanza $5^{n}$ de la Moneda, que previene las consultas sólo an cl caso de pena capital.

Pero debe advortirse que si el robo fue ejecutado entre muchos, no se considera lél porción aprehendida entre los cómplices, para computarlo por grande o periueño, sino el todo que por ellos se robó, sa y así, cjecutándose entro diez ladrones el hurto de 100 pesos, no se estima cono robo pequeño aurcue a cadil uno le tocase solamente diez pesos.

No es exorbitante la pena de desticro en el socavón, después de la de azoles, por considerarse como su accosorio en cuanto conviene al bucn gobicko purgar la república del contagio de hombres faicinerosos. 2 r. Sólo puede dudarse qué tiempo ha de scr do la condenación del delincuente azotado o del que por su calidad se libertó de la pena de azotes. Según derecho, el destivero subiogado a la fustigación, no debe bajar de 10 años, ${ }^{36}$ y el Auto acordado 19, T'it. 11, Tib. 8" de Castilla, así lo determina para con los nobles. Ins plebeyos, por su baja condición, son los únicos susceptibles de la pena de azotes y de otra infamatoria, ${ }^{37}$ y por lo mismo de ser viles deben ser más chaldomente escamontados que el fidalgo, como explica la Ley de Partida. ${ }^{8}$ A cuya decisión es conforme agravarles la pena, acunulando la de socavón a la de azotes que siempre es ordinaria contra los ladrones; 39 pero no habiéndose determinado por la Ordenanza tiompo cierto de socavón, es arbitrario al Juez ${ }^{40}$ y según las circunstancias dol hurto puede aumontar o disminuir el término del desticrno.

Si los robos fueren grandes (que se dice tales pasando de 20 pesos) $y$ los ladrones fueren aprehendiclos infraganti con el hurto en las manos, ya homos visto que deben ser condenados a muerte, según la Real Orden citada to 1782 , formándoles causas breves y sumarias conforme a su privilegiada naturaleza; mas, si no fueren cogidos con el hurto en mano, se les dobe hacer el proceso sin dilación, recibjendo la causa a prueba por un breve término con todos los cargos de publicación, conclusión y citación par'a sentencia, " sin excluír de ser testigo al compañero en el delito, ${ }^{42}$ por ser de los cxceptuados como de difícil probanza; bajo de las cuales declaraciones debe ejecutarse la novísima Real Cédula fecha en 
El Pardo a 22 de marzo de este presente año de 1786 , soble la imposición de pena de muerte a los ladrones. Lo que hace de algún modo difícil esta Real resolución, es que, mandándose gualdar en clla las Leyes del Reino, principalmente la 20, Tít. 21, Libro 5' de Castilla, on que se impone la pena de muerte al que robare de las Casas de Moneda, alguna de las de oro o plata antes de ser fel todo acabada y librada por sl Tesorero, Ensayador, Maestro, Guardas y Escribano, parce que no se necesita robar 20 pesos para incurrir en esta pena, porque aplicándose el adjetivo alguno o alguna, indeterminadamente a una persona o casa con respecto a muchas, 13 se verifica el tenor de la bey en una sola pieza antes de acabarse de amonedar perfectamente, por ser en sí una dicción particular que, denotando singularidad, puede según su significado verificarse regularmente en lo mínimo. ${ }^{44}$

Con todo, la expresión de la citada Ley no debe entenderse tan literalmente que se haya de juzgar impuesta la mayor pena del mundo, que es la de muerte, por el robo de una sola moneda de las que todavía no estén acabadas de perfeccionarse; porque entonces llegaría caso de ser ahorcado un hombre por el valor de medio real; lo que no es creíble de la piedad de nuestros Reyes, en medio de tanta abundancia de preciosísimos metales como Dios les ha dado. Así se ve, que atendiendo a la multitud de ganados de la Provincia de Buenos Aires, no se observa la pena de muerte que impone la I,ey 19, Tít. 14, Partida 7:, contra el ladrón que: hurtare cuatro vacas; ${ }^{15}$ moderándose con tan admirable piedad el rigor del Derecho, que se ha mandado castigarlos con azotes y destierro, a arbitrio del Juez, por Real Cédula de Madrid, a 7 de diciembre de 1766.

Es pues justo investigar el espíritu benigno de las Leyes, recurriendo a la interpretación legal de aquella dicción: "alguna" en que se funda toda la dificultad. Aun en las causas favorables, como son las tocantes a menores, nunca se ha estimado por suficiente motivo para concederles el remedio de la restitución, si hubiese sido mínimo el daño que alegaren; por eso, disponiendo en general una ley civil, ${ }^{46}$ deber sel restituídos in integrum si hubiesen sufrido alguna disminución en su patrimonio, se declaró en otra ${ }^{4 i}$ que el perjuicio no debía traerse a consideración siendo mínimo, y sí, únicamente, cuande fuese grande o notable. Conformándose a estas decisiones civiles, dcclaró la Ley 1*, Tít. 13, Partd. 3, que la confesión hecha en juicio por el menor, sin presencia de su Curador, sólo le perjudica si se tornase a gran daño suyo.

Tratando después la Ley 47 , Tít. 13, Partd. 5 , de la r'cscisión de las ventas, por daño que en ellas le resulta al menor, explica la Glosa $3^{\text {a }}$, que no se debe entender por un daño mínimo, simo por otro más considerable. En cuya conformidad, resuelve la Glosa $4^{\text {it }}$, de otra Ley que es la

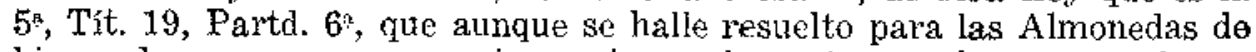
bienes de menores, que a quien mejorare la postura se le entregue la cosa que otro sacó, aun después de rematada, es preciso llegar a este caso solamente cuando el beneficio sea muy notable, de suerte que la venta debe sostenerse si la mejora fuese de poca consideración.

De todos estos principios se deduce que la pena de muerte impuesta contra los ladrones, debe ser efectiva en el caso que el robo sea, ua de una pieza a dos de moneda, sino de cantidad que exceda al valor de 20 pesos (en opinión expresa de Tiraquelo: de jud. in rebus exigüis ferend;

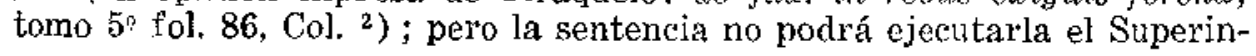


tendente, sin consultarla antes con el Sr. Virrey, en la forma dispuesta por la Ordenama 5 ; de Moneda, mandada guardar en Real Orden de San Ildefonso, a 14 de marzo de $178 \%$, como lo hacen aún los Tribunales Superiores ${ }^{48}$ y lo deben practicar forzosamente los inferiores, ${ }^{49}$ usando de la fómula que retiere a la letra al práctico Elizondo, ${ }^{50}$ y esto es aunque el reo no apele de la condenación, scgún lo resuelven expresamente las Ordenanzas 17 y 18 , Tít. 17, Ijib. 2 ' de las Cenerales del Perú.

\section{NOTICIA VIGESIMASEXTA}

$\begin{aligned} & \text { Subrogación de la superin- } \text { Por la Ordenanza } 29 \text { de la Casa de Mo- } \\ & \text { tendencia. } \text { neda, y por la 7?, Tít. } 12 \text { del Reglamento del } \\ & \text { Banco, debian sustituír los respectivos Con- }\end{aligned}$ tadores, las ausencias o enfermedacles del Superintendente, despachando y firmando como tales todo cuanto ocurriese, así en lo gubernativo como en lo judicial. Sobre esto se dudó de la subrogación que la Nueva Ordenanza de Intendentes le da al Teniente Asesor en todos los encargos de estos Jefes, pero teniendo presente cue por los Artículos $1^{*}$ y $12^{\circ}$ de la nueva Instrucción de Intendencias, se dispuso la concurrencia en una sola persona, do todas las [acultades repartidas antes entre los Jefes de las diferentes olicinas de esta Villa, para cvitar con la unidad del mando, los anteriores liecuentes sucesos de competencias, confusión y embarazos que ocasionaba la diversidad de jurisdicciones y multitud de $\mathrm{Mi}$ nistros a quienes se habian concedido; se declaró por Auto de 4 de mayo de 1786, por el Gobernador de Potosí, en virtud de particular comisión de la .Junta Superior de Buenos Aires, a quién se había consultado el asunto, que el Teniente Asesor debía suplir sus veces, no sólo en lo relativo a la misma Intendencia y Gobierno, sino también en cuanto a las cuatro Supcrintendencias de Casa de Moneda, Banco, Minas y Mita, sin otra diferencia que la de cncabezar las libranzas de la primera a nombre del Jefe, y firmar con la expresión de ser por ausencia o enfermedad de aquél.

La Junta Superior a quien se devolvió el expediente, aprobó esta Providencia y dio cuenta al Rey.

\section{NOTIOIA VIGESIMASE P TIMA}

Labor de cuenta de s. M. Wil primer Jefe de Potosí, en quien se reunieron todas estas facultades, fue Dn. Ventura Santelices y Venero. A él se le confió, en Cédula de Buen Retito a 3 de octubre de 1750 , la nueva planta de esta Casa al modelo de las Ordenanzas formadas para la kle México en 1" de agosto del mismo año (como queda dicho). Desde luego entró a formalizar este sistema, y para dar principio a la labor de cuenta de S. M., conforme a la Ordenanza $6^{*}$ de la Moneda, sacó de la Real Caja, por vía de suplemento, el año de 1752 , doscintos mil pesos, de que obtuvo la aprobación del Superior Gobierno, en 18 de noviembre de 1753 y 10 de enero de 1754 . 
Nueva fábrica de la Casa de Moneda en la esquina de la Plaza, que tuvo su principio el año 1752, hasta el 31 de juIio de 1773 , en que se concluyó; en cuya obra se gastó

1.148 .452 pesos 6 reales. *
$\mathrm{N}$

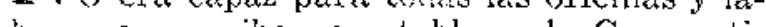
bores que se iban a establecel la Casa antim giaz, que hasta ahon'a nusuticne vestigios bastante visibies en la I'lazít pública, a la escuine del Fste de la mismid cindia donde se halla la Caja Leal, mirando su frente al Norte y el costadio al Oeste. El Superirtendente trató do reedificarla cle mejor fábrica; la empezó, en efecto, a $\delta$ de noviombre de $17 \% 3$; pero freron tan eficaces y poderosas las contradicciones, que obligaron a suspender el suceso de la obra, y a emprenderla de nuevo en el paraje opuesto, donde hoy está, al Noroeste de la Plaza, haciendo esquina con ella. Todo el edificio es de piedra labrada de cantería, con dos altos techados de cedro y otras excelentes maderas; muchas ventanas con lejería de hicr'o y vidrieras, y con no pocos balcones a la calle. El primer patio se destino para habitación de los Ministros principales, con una casa para carta luno, dividiéndose las pertenencias de un solo corredor que tiene en cuadro, con atajadizos le madera que las distinguen por letreros del emplen a quien conlesponclen, con su respectiva entrada y salida por diferentes escaltras.

Los arquitectos de la Casa de Lima, lo lucion tanbién de ista, y por uniformarla a aquel modelo, sin distinguir las diferencias de ambos climas, fabricaron un caserón tan fucite, que puede servir de castillo, pero al mismo tiempo tan incómodo por cl desahogo y mala distribución de sus piezas, que casi es inhabitable; al menos escasea el sol de tal manera, que apenas se logra su calor en los corredores del Norte, Este y Oeste por algunas estaciones del año y sólo pos dos horas a algo más en cada dia. Yo estoy viviendo en la casa del Superintendente, por' habitar és- te la Pretorial como Gobernador; y aunque disfruto una viviendita muy estrecha con dos ventanas giandes que me dan sol dentro de la pieza una hora larga del día y de la tarde, hay ocasiones que, aburuido del encicrro, pagaria a peso fuerte un pedazo de sol en mis colvedores.

En esta magnificencia puramentc material y de perspectiva, sin un solo primor de arquitectura, se gastalon hasta 31 de julio de 1773 -en que se dio por acabata la obra,-.. un millón ciento cuarenta $y$ ocho mil cuatrocicntos cincuenta $y$ dos pesos, seis reales (pesos 1.148.452, 6 reales), comprendidos los gastos de la pitimera y costos de su constitución, instrumentos, utensilios y salarios de los Directores. Puede asegurarse que más de la mitad se malbarató a beneficio de los diferentes Asentistas que contrataron ya las tejas, ya las maderas ya otras especies de materiales. Cualquier Ministro celoso que se hubiera encargado de la intendencia de esta obra, pudiera haber economizado la mitad.

Lo peor es que después de haberse enterrado aquí este tesoro, dejaron tan bajas las paredes que miran al Este, por la parte más peligrosa donde caen las ofjcinas, que más de una vez se han ejecutado por allí unos robos considerables, sobre que se tienen hechas varias representaciones para suplir la altura que falta con tapias aunque sean de adobe crudo o cocido, y no hay duda gue elevando este edificio se gastaría muy poco y se iba a granjear toda la seguridad de la Casa. Es preciso confe- 
sar los defectos, pero también que ya no tienen remedio. En otro paraje pudo hacerse la Casa, por el mismo costo, con todas las oficinas de Real Hacienda dentro de sus cercas; y ya que no fue así, siquiera se hubicran crificarto las habitaciones todas al Este, para su mayor abrigo $y$ saridad, que to paso se lograría poner a la Casa otros tantos Guardas, como sejían los Ministros que la habitasen, por ese mismo costado que tantas veces se ha vencido por los ladrones.

En esta nueva Casa continuó labráncose la moneda de corte o marr - tillo, en las cuatro hoinazas de que habcnos hecho mención en otro ligal, percibiendo los dueños de cilas los dex'echos que les asignó Don Francisco Nestares Marin, siendo Visitador de esta Casa a mediados del siglo pasado de 1600. Don Ventura Santelices reformó esta regla, desde 26 de agosto de 1758 , señalando desile este día, en lugar de los emolumentos, mil pesos de suelco a cada hornacero para su asistencia personal y por la responsabilidad de cualquier falla o merma que resultase, desde el recibo do las platas en rides a la entrega de monedas preparadas perfectamente para imprimirles los sellos; con más 495 pesos por el rédito de 16.500 pesos en que quedó estimada cada hornaza, regulando a razón de un $3 \%$ que todo junto componía 1.495 pesos.

\section{NOTIGIA VIGESIMANOVENA}

Historia de las euatro hor- WSTAS cuatro hornazas exan conocidas, nazas. la una poi" el nombre de "la Pila", como situada junto a la que tenía esta Casa en su patio. Diego Villegas Moreno la compró, en 7 de junio de 1660, a Marcos García de La Torre, en cuien se había subastado en público remate por el Presidente Nostares, quitándoscla a Juan Sánchez Romero, Capataz de hornazas; $y$ últimamente, la adquirió. el Hospital de Belén, en 19 de enero de 1759, por disposición testamentaria de Josefa Villegas Moreno, heredera legítima del referido Diego Villegas. Con motivo de la moneda de cordoncillo, paró esta homaza en 19 de septiembre de 1777.

Las tres restantes pertenecian: la una a los Quintanillas, por compra que licieron al Rey, sus autores Dña. Teresa Muñoz de Céspedes y su marido Dn. Antonio Garć́a, cantero; la otra a los Bareas, que recayó después en Dn. Manuel Tovar y Mur; y la última a los Laredos, por sucesión hereditaria. Todas tres cesaxon en 29 de mayo de 1770 , y al cabo de cuatro meses volvieron a su antigua labor, hasta 14 de julio de 1773 , sin duda porque no se pudo aún dar suficiente abasto a la moneda de cordoncillo.

\section{NOTI I A T RIG E S I M A}

Novedades en los Oficios de
la Moneda en tiempo del Go-
bernador Santelices. razón de derechos de cada marco labrado, en virtud de remate que cele-
$\mathbf{E}_{1}$ dió en 2 de septiembre de 1758 , el goce de 1 maravedí y 19 centavos que el Escribano de la Casa, Dn. Patricio Junquera, tiraba por 
bró en 2 de octubre de 1712 , por la cantidacl de 7.200 pesos, su respectiva media anata y conducción, con titulo interino del Superior Gobierno y aprobación que obtuvo de S. M., en 29 de octubre de 17.1; y en lugar de 1.684 pesos y reales que regularmente rendian estos emolumentos, le señaló 1.200 pesos anuales.

Al Conde de Casa Real de Moneda, en quien habia recaido por herencia d ofjeio de Tesorero, enajenado de la corona a faror de los $\mathrm{Pa}$ tiños, también le suspendió los derechos que tiraba a razón de 13 maravedíes y 99 centavos en cada marco, y le dotó con 13.240 pesos anuales. . Después, en el año de 1753 , lo privó de este empleo por varias causas que le fulminó, todas, o las más, arbitrarias. Yo no he visto el proceso, pero me afirmo en este juicio por haberse declarado su nulidad en Reales Cédulas de 19 de agosto y 14 de septiembro de 1763 , y en su conformidad, la restitución del Tesorero en 7 de junio de 1765 , con el sueldo de 6.200 pesos que el Superior Gobieno le señaló interinamente, como rédito de los 124.000 pesos del principal desembolso de su valor.

Desde luego, fuc muy justa esta morderacion, porque he visto en una liquidación del año de 1652 , que reduciendo solamente la labor a 248.358 marcos 4 onzas, resultaban a fayor del Tesorelo 12.183 pesos 5 reales, 9 maravedíes líquidos, después de pagacios los gastos de carbón y los 8 maravedíes de rebaja para enterar la ley de la moneda, con más la regalía de proveer 12 cuños de la Casa, de tencl en ella aposento y' el derecho de voz y voto en el Cabildo. Después he oido que el mismo Conde confesaba quedarle libres mís de 15.000 pesos, y sucesivamente hubieran crecido estos emolumentos, a proporción que se iba aumentando la labor. $\mathrm{Ya}$ se ve que esto no 'ra conveniente al Rey, y cra forzoso reformar tan excesiva dotación; pero no fue verdadero el camino que tomó el Gobernador Santelices. Obrando con más prudencia, hubiera mejorado la Real Hacienda, sin haber sumergido a esta honrada familia en los embolismos de que hasta ahora no ha podido desenvolverse enteramente.

Todos los interesados a las hormazas $\mathrm{y}$ oficios referidos, reclamaron su perjuicio con muy raronables fundamentos. A estos recursos se determinó en Real Cédula de Aranjuez, a 7 de junio de 1773, que: a Mur y a Laredo se les pagase al respecto de un 5 ó los réditos del principal de sus hornazas, y por consulta posterior de esta Superintendencia, declaró el Superior Gobierno de Lima, que la citada Real resolución debía extenderse a favor de todos Jos dueños de hornazas, $y$ que debia ajustárseles su haber desde cl año de 1758 , en que Santelices los sujetó a un $3 \%$. En las liquidaciones se les abonó, de consiguiente, aquel $2 \%$ que habian dejado de percibir, hasta el $5 \%$ que últimamente se les asignó $y$ aunque corrió este interés íntegro hasta el año de 1781, no percibieron en adelante más que el $4 \%$, pos una voluntarla rebaja que todos hicieron a beneficio de la Real Hacienda.

Fl Escribano Junquera también obtuvo Real Cédula de Aranjuez, a 5 de junio de 1762, en que se le mandó acudir con los 484 pesos 7 reales que había dejado de percibir, para el entero de los 1.684 que antes gozaba, y que continuase tirando el 1 maraverdi y 19 centavos asignados a su oficio. En efecto, verificó su cobranza desde 12 de mayo de 1758, hasta $1^{\circ}$ de septiembre de 1776, en que el Superior Gobierno, por Auto acordado en 2 de mayo de 1775 , extinguió estos derechos, reduciendo el suel- 
do anual del Escribano a 1.200 pesos durante su vida; y para lo sucesivo, dotó la Escribania en 800 pesos, de sucrte que por un justo cómputo gozó Junquera los 800 pesos por su trabajo y el interés de su principal desembolso, que al respecto de $5 \%$, vino a completar los 1.200 pesos de la líltima asignación.

EI Tesorero continuó cobrando los 6.200 pesos que le señaló d Superion Gobieno, hasta 30 de julio de 1776, en que se le privó del oficio por la incorporación que se hizo de él a la Corona, por Auto acordado del Sr. Virrey, su fecha 2 de mayo de 1775 , en virtud de las facultades que lo concedici la Real Cérula de 21 de mayo de 1770, para incorporar todos los Oficios enajenarlos, sin quedarle otro derecho más que para repetir los principales del Oficio y sus réditos chuante el descubierto.

\section{NOTIGIA TRIGESIMAPRIMERA}

Redención de todos los censos y principales que pesan contra la Casa de Moneda, etc.
$\mathrm{C}$ OMO tolos estos intereses reunidos formaban al fin de año una denda considerable, que forzosamente debía disminuír las utilidades de la Casa, mandó el Rey, por Real Orden de San Ildefonso a 2 de octubre de 1785 , que desde luego se redimieran todos los principales y censos que cargasen sobre los expresados oficios, con los 200.000 pesos que por no emplearse en el giro de la Casa, quedaban sobrantes de los 800.000 de su fondo; con la calidad de irse reintegrando sucesivamente $y$ sin intermisión con los réditos que aquellas cantidades devengan o con las ganancias anuales en cuanto excedieren de 100.000 pesos o de la tercera o cuarta parte de cllas, según lo estimare más conveniente esta Superintendencia.

En la liquidación general que formó la contaduría, en 8 de marzo de este año de 1786, resultó contra la Real Hacienda, por razón de principales y censos, el alcance líquido de 185.263 pesos 4 y $1 / 2$ reales. Por Auto del propio mes, los mandó pasar el Superintendente de la Tesorería de la Moneda, a la principal de la Provincia para que allí ocurrieran a ser pagados los acreedores con libramientos formales; y se declaró que el sobrante que se iba a consignar, debía completarse sucesivamente con las cantidades que corlespondiesen a sus réditos, librando cada año su importe a esta cuenta a favor de la Casa; pero atendiendo a que el reintegro sería muy lento y moroso por la cortedad del anual embolso, y que tal vez creciendo la labor en ocasiones de más abundante rescate de plata y oro no alcanzaría el fondo residuo, se ordenó en subsidio provisional del giro, que se agregase todos los años la parte de utilidades que no pasare de 100.000 pesos, reservando provecr conforme al suceso del tiempo.

E1 Monasterio del Carmen de esta Villa, que era acreedor a 72,000 pesos de censos sobre el Oficlo de Tesorero, representó la escasez de fincas libres y cuantiosas en qué colocarlos, ya que éste era el único fondo de su subsistencia; en cuya consideración se les había satisfecho íntegramente el rédito de un $5 \%$, en virtud de Real Cédula de 19 de mayo de 1777, exceptuándolo de la rebaja hechá a los demás interesados; y que no conservándose este capital en las Reales Tesorerías, bajo del mismo pie que antes, se exponía a perecer. El Superintendente calificó estas justísimas causas, y mandó retenej: en las Cajas Reales todo el principal 
al rédito de 5 c, hasta la resolución de S. M., (d) afianzando la Comunidad sus resultados con el propio capital. Por curo medio ha quedato libre la Casa de muchos asiento: cuentas y partiras que llevaba en sus libros con cada acreedor particular, logrando a más del ahorro de estas impertinentes prolijidades, la debida claridar tn su manejo.

Consecuente a estas Fovidencias, sc mandó en Auto de 2 do junio de 1786, que se devolvieim a os herederos del Fsclibano Junquera, los 7.200 pesos de su desembolso, a atencion de haber'se declarado en Real Orden de 14 de agosto de 1788 , que tenia rerecho a ellos sin embargo de la incorporación del oficio a la Covona, con la calidad de consultarse antes a la Junta Superior, donde se aprobo lo vesuelto. Fin el mismo Auto se proveyó saliese a remate el jegimiento auexo a la Fscribanía, y ésta se confirió a un Escribano de los del númelo de esta Villa, (e) con el sueldo de 800 pesos, feneciendose felizmente unos asuntos que han dado tanto que hace: a los Tribunales, cor indecible costo y aun desgracia de muchas familias honradas.

\section{N O TICIA TRIGESIMASEG U N D A} Principio de la moneda de cor-
doncillo y laurel.
$\mathbf{N}$ loriazas poicte hiogo que en hey de las Jornazas; poique luego que en el año de $177:$ se concluyeron enteramente las oficinas respectivas para la labor de la moneda de cordoncillo, con las viviendas destinadas a los Ministros, y las salas de hileres, molinos y volantes. aperadas de los instrumentos recesarios, quedaron ya las Formazs sin ningún efecto. Desde entonces se liniformó nuestra moneda, labrándose toda ella de figura circular, con cordón y laurel, con arreglo a la Ordenanza $6^{2}$, quedando enmendada la imperícceión $y$ evitato cl cercén y la facilidad de falsearse, como se experimentaba con la antigua de tijera; que todas son unas ventajas muy considerables, que compensan con superabundancia el trabajo de alinarse las platas agrias para la nucva estampa, aunque la antigua no necesitase de esta operación.

La demora en ejecutarse las Providencias, muy anticipadas, del Señor Don Felipe V. y Don Fernando VI, para la labos' de moneda de cordoncillo, consistió en que esta Casa fue la última que se fabricó, después de la de México y Lima. Aun en Nueva España vomos que, por haberse opuesto los dueños de los Oficios mayorcs, aleganrlo ser imposible hacer esta labor con los 68 maravedies que les estaben asignados para costos de monedaje y braceaje, fue preciso incorporarlos a la Corona en el año de 1732 ; y sólo así pudo llevarse a efecto, en el de 1733, la soberana resolución de hacerse la labor de cumta del Rey, en beneficio del erario y de la causa pública.

\section{NOTICIA TRIGESIMATERCERA}

Fondo destinado para el giro
de la Casa.

lado el de un millón quinientos cincuenta y nueve mil pesos 51 Para la de 
Lima, se halla dispuesio en la Ordenanza 22, que haya de haber siempre existente el foncio cfećrivo de 100.000 pesos, más o menos, al arbitrio del Virrey, según lo requician las circunstancias y enseña la experiencia, pal'at ias compras de metaleis. Sin duda, haciendo cotejo de estos caudales y labor corriente de aquellas Casas, con la que podía llevarse on Potosí, se determino en Real Orden de Aranjuez, a 11 de abril de 1776, que el Virrey le asignase an fondo de 500.000 pesos, y que, on caso de ser necesario más, se supiicse a la Casa de los caludales del Banco, con la calidad de ir reintegyando en moneda las cantidades que se hibren para su destino.

Don Jurge de Escovedo, con su acreditado amot al Rey, e incomparable eclo por' su mejor servicio, represento en 16 de febrero de 4778 , que cran necesnricis 800.000 pasos. El Sr. Virrey Don Manuel de Guirior, revolvio el experiente, $y$ remitido al Sr. Visitaror General, a consecuencia de las Reales Ordencs iz en que se mandó al Gobernador de Potosí, se entendiese a estas comirones con la Visita General, se aprobó por clla la roferida asignación, en 23 de mayo de 7779 , y se formalizó en esta Villa por Auto de 21 de julio del mismo año.

Con este motivo se tranzó el cargo de 682.211 pesos 7 reales, 17 maravedies gue los Oficiales Reales repetían contra la Casa, por el real no pagado de señoreaje descle 28 de septiembre de 1762; y se ordenó que, omitiendo la cuenta del señoreaje, se hicieran cargo de él los Ministros de la Casa, como de utilidarl, pasando a las Cajas Reales, a fin de año, todo el sobrante de la labor de oro y plata que excediese el fondo de 800.000 pesos asignados a esta Catsa, como se aprobó clespués ell dos Reales Ordenes de Aranjuez, a 21 y 26 de mayo de 1781 .

Pal'a mayor formalidar de la entrega, se había entablado la costumbre de pasar un Oíicial Rcal a recibirse de los caudales que debe entregar anualmente la Tesorería de la Moneda, del Banco y Aduana. Los Oficiales Reales consiguieron Providencia en contrario de la Intendencia General de Buenos Aires; ${ }^{5: 3}$ pero on otra posterior, "i, se mandó continuar la costumbre inviolablemente.

\section{NOTICIA TEIGESIMAOUARTA}

Método en el giro de la Casa. desde la compra de metales hasta su reducción a moneda.
$\mathbf{P}$ los deniśs Ministros de que habla la Ordeuana, después del Superintendente, con el cebido orden y separación, es conveniente
dica y muy abreviada del giro que se observa hacer una descripción metódica y muy abreviada del giro que se observa
en esta Casa, desde la compra de los metales hasta su reducción a moneda, para que el Gobernador moderno lea en poco papel cl dilatado progreso de operaciones en que nunca podría enterarse sin el repaso de toda la Ordenanza y algún tiempo de experiencia.

Las entradas de oro y plata en pasta en esta Casa, que forman la gruesa de su labor, proceden de tres ramos. El primero es el Rescate del Real Banco de San Carlos, de todos los productos de la Ribera de esta Villa, y de los Partidos de Chayanta, Lípez, Chichas y Porco, comprendidos en la Provincia de Potosí; incluyéndose la chafalonía, todo fundido 
en barras, pesadas, ensayadas y diezmadas on la Real Caja.

De este Real Derecho se deriva la segunda entrada, porque deducido (el diezmo) en pasta, st reduce a barras, qu!e también so remiten a esta Casa para su labor en moned:a.

La tercera y última entrada se hace poz los particulares, en barras diezmadas en las Reales Cajas de Tacna, Carangas, Chucuito y Oruro. En este ramo entra cl oro quintado on esta Rea! Caja, que viene de los minerales de Porco, Chichas, Lípez, Chayanta y Tucumán, del mineral de Alconquija y de algunas chafalonías, y del que se trae quintado de afuera en las Cajas de Carabaya, Chucuito, Ia Paz, Chuquicamata, Tipuani y Cocluabamba.

\author{
NOTICIA TRIGESIMAQU I N T A
}

Peso de las barras. Tas piezas de oro y plata deben tener cierha tenido su variedad según los tiompos. El Sr. Toledo, is maudó que las barras no excedieson de 62 y $1 / 2$ hasta 65 marcos, para que 10 se perjudicara la consignación de 12 reales impuesta sobre cada picza, a beneficio de S. M., con el cargo de satisfacer el ducño los costos del carbón. El Sr. Conde de Chinchón, :6 determinó, a pedimento del Fiscal Dr. Luis Enríquez, que los Fundidores de las Cajas de Iima, Potosi, Omuro, Ct:zco, Cayloma, Castrowirreyna, Santiago de truadalcázla y demás donde hubiere callana, no puedan hacer barras de más de 130 a 110 marcos la mayor, bajo la pena de 100 pesos ensayados por carla una. Porque pagándose el derecho de avería por el número de piezas y no por peso, se defraudaba esto ramo en todo lo que pasase de dichos marcos. Por la Ley 9, Tít. 22, Jib. $4^{\circ}$ de Indias, recopilada de Real Cúdula de 1635, se ordenó que las barras de plata no se fundan re más de 120 marcos, declarando las que excediesen, por perdidis y aplicadas a la Real Hacienda. Por la Oxdenanza 10 de la de México, se previene que no se reciba ninguna que pase de 135 marcos; pero por la de Lima, en el mismo capítulo mandado guardar en Real Cédula de 11 de noviembre de 1755 , se varió, extendiendo el peso a 150 marcos y en el oro a 40 el de cada tejo.

Poz último, a representación del Consulado de Lima, declaró el Superior Gobierno, en Auto acordado de 17 de agosto de 1770, que sin embargo de la Ordenanza y Real Códula citadas, se aumente hasta 200 marcos el peso de carla barra de las que se hayan de fundir en las Cajas del Reino, con apercibimiento de que habiendo exceso, se fundirán y dim vidirán en dos piezas, a costa del dueño, conforme a la Orden 10 de la Casa de Moneda; pero respecto de la Real Caja de Potosí, se dispuso por el Sr. Virrey, con fecha de 6 de marzo de 1772, que se arreglasen a 180 marcos. En la Ordenanza 9, Tít. 3 del Reglamento del Banco, se ha mandado guardar esta Providencia, exceptuando las de Guantajaia, que para su más fácil conducción tienen el permiso de 130 mareos cuando més. Con todo, se tolera cierta gravedad eli algunas Cajas, como en la de Oruro, que se funden de 200 hasta 220 marcos, y en la de Chucuito y Tacna, de 165 . 
No obstante esta desigualdad de pesos, sc computa siempre el de ordenanza para el pago de los derechos del Ensayador, a razón de 5 pesos por cada barra sin bocado, en virtud de contrato particular que intervino entre los Mercaderes de Plata que las fundían de su cuenta, con cl dueño de los Oficios de Fundidor y Ensayador de estas Cajas, que fue de la casa de los Zabalas en I ima, que hoy concurren por el Rey, embargados por alcance a favor del ramo de Bulas, y ya está incorporado a la Corona. En las demás Cajas, se pagan 6 pesos por hechura de cada baria y a más el bocado de cada una.

El interesado que trae sus barras fundidas y quintadas en la forma referida, las presenta en la sala del Despacho o de Libranzas, con una razón del tenor siguiente:

\begin{tabular}{ccr} 
Número & Tey & Pcso \\
\cline { 1 - 1 } 51 & 11.22 & -180.4 \\
51 & $21 .-$ & 191.3 \\
52 & $20 .-$ & 202.8 \\
53 & Potosí, con fecha y firma.
\end{tabular}

Esta razón se entrega en la Contaduría y las barras se reciben por: el Portero Marcador, quien las pone en el Tesorillo, avisando la entrade a los Eusayadores; $"$ pero si alguna viene sin las marcas de haber pagado los Derechos Reales, se remiten con persona de la Casa a las Reales Cajas, para que allí se exija su importe. ${ }^{5.8}$

En este estado pasar los Ensayadores con su Oficial a sacarles los bocados (f) pasa el reonsaye, poniendo cada uno en un papel rotulado con el número que tiene la barra de que se sacó, y allá en su Oficina cjecutan la operación según arte, por fuego.y sopella, en hornillos de reverbero, para ajustar la ley de la plata según el peso que hubiere mermado el pälór.

\section{NOTICIA TRIGESIMASEXTA}

Formalidades con que se despachan las Libranzas y se pasan las platas a las oficinas respectivas.
E (g) con la debida formalidad, hacen su apunte los Ensayadores, y con él pasan a la Contaduría a extender su certificación al pie de la razón presentada por el dueño de las barras, asegurando estar conformes en su ley o expresando la diferencia que hubieren hallado.

Luego procede a pesarlos el Juez de Balanza, con asistencia del dueño, del Fundidor y Afinador, (h) que las han de recibir, y del Contador que con su presencia autoriza el acto, tomándose razón por un Oficial de la Contaduría y otro de Tesorería on sus respectivos libros boriadores, del número, ley y peso de cada pieza. El Portcro Marcador marca con tinta las barras y con un martillo en que está grabado este ró- 
tulo: MONEDA, lo imprime en cada una de ellas y quedan renacha-. dis (i) de cuenta de S. M.

En la Contaduría y Tesorría se tica la cuenta de reducción a 11 dineros, con arreglo a la planilla puesta al litu do este capítulo, y estando acordes los ajustamicntos de ambas oficinas, foma la Contaduría el correspondiente libramiento, que intervenido por clla y firmado por el Superintendente, se le entrega al interesado, para que en virtud de él y do su recibo, le fespacho el Oficial 1? de la Tesorería qule vuchve a comprobar en su libro de ajuste lo librado, para evitar toda equivocación) una boleta por la cual paga el Tesorero en la Sala del Despacho contigua al Tesoro, que no tieno otra pucrta más que la de su entrada por la misma Sala.

NOTIOIA TRIGESIIASEPTIMA

\section{Deducción de 17 maravedíes en cada inarco, para gastos de afinación.}

$\mathbf{T}$ ODOS los metales remachados, que no bajan de 11 dineros 20 gratios, sc pasan de podur del Tesororo al del Fundidor Mayor $y$ Guardamateriales, $y$ se depositan en el Tesoro de Fundición, conforme a la Ordenanza 12; pero los denás que no liegan a la ley de 11 dineros 20 granos, so entregan al Afinador, doseontando al interesado $1 / 2$ real o 17 maravedies del valor de cada marco, por razón de costos; pues, aunque por la Ordenanza 10, No 3 , se deben practicar en cada quinquenio los experimentos recesarios para ajustar el importe de estos gastos, nunca se tuvo en esta Casa el cuidado de ejecutarlos, hasta el año de 1774, en que Du. Tomás Alvare? de Accvedo, Fiscal de Charcas, siendo Supcrintenrlente mandó por Aito de 5 de enero del mismo año, que a los vendedores de platas de menos ley de 11 dincros 20 granos, se les exigiera 8 maravedíes por marco, pali los costos de afinación, sin embargo de ser mucho más crecidos; gobeunándose, a mi parecer, para esta Providencia, por la práctica de la Casa de Moneda de México, donde sólo so exige dicha cantidad. Pero como alli sucede esto porque no sube a más el costo de afinaciones, fue preciso reformar este establecimiento a fines de diciembre de 1777 , y desde principios de 1778 siguiente, mandó Dn. Jorge Escovedo que se cobrasen, en lugar de 8 maravedies los 17 que hasta ahora se observa, sin embargo de haber informado el Superintendente de Lima, cue las mermas de la afinación se conceptuaban en 15 maravedies $35 / 47$ avos de otras ell marco, por no haberse juzgado conveniente ni aún posible ajustar por experimentos el cargo puntual de gastos de afinación; porque introduciéndose en esta Casa los metales, ya por cuenta del Banco de San Carlos, ya del ramo de reales y diezmos, ya por otros diferentes dueños particulares, en partidas unas veces grandes $\mathrm{y}$ otras pequeñas, no es verificable la afinación por separado de todos estos metales, pies, a más de entorpecerse el giro de la Casa con cstas prolijas operaciones, serian forzosamente mayores de lo justo los cargos, en consideración de que para afinar dos barras, por ejemplo se gastaría aquello mismo que bastase para la afinación de diez o doce; procediendo de aquí no haberse hecho novedad hasta ahora en este asunto. 
Intervención del Guardana- HECIIA la entrega a las dos oficinas refeteriales en los candales que ridas, de afinación $y$ fundición, se les torma pasan al Tesoro de Fundición. por la Tesorería y Contaduría el correspondicnte cargo en los Libros que respectivamente deben llevar, conforme a las Ordenanzas 23 y $24, N^{\prime \prime} 7$ y 9 . Pero el Guardamateriales no es respousable, aunque tenga junto con el Fundidor, una de las laves del Tesoro de Fundición, según las Ordenanzas 30 y 28, No 7; porque sir concurrencia conduce sólo a no dejar el Tesoro al libre arbitrio $y$ disposición del Fundidor, como sucede con el Superintendente y Contador on el Tesoro principal, de que sólo rosponde el Tesorero y no ellos, annque las llaves estén en poder de los tres por dirigirse su concurso únicamente a la mayor seguridad de la Real Hacienda, conforme a la Orcienanza 24. Por csto es que sólo el Fundidor afianza 30.000 pesos con 15 fiadores, según la Ordenanza 28 , No 4 , y él dá cuenta anual de los metales de oro, y bienal de los de plata. Como aquí se trata solamente de afianzar la responsabilidad de los metales, se exceptuó al Guardamateriales de esta obligación; pero queda sujeto a dar fianza en cantidad de 2.000 pesos para seguridad de los efectos comprados por su mano, conformc al Reglamento que en 6 de agosto de 1778, formó Dn. Jorge de Escovedo, para gobierno del Guardamateriales, aprobado por S. M., en Real Orden de San Ildefonso, a 23 de agosto de 1782, donde, para Cacilitaz el ingreso a este empleo, se rebajaron a 2.000 pesos las fianzas, que antes eran cle 4.000 , y se abonó $1 \%$ en el carbón, $1 / 2 \%$ en la leña y 4 ro en la cebada, separando este Oricio del de Proveedor; pero en este año se han vuelto a reunir anbos empleos conforme a Ordenanza.

\section{NOTICIA TRIGESIMANOVENA}

De la Afinación. $\quad$ EECiBIDOS en la forma expresada por el Afinador y Fundidor los remaches, procede el primero a referir las platas agrias, hasta ponerlas dúctiles, en estado que aligadas en la ley de la moneda, sufran sin quebranto ni desunión los pasos de molinos, hileras, cortes, cordón y cuño en la Fielatura. Par'a esto prepara los hornos necesarios de reverberación, poniéndoles un suelo (que se llama centrada) ${ }^{59}$ compuesto de ceniza de leña y hueso molido de animales, hecha pella humedecida con agua común en que se haya desleído cal viva.

En cada homo pone 18 barras y les da fuego de leña hasta fundirlas. En este estado les echa el plomo que corresponde a la liga que tienen; pongo por ejemplo, para consumir un grano de liga en la plata, se necesitan tres de plomo, $y$ en el oro, a cada grano de liga, dos de lo mismo; ${ }^{\circ 0} \mathrm{y}$ continúa dándoles fuego, $36 \mathrm{y}$ algunas veces 48 horas, hasta que observa que el baño de la plata no trabaja y que poniéndose claro y rutilante como un espejo, se ve en él lo interior del horno. Entonces, con la 
perfecta introducción y mezcla del plomo eu las entrinas de la plata liquidada, ya se ha causado el efecio de extraerse por exhalación todas las materias extrañas o indigestas que acompañaban al metal, intooduciéndose parte de ellas por los poros de la acendrada $y$ el resto so disipa en el aire, quedando la plata purilicada, fina y ductil, sin mezcla heterogénea que la vicie y sólo con las partes propias de su buen temperamento. Así el Afinador sangra los hornos y los vacía en moldes de barras, que ensayadas con la certificación de su ley, se pasan (siendo conforme) a la Sala de Libranzas, donde, pesadas, se entrogan al fundidor.

\section{N O T I C I A C U A D R A G E S I M A}

De la Fundición. BSTE las pasa lucgo, separadas o juntas a la fundición de crazadas, chando en cada callatia til de las dos que tiene la Casa, dos barras, y otras veces arreglan cade una de 550 a 55 marcos de cobre en granalla o fundido en tejos, para su liga y religa, de suerte que cada callana tenga hasta 600 marcos de plata ya ligada, al calor continuo del fuego de carbón a soplo de fuelle. Después de bien mezclada y fundida con la ley fija de 11 dineros, se vacian las callanas en rieleras de hierro, de las suertes de moneda que so quiere acuñar; y pasando a los Ensayadores dos rieles, uno de los primeros y otro de los últimos que se han vaciado, se ensayan por estos y se aprueban estando ajustados a la ley precisa de 11 dinezos justos o con un grano de foble o fuerte; pero excediendo del permiso, los reprueban y es necesario lefundirlos a bañarlos o religarlos.

\section{NOTICIA C UADRAGESIMAPRIM ERA}

Establecimiento de la labor del oro y el método que se observa en su afinación. Para habilitar este nuevo establecimiento se gastaron 8.771 pesos 10 sayes, fundición, afinación, fielatura, herrería, talla y cuño. Se pidieron instrucciones a las Casas de Moneda de Lima y México para entrar con acierto en estas labores; pero no se ejecutan según los modelos.

Aunque esta materia de la afinación del oro es de las más importantes al interés de esta Casa, atendiendo a las muchas mermas que por ticmpos se han experimentado en ella, no es ni ánimo tratarla de propósito, por ser operación propia de la química, a que no me puedo avanzar sin ser facultativo. Voy a referir sencillamente los modos con que se practica esta operación y el que de ellos se ha adoptado en la Casa de Potosí.

Según los químicos, puede afináse el oro de cuatro modos: el primero, con plomo; el segundo, con solimán crudo; el tercero, con antimonio, y' el cuarto, por cimentación, que es lo que llaman los alquimis- 
tas: cimiento red, dánbole este magnítico nondyre porque dicen que el oro es el rey de los metales. En México se usa el scyundo modo, administrando el solimán que recesite cada crazada de oro después de hecho caldo bien caliente, hasta poncrlo suave y dúctil al golpe del martillo, que es por donde se conoce estar ya par'a seguir su labor.

En esta Casa se practica el cuarto modo de afinación o cimiento leal, pero un una forma muy distante de las zeglas que prescriben los químicos modernos de mís fama. Estos, para hacer el cimiento, no usan de más ingredionte que del nitro o salitre y tierra gredosa; pero los nuestros, reducen ol o a granalla, lo infunden en vinagre fuerte dentro de ollas vidriadas, por quince dias más o menos, stgún su antojo; después, mezclan esta gramalla con el magistral o pella, que se compone de partes de polvo de ladrillo, de sal común, de salitre o nitro, de caparrosa y de sal de compás, $y$ lumodeciendo todo con vinagre fuerte y agrio de limon ; hecho pella este magistral, se. pone en ollas de bario blanco fabricadas a este propósito, una capa de dos dedos de grueso, otra de la granalla de oro mojaclo on vinagre fuerte, hasta llenar la olla con estas capas alternativas, que jegularmente componen hasta 20 marcos de oro.

luestas estas ollas hasta d múmero de veinte, en ol horno del cimiento, se le va dando, por grados, un fuego sucesivo de leña keuña por espacio de 48 horas. Habiendo reposado un día o dos, en que se haya enfriado la granalla, se quiebran las ollas, se separa del magistral y se funde on callana tres barretones de 200 marcos, de los cuales se hacen los ensayes por fuego y aguafuerte, y declarada por ellos la ley verdadera de si fineza, se forma la cuenta de su liga y aleación, para ponerlo en la ley de moneda, y la que pidiere de liga se le pone compuesta de tres partes de cobre fino y otra de plata rima.

Algún otro operario de esta Casa, para hacer los manojitos de puntas con que se toca el oro, ha usado en su afinación de iguales partes de salitre refinado, alcaparrosa y bol, hecha una masa bien mezclada y rociada con vinagre.

Lo cierto es que nada de esto tiene conducencia a lo esencial de la opcración del cimiento, porque el vinagre no tiene sobre el oro absolutamente acción alguna; el agrio dol limón ceutí, la alcaparrosa y la sal de mina, a más de inútiles, son muy porjudiciales, especialmente estas dos sales, porque deshechas por el polvo de ladrillo, que por la actividad del fuego tiene virtud para descomponerlds, hace exhalar al mismo tiempo sus ácidos dentro de las ollas, $y$ uniéndose los vapores de la sal con los del salitie, forman agua regia, que es la única que disuelve el oro, y por este motivo se encuentra sjempre en las ollas mucha parte de la granalla fundida en tejos mayores o menores, que es lo más dañoso en esta operación, por deber salir de ella la granalla con el mismo cuerpo y figura que entró.

\section{NOTICIA C UADRA GESIMASEG U N D A}

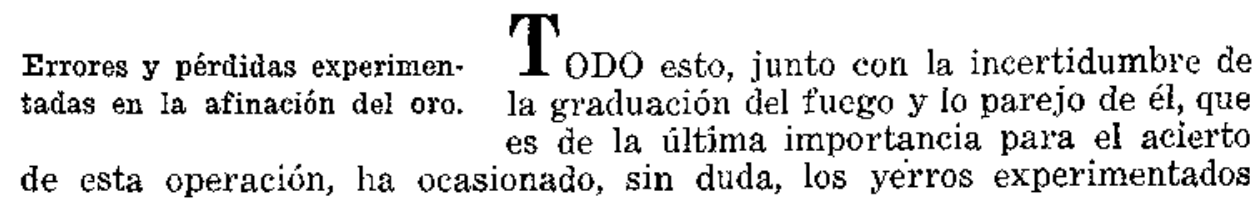


continuamente en la afinación del oro. A fines del año pasado de 1785, malograron dos operaciones stcesivas de alinación con 700 mareos de oro, saliendo dos veces del holno peor que lo que entro. El año rle 1786 sufrió la misma oficina una increíble merma: efectos todos del mal método en que se practican las afinaciones y de no haber fijeza cn el conocimiento de los grados de fuego que son necesarios para acertar con estas operaciones.

Puede también contribuír no poco a cstos desaciertos, el no fundirse en crisoles, de 14 en 14 marcos, para vaciar riel por riel, como se ejecuta en la Casa de México; porque fundicndose en crazadas para hacer rieles, se aventura este precioso metal a cue salga muy designal en la ley, pues, enfriándose luego, no se incorporaría bien la liga, la cual, como más leve, abundaría en la superficie, y de consiguiente, ocasionaría mayores costos en las refundiciones. Además de esto, no alcanza el celo a evitar el hurto de este metal, que por su misma preciosidad y valor, es más codiciado y fácil de sustraerse en partes muy pequeñas, que al cabo de dias hacen subir considerablemente las fallas.

Si no tuviéramos tan a la vista el convencimiento de sel clesarre. glado el método de nuestras afinationes, podríamos atribuir a otra causa las mermas, que son igualnente contingentes quo los aumentos; y es que en los diferentes minerales de donde se trae oro a esta Casa, se experjmenta mucha diversidad en las leyes. Es regular que, unas veces por el fraude de los mismos dueños $y$ otras por venir mal fundidas e incorporadas a las barras y tejos de las cajas foxáneas, traigan en el ccutro menor ley que la que marcaban los ensayes por la superficie de donde sacaron los bocados para ejecutar su operación. A esto es consiguiente que en las fundiciones que después se hacen en la Casa a la perfección, manifiesten su verdadera ley, resultando por fuerza las mermas que se experimentan. Así sucectió en la Casa de México, experimentándose considerables aumentos por principios contrarios on las cuentas que rindió Dn. Manuel de Orendáin, siendo Fundidor Mayor desde el año 1740 hasta fin de 1773. Después que se introdujeron metales de leyes altas y monedas antiguas para rehacerlas de figura circular, dio este mismo Ministro muchas mermas en las fundiciones posteriores. Sobre este inconveniente, no medió más remedio que reducir los tejos al peso de diez marcos el mayor, porque siendo hasta cuarenta como permite la Ordenanza, es fácil de encubrirse cualquier engaño, que después redunda contra la Real Hacienda.

\section{NOTICIA CUADRAGESIMATERCERA}

\footnotetext{
De las cuentas del Fundidor; $\boldsymbol{W}_{\mathrm{L}}$ Fundidor da la cuenta del oro cada tiempo y método de rendirlas. año, y la de plata cada dos, por las demoras en el beneficio de tierras y escobillas, que se practica por peritos conforme a la Ordenanza 28. Estas cuentas se ven y comprueban por el Contador y se aprueban por el Superintendente, sin necesidad de más calificación y sin que salgan de la Casa, a menos de ocurrix sobre aumentos o mermas algún reparo grave que sea preciso consultario a la Superioridad, con arreglo a la Ordenanza $28, N^{\circ} 40$.
} 
De la Fielatura. Se explican las diferentes operaciones de esta oficina; se refieren los utensilios de Ia Iabor; con varias reflexiones importantes para el aumento de rtilitlades.

la más prolija en todas sus maniobras. Para enumerarlas por menor sería menester llenar mucho papel, que sólo conduciría a la curiosidad de su mecanismo, $y$ que omitiéndolo, no hace faita para la instrucción de un Gobernador aplicato, porque a pocos clías de ver el manejo de los instrumentos y las estaciones que corre la plata, puede entender muy bien lo material de las operaciones, las cuales, por mayor, se reducen a lo siguiente:

Ta primera maniobra que se hace con los rieles, es separar los que ticnen rebabas, para cortársclas a fin de facilità los pasos en los molinos. Si las platas son de mala calidad, se pasar a la Sala del Recocho, donde se da fucgo a los ricles hasta que se pongan rojos para que sufran el paso de los molinos.

Ta segunda manjobra es pașar por los molinos, siete veces cada ricl, arreglado a su escantillón o medida en los respectivos asientos, que unos son de muñecas picudas $y$ otros de muñecas lisas, alternando cuatro recocimientos que por lo regular se les dan, aunque algunas veces se aumentan estas maniobras a proporcion de lo que sufren sin abrir grietas las platas do mala calidad sobre acuel pie de tiento y tanteo que por su práctica debe sabur el Macstro de Molinos, que es quien los dirige. De estas máquinas hay tres en una sala alta de la Fielatura, que tiene 33 varas de largo y doco de ancho, y en cada una hay cuatro asientos que sirven para adclgazar los yieles, dandoles respectivamente los pasos hasta ponerlos de ajuste. En lo bajo de la Sala de Molinos está el andén de las mulas, sirviendo a cada uno cuatro $y$ un peón que las gobierna. En todos tres molinos se pucden despachar rieles de doble en un dia de los tres primeros pasos de gordo, ${ }^{62}$ y el que se le sigue de 18 a 20.000 marcos, y de torcero y cuirto paso (que se dan en muñecas picadas) de 14 a 16.000 . De lisas en los tres molinos se pueden despachax lo mismo que de $3^{\circ}$ y $4^{\circ}$ paso. De primera $y$ ajuste, que son los dos titimos pasos que se dan en dos asientos de dos molinos, se despachan en un día 7 a 8.000 marcos, a proporción de lo que sube o baja el andaw regular de las mulas, sin que se pueda formar un tanteo probable de las cantidades de rieles de plata menuda y de oro, nor ser muy poco lo que se labra de una y otro.

Reconocidos los rieles o barras que salieren de ajuste en los molinos, se pasan a la Sala de Hileras, donde se hace la tercera maniobra, dándoles por ellas dos pasos, que llaman de primera y ajuste; de modo que en este último, que está arreglado a su escantillón salgan los rieles, teniendo las monedas que de ellos se cortaren, de cuatro a ocho granos de fuerte; aunque si ascendiere hasta 12 granos, como suele suceder algunas veces, se cortan las monedas en el corte correspondiente de los tres 
que tiene cada Oficial Cortador. Para estas operaciones de hileras, hay once bancos para tirar los rieles por ellos, con sus aparejos de arañas, piñón, chumaceras, bolillos, puentes, escalexillas, argollas, tenazas y tas.

Luego se hace la cuarta maniobra del corte, con quince instrumentos que hay en la Casa, para cortar las cinco clases de moneda: los seis para pesos, tres para medios pesos, othos tres para doses y tres para reales y medios, arreglándose los Oficiales Cortadores, al estado de fuerte o feble que reconocieren, para proporciondr bien sca el corte regular o en el ancho si lo pidiere el fuerte, si el feble on el angosto, proporcionando a estas diferencias los tres granos de mayor a menor, y de menor a mayor, a que están arreglados los tr'es cortes que maneja cada Oficial.

Cortadas las monedas en cospeles, pasan al repeso para ajustarlas al dineral ${ }^{63}$ con dos granos de aumento que se les da por lo que merman en el recocimiento para blanquearlas. Todas las monedas que salen en Caja, ${ }^{61}$ van al cordón, y las fuertes a la hima para arreglarlas a su dineral. Debe ser especial el cuidado de los oficiales de esta quinta maniobra, para que no desperfeccionen el círculo y para dejarlos con grano y medio hasta dos de feble, así porque juntas con las que salieren en Caja con dos granos de aumento, dan mezcladas un feble regular, como para que computando el demerito que recibieron en las cuatro operaciones restantes de cordón, reconocimiento, blanquco y volante, queden en el arreglo y proximidad hacia los 18 granos del feble permitido en levadas de un mar'co. Las demás monedas que se encuentran de cuatro granos de feble se poncn a la cizalla ${ }^{\text {6.j }}$ para fundirse. De las tres clases de moneda menuda, sólo los reales de a dos se repesan y liman, dándoles 18 granos de flierte al marco, por lo que merman en el blanqueamiento y cordón. Las dos clases restantes, de reales y medios, no se liman ni se repesan, porque del corte salen con 18 granos más o menos de fuerte el mar'co.

En este estado se pasan todas las monedas al reconocedor de ellas, y después de pesadas y dadas por buenas, las recibe el Guarda Vista de la misma Sala, por quien se llevan para acordonar a los cuatro tórculos que tiene la Casa, y esta es la sexta maniobra.

La séptima es el blanqueamiento, que sc hace recociendo la moneda en agua común de alumbre de pluma o millu y sal comín. Combinándose cstas sales disueltas en el agua, forman un mordicante que destruyendo la materia alcalina y sulfurosa pegada a la moneda, la limpia y purifica. Cuando ya se ha blanqueado la moneda, se lava con agua pura y se pasa a otro fondo de agua hirviendo mezclada con agrio de Iimón o limas, para acabarla de limpiar y darle un blanco subido, para que acuñada la moneda salga con el lustre y resplandor necesario. El or'o se blanquea del mismo modo, con la sola diferencia de cargar más la mano en el millu, sal, y agrio de limón, y después de secar las monedas, limpiarlas con un lienzo crudo áspero, una por una. (k)

Estando blanqueadas, se hace por el Juez de Balanza el reconocimiento prevenido en la Ordenanza 17. Se pesan en cantidad de 117 marcos y 4 octavos, que corresponde a 1.000 reales, ${ }^{66}$ y se bajan en talegas a la Sala de Volantes, a entregar en manos del Guarda-cuños o su Teniente.

Luego se sigue la octava maniobra, que es la acuñación, en seis volantes situados en lo bajo de la Sala de Cortes e Hileras: cinco de ellos. para acuñar doble y el otro para menudo. Se diferencian de los Cortes, 
en que donde estos tienen cl Macho y la Boquilla, tienen los Volantes los dos troqueles entre los euales so estampa la moneda. En la misma sala de estos instrumentos, hay dos cuartos leducidos, que llaman "Tesorillos", donde se guarda la moneda blanca y la acuñada, bajo de dos llaves que timen en su poder el Guarda-cunos y ol Fiel. La acuñación debc arreglarse en todo a lo rlispuesto en la Ordenanza 19.

\section{NOTICIA C UA D R A G E I M A U I N T A}

Causa de Ia escasez de mone- WS tanta la escasez de plata menuda que da mentila. se padece en estas partes, que llega al extrono increible de andarse buscando muchas veces el trueque de un peso fuerte en medios y reales sencillos una hora o más tiempo por las pulperías de esta Villa, sin encontrar cambio. Ya se ve, no se hace todo ol esfuerzo (que exige esta circunstancia de tener un solo volante) para labrax la necesaria para nuestras provisiones. El único modio de aumentarla sería cuidar con vigilancia que nunca se dejara de labrar siquiera la cantidad de 500 a 600 marcos en cada rendición, como lo ordenó el Superior Gobicrno de Lima, en Providencia de 6 de junio de.1774, dirigida a esta Casa.

\section{NOTICIA C UA D R A G E S I A S E T A}

$\begin{array}{cl}\text { Cantidad que se debe labrar } & \text { CON este concepto dispone la Ordenanza } \\ \text { por Ordenanza. } & 27 \text { de México, que alli se labren cada año } \\ & 10.000 \text { marcos en moneda sencilla de reales }\end{array}$ de a dos, de uno $y$ de a medio; y por lo que hace a Lima, previene la misma Ordenanza 27, numero penúltimo hacia el medio, que sea de la obligación del Fiel, laburar cada año 15.000 marcos (o más, si pareciere al Virrey), y de ellos, la cuarta parte en medios-reales, sin perjuicio de las contratas particulares que se estipularen en los casos de correx la Fielatura en Administración, conforme a la Oronanza $17, \mathrm{~N}^{\circ} 2$ de las de Lima.

\section{NOTI C I A U A D R A G E I M A S P T I M A}

Medios de aumentar la circulación de moneda en el Reino, y perjuicios que se experimentan de la falta de su giro. A PriCANDO en esta Casa 500 marcos,
en cada rendición, para moneda menuda,
abundaria muy en breve en cantidades con-
sidurables, atendiendo a la crecida labor de
485.000 marcos que ha tenido esta Casa, en
iferencia de poco menos en los siguientes. Selos años de 1788 y 84, con diferencia de poco menos en los siguientes. Separa todas las negociaciones interiorés de la Villa y aun del Reino la que se labrase en Potosí solamente, respecto a estar prohibida su extracción a los de España, por repetidas providencias mandadas guardar en la novísima Real Orden circular de 20 de enero de 1773, (l) con el importante objeto de que los mineros, los comerciantes y los particulares no sinticran el daño que se notó, de no tener la que han menester para el preci- 
so pago de jomales, labores y negociaciones, con atraso de éstas y perjuicio de la Real Hacienda y del público.

Sólo así podrá lograrse en este Reino la circulación efectiva y permanente de alguna parte de los inmensos tesoros que producen sus ricos minerales. Porque siendo cierto, como lo observó al antor del libro intitulado "Comercio de Holanda", tan aplaudido por nuestro Ustariz, 67 que sólo el comercio es quien puede atraer a un Estado el oro y la plata que son los primeros móviles de todas las acciones, es consiguiente a la calidad de pasivo que constituye cusi el todo de nuestio comercio, el no poderse atraer jamás por su medio parte alguna, la más mínima, del oro y plata que se extrae de este continente.

Aquí no tenemos manufacturas; aun las primerias materias que se pudieran vender para las fábricas de Europa, y los demás efectos y producciones comerciales de la Amórica, inclusas las Islas de Barlovento, Filipinas y sus adyacentes, se reducen al corto número de 140 especies, que numera y avalúa el nuevo Reglamento y Aranceles Reales para el comercio libre de España a Indias. ${ }^{\circ}$ Aunque todas ellas entren en giro, no exigen circulación de dinero, ni lo atrael a estos paíscs; porque avaluándolas regularmente en Europa por sus precios corrientes, no tienen que pagar los negociantes de España, más que aqucllos que hayan enviado de más los de Indias; y aun esto lo desquitan entre ellos curiándoles otras męrcaderías; de suerte que casi nunca se verifica el recobro de nuestras producciones en valores efectivos y numerarios.

También pucde decirse que en el mismo caso de hacerse a dinero nuestras ventas nada adelantaríamos en cuanto a su atracción, porque como todo lo que vendomos apenas corresponde a una décima parte de los géneros y frutos que compramos, es forzoso que esta gran diferencia influya a la extracción de todas las platas y caudales de la América, que es el mismo argumento de que se vale nuestro sabio politico Ustariz, ${ }^{69}$ para probar el despojo que padece España de su moneda con las naciones extranjeras, asignando por la l'azón principal, habérseles comprado más géneros que los que se les ha vendido.

Sobre todos estos sólidos principios se fundaron las sabias providencias referidas, para que en todas las Casas de Moneda del Reino, se labre cada año determinada cantidad de moneda menuda, prohibiéndose absolutamente su extracción fuera del continente, con el interesante fin de fomentar el comercio interior de unas Prorincias con otras, como que es la base de aquél que se extiende fuera del Reino y el principal origen de la prosperidad del Estado.

El dinero es como la sangre, que por medio de su circulación vivifica el cuerpo y da acción a los miembros. Si estos carecen de su riego, por habérseles extraído toda o reducídose a otros depósitos de donde no vuelve a refluír a las antiguas canales, es forzoso que se esterilicen y amortigüen, como se observa en un brazo yerto y seco porque le faltó la sangre, y en una rama enteramente marchita, porque no le alcanzó el baño del jugo de su tronco. Las ciudades, los países y las provincias, que forman unidas un Estado, son los miembros de este cuerpo político: a proporción de la substancia que los vivifica, es la actividad de sus acciones. El comercio es su primer móvil, para dar impulso a la circulación del dinero por las manos del labrador, del artesano, del negociante y del ciudadano, hasta llegar a ciertos depósitos de donde por varias revoluciones vuel- 
Pincuter

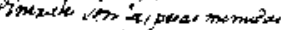

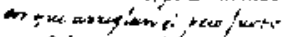

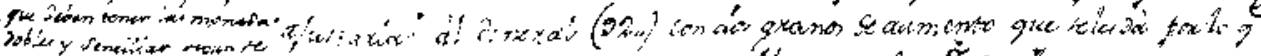

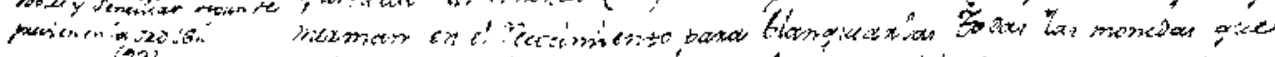

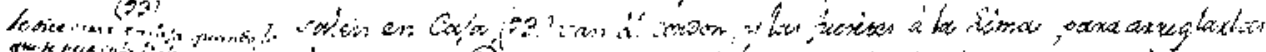

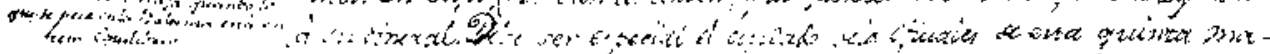

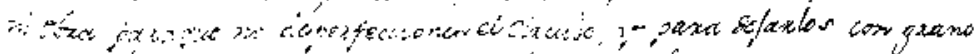

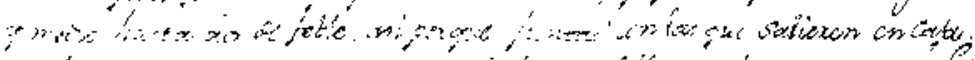

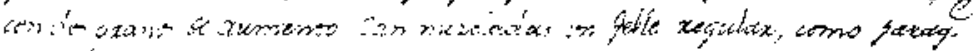

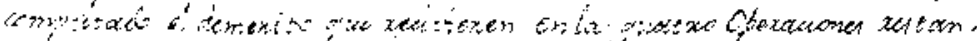

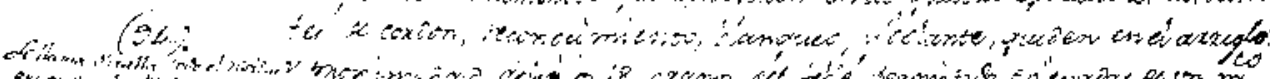

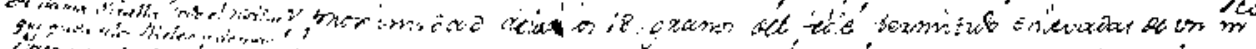

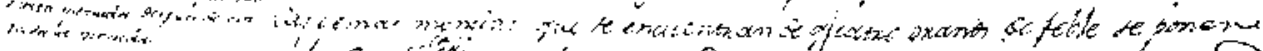

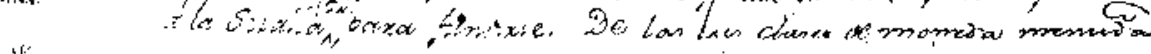

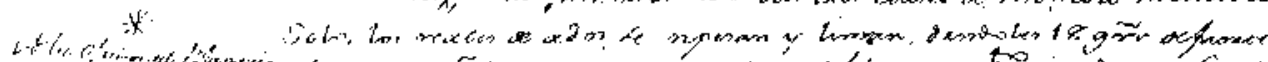

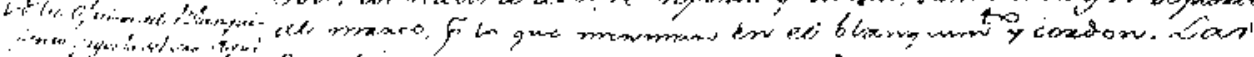

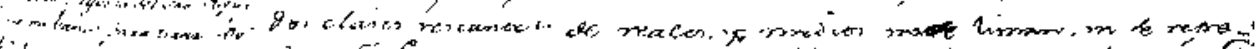

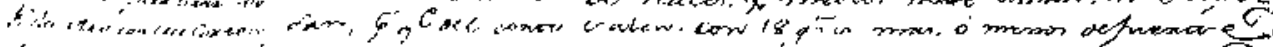

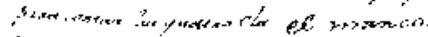

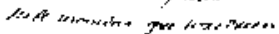

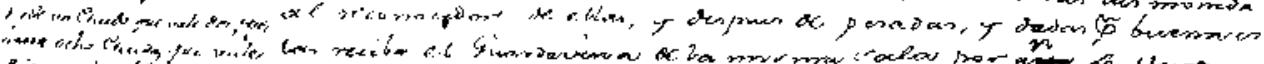

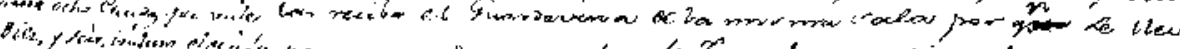

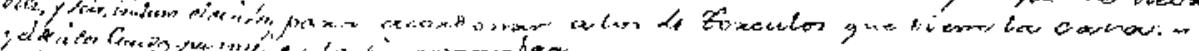

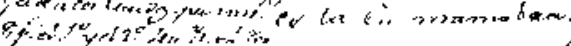

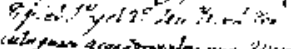

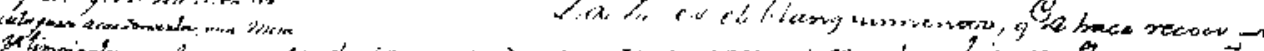

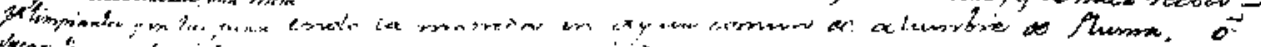

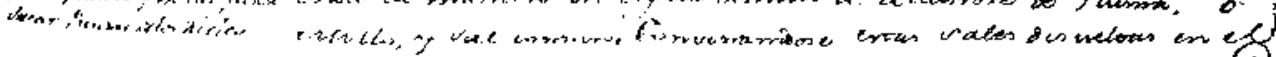

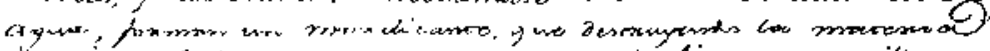

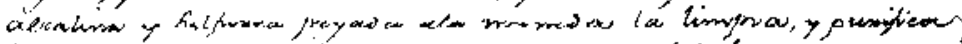

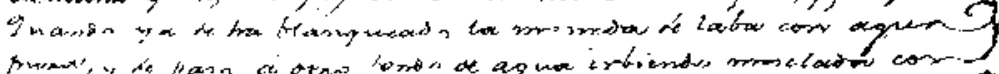

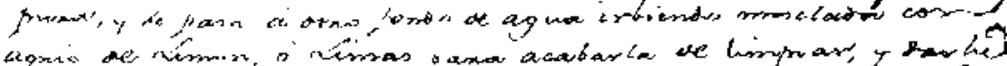

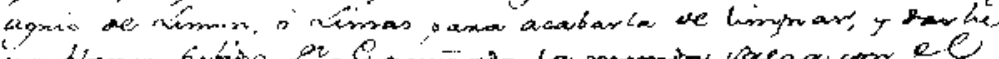

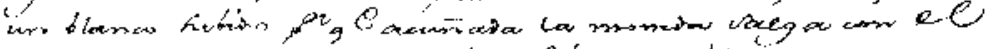

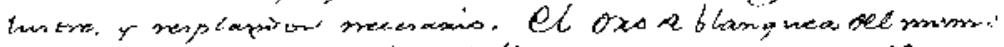

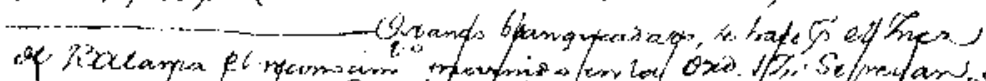

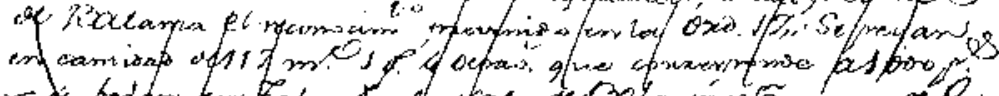

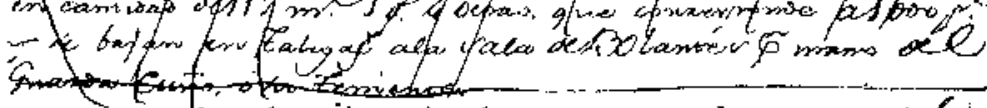

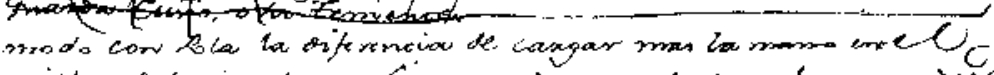

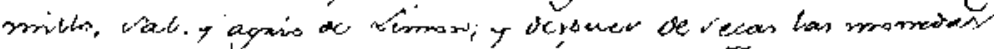

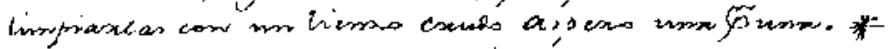

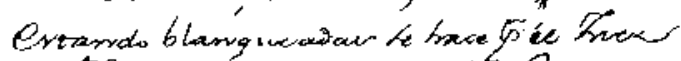

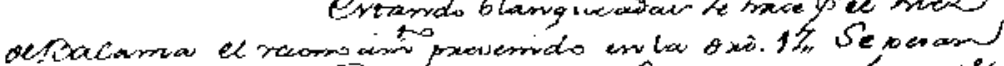

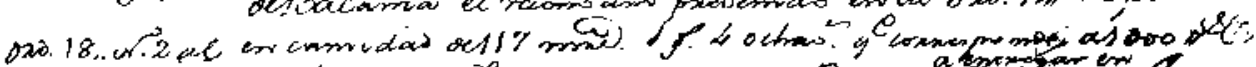
moio

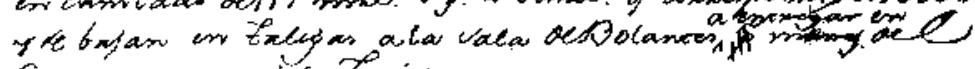

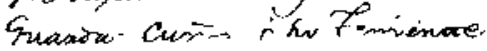

Facsímil de una página del primer volumen del Manuscrito de esta obra, que se conserva en el Museo Nl. de la Casa de Moneda.

(Corresponde el texto a la pág. 194). 


$$
=
$$


ve a circular mediante su cambio por producciones o por trabajos. Pero en habiendo algún obstáculo que suspenda esta circulación desde los depósitos a los canales, y desde éstos a los depósitos, entonces desfallece forzosamente el comercio.

Los grandes negociantes de España son como los depósitos universales de todo el clincro de las Indias, y aunque descle alli circula por otras partes, jamás relluye a nuestros paíscs; de que se sigue que a fin de que no quede sin acción esta gran parte clel Estado de España, es menester reservar en ella uma cinta cantidacl para mantener el comercio interior y para recurso de algunos accidentes, o para mejorar más adelante su condicion. Ello es cierto que el nercader y el artesano nada pueden sin dinero, y aun el cindadano particular, para el gasto diario, para pagar el salario cie los que viven do sir trabajo y para satisfacer a aquellos mercaderes que sólo compran y revenden menudeado, para lo cual es preciso que les entren sus fondos continuamente.

Por estos canales pequeños es por donde se hace la circulación más sensible; pero siempre a dincro y pocas veces al crédito, porque como en torlas estas Provincias hay tan poca agricultura, no sucede lo que en otras partes, de pagarse el costo de las primeras materias con ellas mismas o con bobidas o con ganados al labrador que las trabajó. El ejercicio de la minería pide dinero efectivo para ol pago de los crecidos salarios de los trabajadores, para la compra de los costosos materiales que necesitan y para la continua habilitación de las minas ya aguadas o empobrecidas por otias causas. Jáls maderas, el hierro, el plomo, el cobre, la sal, el azogue, cl carbón y otras mil cosas que se trafican en estas Provincias de unos lugares con otros, exigen caudal pronto para su pago; y siempre que no st reservara una cierta cantidad para estos giros, con prohibición de extiaerse fuera del Reino, sería preciso que todo se hiciera sobre crédito, que aun no se ha establecido por estas partes en su verdadero pie ni es fácil de establecerse.

Io más es que, según se ve por experiencia, todas las producciones de las más ricas minas, nusca llegan a enriquecer al minero, porque cuanto le entra por la una mano, lo despide por la otra para satisfacer al Banco los auxilios, al artesano su trabajo, y al mexcader las materias que le vendió o revondió, para llevar corriente su labor; ya se ve que en cada cambio de ustos tiene su movimiento el dinero y este impulso causa la circulación; al cabo de pocos años, el mercader que vendió muchas materias, cl labrador que expendió a este respecto sus producciones de vinos, aguardientes, trigo, grasa, cueros y ganados, y el artesano que puso mucho trabajo, vendrían a scr unos depósitos pinguies de la moneda menuda de las Américas. Entonces tendría el Rey un recurso seguro para sus desagravios y para defensa de estos Reinos en las ocasiones de guerra y ótros accidentes, echando mano del caudal de sus vasallos por préstamo a interés; y las correspondencias mismas del comercio de España a Indias, estarían menos expuestas a quiebras, porque en cl caso de haberse introducido a ellas más géneros y frutos do los que se pueden consumir o de más valor que el importe de las producciones de nuestras minas, no quebraría el mercader y tal vez ni aun retardaría sus pagos, porque entonces ocurriria a los depósitos referidos de la moneda menuda y sacando la precisa a interés o a premio, la cambiaría con plata doble en las Administraciones de Rentas para remitic a España, quedando la menuda en el país, para el 
sucesivo giro de su comercio interior; de suerte que en el término de medio siglo tendríamos en nuestro continente muchos centenares de millones para todos los interesantes objetos expresados, si las Casas de Moneda del Reino cumpliesen con cxactitud las Providencials que hemos apuntado, $y$ se guardasen con rigor las Reales Ordenes prohibitivas de su extracción; pero las miramos relajadas con notorios daños en la continua saca de plata menuda fuera del Reino, por la ambición do lucrar el premio que pagan por ella igual a la doble. De esto procede, habiéndose labrado en las 645 rendiciones hechas en esta Casa, desde cl año de 1773 , en que comenzó la labor de cordoncillo, hasta el 21 de octubre de este año de $1786,276.856$ y $1 / 2$ marcos, en moneda de doce reales y medio, que importan, reducidos a pesos, 2.353 .270 pesos 2 reales, que no se encuentren en esta Vilia 1.000 pesos para cambios; y para hacerlo en las pulperias, es menester comprar algo de ellas, poi vía de interés. Lo peor es que hay azoguero que no tiene 20 pesos de plata menuda, para pagar leguajes y jornales a los indios mitarios, con visible perjuicio de todos. Nada conviene tanto como el cuidado de mantener en nuestro Continente esta especie de moneda, dando por decomiso la que se sacale fuera del Reino; sólo si, de tiempo en tiempo sería menester recogerla para el cuño, porque su misma circulación la volvería tan feble o falta de ley, que se haría conveniente proporcionarle su debido equilibrio dando correspondencia a su valor intrínseco con el extrínseco.

\section{NOTICIA C UADRAGESIMAOCTA VA}

Sobre el feble de la moneda. I a que hemos hablado del feble, explicaremos menudamente el permitido en todas las suertes de monedas, para mejor inteligencia de la Ordenanza 18 que trata del fuerte y feble de ella. Es menester distinguir el fuerte o feble de peso real o del marco, del que es feble do ley o fineza. I a diferencia se conoce por los granos de que se compone. Cada grano de ley o fineza tiene 16 granos de peso real y un marco de 12 dineros, que es la ley suprema de la plata, y tiene 4.608 granos de peso y 288 granos de fineza, que son las partes en que se dividen los 12 dineros, al respecto de 24 granos eada uno. Considerada pues de este modo una pieza de plata, como un todo compuesto de 12 dineros, se dice muy bien que su título o ley es de $\mathbf{1 1}$ dineros, si la plata contiene una parte de liga, y que es de 10 si contiene dos. A este respecto, ensayada una meneda, si se balla de un grano menos de 11 dineros, será su título 10 dimeros 23 granos y se dirá feble de un grano o, según el lenguaje vulgar, que tiene un grano más de cobre del que debía tener. Lo mismo se entiende en el oro, discurriendo por su división en 24 quilates; y por esta razón, todo lo que hajare de esta ley, será lo que tenga de materia extraña y se dirá que es su feble.

En este concepto corresponde al real de a 8 de feble o fuerte permitido, 2 graros y $2 / 17$ avos. Al real de a 4,1 grano y $1 / 17$ avos. Al real de a 2, 1/2 grano. Al real, 1/4 de grano próximamente. Al medio real, 1/4 de grano, porque el fuerte $y$ feble permitido a cada marco de mediosreales, son 34 granos, como se ve en la siguiente demostración : 
Granos de peso de la moneda.

Granos de fuerte o feble.

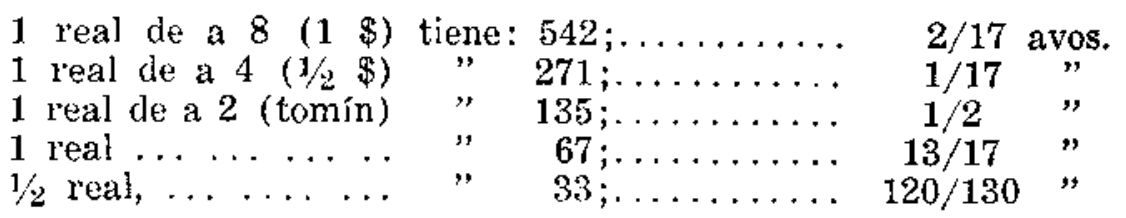

Véase aquí deducidos los 34 granos escasos de feble o fuerte que permite la Ordénanza, según se ha dicho, en cada marco de medio real. Ahora se sigue demostrar la falla de la moneda en sus cinco suertes, para aumentar coll ella en cada marco los 3 reales 33 maravedíes, que es la décimasexta parte menos dos maravedies de aumento en cada marco, según prevención de la Ordenanza 16, para ajustar a este cálculo la ganancia que percibe la Casa en cada 100 marcos, la cual se reduce a 49 pesos 2 reales, 4 maravedies.

Ejemplo de la demostración:

El real $(\$)$ de a $8, \ldots \ldots \ldots$ tiene de falla 16 granos.

El real $(1 / 2 \$)$ de a $4, \ldots \ldots \ldots$ ",$\ldots$ " 8 "

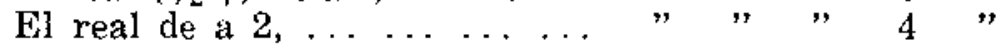

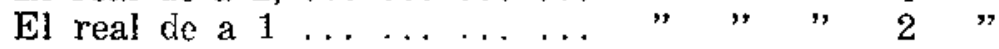

El medio-real ... ... ... ... " " "

Ajustadas las monedas a su debido peso y ley, se aprueba la rendición con las formaliclades y circunstancias que previene la Ordenanza 19, y con asistencia de los Ministros que prescribe ella misma al No 3", tomándose razón por un Oficial de Contaduría y otro de Tesorería, en sus respectivos libros manuales llamados Planillas.

\section{NOTICIA CUADRAGESIMANOVENA}

Formalidades en las Libranzas. $\quad$ $\mathrm{I}$, feble se separa de cada 200 marcos en la plata y de cada 100 marcos en el oro, sobre la mesa; esto es, que contados 1.700 pesos que deberían producir los 200 marcos de plata, u 850 doblones de a 8 escudos los 100 marcos de oro, (si estuviera la moneda ajustada a su legítimo peso) las piezas que sobran son el feble que resulta, aunque de él hay que reintegrar el principal valor del importe de las ochavas y tomines que tienen de quebrado las pesadas de a 100 marcos, respecto de pesarse cada suerte de moneda con separación y no poder verificarse el que salgan las pesadas de a 100 marcos cabales; por lo que acaban de contar la libranza juntos todos los febles de cada 200 marcos en la plata o de 100 marcos en el oro, y reconocido el total importe de ellos, se separa el de los quebrados, que pertenece al principal, y el residuo es el feble líquido que se encierra y guarda con las intervenciones prevenidas en la Ordenanza $19, \mathrm{~N} 74$.

El Tesorero procede a recibir el valor principal de la libranza, en talegas de a 1.000 pesos, por el peso neto de 117 marcos 1 onza 4 ocha- 
vas poco más o menos, que debe tener conforme a la Ordenanza 18, N 2; sirviendo esta operación para calificar de nuevo si los contadores de moneda han padecido equívoco, el cual se enmienda volviendo a contar.

\author{
NOTIOIA QUIN O UAG ESIMA
}

Método de formar los cargos y datas al Fiel y Tesorero en las rendiciones.
C libranza, se extiende la certificación que dispone el $\mathrm{N}$ ? 5 de la Ordenanza 19 , por triplicado, para encer'rar una y remitir dos, por principal y duplicado, a la Corte, introduciendo dentro de ellas las monedas y pallones que se sacaron para ensayes y remisiones. Novísimamente está mandado, en Real Orden de El Pardo a 24 de marzo de 1781, que cada cuatro meses se envíe al Rey, un estado de oro y plata que se amonedare en la Casa, y al fín de cada año el cie todo él, firmado por el Contador y el Superintendente.

De cada rendición resuita partida cle data al Fiel, del número de marcos que entrega, conforme a las Ordenanzas 19 y 20 , y cuatro partidas de reales, dos de cargo y dos de data al Tesorero.

Las de cargo son la utilidad que produce, a razón de 3 reales 32 maravedies en marco de plata, y 7 pesos 7 reales 2 maravedies en marco de oro, que es la diferencia que hay entre los 8 pesos 2 maravedies y los 128 pesos 32 maravedíes de su valor intrínseco respectivo como pasta, y los 136 pesos y los 8 pesos 4 reales del extrínseco en moneda. La otra segunga partida de cargo es el feble que resulta de la rendición, cotejado este valor extrinseco con la moneda contada.

Las partidas de data son las que se sacan para remisiones a España y para ensayes de cada libranza. Estas monedas, previene la Ordenanza $19, N^{\circ} 1$ y $N^{\circ} 5$, sean tres de cada taniaño, una para ensayes y para la arca de encerramiento, y dos para remitir a la Corte por principal y duplicado; pero esta operación se ejecuta solamonte en las tres suertes de moneda de a peso, tostones y doses. En las de reales y medjos, se sacan cinco monedas: dos para ensayes, una para el arca de encerramiento y dos para remisión.

Estas cuatro partidas de cargo y data son las que se forman al Tesorero en su cuenta por cada rendición, conforme al No 6 de la Ordenanza 23. No se le hace cargo del importe del valor intrínseco de los metales como supone la Ordenanza 19, $\mathrm{N}^{\circ} 4$, porque esto sería duplicársele, una vez que al comprarlos, se le formó en especie, recibiéndole en data (en el Libro General de Compras, partida por partida, con la expresión de la Ordenanza $23, N^{\circ} 5$ ) su legítimo valor pagado a los interesados; y en pasta por los remaches entregados al Fundidor Mayor; cuyas existencias de metales, las del Fiel y las que tuviere el Tesorero en el Tesoro principal, al tiempo de hacer el corte y presentar la cuenta, sólo se le consideran por su valor intrínseco; de manera que en cuanto a las pastas, no debe llevar ni lleva otra cuenta que el Libro General de Compras, acimitiéndosele en data el valor intrínseco a que se compraron, y las que se hallan repartidas en otras oficinas. 


\section{NOT ICIA Q U I N C U A G E S I M A P I M E R A}

sobre las mermas de la Dixpuesto ya todo lo perteneciente a Fielatura. $\quad \mathrm{J}_{\mathrm{i} i s}$ obligaciones del Fiel, debe prevenirse que aunque en ninguna Ordenanza se determina sobre las mermas o desperdicios de la Fielatura, éstos se califican y resuelven con arreglo a la Ordenanza 28, No 4, que trata del Fundidor Mayor. En cuya conlormidad rinde el Fiel cada año la cuenta del oro, y la de plata cada dos, por las demoris en a beneficio de tierras y escobillas, que se practica por peritos. Estas cuentas se ven y comprueban por el Contador, y se aprueban por el Superintendente, sin necesidad de más calificación y sirn que salgan de la Casa, a menos de ocurrir sobre aumentos a mermas, algún repar'o gi'ave que sea preciso consultarlo a la superioridad, según Ordenanza $28, N^{\circ} 4, y^{\prime}$ aunque al tiempo de formarse las Ordenanzas corria la Ficlatura por Asiento, se entienden con los Fieles Administradores todas sus disposiciones.

Como son tan varias las operaciones de esta Oficina, pueden montar sus mermas mutchos mikes sólo con variar un maravedí, dando ocasión a repetidas consultas para su determinación. En esta Casa han llegado, en ocasiones, las mermas hasta $19 \mathrm{y} 1 / 2$ marcos en millar, que sin duda son demasiado excesivas haciendo cotejo con las de México, donde el oro no pasa de ocho hasta veintidós onzas en cada mil marcos, y la plata desde catorce hasta veintitrés onzas el millar.

\section{NOTIOIA Q UI N C UAGESIMASEGUNDA}

De las causas a que se atri-
buyen las mermas de la Fie-
latura. y escobillas; a las que pucde añadirse la cuarta, del inmenso desperdicio de cizalla. Es verdad que en esta Casa se han experimentado robos muy considerables de rieles y barras enteras, por cuyo delito fue ajusticiádo el año de 1788, un tal Requena; pero, como estos excesos no son tan continnos que se ejecuten cada año, ni duran por siempre, al paso que, el año que menos, suben las mermas a cinco o siete marcos en el millar, las atribuyen a las demás causas referidas.

Se reputa como principal, la mucha mezcla de bronce que traen las platas de la Ribera de esta Villa y de otros Asientos del Reino; porque moliendo los metales en almadanctas de bronce, que regularmente pesan de diez hasta doce arrobas, se experimenta que al cabo de tres o cuatro meses, han mermado seis, siete y ocho arrobas; lo cual sólo puede suceder desgranándose de las almadanetas el bronce que falta y mezclándose con la plata que se beneficia. La Administración o Factoría del Real Banco conoce muy bien esta trampa; pero la disimula atendiendo a la miserable decadencia de la azoguería, y por no sufrir las mermas con- 
siguientes si apurasen el fuego a las piñas al tiempo de fundirlas para hacer las barras, usarían precaución de vaciar en los moldes el metal luego al punto que se funde la piña.

El Afinador de esta Casa, y el Fundidor Mayor, tampoco ignoran estos arbitrios; pero los suben con otros de igual cautcla para evitar las mermas en sus oficinas. De aguí nace que, no teniendo la Fielatura donde recostar sus operaciones, viene a reconocerse todas las fallas ocultadas de antemano, en la verdadera afinación de las platas, que se hace en la fundición de cizallas.

La tercera causa puede ser el imperfecto beneficio de las tiemas y escobillas. En esta Casa se han practicado tres modos diferentes, en diversos tiempos. El Oidor Don Pedro Tagle, siendo Superintendente, estableció el beneficio ordinario que se da a los metales en la Ribcra, por ministerio del azogue, que llaman por buitrón. Sus progresos no fueron tan felices (como se creyó) bien sea por falta de mayor atención o por la estrechez de la Casa, que no dio mejor lugan a las operaciones; por lo que se varió en tiempo de Dn. Jorge Escovedo, entablándose el segundo método de beneficio por cocimiento, c] año de 1778 .

Al principio se concibió alguna utilidad en varios experimentos que se practicaron; pero a mediados del año de 1780, se llegó a conocer que sobre ser muy dudosas las ventajas, era excesivo el costo y las operaciones demasiado lentas y desproporcionadas para dar salida a las muchas tierras, ciscos y cenjzas que se hacen en la Fielatura, Fundición Mayor de cizalla y afinación.

Entonces entabló siendo Superintendente Dn. Juan del Pino Manrique, el beneficio por sutil en unos pequeños ingenios, semejantes a los que sirven en España para moler aceitunas; ${ }^{70}$ mandó fabricar dos ingenios dentro de la Casa, con el primer destino de moler huesos calcinados para acendradas, y hoy sirven para triturar las tierras, escobillas, ciscos, relaves y cenizas de todas las oficinas. En la misma base donde se mueve la rueda, que es de piedra, con una vara y poco más de diámetro, está la tierra remolida mezclada en agua, y arrojando azogue, recoge este ingrediente a muy poca costa, el metal menudo que se oculta en la escobilla y basuras. Ha sido imponderable la utilidad de esta operación ne solamente para ahorro de las excesivas mermas anteriores, sino también para facilitar a menos tiempo el despacho de las cuentas, que tanto se retardaba antes por la lentitud del beneficio de tierras, reconociéndose mejor esta ventaja, con cotejo al segundo beneficio que se hace de las lamas, donde el costo es mayor que la utilidad.

Yo juzgo que mueha parte de los desperdicios se halla sepultada en los acueductos o acequias por donde se desaguan las lavas del beneficio de las tierras, $y$ es verosímil que se encuentre en ellas un eaudal crecido, si se purificase el barro de su fondo, repitiéndose algunos beneficios de estas tierras, como sucede en los ingenios grandes de la Ribera, de cuyos lavaderos se arrastra por el agua porción de plata mezclada en relaves $y$ en azogue, de tal forma, que las pertenencias de un ingenio a otro, que muchas veces no exceden de dos cuadras, suelen venderse a once y más pesos semanales, a unos indios que llaman Cafuachanis, que tienen por oficio recoger aquellas tielras para volverlas a beneficiar. En esta Casa de Moneda se cuenta que su Tesorero limpió ahora muchos años las acequias, y de gran cantidad de cajones de tierra y barro que juntó, 
se benefició con porción de plata. Ahora que con la moneda de cordoncillo y de oro, debo haber más desperdicio por la cizalla, limaduras y demás operaciones que preceden para ajustarla a su verdadero peso y ley, no pongo duda en atribuír mucha parte de las mermas a las pérdidas en el beneficio de tion'tas, y asimismo que se hallaría un caudal beneficiando las del fondo de las accquias; sir detenerme en decir que sería una de las principales comonias de la Casa limpiar las acequias cada quinquọnio, a más tałdelr, con cuyo cuidado, además de unos grandes ahorros, so palparía este motivo que ahora se ignora de las asombrosas mermas de la Ficlatura.

Tambien puede contribuí no poco el demasiado dosperdicio de la cizalla, por no observarse lo dispuesto en la Orodenanza $27, \mathrm{~N}^{\circ} 4$, de Lima, soble amonedar de los metales cmrielados, las dos tercias partes, de modo que resulte una cle cizalla, con corta diferencia; es decir, que de 9.000 mal'eos dé r'jeles, salgan 6.000 mar'os de moneda y 3.000 de cizalla. En esta Casa se halla en el día reducido a poco más de la mitad de moneda $y$ el resto on cizalla; esto es, que de una partida de 9.000 marcos de rieles, salen 5.000 marcos de moncda y 4.000 de cizalla. Para esto se alega que en ninguna Casa do Moneda del Reino, se ha verificado hasta ahora la disposición de la Ordenanza en lo grueso de la labor, aunque en particulares experimentos hechos, de uno, dos, o más rieles útiles, se ha encontrado la proporción prevenida en dicha Ordenanza, añadiende que, por esta razón, no se manda y sólo se encarga. Ello hace imposible proporcionar la cizalla a sólo una tercera parte de los rieles; pero no puedo creer gue si hubiera un particular cuidado en el asunto, dejase de haber aumento en la proporción de moneda, respecto a la gue ahora se corta. Si d tiempo y el esmero disminuyen estos desperdicios, se experimentarán de consiguiente las veritajas de que ahora earece la Casa, porque a nadie se oculta que bajando de ley la cizalla de plata y oro si se le da un fuego extraordinario o se le mezcla más cobre dél necesario, es forzoso que al menor descuido de estas operaciones, se sigan muchas irremediables mermas, si bien que el actual Fiel Administrador, observa en la fundición y refundición de cizalla de plata, para que no haya alteración en la ley, la religa de cada 450 mareos con 20 ochavas 2 y $1 / 2$ onzas de cobre, con el fin de proporcionar la igualdad de su ley a la que aumenta el fuego, en la scgunda fundición y subsecuentes refundiciones; pero nada de esto deja ser expuesto a quiebras.

Estas operaciones de fundición de cizallas corren a cargo del mismo Fiel, y se hacen cuando éste lo tiene por conveniente, en dos crisoles - callanas de barro que tienen este destino, con sus correspondientes aperos. De la cizalla gruesa se forman unas pelotas de 150 a 170 marcos de peso, encerrando en su interior la cizalla menuda del desgrano de la plata al tiempo de labrarla en los bancos, on los cortes y en los molinos; $\mathrm{y}$ en este estado bajan a la fundición de cizalla. Para la de oro, no hay mâs que una callana chica; y unas y otras se funden al modo prevenido en la Ordenanza 21. 
De la verdadera ecomomía DE todos estos principios resulta que la te la Casa. verdadera conomía de que peizden las ventajas de que cs capaz la Fielatura, y apuntó el Sr. Arriaga, primer Ministro de Inclias, en su carta circular a todas las Casas de Moneda de ellas, se reduce a lo siguiente: El cobre con que se liga la plata y oro, para adecuar su ley al cómputo de 11 dineros la primera y de 22 quilates el segundo metal, mejora o perjurica ambas condiciones, no siendo la suya de la mejor calidad. Se acostumbra mezclar el cobre en granalla; y de esto nace que derramadas de la callana sus partículas menudas, y la tierra que se separa por no ser materia fusible, hace faltar la liga que se calculó, sube la plata de ley y rusulta de menos al peso, con mermas perjudiciales a la Real Hacienda; al contrario es si se afina antes la granalla, porque vaciándola on tejos no tiene peligro de derramarse; se extrae la tierra y más purificado el cobre con el fuego, hace mejor unión con la plata, sale de mejor caliclad y liás cierta su ley para conseguir los aumentos; es verdad que ocasiona alguin costo esta afinación, pero supercrecen las ventajas en la plata. Véase aquí cuánto cuir dado debe ponerse en hacer las mezclas con cobro fundicio en tejos y bicn afinado, buscando el de mejor calidad, para no aventurar unas operaciones de tanta importancia.

No la tiene menos el que los rieles sean bien vaciados, para que todos sean útiles; porque de lo contrario, apenas producen una tercera parte de moneda, causando excesivo costo a la oficina, por la mucha cizalla que resulta.

Sobre todo, conviene que haya siempre en la Fielatura un fondo existente, de 30 ó 40.000 marcos de plata, para girar de continuo con esta masa, por ser el único medio de minorar el crecido gasto semanal de jornales y materiales. No importa menos que la Casa esté siempre bien proveída de buen hierro, acero y herramientas, y principalmente cle Maestros y oficiales hábiles de herrería y cerrajería, porque de su falta proceden gravísimos perjuicios a la Fielatura y Talla.

Observándose estas importantes precauciones se experimentaría en breve las utilidades de que carece la Casa. Se aumentaría la labor, y la Real Hacienda sentiría muchos más aumentos que ahora.

\section{NOTICIA Q U I N U U G ESIMA CUA R T A}

Medios para amentar la $\begin{aligned} & \text { RESPECTO a que el oro deja mayores pro- } \\ & \text { labor del oro. } \\ & \text { ductos, debe procurarse con preferencia el } \\ & \text { aumento de su labor, proporcionando el giro }\end{aligned}$
continuo de sus rescates sin disminuír por ningún caso el fondo con que
debe hacerse; porque los interesados que traen sus oros en pasta para in-
troducir a la Casa, examinan primero si las pagas en moneda se harán
con toda la brevedad que tanto recomienda la Ordenanza 10 , No 1 , por lo 
Rey en cada marco de plata; y a siete pesos, siete reales y dos maravedíes en cada uno de oro, reducido el valor de lit plata a la ley de 11 cineros justos, y el del oro a veintidós quilates. (11)

El mismo estado manifesta en sus correspondientes notas, todas las circunstancias que hacen subir los valores totales a las cantidades expresadas, y al mismo tiempo los fondos, entradas, salidas y ganancias que ha producido el giro de la Casa; de suerte que, a golpe de vista, sc puede comprender el por mayor de toda la economía de esta importantísima Oficina, para que cotejándose las utilidades con los gastos de braceaje, pueda calcular un hábil Superintendente o Director las mayores ganancias que puede rendir, ya sea en utilidades efectivas o en ahorros de economía, que, a mi entender, es el medio más oportuno para los adelantamientos de la Casa.

Y para que nada se eche menos de cuanto es anexo y concerniente a los conocimientos de esta materia, concluyo poniendo dos tablas que sirven para ajustar los valores del oro y plata, por la reducción de sus leyes a dineros y a quilates, conforme a las que debe tener la moneda; todo con el fin de que esta obra sea útil indistintamente al Superintendente y demás Ministros de la Casa de Moneda.

T A B L A I.

PARA AJUSTAR EL VALOR DE LOS MARCOS DE ORO DE 22 QUILATES, DESPUES DE VERIFICADAS LAS REDUCCIONES A ESTA LEY; Y TAMBIEN PARA DEDUCIR EL REAL DERECHO DEL $3 \%$, PERTENECIENTE A S. M., A SABER:

ORO DE 22 QLTS.

$\begin{array}{lrll}\text { Marcos } & \text { Pesos } & \text { Rls. } & \text { Mrs. } \\ 4.000- & 512.470 .- & 4 .- & 24 .- \\ 3.000 .- & 384.352 .- & 7 .- & 18 .- \\ 2.000 .- & 256.235 .- & 2 .- & 12 .- \\ 1.000 .- & 128.117 .- & 5 .- & 06 .- \\ 900 .- & 115.305 .- & 7 .- & 02 .- \\ 800 .- & 102.494 .- & 0 .- & 32 .- \\ 700 .- & 89.682 .- & 2 .- & 28 .- \\ 600 .- & 76.870 .- & 4 .- & 24 .- \\ 500 .- & 64.058 .- & 6 .- & 20 .- \\ 400 .- & 51.247 .- & 0 .- & 16 .- \\ 300 .- & 38.435 .- & 2 .- & 12 .- \\ 200 .- & 25.623 .- & 4 .- & 08 .- \\ 100- & 12.811 .- & 6 .- & 04 .- \\ 90 .- & 11.530 .- & 4 .- & 24 .- \\ 80 .- & 10.249 .- & 3 .- & 10 .- \\ 70 .- & 8.968 .- & 1 .- & 30 .- \\ 60 .- & 7.687-- & 0 .- & 16 .- \\ 50 .- & 6.405 .- & 7 .- & 02 .- \\ 40 .- & 5.124 .- & 5 .- & 22 .- \\ 30 .- & 3.843 .- & 4 .- & 08 .- \\ 20 .- & 2.562 .- & 2 .- & 28 .- \\ 10 .- & 1.281 .- & 1 .- & 14 .- \\ 9 .- & 1.153 .- & 0 .- & 16 .- \\ 8 .- & 1.024 .- & 7 .- & 18 .- \\ 7 .- & 896 .- & 6 .- & 20 .- \\ 6 .- & 768 .- & 5 .- & 22 .- \\ 5 .- & 640 .- & 4 .- & 24 .-\end{array}$

REALES IDERECHOS

$\begin{array}{clll}\text { Pesos } & \text { Rls. } & \text { Mrs. } & \begin{array}{l}10.000 \\ \text { Avos. }\end{array} \\ 15.374 .- & 0 .- & 32 .- & \\ 11.530 .- & 4 .- & 24 .- & \\ 7.687 .- & 0 .- & 16 .- & \\ 3.843 .- & 4 .- & 08 .- & \\ 3.459 .- & 1 .- & 14 .- & \\ 3.074 .- & 6 .- & 20 .- & \\ 2.690 .- & 3 .- & 26 .- & \\ 2.306 .- & 0 .- & 32 .- & \\ 1.921 .- & 6 .- & 04 .- & \\ 1.537 .- & 3 .- & 10 .- & \\ 1.53 .- & 0 .- & 16 .- & \\ 768 .- & 5 .- & 22 .- & \\ 384 .- & 2 .- & 28 .- & \\ 345 .- & 7 .- & 11 .- & 6.000-- \\ 307 .- & 3 .- & 29 .- & 2.000 .- \\ 269 .- & 0 .- & 12 .- & 8.000 .- \\ 230 .- & 4 .- & 30 .- & 4.000 .- \\ 192 .- & 1 .- & 14 .- & - \\ 153 .- & 5 .- & 31 .- & 6.000 .- \\ 115 .- & 2 .- & 15 .- & 2.000 .- \\ 76 .- & 6 .- & 32 .- & 8.000 .- \\ 38 .- & 3 .- & 16 .- & 4.000 .- \\ 34 .- & 4 .- & 24 .- & 9.600 .- \\ 30 .- & 5 .- & 33 .- & 5.200 .- \\ 26 .- & 7 .- & 08 .- & 0.800 .- \\ 23 .- & 0 .- & 16 .- & 6.400 .- \\ 19 .- & 1 .- & 25 .- & 2.000 .-\end{array}$


ORO DE 22 QLTS.

SU VALOR

REALES DERECHOS

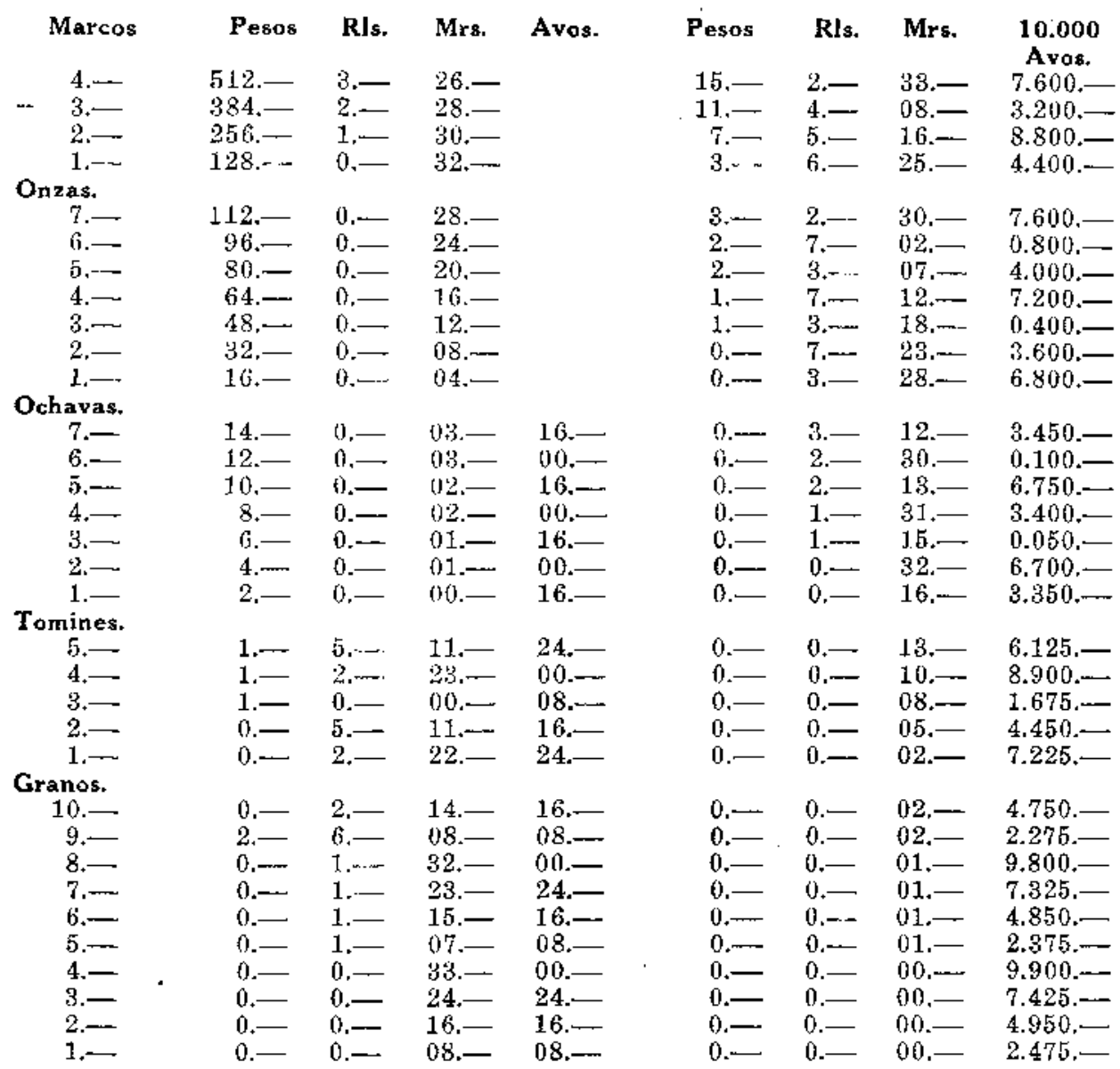

T A B L A I I.

VALOR DE LA PLATA DE LEY DE 11 DINEROS JUSTOS, A 8 PESOS 2 mrvds. Marco.

\begin{tabular}{|c|c|c|c|c|c|c|c|c|}
\hline Marcos & Pesos & RIs. & Mrs. & Onzas & Pesos & $\mathbf{R} \mathbf{l}_{\mathrm{s}}$ & Mrs. & Avos. \\
\hline $10.000 .-$ & 80.073 & 4.- - & $08 .-$ & 7.- & 7.- & $0 .-$ & $01 .-$ & \\
\hline 9.000. & $72.066 .-$ & 1.- & $14 .-$ & 6.- & $6 .-$ & $0 .-$ & $01 .-$ & $16 .-$ \\
\hline $8.000 .-$ & $64.058 .-\ldots$ & 6.- & $20 .-$ & $5 .-$ & 5.- & $0 .-$ & 01... & $08 .-$ \\
\hline $7.000 .-$ & $56.051 .-$ & $3 .-$ & $26 .-$ & 4.- & 4.- & $0 .-$ & $01 . \ldots$ & 00. \\
\hline $6.000 \ldots$ & 48.044 & $0 .-$ & $32 .-$ & $3 .-$ & $3 .-$ & $0 .-$ & $00 .-$ & 24 . \\
\hline $5.000 .-$ & $40.036 \ldots$ & $0 .-$ & $04 .-$ & 2.- & $2 .-$ & $0 .-$ & $00 .-$ & 16. \\
\hline 4.000 & $32.029 .-$ & $3 .-$ & $10 .-$ & $1 .-$ & $1 .-$ & $0 .-$ & 00. & 08. \\
\hline $3.000 .-$ & $24.022 .-$ & $0 .-$ & 16.- & & & & & \\
\hline $2.000 .-$ & 16.014 & $5 .-$ & 22.- & Ochavas. & & & & \\
\hline 1.000 - & $8.007 . \longrightarrow$ & 2.- & 28.- & 7.- & $0 .-$ & 7.- & $00 .-\ldots$ & 07. \\
\hline $900 \ldots$ & $7.206 .-$ & 4. 一 & $32 .-$ & $6 .-$ & $0 .-\ldots$ & 6.- & $00 .-$ & \\
\hline- & 6.405 & 7.- & 02.- & 5.- & $0 .-$ & 5.- & $00 .-$ & 05 . \\
\hline $700 .-$ & $5.605 \ldots$ & $1 .-$ & $06 .-$ & $4 .-$ & $0 .-$ & 4.- & $00 .-$ & 04. \\
\hline
\end{tabular}




\begin{tabular}{|c|c|c|c|c|c|c|c|c|}
\hline Marcos & Pesos & RIs. & Mrs. & Onzas & Pesos & Rls. & Mrs. & Avos. \\
\hline $600 .-$ & 4.804 & 3.- & 10.- & 3.- & $0 .-$ & 3. & $00 .-$ & $03 \ldots$ \\
\hline $500 .-$ & $4.003 .-$ & $5 .-$ & 14.- & 2.- & $0 .-$ & $2 .-$ & $00 .-$ & 02. \\
\hline $400 .-$ & $3.202 .-$ & 7. - & 18.- & 1.- & $0 .-$ & 1.- & $00 \ldots$ & $01 .-$ \\
\hline $300 .-$ & $2.402 .-$ & $1 .-$ & $22 .-$ & & & & & \\
\hline $200 .-1$ & $1.601 .-$ & $3 .-$ & $26 \ldots$ & Tomines. & & & & \\
\hline 100. & $800 .-$ & 5. & $30 .-$ & 5. $\ldots$ & $0 . \ldots$ & $0 .-$ & $28 .-$ & 11. $-1 / 1$ \\
\hline $90 .-$ & $720 .-$ & $5 .-$ & $10,-$ & 4.- & $0 .-$ & $0 .-$ & $22 .-$ & 22 \\
\hline $80 .-$ & $640 .-$ & $4 .-$ & $24 .-$ & 3.- & $0 .-$ & $0 .-$ & 17. & $00 .-1 / 2$ \\
\hline $70 . \ldots$ & $560 .-$ & 4 & 04.- & 2.- & $0 .-$ & $0 \ldots$ & 11.- & $11 .-2$ \\
\hline $60 .-$ & $480 .-$ & $3 .-$ & 18.- & 1.- & $0 .-$ & $0 .-$ & $5 .-$ & $21 .-3 !$ \\
\hline $50 .-$ & 400. & 2. & $32 .-$ & & & & & \\
\hline $40 .-$ & $320 .-$ & 2.- & 12 - & Granos. & & & & \\
\hline $30 . \ldots$ & $240 .-$ & 1. .... & $26 .-$ & $10 .-$ & $0 .-$ & $0 . \cdots$ & 5.- & $05 \ldots$ \\
\hline $20 . \ldots$ & $160 .-$ & 1.- & $06 .-$ & 9.- & $0 .-$ & $0 .-$ & 4.- & $20 .-12$ \\
\hline $10 .-$ & $80 .-$ & 0. & $20 .-$ & 8.- & $0 .-$ & $0 .-$ & 4.- & 04 - \\
\hline 9.- & $72 .-$ & 0. & $18-$ & $7 .-$ & $0 .-$ & 0. & 3. & $19 .-1 / 4$ \\
\hline $8 .-$ & $64 .-$ & $0 .-$ & 76.- & $6 .-$ & 0.- & $0 .-$ & $3 . \cdots$ & $03 .-$ \\
\hline 7.- & $56 .-$ & $0 .-$ & $14 . \ldots$ & 5.- & 0. & 0. & 2. & $18 .-1 / 2$ \\
\hline $6 .-$ & $48 .-$ & $0 .-$ & $12 .-$ & 4.--- & $0 .-$ & $0 .-$ & $2 .-$ & 02. \\
\hline $5 .-$ & $40 .-$ & $0 .-$ & 10.- & 3.- & $0 .-$ & $0,-$ & 1.- & $17 .-1 / 2$ \\
\hline $4 .-$ & $32 .-$ & $0 . \cdots$ & $08 .-$ & 2.- & $0 .--$ & 0.- -- & 1.- & 1) 1. \\
\hline 3.- & $24 .-$ & $0 .-$ & 06. - & 1.-- & $0 . \cdots$ & $0 .-$ & $0 .--$ & $1(1, \ldots-16$ \\
\hline 2.- & 16.- & $0 .-$ & $04 .-$ & & & & & \\
\hline 1.- & 8.- & $0 .-$ & $62 .-$ & & & & & \\
\hline
\end{tabular}

Gabriel de Robles compró en $\mathbf{1 6 . 0 0 0}$ ducados el oficio de Tallador de cuño antiguo de tijera, de esta Casa de Moneda de Potosí; y por fundación de dicho D. Gabricl, recayó en el Colegio de Villa Franca del Bierzo, sin embargo de haberlo renunciado al tiempo de su fallecimiento, en su sobrino Pedro Robles, con quien se siguió pleito en el Consejo, según se acredita por Real Cédula despachada a favor de otro Colegio en 22 de mayo de 1641 , con calidad de perpetuo, vendible y renunciable, en virtud de 8.750 pesos, que donaron a S. M., los ex-Jesuítas. Desde aquel tiempo hasta 14 de agosto de 1767, percibieron los Procuradores de aquel Colegio 4 maravedíes $44 / 100$ por cada marco labrado. Con este motivo de la expatriación, acaecida en 1767, y el de haber venido nombrado para Tallador de la moneda esférica, el año de 1750, Dn. Joseph Fernández de Córdova, con el sueldo anual de $\mathbf{1 . 6 0 0}$ pesos, cesó la casa en la contribución de estos derechos, y se incorporó a la Corona con los demás oficios el año de 1775 , de orden del Virrey Dn. Mamuel Amat, en cumplimiento de la Real Cédula de 21 de mayo de 1770 . En la actualidad es talador Dn. Joseph Castro, por Real Cédula de 3 de julio de 1783, con el sueldo de 1.800 pesos, por lo que no hay Administrador de parte de Ternporalidades, como se preguntó en Real Orden de Madrid, a 7 de diciembre de $1790 .(\mathrm{m})$ 


\section{A P E N D I C E}

\section{Al Capítulo octavo de la primera parte, desde la noticia XXXVI.}

Contiene los artículos más dignos de reforma en esta Real Casa de Moneda, con varios discursos económicos y químicos que manifiestan los medios proporcionados para lograr este fin.**

\section{A R T I C U L O PR I M E R O}

C

OMO los ensayes de metales en las Casas de Moneda sirven de balanza a la fe pública y son una medida infalible para ajustar la ley verdadera del oro y de la plata, han puesto por todos estos respetos su principal cuidado todos los soberanos del mundo en este Artículo así para no perjudicar a los vendedores particulares marcándoles menos ley de la que tienen realmente sus metales, como por evitar perjuicios en la opinión del Gobierno y en las utilidades del Fisco, si las monedas salen con más o menos ley de la establecida por el derecho público de cada Nación; bien sea por impericia de los ensayadores, o por otros motivos sean los que fuesen.

El escrúpulo de nuestro Gobierno se ha distinguido con especialidad en su vigilancia sobre este importante objeto; pues, no contentándose con celar la observancia de los métodos dictados después de largas experiencias por las Ordenanzas de Moneda, ha querido aprovechar sin emulación las mejoras que se han reconocido en otros reinos, con el adelantamiento de las Ciencias Naturales.

A este fin se despachó Real Orden el año pasado de 1786, dirigida a los Superintendentes de todas las Casas de Moneda de América, acompañando la Docimástica o Arte de Ensayes de Mr. Sage, traducida en cas- 
tellano, para que se practicasen nuestras operaciones con arreglo a las advertencias, documentos y modelos de este sabio autol; ; y en efecto, se pasó este precioso libro a los ensayadores de Potosí, con las prevenciones oportunas.

Yo confieso habex vivido en la creencia de que Mr. Sage era el maestro que seguían estos ensayadores en las operaciones de su ministerio; pero en este año del 89 he venido a descubrir mi engaño, no menos que los daños que probablemente debemos recelar, que se han originado de no haberse cumplido las ordenes del Rey en este grave asunto.

Con motivo de hallarse de tránsito en esta Villa el Barón de Nordenflicht, *** (Director general nombrado para las minas del Perú) pasó a la Casa de Moneda, el día 29 de enero, a ruego del actual Superintendente de ella, Don Francisco de Paula Sanz, acompañado de Don Antonio Sacharias, individuo de su expedición, $y$ de otros varios caballeros de esta Villa: reconoció prolijamente las oficinas de ensaye, afinación, fundición y fielatura; se impuso por mayor en el método de su trabajo, conferenciando brevemente las materias con los ensayadores y demáts Jefes de dichas oficinas, prometió volver el día 31, para ejecutar por sí mismo algunos experimentos.

El día emplazado practicaron nuestros ensayadores el ensaye de dos rieles de oro, en presencia de varias personas, y expusieron haber encontrado un solo grano de feble, que es el permitido por la Ordenanza: entonces el Barón y Don Antonio Sacharias, reconocicron los pallones del oro ensayado y preguntaron la ley que señalaba nuestro Dineral : a lo que habiendo respondido nuestros ensayadores, que tenía veinticuatro quilates, replicaron los otros, que debía dudarse, siempre que no hubiesen hecho la disolución del oro por agua regia, porque en su concepto tenía aquel pallón grano y medio de plata.

Para justificar su opinión hicieron ellos mismos el agua regia, añadiendo una tercera parte de agua común (a falta de destilada) en un frasquito pequeño, que tendría media onza de agua fuerte, con otra tanta cantidad de sal común, por no haberse tenido allí a la mano la sal amo- niaca: en el agua regia que resultó de esta mezcla, después de calentada al fuego, sobre una capa de arena fina, hasta quedar la sal cnteramente disuelta, metieron el pallón de oro en presencia de muchos sujetos de carácter, que estaban congregados en el lugar que llaman Iaboratorio de Ensayes. En pocos momentos se disolvió todo el oro, haciéndose imperceptibles en el agua regia todas las partecillas muy menudas que subían hacia el cuerpo de la botellita, en figura de ampollas pequeñitas de color de humo espeso; y al mismo tiempo que parecía haberse reducido en agua todo el oro, se fueron precipitando sensiblemente al fondo del frasquito unas partículas minutísimas de plata, en forma de luna córnea.

Inmediatamente se vació el agua regia para recoger la plata, y extraída que fue, echaron al frasquito limaduras de acero, y conforme se iban disolviendo se fué precipitando el oro, que también se recogió después; aunque no era posible evitar el menor desperdicio por la absoluta falta de utensilios que se advirtió en aquel laboratorio.

Luego que pasaron la plata, salió un grano en un cuarto de luna córnea; atribuyéndose que el otro cuarto que faltaba para el medio grano, no. se había podido recoger por la mala calidad del frasquito. Por la misma causa el oro, que debía resultar de veintitrés quilates y tres cuar- 
tos, salió únicamente de tres quilates y un grano, perdiéndose los veinte quilates restantes.

Con esta demostración se convenció de la poca seguridad de nuestros ensayes, y consiguientemente, el justo recelo con que debemos vivir sobre la certeza de nuestros cálculos en las mermas y gastos de las oficinas, después de aventurar la fijeza con que se debc proceder en la ley de las monedas. Para todo da muy poderosos fundamentos la mala calidad de los hornillos de ensaye, por no haberse acomodado a los modelos de Mr. Sage cstos ensayadores. Los hornillos actuales no tienen más que una puertecilla por donde se meten y sacan las copellas: el fuego encerrado en ellos obra con toda su actividad, sin el arbitrio que se toma en los hornillos de Sage, de templar o crecer el calor cortando la ventilación o dejándola libre con cei'rar o abriy una o las dos puertas que tienen; y de aquí procede que no pudiendo atemperarse el fuego al medio de la operación, es indispensable después de hocha la fusión del piomo con el pallón, que la voracidad del calor haya de causar dos efectos muy perjudiciales: el primero es que la fuerza del Iuego ha de hacer evaporar indispensablemente mucha parte de plomo impregnado con algunas partículas muy pequeñas de plata; el segundo es que al tiempo de vitrificarse el plomo ha de absorber consigo en la copella varias particulillas de plata por las grie. tas casi imperceptibles que abre en ella la actividad del calor; debiendo resultar necesariamente que el pallón saque menos peso, a proporción de estos pequeños desperdicios y, de consiguiente, que tenga otro tanto menos de ley en el ensaye.

El daño procedente de estos errores no se limita en los vasallos vendodores, por io que pierden en el valor de sus platas; lo peor es que trascendiendo el perjuicio a la Real Hacienda, al cabo vienen a servir nuestros desaciertos para provecho de las naciones extranjeras; porque debiendo llevar la moneda once dineros justos, sale en rcalidad con uno o medio grano más, cuyo exceso no conocen nuestros ensayadores por no haber reflexionado en la pérdida del peso que debe causar en el pallón la mala construcción de nuestros hornillos.

Sin duda, csta es la causa por qué en los reinos extranjcros solicitan nuestras monedas con tanta ansia. Por lo que hace a Polonia, me ha testificado el Barón de Nordenflicht, (digno de los mayores elogios más por su buena fe que por sus otras grandes prendas) que en aquella potencia se afanan en recoger cuanto dinero pueden de Indias, para refundirlo; asegurándose que aquel soberano saca bastantes utilidades con este arbitrio.

Si no reformamos nuestras operaciones, el único remedio es que dupliquemos el feble permitido por Ordenanza; pues, compensándose con este aumento la ley que se ocultó en el ensaye, vendrá a quedar el feble legítimo, sin exponernos a los inconvenientes que ya previno el capítulo 18, al fin de las Ordenanzas de Moneda.

Con todo, haciendo justicia a estos ensayadores, lejos de hallar culpa en su conducta, más bien los considero dignos de elogios y de premio; porque el desarreglo no proviene de poco celo, sino de estar observando todavía los documentos, de aquellos autores antiguos, que no pudieron adelantar tanto como los modernos por el atraso de su siglo.

Por otra parte, es un prodigio que trabajen lo poco que vemos, cuando el lugar que llaman Laboratorio es una pieza yerma, sin más que dos 
fuellecitos medianos que por su desaseo no merecerían el aprecio ni de un platero prolijo. No se ven allí más utensilios que un caldero de oro, para el agua fuerte, y en un aparador tosco cle madera unos cuantos frusquitos, que han servido para "Resoli", de manera que cualquiera alfarero algo curioso debe tener en su oficina más mucbles que nuestros ensayadores.

Pero no se puede tolerar que los manojos de puntas con que hacen los ensayes no estén contrastados en la Casu de Madrid; porque no estando marcadas las puntas con el Sello Real, que debe servir por auténtica, de que cada una tiene la misma ley que marca, puede temerse probablemente alguna falsedad en el autor que fabrico las puntas en perjuicio de la fe pública; o al menos este solo recelo bastará para inducir una desconfianza general, que servirá de obstáculo al rescate del oro cn la $\mathrm{Ca}$ sa de Moneda.

Por lo que hace a ésta de Potosí (donde el oro nunca se ensaya pol' fuego y copelia) se saben notoriamente las quejas continuas que hacen los interesados por las bajas de ley que experimontan metales de mineraies conocidos; y aunque los más cuerdos atribuyen estas diferencias a la incertidumbre del ensaye por puritas, lo cicrto es que de pocos años a esta parte ha quebrado notablemente la gruesa del rescate de oro, porque los más, temerosos do escarmentar los perjuicios que otros lloran y publican, quieren asegurar el partido, llevando sus pastas a Lima, Chile o España, así por la prontitud con que son pagados sin esperar cuatro o seis meses, hasta la rendición (como sucede en Potosí) y principalmente porque con aquellas Casas, no tienen la manía que han tomado ya con ésta.

\section{A R T I C U L O SEG U N D O}

M UCHO peor es el estado de nuestras afinaciones: hubo tiempo en que cada marco le tuvo de costo al Rey más de ciento veinte maravedíes, inclusive las mermas, siendo Gobernador Don Jorge de Fscovedo. Después fué bajando a cuarenta o algunos menos maravedies; pero es muy rara la partida que le costea con los diez y siete maravedíes que se descuentan a los dueños de las platas que no llegan a la ley de once dineros y veinte granos; de suerte que es la oficina más trabajosa de la Casa, por lo mucho que da qué hacer al Superintendente y a los demás ministros de la Moneda.

Es la causa principal de este desorden, que desde el tiempo que se separó del cargo de Fundidor mayor la afinación de platas, entraron a servir este destino unos hombres notoriamente imperitos, que apenas habían tenido algunos principios de platería. Por lo que gobernándose servilmente por la razón que dan los ensayadores para la liga del plomo, o no hacen otra cosa que ir echando plomo y más plomo, pareciéndoles que con esto solo se purificará la plata, por habcr oído decir que el plomo es como el jabón, que limpia todas las impurezas de la plata, sin dar un paso adelante, $y$ lo peor cs que no pueden darlo aunque quieran, porque ellos propiamente no son más que unos operarios mecánicos, sin reglas ni principios científicos en el oficio que traen entre manos.

Por esta razón nunca han llegado a conocer que influye no poco a es- 


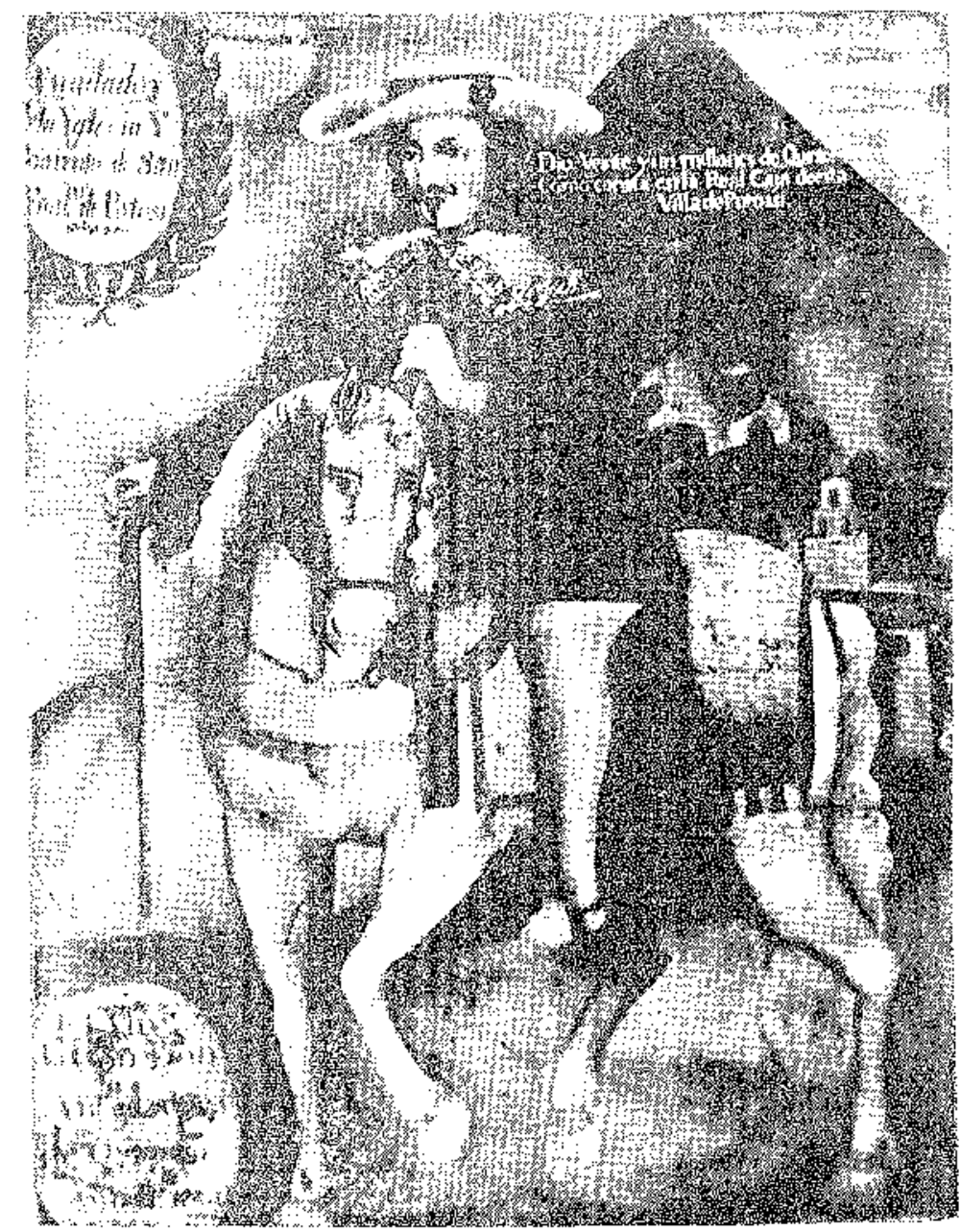

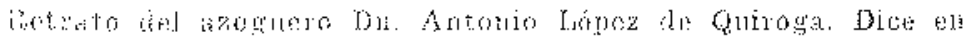

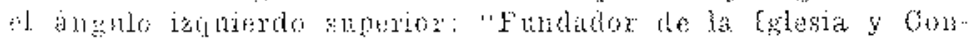

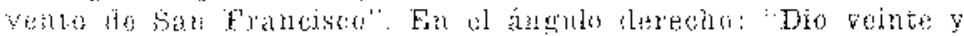

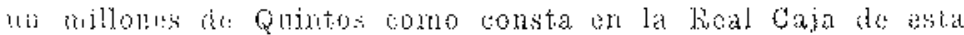

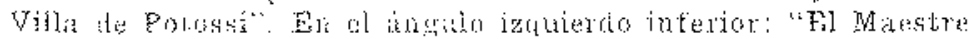

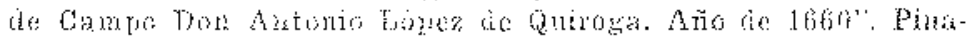

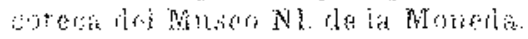




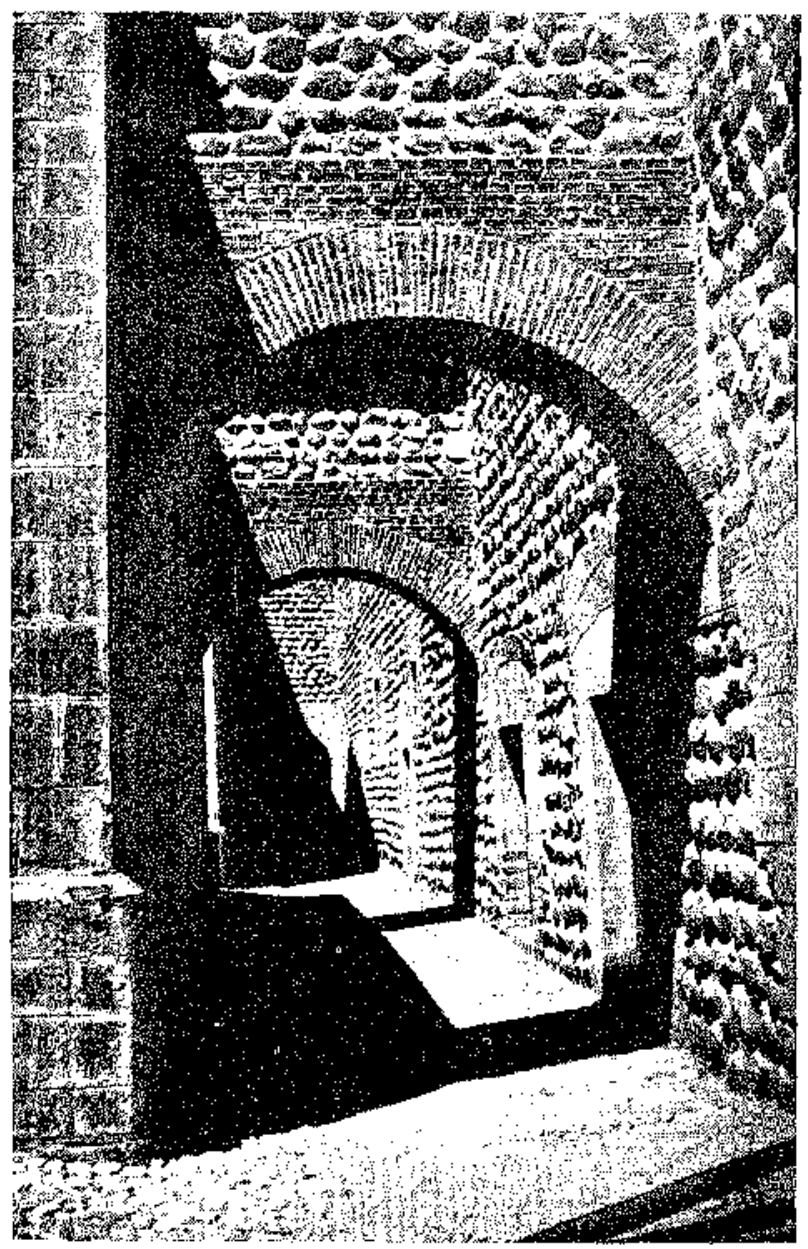

Corredor que comunica el segundo patio con el tercero, de la Casa de Moneda, después de su restauración. 
tos atrasos la forma de hornos de que nos valemos para la afinación. Ellos son de un tanaño tan exorbitante, que en sola una vez recibe cada horno seiscientos marcos de plata, fuera del plomo que le echan para liga. Y así, por grande que sea el fuego, y aunque éste dure desde cuarenta y ocho hasta scsenta horas, nunca puede verificarse la perfecta escorificación que es necesarja para purificar el metal a toda prueba de su ley, al mismo ticmpo que se aumentan los costos, y va siguiendo por todas las oficinas este mismo daño por la mala calidad que ya han contraído los metales.

La figura de los hornos es otro defecto que contribuye esencialmente para el desacierto en nuestras afinaciones. Teniendo como tienen las bóvedas muy esféricas, el cenicero bajo y las chimeneas muy cortas y dercchas, causan on primer lugar, que tirando siempre hacia arriba el fuego se vucha al cielo de la bóveda, y obre poco sobre los metales; de lo cual resulta que sea menester mucho tiempo más para la escorificación, y que usta nunca se haga con toda perfección; lo segundo, que siendo igual la actividad del calor al medio de la operación porque no da lugar la construcción de nuestros hornos a que se atempere el fuego, como queda dicho en el artículo antecedente, entonces se volatiliza mucha parte de plomo, resuelto en vapor, llevando consigo una considerable porción de partículas menudas de plata, de que está impregnado; lo tercero, que con esta exhalación se minora la cantidad del plomo, que es necesaria para perteccionar la afinación; lo cuarto, que saliéndose libremente por la chimenea el fuego y ol aire, no queda sobre el caldo aire suficiente para la calcinación de los metales extraños.

$Y$ es por esto, que al cabo de cuarenta y ocho a sesenta horas de fuego, queda siempre impura y sin afinarse la plata; pues no llegando a escorificarse los metales a causa de no haber perdido su flogisto por falta de aire, se queda en la misma ley que antes, con corta diferencia, saliendo el metal agrio y poco dúctil en perjuicio de las demás oficinas.

Según el tamaño de los hornos y cantidad de plomo que se echa en cada afinación, también es poca la acendrada, para poder absorber todo el plomo vitrificado, y por esta causa es indispensable que volviéndose a mezclar las cales con la plata, salga toda ella impura y agria.

De aquí ha de proceder necesariamente una merma muy considerable, por la plata que se volatilizó arrastrada on las exhalaciones del plomo; y de consiguicnte han de subir los costos, respecto del no mejorarse la ley ni la condición del metal al cabo de dilatado tiempo que se consume en estas operaciones.

Si los hornos tuvicran figura elíptica con chimenea alta, caracoIeada al medio y con la boca inferior estrecha, todo el fuego obraría sobre el caldo al principio de la operación; porque con el cenicero alto habría lugar para más aire, y su salida sería dilícil por la estrechez de la boca de la chimenea.

Por el fuelle que deben tener estos hornos, con un cañón grande de viento, se refrescarían los metales calcinables para hacerles perder su flogisto, $y$ formándose entonces de los metales calcinados el litargirio, la cal del plomo atraería la cal de los otros metales, y todo ello junto se absorbería en la acendrada con la actividad del fuego que se debe apurar al fin de la operación, quedando limpia y pura la plata.

Por otra parte, serían también mucho menores los costos, porque 
Ia escorificación de los metales se abreviaría forzosamente en templando el fuego y en aumentando aire. Y no cue ahora cleciendo cada vez más el calor, sin aire suficiente para la perfecta calcinación, se sigue que al cabo de mucho tiempo, carbón y jolnales, se escorifica una pequeña parte de los metales extraños, quedando mucha porción de ellos en su forma natural para impedir la cxaltación de la plata a su ley suprema, con el valor proporcionado a su mayor fineza en beneficio de la Real Hacienda.

En ese caso veríamos indubitablemente averiguadas las causas de atraso de la Casa de Moneda de Potosí, y experimentaríamos al mismo tiempo unas ventajas declaradas en nuestras afinaciones, para suspender con justicia la ley que manda hacel ol descuento de diez y siete maravedíes para los costos de afinación; porque después de la ganancia que percibiría el Rey, en la mayor ley de las platas, con menos de la mitad de Ios gastos actuales, se lograría el aumento que debe resultar con la reunión de la plata que tiene el plomo con que se hacen las afinaciones.

El Barón de Nordenflicht hizo la separación en prescncia de todos, y vimos que cada diez y seis quintales de plomo conticnen cuatro onzas y un cuarto de plata; con que debiendo reunirse a la masa de afinación la plata del plonto, lejos de haber pérdidas debíamos tener aumentos, no solamente en esta oficina, sino tambiên en todas las demás por donde fuesen corriendo las platas, $y$ principalmente en la Ficlatura, porque con el metal más dúctil, a medida de su mayor pureza, se verificaría la Ordenanza en cuanto a la tercera parte de cizalla, y bajarían los costos de ahora, porque no serían necesarios tantos recochos como se hacen para vencer lo agrio de los metales. El único remedio es reformar el tamaño y la figura de nuestros hornos, con los modelos que el Barón de Nordenflicht ha prometido remitir de Lima; pues, aunque algunos ministros de la propia Casa, imperitos en sus oficios, han creído que otros hornos más pequeños para sólo cien marcos no podián abastecer al corriente de la gruesa de platas que se labra en Potosí, no se han hecho cargo que cada hornada debe vaciarse dentro de cuatro horas, a muy poca costa de carbón y jornales, de suerte que, con un solo horno, se puede practicar seis operaciones en veinticuatro horas, y lograr la perfecta afinación de los mismos seiscientos marcos de plata, que según el método actual de la Casa se afinan mal, con grandes mermas y gastos, al cabo de cuarenta y ocho hasta sesenta horas de fuego.

En otro tanto ticmpo bastaría sólo un horno para afinar mil doscientos mareos, y con cuatro que tuviéramos, alcanzaría para la afinación de cuatro mil ochocientos marcos, con exceso de tres mil seiscientos a lo que en el día se afina en nuestros dos hornos grandes de a seiscientos marcos cada uno, en el término de cuarenta y oche hasta sesenta horas.

La razón que hay para que en estos hernos se abxevien las operaciones es demasiado clara, porque siendo menor su buque y la bóveda casi plana, el fuego obra sobre el caldo con mucha mąyor actividad, y por la misma regla tiene más acción el aire que comunica el fuelle por el cañón de viento, para refrescar los metales y escorificarlos en brevísimo tiempo, sin riesgo de la menor merma; porque teniendo dos puertas para disminuír o aumentar el calor, no podrá exhalarse el plomo, ni volatilizar la plata, siempre que estas operaciones se ejecuten según arte. 


\author{
A R T I O U L O TER G F R O
}

\title{
$\mathbf{E}$
}

$\mathrm{N}$ la afinación del oro y del cobre para su ligación es donde el Rey pierde más, al paso de ser el negocio en que más se trabaja desde el establecimiento de su labor. Son tan excesivas las mermas del oro, que quieln no supiere el método irregular con que se afỉna en Potosí, no podría menos que atribuílas a hurtos, por más que se le testifique la fidelidad de los trabajadores y la vigilancia de los superiores sobre su conducta. Los mismos que estamos viviendo en Potosí, no pudiéramos creer otra cosa, a no ser tan palpable la impericia que es la agresora de estos daños.

Todavía sucede más en el cobre, porque costándole al Rey treinta y seis pesos cada quintal en siendo del mineral de Yavircoya, ha legado ocasión de subir a trescientos pesos con las meimas y gastos de afjnación.

$\mathrm{Y}$ esto no es lo peor; sino el que sucle retardarse seis y ocho meses la rendición del oro por falta de cobre afinado. El Fundidor Mayor que tiene a su cargo estas afinaciones ha llegado a cansarse con sus propios desengaños, y más de una vez ha encomendado la afinación del cobre a los cobreros y también a los herreros, solamente por haber oido decij: que uno u otro de estos artesanos purificaba con perfección este metal.

Actualmente nos hallamos en este caso, sin haber podido rendir la libranza del oro en todo el año que va corriendo, a causa de que el fundidor no ha podido Iigar el oro con ningún cobre de los gue se han afinado dentro y fuera de la Casa.

Lo más sensible es que habiendo entrado en este número una partida de cobre, que afinó el Barón de Nordenflicht, trató de vindicarse este sabio caballero, ofreciendo hacer la ligación por sí mismo, a presencia del Superintendente de Ia Casa y de los demás ministros de ella, en consorcio de algunas personas distinguidas de la Villa, y ẹn efecto, la verificó con tres distintas clases de cobre que había desechado nuestro fundidor, con la circunstancia de que habiéndose llevado el riel a las muñecas e hileras de la Fielatura, se estiró como una masa de cera, a cuya vista expuso el Fiel, que no se había llevado jamás a su oficina oro de aquella calidad, asegurando que las mermas y gastos de la Fielatura procedian de los defectos y vicios con que iban las platas desde la fundición.

Realmente no cabe otro concepto en examinando el método con que se afina el oro y el cobre. Para el primero se usa de la cimentación, la cual se practica poniendo dentro de una olla una capa de granalla cubierta con otra capa de polvo de ladrillo y sal común, humedecido con agrio de limón $y$ vinagre fuerte, sal gema, salitre $y$ alcaparrosa, alternando unas capas con otras, hasta llenar la vasija, la cual se pone al fuego por el tiempo y la forma expresada en la Noticia Cuarenta y una, Capítulo $8^{\circ}$ de la Primera Parte, hasta que se completan cuarenta y ocho horas, que es cuando sacan la olla, dejando reposar dos días más, para proceder a fundir la granalla. 
Para afinar el cobre lo echan en una callana o crisol grande, con porción de carbón por debajo y encima del metal, $y$ le dan fuego por medio de un fuelle cuyo cañón arroja el viento sobre la misma callana; luego que se funde el metal sacan a latos unas pequeñas porciones, que reducidas a tejos, golpean a martillo después de haberse enfriado bien, y siempre que al golpe no se levante escama ni se abran grietas hacia los costados; entonces dan ya por afinado el cobre, sin saber dar razón del por qué.

De esto proviene que en habiendo el menor doscuido en hacer estas tentativas a cada momento, slele pasarse el punto con la fuer'za del fuego, y otras veces se engaña el fundidor con la señal do los golpes, según los experimentos infalibles de las hileras, haciéndose preciso repetir unas operaciones tras de otras con pérdida de tiempo, con mermas y gastos exorbitantes en perjuicio de la Real Hacienda, del giro de la Casa, de la opinjón de sus ministuos y de los interoses del comercio con la retardación de sus caudales.

Una ligera tintura química basta para conocer que el origen de nuestros daños es el clesarreglado método que se observa en las afinaciones. EI agrio de limón, el vinagre fuerte y cualesquiera otros ácidos vegetales que se quiera eehar en la cimentación, serán siempre inútiles; porque a más de su poca acción sobre los cuerpos metálicos, todos ellos se volatilizan en breve con cl calor del fuego, y nada obran en el oro; el polvo de ladrillo, aunque tiene algún ácido vitriólico, es demasiado poco, y no puede descomponer esencialmente la sal para que resulte ol áeido salino que se necesita para extraer la plata y formar la luna córnea. La sal gema, salitre y alcaparrosa, que añaden en esta Casa de Moneda, son los que causan todas las mermas del oro, porque el ácido vitriólico de caparrosa y ladrillo, descompone la sal y el salitre, y coge el álcali de ambas sales; entonces, quedando sólo el ácido de estas sales, se junta uno con otro y forma el agua regia que disuelve el oro; por eso en volatilizándose con el fuego, lleva consigo mucha parte de oro en las exhalaciones del vapor, y queda la misma ley que antes, porque no puede coger la plata que no se extrae ni se disuelve.

Si queremos continuar con la cimentación debemos usar solamente el polvo de ladrillo, sal común y alcaparrosa, con un fuego muy lento, por el término de veinticuatro horas, para que no llegue a fundirse la granalla. En este método abundará el ácido vitriólico para descomponer la sal, y resultando ácido salino suficiente para extráer la plata y formar: la luna córnea, lograremos afinar el oro en menos tiempo y sin ningún desperdicio.

Pero nunca podremos ahorrar todos los costos, porque como la granalla es desigualmente más gruesa o más delgada, el ácido de sal no puede extraer sino la plata y el cobre de la superficie, reduciendo este último metal a una sal media de cobre, y la plata en luna córnea, que queda una parte en la superficie, y otra entre el polvo de ladrillo.

Cimentado que sea cl oro, necesita cocimiento para disolver en sal la luna córnea pegada en la superficie de la granalla, porque sin. esta diligencia, en fundiendo el oro vuelve a reunirse con la plata y no mejora su ley.

Debemos pues entablar en Potosí dos operaciones indispensables: la primera, el cocimiento de la granalla después de la cimentación, y la 
segunda, la refundición de ella por dos o tres veces, hasla que por ensaye real se reconozca estar perfectamentc afinado el oro. La razón está en que extrayendo solamente la plata $y$ el cobre de la superficie de la granalla, es monester volvor a funciir el ácido de sal reduciéndolo otra vez a granalla hasta acabar de cxtraer y consumir la plata y el cobre, que ha de ir asonando en la superficie con las refunticiones.

El Barón de Nordenflicht comprobó este discurso con la experienciá. El mismo oro en granalla, que el Fundidor Mayor decía estar ya afinado perfectamente, lo coció, fundió y refinó con sal nitro en crisoles pequeños de ocho para diez marcos. Concluída la operación en que salió el oro en su perfecto color, de mucha más ley y enteramente dúctil, se reconoció en la tapa con que se cubrió el crisol, en el fondo y en las paredes de esta vasija una sal verde del cobre que se había escorificado. Con lo que se demostró hasta la cvidencia que el oro no se había purificado perfectamente, y que así por este defecto, como por la acrimonia causam da del humo de los carbones, no estaba en estado de ligarse con el cobre, aunque éste fuesc el más purificado.

Todos creimos que el Fundidor se aprovecharia de estos convencimientos para salir de sus apuros, pero hasta el presente mes de noviembre, se halla todavía embrollado con el oro, echándole la culpa al cobre, sin quererse conformar con la buena condición del que afinó el Barón, como está visible en el color perfecto de rosa seca.

$Y$ es el caso, que persuadiéndose refinar el cobre con aumentar el fuego, en vez de conseguirlo, calcinan mucha parte del metal volviéndolo agrio enteramente; porque interpolándose en los intersticios del cobre estas materias calcárcas, salen los rieles como vidriosos, para no admitir maxtillo ni hileras sin quebrarse.

Por lo mismo, conviene scguir el método del Barón a ojos cerrados, haciendo las afinaciones del cobre en hornos de figura elíptica con su gran fuelle que arroje el aine sobre cl mismo caldo, con la dirección de algún mozo hábil que haya visto practicar estas operaciones con aprovechamiento; que sólo así podremos tener repuesto abundante de cobre para las ligas do todo el año, sin exponer la opinión de la Casa a un desconcepto ignominioso y general, que no puede dejar de influír necesariamente a que continuando los atrasos de la labor del oro, llegue al cabo el período vergonzoso de no haber quien quiera rescatar un tejo en esta Casa.

\section{A R T I U L O C UA R T O}

\section{L}

JOS mismos defectes proporcionalmerte son comunes a la oficina de fundición; la plata y oro se ponen en barretones dentro de unos grandes crisoles, que aquí llaman callanas, muy abiertas de boca, pero de poco fondo. Llenan todo el hueco de carbón, y le dan fuego con fuelle; según se va derritiendo el metal, se extiende en la callana, y es regular que ahogue algunos carbones percibiendo la acrimonia del salitre o vitriolo, que abunda en todas estas tierras con que los carboneros acostumbran tapar el fuego para apagarlo; de lo cual resulta forzosamente que aunque se ajuste la verdadera ley en que debe salir el oro y la plata, sacan estos dos metales de ordinario tal acrimonia, que va a causar los per- 
juicios en la Fielatura en la abundancia de cizalla que se desperdicia en el muchísimo carbón que se consume en los recochos, en la excesiva cantidad de moneda pecante en fuerte que es menester refundir, en la porción de instrumentos que se quiebran por la falta de ductilidad, en los metales, y por áltimo, en los salarios que recrecen con la multitud impertinente de operaciones que no se emprenderian si las fundiciones se hicieran con buen método y arte.

Y si, como es factible, sucede que en la fundición haya entrado algún oro de alhajas que hubiese tenido la más peqneña mezcla de estaño, será imposible afinar y labrar el oro de toda la partida, mientras no se use del antimonio, porque un par de onzas de estaño basta para volver agrio un centenar de marcos de oro. Yo concibo bastante difícil que nuestros operarios conozcan semejantes mezclas, al paso que no juzgo improbable que así como llevan al Banco planchas de vajilla introduzcan también en la moneda tejos de oro ya servido; pero para el caso de conocerlo y tratar dé su afinación, estoy informado que a una parte de oro se echan tres partes de antimonio; con el fuego sube hacia arriba el oro, y sobre su superficie todos los demás metales en forma de escoria. El oro, ya purificado en esta forma, se vuelve a fundir, y con el viento del fuelle se evapora todo el antimonio que se había mezclado con él.

De los reparos antecedentcs se deduce con admiración lo mucho que el Rey pierde en las labores de esta Casa, con la desgracia de que aun ni lo conocemos, cuánto más para determinar a punto fijo las mermas y los gastos con distinción de clases. Esta es la causa de no poder formar cálculo seguro sobre los costos permanentes de la Casa a proporción de la gruesa que labra y amoneda cada año; pudiendo añadirse sin temeridad la proposición que he oído al Barón de Nordenflicht, que si el Rey gana ciento cincuenta mil pesos anuales (que es lo más a que llegan las utilidades) él arrendaría de buena gana toda la Casa pagando trescientos mil pesos al año, en la confianza de que iba a ganar cien mil pesos cuando menos; porque dice, que utilizando el Rey de Polonia cien mil pesos por año con cincuenta mil marcos que labra aquella Casa de Moneda, debe ganar el Soberano de España proporcionalmente cer'ca de medio millón de pesos en la gruesa de cuatrocientos a quinientos mil marcos que se amonedan en Potosí.

Yo no salgo garante del Barón, pero puedo afirmar sin arrojo que solamente en la labór del oro pierde el Rey mucho más de doce mil pesos. Véase demostrada la proposición. El oro se compra a los particulares por toque de puntas, pagándoles su valor según la ley que marcan, sin abonar los quebrados de un grano o cuartos de grano que suben sobre modio quilate. Estas cantidades en un rescate grueso componen al fin del año un guarismo muy considerable, y como que es utilidad a beneficio del Rey, debía formarse de ello cargo al Fundidor, ensayando los tejos antes de su entrega por fuego y copella que os donde se conoce la verdadera ley con los más mínimos quebrados. Pero cuando en todas las Casas de Moneda del Reino se tiene buen cuidado de formar este ajustamiento, aquí en Potosí no lo ejecutan por una indulgencia abusiva de los demás ministros, que yo creo no haya llegado a noticia de los Superintendentes.

Observan la costumbre muy reprensible de entregar el oro al Fundidor por las planillas de su compra, a sabiendas de los quebrados que siempre van demás; si el Fundidor fuera científico podría aprovechar es- 
te exceso siquiera en cubrir los gastos de su oficina o para reemplazar las mermas del oro que recibió. Ciertamente, sabemos que nada utiliza, y también nos consta que el Rey es quien lasta los desperdicios y los gastos, después dé no lucrar los quebrados que debían ceder a beneficio de la Real Hacienda; con que es visto que todavía me he quedado corto en asegurar que por año pierde el Rey en la labor del oro más de doce mil pesos, fuera de gastos.

\section{A R T I C U L O Q U I N T O}

C ONCLL1RE con el artículo de las tierras y escorias, que es también de los de mayor importancia en esta Casa de Moneda. Las acendradas de las callanas y hornos, las ccnizas y alguna parte del carbón que ha servido en la afinación $y$ fundición, $y$ toda la tierra delgada de los salones de la Fielatura se vau depositando en el decurso del año, hasta que llegue el tiempo de su bencficio, el cual se reduce a la forma propuesta en la Noticia Cincuenta y dos del Capítulo 8․

La basura gruesa, con paja, carbones al parecer inútiles y otras escorias despreciables, en opinión de los jefes de las oficinas, se va amontonando todo en cierto lugar de los patios, hasta determinado día en que el basurero lo arroja a los extramuros en un costal con que carga la muIa destinada a este ministerio. En la Casa creen que no va ni una brizna de plata, pero todos saben que muchos pobres se emplean en recoger la escoria más remolida dentro de unos platillos de barro, donde ponen agua con un poco de azogue, y removiéndolo todo con un palito, a poco tiempo sacan onzas de plata, más o menos, según su diligencia. Con lo que se prueba el engan̄o que padecen los ministros de la Casa y el perjuicio que por este camino zesulta contra la Real Hacienda.

La economía convenierte en este punto debía ser, a mi modo de pensar, que todas esas basuras se quemasen en cierto día de cada mes, guardando las cenizas con las demás tierras bajo de liave, hasta el tiempo determinado para su beneficio. Que éste no se practique en el método acostumbrado, sino por barriles, como ahora lo ejecutan los mineros de la expedición del Barón.

Para convencer la ventaja y utilidad de esta nueva invención, pusieron en un barril, el día tres de abril, a las cinco y media de la tarde, cuarenta y nueve y media libras de escorias de fundición sin calcinación ni sal, con tres libras de planchitas de cobre y cincuenta libras de azogue: a las nueve y media del día siguiente, al cabo de diez y seis horas de trituración, sacaron la pella de siete marcos, tres y media onzas con cuarenta y ocho libras de azogue.

Después de la quema quedó el piñón en dos marcos siete onzas tres ochavas de plata, con todo, que el ensaye por menor marcó solamente una libra cinco y media onzas de plata en quintal de tierra, cuya correspondencia debía producir, en las cuarenta y nueve libras de escorias, un marco dos onzas, cinco sicte octavos únicamente. Por lo mismo se atribuyó el exceso a cantidad de cobre mezclado con la plata.

Este experimento manifestó en primer lugar, que recogido el azogue de la requemadora se encontraron las mismas cineuenta libras que se habian echado en el barril; en segundo lugar, que en diez y seis horas 
se benefician con más provecho las tierlas que ahora nos entretienen tres semanas enteras, con gastos crecidos de jornales y pérdida de azogue.

Resulta pues, que siendo fácil costcar con mil quinientos pesos, cuando más, una máquina de agua, dentro de la Casa, con dos barriles de a diez quintales cada uno, se pueden beneficia las tier'ras en solo una semana; por principios de una fiel y sabia economía debemos enprender esta obra, abandonando enteramente el método costoso y poco científico que estamos observando a la prueba de innumeiables desaciertos.

E] actual Superintendente, Don Francisco de Paula Sanz, por su notoria versación en los negocios de Hacienda y por sus conocimientos en la economía de las oficinas, y principalmenle por su talento sobresaliente, celo y aplicación al Real servicio, ha llegado a conocel cn el poco tiempo que manda esta Villa, todas las causas de nuestios atrasos, los medios de remediarlos, y la necesidad de establecer una reïorma general en todo lo económico de la Casa de Moneda, haciendo visibles sus deseos por las ventajas del Rey en la protección que ha prestado a todas las observaciones del Barón, y a cuantos mozos han querido aprovecharse de ellas, para promover con decoro los adelantamientos de la Real Hacienda. Muchísimas cosas estarian ya remediadas, y el giro de la Casa correría también sobre otro plan más cientifico, si no estuviesen tan limitadas por la Ordenanza las facultades de los Superintendentes.

Sobre todo debo asegurar, como buen Ministro del Rey, que no se conseguirá jamás arreg]ar del todo la Casa, y poner su giro y todas sus operaciones en el debido tono, mientras no se destine al Barón de Nordenflicht, o a Don Antonio Sacharias o a cualquiex otro hombre sabio en materias de Moneda, con principios científicos de la Química, maquinaria y mecánica, para que venga a residir en esta Real Casa de Moneda, al menos por el término de cuatro años, con las facultades de Superintendente, para el efecto de reformar y establecer cuanto juzgare conveniente para metodizar los trabajos, disminuir los salarios o ajustar a cálculo fijo los gastos, arregiar las opcraciones, y en suma para formar un nuevo plan que sirva para honor y utilidad de nuestro Gobiemo. Sin esto, debe creér'seme, que nuestros negocios caminarán siempre atrasados, y la ignorancia substraerá del Real erario las utilidades que granjea y atrae la emulación y la industria en otros reinos.

\footnotetext{
* No está demás anoticiar al lector con referencia a la historia de la construeción de la Casa Real de Moneda Circular, a datos de los planos del ilustre arquitecto aragonés don Salvador de Villa, a la misión de técnicos españoles dirigida por don Joseph del Rivero, al acopio de materiales de madera de cedro de las provincias chuquisaqueña, $y$ la vemisión por orden del Marqués de la Ensenada, del equipo de máquinas españolas de laminación, etc., que editamos un trabajo titulado "lmagen de Potosi y de su Casa Real de Moneda", en la Ed. Plantié, S. A., Buenos Aires, el año 1943, insertado luego en la revista "Sur" de la Sociedad Geográfica y de Historia "Potosi". En dicho trabajo se registró por vez primera documentos, los principales, de la historia del monumental edifício, que nos fue dado encontrar a tiempo de organizar la Sección de Archivos Coloniales del actual Museo. Al año siguiente, en 1944, el poeta $y$ escritor argentino don Pedro Juan Vignale, editó en los Talleves Peuser, S. A., Buenos Aires, el elegante e ilustrado libro "La Casa Real de Moneda de Potosi", con los datos que hubimos de proporcionarle, complementados con referencias de aito valor documental que existen en el Archivo General de Ia Nación Argentina.
} 
Los estudios publicados por el catedrático y arquitecto señor Angulo Iñiguez, hasta hace poco tienpo Jefe del Laboratorio de Arte de la Universidad de Sevila, sobre arquitectura españolel en América durante la Colonia, contienen importantes detalles sobre la construcción de la Ceca potosina, que nos han servido para ura puntual verificación del fondo documental existente en los archivos potosinos y para la restauración del edificio, con el asesoramiento del Arquitecto don Mario J. Buschiazzo.

Finalmente, con ocasión de cumplirse cuatro siglos de la fecha del descubrimiento del Cerro Kico de Potosi, en abril de 1945, la Universidad Nacional de Buenos Aires, dispuso la cdición mediante la Facultad de Filosofía y Letras, dirigida por su decano el dinámico y erudito historiador don Emilio Ravignani, de una monografía completa de numismática potosina, bajo el rubro de "La Ceca de Ia Villa Imperial de Potosi", cuyo alstor es el Capitán de Navío y Vocal de la Sociedad de Numismática Argentina, don Humberto Burzio.

Esta Editorial, cumpliendo el plan que se ha propuesto llevar a buen término, editará oportunamente una historia puntual de la Casa de Moneda, deste su fundacion hasta los tiempos actuales, disponiendo para ello del nutrido material que le ofrece el Archivo y las fuentes de información que se han detallado en esta apostilla. - Nota de A. Alba.

* El "Apéndice" ha sido tomado del manuscrito del Archivo General de Indias en Sevilla. No está consignado en el libro original de Potosí. El autor, inicia con esta pieza, la Segunda Parte de la obra conservada en España, alterando la división que hizo en los originales que se guardan en el Archivo de la Casa de Moneda; cuyo segundo tomo comienza con el "Discurso Preliminar", que aparece a manera de Prólogo ampliado en el documento del archivo sevillano y que en su origen constituyó el primer capítulo de la parte segunda del manuscrito de l'otosí. - Nota de A. Alba.

*** Nordenflicht, (Barón de) conocido mineralogista sueco en el siglo XVIII. Por Cédula Real dada en Aranjuez el $1^{\circ}$ de abril de 1788 , fre designado como Jefe de la misión alemana para el estudio de la minería en el Perú y la solución de los problemas de su explotación. En el mes de enero del año de 1789 llegó a Potosí. La misión no satisfizo los propósitos que la crearon, por desacuerdos con el Virrey en Lima y se dio más de un informe adverso contra las labores del Barón. Noxdenflicht redactó un Informe al Gobernador Intendente sobre la inutilidad del "Real Socavón", cuya apertura se inició por don Ventura Santelices y Vonero, Superintendente de Minas, escuchadas que fueron las opiniones técnicas de los principales mineros del Cerro Rico. Concluyó su contrato en 1798. Holms, publicó en ese nismo año un "Diario" del Viaje del Barón y comisionados.

En el Archivo de documentos de la colonia organizado en el Museo de la Casa Nacional de Moneda, se encuentran numerosos documentos que servirán para una monografía acerca de los trabajos del Real Socavón. Nota de A. Alba.

1.- Torquemada: Monarquía Indiana, tomo 2", Cap. 23, Lib. 14, fol. 579, col. 1.

2.- Torquemada: Lib. 14, Cap. 14, fol. 560, y Cap. 23 , fol. 579 , tomo 2 .

3.- Torquemada: Lib. 12 , Cap. 12 , tomo $2^{\circ}$, fol. 395 , col. 1.

4.- Torquemada: Lib. 14 , Cap. 14, tomo $2^{\circ}$, fol. 560 , col. 1 .

5.- Torquemada: Lib. $5^{\circ}$, Cap. 13, tomo $1^{\circ}$, fol. 614 .

(a) Por Real Orden de Aranjuez, a 30 de abril de 1789. Cap. 4, se mand6 labrar en las casas del Perú moneda de cuartillo de plata con total arreglo en peso y ley a la demás sencilla de estos Reinos.

6.- Ulloa: Resumen histórico de los Emperadores del Perú, tomo $4^{\circ}$, de su viaje, fol. $92, \mathrm{~N}^{\circ} 142$.

7.-. D. Gabriel Cárdenas Cano: en su Ensayo Cronológico para la Historia de ta Florida, año de 1722 , fol. 364 , col. 2 , in principio.

8.- Séneca: Lib. 6 de Beneficius, Cap. 1", "etíam quod discere supervacum et prodest cognoseere".

9.- $\$ 1$, Inst. de Testam. Ordinandis, Id: "sed ut nihil antiquitatis peritus ignorentur".

10... Ley 1, Tít. 22, libro 5 de Cast., Ley 17, Cap. 13 al fin, Tít. 22, Lib. 4 de Indias. Ordenanzas 10 y 13 al fin, Tít. 17, Lib. 3, de las Generales del Perú.

11.- Véase la Ley 8 , Tít. 23 , Lib. $4^{\circ}$ de Indias. 
12.-Esta Real Cédula se halla al principio de las Ordenanzas de la Casa de Moneda de Lima, impresas de orden del Conde de Superunda, año de 1759 , en la Imprenta Nueva de los Niños Huéríanos.

13.- Cap. $2^{\circ}$.

14.- Cap. $4^{\circ}$.

15.- Cap. $5^{\circ}$

16.-. Art. $5^{\circ}$ de la Ordenanza de Intendentes.

17.- Cap. 5. de la Ordenanza de Moneda.

18,- Cvia. Bolaños, Lib. 2", Cap. 15: Del Consulado, N"13 y 14, fol. 441 .

19.- Ley 24, Tít. $6^{\circ}$, Lib. $9^{\circ}$ de Indias. Bolaños, en lugar citado, $\mathrm{N}^{\circ} 13$.

(b) En el día por la reunión referida en la Noticia XV1, han vuelto a los S.S. Virreyes las propuestas. (Nota del Ms. del A. C. 1.).

20. - Ordenanza 22 de la Moneda, $\mathrm{N}^{\circ} 2$.

21. - Ordenanza 40 de la Moneda, $N^{\prime \prime}$ antepenúltimo.

22.- Ordenanza 40, No penúltimo.

23.- Ordenanza $24, \mathrm{~N}^{\circ}$ antepenúltimo.

24.- Ley $4^{*}$, Cap. $4^{\circ}$ al fin, Tít. 19, Lib. $8^{*}$ de Indias.

25.- Ley $4^{*}$, Cap. final, Tít. 19, Lib. $8^{*}$ de Indias.

(c) El Art. 217 de la Ordenanza de Intendentes, previere la suspensión de los oficiales subulternos, bajo la formalidad de Sumaria, precediendo haber reincidido por tercera vez en las multas que se le imponen por vía de corrección.

26.- Art. $1^{\circ}$ de la Ordenanza de Intendentes.

27. - Ordenanza $5^{*}$ de la Moneda. Ordenanza 22 de $3 a$ Moneda.

28.-Cortiada: en las Decisiones de Cataluña. Decisión 106, $\mathrm{N}^{\circ}$ ij y siguientes.

29.- Gómez: $\$ 1^{\circ}, N^{\circ}$ 57. De acción. Antonio de Ball: Variarum, Líb. 3\%, caso 10, Ni 9 al fin.

30.-Cortiada, Vela, Julio Claro y otros que cita Raynaldo en sus "Observaciones Criminales", Cap. 14, $\$ 11$, tomo 20 , fol. $48, N^{\prime \prime} 5$ y 6 .

31. - En Auto acordado del Superior Gobierno de Lima, a 27 de abril de 1671, que corre al fol. 211 del Tít. 17, Lib. '2 de las Ordenanzas del Perú, se declaró por causa de poco valor la que no pase de 20 \$.

32.- Farinacio y otros que cita Raynaldo en el tomo $3^{\circ}$, de sus Observaciones Criminales. Voto $51, N^{\circ} 5^{\circ}$ hasta $7^{\circ}$, fol. 59.

33.- Auto 19, Tít. 11, Lib. $8^{\circ}$, de los Acordados de Castilla.

34.- Raynaldo, en el tomo $2^{\circ}$ de sus Observaciones Criminales, Cap. 14, s 11 , fol. $48, N^{\circ} 7$ y siguientes.

35.-Raynaldo, Tomo $3^{\circ}$, Observación $17, \$ 1$, $\mathrm{N}^{\circ} 138$, fol. 72 .

36.- Raynaldo, Tomo $1^{\circ}$, Cap. 11, Suplm. 1, $\mathrm{N}^{\circ} 11$, fol. 555.

37.- Ley 5, Tít. 6, Partida 7, et ibid glosa $N^{0} 15$.

38. - Ley 8, Tít. 31, Partida 7, Glos. 1 y 2 Matheria de re criminali, controv. 54, No 30 .

39.- Ley 18, Tít. 14, Partida 7 , et ibid glosa 4.

40.- Raynaldo, Tomo $3^{\circ}$, Cap. $25, \$ 11, \mathrm{~N}^{\circ} 12$, y siguientes, fol. 55 .

41.-- Ley $6^{4}$, Tít. $6^{\circ}$, Lib. $2^{\circ}$ de Castilla. Ley $2^{*}$, 'Tít. 10 , Lib. $4^{\circ}$ de la misma recopilación.

42.- Ley 21, Tít. 16, Partida $3^{*}$, Ley 2*, Tít. 1\%, Partida 7. Caldero, elegantísimamente en toda la decisión 16 , tomo $1^{\circ}$, fol. 97 y en la decisión 67 , tomo $2{ }^{\circ}$, fol. 89. Elizardo, en su Práctica Forense, tomo $1^{\circ}$, fol, 269.

43. - Diccionario de la Lengua Castellána: Palabra "alguno", fol. 56, de la impresión del año de 1783 .

44,- Barbosa, en sus varios Tratados, Dicción 21, $N^{*} 1$, fol. 515. Cenedo: Singulare quinto, fol. $408, \mathrm{~N}^{\circ} 1^{\circ}, 6^{\circ}$ y $8^{\circ}$.

45.- La Ley de la Partida está confirmada por la Ley 12 , Tít. $5^{\circ}$, Libro $5^{\circ}$ de Indias. Gómez, $3^{\circ}$ Variarum, Cap. 5\%, N 13 . Gutiérrez: Cuestionario Criminal 158.

46.- Lex minoribus 25 annis, $6^{\circ}$ f.f. De minoribus. Lib, $4^{\circ}$, Tít. $4^{\circ}$.

47.- Lex Scio $4^{\circ}$ f.f, De in integrum restitutionibus.

48.- Auto 7, Cap. 14, Auto 21, Tít. 11, Lib. 8", Auto 74, Tít. 6॰. Lib. $2^{\circ}$ de los acordados de Castilla.

49.- Elizondo: Práctica Forense, tomo $1^{\prime \prime}$, fol. $316, \mathrm{~N}^{\circ} 1^{\circ}$.

50.- Elizondo: Práctica Forense, fol. $317, \mathrm{~N}^{\circ} \mathrm{5}$ al fin.

(d) S. M. aprobó esta Providencia en R. O. de 1787 , y quedan impuestos a censo sobre estas Cajas los dichos 72.000 pesos. (N. del Ms. del A. G. I.). 
(e) El key ha conferido esta Escribanía al Escribano de Real Hacienda por compensativo dẹ perjuicio causado con la creación de Intendentes con los derechos que tería antes en las cuentas de Corregidores. (N. del Ms. del A. G. 1.).

51.- Consta de un Liffome de aquella Contaduria, en $t^{\mathrm{t}}$ de octubre de 1776 .

52.- Real Orden de 3 de tieiembre de 1776 , y leal Cédula de 21 de marzo de 1778.

53.- Providencia de 11 de marzo de 1780.

54.- Providencia de 16 de mayo de 1780 .

55. - Real Provisión dada junto a la cordillera de los Chiriquanaes, a 5 de julio de 1574, y otra en Arequipa, a 2 de agosto de 1575.

56.- Real Frovisión de Lima, a 31 de mayo de 1631.

57.- Ordenanza $8^{n}$ de la Moneda, y Ordenanza 33 de la misma.

58.- Ordenanza gi de la Casa de Moneda.

(f) Aunque por las Ordenanzas 8 y 9 de la Moneda, están asignados por razón de derechos para costos del ensaye 4 ochavas de peso en cada piezd de plata, obtuvieron los ersayadores de Lima, una Real Cédula de S. Fldefonso, su fecha 3 de agosto de 1763, manditat guardar con parecer del Real Acuerdo en 19 de enero de 1769 , para que en cada pieza de plata se saque un bocado de peso de 6 ochavas en lugar de las cuatro que prefine la Ordenanza para poder compensar los costos que hicieron ver en su recurso tenía cada operación; y en otro superior Decreto de 20 de septiembre de 1768 , se manáo a los Oficiales Reales no permitiesen a los ensavadores excederse en los bocados que sacaren, de las 6 ochavas scñaladas en la Real Cédula citada.

(g) Por la Ley 17, Cap. 7, Tít. 22, Lib. 4 de Indias, y Ordenanza 7, Tíl. 17, Lib. $3^{\circ}$ de las Generales del Perú, está mandado, que los ensayes del oro se ejecuten por fuego $y$ agrua fuerte; y por la Ordenanza 6 de la Casa de Moneda, se previene que se compren los oros quilatados por ensaye real. Sin embargo de todas estas l'rovidencias, nunca se ha innovado en la Casa de Lima, el régimen de recibir el oro por toque de puntas, como se practicaba en la antigua labor de cuenta de los particulsres; antes bion se halla mandado observar este mismo método después del nuevo establecimiento del año de 1751 y 1755 , por Auto del Superior Gobierno, con voto consultivo del Acuerdo, su fecha 20 de septiembre de 1759 , con la consideración de que en plomo, copellas, muflas, utensilios, jornales y en papel para apuntes y certificaciones. subiría el costo de cada ensaye real, a 21 pesos 9 maravedíes, repartidos entre los dos Ensayadores de la Casa de Moneda y el de la Caja Real, y además de ser estas operaciones demasiado gravosas al comercio, vetardarian con su proljjidad de giro de la Casa; por esto, solamente sc exigen 6 reales por cada libra de oro que toca el Lnsayador Mayor del Reino. Lin Potosí se consultó al Visitador General este punto, por Dn. Jorge Escovedo, el año de 1778 , y ge practica tirar 3 reales por narco, partibles entre sí.

(h) Aunque el mismo Fundidor Mayor debe correr con las oficinas de afinar y fundir, conforme a la Ordenanza 28, $N^{\circ} 1$ y 3 , se observa esta Providencia solamente con el oro; pero en la plata, se tonó la resolución de finarse por otro Ministro, y hoy están separadas ambas oficinas por orden del Visitador General, de 15 de enero de 1779 , para remediar las notables mermas que se expe rimentaban, hasta 120 y tantos maravedíes en cada marco. Con este objeto se avisó, en Real Orden de Aranjuez, a 26 de mayo de 1781 , gue a consecuencia de lo representado por el Visitador General, se había mandado pasasen de México a esta Villa, sujetos inteligentes en las afinaciones de plata y oro; pero hasta hoy no se ha verificado esta Providencia.

(i) Luego que hay en el Tesoro, cantidad competente de metales de plata y oro, debe avisar el Superintendente a Jos Oficiales Reales, para el remache, el que se ejecuta con las formalidades de lá Ordenanza 11. Aquí había alguna condescendencia en no hacer concurrir a los Oficiales Reales a este solemnísimo acto; y el Visitador General Dn. José Antonio Areche, mandó que se observase estrechamente la Ordenanza.

59. - En México se hace la cendrada de tres partes de ceniza cernida y cuatro partes de barro fuerte que no tenga mezcla de arena, sin echar mano del hueso de que aquí se usa.

60.- Es prevención de Dn. Bernardo Pedrera Negrote, Ensayador Mayor de los Reinos de España, en su Informe de 8 de junio de 1673, mandado guardar en todas sus partes por Ieal Cédula de 24 de junio del mismo año.

61.- Las callanas son de barro con su crisol en medio, guarnecidas de abrazaderas 
de hierro y dos brazos gruesos para palanquearlas cuando las vacían.

(j) La nueva labor del oro se mandó hacer en esta Casa, después de muchos años de prohibición, en la Real Orden siguiente:

"Informado el Rey, de que se halla ya concluída enteramente la Casa "de Moneda de la Villa de Potosí, con todas las oficinas respectivas para la "labor de moneda que en ella se ejecuta, como tambićn las viviendas destina"das para los que deben vivir en ellas, y las salas de Hileras, Molinos y Volan"tes, aperadas de los instrumentos necesarios paja lat expressada labor que se "hace ya de cordoncillo y del Real Busto; ha resuelto S. M., a consulta del Con"sejo de Indias, de 22 de febrero próximo pasado, que no debe ya subsistir la "prohibición de labrar el oro en aguella Casa, impuesta por Real Cédula de 15 "de diciembre de 1761, con la caljdad de por ahora, vespecto de que estando co"mo está perfectamente concluida y corriente, ha cosado ya la causa princi"pal que motivó aquella Providencia, aunque con la citada clátusula junto con "la falta de noticias que entonces tuvieron de los mineriles injediatos al mis"mo Potosí; y en consecuencia, prevengo a V. Merced, de orden del liey, que ce"sando dicha prohibición se amonede desde ahora en adelante, en la mencionada "Casa de Moneda de Potosí, todo el oro que produzcun los mincrales de las Pro"vincias inmediatas a esa Villa, y por consecuencia, menos distantes que de "Lima, en donde se ha pretendido amonedar hasta ahora; y cuanto se presen"te en ella, indistintamente por los mineros o compradores de este metal, en la "propia conformidad que se practica con la plata, mayormerte cuando está "resuelto por S. M., poco ha, la minoración de derechos de este metal; y a fin "de que tenga debido cumplimiento esta deliberación y que se consiga cl ma"yor incremento de los Reales Derechos y el menor perjuicio de la nación en "su comercio, dispondrá V. M., desde luego que se haga cargo de aquella Su" "perintendencia, se leve a efecto por todos los medios que halle capaces a arrai"gar en la expresada Casa de Moneda la labor de este metal, dándome cuenta "de haberse' asi practicado, para noticia de S. M.-. Dios guarde a V. Merced "muchos años.- El Pardo, 17 de marzo de $1777 "$.

62.- Aquí llaman a este paso: "destropezonar", que quiere decir: igualar Ios yieles de las oquedades y prominencias con que saien de los moldes cuardo los vacían con poco cuidado.

63.- Dinerales son las pesas menudas en que arreglan el peso justo que deben tener las monedas dobles y sencillas, según se previene en la Ordenanza 16.

64.- Se dice "estar en Caja" cuanda lo que se pesa erl la balanza está en perfecto equilibrio.

65.- Se llama "cizalla" todo el residuo que queda de Ios ricles y demás plata menuda, después de cortada la moneda.

(k) A la oficing del blanqueamiento sigue la del oro. Aquí hay un banco para tirar los rieles. Otro con tres cortes para cortar las cuatro clases de monedas que se reducen' desde un escudo que vale dos pesos, hasta ocho escudos que vale diez y seis, incluso el de a 4 y el de 2 escudos, que intportan 8 pesos el primero y el segundo 4 pesos. Id. un tórculo para acordonar, una mesa para limpiar y un tes para sacar puntas de los rieles.

66.- Oxdenanza 18, $\mathrm{N}^{\circ} \mathrm{Z}$ al medio.

(1) El cumplimiento de esta Orden se ha recomendado muy particularmente por otra de Aranjuez, 30 de abril de 1789 , Cap. 5\%. (Nota del Ms. del A. G. 1.).

67:- Ustariz: en su Tratado de Comercio, Cap. 2 , fol. 3 , col. 2.

68.- Reglamento de Libre Comercio, del año de 1778, fol. 174 y siguientes.

69... Ustariz: Cap. 2", fol. 4, col. $1^{\circ}$, y Cap. $3^{\circ}$, fol. 5", col, $2^{4}$.

70.- M. Fresier: en su Viaje de la Mar del Sur, trae al fol. 138, una estampa con el $\mathrm{N}^{\circ} 22$ del modelo de estos ingenios o trapiches.

(11) Se principió la compra de pastas de oro y plata por cuenta del Rey en la Casa de Moneda desde el I5 de agosto de 1753 , con el fondo de 200.000 pesos que se trajeron de la Caja. (Nota de la copia existente en la Sociedad Goográfica de Potosí).

(m) El parágrafo último está consignado en la copia manuscrita de Potosí. (Nota de E.). 


\title{
CAPITULO NOVENO
}

\section{Del Partido de Porco}

\author{
Su descripción Fisica y Geográfica
}

Porco se sigue a la villa de Potosí, continuando su jurisdicción por la parte de Occidente, y se extiende más de 300 leguas en circuito.

Su capital es el pueblo de Puna, distante de Potosí diez leguas. El temperamento de sus tierras es frío, y aunque no muy adecuado para granos, hay muchos valles fértiles para ellos, con algunos ganados mayores y menores, sin contar las alpacas y carneros de la tierra que abundan en la puna.

\author{
NOTIOIA PRIMERA
}

\section{Minerales de Porco. TIENE muchísimas minas ricas de plata} en todo su distrito, como Siporo y Andacava, cuya profundidad y riqueza admira Barba, ${ }^{1}$ fuera de otros lugares de su jurisdicción, donde hay edificados algunos ingenios y trapiches para moler metales, a la ribera de acecuias construídas con mucho arte y costo por los indios, desde el ticmpo de su gentilidad. Pero en la Doctrina de Tomave, están los más ricos minerales de plata, a saber: Ubina, Huanchaca, Mactuyu y el Asiento; todos ellos poco poblados, por escasez de agua.

El cerro más rico que conocieron los Incas, fue el de Ponco, dictante de Potosí seis leguas, según Murilio, ${ }^{2}$ y según otros ${ }^{3}$ siete leguas, de donde se dice que sactron Ta mayor parte de la plata que había en el Templo del Sol de Curianche, (Koricancha) teniendo destinados un considerable número de indios para el trabajo de ellos, como principal teso- 
ro de las riquezas de su Imperio, por no haberse descubierto todavía en aquellos tiempos el famoso Cerro de Potosí, 4 como reservado por la Providencia Divina, para patrimonio de los más justos y piadosos Reyes del mundo. ${ }^{5}$

\section{NOT I C A SEGU N D A}

Repartimiento de Mita para el $\mathbf{T}$ OS españoles continuaron los reparti. Cerro de Porco. mientos para el trabajo de las minas de Porco, como lo hicieron para las de Berenguela en el Corregimiento de Pacajes, famoso mineral, así por sus riquezas, que después dieron en agua, como por haber tenido indios de "cédula" aun antes de Potosí. "A este intento se hallan en los libros antiguos diversos títulos despachados por los Sres. Virreyes, para Alcaldes Veedores y otros oficios del Mineral de Porco, que ya en el día han cesado, desde que se extinguió la Mita de aquel asiento. Por este mismo motivo y porque el Corregidor de Potosi, como Visitador del Cerro, tuvo siempre facultad sobre el entero de la Mita y sus incidencias, se dispuso en Real Plovisión del Sr. Dn. Francisco de Toledo, dada en los Reyes, a 12 de septiembre de 1576, que los Oficiales Reales de Potosí, con asistencia del Corregidor de la Villa, arrendasen las minas de S. M., así las de su Cerro Rico como las de Porco y Berenguela.

\section{NOTICIA TEROE R A}

Pueblos de Porco afectos al Repartimiento de la Mita de Potosí.
C se extinguió como se ha dicho el repartimiento de los indios "cédulas", y ha quedado la Mita de aquella Provincia reducida únicamente para el servicio de las minas de Potosí. Los pucblos afectos a ella, en la dicha Provincia de Porco, son: Chaquí, Yura, Caiza, Toropalca, Tacobamba, Potobamba, Colocaquina, llamada Tinguipaya, Puna, Tomave, Tolapampa y Coroma. Según una certificación del Contador de Retasas, de 15 de junio de 1733, siendo Virrey el Sr. Marqués de Castelfuerte, consta que los citados pueblos, por las últimas revisitas aprobadas en el Superior Gobierno, tenían 418 indios mitarios de gruesa de séptima y 136 para el continuo trabajo, con dos descansos.

Siendo diferentes las distancias en que están de esta Villa los referidos pueblos, según su respectiva situación parece que los leguajes se les debía pagar por el cómputo del camino que tienen que andar desde cada uno de dichos pueblos; pero suponiendo que los mitarios de las Provincias afectas a la Mita de Potosí, tienen destinado un cierto pueblo donde todos ellos se juntan para venir en comunidad, se formó un margesí de leguas por el Capitán de la Mita, en consorcio del Protector, a 25 de septiembre de 1771, siendo Superintendente el Sr. Dn. Pedro Tagle, Oidor de Charcas, por el cual se asignó el pueblo de Santiago de Chaquí como lugar donde se congrega la Nita, y arreglando medio-real por cada legua de las siete que hay de distancia hasta esta Villa, se les paga a todos los mitarios de Porco, por razón de leguaje, tres y medio reales. 


\section{N O T I G A C U A R T A}

De los valles fértiles y ramos de comercio del Partido de Porco.
E Les diecinueve Doctrinas que componen este Partido, se cuentan varios Ayllus y Comunidades pequeñas que no forman pueblo, y por eso sólo se anotan los principales, como cabeceras, en el mapa general de la Provincia de Potosí.

Todo su territorio está poblado, en la mayor parte de indios, y de varios mestizos y españoles, que son los que tienen ocupados los mejores terrenos de los seis valles fértiles del Partido. Fl más pingủe de ellos es la quebrada de Esquíri, poblada por ambas costas de muchas chacras, viñas y huertas, que con el riego del río de su nombre, producen peras, higos, tunas, duraznos y algunas legumbres.

Se recoge bastante vino, pero de mala calidad. Los altos de la quebrada sïrven para crianza de cabras, ganado, lanar, vacuno, y siembra de trigo; y aunque son abundantes las cosechas de este grano, no son buenas las harinas y se venden siempre a prẹcio más bajo que las del Partido de Chayanta y de otros parajes.

El principal comercio de los indios consiste en lanas, carbón y sal. Todos generalmente trafican el primer ramo; pero el segundo es easi privativo de los indios de Toropalca, por caer en su distrito los montes de churquis con que trabajan el carbón, logrando por este medio ser los más bicn acomodados del Partido; como también son Ios de Coroma, por la gran laguna de sal común, con que hacen sus cambios y contrataciones. Sin embargo de todo, es un país de bastante comercio y fomentándosele no dejaría de ser uno de los más ricos.

\section{N O T I C I A Q U I N T A}

De las producciones maravi- $\mathbf{V}_{0}$ debiéndose omitir en la descripción de llosas que se encuentran en este Partido, las noticias singulares tocanPorco. tes a la Historia Natural, para que los Gobernadores en los tiempos de sus visitas practiquèn nuevas investigaciones que adelanten o ilustren sus conocimientos, advierto que nuestro sabio D. Alonso Barba, ${ }^{7}$ refiere en su Arte de los Metales, hallarse en el camino que de esta Villa va al valle de Oroncota, cuando ya se quiere bajar a él, una veta o suerte de piedras com-puestas de conchas y otras figuras demasiado extraordinarias, como sapos, mariposas y otras cosas. Describe la situación de aquel valle, como la más defendida que se conoce en el mundo; muy eminente y cercado por todas partes, en el circuito de siete leguas, de altísimas e inaccesibles peñas, con una pequeña entrada por sólo una parte, después de muy dificultosa subida. Con este motivo refiere la opinión de los que atribuyen estas petrificaciones a la inundación de los mares en aquellos parajes donde se hallan, que aparecieron después de haberse retirado las aguas del territorio que antes bañaron; pero impugna este sentimiento por la altura de semejantes sitios y por la distancia de los mares, pareciéndole un dictamen muy infundado. Si fuesen conchas puramente fósiles las de Oron- 
cota, tendría razón nuestro Barba en no creer que estos f'enómenos fuesen causados del mar, porque, verdaderamente, son puros efectos de la descomposición de las tierras y diversas combinaciones de la materia las impresiones de imágenes de animales o vegetales en las piedras, que siendo esto último, se suelen llamar dentritas o piedras herborizadas; y si Io primero, zoomórfilas. "Así pues, necesitan de más seria observación estas petrificaciones.

\section{NOTIOIA SEX TA}

De varios discursos filosóficos sobre las conchas que se hallan en las montañas de Oroncota.
Y si resultase hallarse conchas fluviales, hecha ya o no su petrificación, no podrá dudarse que el mar las depositó allí, como lo afirma sin perplejidad Bowles, ${ }^{9}$ y se esfuerza a probarlo nuestro ilustrísimo Feijoó. 10

Otros naturalistas dificultan sobre manera que los mares hayan ocupado alguna vez unas tierras tan dobladas, montuosas y distantes; llegando Dn. Alonso Barba, ${ }^{11}$ al extremo de decir que sería locura pensar que la mar hubiese inundado en algún tiempo las tierras de Oroncota y dejado allí sus conchas; y así consideran que las conchas y otros cuerpos pretendidos como originarios de la mar, que se han encontrado en lo interior de la tierra, son puras generaciones minerales y como caprichos muy ordinarios de la naturaleza, a consecuencia de las leyes generales del movimiento. Porque si se atribuye al Diluvio universal y se piensa con Terttliano, Bochart y otros, ${ }^{12}$ que las aguas al descubrir la superficie de la tierra, dejaron en ella los cuerpos que otras diferentes causas los fueron ahondando después, urgen demasiado contra esta opinión las fundadas objeciones que propone el Ilmo. Feijoó ${ }^{13}$ en quien pueden leerse; además que no parece posible que estos cuerpos hubiesen conservado su figura inalterable por espacio de cuatro mil años que han pasado después del Diluvio, resistiendo en 40 sigios a la circulación continua de los minerales, de la materia sutil, de las exhalaciones y de los vapores, que demuelen, trituran y disuelven a lo largo todos los cuerpos que la tierra encierra en su seno.

Otros, no conformándose a que estas generaciones sean terrestres y puramente minerales, ni que sean meras semejanzas de conchas y pescados petrificados, recurren a que estos cuerpos marinos han sido depositados por la mudanza de los mares, que ocupan sucesivamente diferentes partes de la superficie del globo terrestre, en cuya comprobación alega Thevenot varias razones geométricas; pero como estos progresos son demasiado lentos y se terminan en algunos apartamientos cortos de las aguas, ni el mundo es tan antiguo, se hace inverosímil el que haya sucedido alguna mudanza remarcable de los mares.

Con esto se convence el juicio con que Bowles, aseguró ${ }^{14}$ lo difícil que es explicar cómo ha sido el depósito de estas conchas en los parajes más elevados de la tierra.

El Ilmo. Feijoó ${ }^{15}$ atribuye que estos admirables fenómenos se causaron en los sitios que siendo marítimos, se elevaron después sobre el nivel que antes tenían las aguas, criándose montañas que sucesivamente fueron creciendo hasta el estado que hoy tienen, cuyo sistema allana las 
anteriores dificultades con la excelente explicación que hace del crecimiento de las peñas y promontorios, confirmándolo con varios hechos que constan de la Histolia.

Ell cuanto al modo de formarse estas montañas compuestas de conchas, dice M. de Buffón: ${ }^{16}$ que los animales de concha transforman el agua del mar en piedra y que de esta manera producen el coral y todas las madréporas. Esta opinión no es la más probable, por ser difícil concebir que el agua pueda cambiarse on tierra. El agua es un elemento que sólo puede contracr combinaciones, pero sin ser capaz de mudar de naturaleza, y aunque entra en la composición de la tierra calcárea, es como principio constituyente que, cuando llega a separarse, vuelve a recobrar sus propiedades de agua. En pereciendo el animal de concha, se destruye la matcria animal, del mismo modo que el aceite de los demás cuerpos que permanecen en el agua; pero el residuo carbonoso y el principio ácueo quedan combinados con la tierra y componen una parte de ella para siempre $o$ a lo menos mientras esta tierra permanece calcárea. Supuesta esta mudación, como igualnente que cuanta tierra calcárea existe, ha sido hecha por los animales testáceos o de concha, como ha demostrado $M$. de Buffón en su Historia Natural, ${ }^{17}$ puede creerse que obran como los terrestres y cue acantonándose en el mar, eligen su sitio, donde crecen, viven y perecen, quedándose allí y sucediéndose unos a otros. En tal caso, sólo se necesita tiempo para que se vaya formando una cadena de montañas de conchas que ocupen todo el distrito adoptado por tales animales; cuyas montañas continúan creciendo, hasta que por último no encuentran ya los testáceos agua suficiente sobre sí, para mantener allí su domicilio. En csta hipótesis puede fácilmente comprenderse que si en los valles que están al pie de estas montañas no hay conchas, es porque estos valles no eran parte del acantonamiento de tales animales.

1.- Barba: Lib. 1", Cap. 27.

2.- Murillo: en su Geográfica Iijstórica, Lib. 9, Cap. 17, fol. 291. Laet. Lib. 11, Cap. 9 , fol. 465 .

3.- Fr. Diego de Mendoza: Crónica de San Francisco de Charcas, Lib. 1 $1^{\circ}$ Cap. $4^{\circ}$, fol. 29 , año 1545. El P. Calancha: Crónica de San Agustín del Perú, Lib. $3^{\circ}$; Cap. $40, \mathrm{~N}^{\circ} 1$, fol. 743 .

4.- Ulloa: en su Viaje a la América Meridional, Lib. $1^{\circ}$, Cap. $13, \mathrm{~N}^{\circ} 327$, tomo $3^{\circ}$, fol. 190: Murillo, en su Geográfica Histórica, Lib. $9^{\circ}$, Cap. 17, fol. 291. Garcilaso y otros. Barba: Lib: $1^{\circ}$, Cap. 27 , fol. 28 .

5.-Calancha: Lib. $3^{\circ}$, Cap. $40, \mathrm{~N}^{\circ} 2$, fol. 745 .

6.-D. Alvaro Alonso Barba: Lib. $1^{\circ}$ del Arte de los Metales, Cap. $2^{\circ}$, fol. 3.

7.-.-D. Alonso Barba: en su Arte de los Metales, Lib. 1॰, Cap. 17.

8.- Bowles y su ilustrador Azara: Historia Natural de España, pág. 121, No 1 , marginal.

9.- Bowles: Historia Natural, pág. 151.

10.- Feijoó: tomo $5^{\circ}$ del Teatro Crítico, Discurso 15, \$ 12 y 18 , fol. 337 y $347, y$ en el tomo $7^{\circ}$, Discurso $2^{\circ}, \$ 1^{\circ}$ y $5^{\circ}$, fols, 26 y 39 .

11. - Barba: Lib. 17, Cap. 17.

12.- Tertuliano Depaltio: Cap, 2*. Bochart: Lib. 4 Phaleg. Cap. 24 : Ibi adhuc maris conche et bussine peregrinantur in montibus, cupientes Platoni, provare etiam ardue thlutase.

13:- Feijoó: tomo $5^{\circ}$, Teatro Crítico, Discurso 15, § 13, $\mathrm{N}^{\circ} 35$, fol. 338.

14.- Bowles: Historia Natural, fol. 151.

15.- Feijoó: Teatro Crítico, tomo $5^{\circ}$, Discurso 15 , $\$ 18$ y 19 , fol. 347 hasta 350 .

16. - Buffón: tomo 13 en $4^{\circ}$ de su Historia Natural, pág. 11.

17.- Buffón: tomo $1^{\circ}$ en $4^{\circ}$, pág. 272 . 


\section{CAPITULO DECIMO}

\section{Del Partido de Chichas}

Se describe sus principales poblaciones, con los minerales de oro $y$ plata, ingenios y Doctrinas. Su extensión y demás circunstancias.

NOTICIA PRIM E R A

De la extensión y naturaleza TL Partido de Chichas, llamado así desde del terreno de Chichas. cl tiempo de la gentilidad en el Reino del Perú, tiene de largo, de Norte a Sur, cuarenta y ocho leguas, desde el arroyo de La Quiaca, que lo divide de la Provincia del Tucumán, hasta Quirve que confina con Poreo; y de ancho, de Este a Oeste, cuarenta y cinco leguas, que son, desde tres leguas de Esmoraca para adelante que confina con el Partido de Lípez, hasta junto a Livilivi, que está sujeto en lo civil a Chichas, $\mathrm{y}$ en Io eclesiástico a Lípez, como anexo del Curato de San Pablo, que es de su distrito. Tiene mineral de oro, aunque al presente muy atrasado, y en él diez minas registradas. Es el oro de más quilates de todo el Partido, que alcanza hasta 23 quilates, excepto el que llaman "del Cerro", que es de veta; en el mismo Esmoraca, de sólo 17 a 18 quilates, llegando la ley de los demás minerales, por lo general, de 21 a 21 y $1 / 2, y$ no más.

Es país muy quebrado, compuesto todo él de serranías y sólo en la parte de Tarija tiene sus valles. Lo extendido por Chichas, que es desde Livilivi sujeto en lo civil a Cinti (Partido de Charcas) hasta Esmoraca, raya de la Provincia de Lípez, es lo que se llama puna, en partes, demasiado rígida. Sólo en las quebradas se disfruta un temperamento me- 
diano, llamado entre los naturales "Chaupi-yunga", que es un medio entre los dos extremos de frío y calor; de modo que tiene tres temperamentos bien desiguales.

El río principal de este Partido es el Toropalca, que pasando por la Provincia de Cinti, se junta con el de Suipacha y forman el de Pilaya, que hacia las tierras de los infieles se agrega al Pilcomayo y es navegable.

El número de los moradores se gradúa por 60.000 almas; la mitad en los valles de Tarija y la otra en los altos, con poca diferencia.

\section{NOT I I A S E G U N D A} De su Capital Tupiza, y de
otros pueblos principales con
sus respectivos minerales. sisten principalmente con el comercio de géneros cle Castilla y el trabajo de las minas del Cerro de Coroma; poco maíz, trigo y arriería, con algún oro de Estarca, altos de Nazareno y río de Suipacha.

Tiene una iglesia muy decente con bastante adorno de piezas de plata, cuadros dorados y otros utensilios, pero el Sagrario es lo mejor, así por su excelente fábrica como por sus bellas pinturas exterioros de esmaltes no menos que por su bella situación, con una gran ventana que hace demasiado agradable su vista. En dicho Cerro de Coroma hay una mina que llaman "la Blanca", de donde se ha sacado mucha porción de plata; y así allí como en otros cerros muy inmediatos, de distintos nombres, se cuentan actualmente de doce a catorce intereses de minas, pero sólo de la "Blanca" se surten dos ingenios, de a dos cabezas cada uno, y tres trapiches de agua que hay en la Parroquia, en la Ribera de este pueblo. Son anexos del Curato de Tupiza, el pueblo de Suipacha, que es más de españoles mantenidos con la arriería, que es su principal giro, y aiguna corta siembra de maices y trigos.

Hay bastantes veneros de oro; pero ninguno se trabaja con Registro, aunque los indios juquean (a) en ellos.

El pueblo de Estarca es en su mayor parte de españoles. Trabajan en minas de oro que se cuentan en sus inmediaciones, sólo seis u ocho con registro; otros se aprovechan del juqueo en veneros dejados y sueltos. Están comprendidos en la misma jurisdicción de la Matriz de Tupiza, los pueblos de Coroma, San Miguel de Chacapa y la hacienda de Oploca, que tiene sus capillas públicas.

Quebrada arriba, cuatro leguas del pueblo de Tupiza, se halla situada dicha hacienda de Oploca, con otros dos ingenios, de una cabeza cada uno, y se surte el primero de una mina del asiento de Tatasi, nombrada "Palomino", que dista del ingenio catorce leguas. Son pertenecientes a esta hacienda las de Salo y Mochará, sucesivas unas de otras, con tierras muy fértiles para trigos, cebada, maíces, papas y alfalíares, y buenas campañas para crianza de toda especie de ganados. Tiene derecho de Yanaconas, que al presente son 160 indios, con muchos arrenderos. Tiene además un molino, que es el único en el distrito de Tupiza. Los señores Yáñez pretenden tener derecho a esta hacienda, con título de Conda- 
do, que se concedió a su abuelo, por mérito de su ascendiente Quiroga, célebre Azoguero de Potosí, que dio al Rey, por quintos, veintinueve y medio millones. Aun no está declarado este mayorazgo; pero él es un vínculo demasiado pingüe, que si se cultivara con industria llegaría a ser el mejor de la jurisdicción de Charcas y el más extenso, por calcularse su teritorio en cincuenta leguas de Oriente a Poniente.

La Gran Chocaya es otro pueblo de españoles, de cuyas riquezas hace memoria con admilación nuestro viajero Dn. Antonio Ulloa. 1 En su distrito, cuya cabecera es Tatasi, residencia del Cura, con un anexo Ilamado Chorolque, se graduan, lo menos, cien minas de plata, con registro, fucra de dos de oro en Chilco, sin contar otras muchas labores en que juquean los pobres. Los asientos principales son: el de Vetillas, nombrado Portugalete, con tres ingenios de moler metales. Ias platas son de riquísima ley y rinden hasta 100 marcos por cajón; y es de creer que sólo con los desperdicios y desmontes, pudiera enriquecerse un hábil beneficiador que se dedicase a trabajarlos; pero es tan áspero su terreno y tan rígido el temperamento, que en todo el distrito de Chocaya apenas hay sitio donde poder sembrar una carga de semilla.

Los demás pueblos son: Talina, Santiago de Cotagaita, Calcha, Tocha, (actualmente Tocla) Chagnachoca, Escara, Vichacla, Checuati, y otras cortas congregaciones pobladas casi en todo de indios.

Lo más poblado de este Partido es la quebrada de Santiago, cinco leguas abajo del pueblo, que por una y por otra banda hasta doce leguas, confinando con la jurisdicción de Pilaya, está habitado de gentes a la orilla del Río Blanco, que se dice el Río Grande. En esta quebrada y otras del Partido, se siembran maíces, trigo y cebada, con algunos frutales de higueras y duraznos, y una viña que es la única en toda la jurisdicción de Chichas. Hay bastantes ganados mayores y menores; unos que se crían en su distrito y otros que se traen de la Provincia del Tucumán, de cuyas carnes se beneficia el sebo, grasa, charqui, y cecina, para provisión de aquellos minerales y para Potosí, haciéndose las matanzas por mayo o junio, que se regulan de seis a siete mil cabezas.

Además de los minerales referidos, hay muchos veneros en Talina, de que se aprovechan los indios por juqueo; y se cuentan para su beneficio, fuera de los ingenios ya citados, seis molinos xepartidos en los distritos de Santiago de Cotagaita, Tumusla, Chati, Mojo, Talina y Tupiza. Se calcula que todos sus minerales de plata, incluyendo a San Vicente, Monserrate, Tasna, Ubina y Chocaya la Nueva que añade a los de arriba, Barba, ${ }^{2}$ con admiración de sus riquezas, rinden al año más de 60.000 marcos, y los de oro hasta 100.000 pesos.

\section{NOTIOIA TER C R A}

Refiexiones para aumentar las
sacas de plata.
tos, si en los asientos de sus minerales se re-
partiesen con abundancia los azogues y los
mineros tuviesen las precisas habilitaciones y avios para tener sus minas
en corriente labor; pero, como regularmente sobra poco azogue después
de surtir la Ribera de Potosí, y ninguno hay quien se atreva a habilitar 
minas, por la contingencia de su provecho, so experimenta on vez de aumento, atraso en los minerales de la Provincia. Siendo lo más sensible que se desperdicien muchas riquezas, así en la ley, que no han dado, por ignorarse las diferencias y naturaleza de Ios metales, como on las desacompasadas pérdidas de los azogtıes, por hallar'se confiaclo el más importante arte de beneficio de metales, a un indio, mestizo u otro infeliz hombre ignorante, que regularmente emprende esta nobilísima ocupación, como por granjería, a falta de otro ejercicio, sin más estudio ni conocimiento que una grosera experiencia adquirida materialmente.

$\mathrm{Y}$ sólo que se aplicase oportuno remedio en un negocio de tan grande interés, no admitir al oficio de Benefictadores, personas que no fuesen hábiles, con examen y aprobación de la Justicia, como de un ejorcicio público, y además de encargarse a los Subrlelegados de los Partidos, la habilitación y fomento de los mineros, poniendo en poder de ellos cantidades equivalentes para el avío de las minas y rescate de las platas, conforme al espíritu del Art. 134 de la Real: Ordenanza de Intendentes, según se ha practicado en otros tiempos en varios minerales del Reino, veríamos en poco tiempo floreciente la ntinería, aumentando los Reales Quintos, enriqueciendo el Reino y la Casa de Moneda abundante de labores para nervio del Comercio.

A este fin se ve dispuesto por Auto acordado de Lima en 16 de octubre de 1724, para que los Oriciales Reales de Potosí, rencitiesen a los de Chucuito, cada año, 50.000 pesos para rescate de barras, a 143 el ensayado, en lugar de los 23.000 pesos anuales que había ordenado el Sr: Príncipe de San Bono, en 12 de mayo de 1718; cuya orden reiteró el Sr. Virrey Castelfuerte, en Despacho de 15 de abril de 1731 , para que se hiciese ígual remisión al Corregidor de Lípez, de la cantidad de 16.000 pesos anuales, bajo de fianzas. De este modo se evitarían muchas fraudulentas extracciones que se hacen en la Provincia de Chichas, de considerable porción de oro y plata a las provincias del Tucumán y Buenos Aires, por falta de pronto rescate, sin pagar los Reales Quintos.

\section{NOTIOI A O U A R T A}

Domunidades Mitarias, para el
servicio de Potosi. $\begin{aligned} & \text { tosi, y vienen a servirla los indios de las Co- } \\ & \text { munidades de Talina, Santiago y Calcha. Su }\end{aligned}$ repartimiento es de ocho indios de Talina, once de Santiago y seis de Calcha; todos ellos asignados al ingenio que llaman "Agua de Castilla", de la Ribera de Potosí.

En el margen de leguajes, se supone que la Mita se congrega en el pucblo de Santiago de Cotagaita, asigmando la distancia de 30 leguas, que a medio-real cada una, componen 1 peso y 7 reales. En lo que debe notarse lo siguiente: que de Santiago a Potosí, hay treinta y cuatro leguas, según la numeración hecha en el establecimiento de las Postas; con qué, de contado, viene a perder el indio dos reales. Do Talina a Potosí, se cuentan sesenta leguas, y caminando estos infelices toda esta distancia en beneficio de los mismos azogueros, se les viene a defraudar 30 medios, que son 1 peso y 7 reales; y aunque a los de Calcha, que sólo dista 
veintidós leguas, les asigna el margesí los mismos quince reales, suponiendo inverosímilmente que hayan de duplicar el camino juntándose en Santiago, siendo más fácil agregarse en su mismo pueblo, al pasar por allí los demás indios, siempre quedan perjudicados los indios de Talina, pues, aun cuanco se les quitase a éstos lo que se agrega a los de Calcha, vienen a perder el leguaje de veintidós leguas.

\section{N O I I I A Q U I N T A}

Discurso político para hacer feliz al Partido de Chichas.
I 1 L más doloroso es que habiendo minas ricas en Chichas, no tengan el trabajo de sus mismos naturales para su labor, y que Po-
goce al privilegio de la Mita para beneficio tosí, distante tantas leguas, goce el privilegio de la Mita para beneficio
de sus minerales, tan en perjuicio de aquellos infelices indios, que si se repartiexan alli, trabajarian como aquí, sin salir de sus tierras, y los Asientos de aquel P’artido estarían más abundantes y mejor servidos, con la preferencia de su propio bien, a gue es tan justamente acreedor por derecho natural. Así lo juzgó el Emperador Claudio, ${ }^{8}$ estimando por inhumano, crucl y duro, que las fuentes nacidas en propias tierras fecunden las ajenas, dejando secas y ustériles las de su origen.

De esto procede que, por la dificultad de peones, se hallan muchas minas sin labor, $y$ aun los libres que voluntariamente se conchaban, sufren inclecibles injusticias y extorsiones; porque como es una gente sin reflexión, que sólo aspira a lo del día, se alquila fácilmente por el interés de ocho o diez pesos que les adelanta el minero, bien sea en Potosí, donde viene a buschrlo, o en otro lugar, para gastarlos en dos o tres dias que se pasan mientras salen a su destino.

Como allí trabajan fuera de su costumbre, y los alimentos del maíz, coca y charque se les vende a unos precios tan subidos, tratan de desertar en breve, viendo que el salario se consume en comer. El minero que sabe esto muy bien, lo compele con rigor, llegando al exceso de ponerles grillos y otras prisiones como a reos. Les paga su jornal a cuatro reales y al barretero seis, mitad plata, mitad géneros a precios exorbitantes.

Tos domingos se les da ración la mitad del jornal diario, en coca o aguardiente, para toda la semana; al cabo del mes, ajustadas cuentas, regulalmente salen alcanzados; con lo que son unos esclavos disimulados, que trabajan toda su vida por lo que comen y beben.

No habiendo allí Alcaldes Veedores ni Juez que cele su buen tratamiento, padecen innumerables vejaciones, siéndole fácil al minero redimirse de todo cargo al tiempo de las Visitas de minas de los Subdelegados, con tenerlos gratos, y porque a éstos les conviene mantener muchos registros corrientes a cualquiera costa de los infelices, por disfrutar los excesivos derechos que tiran a su antojo.

Dicen que no conviene darles en plata, porque la gastarían toda en borrachela y sería difícil después juntarlos para el trabajo. Lo cierto es que no tienen reparo en darles su salario en aguardiente, emborrachándolos por su propia mano; pero como el minero tiene en esto su granjería, no le duele ch uste caso la borrachera del indio.

Ellos ponen pulperías y prohiben con mil reprobados arbitrios, que 
otros se introduzcan alli a vender. De este modo ponen la ley a sus efectos, $y$ el indio, naturalmente vicioso que no tiene otro lugar donde comprar, consume allí el precio de su penoso sudor, sin sacar más fruto que el rigor y la desnudez. Convendría infinito atarifar los efectos, visitarlos cada mes y tomar a los Mayordomos continua residencia de estos abusos, cuando no se pudiera repartir allí indios.

(a) "Juquean", de juquear, expresión que proviene de la voz quichua "juca" o "jucu", con que se designa a los trabajadores clandestinos de las minas. (Nota de E.).

1.-Ulloa: en su Viaje a la América Meridional, Lib. $1^{\circ}$, Cap. 13 , tomo $3^{\circ}, \mathrm{N}^{\circ} 344$, fol. 199 .

2.- Barba: Lib. 1\%, Cap. 27, fol. 28.

3.- La Ley Proeces 5, Cod, de servitutib et aqua ibi: cum sit durum et crudelitati proximun ex tuis proediis aquoe agnen ortum, sitientibus agris tuis ad aljorum usum, vicinorum injuria propagari. 


\section{CAPITULO UNDECIMO}

\section{Del Partido de Lípez}

Con su descripción circunstanciada y la de sus principales minerales, con varios discursos sobre algunas particularidades extrañas."

\section{$\mathbf{E}_{\mathrm{I}}$}

L tercer Partido de esta Provincia es Lipez, de no menor importancia por sus riquezas. Su extensión es de setenta y cinco leguas por lo ancho y ochenta y dos por lo largo. Su capital es San Antonio, distante de Potosí ochenta y dos leguas, ${ }^{1}$ y se compone de cuatro Curatos. (a) El temperamento es clemasiadamente frío y no adecuado para la agricultura, ni produce más frutos que poca cebada. Abundan sus tierras de vicuñas, alpacas, tarucas, (venados) y llamas. Fue país abundantísimo de minas en otros tiempos, así de oro como de plata. Ulloa ${ }^{2}$ cita entre los más famosos cerros del Perú, el de San Cristobal de Acochala (b) en esta Provincia, por la riqueza de sus minas de plata, asegurando que en algunos parajes se cortaba a cincel; pero se engaña en atrįbuír su decadencia a la falta de gente para trabajarlas, y en suponer que, a no ser esto, sin duda produciria con la misma abundancia, por ser constante que la causa es haber dado en agua.

Barba ${ }^{3}$ cuenta en esta misma Provincia otros dos célebres minerales. El uno en el famoso cerro de Santa Isabel del nuevo Potosí, cuyos metales eran rosicler casi todo plata, criado entre tanta abundancia de azufre, que arớa el metal en llegándole las velas encendidas. El otro, llamado de los Encomenderos, por haber sacado de él inmensa cantidad de plata aquellos indios, y para libertarse de la situación que tenían allí, por razón de encomienda, dos hermanos llamados Tapias; asegurando el citado Barba, que cuando él pasó a ser Cura de Lípez, el año de 1617, en- 
contró las calles de los pueblos llenas de granza menuda cle metal muy irico, que él recogió y aprovechó.

También hay ricas vetas de oro on un cerro junto a Colcha en usta Provincia, y a tres leguas de dicho pueblo se manifiesta un socavón antiguo, en un paraje que llaman Abitunis, que en lenguaje de indio quiere decir "mina de oro". "

En eI cerro llamado de Escapi, (c) dos leguas de Chuica, en la Provincia de los Lípez, se encuentra una labor grandísima de cobre. 5

Asimismo se encuentra rico alumbre de roca junto a Colcha, cabecera de esos pueblos; ${ }^{6}$ capar'osa muy azul, que llaman "Piedra Lápiz" (o Lípez) por el nombre de su Provincia; 'y azufre en mucha abundancia. 8

No sólo oro y plata hay en este Partido, sino también piedras preciosas. Barba "afirma que en el cerro rico de Santa Isabel del Nuevo Potosí, en Lípez, se sacaban entre sus motales de plata, riquísimas y muy maduras piedras de amatistas; haciéndose, por generosidad de la naturaleza, tan precioso este país, como el Pegú y Ceylán, de donde so traen estas piedras según Tabernier on su Viaje a las Indias Orientales; ${ }^{10} \mathrm{y}$ añade Barba, ${ }^{11}$ que en una de las jornadas que hay desde Potosí a los Lípez, junto a la que llaman "Agua Caliente", hay una pampa llena de preciosísimas piedras cristalinas y transparentes como un sol, labradas por la naturaleza en ángulos que rematan en punta. Fn cl día no se conocen ya las maravillas que nos cuenta Barba. Sólo he visto tracr del cerro nombrado San Antonio de Esmoruco, anexo de la Doctrina de Santa Isabel de Lípez, unos grandes cocos, donde se crían a manera de plantas enramadas unas piedras muy preciosas, de color morado y fondo blanco, de los que tengo uno en mi estudio. Quebrado el coeo se ven las piedras unidas, del tamaño de una almendra, y rematan todas las cabezas en puntas agudas; si se lapidaran, no dudo que serian de apreciable uso.

Lo que hay, sobre todo admirable, entre los Irípez y las Salinas que llaman "de Garci-Mendoza", es una llanura de sal muy cristalina, cuya travesía, por lo más corto, tiene diez y seis leguas de ancho y cuarenta o más de largo. En trechos se descubren pozos insondables y en ellos hermosísimos peces. Algunos caminantes que no han querido rodear camino $y$ se han atrevido a atravesar por sobre la pampa de sal, que parece un mar helado, se han hundido, sumergiéndose debajo de la sal, sin saberse más de ellos. Cuatro leguas de las minas de San Cristóbal de Achocolla, hay una laguna pequeña sobre un cerrilio, en cuyo centro hierve el agua con imponderable tumulto, desaguándose por un pequeño conducto; y cuanta por allí sale se convierte en sal colorada. 12

\section{NOTICIA P R I M E A}

De la mina llamada "La $\mathrm{He}$ dionda", y sobre ella se discurre fisicamente.

blaron los minerales del asiento de San Cris-
tóbal de los Lípez, descubrieron dos gallegos una veta de metal riquísimo, tacana entre calichal blanco, que a poco de haberse ahondado no se pudo 
seguir el trabajo, porque despedía de sí un olor pestilente y mortífero, de que se derivo el nombre de "Hedionda", que hasta ahora conserva. Suspendido el trabajo, quisieron continuarlo otros al cabo de cuatro años; pero luego se absturieron por la repentina muerte de los indios trabajadores. Por último, afirma como testigo de vista, que de cualquier parte donde se cavase aquel cer'lo, exhalaba una hediondez tan insufrible, que er'a capaz de matar a cuantos de allí no huyesen; y a mí se me ha asegurado por sujeto de crédito, que pasando él mismo media legua distante de aquel cerro, en ocasion de soplar un recio viento que venía de aquel lado, luego al punto que Jo percibió por la respiración, cayó desmayado al suelo, sin sentido, y le resultó después una grave enfermedad de aquel aire pestilente.

No tiene duda que al rededor de las minas circula una materia que ataca a los instrumentos y a la ropa de los obreros, que algunas veces los sofoca; que apagando frecuentemente las candelas y Ias lámparas, o inflamándose cuusa una explosión y un ruido parecido al tiro de escopeta, a menos que no se refresquen las minas por respiraderos que disipen estas exhalaciones.

El efecto mortal de estos vapores de las minas, se puede atribuír, bien sea a ulia extrema rarefaccion del aire, causada por el calor de las cavernas o socavones subterráneos de cllas, o a la erupción de un vapor muy glutinoso y viscoso, impregnado de azufre y otros antimonios poco saludables.

En el caso de la mina "Hedionda", de Lípez, parece menos oportuna esta explicación, porque en un pozo ahondado apenas una vara, que no se pudo proseguir por la hediondez que salia de la tiezra, en el mismo cerro, asegura Barba, ${ }^{14}$ que pasando por allí al cabo de pocos días, vio en el pozuelo muertos algunos pajarillos y otras sabandijas que había atosigado el veneno que de allí se exhalaba. Este fenómeno no podía proceder de la rarefacción del aire, faltando el demasiado calor que lo debía causar.

A este propósito, reficre Barba, 'is que algunos pensaron que también en las entrañas de la tierra hay cosas muy abominables y hediondas, que corresponden en su modo a los estiércoles de los animales; y aunque este autor no pasa por esta suposición ni explica tan extraordinaria causa, afirma que los metales huelen, por la mayor parte, mal, o por su natural destemplanza o por la mezcla de azufre, caparrosa u otros jugos que casi siempre tienen.

No es extraño discurrir de csto, que impregnada toda aquella tierra de tantos jugos minerales, cxhale de continuo un vapor glutinoso, espeso y azufrado, capaz de matar al que lo respira. Así se ve que después de aquel manantial inagotable de betún que habia en Babilonia, ${ }^{16}$ se encontraba un terreno de pequeña extensión, tan dañoso por la erupción de vapores espesos y azufrados, que al instante perdían la respiración los animales que allí se acercaban. Ellos morían de repente, y la hinchazón de sus cadáveres, con la inflamación de los pulmones, era signo evidente de la infección del aire.

Todo esto conviene físicamente a nuestro caso, porque según Barba, ${ }^{17}$ el olor de aquella tierra era semejante al que tiene ma bodega llena de mosto cuando está hirviendo, grave y pesado, que aun a los que gozaban del aire libre ofendía; scñales todas caracteristicas de la impreg- 
nación de azufre $\mathrm{y}$ de otros venenosos antimonios con que está mezclado aquel terreno.

Por lo visto se convence lo interesante que este Purtido es al Estado, y que con el tiempo puede ser uno de los más ricos del Perḱ, chando la Divina Providencia suspenda el entredicho de sus preciosos metales, como se debe esperar, segin lo nota nuestro Barba. ${ }^{1 *}$

\section{NOTIOIA S E G U N D A}

\section{De las vicuñas y progresos que puede lograrse con el comercio de sus pieles; aplicando en la crianza de animales la econo- mia que se apunta.}

$\mathbf{P}$ su comercio con la apreciable lana de las vicuñas $y$ alpacas de que tanto abunda su terreno. Como que es la mús preciosa materia para sombreros de castor, pañuelos y otros tejidos finos; se dedicañ nuteles-a eazar estos anima-

litos. Aunque son en extremo ariscos y dificiles de ser aprohendidos con escopeta o ballesta, se cogen casi a mano corriéndolos por los cerros a que bajen en alguna quebrada o estrechura, donde se forma un cículo a manera de corral, con unas cuerdas delgadas, sostenidas a trechos de piedras grandes o ramas clavadas en tierra. Entrando all les causa tanto terror aquel corto embarazo, que se estrechan unos con otros, haciendo remolinos, como ovejas dentro de un corral, sin ser capaces de avanzar el cj́rulo; y de este modo cogen cuantos quieren, con la mayor facilidad.

Por más que abunde esta especie, es de temer que según vaya creciendo la población y se aumente el trajin, abriéndose caminos por donnde estos animalitos nacen, viven y se crían si no se pone regla en sus matanzas y correrías, al cabo llegará a consumirse o sc disminuirá notablemente, o al menos, retirúndose en las asperezas más insuperables de las montañas y cerros, llegará a hacerse rara la espccic y en extremo cara una materia que ahora se adquiere tan a poco costo, que un cuero entero de vicuña sólo vale en Lípez, de dos a tres reales.

No sería de poca utilidad y provecho para las fábricas del Rey, que los indios tributarios de Lipez, pagasen sus tasas en vicuña, pues, además del poco costo que se tendría en su primera compra y conducción a España de su cuenta, se lograría dos cosas: la primera, el proveer con abundancia a las fábricas Reales de esta preciosa materia y quitar la absoIuta libertad con que ahora el comercio la vonde a los extranjeros; la segunda, que con este interés trabajarían los indios no solamente en recoger muchas vicuñas, sino también en conservar la especie, para el pago de sus tasas.

Con este último objeto se mandó, por Real Cédula dada en San Ildefonso, a 30 de agosto de 1777, que los indios no matasen vicuñas en las cacerías, y que sólo se les permitiese esquilarlas en presencia de persona de satisfacción que nombrase el Corregidor o Justicia para esta operación. (d) La Audiencia de Chareas (y lo mismo pienso de otras) representó la imposibilidad de este proyecto, porque explicada ya la naturaleza de estos animalitos, se ve que más fácilmente se dejan matar que esquilarse, (e) y en el tiempo que ahora un solo indio aprovecha veinte o treinta vicuñas, apenas podría esquilar una.

Pero en tales cacerías se debe guardar la precaución de no permi- 
tirlas en tiempos de cría y parición, (f) con arreglo a las leyes 1, 3, 8, 10, Tít. 8, Lib. 7 ate Castilla, para evitar la aniquilación de la especie; porque los indios, regulartnente, aprovechan dichas estaciones, con el conocimiento de que las victrñas perseguidas no hacen todo el esfuerzo que otras vecos en huír, por no clesamparat la cría.

Juzgo por más fácil, amidnsarlas cogiendo muchos casales lechones, los cuales, criodos en casa con leche de vaca, se domestican tanto que viven entre las gentes y siguen al dunio como un perrillo, según he visto en Potosí una vieuña criarla en esta forma, lo que podría observarse igualmente con un millón de ellas. Si por cada casal domesticado que el indio presentara al Subrielegado o Justicia de su l'artido, se le asignara un corto premio, obraría en breve grandes progresos el excesivo interés de esta gente, y aumentando a porfía los casales, en pocos años tendríamos muchas manadas de vicuñas domesticadas que poder esquilar, porque las nacidas en los pueblos, se dejarían cuidar on los mismos lugares que tenían por domicilio sus padres y tal vez con el uso y experiencia de muchos años se descubriría en ellas alguna utilidad más que la Iana, a semejanza de los cainieros que llaman de la tierra.

En este mismo Partido hay mucha abundancia de chinchilla, cuya piel es de tanto aprecio aquí y aun en Europa, para forros regalilios de invierno; y también pueden servir para tojidos exquisitos, donde estuviere adelantada la industria. Es un animalite del tamaño que manifiesta la piel; no vo de día y se le caza con las manos, cuando se queda fuera de su cuevita, o cavando ésta, como es fácil, por hallarse casi sobre cl haz de la tiorra. He visto domesticados algunos de ellos, no beben agua, se mantienen do pajitas y cada(casal vive separadamente, con tanta unjón, que muriendo alguno, ol compañero se pega al cadáver hasta morir, y defiende con tunto extremo el macho a la hembra, que viven en continua pelea unos con otros, de suerte que se hacen entre ellos grandes matanzas.

Con estas pieles, las de vicuñay-carneros de la tierra, (llama) con pólvora y azufre hacen su principal comercio los indios de Lípez; pero, de todos modos, es una gente miserable.

\footnotetext{
1.- Ulloa en su Viaje, Lib. $1^{\prime}$, Cap. 13, $\mathbf{N}^{\circ} 345$, tomo $3^{\circ}$, fol, 109. No Ie da a Lípez más que treinta y cinco leguas de extensión, y se engaña manifiestamente.

(a) Vide el Plan de Curatos al final.

2,-Ulloa: loco cituto.

(b) Significa en lengua de indio: dos cerros pegados y abiertos por el medio, en forma de compás nuy estrecho. (Nota de E.).

3,-- Barba: en su Arte de Metales, Lib. 10, Cap. 19 y 28.

4.- Barba: I.ib. $1^{\circ}$, Cap. 26.

(c) Hisckahappi o Quiscahapi en quichua. (Nota de E.).

5.-. Barba: Lib. 1\%, Cap. 29.

6 .- Barba: Lib. $1^{\circ}$, Cap. $5^{\circ}$, párrafo último.

7.- Barba: Lib. 1\%, Cap. $6^{\circ}$.

8,- Barba: Lib. 1\%, Cap, 10

9.-.- Barba: Lib. 1\%, Cap. 15

10.- Tabernier: Lib. 29, Cap, 19

11. - Barba: Lib. $1^{\circ}$, Cap. 15

12.- Barba: Lib. $1^{\circ}$, Cap. 7.

13. - Barba: Lib, 1", Cap. $2^{\circ}$.

14. Barba: Lib. 14, Cap. $2^{\circ}$.

15. Barba: loco citato.

16,_- Diodoro Siculo, Lib. $2 \%$
} 
17.- Barba: loco citato. En la obra intitulada "Errores de la Mineria del Perú" se verán otras noticias modermas.

18.- Barba: Lib. 1\%, Cap. $2^{\circ}$.

(d) Esta orden se fundó en la Polića antigua de los Incas, que tenían ley para lo mismo, según Garcilaso: Lib. 6\%, Cap. 6\%, tomo I, fols. 178 y 179 . (Nota del Ma. del A. G. I.).

(e) Aunque en las cacerías de los Incas, esquilaban estos animales, según Garcilaso: Lib. $6^{\circ}$, Cap. $6^{\circ}$, tono I, fols. 178 y 179 , ésto les era fácil a ellos por el número de más de treinta mil indios que salían a las batidas; pero entre nosotros es imposible. (Nota del Ms. del A. G. I.).

(f) Lo mismo observaban los Incas.- Garcilaso, loco citato. 


\title{
CAPITULO DUODECIMO
}

\section{Del Partido de Chayanta}

\author{
Se explica por noticias su situación, extensión, pueblos principales, su \\ temperamento, minerales, rios $y$ producciones.
}

\author{
NOTICIA PRI M E A
}

De la situación, extensión $\$$
confines de Chayanta, con sus
principales pueblos.

$\mathbf{E}$

USTA Provincia, conocida comunmente por Chayanta, se denomina con propiedad Charcas, pero se ha quedado con el primer apelativo por derivación de su capital, que es el "Esp'tritu Santo de Chayanta". Todo su territorio se extiende 60 leguas de longitud, rumbo Este-Oeste, y en su ancho Norte-Sur hasta 40. Confina por el Norte con Cochabamba, por un desierto estéril de cerca de 30 leguas, en que no se ve nada más que piedras y precipicios, según Laet. ${ }^{1}$ Por' el Oeste, con Paria; por el Sur, con Porco; y por el Este, con Mizque y Yampará. Sus linderos principales son: hacia Cochabamba, Larama; hacia Paria, Guanuni; hacia Porco, Actara; hacia Mizque, Zucuzuma; y hacia Yampará, Guañoma y Zapiri. Está situada esta Provincia al Norte de Potosí, y puesto allí su pueblo cabecera al Oeste, a distancia de 45 leguas de esta Villa Imperial.

Los pueblos principales, donde residen los Curas, todos ellos situados en los Iugares de las Doctrinas, son diez y nueve, a saber: Chayanta, que es el primero, como capital de la Provincia; su población se compone de indios y de mestizos, como hasta treinta familias entre ambas castas; tiene dos Curas que se conocen el uno por el de Chayantacas y el otro por el de Laimes. Ia iglesia es una sola, muy bien alhajada de 
plata labrada; cada Cura reconoce su respectiva feligresía, la cual, aun en el templo mantiene su división entre Laimes y Chayantacas; de suerte que solamente en el uso del Altar Mayor se manejan por semanas los dos Párrocos.

Los demás pueblos son: Aymaya, Panacachi, Pocoata, Macha, Aullagas, Chairapata, Moromoro, Sacaca, Chayala, Pitantora, Guaycoma, San Marcos, Surumí, Carasí, Micaní, Moscari, San Pcdio de Buenavista y Acacio. Todos ellos, o los más tienen sus anexos o vice-Parroquias, donde los Curas celebran una o dos veces al año las féstividades más solemnes. Son de cortísima población, por lo mismo de no residir alli el $\mathrm{Cu}-$ ra ni Ayudante. Solo en Ocurí, viec-Parroquia de Pitantora, se mantiene de continuo un Ayudante, como tambien en Toracar'i, anexo de Acacio; y aś por esta circunstancia, como por los minerales que tienen ambos parajes, es regular lo población de uno y otro.

NOTICIA SE G U N D A

Del temperamento y minerales $\boldsymbol{L}$ OS nueve primeros pueblos o Curatos, de este Partido. son de temperamento rígido de fríos, por hallarse situados en la puna; y aunque en unos es menos acre que en otros, todos ellos son destemplados y poco apacibles.

Pero tienen la ventaja de ser los únicos que disfrutan las riquezas de los minerales de plata. Aullagas es el más famoso de cuantos tiene este Partido; es Asiento muy poblado, en su mayor parte de gente plebeya y muchos vagabundos que viven del juego y de la trampa. Su situación muy incómoda, así por el desorden de las calles y mala forma de las casas, como por la suma frialdad del temperamento y una continua ventilación de aires frigidísimos, que a los no acostumbrados los enferma de vómitos, con vehementísimos dolores de cabeza, que llaman "apunarse", en el país. Con todo, habitan allí con bastante regalo, por las muchas frutas exquisitas que llevan de los valles inmediatos que rodean aquel mineral.

Tiene Ribera de ingenios, todos de una cabeza, de la misma fábri. ca que los de Potosí, y los parajes de sus sitios se llaman: Rosario, Palca, Angostura, Churicala, Ayoma y Guancaraní, bastante distantes del Asiento; aunque el más lejano no pasa de ocho leguas y el más inmediato se acerca hasta media legua.

Esta circunstancia hace subir los costos de los metales, porque habiéndolos de conducir a los ingenios en carneros de la tierra, se paga por cada cajón (que son 50 quintales) desde cuatro y medio pesos hasta ocho, según las distancias.

Agrégase a esto, que todos los metales se benefician por quema, con el fuego de taquia, que es el estiércol de los carneros de la tierra; y según la gruesa de cada hacienda, así crecen los gastos. Yo sé que hay minero en Aullagas, que invierte en sólo estiércol, más de mil doscientos pesos al año.

Por lo mismo, no hace cuenta trabajar a ciegas cualquiera clase de metales, que allí se distinguen con el nombre de brosas, piritas, chamiscos, rayadillos y llampus. Los primeros (siendo regulares) rinden 50 hasta 25 marcos por cajón; los segundos, 80 a 100 marcos; los terceros, 
300 marcos; los de la cuarta especie, 15 a 20 nnarcos; y los últimos, de 8 a 10; de manera que labrándose de esta última ley, quebraría forzosamente el minero, si no tuviere mita y sus ingenios se hallaren muy distantes.

Como al del Rosario tiene 100 indios yanaconas de repartimiento, libres de la Mita de Potosí, con la pensión de trabajar el lunes todos juntos, por el salario de un real, también es el más proporcionado para enriquecer a su amo, como lo hemos visto en Dn. Baltazar Alvarez Reyero, que alli ha formado un caudal de cerca de 300.000 pesos.

Malcocota es otro mineral de plata, situado al Noroeste de Aullagas. Su Asiento es Toracarí, Viceparroquia del Curato de Acacio, distante tres leguas del mineral, el cual no tiene población alguna, por estar en puna rigida. Fil Asiento es apacible, como situado en valle, con dos ingenios de a una cabeza, pertenecientes a un solo interesado.

Aunque sus metales son de muy corta ley, tienen la excelencia de dar la plata a los tres o cinco días de estar en el buitrón, y sin duda obra el azogue con esta extraordinaria prontitud, por ser tan sueltos y areniscos.

En el día está casi abandonado por su decadencia, que en estos países es un efceto necesario del desarreglo en el trabajo; si bien que no es extraño que haya ido a menos, siendo el mineral más antiguo del Partido.

Ocuri es otro mineral antiquísimo de plata, a las 7 leguas al Este de Aullagas; hiay vestigios de cuatro ingenios, pero en el día sólo se trabajan sus desmontes, en quimbaletes, por gentes infelices que no encuentran otro recurso. Con todo, no falta allí un rescate regular de marcos.

Minerales de oro, de nombre, hay dos, ya abandonados en la actualidad. El uno se llama Aymayapampa, jurisdicción del pueblo de Chayanta, a dos leguas de él fuc riquísimo treinta años atrás, $\mathrm{y}$ a eso se atribuye el fastuoso menaje de plata labrada que tiene la iglesia de aquel pueblo.

Con la falsa tradición de haber quedade en gran riqueza cuando se inundaron los planes, emprendieron varios vecinos un costoso socavón de 700 varas, y después de haber extraído el agua, sólo encontraron el desengaño de no hallar metales de costeo.

El otro mincral de oro se nombra Capacinca, jurisdicción del pueblo de Aymaya, ambos al Deste de Chayanta. También fue abundante ahora quince años, pero decayó al cabo de cuatro, conforme fueron ahondando las labores.

De lo cual infieren los mineros prácticos, que las minas de oro sólo hacen sus abortos en las cabeceras, y no alcanzan la profundidad en estos países; motivo que ya se tuvo presente en tiempo del Presidente Gasca, para permitir su labor a tajo abierto.

\section{NOTICIA T E R C E R A}

\section{Continuación del temperamen- Jos otros diez pueblos de este Partido es- to de Chayanta; sus rios y tán en valles templados y apacibles, unos más producciones. que otros; son regalados de frutas, sanos $y$ bien acomodados para vivir.}

Allí son conocidos los valles por estos nombres: la quebrada de 
San Pedro de Buenavista, la de Moscari la de Pitantora, la de Guayeoma, la de Carasí, la de San Mareos, Ia de Quinamara, la de Zucuzuma, la de Micaní y Acacio. Sus tierras son fertilísimas para granos, frutas y legumbres; producen excelentes trigos en los altos y mucho maíz en los bajíos o quebradas; excelentes frutas como duraznos, manzanas, peras, ciruelas, guindas y algunos parrales, distinguiéndose el lugar de Zucuzuma por sus chirimoyas, mucho más sabrosas que las más celebradas de Lima, según parecer de hombres de gusto.

Los mejores trigus se cogen en Pitantora, y es también el ramo más opulento del comercio de este Partido. Por lo regular, se provee Potosí de las harinas de Pitantora; pero generalmente van a Chayanta los vecinos de Carangas, Paria y Porco, a haccr grandes negociaciones de granos en tiempo de cosechas, por todos aquellos valles.

En las mismas quebradas hay maderas de calidad como el roble, la tipa, el algarrobo, el pino, el mazo y el soto.

Toda esta fecundidad se promueve dichosamente por la proporción del riego que goza aquel territorio; y así se cuentan hasta 168 molinos de granos, que prueban bastantemente su abundancia y la de los ríos.

En efecto, hay muchos; pero los principales que bañan todo el Partido, son: Morachaca, de Oeste a Este; Guanuni, de Norte a Sux; Moscari, de Oeste a Sudeste; San Pedro de Buenavista, a igual rumbo; Pitantora y Guaycoma, de Sur a Norte; y de todos juntos se compone el Río Grande, que después de bañar media Provincia, corre de Oeste a Este, metiéndose por la de Mizque, hasta unirse con el de Cochabamba en el paraje de Guayabos; pero ninguno es navegable mientras gira el distrito donde ha nacido.

Mediante estas conveniencias, son indios muy acomodados los de este Rartido; pues, aun en la tuna recogen mucha papa rica, de que hacen el chuño, que es un ramo considerable de comercio en el Perú.

Si se fomentan todas sus poblaciones, conforme al espiritu de nuestro Gobierno, no hay duda que florecerá este Partido, como ninguno de la sierra. Me atrevo a decir que uno de los medios más seguros, es repartir alguna Mita a sus minerales; lo que se puede verificar sin disminuír la de Potosí, señalando alki el exceso que ha acrecido en la revisita practicada últimamente.

1.-Laet: en la descripción de las Indias Occidentales, Lib. 11, Cap. 7, fol. 462. 


\title{
CAPITULO DECIMOTERCERO
}

\section{Del Partido de Tarija}

\author{
NOTICIA PRI M E A
}

De la Fundación de la Villa
de San Bernardo, su capital;
altura, distancia de Potosí, y
su fertilidad. legado, que mandase en la Villa de San Bernardo, sobre las cuatro calsas de Justicia, Policía, Hacienda y Guerra, teniendo consideración a que el Justicia Mayor de Chichas, que tiene su residencia en Tupiza, pueblo cabecera de este Partido, no podía atender con oportunidad a las muchas y frecuentes ocasiones de inquietud que experimentan aquellos vecinos con las irrupciones y hostilidades de los bárbaros Chiriguanos. Y si bien e] actual Intendente Dn. Francisco de Paula Sanz, ha extinguido en este año la Subdelegación de Tarija en cuanto a las dos causas de Justicia y Policía, con todo ha dejado en la misma separación uno y otro distrito, restringiendo ias facultades del Subdelegado a las dos causas de Hacienda y Guerra, únicamente para que cuide de la cobranza de tributos y tenga a su cargo el Gobierno de las Armas, como Comandante General de aquellas milicias; reponiendo enteramente a los Alcaldes ordinarios en la jurisdicción contenciosa y política que se les había disminuído en mucha parte con la extensión del nombramiento que hizo el Gobernador Pino, cuando nombró el primer Subdelegado.

Por lo mismo trataré también separadamente de la descripción de este Partido. Con motivo de la expedición que hizo personalmente el Excelentísimo Señor Dn. Francisco de Toledo a las tierras de los Chiriguanos en el año de 1572, veconoció lo conveniente que era poblar el valle de Tarija, para contener las salidas y las correrias de los Chiriguanos hacia los pueblos recién catequisados de Chichas; $y$ deseoso de verificar 
este útil proyecto hallándose en la ciudad de la Plata comisionó para su ejecución a Luis de Fuentes, vecino de la misma ciudad, por Despacho de 22 de enero de 1574 , concediéndole autoridad para que poblara el valle de Tarija con cuarenta o cincuenta hombres, en la parte que le pareciera más conveniente; para cuya funđación le nombró por Capitán y Justicia Mayor, por el término de seis años, con jurisdicción civil y criminal en el Distrito de veinte leguas hasta los indios Chichas, $y$ de treinta hacia los Chiriguanos y pueblos de Huacané, Huacayrá, y Comechines; de suerte, que según estas distancias, viene a dilatarse el territorio de Tarija sesenta leguas en su longitud Este Oeste, desde las pampas de Taxara hasta la cordillera de los Chiriguanos, de donde siguen los llanos que llaman de Manzo, y en anchura de Norte a Sur poco más de cincuenta leguas desde el punto de confluencia de los grandes ríos del Pilcomayo y San Juan' que hacen la división del Partido de Cinti hasta el Cerro Bayo, que confina la juriscicción de Jujuy mirando hacia las tierras del Chaco a la parte del Este.

El mismo Virrey por otro Despacho dado en Ia Plata, a 12 de mar zo del referido año de 1574, mandó que los Caciques prineipales de Talina y demás pueblos del repartimiento de Chichas de la Corona Real, repartiesen a la Villa de Tarija ciento cuarenta indios, para que las justicias los distribuyesen entre los pobladores con el salario de un tomín por día y algún maíz para su comida, con el destino de servir en los edificios, labranzas y guarda de ganados.

Uitimamente libró otro Despacho en la Plata, a 19 de mayo de 1574, con el fin de promover esta población creando para ella dos Alcaldes ordinarios, cuatro Regidores y un Procuradox con facultad de elegix en lo venidero otros Alcaldes, que debía confirmarlos el Justicia Mayor; y ordenó que por haber sido de la jurisdicción de la ciudad de la Plata el valle de Tarija, continuase en ella la ejecución de la Justicia el Alguacil Mayor de Chuquisaca por medio de sus tenientes.

En efecto, parece haberse poblado aquel valle poco tiempo des- pués, con la fundación de una villa intitulada San Bernardo de Tarija, a ochenta y cinco leguas de Potosí, en veinticuatro grados de altura.

El Padre Mendoza, cronista franciscano de la Provincia de Charcas, no le da nás distancia que cincuenta leguas de esta Imperial Villa, contra el cálculo general de estos últimos tiempos; el cual me parece más verosímil porgue el Rey ha abonado al respecto de ochenta y cinco leguas las dietas del Apoderado Fiscal, que se nombró el año de 1785, para la revisita de los indios tributarios de aquel Partido.

Creo que este cronista padeció la misma equivocación en referir que se fundó aquella Villa el año de 1591, siendo Virrey Don García Hurtado de Mendoza, y que se acabó en forma en el de 1600; porque he leído un Despacho Auténtico, fechado en los Reyes, a 6 de abril de 1582, por el que el Excelentísimo Señor Don Martín Enriquez permitió a Luis de Fuentes, que pudiese poner Tenientes en los repartimientos de Calcha, Talina y Chichas, para defensa de los indios contra los agravios que ejecutaban en ellos los soldados del Tucumán; cuyas providencias prueban incontestablemente, que muchos años antes de la fecha que cita el Padre Mendoza, ya se habia fundado la Villa de San Bernardo; pues suponen la residencia de Luis Fuentes en ella, con ejercicio de jnrisdicción en todo el territorio agregado a su mando. 
Is Villa es busiante grande, tiene iglesia Mayor Parroquial, conventos de Nuestro Padre Santo Domingo, San Francisco, San Agustín y un Hospital do San Juan de Dios.

Posterionmente se ha fundado un Colegio de Padres Misioneros de San Francisco, con el título do Propaganda Fide, ejemplares en su religiosa condueta y muy útiles a la propaganda de la Ley Evangélica en aquellas fronteras de gentiles $y$ en los demás pueblos comarcanos, donde salen a Misión en tiompo de Cuarosma. Fl pueblo Capital es bien formado, con edificios de teja, y corre a su ribcra un río caudaloso, que se aprovecha en acequias parta riego de las chacras $y$ huertas. Es abundante de pescado, que se trae de los muchos ríos que bañan sus inmediaciones, no monos que de ganado, principalmente cerdos, que abastece a Potosí. Su situación es un valle regalado y muy fértil de toda especie de granos de Castilla y de la tierra, frutas, hortalizas y ricas maderas. Tiene muchas viñas de buen vino, aunque regularmente padece el contratiempo de continuos granizos que las destruye, por estar a la falda de la puna de Hiscayache, ticrra muy alta y fría. El temperamento es cálido, y por su constitución $y$ calidad de su terreno gredoso, no fructifica agrio ni dulce.

Su población que es muy numerosa está repartida en las campañas, al cuidado de las haciendas de que subsiste; y como no puede extenderse hacia las ironteras, por las repetidas y cruleles hostilidades de los infieles Chiriguanos, se ha descarriado mucha gente a la jurisdicción del Tucumán, su confinante.

\section{NOTI I I S E G U N D A}

De la mala calidad de las LuS aguas no son de la mejor calidad, y aguas de Tarija. bien sea por su demasiada crudeza o por otxas causas, cuyo examen toca a la Medicina, causan en mucha parte de las gentes una notable deformidad, criándoles en ol pescuezo unos tumores que llaman botos; y llegan a crecer al tamaño de un huevo de avestruz o de un melóndegular, de modo que no pueden ocultarse con ningún arbitrio, y se les conoce en la ronquera que padecen en el sonido de la voz. Por estos defectos naturales y la poca civilidad procedida de la habitación campestre de aquellos naturales y de su rarisimo comercio, se manifiestan al trato como rudos y naturalmente escasos de razón; pero en realidad son astutísimos, de talento e inclinados a pleitos, como siempre se ha reconocido por los ruidosos recursos contra los Corregidores.

\section{N O T I C I A T E R C E R A}

De los darios que causan los infieles Chiriguanos; medios de contener sus irrupciones $y$ de adelantar la población.
SON también fuertes y valerosos en defensa de la Patria; pues, sin tener un soldado veterano o pagado, han mantenido guerra constante contra los indios Chiriguanos enemigos, y puede creerse, según la experiencia que se tiene de estos gentiles, que si aquellas milicias hubieran tenido me- 
jor disciplina en el modo de resistix y hostilizar a aquellos infieles, no se hubieran gastado inutilmente tantos caudales del público, ni los indios hubieran podido mantenerse sin pedir redncción y paces. Porque ellos no pueden internarse al valle, a ejecutar sus invaciones, sino por caminos conocidos, entre quebradas fáciles de impedir su tránsito construyendo en la mayor angostura algunos Fuertes, con su correspondiente guarnición. ${ }^{1}$ En tal caso, como ya no podrían pasar con la libcrtad que ahora lo ejecutan para robar ganados y otras cosas de que subsisten, como gentc que vive sin agricultura y sólo del robo, se verían precisados a retirarse a otros países más indetensos o a pedir reductión, donde vivirían en ley y en policía.

Redimido el valle de Tarija de estos enemigos, ser'ía el más hermoso, fértil y regalado de toda la Provincia de Potosí, porque según su situación, campos, arboledas y plantas, parece que del Tucumán, país de los más floridos del Virreinato, se extendió un brazo de sus hermosas campañas a la falda de estas cordilleras áridas y estériles, para formar el país de Tarija.

Si se formalizara la policía, la población, agricultura, industria y comercio, bastarían las producciones de Tarija para surtir a Potosí de carnes, manteca, sebo y exquisitos granos de la tierra, que son los más precisos para la manutención.

(El parágrafo precedente, breve en su texto, constituye la Noticia Tercera del manuserito de Potosí. Su aulor lo suprimió en el original corregido que destinó a España. En cambio escribió la Noticia Séptima, dedicada al mismo tema de los indios Chiriguanos, en forma amplia. Hemos creido necesario juntar ambas versiones bajo la Noticia Tercera, para mejor articulación del Capitulo referenle a Tarija. $A$ continuación se reproduce el texto del $M s$. del $A$. G. de $I .-$ Nota de A. Alba).

Se refiere brevemente la historia del origen y ferocidad de los Chiriguanos; de la situación de sus pueblos con los progiesos que han hecho en las conversiones de esta nación los Misioneros Franciscanos del Colegio de Tarija, y se proponen los medios de poblar estos terrenos y reducir Ios pueblos restantes para la comunicación del Paraguay con el Perú.
$\mathbf{E}$ la noticia antecedente se acaba de referir por insidencia que los Chiriguanos fueron ciertos indios de nación Guaraní, que temerosos del castigo de Ios portugueses por la muerte alevosa que cjecutaron en Alejo García, se habian acantonado en las fronteras de Charcas sin atreverse a volver a sus tierras; apoderándose para su domicilio de los territorios intermedios a Tarija, Paspaya, Pilaya, Tomina, Mizque y Santa Cruz de la Sievia.

Esta relación es conforme a un manuscrito muy celebrado que escribió Ruy Díaz de Guzmán, natural del Paraguay, en el año de 1612 , y corre con el títu-
lo de "Argentina", con crédito y autoridad en todas las cosas tocantes al descubrimiento y conquista del Paraguay y Río de la Plata; el Padre Nicolás del Techo y el Padre Juan Patricio Fernández, 2 siguieron a la "Argentina" en cuanto al origen de los Chiriguanos alegando por fundamen- 
to gravo de esta historia ol mantenel'se hasta ahora entre los Chiriguanos el lengua.je rlatual que usan los guaraníes. Poro el Inca Garcilaso $s$ contradice esta opinion refiriendo entre otras antigüedades del Perú, en que es versadísimo, y tiene grande reputación este historiador, que el Inca Yupanqui, décimo Rey del Perú, intentó conquistar a estos bárbaros más de cien años antes de entrar Alejo García, según el cálculo del Padre Pedro Lozano ${ }^{4}$ en su Descripción Cologífica; debiéndose dudar, por la fuerza de este poderoso argumento, acerca del origen, que les da a estos bárbaros la "Ar'gentina" y los Padres Techo y Femández.

Sea de esto lo que fuere, lo cierto es que esta nación fue siempre. tan bruta, que según la relación de Garcilaso, habitaba en montañas bravas entro ciénagas, lagos, y pantanos: comia came humana y bebía por regalo la sangre de sus enemigos, habiéndose hecho tan terrible a los comarcanos por' su ferociclad, que ciento ni mil de ellos se atrevían a esperar die Chiriguanos, como afiuma Garcilaso. :

En esto mismo conviencn los citados. P'edres Tccho, Fernández y Lozano, refirimdo menudamente las acciones $y$ hechos más espantosos de la brutalidad de esta nación, y añaden en prieba de ello, que en aquelos primeros tiempos on que comenzaron a querer sujetar las naciones circunvecinas, acabaron muchas de ellas del torlo, y de otras consumieron mas de ciento cincuenta mil indios.

Aunque el Inca Yupanqui informado de su barbaridad y torpezas emprendió conquistarlos con diez mil hombres, desamparó la empresa al cabo de dos años pof la mucha maleza de pantanos, ciénegas, lagos y montañas bravas que hatían casi inaccesible cl pais; ${ }^{6}$ sin embargo aprendió esta gente feroz a hacos casas para su morada, reducidas a unos galpones grandes con sus divisiones pequeñas, donde se reparten los vecinos que son parientes, de sucrte que cada galpón viene a ser como un pueblo. '

E1 año de 1572, intentó hacer la conquista de estos bárbaros el Excelentísimo Sr. Dn. Francisco de Toledo, entrando a sus tierras con mucha gente española, caballos, yeguas $y$ vacas. Experimentó a pocos días de jornada las mismas dificultades que embarazaron el proyecto del Inca Yupanqui, y úitimamente se vió precisado a salir con grandes trabajos malogrando su expedición con pérdida de todo el ganado que se quedó en aquella tierra."

Después de poblado el valle de Tarija, sufrió también su vecindario continuas y crueles hostilidades en unos tiempos más que otros por el interés del ganado que mantenian aquellas estancias; $y$ aunque los españoles de Tarija han hecho tal cual entrada más allá de la Cordillera, nunca han podido conseguir escarmentarlos, y por esta causa lejos de extender las poblaciones y estancias se ha ido extrechando cada vez más aquel territorio de Tarija, sin lograrse provecho alguno de la fertilidad. y conveniencia de los dilatados terrenos que ocupan estos bárbaros.

Ellos a más de crueles son dotados de un natural tan dominante, orgulloso y tirano, que no pudiendo tolerar la quietud de sus vecinos acostumbraron siempre y acostumbran hasta ahora entrar al Chaco a hacer malocas, para destruír y cautival a cuantos rinden, robándoles sus mujeres para cebo de su lascivia. De los vencidos se sirven por esclavos con el nombre de chanos o chánés, y aplicándolos al cultivo del maíz, algo- 
dón, yuca o mandioca, habillas y otros fłutos, para virir más ociosos.

Para mantener en mayor sujeción a estos infelices cautivos, les señalaron tierras para labranza en las inmediaciones de los pueblos conquistadores, imponiéndoles por ley de señorio ciextos servicios y otros reconocimientos serviles, que conservan la memoria del vasallaje por todas las generaciones, y vicnen a ser como arrabales de las poblaciones de los Chiriguanos los territorios accesorios que ocupun los chanos o chanés.

Con estos adscritos o agregados se aumenta notablemente el número de estos bárbaros, y a proporción crece su atiacia para hostilizar. nuestras fronteras y las naciones circunrecinas del Chaco; de suerte que según los cálculos del citado Padre Pedio lozano, ahora cincuenta y siete años, llegaban sus poblaciones hasta treinta mil indios capaces de tomar armas fuera de la chusma de mujeress y iniños.

Toda esta gente estuvo y está situada en los terl'enos intermedios a los ríos Bermejo, Pilcomayo, Parapity, Guapay y Rio Grande, confinando la mayor porción de sus poblaciones con los indios del Chaco, que ocupan la parte de tierras que caen al Este.

El año de 1686 fundaron los Jesuítas Misiones en el valle de Salinas, que está entre los dos ríos Bermejo y Pilcomayo, una Misión con algunos párvulos, que bautizaron en un pueblecillo de los Mataguayos, despachándolos con sus padres y familias al dicho valle de Salinas, que por ser sitio excelente para sementeras fue de grande aprecio para esta clase de hombres a quienes es preciso siempre moterles la fe por la boca; nunca creció esta Misión con todo el fomento que recibió en tiempo de los Jesuítas, $y$ en el día apenas llegará a cuatrocientas almas toda su población.

Los Chiriguanos, que habitan entre los ríos Bermejo y Pilcomayo, no se han querido reducir jamás, sin duda por el fácil recurso que ticnen en las estancias de Tarija para robar ganado vacuno y caballar. Los Tobas son sus comarcanos y tan enemigos entre sí, que no pierden lance atcombate; pero los Chiriguanos viven con tanto cuidado de la irrupción de los Tobas, que por miedo de ellos están poblados los más en las inmediaciones del río Pilcomayo; sirviéndose de este caudaloso río como de asilo y espaldar contra sus ehemigos, y al mismo tiempo se aprovechan de la comodidad del pescado que allí abunda nucho, para trabajar eso menos.

De los otros muchísimos pueblos que ocupan la lonja de tierra que corre de Este a Oeste, entre los ríos Pilcomayo y Parapity se han convertido algunos a esfuerzos de la predicación y celo evangélico de los Misioneros Franciscanos del Colegio fundado en Tarija, de suerte que a fuerza de haber despreciado las tribulaciones y trabajos, que no son decibles, han logrado fundar allí bajo de Cruz y campana las reducciones siguientes: San Rafael de Masary, Imin!, nonbrada Nuestra Señorn de Guudalupe, San José en Tacurú, Nuestra Señora de la Capilla en Saypurú, San Francisco de Azero y la Purisima Concepción de Pilipily; esperándose ver en breve concluída la fundación que se está principiando de otras dos reducciones en Ity $y$ en Tayarenda nombrada Nuestia Señora del Rosario, entre Saypurú y San Francisco de Azero.

Pero es de grande desconsuelo el estar mirando a las ocho leguas 
de Saypurú la mayor porción de estos bárbaros en los mejores sitios de aquella comarca, como son: Tapytá, Tacuarembó, Yvirapucuty, Pirity, obay, fucr'a de otros poco más distantes, cono son: Charagua, Ingahuasi, Capiypependy. Ytacuá, Segura, y Parapity. De todos los cuales este último es el pueblo más hermoso, el más grande y el de mayores conveniencias por su vista, por su situación, por su temperamento y por sus tierras.

También hay muchas poblaciones de Chiriguanos bárbaros entre los ríos Parapity, Grapay y Río Griande; pero no se ha logrado reducir ninguna de ellas lasta el día, con todo de no haber sido menor en éstos la diligencia y el empeño para convertirlos.

Hacia la banda meridional del Río Grande, que cae a las pertenencias de Santa Cruz de la Sierra, continúan otras cuatro reducciones fundadas por estos Misioneros con los nombres de La Santísima Trinidad de Abapó, Nuestri Señora del Camen de Cabeza, Nuestra Señort del Pilar de la Florida, la Asunción de Nuestra Señora del Piray, todas ellas a distancia de trece leguas, unas de otras desde cl Río Grande por bellísimo camino; $y$ el último pueblo del Piray dista treinta leguas de la Ciudad de Santa Cruz.

En las trece reducciones referitias pueden llegar a seis mil almas poco más o menos, los Chíriguanos bautizados de todos sexos y edades: con la esperanza muy probable de que en breves años podemos ver reducida, cuando no toda esta nación, la mayor parte de ella, siempre que la política de mestro Gobierno camine de acuerdo con el celo demestos. Misioneros; protegiêtiolós y honrándolós a mismo tiempo como acreedores exclusivos a cste copioso númcro de nuevos vasallos e hijos, que han conquistado para el Rey y para la Iglesia.

Una de las principales disposiciones políticas que debe tomar el Gobierno para el progreso de estas conversiones, es mandar que en el número de Misioneros destinados para Tarija, se incluya la tercera parte de religiosos paraguayos y correntinos u otros religiosos, que sepan perfectamente la lengua guajaní, que es la misma que usan los Chiriguanos, para que puedan corregir sus errores y demostrarles las verdades del Evangelio en toda su purcza, y con la fiuerza y energía que requiere la rudeza de estos infelices.

Y cuando no tuviere lugar esta providencia será indispensable establecer en el Colcgio de Tarija, una cátedra de lengua para que cursen en ella al menos por el espacto de sejs meses tos relígiosos recicin ventodos de España; porque en el día se está experimentando que aun los Misioneros más antiguos ignoran las cosas esenciales del idioma; no entienden sus frases, y por la impropiedad del dialecto confunden enteramente la significación de las voces malogiando el tiempo y sus tareas con irribción de la palabra de Dios, por los muchos barbarismos que estos gentiles escuchan y burlan en los Misioneros.

Hace pocas horas que sobre este asunto he tenido larga conversación con el hermano Fray Francisco del Pilar, uno de los fundadores del colegio de Tarija, y el que ha trabajado más en la conversión de estos gentiles con todo de no ser sacerdote: él me ha asegurado que no hay Misioneros que sepan bien la lengua, y que este defecto es un obstáculo muy poderoso para la propagación del Evangelio; y aunque este santo religioso es digno de toda fe y crédito sobre su palabra sola, me dio la 
prueba más eficaz en sí mismo con no saber 'xplicar, ni medianamente en el idioma de los Chiriguanos, al cabo de tantos años que vive entre ellos, como lo reconoci yo mismo pos la inteligcncia que tengo de la lengua guaraní.

Esta escasez notoria de operaciones junto con la distancia en que se hallan los pueblos es un impedimento gratísimo a la predicación evangélica, que cstá dictando por sí mismo la resolución que sé debe tomar para acreentamiento de las conversiones. L'or estas piopias causas mandó unir el Sr. Toledo los puoblos del Perú, haciendo tho grande de muchos pequeños, con el fin de que un Misionero sólo, predicara donde apenas podían ejecutarlo scis ú ocho, por la multitud de reducciones en que se repartían: con que siendo ahora igual cl caso, choomos seguir este sabio ejemplo según buena política porque solamente por este medio se pueden evitar los inconvenientes expresados.

A esta conveniencia espiritual se subsoguirá otra de mucha importancia para el buen régimen y economía del Gobicrno: y es, que reunidas las reducciones será mas fácil el cuidado de su quietud, mayores los provechos del trabajo de las comunidades y mucho menos los costos, en vino, cera, aceite, ornamentos y demás utensilios sagrados; de suerte que, si en el día es menester pedir limosna por dos años para fabricar dos iglesias en distintos pueblos, después que éstos se reunan bastará una sola iglesia con la mitad de lo que se impende ahora para dos reducciones.

Pero al propósito de congratular a estos bárbaros y quitarles la ocasión del robo con lo necesario para alimentarse ellos con sus familias, es muy conveniente fundar dos o tres estancias de ganado vacuno y caballar, algunas sobre la misma costa del rio Pílcomayo, y otras sobre la del Río Grande, para suministrarles desde allí las raciones semanales de carne, con la debida cuenta y razón que cleben llevar y de que es regular que cuiden los Padres Misioneros; con eso estarán siempre dependientes de la providencia del Gobierno, y bien sea por agradecimiento o por necesidad vivirán sujetos a sus doctrineros, y temerán disgustar a los Magistrados por no perder el uso de sus beneficios.

Mas, como quicra que habrán de tener entonces a la vista este gratísimo aliciente, y no difícil, que les venga la tentación de alzar'se con todo, para disfrutar en un día lo que reparte entre ellos la economía en muchos días, debemos aseguraz estos establecimientos con el amparo de otros tantos fuertes, bien guarnecidos de tropa y municiones; para que al mismo tiompo de servir de custodia a nuestros intereses, cause temor y respeto tanto a los reducidos como a los bárbaros.

El Gobierno de Cochabamba ha puesto un reducto con el nombre de San Carlos, en la misma reducción de Saypurú, y según me ha informado el hermano Fray Francisco del Pilar, ésta sola pequeña fuerza ha bastado para refrenar toda aquelia comarca, tanto, que después de estar mucho más obedicntes y sujetos los reducidos, muchos pueblos bárbaros han dado muestras saludables de conversión. Lo cual no es extraño en estas gentes porque la fe les entra por la boca, o por el miedo primero que por los oídos.

Con mayor razón nos llamarán a Partido luego que vieren colocados nuestros fuertes, sobre una y otra banda del rio Pilcomayo; pues con esto, en primer lugar, se les ocupa el asilo principal que ahora tienen pa- 
ra indemnizar sus hostilidades y por otra purte recelarán alejarse de sus tievias teniendo ya al enemigo, como strele decirse, en su casa.

Los fuertes que actuamente tenemos al canto de la Cordilera, no sirven más que para gastos y para molestia de nuestras Milicias, porque estando metida la fortaleza en un boqucrón de la seryanía no puede advertip ni obrar cosa alguna de importancia; y como tambićn los indios reconocen las dificultades que tiene la tropa española para marchar sobre cordilleras escabrosas por trecho de nás de treinta leguas, y que jamás se han atrevido los tarijeños a extenderse en sus cxpediciones a las cercanías del Pilcomayo hacia la parte del Este, no tomen intemarse a nuestras posiciones, confiados en que siendo todas sus irrupciones por sorpresa, no encuentran resistencia, y les basta para ponerse en sus tierras el timpo que se toman los españoles para salir del susto, $y$ para prepaw rar la expedicion. De sucrte que las repetidas desgracias de nuestra parte sin escarmiento alguno on estos enemigos han llegado a aterrar nuestros pueblos, hasta el extremo de haberse acantonado todos Ios vecinos de Tarija dentro de Ios terutorios de la Cordillera, por alejarse más de los Chiriguanos con este arbitrio.

No sería así en caso que tuviécamos nuestros fuertes sobre las orillas del río Pilcomayo; porque entonces tendrian que meterse entre dos fuerzas en pasando por los llanos de Manzo para hostilizar a los tarijeños. Al aviso del cañón serła muy fácil cortarles la retirada, y también perseguir'os con la guarnición de los fuertes en liga con los Chiriguanos reducidos, por la cercanía en que dcben estar las reducciones y los reductos.

Escarmentando por estc medio a los pocos Chiriguanos que viven entre los ríos Belmejo y Pilcomayo (que aum en el día no hacen poco en defenderse de los Tobas), se refrenaría al mismo tiempo el paso que tienen por cl Pjlcomayo los bárbaros, que habitan entre los ríos Pilcomayo y Parapity, de modo que en confedexándose los tarijeños con los vecinos de la frontera de Tomina, cochabambinos y cruceños, para una entrada general, lograríamos desalojar a estos infieles alejándolos al interior del Chaco, para avanzar a esa proporción nuestros fuertes, y fundar a su abrigo muchas estancias y poblaciones.

Ayudando el Paraguay por su lado, y por el suyo la provincia de Salta, se pudicra sitiar a todos los bárbaros que ocupan las hermosas campañas situadas entre los dos ríos Bermejo y Pilcomayo, para obligarlos a reducirse, o a pelear para morir; franqueando en la sujeción de estos infieles la correspondencia del Paraguay con el Perú, para muchos y muy útiles proyectos a beneficio de la población, del comercio y de la Religión.

La única dificultad que puede ofrecerse es no haber fondo con qué costear los establecimientos y expediciones releridos; pero realmente no es de consecuencia este reparo, si hacemos buen uso de los arbitrios que advierten las leyes y las concesiones apostólicas. Por Bula de Ia Santidad de Benedicto XIV, Real instrucción de 12 de mayo de 1751 , y Ordenanzas formadas a su consecuencia por el señor Virrey, Conde de Superunda, en 18 de marzo de 1752, con la Real aprobación de once de septiembre de 1755, se halla aplicado todo el producto de la Bula de la Cruzada en cada Provincia para las Plazas, Presidios, Guarnición y Misiones de sus fronteras. 
Para los mismos piadosos fines so ha manchilo inveltir últimarinente el producto de todas las limosnass de Redención de catutivos de la Nerced, por Real Cédula, fecha en Ainnjuez a 14 de dicimbie de 1786; y aunque su sentido literal es para libertir a los cautivos de las fronteras, debe hacerse una extensión farorable de esta Soberana Proriclencia, entendiéndola no solamente para libertar a los cpistianos cantivos por los infieles, sino tambićn para libertar a los infieles cautivos por el error, por el pecado y por el demonio.

En uniendo estos doz fondos, no dudo quo alcancen para la ejecución de los propuestos proyertos; porcue el Cologio de Misioneros de Tarija está sustentando separadamente con los un mil cincuenta pesos anuales que le tiene asignados Su Majestad, por Real Orden de 17 de noviembre de 1777, para vino, aceite $y$ cera; qlickando sobrantes los demás productos para gastos de presiclios y guarnición.

Y cuando fuese menester más fondo no sería exorbitante descontar del Sínodo de los Curas, siquiera un dos por ciento para la dotación de los fuertes de Tarija, así como se rebaja un cinco por ciento para Mo. jos y Chiquitos, en virtud de Rea! Provisión de 17 de julio de 1775, expedida por Ia Real Audiencia de Charcas a consecuencia de Real Cédula de 15 de septiembre de 1772 , a más del tres por ciento que se descuenta por razón de seminario, conforme a la Iey 35 , Tít. 15 , y Ley 7 , Tít. 23, Lib. $1^{\circ}$ de Indias, por ser de igual privilegio nuestro objeto, como dirigido al mismo fin de la conversión de los infieles.

Con un dos por ciento que se desfalcara de los cuarenta y nueve mil setecientos ochenta y un pesos, medio real anuales, que importan los Sínodos de sesenta y dos Curatos que tiene esta Provincia de Potosí, montaría el descuento novecientos noventa y cinco pesos por año; con los cuales se podría dotar una compañía efectiva de treinta blandengues de caballería ligera para guarnición del Presidio propuesto, con sus respectivos oficiales, todos ellos muy bien pagados; quedando todavía un resto competente para refecciones del Presidio.

En observando este plan, yo aseguro que en pocos años lograríamos la felicidad y la quietud de que ahora carecemos.

\section{NOTIOI A C U A R T A}

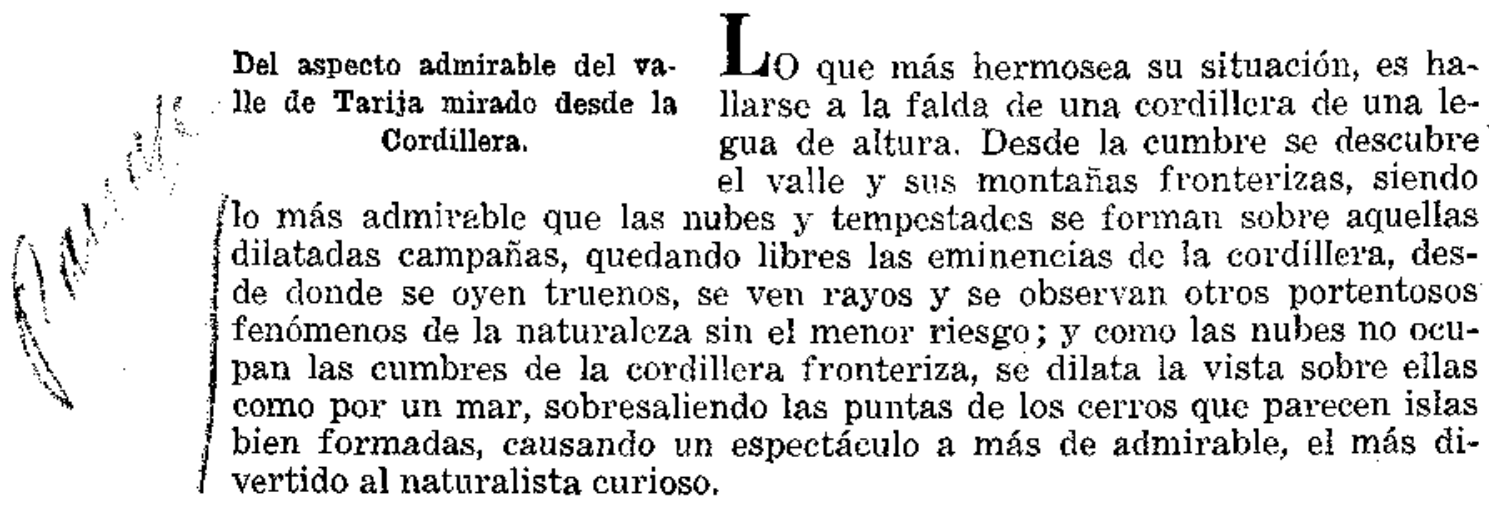




\section{NOT I I A Q U I N TA}

De los huesos de extremado tamaño que se encuentran en este Partido, atribuídos a gigantes. Se expone un discurso físico sobre esta curiosa materia.
I Lo que se elicuentra de más acimirable en aquella tierra, son unas osamentas de extraordinaria grandeza, que ha hecho creer a michos ser de gigantes. Hay muelas, que yo he visto, con peso de doce libras, y cráneos tan grandes como hornos, que puede entrar en ellos un hombre cómodamente, sin traer a consideracion, canillas, costillas $\mathrm{y}$ otros hucsos de espantoso ta-
maño. A este ijitento, afirma el P. Calancha 9 con varios autores, haberse hallado en el reino huesos de grandísimos gigantes y cuerpos de seis varas, y que vió en Lima un esqueleto traído de junto a Potosí, que sus huesos son de excesiva magnitud, que yo creo sería de Tarija, por ser el único lugar donde se han descubierto, aunque dicho autor no lo expresa. Cuando el Cobernador de esta Provincia salió a visitar aquel Partido, fue informarlo de personas de todo crédito, que en una quebrada de aquelja tieria se descubrió en el der'umb: de la montaña, um esqueleto perfecto, que se prolongaba casi por espatio de media cuadra.

Estas relaciones no causarian tanta admiración si ellas se refiriesen a huesos sueltos, de excesiva magnitud; porque entonces se atribuiría a que lo hubiesen sido de elefantes $y$ de ballenas o a piedras $y$ otras especiśs de fósiles semejantes a las osamentas humanas, como suele formarse alguna vez en las cntrañas de la tierra, según las observaciones de Agricola. ${ }^{10}$

I.o que hace demasiado difícil esta investigación, es haberse encontrado esos esqueletos y cuerpos de seis varas, que afirma haber visto el P. Calancha, por no poderse atribuír a nimguna especie de fósiles, porque aunque estas petrificaciones son semejantes a las osamentas humanas, es menester confesar que estas semejanzas no pueden dejar de ser muy groseras, por cuya causa el Sr. Calmet, ${ }^{11}$ sostiene con razón que la tierra no producirá jamás uma unión de muchos huesos proporcionados, que reunidos entre si componen un perfecto esqueleto humano.

Estos principios nos ejecutañ a decir que la tierra de Tarija sería habitada antes del Diluvio, en cuyo tiempo, sabemos, hubieron gigantes y hombres de una talla extraordinaria; y aun después del Diluvio, sabemos que de tiempo en tiempo, se han aparecido hombres de excesivo tamaño; con lo que se convence haberse engañado Varron, ${ }^{12}$ avanzándose a decir que el largo del cuerpo humano no pasa de siete pies. Ello se encuentra en muchos ejemplos bien atestiguados de tallas más altas, fuer'a de aquellas que refiere la Sagrada Escritura, ${ }^{13}$ de Og, Rey de Basan, $y$ de Goliat, cuya marca era de seis codos y un palmo, que hacen diez pies, sicte pulgadas. Herónoto hace ${ }^{14}$ mención de un Capitán de las tropas de Xerjes, que tenía cinco codos o sicte pies y medio de alto. Si se cree a Julio Capitolino, el Emperador Maximiliano pasaba de ocho pies. ${ }^{15}$ Plinio y Solino han escrito que se concujo de Arabia, en el reinado del Emperador Claudio, un gigante nombrado Gabbara, que tenía nueve pies y nueve pulgadas, añadiendo ainbos autores la relación de otros dos gigantes, del tiempo de Augusto, que tenín más de diez pies, cuyos huesos se ma- 
nifestaron largo tiempo después de su muerte. Josefo 1 \& hace mención do un gigante judio, de diez pies y medio, que fue enviado al Emperador Tiberio. San Agustín ${ }^{17}$ nota que una mujer de estatura gigantesca se apareció en Roma, algún tiempo antes de la invasión de los Godos, y sin especificar su altura se contenta con referir que ella se atraía gran concurso de pueblo.

Todos los demás gigantes, arriba de doce a quince pies, que hacen cuatro o cinco varas de altura, deben remitirse a los poetas y pucstos en la compañía de los Titanes o de Esmélade y de Tifeo, de quienes dice Philóstrato, ${ }^{16}$ que estaban encalenados bajo el monte Gibelo, y que los temblores de tierra en Sicilia, exan causados por los esfuer\%os que hacían de tiempo en tiempo para mudar de situación.

Así pues, deben considerarse como desvaríos o delirios de los $\mathrm{Ra}$ binos, la pretensión de que el lecho de fievo de $\mathrm{Og}$, Rey de Basan, que se veía en la ciudad de Rabbaht, no era sino la cuna, y que son excesos de opinión cuanto refieren acerca de gigantes Philóstrato, Pausanias, Plinio y Solino; para cuyo conocimiento basta referir lo que se encuentra en la vida de Sertorio, escrita por Plutarco, que en Africa ${ }^{14}$ se desenterró el cuerpo del gigante Anteo, que tenía sesenta codos de largo; y lo que refiere Heródoto, 20 que en la ciudad de Chemmi, en Egipto, se manifestaba un zapato de Per'seo, de dos codos de largo; llegando Flegon de Tralles al exceso ${ }^{21}$ de dar cien codos al cuerpo de Macrosiris, desenterrado en una isla cerca de Atenas.

Estas noticias como contrarias a toda verosimilitud, deben reputarse como testimonios de una historia fabulosa, lo mismo que estiman los modernos que han penetrado todas las regiones de las Indias orientales, la noticia de Philóstrato y de Pomponio Mela, ${ }^{22}$ que describen ciertos pueblos enteros de indios tan grandes, que se sirven de elefantes como de caballos. Debiéndose contar en este número la ponderación de Quinto Curcio, ${ }^{23}$ acerca de la estatura de los escitas, habitantes de las riberas del Tanais, a quienes pinta tan grandes que los macedonios no les legaban al hombro; $y$ lo mismo digo de los gigantes que describe Magallanes, ${ }^{24}$ en los contornos kel estrecho de sil nombre, en Patagonia y en el Paraguay, como puede verse en Juan de Iaer, $2 \pi$ que lo refuta por el testimonio de ingleses $\mathrm{y}$ holancieses, $y$ en las relaciones modernas de estos otros dos países.

Esto supuesto, aunque no pueda revocarse en duda que han habido gigantes, bien que no procreados por los demonios con el semen sustraído de los hombres, como notó Santo Tomás, ${ }^{20}$ y menos por los ángeles atraídos desde los cielos por la hermosura de las mujeres de la tierra, como pensaron fundados en el libro apócrifo de Enoc 27 Ios Rabinos y otros autores muy estimables, como Josefo $y$ Philon, ${ }^{2 x}$ con muchos Santos Padres de la Iglesia, como San Justino, Tertuliano, San Clemente de Alejandría, San Cipriano y otros; ${ }^{29}$ pero atacándonos a la eficacia de tantos convencimientos como hemos visto, es preciso que busquemos otros principios más naturales con qué explicar la extraordinaria grandeza de los esqueletos gigantescos de Tarija, para no incurrir en las fábulas ridículas que hemos visto despreciar los autores más moderaos y estimables del siglo.

Es lo cierto que los cuerpos más duros experimentan las vicisitudes de los acrecentamientos y de las disminuciones. Platón creía ${ }^{30}$ que 
la superficie de la tierra estaba muy mudada, pues no se reconocía ya muchas montañas y ríos de que han hecho mención los antiguos; a cuyo propósito conviene lo que refiele Pamiano Nardin, 31 de no haber quedado en Roma vestigio alguno de aquella gran roca de donde se precipitaban los condenados a muerte; por el contrario, se han visto aparecer y crecer grandes montañas, rocas y peñascos durísimos, por una lenta y sucesiva vegetación, de que trae admirables cjemplos y forma muy oportunas físicas reflexiones el llmo. Feijó en su Teatro Crítico. ${ }^{32}$ Esto no puede suceder sino on virtud de un jugo que chupa aquel curerpo, el cual difundiéndose por todo ell, lo nutre y aumenta, en la misma proporción que a los árboles el jugo comunicado por sus raices; ${ }^{33}$ y del mismo modo que iu nutrición de las plantas supone necesariamente una distribución de la savia filtrada por muchas canales, asi es menester convenir que la formacion do otros cuerpos, su aumento o su vegetación provienen de que todas estas sustancias están también llenas de canales imperceptibles, que filtran y distribuyen en ellas los jugos de la tierra. Así, si un sitio o territorio abunda de jugo lapidífico, cuyas partículas por razón de su figura y tamaino, sólo pueden unirse bajo de tal determinada combinación, se producirân en él muchos cuelpos uniformes en la figura.

Debe pues inferirse que agregindo a este principio el movimiento, el calor, una circulación continuada y una especie de fermentación insensible, fueron todas estas causas juntas formando on el decurso de muchos siglos al crecimiento o aquella admirable vegetación de los huesos del gigante de Tarija, pareciendo ahora monstruoso a nuestra vista, un esqueleto que en sir principio talvez sería de un tamaño regular o, aunque extraordinario, no monstruoso. Esta es la única explicación que se puede dar en materia tan escondida; y lo que dice Feijoó: ${ }^{34}$ lo más que puede pretender ol discurso en estos nisterios de la naturaleza, es encontrar con lo verosimil.

A mi parecer, la Física más escrupulosa nada puede hallar repugnante a sus principios en este discurso; considerándose que en uno u otro lugar de la tierra, pudo la naturaleza: situar un jugo lapidifico de virtud aumentativa, ell la manera guc otras tierras la tienen para consumir y disolver los cucrpos que se entierran en ellas, así como hay otras que los conservan sin corrupción en Tolosa, Turena y en otros lugares. A este intento, testifican Plinio y M. de Mairan, ${ }^{35}$ que hay tierras sarcófagas, que consumen los cuerpos en muy poco tiempo y casi tan prontamente como la cal. Lo mismo prueban Brocardo, Nicéphoro y Andricomio, en la descripción de Jerusalén, 36 sobre la virtud del campo nombrado Haceldama, que se compró para sepulcro de los peregrinos con los 30 dineros del precio del Salvador, que devolvió a los sacerdotes Judas ya desesperado de su sacrilegio, asegurando que tenía la virtud de consumir en veinticuatro horas todos los cadáveres, reduciéndolos a menudo polvo; de lo que se puede argumentar, por el contrario, que otras tierras pueden tener también una virtud admirable para aumentar los cuerpos, y que puede ser de esta naturaleza el terreno de Tarija. 
Se contradice la historia de
haber sido fabricada por San-
to Tomás, Apóstol, una Cruz
que se venera en Tarija.

A A DemAs de estas maravillas, se atribuye a los bosques de Tarija, el singular privilevio de que habitó en ellos, pisó sus tierras e ilustró a sus naturales con la primera luz del Evangelio, el Bienaventurado Santo Tomás Apóstol, de cuya predicación en muestias Américas y el Brasil, trata difusa $\mathrm{y}$ eruditamente el Agustino Calancha, ${ }^{3 i}$ y lo pretende probar, en cllanto al país de Tarija, el Padre Fray Diego de Mendoza, en la Crónica Franciscana de la Provineia de San Antonio de los Charcas, ${ }^{38}$ con la invención de la milagrosa Cruz venexada hoy en el Convento de San Francisco, que descubrió un inclio cazando renados en la aspereza de una montaña, en csta forma: que a la puerta co una cueva por donde se entró el venado, hacía apacible sombra una gruesa y hermosa palma silvestre, desgajándose por encima del peñasco un arroyuelo, de poca pero de muy cristalina agua; que dentro de la cueva, sobre tres pirámides de medianas piedras, descansaba una Cruz de un grueso madero de árbol de quinaquina, de los muchos que clia!n aquellas montañas, de hasta quince pies de largo y de dos tercias en redondo de grueso, vestido de su corteza natural, con tres clavos de la misma madera, con señales de haber estado en algín tiempo enarbolada en la tierra. Yo no me atreveré a con. tradecir la tradición, que se tiene por tan constante como general entre los indios, de haber predicado el Evangelio en las Indias, el Bienaventurado Santo Tomás Apóstol; pero juzgo por oportuno apuntar cierta dificultad que me ocurre sobre la verosimilitud de que ja Cruz de Tarija, puede tener otro principio, anuque cristiano, no tan admirable ni misterioso.

Es lo cierto que Alejo García, uno de aquellos cuatro portugueses que sálieron de San Vicente el año 1526, por orden de Martín Alonso de Zosa, Señor de aquella Capitanía, para hacer nuevos descubrimientos hacia tierra adentro por el Septentrión, entró a la parte del Poniente con muchos indios guaranies, a descubrir y reconocer estas tierras, persuadiéndoles que volverian a las suyas con mucha ropa y metales preciosos. Unos dicen que hieieron sut jornada él y dos mil indios, por el puerto que llaman de San Fernando, que es un alto promontorio sobre el río del Paraguay; otros dicen que entraron poco más arriba de la ciudad de la Asunción, por un rio que llaman Paíaí, y se intermaron tanto que llegaron a reconocer las cordilleras y serranías del Perú y arrimándose a ellas, entraron por la frontera del Reino, venciendo muchos pueblos de indios, matando y robando cuanto encontraban, hasta cerca de los pueblos de Presto y Tarabuco, donde les salió al encuentro numerosa multitud de indios Charcas, con cuya resistencia volvieron a sus páses, cargados de preciosos despojos; moviéndolos después de largo tiempo este mismo interés a empiender nueva expedición, aunque no con igual suceso, por haberlos obligado las dificultades de la vuelta a fortificarse los unos sobre las costas del río de Pilcomayo y fronteras de Tarija, donde se han quedado con el título de Chiriguanos, poblándose otros sobre el río de Guapay, veinte leguas de la ciudad de San Lorenzo, Gobernación de Santa Cruz de la Sierra. 
Esta constante relación, contestada inviriablemente por la Historia del Paraguay, persuade muy verosímilmente, que el portugués Alejo García hubiese formado y marbolado la Santa Cruz de Tarija, cuando hizo su jornata con Ios indios guaranies a aquél país; pues, siendo cristiano $\mathrm{y}$ de mejores conocimientos para procurar su abrigo, comodidad y defensa, es muy regular que viéndose i'odearlo de peligros, entre gentiles, todos cnemigos, entre fieras y animales bravos, en tierras que él no conocía, levantase el árbol de la Santa Cruz, como divina señal que liberta a los cristianos on las ocasiones de peligro, escogiendo aquella cueva oculta y surtida de agua y buenos sombrios para refrigerat su sed y los ardores de aquél cálido temperamento, no menos cue para defenderse de los insultos de las fieras salvajes, mientras estuviese alojado con sus compañeros on aquellos desiertos bosques.

Vuclvo a protestar que no por esto intento dismizuír la devoción de aquelia Santísima Cruz; sólo digo mi parecer. Quien no quisiese seguir mi discur'so, haga enhorabuena lo que guste, que siempre será plausible su piadosa creencia.

\section{NOTICIA $\mathrm{G}$ S P T I M A}

De los indios tributarios de
Tarija, y sus tasas.

$\mathbf{T}$ y por lo que toca a los Yanaconas de chacros, se cłeclaró por el Virrey Marqués de Castelfuerte, en Provisión do 29 de julio de 1755, que sólo se lcs cobrase el tributo de tres pesos y un real, como se dijo de los de Porco. Antes corría bajo de un solo Corregimiento la jurisdiceión de Tarija y Chichas, y bajo de este mismo pie quedaron después de la erección de Intendencias, hasta que vista la necesidad de crear nuevos Subdelegados para Tarija, dividió ambas juriscicciones el Gobernador nombrado allí.

1.- En li Parte $2^{4}$, Cap. 2, Noticia 6 , $\$ 13$ de los ramos de $3^{\circ}$ clasc; y el Cap. 6, Noticia 7 , sc propone como medio para adelantar las poblaciones de Tarija, acuartelar allí toda la tropa veterana repartidu en las Provincias del Virreinato, con el fin de hacer dos corrcrías al ario para ahuyentar a los infieles hasta acartonarlos en el Chaco, formando reducciones a la defensa de Presidios militares on el país que se fuere rocobrando, o a lo menos en el grande distrito que corre deede Santa Cruz de la Sieria hacia Tarija, para cubrir las fronteras de la Laguna y Tomina, que en el dia se hallan tan expuestas a hostilidades, privandonos de sus muchas tierras fertilísimas para todo género de frutos. Porque, verdaderamente, apenas pueden contener los Misioneros algunas pocas parcialidades con el cebo de las gratificaciones que les hacen, del produeto de sus cortas limosnas. Ningún religioso entiende la lengua: yo mismo to he experimentado hablondo con uno de los Misioneros nuas antiguos, el cual me confesó de buena fe que todos los demás ignoraban el idioma como êl, y que no tenían siquiera un Arte para aprenderlo. En efecto, como sé la lengua, le hice algunas preguntas y comprobé que en lo poco que hablaba decía sapos por culebras. Sobre todo nos perjudicará el proyecto de rescatar cautivos por plata; porque esto mismo ser el cebo para mayores hostilidades, como me aseguró el mismo padre, que los conoce mu bien. Mejor será emplear en Presidios y en Guarnieión las limosnas de cautivos y de butas, agregando el ramo de Sínodos, como se propone en los lugares citados, y nos libraríamos de Ciiriguanos, 
2.-Techo: Lib. 11, Historił 1’araguaya, Cap, 2`, Fernández, in relation, histor. Misión Chiquit. Cap. 1.

3.- Garcilaso: Jib. $7^{\circ}$, Cap. 17 , tomo $1^{\circ}$, fol. 244 .

4.- Lozaxo: en la Descripeión Cojográfica del Chaco, s 8, fol. 57.

5.-. Garcilaso: Lib. $7^{\circ}$, Cap. 17 , tomo $1 \%$, 1ol, 244 , col. 2 , y fol. 248 col. 1 y 2.

6.- Garcilaso: en el lugar citado.

7.-- Garcilaso: Lib. 7", Cap. 17, ton: 1 ", fol. 240̃, col. 2, al fin.

8.- Garcilaso: Lib. $7^{\circ}$, Cap. 17, tomo $I^{\circ}$, fol. 245, col. 2 al fin,-... Acosta: Lib. $7^{\prime \prime}$, Historia Natural, Cap. 28.- Lozano: $\$ 8$, fol. 58.

9.-Calancha: Lib. $1^{\circ}$ de la Crónica de San Agusín, Cap. $6^{\circ}, N^{\prime \prime} 3^{\prime \prime}$, tomo $1^{\circ}$, fol. 36. Que hubieron gigantes en el Peri $y$ en líxico, de tan extraordinaria estatura que los hombres regulare; les llegaban a las rodillas, lo atseguran el cronista Herrera, Década $4^{\circ}$, Lib. "2", Cay. ${ }^{\circ}$, tomo $2^{\circ}$, fol. 35, col. $1^{\prime}$ y $4^{n}$. Década Lib. 10, Cap. $4^{\circ}$, tomo $2^{4}$, fol. 212 , col. $1^{\prime \prime}$. Torquemada: cn su Monarquía Indiana, Lib. $1^{\circ}$, Cap. 13 , tomo $1^{\circ}$, fol. 35.

10.- Agricola: De Nat. Fốsil ; Lib. $7^{*}$.

11.- Calmet: Disertación sobre Gigantes.

12... Aul Gell.- Lib. 3\%, Ca [1, 3\%.

13.-Deuteronomio: Cap. 3", Vers. 11 y Anos, Cap. 2", Vers. 9; y en los libros de los números de Josué, de los Jueces, del J'aralipomenon y de Baruc en donde se habla de gigantes.

14.- Heródoto Polym.

15.- Cerdo apud Capitolin in Maximiminus, dice que su altura exa de siete pies cinco pulgadas.

16.- Josefo: Antiquit Lib. 18, Cap. $6 "$.

17.- San Agustín: Lib. 15, De Civitate Dei, Cap. 23.

18.- Philóstrato: Lib. 5", In apolon. Cap. 5". Ovidio: Metanorphosis, Lib. 15: Vasta giganteis in gesila est infula menbris.

19.- Strabón: Lib. 17 dice que Gabinio, con otros, repartió esta fábula, en su Historia Romana.

20.- Heródoto: Eutel:p.

21.-Flegon: De mirabilibus, Cap. 17.

22.- Memorias de la Acadennia de Bellas Letrnis, torno 1".

23.- Quinto Curcio: Lib. $7^{\circ}$, Cap. $1 \%$.

24.- Herrera: Década 5, Lib, $2^{\circ}$, Cap. $1^{\circ}$, tomo2", fol. 50 , col. 2, afirma, por relación de los indios, que hacia el lío de La Plata, viniejon en balsas unos gigantes tan grandes, que los demás hombres no les llegabarl a la cintura. Estos son los patagones que deseribe Magallanes. En efecto, los europeos los llaman gigantes por ser mucho más altos que ellos; pero no son gijantes como jndica Jordán en su Geografía moderna, tomo d", fol. 178.

25.- Juan Laer; De origin. Gent. Americe, observaciones No 8.

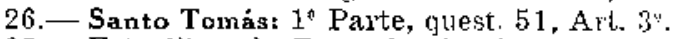

27. - Tste lisro de Enoc, lo cita S. Judas en su Epístola Canónica, vers. 14, y aunque se halla declarado por apócrifo, to supove de grande autoridad San Jerónimo, añadiendo que talyez el Santo Apóstol visitaría algún libro verdadero de Enoc, dicerso del apócrifo, como notan Duhanel y Alapide, en la citada Epistola, tomo 11, fol. 691.

28.- Josefo: Antiquitatum, Lib. 1`, Cap. $3^{\circ}$, traduct. andilly. Philon: judíe de Girantil)us.

29. Todos estos los cita y explica el eximio Suárez, Lib. 10 De Angclis, Cap. 5\%, Nos. 4,9 y 31 , tomo $2 "$.

30.- Platón: In cristia.

31.- Pamiano Nardin: Lib. 5\%, De Ronia reter. Cap. 11 .

32.- Feijoó, en au Teatro Crítico, tomo $5^{\circ}$, Disc. 15, desile el Iarágrafo 16 hasta el 19 , fol. 346 a 349 .

33.- Feijoo: tomo $5^{\circ}$, citado, D. 15, parágrafo 16, N`49,

34. - Feijoó: en su Teatro Crítico, tomo $7^{\circ}$, Disc. $2^{\circ}$, Parárrafo $16, \mathbb{N}^{\circ} 82$, fol. 65.

35.- M. de Mairan: Tratado del Oro Boreal, Sección 2", Cap. 6".

36. Vide Alapide, en el comentario In Matheun, Cap. 27, rerse. 7 y 8, Tít. B. C. y D. tomo 9 , fol. 368 .

37.-Calancha: Lib. $2^{*}$ de la Crónica de San Agustín, Cap. 2 , N* 4 y siguientes, tomo 1. , fol, $316 \mathrm{y}$ siguientes.

38.- Mendoza: Lib. 17, Cap. 21, fol. 120. 


\title{
CAPITULO DECIMOCUARTO
}

\author{
Del Partido de Atacama
}

\author{
NOTICIA PRIM E R A
}

De su extensión; de sus pue-
blos y de la naturaleza y fer-
tilidad del terreno.

E bre la Partido se dilata por lo ancho so100 leguas desde el Río Salado, que lo divide del Reino de Chile ' hasta el de Loa, que sirve de lindero con la jurisdicción de Pica. Su longitud corre de Este a Oeste hasta sesenta y cinco leguas, confinando con la Provincia de Salta y Partido de Lípcz, en la forma que demuestra el mapa general de Potosí.

Todo el Partido se divide en dos Doctrinas, nombradas San Pedro y Chiuchiu, con la diferencia de llamarse la primera Atueama la Alta, y la scgunda Atacama la Baja, guarcłando todos los demás pueblos de sus respectivas comarcas esta misma distinción. La Capital es San Pedro, distante de esta Villa 139 leguas por al derrotero siguiente: hasta Chiuchiu 18; de ahi a Santa Bárbara 12; a Polapi 8; a Tapaquilchas 19; aquí comienza la juxisdicción de Lípez. De este paraje que es una cordillera alta y frigidísima donde han perecido algunos caminantes, se viene a Viscachillas, a las 8 leguas; de ahí, a Alota 7; al Río Grande 15; a Amachuma 16; al Agua de Castilla 9; a la punta de la Cordillera de los Frailes 10 ; a Porco 8, y a Potosí 9; cuyas distancias juntas componen las 139 leguas susodichas.

Este tránsito tiene grandes despoblados, muchos de ellos sin agua ni leña; tales son las 18 leguas desde Sar Pedro hasta Chiuchiu. Las 34 desde Polapi hasta el Río Grande; y de aquí las 22 leguas siguientes hasta Agua de Castilla, sin que se vea siquiera una cabaña donde abrigarse contra las intemperies de aquellos rigurosos climas. 
Mucho más penoso es el camino por donde trajinan regulamente los vecinos de San Pedro; pues, por el ahorro de algumas leguas, hacen de ordinario sus viajes hasta San Antonio rle Lípez, endertando el rumbo por un despoblado de 5 ? leguas, 2 doncle tienen que pasa: una cordillera de 12 leguas, que a más de no toner agua ni bastimentos, es muy expuesta a grandes tempestades do nieve que han quitado la vida a muchísimos pasajeros; siendo contínua la incomodidad de su extremoso frío, por ser esta serranía el mismo corclón de la gran corvillera do Chíie.

Atacama la Alta contiene, fuera de San Pedro, su capital, los pueblos de Toconao, Soncor, Socaire, Peyne, Suzquis, Ingahnasi, con seis aillus más, que se denominan: Condeduque, Scquitur, Coyo, Vetere, Solo y Solcor.

Todas estas poblaciones se componcn do 2.936 personas de la casta de indios, de todos sexos y edades. Viven como los demás de su especie, sin comodidades ni policía; pues, aun la capital donde residía el Corregidor del Partido, no tiene forma de pueblo y las casas están dispersas como islas, con grandes trechos despoblados.

Los Ayllus tienen todavía menos formalidad. Están ropartidos en cabañas muy pequeñas e incómodas, al contorno de San Pedro, en la extensión de seis leguas, entro unos giandes algariobales y chañares que la naturaleza crió allí. Cada Ayllu cuida separarlamente con indecible esmero los de su pertenencia, pov el interés del fruto, de que haecn una bebida que ellos Ilaman "quilapana", y es la chicha (a manera de cerveza) con que se emborrachan en sus fiestas.

Se hallan acantonados en este recinto, para disfrutar el riego de un estero de agua que nace a las seis leguas do San Pedro, de un manantial que sale en una de aquellas quebradas.

Como son muchas las chacras y hucrtas y poca el agua, no puede alcanzar el regadio a mayor distancia; por lo que queda sin cultivo y casi erial un inmenso terreno, por' su naturaleza fértil, que pudiera rendir todos los años abundantísimas cosechas.

En los tiempos de lluvias, en la coidillera, crece el estero; pero sus avenidas no subsisten hasta el mes de octubre, que es cuando más se nccesita el riego para que la semilla sazone bien sin marchitarse con los ardores de aquel clima; por cuya causa no puede aprovecharse para sementeras aquella abundancia intempestiva.

El único modo de que florezca este país, es formar en la quebrada donde ticne su origen el manantial, una grande taguna que recoja las aguas de avenida a su tiempo. Engrosándose entonces tres o cuatro tantos más el caudal actual del estero, podrá surtir agua para regar doce o más leguas de terreno en las ocasiones de mayor necesidad; cesarán las pendencias que riñen de continuo los Aylus entre sí, por el r'epartimiento de aguas; habrán muchas más tievas que đistribuir a los que en el día no las cultivan por faita de agua, asegurándolos con el intevés de la labranza, para que no deserten al Tucumán o a otros países más dichosos (como ahora lo hacen) con perjuicio del ramo de tributos; y cuando ellos no quisieren aprovecharse de estas conveniencias, no faltarán innumerables gentes que a cien manos acepten el repartimiento de tierras; lo cual contemplo muy ventajoso para esta Provincia, pues sólo así se podrá aumentar su población. 
Sigue Atacama la Baja y comprende seis pueblos, a saber: Chiuchiu, Cazpana, Ayquina, Calama, Conchi y Cobija; (que es el puerto de mar) cuyos pobladores, por entoro, no pasan de 721 personas.

Tiene un gran río que trae su origen del cerro llamado de Miño, en la jurisdicción de Tarapacá, y es cl que fertiliza sus terrenos, que no son tan pingües como los de Atacama la Aita.

Corre todo en un cuerpo lasta la inmediación de Calama, donde se divide en dos brazos, gue no tenicndo caja formal hacen muchos derames en la campaña y formai una gran ciénaga de juncos en más de ocho leguas de extensión. Allí ponen el ganado que quieren engordar para grasa, y llegan a tal extremo que le imposibilitan para el procreo; las reses rinden de ordinario seis arrobas de grasa, la cual, derretida, se mantiene en aqucl paraje siempre líquida como ol aceite.

Fn Chacance se reunen los dos brazos con caudal competente de agua más hondo que la estatura de un hombre, por cuya causa hay dos puentes formados de fajina sobre pedestales de picdra. De ahí tuerce su curso hacia Pica, por el embarazo de las lomas altas que vienen desde la costa del mar y ran a desaguar en el Puerto del Loa.

A una legua de Calama, corre un riachuelo salado que sale de los salitrales de Cazpana, y de esto procede ser salobre el agua del río de Miño en Calama, Guacate y Chacance, como notó Fresier, ${ }^{8}$ sin explicar la causa.

Un Corregidor sacó, media legua arriba de Chiuchiu, dos bellas acequias por ambos costades del rio, para riego de sus alfalfares y chacras; sin embargo, se ve poca agicultura en lo genesal, a excepción de Calama, donde bay siembras crecidas de maíz, con que comercian con los moradores de Lípez, Tarapací y Pica.

Ia gente es poco aplicada a la labranza, por la alucinación de no ser a propósito el terreno. Efectivamente, no es tan fértil como cl de Atacama la Alta, porque los muchos salitrales lo embarazan, y por esto preparan la tierra con estiéreol de ovejas que crian a este fin con imponderable cuidado. Pero se lograrian mejores cosechas, si aprovecharan el guano de la isla inmediata a Cobija; pues, se ha experimentado que produce en la tierra el calor más eficaz para mejorar su virtud.

No debe dudarse que con estos auxilios, sería Atacama el Partido más rico de nuestra Provincia, sólo con los productos de la agricultura, que es el interés más sólido de la humanidad. Su terreno es proporcionado para toda especie de labranza y es también el de mayor amplitud para semejante destino. Todo el país se divide en dos valles muy extensos de tiexras lanas y muy limpias, divididas en partes por la cordillera de Lípez y por otras serranías que vienen desde la costa, cortando la campaña unas veces y accreándose a la mar por otras partes, de suerte que el mismo aspecto del terreno acredita su fertilidad. 
De los ninerales y demás producciones de este Partido.
$\mathbf{H}$ Alonso Barba, no asegura de otros en Atacama sino del cobre, afímando que hay mun chas caudalosas vetas y que algunas concluyen en la mar, en farellones grandes de este metal macizo. También calcula por cicrto que debe haber oro, por la abundancia de laspisláauli, en que se cría este precioso metal; pero no testifica que en su tiempo se trabajase ninguna mina de su especie; sin duda porque en aquel siglo no se había descubierto todavía.

Después acá, se han trabajado varias, no sólo de oro sino también de plata, en lo que debemos fundar una esperanza casi segura de que se descubrirân más adelante otras minas, que en el dia se hallan ocultas, bien sea por falta de industria inteligente en matcrias de minería, o porque estas gentes no se aplican a buscarlas, por ol desaliento que les causa su pobreza.

Toma fuerza esta probabilidad en la observación del P. Teville, ${ }^{\circ}$ el cual describiendo las costas de Atacama, dice que son montañas desiertas y estériles, sobre que no se ve planta alguna, y que ésta es marca infalible de los metales que ellas encierran en su seno.

Ya vemos veriflicados estos plonósticos en el mineral de plata nombrado "Chaltipor", y en los de oro de Oloros, Inguhuasi, Susquiz y San Antonio del Cobre. Todos cllos abundan de urat admirable multitud de veneros. No pongo duda en que rendirían mucha riquoza en trabajándose con método y con inteligencia; pero estas gentes jamás se rueven al examen de las minas, ni se atreven a emplear su caudal sino cuando hay ruído de alguna boya en que se puede sacar a cincel el oro y lia plata; por esto es que las de Atacama, se halian entregadas al juqueo ${ }^{7}$ de cuatro indios infelices, que no son capaces de hacer ningún progreso a su ventaja ni en beneficio del Estado.

No obstante, entiendo por informes muy calificados, que de Ingaluasi se saca bastante oro; aunque aquí no se conocen sus productos, porque los vecinos del Tucumán y Salta, con quicnes confina, se los llevan en cambio de carnes y de otros bastimentos, sin pagar quintos, por no haber ningún Ministro que cele su cobranza en aquollos parajes; pues el Subdelegado apenas puede recaudar los tributos y no es difícil creer que no se descuide en hacer su negocio con ol oro.

El mineral de Conchi (que es de cobre) es donde más se trabaja en la granalla. Con todo, están poco aprovechadas aquellas riquezas naturales, porque no tienen ningún establecimiento de industria en qué dar valor a sus producciones.

También refiere Barba, " por fama constante, que en Atacama había finísimos diamantes, (a) y que oyó decir que por un poco de coca ${ }^{\circ}$ que valía dos reales, había dado una india vieja un puñado de piedras brutas, que valieron en España muchos ducados.

No debemos pues admixar ya lo que Tabernier ${ }^{10}$ cuenta como privilegio de la naturaleza en Bizapur, Golconda, Bengala y Borneo en las Indias Orientales y en las Occidentales, el Brasil, suponiéndolos únicos de. pósitos de estas preciosas piedras, cuando las tenemos también nosotros 
en abundancia dentro de nucstros países; aunque la falta que hay de prácticos para conocerlas, las mantiene ocultas a nuestro hallazgo.

Lo mismo dice de las trmquesas y asegura ${ }^{11}$ que estando en los Lípez, de Cura, vió una tan grande como un real de a dos, y debemos creer que si la codicia de las minas de oro y plata no tuviera tan ciegos a los hombres en estos países, ni los privara do otras investigaciones más honoríficas y nobles, quitaríamos con nuestras turquesas el inmenso valor que ahora tiencn en la Europa las que vionen de Persia y de Levante, según Tabernier y Bowles. ${ }^{12}$

No es menos rico estc Partido de hermosísimos mármoles ${ }^{13}$ que hay en abundancia, matizados de celajes, salpicados de negro, amarillo, verde y blanco, de los cuales se han llevado algunos a España, por particulares, $y$ por acá se han fabricado preciosísimas aras. Todavía exceden en lustre $y$ hermosura a los que se sacan a una legua de las minas de berenguela de Pacajes, y serían más estimables si nuestras gentes fuesen de más fino gusto.

En las costas marítimas del mismo Partido, atestigua el citado Barba, 1: que se han sacarlo perlas muy particulares de los mejillones que se vended para comer, sin que ya tengamos que envidial al Golfo Pérsico, Isla de Ceylán, Panamá, California y otras pesquerías, donde se coge esta preciosa piedra.

No es menester pondcrar los grandes mogresos que pudiera tener nuestro comercio, con la abundancia de ramos tan estimables como hemos referido, pues se deja percibir por sí misma la utilidad.

Aun sin el tráfico de piedras preciosas y metales, tienen los de Atacama un tesoro en sólo la fertilidad de sus campos. En otro lugar 15 trato de los muchos productos que puede dejar a esta Provincia, la siembr'at $y$ bencficio del cáñamo, argumentando por la igualdad de aquel terreno con el de Chile, donde este ramo xinde considerables utilidades para jarcia y otros destinos; y desde luego es infalible este cálculo teniendo la experiencia de haber fructificado lelimmente algunas cortas siembras de cáiamo que se han hecho en Atacama. Pero el trabajo es que han suspendido su cultivo, porque viven alucinados con el oro y la plata.

Sobre todo, es más apreciable y abundante el ramo de lanas de vieuña. Hay tanta copia de estos animales en Atacama, que sólo en el año de 1786 , se contaron muertas por aquellos contornos más de tres mil, con las nevadas de la cordillera. Aunque hay vicuñas on toda la sierra, es muy superior en calidad la lana de las de Atacama, por ser más blanca y de mejor madeja; por este interés pasan los vecinos de Salta, con infinidad de perros, dentro del distrito de este Partido, y hacen unas batidas en que arrean millares de vicuñas, aprovechándose ellos, más que nosotros, de sus lanas, como se vé por el mayor comercio que hacen con este efecto; motivo poderoso para celar tal fraude y prohibir las cacerías en nuestro territorio.

Los indios las cogen en unos rodeos de hilos con que circunvalan grandes espacios de terreno, donde las acantonan; como se dijo hablando de Lípez; pero, a más de penosa, no es segura esta especie de cacería; porque entrando con las manadas de vicuñas algún guanaco, rompe este solo el cerco y escapan todas tras él.

El modo más común de Ias cacerías de Atacama, es esperarlas en las aguadas donde bajan a beber al medio día con el excesivo calor del 
sol; los indios se esconden con sus perros dentro de unas pircas (que son paredes de piedra sobrepuesta, sin barro ni argamasa) y allí se mantienen observando cuándo salen del arroyo hacia la serranía, luego al punto sucltan los perros que son diestrísimos, y a poco trecho de carrera van desjarretando multitud de vicunas, porque ia voz que boben se hartan de manera tal, que con el peso del agua pierden la mitad de su agilidad, y fácilmente las alcunzan y matan los perros.

Aprovechan la piel para el comercio y la came para comer, y se puede asegurar que es el único alimento del mayor número de aquellos infelices; tanto, que se expondrian a perecer en prolibiéndoles este recurso.

Sólo se puede remediar incitándolos con algún premio grande a que vayan domesticando estos animalitos, como es fácil, según lo expuesto en otro lugar. ${ }^{16}$ En tal caso, matarían para alimentarse, las que ya no son capaces de procrear, al modo que lo ejecutan con los carneros de la tierra, y después de la utilidad de las lanas y de otros usos a que se pueden aplicar, sería un gran proyecto pasar a España algunas majadas domesticadas, las cuales trasladándose a la sierra, darían esta nueva preferencia a nuestras producciones, como succdió con las ovejas merinas ${ }^{17}$ de Castilla.

\section{NOTICIA TERCERA}

\section{Del Puerto de la Magdalena de Cobija. Se describe su si- tuación y su comarca, con al- gunas reflexiones importantes sobre si conviene o no fomen- tarlo de cuenta de la Real Hacienda.}

COBIJA cae a la parte occidental de Po-
tosí, sobre la costa del Mar del Sur, a distan-
cia de 177 leguas de esta Villa Imperial, en
$22^{\circ} 20^{\prime}$ de latitud, según las observaciones
de Dn. Pedro Manuel de Zedillo, 18 aunque
otros, 19 con corta diferencia, le dan más o
menos altira de Polo.
El P. Teville 20 estuvo en este Puerto y lo describe: que es una rada o ensenada abierta por todas partes, a excepción del lacio oriental; su anclaje bueno; pero por poco mar que haya afuera, con especialidad cuando los vientos aprietan del Oeste, las oleadas que vienen a lo largo, se rompen sobre la costa con tanta violencia que no hay cmbarcación que se atreva a saliv a tierła durante el mal tiempo, sin que corra peligro.

Toda la costa está llena de rocas muy grandes; el mejor lugar para el anclaje, es al Oeste de la Capilla. Las rocas que están al Sur, favorecen el desembarco y ponen los navios a cubierto de la mar gruesa, cuando los vientos soplan del Sur, que son los más generales en toda la costa.

Añade el mismo autor ${ }^{21}$ que desde la bahía hasta Cobija, la costa es un plano de cerca de media legua, que va a teminar al pie de las montañas. M. Fresier, viajero francés, ${ }^{22}$ examinó por más tiempo y con mayor prolijidad el puerto y sus contornos, y emprendió de propósito viaje hasta Lipez, para instruírse mejor de todo el terreno. Fiste autor afirma que es una pequeña bahía de un tercio de legua de hondura, donde se meten los navios a 18 o 15 brazadas de agua, de fondo arenisco y de poco resguardo contra los vientos del Sur, que son los más ordinarios por allí. 
Al parecer, se contradicen ambos viajeros acerca de la seguridad a la parte del Sur; pero lo cierto es que Teville solamente asegura que las rocas ponen iz cubierto los navíos, pero no niega el riesgo cuando apretaren las tempestarlos.

Algunos ponen por seĩales del puexto, tuas manchas blancas que se ven por allí. Fresier ${ }^{23}$ reprueba esta observación, por falibie, respecto de abundar de cllas toda la costa, y asigna por mejor distintivo la mayor elevación que se reconoco clesde Morro Moreno (que está 10 leguas al Sud-Oeste), hasta arriba de la bahía; de suerte que este lugar es el más alto de la costa, aunque con poca diferencia.

El puerto se compone de algunas cabañas de indios, hechas de cueros de lobos marinos. ${ }^{2}$ Por toda arboleda se ven allí dos palmas y cuatro higueras, ${ }^{2 i}$ que pueden scrvir de marca para el anclaje. Junto al pueblo corre un hilo delgado de agua un poco salada, que destila gota a gota y a fucrza de paciencia apenas se puede surtir un navio, al cabo de veinticuatro horas.

Todos los viajexos constatan esta falta, ${ }^{26}$ por más que los naturales quieren persuadir lo contrario por sus fines particulares. Es verdad que en otros parajes hay menos agua; pero esto no quita que sea poca y mala la de Cobija. Tampoco les he creído la calidad curativa de la terciana que le atribuyen; porque uno u otro ejemplar que citan, pudo ser efecto de la casualidad, como de ordinario sanah los atercianados, to tal vez procedido de la fruta que allí se coge; lo que no es extraño en este género de enfermedad.

Absolutamente no hay yerba para las bestias, y es preciso enviar las mulas y demás animales a lo alto de la montaña, para poder subsistir. Aunque allí engorda el ganado por la grosura y solidez del pasto, que hay en poca cantidad, se inficiona la carne de cierto afecto enteramente desagradable al paladar, de manera que se hace incomible.

De esto proviene que el puerto jamás se ha poblado, sino de los infelices pescadores, que viven de sólo pescado desde que aprenden a comer. La aridez del terreno se conoce bien por la esterilidad de las montañas. Se sienten allí con exceso los calores de la zona tórrida, y con no llover jamás es un país casi inhabitable; por cuya causa y por la faita de comercio, testifica Teville ${ }^{27}$ que casi nunca anda allí ningún navío. Añade Fresier, 28 que por ser uñ puerto escaso de todo, jamás ha sido frecuentado po: otros que los franceses, porque estos siempre han buscado para el desembarco de sus mercaderías en la América, los lugares más cercanos a los minerales ${ }^{29}$ y los más distantes de Oficiales Reales, a fin de facilitar el comercio de contrabando y el extravio de la plata.

Con el mismo objeto han tomado anclaje algunos navíos de España y del tráfico de Lima, huyendo de los Oficiales Reales de Arica, porque los Corregidores fácilmonte se convenían a cualquier disimulo cuando el partido fucse lucrativo.

Pero lo que ganaban en mangas perdían en faldas (como dice nuestro adagio) y así vemos que en muchos años no ha vuelto a este puerto ningún navio.

Ya se ha hecho descripción de los grandes despoblados que tiene el camino, a más de penosos, arriesgados. Agréguese ahora que, desde el puerto a Chacance no se encuentra pasto ni leña, y lo que es más, ni uma gota de agua en distancia de 22 leguas. 
De allí a Guacate sigue el mismo dosierto, que continúa después husta Calama; y si bien hay agua en las dos pascanas anteriores, es salobre, y no se encuentra siquiera una cabaña donde abrigarse del sol.

rodas estas dificultades han impedido la frecuencia de embarcaciones en este puerto. Cuando, por el colitratio, solye distar menos Arica de Potosí, (dista 150 leguas) se viene por unos caminos hermosos, llanos y poblados, sin riesgo de cordilloras y te ofos mil trabajos que ofrece el trajín de Atacama.

Considero que ningún mereader querría anclur su navio en Cobija, aunque su puerto fuese de los habitados; porque sobre exponerse a los cuidados penosos ya referidos, allí se estaría eternamente por falta de retorno, y cuando quisiera volverse lo ejecutaría de vacio.

Convengo que el anclaje de Cobija es mejor que el de Arica, por el fondo arenisco y conchoso que aquél tiene; poro jamás contesaré que el puerto sea capaz de fomento.

Lo primero que se busca para una población, según los preceptos de la política, es la comodidad de agua, de leña y de pastos, cuando no muy cerca, a una distancia proporcionada donde sea fácil el recurso; y querer fomentar un sitio privado de todas estas conveniencias juntas, para habitación de hombres, es pretender o matarlos de miseria o pensionar perpetuamente al Rey para que costee la subsistencia. Luego, Cobija no es capaz de fomento, por todas las circunstancias expresadas.

Si el puerto fuera útil y ventajoso al conercio, ninguno sería bobo para que dejase de hacer su negocio por alli. La cxperiencia los ha desengañado ya, $y$ si tentasen de nuevo a la fortuna, serían tan desgraciados los sucesos últimos, como los primeros. Sobre todo, siempre que con el tiempo se reconozca ventaja, el comcrcio mismo fomentará el puerto, como ha sucedido con el do Montevideo en el Río de la Plata.

Entre tanto, no conviene fortaleccrio ni impedir costo alguno de la Real Hacienda; pues, además de estar defendido por su naturaleza y circunstancias de sus comarcas, nada granjeariamos con habilitarlo, que aumentar un cuidado más para el Gobierno en ocasiones de guerra, y exponer al oprobio de las fuerzas o de la fortuna encmiga el honor de nuestras armas con el interés del Estado y vida de los vasallos. Al contrario, estando como ahora despoblado, con la precisa proporción para las pescas del congrio, con que se surte casi toda la costa y mucha parte de lo interior de la sierra, ninguna nación masítima puede pensar en atacarnos por alki, porque, sobre no tener interés, se expondrían a perecer con la cscasez de agua y por imposibilidad de todo recurso para alimentos, que seria preciso buscarlos en Calama, a distancia de 39 leguas desiertas. De suerte que según el estado actial de las cosas, nada tenemos que temer, aunque andara allí la armada más poderosa del mundo. Porque manteniéndose siempre dos centinelas por turno de dos en dos meses, sobre las montañas del puerto, con el aviso de estos se pondrían a salvo los pescadores con los peliejos marinos (que es todo su tesoro), y do esta manera nadie peligraria, y los mismos encmigos levantarían el sitio, vencidos de la propia indefensión.

El mayor interés que pudiera obligar al proyecto de formalizar algún establecimiento en el puerto, sería, como he oido decir, la pesca de ballena. 
Algunos que han visto pasar por la costa una u otra ballena, ya han creido que hay abundancia competente para empeñarnos a la empresa de su pesca. Fs verdad que Dn. Antonio Ullod asegura que en las inmediaciones a Concejución de Chile, $y$ a las islas de Juan Fexnández, vieron algunos ballenatos o ballenas de aquel mar; pero su misma narración indica que son pocas, y cualquiora que se haga cargo del grande silencio que guardan los viajeros Teville y Fresier en orden a ballenas sobre nuestra costa, se persuadiri formosamente de que no las hay, y que son raras las que so llegan a ver al cabo del mes.

Los ingleses, danesus $y$ algumos flanceses van a Groenlandia todos los años, a hacer pesca de ballenas; pero esto es porque aquel mar está tan llono de ellas, que se cuentan hasta quince especies diferentes. Io mismo practican en Terranova casi todas las naciones, principalmente los ingleses, holandeses y franceses, con ta seguridad de que abunda allí tanto el bacalao y la ballena, que algunas veces embarazan el paso de los barcos. "31

Estas obseraciones sirven para conocimiento de la voluntariedad con que se ha pretextado hallarse empleadas on la pesca de ballena las embarcaciones inglesas, que on este año de 1769 se han visto por las costas del Mar del Sur en los puertos de Arica, Pisco, Atacama y otros. Los únicos parajos, que abundan de ballena en nuestros mares de América, sabemos que están desde Castillos a 30 leguas de Montevideo hasta el Estrecho de Magalanes; pero de alli hacia el mar Pacifico son muy poeas las ballenas que se meuentran según las relaciones de nuestros viajcros, para que no se estime por voluntario y paliado el colorido de la pesca. Sin que deba apreciarse el testimonio de algún inglés moderno, porque es de sospechar que se haya meditado apoyar sobre este punto el móvil de las miras por donde se conduce esta nación desde las primeras inquietudes de sus colonias.

Son demasiado sabidas las pendencias que han roñido las Potencias Soberanas sobre el iso libue de la pesca en todos los mares, principalmente en el Océano, queriendo sostener esta licencia en el Derecho de Gentes, que hace comunes a todas las naciones los mares y su pesca por ser un cuerpo indivisible, que no admite limites convenientes, por su misma inmensidad. Contra estas pretensiones, no hay cluda que el Derecho Público suministra apoyos muy poderosos a lavor de los soberanos perjudicados; porque el señor del territorio también lo debe ser de los mares adyacentes, para el anparo, conservación y defensa de los usos del dominio; $y$ es por esto el intitularse los Monarcas de España Reycs de las Indias Occidentales, Islas y Tierra firme del Mar Océano, con un derecho más justificado, que aquel que se arrogó el pueblo romano para apropiarse la dominación de todo el Mar Mediterráneo, y conceder su mando absoluto a Yompeyo ol Grande, desde las columnas de Hércules.

Con todo, quedará más asegurarlo nuestro Derecho en desvaneciendo el falso pretexto de la pesca; porque si Roma defendió la dominación marítima para estorbar los ataques y perjuicios, que experimentó de parte de los Piratas por los cmbarazos que ponían al transporte de víveres $y$ al uso libre de sn concreio marítimo; nosotros debemos amparar a toda costa los límites matemáticos, que fijó sobre los mares de América el Sumo Pontíflee Alejandro VI, como Juez árbitro entre los dos Soberanos de España y Portugal, para impedir el comercio prohibido del 
contrabando en nuestras costas, la ocupación clandestina de alguna de nuestras lslas y otros mil inconvenientes, que callo por notorios a todo hombre de Estado, y porque ninguno ignora que con este fin se establecieron en las Indias los guardacostas, sobre tratado expreso en las Cortes extranjeras de defender la untrada de embarcaciones de otra bandera en los distritos de nuestras pertenencias marítinias: dejándoles libre solamente la navegación para el paso a sus Colonias y establocimientos Americanos, *

Siempre que alguno afiance igual suceso en Cobija, yo confesaré ser bueno el proyecto; pero será menester que el Rey haga todo cl costo, mediante a no haber allí enbarcación ni persona de posibilidad para gastar 10 pesos; pues, apenas pescan el tollo y congrio aquellos infelices, con sedal y anzuelo.

Lo sólido es aplicamos a la labranza del triggo y cáñamo y al trabajo de las minas; y todo lo demás es edificar sobre arena. $Y$ si yo dijera otra cosa, no sería buen servidor del Rey, ni fiel a la verdadera felicidad del Estado: estoy muy cerca de Atacama; he oído los mejores informes y nada escribo que no sea notorio a todos.

* Los tres párrafos anteriores corresponden al Ms. del A. G. de I, (Nota de E.).

1.- Los grandes desiertos de Atacama, de que hace mención D. Antonio de Ulioa en su Viaje a América, Lib. $1^{\circ}$, Cap. 13, $N^{\circ} 358$, tomo $3^{\circ}$, fol. 207, están antes del río Salado, el cual es su verdadero lindero con el reino de Chile, a los 25 grados de latitud, según Murillo. en su Geografía Histórica, Lib. $9^{\circ}$, Cap. 16, tomo 9 , fol. 294 .

2.- Fresier: en su relación del viaje a la Mar del Sur.

3.- Fresier: en su Viaje, fol. 130.

4.- Barba: Lib. $1^{\circ}$, Cap. 29, fol. 30 .

5.- Barba: Lib. 1\%, Cap. 26, fol. 27 al fin.

6.- El P. Luis de Teville, en el Diario de sus observaciones en las costas orientales de la América Meridional, año de 1712, tomo $2 \%$, fol. 589.

7.- Asi llaman en el país el trabajo corto de los que andan a la solicitud de dos o tres onzas de oro, sin emplear labores formales.

8.- Barba: Lib. $1^{\circ}$, Cap. $15,136$.

(a) Don Manue] Fernández Valdivieso, siendo Corregidor ahora treinta y seis años, remitio a Lima varias piedras y encontraron dos diamantes de valor; pero, se ignora el mineral de donde sacaron, porque no se tomó razón de ello. (Nota del Ms. del A. G. I.).

9.- Juan de Laert, en el Lib. 10, Cap. 2, $\mathrm{N}^{*} 40$, fol. 400 de la Descripción General de las Indias occidentales, expiica la firura, naturaleza y propiedades de la coca; yerba tan usada en el Perú, que sólo en él se consume al año el valor de más de doscientos mil pesos.

10.- Tabernier, en su Viaje a las Indias Orientales, Lib. 2", Cap. 15.

11.- Barba: Lib. 19, Cap. 15, fol. 79 .

12.- Tabernier, en el lugar citado. Bowles en la Historia Natural de España, fol. 540.

13. - Barba: Lib. 1", Cap. 16, fol. 15 .

14.- Barba: Lib. $1^{\circ}$, Cap. 26.

15.-- Final del Artículo Primero del Párrafo Unico que sigue al presente Capítulo.

16.-. Vide Cap. 11, Noticia $2^{\circ}$.

17.- D. Antonio Pons en su Viaje de España, tomo 8, carta 5, fol. 190 , No 62 , y tomo 10, carta $7, N^{*} 51$, fol. 199.- Vide a Bowles, sobre el cultivo de estas lanas, en su Historia Natural de Fspaña. Dice Pons, que en tiempo de D. Alfonso último, se trajeron la primera vez las pécoras de Inglaterra, en las naves carracas, y que es el origen de las "ovejas marinas", que el vulgo llama merinos, por su lana. Que estas pécoras se colocaron en los montes de Segovia.

18.-Zedillo: gran piloto que hizo nuchos viajes por la Mar del Sur. 
19.- M. Fresier, en su Viaje de la Mar del Sur, fol. 130, asigna 22 grados 25 minutos. Murillo citando a Le Is!e, en su Geografía Histórica, Lib. 9, Gap. 16, N 9 , fol. 294, pone 22 grados 30 minutos con la cual graduación se conforma Echard ilustrado por Montpalau, tomo $1^{\circ}$, Letr. A. T., fol. 101.

20.- Teville en su Diario de obserraciones, tomo 20 , fol. 589.

21.- Fl mismo: fol, 586, tomo $2^{\circ}$.

22.-Fresier: en su Viaje de la Mar del Sur, fol. 130.

23.- Fresier: fol. 130 .

24.- Fresier: fol. 130 , testifica de 50 casas, pero estas son unas veces más y otras menos, porque como todos son pescadores, se llevan en las canoas los cueros de que forman sus cabañas sobre costilias de ballena, y entonces se minora el número, y crece cuando se juntan en el puerto. No hay más casas formales que las del Corzcgidor, Cura, Gobernador indio, dos bodegas y dos casas de espa. ñoles.

25.- Fresier cuenta 4 palmas y 2 higueras, pero el tienpo ha cambiado el número.

26.- Fresier: fol. 130,- Teville: tomo $2^{4}$, fol. 589.

27.- Teville: tomo $2^{\circ}$, fol, 584 .

28.- Fresier: fol. 130 .

29. - Confina Atacama con Jípez, que en aquelios tiempos tería riquísimos minerales, de donde se extraviaba inmensa cantidad de plata, por la distancia de los Oficiales Reales de Potosí y fraudes de los mismos Corregidores.

30.- Ulioz: en su Viaje, Lib. $2^{\circ}$, Cap. $3^{\circ}, \mathrm{N}^{\circ} 452$, tomo $3^{\circ}$, fol, 275 , y tomo $4^{\circ}$, Lib. $3^{\circ}$, Cap. $1^{\circ}, N^{2} 631$, fol. 387 .

31. - Vide a Jordán, en la Geografia Moderna, Art. $7^{\circ}$, $\$ 1^{\circ}$, tomo $8^{\circ}$, fol. 78 . 



\title{
PARRAFO UNICO
}

\author{
Avisos y reflexiones políticas sobre los destinos y medios con que deben \\ aprovecharse las preciosas materias y producciones que ha criado la \\ Naturaleza en los Partidos que se acaba de describir.
}

\author{
A R T I U U L P R I E R O
}

Varias advertencias económi-
cas para reformar los abusos
dominantes en lo general de la
Provincia contra el buen régi-
men de Policía.

M

Mientras dure el atraso o la inacción de las Artes en nuestra Provincia y en las demás del Reyno, es imposible que se pueda lograr abundancia de materiales, ni promover las producciones que los deben suministrar porque no habiendo manufacturas en qué emplearlos tienen los dueños el inconveniente de no poder darles despacho y este obstáculo les impide también hacer empresas en la proctración de materiales, por el temor de experimentar las grandes pérdidas consiguientes a la posesión de un género inútil.

Así no hay otro remedio para facilitar grandes acopios de materiales, como el vencer la pereza de nuestros ciudadanos y alentar su aplicación a las Artes $\mathrm{y}$ al trabajo de las manufacturas útiles, valiéndose a este fin de providencias inteligentes según las reglas que dictan las ciencias económicas, ayudadas del conocimicnto del país y de Ia experiencia de sus gentes.

Sin embargo se observa un despacho muy favorable de muchos materiales en que tendríamos grandes ganancias, si se tomase un expediente, sabio en su negociación. 
El cobre es uno de los materiales más precisos para nuestra moneda y minería por la porción que se consune en las aleaciones o ligas, para dar a los metales su verdadera ley: cn cedazos y almadanetas para el servicio de los ingenios y tal vez también en cl bencfictio y preparación de los metales en los casos que enseña la Química y Metalurgia.

El cobre que se conoce de mejor calidad y el más a propósito para las aleaciones, es el que se saca del mineral de Escapa, ' en el partido de Lípez, distante de esta Villa ochenta y ocho leguas.

También se saca buen cobre del mineral do Conchi, en el partido de Atacama, cincuenta leguas de Escapa, y aumque no es igual en su pureza y ley, es más abundante.

Por esta causa los que trabajan en Escapa suelen regularmente mezclar los cobres de anbos minerales para nuestro surtimiento de nuestra Casa de Moneda, vendiendo a veinticinco pesos cada quintal que allí sólo cuesta diez y seis.

Yo atribuyo a esa mezcla los repetidos malos sucesos que experimentamos en las afinaciones de las platas, porque siendo más agrio el cobre de Conchi comunica esta cualidad a los cuerpos con que sc liga. $\mathrm{Y}$ así se ve en otras Casas de Moneda, que para evitar los malos efectos que causa el cobre, usan en la afinación del oro, de tejos medianos, que funden de utensilios ya servidos, por suponerse más purificado el cobre con el uso y con el fuego.

Este ejemplo nos enscña que mientras en Potosí no se practique lo mismo, siempre serán grandes los costos de las afinaciones, y para evitar estos gastos será preciso por lo menos poner gran cuidado en que se traiga el cobre puro de Escapa para nuestras ligas con la plata, y de Yavircoya para el oro. A este efecto será menester que se hagan las compras en el mismo mineral por algún sujeto de conducta que se encargue de esta comisión por clenta de la Casa de Moneda; por cuyo medio después de lograrse el intento en la calidad del cobre, se conseguirá tambiên que su costo no suba de veinte pesos ahorrándose al Rey los cinco pesos que van hasta veinte y cinco, que hoy les cuesta, $\mathrm{y}$ sobre todo nunca se padecerá la escasez de este material que se ha experimentado más de una vez.

Si bien sería más conveniente y úcil al Rey, rematar por junto la provisión de los materiales que necesita la Casa de Moneda, como son el cobre, la Ieña, el carbón, el hierro, el acero, el agrio de limón y otras cosas que en el día se compran pox mano de un Oficial de la Casa, llamado Proveedor, y se suministran por el mismo, como Guardamateriales, por ambos oficios asalariado por el Rey. Pues a más de que en tal caso los precios serían los mismos de ahora y tal vez mấs baratos, se iba a ahorrar el sueido del actual Proveedor porque el mismo Proveedor General de la Casa debería hacer los suministros a cada Oficial, con la cuenta y razón que lo ejecutan los demás asentistas de Real Hacienda.

En cuanto al cobre que se consume en almadanetas y cedazos, sería conveniente igualmente que se haga su acopio en barras, por cuenta de la Azoguería y por mano de sus Diputados asalariando un Maestro Fundidor de Aimadanetas para que practique estas operaciones con la pureza correspondiente, porque las que se compren a relance para el servicio de los ingenios, vienen tan cargadas de plono y estaño, que empesando a servir se van desgranando a tanta prisa que una aimadaneta de 
coce arrobas, queda inútil a los seis meses de ajercicio, con merma de la mitad de su primitivo peso.

Ya se ve que todas las partículas desgranadas de cobre y estaño se incorporan en la plata haciéndola de calidad agria y menos dócil a las operaciones de la Moneda, de donde proceden las continuas y crecidas fallas de la Ficlatura, como expusimos on otro huar. ${ }^{2}$

I'or estos incouvenientes conviene prohibir las almadanetas de cobre, estableciendo el uso de las de hierro, de que se servían antiguamente, con la ventaja de que estas duran muchos años cuando aquellas se consumell al cabo de seis meses.

Pero siendo preciso traer estos materiales desde Vircaya, con otros muchos aparejos y utensilios que necesita la minería, también sería necesario rematar por asiento esta provisión, sobre la seguridad de que en Potosí sobran sujetos que pondrian empeño para ser preferidos en esta contrata.

Ello es una lístima que repartićndose cada año entre los azogueros de cincuenta a setenta nil pesos en plata efectiva de los fondos del Real Banco de San Carlos, difícilmente se encontrará uno que se aproveche de este auxilio. A lo sumo compran algunas almadanetas o cedazos al principio del año on que se ejecuta la distribución, y el resto se consime en ficstas y pagamento de otras deudas, totalmente independientes de la mineria, de suerte que hay azoguero que recibe cuatro a seis mil pesos según las cabezas de ingenios en que trabaja, y se puede asegurar que no aprovecha mil pesos.

Me consta que muchos acreedores están esperando el tiempo de los auxilios, como el único momento feli\% para su cobranza, y he visto en podox de ellos varias libranzas que se les ha pagado en el Banco sin entrar ni un peso en poder del azoguero. Es imposible que la minería haga progresos si no se remedia abuso tan perjudicial.

Poco a poco se irá alentando esta noble profesión rematándose por asiento la provisión de materiales a cuenta de los mismos auxilios, porque a Io menos se emplearía una tercera o cuarta parte de estos socorros en el importante objeto de las minas.

El asentista procuraria traer de Vircaya con oportunidad almadanetas de fierro colado, cedazos, combas, picos y otros utensilios necesarios para el servicio de las minas e ingenios; la azogueria tendría un copioso repuesto de estos materiales para pronto recurso de su trabajo con la comodidad de un veinte o veinte y cinco por ciento más barato de lo que hoy le cuestan; $y$ el Gobierno no liallaria embarazos para reconocerlos y prohibir los que no fuesen acomodados para el uso y para la utilidad de los mismos azogueros.

Este expediente vendría a ser el más favorable y feliz pactándose por condición del asiento, que la mitad de los materiales se haya de trabajar en esta Villa con maestros que a este fin debería traerse de Vircaya, porque estos mismos operarios enseñarían a otros oficiales hábiles que con el tiempo pudiesen desempeñar todas las empresas de su profesión.

En este dichoso período hallarían ocupación muchos talentos felices que en el día están sín cultivo, abandonados a la desidia y se repartirían catre ellos mismos las piquezas acumuladas por razón de salarios.

las maderas son otro material de los más importantes no solamente para construcción de edificios sino también para la fábrica de rue- 
das y ejes de los ingenios; pero al mismo tiempo son tin costosas, que una rueda vale más de cien pesos y un eje más de mil, y es la causa que estos materiales vienen fuera de nuestra Provincia de paiajes distantes, como la Laguna, el Tucumán y otras partes.

No es porque no tengamos maderas en nuestra Provincia, porque realmente las hay en el Río Blanco, en la jurisdicción del Particlo de Chichas, sin hacer cuenta de los excelentes algarrobos, robles, sotos, tipas y maras que se encuentran en abundancia eli los Partidos de Atacama y Chayanta, de donde es casi imposible conducirlos por la aspereza de los caminos.

Es el caso que en la Ribera de Potosí, sólo se sirren para ejes de unas grandes vigas, pudiendo destinar a este uso tres o cuatro vigas menores bien empalmadas entre sí y aseguradis con aros y argollas de fierro, como lo ejecutan en el mineral de Ubina $y$ un otros del Reyno.

Es igual la fortaleza y duración, mucho menos el costo y más pronto y fácil el recurso en las muchas maderas de esta clase que tenemos en nuestra Provincia.

Las resultas serían provechosas para la azoguería, por el ahorro de gastos; serían también hucrativas para nuestros ciudadanos, porque se emplearian en este Comercio y disfutando el precio de las maderas, gozaría la Provincia de estas riquezas que no posee en el día; y por último, serían conducentes para renovar y conservar los bosques con nuevos plantíos; ${ }^{3}$ asunto que aunque muy importante y reencargado por las leyes ha sido impracticable hasta ahora por el descuido de estos habitantes, procedido en mucha partc del poco empleo de muestras maderas.

Atacama es un país tan fértil para ol algarrobo, que sin ningún trabajo se ve hacer un árbol de una estaca que se clava en el suelo. Sería muy fácil poblar toda la costa de su bahía con hermosas arboledas, y generalmente el terreno de su distrito; lo eual contribuiría para recigerar en parte el inmenso calor de aquel país y al mismo tiempo para entablar un ramo pinguie de comeleio con los minelales de loa, Guantajaia y Tarapacá, en porciones crecidas de carbón y leña de que se carce en aquellos establecimientos.

En Vetiche (a) perteneciente a Chichas hay buenos principios de f́abrica de cordobanes $y$ badanas; con poca protección tendría grandes progresos. Abundaría este material tan necesario para muchas obras y de paso se fomentarían los rebaños de cabrío en beneficio de los hacendados y de las tierras.

En el Corro Rico de esta Villa se encuentran con abundancia el Bol arsénico, material precioso y necesario para medicina y para la pintura; una arroba de esta admirable tierra rale cuando más caro ocho reales y porque solamente uno $u$ otro indio pobre se dedica a sir saca, tiene tan poca estimación cuando pudiela ser un wamo mu exquisito de nuestro comercio, como lo es en otras partes.

La sal es otro material indispensable para el beveficio de los metales a más de su nocesirlad para los usos humanos. A siete leguas de Potosí están las minas de Yocalla, tan abundantes de sal que habiéndose gastado cada día más de mil quinientos quintales en tiempo de nuestro célebre Barba, ${ }^{4}$ so conservan hasta ahora abasteciendo todos los consumos de esta población, pero el desorden en el trabajo de estas minas es igual al desarreglo en que generalmento cstán todas las minas del Reyno, y 
aunque sea tan admirable la abundancia de sal que la naturaleza ha acopiado en Yocalla, debemos temer, que al cabo llegará a consumirse, coriendo más tiempo sobre los ciento cincuenta años que se está trabajando en ellas desde que el citado Barba cscribió su Arte de los Metales.

El Gobicrno debe aplicar un celo inteligente para evitar un derrumbe o ayzamiento general de aquellas minas arreglando en lo posible su trabajo; porque si llegara a acabalse este recurso seria menester ir a buscar la sal a parajes distantes y a precios más subidos con notable perjuicio del público.

Nuestra principal dicha consjste en que todos los partidos tienen salinas más o menos abundantes, y esta providencia de la naturaleza le ahorra al Gobierno los cuidados que deberia tomarse para esparcir este material por el Distrito de su mando. Lo más admirable es que cuande otros Gobien'nos estudian los medios de distribuír la sal en los puertos de mar para las pescas, se excusa de este afán el nuestro, con todo de ser muy abundante y copiosa la pesquería del congrio, que se hace en el puerto de Magdalena de Cobija, situado en el partido de Atacama a la costa dol Mar del Sur; porque aquellos pescadores aparejah todo el pescado con tierra común sin necesidad de sal, lo que me hace creer que toda aquella tierra es salitrosa.

Esta singularidad es de mayor abono para los pescadores y para los consumidores, porque no entrando el costo de la sal otro tanto más se ahorra en su precio.

Según la abundancia de salinas que hay en el Reino, seria una de las rentas más copiosas si se hubiesen estancado. En efecto, se despacharon varias Cédulas "a los Excelentisimos Virreyes Don Francisco de Toledo y Don Martin Enríquez, para que se incorporasen a la Corona las salinas del Reyno dèl Perú, administrándose por cuenta y beneficio de la Real Hacienda.

Aunque por entonces no se tuvo por conveniente tratar de esta administración, la comenzaron a introducir los Excelentísimos Virreyes sucesores, Conde de Monterrey y Marqués de Montesclaros, pero por otra Cédula de 1609 , que refiere a la letra nuestro sabio político Don Juan de Solórzano, "se mandó cesar en este negocio por los muchos inconvenientes que se representaron y el poco fruto que se sacaba, en cuya ejecución libró superior despacho el Señor Marqués de Montesclaros, a 31 de agosto de 1610, alzando el Estanco de Ja Sal y permitiendo a todos el uso libre de las salinas ea el Reino del Perú.

Nuestro Don Gaspar de Escalona ${ }^{7}$ atribuye la reforma de este arbitrio a la admirable novedad que se experimentó agotándose las salinas y consumiéndose casi generalmente los criaderos y veneros de ellas. Pero me hace fuerza en contrario, que of Señor Solórzano no refiere este motivo más digno de memoria que otros alejados en su obra; y más bien creo haberse mandado suspender el Estanco de la Sal por los perjuicios que se representaron contra los indios; por eso después que se supo que habia salinas que se podían estancar sin perjuicio de los indios, se mandó nuevamente su estanco por otra Cédula de 1632, recopilada en la Ley trece, título veinte y tres, libro octavo de Indias. Ni es creíble que la piedad de nuestros Reyes Católicos, hubiese tratado jamás de hacer prevalecer sus providencias a las que Dios había declarado en contrario tan manifiestamente. 
Si bien me persuado que no se puso en ejecución la citada Cédlula de 1632, así por lo que insinua un pasaje del Padre Avendaño ${ }^{s}$ como porque Escalona nada dice acerca de su cumplimiento, habiundo escrito su obra el año de 1646, catorce años después de haberse librado aquel Real Rescripto.

Ultimamente se mandó renovar por el artículo ciento treinta y siete de la Real Ordenanza de Intendentes la Ley establecida sobre el Estanco de Sal; y aunque en consideración de lo que se informó a Su Magestad, se mandó por la declaración trece de la citada ordenanza que por ahora no se pusiera en práctica lo dispuesto acerca de la Renta de Salinas, por el referido artículo ciento treinta y siete. Pero al mismo tiempo se encarga a los Intendentes que con el mayor cuidado examinen este punto informando de las resultas.

En lo poco que yo entiendo nunca daria dictamen para que se verifique el estanco de sal; porque si las minas de metales preciosos perteneciesen al Rey ya no se administrarian ui arrendarian en ninguna parte del Reino, por el poquísímo provecho que de ello se saca, mucho menos producirían las salinas, principalmente no encontrándose quien quiera administrarlas, como se representó desde el siglo pasado según lo refiere nuestro Solórzano.

Sin embargo es justo y no descubro inconveniente en que aquellos que trabajan minas de sal, ya sean indios, ya españoles, contribuyan a la Real Hacienda con un derecho moderado de Licencias con arreglo al expresado artículo ciento treinta y siete y aun también con el Diezmo, por ser éste un derecho legítimamente introducido en todos los minerales por reconocimiento del Supremo dominio del Gobierno.

En cuanto al salitre que es el material de que se hace la pólvora, se ballan expedidas varias providencias antiguas que refiere Escalona, ${ }^{9}$ para que reconociéndose si le hay en el Perú, se manden muestras a España y se incorporen a la Corona. Las porciones de pólvora que benefician los indios para el consumo de sus fiestas, son la mejor prueba de haber salitre en abundancia y de buena calidad, pero la libertad coni que sc emplean los indios a la fabricación de pólvora, tambièn es un argumento claro, de que no se ha cuidado de este punto.

El artículo ciento cuarenta de la nueva Ordenanza, recordó la importancia de esta materia, mandando estancar la pólvora, y si bien la declaración trece, de la expresada ordenanza, dispuso que por ahora no se pusiese en práctica aquella Providencia, encar'ga al mismo tiempo, que los Intendentes dediquen con especialidad toda su atención a que los particulares no fabriquen pólvora, como antes, contra las regalías de la Corona y seguridad de estos Dominios.

Según la abundancia que hay de salitre y azufre en tocla esta Provincia, con especialidad en el Partido de Lípez, no contemplo fácil poder embarazar la fábrica de pólvora, ni parece conveniente a la primera vista, considerando que una gran parte de los indios de Lipez se mantiene con los productos de la pólvora, que benefician en el pueblo de San Juan anexo de San Cristóbal, y en un paraje nombrado Calcha, supliendo con este ramo de industria. los efectos de la agricultura, de que carece aquel terreno por la calidad de su temperamento.

De Lipez se surten los minerales de Chichas, Porco, Guantajaia y Tarapacá, de toda la pólvora necesaria para los barrenos y demás traba- 
jos de las minas, a un precio tan bajo que la libra sólo cuesta un real. Ia más inferior de España no se puede vender por acá a menos de cinco reales libra, con exceso de un cuatrocientos por ciento al valor común de la pólvora de la tier'ra. Esto ya se ve es muy ventajoso para nuestra minería, principalmente para la saca de los metales de poca ley, pues cuando bajan los costos otro tanto sube el provecho de la mina.

Sin embargo, haciéndose por acá el mayor consumo de la pólvora por los mismos indios en cohetes y en otros fuegos artificiales (en que estos indelices han puesto todo su embeleso) no hay duda que se evitaría la mitad de las cantidades que se fabrican en el dia, prohibiendo con rigor el uso de cohetes, como se ordenó en Real Cédula de 1779 , porque entonces bajando el consumo se minoraría a proporción el trabajo de esta especie.

Para que sea menos abusiva la libertad con que ahora se fabrica la pólvora, sería conveniente que en los mismos lugares donde se beneficia se tomase toda por cuenta del Banco de Rescates, para repartirla entre los demás auxilios a los mineros de la Provincia, que con este arbitrio se recogería ${ }^{10}$ suavemente de poder de los indios toda la pólvora que huvieren fabricado con arreglo a la Ley 9 , título 5 ", libro $3^{9}$ de Indias, y al mismo ticmpo se facilitaría su venta sin necesidad de que salgan de sus pueblos, en solicitud de los compradores con riesgo de desertar para siempre.

Contribuiría mucho hacer guardar la Ley 11 del citado título y libro, prohibiendo fabricar pólvora sin expresa licencia del Gobierno e intervención del Juez Subdelcgado del Partido, porque con esta cautela sexían conocidos los que se cmpleasen en este trabajo, para recoger de su poder las cantidades que hubiesen beneficiado; $y$ siempre que fuesen preferidos en la compra los que tuviesen licencia y decomisados los que trabajasen sin ella. Los mismos indios se denunciarían unos a otros por el interés de la parte que se les aplicase, y de este modo cuando no se extinguiese, se llegaría a metodizar la fábrica de pólvora, especialmente si también se prohibra sacar salitre ${ }^{11}$ y azufre sin licencia del Juez de la Provincia.

El azogue es un magistral tan preciso para el beneficio de los metales, que si faltara este ingrediente se acabaría también la saca de platas en Ia mayor parte del Reyno, a excepción de tal o cual mineral donde se encuentran metales de fundición.

En atención a la necesidad de su uso se permitió por las Leyes y Ordenanzas del Reyno, que dejamos referido en otro lugar ${ }^{12}$ que se pudiesen buscar y trabajar minas de azogue.

Sin embargo se expidieron diferentes ordenes para que no sc permitiese trabajar tales minas en el Perú, ni en México, sin expresa orden del Rey.

En conformidad de estas providencias el Excelentísimo Señor Virrey de Lima, Conde de Superunda, por carta de 8 de julio de 1753, prohibió absolutamente que aun se tratase del arbitrio de trabajar minas de azogue que el Gobernador Don Ventura Santelices, propuso como inmediatas a la Villa de Potosí, para que de este modo no se facilitase el comercio de este ingrediente en perjuicio de los Reales Quintos.

Posteriormente por el artículo 22 , título 6 de las Ordenanzas formadas para la dirección y gobierno de la minería de Nueva España, en 
22 de mayo de 1783 , se concedió la Sacultad libre de deserbyrir y denumciar minas de azogue, bajo la calidad de dar cuenta al Virley y Superintendente Subdelegacto, para que acuerden si convendía cue el descubridor las trabaje de su cuenta entregando on los almacines el azogue que beneficiare, o más biél de cuenta dol Rey, abonántosele algún premio equitativo.

Con lReal Orden de este año de 1786, se mandaron pasar a los Virreinatos de Lima y Buenos Aires, las mismis Ordenamals para que se pusieran en práctica; con lo que se ha renovado la Oriteranza 17, título 19 , hibro $3^{\circ}$ del Perú, que permite descubrimiento de minas de azogue, y ya no hay inconveniente para trabajarlas con el temperamento $y$ calidades nuevamente prescriptas en el artículo 22 citado, título $6^{\circ}$, de las Ordenazas de México. ${ }^{13}$

El que tuviere conocimiento de estos paises, sólo por relaciones, creerá desde luego que en el Reino no ha muchos minerales de azogue, dando asenso a Don Alonso de Barba ${ }^{14}$ que asegura en su Arte de Metales, que la tierra de Potosí es fertilísima de azogue.

Aun los moradores de Potosí, están persuadidos de esto mismo por la tradición de que en años pasados se sacaba azogue en estos contornos. Esto dio mérito el año de 1785 , a tres vecinos de la Villa, para denunciar con poca reflexión una mina de azogue que dijeron haber descubierto en las Pampas que llaman de San Clemente, al Ponicnte de Potosí; pero al cabo vino a quedar el asunto en meras diligencias, sin suceso, conociendo su engaño los mismos interesados; porque en realidad aquel poco de cinabrio que ballaron en su falso descubrimiento no fue otra cosa que haberse encontrado por casualidad el vapor mercurial con el rapor sulfuroso, que penetrando juntos la piedra fomaron aquel cinabrio descarriado, sin fundamento alguno para esperar desenbrimichto de minas.

Con todo, como a ser posible, también es probable que hayan algunos minerales do azogue en miestra Provincia, según la relación del citado Barba, respecto que la fe que él se merece, no debe suponerse desmentida, sino más bicn oscurecida con la multitud de años que regularmentc borran las noticias más seguras; no hay razón para desalentar el descubrimiento de otros minerales fuela rel de Guancavelica, pucs ni la naturaleza agotó allí sus producciones ni puede excusarse de atrevimiento el que negare, como falsa la noticia, que repite Barba en otro lugar ${ }^{15}$ de habcrse traido ricas piedras de azogue de Guarina y Moromoro, pero que no se logró su beneficio, por la muerte violenta y sospechosa de quien trataba de descubrir la mina, que ha quedado oculta hasta ahora.

Si acaso Dios ha reservado para nuestros tiempos el feliz momento de desenterrar estas riquezas, me parece conveniente destcriar una preocupación de que están poseídos los más acerca de los daños que causa el trabajo de las minas de azoguc, para que desengañándose nuestros cilldadanos de esta falsa opmión, se emplcen sin miedo en las empresas de semejantes descubrimientos y labores.

Al temor vulgarizado entre el común de las gentos añadió nueva fuerza el venerable testimonio de nuestro político D. Juan de Solórzano, ia acerca de las graves enfermedades que produce el azogue. Asegura este sabio Ministro, haber visto padecer nenosas dolencias a los trabajadores en las minas de Guancavelica, siondo Visitador y Gobernador de aquella Villa, desde el año de 1616 hasta 1619. Testifica que el polvillo hace 
grande estrago en los que las cavan, y que el who penetra en breve tiempo lasta las medulas de los que le cuecen y benefician, y debilitando todos los mienbros, causa perpetuo temblor en ellos, siendo pocos los que dejan de morir (por más robustos que sean) al cabo de cuatro años, según Mafiolo Plinio y otros que él cita.

Bien se ve que muestro político siguió aquelia opinión de los antiguos, que atribiatin al mereurio la virtud mortíferd del veneno, y al mismo tiempo lo obligó su buen corazón a prostar un asenso pío a las ficciones de los fol"zados y demás trabajadores de Guancavelica.

No fue irlegular su credulidad porque hallo autorizada por los romanos y por los moros la preocupación de que el mercurio era vereno.

Así lo creyeron los iomanos y por eso sólo usaban del cinabrio las matronas, para afeitarse los rostros, $y$ los pintores para sus dibujos. Custodiaron según Plinio, con tanto cuidado la mina del Almaden contra los riesgos de su melcurio, que la cerraban y sellaban con la mayor diligencia, y solamente se abria para sacar la cantidad de cinabrio que se habia de envial a Roma, cada año. Ios moros poseídos de las mismas ideas, dejaroi sin trabajo ni cultivo, aguella célebre mina en todo el tiempo de su dominatción en España.

Poro verdaderamerite no son sino preocupación todos estos recelos. El célebro Don Gulle!mo I3owles en st IIstoria Natural de España, prueba con observaciones lisicas irreprochables la vulgaridad de esta opihión. Asegura ${ }^{17}$ que vio naeer las plantas comunes, erecer, florecer y granar, dentro del recinto de los doce horlus y de sus canales, cn que se cuece la mina para extraer el mercurio.

Sobre esta observación argumenta que, si el mercurio exhalara los vapores vonenosos que se cree, dañalian a la vejetación y a los hombres. Io contrarjo enseña la experiencia; pues, un minero duerme con seguridad sobre una veta de cinabrio, $y$ los forzados que allí trabajan, gozan de perfectísima salud; aunque por una infundada compasión, se cree que su pena es intolorable por las ficciones que ellos hacen, cuando no trabajan más que tres horas al día y le cuesta al Rey ocho reales diarios.

La iglesia y una gran parte del Almaden (que tiene más de trescientas casas) estál sobre el cinabrio, y sus habitantes todos subsisten de los provechos de la mina sin perjuieio de la salud. I-Issta aquí el citado Bowles. No podía citarse otra autoridad más acomodada al intento, ni más respetable por los gr'andes créditos de este célebre físico. Sus pruebas no son testimonio de relación agena, sino observaciones de experiencia propia. Esto basta para persuadir a nuestros ciudadanos, que no trae ningún riesgo el trabajo de las minas de azogue, a fin de que no teman ocuparse en estas empresas, con perjuicio de sus provechos particulares $\mathrm{y}$ del interós público.

Visiblemente malogramos nuestras producciones por el atraso de las Artes. Hemos visto que en Atacama tenemos el célebre mineral de Conchi, y en Lípez el de Escapa; uno y otro de cobre superior al de Chile, pero como no hay artesanos que con nueva forma hagan apreciable y preciosa esta materia, pocos son los que se dedican al trabajo de aquellas minas, y apenas se saca el necesario para granalla de las mezclas o ligaciones en esta Real Casa de Moneda, y para cedazos y almadanetas de los ingenios.

De las ciudades de Copiapó y Coquimbo del Reino de Chile, confi- 
nante con Atacama, a menor distancia de cien leguas, pudieran pasar a los partidos de Lípez y Atacana algunos de los muchos artesanos que trabajan en cobre en aquelios dos minerales, con el notorio provecho que acredita el gran comercio quo hacen los chilenos con las pailas, tachos, calderos y otras obras y utensilios de cobre, que sacan para abasto de las provincias del Río de la Plata y de las del Reino del Perú.

Estableciéndose en nuestros Partidos algunos operarios de cobre trabajarían con ventajoso provecho suyo y con utilidad pública las obras y utensilios que ahora nos traen a vender los chilenos desde tan lejos, con la necesidad de sacar los salarios debidos at to to agente de comercio con más los costos de acarreo.

Después de proveernos de las obras necusarias por un tercio menos de valor que ahora, se promoveria con calor el trabajo de nuestras minas de cobre, se aumentaría la saca de metales, y creciendo a proporción la abundancia de cobre, se entablaría oste nuevo ramo de comercio (de que en el día carecemos) con las provincias del Río de la Plata y con otras del Reino del Perú.

En este feliz periodo siempre sería méls dichoso y lucrativo nuestro comercio, porque se harían las conducciones con más brevedad y a menos costo por la provincia de Salta, sin las interrupciones que suspen-. den ei trajín de Chile, por el invencible obstáculo de su cordillera.

Lo mismo sucedería con los operarios de bayetas y pañetes de la tierra, pues, no careciendo nuestra Provincia de abundancia de lanas ni de aguas para los batanes, a poco tiempo se podrian fomentar muchas fá bricas de esta ropa, con que nos surtiríamos sin la necesidad de comprar la del Cuzco, al precio que quieren ponerle los comisionados de este comercio; y por la mayor inmediación en que se halla esta Villa con las provincias de Charcas, Salta, Tucumán y Buenos Aires, sería mucho más fácil y pronto y menos costoso el acarreo de nuestras ropas, y por esta causa sería más difícil que purliesen sufrir su coneurrencia las ropas del Cuzco.

Los plateros trabajarían obras de gusto, y reduciéndose en vajilla mucha parte de la plata que se extrae sin labrar, se aumentaría notablemente la circulación interior de nuestra Frovincia, con el acrecentamiento del diner'o de los salarios.

Aun los zapateros pudieran hacer grandes negocios, pues, trabajándose en el Partido de Chichas, abundancia de cordobanes, que son la materia primera de la zapateria, pudieran sus profesores hacer fácilmente grandes empresas a muy poco costo, con remitirse cantidades de esta manufactura a las Provincias vecinas, donde no se trabajan cordobanes; porque añadiéndose a la mano de obra el precio de la materia y el costo de su acarreo, siempre sería ventajosa su venta para nuestro comercio aun en concurrencia de los demás vendedor's.

Mucho mayor y más Iucrativo podía ser el comercio de los sombreros de vicuña, si esta profesión fuese protegida hasta llegarse a perfeccionar, por la grande abundancia que hay de lana de vicuña en todos los Partidos de esta Província, con especialidad en Porco, Lípez y Atacama.

Se fabrican excelentes sombreros por unos pocos artesanos, pobrísimos y drogueros que hay en la Villa, y apenas acaban la obra cuando se les arrebata de las manos por una infinidad de compradores. Una vez 
que hay lanas sobrantes, sólo falta aplicación e industria en los sombrereros, y sjempre que este arte llegase a tener algín progreso mediano, sería éste un ramo nuevo y muy pingüe para nuestro comercio; pues, comprándose aquí cada sombrero fino, blanco o negro, a tres y cuatro pesos, ningún mereader potílía tener quiebra en su negociación en concurrencia de los que traen de Europa.

En cl Partido de Tarija se fabrican ponchos tan superiores, que a más de scr muy finos y de bucn gusto por su bella vista y color, son de tan excelente tejiłlo, que tienen la minna jesistencia que el barragán para el agua. Esta última calidad no tienesu los ponchos de Santiago del Estoro, de Córdoba, del Tucumán y de otras partes del Reino. Por lo mismo es indisponsable su preferencia y también la tendría su comercio, si se entablasen fábricas formales que pudiesen producir manufacturas sobrantes.

Por este: mismo tenor se podían mejorar las demás profesiones, supuesto que nuestro suelo feliz por su fertilidad, es capaz de producir todas las materias necesarias a las artes. Pero debe procurarse un conocimiento profundo y bien experimentado de la fertilidad de estos terrenos, para plomover las puoducciones naturales y acalorar después el genio de estas yentes para su aplicación al las artes ${ }^{18}$ que es el único medio para dar impulso a nuestro comercio.

El Reino de Chile saca grandes ganancias del cáñamo, que cuitiva para jarcia cle las embarcacionos que trafican los puertos de la Mar del Sur; y siendo el ter'eno de Atacama muy apropiado para esta siembra, también sería fácil añatiir a nuestro comercio este nuevo ramo, con ventaja muy grande de los que se empleasen en su siembra, cultivo y beneficio, con arreglo al artículo 57 de la nueva Ordenanza. El terreno de Atacama es uno mismo con el de Chile, por ser una misma la costa que une aquel Reino con el del Perú, y es preciso que haya igualdad en las producciones. No sería dificil traer de allí algún beneficiador que enseñase el aparejo dol cánamo, y dándose con buen suceso este paso, no necesitaba más para hacerse rico el Partico de Atacama, y el público también recibiría gran beneficio porque concurriendo a un propio tiempo nuestra jarcia con la de Chile, forzosamente bajaria su precio en provecho de la navegación.

\section{A R T I C U L O SEGU N D O}

\section{$\mathbf{E}$} N la Descripción de la Villa de Potosi y de sus alrededores, hice relación menuda de su asqueroso aspecto por los muchos muladares que la rodean, además de los que ocupan sus principales sitios con elevación sobre la altura de los edificios; allí propuse el medio de purgar estas inmundicias con mucho provecho del bien particular y público.

La suciedad de las calles y sus continuos pantanos, así por las reventazones de las acequias subter'úneas como por los orines de los indios debía ser un objeto proferente para nuestra Policía. Bastante afea este desaseo en el citado fugar y apunté algunos arbitrios para mejorar nuestra población. Si los Comisarios de Cuarteles son celosos y el Magistrado no descuida en promoverlos, no es difícil lograr la limpieza de que carecemos, con tanto riesgo do la salud pública por la impureza del aire de 
la atmósfera que rospiramos.

El año de 1785 mandé en Jeté esta Villa por el término de dos meses en ausencia del Intendente, y sin otra costa más que mis buenas palabras con los Comisarios, que nombré para el efecto, conseguí que se limpiasen las calles principales $y$ que se refeccionase el empedrado de algunas. Aplicanto la atención a este objeto sobre cada vecino para que a la semana limpie, barra y purifique la pertenencia de su casa, es seguro que acostumbrados a este aseo costaría después muy poco trabajo el mantener la limpieza.

No necesita encarecerse la importancia de este asunto porque con sólo poner la vista sobre cualquiera barrio de la Villa se ve su inmundicia y excita el cuidado de remediarlo.

Con todo, creo que debo repetir mis insinuaciones acerca do una calle llamada de las Siete Vueltas. Este cs un tránsito de travesía que corre Norte Sur, media cuadra hacia el Este desde la iglesia de San Agustin; sus entradas son angostas y en lo interior es como un laberinto; porque torciendo la dirección de la calle a todos rumbos son tantos los cuartitos, las puertas, los callejones y tropiezos que se ol'recen dentro de ella, que puesto alli un forastero difícilmente acertará a salir.

Es tal la inmundicia que nadie puede pasar sin taparse las narices y embarrarse los pies. Por lo mismo es el asilo de las mujeres mundanas más perdidas, porque aun los juoces rehtran internarse a deshoras de la noche a semejante pestilencia.

Todo esto clama por el entredicho de tal calle y desde luego, tapándose las entradas del Norte y Sur, queda una salida oportuma hacia el Poniente a la calle trasera de San Agustín. Entonces se minorarían tantas maldades como allí se hacen; se limpiaría la calle y la Justicia aprehendería con seguridad a los rufianes y malvados que por aquelia sola puerta entrasen a distraerse, respecto a que no es calle do comcrcio, ni vive, ni puede vivir en ella otra gente que no sea de lupanar.

Los reparos de empedrados, cañerías, pilas, puentes y caminos, son el objeto más recomendable de la Policía, porque además de decorar los pueblos es un testimonio de su civilidad. Nuestra Villa es la que mús necesita de esta atención, por lo que expusimos en su descripción histórica. No hay duda que sería la más bien reparada si los subalternos encargados en tales refeccienes cuidaran con celo de la buena distribución de las cantidades aplicadas a este fin, que se reducen a la situación siguiente sobre el Ramo de Sisa:

Para gastos extraordinarios de refecciones de las posesiones de Cabildo, Casas Capitulares, Cárcel, Pila de San Roque y otros gastos menudos ...................

Para las cañerías $\ldots \ldots \ldots \ldots \ldots \ldots \ldots \ldots$
Al Mayordomo que las tiene a su cargo $\ldots \ldots \ldots \ldots \ldots \ldots$

Para reparos y composición de los puentes y caminos de la

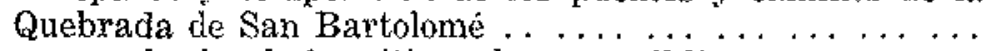

Para empedrados de los sitios y lugares públicos .........."

Para refección de la Casa Pretorial $\ldots \ldots \ldots \ldots \ldots \ldots$

\begin{tabular}{ll}
$\$$ & $600 .--$ \\
$"$ & $300 .-$ \\
& $150 .-$ \\
$"$ & $300 .-$ \\
$"$ & $200 .-$ \\
\hline & $300 .-$ \\
\hline$\$$ & $1.850 .-$ \\
\hline
\end{tabular}


Aunque es cierto que las referidas consignaciones se deben gastar cn el respectivo objeto de su aplicación, sin invertir los gastos de un destino en otro, según lo dispuesto acerca de los ramos de Real Hacienda, ha demostrado la experiencia que el público se halla muy mal servido, principalmente en las cañerías y empedrados, no tanto porque dejen de alcanzar sus consignaciones como porque se hace la distribución sin la debida economía.

El Mayordomo de Cañerías tira el salario de ciento cincuenta pesos, sin qute veomos mejoradas las pilas, ni reparados muchos caños rotos; desquita y tal vez alcanza la situación de su cargo; porque no se cumple el artículo dol Reglamento de Propios ${ }^{19}$ scgún su espiritu.

La inver'sión de estos gastos está mandado que ha de correr por el Juez de Aguas, con intorvención del Procurador General y por una inteligencia material se despachan las memorias del Mayordomo sin previo reconocimiento y examen de las obras, que supone haber hecho o reparado. Ls constante $t$ l poco colo, con que proceden, con todo ser asunto que pide mayor cuidado.

Fl remedio único que yo medito es rematar por asiento anualmente, o por mís tiempo, estas relecciones; pucs a nuis de ahorrarse el salario del Mayordomo, tendria buen cuidado el Asentista de calificar al cabo de seis meses los reparos y mejoras de su cargo, para merecer el despacho de sus libranzas. Ya consignación para Cañerías y empedrados junto con el salario del Mayordomo, importa 650 pesos. Cualquiera se hará cargo do cstas incumbencias por igual cantidad y será más útil al público, porque los que debieren celarlo, como que ya no tienen interés, no mirarán el particular del Asentista. Subre todo las condiciones del contrato pueden asegurar un notable bencficio al vecindario, $y$ entonces se conseguirá beber agua limpia, que tanto importa a la salud pública; se purgarán los sitios comumales de pantanos e inmundicias, por medio clel empedrado, y cl mismo Asentista cuidará de que se refectionen las pertenencias de los vecinos y de erigirles por cuenta justificada los gastos que hicicren, sin necesidad de intervenir la multiplicidad de manos que ahora entorpecen el asmnto por descuidar su obligación los unos en los otros.

Es regular que exceda mucha parte de los mil doscientos pesos restantes de la consignación para reparos de caminos, puentes, cércel y posesiones de la Villa; porque no son tan continuas y necesarias las ruinas, que convenga hacer anuales dispendios. Al menos yo no he visto en cincó años que estoy en la Villa, habcrse empedrado ningún lugar público, incluyendo la plaza principal, ni que hayan necesitado refección los puentes y caminos de la Quebrada de San Bartolomé, ni tampoco las casas capitulares.

Pero es preciso que el tiempo las vaya arruinando insensiblemente y tal vez aumenten las ruinas de golpe, de forma que se necesiten considerables gastos para su reparo. Para este caso (que a más de posible es de indefectible suceso), se deben retener en la Casa las consignaciones sobrantes, sin confundirlas con el residuo líquido que debe quedar libre de las cargas públicas, conforme al Reglamento; porque de lo contrario sería menester solicitar permiso de la Real Audiencia del Distrito, con las justificaciones prevonidas en los artículos 28 y 62 de la Real Ordenanza, para poder librar en los Propios, según la orden novísima de 
14 de septiembre de 1788 . Ello es constante que, aunque en uno o en otro año, no se consuman las dotaciones asignadas para gastos precisos, extraordinarios $y$ eventuales, es casi seguro que al cabo de años se verificará el suceso, de que se necesite aun más de lo que ahora sobra. Esto no puede llamarse sobrante rigurosamente sino un residuo eventual que pormitc la ocasión variable del tiempo; por lo mismo se debe mantener sin incorporar a los caudales libres que se introducen a lit Tesorería, con el destino que prescribe el artículo 41 de la mena Ordenanza.

Y para que los dispendios se ejecuten con equidad y economía, debe representar el Síndico Procuradox do la Villa las obras o reparos que fucre necesario hacerse, a fin de nombrarse alarifes (a falta de ingenieros o arquitectos asalariados del público) para la visita, examen y reconocimiento de las ruinas que se van a releccionar, con la prevención de que informen expresando la calidad y cantidad de ellas, con exacta regulación de su coste, para despachar la libranza conforme a lo dispuesto para caso equivalente en el articulo 266 , de la citada Ordenanza. Pero, para mayor justificación de estos gastos, sexá conveniente que los reconocimientos se practiquen con asistencia de un indiriduo del Cabildo que represente al común.

Descontindo de los siete mil pesos en que se halla arrendado el Ramo de Sisa, así los mil ochocientos cincuenta pesos refexidos como también los mil pesos del salaicio del Teniente, y trescientos cincuenta pesos más para portes de cartas, que dan tres mil doscientos pesos para reparos ordinarjos y eventuales de las lagunas. Algo dije en otro lugar acerca de este asunto; su importancia debe ser toda la atención del Gobiemo, y es preciso inculear algo más.

En las memorias semanales que presenta el Lagunero Mayor, no apean los gastos de sesenta pesos, incluso su salario y el de su Teniente, que importan treinta pesos; al respecto de diez y seis pesos el primero y de catorce pesos el segundo. Los treinta pesos restantes se mandan pagar siempre por un decreto de Cajón con la calidad de verificar el pago con intervención del Procurador de la Villa.

Como ignora la justificación de los dispendios y viniendo jurados, sería cobrarse un enemigo con su oposición o adquirir muchos malos ratos sin provecho; jamás adiciona partida, ni se inmiscuye en pedir comprobantes, porque su intervención se ha creido reducida al preciso acto de la paga, para evitar el perjuicio de los jornaleros.

Lo cierto es que éstos son necesarios solamente para abrir y ccrrar las compuertas de las Lagunas; cuya operación se ejecuta el sábado por la noche y a la madrugada del domingo siguiente, (que es el único día de la semana en que no muelen los ingenios) o cuando se pasa de una laguna a otra el turno del agua. No entiendo para qué efecto se pagan seis y ocho peones semanalmente; porque uno solo de día y otro de noche, es suficiente para estar al cuidado de la Laguna de donde so surtierc la Ribera; principalmente si se atiende a que el Lagunero y su segundo tienen obligación de visitarias diariamente.

Si no es honrado el Lagunero, puede cometer muchos fraudes en estos jornales y más en otros gastos extraordinarios de cal, herramientas y demás menudencias. No hay otro medio de evitarlos como el que presente las memorias intervenidas por los Diputados de la Azoguería; pues como personeros del gremio e instruídos en materia de lagunas, no pasa- 
rán partidas inútiles y con esta cautela reducirćn los dispendios al salario de los lagumeros y al jornal de dos peones. Y cuando convenga hacer alguna obra presenciarán la regulación de su costo, y concurriendo en la compra do matcriales cesará todo engaño y se ahorrará la mitad que ahor't se gasla de mís, de suerte que de los tres mil ciento veinte pesos que montan al año las memorias scmanales a razón de sesenta pesos cada una, quedarán sobrantes mil quinientos sesenta pesos, para emprender la limpia sucesiva de una o dos lagunas anulalmente, en el método que advertimos tratando del asunto.

Entonces veríamos a estos grandes vasos recobrar su primitiva capacidad (ocupara ahora más de arenas que de agua) en estado de surtir la Villa y su Ribura, par'a dos añes y tal vez para más, aunque no lloviese on cllos. Plles se sabe que antiguamente molían cien ingenios con sólo ol agua de lat laguna de? Chalviri; y siendo en el día mucho menor el númoro de ellos y sobre diez y siete las lagunas que se han aumentado, puedo ascgurar que he andarlo escaso en mi cúmputo del agua.

Sin las limpias jamás saldremos de afliccion; porque el medio que algumos proponen do suspender los tajamares dos o tres varas de elevación sobre su altura actual, no es capaz de preveriir la escascz que padecemos continuariente por ser constante que las mismas arenas que se fueren depositando al cabo de seis u ocho años, ocuparán tanto fondo cuanto se hubiese tevado la superficie de la laguna y vendremos a parar en el mismo caso o a intentar la ridiculeza de poner pared sobre paredes hasta igualar la cumbre de los cerros; pero entonces nos quedaríamos sin lagunas porque el aimento de las ticrras y pantanos embarazarían el declive de lis corrientes y lienarían los huecos que ahora ocupa el agua.

En Huesca hay lagunas que allí liaman Pantanos y jamás han pretencido suspender las murallas; pero tienen grande cuidado en limpiarlas cada dos años. Excelente modelo para nuestra Policía, y si acaso no lo practicamos, floraremos sicmpre, la desgraaja de ver que la mitad de las lluvias se reune en el suelo fangoso de las lagunas, minorándose y consumiendose después con los soles el resto de las aguas; sin que logremos su provecho por más de un año, aun en el más abundante y lluvioso.

Reducidas las lagunas a su fondo natural por medio de las limpias bienales, se podría calcular a punto fijo la porción de agua de cada una y el tiempo de su duración en surtir la Ribera de los ingenios y las pilas de la Villa; para que con este conocimiento pueda tomar el Magistrado de Policía, providencias anticipadas al fin del mes de marzo, en que cesan las liuvias, para economizar con provecho el consumo de las aguas, evitando los perjuicios que suire el público y la Real Hacienda, parando la Ribera, aunque sea sólo por una semana en ol año, respecto de perderse entonces treinta mil posos a que sube el rescate semanal del Banco.

Así como sc ha establecido la medida de los pies cúbicos de agua, que cala una nave, para conocer a primera vista el número de sus toneladas o quintales de carga y saber a punto fijo el peso que puede recibir en si buque, quedando navegable, para no exponerlo al riesgo de sumergirse, del mismo modo se debería marcar a la parte interior de las compuertas de las Lagunas, con distinción de meses y semanas la duración de cada vaso, para determinar con certeza el tiempo que tendriamos de agua; y no que ahora se hacen estos cálculos a ojo de buen cubero, según la fan- 
tasía de los Laguneros, con el mal suceso de hallarnos muchas veces repentinamente en estado de parar la Ribera, o de escasear las pilas con unos ahorros odiosos al público, cuando se contaba con agua para muchos meses.

Un año de observación basta para marcar estas medidas en todas nuestras Lagunas, por una operación muy scncilla. Scgún se fuese vaciando una Laguna que esté llena de agua, se debe ir marcando al borde de la pared de la compuerta el consumo de cada semana, hasta acabarla de evacuar. Computando las semanas se van marcando los meses, con números que concursando por la unilad suban hasta la superficic del agua; de suerte que, según esta distinción, se podrá conocer a la vista, para cuálltos meses y semanas tiene cada Laguna.

Sin practicar estas mensuras no ('s posible cómputo alguno evidente, ni es verificable poner tales marcas sin las limpias, porque el insensible aumento de las arenas va robando el ligar a las aguas y desmiente fa cuenta de su duración.

Esta práctica es muy fácil como ya hemos visto, y también es muy conveniente; porque en una visita de lagunas que se haga a fin de marzo o principio de abril de cada año, sabe el Superintendente, sin temor de engaño, los meses que puede moler la Ribera, para economizar el consumo oportunamente o mostrarse liberal en el despacho del agua.

De propósito me he detenido en este punto, porque su imponderable importancia exige toda la atención pública. Sin Lagunas no tenomos agua para beber; sin Lagumas no se pueden moler los metales que se sacan de este Cerro Rico; sin estas moliendas no se puede beneficiar la plata; $\mathrm{y}$ sin la plata no hay rescate, no hay labor de moneda, no hay quintos, no hay comercio, ni hay de qué subsistir, por ser la úniea producción de este país. Considerese cuantas cosas justas dependen del buen manejo de nuestras Lagunas y se verá, desde luego, que es el asunto en que esta Intendencia debe interesar más su celo.

Después de esto debe mirarse como objeto muy principal la decoración del aspecto de la Villa, valiénclose el Intendente de las providencias que preseribe el articulo 64 de la Ordenanza para mejorar sus edificios y evitar las ruinas que desfiguran su ornato y arriesgan el tráfico económico del vecindario. Como fue tan numerosa esta población a principios del siglo pasado, con la circunstancia de ser indios los más de sus habitantes, sucede ahora que con Ia decadencia del mineral y minoración de la mita, apenas ha quedado reducida a una sexta partc del número de sus antiguos pobladores. Ios sitios que ocuparon los indios mitarios y los demás vecinos que se ausentaron, o no dejaron familia, o la dejaron tan pobre, que no tiene poder para nada; se hallan desiertos y valdíos los unos; y Ios otros en paredes yermas y ruinosas que sólo sirven para recordar la memoria triste de lo que fue esta poderosa Villa.

Son lugares de inmundicia y asilos asquerosos, para el libertinaje. No se cuida de su reparación porque no hay con que hacerlas o no se conoce su dueño. Mejor sería despojax estos solareb y señalarlos por vacantes a los que quisieren edificar en ellos; y cuando ésto no se lograse sé conseguía el intento de destruír estos monumentos miserables de nuestra decadencia $y$ en ellos la inmundicia y el refugio de haraganes, de borrachos, de mujeres perdidas y de ladronzuelos perjudiciales.

Aun las iglesias están en igual caso. Pocos años hace, que por el 
procurador de la Villa so representó el estado ruinoso de San Agustín; se mandó practicar reconociniento $\mathrm{y}$ se oudenó st reparación bajo el apercibimiento de mandarla hacer a costa de las lentas del Convento. Como son comunidales exertas toca al Gobiemo la ejecución de tales providencias según l'erejer "o y asi cleberá aplicarse el celo píblico en semejantes circunstancias, sin olvidar la cautela de que se desaloje el barrio o calle de la iglesia ruinosa, cuando fucje próximo el riesgo de su despoblación o caída $y$ no haya arbitrios para precaverla, sin incomodidad del vecindario.

La misma cantidad de los habilantes es causa de hallarse todavía en lo interiox de la población muchas casas techadas de paja, las que además de desfigurir el ornato publico, pueden ser la raíz de nuestra ruina en la ocasión de algún incendio may posible con la multitud de cohetes y otrus fuegos de pólvora, que se continúan usando en esta Villa, sin embargo de la prohibición general que ha vedado en las demás partes del Rcino, este género de entretenimiento. Si no se toma providencia para techarlas de teja 0 no se pone on observancia la orden prohibitiva de cohetes, será sicmpre esta Villa un pueblo ridículo y cuando menos se piense lloraremos wia desgracia irreparable tal vez para siempre.

Los caminos por donde se sale de la Villa, se han mejorado infinito, mediante el colo del actual Gobicrno, pero es tan corta la estación de cada uno que ol más largo no pasa de una legua. Ia carrera de Buenos Aires elá la que necesitaba más reparos por ser la más trajinada e incómoda, por uncl infinidad de picdras guandes y pequeñas, que embarazaban el camino desde el Socavón hasta el parajo de Tabaco-ñño, de tal manera que apresuxéndose la murcha apenas se avanzaba media legua en una hora de tiempo. Hace pocos meses quo se limpió para el tránsito del actual Virrey. Muy facilmente se puede decorar este camino, habilitando una catrera espaciosa con sus calzadas de piedras sobrepuestas a los costados para comodidad de los comerciantes de Buenos Aires y de los indios labradores, que nos proveen de abastos, de leña y de carbón. El medio es restinar a este trabajo los innumerables indios haraganes de las Parroquias que vemos diariamente disipatse en borracheras y bailes por los cantos de la Villa, obligando a los Alcakles y principales de ellos, a que presenten lista de todos los que no fueren artesanos o no tuvieren empleo industrioso conocido de que subsistir, para el fin de distribuir las faenas de la limpia de caminos en las cinco leguas que esta Villa tiene de jurisdicción, por todos sus alrededores.

El proyecto tendrá mejor expediente si se agregan los descansos de la mita, siquicra una vez en cada semana, y los presos de la cárcel con la ración ordinaria de chicha $y$ molletes. Para los dispendios inexcusables se puede echar mano de los trescientos pesos consignados en la Sisa, para composición de los puentes y caminos de la Quebrada de San Bartolomé; respecto de no necesitar reparos y ser justa la inversión de este catdal en otro destino equivalente; pues el camino del Cuzco, que corre por dicha quebrada, no debe gozar mayor privilegio que el de Buenos Aires y Chuquisaca, como Metrópoli de nuestro Gobierno Universal y de la Justicia.

Si los Intendentes emplearen algún esmero en este recomendable objeto de Policía, no será difícil, que en menos de un año, se vean mejorados nuestros caminos en desagravio del oprobio con que se ha mirado 
en tantos años el Gobierno de la Sierra, por la imponderable inaceión de los Corregidores y demás jefes, que ha tenido el régimen de estas Provincias.

Para excitar en estos nuevos Magistrados el clictado de la limpieza, composición y aderezo de las calles y caminos con la decolación de las tarjetas que prescriben los aitículos 60 y 61 de la nueva ovlenanza, no es menester ponerles a la vista la estrecha obligación en uue los constituye la noble confianza de la autoridad, que ejercen por sus grandes empleos ni presentarles el ejemplo de Apio Claudio, de Jilio César, de Augusto y Cayo Graco, que inmortalizaron sus nombres con he construceión de caminos y piedras miliares en todo el Imperio Ronano, para facilitar el comercio de todas las ciudades dependientes de aquel magnifico Estado, 21

Tampoco juzgo preciso moverlos a la imitación de Tatquino el Antiguo y del Edil Agripol, en las grandes obras que proyectaron de las cloacas, albañales o esclusas, para que por las vertientes de las bóvedas corriesen prontamente al río Tíber, todas las inmundicias de las calles, zanjas y plazas de la ciudad de Roma, porque quiero hacerlos insensibles a la felicidad pública en que vincularon toda su gloria estos dos insignes magistrados romanos; y supongo también indiferentes los sentidos para el mal olor de la inmundicia y de los vapores inficionados de nuestras calles y barrios.

Solamente pretendo inculcar en nuestros gobernadoves una noble emulación a las grandes obras que proyectaron los indios en medio de ser reputados todos ellos unas bestias incapaces hasta del sacramento del bautismo. Sabemos por la historia de Túpac Yupanqui, décimo Inga del Perú, incansable a las fatigas de una conquista dilatada con que extendió su Imperio hacia la parte de Chile y Quito, acabó de formar el buen gobierno del Reino, con el establecimiento de cxcelentes leyes para la Justicia y para la policía. Hizo dos caminos superiores ${ }^{22}$ en fábrijea y magnificencia, a los que más celebró Roma: el nno desde Quito hasta Chile, con más de mil doscientas leguas; el otro en los Llanos, que es una calle entre paredes de tapias con grandes arboledas, regadas por acequias hermosísimas, concluyendo cada jornada en una Casa Real destinada para alojamiento del Inga.

No fue menos admirable ${ }^{23}$ el canino de Ia sieria, fabricado de piedras unidas con betún, pues para igualar el piso se excavaron cerros y se levantaron los valles con mayor pinor que la célebre muralla divisoria de la China con la Tartaria, porque ésta se eleva sobre las montañas y desciende en los precipicios y llanuras.

Era tan grande la exactitud del Gobierno en el cuidado de los caminos, que al onceno mes del Calendario Indiano, llamado Uchpanyzky, que quiere decir barredura o el mes de las escobas entre los mejicanos, barrían y limpiaban todos los caminos reales, calzadas y calles, para facilitar los trajines del comercio y demás objetos del bien común. ${ }^{24}$

Este incomparable aderezo de los caminos conducía igualmente al importante objeto de facilitar la carrera de las postas. Aunque sea verdad que para conducir noticias a la corte, inventó y estableció el Rey Ciro las postas en todo el reino de Persia y los Agganos (que así llamaban a los correos) corrían de día y de noche; ${ }^{25}$ se sabe por la Historia, que para dar prontos avisos de cualquier suceso tenían también establecidas las postas los Emperadores de México y del Perú. En la calrera que habían 
de correx los correos, tenían sus alojamientos y casas a manera de torrecillas lamadas Tethyaloyan (que significa lugar donde se aguarda) y allí había puestos hombres muy lijeros y corredores nombrados Pain, que recibiendo unos de otros, segúu iban llevando la razón del caso, corrían en una hora cuatro o cinco leguas, de suerte que en un día volaba la noticia más de cien leguas, como afirma Toxquemada 20 y se comprueba por el hecho que refiere nuestro célebre historiador Solís. ${ }^{27}$

En el I'eríi también vemos derivado de la admirable lijereza de un comeo, el nombre del célebre pueblo de Tiaguanacu, porque habiendo venido al Inga una posta de hacia las tierras de Quito, con nuevas alegres de victoria, on tan pocos días que un gamo lijerísimo (que llaman guanaco) no pudiera haber andado tantas leguas: admirado cl Inga de la brevedad, lo dijo por honrarle (Tiaguanaco) que significa siéntate guanaco, según Calancha. ${ }^{2 \times}$

Con el mismo fin y con el cle transportar las tropas para propagar sus conquistas, mandó fabricar de bejucos tejidos en trenzas, un puente que todavía dura (aunque reparado) en el gran río Apurímac, el cuarto lnga Mayta-Cápac. Construyó otro en el mismo río el quinto Inga CápacYupanqui, y otro más en el desaguadero de la Laguna de Titicaca, compuesto de paja particular, que se ería en el Pcrú, enea y funcias, habiéndolo pasado antes Mayta-Cápac en balsas, que mandó fabricar, a cuyo modelo son hechas las que ahora se usan paya el mismo tin. ${ }^{29}$

Estas grundes obras tan magnificas como admirables en un gobierno informe y rudo, como el de los indios, deben ser un agudo estímulo para que los Intendentes restablezcan en este tiempo de la dominación más sabia, los caminos, las calzadas y los puentes, que fabricaron los indios en este Imperio contra los embarazos de la barbaridad.

En poco más de quinientos años que duró la Monarquía del Perú, en la sucesión continuada de trece Ingas, concuerdan las historias del Reino, que sc fundaron poblaciones y se establecieron leyes; que los indios a posar de su rudeza y decidia natural, apkendieron a tener religión y culto, se dedicaron a la agricultura, fabricaron puentes, edificaron palacios, construyeron caminos y eternizaron su memoria en muchos monumentos sobre magníficos muy preciosos, que nos llenaron de admiración al ticmpo de la conquista. Ya casi están rayando tres siglos desde que se descubrió este grande Imperio. Siempre han respirado sabiduría y justicia las leyes de su gobiemo, pero on medio de tantos Tribunales, Magistrados y Jefes, que han dominado estas Provincias, las hemos visto correr a su decadencia al mismo paso de su duración: destruídos los caminos, arruinados los puentes y olvidada la agricultura, en oprobio de la reputación de nuestro Gobicrno.

Una vez que el incomparable amor de nuestro Soberano Reinante, Don Carlos IV (que Dios guarde) ha elegido desde su exaltación al trono Ministros tan dignos para el mando de las lntendencias, imponiéndoles la obligación esencial de promover los expresados objetos de que hasta ahora no hemos cuidado, deben los nuevos Intendentes sacrificar su celo, cuando no sea por correspondencia a la Real confianza, siquiera por emulación a los indios que siendo bárbaros hicieron mucho más que nosotros hasta ahora.

La Provincia de Potosí, que siendo la más importante no cs la menos desfigurada en sus caminos campestres, clama a gritos por su repa- 
ro, ejecutando más que ninguna la atencion de sus Intendentes; hacia la parte de Buenos Aires hay dos quebradas, la uma llamada de Sococha y la otra más distante, de Saropalca, donde son frecuentes las averías que sufre el comercio y no es rara la detención de nuestros colrcos, por la mala constitución del camino.

Uno y otro paraje es una zanja continuada por ocho leguas, angosta, profunda y pedregosa, que sirve de canal para dos pequeños arroyos en ticrimpo de seca, que se forman en dos grandes ríos en las ocasiones de lluvia.

Son tan rápidas las corricntes $\mathrm{y}$ tan abundantes las aguas, que en tiempo de avenidas ocupa toda la quebrada poi sus dos bordes y es capaz de navegar una embarcación. Las laderas son tan jpendientes que ni a pie se pueden subir; y de aquí proviene que muchas reces están parados los arrieros, cuatro y seis días, hasta que baje la marea y otras veces que por pareccrles que ya ha cesado la avenida, entran al mal paso, caen las cargas en las zangas que abren las corrientes, se mojan las mercaderías, se ponen ilegibles las cartas de la valija, y algunos semahogan sin recurso.

Nos libraríamos deste luego de estos penosos cmbarazos abriendo camino en la falda más descansada de la misma quebrada. La tierta es dócil, y se puede traer algunos arbolitos para fijar puentes volados, sobre vigas elevadas en el costado que no permitiese excavación. En las inmediaciones existen pueblos de indios que pueden aplicarse a este trabajo, y añadiendo el auxilio de algún impuesto temporal en las cargazones es fácil conseguir esta grande obra que seria de las más útiles para nuestro comercio y breve expediente de nuestras postas.

A las cincuenta y seis leguas de la Vilia, se encuentra un pueblo llamado Suipacha, por cuyo costado corre un río del mismo nombre. En tiempo de lluvias se divide en quince o diez y ocho brazos, cada uno bastante caudaloso. Las corrientes son grandes, $y$ con el demasiado fango del suelo, hace difícil y peligroso el paso, porque atollándose las bestias en el pantano y arrebatadas con el impetu del río, se trastornan y caen allí, unas veces con notable avería de las cargas, y otras perecen bestias y jinetes; sin que haya más remedio que aguardar la bajama* a las orillas de la banda opuesta.

Durante la estación de inviemo que no llueve gota de agua, era fácil ahondar una sola de las muchas canales (por donde corre ahora el río) para reducirlo todo a una sola madre y embarazar la inundación que causan las avenidas. En la India no se consideró impracticable la empresa de profundizar el canal del río Nilo; antes se sabe que con esta operación vencieron aquellos naturales la disposición del río en las dilatadas inundaciones, en que solían ahogarse las tierras vecinas por largo tiempo.

Con poquísimo costo se plantearía este gran proyecto; y entonces podría formarse un puente de madera en lo más angosto del canal, o fabricarse dos balsas de cuatro canoas pequeñas con mimbres sobretejidos para el paso de las cargas y caminantes por el corto interés de medio real por persona, y otro tanto por cada carga para aumento de propios de esta Villa. Las caballerías pasarían sueltas nadando, y no correría riesgo alguno el comercio, ni las vidas de los pasajeros.

Ahora no es verificable el uso de canoas, pues, aunque flotasen en alguno de los brazos del río, no podrían pasar los últimos por el emba- 
razo de los albardones o bancos intermedios, que dividen las aguas en distintas ramas; $y$ así es indispensable el recurso de reunir toda el agua en un cuerpo, dentro de un solo canal.

En todos los demas ríos se debía ejecutar el mismo arbitrio, para facilitar el comercio interior y el externo de esta Provincia, con otras del Virteinato, y superar las glavísimas incomodidades que sufren los caminantes en las detenciones de los viajes, ya por los ríos y, también, por los inevitables tropiezos de los malos caminos.

Encargando estas obras a los comisarios de las Doctrinas r'ura. les, aseguro que en medio año estarían reparados nuestros caminos, y si no todos, $y$ los rios con puentes de madera o balsas de canoas, con el adelantamiento de engrosar nuestros Propios con el derecho de portazgo.

Los indios de cada Doctrina, deben distribuínse por faenas a la concurrencia de estos trabajos públicos, ${ }^{20} \mathrm{y}$ los comisarios deben cuidar de ellos, como objeto esencial de su obligación, para dirigir el proyecto y correr con la recaudación de los portazgos, en la forma que se arreglare por el Intendente.

Pero como sin mulas y caballos, quedarían en la misma inacción nucstras postas y el comercio, conviene promover las crías de ganados, en los Partidos de Tarija, Chichas y Atacama, que son a propósito, por la comodidad de los campos y pastos.

Dentro de pocos años abundaría mestra Provincia de muladas y caballos, sin necesidad de ir a buscarlos al Tucumán, sólo con gratificar al vecino que tuvicso tres o cuatro manadas de yeguas y burros hechores para cría de mulas; porcue la ambición del premio y el interés propio incitaría a todos para preferir esta negociación a las demás del Reino.

Los mismos indios, de los principales, y otros medianamente acomolados, se sacrificarían para comprar una yegua, y criar un burro padre (que es muy fácil) para tener una mula; pues, a más de la gratificación que se les concediese, lograrían la comodidad de tener en una sola mula el proyecto de cuatro carneros de la tierra; así porque la mantendrían al mismo costo, como por la cuadruplicada carga, que puede conducir con igual utilidad, y aunque al cabo de dicz o quinec años no se consiguieso otra cosa mís que cada indio tributario de nuestra Provincia, poseyese un par de mulas, podríamos contar seguramente dentro del mismo tiempo, con cincuenta mil cabezas de esta especic de ganado, para todes los menesteres de la agricultura y del comercio.

Nuestras coryespondencias interiores se abreviarian infinitamente más; porque el transporte de todo género de efectos y frutos, sería más rápido, más seguro y más barato, por la misma naturaleza de las mulas; $y$ despues de todo circularía en nuestra Provincia el crecido importe de los fletes; y la preciosa substancia mumeraria; de que ahora se carece en los Particlos, los iría vivificando hasta hacerlos fiorecer en la agricultura, en el comercio, en las artes y en la industria, porque se acostumbrarían a buscar la comodidad de caballerías para sus viajes, con los arreos necesarios, y como que entonces tendrían más necesidades que vencer, trabajarían también a proporción, $\mathrm{y}$ al cabo los veríamos salir de la vida sencilla, pobre, rústica y grosera, en que se han criado y se mantienen, porque no conocen la felicidad que disfrutan los ciudadanos civilizados.

Según las grandes distancias, a que se extiende el Distrito de esta Provincia (como lo hemos visto) no es posible mantener en los pueblos de 
la campaña la armonía y el buen orclen de la Capital, sin la conexión de la Provincia con su metrópoli, por medio del establecimiento de correos periódicos, que corran la posta por el interior del territorio.

De Atacama y Lípez, son muy raras en el año las ocasiones de conducir, por el corto comercio de aquellos Partidos y porque los pescadores y los otros, que negocian cn cueros de vicuña, regularmente trajinan estos efectos desde los Cantones más apartados de la pesca y cacería, sin noticia de Ios Jueces y mandones del Partido. Por esta causa se pasan largo tiempo sin tener corr'cspondoncia de aquellos parajes; y quedan ignorados muchos sucesos importantes que requieren el conocimiento del Gobierno, y algunos ya no admiten providencia, perdiendose la primera oportunidad.

Con estas consideraciones se ordenó en el reglamento de Propios, el establecimiento de un correo fijo y periódico cada dos meses, a los Partidos de Lípez y Atacama, para no exponer la correspondencia de oficio a las contingencias casuales de uno u otro arriero, que viene a esta Vilia. Hasta el día no se ha verificado este gran proyecto y cada vez se hace más sensible su falta, reflexionando que al cabo de cinco anios, que se han establecido las fntendencias, apenas se tiene un corocimiento confuso de aquellos territorios.

Si atendemos solamente la distancia, no parece difícil entablar correo para ambos Partidos; porque contándose de Potosí a Lípez setenta leguas, $y$ de alli otras tantas al pueblo de Chiuchiu, donde reside el ifuez Subdelegado de Atacama, no pasa de ciento cuarenta leguas la carrera de la posta.

Lo que impide este expediente son los caminos. Desde Chiuchiu a Lipez hay que pasar una cordillera de doce leguas, sin agua ni bastimentos, por unos despoblados distantes en que apenas se eneuentran algunas cabañas de indios miserables.

Es impracticable hacer sin riesgo estas marchas a pie; a menos que corrieran la posta aquellos indios cañaris, acostumbrados a caminar como los guanacos. No son a propósito todos los indios, ni son muchos los que ejercitan semejante oficio; y así los arrojariamos a estos infelices al mayor sacrificio, obligándolos sin distinción a corver la posta por aquella carrera.

Es verdad, que por la Iey 4, título 13 , libro 6 , de Indias, deben repartirse indios para tambos. También está dispuesto por el Señol Virrey Marqués de Guadalcázar y el Marqués de Montesclaros, ${ }^{31}$ que se restablezca el entero de mitarios para tambos, eximiendo del servicio de las minas a los que se destinasen para los pliegos. Pero la disminución de los indios, ha obligado a suspender éstas y otras utilísimas providencias, aun por lo respectivo a la mita para mincría; y como efectivamente deben entenderse tales establecimientos con las postas para las carreras de los pueblos capitales, como eran antes y son ahora Buenos Aires, el Cuzco y Lima, no hay arbitrio para emplear indios, al preciso destino de los correos de Atacama y Lípez en derechura a sus cabeceras.

En medio de estas dificultades no encuentro otra proporción para entablar el correo de los Partidos de Atacama y Lípez, que obligar bajo de pena pecuniaria efectiva a los dos Subdelegados, para que el de Atacama remita sus pliegos a fin de cada mes al de Lípez, y éste los envíe con los suyos al pueblo de Tupiza, (que sólo dista cuarenta y cinco leguas) 
en oportunidacl del arribo en aquella cabecera del correo de Buenos Aires, para que el mismo conreo devuclva la cos'iespondencia de este Gobierno o de otra parte, que debe mantenerse en porler de la persona encargada cn Tupiza, hasta la llegarla del que col'ue la Costa, clesde Lípez.

Fácimente so puede arreglar al tiempo til que estos correos deben salir de los Partidos y llegar a Tupiza, para que no se dilate la cominicación, tomándose a este fín los l'espectivos informes al Administrador de Correos de csta Villa y a los Subdelegados de Chichas, Lípez y Atacama.

Lo único que hay que pensar es de qué yamo debe costearse los dos Correos de Atacama y Lípez hasta Tupiza, respecto de suponerse que haya de ser de oficio toda la correspondencia por el eortísimo y casi ningún comercio de aquellos Partidos. Pensionar a los indios en que corran la posta sin salario es un gravanen contrario a la Justicia, y esencialmente opuesto al espíritu de nuestras leyes, en especial habiendo de andar a pie caminos largos, despoblarlos y peligrosos.

Los Subdelegados siempre tienen caballerias de respuesto para visitur las minas de sus P'rovincias, cobrar tributos $y$ para otras andanzas. Regularmonte adguieren estos empleos por empeños, y aunque no tienen sueldo, no lo pasan tan mal como se pondera. Así no juzgo que sea gravamen considerable imponerles a sus of icios la pensión de remitir los pliegos mensualmente a los parajes expresados con sus mismos escuderos y sirvientes.

Y mediante a estar asiguados trescientos cincuenta pesos on el ramo de Propios, por su reglamento para el Parte de Cartas de los Correos de Atacama y lipez, seré conveniente que cn la Administración de csta Villa, se cobren los derechos relativos a und y otra correspondencia, por cuyo medio nunca perderá cosa alguna la l'enta de correos.

Por lo respectivo a las dos carreras generales de Buenos Aires y Lima, se padece en esta Villa una imponderable necesidad que resulta en perjuicio grave de los infelices arrieros; y es que no habiendo posta establecida dentro del pueblo ni en sus contomos, no hay modo de salir de aquí para los pasajeros, que quieren conrer la posta. Sobre esta imposibilidad se ha introducido la corruptela que ocurriendo a cualquier Juez de la Villa, se manda sin escrúpulo ni reparo, que los Pajes, o Alguaciles de los Juzgados, quiten por fuerza las mulas necesarias al pasajero, y sucede muchas veces que al pobre arriero de la costa se le cmbargan sus mulas para el que va a Bucnos Aires con la pensión de ir él mismo o enviar otro a su costa para que las vuelva desde el pueblo de Caiza donde está la primera posta hacia Buenos Aires a catorce leguas de Potosí en rumbo opuesto al camino de la Costa o Cuzco, y si no tiene esta precaución, se pierden las caballerías, o no se les pag'a su flcte, además del atraso que sutren en demoral su tornaviaje a sus respectivos destinos.

Esta relación apenas es un prólogo diminuto de abuso tan extraordinario y perjudicial, pero lo cierto es que va siguiendo y seguirá sin remedio, si no sc entabla una posta en la Villa, como lo considero muy fácil.

La Casa de Moneda tiene las mulas en sus molinos al cargo dẹ un asentista, que las guarda y alimerta entre otros muchos animales suyos, que la misma contrata le da proporción para mantener sin objeto fijo de utilidad. Siempre que a este asentista se le abonase dos reales por cada legua en las caballerías de carga, y un real por el postillón hasta la posta de Caiza, por la carrera de Buenos Aires, y hasta Yocalla por el Cuzco, 
y lo mismo hacia la parte de Chuquisaca, abrasaría el encargo con mil manos con comodidad suya, por lo que interesaba en los flctes; con alivio de los pasajeros por el pronto expediente de sus marchas, y sin gravamen de los arrieros, porque se verían libres de los perjuicios y atrasos con que se ven pensionados ahora.

- Como el correo tiene por objoto no solamente la circulación segura y abreviada de las correspondencias, sino también el transporte pronto, acomodado y poco costoso de los viajantes, complende entre los puntos esenciales de su policía la provisión de ventas y mesones en los parajes de tránsito, con las calidades que recomienda cl artículo 62 de la Real Ordenanza de Intendentes.

Casi en todo el Perú es incrétble el abandono con que se mira tan grande importancia. Los mesones se reducen a una casita poco más honrada que las cabañas comimes dê los indios: toda su capacidad está contraída a una o dos pequeñas piezas asquerosas y pestilentes, sin cama y sin víveres, a excepción de algún camero o gallina, que se encuentra a mayor costo que en los pueblos.

Esto procede de no haber persona de posibles que se encargue de semejante comision. Los maestros de postas legularmente son indios Chontales, y el más honrado algún cholo. Ya se ve que es cortísima la utilidad que interesan en este ejercicio; y como el provecho es el único atractivo de los hombres, no sería difícil mejoras nuestros mesones en un pie muy ventajoso, aplicándoles ticruas para pastos de las caballerías e indios de repartimiento para el servicio de los tambos y pasajeros.

Este punto es de la mayor atención y pucde facilitarse interponiendo su autoridad superior los señores Virreyes, con acuerdo de los Intendentes y precedente informe de los administradoles de correos.

Por conclusión del artículo presente, juzgo digno de advertencia un abuso perjudicial y muy ridículo, que se tolera a los indios de esta Villa en or'den a sepulturas.

En el mes de noviembre que celebra la iglesia la conmemoración pía de los difuntos, tienen los indios las mayores borracheras y fiestas. Como se entiexran en la iglesia de la Misericordia los indios pobres, y en los hospitales todos los enfermos que han muelto allí, no sé por qué principio se empeñan los deudos y paisanos vivos, así de los mitarios como de los yanaconas y criollos a desentel'ar los huesos para trasladarlos a las Pairoquias donde ellos se hallan empadronados, o a otras, que se les antoja.

A este fin concurren a los higares del entierro, llevando por oblación cántaros de chicha y unos castilletes vestidos de cigarros al toque de cajas, con numeroso atompañamiento de hombres y mujeres de la misma casta. Encienden sus luces y se pasan todo el día y la noche en grandes lamentaciones recordando la memoria y costumbres de los difuntos, y a medida que los doloridos van aumentando st embriaguez crece el exceso de los alaridos y demás consiguiente a la privación del sentido.

Pagan al Párroco o Prelado de la iglesia el estipendio de doce pesos entablado, como por tarifa por el desentierro y dobles. Al día siguiente de las exequias cargan con una porción de huesos, muchos todavía no disueltos, que forman un espectáculo horrible $\dot{y}$ asqueroso a quien los mira y los conducen por las calies en comitiva con mucho ruido de cajas entre la confusión que produce la borrachera y la mezcla de ambos sexos. 
Así continúan hasta llegar a la iglesia, donde se rezan las oraciones eclesiásticas al costo de crecidas limosnas, que pagan los alféreces de estas ridículas festividades; de suerte que estos infelices idiotas consumen mucha parte de sus jounales en tales funciones, qize ellos consideran llenas de religiosidad y devoción.

Sería largo referir por menor las ceremonias extravagantes que practican semejantes días, $y$ tal vez horrorizarían al hombre más incivil. Basta lo expuesto para conocer el asco, la fetidez y la inmundicia que insultan los sentidos humanos en unas ocasiones que solamente debe obrar la consideración $y$ la piedad; $y$ a no ser tan puros $y$ antipútridos estos aires por su frialclad y calidad salina, serían inevitables todos los años las pestes $y$ eníermedades epidémicas, que en otros climas produce la corrupción, y tal vez solamente el dcsaseo.

El Papa Bonifacio VIIl llamó horrible y abominable en una constitución extrayagante 82 abuso de desenten'rar los muertos para trasladar los huesos a otros lugares, y lo prihibió bajo de excomunión mayor cxceptuándose de esta pena únicamente algunos casos muy especiales que explica el eximio Suárez, ${ }^{33}$ pero para no incurrir en la censura los ọlre extrajeron de los sepulcros, huesos de difuntos, necesitan expresa licencia concedida con justa causa por cl Superior Eclesiástico, confome a un Decreto del Sinodo Buscoducense referido por el célebre Van Espen, y Claudio Fleur. 54

No puedo creer que los celosos Prelados de Charcas hayan permitido a sabiendas abominación tan detestable. La codicia, que ha sabido avanzarse hasta el santuario en muchas partes del Perú, considero como único origen de tales excesos. Los Prelados viven en el retiro de sus paJacios, sus piadosos ódos coneiben solamente lo que persuaden los Curas; y como hay muchos poseídos de la anxbición, abonan el abuso con colores de piedad y por este camino sigue su curso con la rapidez de un torrente.

Pero el remedio es inny fácil, procediendo de acuerdo la potestad secular con la eclesiástica; ésta en mandar observar las constituciones canónicas, y aquella en quitar la ocasión de quebrantarse mediante las providencias de Policía.

Refiere Cicerón ${ }^{8 \bar{s}}$ que por ley de las doce tablas, confirmada después por los emperadores Adriano, Dioclesiano, Maximiliano, Antonino y Theodosio, ${ }^{26}$ se prohibió bajo diferentes penas enterrar los muertos dentro de las ciudades, con el fin de que los vivos no se contagiaran con el fetor asqueroso y pestilente de los muertos, según la intinuación de San Isidro. 37

La Igiesia prevenida de iguales sentimientos, aunque con otro espíritu más noble $\mathrm{y}$ superior al de la política humana, prohibió también los entierros dentro de las cindades, permitiéndolo únicamente a los euerpos de los mártires.

La sucesión de los siglos posteriores fue debilitando aquella primitiva disciplina, $\mathrm{y}$ comenzaron en el siglo IX, a enterrarse, no sólo dentro de las jglesias, sino también en los atrios, pórticos y cementerios de las iglesias, principalmente después que el Emperador León, revocó en una constitución 36 las leyes prohibitivas de sus predecesores, permitiendo los sepulcros dentro de las ciudades.

A ejemplo de los Obispos, a los Reyes, a los grandes Señores ${ }^{39} \mathrm{y}$ otros varones justos, que se enterraban en las iglesias consagradas siem- 
pre al honor de los mártires, se introdujo desde el siglo $X$, una costumbre casi universal de hacerse dentro de las iglesias los entierros de los demás fieles; parte por piedad de éstos, que para lograrlo contribuian. con grandes limosnas, creyendo santificar sus cuerpos enterrándose inmediatos a los sepulcros de los Santos, y parte por ambición de los eclesiásticos, que allanaron estas pretensiones sin contradicción ni reparo.

La Iglesia deseosa de restablecer la primera disciplina, lo prohibió

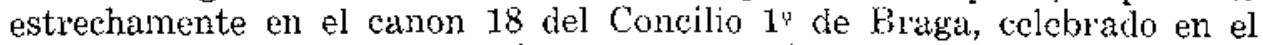
año de Cristo $561^{40}$ y ratificó después en el Coneilio Naunctense del año de 850, que atribuye Graciano ${ }^{41}$ a un Decreto del Sinocio Varense.

Sin embargo vemos tolerada la costumbie re sepultar los mucrtos dentro de las iglesias, para hacer menos irleprensible el abuso, como refiere Van Espen, ${ }^{42}$

A este mismo tenor ha proveído la política civil, difcrentes precaulciones contra el contagio de los sepulcros para conservar la salud pública, ordenando que al instante de morir se sahumen los difuntos con perfumes y olores aromáticos, que son prescrvativos contia los malos aires, y que se hagan los enticrios en cementerios consiuidos con autoridad de los Obispos en los barrios más distantes de las ciudades. ${ }^{4}$

En ninguna parte como en Potosí, se necesita tomar igual providencia, así por el objeto referido, como por quitar la ocasión del ignominioso abuso de trasladar los hucsos de los difuntos contra Ias constituciones Canónicas, y también para ahorrarles a los infelices indios las oblaciones, limosnas $y$ derechos que inútimente contribuyen por este irregular género de exequias, en perjuicio de sus farnilias.

En el día se puede dar expediente a este asunto según la proporción del país. Habiéndose suprimido siete Paryoguias de las catorce, que habia antiguamente en la Villa, han quedado casi sin uso las siete iglesias suprimidas en caljdad de anexos de las restantes. Examinándose cuales sean las menos necesarias, y las más distantes (que en mi concepto son San Bernardo y San Pablo, colocadas la primera al Norte de la población y la segunda al Sur, una y otra en los cantos suburbanos) se pueden aplicar éstas con sus atrios, que son bien capaces, para enterratorios de los indios que murieron en los hospitales, de los pobres y de los demás, que por advenedizos no tuvieron domicilio ni Parroquia.

Con los españoles no sería fácil ni necosavio semejante establecimiento de Policía; ${ }^{44}$ lo primero, porque levantarian un clamor peligroso en ver confundidos sus huesos después de muertos con una plebe de quien tanto se distinguieron en vida; lo segundo, porcue en Potosí es corto el número de españoles, y jamás se ha observado en ellos el abuso abominable de hacer como los indios, la traslación de sus huesos.

Lo mismo digo en cuarto a los indios empadronados en las demás Parroquias; porque hallándose situadas todas ellas en los últímos barrios de la Villa, no hay que temer el contagio de los aires; y para contener las traslaciones abominables de los huesos de los difuntos basta la autoridad Eclesiástica para con los Curas, que son los que pueden quitar y mantener semejantes abusos.

(En el manuscrito que se conserva en el Archivo General de Indias, el Párrafo único que antecede, corresponde al penúltimo Capítulo de la obra. No fue escrito en el libro que inicialmente hizo el Sr. Ca- 
nete, cuyos dos rolumenes, como hemos dicho anteriomente, pertenecen ahora al Museo de la Casa $\mathrm{Nl}$. de Moneda, Sección "Archivos Coloniales", a taryo de la Sociedad Geográfica y de Historia "Potosi".

En cuanto al Capitulo último del mismo nanuscrito existente en Sevilla, - com el gue el autor cier'a su libro resumido y corregido del terto en dos lomos- no lo publicamos porque es una copia exacta del "Proyecto Previo" sobre la anexión de Tarapacá al Virreinato de Buenos Aires, que aparce al comienzo de esta edición completa.

La segunda rarte de la obra, seguin el texto potosino, da principio con el Capitulo sobre el Gobieno antigno de lo Villa de Potosi, que en el manuscrito de Sovilla fue puesto al principio de la parte primera con cl título de "Discurso Preltimar", o prólogo explicativo de los propositos y condición de la Guía Potosina. Siguiendo con mayor fidldiad el contexto del manuecrito que consevamos aquí, mantenemos dicho Discurso como introducción y capítulo primero de la segunda parte de la obra. Nota de A. Alba).

\footnotetext{
1.- Barba: Arte de Melales, Lib. 1", Cap. 29.

2.- Cap. $8^{\circ}$, Parte $1^{\prime \prime}$, Noticia 51 y 52 .

3.- Art. 59 de la Ordenanza de Intendencia.

(a) Vitichi, actualmente. (Nota de E.).

4.- Barba: Lib. 1.", Cap. $7^{*}$.

5.- Vide Solórzano in Folítice Lib. $6^{\nu}$, Cap. $3^{\nu}, \mathrm{N}^{*} 3$.

6.- Idem. loco citato $N^{\circ} 9$, tomo 20, fol. 439.

7.- Escalona: in Gazophilacio Lib. 2", Cap. 23, Parte $2^{\prime \prime}, \mathrm{N}^{\prime} 2$, fol. 214.

8.- Avendaño: Tesauro Indico, título 5\%, Cap. 10, $\mathrm{N}^{\circ} 77$, fol. 177.
}

9.- Escalona: libro 2", Parte $2 "$, Cap. $23, \mathrm{~N}^{\circ} 4$ y 5 , fol. 215.

$10 .-A$ los indios está prohibido por la Ley 31 , título $1^{\circ}$, Lib. $6^{\circ}$ de Indias el uso de las armas en cuya clase se incluye la pólvora en el Tít. $5^{\circ}$, Lib. $3^{\circ}$ de Indias y conviene quitarles uno y otro.

11.- Bowles: Historia Natural de España, fol. 40 y 51 .

12. Parte $1^{4}$, Cap. $4^{\circ}$, Noticia $4^{\circ}$ al fin, folio 44.

13. - No se hán puesto hasta ahora en observancia en el Virreinato de Buenos Aires.

14.- Barba: Lib. $4^{\circ}$, Cap. 22 .

15.- Barba: Lib. 1", Cap. 33 .

16.- Política, Lib. 2", Cap. 16, $\mathrm{N}^{\circ} 21$, tomo 1", fol. 191.

17. - Ibid fol. 8 y 9.

18. - Ustariz: insume todo el Cap. 64, de su teoría y práctica de comercio sobre Jos medios de promover las manufacturas; y pueden aprovechar sus documentos, aplicándolos con inteligencia.

19.n- Reglamento de propios formado por esta Intendencia a 13 de abril de 1784, y Auto de 23 de diciembre del mismo año, en que se modificaron varios artícuIos a consecuencia de un informe de la Contaduria General de este Ramo.

20.- Pereyra: De Manu Regia, Cap, 17, $N^{\circ} 4$.

21.- Rollin: Historia Antigua, tomo $6^{\circ}$, fol. 415 y siguientes.

22.- Montagn. Lib. 3", Cap. $2^{\circ}$, Berg. Lib. $2^{\circ}$, de los yrandes caminos del Imperio, Cap. 28.

23.- Gomara y otros autoreśs citados por Calancha, Lib. 1\%, Cap. 15, N 4, fol. 99.

24.- Torquemada: Monarquía Indiana Lib. $1^{\circ}$, Cap. 35 , tomo $2^{\circ}$, fol. 298 , calumna $2^{4}$.

25.- Rollín: Historia Antigua, tomo 1\%, Cap. 4", Art. 2", fol. 230. El Gódigo Teodosiano en el título de curso público hace mención de los caballos de posta y comprueba la antiguiedad de los Correos.

26.- Torquemada: Mornaquia Indiana, Lib. 14, Cap. $1^{\circ}$, tomo $2^{7}$, fol. 536, columna $1^{8}$.

27.- Soliz: Historia de la Conquista de Méjico, Lib. 2", Cap. 2\%, $\mathrm{N}^{\circ} 3$.

28.-- Calancha: Crónica de San Agustín, Lib. 1\%, Cap. $14 . \mathrm{N}^{\circ}$ 6, fol. 98.

29.-.- D. Antonio Ulloa, en el Resúmen Histórico de los Emperadores del Perú, fol. 4, de su Viaje $\mathrm{N}^{\circ} 34,40,42$ y 48 . 
30.- Ordenanza 34, Tít. $2^{\circ}$, Lib. $2^{\circ}$ del Perú. L. 25, Tít. 12, Lib. 6, de Indias.

31.- Provisión de 30 de abril de 1609.

32.- Extravagante $1^{\circ}$ destestande de sepulturis.

33. - Suárez: "De Censuris Disputatione", 22 sep. 5", tomo 2", fol, 319.

34.-Van Espen: De jure Eccto. Parte 24, Tít. 38, Cap. $6^{\circ}$, $\mathrm{N}^{\circ} 33$, tomo $2^{\circ}$, fol, 344, Fleuri Institutas Eclesiást. Parte $2^{\circ}$, Cap. 9, $N^{n} 3$, fol. 157. Es en todo conforme la L. 11, Tít. 13, Parte $1^{\natural}$ al fín.

35.-Cícero. De legibus, $2,23$.

36.-L. 3, fol, sepulco. violado. L. 12, Código de religiosos et sumplib funery,

37.- Isidor. Lib. 14, origen, Cap. 12.

38 - Novela 53.

39.- La Ley 11, Tít. 13. Parte 1' designa las Personas, que debían enterrarse uni. camente en las iglesias, por particular distinción de sus dignidades.

40.- - Vide Cardenal de Aguirre en el torro 3" de los Concilios, fol. 187, con la nota de Catalano.

41.- Graciano: en el Cánon 15, Cuest. 1', causa 13.

42.- Van Espen De jure Eclesiástico, l'arte $2^{\circ}$, 'lít. 38, Cap. 2 y 3, tomo $2^{\circ}$.

43.- La Ley 2, Tít. 13. Parte $1^{\text {n }}$ hace mención de estos Cementerios y de las Leyes que los mandaron construír en lugares distantes de la Ciudad para que el fedor de ellos (es decir de los muertos) non corrompiese el aire nin matase los vivos.

44. - Esta excepción se puede fundar de algún modo en la Ley 11, 'Tít. 13, Parte $1^{4}$, por la Superioridad de condición en los españoles respecto de los judíos. 


\section{A P E N D I C E}

\section{A los últimos scis Capitulos antecedentes.}

Observaciones sobre los medios más importantes para el mejor servicio del Rey y para felicidad de los indios, habitantes en los Partidos campestres de la Intendencia. **
$\mathbf{E}_{\mathrm{N}}$ blecidos los Subdelegados, que nombran los Intendentes por el tiempo de su voluntad, para que recauden y enteren los Reales Tributos 1 y administren justicia a los naturales de cada Partido y los mantengan en buen orden, obediencia y civilidad. ${ }^{2}$ Admirable fue

el espiritu de la Ordenanza en esta sabia Providencia, para reprimir aquel antiguo despotismo con que los Corregidores abusaron de la libertad débil del indio, en la confianza de que siendo cada uno criatura del Rey, sólo él podía quitarlos del puesto que les dio.

Por el contrario, un Subdelegado no conoce más que al Intendente por autor de su fortuna o de su desgracia; en su disgusto lee diariamente la sentencia de su caída; no tiene más apoyo que la exactitud de su probidad en no desmentir jamás el nivel de las obligaciones de su empleo; teme caer del mando si no honra la confianza de su jefe; y al paso de estar siempre colgado de los labios del Intendente, vive también éste continuamente despierto sobre la conducta del Subdelegado; porque sabe que muy lejos de disculparle su delito, se lo echa sobre sí mismo en manteniendo a un hombre criminoso, que no corresponde a las soberanas ideas de S. M., en alivio de los desdichados indios.

Verdaderamente es así, cuando la elección recae en sujetos de honor, porque con la esperanza de pasar a otras mayores confianzas y vincular en ellas una carrera feliz para su reputación o para su subsistencia, nada hay que les estorbe el desempeño de sus oficios. 
Entonces no olvidan que entre sus obligaciones es la más esencial administrar justicia a los vasallos del Rey; a este fin procuran cumplir el escrupuloso precepto de la Ley 20, 'T'ít. 4, libro 3:" de Castilla, irasladándose por turno de un pueblo a otro de su Partido, cada cuatro meses, no solamente para que tengan más fácil, méls curcano y más expedito el recurso aquellos pobres que por su miscria no son capaces de cmprender marchas dilatadas, sino principalmente pata lemediar con inteligeneia los abusos que, de ordinario, suscita en los pueblos la distancia del superior.

Ya saben en torlo el Distrito el pueblo re altemativa en cada cuatrimestre, y allí ocurrirán todos los que turieron pleitos g'aves, que necesiten actuación de proceso; pero aquellos recursos que más frecuentan los indios, sobre palabras injuriosas, pinadas o golpes en que no intervienen armas, y otras demandas cortas que no exceden do veinte pesos y no admiten autos, ${ }^{3}$ se deben llevar a los Alcaldos Pcdíncos de cada Doctrina, para que con arreglo a las Leyes $10 \mathrm{y} .11$, Tít. 10 , libro 5 " de la Rccopilación de Indias, corten las diferencias y compongan a las partes, de palabra, breve y sumariamente.

Qué contentos tendríamos en tal caso a estos desdichados, pucs, nadie que tenga alguna experiencia de estos países, ignora que, en viendo el indio la cara del Juez, vuelve a su casa tan alegre como si hubicra triunfado de un gigante.

En la cobranza de tributos, son Ios principalnente encargados los Curacas, Gobernadores y Caciques, ${ }^{4}$ con la obligación de hacer los enteros en las cabcceras, por el infimo premio del uno por ciento, quedando: el tres por ciento á los Subdelegados, por la responsabilidad y trabajo en el todo de la recaudación.

En efecto, ellos lo cumplen; pena de gravos vejaciones que sufren si son omisos; si los Subdelegados se descuidan en nombrar por exactores a los indios más acomodados, para el lasto de cualquiera quiebra; y como saben que no les vale cxcusa, tampoco son negligentes cn cubrip el cargo de los padrones.

A poca costa queda solvente el Subdelegado, porque el cobrador apura al cumplimiento del tercio, sin riesgo de que hava fuga aun en caso de alcance, pues no hay ejemplar que un indio arraigado desampare su domicilio, por el imponderable apego que tienen a un retazo de tierra.

A todos estos objetos conduce el sabio y soberano espiritu de la Ordenanza; pero siendo tan natural cl viciarse las cosas humanas, vemos ya en sólo el transcurso de tres años, muchas cosas que en remediándose más tarde dejarán peores consecuencias que llorar. No es extraño, cuando el hombre se corrompió a pocos instantes de su creación, con todo de haber sido la obra más perfecta de la mano de Dios.

Por hallarse Potosi en el centro del Partido de Porco, con varios pueblos al rededor, estoy viendo cada día repetidos recursos (hasta sobre friolcras) que introducen aquetios indios, por deciv. que el Subdelegado está ausente de la capital, a las diez, veinte o las treinta leguas; por cuya misma causa se han devuelto a este Gobierno diferentes despachos que se le han cometido para asuntos de justicias; de suerte que casi nuncu llegan a verlo los indios de las Doctrinas situadas en los confines del Partido.

Y ello es verdad que los Subdelegados, ordinariamente andan de viaje, unas veces en visita de minas y molinos, por el lucro que les deja; 
otras veces a modidas, por el interés de los derechos; y casi siempre en la recaudación de tributos, no tanto por asegurar su entero, como por alistar los indios forasteros que vayan de una a otra jurisdicción; porque como no tienen sueldo, ellos se ingenian en sacarlo por alto de los que empadronin de esta clase en los intermedios de las Revisitas, o por otros arbitrios tal voz peores de los que practicaban los Corregidores, alucinando a los indios con la especie de ser más respetable su autoridad como dependiente de los nucvos Magistiados, con quicnes no so entrometen ni aun las Audiencias.

De cste modo, piensan únicamente en lo que pueden granjear para recurso de alguma desgracia. No administran justicia, porque no residen; no remedian desórdenes, porque no los conocen; no alivian a los indios, porque no los oyen; no cuidan de la policia, porque no tienen medios, y por último, nada más hacen que andar a caza de los tributos, por ser ésto lo único que les interesa. Sirve de prueba un hecho escandaloso, sucedido el año pasado de 1787: salió a visita el Intendente de esta Provincia, y estando de paso en el pueblo de Tinguipaya, ocurrió a él un indio elego, a quien le habia sacado los dos ojos con un cuchillo otro indio encmigo suyo, el que andaba Iibre, por haber compuesto su delito con el Alcalde Eedáneo a costa de unos carneros, sin que hubiese llegado siquierat a noticia del Subdelegado este criminoso exceso. El Intendente le formó la stumaria y con ella lo remitió preso a la cabecera del Partido de Porco, con estrechos encargos de que administrase justicia el Subdelegado, y entonces se averiguró que cstando en la cárcel aquel infeliz, por ciertas cosas, se valió su encmigo de esta ocasión y encontrándolo indefenso en el cepo ejecutó con él esta sevicia inaudita. De lo cual se puede colegir cuántas iniquidades se estarán ejecutando en los confines de cada Provincia, sin que lleguen a saberlas los Jueces, de modo que no es arrojo sospecha1 que los pueblos remotos y pobres, estan vivicndo en una lastimosa anarquía.

El Intendente más celoso, a más no poder, disimula; porque en mudar Subdclegados no consigue otra cosa que exponerse a pasar de malo a pcor. Así se van radicando los abusos y se hace más difícil su remedio.

Yo he meditado que se puede tomar desde luego uno muy permanente, que después de evitar todos los inconvenientes expresados, sirva para formar muchos hombres proficuos al Estado.

Todo estaría consegujdo en scparando la administración de Justicia de la cobranza de tributos. Porque cada empleado sólo cuidaría de lo respectivo a su Departamento, y ya no sería legítima ninguna excusa. El Subdelegado administrar'́a justicia, residiendo en la cabecera el primer cuatrimestre del año, alternando sucesivamente en los demás pueblos del Partido, para que todos alcancen derecho sin dejar sus familias ni tentarse a desertar con las necesidades de una peregrinación miserable; se puede avisar a todos por una vez los lugares de cada cuatrimestre, fijando en las puertas de la iglesia Matriz de cada pueblo, un edicto firmado por el Intendente, donde el mismo, como práctico por las noticias adquiridas en las visitas anuales, señale los pueblos en que ha de residir el Juez del Partido, por una escala invariable en su acuerdo.

Pero es preciso señalarles sueldo y declararles carrera, para que vivan con honor $y$ estimen el mérito con prefercncia a otros intereses. Antiguamente tenía cada Corregidor, en la masa de tributos, 1.562 pe- 
sos y 4 reales de salario; y este mismo se puede asignar a Subdelegados, de suerte que entre los seis en que se divide la Provincia-de Potosí, vendrían a percibir 9.372 pesos al año.

Para esto no sería menester que el Rey sacase un real del producto actual de sus rentas, porque se pueden costear sobradamente los seis Subdelegados, con los aumentos forzosos que deben rendir las visitas mandadas practicar en cada quinquenio, según la multitud de prójimos anotados en los padrones.

Ia Real Hacienda, sólo en la P'rovincia de Potosí, ha avanzado en el ramo de tributos, 39.819 pesos mís de lo que antes enteraban los Corregidores; $y$ proporcionalmente ha sucecido lo mismo en las demás Provincias, quedándole ahora al Key, por una sola operación, todo cl exceso que percibian los Corregidores, sin embargo de los salarios.

Así pues, aunque los Subdelegados tiren iguat sueldo, nada perderá el Rey ni tendrá que gravar el crario en más de lo que hoy está; porque con lo que se adelantase en las Provincias por cada quinquenio, se costearían los salarios.

Estarán los empleos bien servidos; los procurarán hombres de honor, y ocupándose en ellos letrados de probidad, se irin formando en esta escuela unos sujetos jdóneos que puedan después desempeñar las tesorerías, los gobiernos y las togas.

Para la recaudación de los tributos de cada Provincia, se pueden nombrar por la Intendencia receptores particulares, bajo de buenas fiallzas, señalándoles el $6 \%$, como se practica con los del Ramo de Alcabala. Es seguro que no faltará quien se encargue de cllo; pues, regulando el interés de 60.000 pesos que importa Chayanta, le tocan al Receptor 3.600 pesos, que ya es cantidad de codicia; y annque invierta dos mil en los exactores que hubiere de repartix, uno por cada Doctrina, quedan $\mathbf{1 . 6 0 0}$ pesos, que no los gana en el día un mercader con 30.000 pesos de giro.

Todavía se pudiera cconomizar más el negocio, rematando las receptorias en los que las hiciesen más baja en el tanto por ciento; que yo no dudo habrían muchos que quisiesen yecaudar por el $4 \%$, que ahora está señalado.

No costaría ninguna diricultad, autorizando a los receptores y a sus comisionados, con las facultades coactivas y económicas que concede la Ordenanza a los Ministros de la Real Hacienda para las cobranzas, con reserva de los procedimientos judiciales en los Subdelegados.

Se facilitaría esta empresa con la libertad que los particulares tienen para comerciar en los pueblos; $y$ tal rez este interés sólo, sería aliciente poderoso para entrar en las receptorías.

$\mathrm{Y}$ no debe temerse abuso que no se pueda cortar en su origen; porque manteniendo los Subdelegados la superioridart de sus oficios sobre los Receptores y los Intendentes, sobre unos y otros, fúcilmente so descubririan los excesos y se escarmentarían con el castigo.

Siempre se ha experimentado que los negocios sujetos bajo de reglas de buena economía a muchas manos subalternas, son mejor administrados; porque la emulación recíproca y dependencia de unos con otros, estorba los delitos y los abusos. Y por el contrario, un Subdelegado absoluto, a distancia del jefe, se toma más autoridad que él, para hacerse valer el empleo. 
Si se verificara este proyecto, vertamos florecer en breve Ias Provincias, y a los indios aliviados conforme a las intenciones del Rey; y de 110, veremos tambiein dentro de pocos años insultada la libertad de estos infelices, con repartos clandestinos y con otros excesos que no se pueden remediar ni aun conocer; de manera que sólo se diferenciarán nuestros tjempos, de aquellos en que reinaron los Corlegidores, en que éstos ejercían la codicia antorizada por el sistema de la política, y los Subdelegados, por arbitrios secretos de la malicia y de la intriga. Sobre todo, nuestro sabio Gobierno adoptará los mejores medios y los más oportunos para hacer fclices a estos pueblos; que mi ánimo sólo es proponer lo que siento de buena fe para el buen servicio de mi amado Soberano, a quien Dios prospere en estos dominios por una infinidad de siglos.

* El "Apendice" ha sido tomado en su texto del manuscrito de Potosi. No aparece en el de Sevilla. Con estas páginas concluye la parte primera de la obra, según los originales que cursian en nuestro poder. (Nota de A. Alba).

1.- Art. 116 de la Ordenanza de intendentes, y Art. 117, al principio.

2.- Arts. 9 y 73 de la misma Ordenanza.

3.- Ley 1, Tít. 10, Lib. $5^{\circ}$ de Indias.

4.- Art. 117 de la Ordenanza de Intendentes.

A continuación insertamos los cuadros estadísticos y datos conque el aulor dio conclusión a su obra, destinada al Consejo de Indias, que se entuentra catalogada en el Archivo General de Sevilla.

\section{E S T A D O}

No. 1 .

Que manifiesta la cantidad de marcos de plata que ha labrado la Real Casa de Moneda de Potosí, desde el año de 1753 , que empezó a correr de cuenta de S. M., como los de oro, que comenzó el año de 1778. El fondo que tuvo para su giro; Ios ingresos que ha habido; gastos causados, así en la labor de ambos metales cuanto los impendidos en la construcción de la citada Real Casa, últimamente lo entregado en el Tesoro de las Reales Cajas de esta Villa, con el fondo de 800.000 pesos que libre queda para el giro todo hasta del año de 1785. 


\section{A S A BER}

\section{Ramos}

$$
\text { Marcos }
$$

Precios

Total Valor

Plata amonedada desde cl año de 1753 hasta fin de $1785 \ldots$ Oro labrado desde el año 1778 hasta el de 1785 citado .....
$13.082 .859,6$
a $81 / 2$ ps.
$111.204,307,7$
$0.14 .867,0$
a $136 \mathrm{ps}$.
$2 .(121.912,0$

CARGO

Fondo y entrada

$258.712 .7,17$

ondo con que empezó a pirar la Rl. Casa de cuenta de S. M. Las utilidades que ha tenido sobre los marcos de plata labrada, a razón de 3 reales 32 maravedíes en cada uno ........ Los que ha soportado en el oro, sobre los mareos labrados a razón de 7 pesos 7 reales ? maravedíes en cada uno ... . Gastos causados en la construcción u obra maestra de la Rl. Casa ............... Dichos de braceaje en toda la labor de la Moneda de plata $y$ de oro ............... Lo entregado a las Rls. Cajas de Potosí, por razón de utilidades, después de quedar el fondo de 800.000 ps. para el giro.

\section{DATA}

Salida
$1.024 .795,6,17$

$3.425 .355 .4,17$

$1.525 .242 .0,17$

$5.975 .393 .3,17$

$6.821,131.4,18$

\section{RESUMEN Y ESTADO DE ESTA CUENTA}

CARGO Por el residuo anterior $y$ entradas posteriores

DATA Por las salidas y abonos .............

RESTO Por existencias en dinero

Por manera que según se manifiesta por la demostración de arriba, ascienden los ingresos que ha tenido la citada Real Casa, incluso el fondo o residuo anterior de 258.712 pesos 1 y $1 / 2$ reales con que empezó a girar, a la cantidad de 6.821 .131 pesos 4 reales 18 maravedies y los gastos impendidos en la obra material de la Real Casa, braceaje y entregas en las Reales Cajas de Potosí, a la de 5.975.393. pesos 3 y $1 / 2$ reales, quedaron liquidos al fin del año de $1785,845.738$ pesos 1 real 01 maravedí para enterar de ellos en dichas Reales Cajas por las utilidades del citado año de $1785,45.738$ pesos que para dicho efecto son destinados y los restantes 800 mil pesos para el fondo o giro de dicha Real Casa de Moneda.

\section{$\mathrm{N} O \mathrm{~T}$ A $\mathrm{S}$}

1a. - Los marcos de plata en pasta se pagan a 8 pessos 2 maravedíes cada uno, reducidos a la ley de 11 dineros que precisamente han de ser diezmados, y a este precio importan los labrados 104.759 .075 . pesos 3 reales 17 maravedies que juntos con los 6.445 .232 pesos $?$ reales 17 maravedíes a que ascienden 
los 3 reales 32 maravedíes que tiene de ingreso ya hecha moneda, componen los 111.204.307. pesos 7 reales, los mismos que se ven demostrados arriba en. el Total Valor de lo amonedado.

2a. - Los marcos de ovo ya quintaldos, se pagan a 128 pesos 32 maravedíes cada uno, $y$ a este respecto importan los labrados 1.904.725. pesos 16 maravedíes que unos con los 117.186 pesos 7 reales 18 maravedíes que ha habido de ingreso, componen ya reducidos a moneda, la propia cantidad que se cita en el Total Valor de este metal 2.021 .912 pesos.

3a. - Las platas glue se compran son de diferentes leyes; unas bajas y otras altas, $y$ como va dicho se reducen a la de 11 dineros, y para poder fundirse han de subir desde 11 dineros 19 granos, y bajando necesariamente se han de afinar por su acjinonia, cuyos costos los suliren los vendedores de plata, y para ello se les cobra medio real jor marco.

4a. - Las utilidades de cada año varian, unas veces son mís y otras menos, conforme los marcos de plata y oro, que se labra, según ocurren las compras y a este respecto son los costos. Ha habido año que ha subjdo lo labrado en plata a 581.020 marcos, y lo regular que se experimenta un aiio con atro de 400.070 poco más o menos, y por lo que haces a la labor del oro un año subió a 3.532 mexicos, siendo un año con otro to más regular 2,000 marcos más o menos.

\section{DEMOSTRACION}

No. 2 .

De la utilidad If́quida que ha resultado a favor de S. M., en el Giro del Real Banco de San Carlos de la Villa de Potosí, desde el año de 1780 hasta el de 1786 inclusive. A saber:

Ha vendido el Real Banco en la Teal Casa de Moneda de esta Villa, en los años arriba citados, en barras reducidas a la ley de once dineros justos: 2.782 .208 marcos 3 tomines $\mathrm{y} 1$ grano, que a 8 pesos 2 reales marco, importan $\ldots \ldots \ldots \ldots \ldots \ldots \ldots$

La conpra de piñas, Reales Diezmos satisfechos, sueldos y demás pensiones y gastos ascienden a .......

22.278 .121 ps. 3 1/4 rls.

$\frac{22.064 .214 " 51 / 2 "}{213.906 .} 8$

De la demostración antecedente, resulta que habiendo ascendido el valor de las barras vendidas por el Real Banco a 22.278 .121 pesos 3 y $1 / 2$ reales y el de la compra de piñas, Reales Diezmos satisfechos, etc. a 22.064 .214 pesos 5 y $1 / 4$ reales quedaron a favor de S. M. 213.906 yesos 6 reales.

$$
\mathrm{N} O \mathrm{TA}
$$

Aunque el Banco se incorporó a la Real Corona por el mes de agosto del año de 1779 , no se han traído a consideración estos meses para tirar el antecedente $R E-$ SUMEN. 
No. 3.

De los indios que vienen a la Real Mita de esta Villa y las Provincias que contribuyen, según se sacó el año 1780 con el número de los que existían $y$ los que faltaban.

\begin{tabular}{|c|c|c|c|c|c|c|}
\hline & $\begin{array}{l}\text { Deben en- } \\
\text { terar para } \\
\text { Ingenio }\end{array}$ & $\begin{array}{l}\text { Idem p. } \\
\text { Cerro }\end{array}$ & $\begin{array}{l}\text { Enterado } \\
\text { p. Ingenio }\end{array}$ & $\begin{array}{c}\text { Idem } p . \\
\text { Cerro }\end{array}$ & $\underset{\text { Faltos del }}{\text { Ingenia }}$ & $\begin{array}{c}\text { Idem del } \\
\text { Cerro }\end{array}$ \\
\hline 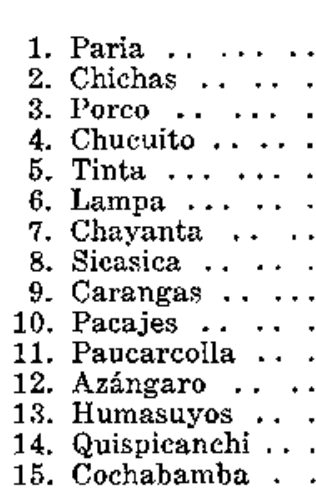 & $\begin{array}{r}123 \\
25 \\
72 \\
127 \\
99 \\
68 \\
183 \\
24 \\
195\end{array}$ & $\begin{array}{r}99 \\
248 \\
385 \\
195 \\
225 \\
302 \\
99 \\
73 \\
341 \\
51 \\
149 \\
111 \\
58\end{array}$ & $\begin{array}{r}121 \\
23 \\
72 \\
126 \\
73 \\
56 \\
178 \\
24 \\
147\end{array}$ & $\begin{array}{r}99 \\
210 \\
316 \\
93 \\
205 \\
302 \\
99 \\
55 \\
315 \\
43 \\
137 \\
111\end{array}$ & $\begin{array}{r}2 \\
2 \\
\\
1 \\
26 \\
12 \\
5\end{array}$ & $\begin{array}{r}18 \\
26 \\
8 \\
12 \\
58\end{array}$ \\
\hline & 942 & 2.336 & 894 & 1.985 & 96 & 351 \\
\hline
\end{tabular}

DEMOSTRACION DE LAS SEIS CASILLAS ANTECEDENTFS:

Según la primera columna debian enterar las Provincias para Ingenio ... 942 Según la segunda columna debían enterar las Prorincias para el Cerro .. 2.336

Total Mita . . . . . . . . . . . . . .

Según la tercera columna enteraron para Ingenio . . . . . . . 894

Según la cuarta columna enteraron para el Cerro $\ldots \ldots \ldots \ldots \ldots$. . . . $1985 \mid \quad 2.879$

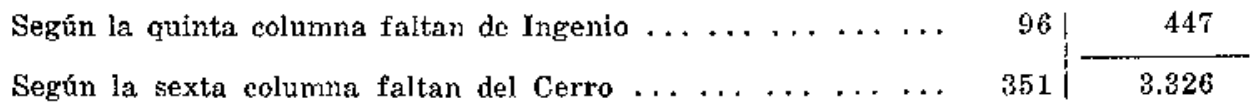




\section{DEMOSTRACION}

No. 4.

De los Reales Quintos sitisfechos a S. M., en las Reales Cajas de la Villa Imperial de Potosí, desde $1^{\circ}$ de enero de 1556 , hasia 19 de julio de 1736, y el Diezmo, desde dicho año de 1736, hasta 31 de diciembre de 1786. A saber:

Prales. presentados

Quintos y Diezmos doducidos.

Desde $1^{\circ}$ de enero de 1556 , hasta 19 de julio de 1736 , consta haberse presentado para guintar 696.712 .575 pesos y que de ellos correspondieron a S. M., por sus keales Quin-

696.712 .575 .ps. 0.rs. tos $\ldots . \ldots \ldots \ldots$ Desde 20 de julio de 1736 , hasta 31 de diciembre de 1786 , consta asímismo, haberse presentado para diezmar $134.357 .786^{\circ}$ pesos 7 reales $y$ que de ellos correspondieron

134.357 .786 .7 . a S. M., por Reales Diezmos ......

139.342.515. ps. 0.rs.

$831.070 .361,7$.

13.435.778. 3 .

152.778.293.3.

De la demostración antecedentc, resulta que, habiéndose presentado en las Reales Cajas de Potosí, para quintar y diezniar en los tiempos que van expresados, el principal de ochocicutos treinta $y$ un millones setenta mil trescientos sesenta y un pesos, siete reales; correspondicron a $\mathrm{S}$. M., ciento cincuenta y dos millones setecientos selenta $\mathrm{y}$ ocho mil doscientos noventa $\mathrm{y}$ tres pesos, tres reales.

$\mathrm{N} O \mathrm{TA}$

El tres por ciento que cobia S. M., en los tejos de oro, que se marcan en es. tas Reales Cajas se comenzó a deducir desde el año de 1777 y se atesoran de 5 a 7.000 pesos anuales.

R A Z O N

No. 5 .

De los Curatos que tiene la Imperial Villa de Potosí: los que abrazan los cinco Partidos de su Jurjsdicción; Sínodos que disfrutan los Párrocos; Valor de los Benefjeios y la Mesara Eclesiástica que corresponde a cada uno, como lo indica este plan de la Villa, Jurisdicción y demás beneficios eclesiásticos. 
CURATOS DE POTOSI

\begin{tabular}{|c|c|c|c|}
\hline Sinodos & Valores & $\begin{array}{l}\text { Mesadas } \\
\text { Eclcas. }\end{array}$ & $\begin{array}{l}\text { Ultimos } \\
\text { valores. }\end{array}$ \\
\hline & $\begin{array}{r}2.600 \\
6010\end{array}$ & $\begin{array}{c}258 \\
59,6\end{array}$ & 3.000 \\
\hline $1.093,6$ & $\begin{array}{l}2.000 \\
2.500\end{array}$ & $\begin{array}{l}108,3 \\
249\end{array}$ & 4,000 \\
\hline $\begin{array}{l}1.250 \\
1.250 \\
1.250\end{array}$ & $\begin{array}{l}1.200 \\
1.600 \\
1.600\end{array}$ & $\begin{array}{l}119,4 \\
158,7 \\
149,3\end{array}$ & $\begin{array}{l}7.000 \\
5.000 \\
5.000\end{array}$ \\
\hline 1.250 & 1.600 & 158,7 & 5.000 \\
\hline 1.250 & 1.600 & 158,7 & 7.000 \\
\hline 1.250 & 1.600 & 158,7 & 5.000 \\
\hline $\begin{array}{l}1.250 \\
693,6 \\
200 \\
397\end{array}$ & $\begin{array}{r}2.600 \\
1.434 \\
594 \\
1.000 \\
400\end{array}$ & $\begin{array}{r}258,1 \\
119,4 \\
49,4 \\
99,2 \\
39,3\end{array}$ & $\begin{array}{l}7.000 \\
4.000 \\
3.500 \\
3.000\end{array}$ \\
\hline
\end{tabular}

Tres curutos de la Iglesia Matriz, cada uno ..... 1 Dicho de piezas ... .. 2 Sacristías de dicha Iglesia ............

San Roque ... ... ...

San Benito y Santa Bárbara ... ..........

Santiago y Copacabana. San Juan y San Martín. San Pedro y San Francisco el Chico .......... Concepeión y San Cristóbal .............

San Pablo y San Sebastián ...........

San Bernardo y San Lorenzo ............ Chulchucani ........

Tarapaya ........

Salinas ... ........

Capellanía de la Cárcel.

\section{CURATOS DEL, PARTIDO DE CHAYANTA} Laimes de Chayanta ...
Chayantacas de Chayanta $\ldots \ldots \ldots \ldots$ Micani $\ldots \ldots \ldots \ldots$ Uruicarasi $\ldots \ldots \ldots$ Aymaya ... ....... Panacachi $\ldots \ldots \ldots$. Moscarí ............. San Pedro de Buenavista $\ldots \ldots \ldots \ldots \ldots$ Moromoro ......... Sacaca ........... San Juan de Acacio ... Pitantora ......... Macha........... Chairapata ........ Miraflores $\ldots \ldots \ldots$

Surumi $\ldots \ldots \ldots \ldots$

Pocoata ... .........

Aullagas ... . . ... .

Chayala .........

Guaycoma ........

$\begin{array}{lrll}800 & 2.400 & 289 & 5.200 \\ 800 & & & \\ 1.093,6 & 2.400 & 239 & 5.200 \\ 1.075,5 & 2.000 & 198,3 & 5.000 \\ 1.093,6 & 1.200 & 119,4 & 5.000 \\ 1.093,6 & 1.200 & 119,4 & 5.000 \\ 1.093,6 & 1.200 & 119,4 & 1.200 \\ & 1.200 & 119,4 & 5.000 \\ 1.093,6 & & & \\ 1.093,6 & 1.600 & 158,7 & 7.000 \\ 1.093,6 & 2.000 & 198,3 & 4.500 \\ 703 & 1.500 & 149,3 & 7.000 \\ 546,7 & 800 & 78,7 & 5.000 \\ 546,5 & 2.000 & 239 & 6.000 \\ 546,5 & 900 & 89,5 & 3.500 \\ 546,5 & 900 & 89,5 & 3.500 \\ 546,5 & 750 & 79,2 & 1 / 2 \\ 546,5 & 750 & 79,2 & 2.400 \\ & 1.800 & 179,2 & 2.400 \\ 546,5 & 1.000 & 92,2 & 4.000 \\ & 1.800 & 179,2 & 1.600 \\ & 1.400 & 138,5 & 4.000 \\ & 1.600\end{array}$

CURATOS DEL PARTIDO DE LIPEZ

San Antonio . . . . ...

San Cristóbal .........

Llica y Tagua ... ......
350
1.093 .6
700

700

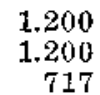

1.200
1.200
717

119,4

119,4

59,6 
CURATOS DEL PARTIDo DE PORCO

\begin{tabular}{|c|c|c|c|c|}
\hline & Sinodos & Valores & $\begin{array}{c}\text { Mesadas } \\
\text { Eclas. }\end{array}$ & $\begin{array}{l}\text { Ultimos } \\
\text { valores. }\end{array}$ \\
\hline Porco $\ldots \ldots \ldots \ldots$ & 546,7 & 1.200 & 119,4 & 2.500 \\
\hline Coroma $\ldots \ldots \ldots \ldots$ & 390,5 & 1.200 & 110,4 & 5.000 \\
\hline Puna $\ldots \ldots \ldots \ldots$ & $1.093,6$ & 2.500 & 244 & 8.000 \\
\hline Otavi $\ldots \ldots \ldots \ldots$ & 200 & & & \\
\hline Tomave ......... & $1.093,6$ & 1.200 & 119,4 & 6.000 \\
\hline Yura $\ldots \ldots \ldots \ldots$ & $1.093,6$ & 1.000 & 99,2 & 4.500 \\
\hline Potobamba $\ldots \ldots \ldots$ & 466,6 & 1.200 & 119,4 & 4.000 \\
\hline Siporo $\ldots \ldots \ldots \ldots$ & 456 & 800 & 78,7 & 2.500 \\
\hline Turuchipa $\ldots \ldots \ldots$. & 483 & 1.200 & 119,4 & 3.500 \\
\hline Pocopoco $\ldots \ldots \ldots \ldots$ & 472,1 & 800 & 78,7 & 3.500 \\
\hline Mataca la Alta $\ldots . .$. . & $57 \mathrm{t}, 6$ & 1.200 & 119,4 & 3.500 \\
\hline Mataca la Baja ... ... . & 604,4 & 1.200 & 119,4 & 3.500 \\
\hline Theobamba $\ldots \ldots \ldots$ & 625 & 2.0010 & 198,3 & 4.000 \\
\hline Tínguipaya $\ldots \ldots \ldots$ & $1,093,6$ & 1.200 & 119,4 & 8.000 \\
\hline Toropalca $\ldots \ldots \ldots$ & 945,2 & 2.000 & 198,3 & 4.000 \\
\hline Caiza $\ldots \ldots \ldots \ldots$ & $617,11 / 2$ & 1.400 & 138,5 & 6.000 \\
\hline Bartolo $\ldots \ldots \ldots$ & 698,6 & 800 & 78,7 & 4.500 \\
\hline Miculpaya . . . . . . . & 538,4 & 1.000 & 99,2 & 4.000 \\
\hline Chaquí $\ldots \ldots \ldots$ & $1.093,6$ & 2.000 & 198,3 & 6.000 \\
\hline
\end{tabular}

\section{CURATOS DEL PARTIDO DE CHICHAS Y TARIJA}

Santiago de Cotagaita..

Talina ...........

Tupiza ............

San Lorenzo de Tarija.. Concepción de Tarija ... Chaguayo .......... San Bernardo de Tarija . Chocaya o Tatasi ....... Calcha ............ Sacristía de Tarija ....

$\begin{array}{rr}937,4 & 2.000 \\ 466,4 & 1.400 \\ 468,4 & 600 \\ 1.003,6 & 800 \\ 546,5 & 420 \\ 546,5 & 420 \\ 1.093,6 & 800 \\ 1.093,6 & 1.600 \\ 937,4 & 1.400 \\ & 600\end{array}$

198,3
138,5
59,6
78,7
35
35
78,7
158,7
138,5
50

6.000

4.000

4.500

4.000

2.000

2.000

4.000

5.000

4.000

\section{CURATOS DEL PARTIDO DE ATACAMA}

$\begin{array}{lllll}\text { San ledro de Atacama . } & 800 & 800 & 78,7 & 3.500 \\ \text { San Franciseo Chiuchit . } & 800 & 800 & 78,7 & 3.500\end{array}$

Demostrado ya el rúmero $y$ entidad de los Curatos, que abraza esta Villa y Provincia de Potosí, se previene que todos los Beneficios que no disfruta el Sínodo entero de 1.093 peros 6 reales lo goza predial en las respectivas haciendas de españoles, que tienen indios yanaconas. El de Coroma del Partido de Porco, goza a más del que señala este estado un $16 \%$ sobre los Juros que reconoce la Caja General de Censos en las tierras de Aullagas y Uruquilia, y haciéndose esta satisfacción por las Reales Cajas de Clucuisaca de orden del Juzgado, se ignora su importancia.

También se adyierte que el presente estado lo he arreglado a la propia Mesada Eclesiástica, que hasta ahora se cobra con sujeción a los Aranceles antiguos, que manifiestan el valor de la segunda linea; el que expresa la cuarta resulta de una certificación que dieron los Ministros de esta Contaduría Principal, con fecha de 12 de diciembre de 1770. Y aunque la contemplo ajustada al verdadero valor de los propios Beneficios, a diferencia de los Curatos de la Villa, por la decadencia a que han 
venido en el genexal; pero como dicha Mesada Eclesiástica se ha deducido por los valoxes antiguos, y los modernos, no han tenido efecto, sin embargo de las repetidas Reales Cédulas expcdidas a éte fin, se podrá conseguir al presente por las certificaciones que por punto general se han pedido a los Curas, con el estableciniento de Intendencias.- Potosí, 10 de julio de 1785.

Nota. - Esta memovia de valores y el respectivo cómputo de la Mesada, está en todo conforme a la que se hizo en Charcas a 8 de mayo de 1634 , por el Licenciado Don Martín de Arriola, Oidor de aquella Audiencia, por Dor AJejo de Benavente Solis, Canónigo, Maestre de Escuela, y por el Contador oficial real Miguel de Aguirre, de orden del señor Presidente Vice-patrono Don Juan de Carvajal y Sande; y allí consta que los Curatos de la Concepción y San Cristóbal eran de frailes mercedarios; San Pedro y San Franciseo, de los dominicos.

\section{E S T A D O}

No. 6.

Del número de Partidos, Repartimientos, Ajcabalas, Tributarios, Enteros y Pobladores de la Intendencia de Potosí:

\begin{tabular}{|c|c|c|c|c|c|c|}
\hline Provincias: & Chayanta, & Porco, & Chichas, & Lipez, & Atacama, & Tarija. \\
\hline $\begin{array}{l}\text { Repartimientos ... } \\
\text { Aleabalas . . . . . } \\
\text { Tributarios antiguos } \\
\text { Tributarios moder- }\end{array}$ & $\begin{array}{r}92.655 \\
3.706 \\
6.118\end{array}$ & $\begin{array}{l}76.365 \\
3.054,4 \\
4.162\end{array}$ & $\begin{array}{r}82.350 \\
3.294 \\
2.895\end{array}$ & $\begin{array}{r}19.800 \\
792 \\
521\end{array}$ & $\begin{array}{r}24.650 \\
886 \\
482\end{array}$ & \\
\hline $\begin{array}{l}\text { nos ... . . . . } \\
\text { Enteros antiguos .. } \\
\text {-Enteros modernos . } \\
\text { Pobladores ... . }\end{array}$ & $\begin{array}{r}8.684 \\
46.355 \\
61.114 \\
54.638\end{array}$ & $\begin{array}{l}6.962 \\
35.232,11 / 4 \\
57.235,1 \\
31.712\end{array}$ & $\begin{array}{l}2.903 \\
20.686,1 \\
18.698,5 \\
18.000\end{array}$ & $\begin{array}{r}910 \\
3.647 \\
6.370 \\
3.864\end{array}$ & $\begin{array}{r}729 \\
4.862 \\
7.184 \\
3.657\end{array}$ & \\
\hline
\end{tabular}

Sumas totales: Repartimientos: 295.820; Alcabalas: 11.732,4; Tributarios antiguos: 14.178; Tributarios modernos: 20.188; Enteros antiguos: 110.782,2 $1 / 4$; Enteros modemos: 150.601,6; Pobladores: 171.371 .

Nota. - Antiguamente estaba unido Tarija a Chichas y se reputa que los tributos de Tarija suben a 6.000 pesos; sus pobladores entre españoles y demás castas son de 50 a 60 mil almas. Los pobladores numerados en los deruás Partidos son todos indios $\mathrm{y}$ se pueden agregar $10 \mathrm{mil}$ almas entre españoles y cholos, que no se han matriculado. Fn Potosí y su jurisdicción $f_{1 a y} 35$ mil almas y entre yanaconas y criollos, que tampoco se han numerado, pagan de tributos 6.646 pesos.

Pobladores de los seis Partidos . . . . . . . . . . . . . . . . . 171.871

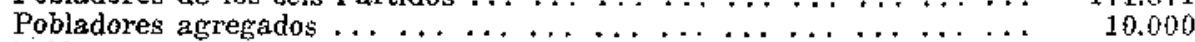

Pobladores de la Capital y su Distrito $\ldots \ldots \ldots \ldots \ldots$

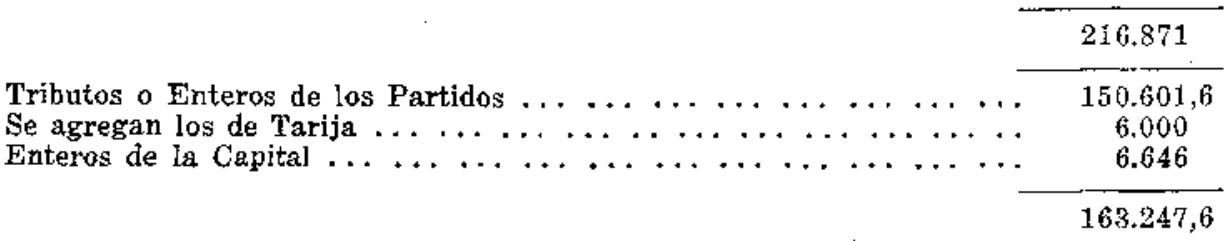

Nota. Se rebajan de esta cantidad los pesos correspondientes al $4 \%$. $\quad 6.529$

Quedan líquidos para el Rey. . . . . . . . . $156.718,6$ 
Fin I Parte]

\section{ESTADO GENERAL}

No. 7 .

Que manifiesta todas las entradas y valores que han tenido los Ramos de la Real Hacienda de estas Reales Cajas principales de Potosí en los diez años que se mencionan.

\begin{abstract}
Años:
Niezmos y eolos

Iliermos da $\ldots \ldots, \ldots, \ldots$.

2 o:o del wo ....... licaless tributos ... ... Ofieirs ventibles ..... Alenbalis $\ldots, \ldots . .$. Minas Estacks ...... Sitios solnues ........ Donativos .......... . Payel sellado ....... Arogues en general ... . Naipes $\ldots \ldots \ldots \ldots$ Cruzada .......... Lanzas $y$ medias anatas Monte de Ministros ... Monte milits . . . . . Tempomalidudes ... ... 5 ojo de Sínodos...... Alcunces de cuentas... Jeudis antikras y moderuat $\ldots, \ldots, \ldots, \ldots$
\end{abstract}

1782

Diezmos y rolos ..... da ... de jhata ......

8 olo det oro .......

Peales tributos ... ...

Oficios vendibles ... ...

Alcabalas .........

Minas Wstacus ........

Silios solarirs ........

Donutivos ... . . . . .

Pnpel sellado .......

Arogues en frenetal ...

Najpes $\ldots \ldots, \ldots, \ldots$

Cruzada ... . . . . .

Lauzas y medias angtas

Monte de Ministros ...

Monte militar ... ....

Temporalidades ......

5 olo de Sínodos .....

Alesrces de cuentas ...

Jeudas antiguas y mo-

dernas ...., .....

1777

1778

1779

1780

1781

\begin{tabular}{|c|c|c|}
\hline 800.676 .53 & $3.51,464,6$ & 315.003 .4 \\
\hline ت1, 告 & 68.00 .5 & $785.71 / 4$ \\
\hline 19.4 & 1.300 .6 & 4.276 .2 \\
\hline 79.803 .7 & 75.209.2 & 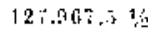 \\
\hline $1.8+1,7 \leqslant$ & $1,721,51$ & 1.230 \\
\hline 4.4 .228 .1 & $42,393,6$ & 47.620 \\
\hline \multicolumn{3}{|l|}{$2: 315$} \\
\hline $2 i$ & & 170 \\
\hline 2.639 .5 & 3.679 .6 & $2.632,11$ \\
\hline \multirow[t]{2}{*}{$19 \times .804 .31$} & $108.295,1$ & 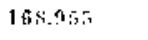 \\
\hline & 2.000 & \\
\hline 4.67 it. & 4.617 .318 & $6.837 .51 / 4$ \\
\hline $1.576,5$ & 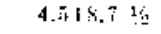 & $1.4 \pi \cdot 1.6$ \\
\hline 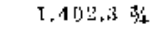 & 273.2 & ai, $5 / 2$ \\
\hline $11.067,1 / 2$ & 10.601 .3 & $7.964,41 / 4$ \\
\hline $3.085 .1 t^{t / 4}$ & $2.469 .5 \stackrel{1}{: 2}$ & 2.464 .1 \\
\hline
\end{tabular}

1783

1784

330.190 .2

$781,71 / 2$

6.103 .6

$159.366,2$

647.6

71.140

850

1.262

$136.592,21$

1. 791,1

426,4

45,8 : 19

8.897, ]

$2.857,7 \frac{1}{4}$

$227, \quad 2$
$400.234 .31: 87.969 .2$

271.4

$5.181,51$,

$128,6 \$ 1,1$

153, $1 / 2$

$92.108,614$

93

1.625 .7

$149.144 .1 \%$

3.157 .21

$748, \quad 1 / 2$

48,4

8.757 .516

$2.361 .3 \%$

308,1
$2.409,4 \%$

$4.643,2$

109.733. 1/2

34, $1 / 2$

$00.028 .3 / 4$

400

170

250

$1.392,41 / 4$

134.735 .1 1.

$1,464,4$

$0.258,61 / 6$

$1.03 \mathrm{G}, 1 \mathrm{~L}$

52,4

$10.540,43 / 4$

$2.577 .7 \%$

535.13
1785

1736

400.062 .1 t/2 $829.109,2$

\begin{tabular}{|c|c|}
\hline 800.4 & $43 ; 1$ \\
\hline$\pi .618,1 \quad 1 / 3$ & $5.378,5$ \\
\hline 8.5 .551 .5 & $123.032 .31 / x$ \\
\hline 799,3 & 758.7 \\
\hline $64.967,6 \mathrm{r} / 4$ & $45.062 .2 \mathrm{I} / 2$ \\
\hline 50 & 5500 \\
\hline \multicolumn{2}{|l|}{196,1} \\
\hline & 2.000 \\
\hline $1,735.21 / 2$ & $3.383, \quad 1$ 任 \\
\hline \multirow[t]{2}{*}{2.500} & 73.250 .5 \\
\hline & $3.295,6$ \\
\hline $6.95 \pi 5,31 / 4$ & $2.757,2 \%$ \\
\hline 1.491 .738 & $456,1 x_{4}$ \\
\hline $78, \quad 1 / 2$ & 45,316 \\
\hline $9.765,71 / 8$ & $9.599,3$ \\
\hline $2,1 \times 1,6$ & $2.540,1$ \\
\hline $439.41 / 2$ & 223 \\
\hline
\end{tabular}

$851.757 .7 \%$

$332.507,1$

L:1 10,2 1/2

$4.449 .51 / 2$

$133.054,7$

241,3

$125.338 .4 \%$

ก0 00

25

1.795 .6

97.530 .2

1.338 .5

600

110.180 .5

816.6

$1.895,41 / 2$

$525.21 / 2$

56

8.833 .4

$2.489 .11 / 2$

500

1.033,

$625.21 / 2$

46,216

$7,045,6$

$2.409 .11 / 2$

$723.41 / 2$

$9.398 .31 / 2 \quad 12.82 \pi, 41 / 6$ 
Totales: Total de entradas por los anteriores Ramos en:

$$
\begin{aligned}
& 1777: \\
& 1778: \\
& 1779: \\
& 1780: \\
& 1781: \\
& 1782: \\
& 1783: \\
& 1784: \\
& 1785: \\
& 1786:
\end{aligned}
$$

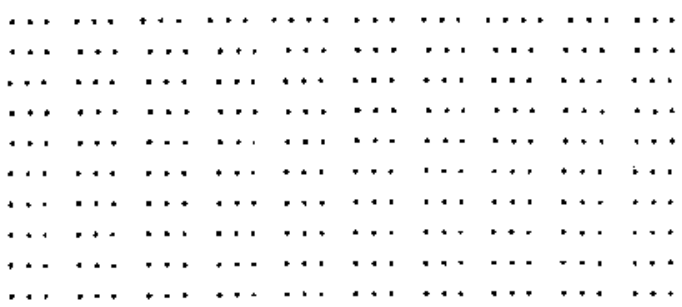

Total general
$379.609,67$ $697.844,5 \%$ $723.439,7$ 1/2 $588.093,61 / 4$ $601.484,6 \quad 6: 8$ $741.688,3$ $792.875,6$ 3is $784.730,3$ 棌 $740.863,23 / 4$ 733.983, 地

$7.144 .614 .1 \%$

Total de entradas según clasificación de lamos en los diez años:

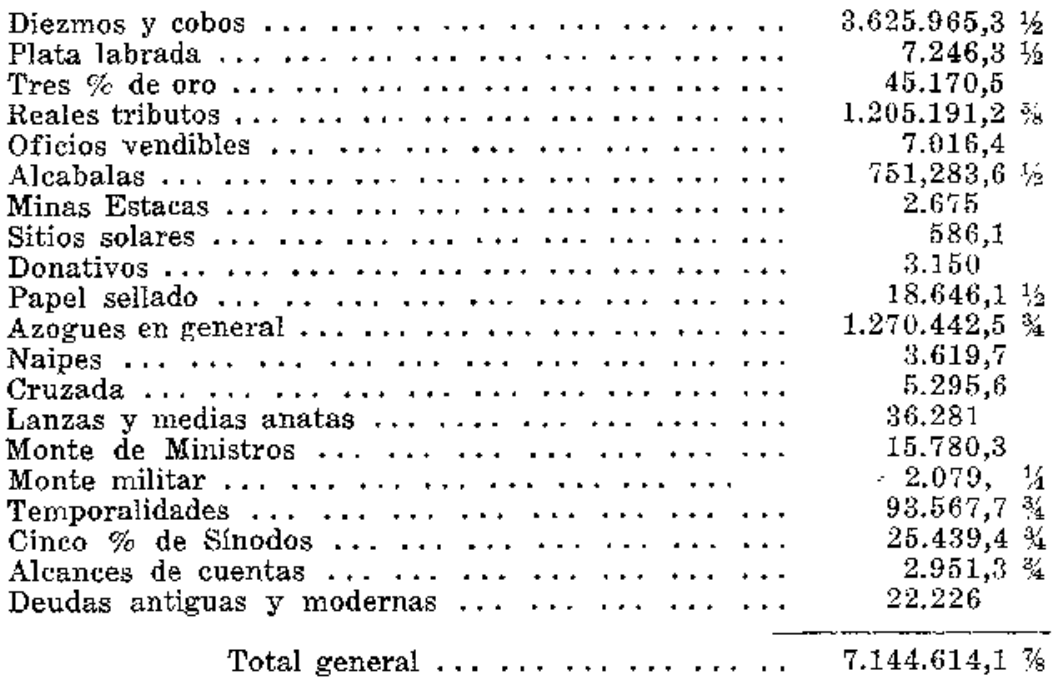

Según parece de las sumas Totales del presente Estado inportan los valores de los Ramos que se expresan en los 10 anteriores años, la cantidad de $7.144 .614,1 \%$, advirtiéndose que van reunidos los Ramos de Azogues del Almadén y Guancavelica, como asimismo el nuevo impuesto de Alcabalas, a causa de que la Administración de este Ramo en los enteros, que hace en esta Tcsorería Principal, no los distingue. Y para que conste de pedimento verbal del Señor Doctor Don Pedro Vicente Cañete, Abogado de las Reales Audiencias del Reino y Teniente Asesor de esta Intendencia, lo firmamos en esta Contaduría Principal de Potosí, en 23 de julio de 1787.- Fermín de Aoiz. - Lamberto de Sierra.

Nota. - Porque el presente Estado sólo manifiesta los'Valores gue han tenido los Ramos de Hacienda Real sin descuento de las Pensiones que anualmente reconoce esta Tesorería Principal de nuestro cargo, se advierte que cstas dichas Pensiones suben a la cantidad de 77.103 pesos $1 / 2$ real al año en esta forma: $\operatorname{los} 26.619$ pesos 6 reales por sueldos del Señor Gobernador Intendente, su Teniente Asesor; estos Ministerios y sus Dependientes, Secretario de la misma Intendencia, Alcaldes Veedores del Cerro y otras diversas cargas 49.783 pesos 2 y $1 / 2$ reales en Sinodos de 62 piezas ecleciásticas, y los 700 pesos restantes los sufre el Ramo de Temporalidades a favor de su respectivo Oficial, Escribano y Recolección de San Francisco de Chuquisaca.- Aoiz.- Sierra. 
No. 8 .

Er que se manifiesta la cntrada $y$ salida lotal por Ramos de Real Hacienda y particulares que ha tenido esta Real Aduana de Potosí: Del cargo de los senores Marqués de Santa Maria de Otavi, Administrador Tesorero, y Contador Don Joaquíu Dulón, desde $7 "$ de junio de 1779 , en que se estableció, hasta 31 de diciembre de 1786 . El cual se forma a pedimento verbal del señor doctor don Pedro Vicente Cañete, Teniente de Gobernador de la Intendencia de esta Provincia.

Cargo de las lintradas que cada Rano ha tenido desde $1^{\circ}$ de junio de 1779 hasta \$1 de dicienbre de 1786 .

Conceptos

Aleabalas de Castilla ... . Aleabalas de la tierra ... Contratos Públicos .... Almojarifazgo ....... Nucvo Inpuesto ....... Pulperías .......... . Alcabala del viento .... Alcabala de Repartimiento Manift. de esclavos .... Encabezonamientos ., .. Decomisos ......... Alcances de Ctas. ...... Partislas menudas ... . Depósilos $\ldots . . . . .$.

Conceptos

Alcabalas de Castilla ... Alcubalas de la lierra ... Contratos Píblicos ... .. Almojarifazgo , . . . . Nuevo Impuesto ......

Pulperiss ... . . . . . Alcabala del viento .... Alcabala del liepartimicrto ... ... ... ..... Manift. de esclavos .... Encabezonamientos . . . Decomisos .......... Alcances de Ctas. ... ... Partidas menudas ... .. Dopósitos ..........
1779

$12.184,3$

$19.987,4$

$3.507,4 \%$

322,4

300

3,246

$4.892,1 \%$

$670,61 / 2$

1783

$20.778,51 / 4$

$51.902,2$

$2.756,6$

593,7

500,0

$14.559,51 / 2$

369,6

250,0

$305,61 / 2$
1780

1781

1782

$$
\begin{aligned}
& 11.971,21 / 4 \\
& 45.870,41 / 4 \\
& 1.920,41 / 6 \\
& 1.726,11 / 2 \\
& 591,2 \\
& \\
& 2.551 \\
& 3.203,51 / 4 \\
& 1.922,2 \\
& 178
\end{aligned}
$$
$1.043,6$ $398,0 \mathrm{t} / \mathrm{s}$

1784

$6.873,5$
$30.575,1$
$2.692,1$

849,8
400
2.695
369,6
175

$10.628,4 \mathrm{H} / \mathrm{s}$ $51.336,11 / 2$ $2.605,51 / 2$ $736,3 \%$ 500 2.946 $1.688 .3 \mathrm{H} / 4$ 209 $152,31 / 4$ 337,2

425,1 $7,13 / 2$

1785

1786

$31.345,71 / 4$
$51.476,31 / 2$
$4.165,7$

$1.860,61 / 2$
500,0
63,0

$74.646,5 \quad 3 / 4$

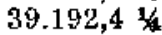

$2.425,614$

$72.882,2$

$45.525,7 \quad 1 / 2$

$4.010,0$

565,2

500,0

$7.563,0$

349,4

836,0 x/4

$4.442,5$

369,4

286,0

445,2

TOTALES: Alcabalas de Castilla ... ... . de 1779 a 1786

$241.311,3$

A]cabalas de la tierra ........

Coríratos I'úblicos ... ... ...

Almojarifazgo ... ... . . . .

Nuevo Impuesto ...........

Pulperias .............

Alcabala del viento ........

Alcabala de Repartimiento .....

Manifestaciones de esclavos ....

Encabezonamientos ... ......

Decomisos .............

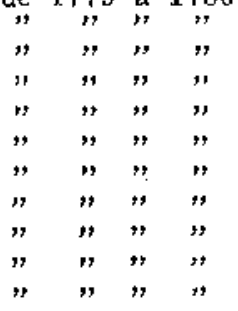


Alcances de Ctas. .......... " " " " "

TOTALES por los conceptos de entxadas, por cada año, coino sigue:

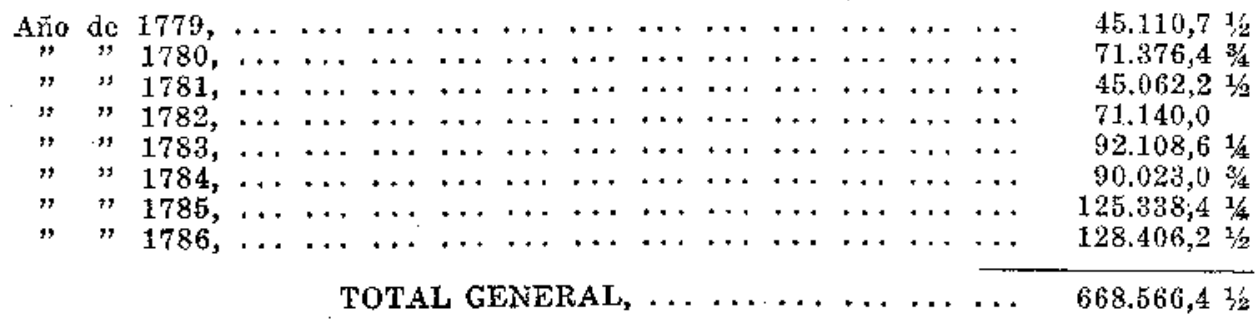

Data a cuenta de las entradas que cada Ramo ha tenido desde $1^{\circ}$ de junio de 1779 hasta 31 de diciembre de 1786 .

Conceptos

Alcabalas de Castilla ... Alcabalas de la tierra ... Contratos Públicos ... . Almojarifazgo ... ... . Nuevo Impuesto . . . . . Pulperías ........... Alcabala del viento ... . Alcabala del Repartimiento ... ... ... ..... Manifestaciones de esclavos .............

Encabezonamientos ....

Decomisos ... ...... Alcances de cuentas .... Partidas menudas ... . . Depósitos . . . . . . .

\section{Conceptos}

Alcabalas de Castilla ... Alcabalas de la tierra ... Contratos Públicos ..... Almojarifazgo ....... Nuevo Impuesto .. . . . Pulperías .......... Alcabala del viento ..... Alcabala del Repartimiento .............. Manifestaciones de escla$\operatorname{vos} \ldots \ldots \ldots \ldots$ Encabezonamientos $\cdots \cdots$ Decomisos ... ...... Alcances de cuentas ... Partidas menudas ... .. Depósitos ... . . . . . .
1779

$12.184,3$
$19.987,4$
$3.507,4 \quad 1 / 2$
$-\overline{22}, 4$
300,0
$3.246,0$

$4.892,1$ 1/2
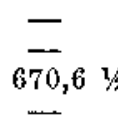

$\leftarrow$

1783

$20.778,51 / 4$

$45.930,21 / 2$ $2.756,6$

$5 \overline{35}, 3$

500,0

$14.559,5 \%$

1781

1782

\begin{tabular}{c}
$11.971,21 / 4$ \\
$45.870,41 / 4$ \\
$1.920,41 / 2$ \\
$1.726,11 / 2$ \\
591,2 \\
$2.580,71 / 4$ \\
$2.905,11 / 2$ \\
$1.922,2$ \\
178,0 \\
- \\
-0. \\
$1.043,6$ \\
\hline
\end{tabular}

1784

$31.345,71 / 4$

$40.481,4 \mathrm{~K} / 2$

$4.165,7$

$1.8 \overline{60}, 61 / 4$

500,0

63,0
$6.873,5$
$30.575,1$
$2,692,1$
- 8
400,0
$2.695,0$

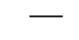

$\overline{175}, 0$

425,1

1785

$62.515,2 \mathrm{~s} / 4$

$31.181,31 / 4$

$2.435,61 / 4$

$5 \overline{65}, 2$

500,0

$1.588,0$

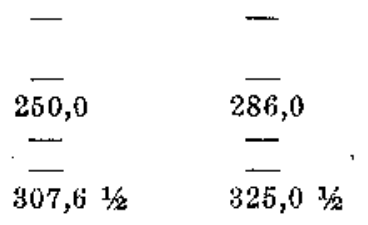

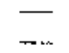

$7,1 \quad 1 / 2$

$10,628,41 / 2$

$51.336,1 \%$

+3. 605,5 1/2

$736,31 / 2$

500,0

1. 246,0

$1.389,73 / 4$

209,0

$152,3 \quad 1 / 4$ 337,2

1786

$27.604,21 / 2$

$31.619,2$

$4.010,0$

260,4

381,4

$\overline{421,2}$

$3 \overline{59,4}$ 


\begin{tabular}{|c|c|c|c|c|c|}
\hline Almojarifazgo $\ldots \ldots$ & $"$ & $"$ & $"$ & $"$ & $1.726,11 / 2$ \\
\hline Nuevo Impuesto $\ldots \ldots \ldots \ldots$ & $"$ & $"$ & $"$ & $"$ & $5.721,4$ \\
\hline Pulperias $\ldots \ldots \ldots \ldots \ldots$ & $"$ & $"$ & $"$ & $"$ & $3.081,4$ \\
\hline Alcabala del viento $\ldots, \ldots, \ldots$ & $"$ & $"$ & $"$ & $n$ & $25.928,4$ \\
\hline Aleabala del Repartimiento .. . & $"$ & $"$ & $"$ & $"$ & $9.187,2$ \\
\hline Manifestaciones de esclavos .... & $"$ & $"$ & $"$ & $"$ & $1.922,2$ \\
\hline Encabezonamientos $\ldots \ldots$ & $"$ & $"$ & $"$ & $"$ & $1.878,6$ \\
\hline Decomisos $\ldots, \ldots, \ldots, \ldots, \ldots$ & $"$ & $"$ & $"$ & $"$ & 670,6 \\
\hline Alcances de cuentas $\ldots \ldots \ldots$ & $"$. & $"$ & $"$ & $"$ & 152,3 \\
\hline Partidas menudas $\ldots, \ldots, \ldots$. & $"$ & $"$ & $"$ & $"$ & $2.439,0$ \\
\hline Depósitos $\ldots \ldots \ldots$ & $"$ & $"$ & $"$ & $"$ & 7,1 \\
\hline
\end{tabular}
como sigue:

TOTALES de la Data a cuenta de las Entradas de cada Ramo, por cada año,

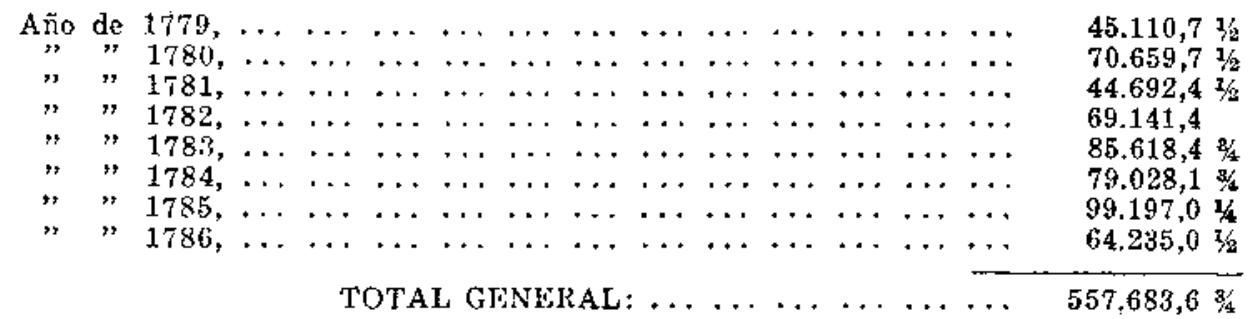

DEM OST RACION

Cargo total de la entrada desde $I^{\circ}$ de junio de 1779 , hasta 31 de di-

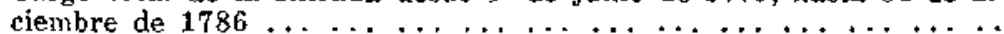
Data hecha en el referido tiempo ...................

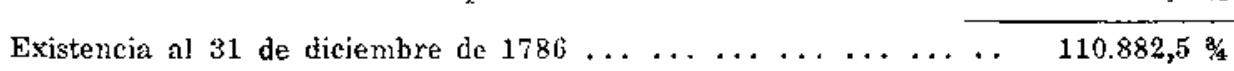

"Según se ve por este Plan, manifiesta cada Banco su entrada total y asimismo su correspondiente Data; y reunido el monto de cada uno, asciende la entrada que ha tenido el Banco de Alcabalas en general, desde $1^{*}$ de junio de 1779, en que se estableció esta Real Aduana, hasta 31 de dieiembre de 1786, la cantidad de 668.566 pesos, 4 y $\%$ reales, y la Data que ha habido en el referido tiempo, la de 557.683 pesos, 6 y $3 / 4$ reales, como se demuestra en la casilla última de los totales, y descontada la referida Data del expresado Cargo, resulta de sobrante líquido a favor de S. M., en fin del expresado mes y año: 110.882 pesos, 5 y $\% / 4$ reales, según se patentiza en la demostración que precede. Real Administración de la Aduana de Potosí, y julio 7 de 1787 ".

$$
\text { "Joaquín Dulón" (Hay una rúbrica.) }
$$

\section{DEMOSTRACION}

No. 9 .

De lo líquido que producen en un año los Ramos de Propios, Arbitrios y Sisa de la Villa Imperial de Potosi, y las Pensiones que tienen, según 
el Reglamento formado por su Intendencia, a 13 de abril de 1784 y Auto modificativo de 23 de diciembre del mismo, A SABER:

Los Propios, y arbitrios producen al año ... . . . . . .

4.100. 5

La Sisa se halla rematada en $\ldots \ldots \ldots \ldots \ldots \ldots$

7.000 .0

D $\mathbf{A}$ T $\mathbf{A}$

1.1.101), 5

Por asignaciones en l'ropios .......... 1.705. 0

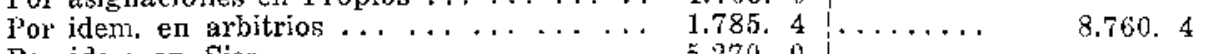

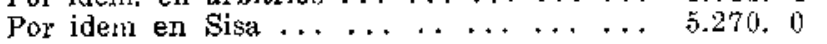

De esta demostración resulta, que ascendiendo las entradas de los Ramos expresados a once mil cien pesos, cinco reales anuales, y las Asignaciones a ocho mil setecientos sesenta pesos, cuatro reales, quedan líquidos dos mil trescientos cuarenta pesos, un real.

\section{I S T A}

No. 10.

De los Excmos. Sres. Gobernadores y Virreyes del Reino del Perú, desde el año 1534, en que se fundó la ciudad de Lima, hasta el de 1777 en que se erigió el Virreinato de Buenos Aires, agregando por territorio todo el Distrito de la Real Audiencia de Charcas y la Provincia de Cuyo, desmembrada del Gobierno de Chile.

\begin{tabular}{|c|c|c|}
\hline Años & $N^{\circ}$ & Nambres y Titulos \\
\hline 1534 & 1 & El Marqués Don Francisco Pizarro, Adelantado y Gobernador. \\
\hline 1541 & 2 & El Licenciado Don Cristóbal Vaca de Castro, Gobernador. \\
\hline 1545 & 3 & Blaseo Núnez Vela, Primer Virrey. \\
\hline 1546 & 4 & La Real Audiencia en vacancia. \\
\hline 1546 & 5 & $\begin{array}{l}\text { Don Pedro de la Gasca, del Consejo de la Inquisición, Presiden- } \\
\text { te Gobernador. }\end{array}$ \\
\hline 1550 & 6 & La Real Audiencia en vacancia. \\
\hline 1551 & 7 & Don Antonio de Mendoza, Virrey. \\
\hline 1552 & $\dot{8}$ & La Real Audiencia en vacancia. \\
\hline 1559 & 9 & Don Andrés Hurtado de Mendoza, Marqués de Cañete, Virrey. \\
\hline 1561 & 10 & El Conde de Nieva, Virrey. \\
\hline 1562 & 11 & La Real Audiencia en vacancia. \\
\hline 1564 & 12 & Fl Licenciado Lope García de Castro, del Consejo, Gobernador. \\
\hline 1569 & 13 & Don Francisco de Toledo, Virrey. \\
\hline 3581 & 14 & Don Martín Enriquez. \\
\hline 1583 & 15 & La Real Audiencia en vacancia. \\
\hline 1586 & 16 & El Conde de Villardompardo. \\
\hline 1590 & 17 & Don García Hurtado de Mendoza, Marqués de Cañete, Virrey. \\
\hline 1596 & 18 & Don Luis de Velasco, Malqués de Salinas, Virrey. \\
\hline 1604 & 19 & Don Gaspar de Zúniga, Conde de Monterrey, Virrey. \\
\hline 1606 & 20 & La Real Audiencia en vacancia. \\
\hline 1607 & 21 & El Marqués de Montesclaros, Virrey. \\
\hline 1615 & 22 & El Príncipe de Esquilache, Virrey. \\
\hline
\end{tabular}




$\begin{array}{ll}1621 & 23 \\ 1622 & 24 \\ 1629 & 25 \\ 1639 & 26 \\ 1648 & 27 \\ 1655 & 28 \\ 1661 & 29 \\ 1667 & 30 \\ 1672 & 31 \\ 1674 & 32 \\ 1678 & 33 \\ 1681 & 34 \\ 1689 & 35 \\ 1705 & 36 \\ 1707 & 37 \\ 1711 & 38 \\ 1716 & 39 \\ 1716 & 40 \\ 1716 & 41 \\ 1719 & 42 \\ 1724 & 43 \\ 1736 & 44 \\ 1745 & 45 \\ 1761 & 46 \\ 1766 & 47\end{array}$

La Real Audiencia en vacancia.

El Marqués de Guadalcázar, Virrey.

El Conde de Chinchón, Virrey.

Ef Marqués de Mancera, Virrey.

E. Conde de Salratiena, Virrey.

F.l Conde de Alba de Jjste, Virrey.

El Conde de Suntiesteban, Virrey.

El Conde de Lenus, Virrey,

La Real Audiencia en vacancia.

El Conde de Castelar, Virrey.

Don Melchor de Lillán y Cisneros, Arzobispo de Lima, Virrey.

El Duque de la Palata, Virrey.

El Conde de la Monclova, virrey.

La Real Audiencia en vacancia.

Fi Marqués de Castell-dos Rius, Virrey.

Dorn Diego Lutirún de Guevara, Obispo de Quito, Virrey.

Fl Excmo. Sr. Conde de Cueva, Gobernador militar.

Don F. Diego Morvillo, Arzobispo de Charcas, Virrey.

El Fríncipe de Santo Mono.

Don F. Diego Morcillo, Arzobispo de Charcas, Virrey.

El Marqués de Castel-Fuerte, Virrey.

Fi Hlarqués de Vega García, Virrey.

El Conde de Superunda, Virrey.

Don Manuel de Amat y Juniet, Virrey.

Don Manuel de Gurior, Virrey.

\section{Excmos. Señores Virreyes de Buenos Aires}

Don Pedro Zeballos, Capitán General de los Reales Ejércitos y de la Expedición del Río de la Plata, primer Virrey.

Don Juan José de Vertiz, Virrey.

Don Nicolás del Campo, primer Marqués de Loreto, Virrey.

Don Nicolís de Arredondo, Mariscal de Campo.

LISTA de los Corregidores que ha tenido esta Villa, desde su fundación, que fue el año 1545 , con la advertencia que sólo tuvieron el título de Alcalde Hayor los primeros que gobernaron, hasta el año de 1561 , en que comenzaron a intitularse Corregidores, después que el Excmo. Señor Conde de Nieva, le concedió el título de Villa, con términos $y$ jurisdicción, en Auto proveído en la cludad de Lima, a 7 de noviembre de 1561 .

$\begin{array}{lr}\text { Años } & N^{*} \\ 1545 & 1 \\ 1549 & 2 \\ 1553 & 3 \\ 1561 & 4 \\ 1563 & 5 \\ 1564 & 6 \\ 1565 & 7 \\ 1566 & 8 \\ 1567 & 9 \\ 1569 & 10 \\ 1571 & 11 \\ 1572 & 12 \\ 1575 & 13 \\ 1583 & 14 \\ 1584 & 15 \\ 1586 & 16\end{array}$

Nombres y Títulos

E1 Licenciado l'olo.

El Licenciado Esquivel.

Egas de Ciuzmán.

Don Juan Cortés.

El Licenciado Don Diegro Alvarez.

Don Gaspar de Saldaña.

Don Diego Pacheco.

Don Juan Pereira, Caballero de Santiago.

Don Gómez Chásez.

Don Jerónimo Luis de Cabrera.

Don Damián de la Bandera.

El General Marcelino.

El Licenciado Gómez Hernández.

Don Alonso Ortiz de Leiva.

Don Eulogio Alonso de Iñigo y Figueroa.

Don Pedro Sorez de Ulloa. 
Don Juan Ortiz de Zárate, de la Orden de Calatrava.

Don Alonso Vásquez de Avila y Arce.

Don Alonso García Ramón.

El Licenciado Juan de Ortiz de Lupidana, Oidor de Charcas.

Don Alonso de Osorio.

El Ljcenciado Narváez de Balde-Román.

Don Alvaro Patiño.

Don Pedro de Lodeña.

Don Pedro de Córdova Mejía, de la Orden de Calatrava.

Don Rafael Ortiz de Sotomayor.

Don Francisco Sarmiento de Sotomayor, de la Orden de Santiago.

Don Felipe Manrique.

El Factor Don Bartolomé Astete de Ullo:

Don Carlos Bazán, de la Orden de Calatrava.

Don Joseph Saenz de Lorduy, de la Orden de Alcántara. Don Juan Vásquez de Acuina, de la Orden de Calatrava. Don Juan Velarde y Triviño, de la Orden de Calatrava. Don Francisco Sarmiento de Mendoza, Oidor de Lima.

Don Gómez de Avila y Vargas, de la Orden de Calatrava. Don Francisco Godoy, Justicia mayor.

Don Gabriel Guerrero de Luna, de la Orden de Santiago.

Dùn Juan Jiménez de Lobatón, Oidor de Charcas.

Don Luis Autonio de Oviedo y Hererra, de la Orden de Santiago, Conde de la Granja.

Don Diego de Ulloa Pereira, de la Orden de Santiago.

Don Pedro Luis Enriquez, de la Orden de Calatrava, Conde de Canillas y de Forneros.

Don Fernando Torres Mejía, de la Orden de Calatrava, Conde đe Velayos.

Don Diego Manrique de Lara, de la Orden de Santiago.

Don Tomás Chacón Medina y Salazar, de la Orden de Calatrava. Don Juan Francisco Tirado de Cuenca, de la Orden de Calatrava. Don Manuel Villavicencio.

Don Joseph Fernández y Valdivieso y Arvizu.

Don Matías de Angles.

Don Pedro Prieto Lazo de la Vega, de la Orden de Suntiago.

Don Manuel Villavicencio y Granada.

Don Pedro Lazo de la Vega.

Don Manuel Urbano Camila.

Don Ventura Santelices y Venero, Oidor de Cádiz.

El Brigadier Don Jaime Sanjust.

Disn Jorge Escovedo y Alarcón, Oidor de Charcas y Visitador General del Rejno, por ascenso.

El Fiscal de Charcas, actual Gobernador y primer Intendente de la Real Hacjenda de Potosi, Don Juan del I'ino Manrique. Don Francisco de Paula Sarz, Superintendente General que fue en Buenos Aires.

FIN DE LA PARTE PRIMERA 
PARTE SEGUNDA 



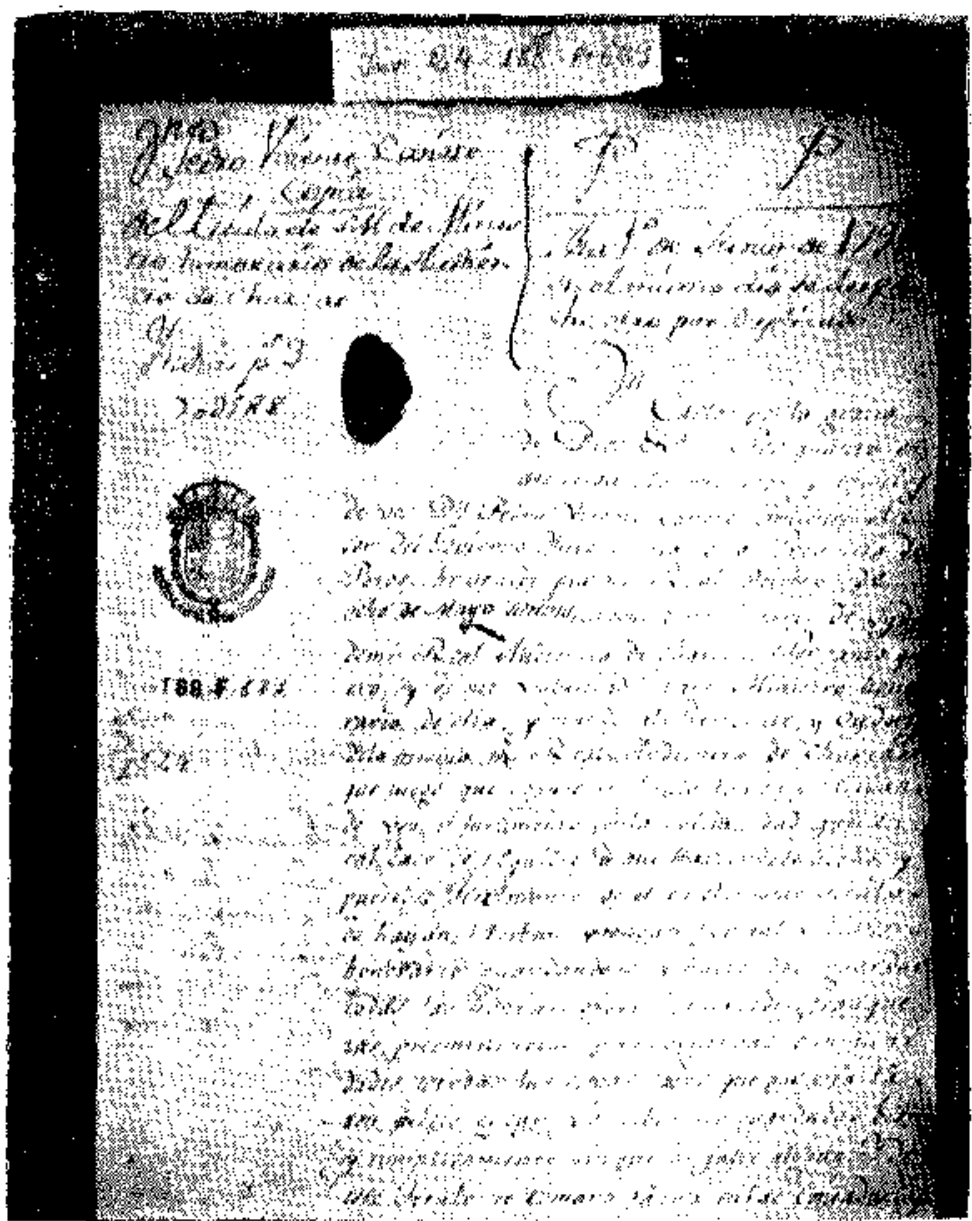

Página primera del nombramiento de Ministro Honorario de la Reral Audiencia de Charcas, hecho por el Rey a favor de Don Pedro Vicente Cañete y Domínguez. Año lle 179l. 
Inv. $21-188 \quad$ F 628

Dn. Pedro Vizente Cañete

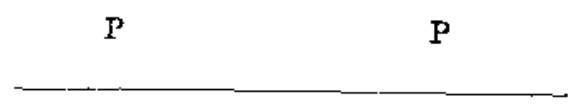

del título de S. M. de Minis

tro honorario de la Audien

Flia. $1^{\circ}$ de Junio de 1791

cia de Charcas.

Indias ps. 3

en di mismo tia se despa.

703588

cho otro por duplicado

Sello.

Archivo General

de Simancas.

188-F-623

I".24
Dn. CARLOS por la gracia de Dios \&a. Por cuanto en atención a los méritos y servicios de vos Dn. Pedro Vicente Cañete, Teniente Ase sor del Govierno Intendencia de la Provincia de Potosi, hé venido por $\mathrm{mi}$ Real Decreto de ocho de Mayo último, en concederos honores de Oydor de mi Real Audiencia de Charcas: Por tanto qui ero, $y$ es mi voluntad seais Ministro hono rario de ella, y mando al Presidente, y oydores de la misma mi Real Audiencia de Charcas, que luego que vean este Título tomen y recivan de vos el juramento, con la solemnidad que ert tal caso se requiere, $y$ que haviendole hecho, $y$ puestose Testimonio de él en el mismo Título os hayan, reciban, $y$ tengan por tal Ministro honorario, guardandoos, y haciendoos guardar todas las honras, gracias, mercedes, franque zas, preeminencias, prerrogativas e inmunidades, y todas las demas cosas que por esta ra zon debeis gozar, $y$ os deben ser guardadas bien $y$ cumplidamente sin que os falte alguna. $Y$ de este Título be tomará razon en las Contadurías 


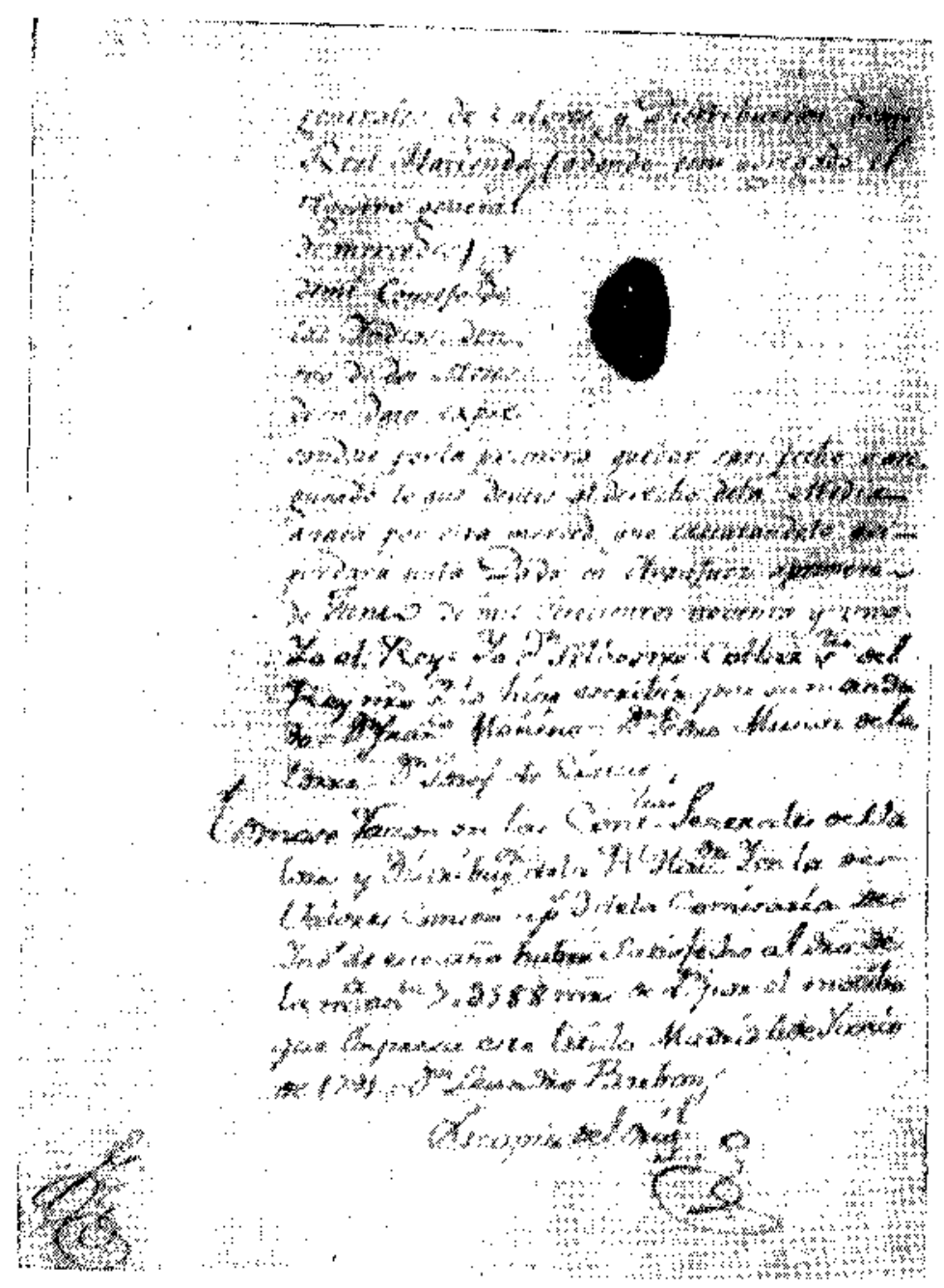

Segunda página del nombramiento de Ministro Honorario de la Real Auriencia de Charcas, a favor de Don Pedro Vicento Cañcte y Domínguez. Año de 1791 . 
generales de valores $y$ Distribución de mi Real Hacienda ( adoncle está àgregado el registro general

de mercedes $y$

de mi Consejo de

las Yndias, den

tro de dos Meses

de su data, expre

sandose por la primera quedar satisfecho 0 asegurado lo que deveis al derecho de la Media anata por esta merced, $y$ no executandolo asi quedará nula. Dada en Aranjuez a primero de Junio, de mil Setecientos noventa y uno. $Y_{0}$ el REY -- Yo Dn. Silbestre Collan Stio. del Rey nt" Sor. lo hize escribir por su manda do.-- Dn. Franc" Monino.-- Dn. Pedro Muñoz de la Torre.- Dn. Josef de Cistue.

Tomose Razon en las Contias. Generales de Va lores $y$ Distribuon. de la $\mathrm{R}^{\prime}$. $\mathrm{Haz}^{\mathrm{da}}$. Y en la de Valores Consta a p 3 de la Comisaría De Inds de este año haber satisfecho al dro de la $\mathrm{m}^{4}$ anta. $703588 \mathrm{mrs}$. (ie $\nabla^{n}$. por el motibo que expresa este Título. Madrid 6 de Junio de 1791... Dn. Leandro Borbon.

Es copia del origl.

Rúbrica

Rúbrica. 


\title{
DISCURSO PRELIMINAR
}

\author{
o

\section{CAPITULO PRIMERO}

Del Gobierno antiguo de la Villa Imperial de Potosí

Se explica el estado politico y civil de la población y de las cinco Provincias agregadas a esta Intendencia, durante el mando de los Corregidores; al mismo tiempo se upuntan algunas advertencias importantes para el sistema del Gobierno reformado. 
$-1$ 


\section{Del Estado Politico y Civil de esta Villa, durante el Gobierno de los Corregidores.}

\section{$\boldsymbol{E}$}

nos, que son: labradores, artesanos y mercaderes. Los primeros hacen nam cer las produeciones; los otros dan a las materias primeras nuevas formas, que sobre hacerlas a propósito para diversos usos, les dan también cierto valor que antes no tenín, $y$ los ultimos las hacen circular, $y$ sirven para acarrearlas desde el productor al consumidor, hallando en el salario que se concede a su trabajo, una parte mayor si hay menos concurrentes y menor si hay muchos.

Los primeros, labradores, regularmente tienen la propiedad de todas las tierras; pero como éstas se van dividiendo entre los hijos a medida de las generaciones, hasta llegar a tal punto que las porciones repartidas no alcanzan ya para la subsistencia de aquellos en quienes hubieren recaido, o se pasan por venta a manos de otro labrador más inteligente, activo, económico y aplicado; porque el primer propietario se vio obligado a venderlas por disipador o negligente, vienen todas ellas o la mayor parte, al cabo de la revolución de algunos años, a parar en otros propietarios ricos, $o$ en mercaderes y artesanos, que en el negocio, en la economia $y$ en las nuevas invenciones de trabajos, han enriquecido haciendo grandes ganancias y ahorros.

Estos grandes propietarios por lo general arriendan sus posesiones a un asentista, que haya de velar en el cultivo. Para gozar de mas quietud y mayores comodidades se van apartando de ellas poco a poco, para juntarse en las cercanias de los mercados, a fin de acudir más pronto a cuanto necesitan. Este concurso atrae y fija en semejante lugar a los artesanos y mercaderes de todas jerarquías, y de todos ellos se forma una ciudad. Lo restante del campo se puebla de heredades, y a ciertas distan- 
cias se van formando lugares donde habiton labradores, jornaleros, artesanos y arrieros que se ocupan en los trabajos de transportes de las moducciones del campo.

En nuestras Amóricas raro es el pueblo que haya tenido tan feliz principio. Mucho pudieva prodrcir acerea del onigen y forma de estas poblaciones; pero siendo mi objeto esta Villa. me concretaré a olla sola, para que se distinga el diferente interés por qué se congregaron sus primeros pobladores, de lo que sucede en lo general de las demas poblaciones.

Segun vimos en la historia dol descabrintento de los minerales de este Cerro Rico de Potosí, luego que se divulgó la fama de su inmensa abundancia, se vinieron de tropel casi todos los vecinos que habitaban en el Mineral o Asiento de Poreo. Lo. más acaudalados pidieron registros en las nuevas vetas descubiertas pare trabaialas; otros concurrieron al olor de las riquesas pare bustutas en el Cerro; los demás se juntaron a ofrecerse al jornal, no lanto por el salario. como por lo que en semejantes ocasiones se les nega del trabajo, $y$ a la medida de esta concurrencia, fue la de los artesanos y meraderes; de suerte que a poco tiempo, después del año de mil quinientos cuarenta y cinco, en que acaeció el descubrimiento, fue esta población una de las más numerosas en estos contornos; pero no fue por entonces más que wn Asiento de Minas, dependiente de la jurisdicoión af La. Plata, como situado en su territorio, del mismo modo que lo es ahora resperto de l'otosi al Mineral o Asiento de Aullagas en el Partido de Chayanta.

En ese tiompo todavia no se habian formado las Ordenanzas de Minas, no se había establecido la Mita, ni estaba formalizado el Gobierno politico de nuestras poblaciones con el buen orden y economía que se estableció después que la experiencia advitió las leyes que debian dictarse para su régimen. Por esto estuvo reducido el mando de la población por muchos años a un Alcalde Mrowo o Jue comisionalo por el Corregidor de La Plata. La limitada autoridad que residia en él y la dependencia de otra jurisdicción distante, hicieron deseudar todos los objetos dignos de la Policía, $y$ se fijó siempre toda la atención en telar sobre el cultivo de las minas por el atractivo de sus riquezas.

Luego que advirtioron los vecinos que al mineral rendia sus producciones con la misma abundancia que al principio, y que mostraba seria permanente y capaz de prover a lo largo la subsistencia de la población, solicitaron erigirla en Villa, exenta de la jurisdicción de La Plata, ante el Sr. Conde de Nieva, tercer Virrev de Lima (a) y Ministros del Consejo, comisarios residentes en aquella capital, para los asuntos de conquista y poblaciones de estos Reinos, of reciendo por esta gracia el respectivo donativo a S. M., en la cantidad que se concertase.

El Señor Don Felipe Segundo, en Real Cédula dada en Valladolid, a diez y ocho de agosto de mil quinientos cincuenta y nueve, por la Princesa, nuestra Señora, insertando otra anterior de Crante, a veintitrés de julio del mismo año, tenía conferido al expresado Señor Conde de Nieva, junto con el Licenciado Birviesta de Muñatones, del Consejo Real $y$ de la Cámara, y a Don Diego de Vargas Carvajal, sus Reales poderes generales $y$ amplísimos para hacer $y$ proveer todo aquello que el mismo Rey podria hacer $y$ proveer de cualquiera calidad $y$ condición, que sea o ser pueda en estos Reinos, y dar sobve ello las Cédulas y Provisiones que con. vengan, en el Real nombre selladas con el sello de la Audiencia. 
En tirtud de lo cual, después do oidas las contradicciones de la ciulad de La Plata, $y$ on consideración do los servicios y lealtad de los vecinos, estantes y habitantes del Ariento de Potosí, se acordó en Auto prozeido on la ciudad de los Reyes, a siote de noviembre de mil quinientos serenta $y$ who, conceder el titulo de Villa con los téminos, jurisdicción y prizilegios que se refieren en la cléusula siguionte: ${ }^{1}$

"Queremos por hacer bien, y merced al dicho Aciento de Potosí, "que sea Villa, y se nombre, y llame la Villa Imperial de Potosí, exen" tándola y eximiéndola de la jurisdicción de la Ciudad de la Plata, dán" dolc término, distrilo y Jurisdicción por si, civil y criminalmente, me" ro, mixlo, imperio, bien así, y tan cumplidamente, como la tienen y ejer" cen les demás Ciudades, y Villas de estos Reinos, y que haya en ella dos "Alcaldes Ordinarios en cada un año, y tengan la dicha Jurisdicción los "que nombre y elija la Justleia, $y$ Regimiento de la dicha Villa; y que " haya cn la dicha Villa seis Regidores Cadañeros, y no haya más regi" dores, $y$ sean nombrados por la :Lasticia, y Regimiento cada año, $y$ el " tiempo de ser cadañeros los dichos regidores dure treinta y cuatro "años contados desde el año primero, que vendrá de mil quinientos se" senta y dos, y más lo que fuere la coluntad de $S . M$., porque pasados " los dichos lreinta y cuatro años, queda a $S$. M., el proveer los dichos "regimientos, perpetuos si bien le pareciere. Que se da a la dicha Villa " para propios de ella el oficio de la Pregoneria y la fiel Ejecutoria, y la " mitad del oficio de la correduria de Lonja ${ }^{2}$ perpetuamente, para que “ el Consejo, Justicia, y Regimiento goce para propios de la renta de los " dichos oficios de Pregonería $y$ mitad de correduria, $y$ nombre entre "si personas de su Cabilde que usen el oficio de fiel Elecutaria, como " se usa en esta (iudad de los Reyes, y conforme a las Ordenanzas, que "tienen, y se hicieren para ello por todo lo susodicho. El dicho Aciento " y Villa ha de dar a $S$. M., treinta mil pesos de plata ensayada y mar" cada, de los cuales, las personas que para ello contribuyesen, se han " de hacer pago de la renta que destinare la dicha mitad de corredu" ría de Lonja y Pregoneria que se da para propios de la dicha Villa".

En el mismo año de mil quinientos sesenta $y$ uno fue nombrado Don Juan Cortés para el Corregimiento de la Villa, con el titulo de Corregidor de Potosí y re la ciudad de La Plata, fijúndose aquí cl asiento principal de su residencia, aunque siempre se conservó por muchos años la formalidad de rectbirse los corregidores en el Cabildo de Chuquisaca, por incluise su territorio en la jurisdicción del propio Corregimiento. Todos los nombrados en adelante, por orden de la Planilla, que aparece en este libro, observaron lo mismö, porque la importancia de los negocios de este riquisimo Mineral, $y$ de la Mita, pedia que las minas del Corregidor fuesen personales para evitar los robos, injusticias y otros desórdenes consiguientes a la opulencia $y$ al concurso numerosisimo de gentes de tan diversas jerarquias.

En lo politico tenia el Corregidor la jurisdicción civil y criminal, que siempre han tenido y tienen los demás corregidores de los Reinos de Castilla e Indias. Como Justicit Mayor era superior a los Alcaldes $y$ demás Jueces de la Villa, y por la calidad de jefe y cabeza de ella, tenía la presidencia de su Ayuntamiento, con las demás facultades anexas a este empleo de que tratan largamente muchos de nuestros autores.

En materins de minas, mita, azogues y demás ramos de Hacienda, 
estaba reducida su autoridad a ciertas limitacioncs que la hacian en todo dependiente del Señor Firrey de Lima y de la Presidencia de Charcas. Para todo lo judicial y contencioso de minas habia un Alcalde Mayor,y para lo económico y directivo de cllas. en cunto a su consciración y buen orden en el trabajo, habian tres leedores subordinados al Corregidor como Visitador del Cerro.

La Superintendencia corría a cargo del Presidente de Charcas, y con este carâter venía a Potosi a visitar cada año las minas y molinos, 3 cuidando que las distribuciones de arognes se hicieran con toda igualdad y equidad, por cuya razón en todo lo perteneciente a Hacienda, cuya administración general por mayor tacaba al S\%. Firrey. y por menor a los Oficiales Reales, estaba el Corregidor obligado a consultar la Presidencia de Charcas y obrar ceñido a su voto y acuerdo. Aun en las fundaciones públicas tenía poca mano el Corregidor, y neccsitaba de la del Cabildo para poder obrar; porque como las cosas de Indias se miraban tan de lejos, como por un anteojo obscuro que apenas descubría el cuerpo sin discernimiento de sus partes, pareció conveniente no confiar a la persona sola del Corregidor negocios de tan grande importancia sin asociarlo con ol Ayuntamiento de la Villa.

Asi concurría el Cabildo por medio de dos Diputados a las visitas ordinarias de la Casa de Moneda, y él mismo tenía a su cargo el manejo $y$ dirección del Hospital, que el año de mil quinientos cincuenta y cinco se fundó en la calle de San Francisco. y en diecisiete de julio de mil quinientos cincuenta y seis se trasladó al sitio en que hoy se halla. Esta intervención dio lugar a que el Cabildo intentase obtener la regalía de su Patronato, no obstante que siempre habia residido en la Presidencia de La Plata; y fueron tan tenaces sus instancias y contradicciones, que no se pudo conseguiv la declaración de cste punto sino después de muchos años, a costa de crecidos costos. Esta partición de mandos ontsionó desde los principios los desórdenes que no ha podido remediar el tiempo ni el gobierno mejorado en nuestro siglo.

De aquí tuvo origen haberse fundado el Hospital en el centro de la población, a un lado de la Plaza mayor, sin considerar los inevitables daños que era forzoso padeciese la salud publica en el contagio de las enfermedades, además del inconveniente de haber de tropezar la vista de todos los moradores a cada paso que diesen en su traiín cconómico, con un espectáculo asqueroso y melancólico que abate los ánimos $y$ choca a la sociedad.

El mismo principio tu'o no haberse destinado sitio para la Iglesia Matriz, y siendo preciso situarla en la Plaza, la fabricaron algunos años después de la fundación del Hospital en un cantón estrecho de ella, al costado del Norte, con tan poca policía que una mitad del templo sobresale como un martillo, que, a más de afear el aspecto público, ocupa una gran parte de este lugar común, embarazando el comercio y demás operaciones económicas de la población.

El Señor Don Francisco de Toledo, caando tino a esta Villa el año de mil quinientos setenta $y$ uno, a visitar sus minas, formar Ordenanzas y poner en orden las demis cosas tocantes al gobierno de estos Reinos, halló establecida esta Villa de tal forma, que sólo podría mejorarse poblándola de nuevo, por lo que únicamente cuidó de formalizar su gobierno como objeto principal de los cuidados públicos. Proveyó Ordenan- 
a as para el manejo y buena cuenta de la Rél Hacienda, regló la satisjacción de los quintos y demás derechos Reales, tasó el precio de los azogues, fundó la Casu de Moneda, creó oficiales para ella, asignó salarios, estableció Parroquias para doctrina de los indios, señaló sinodos para su dotación, empadronó indios, hizo las retasas de sus tributos y revisitó los "cédulas" para el servicio de la Mita, ordenó los rescates de pastas. hizo asientos públicos para estableser la labor de la Moneda y, por último, dio reglas y resortes al Gobie no unicersal de la Villa.

Como era tan numerose la concurche de gentes en este pueblo, usi csprañoles como indios, aplicó esle fanoso Virrey toda su atención en situar rentas permanentes para la caracion de pobres en el Hospital. Instituyo que cada indio pagase medio peso ensayado al año por razón de Tomin, y erigió la Cuja de Granos compuesta de la contribución de medio real, que cala semana satisfacian los indios mitarios bajo el manejo de un Contador y Llaveros, consignando en estos dos ramos la subsistencia de los enfermos y los salarios del Corregidor, como Visitador del Cero, Alcalde de Minas, Protector, Veedores, Capellán de la Cárcel, Administrador, Contador, indios Capitanes, Alguaciles, Catedrático de Lengua, barberos $y$ denús ministros cmpleados en estas dependencias; de suevte que mientras duro su fiel y exucta administracion subia el Tomín a más de seis mil pesos, y los Granos a doce mil seiscientos treinta pesos corrientes.

El Cabildo trio a su caryo este Hospital desde su fundación hasta el año de mil seiscientos diez y nueve, en que se estableció la hermandad de Veinticuatro Hermanos y un Mayordomo electivo de entre ellos mismos, con el título de la Vera Crus, bajo el Real Patronato por el Senov Virey Principe de Esqulache, en Provisión Real, fecha en Lima a treinta de mayo de mil seiscicntos diez y ocho, en virtud de especial comisión que se le confirió en Real Cédula de Madrid, a seis de julio de mil seiscientos diek $y$ siete.

Con estos subsidios y las crecidas limosnas con que contribuyeron los vecinos en bicnes raices y dinero, creció tanto la renta del Hospital, que por el año de mil seiscientos veinte, se puso en el pie de treinta y tres mil cuatrocientos cinco pesos; pero al misma paso fue decayendo en lo sucesivo, de tal manera que importando las rentus el año de mil seiscientos setenta hasta setenta y uno, diez mil novccientos setenta y ocho pesos comientes, apenas alcanzaba a cinco mil pesos en el año de mil setecientos catorce, que es el pie en que hoy subsiste poco más o menos. La Hermandad de la Vera Cruz permaneció bajo la dirección de sesenta y cuatro Mayordomos desde el año de mil seiscientos diez y nueve hasta febrero de mil setecientos, en que el ultimo Mayordomo, Antonio Diaź Jordán, lo entregó a los religiosos Bethlemitas; abolidas ya, perdidas y confundidas muchas de las mejores posesiones de la situación de los réditos del Hospital, siendo la principal el Coliseo de Comedias, que fundo Juan Núnez de Anaya ${ }^{*}$ el año de mil seiscientos diez y seis, con el costo de más de treinta y cinco mil pesos, inclusive su fábrica material que importó doce mil; cuyo arrendamiento anual, que era de nueve a diez mil pesos, fué decayendo desde el año de mil seiscientos treinta y dos en adelante, tan notablemente, que obligó al Mayordomo Don Francisco de Lemus y Haller a venderlo a Juan de Padilla, en el año de mil seiscientos ochenta $y$ siete, con una pulpería anexa, en siete mil seiscientos pesos, 
privando al publico de ma recreación sobremportante a los desahogos de una población atareada en los trabajos de la minera, demasiado conveniente a mantener la sociedad civil, con la sensible resulta de perder el Hospital an fondo no poco lucrativo para subsistencia de sus enfermos.

Advirtiendo los Senores Tirreyes que el tiempo iba ciecutoriando unos desórlenes tras de otros, con repetidas infracciones de las Ordenanzas del buen gobierno, asi en lo perteneciente a mito, civilidad, policia $y$ buenas costumbres de los indios, como acerea de la tranquilidad publica del vecindario, se tomó la providencia de autorizer al Corregidor con nuevas facultades mayores que antes. A este fin. el Señov Pincive de Esquilache concedió 4 el titulo de Teniente de Capitán General al Corregidor. de Potosi, Don Franciseo Sarmiento de Figueron, spnalandole el sueldo anual de mil pesos ensayados de a doce y medio reales por esta calidad, para que con el mando de las amas levantase gente y eastigara con mano fuerte las continuas robeliones oucionalas de las pareialidades $y$ bandos, en que de ordinario estaba dividido este vecindario.

Estos excesos de inquietud llegaron al extremo de erse admitido el duelo en esta Villa, como fuero de la noblert. Calla nurión de las muchas que moraban en ella. formaba con sus compatriotas un cuerpo separado con ol fin solo do sostrne la competencia y la "mulacion. De este género de indexendencia en que vivian al amparo de sus riquezas, y del corto poder del Corregidor, resultaban homicidios en asonadas de gente armada, y no pocas veces se vieron escandalosos choques a manera de batalla entre enemigos; se seguín latrocinios públicos, rapiñas y represalias de caudales y personas de todos sexos, con el mayor escandalo, sin temor ni respeto a la justicia.

Regularmente los mismos jueces eran los que fomentaban los partidos. En fin, esta relación casi unitersal del vecindario. llegó al infeliz punto de trastornar el orden pablico del Gobienno. Para su remedio se armó la autoridad de los Supremos Jefes del Reino, con toda la severidad de las leyes. Se estipendiaron milicias para prender y castigar a los amotinados, $y$ en el ejemplo de éstos se escarmentó el resto del pueblo, publicándose 5 para su mayor sosiego un Bando de perdon general, por orden del Señor Virvey, Marqués de Guadalcázat. ${ }^{6}$

Pero considerando el Superior Gobierno de Lima, que el mejor medio de cortar nuevos encuentros entre los vecinos era la prohibición de armas ofensivas, despachó el Señor Marqués de Guadaleázar, una orden rigurosa, ${ }^{7}$ prohibiendo con pena de muertt, que en la Villa de Potosi $y$ sesenta leguas en contorno, trajesen arcaluces, escopetas, pistolas, pistoletes, cotas, cueros de ante, jubones fuertes, estoques y espadas mayores de marca; y cometió la ejecución y cumplimiento a Salvador Campos, a prevención con las demás justicias, con el salario de quinientos pesos ensayados en tributos vacos, concediéndole toda jurisdicción en las sesenta leguas referidas para dichos casos, que se declararon por el Gobierno $y$ fuero de Guerra. $Y$ porque se tenia de experiencia que esta población abundaba de gente forastert vagabunda, se previno que a los diez días de llegado cualquier forastero, tomase oficio, bajo la pena de dos años de servicio en las galeras del Callao.

Fue preciso reformar también otra especie de vicios que inventó la parte inferior del pueblo, a ejemplo de los poderosos. Se hicieron frecuentes las trampas y alzamiento de bienes, princiystmente en las tien- 
das de pulperia, $y$ se introdujo el más pernicioso delito que hasta ahora dura sin remedio, de hurtar los indios el metal más rico del Cerro, así por la ansa que se les dio en el permiso a de rescatar metales, como por. el atrovimiento que criaban on sus continuas borracheras en las pulperias establecidas en las rancherias y Parroquias, fuera de la población de cspañoles, contra las prohibiciones del Señor Don Luis de Velasco. ${ }^{9}$

Por el detalle de estos excesos, se expidieron repetidas providencias para su remedio. El Señor Yulcsco ${ }^{10}$ orlenó que antes de abrir tienda de pulperia afinasen on antidud do doscientos pesos las prendas $y$ cfectos de ellas y lo ane adeudasen de alcabala $y$ sisa, para evitar las quiebras maliciosas de los pulperos. El Cabildo de esta Villa, anhelando destruír los robos de metalcs, solicitó ante al Senor Virrey Don García Hurtado de Mendozi, por el año de mil quinientos noventa, que se impidiese a los indios el rescatar plata en las rancherias, fuera de la calle del Gato y lara, poraue con el color de que les era propio, hwrtaban en el Cerro el metal más rico. En efecto, así se mandó en repetidas provisiones, desparhándose olras varias por los señores Virreyes Don Luis de Velasco, Marqués de Montesclaros, el Principe de Esquilache y el Marqués de Guadalcáror, ${ }^{11}$ para que inmediatamente se cerrasen las pulperias en las runcherias, bajo la pena de attatro años de destierro y doscientos pesos, con absoluta prohibicion de venderse vino, chicha y aguardiente en el distito de las Parroquias y rancherias de los indios, permitiendo venderles sólo pan, maís, coca y olvas cosas do abasto.

1). tiempo, anxilialo del poco celo en velar sobre el cumplimiento de cstets importantes providencias, las fué obscureciendo insonsiblemente hasta borrarlas. Continuó sin reparo la licencia de rescatar plata los indios en las rancherias y fuera de ellas, y tras de esto mismo siguieron hurtos gravisimos, inctitables, de los metales del Cerro, llegando el atrevimiento y la codicia al extremo de subir los indios desde la vispera del domingo hasta la mañana del dia de trabajo siguiente en gavillas numerosas acompañados de otras gentes de diferentes jerarquias, estados y castas, a robar las labores destinuendo los puentes y cajas de las minas. Este desorden tocó su último punto, y ya se ha hecho irvemediable. Los ladrones (que aqui se llaman chacchas) son tolerados por no haberse cuidado poner limite y excepciones al permiso de los rescates, que es todo el origen de tantas criminalidades, muertes, robos $y$ homicidios que suceden en el Cerro, ya por dertumbes de las minas y ya por las riñas que traba la codicia. Y después llegó al último punto este desorden con la prowidencia que dio a Señor Conde de la Monclova, para que no se haga extorsión al que comertio con los metules que se trafican en el Cerro de Potosi, una vea sacados fuera de la cancha, averiguándole de dónde son o de dónde los sacó.

Las continuas borracheras en que viven ahogados por la abundancia de bebidas prohibidas, que se tenden con publicidad en las rancherias, en las Parroquias y en el mismo Cerro, tal vez por los propios azogueros para duplicar el interés de las pagas, en la ganancia de estos licores, han hecho abandonarse los indios a la flojera, de modo que disminuidas sus fuerzas por la inacción de la embriaguez, no pueden enterar las tareas, perjudicando al hey y al público con la decadencia del trabajo.

Las frecuentes quimeras que arman durante el acceso de los der lirios del vino, chicha $y$ aguardiente, dentro y fuera de la misma Villa, 
aturden su quietud, atolondran al vecindario en las horte más aranzadas de la noche, y ocupan los Juzgados para oirlos, además de periudiear los trabajos públicos en el tiempo que pierden para seguir sus demandas.

Este vicio se ha hecho tan universal y licencioso, que vulnerando con escándalo las estrechas prohibiciones de la Ordenanza, ${ }^{12}$ ha triunfado de ellas impunemente, porque en los dias de trabajo y de fiesta, principalmente on los de guarda, no se te otra cosa que indios borrachos por las calles de Patosí. En ésto consumen todos los jonnales de la semana anterior. De aquí proceden los adullerios y estupros, $y$ tiene su origen la pobreza de los indios, el abatimiento do sus ámimos, la desaplicación al trabajo, la obscuridad de sus pensamientos, el poco amor al Rey, el desconocimiento de la Religión, y la continu incontinencia que los mostituye a todo género de excesos. En verdad digo, que este desorden ha brotado tan largas y tan fuertes raices, que jugo imposible su reforma, $a$ menos de poblar el pais con gente toda nueva.

Fue consecuencia de estos desarveglos la decalencia de la Mita, con perjuicio muy notable de la minería. Para cata disminución tuvieron no poco concurso dos causas muy pincipales: la primera fne haberse descubierto el Mineral de Orvio, en el distrito del Corregimiento de Paria, con muestras de la mayor viqueza y fundadas esperanzas de su permanencia; con este motivo los indios que venían y volvían de Potosí a sus naturalezas $y$ origen, entruban al Asiento de Oruro, $y$ alli se detenáan con el cebo de la codicia, y a persuación de los dueños de aquellas haciendas comarcanas; lo cual dio mérito para que el Señor Marqués de Montesclaros ${ }^{13}$ prohibiese rigurosamente este abrigo donde se receptaban los mitarios.

El Señor Príncipe de Esquilache ${ }^{14}$ arbitió por más oportuno remedio el repartir a las minas del nuevo Asiento los seterientos eineuenta indios de Mita suprimidos ${ }^{15}$ a los Minerales de Garci-Mendoza, Berenguela y Sicasica en los Correginientos de Lípez, Pacajes, Chayanta, Cochabamba, Paria, Omasuyos y Sicasica, a causa de que en cada uno de los referidos reales de minas, sólo habian quedado dos ingenios de a siete mazos, y porque estando las minas muy derrumbadas, maltratadas y peligrosas de trabajar, se pasaron los dueños de ellas con los indios a las minas de Oruro. El mismo Señor Virrey revocó después estos repartimientos por varias causas, en virtud de orden del Rey; ${ }^{16}$ pero continuaron los sensibles efectos del primer desonden.

La segunda causa ero la distancia de los recursos al Superior Gobierno de Lima para solicitar el entero de los indios faltos de la Mita de Potosi contra los Corregidores omisos que, por descuido en reducirlos a sus domicilios o por su interés propio, disimplaban las fallas de la séptima que debía venir para el servicio de este Cerro e ingenios. Con este conocimiento se trató de autoriza' al Corregidor de la Villa para que como más entendido en los negocios de su manejo compeliese a los culpados al reintegro pronto y ejecutivo de la Mita.

Así, el Señor Marqués de Montesclaros, ${ }^{17}$ confirmó las anteriores comisiones dadas por los Señores Virreyes sus predecesones al Corregidor de Potosi, para que habiendo falta en la Mita pudiese enviar contra los Corregidores, a costa de ellos, por los indios faltos, hasta suspender de sus empleos a quien hallase culpado en la omisión. Ya Don Rafael Ortiz de Sotomayor, Corregidor de Potosí, usando de estas facultades conferi. 
das de antenano a su oficio, habia nombrado y entiado por su comisionado a Don Pedro Carvajal, en treinia de notienbre de mil seiscientos ocho, para que notificase a los Corrogidores de las Protincias afectas a Mita, que a los tiompos señalados la despachasen cumplida, con sus comidas, mujeres, hijos y ropas al curgo de Capitanes de autoridad y bajo de padrón $y$ lista firnada por los Corregidores y del Escibano del Partido, con fe del entrego de los indios, on inteligencia que csí los faltos en el padrón, como los fugitivos, debian lolverlos ellos, a costa de culpados.

Entendirion la imporlanciu de esta comisión los demas Señores Wheyse, Príncipe de Esquilache ${ }^{18}$ y Marqués de Guadalcázar, ${ }^{19}$ y ambos a dos, renotando la conferida a este Corregimiento, le cometieron desde luego la Superintendencia en el chtero de la Mita, para poder privar a los Corregidores omisos y enviar cn lugar de ellos quien administrase justicia, con lo que pudo de algún modo mejorarse la Mita; pero, bien sea la indolencia de los posteriores Con'egidores o las insensibles pérdidas que el tienpo causa on todas las cosas humanas, ha continuado la decadencia de la Mita hesta al deplorable estado en que hoy la vemos. No considero otro ienedio que el propuesto en la noticia de la Mita.

En lo que turieron siempre monos mano los Corregidores fue en el Cabildo de esta Villa, porque no obstante que presidian las elecciones de sus oficios y demís atuerdos ovlinarios, nunca se les dio facultad para confimat los nombiamientos, ni la tenian para alterar las determinaciones capilulares arordalas an otras cindades; anticipaban los Señores Vireyes su comisión a los Gobernadoves y Corregidores de ellas, para confimar las electomes de. Alcaldes ordinarios y de otros oficiales chuales, según lo precenido en la Ley 10, Tít. 3, Lib. 5 de Indias. Sólo para Potosí jamás se franquéó esta antoridad: oeurrian a Lima por las confirmaciones y generulmente se acompanaban graves y costosos recursos sobre las Alcaldías. Los nombrados que ya quedaban en posesión del empleo, fácilmente allonaban todas las dificultades, con muchos informes autorizados y docimentados, ganados con el favor de su respeto; no se detenian en cuantiosos descnibolsos para ser amparados, y de este modo triunfaban las más reces con desatre del Corregidon.

Las quejas y recursos contra Alcaldes, aun en los casos más notoros de venganza y atropellamiento, se dirigian siempre a la Real Audiencia. El Conregidor miraba la escenct de estos excesos como del patio de un teatro las reprosentaciones, mudo $y$ sin manos para reprender $y$ castigas: Los Alcaldes se trataban irdependientes, y a la sombra de esta autoridad abusiva se ganaba cada uno grandes partidos con qué sostenerse en el desorden sin temor de la desgracia.

Viendo el vecindario esta gala y lucimiento con que se hacia el papel de Alcalde en Potosí, no habua quien para serlo no se empeñara con el favor, con la amistad $y$ con el dinero. Como aqui no se conocian ningunos Larcios ni Clelios 20 que recusasen el mando y los empleos, se compraban votos a competencia, como en tiempo de la corrupeión de la República Romana, ${ }^{21}$ sin reparar los excesivos precios del soborno. Porque a más de las lisonjas del aura popular, tenían a su arbitrio el pingüe producto de la sisa para minorar los gastos y contentar amigos, principalmente al Ayuntamiento mismo, que entendia en su administracion. No le valía poco la facultad $\mathbf{2 2}$ de nombrar Receptor cada dos años, con el cinco por ciento de premio, bajo de fianzas a satisfacción de los oficia- 
les Reales, porque el electo no quedaba corto en su agrudecimiento a costa del mismo ramo y en periuicio del puiblico; pero se le sabia engañar, como a un cuerpo ciego, con sonidos aparentes de falsos beneficios. Para esto se aplicaron dos mil pesos de la sisa, con permiso del Señor Príncipe de Esquilache, ${ }^{23}$ para compra de un reloj en la Matriz, $y$ se solicitó ante el mismo, en mil seiscientos diez y siete, que se aplicase una parte del mismo ramo para costear una custodia de mil marcos de plata, que se estaba trabajando para el mismo templo, por menta de la cofradía del Sacramento.

En el dia se ve coritente un reloj grande, pero es otro, comprado con los propios en tiempo del Señor Escoredo. La custodia actual será de ocho o diez marcos de plata, y la antigua se aplicó para chapear el Sagrario, que hasta ahora existe. Lo cierto es que, con estos y otros semejantes pretextos, se consmian cada año veintisés mil y mós pesos del producto de la sisa, sin que haya llegado a nuestros tiempos obra alguna. que acredite su fiel manejo y oportuna aplicación en los objetos de su destino. Lo más, es que siendo las casas de Ayuntamiento y Pretoriales unos edifócios públicos los más necesarios en la población, no se fabricaron de. la sisa, sino de otros arbitrios, por Juan Ortiz de Zárate, siendo Corregidor de Potosí, a quien se le fue pagando su costo de penas y condenaciones. ${ }^{24}$

Conociendo el Señor Marqués de Montesclaros que todos estos excesos traian su origen de los malos oficiales que conseguian ser elegidos Alcaldes, por promesas y efectivos sobornos, determinó cerrar este camino, ordenando ${ }^{25}$ que las elecciones de oficios de República se hicieran por suertes, $y$ en cántaro, para evitar escándalos $y$ disensiones, $y$ no pow escrutinio con billetes o cédulas secretas, conno lo había dispuesto el Soñor Don Luis de Velasco; ${ }^{26}$ pero la Vilia obtuvo Real Cédula, ${ }^{27} y$ a su consecuencia, atra Provisión del citaulo Señor Marquess, ${ }^{28}$ para que no se hiciera novedad en practicar las eleciones por votos, como siempre lo habia practicado la Villa de Potosi; porque si la suerte por su incertidumbre ahorra toda diligencia en el ambicioso de los cargos, cierra la puerta al soborno por falta de vendedor, y mide de un mismo modo las esperanzas de todos, también suele of ender el mérito, recayendo sobre el indigno; poderoso motivo que tuvo el grande Augusto para abolir la elección de los Prefectos por suerte, después que la mandó establecer en remedio de la ambición de los Vocales; ${ }^{29}$ por cuyas razones vemos reprobado ya este método en las elecciones, asi eclesiásticas como seglares, ${ }^{3}$ y sólo se practican como licitas $y$ justas las suertes divisorias, según se observa en la Ley 26, Tit. 9. Parte 6 .

No por eso se mejoraron las cosas de la Villa, porque contimuando los aisturbios $y$ alborotos públicos entre vascongados, criollos y andaluces, desde el año de mil seiscientos diez y siete en adelante, fueron tan frecuentes como inevitables los desafios, los homicidios, los robos y otros escandalos perturbativos de la paz del vecindario.

Algunos atribuyeron estas desgracias a las malignas influencias de un admirable comett, que se vio en Potosi, en al año de mil seiscientos diez y ocho, de color de sangre, que alumbraba como fuego, de figura de una hoz, que aparecía a las siete de la noche encima del Cerro Rico, hacia la parte del mediodía y remataba hacia el occidente, hacia el sitio de Munaypata, y se perdia a las diez de la noche. Todos se inclinaron a 
creerlo asi, haciendo memoria de las tristes calumidades que padeció Potosí en el alzamicnlo de Francisco Hernúnde; Girón, Don Sebastián de Castilla y Egrts dr Guzman, (b) después de algún tiempo que apareció sobre el Asiento de lorco, a las sicte de la mañana del día trece de enero de mil qumientos cincuenta y ties aquel formidable y prodigioso cometa, que aun dura en la fodición de las gentes por su aspecto irregular de tres soles, dos lunas do color bermejo, romo tenido en sangre, $y$ de resplandor de fuego.

No parece que fue extraña ni culpable esta credulidad, cuando en el mundo se han observado acaecimicatos muy notables, ya prósperos, ya funestos, consecurntes a las apariciones de cometas, como fue el que se vio en España poeo después que enformó Carlos $\mathrm{V}$. el eual aumentando su resplandor por los grados que crecia la enfermedad, volvió al cabo hacia el Asiento de San Jerinimo su funesta crin. y desapareció en la hora misma que Carlos dejó de virir, según reficre el Padre Estrada, y su traductor Novar. ${ }^{31}$ Discuran como quisicren estos autores, la cierto es que son puamente naturales las causas eficientes de los cometas; aunque algunos con Arixtoleles, 32 digan que se forman de exhalaciones térreas; ot wos, ${ }^{33}$ zue son planetas con movimiento periódico, (c) y otros, finalmente, que se engendran de las faculas desprendidas y arrojadas de la superficie del sol en su monimiento vertiginoso o cirenlar. ${ }^{34} \mathrm{Dc}$ lo cual deducen $y$ pruebun con sólidas reflexiones y fundadisimas observaciones, los matemáticos de juicio y citica, ${ }^{35}$ que los cometas no son pronósticos de desgracias, por más que qu rulgo viru obstinado en creerlo, sólo por la causalidad de algun infausto sinceso en tiemo de algún cometa, y desde luego es demostrable esta rulgaridad on nouenta $y$ ocho cometas ni faustos ni infaustos, que cuenta el l'udre Cusani, entre los ciento sesenta y siete que refiere en su Historia. (d)

Por cuantos lados se mirase esta Villa, era tan melancólico su aspecto, que yo parece iba llegando a su ültimo exterminio. La relajación de costumbres había fijado aqui su domicilio al desorden. La ambición corompia al vecindario en abominaciones y alimentaba como una raíz fecunda los robos, sediciones y turbulentas pavidadades entre los moradores. La formidable peste del año de mil setecientos diez y nueve, asoló más de las dos tercias partes de la población. Ste disminujó la Mila, se arrasaron los ingentos con la espantosa inundación de la Laguna de Charickari el año de mil seiscientos veintiséis, y al agua arrastró con cerea de cuatro millones de caudal, ahogandose en estos preciosos despojos gran parte do los vicios que engendra la abundancia. El Cerro comenzó a ser ingrato al trabaio, empobreció hasta poner en riesga de despoblarse la. Villa, y el desordenado trabajo, sin obsertancia de las ordenanzas en conservar las labores con puentes $y$ otros resguardos prevenidos para evitar dermubes $y$ otros casos en que forzosamente deben peligrar los infelices indios, han reducido esta imponderable montaña al lastimoso estado de tener impedidas sus labores principales y más ricas con los "ayzamientos" que por causa del desorden han sobrevenido después, y están sucediendo continuamente.

Nuestros Reyes han velado sin cesar en la conservación de un pueblo tan importante a la Monaraúa. Entre los Soberanos cuidados siempre ha sido de preferencia el gobierno de esta Villa. Para ella ha diputado on todas ocasiones sujetos ilustres, hombres de letras y personajes de au- 
toridad. Ultimamente por Célulo dada en Sevilla, a ceintidos de octubre de mil setecientos treinta y dos, ordeno a los Señores linoyes de Lima que para mejor cumplimiento de las Provideneicte expedidos on asunto de Mita, nombresen cada dos años un Ministro de la dudicueie de Chareas o Lima por Superintendente de la Filla de I'otosi. con el sobresueldo de cuatro mil pesos, con la calidad de ser residenciados en lo I thintia; concluido este licmpo, apercibrendolos con penta conoral, hasta la de niterte, si por ambición $u$ otros torpes respetos frustrawen ias intenciones de $S . M$.

Lo que sucedió fine nalitiplicinse los mandos, deslucise la autoridad del Corregidor con el poder ostentoso de los Minkistios togados, y arder la Villa en nuevas parcialiades y bandos untio los diferentes personajes encargados de los negocros piulicos. La Coite hegó a conorer que este género de gobiemo iba degeneraido en especie de antaquia, por la recíproca contemplación con que se lisonjoaba al vecindusio yor los respectivos jefes para sostener los partidos, y aplicóo el ádico remedio, reuniendo el año de mil setecientos cincuenta, en Don Fitura Santelices, Oidor de Cádiz, provisto Corregialor de esta Villa, todas las Superintendencias y encargos anteriormente repartidos un diversas personas.

Este nuevo jefe turo que acometer machas $y$ grawisimas dificultades para dar tono politico a un vecindarto relajado. Su meiorable constancia, pureza, desinterés eatremado y aplicación a la reforma, lo avanzaron hasta reponer la población a un estado mas feliz rue antes; porque puesto a cubierto de la grande autoridad con que se decoró a su empleo, resistió con fruto los injustos recursos con que se intentaba cludir. sus providencias. Por fin logró fundar el Banco de Rescates, para fomento y auxilio de la minevía, y establecer la nueva Casa de Moneda, para felicidad del comercio $y$ del Estado. Desterró los contrabandos, acrecentó el erario, mejoró la mineria, y suprimió infinitos abusos que en los tiempos pasados se cultivaban serretamente por los mismos Corregidores. No acabaron todavía de cesar las inquietudes en las elecciones de Alcaldias por la mal entendida emulación de los criollos con los españoles europeos; $y$ se atajó este paso con partir entre ellos este honor. En veintiuno de febrero de mil setecientos sesenta y seis se despachó Real Cédula de El Pardo, para que en Potosí se eligiese siempre para Alcaldes wn criollo con un español, de los que hayan adquirido domicilio o vecindario en ella, en la conformidad que previenen las leyes. De este modo fueron serenando las turbaciones, se plantó la paz, se arrancaron las faginas de capricho y se preparó la ticrya para el nuevo cultivo del Gobierno reformado, en el cual no resultó casi dificultad alguna, porque los Corregidores antiguos estaban dotados en ocho mil pesos, no tenían repartimientos ni otras ridículas granjerías que desluciesen su autoridad, $y$ en los últimos años gobernaron consecutivamente Ministros togados con el salario de sus plazas $y$ el sobresueldo de sus comisiones, portándose con lustre, con honor $y$ con desvelo en beneficio del Rey $y$ del Estado.

Pero hasta aqui nada hemos adelantado en cuanto a la mineria, con ser el ramo principal, y tal vez al único que puede producio los adelantamientos del Reino. El atraso proviene por una parte de la omisión que han tenido los jefes en proteger a los mineros, y en celar los desóndenes que ha introducido la codicia unida con la pobreata en los trabajos metálicos; y más principalmente por la ignorancia en que hasta ahora hemos 
imido de los conorimientos do csta ciencia y de las demás con que tiene insinuación, para preferionar lat: importantes opraciones de su manejo.

Don Francisio de Toledo, quinto Tirrey del Perú, vislumbró muy bien entre las tinieblas de su siglo, los perjucios que habia de causar nuestra impericia $y$ desde entonces clamó por el remedio, que juzgó no ser otro sino una enpedición de alemanes sabios, que nos enseñasen por principios la Mineralogía. Metahurgia, Quimica y demás antes relativas a este objeto. Pero nuestra desgracia pudo más, que llegó a retardar el antídoto hasta estos últimos tiempos on que la sabidura de nuestro actual ministerio ha sabido aprovechar la experiencia y prástica que posee de estos Reinos, costeando de la Real Hacienda al sabio Barón de Nordenflicht, con los mineros de su expedición destinade al Reino del I'tu, para reforma y adelantamiento de nuestra mineria.

Por los preliminares que hemos observado en Potosi, no debemos dudar ya que nos ha ananecito al dia dichoso de aprovechar los tesoros que sorté la Proridencin para premiar la cristiandad y el celo de nuestros Reyes Católicos; pero al mismo tiempo nos han puesto a los ojos en las mismas rentajas del nuevo método de sus trabajos, las inmensas riquezas que debomos llortr perdidas por nuestra ignorancia.

Con todo, la America está respirando nuevos alientos de alegres esperanzas, desde la craltación del Excelentisimo Señor Don Antonio Porlier, al Ministerio de Gracia y Justicia de las Indias, porque este gran hombre de Estado, sabrí unio sus grandes conocimientos de América al amor con que honró a sus habilantes en los dilatados años que hizo su morada en estos Reinos, para saber inclinar las beneficencias del Soberano a favor do estos países, en honor y glorin de toda la Nación.

Como hemos advertido el "Discurso Preliminar" que aparece como prólogo en el manuscrito del Archivo General de Indias, corresponde al Capítulo Primero de esta segunda parte de la obra, en los oxiginales de Potosí. Por esta razón hemos intercalado el texto en este lugar. Nota de A. Alba.

(a) El Señor Conde de Nieva tuvo poder especial para eljo; después se les jrohibió generalmente, en la Ley 6, Tít. 8, Lib. 4 de Indias, el dar títulos de Ciudades y Villas, y el eximirlas de la jurisdiceión de sus cabeceras principales.

1.- Este Auto se insertó en Supremo Despacho de 21 de roviembre de 1561 y se halla copiado en los libros de Cabildo por testimonio autorizado en 24 de junio de 1563, por Juan de Vergara, escribano público, por ausencia de Alonso de Sunta Ana, propietario de Cabilido.

2. - El oficio de Fiel ejecutor ya está incorporado a la Corona, y subsiste solamente la Pregoneria por renta de los propios de la Villa. El de Corredor quedó extinguido luego que por Cédula de 23 de marzo de 1567 , recopilada en la Ley $23, \mathrm{~N}^{\circ} 10, \mathrm{Lib}, 4$ de Indias. Se mando que en estos Reinos se pudiera contratar sin Corredor.

3.- Escalona: Garofilacio, Lib. 1\%, Cap. 46, N*65, fol. 196.

* En el Ms. de Potosi, dice: Anvaya.

4.-- En Provisión de 10 de julio de 1617 .

5.- El Bando se publicó en 29 de abril de 1625 .

6.- En Provisión del misino año.

7.- En Provisión de 6 de noviembre de 1625.

8. - El Virrey Toledo les permitió el rescate de metales, en Provisión de 5 de mayo de 1579 .

9.- En Provisión de 13 de noviembre de 1596.

10.-- En Provisión de 21 de jurio de 1600. 
11. - El Virrey Velasco en Provisión de 13 de dicienbre de 1596; el Marqués de Montesclaros en 31 de marzo de 1615; el Principe de Esquilache en 5 de enero de 1619 ; el Marqués de Guadalcázar en 31 de agosto de 1.625 .

12.-. Orden 9, Tít. 9, Lib. 2 del Perú.

13.- Fn Provisión de 23 de enero de 1609.

14.- En Provisión de 14 de junio de 1618.

15.- El Señor Marqués de Montesclaros en Provisión de 3 de octubre de 1611, suprimió estos repartimientos con arreglo a Real Onden de sol de julio de 1612, referente a otra anterior, y se mandó que con estos reservudos se fueran enterando los que faltaban al señalumiento de Potosí.

16.- Isl Príncipe de Esquilache en Provisión de 17 de febrero de 1621, revocó el repartimiento de Oruro, en virtud de Orden de S. M. por la decadencia que se experimentó en las labores y Quintos, y porque en las rancherías quedó sólo la quinta parte de los indios, dejándolos como antes, pura contero de la Mita de Potosí.

17.- En Provisión de 29 de enero de 1609.

18. - En Provisión de 6 de julio de 1617.

19.- En Provisión de 22 de dicientbre de 1622.

20.- Dos cónsules romanos que por todo un dia estuviedon rehusando el nonbramiento que se hacian recíprocanente con facultad del Seslatio para el empleo de Dictador.

21.- Mario consiguió sexta vez el consulado, sobornando lisi tribus, segian Rollin traducido por Villanueva: tomo $1^{\prime \prime}$, fol, 191.

22.- El Marqués de Guadalcázar en I'rovision de 9 de oclubre de 1628 , concedió a) Cabildo esta facultad.

23. - En Provisión del mes de abril de 1621.

24.- Así se refiere en una Provisión de 1601.

25. - En Provisión de $1^{\circ}$ de enero de 1608.

26. - En Provisión de 20 de noviembre de 1602.

27.- Real Cédula de Madrid, a 3 de jumio de 1611.

28. - En Provisión de 31 de agosto de 1612.

29.- Cornelio Tácito: Lib. $2^{\circ}$ de sus Anales

30.-Cap. $3^{\circ}$ de Sortileg. Tít, 21, Lib. 5".

(b) Ulioa en su Resumen Histórico de los Emperadores del I'erú, tomo 4", fol, 94. $\mathrm{N}^{4} 145$, año de 1553 .

31.- Este discurso acacció en 1558, según Estrada, traductor de Novar; tomo 1", Guerras de Flandes. Lib, $1^{\circ}$, fol. 11.

32. - El P. Juan Baptista de Benedictis er su Filosofía Peripatética del año de 172:3.

33.- El célebre Cassini, citado por Altieri, en el tomo $3^{\circ}$ de los Elementos Filosóficos. Cap. 8, Prop. 33, $\mathrm{N}^{\circ} 383$, fol. 131.

(c) Cassini Domingo. Astrónomo sobresaliente nacido en Niza en 1625. Vivió muchos años y falleció en i’arís. Su hijo Jaime, francés de nacimiento, continuó sus investigaciones sobre Astronomía. Nota de A. Alba.

34.- Castini en su Tratado de la Naturaleza, origen y cuusas de los cometas. Cap. $5^{\circ}$.

35.-Cassini. Parte $2^{4}$, Cap. 12.

(d) Casani José. Jesuíta español del sigio XVITI. Tue profesor en el Cotegrio Imporial de la capital española. Uno de los fundadores de la Reat Acaderia de la Lengua. Fintre muchas obras sobre la Compañía de Jesús, Vida de San Estanislao de Kostka, etc., escribió la nukis conocida en su tiempo: "Origen de los cometas". Nota de A. Alba.

- No queremos dejar pasar sin hreve conentario, el hecho importante de que por primera vez se da a conweer el texto del Auto proveido en I,ima, en 7 de noviembre de 1561, por el Virrey, Conde de Nievu, mediante el cual asciende a categoria de Villa Imperial el asiento mircero de I'otosí, que trascrito litera]mente por el Sr. Cañete en el Discurso Preliminar que antecede (página 329 ), tiene la significación de docunento primordial para la historia de la ciudad. Por otra parte, su contenido contribuve a confirmar la opinión que sostuvimos el año 1945 ("Enumer"ación del succso potosino y "Gesta Iárbara"), en sentido de que cuando se descubrió el Cero Rico, por españoles que trabajábán en el mineral de lorco, no se fundó la ciudad ni se suscribió acta alguna, como afimaron escritores del siglo pasado, sin exhibir para ello documentos fictedignos. La ciudad nació al azar y creció al ritmo del desarrollo e incremento aduuirido por los trabajos de minas del Cerro Rico.- Nota de A. Alba. 


\begin{abstract}
De los Corregidores de las cinco Provincias: Chayanta, Porco, Chichas, Lípez y Atacama, agregadas a esta Intendencia; se explica su autoridad y principales objetos de su manejo $y$ se apuntan algunas reflexiones sobre la importancia de su extinción.
\end{abstract}

$\mathbf{N}$ ción del argumento de esta Noticia, por más que sobre este tratado haya recogiclo nuestro sabio político el Sr. Don Juan de Solórzano, 1 las noticias que puede interesar un Gobernador celoso, para instruírse en el sistema antiguo del Gobierno de estas provincias, y con este conocimiento reglar su conducta en el manejo de los negocios; porque la prolongada sucesión de los años que hán corrido en siglo y medio, descte que escribió su admirabłe Política, ha ido amontonando para la posteridad infinitas circunstancias de diferente género, que exigen diversas observaciones para mantener en equilibrio los varios humores de ma provincia y educarla según su indole.

El espíitu abatido de estos infelices indios, su genio solitario y su incivilidad, su pobreza y su limitada industria pard defonderse do las per'secucionns y ayn para subsistir, obligó encargar a los encomenderos, muy en los principios de la conquista, su enseñanza espiritual y protección temporal en calidad de Patuonos o protectores, "2 porque ol estado del reino no permitía otro gobicrno. Después de algún tiempo pareció más conveniente un Pastor asalarialo, que tuviese por obligación esencial de su ministerio, la educación espiritual y civil de cada municipio de indios, que tuviese cuatrocientos tributarios; " pero, como les faltaba el amparo inmediato de la mano regia, experimentaba su indefensión continuas invaciones en el maltratamiento personal y usurpación de los bienes.

Por estas causas, el Sx. Ijicenciado, lope García de Castro, cuarto Virrey del Perú, comenzó a instituír y poner Corregidores en los pueblos cabeceras de indios en las provincias de su mando. El Sr. Dn. Francisco de Toledo, su sucesor en el año de 1569 , formó reglamentos para metodizar estos ministerios y ordenó con la perfección posible el gobierno del Reino. ${ }^{4}$ Deslindó las provincias, fijó límites, empadronó los pobladores y autorizó a los Corregidores con jurjsdicción civil y criminal, para administrar justicia a los naturales, reducirlos a vida política, libertarlos de opresiones $y$ desterrar sus vicios nacionales, en la misma forma que se ve prescrito por las leyes y ordenanzas municipales. "

Todos los Colregimientos se proveían en propiedad por el Rey, con parecer y consulta de la Cámara; "y los Señores Virreyes, usando de las facultades concedidas por las leyes, " nombraban, cuando sucedía la vacante, personas que sirviesen estos ofieios en el interm que llegaban a ser provoídos por la Real persona, en los principios por el término de un año, y después por el de dos."

A] principio se observaron con puntualidad las leyes $1^{\text {f }}$ y $4^{\text {a }}$ del Lib. $3^{\circ}$, Tít. $2^{\circ}$, y $1^{\dagger}$ y $49^{*}$, Tít. $2^{\circ}$, Lih. $5^{\circ}$ de Indias, continuando los propietarios en el ejercicio de sus cargos, aun después de cumplido el término de sus provisiones, sin ser removidos hasta que se hiciera merced a otros en los mismos oficios, de suerte que, el Superior Gobierno no hacía las nominaciones imerinas sino en los útmicos casos de vacante por muerte natural o civil, por renuncia o por otro equivalente impedimento. 
Como en tiempo del bencficio atmitido en España, por las urgencias de la Corona, "proveyó el Rey indistintamente todos los empleos de América, sin reserva alguna a la provisión de los Sres. Vixyeyes; comenzaron estos a nombrar Justicias Mayoles por dos años, con la misma indistinción, luego que se cumplía el término de lus eineo años de la Real merced, amparando en los cargos a los provistos interinamente, aunque en el espacio de los dos años de dichos nombramientos llegare otro proveído con título del Rey.

Esta práctica se cohonestaba con el pretexto de interesarse la Real Hacienda en la mitad menos de salario que gonaban los interinos, y también la equidad en no despojar al interino a lus cuatro, ocho o más meses de servicio, después de haber costearlo los despachos e impundido considerables molestias y gastos, en los caminos y en su decencia, sin otra cansa que la llegada del propietario; reagravándose este uncliranto con las penosas resultas de la residencia y rendición do cuentas do la Real Hacienda. Por el contrario, ésta y el público (se alegaba) recibían gran beneficio con estas provisiones interinarias, porque a mis de? aumento del derecho de media anata que se adeudaba en cada nomblymiento, alcanzaban pronto desagravio los cuerellantes en las residencias que se despachaban y fenecian en la Audientia del Reino, sin exponer que pereciese la justicia de los vasallos del Rey al cabo del dilatado tiempo en que llegaban a franquearse estos recursos, después die muertos o fallidos los Corregidores y sus fiadores.

Con todo, reconociendo que de la inobservancia de las leyes resultaba a los proveídos por el Rey, el injusto perjuicio de hallarse detenidos en las Américas, por dos años, y otras veces por más tiempo, sin destino, acrecentando empeños difíciles de cubrir $y$, lo que es más, tolerando una especie de engaño en la suspensión de los Reales Iespachos, se libraron diferentes Reales Cédulas 10 para cortar estos abusos, mandando observar rigurosamente las leyes del Reino, acerca de to remover al propuesto, aunque estuviese cumplido el término de sus despachos, hasta la llegada de otro con nueva merced y de no detener con ningún término el pase de ella, declarando que la facultad concedida a los Sres. Virreyes para el nombramiento de interinos por dos años, se debe entender precisamente en los casos de vacante por muerte, privación o renuncja, pero en este último, sólo cuando al renunciante le faltasen otros tantos para el cumplimiento de los scñalados en su título. De manera que habiendo servido ya en el Corregimiento cuatro años o más ticmpo, no debiese el interinario ser amparado en su posesión por más de aquel prociso término que hubiera servido el propietario. Con to que se hizo una declaración sobremanera importante, que sirve hoy de regla para todos los casos de esta clase.

El manejo cada vez más escrupuloso de estos negocios y la mayor experiencia del Reino, despertó el reparo sobre algunos Corregimientos de tan grande territorio, que no siendo verosimil fuesen solicitados por personas de mérito, se quedaban en ellos los provistos por tan dilatado número de años, que se iban haciendo unos empleos casi perpetuos, con muy perjudiciales resultados para el publico, no solamente por la frustración del recurso de la residencia, sino principalmente por la falta de administración en los pueblos distantes de las cabeceras, porque los Corregidores raxa vez los visitaban, por no molestar'se inútilmente en los cami- 
nos, no teniendo interés en ellos. Pot este motizo, se mandó a las Audiencias de Lima y Charcas, informen si sería conveniente umir o dividir algunos Corregimientos del Virreinato del Perú, respecto de no poderlo hacer los señotes Virreyes, por estar reservada al Rey esta facultad por las leyes. ${ }^{11}$

En efecto, oidos los informes de dichos Tribunales, se despachó Real Cédula ${ }^{12}$ determinando que al Corregimiento de Yamparáez, se una el territorio de la ciudad de La Plata, desmembrándose del de Potosí a quien pertenecía, $y$ que en lo sucesivo se proveyesen por los señores ViIreyes los Corregimientos de Atacama, Lípez y Mizque como Tenencias de la clase de aquellos, ya que no es verosimil que haya sujeto de mérito que los solicite en la Corte; y asi lo practicaron, proveyendo estos Coréegimientos por el tiempo señalado en la ley ${ }^{\text {ta }} \mathrm{y}$ más por el tiempo de la voluntad del Gobierno.

Aunque la creación de los Corregimientos tuvo en un principio el principal objeto rle administrar justicia a los indios, on lo civil y criminal, visitar los téminos de las poblaciones, los mesones y tambos; cuidar de su policía; hacerlos trabajar proculando el beneficio y cultivo de las tierras; celar su educación espiritual y a este efecto residir en sus provincias y no ausentarse de clas sin superiox licencia, segun lo prevenido en las leyes del Tít. $2^{n}$, Lib. 5" de Indias, y en la Loy 19, Tít. 17, Lib. 4" de la misma recopilación; lue preciso, después, encargarles la cobranza de los tributos $y$ tasas, para libertar a los infelices indios de las extorsiones con que eran oprimidos por los exactores y encomenderos, que tenían a su caigo en los primeros años del descubrimiento de las Américas, 14 obligándolos al mismo tiempo a los enteros de la Mita, según la séptima del vecindario de cuda Provincia, como lo dejamos expuesto en la noticia tocante a cstc encargo.

Para Ia scguridad de cste ramo de Hacienda, previenen las leyes ${ }^{15}$ mandar guardar por repetidas provisiones de los señores Virreyes, 1 que los Corregidores den fianzas al tiempo que fueren proveídos; que cobraran por los tercios del año los tributos incorporados en la Corona, y los remiticran entera y cumplidamente a la Caja del Distrito, en los plazos señalados; y porque por varios accidentes inculpables, se retardaba el pago, se cortó todo motivo de causa concediéndoles la demora de tres meses para verificarlo después de pasados los tercios respectivos de Navidad y San Juan, en que dcben hacer los enteros, ${ }^{1 i}$ bajo la pena que no cumpliendo esta obligación, se pudiese proceder contra ellos jurídicamente, enviando personas a tracrlos presos con salario moderado, y mantenerlos en arresto, suspensos de sus oficios hasta pagar uno y otro (tercio), conforme a otras Provisiones de los Señores Virreyes Príncipe de Esqujlache y Marqués de Guadalcázal, ${ }^{1}$ concediéndose por varias leyes 19 a los Oficiales Reales de las Cajas del Distrito, Ja jurisdicción necesaria para despachar estas comisiones y preparar la cobranza con otras diligencias, hasta hacerla efectiva.

Porque antes se tomaban las cuentas a los Corregidores al tiempo de sus residencias, abonándoseles rezagos, de que resultaba apelarse a las Reales Audiencias, donde fonecían estos negocios con noticia del Sr. Virrey y del Tribunal de Cuentas; se mandó por varias Provisiones del Sr. Marqués de Guadalcázar y otras cédulas rénovadas por las leyes, ${ }^{20}$ que los Corregidores rindiesen sus cuentas en las Cajas Reales cabeceras 
de sus partidos, y que en caso de resultar agravio o duda en punto de derecho, se determinase por los Oidores que deben conocer en Sala de Ordenanzas. ${ }^{21}$

En virtud de estas disposiciones, rendían sus euentas en las Cajas de Potosí, Ios Corregidores nombrados por el Rey dentro de cinco años, y dentro de dos los provistos por el Sr. Virrey en las Provincias de su Distrito, que eran: Chayanta, Porco, Chichas, Lípez, Atacama, Santa Cruz de la Sierra, Cochabamba, Pomabamba, Mizque, Yamparáez, Fronteras de Tòmina, Pilaya y Paspaya. ${ }^{22}$

El abuso que siempre sabe insinuarse por secretos influjos que arbitra la astucia humana, tuvo poder para corromper' estos importantes establecimientos, convirtiendo en utilidad de los Corregidores, lo que debía ser puro beneficio de los indios, así en lo perteneciente a los caudales públicos, como a su educación y policía. "iOh, gran soberano es el ùmperio del oro!" 23

Ya en tiempo del Sr. Solórzano, siglo y medio antes de ahora, comenzó a introducirse la ira, la avaricia y la crucldad, con otros excesos vulnerativos de la libertad de los indios. Nuestro sabio político ${ }^{24}$ declama, poniendo a la vista varios ejemplos de castigos divinos y humanos contra malos Corregidores, los exhorta a la obediencia de las leyes; y añade que, por no haberse podido atajar estos daños, se ha tratado muchas veces si sería más conveniente que se quitasell y que no administrasen las Cajas y bienes de sus comunidades, porque en lugar de aplicarlos a las necesidades públicas, se aprovechan de ellos en sus tratos y granjerías, enriqueciéndose con este dinero para hacerles una guerra formidable en sus recur'sos.

Como en esto no se tomó resolución, se despacharon varias Cédulas en 1604 , en 1620,1621 y 1636 , recopiladas en las Leyes 26, Tít. 6, Lib. 2; Ley $5^{3}$, Tít. 2, Lib. 5; Ley 35 , Tít. 4, Lib. 6; y Ley 18, Tít. 29, libro $8^{\circ}$ de Indias, mandando que scan castigados con rigor los Corregidores que hicieren uso, trataren y contrataren con la plata de los tributos y bienes de comunidad, con la pena de privación de oficio y destierro, reagravándose hasta la vida, según la calidad del hurto, que en expresión de la ley ${ }^{25}$ llamaban deuda estos substractores.

El tiempo despertó nuevas advertencias para otras negociaciones de no menor importancia y con $\tan$ buena fortuna que todas ellas iban amparadas de la autoridad de las leyes, por la desgracia de retorcerse en perjuicio de los indios, el beneficio que se intentaba sacar a favor de ellos mismos.

Las leyes ${ }^{26}$ permiten a los indios hacer el pago de tributos en especies, exonerarlos de la necesidad de salir de sus casas para negociarlos en dinero, y al mismo tiempo promover en sus poblaciones la agricultura y la industria. ${ }^{27}$ Otras de ia misma recopilación ${ }^{28}$ previenen que no se retasen indios a la Corona Real, hasta después de tres años de la última tasa o matrícula, con el objeto benéfico de libertarlos de las molestias consecutivas a estas operaciones y de concederles algún desahogo en estos intervalos.

En efecto, los indios, principalmente los de Atacama y Lípez, pagaban sus tasas en pescado y lanas de vicuña, que son las especies en que abunda uno y otro territorio. Aunque esto está permitido solamente a falta de dinero y debe hacerse en caso muy notorio y calificado, con las 
cautclas que prescibeis las Ordenanzas 12 y 13 , Tít. 17 , Lib. $2^{\circ}$ de las Generales del Pert (siempre que los frutos no tengan valor tasado por Ordenamza), para evitar que los cobratores los tomen a menos precio y enteren la tasa en cincro, ganando para si el natyor valor de la venta; sin embargo, los Corregidores de los Partidos expresados, recibian allí el pescado $y$ la vicuna a cuenta rle tributos por infima estimación, $y$ después la vendían de su cucnta el Potosí, desde ocho hasta doce pesos el quintal, cediendo en perjuicio de los infelices indios, todo el acrecimiento que hucraban los Corregidores en la negociación. De esto procedía que demorasen los enteros de tributos por mucho tiempo más de los tercios señalados por las leyes, porque toda esta espera habían nenester para la conducción $y^{-}$venta v'entajosa de los rfectos. lo cual, en rigor, era un verdadero trato y contrato con la plata de tributos; y lo más es que cuando estas especies decaían de precio por su abundancia, cumplían con entregarlas en las Cajas del Distrito, perdiendo el Rey en estas ocasiones no solamente lo que ellos ganaban en otras, sino también toda aquella baja de valor que experimentaban los frutos descle su recibo hasta su venta, clespués de abonados los costos. Con estas consideraciones, dispone el Artículo 127 de la mueva Ordenanza de Intendencias, que en Junta de Real tracienda, se señale anuamente los precios equitativos a que se hayan de recibir estas especies por los recaudadores, para quitarles el aibitrio de su regulación. De este nodo se estableció una regla demasiado sólida para el nuevo sistema de Gobicuno yeformado.

Fn la dilariós de las retasas se presentaba otro recurso muy lucrativo on las Provincias: regulatiente no se hacian cada tres años como lo previenen las loyes. Al menos por aquí llegaron a pasar cerca de veinte ainos desde la úlima revisita de los Pactidos agregados a esta Intendencia. Fra forzoso que, aumentándose considerablemente el número de. tributarios, acreciesc a proporción la masa de tributos. A nadie se ocultaba esta notoriedad, pero todos callaban por respeto a una célebre doctrina: "2 que mientras no se hiciese la nueva retasa, se ha de estar y pasar la antigua, sin poder pedir aumento on clla, por decir que le hay en los tributarios.

Como los caciques o curacas se aprovechabath de esta ocasión, cobrando indistintamente los tributos a cuantos los adeudaban en sus $A y l l u s$, y los Corregidores no ignoraban esta granjería, no faltaba de ellos quien entrase en parte muy francamente, repartiendo, como por vía de cautela, padroncillos reservados, fuera de los de la Matrícula, para que se hiciese la cobranza por el número acrecentado de tributarios que constase de ellos; sirve por prueba decisiva el hecho de un Corregidor de Chichas, que, en descargo de su conciencia, mandó restituir al Rey ocho mil pesos adquiridos con este reprobado arbitrio.

A otro de Porco, le formaron causa los Oficiales Reales, por la usurpación de diez y siete mil pesos de tributos que recogió de exceso a los que enteraba en Cajas Reales. Parece cue no se justificó plenamente el hecho. La defensa fue sobremanera vigorosa y al cabo quedó absuelto en los Tribunales Superiores al favor de la citada doctrina del Sx. Solórzano, creyéndose qué en lo judicial no era responsable al cargo que se le formó, principalmente por hallarse apoyada la sabia opinión de nuestro político, en el Art. 124 de la nueva Ordenanza, que alegó el interesado de su parte. Lo cierto es que quicn le sucedió en el oficio, enteró el primer 
año los mismos diez y siete mil pesos que se demandaban a su antecesor; y aunque en los subsecuentes se le rebajaron a 11.000 pesos, se sabe que siempre le quedaron crecidos sobrantes con qué medrax. Si en realidad se cobró antes este exceso, no puede asegurarse, pero se acreditó con evidencia que lo hubo.

Yo conocí de trato muy familiar al Colregidor de quies se habla. Todavía vive y es sujeto de mucho honox y distinción además de su cristiandad; por lo que jamás le creí capaz de tan grande iniquidad. Pero habiendo otros varios que no poseen iguales dotes, se rio por estos cjemplos, cómo por unos argumentos que lisonjean la codicia, pueden vivir falsamente persuadidos que fue licita esta especie de granjería, para no pensar en descargar sus conciencias y también creerse libie's de crédito judicial en cualquier evento, juzgo importante el esclarecimiento de este punto.

Para el fuero extemo, no tiene méts apoyo que la doctrina citada, y para el interno, dicen que con la casualidad de estos aumentos compensan el grave perjuicio que lastarían en caso contrario de disminución de tributos, una vez que siempre deberían hacer los enteros por el número de la Matrícula, aunque fuese efectiva la falla.

Pero nada se opone tanto it este intento como la docirina del Sr. Solórzano; porque este sabio doctor habla en el supuesto de que los Corregidores no hayan cobrado ninguna tasa clemás sobre los tributos de la Matricula; y entonces es muy justo que tampoco se les forme cargo, aunque hubiese crecido su número. El caso es justlficar la cobranza de tributos con exceso a lo que consta de los Padrones, y eximir de su rosponsabilidad a los Corregidores. En verdad, no encuentro cosa más difícil.

Por el contrario, es cosa clarísima quedar obligados a la jestitución en el fuero judicial, siempre que conste haberse cobrado de los jndios y contribuyentes, teniéndose por suficiente para formar este cargo, la cuenta que tuvieren ios fieles o Cogedoles, conforme a lo cobrado o recibido, según la decisión terminante de la Ley 26, Tít. 29, del Lib. 8" de Indias. 30 Por lo cual no es necesario manifestar recibos formales del Corregidor, en que se declare el exceso de las tasas de Matrícula, para convencerlo de usurpación de tributos (como algumos han alegado); porque para cubrirse, despachaban cautelosamente a los cobladores unos resguardos generales en que sólo certificaban el entero de las tasas, sin especificar su cantidad.

Para evitar este recurso, dispone Ia citada Iey, que sea prueba bastante las cuentas de cobranzas de los Corregidores, que en estas Provincias son los caciques y curacas, y siempre que estén comprobadas con los padroncillos reservados que se suele dárseles como planilta de cargo para las recaudaciones; no hay necesidad de más justificación, porque siendo delito de falsedad, según nuestro Solóxzano, 31 goza de probanzas privilegiadas, como los demás crímenes exceptuados.

A esto es consiguiente, que cometan pecado mortal muy grave y con obligación de restitución, como lo resuelve el citado político, ${ }^{32}$ aunque les aproveche el pretexto de tener que enterar los tributos aun en los casos de efectiva disminución de tributarios. Lo primero, porque habiendo aceptado el oficio con conocimiento de este gravamen tan contingente, como el aumento, se obligaron también a todas sus resultas, ya fue- 
sen onerosas, ya benéficas. Lo segundo, porque aunque fuera admisible la compensación l'especto del Rey, contra la doctrina del Sr. Solórzano, ${ }^{3}$ no debe tener lugar en el caso de que tratamos, ya porque las cantidades que sc intentan desquitar no son líquidas y ciertas, son, a saber, las fallas o aumentos de tributos; ya porque exige toda oculta compensación, que el débito sobre que i'ccae séa actual y no potencial, futuro y sólo esperado, como lo es en nuestro caso el perjuicio dic enterar fallas que no existen y sólo se recelan; ya, finalmente, porque esta especie de compensación únicamente es lícita cuando se hace sin injuria ni gravamen de otro, que no sca deudor; luego, haciéndose la cobranza a indios que por no estar empadionados no son deudores, (de lo que les resulta notorio agravio), es injusta, ilicita $y$ pecaminosa, por defecto de los títulos que la justificaren, como concluyen los Doctores citados por Sabelli. ${ }^{34}$

Lo tercero, porque según la observación de los calculadores políticos más exactos de la población, como M. Korseboon y Atruyk, se tiene de positivo que en los años comunes en que no hayan sucedido guerras, pestes, inunclacioncs y naufragios, el numero de hombres que nacen excede al de los que mueren; cuyo cálculo, en las ciudades pequeñas, es de 34 , uno; y en la campaña, do 38, uno; es caso seguro que en todos nuestros Correginientos, en voz de tomorse disminución de sus habitantes, debía esperar'se aumentos por esta regla, principalmente atendiendo a que los indios no se omplean en la gucrua ni la navegación, y que no tenemos aquí colonias en qué evacuar nuestras poblaciones, para que se siguiese su minoración.

Considerando nuestras leyes csta calculacion más verosímil, igualaron los Partidos entre el Corregidor y al Fisco; pero siempre inclinando la equidad hacia el primero, en el supuesto de que nunca o rarísima vez tendria que enterar mís tasas de las que hubiese cobrado; y así no puede presumirse permitida en nuestra legislación la cobranza de exceso de tributos, sin admitir que por un año malo en pura contingencia, se ha querido recompensar al Corregidor con cuatro fecundos y abundantes, en perjuicio de la Real Hacionda y de los indios.

Conclúyase, pues, que con haberse declarado la responsabilidad forzosa cle los Corregideres a los enteros de la última Matrícula, en el caso de aumento, igualmente que en el de minoración de los tributos, no se intentó indultarlos con el cxceso de tasas, "3i al modo que se les obligó al entero de las fallas, sino únicamente evitar el facilísimo recurso de que se valdrian para justificarlas año por año al favor de su autoridad y poder, sobre la inconstancia, abatimiento y pusilanimidad de los indios. Además de esto, debe considerarsc que cuando se llegare a verificar el caso singular y raro de pagar'se alguna lalla de tasas que no se cobraron, no es perjuicio tligno de la menor atención, por el redundante compensativo que los Corregidores recibian en las crecidas utilidades de los repartos que se les permitió con este objeto y po: otras causas demasiado justas y dignas de las miras del gobierno público.

Ya que el mismo progreso del asunto nos ha hecho incidir en los repartos en quc han cometido los Corjegidores tan excesivos abusos, será bien no onitir la noticia de esta materia, por lo que conviene su conocimiento para subrogar otros medios en el sistema del gobierno reformado, al fin de socorrer a los indios y promover su aplicación a la agricultura e industria. 
Como los indios por su barbarie congénita y por su indolencia solitaria vivían descarriados por familias en los campos, a la manera de fieras salvajes, sin sociedad y sin policía, según to reífore el Sr. Solorzano, 3 fundaron los Incas a costa de inmenso trabajo algunos pueblos donde reducirlos, para el establecimiento do su Imperio; pero sin orden, sin calles ni plazas; islería mal plantada de casas, en que vivian como en un rodeo de bestias, según to nota Garcilaso, ${ }^{37}$ y para que pudicran sustentarse con su trabajo y poco a poco ir empeñandose yor este nedio en los cuidados familiares y públicos, hasta la formación de una sociedad civil, se reparticron entre ellos las tierids de cada pueblo en tres porciones: una para sustentación de los sacexdotes y minjstros asistentes on el templo del Sol y servicio de otros ídolos; la otra para el Inca, y la terce. ra para los naturales, obligándoles por este arbitrio al trabajo de los campos y cultivo de las tierras, no solamente para hacer con sus frutos un fondo para el Estado, sino tambión para afianzar la subsistencia de los pueblos y dar base al comercio de unos con otros en los solłrantes.

El Sr. Don Franeisco de Toledo, que hizo personabrente la visita general de] Reino, mejoró estas poblaciones, al mocio de las españolas, dejando siempro en cada una tiejxas bastantes para las sementeras a los indios, sin innovar en esta parte las leyes fundamentales que habian ar'reglado la constitución del antiguo gobierno del Inca; porque aquel gran Virrey conoció que si bien los tiempos respiertan nuevos cuidados, la diversa situación cle los negocios obliga también a la mutación de leyes; pero la constitución del Estado jamás debe variar ni las leyes relativas a este objeto, por los muchos inconvenientes en que tropieza cada disposición política, como se observó en el pueblo romano a quien le sobrevinieron todas sus desgracias y revoluciones con la introducción de los tributos de la plebe, que mudaban esencialmente la constitución primitiva de la república romana.

Como en estos trabajos de los indios ya no tenían consignación la Real Hacienda ni el clero, y solamente se miraban como fondos de su subsistencia para familias particulares, tambión dejaron de velar sobre ellos los magistrados del Estado, quedando reducido el cultivo de las tierras al cuidado de cada individuo, y a la Intendencia de los gobernadores y Curacas su repartimiento equitativo. En la desidia y genial pereza de los indios, encontraron sus mismos Curacas nuevo motivo para diligenciar granjexías con qué enriquecerse y empobrocerlos; porqué con cl pretexto de labrar las ticrras que aquellos desampayaban, comenzaron a darlas en arrendamiento, bajo el colorido de suplir con el flete el valor del cultivo. En pocos años se apoderaron do la mayor parte de los torrenos públicos, $y$ apenas disfrutaban de algunos retazos cortos los indios más activos, para sembrar algún maíz y papas con qué sustentarsc escasamente.

De aquí resultaron dos consecuencias forzosas, según la constitución del país: la primera, que los indios hacendados, que son los que trabajan en las tierras de repartimiento, nunca se esforkaban en cuitivarlas con actividad, por faltarles la esperanza de cambiar los frutos sobran. tes que les son inútiles, por objctos agradables, que sólo se encuentran donde hay artes $y$ manufacturas y otros establecimientos de industrias; porque siendo el primer fomento que ptiede darse a la agricultura la extensión y la variedad de la industria nacional, faltando ésta, también fal$\tan$ los objetos de gusto, que son los que lisonjean y exitan a los posee- 
dores de hercdades a que perfeccionen ol clitivo y repartan entre la multitud los frutos de la tierra.

La otra, es que, quedándose sin ocupación en el trabajo industrioso de la tierra auuella porción de hombres que no entró en el repartimiento de ellas, es también necesario que gucdasen imposibilitados de mantenerse, porque, cono no hay artes, telaies, ni otro establecimiento de industria en los pucblos de indios, no tenian en qué emplearse para poder vivir de su trabajo.

El sistcma de nuestro Gobienno reformado, conoció el fondo de estos inconvenientes y meditó precaverlos en la nueva Ordenanza de Intendentes, declarando el al Art. 57, era su Real voluntad que todos estos naturales gocen una competente dotación de bienes raíces, y que las tierras que se repartan pasen a los que les cupieren, sean indios o de otras castas, con sólo el cominio iftil, para que les sucedan en ellas sus hijos y descendientes de ambos sexos; pero, en nuestra antigua constitución, se creyó que la decadencia de la agricultura en estos países, provenía absolutamente de la desidia de los indios, y se consultó lo mucho que convenia aplical' os por fuera, por algmos medios utiles $\mathrm{y}$ honestos.

Eutre los propuestos, se prefirió el do los repartos, para que los mismos Corregidores que los habian de hacer, cuidasen de la ocupación de los indios para ser pagados con su trabajo, lográndose, al mismo tiempo, surtir los pueblos de toros los efectos necesarios a la provisión de los indios, sin necesidad de desamparar sus domicilios.

En efecto, se adoptó este inedio, dispensando a los Corregidores las yignrosas leyes que estrechamente prohibian ${ }^{38}$ todos los tratos y contratos, nogociaciones y granjerías en los pueblos de su mando. Para arreglar esta nueva dependencia, se estableció en Lima, hacia ol año de 1750, una Junta de Ministros, donde se acordara la cantidad que debía repartixse en cada Provincia, los precios y efectos más oportunos al consumo útil de los indios. Se formó una cireunstanciada tarifa sobre todos estos puntos, y en cuanto a los cinco Partidos de la Intendencia de Potosí, se redujo el repartimiento a las cantidades de la planilla siguiente, con su respectiva alcabala, que debian enterar en las Cajas Reales, a proporción:

\begin{tabular}{|c|c|c|}
\hline Provincias & Repurtimientos & Alcabalas \\
\hline Chayanta... & $\$ 92.655$ & $\$ 3.706$ \\
\hline Porco .... & $" 76.365$ & $3.051,4$ \\
\hline Chichas $\ldots \ldots \ldots \ldots$ & 182.350 & $" 3.294$ \\
\hline 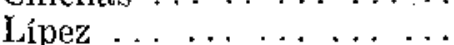 & $" 19.800$ & 792 \\
\hline Atacama $\ldots \ldots \ldots$ & $" 24.650$ & 986 \\
\hline
\end{tabular}

Pa)'a esta tarifa se tiraron muchos cálculos, con el fin de igualar los consumos con la población de cada Provincia, durante los cinco años de cada Corregidor, y se escogieron los efectos más adaptables a la vida simple de los indios, para vestuario y lo más necesario para el trabajo de la tierra y portes de sus frutos, no menos que para poner en movimiento el comercio interior del Reino, que venía a reducirse al fierro, mulas, pañuelos, bayetus de Castilla, y algunos lienzos, con una asignación de precio fijo, que se consideró ser a beneficio de los indios, en que se evitaba la regulación arbitraria de los Corregidores. 
Bien pudo ser que este establecimiento turiese sus principios felices; lo cierto es que, a pocos años, se descubrieron tan graves inconvenientes, que fue preciso proscribirlo, porque nada se logro menos que la dicha y alivio de los indios, a gene aspiraba mestro Gobierno.

Ningun politico ighora que la repartición de las viquezas entre las ciudades, no se hace por ofro medio que cl comercio; ya sea de producciones, cual es el del colono y arrendador, ya de manufacturas, que es el del artessio, ya de comisión, que es el del mercader. Ya se ve que en todas estas especies de comercio, no so consigue más ganancia que a proporción del precio alto que se puede poner a las cosas que se venden, ni hay otro medio de repartir las viquezas entre los comerciantes, que por estos mismos precios; pero en aquellas cinclates doncle el comercio goza libertad entera para vender uno a quien quitre y como quiere, es la única regla de los precios la coneurrencia de vendudores y compl'adores.

Esta Economía Política, que ha hecho la felicidad do otros Estados, nunca se puso en debido ejercicio dentro de nuestras poblaciones. Luego que entraban en ellas los Corregidores, sobrevenía el privilegio abusivo de hacer por sí solos todo el comercio de las Provincias, con el pretexto de abastecerlas con más comodidad $y$ con ofectos más apropiados al consumo útil de los indios. Cortian los pueblos, con el tono de visita. para perseguiz con extorsionos y violencias a cuanto mercader cxtraño hallaban en su jurisdicción, a unos por casados, a otros por usureros, y a los demás por otros delitos que fingia la cavilación, y entre todos sólo quedaba aquél que partía de sus ganancias. De este modo no rabía otra concurrencia que la del Correjidor, y al favor de este inicuo monopolio daban la ley a los consumidores, porque habiendo usurpado los Corregidores el derecho de vender, cllos solos fijaban a su voluntad el precio de sus efectos; y lo peor es que, conocida ya la ganancia de este monopolio, esparció ella misma el espíritu de codicia y de yapiña.

Despejadas las Provincias de otros negociantes, duplicaban tal vez y triplicaban la gruesa del repartimiento, subian los precios a proporción de la carestía inducida de la falta de libertad en los compradores y, sin ceñirse a las especies de la tarifa, no solamente vendían sedas y otros efectos de puro lujo, sino también naipes, anteojos y cuanto podía abarcar la codicia en unos, $y$ en otros la necesidad de recibir lo que querían fiarles en las ciudades capitales.

Para engrosar en las ganancias, incluían en el repartimiento ei reprobado comercio de aguardiente, vendiendolo en todos los asientos de minas con cl mayor exceso, y en los remás pueblos de sus Provincias con una utilidad increíble, jor el ahorro de los impuestos con que está gravado este licor en todas las ciudades del Reino, porque al abrigo de su autoridad fácilmente se introdncia, sin pagar la sisa, la composición $\mathrm{y}$ otros derechos.

De este exceso se seguían los funestos efectos que en este mismo siglo experimentó Inglaterra, por la propia causa, casi con destrucción del Estado. ${ }^{39}$ I Ia mayor parte del pucblo estaba borracho antes de la hora de comer, y en su embriaguez no podia sufrii su continuación, su gritería y sus riñas. Sensiblemente se debilitaban los indios con la bebida in. moderada. Se perdía en salud, la agricultura y todo trabajo industrieso, porque no se observaban las Ordenanzas prohibitivas ni se aplicaron las 
cautelas políticas que tan sabiamente encargc nuestro economista Ustáriz sobre este asunto. to

En el costo de esta continua borrachera, consumian los indios sus cortos salarios, semanales o diarios de la mineria, sin otro trabajo industrioso; nada cuiclaban menos que en emplearse con actividad en la agricullura, porque reduciéndose el cultivo al maíz, cebada, papas y otras grosems simientes a la medida escasa de sus alimentos, no tenían sobrantes inútiles ni apreciables, por ser miforne en todos los pneblos este género de cultivo y no haber en ellos establecimientos de industria con qué exitar ul gusto para empeñal al trabajo. Las misnas mujeres hilan, fabrican y tejen los vesticlos pardos de lana, buda y grosera, con que visten esta casta de gentes on todas sus clases y sexos, sin el nenor estímulo de ambición de mejoral de traje y sin necesidad de trabajar para buscarlo.

Así que se iban acencando o se cumpiían los plazos, era preciso malbaratar los efectus lol repartimiento, vendicindolos por la mitad menos de su costo, y para pagar el resto echaban mano del carnero, de la vaca, del burro o de la mula, y por cualcuier precio salían del ahogo, sin quedarles el menor provecho ste estos lepartimientos. Los que compraban mulas, se ejercitaban de arrieros, dejando el trabajo del campo; por el poquisimo comercio de las Provincias interiores, era menester salir de ellas, hacia ol Tucumán o la costa, para portear cargazones, a fin de pagar con lus lletes su precio y uld otros efectos del repartimiento. Después de peregrinar an año ertero, aponas podían cubrir sus empeños y los tributos, quedando más desutudos que antes y más pobres las familias. Otros menos industilosos padecian mil persecuciones, desamparaban sus domicilios y se refugiaban en los cantones más remotos, en daño de la población de su tierra y un implacable odio contra el gobierno de los Corregidores.

La Real Hacienda era menos aprovechada, porque sobre el seguro de la alcabala de tarifa, so usurpaba el duplo que se repartia demás sobre la gruesa reglada para cada Provincia. El comercio estaba reducido a un monopolio violento y por este medio venía a cnriquecerse uno sólo, cuando el común caminaba a su ruina a pasos largos, sin que hubjera podido remediarse jamás estos excesos, porque la inconstancia de los indios, su misma pobreza y cl alto poder de los Corregidores, cortaban todos los recursos al principio de su caruera.

Al cabo se hicieron sensibles estos imponderables daños en la época feliz de nuestro actual gobicrno, y se proscribió no solamente esta especie de negociación, sino también se mandó desteryar aun la voz de repartimiento, prohibiéndolo absolutamente, bajo de gravisimas penas, el Art. 9 de la Ordenanza de Intendentes; y se otorgó a todos los vasallos indios y de otras castas, una libertad absoluta de comerciar dónde y con quién les acomode, para surtixse de todo lo que necesiten. En efecto, vemos a los pueblos exonerados de este gravoso comercio, desde principios del año de 1784 ; ellos lo van pasando bien, no reclaman ser curtidos por ajena mano, ni echan menos la antigua constitución de su gobierno; pero no se experimenta todavía la felicidad de los indios, ni se reconoce mayor aplicación que antes. En remcdio de esto, puede emplearse otros arbitrios que propondremos después, cuando entremos al Gobierno reformado. 


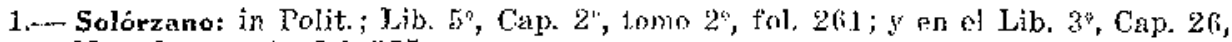
No. 12 , tomo $1^{\prime}$, fol. 375 .

2.- Solórzano: Lib. $3^{4}$, Cap. 26, desde el No, $1^{\text {th }}$ hasta el 12.

3.--Id, id, número 11.

4.- Lib. 46, Tít. 6, Lib. 1" de Indias. Concinio Limense del ario de 1582, Art. $3^{3}$, Cap. 1.1, referido por el Cardenal de Aguirre, en la colección de los Concilios, tomo 6, fol. 38. Concilio Limense 2, prig. 2, Constit. 77 ett.

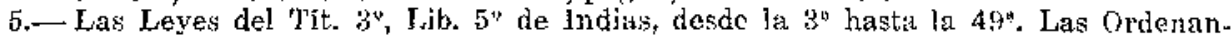
zas del Tít, 17, Lib. 2 de las Generales del Perí, formadis nor el Sr. Toledo, D. García Hurtado de Mendoza y el Duque de la Palata.

6.-Ley 1, Tít. 2, Lib. $3^{\circ}$ de Indias. Solórzano, en la l'olítica, Lib. 5", Cap. 2, No. 1".

7.- Ley 3 , Tit. 2 de Indias, Ley 70 del mismo, y Ley 4, Tít. 2 , Lib. $5^{\circ}$ de Iudias.

8.- Ordenanza 1", Tít. 17, Lib. $2^{v}$ de las Generales del Perü.-- Solórzano, en su Politica; Lib. $5^{\circ}$, Cra. $2^{\circ}$, No. 28 , tono 2 , fol. 266.

9.-F. Tomás, en su opúsculo 21, respondiendo a la Thuquesa de Brabante.

10.- Reales Cédulas de 30 de marzo de 1726,29 de abrit de 1752,7 de junio de 1757, insertas en otra de Aranjuez, a 11 de julio de 1758 , circular para todos los Virreinatos.

11.- Ley 57, Tit. 2, Lib. 3 ; Ley 2, Tíi. 2, Lib. 5 de Tndias.

12.- - Real Cédula de Madrid, a 25 de diciembre de 1773.

13.- Ley 10, Tit. 2, Lib. $5^{\circ}$, de Indias.

14.-Leyes 16 y 17, Tít. 9, Lib. $8^{\circ}$ de Indias; y sobre ellals el Sr. Solórzano en sul Política, No. 16 , hasta 22 , tomo $1^{\circ}$, fol. 167 .

15.- Leyes 9, 10 y 12, Tít. 9, Lib. 8" de Indias.- Ley 64, Tít. 5, Lib. 6" de la misma Recopilación.

16.- El Sr. Dn. García Hurtado de Mendoza, en 7 de octubre ue 1590.- - Ii Sr. Conde de la Monclova, en 10 de marzo de 1692, mandadas obsorvar en l'rovision Real del Tribunal de Cuentas do Lima, a 12 de octubre de 1717.

17. El Sr. Marqués de Guadalcázar, en 30 de diciembre de 1622 , concedió dos meses de plazo el cual se extendió a tres meses por ol Sr. Duque de la Palata, en Provisión de 20 de febrero de 1784. Cap. 27, inserto al fol. 31.1 de las Ordenanzas Generales dei Perú en virtud de Reales Cédulas que allí se citan.

18.- Provisiones de 27 de junio de 1618 y de 30 de diciembre de 1622 .

19.- Ley 2, Tít. 3; Leyes $14,19,23$ y 34, Tít. $8^{\circ}$, Lib. $8^{\circ}$ de Tndias.-Escalona, Lib. 1, párrafo 2, Cap. 6, No. 19, fol. 14.

20.- Leyes 5 y 78 , Tít. $1,12,13,17$ y 29 , Lib. $8^{\circ}$ de Indias.

21.-Ley 36, Tit. $^{\circ}$, Lib. $8^{\circ}$ de Indias.

22,-Escalona, Lib. 1, párrafo 2, Cap. 6, No. 11, fol. 12 .

23. - Horacio, Oda 16 , id, id, oda 9 .

24.- Solórzano, in Política; Lib. 5, Cap. 2; No. 24 y 25, tomo 2, fol. 265.

25.-- Ley 35, Tít. 4, Lib. $6^{4}$ citado.

26.-Leyes 22,25 y 39 , Tít. 5\%, Lib. 6\%; Ley 7 , Tít. 17 del mismo Lib.; y Ley 7, Tít. 24, Tib. $4^{\circ}$ de Indias.

27.- L. collomis cnulia; Cod, de Agricult., Lib. 11.- Platea y ótros con Alvaro Velasco, De jure enphiteutic., G. 20 , No. 6 , fol. 87 , vers. accedit.

28.- Ley 59, Tít. 5, Lib. $6^{\circ}$ de Indias.

29.- Solórzano, in Polit. Lib. 2, Cap. 21, No. 6, tomo 1, fol. 165.

30.- Se contirna con el argumerto de la Ley 43 , Tít. 5, Lib. $6^{\circ}$ de Indias.

31.- Solórzano, ubi supra.

32.- Solórzano, ubi supra.

33.- Solórzano, I Lib. $2^{\circ}$, Cap. 21 , tomo $1^{\circ}$, fol. 284.

34.- Sabelli: Compensatio, No. 47, tomo $1^{\circ}$ fol. 284 .

35.- Derogadas las leyes sobre falla de tributos, se permite por el Art. 124 de ia Nueva Ordenanza, el cómputo después de la Matrícula.

36.-- Solórzano: De jure Indiarum; Lib. 2, Cap. 7, No. 29.

37.- Garcilaso: 1a. Parte de su Historia; Lib. 19, Cap. 12.

38.- Leyes 54, 64, 66, Tít. 16, Lib. 2 ; Ley 24, Tít. 18 ; Ley 32, Tit. 20, cod. Lib. Ley 74, Tit. 3, Lib. 3-Ley 47 , Tít. 2.- Ley 59, Tít. 15, Lib. 5 de Indias. Solórzano, in Política, Lib. 5", Cap. 11, desde el No. 34.

39.- En 1736, se expidió Auto de Pariamento, prohibiendo el uso de aguardientes.

40.- Ustáriz: 'Teórica y l'rúctica de Comercio y Marina; Cap. 54, desde el fol. 194. 


\title{
CAPITULO SEGUNDO
}

\section{De la Tesorería de la Real Hacienda de Potosí}

Se refiere la erección de estas Cajas Reales; la dotación de ellas; su territorio; la autoridad de sus Ministros, con las novedades ejecutadas en su administración y los ramos de su manejo.

\author{
NOTIOIA PRI M E R A
}

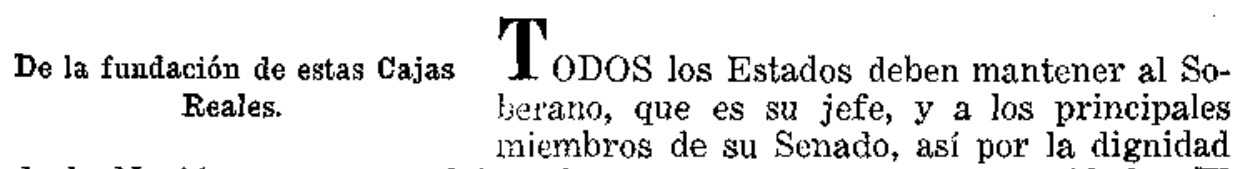
de la Nación, como por el interés que se toma en sus prosperidades. El poder militar de los Príncipes, necesita armas, ejércitos de mar y tierra, plazas fuertes, arsenales y navíos para la defonsa del Reino y hacer respetar su persona y autoridad. El Gobierno no puede subsistir sin Ministros del Estado y sin otros empleados en negocios políticos. Los pueblos claman por su policía y por su decoración; exigen fábricas de calzadas, puentes, caminos reales $\mathrm{y}$ fortalezas. El soberano que no posee tesoros ocultos, como refieren las novelas de los reyes fabulosos, necesita más que nadie que sus vasallos le mantengan y suministren caudalosos subsidios para todas las empresas.

Nuestros Reyes Católicos, que hicieron el descubrimiento y conquista de estos Reinos, a tanta costa de la Corona de Castilla, estaban otro tanto más necesitados de percibir competentes rentas' de estos nuevos Estados, para subvenir at estos gastos públicos y a las dotaciones de los Tríbunales que erigió par'a su gobierno. ${ }^{x}$ Los dominios de este imperio, que recayeron en el patrimonio Real, como fueron tierras y otros señoríos, formaron una base de las rentas del Soberano; pero como no alcanzaban para todas las cargas del Estado, ya fue preciso gravar a cada ciudada- 
no a proporción de sus facultades, con los impuestos, las tasas, los subsidios y otras contribuciones, que son el segundo manantial de las rentas públicas.

Como es moralmente imposible que el Soberano conozca por si mismo todos los detalles de las urgencias del Estado, ni pueda reglar y exigir las contribuciones, emplearlas con justa repartición y llevar sus cuentas y registros exactos, fue menester establecer varios departamentos o Ministerios de Fucienda, con destino a este encargo: uno general, a la Dirección de un solo Jefe, que esté como un árbol plantado en el centro del Estado, cuyas raíces se dilatan hasta sus cxtremos; $y$ otro provincial subordinado, compuesto do rarios enpleados que estén encargados del régimen parcial de cuanto tiene concxión con el ramo de Hacienda de su respectiva Provincia; por cuyos medios pueda gobernarlo todo el Soberano, sin distraerse de sus grandes objetos por pequeños detalles.

En los primeros tiempos de la conquista de estos Reinos, fue variable, confusa y desameglada la administración de la Real Hacienda, así por mayor como por menor, hasta que la misma experiencia de los negocios dictó reglas oportunas para su buena ordenación, como se verá en los períodos siguientes.

Periodo Primero. tas contribuciones pecuniarias, tas contribuciones pecuniarias, que pagaban los pueblos en dinero especies, por razón de quintos o tributos, fuera del oro y plata que se quitaba a los indios por justa represalia de la guerro o por gratuita donación de ellos mismos. El manejo de esta hacienda corría al cuidado del Gobernador o Adelantado de la Provincia y de otros Ofieiales menores destinados a este encargo, con instrucciones particulares. Todo este patrimonio se administraba como una hacienda familiar y doméstica, sin registros exactos y sin formalidad escrupulosa de cuentas. Lo más de este manejo se ignoraba en España, y uno y otro motivo influía para que la administración de los bienes fiscales, fuese en la mayor parte lucrativa para los Ministros y perjadicial al Rcy. ${ }^{2}$

\section{Periodo Segundo. WiSTE desordel dio motivo para que se in- corporase al Supremo Consejo de las Indias,}

la Administración por mayor de la Real Hacienda, en todos los dominios de la América, encargándosele el cuidado de su gobierno, así en cuanto a expedir sus órdenes para su aumento, como en pedir cuentas de su gasto $\mathrm{y}$ justa distribución a los Virreyes y Gobernadores, a quiones el mismo Consejo subdelegaba estos cuidados, bajo de las instrucciones y órdenes que entonces se juzgaron más convenientes, como se colige de varias Cédulas y órdenes Reales que cita el Sx. Solórzano. ${ }^{3}$

\section{Período Tercero. DESPUES creció tanto la masa de la Real Hacienda en estos Peinos, que llegó a emba-} razar notoriamente al Consejo de las Indias para el despacho de los negocios de Gobierno y Justicia, de que estaba encargado por su nativa ins- 
titución. Se juzgó más propio del Consejo de Hacienda, la administración, cucnta y razón cle ella, por lo que se trasladó a éste toda esta jurisdieción, uniéndola al manejo del Real Patrimonio de Castilla. Luego nombró el Consejo de Hacienda, por comisarios para el comercio de la de América, a Ortega de Melgona, Contador de la Casa de Contratación de Sevilla, para que juntamente con Hernando de Ochoa, que lo era de la Contaduría de Tacienda, twiesen la Administración en estas Provincias del Perú; cuyas órdenes se ejecutaron por el Si. Conde rle Nieva, Virrey entonces de Lima, y los explesados Comisarios.

Fstos formaron Sala con dosel y Armas Reales, con el titulo de: Consejo de Cámara y Estado, para el asiento y quietud de estas Provincias y beneflicio de la Real Hacienda, y despachaban con el sello y Registro de la lieal Audiencia. Esta grande autoridad los hizo tan astutos y despóticos, quo desatendiendo lat lorzosa dependencia del Consejo de $\mathrm{Ha}$ cienda, cllos todo lo disponian sin consultarle sino poquísimos negocios, y aur at Virrey, con hallarse presente, rarisima vez. Se vio por estos reprensibles abusos que este establecimiento no habia correspondido al intento, y fue prociso abolir esta mueva jurisdicción, mandándolos cesar e ir todos a España, despućs gue les tomast residencia el Licenciado Pedro Ramílez de Quiñones, Regente de la Audiencia de la ciudad de La Plata. 1

\section{Período cuarto. Por las referidas causas y por el grande} embarazo que causaba a las resoluciones de uno y utio Consejo, por la confusión con que iban de Améxica todos juntos los negocios de Gobierno y Hacienda, con pérdida de mucho tiempo, para dividir los papeles de ambas dependencias, se resolvió seunir al Consejo de Indias, en el año de 1562, la administración por mayor de la Real Hacienda de Indias, restituyendole por' un dichoso postliminio el soberano poder concedido en su creación, no sólo para entender en toda diversidad de negocios y expedientes que están repartidos en los demás Consejos de la Monarquía, sino también en lo tocante a la Suprema autoridad del Legado de la Sede Apostólica, con sola la calidad de que dos Ministros del Consejo de Hacienda pasaren al de lndias, las veces que fuesen Jlamados, para conferił' lo que se dudase en estas materias. ${ }^{5}$

\section{Período Quinto. CoNsIDERANDO nuestro sabio Senado la imposibilidad de proveer con acierto a tan} grandes distancias, sobre negocios de igual importancia; y por otra parto los inconvenjentes de fiar a la dirección de muchas cabezas el gobierno económico de la Real Hacienda, cncargó a los Señores Virreyes privativamentc, la administración, cuidado y superintendencia de todos los miembros de Hacienda y renta de estos dominios, dándoles muchas advertencias sobre la forma en que las habían de administrar, según las instruciones que a cada uno se empezó a despachar, desde el Sr. Virrey Don Francisco de Tolcrlo, como lo refieren los señores Virreyes, Marqués de Montesclaros y Principe de Esquilache, en sus respectivas relaciones. ${ }^{6}$

En efecto, desempeñaron la Real confianza en el nuevo Gobiexno del Tesoro Público estos poderosos Magistrados, con igual desinterés y 
fidelidad con que administró el grande Arístides las rentas de Grecia, usando en lo general, sin abuso, de las ampliaciones casi sin límites que se les concedió en este manejo y explica circunstanciadamente nuestro Escalona, en treinta y dos casos muy particulares. $i$

Período Sexto.

C

OMO los grandes designios no se pueden poner en ejecución desde un lugar por sólo un Regente, $y$ se necesitan tantas manos cuantos fueren los distintos parajes donde se administra la Hacienda que se recoge, fue menester ir fundando en cada Provincia de América otras tantas Provinciales Cámaras de Hacienda y Cajas Reales, para st cobranza, guarda, administración y distribución por menor, señalando ciertos límites exactos a la autoridad de cada una, para que los rayos del círculo de Hacienda se fuesen a reducir sin confusión en un centro común.

Nuestros conquistadores, los Marqueses Don Hernando Cortés y Don Francisco Pizarro, fundaron muchas Cajas Reales en las diferentes Provincias que conquistaron en los Imperios del Perú y Nueva España, y para el establecimiento de otras en las nuevas poblaciones, se les dio igual facultad a los Gobemadores y Adelantados, por varias ordenanzas recopiladas en las leyes. ${ }^{*}$

En esta Provincia de Potosí, que antiguamente? se llamó de Charcas, y después de la conquista: Nueva Toledo, convenía más que en otras el establecimiento de Cajas Reales, por las inmensas riquezas de cste Cerro admirable. En efecto, consta de una nota puesta en las tablas de Memoria de Ia Contaduría, que el año de 1556, después de once años de su descubrimiento, se comenzó a hacer con formalidad el repartimiento de labores; pero no se encuentra el acta de erección de las Cajas, en ninguno de los libros, sin duda por el desgreño con que se llevaron a los principios; y por esto se ignora el año de su fundación.

Sólo se sabe por tradición universal, que estas Cajas estuvieron primeramente fundadas en el Asiento de Porco, distante nueve leguas de la Villa, por ser el mineral de más fuste que encontraron los españoles en actual trabajo, de orden de los Incas, en el año de 1538 que se conquistaron estos países de Charcas; y después se trasladaron a éste de Potosí, cuando se descubrió su portentoso mineral, en tiempo que ya iba en decadencia el de Porco.

Fundación de las Gajas Reales. LAS casas Reales para custodia del Tesoro, se fabricaron el año de 1598 , por Juan

Gutiérrez de Piña, con el costo de 15.000 pesos ensayados de 450 maravedíes, en que se remató la obra en pública subasta, y según la graduación del ensayado por ciento cuarenta y cuatro pesos de nueve reales, conforme a una Real Cédula, de 1714, importó esta fábrica, en pesos corrientes, la cantidad de veinticuatro mil trescientos; pero, arreglando el cálculo al cómputo antiguo, subc a veinticuatro mil diez y seis pesos, un real y catorce maravedíes.

Los Oficiales destinados para el manejo de la Real Hacienda, eran tres, a saber: Tesorero, Factor y Contador; de cuyas facultades y oficios trata difusamente nuestro Escalona y el Sr. Solórzano. ${ }^{9}$ En Potosí ha- 
bia otro Ministro con título de Alguacil Mayor, en tiempo del beneficio de platas, sin responsabilidad ni obligación de residencia personal, con privilegio de nombrar un Teniente para las ejecuciones y demás diligencias tocantes al Tribunal. La plaza de Fuctor, que sirvió su último poseedor Dn. Nicolás del Valle, se mandó suprimir por Real Orden de 11 de octubre de 1775, y sc ratificó en el Art. 92 de la Real Ordenanza de Intendentes del año de 1782 y en otra Real Orden anterior de 1 de jumio de 1781. El primer Intendente de Bucnos Aires, Don Manuel Ignacio Fernández, obligó al Alguacil Nayor Dr. Furmín Aoiz (residente entonces un aquella capital), que riniese a servir en persona su plaza, el año de 1780, y por sus informes fue suprimida, como la del Factor, dándosele por compensativo la Contaduría de las mismas Cajas.

\section{NOTIOIA SE G U N D A}

Del sueldo ale los oficiales Wistos Ministerios de Hacienda de las CaReales. jas de Potosí, so lotaron desde su erección con el sueldo de dos mil pesos ensayados, que al respecto de cuatrocientos cincuenta maluvedies, conforme a una ley de Indias, "equivalente a trece y un cularto reales, por cada peso doble, como lo declara otra ley de la misma recopilación, ${ }^{11}$ suman tres mil trescientos ocho pesos scis reales y veinte maravedies al año; de cuyo valor, descontado el premio y cuño, quelan tres nil doscientos cuarenta, que son los misinos que gozaron por salario de sus empleos.

Debe advertio'se, para inejor inteligencia de este asunto en las novedades que ha sufrido, que los pesos ensayados se dividen en dos clases. La una se llama de Tase, y la otra de Pasta. La primera vale doce y medio reales, cuyo valor ha regido hasta ahora para la cobranza de Reales tributos, con aprobación de Su Majestad, y esta clase es la que se re-

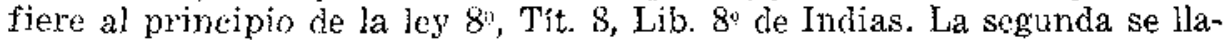
ma de Pasta, porque en ella se satisfacían los pagos de esta especie, y su importe es de trece y un cuartillo reales, como queda dicho, siendo ésta la

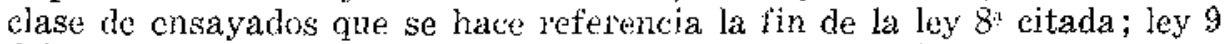
del propio título y libro, y ley 8:, Tít. 24, Lib. 10 de Indias.

Aunque al peso en el Reino ha valido siempre nueve reales para la justa regulación del ensayacto, según cl computo de la ley 3 , Tít. 8 , Jib. 8" citado de Indias, se introdujo cierta alteración abusiva en estimar el ensayado por ciento cuarenta y dos y ciento cuarenta y tres, 12 hasta ciento cuarenta y ocho, con perjuicio de la Real Ilacienda on la administración de los pagos debidos hacer en esta especie, en cuya consideración trató do su desarroglo ordenándose por punto general, en Real Cédula de 1: de septiembre de 1711, que todos los pagamentos que se hicicsen en pesos y ducados ensayados, se redujesen al peso corriente de ocho reales, regulando por ciento cuarenta y cuatro de a nueve reales cada mo. Por ejemplo, cien pesos ensayados de plata, valen ciento cuarenta y cuatro pesos de nueve reales, cuya cantidad multiplicada compone ciento sesenta y dos pesos corrientes, subiendo por esta regla el total de dos mil pesos ensayados, a los expresados tres mil trescientos ocho pesos seis reales, veinte maravedies, de los cuales rebajando el premio y cuño, 
viene a resultar el liquido de los tres mil doscientos cuarenta pesos que tiraron por su dotación estos Ministros de Roal IIacienda.

Pero el Intendonte General de Buenos Aires, Don Manuel Ignacio Fernández, mandó en el año de 1777 , por providencias circulares, que en lo ulterior se considerasen los pesos ensayados, al respecto do doce reales y no más, con motivo de una Real Cédala de 5 de agosto del mismo año, en que al Gobernador de Mojos se le concectieron tres mil pesos corrientes de salario, por dos mil pesos ensayados; y desde este tiempo dejaron de percibir estos Oficiales Reales, los 240 pesos del resto. defalcado, sin embargo de las instancias que han promovido. El Art. 94 de la Real Ordenanza de Intendentes, mandó que por ahota quedaran con el suelclo que en la actualidad gozan, con la calidad de reducirse al de dos mil y quinientos conforme fueren vacando estos empleos, entendiéndose inclusas cualesquiera gratificaciones $y$ ayudas de costa, con positiva prohibición de llevar emolumentos o derechos algunos con ningún motivo ni en ningún caso; sobre lo cual tambiéu se ha representado con informe de esta Presidencia.

NOTICIA TER C E R A

Del territorio antiguo y mo- $\mathbb{H}_{\mathrm{N}}$ su fundación primitiva, comprendía el derno de estas Cajas.

teruitorio de estas Cajas, quince prorincias dilatadas, es decir, otros tantos Gobiernos, $y$ son: Buenos Aires, Paraguay, Tucumán, Chayanta, Porco, Chichlas, Lípez, Atacama, Santa Cruz de la Sierra, Cocliabamba, Pomabamba, Mizque, Yamparáez, Frontera de Tomina, Pilaya y Paspaya. En cl siglo pasado se desmembró la Provincia del Rio de la Plata, agregándosele el distrito del Paraguay, donde ponían Tenientes, de su cuenta y riesgo, los Oficiales Reales de Buenos Aires; y en cuanto a la Provincia del Tucumán, consta que en virtud de Real Cédula de 7 de febrevo de 1622, recopilada en la Ley 10, 2 y 6, hasta 14 del Tít. 11, libro $8^{\circ}$ de Indias, se estableció en la ciudad de Córdoba una casa de Aduana o puerto seco, con varios Ministros Oficiales Reales, que celaron el extravio de los géncros prohibidos que pasaban, sin Real licencia, del Puerto de Buenos Aires a los Reinos del Perú.

Este establecimiento se cometió a Don Alonso Pérez de Zalazar, Oidor de Charcas, el cual lo verificó promulgando una Ordenanza de 37 artículos, su fecha en Córdoba a 19 de julio de 1625, para el Gobierno de la referida Aduana, señalando en el Ant. ", por límites hacia la ciudad de Buenos Aires (para no pasar efectos no permitidos), un pueblecito de indios, llamado San Agustín de Guayastate, distante veinte leguas de Córdoba, y arregló en el Art. 11, las avaluaciones, aforos y derechos de Aduana. Después se trasladaron las Cajas a la ciudad de Jujuy y de allí últimamente, a la Capital de Salta donde permanecon, conforme a la declaración $4^{n}$ de la Ordenanza de Intendentes, de 28 de enero de 1782.

De las doce Provincias lestantes, han quedado agregadas a las Cajas de Potosí sólo cinco, que son: Chayanta, Porco, Chichas o Tarija, Lípez y Atacama. De las otras siete, se incorporaron Santa Cruz, Cocliabamba y Mizque, a la Caja Propietaria erigida el año de 1772 en aquel Grobiemo, y recientemente mandada establecer en la enunciada Villa de 
Coehabamba, Capital de su nueva Intendencia, con todo el territorio senalado en la Declaración $3^{n}$ de la Instrucción de Intendentes. I as cuatro últimas, de 'Tomina, Yampaíáez, Pilaya y Paspaya, se agregaron a la Caja de la cíudad de la Plata, erigida desde el citado año de 1772 , y mandada conservar por el Art. 91 de la referida Ordenanza de Intendentes en dicha Capital.

NOTIOIA CUARTA

De la antoriciad de los oficia- EN la constitución de los negocios de Hales Reales. cienda, se estableció su Gobierno, distinguiendo lo económico de lo judicial y los Ministerius lelativos a mo y otro objeto. Sobre este pie siempre tuvo el Fisco, para la buena cuenta, cubranza y distribución de las rentas del Soberano, sus oficiales particulares, con ol nombre te Cuestores, ${ }^{13}$ y sus Jueces privativos para todo lo judicial, con el título especial de Procuradores del Cosar. 14 Cuando so creaton en las Américas los empleos de Oficiales Realos, se observo ette sencilló metodo: porque entonces no se les dio jurisdiccion para las cobranzas y pleitos que en razón de ella se ofrecielen; por lo cual el Factor, a cuyo cargo corrian todas las cobranzas, compras, ventas o pagos que se hubiesen de hacer con parecer del Gober' nador y de los demás Oficiales Reales, era obligado a ocurrir ante la justicia ordinaria a pedirlo contra los detdores, y a seguir las causas en todas sus instancias, como lo rélicre el Sr. Solórzano. ${ }^{15}$

Esta división de mandos dio pretexto para excusarse de sus omisiones de los Oriciales Reales, echando la culpa a los Jueces ordinarios a quienes acudian a pedir justicia; por cuyo motivo y el de autorizarlos más en bencficio de la Real Hacienda, se despacharon diferentes cédulas, que cita muestio Politico, ${ }^{6}$ y se recopilaron después en las Leyes de lndias, ${ }^{17}$ concediendoles plena mano y jurisdicción para todo lo tocante a ella en primera iustancia, con apelación a las Audiencias de sus respectivos Partidos; $y$ desde este tiempo pasaion de meros Cucstores, a ser comparados a Procuradores del Cesar, intitulándose Magistrados Nacionales, Susceptores, Prepósitos, Arearios, Exdoctores y Cobradores. ${ }^{14}$

Al paso que se les fue acrecentando la autoridad, fueron también incurriendo en diferentes abusos de despotismo, 19 haciéndose importunos y molestos a los súbditos de estos dominios, y los que, en opinión de nuestro Historiador Herrera, ${ }^{20}$ tenían mayor necesidad de ser corregidos.

En las ocasiones que, por ausencia de los jefes, quedó el Gobiemo a cargo de ellos, fueron muxy considerables los perjuicios que causaron con su soberbia, como se comprueba en aquél atentado suceso de Gonzalo de Zalazar y Peralméndez Chirinos, Oficiales Reales de México, que poi pasiones y venganza, mandaron ahorcar a Rodrigo de Paz, Alguacil Mayor de aquella ciudad y primo de Don Hernando Cortés por cuya ausencia se hallaban mandando. 21 Lo mismo ejecutaron en el Paraguay los Oficiales Reales Felipe de Cácercs, Alonso Cabrera, García Banegas y Pedro Dorantes, prendiendo al Adelantado General de aquella Provincia, Alvar-Núnez Cabeza de Vaca, el año de 1542, hasta remitirlo a España, bajo partida de registro. ${ }^{22}$ 
Pero es preciso confesar que cuanto tuvieron de odioso los primitivos Oficiales Reales, otro tanto más fueron timoratos, fieles, nobles, prudentes, integros y detenidos, los que sirvieron estos empleos en los tiempos posteriores, mostrándoso terribles a los defraudadores de la Real Hacienda, al mismo paso que cran suaves $\mathrm{y}$ mansísimos con las personas fieles y devotas al fisco, como asegura Escalona. 2.3

Sobre este pie de absoluto mando usaron sus empleos los Oficiales Reales de Potosí, en todo el Distrito de la Real Audioncia de Charcas, que antes comprendía las quince Provincias referidas en la Noticia antecedente. De suerte que, por estas calidades, eran más honados y más respetables que todos los Gobernadores de estas Prorincias, dependiendo de su mando hasta los vecinos particulares que pretendían el honor de los oficios públicos, por haber ordenado el Sir. Virrey Marqués de Montesclaros, en Provisión de 23 de agosto de 1609 , que, conforme a la orden de S. M., ningún oficio del Distrito de los Charcas, se rematase en otro Iugar fuera de la Villa de Potosí, respecto de haber alli siempre lrombres ricos que puedan comprarlos y afianzarlos con la segur'idad conveniente.

A este grado de autoridad aumentaron la de poner su despacho bajo de dosel con las Armas Rcales, con otras muchas preminencias a que se refiero el Sr. Solómano difusamente, en un Capítulo casi entero de su Política, donde pueden verse muchas importantes cuestiones, que también toca nuestzo Escalona, zi y siempre son útiles, exccptuando el Capítulo que trata de la juzisdicción de los Oríciales Reales, cn la cobranza de Rcal Hacienda. ${ }^{2} \mathrm{~B}$

Aunque una de las preminencias, ya prescritas, fue la de entrar como Regidores, con voz y voto, en los Cabildos y Ayuntamiento de la ciudad donde residieren, no parece inútil tratar este punto, una vez que, aum después de haberse mandado vender por cuenta de la Feal Hacienda, los Regimientos que ellos ocupaban, duran hasta el día muchas reñidas controversias acerca del lugar que les corresponde, cuyas cuestiones supone y no resuelve nuestro Político. ${ }^{27}$

Asiento de los Oficiales ReaIes en el Cabildo.
$\mathbf{L}$ relación de las órdenes antiguas, ya peformadas, sobie la calidad de Regidores en los

Oficiales Reales, y atendicndo a que no quedasen sin lugar en los actos publicos con la Justicia y Regimiento, dispone que se les guarde el sitio y puesto que tenían cuando cran Regidores; y donde lubiese variación, que sobre ésto se guarde la costumbrc. En la averiguación del primer punto, obscurecido por la antigüedad, y del segundo, contradicho implacablemente por los interesados, eran inútiles las disputas que se suscitaban, y yo he visto una muy reñida entre el Alférez Real y cl Oficial Real de la ciudad de Salta, el año de 1779, y otra entre los de lat Capital de Buenos Aires.

No se contentaban con preferir al Alguacil Mayor, como parece lo hacían al principjo, según lo expuesto por el Sr. Solórzano, ${ }^{2}$ pretendían sentarse inmediatamente después de los Alealdes ordinarios, anteponiéndose a todos los Regidores, incluso al Alférez. Real; como éste debe tener por las Leyes 29 al primer voto $y$ mejol lugar después de la Justicia, reina con razón la preferencia que le está acor'dada, atin respecto de 
Ios Alcaldes I'rovinciales, por Real Cédula de Aranjuez, a 11 de abril de 1638 .

En el conilicto rle estas contradicciones, ganaron unos y otros en diferentes tiempos, por providencias ya del Consejo, ya de las autoridades; unas veces dedarando la preforencia de los Oficiales Reales ${ }^{30}$ y otras veces a favor del Alférez Real, mandándose guardar la costumbre de las Jndias, según la cual los Alféreces Reales preceden en asiento a los Oficiales Reales. 31

Ultimamente se despachó Real Cédula de El Pardo, a 19 de marzo de 1777 , en la que haciendo relación de las razones que amparaban el derecho del Alférez Real, Alcalde Provincial y Alguacil Mayor, por el orden que alcgó el Cabildo, con más la súplica interpuesta desde el año 22, por los Oficiales Reales de Buenos Aires, acerca de otra declaración contraria a ellos, se turo presente la dignidad del empleo de Contador Mayor, nuevamente creado on acuella capital, y en consideración al asiento que se le debía dar cono a Ministro Principal del Tribunal de la Real Hacionda con los Oficialcus Reales, se declaró que el Contador Mayor y ellos, debían sentar'se después de les Alcaldes Ordinarios y llevar los uniformes de Comisarios de Guerra que les estaba concedicto.

Tos Oficiaks Roales de esta Villa de Potosí, impetraron otra Real Céduda, de Fum Retiro, a 26 de julio de 1715, mandada guardar por el Sr. Viryey, Príncipe de Santo Bono, en despacho de 18 de marzo de 1777, ordenando al Csbildo, bajo la pona de dos mil pesos, que admitiesen a los Oficiales Reales ei asiento immediato a los Alcaldes Ordinarios, con preferencia a todos los demás.

Cuando yo llagué a Potosí, cxtrañé el no uso de esta preminencia, y hube visto después en el libro de Provisiones de las Cajas, haberse sacarlo copia del refelido Real Despacho, a pedimento de los Oficiales Reales, entendiendo que el Cabildo interpondría alguna súplica tal vez sobre la concurrencia con vestido de color, según he oído decir a algunos. Lo cierto es guc las órdenes posteriores, lejos de reformar esta regla, la han declarado a favor de los rle Buenos Aires, según hemos visto; con que, siendo de derecho que el rescripto del Príncipe para una Provincia se entiende también con las demás, " 2 no juzgo disonante que los Oficiales Reales de Potosí, deban gozar de la misma preferencia con la distineión de sus uniformes de Comisarios de Guerra.

Los Tenientes de Oficiales Reales, entablaron la propia pretensión, por el tenol' de una Cédula antigua, de 14 de noviembre de 1653 , que ordenó tuviesen asientos preeminentes en los Cabildos. La Real Audiencia de Buenos Aires, en su primer establecimiento, mandó Real Provisión de octubre de 1671, que se guardasen a los Tenientes de los Oficiales, conforme a la citada Códula y a otra anterior, de $1^{\circ}$ de octubre de 1598; pero, como en ésta se previno que los Tenientes gozasen dichas preeminencias, con tal que no los prefieran a los Regidores propietarios ni a Ios más antiguos, declaró últimamente la Audiencia de Charcas, en Provisión de 30 de septiembre de 1771; que los Ténientes Oficiales Reales de Córdoba sé sentasen después de todos los Regidores.

Por estas Cajas se nombraban los Tenientes para la ciudad de Ia Plata, Villa de Cochabamba, Mizque y Tarija, en uso de la facultad otorgada por la Ley 7, Tít. 26; Ley 26 , Tít. 4, libro $8^{\circ}$ de Indias, y por una Cédula de 11 de noviembre de 1653 , despachada al Presidente de 
Charcas, Don Francisco Nestares Marim. Estos empleos 1 o deben gozar salario de la Real Hacicnda, conforme a la Iey, ${ }^{3}$ y sí ínicamente un tanto por ciento de las cobranzas, cuyo abono ha tenido rariedad según los países.

En el Departamento de Buenos Aires tiruban Ios Tenientes un $8 \%$ de las cobranzas; pero en éste de Potosí, debian exigir solamente un $2 \%$ de lo que cobrasen, según la relcida Cédula de Nestáes, con la calidad siguiente: que no ejerzan ol cmpleo más que por tres años, ni lo puedan tener por más liempo sin dar cuentas finalos por finiquito; que las llaves de las Cajas en que se dobe meter y guardar la plata, tengan la una el Teniente Oficial Real, otra el Corregidor o Alcalde Ordinario más antiguo, otra el Escribano del Cabildo, y que no valgan las certificaciones de los enteros que hieieren en Arcas, no estando firmadas por todos tres. En el día, no reside en Tarija d Teniente que había dntes, por haberse agregado a la Real Aduama d lamo de Alcabalas, de cuya cobranza cuidaba antiguamente esta Caja.

Entre las facultades explesadas, no se reputatia menor la de tomar cuentas a los Corregidores de las doce Provincials del Departamento de estas Cajas; y aunque según las Icyes 34 solo servian de tanteo, y entre tanto que las tomaban, rovisaban y fenecian los Contadores del Tribunal mayor de ellas; era muy considerable esta intervención, por la superioridad que tenían sobre los Corregidores y por otras consecuencias que no se ocultan. $Y$ en verdad que tambien les eia lucrativa esta autoridad, tanto que fue menester poner límites en ella.

El Contador Mayor, Don José IIerboso, Visitador de estas Cajas, mandó en Decreto de 15 de marzo de 1747, que se exigiese a los Corregidores de Cochabamba, Porco, Chayanta y Chichas, cien pesos por cada año de sus cuentas; a los de Tomina, Yamparácz, Pilaya y Mizque, setenta pesos; y al de Lípez y Atacama, cincuenta; mitad para los Oficiales Reales, por vía de emolumentos, y la otra mitad al Oficial Mayor por su trabajo.

En conclusión, era tan grande y universal la autoridad de estos Oficiales Reales, que tenían mano casi absoluta on los Corregidores, por la dependencia de sus cuentas; en el comercio, por la jurisdicción en los registros y comisos; en los minelos, por la distribución de Azogues y venta de Ias minas de Su Majestad; en la Casa de Moneda, por la cobranza del señoreaje y por la labor de cuenta del Rey; en los indios, por los tributos y rescrvas; en los Curas, por sus sinodos; y finalmente en todos los Ministerios, por sus salarios. De esto resultó atribuírse cierta independencia abusiva, que fue dañoso origen de innumerables competencias y excesos, sobre que sé iundó el dictamen de la r'eforma experimentada. en nuestros días.

\section{NOTIOI A Q U I N T A}

De Ias novedades ejecutadas
en los Oficiales Reales. sen a esta Villa por turno, a cerrar las cartas cuentas de las Cajas y visitarlas; cuyo cumplimiento se reencargó en una Real Cédula de Madrid, 
a 23 de febroro de 1713 . Después se reflexionó la falta de los Ministros para el despacho de la Audicncia y su poca inteligencia en materia de cuentas; por cuyas consideraciones se despachó otra Cédula, de 31 de enero de 1720, ordenando que por tmino pasase a Potosí un Contador Mayor de Lima (de tres en tres años), que alli residiese continuamente, para tomar $y$ fenecer las euentas de los Oriciales Reales, con la ayuda de costo de 1.355 pesos, sobre 3.645 de su salario; $y$ que en virtud de ésto cesasen los Oidores de Charcas de pasar a Potosí, al tanteo de cuentas y visita de minas, como lo habían ejecuteldo antes, conforme a la Ley 29, Tít. 1, libro 8 " de Indias.

Ultimamerte, se juzgó más conveniente autorizar a los Corregidores con esta visita, para hacer más respetables sus personas y empleos, y no distraer de sus ocupaciones a los Ministros; y porque algunos quisieron tratar estas visitas por términos estrechos para embarazar todo recurso, se declaró, en Pual Cócula de Aranjuez, a 28 de abril de 1765, que la visita de las Cajas Reales de Potosí, que está encomendada a los Gobernadores, no es secieta y rigurosa en el sentido de la Ley 11, Tít. 34 , libro 2 de Inclits, sino pública y abicrta, $y$ como tal pueden admitir el Virrey y lat Audiencia, las apelaciones o recursos que sobre ella se hicieren.

La extension y variedad de experiencias sobre los negocios del Reino, hizo conocer en los ejemplos del tiempo, la necesidad de hacer otras mutaciones en la Administración de los ramos de la Real Hacienda. Los azogues que, desde la invención de su utilidad para el beneficio de las platas, corricron a cargo de un lactor particular asalariado, pasaron en el año de 1619, al cuidado de los Oficiales Reales, y se radicó en cllos su mancjo por disposición de nuestras leyes.

I as quiebras antiguas de este rame se hacen increíbles; pero no se descubre más que su arbitraria distribución. Los señores Virreyes dictaron diversas providencias para reglarla, y por más que se vigiló su cumplimiento, nunca se logró su total remedio, porque el interés de los azogucros on tener mucho acopio de este ingrediente, facilitaba caminos para que se les fiase sin mirar la proporción del trabajo que llevaban en corricnte; de que resultaron siempre considerables iezagos.

Descubiertos estos arbitrios en la última Visita General del Reino, se trasladó este manejo a los Ministros de Real Hacienda del Banco de Rescates, titulado "San Carlos", bajo de unos escrupulosos reglamentos, que ascguraron de l'mate su fiel y eqquitativa repartición, sin riesgo de la Real Hacienda. El acierto se prueba de los buenos efectos, y con este conocimiento se confirmó esta nueva Administración en la Real Ordenanza de Intendentes, separando de ella para siempre a los Oficiales Reales. Lo mismo se ejecutó con el manejo de alcabalas, por solicitud de los propios Oficiales Rcales. Para su administración se estableció en esta ViIla una Real Aduana, el año de 1779, con Ministros particulares, a cuyo cargo corriese su manejo, bajo de especial reglamento. Desde entonces se desmembró este Real Derecho del cuidado de las Cajas Reales y se agregó para siempre a la oficina referida.

En el mismo año de 1779 , se mandó suspender por la visita general, la cobranza del real de señoreaje de todas las platas que se sellaban en esta Casa de Moneda. También se canceló de orden el cargo de más de seiscientos mil pesos, que hacían cargo los Oficiales Reales por los caí- 
dos de este ramo, desde el año do 1762 hasta 1777 ; quedando desde entonces ambas oficinas sin más correspondencias que las rentas de platas de diezmos, que se pasan en baryas, para su labor de las Cajas a la Moneda.

Esta insensible mengua de la autoridad de los Oficiales Reales, se fué aumentando de día en día; de tal manel'a, que al cabo llegó a perderse la porción más preciosa le sus facultades, como por un aluvión político, tan inesperado como dichoso.

Nucstro sabio Gobierno practicó un admirable letroceso hacia los primeros tiempos de la conquista cie estos Reinos, considerando que, así por lo dispuesto por ul Derecho liomano, como por lo que se cjecutó en aquel entonces con la administración de la Real Thacienda, debía observarse el antiguo método, como una ley fundamental, el prirnitivo mancjo, para mayor exactitud en la buena cienta de las lentas del Soberano; creó en las Indias unos nuevos Magistrados, intitulados Intendentes, con distrito señalado con el nombre de Provincias, para la dirección por mayor de todas las rentas reales.

La administración por menor de los Oficiales Reales, no había producido los mejores efectos sobre el pie de su anterior establecimiento. Por esto, en los nuevos reglamentos del sistema actual de nuestro Gobierno, se metodizó con prodigiosa coordinación la economía de la Real Hacienda, enlazando las correspondencias con tal intimidad, que el Soberano y el Superintendente General o Ministro de Hacienda (que en algunos países se llama Contador General), jamás ignore las munores dependencias de los Departamentos del Reino.

A este fin se fundó cn cada Intendencia, sobre las antiguas Cajas Reales, una Cámara Provincial de Hacienda subdelegada, con un Intendente puesto a su frente por su jefe y Presidente, con otros Ministros y empleados en el mismo Departamento bajo de sus órdenes. Cada una de estas Cámaras o Cajas, está encargada del régimen particular de cuanto tiene conexión con el ramo de Hacienda de su respectiva Provincia. $Y$ porque la dirección de todas las rentas públicas de la Provincia, reside en el Intendente, se le da cuenta por la Cámara Provincial de cuanto ocurre en ella, y este jefe examina los negocios y los comunica a la Superintendencia Subdclegada del Reino, para que disputando en las conferencias ordinarias a la Junta Superior de Hacienda, se decidan con acierto y $\sin$ retardación; pero aquellos que parecen de bastante importancia para merecer la atención del Sobcrano, se le hacen presente por la vía reservada del Ministerio de Indias, en quien reside la Superintendencia General de Hacienda, para que recibiendo este mismo sus Reales órdenes, obre en su consecuencia. Arreglando en estos términos el sistema general para la adminjstración de Hacienda, se mantiene una armonía, un orden y una correspondencia admirable en el Estado.

Conforme a este nuevo sistema, se ha innovado también la autoridad de los Oficiales Reales en las concurrencias y Juntas de Hacienda, formándose estos acuerdos en diferente forma que antes se practicaba; con lo que se ha mejorado incomparablemente la economia de la Administración.

Las Leyes de la Recopilación de Indias, distinguen tres clases de Juntas y Acuerdos de Hacienda: unas ${ }^{3} \bar{y}$ tratan de los Ackerdos o Juntas ordinarias que al principio se celebraban los miércoles, y después los jueves de cada semana, para tratar y conferir en ellas las materias tocan- 
tes al acrecentamiento y achinistración de la Real Hacienda; se hacían en las Cajas Feales, y concurian a ellas (donde no residía Audiencia) los Gobemadores $y$ los Oficiales Reales, con roto decisivo; y en las ciudades donde labia Tribunal, asistía el Virrey o ?residente, con los Minis. tros, Oficiales Reales y Contadores Mayores destinados por ordenanza. ${ }^{36}$ Otras ${ }^{3-}$ disponen las Juntas de Almonedas, que se componen del Gobernador, Oficiales Roales y el Fiscal. Otras, finalmente, hablan de las Juntas o Acuerdos Generales de la İeal IIacienda, que antiguamente se hacían para resolver sobre gastos extraordinarios y necesarios. En las ciudades Capitales, $3:$ asistían a estos Acuerdos el Virrey o Presidente, Ministros de la Audiencia, Contadores Mayores y Oficiales Reales, y en los demás pucblos, a Gobernador con estos últimos. ${ }^{39}$ En las resoluciones se debia estar a lo que votase la mayor parte, y en igualdad de pareceres, al del Presilunte, ${ }^{40}$ dándose cuenta de todo a la Real persona; ${ }^{1}$ con la diferencia que los Gobnmadores de las Provincias donde no residía Audicncia, podian ejecutar lo akordado y dar chenta al Virroy o Presidente, si las ocasion? fuesen tan indispensables y ejecutivas, que no se pudiese aguardai su l'esolución. 4"

Por la iliteva Ordenanza de Intendentes, se lia subrogado a las Juntas ordinarias re Hacienda, otra intitulada Semanal de Gobierno, que debe celebrarse on casa del Intendente, en el dia de cada semana que él señalare, con los Ministros de Real ITacienda, Principales de la Provincia $y$ los Administradores, Contadores y Tesoreros particulares de cualescruiera de ias rentas Reales, siendo of dictamen de todos puramente informativo, a excepcion del Intenderite, que puede acordar por sí las providencias que estimare por más efectivas y oportunas, después de haber oído los pareceres, sin obligación de dar clienta a la Iunta Superior, sino de aquellos puntos que, entre los demás que se trataren, necesitasen de más serio examen y mayor autoridad, según lo dispuesto en los artículos 204 y 205 de la citada Ordenanza, por cuyo tenor se ve hecha en la antigua Junta una mutación esencial, no solamente en el número de votos, sino también en la calidad de ellos, es decir, que habiendo sido decisivos antes, son ahora puramente informativos.

La Junta de Almonedas se ha mandado mantener con arreglo a las Leyes 2 y 3 , Tít. 25, libro $8^{\circ}$ de Indias, acrecentando al Gobernador y Ministros de Real Hacienda que anteriormente la componían, el Teniente Asesor de la Intendencia y un Defensor de la Real Hacienda, que debe nombrar el Intendente, conforme al Art. 146 de la Ordenanza.

En lugar de las Juntas y Acuerdos Generales de Real Hacienda, para la ejecución de gastos extraordinarios, de cualquiexa calidad que sean, se estableció por el Art. 100, una Junta con el nombre de "Provincial de Real Haciencla", compuesta además del Intendente y Oficiales Reales (que eran, segúu nucstras leyes, los únicos Vocales), del Teniente Asesor y un Promotor Fiscal con voto, en las casos que no actuare como parte. Pero no se hizo mutación en el modo y tiempo prevenido por las leyes para ejecutar las providencias, $\mathrm{y}$ también en este nuevo sistema, debe darse cuenta con testimonio de lo acordado, a la Junta Superior de Buenos Aires, por mano de la Superintendencia, y esperar su resolución; y sólo en los casos urgentes y ejecutivos, como reparación de Almacenes, conducciones u otros igualmente necesarios, pueden los Intendentes anticipai sus providencias con acuerdo de la Junta Provin- 
cial, y representar después a la superioridad de Buenos Aires, según lo dispuesto en el citado Art. 100 y 267 de la Nueva Instrucción de Intendentes.

Sobre todo se ha hecho la mayor novedad en la antigua jurisdicción de los Oficiales Reales, reduciendo estos Ministerios a su primitiva constitución; esto es, que dejándoles el cuidado de todas sus cobranzas y pagos de Real Hacienda, no pueden ya verificarlas judicialmente, porque habiéndoseles privado por los artículos 72, 7:1 y 131 de la Ordenanza, de la jurisdicción contenciosa concedida por la $\mathrm{L}_{\text {ey }} 2$, Tít. 3, Lib. $8^{\text {" }}$ de la Recopilación, a los Oriciales Reales, para la cobranza de los ramos del Real Erario, declarándose en todo l'tunida y trasladada a los Intendentes en sus respectivas Provincias, con inhibición de dichos Ministros; deben estos acudir a los expresados jefes para todo lo judicial, ejerciendo únicamente las facultades económicas y coactivas conducentes a la administración y cobranza de la Real Hacienda.

Los Oficiales Reales de Buenos Aires consultaron az la Junta Superior, el espíritu de la Ordenanza en los citados artículos; y habiendo resuelto que debían entenderse como sonaban, se aprobó-osta determinación en Real Orden de 6 de junio de 1785, declarando que las facultades económicas y coactivas, sólo son para requerir a los deudores morosos, siendo necesario, ante Escribano de la Real Hacienda, dando cuenta al Intendente, en caso de no verificarse por este medio la cobranza, para proceder a la ejecución y demás diligencias judiniales.

De este modo nunca podrán pretextar sus omisiones, como antes lo hacían, culpando a las Justicias ordinarias, ante quienes acudian a pedir justicia, porque preparada la ejecución con requerimientos e interpelaciones a los deudores, obrarán prontamente los Intendentes, teniendo a su cargo la inspección, el conocimiento y la dirección privativa de todas las rentas reales.

En cuanto a las preeminencias de los Oficiales Reales y a las prohibiciones que recogió nuestro Escalona en dos Capítulos enteros, ${ }^{43}$ no se ha hecho mutación alguna; pero debe añadirse la de poder despachar Libramientos contra sí mismos, como antes lo hacían, por haberse derogado en el Art. 97 todas las leyes que ordenaron cl uso de las expresadas Jibranzas.

\section{NOTIOIA S E X TA}

De los Ramos de Real Hacienda del cargo de estas Cajas de Potosí.
A bién se llaman rentas del Estado y rentas del Soberano en el sentido más general, proceden de dos causas: o de los dominios o de

las contribuciones, son muchas y muy diversas las estaciones, micmbros y géneros que se comprenden en cada una de las clases referidas de Real Hacienda. Nuestro Escalona is recopila en un breve sumario todos los ramos, que siendo distintos en su raíz, se reunen como en tronco en la masa general del Patrimonio Fiscal; y con la misma distinción los explica uno por uno, en el discurso de 36 capítulos muy prolijos y eruditos. 45

Dejando este tratado a quien quisiere instruirse en la gruesa masa general de todos los ramos y géneros de Real Hacienda en las Indias, 
me contraelé aquí solamente a los que se administran en Potosí, de cuenta de su Majestad, bien sea por los Oficiales Reales de estas Cajas, o por otros Ministros por vía de Receptoría y Tesorería especial, con la obligación de dar cuenta y vaciar los caudales en la Principal de esta Provincia; pero según la distinción con que se manejarl, pondré separadamente los respectivos ramos, incluyendo en la siguiente planilla, en primer lugar, los que cor'len y se administran bajo de unas mismas Ilaves y arcas del Tosoro Principal, y consecutivamente los otros, explicando por parágrafos los que necesiten de mayor examen. Y respecto de estar mandado para claridad de las cuentas, que en ellas se distingan en tres clases los ramos de Hacienta, colocando en la primera los que en todo rigor son pertenecientes a ulla, en la sogunda los ramos que se vacían en estas Cajas por las otras de afuera, y en la tercera otras estaciones o miembros de Real Ilaciendi, se irán asentando en la misnta, conforme a los siguientes:

\section{$S$ U M A R I O S}

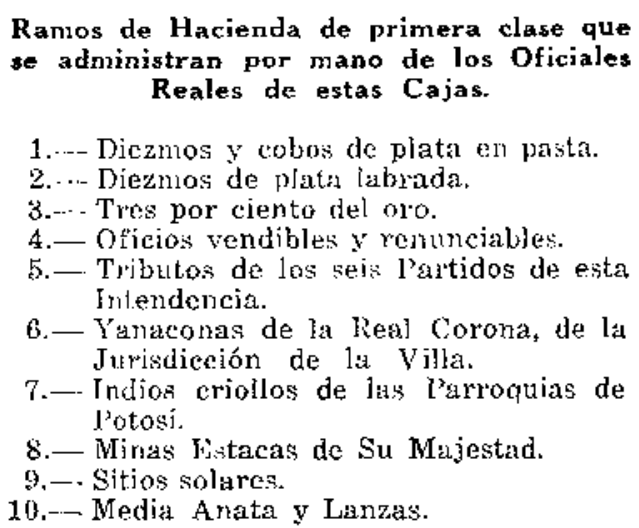

Ramos de Hacienda encargados a otros Ministros y Oficines por vía de Receptoria y Tesorería especial.

11.- 1'apel sellado.

12.- Naipes.

13.- Bulas.

\author{
14.- Casa de Moneda. \\ I5. - Real Banco. \\ 16. - Real Aduana. \\ 17.-. lás Cajas de aluera.
}

Ramos de Hacienda de segunda clase.

1.- Penias de Cámara.

2.-- Novenos.

3.--- Mesadas Eclesiásticas.

4.- Medias Anatas Eclesiásticas.

5.- Vacantes menores.

6.- Donativos.

7.- Alcances de Cuentas.

8.- Vacantes mayores.

\section{Ramos de tercera clase.}

1.- Montepío de Ministros.

2.- Montepio Militar.

3.- Cinco por ciento de Sínodos.

4.- Inválidos.

5.- Real Orden de Carlos III.

6. - Depósitos.

7.-.- Tenuporalidades.

Párrafo primero. - Diezmos y $\mathbf{N}$ UESTRO sabio político el Sr. Dn. Juan Cobos de plata en pasta. de Solórzano y el erudito Escalona, ${ }^{46}$ recogieron copiosas noticias sobre el origen de esta regalia, sobre el tiempo de su introducción en las Indias y sobre la cuota que por usta razón se exigía para la Real Hacienda. Las Leyes 1 al 10 y siguientes, título $1^{\circ}$, libro $8^{\circ}$ de Indias; la ley $2^{\circ}$, título 19 ; ley 12 , título 22 ; ley 6 , Tít. 28; ley $1 \%$, Tít. 24 , libro 4 de la misma Recopilación y la Ordenanza $8 *$, Tít. 36, libro $1^{\circ}$ de las Generales del Perú, establecieron una regla invariable para la satisíacción del quinto de todo el oro y plata que sc sacaren de minas, o fueren habidas en batalla, entrada y 
rescate, resolviendo diversos casos gue antiguamente se disputaban como exceptuados de esta regalía; también señalaron el tiempo y lugares en que se debía hacer manifestación de estos metales y pagar el derecho de ellos, imponiendo graves penas a los contraventores.

Sobre esta antigua asignación, con otras varias cucstiones que en diferentes tiempos se ha movido accrea de esta matera, juzgo impertinente tratar, pudiendo keerse sus decisiones en los citados Regnícolas y otros autores realistas a quicnes ellos se roficren; en especial cuando en el sistema de nuestea legislación nada csencial so ha innovato en el punto de esta regalía; antes bien, se lian mandado guatdar mestras loyes de la Recopilación por el Alt. 180 de la Nheva Gricranza de Intendentes, en la forma explicada por la Declaiación $11^{:}$de cla nisma.

En cuanto al mincral de Potosí, (que es mi priner objeto) dice muestro Escalona, ${ }^{17}$ que los señores Vir'syes sucesores del Licenciado Castro y Conde de Nieva, mandaron coblar al quinto de las inmensas riquezas que produjo desde su descubrinicito. Al cabo de veintiún años, contados desde el de 1566, se acabó el metal rico de iundición, llamado tacana. Los azogueros de la Villa hubieron de despoblarse y pasarse a vivir a otros lugares, por el poco provecho que los dejaba el trabajo de minería; representaron estos graves motivos y principalmente on la decadencia fundaron que se les debía rebajar el quinto al diezmo. Dl Soñor Don Francisco de Toledo, ante quen se hizo esta prevención, en voz de mandar minorar el quinto, ordenó el año de 1574, en la instrucción 4 a de las Ordenanzas de los Oficiales Reales, que continuasen cobrando ol quinto como lo cobraron antes; y por el Capitulo 87 de las mismas Ordenanzas, previno a los Oficiales Reales, que compeliesen a quintar la plata a toda persona que hubiese comprado azogue, aunque no luese minero.

Continuando los atrasos de este mineral, por el orden que se hizo relación en su historia, esforzaron los azogueros la pretensión de quintar al diezmo, alegando que, sobre la pobreza de los metales, se añadía el cmbarazo que estando rotas las Cajas no podía un indio sacar en una semana lo que antes sacabn en un día, con más el excesivo precio en que se vendían los azogues, contra las órdenes de su Majestad. Para resolver, se mandó despachar Real Cédula de Madrid, a 26 de íebrero de 1628, ordenando al Sr. Conde de Chinchón, que uniformase el precio de los azogues puestos en Lima y el de Guancavelica trasportado por Arica.

Como nada se adelantó con estas diligencias, se repitieron nuevos recursos en este siglo, haciendo ver la necesidad de quintar al diezmo, una vez que, a medida de la decadencia del mineral, se había aminorado el número de la Mita, acrecentando esta falta los costos del beneficio tan considerablemente, que si no se concedía algún indulto, cra imposible la continuación del trabajo de mineria.

Atendiendo que el quinto es una renta líquida sobre el producto que reditúan Ias minas de los particulares, y sobre el impuesto de los cortos valores que rinden, y que importando crecidas sumas los gastos que ocasionan sus trabajos, pocas veces reditúan más de un $2 \%$ del capital que se emplea en ellas, sin ser raro haberse reducido a nada por los malos progresos de la labor, se resolvió al cabo las solicitudes de la Azoguería, despachándose Real Cédula cle El Pardo, a 28 de enero de 1735, de que se hace relación en el Art. 133 de la Real Ordenanza de Intendentes, ordenando que se rebaje el quinto al diezmo, y en ella misma se revocó 
expresamente la ley $1^{\prime \prime}$, título $1^{\prime \prime}$, libro $8^{\circ}$ de Indias, que reguló esta regalía al quinto, libre de costos. El Superior Gobiomo de Lima mandó guardar y cumplir este Real despacho, por Decreto de 28 de abril de 1736, y se publicó por bando de Iima, Capital del Virreinato del Perú, en 5 de julio del mismo año, desde cuyo tiempo se quinta el diezmo. 4 "

Sin embargo de que este ramo de llacienda está destinado a pagar consignaciones divei'sas de los otros miembros de las Cajas, con la escrupulosidad, formalidades, asertos y razón, que refiere Escalona, ${ }^{49} \mathbf{y}$ por esta causa se consume en el Reino mucha parte de su monto; con todo, se ha mandacto en Real Orden de 2 de junio de este año de 1786, 50 que el producto de los diezmos se remita en pasta a España, para surtimiento de las Casas de Moneda de aquellos reinos, de las platerías y de otras fábricas; ta cual Real disposición se ha mandado cumplir por la Superintendencia de Puenos Aires y por esta Intendencia, ordenándoseles a los Oficiales Reales que cuiden de hacer las remisiones en las ocasiones de situados.

Por el mismo ensaye y valor de las barras, por donde se deduce el derecho del diezmo, se saca primero scgún la ley, 51 el uno y. medio por ciento del Ensayador, fundidor y marcador, conocido vulgarmente por el de cobos, por haberlos enajenado el Señor Entperador Carlos V., y cedido al Comendador Mayor Don Francisco de los Cobos, en estos reinos del Perú; pero se incorporaron después en la Corona estos derechos, recompensándose al Comondador con el Marquesado de Camarasa, según refiere nuestro Escalona. 3 ?

Para la fundición de todas las platas, se estableció en estas Cajas de Potosí, cuatro Callanas Reales o crisoles; pero, al presente, no se hace uso más que de una sola.

'También se creó el Oficio de Ensayador, fundidor y marcador, y se remató en un vecino de Lima, de la familia de los Savalas, asignándole por razón de derechos, cinco pesos de hechura por cada barra, con obligación de costear la fundición, en ensaye y el salario del Teniente que residía en estas Cajas, fuera del sueldo anual de 1.944 pesos, que satisfacía la Real Hacienda a honor de este empleo.

Antiguamente pagaban estos derechos los Mercaderes de plata para quienes se hacía el rescate. Después de establecida la Compañía de Azogueros y en su lugar oi Real Banco de San Carlns, lo satisface esta oficina, costeando los tres fundidores subalternos que tiene destinados a este fin, y los demás gastos del carbón.

La Real Hacienda los percibe dosde el tiempo que se embargó el oficio al dueño propietario, por alcance cuantioso de cuentas que resultó a favor del físco. Desde aquel entonces se nombró ensayador, con dos mil pesos anuales de sueldo, olle se pagan por las Cajas y hasta el día se mantiene en pie.

Las fundiciones de piñas a barras, se hacen los martes de oada semana, que algunas veces sigue los miércoles haciendo mucha gruesa. Para esta operación, se pasan del Real Banco en costales todas las pastas, arregladas al peso de ciento ochenta marcos en la misma balanza del rescate, $y$ sobre este pie se funden dos barras en cada crasada, $\mathrm{y}$ después de vaciadas y frías, se pasan a la oficina del ensaye, por cuya ley se deducen los Reales derechos de diezmo y cobos. 
Antes de ahora era más difícil y arriesgada esta calculación, y con este conocimiento formó el Tribunal de Cuentas de Lima, en el año de 1769, un reglamento metódico pava deducir con separación los derechos del uno y medio de cobos y el diezmo, que pertenecen a Su Majestad, en la plata que se marca, funde $y$ sella, con unas tablas circunstanciadas de los valores fjjos de las platas en malavedíes y pesos, según sus leyes, de suerte que por ellas y por otras advertencias $y$ planillas que se agregaron en comprobación del Tribunal de cuentas, puede ajustarlas con todos sus qucbrados cualquier Oficial de las Cajas Reales, lesde la ley de 12 dineros, hasta 11 dineros en que está mandado se labre y forme la moneda.

Párrafo segundo. - Diezmo de
plata labrada. ración y las penas en que incurren los plateros que labiaren y los que las usaren o las extrajeren de las-Provincias de las Jndias, sin haber satisfecho este Real Derecho cn las Reales Cajas, trata eruditamente nuestro Escalona, $" \overline{3}$ y lo declaran decidiendo muchos casos especiales las leyes $34,47,48,49$ y 50 del título 10 , libro 8 de Indias. En todas las concurrencias se puede registrar estas fuentes, para no repetir aquí resoluciones tan vulgares.

Sólo si, debe advertir'se que habiéndose reconocido a fines del siglo pasado, los muchos fraudes que se ejecutaban en labrar plata de vajilla o alhajas, de plata no quintada y marcada, y haberse aumentado este desórden con el abuso introctucido de comerciar con la plata labrada, variando su esencial destino, que debía ser para el servicio de las casas, despachó su Provisión el Sr. Virrey, Euque de la Palata, en 13 de mayo de 1682, prohibiendo poder sacar de este Reino, por ticrra firme u otras partes, por ninguna persona, plata labrada, aunque sea con pretexto de ser vajilla para el uso y servicio de quien la saca, bajo pena de perdimiento de ella o de su valor, aplicado por tres partes, con más la mitad de sus bienes para la Real Hacienda y tres años de Valdivia, quedando comprendidos en estas penas los Maestres, Escribanos, Pilotos, Contramaestres, Arrieros y todos los tereeros o corredores para los contratos de plata labrada y para su extracción; y se declaró por privilegiado este crimen para poderse probar con testigos singulares, en los términos prescritos por la ley $8^{\text {a }}$, Tít. 16 , Lib. 3 ; ley 45 , Tít. 15, lib. 5'; y ley 17, Tít. 17, Lib. $8^{\circ}$ de Indias.

Dio mérito a esta providencia, el comercio ilicito y perjudicial que se hacía en Panamá y demás puertos de tier'ra firme, con piata labrada sin ley justa; haciéndose difícil la averiguación del quinto y de su ley, porque, como se sacaba del Reino, no podía llegarse a esta noticia $y$ reconocimiento. Por esto se prohibió absolutamente su extracción, y sólo se prometió licencia particular del Gobierno para sacar la vajilla que fueve del uso y servicio de quien la iba a extraer.

Aunque con estas conminaciones se atajó en gran parte la extracción fraudulenta de la plata labrada, y se evitason los denás efectos del comercio perjudicial que se hacía con ella en ticria firme, jamás ha podido conseguirse la perfecta observancia de las leyes Municipales en cuanto a quintar y remachar la vajilla de uso de cada uno; porque sólo aque- 
llos qua tienen Guc sacarla fuera del Reino, cuiclan de practicar esta diligeneia por el temor del comiso.

En las Provincias de las Indias, principalmente en éstas, donde se trabajan rieos minerales de plata, rata es la persona que no emplee una gran parte de su caudal en vajitlas y alhajas, y yo conozco en esta Villa quién ticne más de treinta mil pesos en esta especie.

Todas estas porciones de plata, se trabajan de piña o pasta no quintada, y como no se teme acr on comiso por hacer uso de ella, nadie procura que se quinte desptiés de labrada, pudiendo asegurarse que, si se trajera al quinio toda la plata labrada del uso y servicio en estas Provincias, subiría por una vez este ramo a una cantidad excesiva y sería siempre uno de lus más pingües, si se llevara a todo rigol el cumplimiento de las leyes, respecto de enseñarnos la experiencia, que todo minero emplea la mitad o kna tercera parte cuando menos de su trabajo, en plata labrada de vajilla y alhajas, haciendo consistir en este género de lujo la prineipal observación de su riqueza.

No juzgo impracticable el remodio, si suavizándose en parte la cuota de esta regalía, se aplica con pradencia y celo de los Jefes en hacer cumplie las loyes.

Tistanclo yo on Pruenos Aires, a fines de] año 84, observé que muchos de sus prieipales vecinos empenados en insinuaciones políticas del gran Superintenciento actual de Real Haciencla, Bon Francisco de Paula Sanz, presentaron al guinto sus vajillas, templando con este arbitrio el rigor do las mucras órdenes con que se hallaba esta misma acción ejecutadia en otras partes; puclicka producirse iguales cfectos, en especial, si para evitar el clamestino uso de la vajilla, en fraude de los Reales quintos, se indultara alguna rebaja, como so ha practicado en cl oro a este propio fin. En tal caso, no debe dudarse que se facilitaría demasiado la observarcia de las leyes, a vista del favor que recibían los pueblos.

En Potosí es muy frecuente el rescate de vajilla en el Real Banco, por neccsidades de sus dueños. Este fondo público, ya incorporado a la Fieal Corona, satisface a la Real Caja los derechos de diezmo y cobos de las planchas o barras que funde de cllas; se ahorraría este costo en beneficio del Fianco, si no se recibiese plata labrada de vajilla o en alhajas no estando quintada $y$ marcada en la Real Caja, y no debe temerse por esto minoración en el rescate, porque la precisión de hacerlo el dueño necesitado, venceria forzosamente la dificultad por donde debe pasar en solicitud de su alivio.

A este efecto, sería conveniente aforar el marco de vajilla en algo menos de los seis pesos en que ahor'a se avalúa para exigir el diezmo, ${ }^{54}$ quedando corriente su precio a razón de ocho pesos para la paga del uno y medio por cicnto de cobos por cuenta del Banco, que en rigor es lo único que adeuda esta oficina, por ser quien funde la vajilla para hacer las barras. วิโ

De la plata labrada que se conduce con destino para los Reinos de España, se cobraba antes en las Cajas de Buenos Aires cl tres por ciento de avería, regulando para su exacción a ocho pesos el marco, ${ }^{56}$ y en esta Villa se mandaba afianzar o depositar el importe de este derecho, $57 \mathrm{y}$ sólo quedaba exceptuada de él la plata labrada que se justificaba con juram mento del interesado y se reconocía ser alhajas propias para su uso o para el culto divino. 58 
Así como ahora no se cobra ya el derecho de avería, ni se ha cobrado nunca el uno y medio por ciento de cobos de la plata labrada que sale para Buenos Aires, 59 pudiera también minorarse el diezmo al tres por ciento a que se ha rebajado este derecho on el oro, o a lo menos reducir su aforo a razón de 5 pesos el mareo. Fintonces veríamos que sacaban para Buenos Aires partidas gruesas de chafalonía, bien sea para remitir a España o para comerciarla en aquella capital; porque si en el día no lo ejecutan, es por no haccrles cuenta esta negociación, por el costo de su compra y el acrecentamiento que recibe con el die\%mo; hecha la rebaja de este derecho, vendría a quedar en una buena proporeión todo el impuesto de la plata labrada según el avalúo del nuevo Reglamento para el comercio libre, y no quedaría sepuitado en estos Reinos cl inmenso cauldal que se posee en vajilla y ahajas inútiles por su abundancia y poco gusto.

Párrafo tercero. - Tres por AnTrguAMENTE se quintaba el oro al ciento del oro. misno respecto que la plata, con la diferencia de hacerse su avaluo por quilates y el de

la plata por dineros. ${ }^{60}$ Las leyes de la recopilación, citadas en los anteriores parágrafos y nuestro Escalona, ${ }^{81}$ tratain de este asunto conforme al sistema primitivo. Para ajustar el valor del oro, se usó, hasta el año de 1728, de las pesas de Castellano, $y$ desde entonces en adelante, del Marco Real de Castilla, conforme a la pragmática del mismo año, que es como ahora se observa.

No obstante las estrechas prohibiciones de contratar con el oro sin quintar, eran frecuentes y considelables las extracciones que se hacían de esta Provincia para Buenos Aires, del oro en pasta, extraviándolo en fraude de los Derechos Reales y perjudicando al público por lo que perdía el comercio con la falta de moncda, aun en el caso de pagar los quintos. En atención a uno y otro objeto, prohibió el Superior Gobierno de Lima, ${ }^{62}$ la saca para Buenos Aires del oro en pasta, y se confirmó esta prohibición para evitar todo trato ilícito con las Naciones extranjeras, en Réal Cédula de Buen Retiro a 15 de diciembxe de 1761.

Luego que se erigió el Virreinato de Buenos Aires, libró despacho su primer Virrey, el Excmo. Sr. Don Pedro Zevallos, ${ }^{63}$ prohibiendo, bajo la pena de comiso, extraer para Lima del distrito de su mando, oro en pasta, tejos y polvo, y sólo permitió para Buenos Aires el diezmado.

Durante su Gobierno se cuidó de observar esta providencia, que si hasta ahora se cumpliexa, no sería poco provechosa para aumentar la labor y utilidades de la Casa de Moneda de Potosí, y al mismo tiempo para dar más nervio al comercio, con la abundancia de moneda. Después se relajó enteramente la prohibición y circula el oro libremente por todo el Reino, con mucho perjuicio de los Reales Derechos, por la facilidad de su ocultación y extravío.

Para suprimir este desorden no ha bastado el singular indulto concedido en Real Cédula de San Ildefonso, a 12 de octubre de 1778, 64 rebajando los derechos del oro, incluso el de cobos que se paga en el Perú, al $3 \%$ al tiempo de quintarse en toda la América, y al $2 \%$ a su entrada en España, comprendidos en esa cuota todos los derechos y arbitrios que contribuye este metal; porque los mercaderes estudian todas las cautelas po- 
sibles y proporcionadas al grande valor de la moneda de oro, para conducirla fuera de Registro y defraudar el $2 \%$ impuesto a su entrada en España. Por esto es que paga en Potosí el crecido premio desde un cinco hasta un ocho por ciento $y$ talyez hasta un diez, atendiendo a que sale aun dos menos, por aquel dos de entrada que defraudan.

Se conocería mejor este grande extravo, si a Ia Aduana del Puerto de Buenos Aires, se remitiese anualmente m extracto por mayor de los rescates de oro que hacen las casas de Moneda de Potosí y Chile, para cotejar su griesa con los registros de embarque, ${ }^{6}:$ por sel notorio que de un año par'a otro, casi no queda cil el Reino moneda de oro del cuño precedente. Yo no me atrevo a dictar precanciones, reservadas a los altos conocimientos de nuestro sabio Gobierno. Nada como la experimentada prudencia del Ministerio de España, para ajustar el remedio a medida del daño.

En conclusión, debo advertir que siendo tantos y tan ricos los minerales de owo que se han trabajado cn los Corregimientos comarcanos del Distrito de las Cajas Reales de Potosí, no se ve un solo asiento en los libros Reales por yazón de los quintos de este metal hasta el año pasado de 1777 , y principios del 78 , cu que habiéndose rebajado (según se ha dicho) este derecho al $3 \%$, se principió a satisfacer esta regalía y se atesoraron desde entonces de cinco a siete mil pesos anuales por razón de este Rcal Derecho. Véase ahora el sinnímero de miles que se habrá defraudado a la Corona en el espacio de dos siglos enteros.

Sin embargo, para que se va las inmensas riquezas con que Dios ha dotado a la Corona de Castilla con el señorío de estas tierras, pondré aquí un resumen general de los dos derechos, quinto y diezmo, cobrados en sus respectivos tiempos, hasta el año de 1783, con demostración del total caudal presentado por los mineros, con arreglo a una certificación de 16 de junio de 1784, remitida al Rey por Don Lamberto Sierra, Tesorero Oficial Real de cstas Cajas, en comprobación de los increíbles frutos de este Cerro. Pues, la razón certificada que traslada Escalona so no es tan puntual ni avanza los tiempos posteriores de nuestro siglo.

RESUMEN GENERAL DE LOS DOS REALES DERECHOS, QUINTO Y DIEZMO, COBRADOS EN SUS RESPECTIVOS TIEMPOS, CON DEMOSTRACION DEL TOTAL CAUDAL PRESENTADO POR LOS MINEROS.

\begin{tabular}{|c|c|c|c|c|}
\hline \multicolumn{2}{|r|}{ Años } & Reales & Derechos & Principales \\
\hline 1556 & hasta 1736 & $\ldots \ldots$. . . Rls Quintos: & $139.342 .515,7$ & $696.712 .579,3$ \\
\hline 1736 & $" 1783$ & $\ldots \ldots \ldots$. . . Rls Diezmos: & $12.380 .131,2$ & $123.801 .314,3$ \\
\hline & & $\mathrm{T}$ o $\mathrm{t}$ a 1 e $\mathrm{s}: \ldots$ & $151.722 .647,1 \quad 3 / 4$ & $820.513 .893,6$ \\
\hline
\end{tabular}

NOTA. - Habiéndose evidenciado en la Noticia de este Cerro, con autoridad de Historiadores clásicos del Reino, que los mineros y mercaderes extraviaron, sin pagar quintos, otro tanto de lo fundido y marcado en estas Reales Cajas, resulta que la gruesa del caudal extraído de nuestro Cerro, asciende a más de 1.600.000.000 (MIL SEISCIENTOS MILLONES), cuyo sonido basta para admirar a todas las potencias del mundo. 


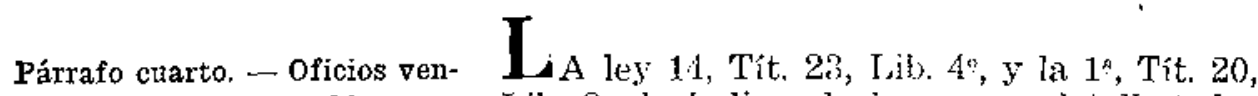
dibles y renunciables.

Lib. 8 de Indias, designan por detalle todos los of icios vendibles y romunciables de las Indias. Nuestro Escalona, ol Sr. Solózano y el SH. Iarlea, tratan difusamente ${ }^{6-}$ del tiempo y causas por qué se comenzaron a ronder cu la América; promueven diferentes cuestiones y citan rarias resoluciones sobro dudas y pleitos seguidos por razón de ventas, renunciaciones o confirmación de estos oficios; explican todas las calidades y condiciones que deben tenex estos contratos y las personas que han de sorvir los empleos y el tiempo en que los pucden renunciar o acoptar, $y$ en los que deben presentar la confirmación Real.

Las leyes de $\operatorname{los}$ títulos 20,21 y 22 clel libro 8 de Indias y otras de la misma recopilación, que se citan al fin de sus remisiones, declaran con puntualidad y casos de este tratado.

Nada esencial puedo añadir que no esté escrito on Ios autores citados; y así, expondré en compendio algunas proxidencias modernas, para mayor inteligencia del asunto y para conocimiento de las leyes reyocadas on ellas. Por último, me contraeré a los of icios de esta Villal y propondré el único medio de acrocentar esto ramo, reducido en ol día a una casi irreparable decadencia.

La práctica que se observa para poncr expedito el uso de los oficios, por venta o renunciación, se leduce a las siguientes estaciones. Inego que haya vacado el oficio por alguna de las causas que inducen su caducidad y devolución al Real patrimonio (y lo mismo es que se haya creado algún oficio de nuevo), se provee Auto por el Intendente a quien toca la dirección por mayor de todas las rentas Roales, ${ }^{n}:$ para que se saque a público pregón y remate, precediendo la tasación $y$ prueba del frito y verdadero valor del oficio por testigos idóneos, con citación del Promotor Fiscal y con intervención de los Oficiales Reales, agregándose en parte de averiguación, certificación de ejemplares de las ranteriores precios en que se hubiere rematado. ${ }^{60}$

Se corre vista al Fiscal, de las averiguaciones y probanzas del valor cierto del oficio, conforme a la ley 14 , Tít. 21 , Lib. $8^{\circ}$ de Indias, y no contradiciendolo, se provee otro Auto declarando ser justo y verdadero valor del oficio tantos pesos, $y$ se manda dar los pregones dispuestos por derecho, para que se haga el remate en el mejor postor.

Aunque la ley 13 , T'́t. 20 , Lib. \&" de Indias, dispone que cuando vacare algún oficio, se pregone cada semana, sin declarar el número de días que ha de durar el pregón, se debe observar en estas ventas lo dispuesto en las demás almonedas de Hacienda Real, por ser los oficios uno de los principales ramos de Real Hacienda; ${ }^{70}$ esto es, que gozando los bienes fiscales el mismo privilegio que la hacienda de Ios monores, ${ }^{11} \mathrm{cu}$ yas ventas deben pregonarse por treinta dias, conforme a la Ley de Paxtida, 'T' se debe guardar en nuestro caso igual solemnidad, dándose treinta pregones continuos en otros tantos días, según zesuclven Escalona y Alfaro. 73

Dentro de estos términos se han de admitir las posturas y mejoras que se hicieren en Junta de Almonedas, coll voz de la mayor parte de los Vocales y con asistencia del Fiscal, so pena de nulidad; "74 y subs- 
tanciados los expedientes en esta forma: se deben enviar a la Superioriflad de Buchos Aires, para que oyéndose alli instructivamente al Contador General de Real Hacienda y como parte al Fiscal, se determine sobre el valox y demate lo que más convenga, $y$ los devuelva al Intendente, para la ejecución de lo que so le ordenare, conforme al Art. 145 de la Nucva Ordenanza de Intendentes.

Respecto de que la ley 22 , Tít. 20, lib. $8^{\circ}$ de Indias, supone alguha diferencia do las ventas de oficios que se han de servir en el mismo lugat donde se luace el romate, a los que se han de usar en otro distinto paraje, rlobo advertir lo prevenito en este punto por los Señores Virreyes, en detaración de la Ordenanya y lo que en el día se practica.

Fi Sr. Marques de Montesclarns, en provicincia de 23 de agosto de 1609 , previno a los Oficiales Reales del Paraguay, Tucumán y Buenos Aires, que luego gue vacaren los olicios en la parte donde hubiere de ser el uso y ejercicio de ulos, se trajeran en simoneda por el témino de treinta dias y so armitiosen las posturas y pujas que hubiere, y con fianzas para la quiebra, citadas Jas partes para cl remate, las remitiesen a los Oriciales Reales de la Vilia de I’otosí, para que lo verificaran sin necesidad de etra requisitoria.

Pasado algún tiempo, pidió Dn. Lais Enxiquez, Fiscal de Lima, que se ordenabe a los Oficiales Reales de buenos Aires y el Tucumán, no alterasen el orden prevenido por al Gohierno para los remates; $y$ en efecto, así lo mandó el Sr. Narqués de Guadalcázar, en providencia de 29 de febrero de 1624, disponiendo que dados nueve pregones en los lugares donde se han de usar los oficios, 'is se cemitiese a Potosí, para que al fin de los treinta se rematasen por los Oriciales Reales de esta Villa.

Ėl método de esta provisión se observa en todo el Reino, y deberá practicarse en los oficios vendibles de Tarija; por lo respectivo a esta Intendencia, y para la venta de los oficios de la Capital, se daban en ella misma treinta pregnnes continuos.

Supuesta la aprobación de la Junta Superior para el remate, deben darse tres AImonedas más en tres días diversos, pregonando el oficio en el lugar acostumbrado, y en el tercero $y$ último verificar el remate cn cl mayor postor, según lo explica Peregrino. io

Fin este estado, constando los debidos enteros en Cajas, por certifieación de Oficiades Reales, conforme a las leyes 12 y 20, Tít. 21, Lib. $8^{\circ}$ de Indias, dispone el Art. 145 de la Ordenanza citada, que se vuelvan a remitiv los expedientes a la misma Junta Superior, pas:a que aprobado el remate por clla, los pase su Presidente, con oficio, al Sr. Virrey, para la expedición y despacho de los correspondientes títulos; devolviéndose después de esto por el Gobierno los mismos expedientes a la Superintendencia, para quo tomándose razón de ellos on la Contaduría General de Real Hacienda, se devuelvan originales al Intendente respectivo, para que allí se archiven.

No excediendo de mil quinientos pesos el valor de los oficios rematados, queda a cargo de los Intendentes la solicitud de la Real confirmación, que antes corría al de los Fiscales de las Audiencias y Promotores Fiscales de Real Hacienda; para cuyo fin debe pagar el interesado, por vía de donativo, un diez por ciento del valor del remate, sin que le pare el menor perjuicio por el transcurso del término de ley. 
Pero siendo de mayor cuantía, deben acudir por la Real confirmación las mismas partes, sacando los testimonios correspondientes, con arreglo a la ley 24 , Tít. $2^{\circ}$ y $3^{\circ}$, Tít. 22 , Lib. $8^{\circ}$ de Indias, y a la declaración que se hizo de ellas en Reales Cédulas de 19 de septiembre de 1773, 5 de diciembre de 1775 , y a la última de Aranjuez, a 18 de diciembre de 1782 , reducidas a enviar con separación el testimonio del títuło, donde sólo se comprenden las cláusulas substanciales, que por mayor justifiquen su despacho y el de los Autos a la letra, de que resulte por menor esta misma justificación.

También debe acompañarse testimonio separado de la información que deben dar los pretendientes (e incluírse en los autos de remate), la calidad de su persona, edad, suficiencia $y$ demás partes necesarias, según lo dispuesto en Real Cédula de San I orenzo, a 2 de noviembre de 1775.

Aquí advierte Ramiro Valenzuela, ilistrador del Sr. Solórzano, ii que presentándose a pedir la confimación el el Consejo, no se repara (en la práctica) el transcurso de los seis arios señalddos para las Reales confirmaciones, por las leyes 5 y 6. Tít. 19, Lib. 6" de lndias; en cuya conformidad, constando la presentación en el Consejo dentro del témino, parece no deberse hacer novedad en el oficio; pero debe advertirse que, para evitar los fraudes que se hacían para provrogar el tiempo de las confirmaciones, renunciando los oficios antes de cumplirse el prefinido para ellas a los renuncinntes, se despachó Real Cédula de San Ildefonso, a, 22 de agosto de 1774, declarando que en las rexunciaciones que en adelante se hicieren de cualesquier ofieios vendibles, no se señalen a los sujetos en quienes recaigan, más término que el que faltar'e a sus causantes para completar el que se les hubiere prefinido para impetrar la Real confirmación.

No son tan dilatadas las estaciones en el caso de renunciación, porque si esta se hubiese hecho legítimamente, sobreviviendo veinte días después de éllo el renunciante, y presentándose el reiunciatario dentro de los setenta señalados en la Ley 4 , Tít. 21 , Lib. $8^{\circ}$ de Indias, 's se da vista al Abogado Fiscal; y no poniéndose contradicción de su parte, se provee segundo decreto para la tasación del futuro valor del oficio, en la forma que se dijo de las ventas.

Practicadas estas diligencias en los mismos términos, con intervención de los Oficiales Reales y citación al Sr. Fiscal, se despacha con su audiencia el tercer decreto, reducido a declararse ser el valor del of $\mathrm{i}$ cio tantos pesos, y enterando en las Cajas mitad de ellos (si es primera renunciación) o el tercio (si es segunda y de allí en adelante), con certificación de ello y de haber pagado los derechos de medla anata, conforme a la práctica que refiere Escalona. ${ }^{9}$ Se remiten los autos a la Junta Superior, para que su Presidente los pase al Sr. Viriey, con ofielo, para el despacho de los títulos en la forma acostumbrada, con arreglo al Art. 145, ahorrándose los pasos y substanciaciones que se previenen para las ventas, sin omitirse los relativos a la confirmación según la cuantía de los oficios.

Aquí pueden ocurrix dos casos, que ya han sucedido en otras partes y se hallan declarados en la ley 9, Tít. 21, Lib. $8^{\circ}$ de Indias. El primero es, si llegare a hacer una renuncia indeterminada, por ejemplo en la persona en quien se rematare el oficio, para asegurar por este medio un 
peligro de perderlo por defecto de renunciación. El segundo es, si el renunciatario (siendo per'sona cierta) no hubiese aceptado el oficio ni querido prescutarse con tiempo con la renuncia. La ley citada declara por perdido el oficio y lo manda vender por cuenta y beneficio de la Real Ha. cienda, excluyendo a los herederos del remmciante de poder pretender derecho a ninguna parte de su valor.

La ciudad del Cuzco representó ios inconvenientes y perjuicios que resultaban, así a los interesados cono a la Real Hacienda, en que declarados por vacos los oficios, no habia gutien a cllos hiciese postura; en cuya considcración se despachó Real Cédula de Buen Retiro, a 21 de fobrero de 1789 , derogancio expresamente la Ley citada re! Tít. 21 , Lib. $8^{\circ}$ de Indias; $y$ se mandó que en los casos de defecto de aceptación y presentación del renunciatario dentro del tiempo de la ley, se guarde lo dispuesto en la ley 7, Tít. 22, Lib. $8^{\circ}$ de la misma recopilación, vendiéndose por cucnta ciel Rey, como oficio raco, con el eneargo de devolver y restituir a los herederos dol renunciante, de lo precedido del oficio, las dos tercias partes dol precio en que se vondiere.

Sobre el otro caso, consultó al Consejo el Fiscal de la Real Audiencia de Guatemala, con motivo de mat renuncia indeterminada que hizo del oficio de Regidor Mayn de la cialad de lcón de Nicaragua, dudando si en csta parte debería estimarse por derogada la ley, no comprendiéndose on su sentido; y se resolvió, por Real Cédula dada en San Lorenzo, a 26 de octubre de 1767 , que debían estimarse válidas las renunciaciones indeterminadas de los oficios vendibles y renunciables de las Indias. Por lo que, sucediendo algún caso de esta naturaleza, deben percibir los herederos del renunciante, la mitad o el tercio del valor en que se rematare el oficio.

Pero, si en el entretanto se arrendaren oficios u otros legítimamente renunciados o que vacasen por falta de confirmación, no deben tener parte alguna los herederos de estos arrendamientos, como se declaró en Real Cédula de San Ildefonso, a 29 de agosto de 1733.

En Potosí son raros los casos, porque también son pocos los oficios. Todos los de Casa de Moneda y Cajas Reales que antes se vendían, se hallan ch el día incorporados a la Corona, y enteramente abolida la calidad y compra. I os únicos vendibles y renuriciables, son los Regimientos de la Villa; pero no hay quien los compre, desde que al Cabildo se le quitó la administración y manejo de los propios y sisa, y mucho menos ahora que por el nuevo sistema de Intendencias, se ha limitado más su autoridad y la de los Alcaldes Ordinarios, que se elegían con sus votos.

Ya el vecindario no encuentra aliciente en estos oficios $y$, por lo que veo y oigo, quedarán para siempre sin uso los oficios que fueren vacando, porque en realidad, un vecino honrado sólo avanzat ocupaciones y tareas en la compra de los Regimientos.

Yo no encuentro arbitrio tan feliz para meterio en codicia, como el conceder a estos oficios el fuero ecuestre munieipal, para que los Regidores no sean reconvenidos como Jefes del Cabildo, al modo que en honor de los empleados en Rentas y Real Hacienda, se les concede el fuero pasivo de Hacienda y el de Guerra, según la clase de los Ministerios. Entonces se experimentaría bien presto los efectos de una noble ambición por estos oficios y su fuero atraería a todo el vecindario en su solicitud. 
Párrafo quinto. - Tributos de los cinco Partidos de Chayanta, Porco, Chichas, Lípez $\mathrm{y}$ Atacama, inclusos los Yanaconas.
$\mathbf{L}$ Lib. 6\% de Indias, de clara la obligación que tienen todos los indios pacilicados y reducidos al vasallaje de la Corona, de acudir con algún tributo, en reconveimiento de señorío y supremo dominio del Rey.

Ias leyes siguientes del mismo Título, detallan el tiempo, las personas y las tasas que deben sutisfaccr, cxplicando caso por caso, con la mayor claridad.

Nuestro sabio político, Dn. Juan de Solózano, sk recogió en dos capítulos enteros muchas excelentes decisiones, por vía de comentario de nuestro Derecho Municipal, y en los casos ocuryentes, se puede leer este docto tratado.

Como uno de los Partidos de esta Provincia de Potosí, es Tarija (comprendido en el de Chichas), y en su frontera hay indios de naciones infieles, llamados Chiriguanos, y de estos mismos tenemos allí algunas reducciones al cargo del Colegio Franciscano de Propaganda Fide; no es inoportuno explicar el verdadero espíritu de la ley 3, Tít. 5", \},ib. $6^{\circ}$ de Indias, que ordena: "no puedan ser" encomendalos ni paguen tasas por diez años, ni compelidos a ningún servicio los indios infieles reducidos de su voluntad a nuestra santa fo Católica, y que recibieren el santo bautismo, solamente por la precicación del Santo Frangelio".

Este mismo plazo se les concedió, por una Feal Cédula de Aranjuez, a 18 de mayo de 1674 , pero bajo de dos importantes declaraciones. La primera, que ni después de pasado, se les obligare a tributar hasta dar cuenta de ello y esperar la resolución on respuesta de la noticia que se diere de estar próximo a cumplirse; la segunda, que este indulto se cntiende habiendo perseverado en la fe; porque si se alzasen, pierden el privilegio, por delito de prevaricación.

Por otras dos Cédulas de 7 de abril de 1648, y de Aranjuez, a 20 de abril de 1681, se concedió a los indios recién convertidos, la libertad de que no tributasen veinte años, ampliando a otro decenio más el primer plazo de la ley.

Se declaró que dicho tiempo les corra continuo a los que siendo de edad capaz de razón se redujeren de nuevo a la fe voluntariamente y sin fuerza, contándole a cada uno desde el día que se redujere, con advertencia de que no dcben gozar de este privilegio los niños que nacieren de padres cristianos ya reducidos, porque estos gozan ya del otro privilegio de menores hasta los 18 años, y no les conviene la calidad de reducirse por el acto heroico de propia voluntad, que propone el mérito de los capaces de razón.

Ultimamente, por Real Cédula clada en San Tldcfonso, a 30 de agosto de 1744 , se ordenó que para la población de reducciones, se arreglen a las leyes; principalmente a las del Título 3 , Lib. 6 , y a la Real Cédula de 5 de noviembre de 1741 , y a la circular de 14 de mayo de 1786 , en que además de la relevación de tributos por diez años, que concede a los indios nuevamente convertidos la ley 3, Tít. 5, Lib. $6^{\circ}$, se manda que no contribuyan por otros 20 años, por ser el mejor atractivo que ha enseñado la experiencia para reducirlos a población. 
Supuestas estas reglas para mestros indios de Tarija, pasemos a los demás pacilicados desde la conquista de estos Reinos.

Luego que se cunplió el tiempo del indulto, se comeuzó a empadronar y a exigir el tributo a los indios de los Partidos de Porco, Chayanta, Chichas (en que se incluía Tarjja), Lipez y Atacama, perteneeientes a esta Intendencia. En el título 5", libro 6", citado, y en el título 9", Lib. 8" de la Recopilación de Indias, sobre que formó un docto comentario el Sr. Solólzano, "se trata al modo y solemnidades de los padrones, el tiempo que debe pasar entre una y otra matricula, la forma de las cobranzas, las especies en que se debe pagar el tributo, las personas que cuidan de recaudarlo y las penas impuestas a los que hiciesen uso y contrataren con clos declaranilo otro, varios casos muy uspeciales tocantes al fuero judicial y de la conciencia. Sería, a más de inútil, reprensible reproducir estos cscritos, siendo tan vulgares en nuestro Reino.

En la Nueva Ordenanza de hntendentes, se trata esta misma materia, desdo el Art. 116 hasta el 128. Hstablece especiale's solemnidades para la concesion de esperas on los casos de esterilidad; estrecha la exacción de tributos por el preciso témino y numero de los padrones, derogando las leyes que permitian las pelaciones juraras y otras diligencias judiciales pala justificar las fallas; designa por nuevos cobradores a los Subdelegados y Alcaldes ordinarios, senalándoles el tres por ciento de la gruesa; da forma para haces los empadronamientos y Revisitas generales, $y$ extiende a cinco años el trienio que antes estaba emplazado para estas operaciones.

En cumplimiento del Art. 121, formó en $1^{\text {th }}$ de julio de 1784 , el Sr. Visitador General, Don Jorge de Escovedo, una instrucción metódica de Revisitas, y en su conformidat se han actuado ya en la mayor parte de las Provincias de este Reino.

Consiguiente al Art. 118, dio con la misma fecha otra instrucción o advertencias para los Subdelegados, en la cobranza fiel y diligente de los tributos. Por el Art. 4 de estas advertencias, se limitó a sólo đos meses los tres que antiguamente tenían de plazo para hacer los enteros después de emmplido cada tercio, "soncediéndoles un mes para que cobren y otro para que dentro de él enteren, de modo que el tercio o semestre cumplido en junio, ha de enterarse finalizado agosto, $y$ el que cumple en diciembre, concluído febrero.

Los Subdelegados claman, alegando por imposible el poderlo verificar, atendiendo a la dificultad de cobrar a los indios, sin largas moratorias, por la suma pobreza en que quedaron las Provincias, de resultas del antiguo gobierno de los Corregidores; en especial ahora, que por las nuevas Matrículas ha crecido considerablemente el número de tributarios y la cantidad de sus tasas, cuando aun antes de esta operación, enteraban de su propio dinero despućs de cumplidos los tres meses de plazo, por los rezagos que dejaban los indios, siendo mucho menor su número, como se ve en las planillas siguientes, cotejando la gruesa anterior con la actual de tributarios y los respectivos enteros en las Cajas; debiendo espcrarse el mismo crecimiento en los demás Partidos de esta Provincia que se van visitando. *

Por el mencionado estado se reconoce que habiendo crecido el entero del Partido de Porco, a veintidós mil pesos más que antes, parece justa su reclamación en cuanto a la estrechez del plazo; bien que ciñéndolo 
a dos meses, el Sr. Visitador General no ha hecho más que hacer revivir Ja Provisión del Sr. Marqués de Gtadalcázar, de 30 de diciembre de $\mathbf{1 6 2 2 ,}$ que concedió este mismo plazo.

Con todo, no hallándose revocadas, las anteriores Ordenanzas que conceden, con aprobación Real, la moratoria de un trimestre después de vencido cada tercio, juago deber inteipretalse de todos modos el Art. 14 de las citadas advertencias.

El primero, a que el plazo de dos moses solamente debe entenderse para los enteros de corta consideración. Fi segundo es que esta moratoria es siempre prorrogable hasta los tres meses, en aquellos Partidos que tienen que enterar grllesas crecidas, porque en materia de Real Hacienda, se ha dispuesto que las esperas en deuclas crecidas no deben pasar de tres meses, y en las menores de dos, queclando reservada a sólo el Rey la facultad de poder prorrogar estos plizos cliando están prefinidos por las leyes, como lo resuelve Peregrino s: y lo declara, por lo respectivo al Virreinato de Buenos Aires, la Nueva Ordenanza de Intendentes, en los Arts. 114 y 125, concediendo esta autoridad privativa a la Junta Superior en los casos de calamidarl notoria, y a los intendentos únicamente la facultad de informarse de la imposibilidad de los pueblos, para poder consultar a dicha Junta Superior, dejándoles integras las facultades por el Art. 113, para despachar los apremios contra los Subdelegados, si hubieren diferido la exacción $y$ entero, sin embargo de sus anteriores avisos y cartas órdenes.

Aunque los Subdelegados ahora ticnen el mismo cargo que tenían antes los Corregidores para hacer la recaudación y entero de tributos, no fue en aquellos tiempos ni hoy es uno mismo ol origen de la cobranza, porque a unos sc les exige por vía de mera recaudación, con preciso arreglo al cargo de padrones, y a otros se les cobra por vía de arrendamiento, sin respecto al número de tributarios, y sí, unicamente a la cantidad del contrato, para lo que es el entero en Cajas; porque siendo diversas las clases que hay de indios, a saber, unos originarios y otros forasteros y los demás yanaconas, era también un ramo mís contingente que otro, a proporción de la clase de los detidores y contribuyentes, porque fue preciso reducir a concierto muchas de estas cobranzas, para cvitar el caso posible de que el Rey llegase a perder una mitad, con la fuga o transmigración de los forasteros o yanaconas.

Atendiendo a estas contingencias se arrendó este ramo a los Corregidores, de muchos años a esta parte, y porque aun en ellos mismos lo recusaban por la propia consideración, se llegó a rematar, a mediados de este siglo, en un solo arrenciador del ramo te yanaconas de toda la com. prensión de esta Intendencia, incluso los de la Villa; pero después se fué desmembrando sucesivamente por Partidos, y cada Corregidor tomó a su cargo el suyo sobre el pie de arrendamiento, cil cl que hasta ahora se persevera.

Conviene entender esta materia a la perfección, y así paso a explicarla para que no se ignme el origen de un ramo tan pingie, y para que puedan tomarse con mejor' conocimiento providencias oportunas en beneficio de la Real Hacienda.

Entre los yanaconas hay unos que se llaman forasteros, y otros yanaconas de chacras; los primeros son aquellos indios vagos, que han descrtado de su domicilio y naturaleza, sin aplicación a ningún destino 
fijo, y estos se denominan yanaconas de la Roul Corona, los desmembrados antiguamente de slis reducciones $y$ pueblos, se aplicaban a servir espainoles en sus heredades y chacras, para labrarlas o cultivarlas, según lo explica nuestro Escalona.

El Sr. Virrey Don Francisco te Toleto, por Provisión dada en la Plata, a 27 de noviembre de 1754 , mando cobrar a cada yanacona de Porco, seis pesos ensayados, que hacen nueve pesos, y tres reales. El mismo Sr. Vir'tey señaló después, por otra Provisión fecha en Fotosí, a 12 de mar\%o de 1755, a cada yandeorit de Forco, la tasa de siete pesos ensayados y illácalos, emparironando ciento sesenta y ocho indios de esta clase, cuya tasa importó en aque] timpo mil ciento setenta y seis pesos (\$ 1.176) de la misma moneda.

En la Revisita practicada por On. Manuel Venero, en el año de 1729, se retasaron los yanaconas de Porco a siete pesos cada uno. Sobre varias didas resultadas con este motivo, informó el Tribunal de Cuentas, que ol Sr. Toledo habia mandado, poi. la Ordenanza 14, que se les cobrase un peso ensayado, el cual se aumentó por las retasas del Sr. Duque de la l'alata, a dos pesos ensayados, que hacen los tres pesos un real, que se lia acostumbrado exigrirles; lo die se confirmó posteriormente por dicho Sr. Toledo, tasando of tributo tie los yanaconas de chacras de este distrito en los mismos dos pesos msayados.

El Sr. Duque de la Palata no dio determinación clara en esta materia; y aunque el Si. Conde de la Monclova, en despacho de 27 de abril de 1692 , tratando acerca del tributo que debían pagar Ios indios forasteros, cleterminó que mientıas no se actuasen nuevas Revisitas, se cobrase a los indios forasteros, de cualquier género que fuesen, el tributo que les estaba tasado o hubicse estado en costumbre de pagar antes de la numeración mandada hacer por el Duque de la Palata, como no excediese de siete pesos; no por esto deben incluírse en este número los yanaconas de chacras, porque siendo estos los que empadronó el Sr. Toledo en la Villa de Potosí y en las ciudades de La Paz y Arequipa, no se deben reputar por forasteros, sino más bien por originarios de las chacras de ellos y todos sus descendientes, por las razones que elegantemente explica nuestro citado Escalona. ${ }^{45}$

En conformidad de este dictamen del Tribunal de Cuentas, determinó el Sir. Virrey, Marqués de Castelfuerte, en despacho de 28 de julio de 1731 , que no se hiciese novedad cn continuarse cobrando los tres pesos un real a los yanaconas de chacras, como sienpre se había observado, debiendo correr los sicte pesos en los yanaconas de la Real Corona.

Por la última Revisita actuada en 30 de septiembre dol año corriente de 1786, por el Subdelegado de Porco, resulta el número de 1.213 yanaconas, residente en quince Doctrinas de dicho Partido; los cuales, a razón de 3 pesos los quince, de cinco los 57 y de siete los restantes 1.141 indios, adeudan juntos 8.317 pesos.

De esto resultan dos reparos bien notables. El primero es, que habiendo solamente dos clases de yanaconas, se advierten tres clases de tasas, cuando en el Partido de Chichas se ha observado invariablemente que el forastero pague 7 pesos al año, y el yanacona 3 pesos un real, aunque los originarios satisfacen 10 pesos, por la comodidad del uso de las tierras. El segundo reparo es, que no habiéndose empadronado más de cien- 
to setenta $y$ ocho yanaconas en Porco, al ar̃o cle 1557, so encuentran en el día 1.213 , que son diez tantos más que los de aquel tiempo.

Conque se prueba el criminal descuido que tavieron los Corregidores en recoger los indios dentro de sus poblaciones $y$ on reducirlos a sus domicilios para no perjudicar la aplicación de la mita y otros servicios públicos. También se acredita el abuso de acrecentar la tasa, porque a no ser así, no se encontraria esta tercera clase de cilco pesos, sino sólo de tres o de sicte.

Sin embargo de haber mereculado este lamo a 8.317 pesos, como se ha visto por lo respectivo, solamente a la l'rovincia de Poreo so ha pretendido mantener el antiguo arrendamionto reducido a cuatro mil setecientos anuales, creyéndose más útil al Rey, pot' evitarse rle este modo el riesgo de las contingencias.

He oído inclinarse los más a este parecer, pero, en mi concepto, sin considerar otros mayores inconvenientes que se evitarían en la administración, reglando las cobranzas por el preciso número de tributarios y sus tasas.

l'ara entrar en este asunto por detalle, examinemos primero una cuestión de las más graves en el sistema político. Consiste co si os más ventajoso arrendar las rentas dol Fstado, o administrarlas de cuenta de Ia Real Hacienda.

Un célebre político francés moderno, asienta esta cuestion a modo de un problema, pero al cabo decide su voto a favor de las rentas en la Administración, con la calidad de que Ios Oficiales receptores y colectores sean personas muy íntegras y hábiles.

Por el arrendamiento fue apasionado acérrimo el Cardenal de Fleury, persuadido de que podía contar con un fondo seguro sobre la cantidad de cada ramo de Hacienda y la exactitud de su pago, y por esto llamaba a los Asentistas Generales de Francia, "las cuarenta columnas del Estado".

Esta razón de sonido dulce y brillantez aparente, condujo la mayor parte de los Gobiernos a adoptar sus máximas.

Para España misma fueron muy respetables por mucho tiempo, hasta que en el feliz reinado del Señor Don Felipe V., dio a luz nuestro gran político Don Jerónimo Ustáriz, la Teoría y Práctica del Comercio y de la Marina, cuya obra fue tan cclebrada, que según el sabio político de Europa, él y Montesquieu son los únicos autores que han escrito más sensatamente sobre la política económica; asegurando otro moderro, que sólo esta obra era capaz de haber hecho feliz a España, si se hubieran adoptado las ideas de su autor.

Así pues, uuestro gran político, en distintos lugares de su obra 86 critica los arrendamientos, convence de sus grandes inconvenientes $y$ prueba la preferencia de las administraciones, con positivas experiencias de los acrecentamientos de la Real Hacienda por cste medio, en cotejo de otros grandes atrasos causados por los arrendamientos.

No me valdré de sus argumentos como contraílos principalmento a la renta de Alcabalas; pero apuntaré otros de igual valor, aunque de menos luz, para convencer de que la Administración del yamo de Yanaconas, es más conveniente y últil que su aryendamiento.

Primeramente, no puede dudarse que estando este ramo administrado con integridad, de cuenta de la Real Hacienda, puede utilizarse el 
estado de las crecidas cantidades que ganan los Subdelagados en sus arriendos.

Lo segundo, aunque los gastos de Administración y cobranza hayan de disminuil una gran parte de este provecho, el Estado nunca llega a perder enteramente estos salarios, porque sicmpre vuelven a entrar con ventaja en la masa gencial, a diferencia de los gastos que hace un particular en los salarios que consigna a uno o muchos sirvientes; pues, éstos, desde luego, se pierden y nunca volverán al provecho de su bolsa; lo contrario sucede en el Estado, poroue el tanto por ciento que concede a los Administradores, colectores o receptores, es utilidad para el Estado mismo, siéndolo para los miembros de que se compone.

Lo tercero, los Subdelegados para acrecentar. Ios productos del Asiento, es forzoso que consientan, abriguen y aun congratulen a los indios vagabundos y prólugos de los pucblos de su origen, porque cuantos más sean los de esta clisse, so ammenta la gruesa de tributarios yanaconas. Así so llonarân las Pruvincias de hombres sin destino, por falta de tierras y do otros cstablecinientos de industria; consumián estos haraganes mucha parle de los frutos escasos del país y todos vivirán más necesitados por fuerza. De este desorden se seguirá no cuidarse ni cumplir las órdenes del Reino, en restituír los incios vagos a los pueblos de su naturaleza $\mathrm{y}$, consiguientemente, se perjudicará el privilegiado servicio de la Mita, pos' disminución de la séptima en las Provin ias mitarias; y los tributos que hubiera utilizado el Rey, por mano de los cobradores de cada pueblo, ganará el arrendatario, por título de su arrendamiento, en perjuicio de la Real Hacienda.

Si los Subdelegados no hubieran de percibir estas gananeias, no receptaran tantos vagabundos como ahora, hos apremiaran a que sirviesen amos conocidos y el temor de esta sujeción los iría disipando insensiblemente hacia sus domicilios; de manera que el poco provecho de la Real Hacienda en el primer quinquenio, sería feliz origen del grande acrecentamiento en los siguientes, además de establecerse, por su medio, mejor orden en las Provincias.

Lo cuarto, los arrendamientos exponen los pueblos a muchas violencias y demasías de los Subdelegados, porque accrcándose el tiempo de los enteros, es factible que presionen a los indios a excesivos pagos, para reglar los productos a medida de la ambición, afligiendo a los contribuyentes, en las cobranzas, con apremios y otras vejaciones. Ya se ve que en este caso se cumplirá el entero en Cajas; pero la utilidad injustamente granjeada por un solo individuo del Estado, scrá evidentemente ruina del gran número de otros más necesitados, a quienes su misma pobreza $y$ fialta de posibilidad hace acreedores a las clemencias del Soberano.

Los tributos de la nasa general se recaudan por los mismos indios principales o curacas y gobernadores, con la suavidad que merece la semejanza de su condición y el mayor conocimiento de la incposibilidad de cada uno. No será esto así en el ramo de yanaconas, porque mirándose como una masa propia de los Subdelegados, destinarán ellos mismos unos cobradores exactos, que sin ninguna consideración exijan el tributo, tal vez mayor que la tasa, cn agravio de los indios, usando de rigores indebidos para acreditar su exactitud. Lo peor es que estos excesos pasarán sin castigo y aun tal vez sin la menor noticia de los Jefes; porque estos indios, por lo regular pobrísimos y amedrentados de su misma descreión, humi- 
llan su cerviz a todas las violeneias, y como viven luera de su Patria, sin caciques ni gobernadores propios que reclamen sus derechos y promuevan su defensa en los tribunales, sufren sin resistencia todas las demasías y apremios de la ambición.

Por todas estas consideraciones, prudentemente reflexionadas, en la Real Ordenanza de lntencientes se ha mandado preferir la Administración bien reglada, a los arrendamientos de los ramos de la Real Hacienda, en los Arts. 106, 107, 108, 109, 130, 131 y 201, excitando en este último la atención de los Intendentes a un escrupuloso cnidado para examinar las conveniencias de los justos arrendamientos, permitiendolos únicamente en los ramos de corto momento, pero siempre con la precisa calidad de sacarse a pública subasta en Junta de Alnonedas, para que se rematen en los mayores postores.

Yo no gradúo por "cle poco momento" el ramo de yanaconas, subiendo su importancia a más de 10.000 pesos; y cuanco d riesgo de minorarse lo constituyese en esta clase, convendria poner su arrendamicuto unido a otros ramos menores de Hacienda, en manos de personas 10 de tanta autoridad como los Subdelegados, para efitar los claños, lus abusos, las violencias y las demasías que pueden concterse en las Provincias.

Párrafo sexto. - Yanaconas de la Real Corona, de la jurisdicción de Ia Villa; a saber: Chulchucani, Salinas, Tarapaya, Cantumarca, la Matríz y San Roque. cimiento alguno de señorio. Enterado el Rey do este desorden, mandó que los visitasen, numerasen, expadronasen y señalasen tasa, según Escalona. 87

Conforme a esta orden, numeró y empadronó los de de esta Villa el Sr. Don Francisco de Toledo, al tiempo de su visita general; mandó que pagasen tributo y los dio caciques para su gobierno. También los redujo a Parroquias donde tuvieren Doctrina, y en el año de 1572 hizo erigir en Potosí a este fin trece Parloquias, seis nuevas y siete antiguas; y señaló a cada Cura 800 pesos ensayados, "s' por vía de sínodo.

Todos los yanaconas empadronados en el asiento y Villa de Potosí, en sus Parroquias y rancherias, llegaron al número de seiscientos setenta y cuatro; cuya tasa señaló el $\mathrm{Sr}$. Toledo, a razón de 9 pesos de plata ensayada y marcada, en cada año, por una Provisión fechada en esta Villa, a 12 de marzo de 1757 ; y a este respecto montó cntonces la tasa anual a 6.000 pesos, corriendo su cobranza en aquellos tiempos y en los posteriores, por diversas manos, como se verí después.

Fuera de estos indios empadronados en la primitiva, venían a esta Villa sucesivamente otros indios vagos y forasteros, que son los que en todo Distrito llaman "Yanaconas de la Peal Corona". Ya fue preciso distinguir esta clase do los primeros que se cmpadronaron, porque ya se reputaban por criollos; y entonces se comenzó a empadronarlos separadamente y se les asignó por Parroquia propia la de San Roque, que es la que hasta ahora recollocen los indios yanaconas, en cuyas tasas se si- 
tuó para el sostenimiento del Cura, el sínodo de 1.093 pesos 6 reales, y los 1.572 pesos que goza de salario el Capitán Mayor de la Mita, con la calidad que no alcanzando para estas pensiones, se le paga el entero al Capitán, de la gruesa de tributos de todos los indios yanaconas de la jurisdicción de estas Cajas.

Desde el principio se arrendó este ramo y consta por varios documentos, que el año de 1.687, lo remató Ambrosio Ruíz de Villodas, en 5.860 pesos. Baltazal de Aguirre, en el año de 1729, apenas lo arrendó ya en 2.350 pesos, sin duda porque la decadencia de nuestro mineral privó el antiguo aliciente que tenían los indios para desamparar sus domicilios.

Posteriormonte, se quiso obligar a los Oficiales Reales que administrasen este xamo; $y$ habiendo hecho recurso al Superior Gobierno de Lima, se mandó en Auto acordado, de 21 de julio de 1755, que continuase en arrendamiento la cobranzat de los tributos de yanaconas, sin gravar con ella a los Oticiales Reales.

Ullimammite, tiene en Artministración Diego González, con el salario de 1.000 pesos al año, $y$ entera en sus dos tercios o semestres, por total de cstos 1 ibutos, la cantidad de 3.246 pesos. Cualquiera advertirá que es excesiva esta asignación, y por más que se pondere este trabajo, no faltaría quien administrase por menos el ramo.

Estos indios están repartidos en ciertos scrvicios personales, a más del gravamen de las tasas, en esta forma: por Decreto de 17 de diciembre de 1688 , consccuente a la retasa general que se hizo después de la numeración de estos indios de todas estas Provincias, asignó el Si. Virrey, Duque de La Palata, los indios yanaconas siguientes: treinta a la Iglesia Matriz, para que alternándose diez de efectivos trabajos, cada cuatro meses, tuviesen ocho meses de descanso al año. A cada Convento de religiosos, quince indios, con cinco de trabajo alternado como los de la Matriz. A las Reales Cajas, doce. Al Lagunero de la Villa, dieciocho. Al Capitán de Mita, doce. A cada uno de los Hospitales, scis. Al Convento de Carmelitas Descalzas, doce. A las Justicias, para las diligencias judiciales, sesenta. Para el scrvicio de los presos de la Cárcel, doce. Al Ensayador de la Casa de Moneda, para la fundición y reducción de las basuras en rieles, once. Para el servicio de la Casa de Moneda, cuatro.

Con el tiempo ha variado sobremanera este repartimiento $\mathrm{y}$ en el día se reduce a cuarenta y ocho indios para la Matriz, fuera de dos Curacas, alternándose cuatro de efectivo trabajo en cada mes. Al Hospital de Belén, diez y siete. A los Conventos de Santo Domingo y San Francisco, quince para cada uno. A la Casa de Moneda, trece. A la Caja Real, seis. Al Capitán de Mita, dos, con título de cañaris. $\mathrm{Y}$ a San Roque, veinticuatro, repartidos dos por cada mes, con el nombre de pongos; habiéndose abolido los antcriores repartimientos a las Justicias, Cárcel y demás Conventos.

Aunque se ha dudado si esta asignación debe entenderse sin gravamen de tasas ni jornales, respecto a que en ella sólo se exceptuaron los once del Ensayador y cuatro del servicio de la Moneda, mandándoseles pagar jornal, es regular que el ánimo del Sr. Virrey fuese que contribuyeran las tasas todos los indios yanaconas del antecedente repartimiento, como que siempre ha contribuído 200 pesos el Mayordomo de la Ma- 
triz, por los indios de su asignación, abonándoseles a los arrendadores de este ramo a cuenta de su asiento, en la misma cantidad.

Ódo sobre esto el Tribunal de Cuentas y los dos Fiscales, resolvió el Sr. Virrey, Marqués de Castelfuerte, por Despacho do 31 de julio de 1729 , que el Mayordomo de la Fábrica continuase pagando los 200 pesos de los yanaconas, sin hacer novedad. Siendo los otros de una misma naturaleza, parece deben sujetarse a la misma decisión, aunque literalmente no los comprendió, por habersc entonces tratado solamente de las tasas de los yanaconas de la Matriz; pero deben exceptuarse los del servicjo de San Francisco, por haberlos relevado de tasa el Sr. Don Francisco de Toledo, por su Provisión dada en Potosí, a 7 de abril de 1575, cuya especial excepción afirma la antecedente rogla, en contrario de los que no presentaren igual privilegio. Párrafo séptimo. - Indios
criollos de las Parroquias de
Potosí.
L dios que empadronó y retasó en esta Villa el Sr. Don Francisco. de Toledo, asignándoles Parroquias para su Doctrina, según se ha visto en el parágrafo antecedente, son los llamados ahora "Indios criollos de las Parroquias". Este ramo corre separado de los yanaconas de la Corona, que rigurosamente son los indios vagos y forasteros.

Al principio de la numeración y retasa de los yanaconas de esta Villa, nombró el Sr. Toledo para la cobranza de sus tributos, trece indios Alguaciles, uno en cada Parroquia, todos ellos libres de tasa y sujetos al cuidado de un Principal, con el salario de 200 pesos corrientes. A poco tiempo se experimentó una muy notable omisión en estos cobradores; por cuya causa nombraron los Oficiales Reales, para hacer las recaudaciones, a un tal Ibarguren, con 400 pesos que montaba el salario del Principal y tasas de Alguaciles, El Sr. Toledo aprobó esta Providencia en 7 de octubre de 1577; pero el Sr. Marqués de Cañete, rebajó después este salario a cien pesos solamente, en Despacho de 6 de noviembre de 1593.

La epidemia general de los años 1713 y 1721 , asoló mucha parte de las poblaciones del Reino, pero en esta Villa fucron más funestos sus estragos. Por poco no consumió las castas de los indios, y su notable disminución obligó a suprimir seis Parroquias, que en el año de 1572 mandó erigir el Sr. Toledo, quedando reducidas a las siete más antiguas. Estas se han conservado para Doctrina de los indios criollos u originarios de Potosí, satisfaciéndose a los Curas su sínodo de la Real Hacienda.

Este ramo estuvo, como el antecedente, muchos años atrás en axrendamiento; pero en el día corre en Administración, a cargo de Don Pedro Nogales, satisfaciendo al año dos mil ochocientos pesos, por el total de las tasas, que es la misma cantidad que en años pasados pagaba en calidad de arrendatario.

Si volvemos la consideración a los primeros tiempos del establecimiento de este ramo, se advierte que no ha padecido disminución alguna, porque resultando de la retasa primitiva que mandó hacer el Sr. Toledo en el año de 1575 , el monto anual de 6.066 pesos, no se repara en el dia más diferencia que veinte pesos en el producto de los yanaconas de la Corona y criollos, que entonces corrían unidos para igualar aquella antigua tasa. 
Desde luego, puede afirmarse que pocos ramos se habrán mantenido on tan buen pie como éste, en medio de las notorias calamidades que han disminuido tan notablemente el número de los contribuyentes; ni es dudable la posibilidad de su aumento si los dos ramos corriesen a cargo de un solo Administrador, porque siendo en este caso menores los costos de la cobranza, subirian forzosamente los productos, a beneficio de la Real Hacienda.

Puesta en este pie la Administración de uno y otro ramo, no faltaría quien la tomase a su cargo por cl premio de un $4 \%$, como lo ejecutan los Subdelegados, ni hay razón para que un cobrador particular, con menos trabajo tenga más salario que los Subdelegados que tienen que atender a otros objetos, con una responsabilidad tan considerable sobre toda gruesa de tributos de su Provincia.

Después de todo, debe correr este ramo a cargo de los Alcaldes Ordinarios, como dispone la Real Ordenanza, y entonces su recaudación se haría sin más costo que el de un $4 \%$ de los Curacas, y ahorraría el Rey los crecidos salarios que ahora tiran los Administradores y arrendadores.

Párrafo octavo. - Minas Es $\mathbf{P}$ OR las Ordenanzas 10, 13 y 19, Tít. 19, tacas de Su Majestad. Lib. 3 de las Generales del Perú, se asigna a

Su Majestad, por derecho de suprema rega-

lía en cada descubrimiento de minas, una de sesenta varas en las de plata, entre la descubridora y la salteada; y en las de oro, de cincuenta varas, en la forma y con las calidares que explica nuestro Escalona. ${ }^{89}$ En Nueva España no se practicaba, según sus nuevas Ordenanzas, esta asignación de Mita para Su Majestad, como enseña Dn. José Sanz, citado por Gamboa. ${ }^{90}$

Del arrendamiento y venta de estas minas de la Corona, y de la conveniencia que puede resultarle al Rey de labrarlas por Asiento o más bien por Administrador de su cuenta, trata muy sensatamente nuestro Escalona, ${ }^{91}$ y aunque reprueba como abuso ${ }^{92}$ de estilo de algunos Oficiales Reales, el vender libremente estas minas a su arbitrio, como cualquier otro ramo vendible, sin considerar si son ricas y poderosas o puramentc temporales y pobres, para proceder a venderlas en este último caso, $y$ en los dos primeros a arrendarlas o administrarlas según se hallare de mayor utilidad y eonveniencia a la Real Hacienda, según lo prevenido en la ley 2, Tít. 11, T.ib. $8^{\circ}$ de Indias, y en la Ordenanza 7, Tít. 12, Lib. $3^{\circ}$ del Perú; con todo, aconseja el citado autor, ${ }^{93}$ que es mejor y más conveniente al Rey, venderlas o arrendarlas, por las contingencias de la poca ley de los metales.

Solamente cuando con evidencia de las riquezas y del caudal al parecer indefectible, se reconociere que no habrá quién le pague justamente en el remate y que le estará mejor a Su Majestad ir gozando sus frutos, en tal caso conviene ponerlas en administración de persona fiel, celosa $y$ versada en cl ministerio.

En este concepto, desde que sc atrasaron las minas del Reino, se estila por inconcusa práctica vender las minas del Rey en público remate, como cualquier otro ramo de Real Hacienda; porque trabajándose de su cuenta, sc haría gastos sin provecho, y porque no es fácil encontrar 
quien las arriende, hallándose todos en libertad de registrar minas de igual fuste en otras partes.

Pero en estas subastas se procede regularmente sin el examen necesario para calcular el justo valor de las minas; porque toda la operación se reduce a mandar tasar las minas del Rey, por unos sujetos que se nombran arbitrariamente con el título de Peritos, sin que conste de su inteligencia y sin que hagan otra cosa que apreciar la mina a vista de ojos, sobre cuyo valor se pregona la venta sin otra diligencia.

Para precaver estos inconvenientes, se previno en Real Orden de Madrid, a 13 de marzo de 1762 , que observándose el contenido de la ley 2 , Tít. 11, Lib. $8^{\circ}$ de Indias, se arrienden o vondan las Estacas minas del Rey, como más conviniere al Real selvicio, con la condición que a más de sacarlas al pregón para uno u otro fin, se examinen y leconozcan por Peritos la calidad, naturaleza y ley de los metales, para que con este conocimiento se admitan las posturas y se rematen en el mayor postor.

Según esta providencia, debe constar por diligencia el reconocimiento y ensaye, y conforme a la ley que resultare ejecutar la tasación de la mina, a fin de evitar todo engaño en los pregones y remates de este ramo de Hacienda.

\section{Párrafo noveno. - Sitios solares.}

$6 6 \longdiv { \mathrm { T } }$ "co, 94 que en otros Reinos y" diciones divi-

"dió los dominios, en éste del Perú lo aplicó "todo al Señor de él. De manera que no sólo porque lo trae el P. Acosta, "en el libro de "Historia de Indias", Cap. 15, sino por tradición y dicho "de indios viejos, se sabe que el Inga, como Supremo Rey de todo, daba "y quitaba tierras, y lo dicho del dominio reservado al Príncipe sólo en "este Reino. Es muy ordinaria alegación (quan facere solet) para excluír "a los indios que piden tierras vendidas por orden de S. M, y la comprue"bo por la Real Cédula de 1" de noviembre del 91 (que es la ley 14, Tít. 12, "Lib. 4" de Indias), en que S. M., dice: _-. "Por haber yo sucedido entera"mente en el señorío que tuvieron en las Provincias los Señores de ellas, "es de mi patrimonio y Corrona Real el seirorío de los baldios, suelo e tic"rra de ellos, que no estuviere concedido por los Señores Reyes mis pre"decesores". De manera que el dicho derecho del dominio universal de tie"rras en este Reino, no repugna al delccho divino, y así fue transmisible "a S. M., en este su Reino del Perú".

En virtud de este supremo dominio, se mandaron repartir al,principio de la pacificación de estos Reinos, los sitios necesarios para las poblaciones de ciudades, villas, ejidos y dehezas para propios, solares, tieras y aguas, para chacras, casas y estancias de particulares, rescrvándose las restantes a $S$. M., para hacer merced y disponer de ellas a su Real voluntad, en la forma y en el tiempo, y con las solemnidades que preseriben las leyes del Tít. 7 y 12, Lib. $4^{\circ}$ de Indias, para cuya inteligencia escribieron doctos comentarios nuestro Escalona y el Sr. Dn. Juan de Solórzano, ${ }^{95}$ a quienes se puede ocurrir en los casos de duda.

Todos los repartimientos hechos a los primeros pobladores y los que se han ido haciendo en adelante, traen inbibita la condición precisa de no poderse traspasar ni vender a iglesia, monasterio ni a persona 
eclesiástica, bajo la pena de perdimiento y de poderse repartir a otros,

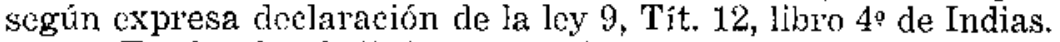

In 21 de abril de 1705, hizo consulta a Su Majestad el Consejo de Indias, para que se mandase renovar la ley de Don Alfonso VI., citada en los Autos Acordados de Castilla; ${ }^{96} \mathrm{y}$ el Fiscal del mismo Consejo, pidió su obser'vancia en el año do 1714, y la sobre carta de la ley 10, ya citada de Indias, según refierce en el Auto 15, parágrafo penúltimo, Tít. 1, I.ib. 4" de los Acordados de Castilla, sobre cuya explicación escribió varias excelentes resoluciones nuestro insigne jurisconsulto Olea. ${ }^{97}$

Ultimamente se ordenó, por el Art. 129 de la nueva Ordenanza de Intendentes, que no se pueda hacer venta ni cesión de bienes raíces a eclesiásticos del interior de la Provincia, bajo la pena de la ley 30, Tít. 13, Lib. 8" de Indias, al Escribano que autorice tales instrumentos; en cuya virtud, no precediendo el permiso de estos magistrados, son nulas todas las enajenaciones en manos muerlas, por la condición impeditiva de traslación de dominio, por lo que serán incompetentes los Jueces Reales para el conocimicnto de estas causas y de todas sus incidencias.

Todas las tierras enajenadas con el vicio de nulidad, y las que habiéndose repartido a los indios se hubieren despoblado en cl todo, se vuelven a incorporar a la Corona por el derecho de reversión, y puede S. M., disponer de ellas, vendiéndolas o repartiéndolas a otros vasallos, según una famosa resolución de nuestro político el Sr. Don Juan de Solórzano. ${ }^{39}$

A este efocto se han dado muchas instrucciones particulares, además del reglamento contenido en el Tít. 12, Jib. $4^{\circ}$ de Indias; por la Real Cédula de San Iorenzo, a 30 de octubre de 1692, se dio la comisión a Don Bernardo Valdés y Girón, del Consejo, Cámara y Guerra de Indias, para la Superintendencia de la composición y venta de las tierras de estos dominios, insertando allí mismo la correspondiente instrucción para su manejo.

Por otra de $1^{1}$ de marzo de 1717 , se le confirió este mismo cncargo a Don Diego de Zúñiga, del propio Consejo; y en 29 de agosto de 1735, se le subrogó a Don Antonio de Pinedo, por Juez de todas las ventas e indultos de tierras en estos dominios.

Ultimamente, por Cédula de 12 de diciembre de 1743 , se refrendaron todas estas comisiones en Don Antonio José Alvarez de Abreu, Marqués de la Regalía, con la autoridad de poder nombrar Subdelegados en esta parte del Perú para las ventas y composición, bajo la calidad de darse cuenta de ellas antes de despacharse las confirmaciones, con otras muchas cláusulas llenas de honor y poderío.

El tiempo hizo conocer los graves perjuicios que sufrían los vasallos de estos dominios, con tener que acudir precisamente a la Real persona a impetrar las confirmaciones, y fue preciso alterar-el antiguo sistema.

En efecto, se despachó la última instrucción con 14 capítulos, en Real Cédula dada en San Lorenzo, a 15 de octubre de 1754, poniendo en el primero a cargo de los señores Virreyes y Presidente, la facultad de nombrar Ministros y Subdelegados para practicar la venta y composición de los terrenos realengos y baldíos, con poder para subdelegar su comisión en otros, para las partes y Provincias distantes de las de su residencia. 
Como todo el fin fuc aliviar a los vasallos, se previno a los Ministros Subdelegados, que puestos los expedientes en estado de despachar los títulos, se remitiesen por consulta a las Audiencias respectivas, para que vistos con audiencia de sus Fiscales, se devolviesen (no ofreciéndose reparo) para la expedición de los títulos, comctiéndose a las mismas $\mathrm{Au}$ diencias la facultad de librar la Real confirmación y de conocer todos los recursos y demás instancias en materia de tierras.

Finalmente, ya mejorado nuestro gobierno de las Indias, por Ia Nueva Ordenanza de Intendentes, se constituyó a estos Magistrados, en el Art. 78, por Jueces privativos de las dependencias y causas que acurrieren en el Distrito de sus Provincias, sobre ventas, composición y repartimiento de tierras realengas y de señorío, reglando su conocimiento sobre el pie de la instrucción citada, del año de 1754, con la diferencia de trasladarse a la Junta Superior de Buenos Aires, para lo respectivo a su Virreinato, todas las facultades anteriomente concedidas a las Audiencias, para el despacho de la Real confirmación y para la segunda instancia de los negocios de esta clase.

Asi pues, respecto a que en esta Provincia hay muchas tierras realengas, principalmente en el pueblo de Tarija, y sobre ellas ocurren muchos casos frecuentes, no será impertinente exponer aquí, en compendio, el modo de practicar las diligencias para que los Intendentes de Potosí, procedan en adclante con guía de toda seguridad.

De dos modos se adquieren las tierras rcalengas: o por composición o por compra. El primer modo sólo tiene lugar en el que hubiere posédo por diez años, según la ley 19 , Tít. 2 , Lib. $4^{\circ}$ de Indias, y no concurriendo esta calidad, es preciso valerse de la compra, que es el segundo modo de adquisición.

En cualquiera de estos dos casos, se presenta el interesado denunciando por realengo o vacante el terreno que intenta componer o comprar; designa su situación, su distrito, sus linderos y vecindades, pidiendo que se le adjudique, segín el caso en que se halla.

Para evitar los inconvenientes de vender tierras a españoles, en perjuicio de los indios, se manda recibir información de la calidad de realengo, con citación del Promotor Fiscal de Real Hacienda y del Protector de indios, $y$ con audiencia de ambos se declara su pertenencia al Real patrimonio.

En este estado, se provee Auto de tasación, nombrando personas inteligentes para la averiguación de su valor, medida y justiprecio, con arreglo a las comodidades que gozare de regalio, su mayor o menor distancia de las poblaciones, los montes, pastos y aguas, riegos y abrevaderos que les estuvieren más cercanos e hicieren más útil su labor y cultura; citándose para esta diligencia al Promotor Fiscal y a Ios circunvecinos del terreno. Si en estas operaciones no resulta contradicción, se compone, ajusta y transige con los poseedores por el Intendente, con intervención del Fiscal, con atención al ticmpo que lo han disfrutado y a su calidad y extensión, en una cantidad moderada.

Instruídos los autos con estas solemnidades, en estado de despachar el título, se remiten originales a la Junta Superior de Buenos Aires, para que, oídos instructivamente el Contador General de Real Hacienda y el Fiscal, ${ }^{90}$ se devuelvan para la expedición del título, o determine lo más conveniente, a fin de que puedan recaer sin nuevos embarazos las 
confirmaciones correspondientes de la Junta Superior.

Si el caso es de compra, después de verificada la averiguación, medida y tasación en la forma explicada, se sacan a público pregón y remate y se traen en Almoneda por treinta días útiles, dando un pregón en cada uno de ellos. 100

Admitidas en Junta de Almonedas las posturas y mejoras que se hicieren dentro do ese término, del nodo que queda dicho sobre los oficios vendibles $\mathrm{y}$ renunciables, se da cuenta con los autos originales a la Junta Supcrior, para que en vista de la diligencia de medidas, avalúos, pregones $\mathrm{y}$ posturas, determine con audiencia instructiva del Contador de Real Hacienda y del Fiscal, sobre la ejecución y expedición de los títulos. Luego que estuvicren librados, acude el interesado a impetrar Ia confirmación ante la misma Juntá Supcrior, donde se ve el proceso formado en orden a las medidas y avalúós de las ticrras y del título, examinando si la venta o composición está hccha sin fraude ni colusión y en precios proporcionarios y equitativos, con audiencia instructiva del Contador $y$ dol Fiscal; $y$ con atención a todo esto, constando el ontero en Cajas del precio de la ronta o composición, del derecho de media anata y del derecho pecuniairo que se rcgulare correspondiente, se despacha entonces en el Real nombre la confirmación de los títulos, quedando para siempre ejecutoriacio el dominio de las tierras.

Pero, si se movieron pleitos, bien sea sobre las ventas o sobre las composiciones, se deben instrusir legítimamente, con un Promotor del Real Fisco, determinándolos según derecho, el Intendente, con dictamen de sa acesor ordinario y con apelación a la Junta Superior de Fracienda.

Se previene por conclusión, que las ventas y composiciones, solamente recaen en terrenos realengos $y$ baldíos, $y$ de ningún modo en los lugares públicos, comunes y concejiles, como son plazas, calles, ejidos y dehezas de los pueblos; de tal manera que ni los Señores Virreyes que entendían en estos negocios, ni la Junta Superior, ahora pueden vender, componer o repartir lugares públicos de las ciudades, bajo la pena de nulidad, como resolvió la Real Audiencia de Lima, en un caso de esta naturaleza, según refiere el Sr. Solórzano. ${ }^{101}$

\section{Párrafo décimo. - Media $\mathbf{A}$ imitación de la Curia Romana, dice Anata y Lanzas. Escalona- ${ }^{102}$ que nuestros Reyes introduje- ron el derecho de la media anata, y afirma} que se comenzó a cobrar en este Reimo del Perú, gobernando el Sr. Conde de Chinchón, en virtud de Cédula Real. Las leyes, principalmente la $3^{\mathrm{a}}$ del Tít. 19, Lib. $8^{\circ}$ de Indias, mandan pagar la media anata a todos los oficios, meicedes y honores, títulos y rentas que se dieren por el Rey, sus Consejos, los señores Virreyes y otros Ministros suyos, siempre que para ello sea necesario Cédula o Despacho; regulando este derecho por la mitad de los que el primer año importare el verdadero valor de los sueldos y demás emolumentos que se gozaren en cada oficio.

En esto mismo se advierte la suavidad de esta contribución, cuando en la Curia Romana se paga anata entera, mitad para el Papa y la otra mitad para los Cardenales, por la ocupación y trabajo que el uno y los otros se toman en examinar los negocios en el Consistorio $\mathrm{y}$ hacer las provisiones, según Thusco. ${ }^{103}$ 
Solamente en casos de inevitable urgencia, se ha mandado satisfacer en nuestros dominios anata cntera, como sucedió en el año de 1705; pero luego que cesaron los motivos, se despachó Real Cédula de San Lovenzo, a 13 de junio de 1717 , derogando otra de 13 de julio del referido año de 1705 , y se ordenó que se cobrase en adelante solamente la media anata, como se había practicado con arreglo a las reglas de este derecho.

Uitimamente, se prescribieron otras nuevas para el pago y seguridad de la media anata, por Cédula de 26 de mayo de 1774 , y se reducen a que los provistos para empleos satisfagan integramente la media anata del primer empleo, descontando por cuatro partes en el término de cuatro años, y si antes fallecieren, de sólo el tiempo de su posesión, a prorrata, sin obligarlos a dar fianzas ni imponerles otro giavamen; que los Ministros togados, Oficiales Reales y demás empleados cn el Ministerio Político y de Hacienda, que ascendieren de una Audiencia y Cajas menores a otras mayores dentro de las Secretarías u oficinas en que sirven, contribuyan sólo el aumento del sueldo, por razón del honorífico, entendiéndose lo mismo con los demás empleados que, sin aumento de sucldo, sean ascendidos a destinos de mayor graduación y descanso; pero que no se haga descuento a aquelios en quienes se verifique remoción o paso a destino de igual honor y sueldo; y tiltimamente, que no paguen media anata los empleos militares sin mezcla de político ni de administración de Real Hacienda.

Las mismas excepeiones gozan todos los empleos y oficios de cualquier creación y de cualquier clase que sean, y tambiên los jubilados, aunque sea con todo el sueldo o con la mitad, según Real Cédula de El Pardo, a 27 de enero de 1768. En cuanto a los provistos de empleos de primera creación (que no adeudan media anata) ascendidos a otro de distinta naturaleza, se debe computar en la regulación el aumento del sueldo que lograren en los ascensos, con respecto al que gozaban en sus anteriores empleos, según lo dispuesto en Real Orden de El Pardo a 4 de febrero de $\mathbf{1 7 8 5}$.

Con estas providencias se han variado en mucha parte las reglas y Aranceles antiguos que refiere Escalona, ${ }^{104}$ para cl ajustamiento y exacción del derecho de media anata, quedando inútiles las más, por defecto de observancia. Para evitar confusiones en la generalidad de los casos, pondré un estado de los empleos, oficios y mercedes que adeudan media anata en esta Villa y con relación al estado de su actual constitución.

\footnotetext{
Cada indio mitayo, por media anata y su conducción a España .. . .

Una licencia de Molínos para semilla . . . . . . . . . . . . . .

Una licencia de Molinos para metales . . . . . . . . . . . . . .

Una licencia de Huacas $\ldots \ldots \ldots \ldots \ldots \ldots \ldots \ldots$

El servicio pecuniario para esta licencia ... .............

Una licencia para administrar bienes propios durante la menor edad, o para descubrir y trabajar Huaca, incluso la conducción a España $\ldots \ldots \ldots \ldots \ldots \ldots \ldots$

Un Protector de naturales paga la $8^{\circ}$ parte del salario $y$ su conducción a España .................................

Un Alcalde Veedor del Cerro de Potosí, lo mismo ... . . . . . . .

La composición de tierras, cinco por ciento del importe y su conducción $\ldots \ldots \ldots \ldots \ldots \ldots \ldots \ldots \ldots$

Lagunero de Potosí, por décimas y su conducción ... . . . . . .

Un Juez y Administrador de Censos, sin salario, por segundas, incluso la conducción $\ldots \ldots \ldots \ldots \ldots \ldots$

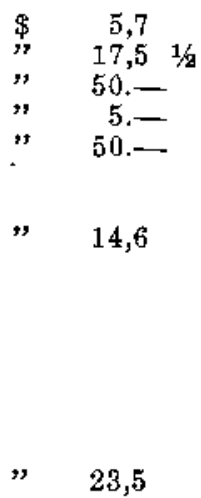


$\mathrm{U}_{n}$ Juez de Aguas, lo mismo $\ldots \ldots \ldots \ldots \ldots \ldots \ldots \ldots$ Protector sin salario, lo mismo $\ldots \ldots \ldots \ldots \ldots \ldots$ Un Escribano paga el tercio del 2 y $1 / 2$ por ciento del valor del oficio y su conducción ... . . ...................

El signo de un Escribano, con la conducción ... .........

Un Teniente de Alcalcte l'rovineial $\ldots \ldots \ldots \ldots$

Un Médico o Abogado examinados $\ldots . . . \ldots \ldots \ldots$

Un Cirujano $\ldots \ldots \ldots \ldots \ldots$

Todo Maestro examinado en oficio mecánico, con tienda pública, ..

Un Toniente General de Provincia, sin salario, paga cada año ...

Un Justicia Mayor de l'rovincia, sin salario, paga por el honor de cada año $\ldots \ldots \ldots \ldots \ldots \ldots$

Un Título de Castilla $\ldots \ldots \ldots \ldots \ldots \ldots$

Capitán de la Mita, siendo de por vida $\ldots \ldots \ldots \ldots \ldots$

\begin{tabular}{lr}
$"$ & 9,6 \\
$"$ & 16. \\
$"$ & 9,6 \\
$"$ & 6,4 \\
$"$ & 6,4 \\
& 23,5 \\
& \\
$"$ & 23,5 \\
$"$ & $1.220,1$ \\
\hline & 921,7 \\
\hline
\end{tabular}

NOTA. - A rú, se relevó de este derecho, por Real Orden de 4 de agosto de 1761, remitida a la Caja por el Superior Gobierno, en Decreto de 7 de junio de 1762.

Además de la media anata, se paga el servicio o derecho de Lanzas de los títulos de Castilla, a razón de 500 pesos cada uno, desde la fecha de los despachos que se expiden para el uso de estas gracias, y no desde cl díc cn que so conceden ni desde el de su publicación, como se declaró pox Real Cérula de San Ildefonso, a 25 de julio de 1773.

Los tres títulos de la jurisdicción de esta Intendencia, nombrados: de Carma, de Santa María de Otavi y de Casa Real de Moneda, sólo el primero paga el derecho de Lanzas; el segundo está relevado por Cédula de 2 de junio di 1750 , y el último igualmente por otro Real Despacho.

Sobre los modos de pagar y redimir los derechos de Lanza, se despachó Real Cédula de San Ildefonso, a 6 de septiembre de 1773 , dando facultad a todos los títulos de Castilla para redimirlos perpetuamente exhibiendo en la Tesorería General 160.000 reales de vellón y en las Indias 10.000 efectivos, para que precisamente se convierta este producto en redimir por su orden, antiguiedad y cabimiento, los censos que tiene contra sí la Real Hacienda en estos dominios.

Para la recaudación de estos derechos de Lanzas y medias anatas, está mandado se forme una Junta en cada Virreinato, compuesta del Decano de la Audiencia, Regente del Tribunal de Cuentas o en su defecto el Contador más antiguo, del Juez de Lanzas y del Fiscal; y consiguientemente se han declarado las dudas siguientes:

Que a los poseedores pobres, que no pueden pagar lo atrasado ni lo corriente, se les admita a equitativas transaceiones, recibiendo en pago cualesquier débitos contra la Real Hacienda, aunque sean de los reinados pasados, sirviendo de gobierno para la justificacióp del origen, certeza y existencia de tales créditos, las reglas dadas para el pago del $6 \%$ de débitos atrasados de Rcal Hacienda (que se hallan en Real Orden comunicada por el Bailío a Don Julián de Arriaga, de Madrid, a 25 de enero de 1763), concediéndose estas transacciones sin perjuicio de Ja facultad de redimir de pronto sus Lanzas, precediendo seguridad de pagar a plazos aquellos en que se transigiese lo atrasado. Que los demás sumamente pobres, que no pueden pagar lo atrasado ni lo corriente, ni mantener la dignidad, queden suspendidos de la firma y honores, con derecho de gozar de ellos siempre que rediman las Lanzas y no hayan ejercido oficios sórdidos. 
Que si en las familias de los títulos imposibilitados, hubiere dentro del cuarto grado de consanguinidad, persona rica que solicite la gracia para sí, se dé cuenta al Rey para su aprobación con la calidad de entrar redimiendo el servicio de Lanzas, satisfacer la media anata de transversal y dejar asegurado este derecho para lo sucesivo.

Que para que no sea gravosa la diligencia del título de sucesión, acudiendo el interesado al Virrey o Jefe respectivo del Distrito, noticiando el caso de sucesión y supliendo la continuación de honores y preeminencias, provean interinamente que, precediendo pago de media anata, entren en posesión y se dirija por el Consejo de Cámara la representación del nuevo poseedor, para que se dé cuenta al Rey y se expida la consiguiente carta de sucesión, tomándose razón en la Contaduría General del Consejo.

Por el Art. 144 de ja Real Ordenanza de Intendentes, se mandó erigir en la Capital de Buenos Aires, un Juzgado privativo para el cobro de los Reales derechos de Lanzas y Medias Anatas en todas sus Provincias, con total independencia del que hay en Lima, encargando esta comisión a un Oidor que el Rey nombrase de los de su Audiencia pretorial, y a los Intendentes de Provincia, como a los Subdelegados de este Ministro, en sus respectivos territorios; y al mismo tiempo establece en esta Capital, una Contaduría de este ramo a cargo del Contador de Resultas más moderno de la Contaduría Mayor de Cuentas, con la conveniente instrucción y reglamento, para la dirección y manejo de la Oficina y del Juzgado.

Párrafos once y doce. - Pa- LAS leyes 15 y 18 del Tít. 23, Lib. $4^{\circ}$ de pel sellado $y$ Naipes. Indias, tratan del Estanco de Naipes y de la Administración de papel sellado al cargo de los Oficiales Reales. Sobre el primer ramo, sc dispone que se arriende, y sobre el segundo, que se venda el papel, distribuya y reparta con la mayor legalidad y pureza, para evitar fraudes y falsedades.

Nuestro Escalona ${ }^{105}$ hizo en dos capítulos el comentario de las Cédulas, de que se recopilaron después las dos leyes referidas, y no puede decirse alguna cosa especial sobre su exposición. El Ilmo. Barbosa 106 también habla de la Pragmática expedida por Don Felipe IV, a 15 de diciembre de 1636, de que se formó la ley 18 citada; pero principalmente se contrae a probar que no comprende los tribunales eclesiásticos.

El Estanco de Naipes nunca se estableció con solidez, y así en nuestros tiempos, se comerciaban libremente en estas partes del Reino, mirándose como abolida y prescrita la ley municipal que lo prohibía. Al contrario, siempre estaba estancado el papel sellado, comforme a las lcyes. Un Oidor de Charcas era el Oidor de este ramo, y cuando faltaba papel sellado del corriente, ocurrían a él los Oficiales Reales de Potosí, solicitando permiso para el resello; y con precedente audiencia Fiscal, se concedia la licencia en la forma ordinaria para resellar el papel necesario.

Con motivo del establecimiento formal de la Dirección de Tabacos, en la Capital de Buenos Aires, se metodizó la Administración de esta Villa, bajo las reglas e instrucciones correspondientes, mejorándose el antiguo plan en que se estableció en Potosí esta renta, desde el año de 1756, 
gobernando el Señof Virıey Don José Antonio de Velasco, después Conde de Superunda.

Puesta la administración sobre este pie, se le incorporó el ramo de Naipes a principios del año 1779 , sin uinguna asignación por su manejo. Ultimamente se ratilicó para sicmpre esta incorporación, por el Art. 141 de la Real Ordenanza de Intendentes, ordenándose esto mismo para con el ramo de papel sellado, por el Art. 142, en cuyo cumplimiento corre su expendio en esta Villa, desdo el año 1784, a cargo del Administrador de Tabacos, con el premio de un cuatro por ciento, para los receptores que lo venden, sin que el Administrador principal sea partícipe en este indulto.

Conforme a las reglas nuevamente prescriptas para este ramo, el Intendente de cada Provincia es quien habilita el papel necesario a falta del corriente, con acuerdo del Superintexidente, a cuyo efecto debe sustanciarse expediente, oyendo instructivamente a los Ministros de Real Ham cienda (que son los que distribuyen el papel a las Administraciones de Estancos) $y$ al Promotor Fiscal como parte, para proveer el resello con audiencia de estos.

Si en esta Villa se practicara, como en el Feino de Chile, que ningún habitante saliese de la población sin licencia por escrito en papel sellado, y se presentaran tambión on la Aduana las memoxias de efectos en papel sellarlo, crecería este ramo otro tanto más de lo que ahora rinde. Porque sir estc recurso nunca se conseguirá su acrecentamiento, respecto que en los Partidos de este Intendencia, como que son poblaciones de indios, apenas se hacen actuaciones judiciales.

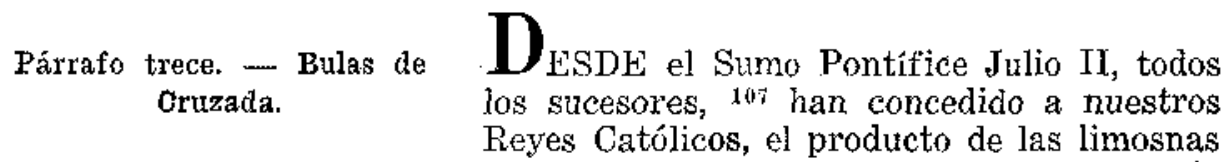
de la Santa Bula de Cruzada, de vivos y difuntos, composición y demás gracias contenidas y anexas a elia, para gastos en la defensa de la Iglesia contra sus enemigos.

Nuestro Escalona 108 asegura que es una de las rentas más considerables que S. M. tiene en las Indias; y calculando su monto el Sr. Don Juan de Solórzano, ${ }^{109}$ afirma que algunas veces suełe llegar a 600 y a 800 mil ducados.

Por la importancia de este ramo y, principalmente, por los recomendables fines de su aplicación y destino, han velado siempre nuestros Reyes sobre su exacta, ficl y diligente administración, recaudación y cobranzas; por no haberse seguido el método regular y preciso en este prjvilegiado manejo, resultaron en algunos Obispados de las Indias, quiebras de muchísima consideración, quedando incobrables las más, en poder de los Tesoreros, por no haber dado algunos fiadores como debían, y haberlos dado otros sin las hipotecas $y$ abonos necesarios, entrando entre estos vicios, otros enantiosos consumos inútiles y supérfluos, en gastos indebidos de salarios y ayudas de costas excesivos, de los dependientes del mismo tribunal.

Para contener este desorden y evitar Ios perjuicios que, sobre los ya expuestos, se seguían a los vasallos, de gravarlos con arbitrios en ocasión de guerra, por no alcanzar el producto de la limosna, se impetró 
Breve de 1a Santidad de Benedicto XIV, en 4 de marzo de 1750 , por la que concedió a los Reyes de España y de las Indias, por regalías de la Corona, la plena facultad de administar, recaudar y distribuir con independencia del Comisario General de Cruzada y demés Apostólicos, sobre el producto de la Santa Bula y de las gracias que le son anexas; con más la autoridad de poder elegir y diputar personas eclesiásticas (que fueren gratas y aceptables a S. M.), para exigir las limosnas, rentas y proventos que procedieren de la Santa Bula.

En uso de estas facultades, se expidió la Real instrucción de 12 de mayo de 1751, para que los señoves Virreyes formasen las Ordenanzas correspondientes a un nuevo establecimiento en la recaudación y distribución de dicha limosna; on cuya consccuencia lo verificó cn Lima el Sr. Conde de Superunda, con fecha de 18 de marzo de 1752, ${ }^{110}$ y se aprobaron en Real Cédula de 11 de septiembre de 1755, según se hace mención en el Art. 147 de la Ordenanza de Intendentes, con la prevención de que se observe todo lo dispositivo de las de Lima, que hasta el presente han gobernado en este Virreinato, y se forme para lo económico, por la Superintendencia General de Real Hacienda, otro reglamento conforme al método observado en la Nueva España.

Aunque la Superintendencia de este ramo en el Arzobispado de Charcas, se concedió al Presidente de la Real Audiencia de la Plata, por la Ordenanza $1^{3}$, Tít. $5^{\circ}$ de las de Cruzada, en el día se ha reunido en cada Intendente de Provincia respectivamente, la particular de su territorio, por el citado Art. 147. En cuya conformidad, porque no reside en esta Vilia el Tesorero Diocesano propietario, ha nombrado ya el Intendente, en este año de 1786, persona a cuyo cuidado corra la recaudación y distribución de la Bula, con arreglo a las Ordenanzas $1^{n}$ y $10^{n}$ del Tít. 2, precediendo a su recibo la solemnidod y seguro de flanzas que prescriben las Ordenanzas $3^{a}$ y la $10^{a}$ del Tít. $4^{n}$.

Respecto a que en este ramo intervienen dos jurisdicciones, espiritual y temporal, se ha dispuesto por el Art. 148, que corran separadas, para evitar dudas y embarazos, concediemdo privativanente a cada Intendente en su Provincia, la primera instancia en todas las causas temporales de Cruzada, con apelación a la Junta Superior; y aś́, será de su conocimiento todo lo contencioso que ocurra en orden a la recaudación $\mathrm{y}$ administración de los productos de la Cruzada, ustrpación y ocupación de ellos, con todas sus incidencias, quedando reservadas a los Comisarios Subdelegados de calla Partido, las causas tocantes a la Administración de gracias espirituales, falsedad o substracción de Bulas y demás pertenecientes a las facultades de los Comisarios ejecutores del Breve Apostólico de 4 de marzo citado.

Esto es lo más esencial que importa saber acerca del ramo de Bulas, para que advertido de sus respectivas facultades, el Intendente proceda con acierto. Sobre todos los demás pumtos, cuestiones, dudas y notieias tocantes al origen de esta concesión, a su etimología, a los Pontífices concedentes, a los tribunales erigidos en el Reino para su despacho, a la administración de estas rentas y resolución de ambos fueros, el de conciencia y el judicial, tratan amplia y eruditamente nuestro Solórzano y Pérez de Lara, 111 con los innumerables autores que en ellos se citan, además de las decisiones claras y termimantes de las leyes del título $1^{\circ}$, Lib. $1^{\circ}$ de Castilla, y Tít. 20, Lib. $1^{\circ}$ de la Recopilación de Indias. 
Añadiré solamente dos cosas: la primera, que por Real Cédula dada en Buen Retiro, a 19 de junio de 1761, se mandó guardar y cumplir otra de 3 de julio de 1749, ar'eglada a la ley 18 , título $20, y$ la $6^{\text {a }}$, título 12 , libro $8^{\circ}$ de Indias, para que los Oficiales Reales corran con la recaudación y administración de los bienes mostrencos y $a b$ intestatos, y de ningún modo el Comisario de Cruzada. La segunda, que en atención de hallarse aplicado el producto de la Bula en cada Provincia, por el citado Breve y Ordenanzas, para las plazas, presidios, guarmición y misiones de sus fronteras, podría hacerse con estos caudales algunos últimos Fuertes y dotar plazas efectivas para su defensa en el Partido de Tarija, tan combativo por los infieles Chiriguanos, o aumentar Misioneros para su conversión, o crear un gobierno militar experto, estipendiado de este ramo, para el régimen y disciplina de aquellas milicias. Debe esperarse que por este medio el país se poblase más, y su vecindario puesto a cubierto de hostilidades, podría hacer progresos útiles en la agricultura.

Párrafos catorce y quince. - $\mathbb{W}_{\mathrm{N}}$ las noticias respectivas a la casa de Casa de Moneda y Real Banco. Moneda y al Real Banco de San Carlos, queda explicado detalladamente el método de su Administración y los productos anuales que percibe la Real Hacienda, de ambas oficinas. No hay necesidad de reproducir estas relaciones, y en cualquier caso que ocurra, se encontrará en los referidos lugares lo que se deseare saber.

$$
\begin{gathered}
\text { Párrafo dieciséis. - Real } \\
\text { Aduana. }
\end{gathered}
$$
se extraen de los Reinos de Castilla a estos de las Indias; ${ }^{112}$ bajo de cuya calidad es uno de los objetos más interesantes de Hacienda, pues, en las partes donde el comercio sea muy floreciente, como en el Oriente, es tanto el producto de esta especie de contribución, que sólo las Aduanas establecidas allí, recogen todo el caudal necesario para la subsistencia del Estado. Ll segundo, en cuanto es Casa en que se introducen todas las mercaderías que entran y desembarcan en los puertos de América, y los que retornan a los de España, para registrar alli y pagar o asegurar los derechos, 113 porque según nuestro político el Sr. Don Juan de Solórzano, 114 esta palabra Aduana, que es un vocablo corrompido, deriva de Divanum, que es voz griega y significa la casa donde se cogen los derechos; de donde se llamó al principo Divana o Adivana. En cualquiera de estas dos consideraciones, corresponde privativamente al Ministerio de Hacienda, el conocimiento sobre Ias Aduanas del Reino.

Cuando comenzó a establecerse el comercio de nuestra metrópoli en estas Colonias, se impuso el derecho Almojarifazgo sobre todas las mercaderías que entrasen en todos los Puertos de España e Indias y se llevaren $y$ navegasen a ellos por ambos mares; por lo que ha venido a usurparse este nombre privativamente para todos los derechos, rentas e impuestos maxítimos, aunque comprenda generalmente los demás tributos Reales en su rigurosa significación, según nuestro Solórzano. ${ }^{11 \kappa}$

La tarifa de este impuesto se arregló por varias cédulas antiguas 
y por dos que particularmente tratan de este derecho; la una, de San Lorenzo, a 12 de julio de 1598 , y la otra de Madrid, a 28 de diciembre de 1668, se declaró que en conformidad de la Real Cédula, fecha cn el Bosque de Segovia, a 29 de mayo de 1566, acordada en el Conscjo a 24 de ju nio del mismo año, (y recopilarla en la ley 1, Tít. 15, Lib. 8? de Indias) se paguen de los efectos que se traen de España a Indias, en los Puertos de ellas, por derecho de Almojarifazgo, el 10 por ciento del común y verdadero valor que tuviere en las partes y lugares donde se hubiere de hacer la cobranza, y no según el afuero y avaluación hecha en España, donde también se pagaba este derecho por la saca y salida de los géneros. Que de cuanto pasase de Indias a España, se pagase el 2 y 1/2 \%, y de las mercancías que se tratan en unos y otros Pueptos do las lnidias, el $5 \%$ de entrada (que es el derecho antiguo de Almojarifazgo) y de salida $2 \mathrm{y} \mathrm{t/2} \%$; pero de los géneros que se conducían de una parte a otra en las Indias, no se pagaba este derecho por la saca y salida, sino por la entrada el $5 \%$, no de todo el valox que en si tenían, sino del mayor crecimiento que tuviesen en las partos donde los llevan a vender, respecto al que tenían donde se sacaron.

$\mathrm{X}$ aunque conforme a estas Cédulas y a la ley $1^{\mathrm{a}}$ citada del Tít. 55, Lib. $8^{\circ}$ de Indias, montó el Almojarifazgo a $20 \%$ que efectivamente sc. pagó y cobró por mitad en los Puertos de España y de las Indias, lo cierto es que al principio se cobraba solamente un $15 \%$ en la fornta roferida, como afirma Juan de Matienzo, citado por el Sr. Solórzano, to hablando del estado que tenía en.su tiempo este derecho.

Pasados los primeros tiempos de la conquista, ya pareció conveniente ir introduciendo otros derechos y contribuciones debidas a la Soberanf́a, de que se había eximido hasta entonces a estas Provincias. Se comenzó por la Alcabala, pou' ser el derecho universal de todos los Reinos, enviando a Nueva España en el año de 1574, un Arancel formado al modo de los de España, de las cosas y géneros de que se había de pagar, y de la forma en que se había de cobrar y administrar; ${ }^{11}$ a a cuyo propio fin se despacharon tamblen para el Peru otras varias Cédulas encargadas al Sr. Don Francisco de Toledo, quinto Virrey de Lima. ${ }^{118}$

La consumada política y pruatencia de este gran Virrey, le obligó a no hacer novedad por entonces, y con su ejemplo practicaron lo mismo sus sucesores, los señores Marqués de Alcañizas y Conde de Villar.

No se consideró justo autorizar este ejemplar, con mantener al Reino del Perú eximido de una contribución corriente en Nueva España; por lo que se despacharon varias Cédulas en 1591, con otro Arancel particular para el efecto, apurando al Sr. Don García Hurtado de Mendoza, octavo Virrey de Lima, (después Marqués de Cañete) para que estableciese el derecho de Alcabalas del Perú.

Fueron muchas las contradicciones y en muchas partes se concitaron los ánimos con inquietud; pero, al cabo, triunfó con su diligencia de estos grandes obstáculos, estableciendo en el año de 1593 , 119 la cobranza de un $2 \%$ a título de Alcabala, ${ }^{120}$ debiendo contarse por una inesperada felicidad y entre los mayores servicios de aquel Virrey, haberle dado asiento y cobro fijo hasta estos tiempos, según la ponderación de Escalona. ${ }^{121}$

El grande interés de nuestro comercio, por los inmensos caudales que se enviaba a España de nuestras Américas, despertó la codicia 
de los extranjeros y les infundió el espílitu de rapiña. Una embarcación española de la carrera de Indias, era el objeto de la ambición de todas las naciones de Europa. Por todas partes distribuían espías para descubrirla y rara vez no caía en manos de enemigos, convirtiéndose nuestra fortuna en una victima infeliz de la piratería.

Nuestros mares de Europa se hallaban infestados de los moros. Jos holandeses interceptaron y saquearon nuestras embarcaciones, dejando casi arduinada nuestra floreciente marina. Unidos, en fin, los franceses, ingleses y dinamarqueses, en una liga ofensiva y defensiva contra España, se señorearon de todos sus maves, ocuparon todo el tráfico de su comercio, y todos juntos en cuerpo de nación y repartidos en más número de cuatro mil piratas, pasaron a cuchillo la guarnición de Venezuela, saquearon a Veracruz, Cartagena, Porto Bello y Panamá, y desolaron con tiranía casi todo el Perú, conservando hasta ahora, en testimonio de esta infausta invasion, el francés, las Islas de la Martinica, Guadalupe, Granada y otras, y el inglés, la Barbada antigua, Monserrat, con otras varias de las Antillas pequeñas, llamadas de Barlovento.

Por todas partes nos rodeaban inevitables desgracias, como consecuencia de las poderosas usuxpaciones $y$ de la insolente rapacidad y piratería de los extranjeros. Oprimida España, así en Europa como en la América, se hallaba reducida a la infeliz imposibilidad de poder restablecer su comexcio, aun tambićn de defenderse.

La Francia, como más vecina, estaba sobre las ocasiones, para sacar de ellas todo su provecho; y así fue que unida con esta potencia, Inglaterra, a mediados del siglo antcrior, atacó a Santo Domingo con el mayor ímpetu y vigor; y aunque no fue feliz cl suceso en este Puerto, logró quitarnos la Jamaica, por medio del Almirante Guillermo Pen, con la fuerza de una Escuadra de doce navíos.

A estas pérdidas en la América, se añadían otros grandes cuidados en la Europa misma, por las convulsiones de Nápoles, por la derrota de la Infantería española en Rocroy, y otras muchas desgracias experimentadas con grande daño nuestro en los Países Bajos, fuera de otras funestas divisiones intestinas del mismo Reino.

No contentos los extranjeros con tan grandes provechos como sacaban de las invasiones con que infestaban nuestros mares, nuestros puertos y todas nuestras costas, meditaron nuestra última ruina con la guerra clandestina del contrabando, tanto más lucrativa para ellos, cuanto exa destructiva de nuestro comercio, por la imposibilidad de cerrar las puertas al fraude, respecto que nuestras manufacturas no podían sufrir la concurrencia de las extranjeras, por los mayores precios de nuestros salarios y frutos.

Así comenzó infelizmente el comercio clandestino de la América, en la Bahía de bastimentos, cerca de la Tierra Firme, en la América Septentrional, y se propagó sin dilación a las demás costas y puertos. Fue tan impetuoso el desórden, y los excesos tan graves, tan insolentes y descubiertos, que no pudiéndolos contener las prohibiciones publicadas el año de 1614, con pena de muerte y confiscación de bienes, se estableció en el de 1648, la Armada llamada de Barlovento, con destino a reprimir las invasiones de tantos corsarios, el contrabando y la piratería de los extranjeros.

El crecimiento de los gastos para la dotación de esta Armada, obli- 
gó también a aumentar en el derecho de Alcabala otro $2 \%$, haciendo subir todo el impuesto a un $4 \%$. ${ }^{22}$ Pero no habiendo sido todavía suficientes estas contribuciones, se estableció otro derecho de un $2 \%$ con el título de Unión de Armas, aumentado sobre el Almojarifazgo que se impuso para la defensa marítima de la Armada del Sur.

A poco tiempo después, se mandó cobrar otro $3 \%$, por título de avería, establecido para el apresto, manutención y dote de las Armadas que se envían para asegurar las flotas, amparay y defender los navios mercantes, trayéndolos en su conserva y compañía, y castigando a los enemigos que intentasen robarlos y hacer presa en ellos, scgún lo explica la ley $1^{\text {a }}$, Tít. 9, Lib. $9^{\circ}$ de Indias; llamándose "avería", según nuestro Solórzano, ${ }^{123}$ porque de este modo se conscrvan los haberes de los navegantes; y en este orden se vinieron a reducir a la avería, almojarifazgo, alcabala y unión de armas, todos los derechos que contribuían antiguamente las cuatro clases de mercaderes de que se componía el comercio del Perú, a saber: los matriculados, otros no comprendidos en la Matrícula, los cargadores de galeones, y los que en España percibian por modio de los que volvian del Perú, rentas, encomiendas, escrituras, libranzas u otra especie de caudales propios, por suplementos hechos a pasajeros, cargadores, Corregidores, Ministros y toda suerte de provistos, cuya universal comprensión de comercio explica el Norte de la contratación. ${ }^{124}$

Para la mayor seguridad de estas flotas, se arbitró por prudento precaución el despacharlas de un mismo puerto, escoltadas de navíos. El tráfico de Ia navegación a Indias, se limitó con muchas restricciones en la Cédula de 15 de enero de 1529 , y la calidad del comercio exclusivo y limitado, estancó el de toda la nación en Sevilla hasta el año de 1716, en que se trasladó a Cádiz bajo el mismo pie.

Se restringió también a ciertos puertos de América el desembarco de los efectos, reduciendo la navegación a Ios precisos tiempos de Ios galeones y flotas. Los dos Reinos de Nueva España y del Perú, tenían la concurrencia de todo el comercio en las ferias de Porto Bello y VeraCruz, bajo de escrupulosos reglamentos que or"denaban la economía de los empleos, la conducción de caudales y la vigilancia contra el fraude del contrabando y demás comercios clandestinos.

Llegó este celo hasta el punto de prohibir, el año de 1596, por el Sr. Virrey Don García Hurtado de Mendoza, por providencias confirmadas en varias Cédulas Reales, recopiladas en las leyes 68,69 y 70 , Tít. 45, Lib. $9^{\circ}$ de Indias, el comercio de mercaderías entre los Reinos del Perú y Nueva España, cerrándose absolutamente la navegación aun para el de azogues anual, que se remitiera al Puerto de Acapulco, por las introducciones de mercaderías de China y de flota, extravíos de plata $\mathbf{y}$ de oro y defraudación en Tierra Firme, ciñendo rigurosamente el permiso de los navíos solamente a la Provincia de Guatemala y Puertos de Sonsonate y Realejo, para abastecer al Perú, con los frutos de brea, alquitrán y tabaco.

Pero se procedió con la justa precaución de poner en Lima un Juez privativo que celase las entradas de mercaderías de China y conociese de esta causa, aprehendiendo y castigando a los contraventores, hasta el último rigor de quemar públicamente las ropas decomisadas.

El tiempo relajó estas prohibiciones, a la sombra de otras conveniencias del Estado. Se mandó despachar cada año dos ravíos de gue- 
I'ra, cargados de cacao de Guayaquil, de cucnta de la Real Hacienda, al Puerto de Acapulco; con lo que se abrió nueva puerta a la exacción de la plata y más considerablemente del iro.

Se permitió enviar registros a Buenos Aires, en 1581, con la precisa limitación de 500 toncladas, para el abasto de aquella Provincia y las de Tucumán y Paraguaty. Por otra Cédula de Valladolid, a 20 de agosto de 1602, se concedió a la misma ciudad, que pudiese remitir de los frutos de sus cosechas, al Brasil, Guinea y otras isias circunvecinas, 2.000 fanegas de harina, 500 quintales de cecina y 500 arrobas de sebo, con permiso de retornar las cosas neccsarias, como ropa y demás menesteres para su abasto.

De esto resultó bien pronto un abuso criminal del privilegio. Comenzaron a introdurir cuantiosas cargazones, unas de permiso y otras de contrabando, en especial después que los portugueses fundaron, el año de 1679 al de 1680, la fortaleza que llamaron Colonia del Sacramento, en la margen septentrional del Fío de La Plata.

los navios que llegaban a Buenos Aires, hacían una feria continuada de géneros prohibidos con aquel establecimiento portugués; abazrotaban de efectos muy baratos todas las provincias vecinas; enviaban Comisarios a las del Perú, para rescatar plata y oro virgen, en piñas, pastas, tejos y en polvo, y no eran pocos los que conducían furtivamente estos preciosos metales, para negociar con mayor provecho en el mismo Puerto.

La distancia de 880 leguas que hay de Buenos Aires hasta Potosí, las más despobladas y desiertas, sin justicias ni resguardos, facilitaban el fraude con el auxifio recíproco de tanta multitud de interesados. El comercio de Lima sentía los efectos de estas clandestinas negociaciones, y todo el Reino experimentaba el perjuicio en la disminución del dinero, que extrayéndose del Perti al Río de La Plata, imposibilitaba los despachos de las flotas en sus plazos acostumbrados.

La Real Hacienda participaba consiguientemente estos daños, que se hicieron más notables con motivo del asiento ajustado con los ingleses, el año de 1714, para la introducción anual de un navío de negros a todas las Indias; porque con pretexto de la desnudez y necesidad de abrigo de los esclavos, consiguicron cxtender las capitulaciones del Real Asiento, a la licencia de poder llevar 50 toneladas de bayetas, para camisetas y cotones de los negros bozales, a los cuales vestían con pañetes y bayetas de la tierra, al costo de cuatro reales vara, comerciándola de Inglaterra al precio de trés pesos.

Como esta introducción era tan frecuente $\mathrm{y}$ había dispensación para internar las personas y las mercaderías, corrían por todo el Reino las inglesas y portuguesas; atraía este comercio la mayor parte de los metales del Perú, y venía a ser casi todo este continente un optlento patrimonio de las naciones extranjeras, como lo afirman Montesquieu y el autor del libro titulado: "Interés de Inglaterra mal entendido"; asegurando el primero, que de los cincuenta millones en que se estimaba el tráfico anual de las Indias, sólo sacaba España dos millones y medio, que es cabalmente la vigésima parte; y el segundo, que por la parte de Jamaica, producía el comercio ilícito de Inglaterra, pretextando también el mismo asiento de negros, el retorno de seis millones de pesos, en plata, oro, añil y cochinilla. 
Solamente en el ramo de quintos, se comprobó por las cartas-cuentas de Potosí y Oruro, que se percibieron de menos 214.000 pesos, en el año de 1715 , no por otra causa que por el comercio clandestino de piñas. A esta defraudación de quintos, seguía la miseria del comercio, la pérdida del derecho de avería, el no uso del de alcabalas, la suspensión del tráfico y el consumo de los caudales del Reino.

Explicada ya en lo general y en grande la historia y progresos de los impuestos y derechos Reales en aquollos primeros tiempos, pasemos a ver en particular lo que sucedía en Potosí. A ejemplo del Consulado de Lima, que a mediados del siglo anterior administró por asiento los derechos de Almojarifazgo, unión de armas, alcubala y avería, se ejecutó el encabczonamiento (capitación) de la ciudad de La Plata y Villa de Potosí, con sus Partidos, por cinco años, a 7 do julio de 1594, cn la cantidad de 6.000 pesos ensayados cada año, que al respecto de 12 reales y medio, importan noventa y tres mil setecientos cincuenta pesos.

La cobranza de esta alcabala y del derecho de avería impuestos sobre las barras, corría al cargo de los Oficiales Roales de Potosí, como todos los demás ramos de Real Hacienda, con arreglo a la ley 3is, Tít. 15 del libro de Indias, y las mismas Cajas scrvían de Casa de Aduana, para las avaluaciones y cobranzas de derechos, según lo dispuesto en las leyes 19,20 y 21, Tít. 34, Lib. 9 de la misma recopilación. Pero no bastaba toda la exactitud de los Ministros para poner en su debido balance Ia justa administración de estas contribuciones, porque al abrigo de las cautelas de los contrabandistas, se defraudaba por lo menos la mitad de los derechos de alcabala, quintos y avería en la internación de géneros prohibidos y extracción clandestina de plata y oro virgen, como lo comprueba el hecho notorio referido en Cédula de 7 de febrero de 1622, de que esperaban en Cádiz los navios de las naciones, la llegada de los Registros de Buenos Aires, para trasladar a sus buques las pastas, piñas y tejos de plata y oro que habian extraido de estas Provincias, sin quintar.

El buen efecto de estos artificios que practicaban la codicia y la ambición para las defraudaciones, contra la vigilancia de los Ministros, puso de concierto casi a todos nuestros comerciantes a que se hiciesen contrabandistas. La multitud de estos empleados y de la gente armada con designio de imprimir los fraudes, consumían forzosamente la mayor parte de los derechos de Aduana y demás rentas, y al mismo tiempo eran otros tantos ciudadanos de quienes se privaba el Estado, para la agricultura y las artes.

El crecido derecho de toneladas, aumentado sobre el costo de los fletes, casi imposibilitó el comercio de géneros de España, y esto mismo favorecía el tráfico clandestino de los frutos extranjeros.

El último Reglamento del Palmeo, del año de 1720, causó iguales perjuicios a la navegación y fábricas de España, porque imponía iguales derechos sobre los géneros finos y los bastos, ocultando la cantidad y calidad de los cargamentos, a causa de hacerse los aforos y avaluaciones por fardos y cajones cerrados, sin especificación de los efectos.

Además de esto, estaba mandado, con arreglo a una doctrina del Sr. Solórzano, ${ }^{125}$ por varias Cédulas de $1688,1689 \mathrm{y} 1717$, que los Oficiales no pudiesen proceder a la apertura de petacas, cajas y cajones, sin las disposiciones que previene la ley 10, Tit. 17 , Eib. $8^{\circ}$ de Indias, y Cédulas referidas, que se reducen a prescribir por requisito de la apertu- 
raz, el estar presente el denunciador, señalando ia pieza en que se contiene el contrabando.

De esto procedía que en un cajón de vidrios, avaluado en 8 pesos por el antiguo reglamento, internaban sedas y galones ricos de muy subido valor, defraudando en cantidades muy considerables a la Real Hacienda.

Finalmente, despertamos de nuestro antigno letargo. En el año de 1748, se abolió la práctica de galeones de Tierra Firme, establecida en el de 1571; se estableció la navegación por el Cabo de Hornos, y comoxzó a tener nuestra Metrópoli una comunicación directa e inmediata con estas Colonias. En 1728, so erigió la Compañia de Guipúzcoa, en la Provincia de Caracas. En 1762, se extendió el comorcio de España a las Islas de Barlovento y Provincias de Campeche, Santa Marta y Río del Hacha. El z de febrero de 1778 , se incluyó en esta concesión del comercio libre la ciudad de Buenos Aires, con internación por ella a las demás de América Meridional, y extensión a los Puertos habilitados en las costas do Chile y el Perú, señalando en cl Art. 5" de dicho Real Decreto de 2 de febrero, por puertos habilitados en España, los de Sevilla, Cádiz, Málaga, Alicante, Cartagena, Barcelona, Santander, Coruña y Gijón del continente, y el de Palma y Santa Cruz de Tenerife, por lo respectivo a las Islas de Mallorca y Canarias.

Este gran proyecto, rescrvario solamente al feliz gobierno del mejor Monarca de España, Don Carlos III (que Dios guarde), se perfeccionó al cabo de tantos siglos, con el fomento del calor y luz de nuestro actual Ministerio, en el célebre Reglamento para el comercio libre de España a Indias, de 12 de octubre de 1778, confirmando las anteriores concesiones y dispensando otras nuevas gracias, para la felicidad de sus vasallos.

En la Península de España se habilitaron, por el Art. 4", algunos puertos más que antes, y por el $5^{\circ}$ se señalaron en la América muchísimos más puertos de destino, para las embarcaciones del comercio libre, concediendo por efecto de amor sin ejemplar a todos sus vasallos, enter'a libertad de los antiguos derechos de Palmeo, Toneladas, Santelmo, Extranjerías, Visitas, Reconocimientos de Carenas, Habilitaciones, Licencias para navegar y demás gastos y formalidades anteriores y consiguientes al proyecto del año de 1720 .

Un comercio dormido y casi muerto por espacio de más de dos siglos, se ve ya repentinamente restablecido. Ia navegación ha tomado progresos increíbles; la agricultura se mira resticitada, y sobre su base floreciente la industria, las fábricas y la población. De suerte que si Dios prospera el dichoso gobierno de nuestro Monarca, acrecentando su vida por los años que necesita la Monarquía, recobrará el Estado, con muchas ventajas, sus antiguas pérdidas; volverán sus vasallos al feliz goce del siglo XVI; el comercio floreccrá hasta hacerse la emulación del siglo de Carlos V y Felipe II; la marina restableccrá su antigua opulencia, y vendrá a ser España el depósito de las riquezas y la mayor potencia del mundo.

Porque, a la verdad, todas rlas formalidades de este nuevo Reglamento, son como las de un médico escrupuloso, que cura al parecer con rigor, porque sólo de este modo encuentra el remedio a una enfermedad envejecida. 
Los Registros exactos, las avaluaciones justas, la red de resguardos, la excepción protectiva de nuestros frutos y el gravamen de los extranjeros, todo sc encamina a castigar de todo exceso los procedimientos de nuestras Aduanas y a impedir el comercio ilicito, en la concurrencia libre del nuestro en los principales puertos de América. Así vemos extinguido en nuestras colonias el tráfico clandestino, y abarrotados nuestros puertos con sólo efectos de España, sin que se conozca cl fraude sino en la raíz de la navegación, por la ambición de algunos mercaderes.

En este estado, era imposible que pudiesen despachar con exactitud los negocios de Adurna, las Cajas Reales destinadas antes para esta. Administración, junto con los demás ramos de Hacienda. La concurrencia de la infinidad de negocios, pedía la separación de sus administraciones, porque oprimidos con tanta mole los Oficiales Reales, confiaban a subalternos algunos ramos melios lucrativos, $y$ abatidos siempre con el manejo absoluto de los demás, vinieron a caer los miembros de la Real Hacienda en una general parálisis.

Para restablecer su movimiento, se mandaron erigir Casas de Aduana, separadas de las Cajas Reales. Desde el año de 1773, habían solicitado esta segregación los Oficiales Reales de Potosí; pero no tuvo efecto, por la división del Virxeinato de Lima, c incorporación de esta Villa al de Buenos Aires.

Comenzó a entender en esta solicitud, Don José Antonio Areche, Visitador General del Perú, y en 15 de enero de 1779, autorizó a Don Jorge Escovedo, Gobernador de la Villa en aquel entonces, para la plantación y establecimiento de la Aduana en clla.

En efecto, lo ejecutó cn 10 de junio del mismo año, sobro el pie del Reglamento de Lima, con la variedad conveniente a las circunstancias del país. Nombró Ministros y subaltemos para la Administración de la Aduana, con Ios sueldos respectivos, cuyo total importa 11.942 pesos. S. M., aprobó los empleos y sus respectivas dotaciones, en Real Orden, fecha en Aranjuez, a 7 de abril de 1785, declarando que sólo necesitan de Real confirmación, los empleos de Administrador y Contador, porque todos los demás deben quedar a nominación del Intendente que es o fuere en lo sucesivo, y sin sujeción a medio sueldo en caso de interinidad.

\section{NOTIOIA UNIOA}

\section{Ramos que administra la villa de Potosí.}

Artículo primero. - Alcabalas. A cargo de la Real Aduana de esta Vilia, Alcabala de todos los efectos de Castilla que sc internan a ella, por la vía de Buenos Aires o por las de Lima y Cuzco. En los primeros se considera el aforo de la Real Aduana de Buenos Aires, aumentándose aquí un $16 \%$ sobre las avaluaciones que traen, por la exacción de la alcabala. En los segundos y en todos los demás, que se internan con guías, sin constancia de haber sido aforados en la capital de Buenos Aires, se avalúan en esta Aduana y sc deduce la alcabala sin cargar aumento algu- 
no, con la obligación de pagarla dentro del término de cada año, desde la internación.

Lo mismo se ejecuta con los efectos de la tierra, como son ponchos, pellones, grasa, jabón, mulas, yerbas y otros de esta especie, que producen las Provincias del Paraguay y Tucumán, con la diferencia de pagar se esta alcabala dentro de los seis meses, y de aumentarse en la yerba que viene aforada de. Buenos Aires, un $150 \%$, para la deducción de este derecho.

Las madcras y otros firutos do los Partirlos interiores de la sierra, se regulan por los Guardas camineros, dependientes de la Aduana, arreglando los precios a la tarila que tienen según la variedad de los tiempos, y a este respecto sc cobra la alcabala. Este derecho estaba reducido al $4 \%$ : dos por la antigua alcabala y otoos dos por la moderna, para la Unión de Armas, con arreglo a la Real Cédula dada en San Ildefonso, a 5 de oetuble de 1737 ; pero, últimamente, se mando cobrar el $6 \%$ (como ahora se practica), en Real Cédula de San IJdefonso, a 3 de noviembre de 1776, ${ }^{126}$ por haberse libertado al comercio de los derechos de Al- mojarifazgo y Avería, exceptuando de esta regla solamente a las Provincias de Frontera, en que se mantiene la cobranza al $4 \%$ como antes.

Con motivo de haberse declarado en los axtículos 1 y 2 del Real Decreto de 2 de febrero de 1778, que de todos los frutos españoles se cobrase solamente un $3 \%$ al tiempo del embarco, en las respectivas Aduanas de la Península, y otros tres al tiempo del desembar'co en las de América, ordenándose en el Art. 7 del mismo Real Decyeto, que entre las Provincias e Islas contenidas en la concesión del comercio libre de las Indjas, se pudiese comerciar con los frutos y géneros respectivos, bajo de estas mismas reglas, consultaron, entre otras dudas, los Oficiales Reales de Buenos Aires, si de los flutos de estos países, transportados a otros del propio contincnte, debería exigirse el mismo $3 \%$ que pagan los efectos españoles conducidos de Europa; y entre tanto se decidía este punto, intentaron cobrarlo de la yerba que salía de Buenos Aires a Mendoza, para internar al Reino de Chile.

En vista de los informes con que acompañó esta consuita el Intendente General do Buenos Aires, resolvió el Rey, en Real Orden de 8 de febrero de 1779 , que se guardase el Art. 39 del Reglamento nuevo de 12 de octubre de 1778 , exigiéndose las moderadas contribuciones de salida y entrada que se hallan ya establecidas en el tráfico marítimo de unos puertos a otros de los habilitados en la América, sin hacerse novedad en el interior de las provincias, que deben subsistir como antes, sin la menor alteración. Con esta providencia cesaron las anteriores pretensiones, y no se exige de los frutos de la tierra, en su internación a esta Villa, más que el Real'derecho de alcabala al respecto de un $6 \%$.

De esta regulación está eximiclo solamente el Partido de Tarija, donde se cobra la adcabala al respecto de un $4 \%$, como país fronterizo a los infieles indios Chiriguanos, que incesantemente hostilizan aquella tierra; y aunque ha pretendido la misma franquicia el vecindario de Chichas, en cuya antigua Provincia se comprendía Tarija, se ha tenido presente que siempre se ha acostumbrado cobrar alli el $6 \%$ íntegro; con cuyo conocimiento se ha mandado guardar la costumbre por esta Intendencia, en una solicitud nuevamente cntablada, por auto de 2 de diciembre de 1786. 
En los Partidos de Chayanta, Porco, Chichas, Tarija, Lípez y Atacama, pertenecientes a la Provincia de Potosí, se consideraban dos especies de Alcabalas en tiempo de los Corregidores. Se llamaban alcabalas de tarifa, las que se satisfacían según la gruesa de sus respectivos repartimientos, y sumando el cómputo de todas, importaba el total 11.832 pesos; todo lo demás que sc vendía por otros mercacleres fuera de los repartimientos, también adcudaba alcabala y se llamaba de viento, por su incertidumbre y contingencia.

En el día subsiste únicamente esta última especie de alcabala, por haber cesado los repartimientos. Este Real derecho se halla arrondado en los tres Partidos de Chayanta, Porco y Chichas, en esta forma: el de Chayanta, en 2.075 pesos, y el de Chichas en 1.500 pesos. *** Las alcabalas de Atacama, corren en Administración a cargo del Subdelegado, y también las de Lípez, por no haber habido postot a ollas. El primero entera por ahora 68 pesos al año, $y$ el segundo ticne la obligación de presentar. los productos anuales, bajo de juramento y cuenta que acredite la recaudación.

Estando tan a la vista la decadencja de este lamo, es menoster estudiar algún medio para su adelantamiento. Yo comprendo por más ventajosa la Admbnistración bien arreglada, que los ar'rendamientos, por todos los fundamentos alcgados en el parágrafo $5{ }^{n}$, que trata de los tributos Reales. La nueva Ordenanaa de Intendentes, adopta este sistema en los artículos 106, 107, 108, 109, 130 y 131, y solamente en los ramos de corto momento, como son las alcabalas de Atacama y Lípez, se debe proceder a su arrendamiento, con todas lats soleminilades prevenidas en el Art. 201 de la misma Ordenanza.

Porque, siendo pingües y de un comercio regular los otros cuatro Partidos, de Chayanta, Porco, Chichas y Tarija, no será extraño que los Asentistas hagan crecidos empleos y abracen una gran parte de las negociaciones de aquellos países a la sombra de su autoridad, defraudando los intereses del ramo en que se dejaron de pagar cllos. Por esto, parece más conveniente encargar la cobranza, por recepturía especlal, a los mismos Subdelegados, con el salario de un 6 s' del dinero que dieren cobrado, con arreglo a la ley 42 , Tít. 13 , libro $8^{\circ}$ de Indias; obligándolos a presentar al fin de cada año, una cuenta formal y razón exacta de las alcabalas de su Partido, en libres rabricados por el Administrador y Contador de Real Aduana, expresando en ellos los parajes, tiempos y personas, sin fraude ni omisión, según lo dispuesto en el Art. 160 de la Ordenanza de Intendentes, $y$ cn la ley 34 y siguientes, hasta 42 , del Tít. 13, Lib. 8: de Indias.

No debe temerse que los Subdelegados resistan encargarse de esta receptoría, teniendo un compensativo tan justo, que remos que no faltan ahora pretendientes de las Subdelegaciones, por la corta utilidad del 3 o que se les abona por la cobranza de tributos; y siempre que no quisieran aceptar este cargo, no faltarían otros muchos que lo solicitasen con ruego y con instancia.

Conviene que se observe esta misma formalidad de los libros, en los arrendamieritos, con arreglo al Art. 161 de la citada Ordenanza, no solamente para veniv en cabal conocimiento de los productos anuales de cada Partido, sino también para evitar las injustas exacciones de los Asentistas, según e] concepto de Peregrino. ${ }^{127}$. 
Contemplo todavía esta precaución más indispensable en los arrendamientos de la alcabala de Pulpcrías; porque el Asentista, que en el presente año ha subastado esto derecho en 525 pesos, no pucdo creer que se contente con repartir a los innumerables pulperos de csta Villa, lo líquido de esta contribución, con el $5 \%$, prorrateado entre ellos, por la cobranza, conducción y paga en las arcas de la Aduana. Es de presumir más bien que arregle los pagos a medida de su ambición, compeliendo a los contribuyentes a injustas y cxcosivas exacciones, con el pretexto de graduarlos al ropuesto diario de licores, que al cabo del año formen en su continuo regiro la renta de un capital considerable.

Es vordad que en años pasados se hizo, por el Vista de la Aduana, un repartimiento moderado, encabezonando todas las pulperias de la Villa para este efecto; pero, aunque el Asentista proteste que sujeta sus cobran\%as a esta operación, yo no le creo ni creeré jamás. Si los pulperos no clamán, será este silencio un efecto necesario de ignorancia en los unos $y$ de suma pobreza en los otros. Fl remedio único para evitar toda vejación, cs calificar los arrendamientos con la condición de llevar libros de cuenta y lazón cxacta, ell los mismos términos que los receptores. Con esto se reconocerá también si conviene continuar los arrendamientos, o más bien hacer las recaudaciones por administración y equitativos encabezonamientos.

Este último método es el que se ha adoptado en esta Villa, para la cobranza de las alcabalas de tiendas; pero no deja de ser irregular el pie de su establecimiento, que es en esta forma: el Intendente comisiona en tiempo oportuno a su Teniente Asesor, para que, en consorcio del Administrador y Vista de la Aduana, practique el cncabezonamiento (capitación o catastro) de todas las tiendas de menudeo, donde se revenden mercaderías compradas aquí a Ios comerciantes que internaron sus Registros con Guía de Buenos Aires o lima, y al mismo tiempo nombre a su arbitrio dos individuos del comercio, que hagan las avaluaciones y aforos de cada tienda, para justificar el repartimiento.

Si estos dos mercaderes fuesen elegidos por los demás de su gremio, y tuvieran la voz y representación de todo el cuerpo, sería por cierto un arbitrio muy prudente para evitar recursos, respecto que el común y la universalidad de los mercaderes del pueblo, se había comprometido en dos de sus individuos como árbitros reguladores de la contribución respectiva a cada uno. También sería muy legal esta intervención, si los dos melcaderes u otios más del común se ajustaren a pagar una cantidad señalada por el importe de las alcabalas de tiendas, haciendo la personería de todos, bajo de fianzas abonadas; porqne en este caso se despacharían los apremios contra los que se apersonaron en el encabezouamiento, y contra sus fiadores, sin molestar a los particulares contribuyentes, cono se practica contra las Justicias y Regidores de los pueblos cncabezonados; y esto sería desde luego mucho más ventajoso para el mejor expediente de las cobranzas y menos gravamen de los contribuyentes.

Pero aquí no se ejecuta el encabezonamiento por vía de ajustes equitativos con el gremio, ni se entiende el encabezonamiento en el sentido de sex una cantidad y porción cierta en que los mercaderes están ajustados de pagar por el importe de las alcabalas; y por consiguiente, es del todo inútil la concurrencia de los nombrados por la Intendencia; 
porque, si resultase algún agravio, no podrá embarałarle su recurso al contribuyente la anuencia que prestaron al repartimiento los dos individuos de su gremio, respecto de no ser parte no habiendo sido nombrados por él como apoderados ni como árbitros.

Lo que significa rigurosamente en Potosí el encabozonamicnto, es el registro, matrícula y empadronamiento de Ios tenderos, para la imposición de la alcabala. Esta operación es absolutamente privativa del Intendente, en consorcio del Administrador de Ia Real Aduana, conforme al espíritu de la ley 47, Tít. 13 del libro $8 "$ de Indias; y por lo mismo, viene a ser por demás la concurrencia de otras cualesquiera personas, sean las que fueren. Para areglar el repartimiento a una medida equitativa, basta el cálculo experimental del Yistar; $y$ si ćste se excediere, luego, al punto, podrán apear el agravio los filinistros que ejecutan el encabezonamiento, cargutio la contribución que fueve justa, bien considerados los bienes, tratos, negociaciones y granjerías del mercader contribuyente; pero no deberá ponerse toda la atención a lo que enionces existiere en la tienda, sino más bien a str continuo regiro, para que, haciéndose el encabezonamiento por su justo valor, con la graduación de estas circunstancias, como dispone la ley 46 , Tit. 1\%, Tib. 8 te Indias, no quede perjudicado el Roy ni se grave el vasallo.

Concluidas las operaciones del repartimicnto, debe enviarlas al Intendente el comisionarlo que las hubiere practicado, para que las apruebe y señale los tiempos de la contribución, si ya no estuvieren señalados.

Advertidos ya estos tres diferentes modos de recaudar, a saber: por administración, encabezonamiento, o arrendamiento, vamos a indicar algunos puntos especiales sobre alcabalas de las Indias, según las peculiares y novísimas declaraciones en esta materia, por vía de apendice a los Aranceles que propone Escalona, ${ }^{12} \mathrm{y}$ por comentarío de las leyes del Tít. 13, Lib. $8^{\circ}$ de Indias, y del Tít. 17, Lib. $9^{\circ}$ de Castilla, jlustrado por nuestro Solórzano. ${ }^{130}$

Los indios no deben pagar alcabala de la ropa llamada de abarca, ni de la que fuere de la propia labov, ni de los frutos de sus cosechas, ni de la coca, ni del ají, a menos de justificarse haberla comprado a suje-, tos que adeudan este Real Derecho. ${ }^{180}$

Los indios de Mita tampoco deben pagar alcabala, ni los derechos de mojón y el de los efectos y frutos que conducen de sus pueblos para mantenerse en esta Villa, durante el tiempo de sus tandas, como lo declarô el Superior Gobierno, en el año de 1747.

Asimismo, están libres de alcabalas en todos los asientos de minas, las carnes vivas y muertas, las semillas y legumbros que son de primera necesidad, conforme a una declaración del Visitador General del Reino, Don José Antonio Areche, en 9 de marzo de 1780; no obstante lo cual, se cobra este derecho en Potosí, del charque, cecina, grasa y sebo.

Las ventas forzosas que se ejecutan de orden del Rey, en los tribunales, también son exceptuadas de alcabala, por Real Orden de 22 de enero de 1770 , despachada con motivo de las ventas de las fincas de los regulares de la Compañia de Jesús, expatriados.

Las reventas de ingenios gozan de la misma franquicia, por Real Cédula de Buen Retiro, a 30 de junio de 1762 ; y así se practica cobrar la alcabala únicamente de las casas, carneros, negros y demás especies de su servicio. 
Por el contrario, adeudan alcabala todos los contratos de comercio, ya sea consignativo o rescrvativo, los de cnfiteusis y los de locación y conducción que pasaren de diez días, conforme a una Real Cédula de San Ildefonso, a 21 de agosto de 1777.

También se debe pagar este Real derecho de todos los asientos y contratos en génelos de Estanco y otros ramos de Real Facienda, en virtud de Real Orden de 17 de septiembre de 1778 , en que se mandaron guardar los dos anterioros de 29 de septiembre de 1752 y 11 de julio de 1771; y así se comenzó a cobrar en Bumos Aires, en todo lo que de cuenta de la Real Hacienda se compra para la marina y de las provisiones de Asentistas de víveres.

Por vía de precaución para cvitar los fraudes que pueden cometerse contra este ramo de Real Hacienda, se ha prevenido la observancia de dos precauciones muy importantes. La primera, que para la venta de géneros pertenccientes a los Oficiales de la Atmada o del Ejército, se les tome formal juramento $y$ que no les sea equivalente su palabra de honor, por aseg!t'arse mejor de este modo la recaudación del Real derecho de Alcabala, según lo dispuesto en Real Orden de San lldefonso, a 10 de septiembre de $176 \%$. I a segunda, que en los transportes de efectos desde Buenos Ailea a esta Villa, y demás lugares re tráfico interior de estas Provincias, se pasen por los Intendentes, unos a otros, los respectivos avisos de las cargazones, además de las Guías de las Aduanas, con arreglo al Art. 213 de la Ordenanza de Intendentes.

Entre todos los afectos que adeudan derechos, han sido siempre los más recargados los negros. Desde el principio de la conquista se permitió introducir negros, con el fin de relevar a los indios del servicio personal. A poco tiempo causaron graves alborotos de sedición y fue preciso prohibir su internación a las Indias, y formalizar las encomiendas, para que los mismos indios sirviesen como siempre lo habían ejecutado bajo el Imperio de los Incas.

Según las resoluciones que experimentaron las encomiendas, se fueron permitiendo algumos asientos de negros, para que fuera menos sensible la falta de los indios cuando llegare ol caso de abolir el uso de las encomiendas, como lo verificó el Rey Don Felipe IV.

Con este objeto, dice Don Pedro Varela y Ulloa, ${ }^{131}$ que se contrataron algunos asientos de negros; contando cuatro: el primero, reinando Felipe IV, y el ultimo en tiempo de Don Felipe V, ajustado con los ingleses el año de 1714. Fuera de estos, he visto yo otro asiento más antiguo, en el reinado de Don Felipe II, por una contrata celebrada en Madrid, a 2 de enero de 1596, por Pedro Gómez Reniel (o Renjel), obligándose exclusivamente a proveer de esclavos todas las Indias, por el término de nueve años, satisfaciendo a la Real Hacienda 900.000 pesos, a razón de 100.000 en cada uno; por lo que debe contarse este asiento por el primero en las Indias.

En los posteriores no se estipuló pagar cantidad cierta por la gruesa de los negros que se internasen, sino que más bien se impuso sobre cada pieza un derecho crecido a favor de la Real Hacienda.

En el Capítulo 26 de la Ordenanza que formó Don Alonso Pérez. de Salazar, Oidor de Charcas, a 13 de julio de 1725 , para el gobierno de la Aduana de la ciudad de Córdoba del Tucumán, se impuso sobre cada negro que se internase al Perú, 57 pesos 6 reales, por los derechos de li- 
cencia y Aduanilla, además de siete y medio por ciento de Almojarifazgo y diez por ciento de Aduana.

Este derecho se arregló con más formalidad en el asiento de los ingleses, computando cada pieza para el pago de derechos, por cierto número de pies; cuyas reglas se observaron en Buenos Aires, a principios de la erección de su Virreinato, con las primeras embarcaciones portuguesas que internaron negros en aquel puerto.

Ultimamente se despachó Real Orien, con lecha de 4 de noviembre de 1784, concediendo la rebaja de derechos a sólo un $6 \%$ de introducción de cada negro, regulando su valor en 150 pesos, aunque tenga mayor precio y sin diferencia de edad, sexo ni clase; de modo que por cada cabeza se satisfaga por alwora únicamente nueve pesos en ambas Américas. Algunos han querido entender como derecho de Alcabala el derecho de los negros; pero la Real Ordenanzá citada está bien clara y decisiva, que sólo su contexto y soniclo basta para conocer que los 9 pesos de contribución por cada cabeza, es por razón de entrada y no de Alcabala cono se practica con los géneros, cobrándose en las Aduanas un $6 \%$ de los de fábrica española, sin incluir la Alcabala quo adeudan en sus respectivas ventas.

Artículo segundo. - Sisa y
nuevo impuesto sobre el efecto
del Aguardiente y Vino. Virreyes, Príncipe de Esquilache y Marqués de Guadalcázar, para reparo y fortificación de las lagunas, puentes y caminos. En el vino, aguardiente $\mathrm{y}$ en las carnes vivas ha tenido su variedad cste ramo; pero en el día se paga diez reales por cada carga de vino, y veinte reales por la de aguardiente. El ganado mayor adeuda dos reales por cada cabeza, siendo de edad, y un real por las medianas y chicas; el ovcjuno, a medio-real por cada uno, y a medio-real por cada carmero, y por los lechones a cuartillo.

Por tiempos ha corrido el Cabildo con la administración de este ramo, y en otras ocasiones los Oficiales Reales, para reintegrar los suplementos que ha hecho la Real Hacienda, cuando la sisa no ha alcanzado para todos sus destinos; pero siempie se ha entcrado su producto anual en las Cajas Reales para evitar fraudes, en dos plazos, a saber, San Juan y Navidad.

Cuando esta Villa era más poblada, y por consiguiente mayor el consumo de frutos, liegó a subir la sisa a 26.000 pesos en el año de 1626. En el día se halla arrendada en 7.000 pesos. El Asentista se queja de las quiebras; pero según lo que oigo generalmente, podría rentar mucho más si se recaudase por administración.

Además de la Alcabala y Sisa, paga el aguardiente otro derecho de doce y medio por ciento, llamado el nuevo impuesto, mandado cobrar en Auto de 23 de junio de 1777 , proveido en Lima, en Junta General de Tribunales. Ambos derechos se pagan de cada quintal, el de Alcabala en el lugar de la venta, y el de nuevo impuesto en la extracción, ${ }^{132}$ y sólo en el caso de no constar en la guía con que se interna estar ya pagado, entonces se cobra según el aforo de la plaza en que se vende. 
Esto último se verifica de ordinario en los aguardientes de Mendoza y San Juan de la provincia de Cuyo (conocida aquí por Chile), porque siempre vienen a pagar el mucro impucsto en el lugar donde los conducen. Por esta razon hacen mayor cuenta a esta Caja; pues, acrecientan su fondo para proveer oportmamente a todas las atenciones del Virreinato, que cn la parte principal se socorre en la Tesoreria de Potosí.

Este derecho de nuevo impuesto, en lo gencral, está aprobado en Real Orden de 16 de marzo de 1779, scgún instruye una carta de la Intendencia de Buenos Aires, su fecha 16 de julio del próximo pasado año. Cuando los Oficiales Reales corrían con su recaudación, tiraban un $2 \%$ del protucto de este ramo, por disposición del Sr. Virrey de Lima, en 4 re agosto de 1777; ahora está incorporado su manejo a la Real Aduana y no se exige gratificación alguna.

Es increíble el consumo de licores que hay en esta Villa, printipalmente del aguardiente; pues, no pasando su población de treinta mil almas, incluso los pagos y burgos de sus alrededores, anda cerca de cuatro mil quinlales el aguardiente que sc interna para el abasto de ella, no bajando su precio corriente de veinte a veintiséis pesos, y por tiempos, hasta treinta.

Son infinitas las pulperías donde se despacha esta maldita bebida, fuera de las chichorias simúmero, reparticlas desde la Plaza por todos los contornos de la Vilia. El que quiere abre su pulpería, muchas veces sin más principarl que diez o doce pesos de aguardiente, sin pedir licencia al Gobienno $y$ sin guardar más fornalidad que su antojo. La indebida multiplicación de estas oficinas re libertinaje $y$ de desorden, ba motivado que en ciertos baryios de este vecindario se vean abiertas tantas pulperías, que bastarían para surtir un pueblo entero.

Allí es donde concurre de día y do noche la gente baja de la Vilia, a embriagarse sin límites. De esto proceden continuas riñas, insultos y averías, a más del gravísimo inconveniente de que perdiendo estos hombres por la embriaguez la acción para el trabajo, ninguno se dedica a él voluntariamentc, y el que va forzado a las minas o a otra ocupación industriosa, consume al instante cuanto gana, en los excesos de sus borracheras.

En mi concepto, csta es la causa principal del exterminio de los indios y de su increíble inaceión; y debe ser también el primer objeto de los euidados del Gobiemo. Desde el siglo pasado se meditó el remedio, y después de muchas conferencias que tuvo este Ayuntamiento, juzgó más a propósito el de minorar el número de pulperías, a sólo 24 en toda la Villa. Ultimamente vinieron a reducirse a veinte, que som las mismas que subsisten en el día por ordenanza.

Se ha visto que nada se adelantó en Io substancial, porque se fueron introducicndo, con título de abastecer la Villa, otras pulperías, con tanta libertad que ha llegado al fin al excesivo número que hemos referido. Para este caso, preveniclo ya en la ley 12, Tít. 8, libro 4ํ de Indias, se dispuso on ella misma que, las pulperías que no fuesen de ordenanza, paguen al año desde 30 a 40 pesos, por vía de composición por la facultad que se concede para abrirlas y vender el aguardíente para el abasto de los pueblos.

Nuestro político Ustáriz, ${ }^{13}$ atendiendo a que cuanto más barato se vende el aguardiente, se bebe mayor cantidad, particularmente por 
la gente común, a cuya salud daña el exceso, propone el mismo arbitrio ya decidido por la ley, de imponerse a cada ticnda un derecho proporcionado sobre los demás impuestos, con el fin de que hubiese menos vendedores, encareciéndolo por este medio; y de paso se lograba que no bebiéndose tanto por lo subido del precio, padecería monos la salud, sin que pueda juzgarse perjudicial al público, así porque no es alinento necesario a la vida del hombre, como porque este gravamen se dirige únicamente a corregir el vicio y evitar sus perniciosas consecuencias.

La nueva Ordenanza de Intendentes, en el sit. 138 previene: que todas las pulperías que no son de ordenanza, paguen el derecho llamado de composición, por la licencia para abrirse, ordenando que proceda a su establecimiento la de los respectivos Intendentes ell las Villas y ciudades de su mando. En ninguna parte más que aquí conviene la observancia de esta Real disposición, y verificado el cumplimiento de la Ordenanza, crecería este ramo a un cuádruplo de lo que produce actualmente, y también se corregiría gran parte dẹl desórden que, de otro modo, es irremediable.

En cuanto a las chicherias, dispone la ley 12 citada, libro 4', Tít. $8^{\circ}$ de Indias, que no se graven con impuestos; y aunque militan en ello los mismos motivos expresados en el aguardiente, porque también embriaga la chicha, juzgo conveniente que no se haga novedad, porque estos infelices se alimentan con esta bebida, más que con la cerveza en Holanda y otras partes de Europa; por lo que debe quedar excnta, como los demás frutos de primera necesidad.

Fabrican esta bebida, de la harina de maíz, mascándola las indias en corrillos que forman en las aceras de las calles; bien humedecida la masa, van formando unas bolas menores que las de truco; hacen luego fogones donde tuestan esta masa $y$, después de seca, la echan en grandes tinajones con agua caliente, para que allí fermente la harina y se haga esta asquerosa bebida. Ella es una inmundicia; pero para los indios es un regalo y alimento, a mi parecer muy robusto, pues todos vemos que estas gentes se mantienen bien nutridas con la continuación de su uso, sin más comida que un platillo muy mediano de carne de llama o carnero de la tierra, condimentado con ají y papas.

Nada importa tanto como formax la subordinación del pueblo, interviniendo los Intendentes en todos los actos que el vecindario ha creído hasta ahora indiferentes y sin dependencia de la inspección de la política. Contribuye también a ir adelantando este ramo decadente, para que no sufra tanta quiebra el derecho de Alcabalas, cuando se vayan minorando las internaciones de géneros de Castilla, cuyo caso es forzoso que llegue luego que al cumplimiento de los plazos no se remitan sus valores a Buenos Aires, bien sea por falencia de los fiados, o porque la excesiva concurrencia de mercaderes en Potosí, ha hecho abaratar los precios hasta el grado de no poder vender géneros sin pérdida considerable en los principales.

En el año de 1779, en que se estableció la Aduana, produjo solamente cuarenta y ocho mil ciento diez pesos, siete y un cuartillo reales, no por falta de vigilancia en el cobro de Alcabalas, sino porque la escasez consiguiente al embarazo de nuestra navegación por causa de la guerra con el inglés, no dejaba muchos sobrantes en el consumo de Buenos Ajres. Después de publicada la paz, se doblaron los envíos y la misma 
libertad del trálico arrastró a la sierra infinidad de efectos, aumentando estas entradas el ramo de Aleabalas a proporción de sus valores. De aquí procedió el notable aumento que se adviexte en los años posteriores, según la planilla siguiente, a cuya continuación se pone otra de los sueldos con que están dotados los Ministros y demás dependientes de dicha oficina, para que a golpe de ojo se instruya un Intendentc moderno, en las ganancias de la Real Aduana.

\section{ESTADO DE LOS PRODUCTOS DE LA REAL. ADUANA}

Desde el 1o. de junio de 1779 , hasta 21 de octubre de 1785 , en que van corridos seis años cuatro meses desde su establecimiento.

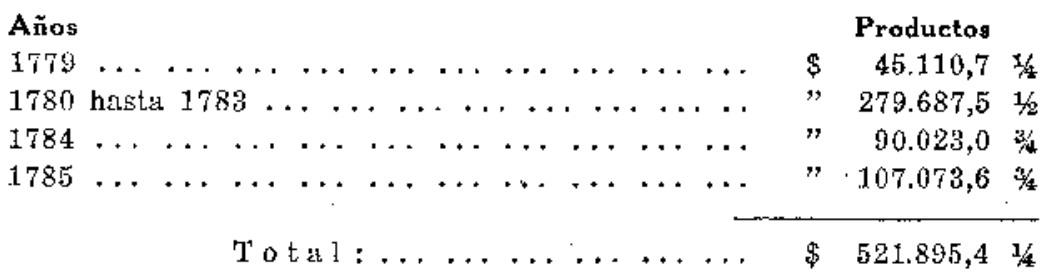

E S T A D O D E E E O S

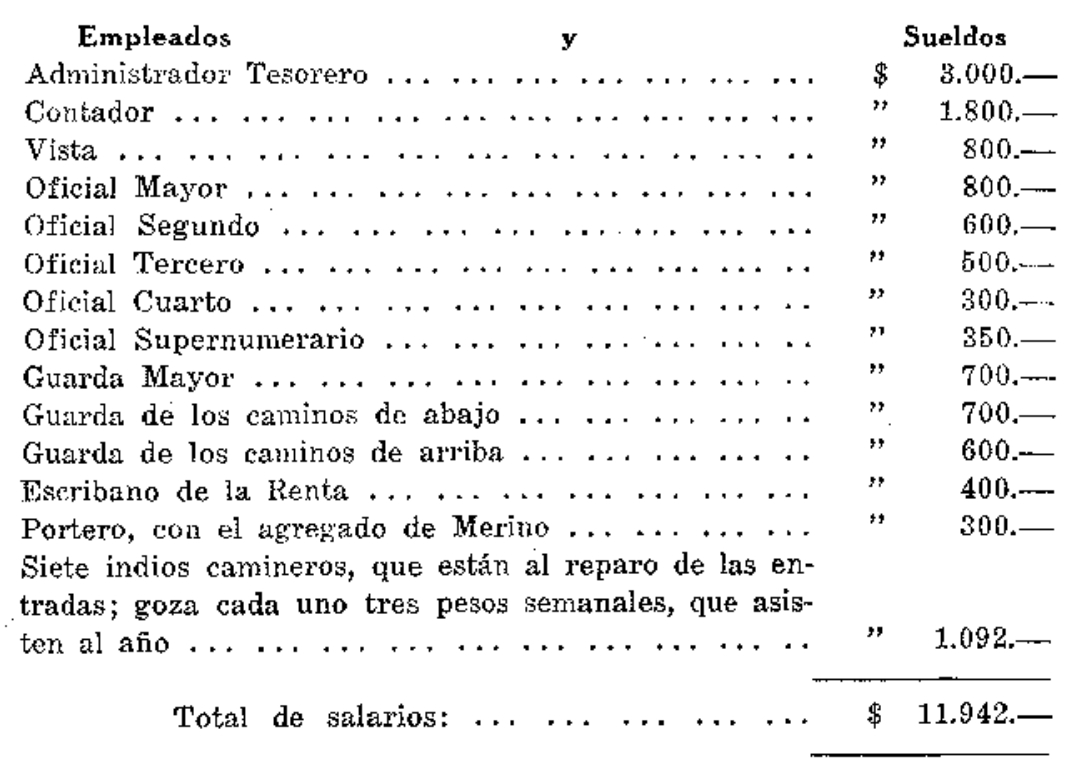

Párrafo décimoséptimo. - Las $\mathbf{W}_{\mathrm{N}}$ este ramo se comprenden cualesquieCajas de afuera. ra caudales de la Real Hacienda, que se administran y cobran en las Cajas Reales que vacían sus fondos en ésta de Potosí, para remitirlos a la Tesorería General de Buenos Aires, y son las siguientes: Oruro, La Plata, Cochabamba, Chucuito, Carangas, Carabaya y La Paz. 
RAMOS DE HACIENDA DE SEGUNDA CLASE

Párrafo primero. - Penas de $A$ UNQUe se notan varias diferencias enCámara. tre las multas y penas de Camara, unas y otras son de la regalía del Principe, ${ }^{134} \mathrm{co-}$ mo frutos de jurisdicción. 13. Nuestro Escalona 1:6 formó un docto comentario sobre este ramo de Real Hacienda, en uno de los capítulos de su Gazofilacio, resolviendo muchas útiles cuestiones que se pueden altercar: en los tribunales. To mismo ejecutaron nuestro Solórzano, Antúnez y Peregrino, ${ }^{137}$ con otros autores célebres que cllos citan y pueden servir de guía para los casos ocumentes.

Las leyes del Tít. 14, libro $2^{4}$ de la recopilación de Indias, tratan con detalle de las penas pccuniarias y condenaciones, aplicadas por la Cámara a gastos de Justicia, a Estrados y a las partes por satisfacción de sus injurias y daño. Pondiró en grande lo más substancial a la administración $y$ cobranza de este ramo, las formalidartes que deben obser. varse en las condenaciones, las persomas que tienen a su cargo estos productos, y algunas cuestiones especiales que pueden ocurrir en la príctica.

En las ciudades y villas de España (como es Potosí), donde no hay nombrado ni reside receptor particular de penas de Cámara y gastos de Justicia, deben entrar en poder de los Oficiales Peales todas las condenaciones que hiciesen las Justicias; ${ }^{13 s}$ y aunque se Ios aumente trabajo por los libros que deben llevar para la cuenta y razón de este ramo, les está prohibido todo acrecentamiento de salario además dol que gozaren por sus oficios principales, 139

La ley 39, Tít. 25, libro $2^{4}$ citado, de nuestra Recopilación, dispone con arreglo a la ley 35, Tít. 6, libro $3^{\circ}$ de Castilla, que los Fscribanos del Cabildo de las ciudades y pueblos de españoles, tengan cuidado de cobrar las penas de Cámara, gastos de justicia y condenaciones aplicadas a obras públicas, $y$ de entregarlas dentro de un mes al Receptor o a la persona que por él se nombrare. No por esto se opone a la ley 2 del mismo título y libro, que pone al cargo de los Oficiales Reales la cobranza y receptoría de este ramo, porque la ley de Castilla que arriba se cita $y$ transcribe, debe guardarse cn las Indias según el sistema de su gobierno, es a saber: que residiendo en la América Oficiales Reales (que no hay on España), con la obligación esencial de cobrar, recibir y custodiar la Real Hacienda, es inseparable de su manejo todo to que a ella pertenece; $y$ solamente en aquellos pueblos donde no hay Oficiales Reales, debe observarse la ley 39 referida, en cuanto a encargar cstas cobranzas a los Escribanos de Cabildo.

Explicado así el sentido de ambas leyes, debe advertirse que según la Nueva Ordenanza de Intendentes, ya no pueden hacer apromios judiciales los Oriciales de la Real Hacienda, por haberles privado de la jurisdicción contenciosa que antes ejercian; por lo que, precediendo los requerimientos precisos, deben acudir al Intendente, para que despache los mandamientos oportunos a la cobranza, como único Juez privativo de todos los ramos y dependencias del Real fisco.

Para que se puedan solicitar con tiempo las recaudaciones de este género, y los Oficiales Reales tengan recaudos con qué poderlo hacer en la Intendencia, está prevenido ${ }^{140}$ que los Escribanos ante quienes se 
hicieren por las Justicias cualesquiera condenaciones, tengan libros dónde escribir las penas y multas para la Cámara, gastos de justicia y estrados, y para otros efectos, con distinción y separación; y cada mes den testimonio por menor do las que fueren a los Oficiales Reales, dando fe de que ante ellos no han pasado otras condenaciones de multas más de las que refieren y están asentadas en sus libios.

Esto es en el caso de no haber Fscribano de Cabildo; porque donde lo hubiere, se le han de notificar por los Éscribanos Públicos o Reales, ante quienes se hiciere la condenación, el mismo día, para que se asienten y firmen las partidas respectivas, en un libro que ha de tener el de Cabildo, numeradas todas las fojas y ubricarlas por el Corregidor, con distinción y claridad, día, mes $y$ año, y nombre del $J$ uez que las condenare, ${ }^{111}$

Los Gobelnadores y demás Jueces tambien deben tener por otra ley 14: sus libros de condenaciones aplicadas a la Cámara y fisco. El Art. 51 de la Ordenanza de: Intchidentes, previene a los de cada Provincia celen la versación de las penas pecuniarias impuestas por los Alcaldes y Subdelegados, bicis sta pertenecientes a la Cúmara o a la causa pública, y que lleven chenta exacta de este ramo, correspondiéndose sobre él con los Regentes de las Audiencias respectivas, como Subdelegados en el distrito del Tribunal, contorme al Art. 57 de la Instrucción de 20 de junio de 1776, cesando en este cargo los Decanos, que antes corrían con este encargo, manejo, destino y gobjerno de cistos caudales, con arregio a las leyes 19, 20, 21 y 22, Tít. 16, Lib. 2" de Indias.

Las solemnirlarles y los casos on que se puede librar contra este ramo, deciden con claridad las leyes del título 25 , libro $2^{\circ}$ de Indias; conforme a la 31 del mismo título y libro, no debe ser suelto de la prisión el que fuere multado, siu estar pagada primero la condenación, y si la soltura fuere en fiado, debe constar de la fianza por testimonio de to proveído.

Por lo cual se procede efectivamente a la exacción de las condonaciones y multas, y caso de interponerse algün recurso dara la Real Hacienda, no se admita sin que con efecto, ante todas cosas, se deposite la multa en la Receptoria de penas de Cámara; " pero de las multas y condenaciones hechas por las Audiencias, no se admita apelación ni recurso, aunque sea para el Virrey, ${ }^{144}$ ni tampoco para el Consejo Supremo de Indias, no habiendose interpuesto el recurso de súplica en las mismas Audiencias. ${ }^{145}$

Esta facultad de imponer multas y penas pecuniarias, está prohibida a los Jueces Eclosiásticos, respecto de los legos, por la ley 47, Tít. 7 , libro $1^{\circ}$ de Indias, a que se conforma el común sentir de los Doctores. ${ }^{146}$ Con todo, nuestro sabio político Dn. Juan de Solórzano, ${ }^{147}$ siguiendo el espíritu del Concilio Tridentino, en la Ces. 25, -De reformation,Cap. 3", y Ces. 24, Cap. 8", resuelve, conciliando ambas decisiones, Real y Canónica, que la prohibición de hacer condenaciones pecuniarias, se cntiende, como en dicha ley se expresa, por causas livianas y con la dalidad que se apliquen a usos píos, y no los conviertan en los suyos pro. pios. Pero los indios no pueden ser condenados absolutamente, por ninguna causa ni razón, conforme a la ley 6, Tít. 10, Lib. $1^{\circ}$ de Indias, ${ }^{148}$ bien entendido que, para cobrar estas multas a españoles legos, se ha de invocar el auxilio Real, con arreglo a la ley 12 del mismo Tít. y Lib., im- 
plorando en las Audiencias por pedimento, según la ley 13, Tít. 10, libro 10 citado, y a los demás Jueces, por exhorto, según la nota de Ramiro Valenzuela. ${ }^{143}$

En conclusión, propondremos aquí una clestión bien aitercada, a saber: si debe ser preferido el físco o más bicn ol particular en la sátisfacción de su injuria y daño, cuando la contenación no alcanza para los dos objetos; por ejemplo, porque siendo la multa de mil pesos, no se le encuentran al condenado más que quinientos. Bl Sr. Cobartubias 1:0 da la preferencia al fisco; pero el célebre Poregrino, ${ }^{1 n 1}$ después de citar la autoridad de Tiraquelo, que hace concurrir a prorrata al fisco y al particular, resuelve por más conforme a razón la preferencia del particular damnificado.

Yo no me atrevo a decidir entre dos oposiciones tan graves. EI que se hallare en el caso, reflexione lo nicjor y resuelva lo que juzgare por conveniente, teniendo siempre a la vista aquella célebre sentencia de Plinio en su Panegírico a Trajano, con las siguientes elegantes palabras: - "Eodem foro utuntur principatus et libertas que precipuas, tua "gloria est coepius vincitur. Fiscus, cujus mala causa nunquam est, nist "sub bono Principe".

Por último, debe tenerse entendido que, en las Indias, son al doble las penas impuestas por las leyes de Castilla, donde no se tasare cantidad señalada, según lo dispuesto en la ley 13, 14, 15, Tít. 5", libro 9, y ley 9, Tít. 8, Lib. $7^{\circ}$ de nuestras Municipales; exceptuándose las penas de juegos prohibidos, que son al cuatro tanto, por la ley 1, Tít. 2, Lib. 7 ? de Indias; y aunque en estos casos apele el condenado, no tiene lugar su recurso, porque las leyes penales no admiten apelación, conforme a la ley 2, Tít. 7, libro 40 de Castilla.

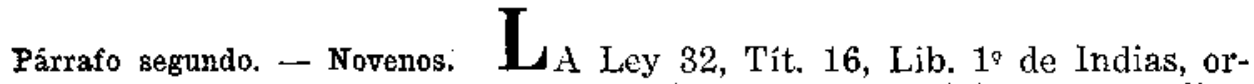
dena la distribución metódica de los diezmos, así en cuanto a las Iglesias Catedrales, como a las Parroqulas de estos dominios. De toda la gruesa, separa dos partes para el Prelado y $\mathrm{Ca}$ bildo, y las dos cuartas partes restantes se reparte en nueve cuotas: dos novenos para el Rey; noveno y medio para los hospitales de cada pueblo; el otro noveno y medio para la Fáfrica de las Iglesias Catedrales o Parroquiales; y los otros cuatro novenos aplicados para el sustento de los Curas y Ministros que han de asistir: a la administración de Sacramentos y al culto en cada Parroquia.

Sobre la pertenencia de los dos primeros novenos al Rey, tratan el Sr. Solórzano y nuestro Escalona, ${ }^{152}$ Las leyes 24, 25 26, 27 y 28 , Tít. 16 , Lib. $1^{\circ}$ citado; y $\operatorname{los}$ artículos 150, 162 y 167 de la Ordenanza de Intendentes, declaran expresamente que corresponden al Real patrimonio, como reservados a nuestros Reyes Católicos por concesiones Apostólicas.

Por esta calidad corre a cargo de los Oficiales Reales su administración, cobranza y receptoría, y es de la obligación de sus oficios dar cobrado o diligenciado el importe de los dos novenos. 1:3 A este efecto está prevenido ${ }^{154}$ que la Junta de Diezmos despache los recaudamientos firmados por el Intendente $y$ por uno de los Jueces Hacedores, autorizándolos el Escribano, para que los Oficiales Reales practiquen la co- 
branza; cn consecuencia, leben tomar fianzas a su satisfacción y contento de los mismos aruendadores contra quienes se les diese el dicho recaudamiento ${ }^{15}$ y también de los Administradores de los Diezmos, por el importe de los dos novenos que incluyen. ${ }^{156}$

Para todas las materias de Diezmos, es privativo el conocimiento de la Junta, según los Arts. 154 y 155 , con la diferencia que, conforme a los casos declarados en la misma Ordenanza, proceden los Jueces Hacedores, unas veces económicament y otras por vía contenciosa, pero siempre con la misma jurisdiceión Real delegada, según la naturaleza de bienes temporales que conservan los Diezmos de estos dominios.

En las Cajas de Potosí, no entran ni se administran estos dos novenos; porque verificándose los hacimientos y remates en la ciudad de La Plata, donde reside la silla Arzobispal y el Coro de los Canónigos, se encierra en aquella Tesorería el producto de estos caudales.

Los otros sicte novenos restantes, se consumen también en Chuquisaca, contra expresos capítulos de la erección de aquella Iglesia y de la división dispuesta por las leyes. Por un abuso inveterado, se comenzó a observar la aplicación del noveno y medio, integro, deducido de toda la gruesa do los Diezmos, para la fábrica de la lglesia Metropolitana, exchyendo indebirmmento a las demás Iglesias Parroquiales de la Diócesis de la participación que les da la ley en el noveno y medio de los Diezmos de su territorio, para la fábrica de ellas,

Del mismo modo percibe el Hospital fundado en aquella capital, del montón y masa decimal de todo el Arzobispado, en el noveno y medio que rebía aplicarse para fundar hospitales en todas las villas, pueblos y cindades de indios y españoles, extendiéndose esta corrupción hasta incluírse en la masa Capitular los cuatro novenos restantes, destinados para sustento de los Curas y demás Ministros de cada Parroquia.

Ll Licenciado Don Pedro Frazo, siendo Fiscal de Charcas, por el año 1671 , reclamó vigorosamente $15 i$ contra este abuso sostenido con la erección de la misma Iglesia Metropolitana, pidiendo que, separados los dos novenos de Su Majestad, se distribuyese los sicte restantes, por el orden y grado dispuesto por las leyes, para fundar hospitales en todos los pueblos del Distrito, para mantener o mojorar la fábrica de las lglesias Parroquiales y para sustentar los clérigos que las hayan de servir. El Rey mandó continuar esta demanda; pero vemos que el abuso ha continuado con fuerza superior a las leyes ${ }^{158} \mathrm{y}$ a la erección.

De esto proceden muchos irreparables inconvenientes, que claman su romedio sin cesar: 10 Por amplísima que sea la fundación del Hospital erigido ev la capital de la Diócesis, respecto de su mayor fondo deducido de toda la gruesa de Diezmos del obispado, será demasiado molesto para algunos pueblos, y para otros imposible, el desamparar sus vecindades para solicitar su curación en el Hospital de la capital. 20 Aunque los Curas sean laboriosos y dedicados al cutto de sus iglesias, no pueden conservar la fábrica de ellas con decencia y aseo, por falta de medios.

En esto consiste que hayan tantas iglesias indecentes, que no parecen casas del. Señor, ni lugares sagrados dondé se ofrecen sacrificios a la Majestad. 3" El Rey sufre el injusto gravamen de sustentar a los Curas de indios, con crecidos sinodos de su Real Hacienda, debiendo dotarse los Curatos por los Cabildos de las Iglesias Catedrales y demás per- 
ceptores de Diezmos, para cuando estos efectos sean suficientes, como hasta aquí son, para uno y otjo destino.

Son reiteradas las providencias que se han expedido ${ }^{159}$ a este importantísimo fin: se ha mandado formar on las capitales Juntas autorizadas para averiguar los productos de cada Curato, reservando al Sínodo o Diocesano la purilicaciól de este punto. Todas las diligencias que se han practicado hasta ahora, contemplo infructuosas; pues, los Curas se desvelan estudiando la ocultación de sus deredios y subvenciones, porque conocen que el tiro es a quitarles los sínodos y que será muy difícil o poco menos que imposible que los Cabildos no teternicen la oposición que hicieren en cuanto a dotarlos con los Diczmos, que hasta ahola se han aplicado integramente a la Mesa Capitular.

Todas estas causas ejecutan el Hinisterio de Ios Intendentes a solicitar con instancia el cumplimicnto de las leyes, ${ }^{160}$ porque mucha par. te de la despoblación de estos distritos en tiempos calanitosos de peste, consiste en no tener los pueblos bospitales donde ser curados los indios.

Ehtre tanto st verifiquen estas disposiciones, chbe cuidars principalmente en Potosí, de dos cosas: la primera, que los eclesiásticos y comunidades religiosas, no entren en más posesiones de Haciencla raíz, en aumento de las que tienen, por la gran baja de los Diezmos on los Partidos de esta Intendencia; paguen alcabalas de todos los frutos que vendiesen, como están obligados, scyún doctrina de Escalona, 161 Carrasco, Lazarte, Lagunes y Olea. ${ }^{162}$ Que no habiendo omisión en la cobranza, se atumentaria considerablemente este ramo de Real Hacienda.

$\begin{array}{ll}\text { Párrafo tercero. - Mesadas } & \text { TN remuncración de los excesivos gastos } \\ \text { Eclesiásticas. } & \text { que sicmpre han hecho nuestros Reyes a } \\ \text { costa de su Real Erario, en defensa y pro- }\end{array}$ pagación de la fe católica, se les concedió por la silla Apostólica la mesada eclesiástica sobre todas las Provincias de Real presentación; y en su virtud se mandó cobrax este derecho para la Real Hacienda, descle principios de 1625, con la calidad de verificarse la cobranza de la renta del primer mes (que se llama mesada), luego que hubiesen pasado cuatro meses después de tomada posesión de la Digniłar, prebenda y beneficio, y que el valor de dicho mes se regule conforme a lo que rentado en los cincos años las Piezas Eclesiásticas que adeudan la mesada; entrando en el cómputo no solamente el valor de las rentas, Diczmos y gruesa de los Prebendados en cada uno de ellos, sino también lo que hubiesen valido las subvenciones, proventos y otros emolumentos de ellas en el mismo tiempo.

De suerte que, juntando de por sí el monto de todos los valores en los cinco años precedentes, se distribuirá por iguales partes en cada uno de los meses que componen el quinquenio, para averiguar el valor líquido que cabe y corresponde a cada mes, y lo que montare la renta del primer mes, es lo que se cobra por derecho de mesada, con más ol $18 \%$ de conducción a España, y el uno y medio desde esta Tesorería a la General de Buenos Aires.

Isa primexa concesión fue de Urbano VIII, por quince años, que después prorrogó el Sumo Pontílice Inocencio X, por otros diez años al Rey Felipe IV, por su Breve dado en Roma, a 4 de octubre de 1644, en el 
primer año de su Pontificado. Los Papas sucesores Alejandro VII, Clemente IX y X, Inocencio XY, Alejandro VIII, Clemente IX, Inocencio XIII, Benedicto XIIT, Clemente XII, y Benedicto XIV, hicieron sucesivamente las prerrogativas do esta glacia, y por último la renovó el Papa reinante Pío Vl, en su Breve de 16 de junio de 1778, por todo el tiempo de la vida de nucstro invicto Monarca Carlos III (que Dios guarde).

Las leyes 1 y 6 del título 17 , Lib. 1o de Indias, establecieron Ios principios reguladores de este derecho, y cncargaron a los Oficiales Reales, así la computación del importe de la Mesada, como su cobranza y la calificación y admisión de fianzas. Fin la plantación de Intendentes de América, se innovó este método y se prescribieron otras reglas más equitativas para la exacción de esta mosada.

Desde el Art. 187 hasta el 194 de la Nueva Ordenanza, se prefirió el nuevo reglametito que debía gobernar en lo sucesivo en el manejo de este ramo. Conforme a este sistema, todos los beneficios que no llegan a 413 pesos 4 roales, 28 maravedíes y no bajan de 212 pesos 4 reales, adeudm únicamonte al dexcho de mesada. ${ }^{163}$ Antiguamente corría a cargo de los Oficiales Reales, su regulación, cobranza y seguro; pero ahora todas cstas disposiciones se entionden con los subcolectores o Comisarios de Cruzarla de cada Diocesis, mediante quedar bajo su jurisdicción $y$ conocimlento las dependencias de este derecho. ${ }^{164}$

Para ajustar los importes, verificay la recaudación y admitir las fianzas de pagar a los cuatro meses después de pagada la posesiớn de Ios bencficios, deben remitj. los Intendentes Vice-Patronos a los subcolectores, todas las presentaciones que se hiciesen cn sus Distritos, tomándose antes razón de ellas en las Contadurías Reales de provincia.

Recibidos los despachos, procede el Subcolector a regular la renta de la mesada, por los cuadrantos y demás diligencias con que debe instruír este ajustamiento, y Inego que está avcriguado su verdadero valor, hace afianzar el pago y cobranza de Ia mesada adeudada por la presentacion, pasando a las Cajas Reales los Subeolectores para que procedan a haccr efectivo el pago.

Al fin de cada ar̃o, deben pasar los Intendentes de Potosí, al Tribunal Mayor de Cuentas, una razón circunstanciada de todas las presentaciones que en todo el año próximo anterior hubieren hecho en sus Distritos; para que estas noticias sirvan para el mejor gobierno de la Contaduría, en el cxamen, glosa y fenecimiento de las respectivas a cada Intendencia. ${ }^{165}$

Asimismo, deben los Intenclentes lemitir anualmente a la Contaduria Mayor y a las Reales manos, por triplicado, relaciones individuales de lo cobrado a cuenta de este ramo por los Oficiales Reales, con visto bueno del Subcolector, con otras igualmente circunstanciadas de lo adeudado, con las diligencias practicadas para su pago, ${ }^{166}$ cuidando con vigilancia que los Oficiales Reales no retarden los avisos cuando no se enterase la Mesada al cumpliniento de los cuatro meses, sin omitir los oficios correspondientes a los Subcolectores, para que por su parte no disimulen a los deudores en perjuicio de la Real Hacienda.

En la generalidad dc estas reglas se comprende todo el sistema renovado en materia de Mesada. Nuestro Escalona trató de este ramo, ${ }^{16}$ entre otros de Real Hacienda, pero tan diminutamente, que su comentario de nada pucde aprovechar en el día. Sólo debo advertir en conclu- 
sión, que el subcolector debe correr el riesgo de los fiadores que admitiere y calificare a su arbitrio; y pal'a evitarlo no tiene más recurso que aprobar la jdoneidad de las fianzas con informe y anuencia de los Oficiales Reales, que hacen aquí la parte del Rey en la receptoría de estos caudales.

Párrafo cuarto. - Medias WS tan antigula la exacción de la anata Anatas eclesiásticas. eclesiústica en la Curia Romana, que la hace muchos años anterior a los Concilios de Viena y Constanza el Eminentisimo Luca. ${ }^{16 s}$ Queliendo distinguir los tiempos con mayor individualidad, atribuye el Ilmo. Fermosino, $169 \mathrm{su}$ origen al Papa Juan XXII, siguiendo el testimonio de Hosttiense y Juan Andrés. El doeto Fagnano, ${ }^{170}$ con otros uItramontanos, pone la institución de las "Annatas" mucho antes que el reinado de Juan XXII, y establece su origen por de tiempo inmemorial, afirmando ${ }^{i} i 1$ que lo que no se ignora es el principio de la media anata, introducida por Bonifacio IX, cuya forma arregló su exacción, no como antes a pagar los frutos del primer año íntegro en tres sucesivos, enterando en cada una tercera parte; sino que redujo el pago de la anata a la mitad del valor del año, pero con la obligación de hacerse la cobranza de contado, por el Provisto, con su propio caudal. El doctísimo Van Espen li: se hace cargo do estas noticias, pero reprueba, como indebido fuera de Roma, el aso de la anata eclesiástica.

Sea de esto lo que fuere, lo cierto es que en las Indias nunca se acostumbró la exacción de este derecho, y por eso no se encuentra en la Recopilación nada que trate de este ramo. A mediados de este siglo tuvo principio la concesión de esta gracia, por Bula del Papa Benedicto XIV, de 10 de mayo de 1754 .

Aunque desde su principio podía S. M., percibir una media anata eclesiástica de todos los Provistos, a nominación Real, se mantuvo suspensa hasta el año 1777, en que por Real Cédula de El Pardo, a 26 de enero del mismo año, se mandó poner corriente su cobranza desde el día que se publicase aquella Real resolución.

En la nueva Ordenanza de Intendentes se establecieron reglas equitativas para la Dirección de este ramo, desde al Art. 182, hasta el 186 inclusive; se exceptuaron de su pago los Curas, por particular induito, y se sujetó la cobranza de esta derecho, bajo la misma instrucción for'mada para la Mesada Eclesiástica, con la diferencia que los Provistos que adeudan media anata, que son aquellos cuyas ventas excedieren de 413 pesos cuatro reales 28 maravedíes, ${ }^{173}$ deben pagar este derecho delltro de dos años contados desde el día de la Real presentación, con la calidad de prorrogables por otro año y no más, según el equitativo arbitrio del colector general y de los subdelegados. ${ }^{174}$

En Potosí no es necesario un conocimiento exacto de esta materia, porque siendo Párrocos todos los Provistos para esta Intendencia, no adeudan media anata sino Mesada. Solamente los Oficiales Reales de las capitales de Obispados donde hay canongias, debe enterarse muy fundamentalmente sobre este asunto. Con todo, debo advertir que la Sacristía Mayor de Potosí, produce, según opinión general, la renta de más de 800 pesos anuales. El beneficio de presentación Real no está incluso 
en la excepción de media anata por no ser curato y, por lo mismo, debe satisfacerla cono cualquicr Prebendado, para que no se perjudique la Real Hacienda.

Párrafo quinto. - Vacantes $\mathrm{V}$ ACANTES menores se entienden aquí menores. $\quad$ los frutos o rentas correspondientes a cada Dignidad, probenda o beneficio en la gruesa o masa decimal, precisamente, que se devengan desde el fallecimiento, traslacion o lemuncia de los poseedores, hasta la posesión de los provistos en su lugar, que tocalan a los primeros, si vivieran o estuvieran en actual survicio.

No se compurten aruellas porciones que por razon de subvenciones, aniversarios u otros títulos, se debian distribuír entre ellos, ni tampoco se incluyen las iglesias que tengan la asignación de su congrua en Cajas Reales y se llaman vulgaimente sínodos. Porque los primeros se adquieren absolutamente por los Ministros interinarios e interesados y los últimos quedan a beneficio de la Real Hacienda, de cuyo fondo y cuenta se les asistia en vida. ${ }^{1}$.

Tampoco entran en esie concepto aquellos frutos y bienes que dejan adquiridos los beneficiados difuntos; porque según nuestras leyes, pertenecen a sus herederos, por testamento o ab-intestato, 176 aunque se haya ganado intuises Eclesie y no sean patrimoniales heredados, legados o donados por sus parientes o amigos.

Mucho tiempo se disputó la pertenencia de las vacantes menores de las Indias, a favor de la Corona Real; insistían demasiado en excluír a la Real Hacienda, las Dignidades, Canónigos, Racioneros y demás oficios Eclesiásticos, que pretendían tencr algúnt interés en estos frutos, por derecho de acrecencia.

Estas alteraciones mantuvieron muchos años indecisa la cuestión, hasta que el Sr. Don Folipe V, resolvió a favor de la Real Corona, por su Real Decreto de 20 de septiembre de 1737. Diez años antes de que se publicar'a esta Real declaración, trató el mismo punto nuestro docto Marqués de la Regalía, Dn. José Alvarez de Abreu, ${ }^{17}$ convenciendo en su fundado discurso juridico sobre vacantes, que las menores de estas iglesias y beneficios pertenecían al Rey, igualmente que las mayores. Este sabio docto alegó cuanto puede discuruirse en la materia, y ya es inutil inculcar sus pensamientos, hallándose decidido en punto por la soberana autoridad de nuestros Reyes.

No obstante, se suscitaron en Caracas muy reñidas controversias sobre este mismo particular; de que resultó despacharse Real Cédula de San Iorenzo, a 31 de julio de 1780, ordenando, con la calidad de por ahora, que no se hiciera novedad sobre la cobranza y entero en Cajas Reales, de las vacantes de Curatos y Sacristías mayores que gozan por asignación para sus alimentos, renta en los Diezmos de estos dominios; hasta que precediesen los informes que se pidieron acerca de si deben ser comprendidas las vacantes de Curatos que perciben diezmos.

Cuando estuve de Asesor en la Provincia del Paraguay, dirigí el informe de aquel gobierno, a fines del año 1782, fundando no encontrarse inconveniente para enterar en Cajas Reales las vacantes de aquellos Curatos y Sacristía mayor de la Iglesia Catedral, que perciben diezmos 
en el Paraguay; pero, entre tanto, continuaron percibiendolos los Curas interinarios, como se había practicado en los tiempos anteriores.

A fines de 1783, llegó la Nueva Ordenanza de Intendentes, renovando por los Arts. 178 y 179 el citado Real Decroto de 1737. A la sazón se hallaba vacantc uno de Jos Curatos de la Catedral y cabalmente pidió el Párroco interino la cuota decimal que le tocaba por la crección, después de publicada dicha Ordenanza. El Promotor de la Real Hacienda contradijo esta solicitud; pero, se declaró, con arreglo a la referida Cédula de 1780 , que no dcbía hacerse novedad entre tanto que se resolviese en la Corte, a vista de los informes que ya estaban remitidos. En efecto, percibió sus diezmos el interesado, y se dio cuenta con autos a la Junta Superior.

No tengo noticia de las resultas, pero es regular que ya se haya tomado providencia; bien que en esta Provincia de Potosí, nunca se ofrecerá alteración sobre este negocio, porque no hay prebondas ni canongías, ni tampoco están dotados los Curatos en la masa Docimal; y que se verifiquen las repetidas órdenes de que los sacertotes $y$ demás perceptores de Diezmos hagan la dotación correspondienti, no debe ocur'tir duda en enterar las vacantes en Cajas Reales, respecto que nunca so ha practicado lo contrario en Potosi, y cono que no hay matcria en qué hacer novedad, tiene toda su fuerza la nueva Ordenanza para ejecutarse a la letra.

Por comisión particular conferida en despacho de 25 de junio de 1712, corríar antiguamente los Oidores Sub-Decanos de las Audicncias, con la cobranza del producto de las vacantes. Después se revocó esta orden, por Cédula de Madrid, a 26 de enero de 1719 , poniendo al cuidado de los Oficiales Reales el recobro de este ramo, como otros cualesquiera de Real Hacienda, y es lo que ahora se practica.

Párrafo sexto. - Donativos. BNTRE los ramos de Real Hacienda se comprenden los donativos, que son ciertos servicios pecuniarios que se enteran en Cajas Reales, por' la gracia de licencias para Molinos, por las confirmaciones de títulos do tierras y de of licios Concejiles, en una cantidad tasada por avaluación hecha en las Contadurias Mayores de Cuentas; como también acuellas donaciones graciosas que hacen los vasallos, en casos de necesidad, a la Corona, según el ofrecimiento de cada uno, sin violencia y a ruego de los jefes del reino; cuyo método refiere circunstanciadamente luestro Escalona. ${ }^{178}$

Párrafo séptimo. - Alcances
de Guentas. las noticias que alguma vez se pueden solicalona, en dos capítulos enteros. ${ }^{179}$.

Nuestro político Dn. Juan de Solórzano, ${ }^{180}$ y las leyes 27, Tút. 1\%, y la $1^{*}$ hasta la $6^{n}$, Tít. $4^{\circ}$, y particularmente la 27 , Tít. 29 , libro $8^{\circ}$ de Indias, y el Art. 95 de la Nueva Ordenanza, deciden con más puntualidad la obligación in-sólidum y la mancomunidad de los Oficiales Reales, para ser reconvenidos y ejecutados los unos por los alcances, delitos, excesos 
y descuidos cle los otros. Esto puede servir de apéndice al comentario de Escatona.

Conlome a la ley 27, Tít. 29, Lib. 89 citado, deben pagarse los alcances de euentas, a lo más, dentro cle tres días, o se debe proceder con mayor rigor contra los Oficiales alcanzados, scgún el espiritu de esta ley.

El sabio Per'cgrino, ${ }^{\text {sil }}$ explica excelentemente el método práctico de proceder on este caso. En virtud del instrumento ejecutivo de alcance, no se deja libre al durdor, ni basta cl mandamiento simple de pago dentro de tres días, porque entonces se retardaría la cobranza exponiéndola a cuicbra por medio de la ocultación de bienes, que prudentemente debía temerse durante los tres días.

La práctica legal es, que visto el alcance, sc toma la tenuta de los bienes del deudor', a la manera que obra el primer decreto en la vía de Asentamiento; se Io intima que dentro de teréco día exija la tenuta, pagando la deutat; y para el caso contrario, se le cita para las substanciaciones y romate. De este modo se adelantan las estaciones del cobro y aquel plazo de tres dias no da lugar a fraudes, y solamente sirve como término do citacion para vulificar el remate de los bienes con que debe cubrirse la Real Hacienda.

Apuntare, por último, un caso particular, de que puede resultar gran perjucicio a los Ministros de la Real Hacienda. Algunas veces se puede asentar en los libros Reales, una partida de pago, antes de verificarse éste, por cfecto de confianza en el deudor; si éste no satisface el débito, quedan responsables al alcance los Oficiales Reales, sin que baste ni ios aproveche la excepción de la no entrega. Pero cuando el pago constase por sola certificación del Tesorero, no queda enteramente libre el deudor; porque si cjccutado en primer lugar el Oficial Real, resultase insolvente, queda expedito el regreso contra el deudor fiscal para cubrir la Real Hacienda. ${ }^{1: 2}$ En este concepto, deben tener la mayor vigilancia de no omitir los asientos correspondientes en los libros Rcales, y de no anticiparlos al pago, para no quedar responsables de los apremios de estas causas privilegiadas.

Párrafo octavo. - Vacantes P ARA mayor conocimiento de las vacanMayores. tes de los Prelados y de aquellas que pertenecen a la Corona Real, se deben distinguir dos especies de frutos Episcopales. A la primera especie pertenecen los frutos de la Dignidad y son en dos maneras, a saber: aquellas rentas que de la gruesa del diezmo perciben y gozan los Prelados Metropolitanos y Diocesanos, por razón de estipendio y congrua sustentación, en virtud de las erecciones de la Iglesia y órdenes de Su Majestad; 183 o son aquellos emolumentos eclesiásticos, que siendo frutos verdaderamente de la Dignidad, no proceden del derecho Decimal, como son las cuartas funerales, manuales, subvenciones, oblaciones y atros cualesquiera proventos o réditos que por razón de la Prelatura perciben Ios Obispos ${ }^{184}$ y se les debe de derecho, por el honor y más cómoda sustentación de la dignidad Episcopal y de sus exigencias, como también del cuidado que tienen o deben tener do la protección de los clérigos e Iglesias de sus Diócesis, y de la ejecución y cumplimiento de las obras pías que dejan los difuntos, como lo explica nuestro célebre Solórzano. ${ }^{185}$ 
De la segunda especie son los frutos jurisdiccionales que provicnen de la Jurisdicción o por ocasión de ella, como son: muitas, condenaciones, elecciones de Magistrarlos o de otros oficiales de Justicia, nombramientos de Notarios, confiscaciones, perdones; las nominaciones, colocaciones e instrucciones de los Beneficios Patronados y otros emolumentos honoríficos, a que se refiere muy por menor nuestro Lagunes. is

Los furutos de la primera especie y los bienes que con ellos dejan adquiridos desde que fallecen los prelados, no son las vacantes de que hablamos, porque son lo que llamamos "expolio" pertenecientes a las Iglesias, sobre cuya materia tratan las leyes 37,39 y 40, Tit. 7, Lib. $1^{\circ}$ de Indias, y los Arts. 196 hasta 199 inclusive, de la Real Ordenanza de Intendentes.

Tampoco se comprenden los de lá segunda especie, porque pasan, con la Jurisdicción, a la Sede vacante, excentuándose unicumente los derechos del sello y otros semejantes anotatos por Frazo, ${ }^{1}{ }_{i}^{-}$quo tocan y se reservan al futuro Prelado.

Asi pues, los frutos Episcopales que tienn el nombre de Vacantes Mayores, en la docta obra de nuestro Ilustrisimo Abreu, $1 \mathrm{~s}$ son las rentas de la Dignidad Épiscopal, gue se devengan despliés de muerto el Prelado, hasta la venida del nucvo poseedor, y que tocarían al Prelado difunto si vivicra. Son los mismos frutos comprendidos en la primera clase de la primera especie, esto $\mathrm{ch}$, los correspondientes al Episcopado ent la masa Decimal, qué no percibió ni adquirió el P'elado en stl vida; porque ya dijimos que los que dejó adquiridos al timpo de su fallecimicnto, componen otra categoria de bienes, llamados "Fxpolios".

Los frutos comprendidos en la segunda classe de esta misma primera especie, que no proceden del derecho Decimal, y otras de esta naturaleza, no entran en el concepto de Vacantes Mayores, según expresa declaración, de la Nueva Ordenanza en el Art. 178; tampoco pasan de la Sede vacante, porque ésta no hereda la Dignidad, aunquo sucede on la Jurisdicción; no se reservan al futuro Prelado, porque antes de serlo no es acreedor a ser rentado ni hay derecho para recompensarle la protección y cuidado que todavia no ha tenido.

Por estas causas se declaró en Real Cédula de San Yorenzo, a 22 de octubre de 1768, que los sucesores del Prelado difunto no deben cobrar la cuarta funcral $y$ de ovenciones causadas en tiempo de vacante, como anteriormente ya lo había decidido la ley 51, Tit. 7 , Lib. 10 de Indias, en cuyo concepto no deben contriburila los Curas doctrineros, según la disposición de nuestras leyes ${ }^{189} \mathrm{y}$ quedan suspensas sin exención ni aplicación todas esas rentas por todo el tiempo que durare la vancante de Ia Iglesia.

Habiéndose esclarecido con la posible individualidad la naturaleza de las vacantes mayores pertenecientes a la Coroma Real, es inútil tocar las muchas cuestiones que inciden en este punto, porque todas ellas pueden verse en nuestros célebres regnícolas Solórzano, Escalona $y$ Abreu, ${ }^{190}$ respecto que mi objeto sóło es demostrar los ramos de Real' Hacienda, y entre ellos, este de las Vacantes Mayores. Pero como en Potosí no reside Silla Episcopal ni Metropolitana, tampoco se administra este ramo en sus Cajas Reales, y solamente lo recibe entre los demás caudales que se le remiten de las otras Cajas del Distrito, para su envío a 
la Tesoreria General de Buenos Aines; por cuya causa, no necesita este punto de mayor ilustración.

\section{RAMOS DE TERCERA CLASE}

Párafo primero. - Montepio $\mathrm{C}_{\mathrm{N}}$ el Viryeinato de Lima y en la contade los Ministros. duria Coneral de Buenos Aires, Consejo de Indias, se han formado en diferentes tiempos, varios regianentos inclividuales y específicos, para el manejo del Montepío de Ministros, declarando los descuentos que deben sufrir los sucldos que gozan durante su vida; los empleos comprendidos en este benelicio; las pensiones señaladas a sus riudas e hijos, y los documentos quo han do presentar los interesados, para obtenerlas.

En toclas las oficinas de Real Hacienda se encuentran noticias puntuales acerca de este munto. Nada importante puede añadirse aqui, sino la advertencia de que las viudas e hijos de los Ministros de Justicia $y$ Hacienda, deben ealificar su derecho ante el respectivo Intendente, y aclarada la pertenncia de la pensión, se da cuenta a la Junta Superior, por mano del Sr. Superintendente Subdelegado, para que después de ejecutoriado el derecho de obtener la pensión, se pase la orden correspondiente para su pago a las Cajas del Departamento donde debe verificarse.

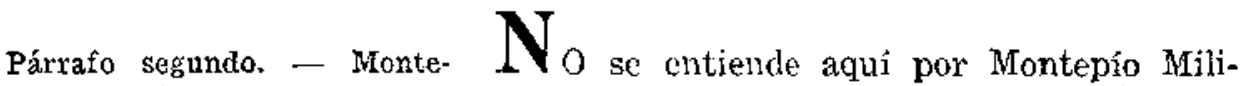
pío Militar. tar, precisamente aquel fondo exclusivo que se va creando con el descuento de los sueldos de Oficiales Militares, Ministros de Guerra, Hacienda y Marina, comprendidos en su goce, para pensionar a sus viudas e hijos, en honor al servicio que prestaron al Estado. ${ }^{191}$ También entra en este concepto, por lo respectivo a las Cajas de Potosi, cierto descuento de ocho maravedícs en cada peso del importe de las limosnas, que se contribuye por esta Real Tesolería, al Convonto de San Francisco de esta Villa y al Colegio de Misiones de la misma Orden de la Villa de Tarija, para vino y aceite.

Hasta fines de diciembre de $\mathbf{1 7 7 1}$, se hizo generalmente tal socorro por estas Cajas, a los Conventos de la Observancía y Recoleceión Seráfica de la ciudad de La Plata; a los de la Observancia y Recolección de la ciudad de Cochabamba y al de Mizque, con arreglo a las nóminas juradas que presentaban sus respectivos Prelados del número de religiosos sacerdotes conventuales, satisfaciéndose quince pesos por cabeza de cada religioso, y ai respecto de una y media botijas de vino destinadas a cada sacerdote para el santo sacrificio de la Misa, a razón de diez pesos cada botija, con más sesenta pesos para doce botijuelas de aceite, a cinco posos cada una, asignadas par'a la lámpara del Santísimo Sacramento de aquellas Iglesias. ${ }^{192}$

En el día se hace esta contribución para los expresados Conventos de Chuquisaca, Cochabamba y Mizque, por las respectivas Cajas, habiendo cesado de ejecutarse en las de esta Villa, desde que en el año 1773 se erigieron en Tesorerías Provinciales aquellas que antes fueron subalternas de ésta. De suerte que la contribución está reducida al Convento 
de San Francisco de la Villa, con sujeción a la lista jurada del Prelado, que cada año presenta el Síndico en los mismos términos arriba explicados, ejecutándose la paga en virtucl de Real Céclula de 26 de mayo de 1777 .

Al Colegio de Misioneros de Tarija, tiene destinados Su Majestad, sin el requisito de nóminas, por Real Orden de 17 de noviembre de 1777 , un mil cincuenta pesos anuales para vino, acoite y cera, y el sobrante destinado para gastos de la conversión de inficles; pero del total importo de estos socon'ros se deducen igualmente los ocho maravedies en cada peso, por razón de Montepío Militar, en conformidad de planilla que el año de 1768 dirigió la Real Caja de Lima, a consecuencia del Reglamento formado allí por el Sr. Virrey, a 30 de agosto de 1772 , conformándose al de Su Majestad, de 20 de abril y 23 de septiombre de 1767,24 de enero de 1764 y de la Real Declaratoria de 17 de jumio de 1763.

Es demasiado sensible que esta obra, en cue tanto resplandecía la soberana piedad del Rey, no se halle libre de muchos fraudes que perjudican la Real Hacienda, $y$ es de temer que descubicrtas estas maquinaciones con el tiempo, se prive a los Conventos del socorro de vino y aceite que tanto han menester, a la manera que se les quitó en el siglo pasado las situaciones que tenínu cu las Cajas Reales para viático y botica, por evitar los grandes frandes de que se les convenció. Si mo fucra tan notorio, no me atrevería a decix que en algunos Conventos donde apenas hay scis u otro religiosos sacerdotes, se presentan en listas otros tantos más, para aumentar la contribución; y ya se ha visto que, pasando la revisita un Ministro de Real IIacienda, se cncuentra cabal el número de la nómina, porque uniforman con el mismo hábito a otros religiosos sacerdotes que solicitan a este efecto. El ínico remedio de este exceso, y de que jamás llegue el caso de quitárseles una limosna tan grata, en pena del abuso, es conceder a los Conventos una situación fija, arreglándola al número de ocho religiosos que debe tener cada Convento, en conformidad de Bulas Pontificias. Con este arbitrio se loguaria que, a más de mantener sus privilegios a cada Conventualidad religiosa, se quitaría la ocasión de llenar unos Conventos pobres (que no son casas de estudios), de religiosos inútiles a su servicio, al paso que gravosos al público y al Rey, por las limosnas con que se manticnen.

Cuando no conviniese tomar esta providencia, por algunas razonès que yo no aleanzo, es muy justo abrazar el partido de darles el vino $y$ el aceite en especie, $y$ no en dinero, como se ordenó desde cl principio de esta concesión, en Real Cédula de Galapaz, a 26 de noviembie de 1571, y en otra de Madrid, a 18 de enero de 1575. De este modo habria menos interés, atendiendo a las estaciones que debían correrse para reducir estas especies a dinero; sería mâs fácil la justificación de cualquier fraude, y por último, en lo general, no se invertirían los piadosos destinos de esta real Iimosna, en perjuicio del Rey $\mathrm{y}$ de las iglesias regulares.

Párrafo tercero. - Cinco por Para la dotación de los sacerdotes docciento de Sínodos. trincros de las Misiones de Moxos y Chiquitos, se mandó rebajar por la Real Audiencia de Charcas, un $5 \%$ de los sínodos de todos los Curatos de la comprensión de esta Real Caja, por providencia de 17 de julio de 1775 , expedi- 
da a consecuencia de Real Cédula de 15 de septiembre de 1772 , porque el peso de tributo señalado a cada indio de los mandados empadronar por Real Cédula de Buen Retiro, a 17 de diciembre de 1743, no alcanzó en estos últimos tiempos para satisfacer a los Misioneros el sínodo de 200 pesos asignados para cada uno, por vía de congrua de sustentación.

También se descuenta de los sínolos un $3 \%$ del Seminario, conforme a la ley 35, Tít. 15 y ley 7, Tít. 23, Lib. 1" de Indias. La Real Audiencia de Charéas, en Real Provisión de 4 de man"zo de 1595 , mandó que hicicran la refención de este importe los Corregidores, por cuya mano se liacían antes los pagos de los sínodos, en observancia de la ley 19, Tít. 13, Lib. 1" de Indias. Ahora deben satisfacola en el Roino del Peru, los Oficiales hoales, en cumplimiento de nu Auto civeular del Visitador General, de 17 de mal'zo de $\mathbf{1 7 7 9}$, y de lo dispuesto novisimamente en el Art. 128 de la Real Ordenanza de 28 de enero de 1782.

Habićndose declarado que estos pagos deben hacerse en las mismas Tesorerías Reales, a los Curas o a sus apoderados, sin demora, por Jos Ministros de Real Haxienda, con expresa derogación de la ley 19 cjtada, Tít. 1\%, lib. $1^{n}$ de Indias, es consiguiente que la retención y descuento, así del $5 \%$ de los Misuteros de Chiquitos, como el $3 \%$ del Seminario, debe ejcentarse en las mismats Cajas Reales, para evitar recursos contra los Curas en la cobranza de estos descuentos; con cuya consideración se había ordenado por esta lntendencia, a solicitud del Ilmo. Sr. Arzobispo de Charcas, que se hagan en las Cajas Reales, para mayor seguridad.

El que mirase por de fuera estas pensiones, juzgará que se hallan sobremanera gravados los curatos. Yo concibo todo lo contrario, porque habiéndose dism nuido, si no todas, las demás Doctrinas de aquel númelo primitivo de indios con cuyo respecto se hizo la asignación de sínodos, no puede dudarse que los Curas deberian gozar menos cantidad de sínodos del que ahora pereiben, si se les hubiera de rebajar en proporción del número de indios tributajios que se encontrasen de menos en cada pueblo, como se resolvió en Real Códula de Buen Retiro, a 10 de noviembre de 1739.

Ya que no se pone en práctica esta justisima providencia, de que resultaria al Rey notable beneficio, en lo general de todas las provisiones del Perú, no deben estimarse agraviados los Curas, si por un arbitrio más político se llegase a gravar sus sínodos con algunas pensiones más de las que hoy sufren.

EI Sr. Don Francisco de Tolcdo, en provisión de 1572 y 1574, señaló a cada Cura 800 pesos ensayados, que al respecto de doce y medio reales, hacen 1.250 pesos, cuya cantidad llaman S'nodo entero. Rebajando el $8 \%$ de este total importe, quedan libres 1.150 pesos, que en la actualidad perciben muchos de los Curas de estas Provincias. Si se averigua el número de los tributarios a que sc ajustó esta dotación, son muchas las Doctrinas cue no guardan proporción. Por lo mismo, se hará menos sensible la rebaja prevenida por la citada Real Cédula de 1739 , si el todo o alguna parte del sínodo que debía rebajarse por razón del exceso se pensionase para el importantísimo objeto de aumentar Misiones en e] Partido de Tarija o para fortificar aquella frontera, dotando plazas militares efectivas que le sirvieran de guarnición.

Los sesenta y dos Curatos de esta Pronincia de Potosí, perciben 
anualmente la suma de 49.781 pesos madio real; los de fuera en al ramo de tributos; y los siete de esta Vilan, w la Real Hacionda. Pensionando este total importe con un $2 \%$ más, sobre los ocho releridos, debería descontarse de la gruesa de los sínodos, novecientos noventa y cinco pesos.

Con esta cantidad se pociria dotar. ma Compañia electiva de treinta blandengues, que guarneciesen un reducto o presidio bien fortificado, en alguno de los boquerones más frecuentados de aquella frontera, señalando veinte pesos a cada soldado, treinta $y$ cinco al Capitán, treinta al Teniente $y$ veinticinco al Alférez, con obligación de hacer correrías con los dos tercios de esta gente por el contón de los denés presidios de la frontera, así de los milicianos sin sueldo, como de los blandengues estipendiados, con el cargo de residir en el presidio principal, para estar más a la mano de las invasiones de los geritiles, manteniendo correspondencia con los Misioneros, para recibir col opurtuniclad los arisos que se les comunicasen de cualquier intento de hostilidad, que numen es reservado entre los infieles.

Párrafo cuarto. - Inválidos. Wi, ramo de Inválidos se colió en estas Cajas, desde el año 1776 hasta el 79 , en virtud de Carta del Excmo. Sr. Virrey de Lima, do :3 de enero del 76, consecuente a Real Orden de 11 de encro del 75 ; se exigian octho maravedies en cada peso, de los militares que no gozaban sueldo por sus grados y lo obtenían por oficios políticos, $\mathrm{y}$ de éstos los pagaban en quella parte que correspondía al puesto militar del grado que gozaban, como eran los señores Benavides y San Just, los Cor'regidores de este Distrito y los dos soldados de la guardia de dicho Si. Virrey, que hubo en es tas Cajas. Cesaron estas contribuciones en virtud de Carta del Tribunal Mayor de Cuentas de Lima, de 25 de septiembre del 77 , referente a Superior Billete de dicho Sr. Excmo., de fecha 2 del mismo mes y año; esto es, en orden a los Oficiales de Milicias, y que sólo se exigiese a los del Ejéreito de Su Majestad.

En la actualidad, está mandado por Real Orden de 22 de marzo de 1786, que corrobora la indicada de 14 de enero del 75,5 otra del $\mathrm{Sr}$. Intendente General de Buenos Aires, de 13 de septiembre del 86 , se hagan los descuentos de este ramo al mismo tiempo que del Montepío a las tropas veteranas que se hallan en estas provincias, $y$ a los Oficiales de los Ejércitos que sirvan de empleos mixtos o Corregimientos, Alcaldías Mayores, u otras puramento civiles, cuyos ajustamientos para la paga, por lo que hace a dicha tropa, están suspensos hasta tanto que de la ciudad de La Plata, donde reside la Plana Mayor del Dostacaniento de esta Villa, se den las razones conducentes a esta importancia.

Párrafo quinto. - Real Orden La Real y distinguida Orden española de de Carlos III. Carlos III, fue fundada por el Rey nuestro Señor, a 19 de septiembre de 1771 , cn celebridad del dichoso nacimiento del Sr. Infante, Carlos Clomente Antonio. $\mathrm{Su}$ Majestad es el Jefe Gran Maestre de esta Orden y perpetuamente los Señores Reyes que le sucedieren en el gobierno de la Monarquía. Los Caballeros, Grandes Cruces y Pensionados, las insignias de esta Dignidad 
y todas las demás pcrtenencias a esta nucva Orden, recogió eruditamente el Licenciado Don Manuel Martínez, en el tomo séptimo de la "Libre-

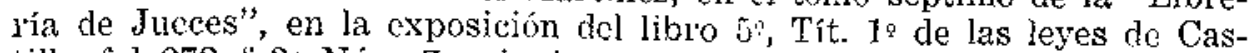
tilla, fol. $272, \$ 3 "$, Num. 7 y siguientes.

Para la pertencicia y perpetuidad de la dote anual de 40,000 pesos, señalados sobre las Mitras y Prebendas de algunas de las Santas Iglesias de Indias, para gastos y pensiones de esta distinguida Orden, se mandó deducir a prorrata lo que corresponda a las Vacantes Mayores y Menores, en los términos prevenidos en Real Cédula circular de 13 de diciembre de 1777 y en el Auto 180 de Ia Real Ordenanza de Intendentes.

En esta Caja no se tiene cuidado de hacer estas deducciones, porque las pensiones comprendon otras Provincias donde hay Ofieiales Reales propietarios, que deben estar a la mixa del cumplimiento y observancia de estas Reales resoluciones.

Párrafo sexto. - Depósitos. $\mathbf{D}_{\mathrm{E} \text { la materia de Depósitos que se hacen }}$ en las Cajas Reales, ya sea de herencias vacantes, mientras se averigua ol derecho de quien legítimamente debe adquirirlas; ya de los bienes que se estiman como dejados para derechos, ya de difuntos, ya de comisos y ya de otras cuaiesquiera clases, tratan detenidamente las Leyes Recopiladas de Indias. ${ }^{193}$ Este es un ramo que no pertenece a la Real Hacienda, cn el entretanto se maneja en calidad de depósito; pero, por el interés próximo o remoto que puede tener el fisco, se custodian los bienes on las Cajas Reales para su mayor seguridacl. No necesita este punto de explicación particular, porque sin disponer de los depósitos para ningún destino, se conservan íntegros a la disposición del Juez que los mandó hacer, llevándose de su entrada y salida una cuenta clara y distinta de los demás ramos.

Párrafo séptimo. - Tempora- Los regulares que se llamaron de la lidades. Compañía de Jesús, fueron extrañados de España y de sus Indias, por Real Decreto de 27 de marzo y Pragmática sanción de 2 de abril de 1767, con ocupación de sus temporalidades. Para el conocimiento de las materias de este grave negocio se formó un Consejo extraordinario, compuesto de celosos Ministros nombrados a elección de Su Majestad. En las capitales de provincia se establecieron varias Juntas, llamadas Provinciales, con la concurrencia del Presidente, Obispo, Oidor Decano, Fiscal, un Regidor y el Sínodo del Común, donde residía Audiencia, y de no, del Gobernador Obispo, del Asesor y del Procurador General del pueblo; erigiéndose on los demás lugares otras Juntas, nombradas Municipales, con absoluta dependencia de las Provinciales.

A estos Tribunales se les remitió una colección de providencias con fuerza de ley, para decidir todos los asuntos que ocurriesen, bien fueren sobre pleitos entre particulares y el Rey, o por el contrario, sobre aplicaciones de las temporalidades ocupadas, o ya finalmente sobre otras incidencias de este género.

Después se aclararon las pertenencias, se aprobaron las aplicaciones y demás destinos que se acordaron de estos bienes; se vendieron 
en público remate, con las mismas solemnidades que cualquier ramo de la Real Hacienda, y so fueron enterando los valores on las respectivas Cajas Reales, a disposición de las Juntas Provinciales, según las providencias dadas por el Rey para los objetos píos a que se destinó últimamente estos caudales.

Ia Caja Real de Potosí, cumple los Libramientos de la Junta Provincial de La Plata, auxiliada por el Intendente de esta Provincia. Es poco o nada lo que mantiene perteneciente a este ramo, porque estos países no son a propósito para haciendas, en rue tenían todo su fuerte los regulares expatriados; por lo que no es monester dilatarnos más en el comento de este punto.

1.-En 1524 se formó el Supremo Consejo de lasindias; se establecí́ el Tribunal de la Contratación, en Cédula a 7 de febrero de 1502.

2.- Escalona, en su Gazofílacio, Lib. 1, Cap. 10, fol. $1^{*}$, No. 1.

3.- Solórzano, en su Política, Lib. 6, Cap. 15, No. 1 hasta 3 inclusive.

4.- Escalona: en Gazofilacio, Lib. 1", Cap. 1", No. 3 hasta 5.- Solórzano: en sul Política, Iib. 6", Cap. 15, No. 4.

5.- Solórzano: en su Política, Lib, 6", Cap. 15, No. 5. Escalona, Lib. 17, No. 5.

6.- Solórzano: in Política, Lib. 6", Cap. 15, No. 6 hasta 9.-- Escalona: in Gazofilacio, Lib. $1^{\circ}$, Cap. 2, No. 2, párrafo antepenúltimo, fol. 5.

7.- Escalona: in Gazofi]acio, Lib. 1", Cal. 3" hasta 35, desde el fol. 7 hasta el 144.

8.- Ley 11, Tít. $3^{\circ}$, ley 2 , Titit. 7 , Lib. 4 de Indias.

9.- Solórzano: Política, Lib. 6\%, Cap. 15 desde e! No. 10.- Escalona: in Gayofilacio, Lib. $1^{\circ}$, Cap. $1^{\circ}$ y siguientes, fol. 1. Véanse al fir del libro las Ordenanzas de Oficiales Reales.

10.- Ley 8 , Tít. 24, Lib. 4" de Irrdias.

11. - Ley 9 , Tít. 8, Lib. $8^{\circ}$ de la liecopilación de Indias - Solórzano, calcula el nismo valor de $\operatorname{los} 13$ y $1 / 4$ reales en cada peso. Politica, Lib. 6\%, Cap. 19, No. 3 , fol. 242 , tomo $2^{\circ}$.

12.- Escalona: en Gazophil., Lib. $1^{\circ}$, parte $2^{\circ}$, Cap. 12, No. 4 al medio, dice que se ha de reducir cada cien pesos ensayados a 14.3 pesos de a 9 reales, fol. 34.

13.- Escalona: in Gazophil., Lib. $1^{\circ}$, párrafo 2, Cap. 1\%, No. 2.- Solórzano: in Política, Lib. $6^{\circ}$, Cap. 15, 12, 17, tomo $2^{4}$, fol. 507.

14.- Peregrino: De Jure fisei : Lib. $6^{\circ}$, Tit. $3^{\circ}$, No. 1, fol. 173.

15.-Peregrino: De Jure, Lib. $7^{\circ}$, Tít. $1^{\circ}$, No. 1.

16.-- Solórzano: in Política, Lib. $6^{\circ}$ cito. Cap. 15, No. $1 \mathrm{t}$.

17. - Ley 2, Tít. $3^{\circ}$ Libs. 14, 19, 23 y 24, Tít. $8^{\circ}$, Lib. $8^{\circ}$ de Indias.- Ley 14, Tít. 12, Lib. $5^{\circ}$ de la misma Recopilación.

18.- Escalona: Lib. 19, Parte 2", No, 2.- Solórzano: in Política, Lib. 6, Cap. 15, No. 17.

19.- Solórzano: loco citato, No. 11.

20.- Herrera Década $8^{\circ}$, Lib. $8^{\circ}$, Lib. $7^{\circ}$, No. 18.

21.- Torquemada: Monar. Indiana. Lib. 5, Cap. 2 al 4, Tom. 1\%, fol, 588.

22.- Ruy Diaz de Guzmán: Historia del Paraguay, Lib. 20, Cap. 4 y 5.

23.- Escalona: in Gazophil, Lib. 1", Cap. 1", No. 1.

24.- Solórzano: in Política, Lib. $6^{\circ}$, Cap. 15, No. 11 y sisuientes.

25.- Escalona: Lib. $1^{\circ}$, Parte $2^{\circ}$, desde el Cap. $1^{\circ}$ hasta 10.

26.- Escalona: Cap. $6^{\circ}$ del Lib. $1^{\circ}$, Parte $2^{\circ}$ del Gazophil.

27.- Solórzano: Lib. $6^{\circ}$, Cap. 15, No. 12, sobre preeminencias de los Oficiales Renles.-- Vide Escalona, Lib. $1^{\circ}$, Parte $2^{n}$, Cap. 18, fol. 47.

28.- Solórzano, en lugar citado.

29.- Ley 4, Tít. 10, Lib. $4^{\circ}$. Ley 13 , Tít. 3\%, I ib. $5^{\circ}$ de Indias.

30.- En Real Provisión de la Audiencia de Charcas, de 14 de julio de 1757, a favor de los Oficiales Reales de Jujuy.

31. - Real Cédula fecha en Ralzaín, a 16 de junio de 1722 .

32. - Parlad ${ }^{\circ}$ : Lib. $2^{\circ}$, Rerum quotidiam, Cap. final; $5^{n}$ parte, Nos. 10 y $26, y$ otros muchos citados por Barbosa. Voto 4, No. 35.

33.- Ley 7, Tít. 26, Lib. $8^{\circ}$ de Indias. 
34.- Ley 28, Tít. 1\%, Lib. $8^{\circ}$ de Indias.- Ordenarza 24, Tit. 27, Lib. 10 de las Generales del Perú. En autos acordados del Superior Gobiemo de Lima, de 2 de jurio de 1750,5 de marzo y 19 de octubre de 1759 y 22 de abril de 1760 , se mandó que lus cuentas de los Corregidores, las tomen, ajusten y sentencien los Oficiales Reales de las Cajas respectivas, y se revean en el Tribunal de cuentas.

35.- Leyes 11, 12, 13, Tit. $33^{\circ}$, Lib. $8^{\circ}$; Ley 159, Tit. 15; Ley 24, Tít. 16, Lib. $2^{\circ}$; Ley 56 , 'Tít. $3^{\prime \prime}$, Lib. $3 "$; Ley 17 , Tit. 14, Lib. $3^{\circ}$; Ley 1 , Tit. $8^{\circ}$, Lib. $8^{\circ}$ de Indias.

36.- Escalona: Lib. 1", Parte 1", Cap. 4", caso 1\%, fol. 13.- Solórzano: en su Política, Lib. $6^{\prime}$, Cap. 15, No. 30 .

37.- Leyes 2,3 y 4 , Tít. 25, Lib. $8^{\circ}$ de Indias.

38.- Ley 20, 'Tít. 18; Ley 132, T'it. 15, Lib. 2'- Ley 57, Tít. 3\%; Ley 6, Tít. 7, I,ib. $3^{\prime \prime}$ de Judias.

39. - Leyes 13 y 14 , Tit. 28 , Lib. $s^{2}$ de lndias.

$40 .-1$ Ley 12, Tít. 28 , Lib. $3^{\prime \prime}$ de Indias.

41.- Ley 12, Tít. 27, Lib. 8" de Indias.

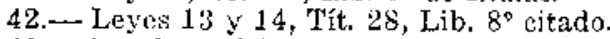

43.- Escalona: Lib. $1^{\circ}$, l'arte $2 "$, Cap. 17 y 18 , fol. 44 y siguientes.

44.- Escalona: Lib. 2", Parte 2", Jul. 93.

45. - Escalona: Lib. 24, Parle 2", desde oI Cap. 1 hasta el 36, fol. 96 hasta 284.

46. - Solórzano: in Polílica, Ijib. 6", Cap. 1", desde el No. 19 hasta 33 , tomo $2^{\circ}$, fol. 427 hasta 430.-- Escalona: ju Crazophil,, Lib. 2", Parte 2, Cap. 19 per totum, fol. 96.

47. - Escalona: en el lugar citato, No. 4 al fin.

48.- Los nuevos poblados y algunas Mitas tienen el privilegio de quintar al diezmo seyún lass leyes 19 y 24 , Tit. $3^{\circ}$, Lib. 4, ley 53, Tít. 10, Lib. $8^{\nu}$ de Indius.

49.- Escalona: Lib. 1\%, Parte 2:, Ciap. 11.

50.- Hita heal Orden es conforme a la ley 14 , Tít. $6^{\circ}$, Lib. 20 y 52 , Tít. 10, Lib. $8^{\circ}$ de Indias. Aunque de estas remisiones de pastas resultaria minorarse la labor on las Casas de Moneda del Remo, y a proporción la granancia siempre la tendrá el Rey en las Casas de Jispaña, donde se labrare. Bien que, quedando pocos sobrantes en la Tesorería General de Buenos Aires, convendría reducir el envío de pastas a la previa cantidad de los residuos que deben ir a España, para no malbaratarlos en Buenos Aires, cambiando las barras en moneda.

51 - Ley 19 , Tít. 10 , Lib. $8^{\circ}$ de Indias.

52.- Escalona: Lib. $2^{n}$ ie Gazophil, 1’arte $2^{\sharp}$, Cap, 1", No. 12, fol. 98.

53.- Escalona: Lib. 2", Cap. 1", No. 17 hasta 19.

54.- Por Decreto del Superior Gobierno, de 22 de agosto de 1755 , se mandó guardar la práctiea que informaron los Oficiales Reales de I,ima, de avaluarse la vajilla a razón de seis posos por marco para el diezmo.

55. Por el antecedente Decreto ae mandó guardar la costumbre de cobrar el 1 y $1 / 2$ to de cobos de chafalonía que se funde para hacer barlas, arreglando su precio a razón de 8 pesos.

56.- Así estaba prevenido en el Decreto antecedente.

57.- Por Real Cédula de San Ildefonso, a 5 de septiembre de 1753.

58.- Según la planilla remitida de Lima a estas Cajas, con fecha 26 de marzo de 1753 .

59.- Decreto del Superiox Gobierno, de 2 de agosto de 1755 .

60.- La ley 11, 'Tít. $8^{\circ}$, Lib. $8^{\circ}$ de Indias, trata del valor del oxo.

61. - Escalona: Lib. ' $2 \%$, Parte $2 "$, Cap. 1\%, \$ Quinto, del oro, fol. 99.

62. - En 18 de agosto y 23 de noviembre de 1753.

63.- De la colonia del Sacramento, a 8 de julio de 1777 .

64.- Vćase el fin del nuevo Reglamento para el comercio libre, fol. 257.

65. - Ahora conviene más esta precaución, por la absoluta libertad que tienen los comerciantes de sacar el oro por su. cuenta para España, en rirtud de la última Real Orden de 15 de septiembre de 1786.

66.- Escalona: Lib. $1^{\circ}$, Parte $1^{\circ}$, Cap. 35, fol. 189, No. 58 hasta 60.

67.- Escalona: Lib. 2\%, párrafo $2^{\circ}$, Cap. 10, fol. 159 hasta 174.- Solóxzano: in Politic., Lib. $6^{\circ}$, Cap. 13, No. 4 y siguientes, fol. 484,-- Larrea: Allegac 86, fol. 69, y Allerac: 98 , fol. 113 .

68. - Art. 62 de la Real Ordenarya de Intendentes. Fiste caso toca a la administración por mayor, según Escalona, Lib. 1. ${ }^{\circ}$, Cap. 11, Parte 1*, fol. 36. 
69. - Estas dilig'encias se hallan prevenidas por las leyes 14,22 y 24 , Tít. 20, leyes 11, 14 y 15, Tít. 21, L.ib. $8^{\circ}$ de Indias. Aunque el Art. 145 indica que la tasación del valor se debe posponer a los pregones, lo contritrio se atvierte en la ley 23, Tít. 20, Lib. $8^{\circ}$ de lndias.

70.- Escalona: Lib. 2", Parte 2n, Cap. 10, fol. 159.

71.- Ley 10, Tit. 19, Parte 6?.

72 .. Ley 60, Tit. 18, l'arte $33^{n}$.

73.- Escalona: Iib. 1", Parte 2", Cap. 16, No. 13, fol. 41; Lib. 1", Parte 1", Cap. 25, caso 22, No. 39.- Alfaro: De Of, físcalis, glos 34, s 1", fol. 267 .

74.-. Ord. 4, Tit. 5*, Ord. 19, Tít. 35, Lib. ${ }^{\circ}$ del Perí.- Leyes 3 y 4, Tít. 25, Lib. $8^{\circ}$ de Indias.

75. - El Sr. Marqués de Montesclaros dispuso este propio or'den, en Provisión del Callao, a 21 de marzo de 1613.

76.-Peregrino: De Jure Fisci, Lib. $6^{\circ}$, Tít. $4^{\circ}$, No. $^{\circ}$, \$ in partibus, fol. 176.

77.- Valenzuela explicando la ley $4^{n}$, Tít. 22 , Lib. $8^{*}$ de Indias. Fon el Lib. $2^{\circ}$ de la Polit. Indiana, Cap. 28, No. 48.

78. - Por Real Cédula de Buen Retiro, a 17 de diciembre de 1759 , se decłaró que el término de la ley debía contarse descle el que se hiciere saber la renuncia al interesado no antes.

79.- Escalona: Lib. 1", Parte $1^{4}$, Cap. 11, caso 89, No. 1 hasta 5.

80. - Solórzano: Lib. $2^{\circ}$, Cap. 19 y 20 , Tom. $1^{\circ}$, fol. 152 hasta 164.

81.- En el original no aparece la nota correspondiente. (N. de E.).

82.- Véase la Noticia $2^{\circ}$, Parte $2^{\circ}$, Cap, $1^{\circ}$.

* Véase el Fstado No. 6, pág. 314 de este líbro: (Nota de E.).

83.-Peregrino: De Jure Fisci, Lib. $6^{\circ}$, Tít. $7^{\circ}$, Nos. 12 y 13 , fol. 194.

84.- Escalona: Lib. 20, J'arte 2", Cap. 19, No. 1, fol. 201.

85. - Escalona: Lib. 26, Parte $2^{4}$, Cap. 19, per totuni, fol. 201.

86,- Ustáriz: Cap. 58, fol. 147, Cap. 8\%, fol, 245, Cap. 10i, fol. 390.

* Voz quichua que significa: hombres grandes. (N. de E.).

87.- Escalona: Lib. 2\%, Parte 2", Cap. 19, No. 3.

88. - Consta de una Provision de 25 de abril de 1574.

89.- Escalona: in Gazophil., Lib. 2\%, l'arte $2^{n}$, Cap. 2", Palabra Minas de S. M., fol. 99, y en el mismo Lib., Cap. y 'Mar, Tít. $1^{\circ}$ de las Ordenanzas de Minas, No. 18, fol. 108 .

90.- Gamboa: En su Comentario de las Ord. de Minas, Cap. 2\%, No. 18.

91..- Escalona: Lib. $1^{\circ}$, Cap. 15, caso 12, fol. 57.

92.- Escalona: loco citato.

93.- Escalona: Lib. 2", Parte 2", fol. 100.

94.-Carrasco: Cap. $3^{\circ}$, de Inmunit. Ecletiar., $\$ 22^{\circ}$, No. 1.1, fol. 45.

95.- Escalona: Lib. 2\%, Parte $2^{\circ}$, Cap. 20 , fol. 203 hasta 212 , y en el Lib. $1^{\circ}$, pág. 1 , Cap. 25, caso 22.- Solórzano: In Polít., Lib. 6", Cap. 12 per totum., Toul. 2", fol. 480 .

96.- Auto 4, Cap. 33 , Tít. $1^{\circ}$, Lib. $4^{\circ}$, Auto $1^{\circ}$, Tit. 10, Lib. $5^{\circ}$. La ley do Don Alfonso VI., es la $7^{\circ}$, Tít. $9^{\circ}$, Lib. $5^{\circ}$ de la Ordenanza.

97.-Olea: De cetione Juris, Tít. $2^{\circ}$, Cuest. 4, Resolut. 3 y 10, púx. 59.

98. - Solórzano: in Politic., Lib. $2^{\circ}$, Caj. 24, No. 39 hasta 45.

99. - Esta piáctica debe observarse como conforme al Art. 145, que dispone lo propio para el caso equivalente.

100.-- Escalona: Lib. 1\%, Cap. 25, caso 22, No. 39, fol. 103.

101.- Solórzano: Lib. $5^{\circ}$ de su Política, Cap. 13, No. 48, fol. 385.

102.- Escalona: Lib. 20, Farte $2^{2}$, Cap. 36 trata de las medias anatas.

103.- Thusco: Let. A. Concluc. 398 , No. 10.

104,- Escalona: Lib. 2", Parte 2", Cap. 36, fol. 256.

105.- Escatona: Lib. $2^{\circ}$, Parte 2", Cap. $4^{\circ}$, fol. 136, y Cap. 29 , fol. 224.

106.- Barbosa: fol. 120 , Lib. 3 ?

107.- Pérez de Lara: Compendio de las tres gracias, fols. 6, 130 y 147.

108.- Escalona: Lib. 2", Parte 2a, Cap. 34, fol, 240.

109.- Solórzano: in Politic., Lib. 4\%, Cap. 25, No, 10 al fin, Tom. $2^{\circ}$, fol. 220.

110. - Estas Ordenanzas corren al fol, 322 de las Generales del Perú.

111.- Solórzano: Lib. $4^{\circ}$, Cap. 25, per totum.- Pérez de Lara, en su Compendio de las tres gracias.

112.- Leyes 38 y 39 , Tít. 19 , Lib. $8^{\circ}$ de Indias.

113.-- Ley 30, Tít. 15, Lib. 8" citado. Leyes 19 a 22, Tít. 34, Lib. $9^{\circ}$ de Indias. 
114.-- Solórzano: in Politic., Lib. $6^{\circ}$, Cap. 10, No. 7, Tom. $2^{\circ}$, fol. 472 . Véase Dic. Español palabra "Aduana".

115.- Solorzano: in Tolit., I,jb, $6^{\prime}$, Cap. $0^{\circ}$, Nos. $3 \mathrm{y} 4$.

116.- Solórzano: in P'olit., Jib. 6", Cap. 9", No. 8.

117. - Solórzano: in Polit., T.ib. 6", Cap. 8\%, Nos. 16 y 17.

118.- Solórzano: ibidem, No. 19.

119.-. Ulloa, en su Viaje, Tom. $4^{\circ}$, No. 175 , fol. 116

120.-- Solórzano, Jib, $6^{\circ}$, Cap. $8^{\circ}$, No. 19.

121 - Escalona, Lib. "2", l'arte 2", Cap. 9", fol. 143, No. 2.

122. - Solórzano: J.jb. $\left(5^{4}\right.$, Cap. $8^{4}$, No. 20.

123.- Solórzano: Lib. 6\%, Cap. 11, No. 9.

124.- Don José Vastía: Lib. 1", Cap. 18, No, 2 ,

125.- Solórzano: in Trolit., Lib. 6", Cap. 14, No. 7, Tom. 2", fol. 405.

126.- Hista Iueva l'solución se cita en el $A r t$. 129 de la Ordenanza de Intendentes.

* Por omisión, sin duda, en el original no se halk consignada la cantidad en cue se arrendaban las alcabalas de Porco. - (Nota de Ed.).

127.-Peregrino: De jure İisci, Lib. $6^{\circ}$, Tit. $5^{\circ}$, No. 17, fol. 184.

128.- Escalona: Lib. 2", I'srte 24 , Cap. $9^{\circ}$, per toium, fol, 146.

129.- Solórzano: I,ih. $6^{\prime \prime}$, Cap. 8", Tolu. $2^{\circ}$, Fol. 461.

190. - Fista franquicia so decláró por la Real Audiencia de Lima, en auto de revista de 12 de marzo de 1687 , reprociucito en otro de la de Charcas, a 4 de abril de 1704. Wste mijamo prisilegio se concedió a los indios de Buenos Aires, en Real l'rovsión sobrecurtada de la Aud. de Charcasts, en $1^{\circ}$ de junio de 1655 , nianduda ghaudir en Real Cédula de Madrid, a 4 de julio de 1684.

131. - Don Pedro Varela y Ulloa, Sobre las reflexiones imparciales del Abate Nuix, s 12 , Reflex. 1, tol, 103 , Jetua L, marginal.

132. - Asi lo declaró ef Wximo. Sis. Virrey de Limá, Don, Manuel de Guirior, en 16 de noviembre de 1778 .

133.-Ustáriz: Teoria y Práctica del Conercio, Cap. 54, fol. 134, columna 2.

134.- Antúnez: Te Torration, Lib. 3", Cap. 24 , Nos. 2 y 3, Tom. $2^{\circ}$, fol. 255.

135.-., Solórzano: in Politic., Lib. 6", Cap. 11, No. 10, Tom. 2甲, fol. 478.

136.- Escalona: Lib. 2", Parte 2", Cap. 13 , fol. $18 \%$.

137.- Solórzano: Lib. 6", Caj. 11.-- Antúnez: Lib. 2, Cap. 18, No. 22, et Lib. 3, Cap. 34, No. 1,‥ Peresrino: De Jure Fisei, Lib. $4^{\circ}$, Tít. $8^{\circ}$ per tot., fol. 119.

138. - Tey 2, Tít. 25, Lib. $2^{\circ}$.

139.- Ley 19, 'Tít. 25 , Lib. 2 nitado.

140.- Lcy $8^{\circ}$, y 39 , Tít. 25, Lib. $2^{*}$ de Indias.

141.- Ley 39 , Tít. 25, Lib. 2" citado.

142. - Ley 40 , Tít. 25, Lib. $2^{n}$ citado.

143.- Real Cédula de 12 de mayo de 1743, recopilada en el Auto 2, Tít. 26, Lib. 89 de los Acordados de Castilla.

144.- - Real Cédula de 19 de noviembre de 1773 .

145. - Reat Cédula de 20 de jullio de 1776 .

146. - Jerónimo de León, en la Decis., Valentina 154, Nos. 5 y 6.- Larrea, en la Decis. Granatense 1 , No. 20.- Vela en la Prec., Cap. $1^{\circ}$ de Ofic. Judiensis Ordinaxio. Part. $1^{\circ}$ de Episcop. 11-118, Tom. $2^{\circ}$, pág. 344.

147.- Solórzano, en su Polit. Lib. $4^{\circ}$, Cap. $7^{\circ}$, No. 41 , Tom. $2^{\circ}$, fol. 47.

148. - Vide Trat. de Patronat, Cap. 86, No. 18, Tom. $2 \%$, fol. 275.

149.- Ramiro Valenzuela: en la Jlustración de Solórzano, Lib. $4^{\circ}$ de su Polit., Cap. $8^{\circ}$, No. 86.

150.-Cobarrubias: Primo variar. Cap. 16, No. 8.

151.- Peregrino: De jure fisci. Lib. $4^{\circ}$, Tít. $8^{\circ}$, Nos. 12 y 13, fol. 120. Vide Valero, Revitarium fiscalium, \$ 5 , Tít. 29 , No. 11.

152.- Solórzano: in Polit. Lib. 4", Cap. 4", No. 29, Ton. 29, fol. 24.- Escalona, en su Gazophil., Lib. 2", Parte 2", Cap. 32, fol. 236.

153.- Art. 263 de la Ord.

154. - Arts. 157, 167 .

155.- Art. 167 .

156. - Art. 163.

157.- Frazo: De Reg. Patronat., Cap. $7^{\circ}$, No. 55 y siguientes, Tom. $1^{\circ}$, fol. 110.

158. - Leyes 1, 2 y 3 , Tit. $4^{\circ}$, Lib. $1^{\circ}$ de Indias.

159. - Real Decreto de 27 de julio de $1760 .-$ Real Cédula de San Lorenzo, a 21 de agosto del misumo año.- Real Cédula de El Parío, a 20 de enero de 1752. 
160.- Es expresa la prevención del Art. 195 de la Ordenanza de Intendentes, encargando este cuidado a los de cada Provincia.

161.- Escalona: Lib. 2\%, Yarte 2*, Cap. 32, § 2, No. 9, fol. 238.- Art. 129 de la Ord. de Intendentes.

162.- Gazophil., Lib. 2", Parte 2", Cap. 32, \$ 2, No. 4, fol. 238, y Cap. 9", \$ 1, No. 4, fol. 152.- Carrasco: De Leges, Recopilación, Cap. 6", 8 , No. 6.-. Lagu. nes: De fructibus, $2^{*}$ Parte, Cap. $7^{\circ}$, No. 30 . Olea: De cetione, Tít. $6^{\circ}, \mathrm{Q} .3^{*}$, At., No. 2, pág. 341.

163.- Axtículo 192 de la Ordenznza.- Los Párocos esián oblixados solamente al pago de la mesada, aunque las rentas de sus Curatos lleguen y excedan de la expresada suma, según el Art. $6^{\circ}$ de la Instrucción de 31 de julio de 1777 , cit. en el Art. 182.

164.- Art. 190 de la Orderanza.

165.-. Art. 191.

$166 .-$ Axt. 188.

167. - Escalona: Lib. 29, Parte 2", Cap. 35, fol, 251.

168. - Card. de Laca: De Beneficis, dise. 89, No. 2, Tom. 12, fol. 143.

169. - Fermosinos in Cap. Ecclesie Destmo. de Constitutionibus, Q. 19, No. 22, tomo 10, fol. 340 .

170.- Fagnano: in Cap. Preterea Decmo. cte., No. 14, al fin, Tom. $3^{\circ}$, fol. 69.

171. - Loco citato: No. 10.

172.- Van Espen: De Jure Ecco., Parte 2", Tít. 24, Cap. $4^{4}$ desde el $\$$ 18, Tom. $2^{\circ}$, fol. 82 .

173.- Art. 192 de la Ordenanza.

174.- Art. 10 de la instrucción citada en el Art. 182 de la Ordenanza.

175.- Art. 178.

176.- Ley 13, Tít. $8^{*}$, Lib. $5^{\circ}$ de Castilla. Ley 6, 'T'́t. 12, Lib. $1^{\circ}$ de Indias. Ley 53 , Tít. $6^{\circ}$, parte $1^{7}$.

177.- Abrea: Sobre vacantes, Parte 5\%, $\$ 1^{\circ}$, No. 684 , fol. 328 hasta fol. 357.

178. - Escalona: Lib. ${ }^{\circ}$, Cap. 31, fol. 127.

179. - Escalona: Lib. $2^{\circ}$, Parte $2^{\circ}$, Cap. 9*, fol. 24, y Cap. 13, fol. 81.

180.- Solórzano: in Polit., Lib. 6", Cap. 19, Nos. 25, 26 y 27, Tom. 2*, fol. 509.

181.-- Peregrino: De jure Fisci, Jib. $6^{\circ}$, Tít. $4^{\circ}$, fol. 176 .

182, - Peregrino: De jure Fisci, Lib. 6\%, Tít. $3^{\circ}$, No. 3 , fol. 173 , et Lib. $6^{\circ}$, Tít. $4^{\circ}$, Nos. 10 y 11, fol. 176.

183.- Muchos autores, con Abreu, en su "Victima I,eg.", 1" P., Art. 2, No. 273, Tít. E. fol. 140.- Ley 41 , Tít. 7", Lib. $1^{\circ}$ de Indias.

184.- Abreu, obr. cit., 274 .

185.-- Solórzano: "Polit." Lib. 4", Cap. 22, No. 7, fol. 185.

186.- Lagunes: "De fructibus", P. 1", Cap. 21, No, 214, y en otras muchas partes de este célebre tratado.

187.-Frazo: Cap. 21, No, 26.- Ramiro Valenzuela, en "La Polit. Ind,", Lib. 4", Cap. 11, No. 51.

188.-- Abreu, en su "Victima Legal" per totum.

189.- Leyes $5,15,16,41,50,51$, Tít. $7^{\circ}$; Leyes $2,3,5,6,8,10$, Tít. 18, Lib. $1^{\circ}$ de Indias.

190.-- Solórzano: "Polit.", Lib. 4", Cap. 12, No. 5 y siguientes.— Escalona: Lib. 2", Parte 2a, Cap. 23, fol. 233,- Abret, en su "Víctima Legal", fol, 328.

191.- Para este mismo fondo se asigna en el Art. 181, la tercera parte del producto líquido de las Vacantes mayor'cs y Menores de las Iglesias de Indias, bajadas las cargas legítimas de todo el ramo, ordenándose la recaudación de este importe como los demás del mismo Monte; pero estas Cajas no tienen este cuidado porque en su distrito no reside Iglesia Catedral ni Coro Canonical.

192. - En virtud de Cédula Real de 5 de julio de 1671, se pagaba de estas Cajas a Jos seis Conventos de Franciscanos de l'otosf, Chuquisaca, Cochabamba, Tarija, Mizque y pueblo de Pocona, $151 \mathrm{y} 1 / 2$ botijas de vino de Locumba, para misas, a razón de botija y media para cada uno de los religiosos sacerdotes de estos Conventos; con unás 12 botijuelas de aceite a cada Convento, regulando la botija de vino a 10 pesos y la de aceite a 5 pesos.

193.- Ley 3 , Tít. $4^{\circ}$, ley 80 , Tit. 32 , Lib. $2^{\circ}$ - L Ley 13 , Tít. $6^{\circ}$, ley 7, Tít. 12, ley 6 , Tít. 17 , Lib. $8^{\circ}$ - Ley 44, Tít. $1^{\circ}$, ley 13, Tít. 14, ley 20 , Tít. 14 , Lib. $9^{\circ}$ de Indias.- Vide Solórzano, in "Jolit.", Lib. $6^{\circ}$, Cap. $6^{\circ}$, al No. 13 y siguientes, Tom. 2\%, fol. 454. 


\section{CAPITULO TERCERO}

\section{De las estaciones de la Real Hacienda}

$\mathbf{L}_{A}$

A distinción de orden y clases con que se han enumerado los miembros y ramos de Hacienda, que se administran, recaudan y entran en las Peales Cajas de Potosí, denota la propiedad con que se llaman Estaciones de Real Hacienda, porque cada una tiene su administración particular, su cuenta separada y su destino diverso.

Cada ramo, aunque sea miembro de un mismo patrimonio, tiene particular a distintos objetos y sufre separadamente las consignaciones dispuestas por Su Majestad, del mismo modo que hacen sus oficios los miembros en un cnerpo, sin confundir las opcraciones de los unos con las de otros; porque la consonancia del mismo todo, exige que las partes hagan sus servicios con distinción, para evitar el desorden que se seguiría de proceder todas juntas a una misma obra.

Ia buena economía y distribución de cada ramo, resiste la invención de sus destinos para que se eviten confusiones y recuentos en las cuentas de este género, l'eteniendo cada cual estrechamente su cargo y data. Por este fin está prohibido que las 'consignaciones de un ramo se suplan de otro y lo que se debe en una Caja se pague de otra, como sería satisfacer de Novenos lo consignado en Tributos, o en la Caja de Cochabamba lo debido en Potosí.

A más de las Cédulas y providencias que cita nuestro Escalona, 1 confirmatorias de la observancia de estas estaciones, se ratificó lo mismo por Real Cédula de 20 de abril de 1771, dirigida al Capitán General de Buenos Aires, con motivo de haberse gastado mucha parte de los arbitrios de aquella capital en la composición de la moneda, declarando que ni el Gobernador ni el Cabildo pueden invertir los arbitrios destinados a ciertos y deter'minados fines. 
Se mira con tanto rigot esta buena economía, que tampoco se admite compensación de una Estación con otra; cono si alguno fuese deudol al ramo de Tributos y acreedor en el de Alcabalas, no puede hacer el pago por vía de compensación ni concuasarse un débito con otro, según lo opina Escalona por más seguro, 2 y lo deciden expresamente la ley 26 , Tít. 14 , parte $5^{\natural}$, Ia ley 18 , Tít. 28 , Lib. $8^{\circ}$, y la ley 22 , 'rít. $8^{\circ}$, Lib. $9^{\circ}$ de la Recopilación de Indias.

Cuando la deuda y el erédito recaen en un mismo miembro de Real Hacienda, da a entender Escalona, que tiene lugar la compensación; pero aun en este caso la excluyen con tanta generalidad los Sres. Solórzano, Balmaceda, Acevedo, Lizarte y Escobar, " que segín estos autores nada deberia pagarse al acreedor que también sea dendor fiscal, aunque tenga Libranza, hasta haber satisfecho a la Real I-Iacienda, por considerarse a'ésta siempre solvente en cualquier acontecimiento.

Ultimamente, la Nueva Ordenanza de Intendentes, queriendo evitar el costo de dos conducciones inutiles que sufría la Real Hacienda, tratándose de caudales de dos Tesorerias de distintas Provincias, resuelve en el Art. 103, que habiendo débitos entr'c unas y otras, se permuten recíprocamente, anticipando aviso a la Superintendencia de Buenos Aires, como se declaró en Orden Superior de 16 de abril de 178.5. Fn csta conformidad, cuando la Caja de Charcas debe alguias cantidades a la de Potosí, por cualquiera de los ramos peculiares a su administración o por los que debe vaciar aquí para su envio a Bucnos Aires, y al mismo iiempo tiene que entregar la Tesorería de esta Villa algunas cantidades a un vecino de La Plata, se practica ahorrarle al Rey el costo de aquella conducción, librando al interesado, contra los Oficiales Reales de Chuquisaca, a quienes se pasa en abono otra tanta cantidad por inedio de esta permuta, con la calidad de comunicarse aviso a la Superintendencia General del Río de La Plata, con arreglo a la citada Ordenanza y su respectiva Declaración.

1.-Escalona: Lib, $1^{\circ}$, Cap. 36, fol. 145, y Lib. 2, Parte 2a, Cap. 11, fol, 32.

2.- Escalona: Lib. $2^{\circ}$, Parte $2^{4}$, Cap. $8^{\circ}$, No. 5, fol. 24 , y Cap. 11 , No. 7 , fol. 33.

3.- Solórzano: in Política, Lib. $2^{\circ}$, Parte $2^{3}$, Cap. 21, No. 28. Balmaceda: De Colectis, cuest. 110.- Acevedo: in Lib. 5", Tít. $7^{\circ}$, Lib. 9", No. 3,-- Lazarte: De décima vendit, Cap. 8", No. 36. - Escobar: "De ratio", Lib. 2", Cap. 36, No. 5. 


\title{
CAPITULO CUARTO
}

\section{De los libros de la Razón General de la Real Hacienda}

\begin{abstract}
A
la distinción de ramos que componen la masa general de la Real Flacienda, es consiguiente ja diversidad de libros que instruyan separadamente la cuenta de cada uno de ellos; para que ésta sea más clara y metódica, la recaudación más pronta y expedita, y en cualquier tiempo más fácil la averiguación de las pertenencias fiscales y de los fraudes de los Ministros.

Nuestro Escalona ${ }^{1}$ insume un capítulo integro de su "Gazophilacio", en referir los libros que los Oficiales Reales deben tener para el manejo del Real Erario; explica sus diferencias y advierte el método de llevar las cuentas con claridad y expediente.

Fuera de los libros que debe haber en la Caja Real de cada Provincia, para la Administración de los ramos, rentas y derechos pertenecientes al Rey, en su respectivo distrito, dispuso el Sr. Don Franciseo de Toledo, siendo Virrey del Perú, que en la capital del Virreinato hubiese un Libro de la Razón General de la Real Hacienda, de todo su territorio, donde se fizera asentando con claridad y distinción toda la Hacienda Real de cada ciudad, mediante una razón que los demás Oficiales Reales de tierra deberían enviar, para que sirviese como cabeza y tronco de todas las rentas distribuídas al cal'go de las Cajas particulares del Virreinato.

Esta adrirable propuesta, con las instrucciones que formó aquel gran Virrey, de quien hace memoria nuestro Escalona, ${ }^{2}$ (con el sublime elogio de no haber errado en cosa alguna tocante a la Administración $y$ Gobierno de estos Reinos) se aprobaron por diferentes Cédulas, que cita $y$ transcribe el referido autor; pero no han bastado los reiterados encargos, que se han reproducido en otras posteriores y en las leyes del título $7^{\circ}, \mathrm{J}$.ib. $8^{\circ}$ de Indias, para haberse efectuado la formación de dicho Libro General de la Real Hacienda.
\end{abstract}


Entre todos Ios medios de mejoral el mancjo de los ramos del Real Erario, nada se estimó tan conducente a su logro como cl establecimiento del libro propuesto por el Sr. Virrey Toledo. En este concepto previene su formación sin demora el Art. 104 y el 105 de la Orienanza de Intendentes, prescribiendo reglas y advertencias especificas para ello, con el encarecimiento de que los Intendontes dediquen los principales cuidados en este asunto, con absoluta preferencia a todos los donás del Ministerio de su cargo, sin perdonar diligencia ni fatiga. Yo me persuado que el celo de estos muchos Jefes, habrá vencido las dificultades que hasta ahora han embarazado tan importante obra y que a esfuerzo de sus fatigas ya estarán averiguados el origen, progreso y littimo ostado de las rentas de sus Provincias. No obstante, como mi gratitud a la soberana confianza y el deseo que empeña mi aplicacion para ser de algún modo útil al Rey y al Estado donde nací, me han conducido a escribir esta obra, no omitiendo apuntar en ella las noticias conducentes a ese nobilísimo objeto. Mucho más pudiera yo haber adelantado, si hubiera tenido autoridad para abrir los archivos y reconocer los Registros Públicos; no faltará alguno que mejore este trabajo, que yo satisfago con lo que puedo a los conatos que me han arrebatado a esta tarea.

Por otra parte, la imponderable vigilancia de nucstro feliz Ministerio, no pierde de vista este negocio, $y$ con las nuevas instruciones que, a principios de este año de 1786 , se han mandado poner en práctica para la cuenta y razón de Real Hacienda, se van preparando a su nuevo manejo los caminos deseados por donde en breve llegará a su última perfección la Administración del Real Erario en estos dominios.

Desde el Art. 205 hasta el 211 inclusive, de la Real Instrucción de 28 de enero de 1782 , se anticiparon a cste propio fin importantes prevenciones para la formación de Arcas mensuales, de razones exactas, sacadas de los Libros. Reales, sobre la existencia de caudales, con distinción de monedas y pastas, de estados individuales de todos los valores de los Ramos de Real Hacicnda, de Inventarios formales a principio de año y de relaciones puntuales de los empleados en rentas, con las circunstancias, claridad, método, tiempo y forma que prescribe la citada Ordenanza.

Estos nuevos documentos, inusitados en el método antiguo de la Administración del Real Erario, sirven de apéndice a los comentarios citados de Escalona, sobre los libros que deben levarse para el manejo de la Real Hacienda. Un Ministro exacto, que quiera proceder con acierto, es menester que arregle en todo la ordenación de sus cuentas y asientos de partidas de este nuevo establecimiento, y los Intendentes deben cuidar' celosamente de su puntual cumplimiento.

\section{NOTICIA PRI M E R A}

De los gastos, sueldos y pen-
siones de Ia Real Caja de
Potosí. dales que le entran, porque no existiendo ya las crecidas situaciones que antiguamente tenían en ella la Universidad de Iima, el Hospital de San 
Andrés de la misma ciudad, y otras comunidades y personas particulares del Reino, ${ }^{3}$ es por demás hacer enumeración de ellas.

fos estados y cuadoos del final de la primera parte, manifiestan muy por monor los sueldos, sínodos, pensiones y cargas que minoran el fondo de la Tesorería, principalmente de esta Provincia. A la vista se comprende este astunto sin necesidad de explicación, y solamente debo advertir que el total de noventa y dos mil ciento catorce pesos, uno y medio reales a que alcanza su importe, resulta del agregado de 49.781 pesos que montan los sínodos de los sesenta y dos Curatos de esta Provincia, sin incluír jornales de los indios que trabajan en las fundiciones de la Caja, ni otros salarios menores.

\section{N O T I C I A S F G U N D A}

Resumen general de los sueldos, y pensiones que sufren las oficinas de la Real Hacienda de esta Villa.

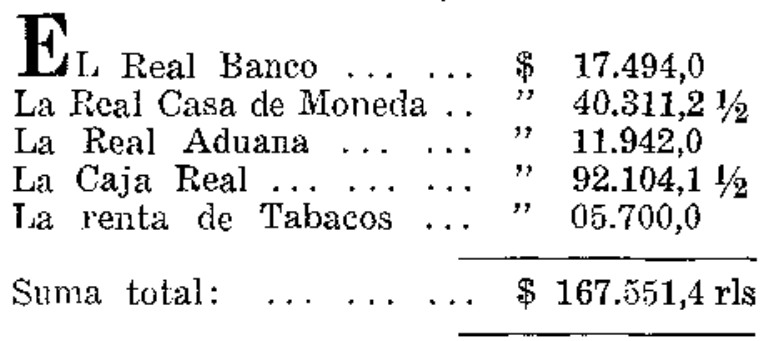

La antecedente demostración acredita que todos los fondos de Real Hacienda que se enteran, recaudan y administran en las oficinas de esta Villa, sufren el descuento de CIENTO SESENTA Y SIETE MIL QUINIENTOS CINCUENTA Y UN PESOS, CUATRO REALES, sin comprender los jornales y otros salarios menores que no se incluyen en los es tados de arriba $y$ son tan cuantiosos que sólo la Real Casa de Moneda satisface semanalmente en jornales, más de seiscientos pesos, cuya cantidad multiplicada por cincuenta y dos semanas, importa TREINTA Y UN MIL DOSCIENTOS PESOS anuales. A esta proporción tienen también sus descuentos las demás oficinas; pero en rigor no deben deducirse sino los sueldos y pensiones fijas, que son las que quedan anotadas en el resumen anterior.

1.- Escalona: Lib. 2", Cap. 5".

2.-. Escalona: Lib. 1\%, Cap. 28, caso 25, fol. 117.

3.- Fsta Caja pagaba a Ia Lniversidad de Lima 1.000 pesos ensayados, amualmente, situados en los dos novenos del Arzobispado de Charcas; otros 1.000, para el Hospital de San Andrés, de los Tributos de los Indios de la consignación de Lanza; y otra irual cantidad a los Corregidores, como Tenientes de Capitanes Generales, en residuos para buenos efectos $\mathrm{y}$ tributos vacos. 



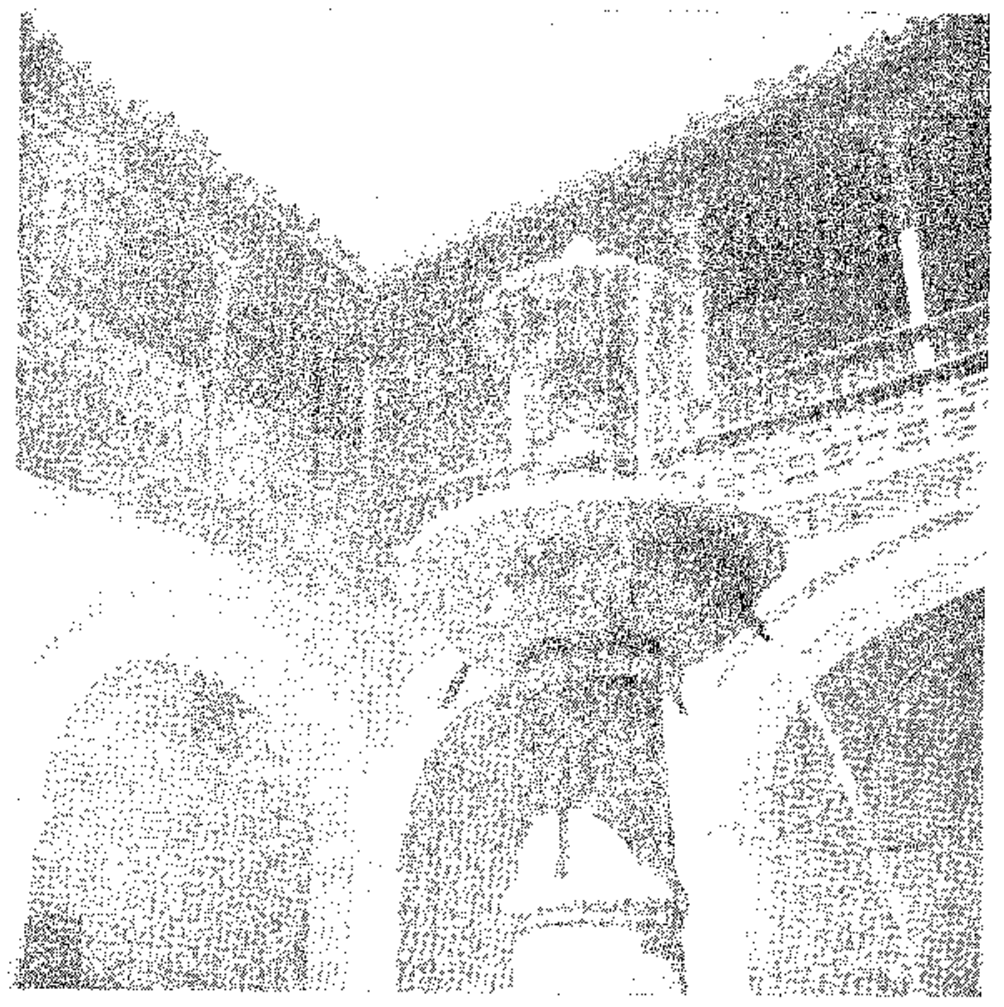

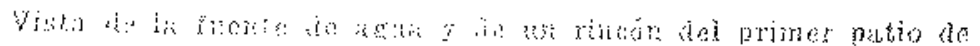

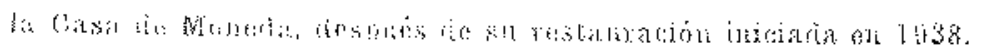




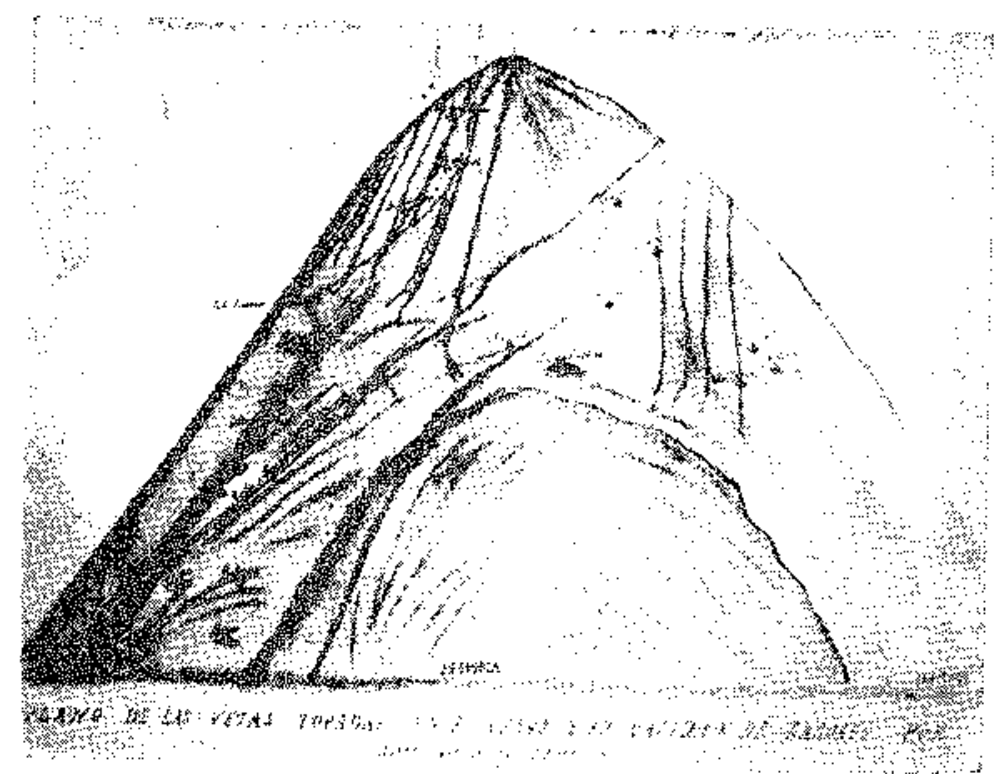

Dibajo del Cerro de Potosí, con la dirección dis stus principa les vetas de plata "topactas", hocho por iton Nicotás Benino. (Sigilo XYi). 


\section{CAPITULO QUINTO}

\section{Del envío anual del Real Tesoro de las Cajas de estas Provincias, a la Tesorería General de Buenos Aires.}

Cundo Lima era Capital del Perú y Provincias del Río de La Plata, toda la Hacienda qie recogía en sus distritos la Caja de Potosí, Oruro y Lá Paz, se remitía al Puerto de Arica, por fines del mes de abril, de forma cue llegasc al Callao a los primeros de mayo. Los Oficiales Reales del Cuzco, Carabaya, Castrovirreina, Arequipa, Trujillo y Huánuco, ejecutaban la remisión de ordinario en los propios meses, por tierra, con arrieros afianzados que entregasen la plata en Lima, el día fijo que se les señalaba.

En las cartas-cuentas del envío de estos caudales, se ponía relación distinta del oro y plata, en moneda y pasta, expresando con claridad las cantidades de cada género, para evitar los fraudes. Las barras y tejos pertenecientes al Rey, iban ensayados, con su marca, ley y expresión de su peso, con total separación del dinero de particulares, por la. confusión, dificultades e inconvenientes que se experimentaba de lo contrario.

Luego que volvía de Panamá la Real Armada, se destinaban los Galeones necesarios al Puerto de Arica, para traer la plata de Potosí, Oruro y Ia Paz, el año siguiente, manteniéndose carenados, aprestados, surtos y prevenidos para fin de febrero $y$ en estado de partir a principios de marzo; con cuya ocasión, para ahorrar costos, solía enviarse en los mismos Galeones dos o tres mil quintales de azogue, de los que venían de España o de los que habían en el puerto de Chincha. ${ }^{1}$

A la llegada de la Armada al Callao, de su tornaviaje de Arica, 
se asignaba día perentorio para su salida a España, tomando antes noticia del Consulado, de los días que había menester para el despacho del comercio; y cumplido el plazo, se hacía a la vela sin dilación ni espera. ${ }^{2}$

En Ios Asientos que celebraron en los tiempos posteriores para el trajín de azogues, principalmente el año de 1756, se estipuló por condición que los mismos asentistas debían retomar de las Cajas del Virreinato a la matriz de Lima, los caudales que se les entregase por aquellas, sin promio ni gratificación alguna, corriendo ellos con la conducción de la plata, bajo los fletes de los azogues, sin exigir otro interés. Este fue el último estado del envío de caudales del Real Tesoro, cuando se erigió el Virreinato de Buenos Aires, agregándole todo el tepritorio de la Audiencia de Charcas y Provincia de Cuyo, el añe de 1577.

Ahora se hacen estos envíos a la Tesorería General de Buenos Aires, por mano del Asentista General de Azogues, que se obligó en público remate de 11 de agosto de 1779, a conducir los caudales del Real Erario a la Villa de Potosí, y de ella a Buenos Aires, en la forma siguiente:

Los acopiados en las Cajas de La Plata, por luno y medio reales \%; los de Oruro, id; los de Carangas, a 5 y $1 / 2 \%$; los de La Paz y Chucuito, id; los de Carabaya, a 7 y $1 / 2 \%$, en premio de su conducción a Potosí, y los de esta Villa a la Tesorería Gencral de Buenos Aires, (las cantidades de salarios que están situados por Real consignación en la Tesorería de Potosí) a 8 reales \%, con calidad de llevar tres situados en cada año de los cinco del remate.

Se dudó en aquel tiempo, si debería correr bajo de este mismo método la conducción de los caudales de las Cajas de Ia vereda o tránsito, que entonces eran las de Jujuy, Tucumán, Santiago del Estero y Córdoba, las cuales en el día están reducidas a solas dos, en las capitales de Salta y Córdoba. Se consideró que, aunque antiguamente se pagaba ocho reales por cada ciento, debía minorarse este premio, atendiendo a que se pagaba lo mismo por los envíos de Potosí, con estar más distante; precedió informe de la Contaduría Mayor, y con la vista físcal, se declaró por la Intendencia General de Buenos Aires, a 19 de abril de 1780, que por todas las conducciones de las Cajas de la vereda se pagara solamente 6 reales $\%$.

Es notorio el beneficio de la Real Hacienda en la rebaja del premio con que ahora se conduce el Real Tesoro, rospecto a los tiempos anteriores; pero pudiera mejorarse con más ventaja haciéndose estas conducciones libres de fletes, con arreglo al remate referido de 1756 , recompensando este ahorro con lo que gana el Asentista en la remisión exclusiva de los azogues, o practicándose estos envíos en el método que dejamos propuesto en otro lugar. ${ }^{3}$

Estas remisiones se llaman abusivamente "situados", mantemiendo el nombre que antiguamente tenían, a causa de que de estas Cajas se remitían anualmente a Buenés Aires las cantidades de salarios que estaban situados por Real consignación en la Tesorería de Potosí. Consta que el situado de Buenos Aires el año de 1716, montaba 185.113 pesos 4 reales. Con diferencia de poco más o menos, en los años posteriores.

Regularmente, sufría muchos retrasos el pago de la guarnición de aquella plaza, y para evitarlos se despachó Real Cédula de Madrid, a 20 de noviembre de 1714, ordenando al Gobernador y Oficiales Reales de Buenos Aires, que en cada año remitiesen a los de Potosí y al Sr. Vi- 
rrey, certificaciones juratas y firmadas con toda distinción, claxidad y separación del producto anual de cada uno de los ramos de Real Hacienda que entran en aquelias Cajas, para que tanto menos de lo que produjercn se envíe en el situado, con prevención de que para averiguar lo líquido que se debicse remitir por razón de situado, en cada año, dirigiesen también al mismo tiempo, certificaciones de todas las plazas y empleos que gozaren sueldos de la dotación; y que a este fin se pasasen muestras en cada final de mes, con asistencia del Gobcrnador, la del Cabo de la caballería, Sargento Mayor y Oriciales Reales.

El importe total de esta dotación entregaban los Oficiales Reales de Potosí a un vecino de la Villa que nombraba por su apoderado la Guarnición de Buenos Aires, y caminaba este caudal por cuenta y riesgo del mismo situado, corriendo al cargo de la propia guamición el cuidado de que se le dirigiese a tiempo, con arreglo a las órdenes que para ello hubiese dirigido al consignatario.

Con el tiempo, se lejó de nombrar apoderados; y como por la citada Real Cédula, tenian facultad estos Oficiales Reales para hacer por sí solos el pagamento del situado, sin necesidad de Libramientos del Superior Gobierno, comen\%aron ellos a nombrar situadistas a su arbitrio.

En breve se introdujoron abusos muy considerables, en cuyo remedio se mandó por el Superior Gobierno de Lima, en Auto acordado de 16 de outubre de 7760, que ofrecindose conducir dinero o efectos de cuenta del Rey, para Pumos Aires u otra parte, se pregonase y sacara a remate, para que los conduzea bajo de fianzas cormespondientes el que hiciese mayor beneficio, para evitar colusiones.

Después de crigida en Caja matriz del Virreinato, la de Buenos Aires, como era antes la de Lima, ya no se remiten los caudales del Real Erario por xazón de situado, sino como sobrante de las Tesorerías de estas Provincias, para que allí se depositen y vuelvan a circular por el Reino, como dispuso la naturaleza con la sangre del cuerpo humano respecto del corazón.

Por esta causa se deben reputar como anticuadas las reglas que se observan en las conducciones de situados, cuidándose únicamente de que se cjecuten sin merma y disminución, o al menor costo posible, atendidas las cixcunstancias de los ticmpos, una vez que no tenemos principios fijos regulativos de ese punto, pues, Escalona ${ }^{4}$ en el diminuto comentario que escribió del situado de Chile y de su conducción, nada más hizo que apremiar el cuidado de los señores Virreyes, para evitar fraudes y colusiones.

Por apéndice de este capítulo, no me parece disonante el arbitrio que voy a proponer para conducir sin costo los azogues a Potosí, y de estas Cajas, el Real Tesoro a Buenos Aires, en caso de no estimarse oportunos los avisos ya propuestos. A imitación del destino que se daba a los Galeones de la Real Armada, podía destinarse cada año una fragata de las del cargo del Comandante del Río de La Plata, para que en ella se condujesen los azogues del Almadén al puerto de Arica, o al de Magdalena de Cobija, del Partido de Atacama.

El Subdelegado puede cuidar tener mulas prontas al plazo señalado para su envío hasta Potosí, que distando poco más de cien leguas, no se demoraría arriba de quince días. De este modo, se daba ocupación a los vecinos de Atacama, que en el día están reducidos al triste empleo 
de pescadores. También se ejercitaba la Marina de las fragatas, que en tiempo de paz percibe los sueldos sin ningún trabajo. Este proyecto se presenta tanto más conveniente y fácil, para que enviándose cada año a Malvinas una fragata con víveres y plata de situado, de aquella misma Isla podía pasarse fácilmente al puerto del Callao, conduciendo de lastre cuatro o cinco mil libras de azogue; y de retorno, los caudales del Rey.

$\mathrm{Y}$ porque en tiempo de guerra sería expuesto a muchos riesgos este envío, puede reservarse para este caso la incorporación de estas conducciones al correo de encomiendas, que sin duda trae al Rey visibles ventajas, según lo hemos expuesto en otro lugar. 5

1.- Chincha es puerto de la América Meridional, en la provincia de Lima; tiene azogue.

2.- Nuestro Escalona, Lib. $1^{\circ}$, Cap. 35 , caso 32 , fol. 137 , refiere muy por menor las circunstancias de nuestros envíos.

3.- Parte $1^{*}$, Cap. $4^{\circ}$, Noticia 7 hasta el fin, y parte $2^{4}$, Cap. $5^{\circ}$.

4.- Escnlona: Lib. $1^{\circ}$, Cap. 32, Cas. 29 , fol. 132.

5.- Parte $1^{\circ}$, Cap. $4^{\circ}$, Noticia 7, hasta el fin. 


\title{
CAPITULO SEXTO
}

\section{Del nuevo sistema de Intendencia y Reforma de la Ordenanza de Real Hacienda, en los dominios de América.}

Se explica las facultades de estos nuevos Magistrados y los casos en que versa su autoridad en materia de Hacienda, Policía, Justicia y Guerra. Con enumeración de los objetos principales de estas cuatro causas.

\author{
NOTICIA PRIM E R A
}

Del establecimiento de Inten- LA unión de las Intendencias a los Corredencias. gimientos, fue una idea noble, que habiendo nacido en España, tuvo su progreso entre las naciones extranjeras, con ventajas muy sobresalientes de su gobierno, como una preciosa semilla que arrebatada del árbol donde se crió, prende en otro suelo extranjero, donde la recogen y cultivan.

Las utilidades de este gran proyecto exitaron, con el tiempo, el cuidado de su implantación en España, con la fundada esperanza que también llegaría a mejorar nuestro Gobierno económico y la Justicia, restableciendo su antiguo esplendor obscurecido con los disturbios de la guerra; que la política recobraría nuevas sensaciones que imprimiesen actividad y movimiento a los magistrados y demás personas encargados de la atención de sus dignos objetos, y que, por último, se extirparían de raíz, a esfuerzo de la mano autorizada de estos nuevos Magistrados, los desórdenes y abusos que cón el apoyo de la infelicidad sucesiva de las calamidades del Reino, se habían posesionado tiránicamente de los Jueces, de los particulares y de los mismos pueblos, en la inversión de las leyes, 
en su inobservancia, en el abandono de la justicia, en la usurpación de las rentas del Rey y del público, en las discordias de los vecindarios y, por último, en el absoluto poder abusivo de los mismos Jueces, por la distancia en que vivían de los Supremos Jefes de la Nación.

En remedio de estos gravísimos perjuicios, resolvió nuestro glorioso Monarca Don Felipe V, establecer en cada una de las Provincias del Reino, una Intendencia comprensiva de las cuatro causas, de Justicia, Policía, Hacienda y Guerra. Publicó en 4 de julio de 1718, la Real Ordenanza para este nuevo gobierno, con 143 Capítulos, sin incluír las instrucciones del Tesorero General y Contador Principal de la Intendencia, y nombró para ejercerlas personas de autoridad, grado, representación, celo y aptitud, confiando a la mano autorizada que les dio, el régimen económico de los pueblos y de las rentas reales.

A ejemplo de este gran Príncipe, mandó expedir en Buen Retiro, a 13 de octubre de 1749, la Majestad del Sr. Don Fernanto VI, otra Real Ordenanza, con 146 artículos, para el restablecimiento c instrucción de Intendentes de Provincia y de Ejército; porque la decadencia de los comercios y manufacturas, por falta de cosechas y otras extremosas calamidades causadas en cuarenta $y$ ocho años de sangrientas y continuadas guerras, pedían con clamor do todo el Reino, que la poderosa mano del Rey restableciese los antiguns resortes de nuestro gobierno, dormido y casi paralítico.

El dichoso reinado actual de Don Carlos IIr, que serí siempre una de las épocas más memorables de nuestra Monarquía, quiso también extender a los dominios de América este beneficio de la Nación, imitando los grandes planetas del cielo, que no tienen movimiento sin operación ni aspecto sin influencia.

Llegó el tiempo inesperado de la rebelión de estas Provincias, tan infausta para los insurgentes e infelices en sus causas, como dichoso en los efectos de la piedad soberana del Rcy. Se miró lénguido, decadente y postrado este cuerpo de la Nación, y en el rebato de este accidente se declararon los humores mal complexionados, que mucho antes indicaban enfermedades envejecidas.

Cuanto se hace reparable la curación de un enfermo andante, fue en nuestro caso, necesario otro nuevo sistema que reformase los antiguos desórdenes que al cabo postraron este cuerpo vicioso y enfermizo; entonces se puso sobre la mano vigorosa del Rey, y después de bien reflexionados informes, se mandó establecer en el nuevo Virreinato de Buenos Aires y distrito que le está asignado, un Intendente de Ejército en aqueII Capital, y ocho Intendentes de Provincia en las ciudades de: la Asunción del Paraguay, Córdoba del Tucumán, Salta, Villas de Cochabamba, La Paz, La Plata, Potosí y Chucuito o Puno, con el territorio, autoridad y sueldos sabiamente prefinídos en la Real Ordenanza dada en El Pardo, a 28 de enero de 1782 , y en las declaraciones incorporadas a ella, su fecha, en San Ildefonso, a 5 de agosto de 1783.

El objeto es gobernar estos pueblos y habitantes, en paz y justicia; cuidar de su policía, y recaudar los intereses legítimos del Real Erario y del público con integridad, celo y vigilancia.

Las sabias Leyes de Indias y las Reales Ordenanzas del Sr. Don Felipe 'V, y Don Fernando VI, - augustos padre y hermano de nuestro augusto Soberano,- sirvieron de modelo a nuestro imponderable estable- 
cimicnto; pero se ajustaron sus reglas con tanta prudencia, que sólo se mandaron observar en lo conveniente, con las ampliaciones, restricciones y declaraciones explicadas en la Ordenanza, teniendo presente la situacion de los lugares, los intureses de nuestro comercio y de los vecinos, el clima, las producciones naturales del país, el genio del pueblo y otras mil circunstancias, que deben consiclerarse en las leyes, para que lleguen a combinar la utilidad pública con la justicia.

\section{NOT I C I A S E G U N D A}

De la reforma de la Adminis- $\mathbb{W}_{\mathrm{N}}$ otro lugar, ${ }^{1}$ reduje a una historia petración de la Real Hacienda. riodica la evección de las Cajas Reales o Cámaras Provinciales de América, contrayéndome principalmente a las de Polosi, cuyo territorio, autoridad y sueldos expliqué en detalle, con las novedades recientemento ejecutadas en ellas.

Aquel métorko antiguo, cotejado al uuevo sistema de Intendentes, manifiesta a golpe de ojo la ventajosa réroma de la Administración de Real Hacienda. Ya se ve que los tres Oficiales Reales que de ordinario administraban of Real Erario, con el nombre de Contador, Tesorero y Factor, eran otros tantos jefes de todo el distrito de la Caja. Este alto poder paró en breve a despótico y abusivo, en perjuicio de los vasallos y del Rey, por la distancia en que vivían del Supremo Jefe de la Real Hacienda, que era el Sr. Virrey. Muy por menor quedan notados los abusos que rlesde los principios tomaron posesión de los empleados en estos Ministerios.

Las más de las Cajas Reales o Cámaras Provinciales del Virreinato, ${ }^{2}$ se hallaban acéfalas y sin correspondencia en el sistema administrativo de la Real Hacienda, porque los Oficiales Reales empleados en su departamento no tenian a su prente un inmediato Jefe a cuyo cargo estuviese confiada la dirección de las rentas. De aquí procedía la lentitud en el examen de los negocios, cl abandono de los designios ventajosos al Erario y la omisión de representar a tiempo oportuno al Departamento de la Capital lo inconveniente al Erario, con la capacidad y talento de los empleados, en quc consiste principalmente la utilidad de tos ramos de la Real Hacienda.

Para evitar estos envejecidos perjuicios, se destinó en la capital de cada Provincia, al frente de los Ministros de Real Hacienda, un Intendente que reasumiendo en sí lo jurisdiccional de Gobierno y Justicia en las dependencias de rentas, debiese conocex privativamente de todas las causas en que tuviese algún interés la Real Hacienda; confiándose a la privativa inspección del mismo, la dirección por mayor de todas las rentas reales, con reserva a los Oficiales Reales y a los Subdelegados, la administración por menor de ellas mismas, por ser cosa indecente que el que gobierna tenga el gasto de paz y guerra en su mano, como se le enunció al Presidente la Gasca, en cierto capítulo de instrucciones; de suerte que los Oficiales Reales han quedado sin acción para proceder judicialmente, reduciéndose sus facultades a requerir a los deudores y proponer en las Juntas semanales de Gobierno, los designios que cada cual indicase por más ventajosas a la Real Hacienda. 
Varios casos de la Administración por mayor, en que versa la autoridad de los Intendentes; con distinción de los que necesitan consulta de la Junta Superior de Buenos Aires.

Párrafo primero. - Juntas de Hacienda.
$\mathbf{L}$ Hacienda, tocaba antes privativamente a los Señores Virreyes, y aunque su autoridad era suprema en el Reino, habían casos en que, según las leyes, debían proceder con voto y acuerdo de las Juntas de Hacienda. Ahora se ha trasladado en los Intendentes mucha parte de aquellas facultades, por haberse sujetado a su privativo conocimiento la dirección por mayor del Erario de sus Provincias; ${ }^{3}$ pero siempre con dependencia a la Junta Supcrior y al Superintendente Subdelegado, que es st Jefe, para darle noticia de cierta clase de negocios graves $y$ esperar su resolución en algunos y excusando otros, según su calidad.

El primer caso de la Alministración o Direccion por mayor de la Real Hacienda, es convoear la Junta de acuerdos. Antiguamente, tenían voto decisivo todos los vocales; ahora solamente lo tienen los que componen la Junta Provincial de Real Hacienda, en la forma dispuesta por los Arts. 100 y 267 de la Nueva Ordenanza. Los de la Junta semanal de Gobierno, que se ha subrogado al los Acuerdos ordinarios que, en tiempos pasados debían celebrarse los miéreoles y jucves de cada semana, sólo tienen voto informativo, por ser del Intendente, privativamente, la facultad de decidir lo más conveniente, después de oídos los pareceres; bien que, tratándose algunos puntos que necesitan de más serio examen y mayor autoridad, deben dar cuenta los Intendentes a la Junta Superior de Hacienda, con arreglo al Art. 205.

Estos actos de conferencias son de la mayor utilidad al Real Elario, porque cada vocal propone las dudas, los designios y las ideas más ventajosas a su mejor administración, sin lisonja ni contemplaciones, según lo prevenido en la ley 7 , Tít. 18 , Parte $4{ }^{n}$. Por otra parte, el Intendente se ilustra con las noticias que adquiere $\mathrm{y}$ mediante ellas mismas puede dirigir con más acierto las rentas de su cargo; por lo mismo, es cargo grave de residencia la omisión voluntaria de estas Juntas, ${ }^{4}$ con las formalidades prevenidas en los citados artículos de la Ordenanza.

En las Juntas Provinciales es menor la autoridad de los Intendentes, porque sin embargo de tener la dirección por mayor y lo jurisdiccional de Justicia en todos los negocios de Hacienda, por los Arts. 72 y 74, ellos sólos no deciden, porque su voto entra en concurrencia con los demás; no pueden revocar las resoluciones de la Junta, porque teniendo fuerza de cosa juzgada, a la Junta y no a otro toca deshacerla, según la variedad de los tiempos. Tampoco pueden los Intendentes ejecutar lo acordado, antes de dar cuenta a la Junta Superior, y aún en los casos urgentísimos èr que es necesario anticipar sus providencias, deben hacerlo con acuerdo de la Provincial de la Real Hacienda, con arreglo a los artículos 100 y 267. 


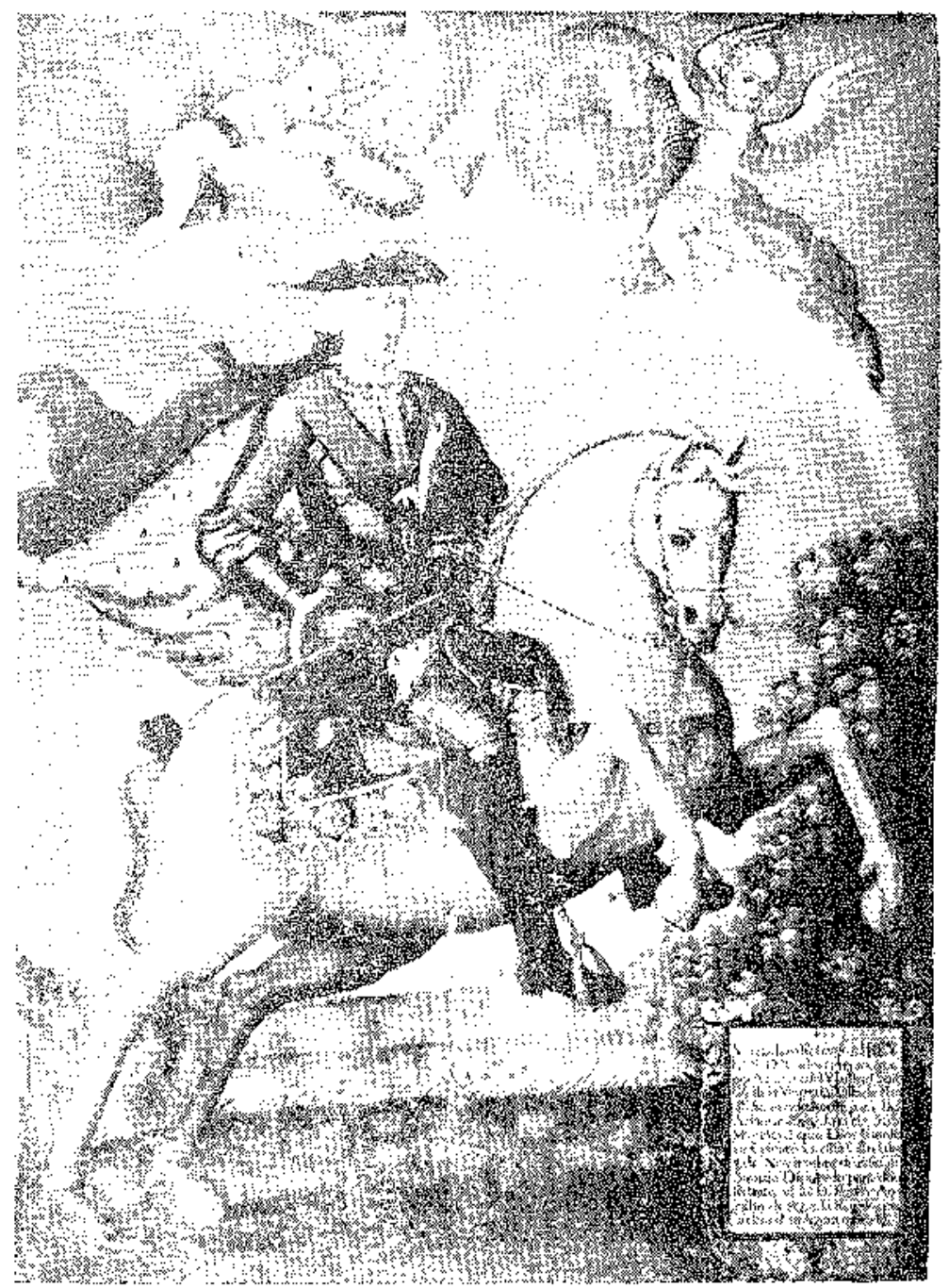

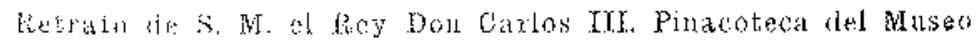

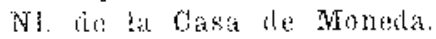

isiglo $x \vee[1]$ ). 
EN EL ESCUDETE DEL ANGULO

DFRECHO INFERIOR, DICE:

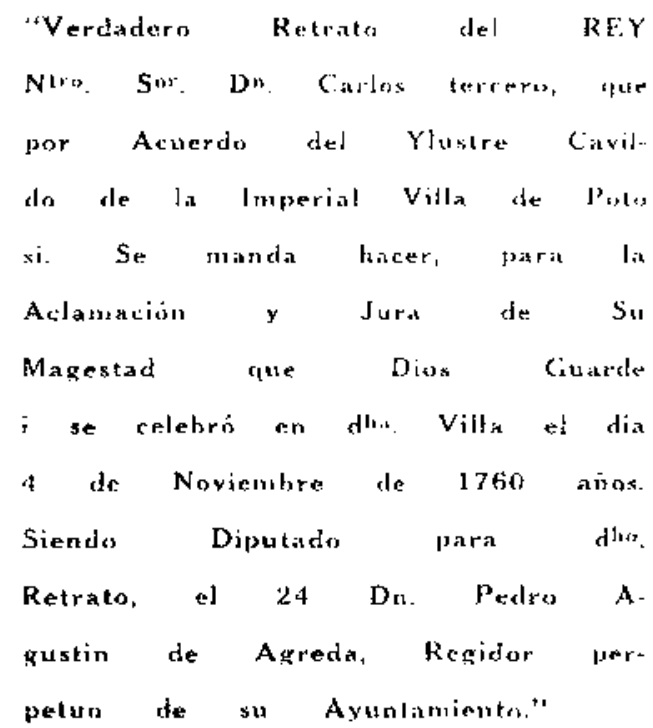


Párrafo segundo. - Libra- AUNQUE en la dirección por mayor se inmientos sobre Real Hacienda. cluye, al parecer, un poder absoluto y libre para disponer de la Hacienda que se administra, nunca lo pudielon hacer ni aun los señores Virreyes, para aumentar' salarios, condonar y remitir tributos, o expender los caudales de Real Hacienda on cualesquiera destinos, sin particular orden del Rey. Nuestra Recopilación de Indias reiteró en muchas leyes estas prohibiciones, y el Art. 97 de la Ordenanza las mancó guardar a la letra, haciendo responsables de su contravención, a los Ministros que pagaren tales Libranzas, exceptuando únicamente las que se acordaren por la Junta Superior.

Sin embargo de todos aquellos casos repentinos y extraordinarios, que la dilación de consultarlos podría causar daño ixreparable, como serían: accidentes de alboroto, nuevas de guerra y enemigos, reparación de almacenes, conducciones, y otros igralmente necesarios, urgentes y ejecutivos, pueden los Intendentes provecr el pago de estos gastos, con acuerdo de la Junta Provincial, firmándose las Libranzas por todos los vocales de ella, como es de derecho, ${ }^{5}$ lespecto de no concurrir en Ios Intendentes Ja suprema autoridad que ladicó en los señores Virreyes, la disimulación de firmar ellos solos cstas Libranzas.

En la Junta se deben tasar las cantidades del gasto, sin dejarlas al arbitrio del Jefe; ${ }^{6}$ pero, si cl caso fuera tan ejecutivo y repentino que no deje esperar, pucde expender el Intendente los caudales necesarios, formando al instante la Junta Provincial, para ejecutoriar el gasto con su acuerdo. 7

Párrafo tercero. - Transac- $\mathbb{H}_{\mathrm{N}}$ virtud de los poderes sin límites que ción de negocios fiscales. tenían los Señores Virreyes, para el gobierno de estos reinos, con libre y general administración, podian transigiv: los negocios y deudas fiscales, ofreciéndose partidos útiles a la Real Hacienda, como lo practicaron los señores Marqués de Montesclaros, Príncipe de Esquilache y otros. 8 Los Intendentes no pueden ejecutar lo mismo, aunque este caso sea correspondiente a la Administración por mayor; porque siendo todavía más grave que el punto de esperas, debe cuando más decidirse uno y otro, por unas mis. mas reglas, esto es, que sin resolver la transacción, se debe dar cuenta de la propuesta a la Junta Superior, con información de su utilidad, para que determine lo más conveniente, usando de la autoridad superior, que antes era propia de los Señores Virreyes, con arreglo a los artículos 114 y 125 de la Ordenanza.

Párrafo cuarto. - Composi- TA composición de los delitos y remisión ción de delitos. de las penas de los delincuentes, es regalía privativa del Soberano, según la ley 1, Tít.

32, Parte 7. Los Señores Virreyes, en uso del poder cumplido y absoluto que les concedía la ley 2 , Tít. 3 , Lib. $3^{\circ}$ de Indias, podían perdonar y dejar libres a los delincuentes, conforme a derecho, en cuanto a lo criminal, reservando su derecho a las partes en lo civil, daños e intereses, conforme a la ley 27 , del Tít. 3 , libro $3^{\circ}$ citado; pero esto que es componer 
delitos, redimiéndolos por cicrtas cantidades que se pagan al fisco, como precio de renisión de las penas, nunca lo ejecutaron sin comisión particular del Rey, como lo indica un capítulo de carta remitida al Señor Don Francisco de Toledo, de que hace mención Escalona. ${ }^{9}$

Mucho menos lo podrán hacer los Intendentes, aunque tengan la dirección por mayor, porque semejantes utilidades son reprobadas por todo derecho, respecto de introducir en el comercio humano los crímenes y dar ansa para delinquir a todos los ricos, con la insolencia que lo ejecutaba aquel Lelio Neracio, hombre inicuo que se deleitaba en palmear la cara de otros ciudadanos, a trueque de la pena pecuniaria, que llevaba pronta en una bolsa a hombros de un esclavo, segín la cantidad tasada por la ley de las doce Tablas. ${ }^{10}$

Aun entre los particulares está prohibido transigir y componer ảelitos por dinero, como to declara, en el crimen de adulterio la ley 22, Tít. 19, Partida $7^{2}$, y aunque esta misma ley lo permitc. criti'e otros delitos no exceptuados, para que el $J u e z$ no proceda a imponer pena ordinaria al reo, con todo su odio de los delitos, dispone la ley 4, Tít. 10, y la ley 10, Tít. 24, Lib. 8" de Castilla, que aunque haya perdón de parte, siendo el delito y la persona de calidad que justamente pueda ser condenado en pena corporal, sea y pueda ser puesta la pena de servicio de galeras. ${ }^{11}$

Pero puede llegar el caso de delinquir algún insigne y excelchte artífice en la eiencia de Metalurgía o Mincralogía, que siendo rico quiera redimirse con dinero. Son vulgares los principios del derecho para libertar la vida de un hombre crimituso de estas circunstancias, por remisión graciosa, precediendo consulta del Soberano; ${ }^{2}$ y parece menos difícil perdonarlo, componiendo su delito. Yo así lo juzgo; mas sería necesario suspender el castigo y dar cuenta al Señor Virrey y Junta Superior de Buenos Aires, para que el primero, en cuanto a lo criminal, y la Junta por el interés fiscal, consultasen al Rey la providencia, manteniendo entre tanto al reo en segura custodia, como lo indica la ley 17, Tít. 8, Lib. $7^{\circ}$ de Indias.

$\begin{array}{cl}\text { Párrafo quinto. - Expensas } & \text { ToCA a la Administración por mayor li- } \\ \text { de Misioneros. } & \begin{array}{l}\text { brar sobre la Real Hacienda, para expensas } \\ \text { de los religiosos Misioneros que se despa- }\end{array}\end{array}$ chan a doctrinar y convertir indios. Los señores Virreyes gastaron siempre del Real Erario en estos piadosos objetos, con el cuidado y cautelas que apunta nuestro docto Escalona. ${ }^{13}$

Los Intendentes no pueden ejercer la misma autoridad, si no es para los pagos de las pensiones que procedieren de Ordenanzas, Cédulas o Despachos Reales, con el "cúmplase" del Superintendente, conforme al Art. 98; y para otros gastos que no tengan igual principio, deben esperar las resoluciones de la Junta Superior, con arreglo a los artículos 97 y 99 de la Real Ordenanza.

Párrafo sexto. - Costeo de $\mathbf{L}$ os señores Virreyes, como AdministraIglesias. dores Generales de Real Hacienda, libraban antes contra ella la tercera parte del costo 
de las fábricas de Iglesias de españoles, ya fuesen Catedrales o Parroquiales, con ar'eglo a las leyes 3 y 4, Tít. 2 ; y ley 2, Tít. 3, Lib. 1o de Indias guardando la forma de la ley 5 , Tít. 6 del mismo libro, en los casos de reedificación por causa de ruina o de ampliación del edificio.

Los Intendentes no pueden despachar estas libranzas, sin embargo de estarlas confiada la dirección por mayor; porque conforme al Art. 66 de la Real Ordenanza, no debe construírse Iglesia alguna, sin que los dibujos de sus planes, alyada y coltes que se presentaren a la Intendencia, se remitan a la Junta Superior, para que ésta los haga examinar por arquitectos peritos, y cerificados por ellos y propuestos los medios que conceptíen más adaptables al logro de los proyectos que se forman, con proporción al gasto que quieran o puedan hacer las personas o ramos que las hayan de costear, recaiga la aprobación de la misma Junta. En cuya vista debe preceder esta Superior consulta, suspendiendo on el interin librar sobre la Real Hacienda, lo cual no debe causar más costo que el que se proyectare por los peritos y se aprobare por la Junta Superior.

Esto mismo se debe practicar en la edificación de Ias Iglesias de indios, conforme a las leyes 6 y 7,19 y 23, Tít. 2, Lib. 19 de Indias, por el interés que tiene el Rey en la cuarta parte de los tributos aplicados parà estas fábricas.

En cuanto a la fundación de Iglesias en los pagos, valles y chacras de los Encomenderos que ticnen Yanaconas, dispuso el Sr. Toledo, en una Ordenanza referida por Frazo, ${ }^{14}$ que se hagan a costa de los duenos de las chacras, ayudando los Yanaconas y los demás indios que hubieren de ser doctrinados en ellas, y Su Majestad dará el socorro que pareciere al Virrey. Para la regulación de este real subsidio se debe ocurrir a la Junta Superior, y por ella misma proporcionarse el gasto entre las personas contribuyentes, con arreglo al citado Art. 66; porque no podrán los Intendentes rosolver la fundación o reedificación de Iglesias, ya sean de españoles o de indios en sus Distritos, sin consulta y aprobación de la Junta Superiox de Buenos Aires.

$\begin{array}{cl}\begin{array}{c}\text { Párrafo séptimo. - Esperas } \\ \text { de Deudores fiscales. }\end{array} & \begin{array}{l}\text { berano, por cuya representación ejerce la } \\ \text { suprema autoridad del Reino, podía conce- }\end{array}\end{array}$ der esperas a los deudores de la Real Hacienda, con inhibición de las Audiencias; ${ }^{15}$ y aunque por la ley 13 , Tít. 8 , Lib. $8^{\circ}$ de Indias, se prohibe absolutamente que las puedan conceder en ninguna cantidad ni aun los señores Virreyes, se debe entender exceptuando el caso de resultar evidente utilidad y beneficio de la Real Hacienda, como se declara en la ley 24 , Tít. 21 , Lib. $8^{\circ}$ de Indias, con la calidad que se hagan autos por donde conste con conocimiento de causa de la espera.

Consiguientemente están prohibidos de concederla los Oficiales Reales, ${ }^{16}$ como también los Contadores de Cuentas, sin precedente consulta $y$ orden de los señores Virreyes, ${ }^{17}$ por ser donación temporal de Real Hacienda, cuyo beneficio conste en el tiempo, que es parte de precio; y a estos Ministros sólo les toca cobrar con la puntualidad y buen modo que requieren la materia y personas de los deudores. ${ }^{18}$

Tampoco pueden dar esperas los Intendentes de Provincias, aun- 
que tengan la dirección por mayor de la Real Hacienda, según lo resuelto en los Arts. 114 y 125 de la Nueva Ordenanza. Por esto, cuando se pidiera alguna dilación moratoria, por causa de calamidad, epidemias o porque no se puede vender sin grave perjuicio los bienes con que ha de pagar a la Real Hacienda, o porque no se encuentra compradores, deben los Intendentes averiguar estas causas sumaria y exactamente, dando cuenta con Autos a la Junta Superior, para que conceda la espera que estimare conveniente, bajo de fianza, como es de derecho. ${ }^{19}$

Entendiéndose por punto general, no haber lugar a la espera cuando la deuda resulta de depósito, de Administración de la Real Hacienda y de arrendamiento cuyos frutos está percibiendo el deudor; 20 ni tampoco por el importe de oficios concejiles, si no es el caso de la ley 24 citada, del 'Tít. 21, Lib. 8" de Indias.

Como el que paga tarde, paga menos, y también el tiempo es parte de precio, opina Escalona, ${ }^{21}$ que por el tiempo de la demora debe satisfacerse al Rey un $10 \%$ de interés al año, conforme a la ley 9, Tít. 18, Lib. $5^{\circ}$ de Castilla. Pero, según nuestro Derecho de Indias, los deudores que gozan esperas, no deben pagar más de un 5 ; anual de intereses, por el tiempo que de ella gozaren, como lo resuelve la ley 61, Tít. 6, I ib. $9^{\circ}$ de Indias.

Aunque la Nueva Ordenanza no determina el pago de intereses ni su cantidad, se pueden exigir conforme a dicha ley; bien que, cuando la espera se pide y se concede por causa de pobreza, así como basta la caución juratoria, sin fianza, para no hacer frustratorio el beneficio del Príncipe, 82 juzgo que, por equidad, tampoco debe llevarse intereses, pam ra que no se haga más difícil la cobranza con el acrecentamiento de la deuda.

Párrafo octavo. - Venta de $\prod_{\text {AMBIEN toca a la Administración por }}$ Oficios. mayor la venta de Oficios Concejiles. Este negocio comprende tres partes: la primera es la presentación del renunciatario o comprador del oficio; la segunda, su venta; y la tercera, el despacho de los títulos para ejercerio. Todas tres pertenecían antes privativamente al Si. Virrey, como Administram dor General de Real Hacienda. ${ }^{23}$ Ahora, es del conocimiento privativo de los Intendentes el ejecutar estas ventas, admitiendo las posturas hasta el estado de remate; pero, su aprobación y el despacho de los títulos, toca a Ia Junta Superior y al Sr. Virrey, ch la forma prevenida en el Art. 145 de la Ordenamza.

Párrafo noveno. - Dudas en WL declarar las dudàs en materias de Hamateria de Hacienda. de cuentas y del Fiscal. ${ }^{24}$ En el dia, corresponde a los Intendentes, por el Art. 101, así en los negocios de oficios, como entre partes; pero, si diere lugar la materia y lo mereciere su gravedad, deben consultarlo a la Junta Superior, conforme a lo prevenido en el mismo artículo. Se debe oír instructivamente a los Oficiales Reales y al Promotor Fiscal, admitiendo a la Junta las apelaciones que se interpusieren, en la forma que 
resuelve el Sr. Solorzano, cuando se hace recur'so en las declaraciones sobre dudas de Patronato. ${ }^{25}$ Todo esto se entiende: bien sea la duda sobre el hecho o sobre el derecho del fisco contra el particular, o por el contrario, como lo resueke Peregrino. ${ }^{26}$

Párrafo décimo. - Manejo $\mathbb{E}_{\mathrm{S} \text { caso de Aciministración por mayor, el }}$ del Ramo de Alcabalas. arrendar, administrar o encabezar las Alcabalas y otros ramos de Real Hacienda. 27 Los lntendentes tienen ahora, como antes los señores Virreyes, el cuidado de celax las cobranzas y el mayor aumento que, con justicia y equidad, sc puede dar a sus productos; prefiriendo la administración a los arrendamientos, y a cstos los equitativos encabezonamientos, como más suaves para los contribuyentes, con las cautelas prefinidas en los Arts. $106,107,110,111,130,201$ y 202 de la Ordenanza.

$A$ este fin deben instruirse de los respectivos administradores, del estado de las rentas de su cargo, por medio de las noticias que suministran las conferencias cie las Juntas semanales dispuestas por el Art. 204. Sin esto examen, nada se puede adelantar en la Provincia. Por lo mismo, reputo este acto por indispensable y de mucha responsabilidad a los Intendentes que lo omiten sin grande necesidad.

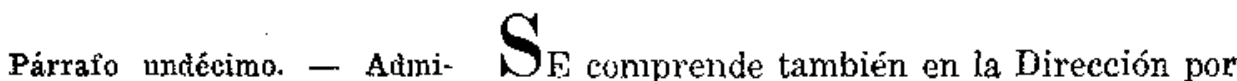
nistración de Estacas Minas mayor, arrendar, vender o administrar las del Rey. Minas de la Corona. ${ }^{28} \mathrm{La}$ ley 2, Tít. 11, Lib. 8: de Indias, mandada guardar en Real Oyden de Madrid, a 13 de marzo de 1762, previene la forma que debe obscrvarse en este ramo (le Real Hacienda. En otro Iugar ${ }^{29}$ dejamos expuesto latamente acerea de lo mismo, y no hay motivo para reproducirlo aquí.

Párrafo duodécimo. - Repar- $\mathbb{E}_{\mathrm{L} \text { repartimiento de indios para labrar }}$ timiento de Mita. y beneficiar minas, corría a cargo de los señores Virreyes, como Administradores Generales de Real Hacienda, ${ }^{30}$ en cuyo departamento se incluye la minería, como uno de sus objetos. Por otras varias Ordenanzas del Perú, se declaró ${ }^{31}$ por caso de Gobierno sólo anexo y perteneciente al Sr. Virrey, como tal Virrey, Gobernador y Capitán Genexal de estos Reinos, todo lo tocante al dar y quitar, poner y remover los dichos indios, y proveer en todo lo demás contenido en los capítulos y ordenanzas del Perú, con inhibición de los Corregidores de esta Villa y otros cualesquier Jueces y Tribunales. Estas decisiones se oponen a la doctrina de Escalona, porgue si la autoridad para repartir mitarios procediera de la administración por mayor de la Real Hacienda, no hubiera declarado la Ordenanza por de Gobierno estc caso y perteneciente al Sr. Virrey, como a Gobernador y Capitán General, sino como a Superintendente de todos los ramos de Hacienda. Por estos fundamentos, juzgo pertenecer privativamente al Sr. Virrey el conocimiento de la Mita, como se ha ejecutado en el Reino de México y se practica en otros de Europa. 
Entretanto deben abstener'se los Intendentes, como inhibidos por la ley, de entrometerse en materia de repartimiento, estando advertidos que ni por delitos que cometan los azogueros o por otras causas inductivas de privación de los indios, pueden quitarlos, removerlos, ni depositarlos sin consulta del Sr. Virrey, como se declara en la Ordenanza 12, Tít. 13, Lib. $3^{\circ}$ del Perú. Y aunque llegare el caso de stijetarse este negocio a la Superintendencia de Real Hacicnda, deberá entenderse con la Junta Superior la autoridad que ahora ejercen los Sres. Vizreyes; reservándose al Intendente de Potosí, la que le concede la Ordenanza 35, Tít. 10, Lib. 3\% del Perú, para poder enviar por los indios que faltaren, a costa de los Corregidores, Gobernadores o Subdelegados omisos en la remisión de sus respectivos repartimientos.

Párrafo décimotercero. - Arrendamientos de Minas, por cleudas fiscales.
L por deudas de azogues y de otros cualesquiera ramos de Real Hacienda, hasta que acaben de pagarlas sus dueños, debían comunicarse en Potosí, con el Presidente de Charcas, en calidad de Superintendente, como punto de gobierno, reservándose su confirmación al Sr. Virrey, como Administrador General dal Real Erario.

Para la formalidad de estos contratos, despacharon varias Provisiones 32 los Sres. Virreyes: Marqués de Guadalcáar y Conde de Chinchón, ordenando que las minas e ingenios de moler metales, se arrienden en la Villa de Potosi, con la licencia del Superior Gobicmo, por escrito; con la prevención de que cuando se fuera a pedir aprobación del remate (dentro de cuatro meses desde el día de su efectuación), se llevare testimonio o certificación auténtica, de que la persona en quier se quiere hacer el arrendaminento, no tiene otros a su cargo; porque ninguno puede arrendar por sí, ni por interpósita persona, más de un ingenio y las minas pertenecientes a su dueño, pena de destierro a diez leguas al contorno de la Villa.

Atendiéndose al mal uso que harían los arrendatarios de los indios de mita señalados y repartidos a los ingenios y minas, vendiéndolos a otras personas, a siete pesos cada semana, con el perjuicio de quedar cerrados los ingenios en mayor tiempo del ario y parar las labores por falta de trabajadores, declaró la Oidenanza 8, Tít. 13, I ib. $3^{n}$ del Perú, que los Oficiales Reales u otras Justicias no pueden arrendar ni fletar los ingenios y minas con indios, aunque sea para cobrar Hacienda Real.

Todos los frutos de estos al'endamientos deben entraz ch Cajas Reales y hacerse de su monto seis partes: Ia $1^{\text {a }}$, para alimentos del dueño del ingenio, no teniendo otra hacienda de qué sustentarse; la $2^{\text {para }}$ los reparos necesarios de la finca, excepto el caso de necesitar rueda o eje, porque entonces debe librarse su costo, aunque exceda la sexta parte, con las precauciones que dictan dichas Provisiones; las otras dos efectivas, para $\mathrm{Su}$ Majestad, sin concurso de acreedores, las cuales entran en las dos restantes, en el lugar que les tocare, y no habiéndolos, debe quedar todo por cuenta de la deuda fiscal con más lo que cobrare de la parte aplicada para obras mayores, no gastándose en ellas.

De este modo se cubre la Real Hacienda, se proteje la minería, son aliviados los indios y se consulta al deudor salvándole lo más preci. 
so, como son los alimentos, en la parte que le basta para sustentarse, como sabiamente consideró nuestro Escalona. 33

Aunque los Intendentes tiench a su cargo la división por mayor de la Real Hacienda, sienpre deben dar cuenta a la Junta Superior de estu clase de arrendamientos, para que conste el cumplimiento de la Ordenanza y tenga entendido lo que se ejccuta en su conformidad, para que provea lo que hallare más convoniente en uso del Gobierno Superior de Real Hacienda que en clla reside.

Párrafo décimocuarto. - Co- UONIORME al Art. 105 de la Nueva Orbranza de Real Hacienda. denanza, y a los derechos que cita nuestro Escalona, ${ }^{3}$ deben cuidar los Intendentes del cobro puntual de las deudas fiscales, informándose para esto, escrupulosamente, del descubierto de cada ramo, en las Juntas sernanales de gobierno, sin permitir que se disimulen moratorias en la recaudación de aquellos miembios de Hacienda, que deben pagarse sin dilación, como son: los quintos, almojarifazgos, tributos, etc., celando al mismo tiempo que no se excertan los plazos de la media anata, mesada, alcabala, servicios graciosos, oficios vendibles $y$ otros.

Párrafo décimoquinto. - Fian-

D zas de Oficiales Reales. Reales $y$ otros Ministros que deben dar fian. zas antes de entrar al uso de los empleos, las den, las renueven y las subroguen otras abonadas, en caso de falencia, quiebra o ausencia de los primeros fiadores; celando el cumplimiento de las leyes del Reino, que así lo disponen ${ }^{95}$ sin perjuicio del reconocimiento que pueden hacer de ellas los Contadores de Cuentas, ${ }^{36}$ debiéndose tener entendido que la subrogación de nuevos fiadores, no releva de responsabilidad a los antiguos, según Larre, a quien se refiere Escalona. ${ }^{37}$

Párrafo décimosexto. - Nombramiento interino de Oficiales Reales.

$\mathbf{E}$ Viriey, como Administrador ceneral de Ffacienda, nombraba antes los Oficiales Reales en interin, con la mitad del salario, según lo disponen las leyes, ${ }^{38}$ con la calidad de no poder ser removidos sin causa, como se decide en dichas leyes y lo resuelve con sólidos fundamentos nuestro Escalona. ${ }^{39}$

Los Intendentes no pueden hacer estos nombramientos con título, como lo indica el Art. 217 de la Nueva Ordenanza. En caso de vacar estos empleos, pueden nombiar quien los sirva provisionalmente, mientras da cuenta con la respectiva propuesta a la Superintendencia, para que con arreglo a la Real Ordenanza de 7 de octubre de 1778 , se provea por ella el interinato.

Aun con los Subdelegados, que son a nombramiento de los Intendentes, segûn los Arts. 8, 9, y 73 de la nueva instrucción, se previene que habiendo de nombrarlos en algún otro pueblo de su Provincia, fuera de los pueblos cabeceras indicados, proceda consulta y aprobación de la Junta Superior, dándose por ella misma cuenta ai Rey, por la vía reservada de las Indias. 


\section{Párrafo décimoséptimo. - WNTRE los casos de la Administración Rendición de Cuentas. por mayor, no es el de menor importancia que los Intendentes cuiden que los Ministros} de Real Hacienda y los demás Adninistradores Cenerales o particulares de cualquier ramo, formalicen, ordenen $y$ justifiquen stis cuentas anualmente, y las remitan a la Contaduría mayou de Buenos Aires, a los plazos señalados, "apremiándoles a que cumplan en el caso de voluntaria o culpable retardación, por el medio de arrestarlos en sus casas u oficinas, como se declara en ol Art. 214 de la Nueva Ordenanza.

Por la ley 5, Tít. 29, Lib. 8ः do Indias, estaba cometido este encargo a los señores Virxeyes, Presidentes Protoziales y Gobernadores Capitanes Generales que tenían anexa la Superintendencia de Hacienda, como los de Filipinas y Buenos Aires, con la facultad de proveer que a los Oficiales Reales que no dieren sus chentas a tienpo, no se les libren ni paguen sus salarios, hasta que lo hayan cumplido.

La misma facultad se ha incorporado en todas las Intendencins de Provincia, pero se ha imnovado la pena impuesta en la citada ley municipal, porque atendiendo a que los salarios de ordinario apenas alcanzan para la decente sustentación rle Jos Ministros, y al inconveniente de exponerlos a una mendicidad vergonzosa, o malversación futura con la privación de los sueldos, se trocó esta pena en la de arresto; y así, no deben reputarse acumulativas ambas penas, sino preferida la última entre las dos citadas, que siempre han sido puramente alternativas, al arbitrio de los Jueces, según el contexto literal de la ley 50, Tít. 46, Lib. 94 de la recopilación de Indias.

Párrafo décimooctavo. - A- Como Administrador General de Real valuaciones. Hacienda, mandaba el Sr. Virrey privativamente que se tasara el mayor valor que tenían en Lima las mercaderías introducidas de Panamá, tomando parecer a los Contadores Mayores, al Fiscal y a dos mercaderes nombrados por el mismo Virrey; y por equidad se elegía el precio mediano entre el mayor y el menor que hubieren tenido los mercaderes en los 30 días primeros siguientes a su llegada. Después se alteró esta práctica, y se adoptó la de fijar los precios en los Acuerdos de Hacienda, por las pruebas e informaciones de testigos que recibían los Oficiales Reales sobre el común $y$ verdadero valor de los efectos, para la deducción equitativa del Almojarifazgo y Alcabala, ${ }^{41}$ según refiere Escalona.

Este método de avaluaciones $y$ aforos, se ve aprobado en las leyes 8 y 9, Tít. 16 del Lib. $8^{\circ}$ de Indias, con varias declaraciones que añaden las siguientes del mismo títuio y libro.

Ultimamente se establecieron las Aduanas, con un Ministro con título de Vista, para el reconocimiento y aforo de todas las mercaderías. Debe ser persona perita y versada en los precios verdaderos y comunes de los efectos, y así procede él sólo a tasarlos, con aprobación del Administrador, haciéndose de estas tasaciones el cargo de derechos a las partes interesadas, sin necesidad de otras pruebas y sin admitirse recursos suspensivos, con pretex to de agravio. 
Las leyes 2 y 3 del Tít. 16 , Lib. $8^{\circ}$ de muestra Recopilación, encomicndan a los Oficiales Reales solamente el aprecio de los efectos por su justo valor, de forma que las rentas no reciban disminución, ni los dueños agravio, encargándoles se informen primero de personas peritas para hacer con acierto las avaluaciones; aunque los Vistas se deban presumir muy peritos justificados, no son singulares los casos en que salen muchos quejosos y otros favorecidos, por odio, amistad o capricho del avaluador. No sucede esto en los puextos, porque ya se sabe que sobre los aforos del arancel o reglamento del libre comercio, se carga un cinco \% más de derechos. En las provincias interiores es donde corre mayor riesgo, porque mudándose los precios a medida de la coneurrencia de los vendedores, se experimenta novedad de un mes a otro, y aquí campea el antojo de los Vistas.

Para cortar todo abuso, scría conveniente que de cuatro en cuatro meses se recibiese por el Administrador de Aduana, con intervención del Vista, una información del verdadero común y corriente precio de los efectos más usuales, y que a estas availtaciones se ajustasen los derechos que se hayan de exigir en la Villa. Bien que juzgo muy oportuno que revisados los precios en la Junta semanal de Gobietno, de la última semana de cada mes, conferenciasen todos los vocales en orden a su último estado, y con parecer de ellos, podría el Intendente resolver la novedad que juzgare más útil al Rey y menos gravosa al conercio.

Párrafo décimonono. - Teso- LOS tesoros no pertenecen in sólidum al ros $y$ Huacas. fisco, según el derecho y costumbre de España, como supone Vinio, ${ }^{42}$ persuadido de la autoridad de Giocio; pues, aurque por la ley 7 del Ordenamiento, Tít. 12, Lib. 6, y la ley 1*, Tít. 13, Lib. $6^{\circ}$ de Castilla, se insinúa que los tesoros son del Rey, reservando la cuarta parte para el inventor o manifestante; pero, según Gregorio López, 43 Gutiérrez y otros que cita Antúnez, ${ }^{44}$ se entiende de los tesoros hallados en lugares públicos o pertenecientes al fisco, o de los encontrados por arte nágica, quedendo fuera de estos casos en su vigor el Derecho Romano.

Pero por Derecho Municipal de Indias está dispuesto que, de Ios tesoros hallados en Huacas, Oques, Templos, Adoratorios, en casa, heredad o tierra u otra parte pública o secreta, concejil o particular, se saque uno y medio de ensayado, después el quinto, y lo demás se parta por mitad, Câmara y hallador, bajo la pena de perderlo todo, y otro tanto más si no to manifestare, conforme lo resulelve la ley 2 , Tít. 12 , Lib. $8^{\circ}$ de Indias; la Ordenanza 9 $9^{n}$ Tít. 36 , Lib. $1^{\circ}$ de las Generales del Perú, y lá Real Cédula de 1573, referida por Escalona y el Sr. Solórzano. 45

Mediante el interés que tiene el Rey en estos enterramientos, nadie sino el Sr. Virrey, como Administrador General del Erario, podría dar licencia para descubrirlos y sacarlos. ${ }^{46}$ La práctica en pedirla $y$ despacharla, era la siguiente, que es la misma que debe observarse ahora con los Intendentes, por haber recaído él ellos la dirección por mayor de las rentas reales todas.

El interesado se presenta haciendo relación del lagar donde está el tesoro, y habiéndolo por registrado y legítimamente manifestado, pide licencia para poderlo sacar y el despacho de la Provisión ordinaria de 
Huacas. El Gobiemo o Intendente provee como lo picle, con la calitad de comenzarlo a trabajar dentro de tres meses y proseguir en su labor hasta haberlo ahondado cuatro estados en profundidad y largo, y tenerlo poblado de ordinario con negros y no con indios, bajo la pena de despoblado y la de manifestarse el despoblado a los Oficiales Reales, para que nombren los sobrestantes o veedores ante quienes se labre y lleve cuenta de lo que se sacare, con cargo de remitir vazón de ello carla dos meses, bajo pena de perdimiento de lo que se extrajere sin esta formalidad, y de la mitad de sus bienes. ${ }^{4} 7$.

Los Subdelegados que se han substituílo a los Corregidores, es regular quieran arrogarse la facultad de concedel estas licencias, como antes Ias podian dar aquellos, según la doctrina de Escalona. ${ }^{48}$ Por lo mismo, debo advertix que nuestro autor habla en el supuesto que tuvieren comisión del Superior Gobierno, una vez que él mismo enseña ${ }^{49}$ que estos permisos eran privados al Sr. Virrey, aunque también podrán concedertos los Subdelegados, por comisión de los Intendentes de sus Provincias.

Párrafo vigésimo. - Venta g $\mathbf{W}_{\mathrm{N}}$ otro lugar 50 traté extensamente socomposición de Tierras. bre el método práctico de vender y componer las tierras de la Corona Real; expuse las estaciones de este negocio y la autoridad a cuyo cargo corre. Aquí sólo debo añadir que por el Art. 78 de la Nueva Ordenanza, los Intendentes son Jueces privativos de las dependencias y causas de este género y queda comprendido este caso entre los demás de la Dirección por mayor de la Real Hacienda, del modo que antes conocían de él los Señores Virreyes, aunque ahora con varias limitaciones, que ya expliqué en esta obra.

Párrafo vigésimoprimero. - CoMo caso de Gobierno Superior de HaRevisitas. cienda, tocaba al Sr. Virrey mandar hacer nuevas revisitas cada tres años, con citación

del Fiscal y de los Oficiales Reales; o antes, si a pedimento de Protector o de los Caciques de toda la comunidad, se calificaba disminución notable, por calamidad, muerte o ausencia de tributarios. En estas Matrículas intervenian muchos oficiales inutiles, con el título de Alguacil Mayor, Defensor de Indios y Defensor de Real Hacienda, para las estaciones y diligencias que encuentra por menor nuestro Escalona, $\mathbf{5 1}$

Las experiencias sucesivas han dictado otras providencias, $y$ alterando el antiguo sistema, han mejorado nuestro gobierno. Se establecieron las Intendencias en la América, y se creó en la capital de Buenos Aires un Superintendente General Subdelegado, a cuyo cuidado, dirección y manejo corriesen todos los ramos y productos de Real Hacienda, separándolos absolutamente del conocimiento y jurisdicción de los Señores Virreyes.

Consecuente al Art. 2, de la Nueva Ordenanza, en que se planteó y dispuso este nuevo establecimiento, se concedió por ol Art. 118 a los Intendentes, omnímoda jurisdicción en el ramo de tributos, como en los demás productos de Real Hacienda, extendiéndoles las facultades el Art. 120 hasta el 124 inclusive, para practicar en cada quinquenio, por sí o por 
sus Comisarios, las visitas para empadronamiento, numeración, cuentas y matricula de Tributarios, con separación de las castas que deben satisfacerlos, aunque sean sirvientes domésticos de los Virreyes, Magistrados, Prelados, Eclesiásticos y cualesquier otras personas exentas o poderosas, sin asistencia de otros oficiales que el del Juez de Matrícula, un apoderado Fiscal, un intérprete $y$ un amanuense, con absoluta supresión de los demás empleados que intervenían antes en estas operaciones, según lo resuelto en el Art. 4 hasta el 10 inclusive, de la última Instrucción Metódica de Revisitas, su fecha, $1^{\circ}$ de julio de 1784.

Antes de cumplir el quinquenio, no se pueden renovar las Matrículas, a menos que el aumento de los Tributarios o su disminución fuere tan visible, que en justicia deba ser oída la parte del fisco, la de los Encomenderos o la de los recaudadores, porque entonces podrán los Intendentes proceder judicialmente, por medio de revisitas y retasas, en la forma que lo disponen las leyes 54 y siguientes hasta 59 inclusive, del Tít. 5, Lib. 6. de Indias, citadas en el Art. 124 de la Ordenanza, sujetando todos estos procedimientos a la aprobación de la Junta Superior, del modo que prescriben los Arts. 122 y 123 de dicha Instrucción de Intendentes.

En Acuerdo de Juntas, su fecha 12 de enero de 1764, mandó el Sr. Virey, Don Mianucl de Amat, que practicándose revisitas en las Provincias afectas a la Mita de Potosí, debe hacerse con citación del gremio de Azogueros, nombrado éstos persona que conelir"a a su actuación. La posterior Instruceión metódica, ya citada, a sabiendas del interés de la Aroguería, no previno más citación, en el Art. 11, que la de los Encomenderos que gocen situaciones proporcionadas a la gruesa o número de los contribuyentes, por el interés del aumento o rebaja de la pensión. Nada dispuso sobre la citación de los Azogueros; antes bien, proscribió la multitud de Oficiales que antes concurrían con crecidos costos de parte de los interesados, además del pexiuicio de retardarse o confundirse la Matrícula.

Por estas razones, debe entenderse la orden referida del Sr. Amat, reducida al preciso caso de verificarse la revisita particular de alguna Provincia, a pedimento de la Azoguería, sin intervención del Fisco; porque las numeraciones que se practican con las solemnidades prefinidas en la Ordenanza, se reputan legítimas y bien calificadas, una vez que, siendo de mayor privilegio el interés del Rey, no se contradijeron las operaciones por su apoderado Fiscal.

Según el antiguo sistema, era facultativo a los Corregidores dar reservas de tributo y Mita a los enfermos, viejos e impedidos corporalmente. Algunos de los que hacían granjería del oficio, sacaban ventajosos partidos de este ramo, porque cuantos indios les presentaban seis u ocho pesos, negociaban su reserva. En el día se ha cortado este abuso, cometido privativamente a los Intendentes Ia autoridad de reservar las clases de Tributarios que refiere el Art. 25, hasta el 28 inclusive, con las formalidades explicadas allí mismo.

En cuanto a libertar del Tributo a los que pretenden excepcionarse con el pretexto de ser mestizos, hijos de español, usaron también indistintamente de esta facultad los Corregidores, apoyados del tenor de varias leyes en que se concede a los mestizos este privilegio, y pueden verse en el Sr. Solórzano. 52 
Aunque este sabio Doctor declama contra el abuso que comenzó a introducir más privilegio a favor de la iujuria que de la castidad, es cosa sentada que el mestizo no tributa, siempre que justifique debidamente esta condición y cualidad.

El Superior Gobierno de Lima, por Auto acordado de 8 de julio de 1726, prohibió a todas las Justicias el recibir semejantes informaciones, sin presentarse primero la fe cle bautismo autorizada por el Páxroco y comprobada por el Corregidor del Partido, por cuya mano se debia dar parte al Sr. Virrey, con las diligencias para su aprobación. El Art. 32 de la Instrucción Metódica, exige dos informaciones: una por parte del interesado, con previa citación del Fiscal, $y$ otra de oficio, por medio $\mathrm{e}$ intervención de los Gobernadores, Alcaldes y Oficiales indios de los pueblos donde son originarios los pretendientes; con más el informe jurado de los Curas, fe de bautismo y casamicnto, y certificado de lo que constare acerca de este punto en la última Matrícula; cuyos documentos se deben remitir por el intendente a la Junta Superior, para que se decida el punto y se tome la respectiva razón en la Contarluría de rentas.

Sin embargo, yo comprendo que ya era tiempo de ir disimulando el pago de los tributos por parte de los mestizos que cn adelante cumpliesen la edad de 18 años, sin admitirles información sobre esta calidad, ni oírles acerca de ella, porque si en menos de 300 años que tiene de conquista este Reino, se ha minorado casi la mitad de los indios, no tanto por aniquilamiento, cuanto por haberse transformado en otras castas, como son los mestizos y otras, debemos temer may problablemente que dentro de otros tantos siglos se volverán mestizos nuestros actuales indios y si continuamos libertándolos de tributo, nos quedaremos al cabo de dicho tiempo sin tener tributarios, ni quien nos sirva en las minas y otros trabajos públicos importantes al Estado.

La justicia de este proyecto queda sostenida en la antecedente obra de nuestro sabio Solórzano; y la facilidad de su expediente se concibe de que su causa no es común, como sucede con los mestizos antiguos, que tratándose ya en clase de españoles, sería inverificable hacerlos contribuír sin peligro de conmoción. En lo demás, que de nuevo quisieran salir de la clase de tributarios, no se interesa otro que el mismo pretendiente, su clamor será despreciado por único, y cuando hubiere algún rumor sobre la novedad, se apagará en breve con los buenos medios que tomase el gobierno.

$Y$ siendo consiguiente a estas prolijas operaciones, el cuidado de la exactitud en la cobranza de los tributos, se impuso a los alcaldes ordinarios de los pueblos y ciudades, por obligación esencial de sus oficios, la de correr con la recaudación y entero de las tasas, bajo la indispensable responsabilidad con su persona y bienes, de mancomún a la paga, si ésta se atrasare por su descuido o abandono, sin diferenciarse de los Subdelegados en esta parte, sino en que estos últimos afianzan a satisfacción de los Ministros de Real Hacienda, como se previene en los artículos $8,9,73,116,118,122$ y 124 de la Nueva Ordenanza.

Poniéndose en práctica estas providencias en Potosí, ahorraría la Real Hacienda los crecidos salarios de administración que paga a los recaudadores de los tributos de yanaconas e indios criollos de la Villa. Ahora percibe el Administrador del ramo de yanaconas, mil pesos anuales de la gruesa de 3.246, que entera en Cajas Reales. Si los Alcaldes ordi- 
narios colrierau con esta recaudación, se rebajarían solamente 12 pesos para los indios alguaciles cobradores, por razón del cuatro \% señalado por la cobranza en los Arts. 177 y 128 de la Ordenanza de Intendentes. Y véase aquí, cuánto más ventajoso le sería a la Real Hacienda este partido.

Párrafo vigésimosegundo, -Imposición de Juros. se hace pieciso vender e imponer Juros sobre las Cajas Reales, para consultar los alivios de la Corona. En el Reino tencmos repetidos ejemplares de haberse así ejecutado, y hasta ahora subsiste sobre estas Cajas de Potosí el principal de 117.119 pesos $7 \mathrm{y} \%$ reales, impuestos por veintidós comunidades de indios del distrito de la Real Audiencia de Charcas.

Según los accidentes, no había lugar muchas veces de que preceda orden del Rey. Con todo, como los señores Virreyes eran cabezas o Jefes de la Administración de Real Hacienda, solían proceder a la imposición de Ju*os, usando de los amplísimos poderes anexos a su dignidad, $y$ aun en el caso do haberse despachado ordenes gencrales a este fin, debían los Oficialos Realos consultar estas ventas e imposiciones.

En fuerza de la dirección por mayor de la Real Hacienda que tienen los Intendentes, no pueden sin orden especial del Rey, hacer ventas e imposiciones de Juros; porque esto sería librar sobre la Real Hacienda el importe de sus réditos y gravar al Erario, contra las prohibiciones de las leyes. Solamente la Junta Superior, subrogada en todo a los Señores Virreycs, con las facultades y autoridad suprema que éstos ejercían, según lo disptesto en el Art. 105, al fin de la Nueva Ordenanza, podrá proveer la imposición de Juros, consultando luego al Rey, en aquellos casos tan indispensables que la dilación causaría daño irreparable; y los Intendentes de Provineia estarían obligados entonces a solicitar estas ventas de Juros y a proponerlas a la Junta Superior.

Párrafo vigésimotercero. - E- LoS Señores Virreyes, como administrarección de Cajas Reales. dores mayores de la Real Hacienda, prefijaban en casos necesarios los lugares y sitios donde debían colocarse las Cajas Reales, y usaban del arbitrio de abolir las que hallaban por conveniente, o de separar algunos ramos, encargándolos a otra Caja, para su mejor expediente, como se ejecutó segregando de Potosí la exacción de los tributos de Paria y Carangas, cometiéndola a los Ministros de Oruro, fuera de otros muchos ejemplares que refiere Escalona, ${ }^{53}$ citando los gobiernos del Señor Toledo, Marqués de Guadalcázar y Conde de Chinchón.

En el sistema de Intendencias, ha recaído esa autoridad en la Junta Superior y ella sola puede ejecutar estas novedades por el Art. 31 de la Ordenanza, concediéndose por ella misma a los Intendentes, la facultad limitada de proponer y representar lo conveniente a este asunto.

Del mismo modo deben proponer los oficiales subalternos y sueldos necesarios para e] servicio de las Cajas, y el tanto \% de los Tenientes que hayan de servir - las Tesorerías menores o sufragáneas; y aunque la Junta puede mandar ejecutar lo primero, ínterin da cuenta al Rey, 
debe suspender la dotación de los Tenientes, hasta la resolución de Su Majestad, conforme al Axt. $3^{\circ}$ de la citada Ordenanza.

Párrafo vigésimocuarto. - Arbitrios para aumento de la Real Hacienda.
I cian antes para acrecentar y boneficiar el Real Erario, por medio de arbitrios equitativos y justos, is deber ahora los Intendentes de Provincia tratar, y con preferencia, en las Juntas semanales de gobierno, los modos de aumentarla en todo lo posible y justo, conforme al Art. 204 de Ja Ordenanza.

Pero deben escuchar con discernimiento a los arbitristas, despreciando las cavilaciones y adoptando solamente aquellos proyectos que sobre aumentar las rentas del Soberano sirvan para prosperar la opulencia del Estado. Todos los demés son dignos de menosprecio y aun de castigo, como destructores de los países.

Párrafo vigésimoquinto. - A. - péndice de los objetos de la Dirección por mayor de Real Hacienda.

$\mathbf{L}$ conducir sus cuidados un Intendento exacto, hábil y amador del Rey y de la putria, viene a reducirse a un solo principio universal, como es sacar todo el partido posible de todas las producciones de la naturaleza, para que al mismo tiempo que la sociedad disfrute de las que nacen, crecen y se crían en los campos, en los bosques, en las aguas y en los mismos subterráneos, se cultiven todas ellas con talès progresos que le redunden al Estado, por medio de las contribuciones que pueden hacer los vasallos con los recursos que les franquean los propios frutos del país.

A tientas no puede procurarse esta felicidad. Son menester muchas medidas exactas y no equivocadas para reglar un sistema que sea ventajoso para el Estado, por medio de las contribuciones. El Jefe de la Hacienda debe conocer esencialmente la situación del lugar, el aire, el clima, la naturaleza del terreno, el grado de fertilidad, los ríos, las producciones naturales, el ingenio de los habitantes, los mares, puertos, sus límites y vecinos, sus fuerzas, su feble y otras mil particularidades.

A este fin, impone a los Intendentes el Art. 21 y el 22 de la Ordenanza una obligación perpetua de visitar sus Provincias cada año, por sí mismos, si no es en el caso de absoluta imposibilidad, en que podrán enviar sus comisarios subdelegados, para que tirando sus serias reflexiones sobre el campo mismo, puedan promover la agricultura, el comercio, la industria y la minería, dispensando la estrecha prohibición de visitar los Distritos más de una vez, durante el tiempo de sus oficios, que se impuso a todos los Gobernadores, Corregidores y Alcaldes Mayores, por la ley 21, título 2, libro $V$ de Indias, porque el temor de que los puebios fuesen molestados con estas visitas, se evitó enteramente con haberse mandado practicar sin ningún gravamen.

Entretanto se mediten otros arbitrios para acarrear las riquezas a este país, voy a proponer tres objetos muy ventajosos, que no deben confundirse con las demás operaciones de Hacienda, y merecen por su importancia, tratarse separadamente en tres secciones distintas. 
Sección primera. - Impuestos
sobre las Tierras.

$\mathrm{N}$

Lo hay contribución más justa que aque. lla que pagan (en todos los reinos) las tierras de la campaña, a proporción del grado de su csterilidad, para que no se desaliente la agricultura con el gravamen del impuesto. Fs demasiado crecido y ventajoso el producto de este subsidio y los Ministros de Hacienda nunca lo pierden de vista entre los ramos de su manejo. Con todo, nuestros Reyes han sido siempre tan benélicos a los naturales y habitantes de estos países, que por su alivio han querido privar a su Erario de las entradas de esta lucrativa contribución.

Me escollaría desde luego en los invencibles inconvenientes que han suspendido este proyecto, si yo intentare promoverlo. También me haria despreciable en quever establecer con la pluma la plantación de un sistema que hasta ahora no se ha pretendido sostener con la fuerza. Lejos de mí, scmejante cavilación; no es esto lo que solicito. Es otra cosa muy diferente, que no perjudica al vasallo, ni puede agitarlo para la queja, y en todo se conforma al espíritu de nuestra moderna legislación y al estado de las Indias.

En otro lugar sí referi los repartimientos de tierras comunales, que hizo ol Señor Virrey Toledo a los pueblos de indios del Reino del Perú, para que activándose todas, se fuese formando con sus productos un fondo de comunidad en alivio de las necesidades de las mismas poblaciones.

I os poderosos do cada Distrito hallaron en la codicia de los Caciques y en la indolencia de los miserables indios, una puerta bien franca para adchuirir la propicdad de los mejores terrenos, porque apoyados de los mismos Corregidores sin encontrar oposición en las comunidades, consiguieron tomar a censo las tierras más fértiles, con pretexto de ser inútiles a los indios.

Las más estériles, que no eran dignas de ambición, se dejaron a los pueblos en calidad de suficientes para los destinos propuestos en las leyes. Nadie cuida de estos productos; los Caciques son los árbitros de las tierras; hacen las reparticiones como se les antoja, y como no se les toma cuenta de su manejo, usurpan sin temor los valores de los arrendamientos, en perjuicio de la viuda, de los pupilos y de los demás tributarios, que no teniendo en qué emplear su industria y su trabajo, viven abandonados a la holgazanería en sus propios domicilios, o desertan a otra Provincia, con su familia o sin ella, para entregarse a todas las distracciones de los vagos y malentretenidos.

La irregularidad de este sistema se demuestra con dos principios universales, según las leyes sociales. El primero, es que los dominios se dividjeron por dictamen de la razón para evitar la discordia que pare la confusión de las propiedades y escusar las usurpaciones de los más poderosos, no menos que para alentar la agricultura, con el interés de cuidar cada uno de su propia pertenencia. ${ }^{56}$ El segundo, se reduce a que todas las propiedades se formaron sobre algún interés; según fuere el interés, así son las sociedades, quiero decir, que si el interés es permanente, la sociedad es durable; y por el contrario, se disuelve luego que el interés se acaba. Por esto es que los gobiernos bien reglados, nada promueven tanto como la agricultura, porque la tierra agradecida siempre al cultivo del hombre, sobre poco más o menos, jamás le falta con lo necesarto para la vida, y muchas veces produce aun lo supérfluo. 
Este interés tan permanente, como el suelo que es su raíz, fija la sociedad donde ha de subsistir para siempre. Lo cierto es que sin tierras, no puede haber agricultura. Sin agricultura, no hay industrias ni comercio, porque faltan las materias primas para el cmpleo de las artes, y hasta aquellas producciones en bruto que se transportan por sobrantes a otros países. Por último, sin comercio, industria y agricultura, no hay población, porque no hay interés, que es quien atrae los hombres a la sociedad, siguiéndose de este desorden la resultante ncesaria de no haber reino, o de irse disminuyendo por grados hasta su exterminio.

Puntualmente íbamos oxperimentando ustos funestos efectos en nuestras Américas. La imponderable miseria en que vemos abandonados a estos infelices, persuadía haber'se comprendido en las formidables maldiciones con que Dios amenazó a sta pueblo por boea de Isaías. En efecto, arrojados de sus propios establecimientos, clamaban por la restitución en sus derechos. Ya no el'a tiempo de dilatarse el jemedio, porque el Reino se exponía a decaer sin esperanza de convalecer.

Nuestro sabio Gobierno conoció que la falta de tierras era el único o el principal origen de la decadencia de nuestras poblaciones y de los demás ramos de Estado; y trató luego de mejorar el antiguo sistema, ordenando que todos los indios casados participen de pequeñas propiedades, en suerte proporcionadas para dotación de su subsistencia.

Porque según principio asentado de la Política, nada promueve tanto la pronta multiplicación del pueblo, como la división de las tierras en pequeñas partes. La causa es que, multiplicándose las producciones a proporción de las tierras, crece la cantidad de habitantes, al paso que se aumetan los frutos de qué sustentarse. Por esto se advierte que la Cataluña y otras provincias septentrionales de España, son mucho más pobladas que las interiores, donde son grandes las labranzas.

Con este noble objeto, previene el Art. 57 de la Nueva Ordenan$\mathrm{za}$, los repartimientos menudos de tierras, bien sea realengas o baldías de las comunales o privadas, con la calidad de inalienables y trasmisibles a los herederos con sólo el dominio útil, quedando el derecho reservado a la Real Corona, bajo la pena de privación en caso de no aplicarse a su cultivo para repartirse a otros que cuiden de utilizarlas.

Aunque no son claras, ciertas y demostrativas las palabras de esta Ordenanza, en cuanto a la constitución de Ia enfiteusis, se colige conjeturalmente, que no fue otro el ánimo de Su Majestad, que el de establecer en todas las tierras mandadas repartix, una enfiteusis mixta, respecto de habcrlas de adquirir los indios para sí, sus hijos y herederos, 57 y de concederles a todos ellos para su cultivo, siembra, utilidad y mejoramiento, que es el significado propio de la enfiteusis.

Sobre este supuesto, $y$ el de ser justísimo que Su Majestad recobre de algún modo las cantidades que va a perder, aprovechando las tierras realengas que manda repartir a los indios, juzgo que podría formarse un ramo bastante pinguie con el producto del impuesto sobre cacla medida o suerte de las que se repartieren.

Todos saben que esta contribución debe proporcionarse al grado de fertilidad de las tierras, precediendo reconocimiento prolijo por donde conste la calidad de cada una y sus respectivas medidas, para el ajustamiento del impuesto, para que se haga con justicia y equidad. En nuestro caso no juzgo conveniente proporcionar la contribución de los frutos 
de cada territorio, porcue esto sería una especie de arrendamiento más bien que la enfitensis.

Una pensión moderarla en reconocimiento del dominio directo de la Corona, contemplo que se debe imponer a cada cuadra de tierras, regulando cada suerte de 50 varas, a cinco pesus anuales, y a esta proporción las medidas menores, como se ejecutó en Buenos Aires, concediendo a aquella capital, por Real Cédula de 7 de septiembre de 1766 , el impuesto de cinco pesos sobre cada solar o cuadra de su ejido, para que de ese producto, ramo o arbitrio, se concluyesen las casas capitulares, en atención a que lallándose ya poblado todo el ejido, serían muy graves y fundadas las quejas de los que se habían empleado en su cultivo, si se les hubiese de arrojar de aquellos establecimientos.

Este excelente modelo sirve como de principio regulativo del impucsto sobre las tierras del Perú. Ya hemos visto que los caciques, en vez de ecónomos, son unos perpetios usurpadores del producto de las tierras de comunidad; ellos las distribuyen a personas de su aceptación, sin guardar orden, equidad ni justicia. Jos más individuos de casi todas las comunidades, viven quejosos, agraviados y descontentos, al ver las tierras comunes reducidas al dominio privado de los caciques.

En medio de la tiranía, viven sobremanera contentos los que merecen el arrendamiento de un corto pedazo de tierra, sin reparar en precios. ¿Cuánto más gusto tendríali estos infelices, recibiendo de mano del Rey una cuadra medida o suerte de tierras para siempre, sin dependencia de los caciques, bajo de una pensión tan moderada que les sale cuatro veces menos que los arrendamientos anteriores? Lejos de quejarse, elogiarían la providencia, darian gracias al Rey, alentarían su industria y arrojarían de sí la desidia a que están hoy abandonados por consecuencia de su propia miseria.

Sabemos que todas las subsistencias están en manos de la parte de la nación que posee el dinero o las tierras; que quién nació sin bienes y se halla reducido a sus facuitades naturales, sin más posesión que su fuerza o alguna parte grosera y fácil, es la clase más miserable de la sociedad, porque todo su vivir depende únicamente de su jornal; por último, que como nadie da cosa aiguna de balde, es preciso que todos los hombres que nacen sin bienes raíces, vendan su trabajo a los ricos, empleando en servicio de ellos todas sus fuerzas desde el primer momento en que pueden hacer uso de ellas. De esto procede que nuestros indios jamás han podido instruírse para salir de la primera barbarie en que los encontramos, porque todos los momentos de la vida apenas son suficientes para ocuparse en un trabajo industrioso de qué poder vivir: crecen y mueren tan pobres como nacieron, porque el cambio de su trabajo es siempre tan desigual que difícilmente alcanza para surtir los alimentos.

Sin embargo, como toda propiedad aunque pequeña, es fuente de beneficio y de distinción, se contemplaría cada indio que llegase a adquirirla, por el hombre más feliz, a trueque de una pensión tan corta. Ellos mismos denunciarían las tierras comunales y baldías, ofreciéndose a la contribución del impuesto; $y$ desde luego sería éste el único o el singular entre los ramos de Hacienda, establecidos sin queja del pueblo.

Además de esta conveniencia, resultaría otra no menos importante a Ia quietud del Reino, cual es extinguir los innumerables litigios con indios, sobre tierras, mediante las nuevas medidas, apeos, repartimien- 
tos y límites que se les señalase, dejando a cada pueblo un terreno corto, en calidad de ejido, para salida, desahogo y pastoreo de los ganados de labranza.

Al mismo tiempo de recaudarse los tyibutos, so mandaría hacer Ia cobranza del impuesto, bien fuese on dinero o th especie tasada, conforme a lo dispuesto en el Art. 127 de la Nueva Ordenan\%a, una mitad, que se aplicase para fondo de comunidad crecería tan prontamente que en breves años habria caudal suficiente para fundar un Lombardo o Monte de Piedad, que diese a préstamo sobre los ralores de las mismas tierras, aquellas cantidades que se necesitasen para pagar el impuesto o para tener corrientes las labranzas, mediante la compra de bueyes y de otros materiales indispensables. Habria entonces con qué fundar y dotar escuelas de lengua castellana y de otras artes demasiado útiles para instrucción de los indios y para hacerles ventajoso su trabajo.

La otra mitad sería un nuevo ramo de Hacienda con que pudiera sustentarse un destacamento veterano on el pueblo cabecera de cada Partido, además de la capital, para mayor seguridad de las Provincias, sin necesidad de echar mano de otros miembros ya gravados con otras consignaciones de igual importancia.

El modo de reglar este utilísimo proyecto es, que los Subdelegados reconozcan prolijamente los terronos comunes realengos y baldíos de sus Partidos, informando las suertes que serán necesarias para ejidos o praderas de los ganados de labranza de cada comunidad, para dejar estos terrenos sin repartimiento, por ser cosa indubitable que sin pastos no hay ganados y sin ganados no hay agricultura. Con estas noticias que deben hacer su referencia al distrito de cada parcialidad, es fácil hacer cotejo con los padrones de Revisitas, para hacer las medidas y distribución de suertes, según el número que se encontrare, en los términos que prescriben los Arts. 46 y 48 de la Instrucción Metódica de $1^{\text {? }}$ de julio de 1784; que jgualándose de este modo todos los indios en sus arraigos y propiedades, se abolirá en pocos años la clase de los vagos y se aumentarán los matrimonios, que tanto recomiendan las leyes del Reino ${ }^{58}$ en beneficio de la población.

Sección segunda. - Alcabala HEMOS expuesto en otro lugar 59 los mude arrendamiento de Diezmos. chos motivos legales en que nuestros regnícolas fundan la obligación de Ios arrendamientos de Diezmos, para pagar alcabalas del importe de la gruesa; y también promoví el cuidado de los Intendentes sobre su cobranza, citando el ejemplo de Escalona, que siendo Corregidor de Jauja, lo entabló en sus Provincias.

Aunque supongamos que a los cinco Partidos de Potosí, sólo les cabe una cuarta parte de toda la masa decimal, que en este Arzobispado de Charcas asciende a ciento treinta mil pesos, tendríamos que contar de fijo con dos mil pesos anuales de Alcabalas, que es la cuarta parte de siete mil y ochocientos, que monta el $6 \%$ sobre los dichos ciento treinta mil pesos de Diezmos.

El único reparo que puede oponerse, es no estar en práctica su recaudación; pero esta objeción es demasiado f'rívola, no debiendo ignorarse que son imprescriptibles los tributos y demás derechos reales, en que 
se incluye la Alcabala, como to deciden muchos textos elementales ${ }^{60} \mathrm{y}$ más expresamente nuestro derecho Rcal. ${ }^{61}$

En cuya vintud afirma nuestro Lazarte, 62 que no puede aprovechar para no pagarse, el que se alegue no haberse cobrado jamás la $\mathrm{Al}$ cabala en este o aquel lugar, a menos que se manifieste por escrito el privilegio del Príncipe; de tal manera que ni el transcurso del tiempo inmemorial es suficiente para relevar al vasallo de esta obligación; 63 aunque otros Doctores graves sienten lo contrario."

Por lo mismo, no hay inconveniente de hecho ni de derecho, para que al tiempo de cerrarse los remates en la Junta de Diezmos de Chuquisaca, se solicite por esta Aduana una razón ccrtificada de los arrendamientos comprensivos del Distrito de la Intendencia de Potosí, para formarles el cargo correspondiente a la gruesa de cada Partido o Doctrina, obligando a los fiadores a que hayan de responder por este ramo de Hacienda, igualmente que por los Diezmos.

Al principio se puede adoptar este método como más expedito $y$ fácil para la cobranza, pero siempre sin perjuicio del aumento de valores, que según la canticlad de frutos recolectados acreditare la cuenta jurada que doben presentar los arrendadoles de los efectos que percibieren, con expresion rle parajes, tiempo y personas, con arreglo a los Arts. 160 y 161 de la Nueva Oxdenanza.

$Y$ para que el cargo sea legitimamente instruído, se puede pedir cada año al Contador Real de Cuadrantes, un extracto en relación de dichas cuentas; suspendiendo en el entretanto la cancelación de los remates y fianzas, hasta que haga constar cl interesado estar solvente con esta Aduana.

Esta misma operación servirá para reconocer y examinar, cada año, la consistencia y calidad de las cosechas, las cantidades sobrantes de frutos y los que se necesitan para abasto de los pueblos, a fin de proporcionar con tiempo el permiso o prohibición de extraerse fuera de la Provincia, para precaver carestías, arreglándose a lo dispuesto en la ley 17, Tít. 5, libro 5" de Indias, que sólo permite sacar para otros lugares, lo que sobrare donde se cogieron los frutos, con el menor perjuicio y daño que se pueda.

Sección tercera. - Siembra de $\boldsymbol{L A}_{\mathrm{A}}$ siembra de tabaco, su aparejo y fâm Tabaco. brica, es según todos un objeto de la mayor ventaja del Departamento de Haciènda y un

origen lento de muchas riquezas, por su considerable despacho, aun en el caso que la hoja no sea tan excelente como la de Virginia, Habana, Brasil, Paraguay y otros parajes de América.

En estas Provincias tenemos las mejores proporciones para cultivar con demasiado provecho esta preciosa planta. Los terrenos de Valle Grande, Chilón y Samaipata son los más a propósito por su bondad para el tabaco, y por este respecto se han reducido allí las siembras a cargo de personas obligadas por contrata al surtimiento de las administraciones generales de esta Villa, La Plata, La Paz y Cochabamba, quedando enteramente prohibido el cultivo que antes se practicaba en el Partido de los Yungas, el de Tomina con su frontera y el de Bermejo en la jurisdición de Tarija. 
La poca uniformidad en las entradas de este ramo, indica claramente que su origen son los contrabandos y fraudes, pues que, no habiendo crecido la población, debía ser en todos los años uno mismo el consumo; pero, como los contrabandistas venden en unos años más tabaco que en otros, es consiguiente que entonces tengan menos despacho las administraciones de estas rentas.

Por esta razón no se ha liquidado a punto fijo el producto anual de esta Administración General, así en lo respectivo a la Villa, como a todos los demás Partidos que estuvieren sujetos a ella, y sólo se computa desde el año de 1756 hasta el de 1764 el consumo, como de 25.000 pesos; desde este año hasta el de $1779,16.000$ pesos; de éste al de 1784, 20.000 pesos; y en este último, 15.775 pesos.

Algunos prácticos del país opinan, que el único medio de minorar los contrabancios, cuando no se extinguiesen del todo, es réducir a uno o dos sujetos exclusivamente, la siembra, fábrica y recolección de toda la gruesa de tabacos que se necesitan para surtir las referidas administraciones de Potosí, La Plata, Cochabamba y La Paz, porque el propio interés de estos Asentistas celaría sobre los demás hacendados, para que no cometiesen fraudes.

El remedio no es radical, porque estos mismos obligados cometerían también los fraudes que ahora ejecutan los otros. Bien que era menos embarazoso el velar sobre ellos por medio de celosos resguardos, siempre que se limitasen las siembras a un número determinado de plantas, a proporción del consumo.

Mucho se pudiera remediar con esta providencia. La Dirección General de Buenos Aires sabrá dictar con su prudencia los mejores medios de extirpar el contrabando. Yo únicamente advierto que, trayendo semillas del Brasil o Paraguay, se podría mejorar otro tanto más la calidad de estos tabacos, y por lo que hace a su aparejo y fábrica, sería muy conveniente que algunos de los muchos maestros portugueses que pasaron a enseñarla en el Paraguay, viniesen a esta Provincia con el mismo destino.

\section{NOTICIA C U A R T A}

De lo jurisdiccional de Justi.
cia en las dependencias de
Rentas. lo respectivo a las cobranzas como en todas sus incidencias, 65 ya sean sobre cualesquier ramos, rentas y derechos reales, generales o particulares, administrados o arrendados, ${ }^{6}$ como son los tabacos, pólvora y naipes; ${ }^{67}$ ya sobre comisos, contrabandos y condenaciones. ${ }^{68}$ De tal forma que, aunque los Subdelegados hayan formado las causas de este género, sólo pueden proceder hasta ponerlas en estado de sentencia y remitirlas al Intendente de Ia Provincia, para que la pronuncie en justicia, con acuerdo de su Asesor. ${ }^{69}$

Asimismo, son Jueces privativos de todas las dependencias que ocurrieren sobre las ventas, composiciones y reparticiones de tierras rea- 
lengas, con la calidad de determinar estos negocios con dictamen de sus Asesores ordinarios. ${ }^{70}$

Por lo que mira a las confiscaciones, una vez pronunciada y ejecutarta la sentencia, toca a los Intendentes verificar la enajenación de los bicnes y el importe de su cobro, como también el conocer de los pleitos e instancias promovidas sobre los efectos confiscados, ${ }^{71}$ proveer el cumplimiento de todas las cédulas y ódenes, iz y la averiguación, cobro y aplicación a la Real Hacienda, de las presas, naufragios, arribadas y bienes vacantes, dindo cuenta con diligencia al Rey, por la vía reservada. ${ }^{73}$

De estas cuatro últimas especies de causas, cualquiera de las tres primeras debe considerarse rarísima en la Intendencia de Potosí, porque el único Puerto de su Distrito, que es la Magdalena de Cobija en el Partido de Atacama, no es de los habilitados en el reglamento de libre comercio de España a lndias, it ni se frecuenta por los navíos de la carrera de Jima y Chile, por la poca proporción de arrieros, y porque es más expedito y socorrido el Puerto de Arica, situado en la misma costa. .

Con todo, si octurieren algunos casos de igual naturaleza, son terminantes para presas las leyes $4: 1$ y siguientes, hasta la $7^{*}$ inclusive, del título 13, Lib. $3^{\circ}$ de Indias. Para aribarlas, el Art. 41 del Reglamento citado del comercio libre y las leyes del título 38 , Lib. 99 de la misma recopilación, hasta la vigésima, leduciéndose las posteriores hasta la 25 del propio título y la 20 del título 25 del mismo libro sobre naufragios y derrotas, a las cuales puede añadirse la ley $7^{\text {? }}$, titulo 9 , partida 5 ; leyes 4 y 10, título 12, Lib. 6" del Ordenamiento, y la leyes 9 y 11, título 10 , libro 7 de Castilla, con to expuesto sobre ellas por el Docto Lagunes 75 y Solórzano.

El caso más contingente es sobre bienes vacantes. Por lo mismo, apuntaré con alguna especialidad aunque en breve, el método a seguir en estos expedientes, con las leyes y doctrinas que facilitarán el trabajo para entender y decidir estos juicios.

Los bienes sin dueño se dividen en tres clases: unos se llaman mostrencos, porque no tienen dueño conocido ni persona a quien restituírlos; los otros se denominan propiamente vacantes, porque en la muerte intestada de alguno queda vacante la herencia, es decir, que no hay herederos que los representen; los otros son los que dejan los extranjeros por su muerte.

Algunos autores clásicos, ${ }^{76}$ movidos por la decisión de la ley 12, título 8 del libro $5^{\circ}$ de Castilla, son de sentir que, no hallándose parientes del difunto, dentro del cuarto grado, entra el Fisco. $Y$ esta opinión parece muy conforme a la ley 3 , título 9 , y a la ley 3 , título 10 , Lib. $1^{9}$ de Castilla, por las cuales se ordena a los Tesoreros y Factores de la Cruzada, que pidan $y$ demanden los abintestatos de los que no dejan herederos dentro del cuarto grado.

No obstante, deciden lo contrario otros regnícolas de la mayor nota, 77 fundando la sucesión de los parientes dentro del décimo grado, con exclusión del Fisco, en la ley 6, título 13, Part. $6^{*}$, que así lo declara y no debe reputarse corregida por la ley 12, título 8 , Lib. 5 citado de Castilla. Porque no prefiniendo los grados de parentezco a que se debe extender la sucesión, lejos de enmendar el derecho antiguo de Partida, antes bien se debe suplir por él su disposición indefinida, para evitar que se pretenda suceder hasta un grado infinito entre transvarsales, una vez que no 
se asigna, declara ni limita en la ley Real recopilada el parentezco a que haya de preferencia el Fisco.

Esta opinión es la más común y seguida por mestros Tribunales en la práctica, y conforme a ella se deben decidir los pleitos que ocurrieren sobre herencias intestadas en el caso propuesto y en los siguientes:

Primero: Que los hermanos o hermanas del difunto, auncue no sean legítimos, sino naturales, $y$ medios hermanos por parte de padre o de la madre, excluyen al Fisco y también a cualesquicr tíos o tías y parientes universales, conforme a la ley 12 , título 13 , Partida $6^{\circ}$, queriendo sea reciproca esta sucesión; de suerte, gue como el hermano legítimo les había de suceder a ellos, ellos le suceden igualmente a él, segín Matienzo, Souza, el Sr. Solórzano y Carrasco, "s que reficlen una decisión de la Real Audiencia de Lima.

Segundo: Que en defecto de parientes dentro del dócimo grado, excluyen al Fisco el marido o la nujer sobrevivientes, sucediendose reciprocamente el uno al otro, conforme a la ley 23 , título 11 , Partida $47, y$ a la ley 6, título 13, Partida 6, y a otros graves fundamentos que refieren Antonio Gómez, Matienzo, Molina, Velasco y otros clásicos autores citados por Souza y Lagunes, is impugnando la contraria de Tollo Fernández, a quien sigue y sostiene Carłasco. ${ }^{30}$

Tercero: Que muricndo intestato algún clérigo, sin dejar herederos dentro del décimo grado, no le sucede el Fisco, como opinaron Antúnez, Fajardo y Carrasco, $\$ 1$ sino el Obispo, en todos los bienes patrimoniales, ya sean muebles o laices, para distribuírlos en obras pías; y la Iglesia a cuyo servicio estaba destinado el difunto, heveda todo lo ad- quirido in tuitu Eeclesie. según resuelve con muchos fundamentos el docto Lagunes, ${ }^{2}$ citando a Doctores regnícolas muy célebres.

Si los parentezcos del difunto distraen en más del décimo grado, en cualquiera de estos casos, se radica en los Intendentes la jurisdicción privativa para averiguar la vacante de los bienes y proceder al cobro de su importe y aplicación a la Real Hacienda, cesando desde luego la autoridad de los Juzgados de difuntos, porque el conocimiento que se les concede por las leyes del Tít. $32 \mathrm{Lib}$. $2^{\circ}$ de Indias, se limita a las causas de intestatos en que hay parientes de mejor derecho que el Fisco. Por lo mismo, faltando estas circunstancias, o no constando que el finado tuviese parientes propíncuos en aptitud de heredarle, nada tienen que hacer los Jueces de difuntos, pues, aunque antiguamente ponian la mano en los bienes vacantes, en ciertos casos que prefinen las leyes 28, 40, 49 y 69 del citado título y libro, no lo ejecutaban por sí solos, sino con intervención de los Oficiales Reales, cuya autoridad era indispensable, interesándose la Real Hacienda en este ramo, que nunca fue ni lo es de los menos pingüies.

Pero no siendo suficiente que estos bienes pertenezcan al Fisco, para que se digan de la Corona Real, es disposición de todos los Derechos que se haga solemne incorporación en ella de todos los que deben recaer en el Fisco Real, bien sea por comiso, o por confiscación o por vacantes. ${ }^{\mathrm{B}} 3$

Muchos autores apuntan 84 el modo de practicar la incorporación, unión, ocupación o aprobación de estos bienes a la Corona, pero no lo instruyen puntualmente en cuanto a las diligencias, solemnidades y pre- 
gones que deben preceder para aplicarlos al Fisco, bien sea por dejar en su valor la práctica y estilo de cada Tribunal, o porque la suponen sabida por notoriedad, según la resolución de nuestras leyes.

Entre todos, los que mejor explican este punto son Antúnez, Peregrino y nuestro político Si. Don Juan de Solórzano, stos cuales ensenan que, denunciada en la Cámara Fiscal la muerte intestada de alguno, sin dejar herederos dentro del décimo grado, se recibe información sumaria del hecho y constando que ol difunto falleció intestato, se hace inventario solemme de todos los bienes que se dicen vacantes; en este estado, se mandan poner edictos a pedimento del Defensor Fiscal, llamado que parezcan y se legitimen los que pretendieren ser parientes del difunto, dentro del décimo grado, y para que llegue a noticia de todos, se dan pregones por término de dos años en nuestras Indias, así en la Provincia donde hubiere fallecido el difunto, como en los lugares de su natwraleza. Si pasado este término, no hubiere comparecido alguno a calificar su parentezco, se corre vista al Procurador Fiscal, y a su instancia se pronuncia sentencia, declarando que todos los bienes del difunto pertenecen al Fisco, como vacantes, $y$ en su virtud se apropian e incorporan a la Corona Real, procedióndose a su venta y subasta.

Las leyes del título 11, libro 9 " de Indias, previenen esta misma práctica, especifjeando las calidades con que se debe hacer la publicación y diligencias sobre bienes de difuntos, y la citación de los interesados. Ninguna cireunstancia se omite de las necesarias para la solemnidad de este gébero de juicio. Cualquiera duda es fácil de decidirse con la lectura de las citadas leyes y autores; por lo que omito alargarme en este punto.

En cuanto a la segunda clase de bienes, llamados mostrencos, se hallan prevenidas iguales diligencias, aunque menos morosas, y se reducen a que si alguno encontrare bienes ajenos sin dueño conocido, o se hallaren algunos depósitos, sin persona a quien restituirlos ni herederos que la representen; se forme juicio público a pedimento del Fiscal, dando un pregón en cada mes pol el término de un año y dos meses, y para justificación de estar diligenciados, debe oírse al Depositario por el derecho de su oficio, y a las demás personas interesadas que comparecieren a legitimar sis acciones hasta el auto declaratorio de incorporación, on la forma explicada, conforme Io resuelve la ley 7 , título 13 , libro $6^{\circ}$ de Indias; ley 18 , título 20 del libro $1^{*}$ de Indias; ley $7^{*}$, título 12 , Lib. $8^{\circ}$ de la misma recopilación, mandadas guardar en la ley $6^{*}$, del propio título y libro.

Y aunque por la ley 11 , título 5 , libro $5^{n}$ de nuestras municipales, se mandan pregonar los ganados mostrencos, por diez días, con la calidad que no pareciendo el dueño de un Consejo a otro, se aplique a la Cámara, esto se entiende en los lugares donde se halla establecida la atestación; porque en los demás pueblos, como Potosí, donde no se conocen semejantes Juzgados, se deben guardar las leyes precitadas y su disposición general acerca de bienes mostrencos, su averiguación y cobro, como los demás bienes vacantes. ${ }^{85}$

Jos bienes de los extranjeros que mueren en estos reinos, también pertenecen al Fisco, con la distinción que explica nuestro Escalona; ${ }^{87}$ porque estando prohibidos de residir y tratar en las Indias, no pueden disponer en su muerte de los bienes que en ellas adquirieron, por 
muchos años que las hayan habitado, como se observa en el Reino de Francia, tomándolos el Fisco como vacantes, y tambićn se estila en nuestras Indias, conforme a un consejo del Sr. Solórzano, son quien se conforman las leyes 3,6 y 26 , título 27, libro $9^{\circ}$ de Indias, declarando por perdida toda hacienda adquirida en ellas por los extranjeros.

Si el Fisco puede apropiarse también los bienes que dejan los extranjeros por su muerte, instituyendo ellos por herederos a personas naturales de estos reinos, es punto disputable, según el contexto de la ley 43 , título 32 , libro $2^{v}$ de Indias, y de la ley $1^{i}$, título 18 , Partida $2^{n}$, donde solanente se prohibe la enajenación en hombres de fuera del señorío, pero no en personas naturales del Reino, como declara otra ley del Ordenamiento, citada por Salcedo. ${ }^{80}$

Sin embargo, es más probable que pertenecen a la Cámara, porque habiendo sido adquiridos contra las prohibiciones de las leyes, se deben reputar desde su origen por perdidos y sujetos a confiscación. Esta opinión se confirma indubitablemente, por la Rsal Cúdula fecha en Madrid a 6 de julio de 1766, porque habiéndose declarado en ella por punto general, que no se encuentren los bienes de extranjeros que muriesen en América, estando casados con españolas o indias y dejando hijos habidos en ellas, es consiguiente la inducción que no puede scr heredero del extranjero el que no fuere hijo suyo, cono también que en este caso deben secuestrarse sus bicnes y aplicarse a la Cámara como vacantes.

En conclusión, debo prenotar dos casos que pueden ocurrir con frecuencia a los Intendentes, en materia de contrabandos, para que no vacilen en su resolución. El primero es, que las causas de los extranje. ros, por ilícito comercio, se deben substanciar y determinar en estos reinos, donde fueren aprehendidos, hasta imponerles la pena correspondiente, sin permitir que pasen a sus dominios, para no dejar sin castigo un delito como el de contratarse ilícitamente, según se declaró en Real Orden de 7 de mayo de 1776.

El segundo, que si en los registros que se puede hacer en las Aduanas, de las petacas y baúles de los eclesiásticos, se hallaren algunos bienes sin recaudos legítimos, a más del comiso en que incurren, sin que valga el pretexto de llevarlos a sus Conventos, a menos de manifestar certificación jurada de sus Prelados, deben los Intendentes pasar a éstos sus oficios para que los castiguen con demostraciôn, y siendo omisos en ejecutarlo, puede proceder a extranarlos de la América, como se declara en Real Cédula dada en Roma, a 7 de mayo de 1730, la cual, aunque habla con las Audiencias, debe entenderse ahora también con los Gobernadores Intendentes, así por lo dispuesto en la ley 19, título 8, libro $7^{\circ}$ de Indias, como porque en ellos reside la omnímoda jurisdicción en materias de Hacienda $y$ en todas sus incidencias.

Párrafo primero, - De Ias apelaciones $\boldsymbol{y}$ competencias en las causas de Facienda.
$\mathbf{L}$ cuyo establecimiento y facultades tratan detalladamente los artículos 3 y 5 de la Real Ordenanza de Intendentes, es el único Tribunal que puede conocer de las apelaciones y recursos que se interpusieren en las causas en que tenga algún interés o perjuicio la Real Hacienda, o que toquen a cualesquiera ramos y derechos suyos, conforme al Art. 
74 y 75 de la citada Ordenanza.

También tiene jurisdicción para conocer y deciđir las competencias que se suscitaren entre los Intendentes y cualquiera otro Tribunal, con la calidad de cjecutarse provisionamente y dar cuenta al Rey para su aprobación. Pero, cuando la competencia o duda fuere sobre las facultades de la Junta Superior, debe resolverla cl Señor Virrey, con la misma circunstancia de ejecutarse interinamente, conforme al Art. 75.

Asimismo, ofreciéndose competencia sobre el conocimiento de negocio que sea relativo a las personas y demás Ministros de Hacienda que gozan ol fuero militar, sería decidida por el S1. Virrey, en la Junta que debe él presidir, compuesta del Intendente General y del Regente, como sería el caso gute los Jueces ordinarios procediesen de oficio a instancia de parte civil y criminalmente contra dichas personas y se dudare del desafuero para conocer de la causa, o declinase el reo reclamando su fuero, o lo ejecutase su jefe natural; entone's deben ponerse a disposición de éste los Regentes y consultar el asunto con los autos o su copia al Señor Virrey en la citada Junta, conforme al Art. 83 de la Ordenanza.

No solamente en este caso, sino generalmente en los que se ofrecen de gravedad, pertenecientes a la Real Hacienda, debe la Junta Superior dar cuenta de sus resoluciones, por la vía reservada, como se ordenó en la Real Cédula de Buen Retiro, a 7 de febrero de 1756, revalidando los Reales Decretos de 20 de enero y 11 de septiembre de 1717 y la Real Cédula de 18 de mayo de 1747.

Bien entendido que, agraviándose alguna parte de lo proveído por la citada Junta, no debe admitir ésta los recursos, sino para el Rey, en los términos que prescriben los artículos 74, 82 y 83 de la Instrucción de Intendentes de América, con las cuales providencias ha quedado enteramente revocada la ley 14 , título 12 , libro $5^{\circ}$ de Indias, que concedía a las Audiencias del Reino el grado de apelación o agravio en las causas de Real Hacienda, de que hubiesen conocido los Oficiales Reales u otros Ministros.

En los negocios que decidiere el Intendente General de Buenos Aires, como Superintendente Subdelegado de Real Hacienda, no hay apelación a la Junta Superior, porque el Art. 74 que la autoriza para la admisión de recursos en materia de Hacienda, no habla del Superintendente, sino en cuanto Intendente de Provincia. Así cleberá observarse la Real Orden de 12 de agosto de $\mathbf{1 7 7 9}$, en que se dispuso que el Intendente General no admitiera de su Tribunal recursos de apelación sino a la Real persona, por la vía reservada.

Párrafo segundo. - De las personas y Ministros comprendidos en el goce de fuero militar, y del pasivo de Hacienda. a los primeros, como a sus jefes naturales políticos y militares, quedándoles libre su recurso a la Junta Superior.

Todos los demás Ministros y subalternos, empleados en la Dirección, Administración y resguardo de las rentas reales, gozan el fuero pasivo del Ministerio de Hacienda, solamente en los negocios y causas ci- 
viles y criminales que proceden de sus oficios, o por motivo de ellos, quedando sujetos a la jurisdicción real ordinaria en todas las que no sean de esta naturaleza. ${ }^{\circ}$

La Ozdenanza 7, título 10 del Reglamento del Banco, previene que cuando sus Ministros y subalternos merezcan prisión, embargo de bienes o ejecución, se pase anticipado aviso, por oficio al Superintendente, para que poniéndose otro sujeto en su lugar, no so exponga el real servicio en los caudales y papeles que tuvieren a su cargo. Esto mismo se halla dispuesto generalmente en los Arts. 85 y 86 de la Ordenanza de Intendentes, con la notable declaración que no debe proceder el aviso u oficio de la justicia al respectivo Intendente, cn los casos criminales ejecutivos infraganti y en otros actos judiciales en que por ello tal vez se aventure la recta administración de Justicia; y que antes se haya de diferir hasta después de evacuadas las diligencias que pidan o recomienden el secreto, verificándose entonces dicho oficio, a fin de que sc atienda al real servicio según lo exijan las circunstancias.

La Ordenanza $5^{\text {a }}$ de la Real Casa de Moneda, también declara que, en los casos de que pueden conocer las Justicias Reales contra sus Ministros, oficiales y dependientes, no se ejecuten los mandamientos de prisión y embargo que se libraren, sin dar antes cuenta al Sr. Virrey. Los Superintendentes de Potosí, pretendieron adaptarse esta autoridad; pero, el Superior Gobierno de Tima ${ }^{\$ 1}$ declaró lo contrario y se aprobó después por el Rey, ordenándose al Alguacil Mayor que reciba en la Cárcel a los que enviaren Ios Jueces ordinarios, sin necesidad de dar antes cuenta al Superintendente, y sí, solamente después de ejecutada la prisión, para que se subrogue en su lugar a otro.

Ahora que se han aumentado las facultades de los Superintendentes, por la reunión de este empleo al de la Intendencia, se ha innovado también la citada disposición y sus respectivas declaraciones; y así, observándose los mencionados artículos 85 y 86, para con los Ministros y demás subalternos de la Moneda, deberá pasarse al Intendente el aviso anticipado que se previene, para ejecutarse la prisión y embargo que ordenaren los Jueces ordinarios, según la diferencia de los casos que se ha explicado arriba.

Si fueren causas y negocios civiles los que motivaron la prisión o embargo, no deben ser presos en las Cárceles los Oficiales de los libuos reales, y los subalternos de las demás oficinas de la Casa de Moneda o del Banco, a fin de que no se perjudique el expediente de los negocios de su cargo con la separación de las personas; con cuya consideración ordenó el Sr. Toledo, ${ }^{92}$ que estos arrestos se ejecutaran en las mismas oficinas, para que detenidos en ellas los subalternos apremiados, continuasen ejercitándose cada uno en su respectivo empleo, servicio o ministerio.

\section{N. O T I I A Q U I N T A}

De los objetos principales de $\mathrm{DL}_{\mathrm{L}}$ fin con que se han formado todas las Policía. sociedades del mundo, indica la grande importancia de un Estado. E1 hombre, como animal sociable, siempre ambicioso de mejorar su condición (a diferen- 
cia del animal solitario), se unió a sus semejantes por una convención recíproca, no solamente para resistir con mayor actividad y fuelza a los perturbadores de su sosiego, sino principalmente para procurarse más, como conveniencia, comodidades y seguridad, que no tendría viviendo solo, desamparado y disperso. Pero sicndo imposible conformar el dictamen de la multitud a la conservación y prosperidad general, fue necesario transteríl al mismo tiempo, en uno solo, una autoridad superior a todas, que solicitase la utilidad pública y particular de los diforentes miembros de la sociedad.

Para conseguir este noble interés, se ha tomado el Gobiemo soble sí d cuidado de los medios más propios para hacer felices a los ciudadanos. El conocimiento de ellos con respecto al interior del Estado, es to que se llama Policia, y es también uno de los grandes objetos de la $\mathrm{Po-}$ lítica en goneral y uno de los r'amos principales del Gobierno.

Además de molesto, sería dificil referir en detalle las infinitas individuaciones que comprende la Policía de las ciudades y de los campos, en abstracto. $Y$ cuando fucre posible, perdería tiempo en tocar objetos inconducentes al de esta obra. Me contraeré a los artículos principales, que constituyen en lo general el sistema de la Policía, y por grados jré explicando, según mis conocimientos, aquellos más proporcionados para la prosperidad de esta Provincia.

Lo esencial de las Policías, es lo lelativo al fin para que se formaron las socicdades. Dijimos que el mejorar de condición y comodidades, unió a los hombres para establecer los Estados, y a esto es consiguiente que el arte de gobelnar bien, les debe procurar seguridad, limpieza y alimentos baratos, que son sólo el compendio del asunto de la Policía.

Entremos pues a las individuaciones de cada artículo, que así se hará su detalle con distinción y buen orden.

$$
\begin{gathered}
\text { Articulo primero. - Segu- } \\
\text { ridad. }
\end{gathered} \begin{aligned}
& \text { bien organizada, es el modelo más propio } \\
& \text { para el régimen de la república. Vemos que }
\end{aligned}
$$

el jefe de cada casa cuida generalmente de todos sus dependientes, y por más corto que sea el recinto de su jurisdicción económica, encarga la atención de la familia a otros celadores inmediatos de su conducta. A los hijos, les destina un ayo juicioso, ilustrado y prudente, que los eduque en los principios correspondientes a la calidad de caballeros; y a los criados constituye bajo del imperio de un mayordomo activo, industrioso y económico, que cele su conducta y averigue los procedimientos de cada uno en particular, cuidando del decoro y seguridadide la casa donde viven.

Esto mismo se practica en todas las ciudades civilizadas y se debe practicar también en las demás que se quiera civilizar. Como los pueblos son grandes, es difícil que el jefe que tiene a su cargo el gobierno, pueda por sí sólo atender en detalle todos los objetos que abraza la seguridad del vecindario. Por lo mismo, además de los Jueces ordinarios, destinados para administración de Justicia, se nombra en cada cuartel o barrio de la ciudad, un Comisario de la Policía, sin jurisdicción contenciosa, civil ni criminal, con facultades puramente económicas, para que en su distrito o departamento cuide del buen orden de la sociedad y vigile sobre todos los objetos de la Policía, sea en general o sea en particular. 
En la Villa de Potosí, que no está cercada ni puede verificarse este resguardo por falta de medios, por más que se encargue en el artículo 65 de la Real Ordenanza, entran y salen infinitos jugadores, vagabundos, ladronzuelos y malentretenidos, sin más ocupación ni oficio que el de sorprender a los menos vigilantes en sus rapiñas y hurtos, o el de ganar asilo contra la persecución de otras Justicias del Reino, ocultándose en los ranchos de los indios, en los tambos o mesones, al precio de los mismos robos.

Contra estos abusos, proveyó de remedio la Ordenanza 12, título 9, libro $3^{\circ}$ del Perú, ordenando a las Justicias que no consientan jugadores y vagabundos en los asientos de minas, o que los destierren, bajo la multa de doscientos pesos en caso de omisión. El Señor Marqués de Guadalcázar, ${ }^{93}$ para evitar los perjuicios que produce esta casta de gentes, dispuso que a los diez días de llegado cualquier forastero a esta Villa, tomase oficio, bajo la pena de dos años de servicio en las galeras del Callao. Cuanto tienen de reflexión y justicia a beneticio del buen orden de la república estas providencias, otro tanto más se han retardado s!ıs importantes objetos por falta de observancia; porque el Gobernador y los Alcaldes, ocupados en muchos ramos que abraza el cuidado del primero, $\mathrm{y}$ en los infinitos enredos que escuchan los otros entre estas pobres gentes, sobre chismes, injurias, golpes y otras frioleras, apenas aprovechan el día para atender a lo principal; $y$ en el entretanto, cada uno vive como quiere, entra y sale a la hora que se le antoja, sin la monor noticia de los Magistrados. Se fomentan las borracheras, sc establecen los juegos de azar y envite, y se perturba el orclen y el sosiego público, con tanto escándalo, que las más de las noches oímos las grulladas de gente baja que anda toda la Villa, unas veces con guitarras, para paliar su libertinaje con pretexto de recreación, y otras veces, metidos en pendencia entre hombres y mujeres cargados de borrachera, atolondran la Villa con voceríos insolentes, cuyas ręsultas son casi siemple, heridas y otros desórdenes.

No encuentro otro medio para introducir el buen orden, que la división de la Villa en doce cuarteles, ${ }^{94}$ al car'go de Comisarios domiciliados, que tengan la Intendencia subalterna de la Policía y juzguen sobre los pequeños pormenores de este ramo. Al ingreso de sus oficios, que anote cada uno en su departamento, el número de kombres, de mujeres, de niños, de domésticos y de inquilinos que se encuentran en cada casa, para saberse el número fijo de los habitantes del pueblo, expresando en estos padrones la calidad de artistas y demás oficios que ejercerían en la república, para calcularse si el pueblo tiene los artesanos y oficiales necesarios para el despacho de todos sus establecimientos de industria.

Los mesoneros (que en Potosí llaman "dueños de Tampos") y cualquier otro vecino que admite huéspedes en su casa, deben fórmar una lista diaria de los que entraren y salieren de sus hospedajes, con la obligación de enviarla todas las noches al Comisario de su Cuartel, para que éste averigüe el empleo del forastero y la causa de su venida, que descubierto con esta precaución el designio y la conducta de los entrantes y salientes, podrá el Magistrado de la Policía señalar destino a los que tengan oficio y desterrar a los demás vagabundos, o aplicarlos al servicio público de las minas, si fuesen gentes capaces de servir con su jornal.

Esto último sería convenientísimo para reenplazar las notables 
faltas que padece el núnero ordinario antiguo de la Mita. A este fin dispone la Ordenanza, que todos los días se junten en la Plaza los jornaleros, para que los aplique en algun trabajo industrioso el Justicia Mayor. No hay ejemplar que esto se practique, y de aquí procede que no hay día de la semana que no se vean por las calles, por las chicherías y por los contornos de la Villa, innumerables hombres, algunos solos y los demás apandillados, perdiendo tiempo en una indecorosa holgazanería, cuando no emborrachándose públicamente.

Ya se ve, que estos ociosos usinpan su trabajo a la minería, a las artes y otros establecimientos de inriustria, privando a la sociedad de los provechos de su aplicación. Este abandono es digno del mayor reparo. En mi concepto, nada convendría más que cada Comisario, bien informado por sus propios padrones y por las listas de los mesoneros, cuáles son jornaleros y cuáles artesanos, les obligase diariamente a tomar sus respectivos cmpleos, hacienclo jurtar a este efecto a los primeros en la Plaza pública, para que se les destinara ocupación en qué trabajar, celando al mismo tiempo que en las plazuelas, ranchos y solares de su barrio no quedase ningín malentretenido, bajo la pena de diez días de cárcel y de otros tantos de servicio on obras públicas. Entonces veríamos bien surtidos de trabajadores todos los ingenios que no tienen mita 0 a lo menos se purgaria la Villa de tanto haragán, que coneurriendo a consumir los abastos, contribuye no poco a su gran carestía.

Para formalizar esta grande obra de la Policía, deben los Comisarios repetir eada tres meses la división ordinaria de sus Cuarteles, registrando las casas de la gente pobre, tamberos, chicheros y pulperos o taberneros, para descubrir las personas sospechosas, las mujeres de mal vivir, los jugadores, los ocultadores de hurtos y los vagabundos; y al fin de año, concluír con una visita general, sin excepción de casas, para renovar el empadronamiento y enumeración circunstanciada que hubiesen hecho al ingreso de sus oficios; así para instruír al Soberano, por estas listas, de los progresos de la población y de la industria, como también para que el Magistrado de la Polícía conozea la calidad de los ciudadanos y los oficios a que sc emplean para mantenerse.

Conviene también que cada Comisario forme un extracto separado de los muertos entre año, de cada estado, españoles, indios y mestizos, expresando la edad a que llegó cada muerto y el género de enfermedad de que murió; el fin es averiguar el carácter de las enfermedades $y$ achaques más comunes en cl clima y si son contagiosos o peligrosos, para reflexionar los remedios más oportunos a su curación, cuidar con tiempo de que no se propague la peste y procurar el establecimiento de más hospitales, o de aumentar las camas para los enfermos. Con haber dos hospitales en Potosí, muere la mayor parte de los indios, sin entrar en ellos, porque un capricho de ignorancia les ha hecho creer que entrar al hospital, es como prepararse al sepulcro. Por esto quieren más bien abandonarse a la miseria de sus ranchos, donde mueren como perros, sin asistencia y tal vez sin curación. Pero la verdadera causa de esta incréible repugnancia, es porque en los hospitales les prohiben el uso de la coca, aguardiente, chicha y de otros pastos brutales con que se alimentan.

Al cabo del año, pierde el Estado muchos ciudadanos, por su propia incivilidad. Sería conveniente que los Comisarios cuidasen de mandarlos trasladar a los hospitales, obligando a los Curacas o Alcaldes de 
las Parroquias, que denuncien los enfermos, bien sean los estropeados en las minas o los achacosos de cualquier género de enformedad, para que se procure su curación.

Admira que después de tantos siglos como han pasado desde la pacificación de estos reinos, estén todavía embrutecidos estos infelices. Son muchas las causas que influyen para ello. Lo cierto es que la misma miseria que les reconocemos y confesamos, debe exitar nuestra compasión, así por honrar a la humanidad, como por el interés de la población.

Aun es más lamentable el estado de la campaña; porque un Subdelegado sin auxilio de otros Jueces subalternos, apenas tiene lugar para correr como un relámpago las dilatadas Provincias que ticne a su cargo, ya para recaudar los tributos, ya para visitar las minas, y finalmente para otras cosas de que ellos se saben aprovechar. Si son Provincias de mineral, cada asiento es domicilio de culantos haraganes tiene la comarca. Todo se disimula para que el aguardiente tenga su consumo, y la autoridad halle arbitrios para el provecho.

Los pobres indios son quienes padecen en las opresiones y agravios. Los más de ellos viven retirados en las quebradas de la serranía, al favor de un estrecho pedacito de tierra. Nadie sabe de qué viven ni qué comen, hasta que mueren, por los derechos de entierro. Los vagabundos de la propia casta que llaman yanaconas, hostilizan los vecindarios con robos y usurpan a los demás lo que consumen en la comidà. Pero encuentran abrigo por el interés de las tasas a que contribuyen. Se cuidan con extraordinario celo de cobrarles el impuesto de los tributos, sea como fuere; pero nadie cela que se apliquen a la agricultura o a otro trabajo industrioso, ni de repararles las ruinas de las continuas inundaciones, ni de dirigir sus empleos en las ocupaciones de que pueden sacar mejores partidos.

Todavía viven como salvajes, sin asilo en sus enfermedades, porque en todas las cinco provincias rurales de esta Intendencia, no hay siquiera un hospital; todos ellos apenas tratan de procurar lo muy necesario para vivir con miseria, porque carecen de civilidad, de policía y de educación. Por último, puedo asegurar que no entienden de religión, porque la distancia de los anexos a las Parroquias Matrices, no permite a los Curas el instrú́rlos en el Catecismo de la Iglesia; de forma que los más o muchos de ellos llegan a oír una misa, cuando más, al año. Discúrrase ahora, ¿cómo podrá adquirir progreso nuestra religión, sin agricultura, sin industria, sin civilidad, sin educación y casi sin religión?

El remedio más pronto sería nombrar en cada Parroquia o Doctrina campestre un comisionado español o mestizo, de legítimo matrimonio, con título de la Intendencia, para que cada tres meses visitase su distrito, y empadronara los españoles, mulatos y demás castas que no pagan tributo, con individuación de sus sexos, edades y oficios, para remitir en cada trimestre estas listas al. Intendente, con el fin de proveer lo conveniente a estos habitantes y para que se conozca el número de cada vecindario, respecto de que los padrones de revisita comprenden solamente a los indios tributarios y los demás individuos de esta casta.

Importa mucho acompañar estas ennumeraciones con informe instructivo de un resumen por mayor de los muertos en el departamento de la Doctrina, sacado de los extractos mortuorios de la Parroquia, expresando el género de enfermedad de quc murieron los más, principalmen- 
te si hay peste que demande la atención del Magistrado de Policía, para que confrontando estas listas con las de revisita, se calcule el estado de la población en el intervalo de los cinco años en que se deben practicar, $y$ segun las ocasiones se tome la providencia de enviar médicos asistidos con medicinas del hospital, obligados a la curación de los indios, para que asistan al Partido infestado, hasta extinguir el contagio y salvar los cnfermos de más liesgo.

Entre las obligaciones de estos Comisarios, debe ser la principal el examer de los ierienos, de su clima y del grado de su fertilidad, para proponer a la Intendencia los medios de reparax el daño de las inundaciones con buenas calzadas, y los frutos que se pueden aprovechar en cada territorio; las arboledas que será conveniente plantar, para humedecer con el rocío que recugen la aridez de las quebradas y valles, y facilitar por este medio las lluvias tan importantes en cstos países, además del acopio de Jeña y madera para surtimiento de las minas y demás poblaciones de la Provincia.

Con estos conocimientos se podúćc ordenay. la siembra del lino, del algodón y cáñano; del trigo, maíz y otros productos comerciales, fuera de las papas y de otras especies propias para el mantenimiento de los indios, a fin de promover el comercio de los frutos sobrantes o no necesarios por falta de uso o consumo entre ellos.

Señalando a cada Comunidad o Aillu cl número de plantas de cada especie, con vigilancia de su cumplimiento, se fomentaría la agricultura, y después de subsistir, el tiempo mismo iría acostambrando a los indios en el trabajo, con la codicia del provecho. El Comisario de la Parroquia deberá remitir un extracto de los plantíos y siembras de su departamento, con distinción de las especies de cada fruto, informando al tiempo de la visita trimestral el estado de las chacras y la esperanza que prometan; y al fin del año, el producto de las cosechas, por relación jurada de los arrendadores de los diezmos de cada Partido o Provincia.

Pero Io principal es el cuidado de cercar las heredades de arboledas útiles, que además del provecho sirvan de defensa a las posesiones; procurando al mismo tiempo introducir en los indios el espíritu de población, atrayéndolos a formar domicilio, a distancias proporcionadas, en pueblecitos formales donde vivan con ley, con doctrina y con civilidad; a cuyo efecto sc puede conceder alguna corta gratificación a cuantos poblaren casa en los sitios que se destinare.

La sociedad, aunque sea compuesta de hombres salvajes y embrutecidos, propone muchos ejemplos de enulación, para que los ciudadanos procuren adelantarse a vista del interés ajeno, ya sea en la agricultura, ya en las artes, ya en la industria. También introduce sucesivamente el amor a sus semejantes, con unos sentimientos nobles de humanidad. La educación encuentra más apoyo y tienen menos embarazo las leyes de Policia y civilidad. Finalmente, es menos la miseria, por la mayor oportunidad de remediarla. Así pues, veríamos en breve progresos muy notables en nuestra población, si se verificare reunir a los indios en sociedades, por muy pequeñas que fuesen.

Porque minorándose la miseria, que es el principal agente de la destrucción del género humano, cesaría también el origen de las emigraciones de nuestros indios, de las enfermedades epidémicas, y de otros infinitos males; pues sabemos que la mayor parte de los indios llamados 
Yanaconas, que en propiedad son los vagabundos de esta casta, desamparan sus domicilios porque no tienen qué comer y poxque viviendo como salvajes en valles o quebradas solitarias, experimentan el exterminio de sus hijos y familia al rigor de las enfermedades.

Por otra parte, parecen disculpables estos infelices, porque realmente son indiferentes o inútiles para ellos las justas reglas de nuestra sabia legislación; pues, si son las leyes de propiedad, nada importan para el indio, porque nada posee; si son las de justicia, también las mira con indiferencia, porque no tiene qué defender; si son las de la libertad, digo lo mismo, porque no tienen con qué comprax. Esta es una demostración incontestable de que la miseria o pobreza del inclio, es la causa principal de su abandono, de su incivilidad y por último, de su desaplicación al trabajo. Póngaseles a la vista el interés; hágaseles que posean alguna propiedad; entonces se experimentará sin dilación, que ellos mismos solicitan su conveniencia y su educación, para defenderse contra los perturbadores de su interés.

En los pueblos ya establecidos y en los que se fueren estableciendo, es fácil entablar escuelas de la lengua castellana, que es el medio principal de civilizar al indio; porque habiéndose seguido después del Diluvio la dispersión de las gentes, como consecuencia de la división de las lenguas, no obstante de ser entonces todos los hombres de una misma casta $y$ familia; es preciso confesar que la diversidad del idioma en nuestros indios, es el orjigen de su desamor a nuestros españoles, de su repugnancia a nuestras costumbres y leyes, $y$ de su poca inteligencia en los principios de la Religión, que es el vínculo de todas las sociedades y Estados. 95

También puede decirse que es la raíz del poco progreso en las artes; porque la naturaleza de su lengua, que es el primer principio de todos los conocimientos, no es capaz de hacerles conocer las nobles ideas y los elementos de nuestras artes y ciencias, y por esto es que, después de tantos siglos que han cultivado sin interrupción tantas artes y ciencias, nunca han logrado ventaja ni aun igualdad con los mismos pueblos de Europa, según la observación de los sabios historiadores.

Además de esto, se pueden establecer escuelas de algunas artes lucrativas, como son la escultura, grabado, pintura, la carpintería, herrería y otros oficios necesarios para el trabajo de la agricultura y de las minas, obligando a los artesanos más hábiles de cada Partido, que se avecinen en los pueblos y que tomen a su cargo los muchachos más hábiles que sepan la lengua castellana, para instruírlos en los oficios; que si este proyecto se fomenta con libertar de tributo desde los dieciocho hasta los veinticinco años al indio que saliere aprovechando en algún oficio o arte, es de creer que dentro de pocos años tendríamos en nuestra Provincia muy hábiles artesanos que, sobré la utilidad pública, serian unos ciudadanos bien acomodados o a lo menos capaces de subsistir por sí y de mantener con decoro sus familias.

No serían menos importantes estas poblaciones para instruírlos en la doctrina cristiana, para cuidar de que guarden religiosamente los domingos y otros días de precepto, no menos que para prohibirles el abuso de emplear los dias de trabajo en bailes indecentes, en borracheras $y$ en otros concursos perjudiciales donde pasan el tiempo, usurpando a la agricultura los provechos de su trabajo, fuera de los agravios y enemis- 
tades cue se causan tinos a otros en scmejantes asambleas, sin poderse remediar por falta de Juez y por las distancias en que viven.

Entre las causas que más influyen en la decadencia de nuestra agricultura, comercio y población, son los trajes impropios y ridículos que mantiencn los indios, a diferencia de los demás individuos de la nación. $"$ Los hombres visten un calzón bombacho y un chaleco o chupa corta, de color pardo y una manta que llaman poncho, metida por la cabeza sobre los hombros, del mismo color que la nabunda, de un tejido muy recio que benefician ellos mismos. La ropa interior es una camiseta que liaman cotón, de bayeta de la tierra, amarilla, verde o azul. El sombrero es una montera de badana de la tierra, parda o negra, con unas aletas interiores de cucro de vaca; que les defiende la cara del agua y del sol. El calzado es una suela de cuero crudo, afiamzado al tobillo con unos látigos o correas que pasan por entre los dedos. Es una especie de sandalia, con la diferencia de que deja descubierta toda la parte superior del. pie, y se llama ojota entye los indios. Las mujeres traen una especie de camiseta larga, sin mangas, y se envuelven con ótra manta de algodón) y lana, fabricada por ellas mismas.

Es tan hurable este vestido, que por larga que sea la vida de los indios, apenas consumen dos trajes de esta clase, quedando para sus hijos los que usarou on primera edad; de forma que las indias no remudan traje hasta casarse, $y$ así se conocen las solteras en que llevan la ropa más corta, por' ser la misma que se les puso a los siete u ocho años.

Dicen algunos, que la nuanía de traer el coloxmegrompardo, es para mantener la memoria del exterminio de sus reyes y de la perdida de su libertad. Bien se puede creer, porque ningún otro principio pudiera tener tanto influjo para mantener el uso de tales vestidos a vista de otros mejores que usamos los españoles. Esta es una prueba de la incivilidad de los indios y objeto el más digno de la atención de un Magistrado político; porque, en primer lugar, estos trajes siempre impropios y ridículos, son incómodos por su poco abrigo y por su ningún decoro. En segundo ligar, porque mantenidos en el método brutal de comer poco y malo, $\mathrm{y}$ de vestirse menos, no sienten interés para arencjur su feliciond ocupando las manos a los trabajos industriosos. En fercer lugar, prrque siendo indios más de la mitad de nuestros habitantes americanos, se perjudica notablemente cl comercio de nuestras manufacturas españolas, por la falta de consumo. ${ }^{97}$ De forma que si en otras circunstancias se consumieran ocho millones anuales de efectos, en las presentes se consume la mitad menos, por la diferencia de trajes que usan los indios.

Por estos motivos, y principalmente por la ridiculezat de los vestidos moscovitas, les hizo quitar por fuerza las barbas y mudar de traje el célebre Pedro I, siguiendo la méxima, que con vestir a los salvajes se empieza a humanizarlos. Este es el mismo caso en quemos hatfanios y no sería injusto ni intiprudente echar mano de las mismas providencias. Pero se puede lograr el efecto por términos de suavidad, que es el medio más conforme a nuestra legislación.

Reuniéndose los indios en sociedad, hay varios empleos que darles, ya sea de Alcaldes, de Curacas, de Gobernadores, o de Alféreces. Cualquiera Ministerio de estos, es para ellos objeto de grande codicia, y es tal su rudeza, que por salir en una procesión con bandera y pendón en la mano y pascarse aquel día al son de la caja y clarín, ostentando el al- 
ferazgo, gastan sin reparo cincuenta o más pesos, que no expende en todo el año un indio de familia larga para mantenerse.

Exitándolos por este lado de flaqueza, con establecer por condición que ningún indio pueda ser Alcalde, Gobernador a Alférez, sin que traiga el traje español, seis meses antes del nombraniento del oficio y por todo el tiempo que lo ejerciere, considero muy fácil que mudase de traje dentro de pocos años, y no hay duda que se propagaría más breve, si concurriesen los Curacas a este proyecto, por el imponderable ascendiente que tienen sobre el espíritu del indio.

En este caso trabajarían más, porque con la elección de vestidos y tal vez de alimentos, adquirivían más necesidades que les obligasen a aplicarse a los trabajos industriosos; vivirían con más comodidad, según la clase del vestido y progresivamente irían saliendo de la miseria que los destruye con tanto perjuicio nuestro.

Entretanto, se debe cujdar de preservarlos de las pestes, con que regularmente son afligidos, por la suciedad y desasco de sus trajes, que es una de las causas que más influyen para promover los contagios y epidemias. Entre todos estos males, el que mâs destruye la casta del indio, es el de las viruelas; por lo mismo, voy a contraeme con particularidad sobre su asunto.

En la Apología que escribió 9 con singular erudición el doctísimo español Don Pedro Rodríguez Campomanes, contra las falsas acusaciones de los extranjeros que atribuyen a la inhumanidad de los conquistadores, la notable disminución de los indios, se expresa lo siguiente: "Dos "causas pueden haber minorado los indios, conviene a saber: las virue"las y las mezclas de las varias castas.

"La primera fue una causalidad, y a que debe ocurrirse con intro"ducir la inoculación, que en parte alguna puede sex más provechosa, aun"que en todas es un r'emedio singularísimo y de grande importancia".

Yo venero el dictamen de nuestros sabios escritores, y es digno de mayor elogio el celo con que propone la inoculación, como remedio úni. co de restablecer nuestra población. Aplaudo también el estudio y las profundas indagaciones de los autores sobre la patria, generación y naturaleza del miasma virulento; absteniéndome de entrar en la disputa de si esta enfermedad fue o no conocida de los antiguos y si su gérmen sacamos al nacer, como semilla derivada de nuestro primer padre, la cual, por ser de naturaleza en el hombre, además de inevitable, es necesario que se desenvuelva, para facilitar' al cuer'po que crezca y se perfeccione.

Pero siguiendo los principios de los mismos protectores de la inoculación, soy de parecer que no es conveniente el suero entre nuestros indios, porque siendo constante que el suero de este remedio jamás es infalible, no siempre feliz, siempre dudoso, y alguna ve $z$ mortal, sería para la rudeza de los indios un motivo de alteración, si viesen que en vez de sanar de sus enfermedades, moxían con el mismo remedio en que se les aseguraba su preservación; pues, en su ánimo suspicaz se apoyaría luego la reflexión que el español había introducido la inoculación para exterminar su casta.

Además de esto, es punto confesado por todos, que la inoculación no pone a cubierto de las viruelas confluentes, ni promete con certeza que los enfermos volverán a escapar; antes, por el contrario, depone la experiencia, contestada con muchos ejemplos por el ilustre Mead, que 
muchos años después de la inoculación se ha visto sobrevenir más viruelas adquiridas por la vía del contagio y funestas al enfermo, bien sea quitándole la vida, o dejando en las partes del cuerpo en que se hizo la inoculación, algunas llagus de mal carácter, en memoria de la temeridad.

Sobre todo, la razón principal que los inoculadores alegan con la mayor confianza, para la seguridad de este remedio, que consiste en la ventaja de preparar los sujetos antes de darles las viruelas, es la misma que más persuade no ser practicable ni conveniente entre nuestros indios; lo primero: unas gentes miserables, luckas, mal vestidas y peor alimentadas, no son capaces de seguir puntualmente el método que se les prescriba, ni ticnen posibilidad para ello; lo segundo, es menester bastante tiompo para la preparación, para que el suceso corresponda al intento, y no es posible medir esta circunstancia en unos hombres que nccesitan trabajar para comer o vivir aplicados en servicios de diferente género a que están destinados por nuestra legislación; lo tercero, en estas preparaciones se trata de cambiar enteramente la constitución de los sólidos (de cujo estado depende la constitución de los humores), para poner a un sujeto en estado de subyugar el veneno del virus de las virile]as.

En los indios casi no es posible producir tales mutaciones, porque sus alimentos groseros además de escasos, su vida brutal, sus continuas borracheras $y$ la intemperie en que viven, es forzoso que engendren ${ }^{-h}$ mores tan indócilus y crasos, que sea muy difícil prepararlos en forma que resulte poco dañoso y casi sin fuerza el veneno de las viruelas. Y, véase aquí por qué es impracticable y de ningún modo conveniente entre los indios el uso de la inoculación.

Pero si acaso se considera posible producir tales mutaciones para llegar a debilitar el veneno, creo más oportuno y fácil emplear el z'égimen y remedios que dictó el célebre Rassis, médico árabe, en su método de dirección de curación de viruelas, para preservar de ellas, cuando ya reinan, a los que están en el caso de temerlas, que son aquellos en cuya sangre se ha introducido ya el miasma o el gérmen de esta enfermedad, como hijos de los que la han tenido, o más bien, para prevenir sus funestos efoctos, embotando la actividad del vencho y tal vez llegando a destruírle.

Para esto empleaba el citado médico, principalmente los ácidos vegetales, como el zumo de naranja, de limón, de veróberis, de frambuesa y de moras, $y$ también el de lechuga, de dracúnculo y el agua de agraz que reducía a jarabe aglegándole azúcar y un poco de alcanfor.

Sin embargo, como por estos medios solamente se procura hacer que sean las viruelas más discretas $y$ benignas, y apenas quedará alguno en quien no se comunique esta enfermedad por medio del contagio exterior, cxitándose en el cuterpo el gérmen con que se nació, es más conforme a la política tomar contra las viruelas las mismas precaucioneś que se ponen en práctica contra al peste, por ser el medio único para llegar a conseguir hoy día hacer exentas de ella a las naciones, como lo estaban otras veces.

A este fin se ha comunicado a las Américas una estrecha Real Orden, con fecha del año 1786, acompañando una disertación físico-médica, de Don Juan Gil, Cirujano Real del Monasterio de San Lorenzo y su sitio, para que se observe el método que prescribe para preservar a 
los pueblos de la viruela, hasta lograr la completa extinción de ella en todo el Reino. En sustancia, se reduce a suponer la imposibilidad de contraerlas el que se halle distante de los contagiados y de su atmósfera; y sobre este pie advierte el proyecto de destinar cn carla pueblo una ermita o casa de campo, distante medio cuarto de legua, poco más o menos, y apartada de caminos pasajeros y de los vientos dominantes, para que inmediatamente que se deje ver algún virulento, sea trasladado allí, separándolo del comercio de las gentes, para que no inficione a los demás.

Propone muchas precauciones útiles para que los médicos no contagien sus vestidos con este veneno, y aconseja el cumplimiento de las antiguas ordenanzas de los. Magistiados, que señalaban médicos determinados para las enfermedades contagiosas de todas clases, y prescribe el método de estas curaciones, según el estado de la enfermedad.

Las naciones más bárbaras no han encontrado mejor asilo contra esta peste exterminadora, y se sabe que los hotentotes toman el partido, aunque temerario y brutal de apartar de si a flechazos a los que teniendo las viruelas se acercan a las gentes que tienen salud.

Nuestro. Gobierno, prevenido del dictamen niús suave de humanidad, ha proveido también la separación de los virulentos, de un modo correspondiente a la sabiduría y buen orden de su política. Pero, con desconsuelo universal, no se ha verificado todavía este importantísimo establecimiento. Faltan los medios para su plantación, y por lo que respecta a Potosí, se mantiene dormido el expediente que se comenzó a criar para ponerlo en práctica.

En Caja existen sobre once mil pesos sobrantes del ramo de Propios y Arbitrios y el Juzgado de Censos de la ciudad de La Plata, tiene muchos millares pertenecientes a los caudales de Comunidad de los indios de esta Provincia, para los destinos prescritos en las leyes del Reino. Todos estos caudales públicos por su institución nativa y esencial, al alivio de los pueblos. Nada puede ser más benéfico que asegurarle al ciudadano su vida y su salud; de lo que se deduce la necesidad de invertir parte de dichos caudales en la edificación de las casas de campo para hospitales de virulentos.

Nunca sería excesivo el gasto construyendo uno en esta Villa y en cada pueblo cabecera de los Partidos de esta Intendencia, ni es de creer que la Junta Superior de Buenos Aires, tarr prevenida de justificación y de celo por el bien público, dilatase dar providencia sobre estos expendios, precediendo las informaciones de necesidad y utilidad, que previene la Ordenanza.

Entre tanto se verifique este interesante proyeeto, debemos buscar algún preservativo experimentado contra el mal contagioso de las viruelas; no sea que se repita el trágico suceso con que se introdujeron en la Nueva España el año de 1520, acabando con la mitad de los habitantes de las provincias invadidas.

El Señor Berkeley, Obispo de Doine, da la composición del preservativo más inocente contra este contagio, en una de sus obras intitulada en inglés; Siris, esto es encadenamiento de pensamientos diferentes, y no se reduce más que a usar por algún tiempo el agua de pez líquida: Goudron, cuya significación aunque se encuentre muy discorde en los diccionarios, no hay riesgo ni escrúpulo para hacer uso de la pez común negra, que se vende en las boticas. 
En las colonias inglesas de la América, fue donde se descubrió y se comenzó a usar este preservativo, que se practicó después en Inglaterra misma y en frlanda, con tan buen suceso, que asegura el Ilmo. Berkeley, que de todas las personas de su conociniento que la han usado, ninguna hubo que dejase de escapar de mal tan inoportuno.

El modo de preparar esta agua, es echando sobre dos azumbres de pez liquida, dos azumbres de agua fría, mezclar o revolver bien el todo por cinco o seis minutos. Tapando la vasija en que se haya hecho la infusión, después de haberla dejado reposar por cuarenta y ocho horas, se saca el licor en claro y se guarda cn botellas tapadas con la mayor exactitud, para beber de esta agua por todo el tiempo que se quiera, en la medida de un cuartillo por la mañana, dos horas antes de comer, y otro cuartillo por la noche, dos horas después de haber cenado; pero según la calidad del estómago más o menos endeble, será conveniente que se dirija la opcración por un buen médico, advirtiendo que este régimen debe seguirse especialmente en las ocasiones en que el aire corre impregnado de los vapores malignos de las viruelas.

Los antiguos miraron esta infusión, como un grande recurso contra las úlceras, los vencnos, las mordeduras de animales ponzoñosos, la perlesía, la asna $y^{\prime}$ otras diversas clases de enfermedares que proceden de corrupción de la sangre y putrefacción de humores, y observando el modo con que se hace esta agua en las colonias inglesas de América, resulta muy parecido al que tenían en práctica los antiguos macedonios para hacer la suya.

No puede apetecerse remedio más sencillo, inocente y experimentado; por lo mismo sería conveniente que los Curas persuadiesen su uso a los padres de familia en general y en particular, valiéndose de los muchos arbitrios que diera la prudencia en tales casos, para dar eficacia a los consejos; como también que los médicos apoyasen este régimen para que así llegue a propagarse entre los ciudadanos y se logren sus buenos efectos, mientras se verifican establecimientos prevenidos para la extinción total de esta peste.

De resultas de estas epidemias y de otras enfermedades que suelen invadir a los habitantes de este país, quedan sus hijos huérfanos, menores de edad, abandonados a la miseria, sin medios para una educación decente.

La providencia ordinaria de todos los reinos cultos y civilizados, es la creación de casas de huérfanos, para darles alimento y doctrina, hasta cierta edad. En Potosí es inverificable se practique, por falta de fondos públicos, ni creo que sea indispensable, porque casi todos son hijos de indios o mestizos y de baja calidad, para los cuales hay otro recurso de mejor expediente.

Aquí generalmente solicitan hijos ajenos, que crian para servixse de ellos después de grandes, en los muchos ministerios serviles, que prometen los diferentes trabajos de las minas, ingenios, chicherías, etc. Conocida esta propensión y la clase de huérfanos, por las listas de los Comisarios de Cuarteles, sería muy fácil encargarse por el Magistrado de Policía la educación de estos infelices, según su edad, bien sea a los muchos artesanos que tiene la Villa, o a otras personas de las muchas que solicitan estos sirvientes, imponiéndoles la obligación de dar cuenta a su tiempo de los empleos a que los destinasen. ${ }^{99}$ 
Lo que sí, importa más que todo, es el establecimiento de una casa de corrección para mujeres mundanas. Son muchas las que viven con el provecho de su libertinaje; y para que su porte cscandaloso no corrompa las costumbres de la clase superior del mismo sexo, conviene separar de la vista estos malignos modelos de la incontinencia. Es verdad que Ios Jueces celan sobre su conducta y depositan a las más relajadas en varias casas particulares que toman a su cargo estas resoluciones como por granjería. Pero como todas estas dixectoras son mujeres, y algunas de ellas muy pobres, sin las mejor'es pruebas de buena vida, es consiguiente la poca seguridad de tales casas, pudiendo crecrse sin temeridad, que en estos domicilios sacan mayor fruto los amanies.

Por estos motivos estamos en la necesidad de establecer una Casa pública de Corrección. Para esto es muy proporcionada la casa antigua que dejaron las mujeres honestas, que tienen cl título de "Recogidas" en la Villa, y se han trasladado por orden del Rey al Colegio de los ex-Jesuítas. No tiene destino alguno dicha casa y si no se habita, legará a arruinarse en poco tiempo. Su sitio es calle por medio a la Iglesia de Ia Compañía, y tiene esta proporión más para oíl la misa y doctrina del Párroco que reside en ella.

El inconveniente de no haber rentas para mantenerlas, es fácil de vencerse, por una parte, con limosnas públicas, por otra, con las condenaciones de los rufianes, y últimamente, con el trabajo de las mismas mujeres. Solamente con la fábrica de velas e hilanza de pabilo y lanas, se puede formar un fondo equivalente o a lo menos mantener la subsistencia diaria de la casa. La de Buenos Aires no tiene otras rentas; y quien supiere lo que se gana en Potosí, en sólo el renglón de las velas, conocerá el fácil expediente de este proyecto.

A estos arbitrios se pueden agregar doscientos pesos que cstán asignados anualmente por el reglamento de propios, para la dotación de un maestro de primeras letras; pues, aunque se reputa por indispensable su establecimiento, y en este concepto se aplicó para Escuelas cl tercer patio del Colegio de los ex-Jesuitas (que en el día sirve de Cuartel para la tropa), sería más fácil y conveniente suplir csta providencia con el recurso de los Conventos, es a saber, que respecto de estar obligadas las comunidades religiosas a prestar algun servicio al público, en correspondencia a los beneficios y subsistencia que reciben de él, se les incitase por el Cabildo a destirlar en cada capítulo provineial un religioso, sacerdote o lego, de suficiencia y probidad para la enseñanza de los niños de la Villa, dentro del mismo Conyento.

No es gravamen para ellos y el público reportaría considerable alivio, subrogándose a un maestro, tres o cuatro, sin salario en los caudales de la Vilia; porque será peor que siga la inacción en que ahora estamos, y no tengamos escuela ni casa de corrección.

Mediante estas providencias y con la de no permitir que ninguna persona salga de la Villa, sin licencia expresa, por escrito, del Gobjerno, como se estila en todas partes, llegará a afianzarse una seguridad, aunque no inviolable, de mucha importancia a la quietud pública y particular del vecindario, reservando a la experiencia, buen juicio y prudencia de los gobernadores los demás objetos que abraza este primer artículo de Policía.

En este lugar juzgo digno de referirse otro punto que merece la 
atención del Gobierno, como perteneciente a la seguridad y conservación de las vidas de los vasallos del Rey, y son las corridas de toros, entabladas en esta Villa casi descle el principio de su fundación, desde el día de Reyes hasta el último cle Carnaval, en los días que destinan los Alcaldes ordinarios. El Superior Gobierno de Lima, por varias provisiones mandó conservar esta diversión, anualmente, a costa de los gremios, para que distraído el vecindario con el ruído de semejante espectáculo, cesasen los vecinos de cometer los grandes excesos que ejecutaban en tales días, llegando al extremo de encervarse hombres y mujeres en casas alquiladas para este fin, permaneciendo allí la mayor parte de la Cuaresma, en bailes, comilonas y otras ignominiosas recreaciones.

A primera rista, parece ser el establecimiento más justo, pero para que se pueda tomar la precaución que dicta la humanidad en medio de tantas desgracias como suceden en estas corridas de toros, apuntaré en compendio el modo en que se hacen.

Encerrados los toros en un corralón situado en el barrio de San Martín (que llaman "el Toril"), salen a caballo, entre las dos y tres de la tarde, los Alcaldes ordinarios y los de la Hermandad, con un numeroso acompañaminnto; $\mathrm{y}$ al toque de claríl vienen todos a la Plaza, distinguiéndose los Alcaldes y los personajes principales en las banderas de tafetán que traen en la mano, $y$ en las divisas de zicas cintas de tela que levan prendidas en los sombreros. Presentados en media Plaza, hacen su venia al Gobernator que les está aguardando en su balcón; y hecha esta ceremonia, salen todos a carrera abierta, luciendo los buenos caballos, hasta llegar al "Toril".

Todas las calles por donde se ha de conducix el toro, están llenas de indios; pero el mayor número se acantona en los cuatro costados de la Playa, que no tiene más barrera que los cuerpos de los miserables indios. Habrán por lo menos de tres a cuatro mil indios mezclados con indias, por los alrededores de la Plaza, en el pórtico de la Matriz, en la plazuela inmediata de la Misericordia y bajo de algunos pocos andamios que levantan algunos españoles y cholos.

Luego que oyen el toque del clarín y el estiuendo de tanto caballo que viene delante del toro amarrado de una cnerda larga de cuero por las astas, corren las gentes a buscar las calles de traviesa; pero como la multitud arrebata en su tumulto niños, viejos y majeres, casi todos ellos borrachos, son frecuentes los casos en que al pasar el toro, mata, hiere o maltratá al que encuentra caído en el tránsito o parado en las esquinas, privado de advertencia por'su embriaguez.

Llegando a la Plazuela de la Misericordia, situada al costado oriental de la Plaza Mayor, no sólo es inminente sino horroroso el riesgo, porque habiendo de pasar el toro por la brecha que abren los indios acantonados allí, se arrojan en la fuga unos sobre otros, a manera de oladas sordas de la mar, hasta llegar a oprimirse todos en tal forma que no pueden dar un paso. Si el toro es bravo, emprenden tal carrera los de a caballo, que viéndose apurados, avanzan sobre los indios para salir del riesgo como se pueda. $Y$ en una de estas ocasiones he visto yo, rodar en la Plaza un caballo que iba de tropel entre los indios, pisando ya arriba ya abajo de los cuerpos de cstos infelices, con el daño que se deja entender a primera vista.

Si el toro es de malicia, acomete al pasar, y de refilón se lleva en 
las astas, hiere, pisotea o maltiata a los indios que encuentra indefensos, bregando contra los demás que le embarazan en la fuga.

Pero son mucho mayores los daños que se causan después de amarrado el toro en una argolla puesta a este fin ell medio de la Plaza, porque todo su ámbito se cubre de cincuenta o más indios que por todas partes llaman al toro, con tanta barbaridad, que rara vez cscapa ol que es acometido. Lo peor es que se liberte aquel infeliz, que persigue el toro, estirándose la cuerda con violencia al tiempo de avanzar la fiera, voltea a unos de cabeza, a otros de espaldas y a otros de barriga, con tal ímpetu que rara es la tarde en que no muera alguno en la misma Plaza, al impulso irresistible de estas caidas, y los más quedan lisiados del pecho para siempre y otros mueren al poco ticmpo, llenos de miseria, con abandono de sus pobres familias.

En la última tarde de Camestolendas de este año, vi sacar de la Plaza un pobrecito indio casi inmóvil de una caída con la cuerda; y aunque prontamente mandé llevarlo al Hosnital, se me dió cuenta de haber expirado poco antes de llegar, sin que pudiese alcanzar confesión ni algún otro sacramento. Fuera de éste que yo mismo vi, fueron muchísinios los que pasaron esta tragedia en este año; de suerte que puede asegurarse que por lo menos mueren ocho o diez y tal vez más en nuestras corridas anuales, unos de resultas de heridas y los demás de los golpes con la cuerda.

Cualquiera que no haya perdido los sentimientos de humanidad, no puede menos de horrorizarse con semejante espectáculo; y lo que más se admira es, que no sucedan mayores desgracias, porque los toreadores son unos indios pesados, chentales, que se arrojan al peligro sin arte y sin conocimientos; ellos mismos atraviesan sobre la cuerda, sin reflexión ni tino, por estar cargados de embriaguez, en tal extremo que se ponen a beber al canto de la Plaza, hasta que preocupada la vista con la borrachera, apenas descubren al toro del tamaño de un carnero y entonces le acometen sin temor, porque ya van privados de conocimiento.

En compendio, este es el método con que se juegan los toros en Potosi, y es tal la maña de los vecinos que suponen que habrá un gran disgusto en el público, si se prohibe una diversión que es pura barbaridad.

Ya se sabe que el Gobierno ha tolerado siempre las juntas del pueblo en los paseos, espectáculos y otras recreaciones generales, por ser menos malo sujetar el concurso de toda la plebe a un lugar sólo donde la presencia de los Jueces, junto con el decoro y dignidad de las personas asistentes, y la diversión pueda embarazar mayores excesos que en tales días suelen cometerse en las calles y en los barrios distantes de la ciudad; pero esto debe entenderse con tal temperamento que no peligre la salud de los hombres.

La falta de este indispensable cuidado en las corridas de toros, obligó a la Santidad de Pío V, 100 a prohibirlos absolutamente bajo de excomunión mayor, para evitar de este modo las muertes, las heridas, las fracturas de huesos y otros graves daños que de ordinario sucedían; y aunque después, a instancia de los Reyes Católicos, se moderó esta constitución por Bulas posteriores de Gregorio XIII, y Clemente VIII, 101 fue con la calidad de observarse dos precisas condiciones: la primera, de no hacer corridas en días de fiestas; la segunila, de procurarse por el Gobierno evitar en lo posible todo peligro de muerte $y$ de heridas. 
Sobre este supuesto, es segura la práctica y se defiende como tal por muy clásicos doctores, ${ }^{102}$ la opinión de que siendo diestros los toreadores y la fiesta de toros se hace con aquella precaución que quite el peligro de que resulten muertes y heridas, es licita y libre de culpa.

Toda la dificultad consiste en el hecho, es decir, en los medios que se pueden elegir para preservar de todo riesgo a los toreadores.

Fray Manuel Rodríguez, 103 juzgó por suficiente la diligencia de conrer toros descornados, poniendo en la Plaza guaridas inmediatas dónde poderse refugiar los toreadores, sin permitir que hagan este oficio los que no fuesen diestros y experimentados en el arte, con feliz suceso. Y añade el citado autor, que este es el modo con que ordenó que se hiciesen las corridas de toros, la Reina Católica Dña. Isabel.

El célebre Juan Guticirrez, i01 juzga por más seguro correr los toros en l'laza abierta o en las calles, amarrados a una soga por las astas o por los pies, que es lo mismo que se ejecuta en Potosí. No pongo duda que en otras partes se evita todo peligro con esta precaución; pero en esta Villa lo aumenta $y$ es la ocasión de experimentarse tan tristes tragedias.

Porque en otros lugares salen a torear el toro amarrado, unos hombres sensatos, que aunque no sean muy ligeros ni diestros: en el arte, miden con conocimicnto la extensión de la cuerda, para no avanzarse más trecho que aquel que pueda vencer el printer arranque de la carrera; por cuyo medio, cuando había de acometerlos el toro, se le detiene con la soga. En Potosí, por lo que hemes visto, se arrojan estos bárbaros sin reflexión y sin tino, y la misma soga, no solamente los expone a mayor riesgo, sino también es la causa de muchas muertes y de otros mayores daños que no ejecuta el toro.

Así, es menester ponernos de acuerdo con la razón, para decir sin temor, que es una barbaridad mezclada con tiranía permitir tales diversiones, que siempre se costean a expensas de la vida de tantos hombres. $Y$ a la vista de tan graves daños, como suceden en estos furiosos espectáculos, sería muy justo exclamar cona el Excelentísimo Cardenal Jiménez de Cisneros, según su historiador Marzolier, que es mejor correr el riesgo de desagradax al pueblo per algún tiempo, que darle espectáculos poco convenientes a la humanidad y a la santidad de la religión que profesaba.

Lo cierto es que los toros se pudieran suplir con juegos de cañas, de sortija y con otras recreaciones muy propias én la nación españolă que refiere García por menor, ${ }^{105}$ todas ellas libres de perder la vida aun la salud. Tampoco dudo que las gentes de razón tendrían mayor di vertimiento en semejantes espectáculos: los indios se acostumbrarían en breve a gustar de ellos más que los toros; toda la plebe aprendería a tener amor al aseo y a la galanura; y por último los gremios, que a falta de propios de la Villa, contribuyen para estas diversiones con arreglo a derecho, ${ }^{106}$ no llorarían por mal logradas sus contribuciones, porque habiendo de correr ellos mismos las cañas o sortijas, darían por muy bien empleado el dinero que se gastare en sus propios lucimientos; bien entendido, que con dos nil y más pesos que cuestan en cada año las corridas de toros, sobra fondo paxa aderezar unos espectáculos magníficos, que sobre divertir al pueblo, servirian de escuela para el buen gusto.

Si no agradare este pensamiento y se quisiere ir con la corriente del capricho de nuestro populacho, en mantener las fiestas de toros, la única precaución que encuentro es cercar la Plaza con un palenque bajo, 
que no embarace la vista del toro al concurso del pucblo; poner un "toril" en la inmediación al corral, para echar de allí los toros a la Plaza, descornados y trabado un pie con la mano contraria, de modo que cuando quiera arrebatarse en carrera para acometer, caiga con el embarazo $y$ quede libre el toreador. De este modo, aunque toreen todos como ahora, será muy raro el que pille el toro, y cuando esto suceda, no podrá recibir daño grave. Cesarán los acontecimientos de los caballos, ya no habrán muertes de las caídas con la soga y el pucblo todo se divertirá sin riesgo, quedando el arbitrio de sacar los toros que se jugaren, a lazo por las calles, para que la gente de a caballo tenga esta ocasión de recrear. se, corriendo sin peligro de pisotear a nadic.

Siguiendo este método, debo advertiy dos cosas: la primera, que aunque Juan Gutiérrez y el sabio Gregorio López, 107 son de opinión que a los que mueren en las corridas de toros, no se les debe dar sepultura sagrada, sin embargo que hayan confesado y comulgado; lo contrario es más verdadero, y lo prueban con incontestables fundamentos el Ilustrísimo Villarxoel y Fray Manuel Rodríguez. ${ }^{108}$

La segunda, que la prohibición de correr toros en día de fiesta, ha perdido en España su fuerza por la inobservancia, y se ha introducido por práctica general del Reino, señalar cualquier día del año para las corridas, sin que los Obispos deban entrometerse en este asunto, por ser propia y privativa esta facultad de los Magistrados Reales, como se declaró en competencia que suscitó el Obispo de Buenos Aires, Don Fray Sebastián Malvar, con el Excmo. Sr. Don Juan José de Vertiz, por Real Cédula fecha en Madrid, a 6 de diciembre'de 1782, bien que en ella misma se le previno que procurase señalar para las funciones de toros, dias que no fuesen de riguroso precepto.

Ultimamente, debe contraer el Intendente de Potosi, toda su atención al cumplimiento del Art. 63 de la Ordenanza, obligando al Alcalde Provincial de la Villa, y a los de la Hermandad, reconozcan los campos, montes y caminos de toda la Provincia, para la debida seguridad del comercio de los pasajeros. Estos Alcaldes jamás salen media legua de la Villa y sólo traen la vara por pura ostentación; ellos son responsables de los insultos y robos que se cometieren en sus distritos, por no haber visitado con frecuencia los tránsitos y despoblados.

Esta pena conviene hacerla efectiva para despertar en ellos esta grave obligación; pues, en dos robos que se han ejecutado de algunas piñas que traían de los minerales de afuerd, ni siquiera se ha intentado hacerles entender la responsabilidad.

Lo mejor será evitar este caso, obligándolos bajo de multa, a que nombren desde luego sus euađrillexos y guardas de montes en el distrito de esta Provincia, para que reconozcan frecuentemente los despoblados tránsitos, caminos y campos donde la seguridad pública merece más vigilancia.

1.-Cap. $2^{n}$, Noticias $1^{\mathrm{g}}, 4^{\mathrm{n}}$ y $5^{\mathrm{g}}$.

2.- El Art. 91 de Ia Nueva Ordenanza enumera todas las Cajas Reales del Virreinato.

3.- Art. 72 de la Ordenanza de Intendentes.

4.-- Escalona: Lib. $1^{\circ}$, Cap. $4^{\circ}$, Nos. 2,6 y 7 .

5.- Escalona: Lib, $1^{\circ}$, Cap. $5^{\circ}$, No. 10. 
6.- Escalona: Id No. I5.

7.- Escalona: Id, No. 15, Art. 267 de la Nueva Ordenanza.

8.- Escalona: Lib. $1^{\circ}$, Cap. $6^{\circ}$, Nos. 5 y siguientes.

9.- Escalona: Lib. 1', Cap. $7^{\circ}$, No. 3.

10.- Phavorino refiere esta historia, en "De Penis Temperandis", No. 28, tomo 7", fol. 59 .

11.- Sobre la inteligencia de estas leyes véase Martens: De re criminali; controvers. 27, Nos. 21 y 22.- Molin: Justicia y Jurisp.; tomo 19, Disp. 47 Nos. 8 y 9.- Gómez: tonio $3^{\circ}$, Cap. $3^{4}$ al No. 50.- Antúnez; De donationib.; Lib. 2\%, Cap. 18 al No. 150.

12.- Tiraquelo: tomo $7^{\circ}, \mathrm{Cap} .50$, fol. 86 .

13.- Escalona: Lib. $1^{\circ}$, Cap. $8^{\circ}$. El Art. 189, trata de los gastos de Misiones.

14.- Frazo: "De Patronatus"; Cap. 83, Nos. 6 y 7.

15.- Escalona: Lib. $1^{\circ}$, Cap. 10, No, 16.- Ley 95, Tít. 15, Lib. $2^{\circ}$ de Indias.

16.- Ley 7 , Tít. $4^{*}$; Ley 14, Tít. $8^{\circ}$, Lib. $8^{\circ}$ de Indias.

17 .- Ley 73 , Tít. $1{ }^{\circ}$, Lib. $8^{\circ}$ de Indias.

18.- Ley 15, Tít. $8^{\circ}$, Lib. $8^{\circ}$ citado.

19. - Escalona: Lib. $1^{4}$, Cap. 10, No. 10.

20.- Escalona: Lib. 1", Cap. 10, Nos. 12, 13 y 14.

21.- Escalona: Lib. $1^{\circ}$, Cap. 18, No. 9.

22.- Escalona: Lib. 1\%, Cap. 10, No, 11.

23. Escalona: Lib, $1^{\circ}$, Cap. 11 .

24.- Escalona: Lib. 10 $^{\circ}$, Cap. 12.

25.- Solórzano: in "Política", Lib. 4", Cap. 3, desde el No. 17 hasta el No. 23.

26.- Peregrino: "De jure fisci", Jib. 6", Tít. 6", No. 33, fol. 100.

27.- Escalona: Lib. 1\%, Cap. 13.

28.- Escalona: Lib. $1^{\circ}$, Cap. 15.

$29, \ldots$ Capitulo 29 , Nolicia 6 , \$ 8 .

30.- Escalona: Lib. $1^{\circ}$, Cap. 16 , fol. 58.

31.- Ordenanzas 28 y 37, Tit. $10 ; \mathrm{y}$ Ordenanza 14, Tít. 13, Lib. 3॰, de las del l’erú.

32 - Provisión de 30 de septiembre de $1620,1^{\circ}$ de abril de 1627,30 de abril y 2 de octubre de 1629 , agregados al fol. 317 de las Ordenes Generales dèl Perú.

33.- Escalona: De Gazophil. Lib. $1^{\circ}$, Cap. 17, caso 14, No. 3 al fin, fol. 65 .

34.- Escalona: Lib. 1\%, Cap. 18.

35. L Leyes 1 a 7, Tít. 4", Lib. $8^{\circ}$ de Indias.- Leyes 22 y 25 del mismo Tít. y libro. Ley 35, Tít. $1^{\circ}$, Lib. $9^{\prime \prime}$ de la misma recopilación. Leyes 9 y 10 , Tít. $9^{\circ}$, Lib. $8^{\circ}$ de id.

36.- Ley 104 , Tít. $1^{\circ}$, Iib. $8^{\circ}$ de Indias.

37.- Escalona: Lib. $1^{\circ}$, Cap. 19, No. 3, fol. 74.

38.- Ley 47, Tít. $2^{\circ}$, Lib. $3^{\circ}$; Ley 24 , Tít. $4^{\star \prime}$, Lib. $8^{\circ}$ de Indias.

39.- Escalona: Lib. $1^{\circ}$, Cap. 20, No. 3.

40.- Escalona: Lib. 19, Cap. 22.

41.- Escalona: Lib. $1^{\circ}$, Cap. 23 , Nos. 1, 2 y 3 .

42,-Jn. V. Tesauros 39 Instit., Tit. $1^{\circ}$, Lib. $2^{\circ}$

43.- Grg. in Ley 45, Tít. 28, parte $3^{\circ}$, glosa $7^{*}$.

44.- Antúnez: "De Donat.", tomo $2^{\circ}$, Lib. 3", Cap. $3^{\circ}$, No. 90.

45.- Escalona: Lib. 1", Cap. 24, Lib. 2, Farte 2‘, Cap. 2॰, fol. 126, y al fin, entre las Ordenanzas para Oficiales Reales.- Solórzano: in "Polit.", Lib. 6", Cap. 5, No. 16.- Id Ramiro Valenzuela: No. 32.

46.- Escalona: Lib. 1\%, Cap. 24.

47. - Este método está en todo arreglado a una Providencia del Sr. Toledo, fecha en La Plata, a 30 de enero de 1574.

48.- Escalona: Lib. $2^{\circ}$, P. 2, causa 2, No. 2.

49.-Id: Lib. $1^{\circ}$, Cap. 24.

50.- Cap. $2^{\circ}$, Noticia $6, \$ 9$.

51.- Eccalona: Lib. $1^{\circ}$, Cap. 27.

52.- Solórzano: in "Polílica", Lib. $2^{\circ}$, Cap. 30, No. 28 hasta 31.

53.- Escalona: Lib. 1", Cap. 29.

54.- Escalona: Lib. 1\%, Cap. 29.

55.- Parte II, Cap. $1^{\circ}$, Noticia 2, pág. 348.

56.- Así lo refiere Inocencio, in Cap. "quod superhis de voto".

57.- Velasco: "De jure Enphiteusis." Q. 42 y 43. 
58.- Ley 13, Tít. $8^{\circ}$, Lib. $6^{\circ}$ de Indias. - Ley 4, Tít. 11 del mismo Lib. y el Art. 124 de la Ordenanza.

59.-- Segunda parte, Cap. $2^{\circ}$, Noticia única, $\$ 2$, fol. 417 , al fin.

60.- Res ficit 4 inst. de usurpationibus.

61.-Leyes 6 y 7, Tít. 29 , p. 3, Lib. 1", Tít. 15, Lib. 4\%. R. C. Lib, 1", Tít. 18, Lib. 9 , Cod. con otras muchas leyes que cita Lazarte en la adic. al Cap. 19. No. 5, fol. 44 vta.

62.- Lazarte: De Décima, Cup. 19, No. 7, fol. 180.

63.-Id. No. 5.

64.- Peregrino: De jure fisci, Lib. 1", T'ít. 2", No. 64, fol. 11.- Antúnez con muchos doctores, tomo $2^{\circ}$, Lib. $3^{\circ}$, Cap. 45 , No. 24, Ley 28 , fol. 337.m Solórzano: Politic, Lib. $4^{\circ}$, Cap. 12, No. 33.

$65 .-$ Art. 74 .

66. - Art. 72 .

67.- Art. 76.- Pero lo económico corre a cargo de la Dijección General de Buenos Aires.

68-- Art. 77; vid. sobre los descaminos y contrabando de comercio ilícito con extranjeros, las leyes del Tít. 17, Lib. $8^{\circ}$, de Indias, la ley 8 , Tit. 13, Libs. $3^{\circ}$, $7^{\circ}$ y siguientes; Tít. $27, \mathrm{Lib} .9^{\circ}$ de la inisma recopilación; y a Salgado, en su célebre tratado de contrabandos. En cuanto a tabacos, véase la Instrucción formada en El Yardo, a 17 de marzo de 1778, por el Excmo. Don José de Gálvez, sobre el modo de sustanciar las causas de fraude de tabacos, y sus penas; advirtiéndose que la pena al duplo, prevenida por el Art. 25 de las citadas instrueciones, se conmutó por Real Ord. de 19 de septiembre de 1779 , en cinco años de presidio por la primera vez; ocho por la segunda; por la tercera en diez, con la calidad de no salir de él sin la Real licencia.

69.- Arts. 73 y 112 .

70.- Art. 78 .

71.- Art. 79 .

72.- Art. 81 .

73.- Art. 80 .

74.- Art. 5" del Reglamento del Libre Comercio.

75.- Lagunes: De Fructibus; I' parte, Cap. 27 , § único, No. 47 , fol. $349 .-$ D. Solórzano: in Polit., Lib. 6", Cap. 6" al No. 18, tomo 2", fol. 455.

76.- Escalona: Lib. $2^{\circ}$, Parte $2^{\circ}$, Cap. $5^{\circ}$, fol. 196.- Alfaro: De Of. Fiscalis, Glosa 20, No. 129.

77.- Carrasco, Cap. $7^{\circ}$, de Quinto honor intestatis; No. 44, fol. 141.- Lagunes: Parte $1^{*}$, Cap. 27 , No. 115 a 122 , fol. 142. Solórzano: in Polit., Lib. $5^{\circ}$, Cap. $7^{\circ}$, No. $36 ;$ y Lib. $6^{\circ}$, Cap. $6^{\circ}$, No. 14.- Paz in Praxi; tomo 13, No. 2, fol. 125.- Souza: De Regulis Juris, Parte $1^{4}$, No. 160, fol. 47.- Carrillo: De Terciis; Lib. $6^{\circ}$, Cap. 41 , No. 153 , tomo $7^{\circ}$, fol. 429.

78.- Matienzo: en la ley 6, Tit. $8^{\circ}$, Lib. $5^{\circ}$ de Castilla, Glosa 4, No. 11.- Souza: De Regulis Juris; Parte $1^{4}$, fol. 46, No. 157 al med-Colórzano: De jure Indian.; Lib. $4^{\circ}$, Cap. $7^{\circ}$, No. 42 , y en la Polit., Lib. $5^{\circ}$, Cap, $7^{\circ}$, No. 37 . C C. rrasco: Cap. $7 \%$, Nos. 40 y 41 .

79. - Souza: in Leg. femine; \& de Regulis Juris; Parte $1^{*}$, No. 161, fol. 47.- Lagunes: De Fructibus; Cap. 27, 1' Parte, Nos. 122 hasta 129 , fol. 343.

80.- Carrasco: Cap. $7^{\circ}$ de Quinto bonor intestatis; No. 47 y siguientes, fol. 141.

81.-Antúnez: De donationibus; Lib. $3^{\circ}$, Cap. 20, ex. No. 10.- Fajardo: Adegations.; Tít. 45.- Carrasco: Cap. $7^{\circ}$, No. 15, fol. 136.

82.- Lagunes: De fruetibus; $1^{+}$Parte, Cap. 27, No. 129, hasta 139 , fol. 326.

83.- Antúnez: De donationib.; Lib, $3^{\circ}$, Cap. 43 , No. 94 , tomo $2^{\circ}$, fol. 326 .

84,-- Escalona: Lib. 2\%, Parte 2", Cap, $5^{\circ}$, No. 4, fol. 137.-Carrillo: De Tertiis; Cap. 41 , No. 152 , tomo $7 \%$, fol. 428 ; y otros muchos citados por Lagunes, en De fructibus, 1* Parte, Cap. 27, No. 111, fol. 341.

85.-- Antúnex: De donationibus; Lib. $3^{\circ}$, Cap. 43, No. 96, tomo $2^{\circ}$, fol. $327,-$ Peregrino: De jure físci; Lib. $4^{*}$, Tít. $3^{n}$, No. 30 , fol. 104 vta.- Solórzano: in Polit.; Líb. $5^{\circ}$, Cap. $7^{\circ}$, No. 38 , et Lib. $6^{\circ}$, Cap. $6^{\circ}$, No. 16.

86, - Sobre los bienes vacantes y mostrencos, y su aplicación al Fisco, trata ampliamente Peregrino, en De Jure Fisci, Lib. $4^{\circ}$, Tít. $3^{\circ}$, fol. 102 .

87.-Eecalona: Lib. 29, P. 2, Cap. $5^{\circ}$, No. 12, fol. 138.

88.- Solórzano: Polit.; Lib. $3^{\circ}$, Cap. $6^{\circ}$, Nos. 35 y 36.

89.- Salcedo: De Leg. Polj́tica; Lib. 24, Cap. 16, fol. 309. 
90.- Art. 84 de la Ordenanza de Intendentes.

$91 .-$ Cap. $8^{\circ}$, sobre la Casa de Moneda, Noticia t23, Pág. 175. l'rimera parte.

92. - In la Provisión de La l'az, a 5 se junio de 1575 , obedecida en Potosí a 9 de julio del mismo año, por el Licenciado Gómez Hernández, Corregidor de la Villa.

93.- En provisión de 6 de noviembre de 1625.

94.- Las reglas que deben observarse en la división de cuarteles y jurisdicción de sus Conisarios o Alcaldes de Barrio, se puede ver en la Cédula Real de 6 de octubre de 1768, que refiere Martínez, en su Librería de Jueces; tomo $6^{\circ}$, fol. 81, No. 283, en el \$ 4, del 'Tít. 6\%, Lib. $2 *$ de Castilla; con otras dos Cédulas de 1769 y 1770 , que transcribe en el mismo tomo, fol. 56, No. 209 y cn el fol. $63,170,228$.

95.- L'or la ley 18, Tít. 1", Lib. 6\% de Indias se declara que en la lengua de los indios no se pueden explicar con propiedad los misterios de nuestra fe, sin grandes errores; f por esto se mandó erigir escuelas de lengua castellana, por Reales Cédulas de 28 de enero de 1778 , 5 de noviembre de 1782 - Solórza. no, en la Política, Lib. $2^{*}$, Cap. 26, No. 37.

96.- Solórzano, en su Política, es de sentir que debe obligarse a los indios que usen nuestros trajes y vestidos, paxa que asi fueran más políticos y amantes de nuestro trato y costumbres. El Ilmo. Sr. Don Juan de Palafox, en la Historia de la conquista de la China, por el Tártaro, tomo 1", Cap. $4^{\circ}$, No. 5, fol. 299, aprueba la providencia que dieron los tártaros para que los chinos vis. ticsen lacgo al uso de la 'lartarja, asegurando que la conformidad de los trajes, es causa de la corformidud en las costumbres; y añade que, siendo muchos más en número los contulustados, no conviene distinguirlos con el vestido, para quitarles esta señal de su prepotencia.

97.-. El Sr. Solórzano, en su Politica, Lib. 2\%, Cap. 26, Nos. 41 y 42 , opina con Matienzo, que además de la conveniencia propia que lograrian los indios, con ser más políticos usando de nuestros trajes, se acrecentaría una utilidad en las mayores cantidades de oro y plata que sacaríamos de ellos, comprando y usando de este géncro de vestidos.

98.- L'rimera parte del Apćndice de la Educación Popular; pág. 171.

99. - Liste arbitrio es conforme a la Ordenanza 27, Tit. $2^{\circ}$, Lib. $2^{\circ}$ de las Generales del Perú; y no habiendo quien se haga cargo de los huérfanos, debe alimentárseles de la Caja de Comunidad.

100.- Bula dada a 7 de las Calendas de noviembre de 1567.

101 - Bulas de 25 de agosto de 1575 y 1.3 de enero de 1596 .

102,- Rodriguex: tomo $3^{\circ}$, Cuestiones regulares; Art. $1^{\circ}$, Q. 68, fol. 376.- Navarro en su Manual, Cap. 15, No. 18. García: De expensis, Cap. 21, No. 29, fol. 201. Suárez: tomo $2^{\circ}$, De Religioni, Lib. $2^{\circ}$, Cap. $4^{\circ}$, No. 7. Villarroel: El Gobierno eclesiástico; parte $1^{\prime \prime}$, cuest., 3 , Art. 8 , Nos. 34 y 40 , tomo $1^{\circ}$, fol. 354 . Gutiérrez: Lib. 1\%, Cuestiones Canónicas, Cap. $7^{\circ}$, No. 13.

103.- Loco citato.

104.-- Gutiérrez, Lib. 1\%, Cuest. Canon.; Cap. $7^{\circ}$, No. 14, fol. 47 .

105.- García: De expensis; Cap. 21, No. 29.

106.--Garcia: De expensis; Cap. id, No. id, al fin. Bobadilla, en su Politic., Lib. $5^{\circ}$, Cap. $4^{\circ}$, Nos, 20 y 25 , tomo $2^{\circ}$, fol. 579 .

107.--Gutiérrez: Lib. $1^{\circ}$, Questión Canónic.; Cap. $7^{\circ}$, Nos. 2 y 3 . Greg. López: en la ley 10 , Tít. 13 , Partida $1^{\star}$, glos. 1 y 2 , referente a la ley 57 , Tít. $5^{\circ}$ Partida $1^{\circ}$, glos. 2 al fin.

108.-. Villarroel: Gob. Eclesiástico; parte $1^{\natural}$, cuest. $3^{\circ}$, Art. $8^{\circ}$, concl. 3, No. 45, tomo 1\%, fol. 355. Rodriguez: Cuest. 68, Art. 2, vers. 3, fol. 378. 



\section{APENDICE A LA NOTICIA QUINTA}

\section{Consideraciones más delicadas que pueden tocarse en toda la obra.}

Abraza los abastos, los oficios mecainicos, los materiales para obras y los surtimientos de mercaderias que necesitamos para subsistir con comodidad, respecto de incluirse todos estos menesteres bajo el nombre de alimentos, según la declaración de la Ley 2, Título 19, Partida 4a.; para no confundir estos objetos trata de por sí cada uno de ellos, según el por menor de sus circunstancias.

Párrafo primero. - Alimentos. $\mathbb{W}_{\mathrm{N}}$ la Economía Política no hay sistema que más agite la meditación del Gobierno, como el de los granos y abastos; y como son tan diferentes los principios y las opiniones de que pende su policía, nada hay tan difícil para acertar con las medidas justas de las subsistencias.

Es preciso que el Gobierno conozca la población, la producción y el consumo, para que sepa calcular la producción de la cantidad de trigo, con la necesidad que hay de él. Pero siendo casi imposible una averiguación clara en este punto, apenas se llega a formar una idea de ello por conjeturas.

Con esto, aunque realmente no se disminuya la cantidad existente, cualquiera voz esparcida de carestía inquieta al pueblo, y si ve que algunos compradores fingidos manifiestan prisa a comprar, aumenta sus recelos de que falte. Por más de que esta inquietud sea efecto de una opinión pública, indeterminada y vaga, produce al instante las revoluciones en los precios. Porque como estos son un compuesto de realidad 
y de imaginación, aunque el motivo para la subida del precio no sea justo ni considerable, entra luego a avaluarlo a su antojo la imaginación del pueblo, exitándolo muchas veces hasta aumentar las pretensiones de los interesados; y así vienen en estas cil'cunstancias a reputarse los precios, como opiniones.

El hacendado, que no ve en el trigo més que un fruto de sus afanes y una producción de su terveno, emprende a disponer de él arbitrariamente, como de lo demás de sus rentas.

El comerciante, que no percibe en este comestible más que una mercadería, que se vende y que se compra, quiere adquirirla y revender a su gusto, con su interés, y solicita que se rija su circulación por las leyes generales de comercio.

Apurado el pueblo con la amenaza de carestía, reclama su conservación, y por más que se niegue a las reflexiones, conoce que para vivir en la tierra que habita, necesit del trigo, que mira como clemento preciso para subsistir.

Separadas entre sí estas tres clases de ciudadanos, por la contrariedad de sus pretensiones, invoca el hacendado los respetables derechos de propiedad; el comerciante los de la libertad; y el pueblo los de la humanidad.

En medio de este choque de intereses, de principios y de opiniones, es donde el Gobierno debe buscar la unión de estos tres órienes de ciudadanos, separados entre sí, para que manteniéndose en armonía las clases que dividen la sociedad, no se ofendan por el poder excesivo de la propiedad y de la libertad los derechos imprescriptibles de la humanidad.

Con el objeto de defender al pueblo contra la opresión, bien sea precaviendo las desdichas que causa la alteración de precios; acudiendo al socorro de la multitud en ocasiones de carestía, con oportunas precauciones, ha formado el Gobierno muy de intento, varios reglamentos, con el nombre de Policía de Granos.

Como el número de los hacendados es muy corto, comparado con el de los demás hombres, que no Io son; y sobre esta mayor concurroncia se agrega la prodigiosa desigualdad de que estos viltimos son hombres que se ofrecen a vender su trabajo para vivir hoy, y los otros se to compran para aumentar su lucro o comodidades; es consiguiente que los unos darán siempre la ley, y los otros se verán precisados siempre a servirla, porque a los unos los obligan los instantes y a los otros les da imperio su fortuna. Dos circunstancias fortifican por grados sucesivos este poder imperioso: la primera es, que resumiéndose insensiblemente las posesiones cortas en manos de los ricos, cada vez más, se va disminuyendo el numero de los hacendados; y como en todo cambio o permuta depende en mucha parte la fuerza de los vendedores y compradores, del número respectivo de los unos y de los otios, es preciso que se aumente a proporción el imperio del hacendado sobre los hombres cuyo trabajo compra. La segunda es, que según se va envejeciendo la sociedad, se van amontonando también muchas porciones de joyas, espejos, edificios, diamantes, vajillas y otras obras de industria (propias para el lijo o la comodidad), que excediendo a la vida de los hombres, establecen una concurrencia sorda y permanente contra el trabajo nuevo de los artesanos, imposibilitando cada vez más sus pretensiones.

Estos obstáculos fortifican más el interés del hacendado, para 
procurar reducir siempre al precio más bajo la recompensa de los trabajos quc compra. Pero se aprovecha mejor en las subidas de precio, ya sean causadas por rerdadera carestía, o por sola su opinión.

Porque, mientras se aumente el valor de los granos, mantienen abatido el precio del trabajo y se aprovechan del suclor del jornalero, percibiondo en esta despropou'ción nn nucvo beneficio en el cultivo, que puede cmpeñarlo a muevos desmontes.

De este modo el infeliz artesano, que cuando el pan estaba a precio moderado, ahorraba algunos sucldos para acudirse en una enfermedad, luego que sube insensiblemente el precio renuncia aquellos ahorros o disminuye a sus hijos el alimento, haciéndose sordo a sus lágrimas, o se niega a sí propio la subsistencia necesaria para mantener sus fuerzas.

Por iltimo, a medida que se cucarece el pan $y$ el artesano ya no ticne sus antiguos ahorros, se ve precisado a trabajar para no morir; expone su vida y la de su familia, mientras el hacendado va retardando los acrecentamientos de su lujo.

Sobre estas aflicciones del pueblo, tiene tanta influencia la intervención de los concrciantes, que su concur'rencia encarece más el trigo, disminuyendo el múmero de los vendedores con quienes los consumidores tienen que tratar, y también porque aumenta el poder natural de los que le venden sobre los que consumeir.

Cada uno de los comerciantes que intervienen en el comercio de trigos, toma por lo regular, según su fuerza, el lugar de un número crecido do hacendados; porque obrando con sus capitales, duplicados de ordinario con sll crédito, si quisiere emplear todo este caudal, que lo supongo reducido a diez mil pesos, podrá comprar todo el trigo producido en las tieł'ras de un Partibo entero, que podrán muy bien estar repartidas entre doscientos o trescientos hacendados.

Entonces, cada comerciante resultarâ vendedor único, con respecto a la masa de los consumidores de aqueHa cantidad de trigo que, sin su intervención, hubiera podido venderse por doscientos o trescientos hacendados; y por consiguiente esta intervención disminuye la concurrencia favorable a los consumidores, porque minora el número de los vendedores con quicnes tenian que tratar.

Estas ventas y reventas sucesivas que han hecho con ganancia los hacendados o sus aryendadores, Ios comerciantes, Ios trajineros y otros agentes del comercio, van encareciendo proporcionalmente el comestible, en perjuicio de los consumidores; porque cuando más hubiesen sunido el precio del comestible en manos del hacendado, aquellos comerciantes por su número y por su rivalidad, tanto más tienen que exigir de los consumidores al revender.

Después de esta observación se advierte nuevo motivo de encarecimiento en el poder que aumente a los comerciantes su misma intervención; porque cllos no deben como los hacendados para pagar los jornales, o para gastar, si no para guardar, como un capital estimable, por el tiempo a que los empeñe su interés, para lograr mayores provechos.

De aquí proviene, de necesidad, mayor carestía, así para la ganancia equitativa que luera todo agente de comercio, como porque se pone en movimiento la opinión pública y disminuye la concurrencia de las primeras manos, que es la única provechosa para los consumidores.

El fin de colregir estos abusos, obligó a poner tasa a los granos, 
bajo las penas que pronuncia la ley $1^{\text {a }}$ con las siguientes, título 25 , Lib. $5^{2}$ de la Recopilación de Castilla, para mantener de este modo un justo equilibrio en las subsistencias de todas las clases de la sociedad.

Asimismo, se prohibió la extracción del trigo fuera del Reino, por las leyes 25,26 y 27 , título 18 , I,ib. 6 de Castilla, porque suponiéndose que mestras tierras producen, $m$ año con otro, tanto como consumimos, discurrian que con la extracción nos faltaría, o a lo menos, que nos expondríamos a que nos faltare una parte del cue nos es necesario; pero quedó abierto el permiso para la introducción, para que con ella se pudiera suplir lo que faltare en un año de escasez. '

Véase aquí, en compendio, los principales fundamentos de nuestra antigua legislación de granos, cuya obsorvancia debía ser positiva y absoluta en aquellos y en estos reinos.

El tiempo despertó muchas advertoncias en nuestra cconomía política, para conocer y remediar los inconvenientes de los primitivos reglamentos de granos. $Y$ en efecto, ilustrado nuestro Gobicmo por los talentos incomparables de nuestro Soberano reinante, el Señor Don Carlos III, cambió la antigua práctica, formando con otras leyes más sabias y económicas, la época más feliz de nuestra Monarquuía.

Porque realmente, aunque se llegare a conocer la población, la producción y el consumo, y la rclación de la cantidad de trigo con la necesidad que había de él, nunca podrían calcularse equitativamente todos los gastos de cultivo, de almacenes $y$ de acarreos, para obligar a los labradores y comerciantes con justicia, a que vendiesen su trigo al precio que les estaba tasado, sin que, las más veces, quedasen perjudicados con la quiebra de su principal costo.

Además de esto, experimentando los labradores despreciados sus frutos en los años abundantes, y que en los cstériles no sacaban, por la tasa, el costo de sus gastos y fatigas, se veím oprimidos y en estado de no poder continuar sus labores, $y$ el puebio sin los granos necesarios para su alimento y sin recurso a su compra, por estar prohibido el libre comercio y los mercaderes de granos.

Para ocurrir a estos graves inconvenientes, que sobre debilitar la abundancia del Reino, impedían a la agxicultuka sus importantes progresos, se promulgó una ley general, en 11 de julio de 176j, recopilada en la ley 15, Tít. 25, Lib. 5 de la Recopilación de Castilla, impresa el año 1775, derogando enteramente la antigua tasa de los granos, con el permiso de su libre comercio, en la forma que expresa dicha ley y otra provisión declaratoria recopilada en el mismo título y jibro, su fecha 30 de octubre del propio año de 1765 l'enovando por este medio otra Pragmática Real que se despachó en Ebora, por el Señor Don Felipe III, en el año de 1619, a beneficio de los hacendados y de sus arrendadores, con expresión literal de los mismos motivos que quedan referidos. ?

Ello se mete por los ojos el inconveniente que, si no se permite $\mathrm{ex}$ traer, es consiguiente que el labrador venda menos cantidad de trigo $y$ a precio más bajo; y siendo por esta causa menos rico, ya no se halla en estado de cultivar tanto, $y$ se le hace preciso cultivar menos.

La resulta de estos principios debe ser una cosecha en cada año menos abundante, y la extracción que se prohibió para evitar la escasez, produjera un suceso contrario para que con efecto llegara a faltar el trigo y nada suplir la introducción, porque hallándose cerrado el paso para 
la salida, no cuerrán introducir trigo, a riesgo de verse forzados a venderlo con pérdida.

Después de esto, como una circulación libre, pone necesariamente el trigo a nivel por todas partes, nadie se empeñará a extraer el que fueree necesario en el lugara donde se compró, porque no se tendría ganancia en venderlo chl otra parte.

La luerza de estas consideraciones se halla muy comprobada con repetidas experiencias en el Reino de lnglateira, respecto de sus granos, y en las provincias meridionales de España, con especialidad en Máaga y sus contornos, respecto de su vino y pasas, pucs, sin embargo del permiso absoluto que hay en aquel Reino para sacar los granos en tiempo de abundancia, con el agregado do dos reales y medio de plata que se paga de gratificación del Real Erario, por cada fanega de trigo que se extrae del Reino, cuando su precio no excede de cierta cantidad determinada, jamás se ha padecido hambre en cl dilatado timpo que se observa esta providencia.

En Málaga ha producido tales progresos la saca de sus vinos para los reinos de Inglaterra, Suecia, Holanda, Hamburgo y de otras partes, que los montes y alturas que antes estaban sin cultivo, se han labrado después para viñas en la extensión de muchas leguas, aplicando para granos todas las llanuras que ocupaban las viñas en tiempos pasados, por el distrito de dos leguas cuadradas escasas, porque siendo regular que el número de labradores se proporcione al consumo, despacho y saca de las producciones y frutos, fue consiguiente el aumento del cultivo a medida qlue fué creciendo la saca, por la mucha gente que se empleó en la labranza para acrecentar las cosechas que facilitasen la abundancia para tener que vender más.

Convencido nuestro sabio Gobierno con estas notorias utilidades que son el mayor fomento con que se puede alentar la agricultura, permitió la extracción de granos de unos pueblos a otros, por el Cap. 58 de la Instrucción de Intendentes, de 4 de julio de 1718, brdenando a los de cada Provincia la observancia de todas las precauciones que se hallan dictadas para iguaks casos, por la ley 29 , título 18 , libro $6^{\prime \prime}$ de Castilla, que se reducen a que solamente se saque el trigo sobrante de la gruesa de granos que se necesiţaren para el abasto de aquel año y para la sementera del siguiente, con arreglo a los cálculos del consumo de cada pueblo, dejando siempre al prudente arbitrio de los Intendentes la prohibición o permiso de las sacas, según las circunstancias de escasez o abundancia que anunciare el año, con precedente consulta del Consejo.

Atendiendo a la mayor importancia de este mismo objeto, dispone el Art. 67 de la nueva Instrucción, de 28 de enero de 1782, que cada cuatro meses envíen los Intendentes de América, al Excmo. Sr. Virrey y al Intendente General, relaciones puntuales de la escasez o abundancia de frutos en sus Provincias y de sus respectivos precios corrientes, para que con este conocimicnto providencien ambos Jefes de común acuerdo y a tiempo oportuno, el socorro de los pueblos necesitados a la libertad del comercio de los frutos sobrantes.

El Derecho Municipal de Indias había permitido mucho antes, por las leyes 8 hasta 12 del título 18 , libro $4^{\circ}$ de la Recopilación, el libre comercio interior de los granos, para todas las Provincias de América, im- 
poniendo graves penas a los que pusiesen impedimonto a la franqueza de este trajín de una parte a otra.

Esto mísmo se concedió en los r'cinos de Castilla, por el capítulo 3 de la ley 15, título 25, libro 5" de la Recopilación; pero es tan general su sonido, que no se encuentra modificación alguna en todo el contexto de las citadas leyes de una y otra Recopilación.

Así pues, deben declararse estas providencias, según las particularidades que explica el Art. 67 de nuestra Nueva Ordenanza, entendiéndose permitida la libertad del comercio de los crutos de cada Provincia, en aquellos solamente que quedaren sobrantes, después de bien abastecidos los pueblos, como se previene en la ley 17 , título 5", libro $5 "$ de Indias, en cuanto a la saca de granos.

Aunque mediante este sabio sistema sea probuble que en nuestras Provincias no se padecerá escasez, por lo regular nunca se ha querido mostrar indiferente nuestro Gobiemo en materia de subsistcncia. Su principal cuidado ha sido siempre prevenir las carestías $y$ subidas de precios, con precacuciones económicas, que al mismo tiempo de confor marse con el orden variable de las cosas, tengan tales medidas que puedan aplicarse a todas las circunstancias y prevenir la intervención frecuente del Gobierno en el manejo de granos.

Con este fin se ha mandado por los artículos 58 y 69 de la Ordenanza, que en las capitales y demás pueblos de sus Provincias se establezcan Pósitos ${ }^{3}$ y Alhóndigas, con arreglo a la ley 11, título 13, y a la ley 19 , título 14, libro $4^{\circ}$ de la Recopilación de Indias, para que estos acopios anticipados de trigo para el abasto público, sirvan de recurso contra los efectos imprevistos del comercio en alivio de los labradores y del pueblo.

Muchas son las utilidades de semejante establecimiento y son bion conocidas sus reglas y fines en las leyes 17, y 18, título 11, libro $5^{\prime \prime}$; y en la ley 9 , título $5^{\circ}$, libro $7^{\circ}$ de Castilla; pero la constitución de ranchos lugares, ha servido de obstáculo para su plantación.

Son demasiado grandes las ventajas que producen las Alhóndigas, para que por todos medios se procure entablar su plan. En todas partes son necesarias, pero en Potosí, puedo asegurar que son indispensables, no solamente para tener en las moderadas provisiones de estos acopios, una salvaguardia contra las crisis imprevistas y momentáneas del comercio, sino también para cortar un abuso criminal, que hasta ahora ha sido irremediable, de salir por los cantos y caminos de esta Villa, ciertas personas liamadas yarkiris, que tienen por oficio quitarles a los indios los granos, legumbres ' semillas y demás abastos que traen para vander, antes de llegar a la población; y son tan atrevidos estos agentes maligmos de la codicia, que cuanco el indio se vesiste a soltar sus frutos por aquel precio que le proponen, hacen ellos una represalia violenta, valiéndose del despoblado donde ejecutan tales incivilidades, para insultar al indio de palabra y no pocas veces maltratarlo de obra.

Esta abominable negociación llaman "jarkay" en Potosí, y es el expediente más lucrativo que encuentran los panaderos, los cancheros, los pulperos, los mayordomos de ingenios y gemeralmonte les demás vecinos del pueblo, para hacer el consumo de los abastos más necesarios, a menos costo de la mitad de su justo valor.

$\mathrm{Y}$ lo peor es, que este abuso es el origen fecundo de la infinidad de regatones * que encarecer los precios en medio de la numerosa concurreh- 
cia de manos ell quienes están repartidos los frutos que vienen a esta Villat porque, sorprendidos por los jarkiris los indios que acarrean los abastos, vienen a reducir su despacho a los cancheros, que son unos monopo- histas verdaderos, que estancando el efecto, dan después la ley a los consumidores, cobrando Ia subida de un veinticinco por ciento más que hubiera vendido el indio; de suerte que, cuando este pueblo debía ser uno de los más baratos de la sicrra, por los muchos trajineros que concurren con sus efectos al mercado, es el más caro, por causa del monopolio criminal que se hacc por los cancheros y panaderos mediante los jarkiris.

Todos cstos excesos quedarían remediados desde el punto que se estableciesen las Alhóndigas, porque observándose las sabias reglas que para este caso prescribe la ley 13 , título 19 , libro $9^{\circ}$ de Castilla, se vendería solamente en Alhóndiga de la Villa, los granos, harinas y demás semilas que los trajineros, labradores y demás comerciantes condujesen para su abasto. Así creo que naća importa tanto como la plantación de la Alhóndiga, y no juzgo que haya embarazo insuperable.

Entretanto, también es fácil reprimir el abuso de los jarkiris y entablar los acopios por otro modo muy oportuno, que ahorraría a la Policía el que tome el manejo de las subsistencias por medio de órdenes arbitrarias, en los muchos accidentes que ocurren en materia de granos.

La ley 13, del título 19, del libro $9^{\text {n }}$ citado, de la Recopilación de Castilla ordena que, en defecto de Alhóndigas, señale la justicia y Regidores de La Plata, otro lugar público donde se vendan los granos y semillas, depurando las calles por donde se hayan de introducir, con absoluta prohibición de poderse comprar los dichos frutos, fuera de las ciudades y Villas, en los caninos, bajo la pena de pagar la Alcabala con el dos tanto y del perdimiento de la cuarta parte de ellos. La ley 26, título 3, libro $6^{\circ}$ de Indias prohibe también tomar a los indios contra su voluntad, bastimentos y otras cualesquicr cosas, bajo la multa, que lo de otra forma se les tomase, se les haga satisfacer con el doble y más el cuarto tanto, mitad para la Cámara, y la otra, dividida entre el Juez y el acusador.

En Potosí, no tiene lugar la Alcabala doble, impuesta por la ley de Castilla, respecto de entrar todos los bastimentos libres de derecho, por ser asiento de minas; pero es verificable la pena de descamino en la cuarta parte de los frutos, aplicada a los denunciadores, acusadores o aprehensóres, que tiene gran consonancia con la citada ley de Indias, porque en ellas se hace la misma adjudicación, aumentando la pena hasta el cuarto tanto, en que interesa a la Cámara y al Juez.

Bien sea el Procurador General o el Alguacil Mayor, debía hacerse cargo de celar los caminos por donde se introducen las semillas, granos y legumbres, hasta la extensión de las cinco leguas de su territorio, para que cesasen las represalias violentas de frutos que hacen los jarki ris, y también para que en derechura viniesen con ellos a la Plaza para su venta, haciendo efectiva a favor de ellos la cuarta parte que señala la ley, con más el doble a beneficio de los indios; que viendo éstos el interés que tienen en acusar a los jarkiris, rara vez quedará sin castigo este exceso y no se dormirán en las diligencias los Jueces y menos. los celadores.

$Y$ cuando no parezca conveniente pensionar con tal cargo a los dividuos del Cabildo, considero muy a propósito para él a los Guardassés

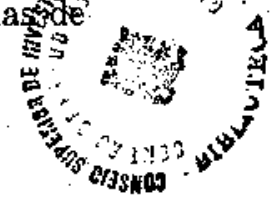


los caminos, que mantiene la Real Aduana para celar fraudes y extravíos; porque siendo la ocupación de estos espiar los caminos y demás cntradas y salidas de la Villa, no será pensión celar de paso a los jarkiris y franquear la entrada a los indios que traen bastimentos, y siempre que se les interese en la pena de la ley, por un bando general, serán celadores exactísimos, por cuyo único medio podrán lograr los trajineros más libertad en su comercio, y la Villa el gran beneficio de la baja de los precios, por la mayor concurrencia de las primeras manos, en cuienes estarán repartidos los abastos.

De este modo también se conseguixá el cumplimiento de la ley $\mathbf{1 0}$, título 10 del libro $6^{*}$ de Indias, en que se previene que los indios pueden vender libremente y sin tasa sus bastimentos, danclo por razón, que entonces acudirán de su voluntad y habrá abundancia de todo lo necesario. Por ahora es muy imperfecta la observancia de esta ley, porque los jarkiris imponen una tasa clandestina, injusta y arbitraria a la mayor parte de los abastos, con lo que queda agraviada la libertad de los indios, y si acuden a la Villa con sus granos, es más por fuerza de necesidad que de voluntad propia, minorándose la abundancia que tendríamos si fuese del todo libre la concurrencia de estos infelices.

Debe suponerse qno, cesando por los referidos merlios la intervención de los jarkiris y monopolistas, lograremos abundancia de granos, a medida de su libre comercio; y así, pasaremos ya a proponer el plan de los acopios, que sin embarazar la circulación del trigo, mantenga sus precios a nivel y sea pronto recurso para las ocasiones de carestía.

La mediación de los panaderos, me parece que puede suplir mejor que ningún otro arbitrio el establecimiento de Pósitos y Alhóndigas para hacer las provisiones de granos.

El capítulo $7^{\circ}$ de la Real providencia de 30 de octubre de 1765 , recopilada al fin de la ley 15 , título 25 , libro $5^{\circ}$ de Castilla, aprueba y autoriza este plan, ordenando que en los pmeblos de donde es preciso traer los granos de acarreo, se procure establecer con acuerdo del Ayuntamiento $\mathrm{y}$. Síndico del común, el número de panaderos que baste a tenerlos surtidos y abastecidos de pan, sin escasez, con la precisa obligación de amasar y vender cada uno de ellos la porción djaria de pan correspondiente que se les señale.

Los panaderos, por su oficio, tienen, la mayor parte, una provisión más o menos grande, a lo más o menos habitual; por lo mismo, con arreglar sus compras, tho se va a ejecutar novedad alguna en lo esencial, más que acrecentar el acopio o hacerlo más cierto y más general, sin necesidad de cauclal efectivo, porque las más veces lo podrán conseguir de los arrendadol'es o de los hacendados, o de los mismos comerciantes, a sólo crédito, por ser para corto tiempo semejantes provisiones.

Toda la dificultad consiste en arreglar el plan de estos acopios. Para esto es menester considerar el tiempo de las cosechas y la época del año en que regularmente suele estar el trigo a precio más barato, con dos fines: cl primero, por la ventaja de los panaderos, $y$ el segundo, por prevenir la extracción que ordinariamente se ejecuta en los meses en que bajan los precios.

Como en este Reino del Perú los equinoccios y tiempos son al contrario que en España, sucede que las cosechas y siegas del trigo y demás frutos, (que en España se hacen por agosto y en Francia por julio), son 
aquí por diciembre, enero, febrero y marzo; y así, dice Don Francisco Carrasco, ${ }^{4}$ que la Real Audiencia de Lima sigue este trueque de tiempos, aconodando en ellos los meses de la cosecha, para el uso del privilegio concedido a los labradores.

Siguiendo csta diferencia de tiempo, será conveniente que nuestros panaderos hagan sus acopios proporcionalmente, en aquella época que hacen los suyos los de Francia, donde se sigue este plan de provisión, a falta de los Pósitos.

En aquel peino está señalado por tiempo más oportuno, el primero de febrero, hasta fin de junio, dando libertad a los panaderos, para hacer a si arbitrio la provisión desde este mes en adelante, atendiendo a que entonces la venta gradual de ella misma y después la abundancia del trigo nuevo, bastarían para evitar toda inquietud y alteración en los precios. Por cl contrario, un acopio constante de granos que no son necesarios, fomentaría un capital inútil y sería un medio más de encarecer el comestible.

Conforme a las reglas de este plan, los panaderos no pueden sufxir el menor perjuicio, porque el trigo que comprasen en los tiempos del año en que haya bajado su precio, lo revenderían cuiando este comestible tiene comunmente mayor valor.

Por otra parte, no se cmbaraza con estos apoyos la circulación del comercio, porque los mismos panaderos encargados en la compra de trigos, ocupan el lugar de los comercios, y sosteniendo el precio de los granos en la época de abundancia y moderándolo en el de Ia escasez, contribuyen de este modo a la igualdad tan deseable de los precios.

Los mismos principios deben dirigir el método de nuestros acopios, con la diferencia que nuestros panaderos deben hacerio desde el $1^{\circ}$ de julio hasta último de octubre, por ser entonces el fin del otoño, que en todas partes es la época de la mayor abundancia.

Las cantidades que cada panadero debe comprar para fondo de esta provisión, deben arreglarse a la población, al consumo de ésta y al despacho de las panaderías, teniendo siempre consideración a la calidad de los habitantes, esto es, si todos ellos eomen pan o se suplen de otros alimentos, y si las familias particulares amasan y se hacen su pan, para obligar a los panaderos conforme a estas observaciones a que se provean de una cantidad de trigo más o menos grande.

Sin embargo, la libertad absoluta de comercio interior de granos y la dificultad de conocer por un cálculo seguro el verdadero supérfluo de nuestras cosechas, suelen acasionar una repentimz carestía, para cuyo remedio no basta la provisión de las panaderías, metiendo al Gobierno en muchos cuidados la inquictud pública, que es la resultante indispensable de las subidas de precios ocasionadas por la escasez.

La proposición no puede ser más clara ni de mayor importancia en materia de Economía Política. Al tiempo de una nueva cosecha vemos regularmente amontonadas y detenidas muchas porciones de trigo en las trojes de los hacendados; pero no siendo posible en aquel estado averiguar si hay igualdad entre todas las subsistencias y todas las necesidades del Reino o de la Provincia, lo más común es formar juicio a favor de la abundancia.

Los hacendados, que estiman como supérfluo el resíduo de subsistencias que cobran a la suya, se exitan a venderio, por recelo de que no 
les toman otros la delantera. Entonces son los precios muy bajos, y aunque por esta caliclad se habilitan muchos consumidotes, lo general es quedarse la mayor parte de ellos sin provisión, porque los más sólo viven diariamente de lo mismo que trabajan y no pueden comprar al precio de la cosecha la cantidad de trigo que necesitan para mantenerse al año.

Los comerciantes, que siempre están observando las menores crisis del Estado, se apresturan a hacer crecidos acopios, para revender en la época de carestia dentro de la misma Provincia, o para extraer el trigo fuera de ella cuando les acomode.

Si la cosecha de trigo rindió únicamente aquella cantidad que igualare a la necesidad, queda expuesta a perecer mucha parte de los habitantes que, por falta de dinero, no pudieron comprar en la cosecha la porción que habían menester para mantenerse on el año, una vez que suponemos que los comerciantes tienen acopiada aquelta cantidad de subsistencias con que esos infelices debían vivir.

Lo más es que, aunque los comerciantes no hayan verificado compras de trigo, es preciso que siga la misma calamidad, porque como la igualdad entre las subsistencias y las necesidades de un reino o de una provincia dilatada, jamás puede cxistir en todas sus partes y en todos instantes, aun cuando la circulación del comestible fuere my rápida y bien dirigida, bastaría que cualquier habitante tomare más parte de lo que le correspondía, para que otro se viese más necesitado.

Con esto, exita a todos tal ardor de comprar, el temor de ser uno de los desdichados, que los que tienen trigo doblan o triplican el precio ordinario, siguiéndose a esta revolución una subida repentina de valores, que inquieta al pueblo $y$ pone en consternación al Gobierno.

Otras veces depende la alteración de plecios, de una falsa carestía, que hace recelar al pueblo la maña de los vendedores en ocultar la masa de granos que se consideran necesarios para mantener a nivel su valor. En este caso son menester unas providencias muy inteligentes sobre la circulación de los granos, y unos cuidados continuos sobre los socorros del pueblo; pero deben ser tan circunspectos que no se descubra Ia inquietud del Gobierno, porque además de instruír y dar luz a los monopolistas, acrecienta los recelos de falta y encarece los precios.

Por lo mismo, antes que el gobierno emplee su autoridad y fuerzas en el manejo de trigo, debe consiclerar si el interés del comercio sólo podrá remediar la carestía, y a este fín debe reflexionar si la desproporción en las necesidades se balancea con otra desproporción semejante en los recursos; esto es, si en las Provincias inmediatas hay abundancia de trigo con que fácilmente se pueda socorrer la nuestra, o si allí se padece igual carestía.

En este caso, es menester ampliar el comercio, porque el trigo transportado de una provincia a otra, viene'a ser como extranjero para la provincia que no lo produjo; y por lo mismo de que no le hubiera tenido sin el concurso de los comerciantes, conviene protejerlos, una vez que, cuanto mayor sea el número de las manos entre quienes estuviere repartido el trigo, tanto más pronto será nuestro socorro, y a esta proporción será tanto más favorable y útil a la concurrencia que resulte para los consumidores.

Por todas estas graves consideraciones políticas, permitió absolutamente la compra y venta libre de los granos en todo el interior del 
Reino, la ley 15 , título 25 clel libro $5^{\circ}$ de Castilla, extendiendo amplia facultad a los comerciantes, no solamente para transportarlos de unas provincias a otras, almacenarlos y entrojarlos donde mejor les conviniese, sino también para extraerlos e introducirlos de fuera del Reino.

Pero atendiendo a muchos casos de carestía y a los fraudes de los monopolistas, se previene el hugar y forma de los almacenajes, con el fin de recurlir con seguridad a los comerciantes, para que del trigo acopiado se hagan repuestos para el abasto público, pagando su coste y los portes a los precios corrientes o por ajustes voluntarios, $y$ a estas medidas arreglar el precio del pan cocido para surtimiento de los pueblos.

Como para tales urgencias sería preciso sacar dinero de la Caja de Propios, debería observarse también lo «ispuesto por las leyes, ${ }^{5}$ sobre libramientos contra la Real Hacienda, en las ocasiones ejecutivas e indispensables en que no se puede aguardar resolución superior, sin daño irreparable; esto es, que el Intendente podría echar mano por lo pronto de toda la plata que necesitase, $y$ despues dar cuenta con justificación a la Junta Superior. "

Si bien cit por lo respectivo a Potosi, consideramos muy irregtilar el caso cn cue sea menester tomarse por la Intendencia tales providencias; lo primero, porque con la prohibición promulgada en el artículo 6 de la ley 15 , título 25 , libro $5^{\circ}$ de Castilia, para que con ningún pretexto se puedan establecer colradias, gremios o compañas en el comercio de trigo, quedan excluídos todos los monopolistas, y consiguientemente, la misma libertà de trajín de granos, dirigirá a tiempo oportuno una circulación rápida $y$ bien ordenada a este comestiblé, para surtir los pueblos necesitados, sin necesidad de repuestos. Lo segundo, porque cuando llegara a suceder que escaseasen los trigos en los Partidos de Porco y Chayanta, donde recogen las mayores cosechas, tendríamos un pronto recurso en la pinguísima provincia de Cochabamba, nuestra confinante; y como entonces se vendría a balancear nuestras necesidades con la proporción en los recursos, no debería afligirse el Gobierno para intervenir por sî en la administración de los granos; antes bien, con ocultar sus cuidados y proteger con inteligencia la circulación del trigo, conseguirá en breve un copioso surtimionto.

Por todas estas contingencias, se debe cuidar con prudencia que la extracción libre de granos de la Provincia, no sea dañosa a sus habitantes, ya ocasionando un vacío efectivo, o tamblén porque llegue a privarnos de un supexflto absolutamente necesario para mantener el equilibrio tan importante entre las fuerzas desiguáles de los consumidores y vendedores de este comestible.

En la Provincia de Potosí, es muy dificultoso este cáléulo, respecto de ser absolutamente inciertos todos los principios por donde se debe guardar la relación que tiene la masa del trigo existente en la Provincia, con las necesidades de sus habitantes; porque cuando se legase a conocer con evidencia, la población por los padrones y las cantidades de trigo de cada cosecha, por relaciones juramentadas de los arrendadores de Diezmos, no es posible formar un juicio seguro sobre la produeción ni consumo, ni calcular el vacío o el superfluo del comestible.

Véanse aquí aclaradas estas proposiciones, por los siguientes discursos. La producción de cada Provincia no se entiende precisamente por el rendimiento regular de sus respectivas cosechas, sino por aquella can- 
tidad de subsistencias que el pais puede producir; ten este sentido no hay duda que nuestras producciones pueden exceder infinitamente a la pobla ción, atendiendo a los inmensos baldios que hay por desmontar en cada uno de los cinco Partidos de esta Intendencia. En cuyo cotejo se advierte tan grande desigualdad, que al paso de igualar a la extensión de toda España el territorio de cada Partido, no llegan todos juntos a la vigésima parte de la población de aquel reino.

Por otra parte, el mayor número de indios habitantes en la campaña, no come pan y suple este alimento con f'utas, legumbres y cebada; y aunque de ostas especies es tan poco to que consumen, que un espanol apenas podria vivir al día con lo que el indio se alimenta en dos; pero no debe admirarse esta frugalidad, porque es una resulta necesaria de las borracheras de la chicha y de los ayunos en que tiencm habituado su estómago desde la niñez, como efecto de la miseria cn que nacen, se crían $\mathrm{y}$ viven hasta morir.

El método de vida es un tropiezo muy grande para el Magistrado de la Policía, porque nunca pucde conocer la relación del consumo con la población; y así, por más seguro que se halle en el número de los habitantes, no podrá calcular las subsistencias, porque entre los indios la población no es medida del consumo. Consiguientemente, no pod̀á formar juicio seguro, ni aún probable al vacío o superfluo del trigo, aunque sepa de cierto las cantidades cosechadas en la Provincia.

Si con el recelo de escasez, al parecer bien fundado en las incertidumbres de esta materia, se qujele poner límites a la extracción de granos fuera de la Provincia, se seguiría condenar a los españoles hacendados algo considerables, a grandes privaciones; porque no pudiendo sacar a otras partes de más consumo su trigo superfluo, para darlo cn cambio de dinero o de otros bienes que producen las comarcas inmediatas, era forzosó que este obstáculo sirviese de un desaliento muy notable para la agricultura.

$\mathrm{Ni}$ por esto se avanzaría a la abundancia, porque con desanimar a los hacendados ricos, con la pérdida del superfluo de sus cosechas, nunca llegarian a conformarse los demás pobladores indios, faltándoles a todos por igual los incentivos del cultivo. Es decir, que en nuestros pucblos no hay telares, artes, manufacturas ni otros establecimientos de industria que pueden lisonjear el gusto a los hacendados o dueños del trigo; faltando estos objetos agradables, en que puedan cambiar los frutos sobrantes, que les son inútiles, no queda motivo en qué fundar las esperanzas del trabajo y es preciso que desfallezca la actividad del cultivo.

Véase pues, cómo no se iba a adelantar cosa alguna por impedir la venta de los trigos para fuera de la Provincia; y también que con cuantas providencias se expidiesen a este tin, nunca se podrá deducir un cálculo probable entre el superfluo necesario y el superfluo sobrante.

En medio de esta obscuridad y de la precisión de no descansar el Gobierno sobre el cuidado ambicioso de los comerciantes, no queda otro remedio que, según las circunstancias generales de la Provincia, aforar los precios del trigo para las estaciones del otoño, del invierno y primavera. " De suerte que, no llegando el trigo a tal precio, según los tiempos, se permita extraer, y se prohiba luego que suba a la tasa del aforo.

Para esto se requiere mucha prudencia y grandes inteligencias en materia de granos; y como así siempre se gobierna según la calidad de 
las circunstancias, no se puede dar advertencia sino sobre dos cosas: ia primera, que el precio do los trigos debe ser libre de tasa parą todos los hacendados, conforme a la ley real; la segunda, que el aforo sólo debe servir para arreglar el precio del pan cocido que vendieren los panaderos.

Sobre este último punto, también debe prevenirse que aunque entre los políticos se duda qué es lo que será más ventajoso, sujetar el peso al precio o el precio al peso, esto es, cual de los dos convendrá variar en el caso de estar el trigo más o menos barato pero que por efecto de una larga $y$ acreditada experiencia, se ha adoptado en toda Europa, fijar el precio y variar el peso, según las circunstancias del tiempo.

Pascmos ahora a las demás semillas, legumbres y vituallas, de que también es preciso proveer a los pueblos. Estos abastos y mantenimientos se pueden considerar en dos maneras: unos, traídos de los reinos de España a las Indias, o por los mismos indios cosecheros y labradores a las ciudades y pueblos de la propia Provincia del Distrito; otros, los que han comprado a las primeras manos los regatones ordinarios, para revenderlos.

Los mantenimientos de la primera clase se pueden vender por mayor o por menor de primera venta, a como los dueños quisieren y pudieren, sin ponel'se precio ni tasa a ellos, y sin prolibición de sacarlos libremente, de unas partes a otras, no habiendo necesidad en los pueblos donde primero Ilegaren, como expresamente lo resuelven la ley 6 , título 18 , libro $4^{*}$, y la ley 70 , título 46 , libro 9 de Indias.

Por estas mismas leyes se declara que la tasa sólo debe ponerse a los regatores que compran cosas de comer y beber, para revender; de suertc que estando al teno: de estas providencias, no se puede poner tasa ni precio a los bastimentos o mercaderías que se trajesen de España a Potosí, ni tampoco a los mantenimientos que introducen los indios, para que asi acudan de su voluntad $\mathrm{y}$ haya abundancia de todo lo necesario, según lo dispuesto en la ley 10, título 10, libro 6 de nuestra Recopilación.

Pero el trabajo es que, por no haber Alhóndiga ni otro lugar público señalado para vender los abastos, se han establecido en Potosí unos hombres titulados "cancheros", que a trueque de anticipar al indio algunos socorxos para cl pago de sus tributos, o porque les fían lo que necesitan, se han apoderado con tanto despotismo del arbitrio de estos infelices, que los cancheros son los dueños de cuanto bastimento recogen aquellos en sus cosechas. Ellos pagan al indio el precio que les acomoda y después les dan la ley en la reventa, subiendo los precios a más de un 25 o $50 \%$.

Estos son verdaderos regatones, a quienes se les debe poner una tasa inviolable, con consideración al costo de los bastimentos, de suerte que les quede una ganancia modesta, libertando al público de las subidas excesivas con que lo oprimen.

La postura y tasa de los alimentos que revenden los regatones, estuvo encargada a la justicia de cada ciudad, con un Regidor que nombrase el Cabildo, por una Cédula antigua de 1535 , recopilada en la ley 22 , título 9, libro $4^{\circ}$ de Indias; despućs se reformó este método, por causa de los muchos fraudes que los Alcaldes ordinarios y Regidores cometían en perjuicio de la república, poniendo excesivos precios a los mantenimientos, que vendían ellos mismos o sus deudos, que regularmente tenían chacras en los contornos de los pueblos; y se despacharon dos Reales 
Cédulas, de que hace mención Escalona, ${ }^{8}$ dirigidos a los Excmos. Señores Virreyes, Don García de Mendoza y Marqués de Guadalcázar, para que pudiesen remitir a los Alcaldes del Crimen, las causas de los abastos del pueblo.

La Cédula de 1621, cometida al Excmo. Marqués de Guadalcázar, se recopiló después en la ley 27, título 17, libro 2" Ge Indias; y por lo que hace a otras ciudades donde no residen los Señores Virreyes y Audiencias, se despachó otra Cédula en 1573, recopiladia en la ley 11, título 3 , libro 5 , inhibiendo enteramente a los Alcaldes ordinarios, para que nunca se entrometan en posturas de mantenimientos ni otras materias de Gobierno, y cometió este encargo al Gobernador o Corregidor de las ciudades con los fieles ejecutores.

Posteriormente, otra Cédula de 1633, recopilada en la ley 6 citada, del título 18, libro $4^{\circ}$ de Indias, se mandó tasar los precios, como mejor pareciere a los Gobernadores o Justicias. Pero esto no debe entenderse como facultad concedida acumulativamente a los Gobernadores con las Justicias, para que unos u otros puedan poner posturas a los bastimentos, a prevención, sino únicamente para que, donde no hubiere Gobernador, se tasen los alimentos por las Justicias; es decix, que los Alcaldes no pueden conocer de abastos, a menos que no resida Gobernador en aquel pueblo o ciudad donde ellos ejercen jurisdicción.

Esta interpretación se deduce claramente del contexto uniforme de las citadas leyes del Reino, y es conforme a lo que siente Ramiro Valenzuela, ${ }^{9}$ en la explicación de la ley 20 , título 3 , libro $5^{\circ}$ de la Recopilación, donde sin embargo de concederse en ella jurisdicción civil y criminal a los Alcaldes ordinarios, para proceder el un compañero contra el otro, opina que ésto solamente puede tener lugai donde no hay Gobernador; porque donde lo hubiere debe ser el Juez en lo civil, así como la Real Audiencia puede conocer en lo criminal o en plcitos muy graves, por la ley 71 , título 15 , libro $2^{\circ}$ de Indias.

En Potosí no se observa la disposición de estas leyes. No sólo los Alcaldes, también el Cabildo mismo, se mezcla en causas del abasto, y de ahí viene el poco arreglo en los precius de los mantenimientos. Si el Gobernador únicamente interviniese con cl Fiel Exactor, habría en esta materia menos confusiones, y como no tiene interés alguno en los mantenimientos, se haría su tasa con más equidad.

Y no que ahora, es tan grande el abuso de los cancheros, que comprando ellos al indio cada dorado a seis pesos, y tal vez a menos, y el par de sábalos a real, con el pretexto de surtir a precios acomodados las casas de los Jueces, revenden después el dorado hasta doce y veinticinco pesos y cada sábalo a real y medio hasta tres reales.

Cuando el pobre indio se resiste, lo amenazan con que darán parte a los Pajes o Alguaciles de los Jueces, para que vengan por el pescado, asustándolos con que les quitarán por la mitad menos de lo que ellos (los cancheros) pagan. Otras veces pretextan la autoridad de los mismos Jueces, y suponiendo falsamente tener encargo de ellos, se apoderan de las mejores piezas, para revender de su cuenta a precios tan subidos, que después de sacar el costo se regalan con rico pescado del que les queda libre.

Lo peor es que muchos de estos monopolistas avarientos, guardan el pescado fresco, hasta que se consuman las porciones que han entrado 
de este género, para rlar la ley en su reventa, y cuando tratan su despacho, muchas veces ya está podrido o corrompido el pescado; pero, es tal la manía de cstas gentes en comer pescado fresco, que no reparan en el mal olor, cuando hay escasez; porque entonces tíenen la mayor gala en poner un dorado a la mesa, convidan a los amigos, se festeja el buen bocado y se celebra la generosidad del convidador.

De esto procede que al fin del invierno, en que se acaba la pesca en los rios, stielen traer unos sábalos medio corrompidos $\mathrm{y}$ aparejados con remojos falsificados para disimular este vicio; pero como por la mania del lugar numca faitan compradores, son muchos los que enferman de esquilencia, de anginas y de otros achaques que, generalmente, he oido atribuíl al pescado. $Y$ es opinión general, que aunque no se reconozea corrupción, vicne por sí mismo enfermizo el pescado de cierta peste que padece en aquella estación del año; lo cual no es difícil de creerse, cuando se acredita por la experiencia que los ganados y demás animales tienen sus enfermedades características, de que padecen muchos.

En la volatería se nota el mismo desorden, y lo mismo he visto entre el hueso $y$ carne de la pechuga, a tiempo de trinchar ave, un enjambre de gusanitos muy pequeños que siempre acompañan la corrupción. Esto no puede menos de ser muy nocivo y requiere gran vigilancia para que no se contagie la salud publica.

Consiste en que la volatería que no se consume en un día la guardan para el otro, $y$ así continúan en los siguientes. Es difícil reconocer su estado, porque las ventas se hacen por los cancheros, que siendo varios $\mathrm{y}$ habitando en barrios tan distantes, no es posible velar sobre la conducta de todos.

Por esta causa convendria que al menos el pescado y la volatería se vendiesen en la Plaza o en otro lugar público que el Gobierno señalare, con acuerdo del Cabildo, para que el Fiel exactor pueda reconocer y tasar estas especies, sin agravio de los dueños y sin perjuicio de los consumidores, publicándose por bando, que los indios cumplen con acudir a las Plazas y mercados, donde todos puedan comprar lo que fuere su voluntad y que no tienen obligación alguna de llevar a las posadas de los Ministros de Justicia ningún gémero de comestible, porque cumplen con venderlo públicamente, según lo resuelto en la ley 12 , título 10 , Lib. $6^{\circ}$ de Indias.

De este modo se cortarán los grandes abusos que se han inveterado en esta Villa, los indios recobrarán su libertad y el público disfrutará los beneficios de que ahora carece.

Párrafo segundo. - oficios $\begin{aligned} & \text { Aunque la jurisdicción de la Policía se } \\ & \text { Mecánicos. }\end{aligned}$
$\begin{aligned} & \text { extiende en Potosí sobre todos los oficios me- } \\ & \text { cánicos, lo mismo que en otros reinos, no de- }\end{aligned}$ ben ser iguales los cuidados del Magistrado que tiene a su cargo este ramo, porque son en todo diferentes los abusos de tales profesiones en esta Villa. En otras partes, se hallan erigidas en cuerpos de oficios; tienen muchas prerrogativas, gozan privilegios exclusivos y tienen por su constitución mucha parte de modipodio con otros usos ridículos y ceremonias frivolas, que más de una rez han sido objeto de reforma para el Gobierno.

Las funciones ruictosas de sus cofradías, las contiendas inútiles 
con sus compañeros, los disgustos con los aprendices y el erecido costo o deterioro de las obras, suelen motivar continuas quejas que dan mucho que trabajar a la Intendencia de Policia, no meros que en avenir a los Maestros que admitan en su gremio ciudadanos que no sean notoriamente viles e infames, impidiendo el abuso que hacen de sus privilegios en estas exclusivas.

En Potosí, y generalmente en las demás partes del Rcino, casi es todo lo contrario, y a esta proporeión deben sei nuy diversas las inteligencias del Magistrado de P’olicía en esta materia.

Los sastres, zapateros, sombrereros, peluqueros, albañiles, carpinteros, cerrajeros, herreros, plateros, batidores de oro y plata, tiradores y las demás profesiones que trabajan en materias pueciosas, o para el alojamiento, vestuario y comodidad de los ciudadanos, son en Potosí más bien objeto de irrisión que de cuidado para la Economía Política.

No hay gremios que, en formca de cucrpos, procuren sus ventajas: cada uno pone tienda de zapatero, sastre u otro oficio que quiere, y donde so le antoja, sin aplobación de suficiencia ni examen de costumbres. De aquí nace que un hombre ignorante y vil, se atreve a emprender trabajos difíciles y costosos, que no entiende ni tiene ánimo do cumplir. Por ejemplo, un platero, que ha usurpado indebidamente esta opinión, toma el importe de muchas centenas de pesos en plata y oro, engañando al dueno con mil promesas de su prontitud y habilidad; regularmente se pasan dos y tres plazos sin entregar las obras, hasta que intcrviene la fucrza de la justicia. Entonces, pagan al primero con la plata del segundo, pero con tanto engaño que, deslustrándose a poco tiempo el blanco exterior do la obra, se viene a reconocer la liga excesiva de cobrc con que se ha adulterado en mucha parte la verdadera ley de la plata o del oro.

Con estos robos cubren al principio stis trampas y cultivan los abominables vicios de que están poscidos, y al cabo de considerables dilaciones a que los obliga su propia igmorancia y el descubierto en que se hallan, alzan su tienda, quebrando en crecidas cantidades de pesos.

Ya se ve, como no hay Jurados que reconozcan y aprecien las obras, ni hay cuerpo formal a quien temer su cxclusiva, van cstos tramposos con gxande contento a la cáicel, con la esperanza que después de scis o más meses de prisión, saldrán libres a continuar con ol oficio, los petardos. Generalmente, estos artesanos quebrados, cambian su trabajo en un 25 menos del jornal y con este cebo son muchísjmos los que vuelven a ocuparlos, y por consecucncia, otros tantos los que se perjudican en el nuevo alzamiento de tienda y bienes, que hacen ya con más facilidad a medida de su menor verguienza.

La conducta de los demás oficios viene ajustada al modelo de los plateros. Hay muchísimos artesanos, porque ellos mismos son los que se dan la opinión y el permiso para trabajar.

Todos ellos, (excepto uno u otro) andan descalzos, rótosos y tan indecentes que más parecen mondigos que artesanos. De ordinario, e] macstro es el todo de su oficina, porque en él sólo se encierran los of icia. les; pero como el trabajo de sus manos no le alcanza para todos los menesteres, abarca más obras que las que puede despachar, ajustando los jornales a precios bajisimos, para atraer marchantes, y a trueque de toner que gastar anticipadamente más de la mitad del valor de las obras.

Luego se distraen en el juego y en otros vicios donde consumen 
la plata; avanza el ticmpo, instan los acreedores, el artesano se esconde; pero como no trabaja y es preciso que coma, empeña por un lado algunos materiales, vende otros, y de este modo, cuando menos se piensa, queda debiendo los jomales y las obras; al cabo, va a parar en una cárcel y cata aquí un hombre perdido $y$ perjudicial a la sociedad, porque no pudiendo ya vivir sino de aquel oficio mal aprendido, continúa sus trampas por toda la Yilla.

Es tan unirersal este desorden, que se extiende generalmente a todos los artesanos, con la desgracia de convertiv en viciosos aún a aquellos que por sus principios daban muestras de ser los más honrados en su oficio, porque la mutitud de artesanos tiene reducidas las profesiones a tan cortos provechos, que todos a portía se empeñan a ganar parroquianos con la baja de precios, obligando igualmente a los que los tienen, a que trabajen tambien por menos salario.

Muchos dir estos quedan sin tener de qué vivir, aunque posean unos mismos talentos $\mathrm{y}$ hal $\mathrm{vez}$ genio más feliz, porque les es imposible trabajar en concurreucia con los que comenzaron antes que cllos y que se hallan boyantes; pues, se está viendo por la experiencia que las gentes ricas se van unas tras otras, sin saber por que, a unas mismas tiendas, y que un artesano hábil o dichoso, ejercita casi exclusivamente su oficio.

Ia tropa restante de of iciales desdichados se hallan privados enteramente de dinero, porque no ganan salario, por otra parte no tienen crédito porque les falta reputación, que siempxe consiste en el aplauso poderoso de los parroquianos. Sin dincro $y$ sin crédito, no pueden comprar las materias primeras, ni hacer acopio de las que necesitan para trabajar en sus respectivos olicios. Al verse destituídos de protección, de crédito $y$ de dinero, $y$ precisados por otxa parte a vivir de aquel oficio que aprendieron, porcue el país no proporciona otra ocupación, entonces oficcen su trabajo por la mitad menos de los salarios corrientes, para atracr la concurrencia de los pobres que necesitan obeas.

Pero, como el trabajo de toda esa semana apenas rinde el producto equivalente a la subsistencia de cuatro días, y no trabajando las fiestas, se queda aquel dia sin tencr de qué vivir, hace su recurso a las trampas y al engaño, y por este medio llegan aum los más honrados, al cabo de poco tiempo, a ser tan viciosos como los más perdidos de su oficio.

Lo más sensible es que redundan contra la sociedad los perjuicios que experimenta con su miscria csta clase de ciudadanos; porque los labradores ricos, los comerciantes $y$ los mineros que hubieran empleado mucha parte de sus caudales en obras de lujo para su magnificencia 0 comodidad, se abstienen de estos consumos, empleando el dinero fuera de la Provincia en los utensilios que necesitan; y como también faltan los objetos agradablos que presentan a la vista las artes, cuando ya han hecho sus progresos, van atesorando los comerciantes poderosos las ganancias de sus negociaciones, sin resolverse a gastar en manufacturas; al cabo de tiempo determinado, resuelven irse a otra parte a gozar de las ventajas que facilita el dinero, y como dueños de transportarle a donde les llama la felicidad, desamparan nuestra Villa y se van a los climas templados, hacia los países en que florecen las artes $y$ las ciencias o son agradables las costumbres de sus habitantes. De suerte que siendo Potosí, origen de las riquezas muebles en la producción de sus ricos metales, es el 
lugar más pobre, porque todo el dinero va siempre a depositarse en otros parajes donde se consigue mayor felicidad.

De esto procede que, entre la clase de nuestros ciudadanos no se reparten las riquezas muebles con proporción ni equidad. En otras partes, los artesanos acumulaj riquezas, bien sea en los salarios que economizan o en los valores equivalentes de las materias que ticnen acopiadas. Este progreso aumenta el comercio y multiplica la circulación interior de la masa numeraria, aumentando la folicidad de la población. Todo esto nos falta en Potosí. Si comercio, en realidad grande, sólo sirve para sacarnos el dinero, y con ser este pueblo el manantial de las riquezas del Reino, es donde se encuentra menos dinero en poder de los ciudadanos.

Pero este mismo desorden es el medio más proporcionado para arreglar los oficios. Los muchísimos artesanos que vemos en el día sin ocupación, por haber querido manejarse por sí solos, para ocultar sus trampas $y$ ahoryar los salarios de oficiales y aprendices, viendo al cabo que no tienen ya de qué vivir, tomarán otro oficio o se agruparán en oa:lidad de oficiales de otros artesanos más hábiles o más dichosos; y poco a poco se irá proporoionando el número de sastres y plateros, a los que sean necesarios; estos mismos arreglarán después los consumos a que cada uno tiene derecho y se distribuirán entre todos las riquezas acumuladas, en razón de los trabajos.

Forzosamente se ha de venir a experimentar esta dichosa revolución, siempre que dejemos libre el uso del trabajo de los artesanos, $y$ al mismo tiempo concurra la potencia soberana a mantener el buen orden con su protección, sin usar de preferencias, porque si el Gobierno inteligente del carácter nacional, escalona su espíritu y vence los funestos efectos de las costumbres perjudiciales introducidas en este pueblo; castiga la pereza y corrige con método y regla a los artesanos tramposos, sin permitir que pongan tienda pública los que no hubieren aprendido perfectamente el arte, con audiencia del Procurador de la Villa; ni los que no tuvieren los oficiales necesarios para el despacho de las obras que acumulan; se irá insensiblemente metodizando la concurrencia de los artesanos; ninguno tomaría oficio cuyos salarios no sean suficientes para vivir, $y$ por este medio se arreglará al cabo el número de los artesanos necesarios, que siendo hábiles y honrados, mantendrán el bucn orden a propósito para repartir entre sí las riquezas con que, después de subsistir, puedan acumular ahorros, para tener recurso en sus enfermedades y dotar a sus hijos, a proporción de su estado y calidad.

Es verdad, que estas riquezas nunca se podrán repartir con toda igualdad entre los artesanos, porque siempre se enriquecerá a proporción aquél que más trabajare y mejor, o el que fuere más dichoso para la concurrencia de los parroquianos; pero, además de que no podrá quejarse ninguno con justicia, respecto que cada cual ocupa un lugar, procediendo aquella desigualdad del genio más o menos raro, cada cual tendrá que mantenerse según su condición, y ninguno podrá enriquecerse mucho más que sus concurrentes, una vez que la única regla de los precios, ha de ser la concurrencia de los artesanos, según el género de obras; y aunque algunos ganarán menos y otros más, todos se contentarán con disfrutar las cosas que disfrutan en general los del mismo oficio. $\mathrm{Ni}$ es 
posible mantener un equilibijo permanente en las riquezas de un pueblo ya civilizado, porgue la concuriencia y la indusiria que promueve la competencia entio los ciudadanos, es preciso que cause un continuo balanceo de riquezas y de población, según el estaclo de revolución en que se hallare la Provincia.

Jamás será posible mantener a los ciudadanos en una perfecta igualdad, sin prohibirles toda la división y los progresos del talento; y para ésto sería necesario hacer sus bienes comunes y condenarlos a que viviesen, por la mayor parte, sin hacer nada; lo que no es posible.

En el cúmulo de estos medios, que, al parecer conducirán a nuestra población pos grados, a la felicidad, se descubre un inconveniente muy poderoso, originado del mismo carácter nacional cle estos países. Sus gentes, que mantienen hista ahora al sabor de aquella primitiva simplicidad en que se criaron. según la indole de su antiguo Gobierno, se contentan todavía con los tejiclos groseros y con los pobres alimentos de granos, legumbres y cartes de los carneros de la tiema, que se denominan llamas. sin procinar otras comodidades para sus habitaciones, que unas pequeñas cabañas, donde en una sola pieza viven los matrimonios, con los hijos; alli ducmen sobro el suelo, sin más camas que un asqueroso cuero, en compaña die los perros, entre la paja $y$ el humo de la lumbre en que se calicntan.

Tienen una mitarl menos de necesidarles que nosotros y es para ellos una fortuna el goce de aquellas cosas, que aunque llegan a disfrutarlas las naciones civilizadas, no son bastantes para salir de una miseria lastimosa.

A proporción de sus pocos menesteres, alcanzan lo bastante para mantenerse por poco que trabajen. Por esto os que no se desvelan para buscar en qué emplearse, porque con la ocupación de una cuarta parte de estos naturales, en los trabajos diarios del cultivo y de sus tejidos groseros, hay bastante para la subsistencia de todos.

$\mathrm{Ni}$ es posible ennoblecer estos genios, mientras conserven la falsa idea de ser la minería, entre todas las artos, la única acomodada para enriquecer y cuando menos para aprovechar el trabajo con más prontitud y a menos costo.

El indio ve por la experiencia que la agricultura necesita de tierras y de ganados para labrarlas, granos para sembrar, agua para el riego, fierro y madera para los arados, pastos para las bestias, trabajo y diligencia parta el cultivo, tiempo para que las sementeras nazcan, crezcan y granen, $y$ por último, fortuna para lograr las cosechas y aprovechar los frutos.

La molestia de esta penosa solicitud y la pereza congénita de los indios, les hizo mirar siempre la agricultura con horror tan grande, que en tiempo de la dominación de los Incas fue preciso obligarlos al cultivo, bajo la conducta de celadores públicos, para que tuviesen de qué vivir.

Después de la conquista, fué adelantando poco a poco el celo de la agricultura, por el interés del oro y de la plata. El cultivo de las tierras se trocó en cultivo de las minas y se hizo preciso emplear en su trabajo una gran parte de los indios. Ltiego que estos observaron el ansia con que todos corrían al rescate de los metales, sin necesidad de buscar ellos compradores, juzgaron a la minería por la más importante y la más útil 
de las artes; y desde entonces hasta ahora conservan esta errada preferencia, por más acomodada a su índole ambiciosa y lerda, por la facilidad con que en un día recogen una o dos libras de metal, que reducen a plata cfectiva con que se emborrachan y tienen un dia bueno, sin haber tenido los cuidados, los gastos y las esperas que necesita la agricultura para dar provecho al labrador.

En este estado, es forzoso que los más queden imposibilitados de mantenerse, porque no teniendo todos minas en que trabajar, tampoco tendrán ocupación. Las artes se miran con lastidio, por el desgraciado suceso de todos sus profesores y siendo las que se ejercitan muy pocas, sobre ser las más comunes y groseras, no admiten más individuos en sus gremios, porque si hubieran de trabajar todos juntos, la misma circunstancia les quitaría el provecho y al cabo los induciría a los desordenes que hemos explicado, la falta do salarios con qué poder subsistir.

Permaneciendo más poblaciones sobre este pie, nada puede aprovechar que carla uno tenga entera libertad para elegir sus ocupaciones, porque si los propietarios se mantienen, de generación en generación, habituados a unos nismos consumos, preciso es que no haya habido variación en sus gustos y que siempre se cultiven las mismas producciones, que se trabajen Ias mismas obras y que se haga la mismáa especic de comercio.

Quedando así uno mismo el uso común de las cosas, también se continuará al uso de unos mismos vestidos y utensiljos, y no habrá necesidad de und multitud de otras cosas, que en los países eivilizados han despertado la industria con su profuso conocimiento para promover las artes y dar ocupación a todos en sus progresos, facilitándoles los medios de emplearse y de subsistir trabajando.

Fuera de ésto, se halla el comereio de nuestra población limitado a sus posesiones: apenas produce su suelo los consumos necesarios para sus moradores; no se conocen en ellos los nuevos gustos, que son los que multiplican las producciones de las materias primeras $\mathrm{y}$ de las formas que reciben por las artes; y faltando de esa sueite el impulso al comercio, jamás se alienta la agricultura ni se promueve la industria.

Solamente la protección soberana del Gobiemo y su inteligencia en acalorar el espíritu nacional, puede promovei los talentos, para que inventando obras más raras y de mayor gusto, se multipliquen las necesidades de los genios delicados y tengan en ellos un nuevo fondo de artesanos. Porque si se trabaja, no es otra cosa que una acción o un encadenamiento de acciones, con el designio de sacar de ellos un beneficio, es consiguiente donde no lo hubiese, que ninguno se aplicará al trabajo y tampoco procurarán trabajadores aquellos ciudadanos que bien hallados con sus antiguos usos, no tienen necesidad de procurar otros nuevos.

Si se declara la protección del Gobiemo para las artes, habrán muchos operarios interesados en establecer en nuestros países, pasando de otras partes, donde la numerosa concurrencia de otros artistas les ha quitado el provecho. Estos mismos irán enseñando sus oficios a nuestros ciudadanos, y a poco tiempo tendríamos manufacturas a precio muy bajjo del que ahora nos cuestan, pues, a más de que las hechuras a mano de obra sería más barata por la economía general de estas gentes, tendría de menos el costo de acarreo, que hace encarecer las obras o manufacturas extrañas. 
(El Parrafo Tereno acerca de "Materiales para obras", del Manuscrilo de Potosi, no se inserto porque corresponde en toda su extension al Articulo $1^{\text {: }}$ del Purrafo tinito del Capútulo XIV de la Parte Primera de este libro, según el terto del Hanuserito del Arohivo General de Indias.- Téase págs. 275 a 285). Nota de A. Alba.

Párrafo cuarto. - Surtimientos de mercaderías para provisiones de Ios pueblos; se explica la Declaración 7 a. de la Nueva Ordenanza, y se propone un arbitrio fácil y libre de inconvenientes en su ejecución.
M ta, se esturieron manejando por si mismos nuestros indios, sin obstáculos en su libertad para adquirir lo necesario a su vida y a su estado. Otros tantos años se pasaron en estudiar su indole y promover la dicha de que fresen capaces; pero ellos se quedaron tan pobres como siempre, y al cabo de tantas generaciones, en Foz de acumular riquezas, esparcieron la miseria ell sus familias y cnvilecicron la libertad con el abatimiento de la industria y del talento.

Todo ello fue una consccuencia indispensable del carácter nacional del indio; su gcilio es frío, perezoso e indolente, y por eso sólo es capaz de recibir y commicar impresiones lentas $y$ muy medidas. No tiene sensibilidad del tiompo, se opone a prever lo futuro, y así apenas cuida del día on que vive, sin acordarse del siguiente; no tiene fuerza en su ingenio el espiritu de imitación, por faltarle fulzura y flexibilidad de las costumbres que la producen, por eso mira las felicidades y escucha las fortunas, como el gue se ve y oye hover, sin sacar el menor fruto, y por último no es capaz de exagerar el bien ni el mal, porque carece de vivacidad en el alma.

Siempre, cuando al indio se le deja andar al paso de su natural, equivoca la libertad con la ociosidad, confunde el favor con la independencia $y$ entiende que la protección de su. libertad es para vivir sosegado en la pereza, para abatirsc en la indolencia y para ocostarse en un reposo criminal, sin pensar más que en el momente que vive.

Era menester que el indio abriera los ojos y saliera de sí mismo a reflexionar las relaciones de su estado con la felicidad de la sociedad, para que pudiera hacer: uso noble y provechoso de su libertad. Pero aun no ha llegado oste feliz período.

En este estado miserabie, en que apenas podían granjear con su trabajo, Jo preciso para subsistir el día en que viven, no era posible adquirir por sí todos los menesteres que influyen al adelantamiento de la industria, porque la libertad absoluta de comerciar dónde y con quién le acomode, para subsistir de todo lo que necesiten, de nada podía aprovecharles, no teniende con qué comprar ni qué vender.

Por esto, aquella libertad indefinida, sin propiedad de qué poder disponer, venía a ser una dicha para el indio sólo en un concepto abstracto $y$ era un bien puramente imaginario, parecido a las felicidades platónicas; y muy distante de serle iitil según las combinaciones de sus costumbres, ella misma llevaba tras de sí la esclavitud y lo arrastraba a la miseria, como slicede en todas las naciones bárbaras y salvajes, que siendo las más libres, son también las más miserables, porque no tienen qué vestir ni aun qué comer. 
En efecto, parecia ser una constitución fantástica, la que toleraba semejante abuso de la libertad, pues la franqueza de ella, era más bien una verdadera esclavitud que impedía la felicidad de la nuchedumbre, después de destruir al particular; no podía reputarse saludable una libertad que se oponía al bien general.

Ya se hizo indispensable entrar en la pretensión de fijar los gra. dos de la libertad individual de nuestros indios, para remediar el abuso que la hacia dañosa; pero al mismo tiempo se temía el riesgo que los obstáculos puestos para contener el capricho insensato de una libertad indefinida, sirviesen como de agentes para que los poderosos mejorasen su suerte, a costa del infeliz indio.

Los Corregidores, en medio de las estrechas prohibiciones con que se proseribieron desde el principio Ios excesos de la avaricia, no eran los que menos oprimian la libertad del indio, mucho antes de tener límites. Ellos ejercían negociaciones, tratos y contratos en los pueblos de su mando, contra las leyes prohibitivas, 10 y fortificando cada vez más las prerrogativas de su poder abusivo, consiguieron someter a su arbitrio la disposición de todos los bienes y felicidades del indio, o más bien, la de su miseria; pues, pagándoles el trabajo lo menos que era posible, les vendían los vestidos, los comestibles y Ios materiales, lo más caro que podían, hasta reducirlos a lo puramente necesario para quo vivieson menesterosos siempre de su favor.

Estos excesos de avaricia causaron al cabo un escándalo general, que exitó en nuestro Gobierno los cuidados más enérgicos de su remedio; pero era difícil descubrir entre las tinieblas de aquellos siglos la luz de un sistema feliz en sus combinaciones, capaz de destruír la avaricia y de ennoblecer la economía, sin perjuicio de la libertad.

El indio era considerado enemigo de su propia dicha, por la indolencia de su genio frío $y$ perezoso. El Corregidor era mirado como un agente activo de su interés, para hacer valer su autovidad, sin atender proporciones con el bien o el perjuicio general. Era imposible exaltar el espíritu abatido del indjo, sin ennoblecer su naturaleza; y no se alcanzaba arbitrio para destruír la avaricia sin destruír los Corregimientos, que era una empresa muy superior al siglo pasado.

Entonces se ideó corregir el vicio inventando los repartos, como remedio para contener la avaricia de los Corregidores en sus antiguas negociaciones clandestinas y delincuentes; y al mismo tiempo levantar al indio del reposo criminal de su pereza, con la necesidad de pagar los avíos.

Se permitió a los Corregidores la negociación que antes se les había prohibido, para que haciendo convemencia del delito, olvidasen la primera avaricia, que era más peligrosa como más secreta, por otra avaricia permitida sobre ciertos límites, que también eran los grados que se fijaban a la anterior libertad indefinida del indio, para que le fuese saludable.

Las especulaciones que se indicó en la teórica de este plan, se consideraron en su origen las más conformes con el interés nacional del indio. Pero, ya sea por la superioridad de los Corregidores en el mando y en la razón, ya por la desigualdad de los indios en su rudeza y abatimiento, redundó a breve tiempo la avaricia y vició los mismos medios con que se intentó establecer la economía. 
El Corregidor había de ser el Juez y la parte, el vendedor y el árbitro, por último, el superior y el igual; y como miraba fácil el imponer la ley al miserable, transtornó luego las leyes que se dictaron para la felikidad de los indios; convirtió en avaricia la economía; esclavizó la libertad con cl abuso de su remedio; esparció el desprecio universaĺ del conercio, con lo que había de envilecer el monopolio; tiranizó al indio, oprimiéndolo con lo que sólo se inventó para domar la vileza de su ánimo; y en fin, hizo senda para el monopolio, del camino que se abrió para alentar el comercio.

Aun las cosas más pcrfectas suelen viciarse, conforme se alejan de su principio, y cuando menos, según se van envejeciendo con el tiempo, al cabo llegan a cicrto período de donde comienzan a decaer. Así era forzoso que estos defcctos más rápidos y más urgentes, cn un establecimiento fundado en su principio sobre el vicio, y que por la dificultad de sus combinaciones, embarazó que se formase una idea justa y verdadera de todos los abusos que traería consigo después de algunos años.

Según sc fueron complicando los excesos, ya se comenzó a oír la voz de la multitud en la angustia, y fue preciso estudiar de nuevo las aflicciones para cvitar los funestos efectos de los consejos perniciosos de la miseria, a que suelen cedel fácilmente (aunque en secreto) los hombres impacientes de su infortumio.

Para conformarse nuestio Gobierno con la opinión pública contra los reparos, observó con sabiduría por mucho tiempo el impulso de su indignación y de sus resentimientos; pues, aunque el pueblo suele producir al principio, según las especulaciones de su interés, unos sentimientos razonables, de ellos mismos nacen después unos sentimientos injustos, que equivocando la verdadera fortuna, lo arrojaron más allá de los límites con la vehemencia de las exageraciones, excediendo el efecto a los deseos.

Conocio, dosde luego, que por medio de los repartos se promovían los nobles efectos de la industria y labranza; pero considerando también que en sostcnerlos iba a mantener en la opinión pública el concepto de la avaricia.

Así pues, para borrar la excesiva ojeriza de los indios contra estos antiguos obstáculos de su libertad, ideó nuestro sabio Ministro el ventajoso sistena de Intendencias, aniquilando hasta la memoria de los repartos y de los Corregidores, con proscribir su nombre, porque como el indio nacido en el abatimiento, criado en la obediencia y hostigado del dilatado espectáculo de su servidumbre al imperio de los Corregidores, había hecho un agradable encanto para sus primeros sentimientos, de sólo el nombre de libertad; era forzoso que le pareciese que óa de nuevo sus cadenas, al oír el nombre de repartos y de Corregidores, aun después de proscrito su gobierno.

Sin embargo, atendiendo nuestro Gobierno que en algunos pueblos, por su miseria, podría ser tal vez inútil el singular beneficio de la libertad para el deseado fomento de la industria y la labranza, se propuso precaver estos inconvenientes, resolviendo por declaración $7^{\mathrm{s}}$ de la Nueva Ordenanza, que de cuenta de la Real Hacienda, se avíe a los naturales, del hierro, aperos, mulas $y$ otros utltiles necesarios a su industria y labranza, hasta que ellos puedan comprar por sí mismos, y proveerse de lo que necesiten para sus respectivas ocupaciones $y$ tener de 
qué subsistir y alimentar a sus familias; pero, al mismo tiempo ordenó, que nunca y por ningún caso se diese el nombre de repartimientos a las expresadas anticipaciones, sino precisamente el nombre propio de socorros, sin duda por ser el más honroso y agradable a la humanidad.

Esta sabia providencia que ha dictado el piadoso corazón del Rey, en testimonio de su real generosidar, al paso que es la más bienhechora y admirable en toda nuestra legislación, tanubién es la más digna do meditación en sus efectos; porque, si no se contienen sus nobles ideas en los justos limites que preseribe la citada declavación do muestra Nueva Ordenanza, en lugar del bien, causaria el mal y a la rexdad se substituirá el error. Es preciso, pues, someterlas a todas las combinaciones económicas, para que la exagcración no engañe a la prudencia; y en el examen do estas modificaciones es donde se ha detenido la mano ejecutora, porque ciertamente, el socorrer a otro sin necesidad. seria hacerlo necesitado por violencia, y no robarle a la libertad sus progresos en vez do excitar la Industria. Al principio no se pudieron notar suficientes las relaciones y necesidades de estos pueblos. Fil tiempo ha nultiplicado los objetos de nuestras observaciones y ya es preciso explicar estos nuevos descubrimientos. .

Desde el año pasado de 1780 , se ha visto por la experiencia, que los indios han subsistido y alimentado sus familias, con especialidarl los de Charcas, Potosí, La Paz y Puno, sin haber solicitado ser habilitados como antes por ajena mano.

Sabemos también que los pucblos de las Provincias del Paraguay, del Tucumán y Salta y del reino de Santa Fe, nunca han estado sometidos a la ley de los repartos; pero torlos han subsistido, floreciendo mlichos de ellos en la industria $y$ en la labranza, principalmente los que tuvieron a su cargo los ex-Jcsuítas, con el nombre de Misiones del Paraguay.

No parece necesaria más prueba para persuadir gue nuestros indios han hallado en su libertad un encanto, a más de agradable, provcchoso y que viven contentos en haber salido de su antiguo odioso pupilaje, para buscar por sí mismos las ocupaciones más luerativas, cuando autes era todo su patrimonio la esclavitud y la miseria

Los mismos hechos son la exageración más enérgica de que nuestros pueblos no necesitan ser socorridos par'a poder vivir, pues, habiéndose manejado por $\$$ í mismos desde el año de 1780 , obrando y resistiendo a los obstáculos de su libertad y de su fortuna, el mismo tiempo irá fortificando este impulso, pala defender las prerrogativas $y$ los nobles derechos de la libertad, que es el alma, el manantial y el origen de las riquezas y de la felicidad. Y conforme fueren conociendo que la compasión por ellos mismos sirvió para hacer valer el interés de los Corregidores, afligirán por instantes su imaginación con la desdicha pasada, para procurar por si mismos su pan y su vestido.

Verdaderamente, no se reconoció hasta el año di 1785 , que tuviesen necesidad de scr socorridos los naturales de estas provincias; antes bien, se creyó todo lo contrario, por las numerosas partidas de mulas que se internaron al Perú; pues, si los indios no hubieran tenido medios ni proporciones para comprarlas, se hubiera suspendido necesariamente su comcrcio por falta de expediente.

Ello fue ast, pero no por efecto ni consecuencia do la libertad de los indios, sino más bien de otras causas exturaña e imprevistas, que ha- 
biendo resultado de las circunstancias irregutictes del tiempo ya no existen en el día.

Con las revoluciones del año 1780 , se indultaron las Provincias de pagar las erecidas cantidades que anteriormente se les había repartido en mulas y otros aperos útiles, además de los grandes caudales que aprovecharon en sus diligentes mpresas, asi en efectos como en dinero.

El acopio de todas ustas riquezas fue un manantial de donde se aviaron los indios de todo lo necesario en aquellos primeros años, con cuyo atractivo se apresuraban los troperos de mulas y otros habilitadores a internar sus mereaderias en las Provincias del Perún.

Después aca, se ha ido disminuyendo al comercio con los naturales, por los mismos grados que han escaseado sus facultades. Ellos, abandonados como siempre a la pereza, no han sabido aprovecharse de los fomentos que les concedió el piadoso corazón del Rey, relevándolos de pagar los repartos, ni del benelicio que sacaron de la desdicha ajena.

Mientras poseían las riquezas que acumularon los accidentes del tiempo, se apresuraron al consumirlas en el cambio de sus menesteres; pero sin pellexion ni inteligencia, porcue no era fruto de su trabajo ni de su industria; y a pocos años, hen llegado ya a las puertas de sus antiguas miscrias, sin hallar en la libertad todo el recurso que esperaban, por faltarles propiedad de qué poder disponer. Y véase cómo ąuellos intervalos de felicidad, sólo han servido para convencer la poca aptitud del indio para manejarse por sí mismo.

La escasez de maderas y de otros frutos del país, que se conducen en mulas, y el flete exorbitante de dieciocho a veinte pesos a que han subido ahora los acarreos de Jujuy, desde doce pesos en que antes corrían, son la mejor prueba de haber recaído estas Provincias en su primitiva pobreza; pues, si tuvicran posibilidad para comprar mulas, se experimentaría en los trajines un mismo expediente y no hubieran encarecido los fletes, que sicmpre suben cuando baja la concurrencia de mulas.

En comprobante de esta notable disminución, son bien sabidos los ejemplares de varios troperos, que habiendo internado mulas a este Virreinato $\mathrm{y}$ al de Lima, han tenido que devolverlas a los potreros y dehesas de Salta y Tueumán, con muchas quiebras, por no haberlas podido vender en los pueblos de indios; y más de una vez ha sido menester usar de medios extraordinarios para conducir azogiles y tabacos, por falta de mulas, como nadie lo ignora.

Si algunos troperos tienen la fortuna de hallar despacho de sus mulas, no es porque los indios se las compran, sino porque reparten $\mathrm{m}$ tre los españoles y mestizos de la Provincia, las más de ellas al fiado; estos mismos suelen fiarlas a tal cual indio horrado, en precios muy sibidos, para que se emplee en la arriería, y este es el único medio por donde los indios afortunados vienen a principiar el negocio de mulas.

Además de la evidencia de los hechos, ellos están contestados por los mismos Jueces de los Partidos, atribilyendo todas estas lastimosas resultas a la falta de suministros en nuestros pueblos.

I a misma razón también lo persuude; porque si el indio ha de subsistir únicamente de su jornal, y íste, por lo regular, es el más pequeño, por el cmpeño ome tienen los propictarios sobre él, es consiguiente que su trabajo sea una medida muy escasa de su subsistencia, y que no pudiendo ahorrar ninguna parte del salario, vivirá siempre abutido en la 
miseria, sin tener con qué comprar los apcros necesarios para su labranza, y como también carece de crédito para que debajo de su firma se los confien, viene a quedar inútil la libertad que se le la concedido para comerciar por sí mismo.

Confiar al tiempo el remedio de la miseria, es un recurso domasiado incierto y contingente, $y$ es de temer cule en vez de mejorar mestros pueblos, los arxastrará a su ruina.

El mismo tiempo nos ha dictado este sabio documento, pues, no habiendo podido subsistir los indios por sí mismos con la libertad absoluta que gozaron por más de dos siglos, antes del establecimiento de los repartos, no encuentro fundamento para juzgar que esta libertad de ahora sea para el indio más feliz, no habiendo muclado do cauicter ni él, ni el tiempo, ni la fortuna, si bien contemplo más juicioso el dictámen contrario, por los mismos efoctus que se van experimentando en el corto tiempo de siete años.

$\mathrm{Ni}$ pucde persuadir lo contrario el ejemplo de los indios del Paraguay y del reino de Santa $F e$, pues, annue Ios primeros nunca estuvieron sometidos a la ley de los repartos, han disfítado y disfrutan siem. pre los socorros proporcionados y copiosos del fondo pinguie de bienes de Comunidad, que poseen aquellos pueblos en mayor abundancia que nuestras ciudades de españoles; y así, todos los naturalos de la Provincia y Misiones del Paraguay, hatlan el cleseado fomento de su industria y labranza, en los socorros que le facilitan sus mismas Comunidades.

Los otros del reino de Santa $F e$, están más civilizados, conocen mejor las relaciones de su trabajo con su subsistencia y tienen más establecimientos de industria en qué ocuparse para no ser miserables. Porque allí adquieren las riquezas y las esparcen entre sí por el esfuerzo de los mismos talentos ayudados de las nocesidades ajenas.

Por el contrario, en nuestros pueblos no hay establecimiento de industria en qué poder ocuparse sus naturales. Muchos de ellos se quedan sin empleo, porque no todos tiehen tierras para la labranza, que es su única ocupación; pero como estos miserables cultivan por sí mismos para sustentar su familia con el fruto que sacan, y otros para cl hacendado rico, por un escasísimo salario, apenas ganan el pan para recompensa, y aunque vivan hoy, los aflige la misma desdicha de que es menestex trabajar para mantenerse mañana. De suerte que el único interés de la clase más numerosa de estos infolices, que nacieron sin bienes de fortuna, es sustentarse ganando con sus servicios una moderada parte de lo supérfluo del rico o de las producciones de la tierra, viendo renacer para ellos algún día el propio temor de vivir hoy y trabajar para mañana.

No pueden, aunque quieran, empeñarse a grandes cultivos, porque ni tienen cómo hacer los grandes desembolsos que requieren estas empresas, ni poseen tierras equivalentes, ni es capaz una mano sola de romper más tierra que la precisa para alimentarse.

Obligados siempre estos infelices a combatir su miseria, tienen de sí toda la timidez que da la experiencia para no elevar su espiritu a las meditaciones de una felicidad que miran como imposible. Fsta aflicción hace más perezosas sus manos, para procurar solamente una manutención más escasa de lo regular.

Tampoco tienen el sentido de las artes para exitarse a mayor cul- 
tivo, con la esperanza de cambiar los frutos por objetos agradables, $\mathrm{x}$ siempre se quedan en estado de necesidad, sin tener cosa que repartir entre la multitud, ni sobrantes con qué hacer cambios considerables para dar impulso al comercio.

Todas estas Provincias son solamente agrícolas, que nada pueden comprar sino en razón de su sobrante. Bien es que tenga cada particular la libertad de disponer de sus bienes como le pareciere; pero no teniendo más que lo preciso para su consumo, sería nccesario que diese en cambio de lo que comprare los frutos que necesita para alimentarse; y así vendrían a quedar sin los mantenimientos sulicientes.

Por esto se ha disminuido el comercio en los pueblos de los indios, de tal manera que vendiéndose antes en toda esta Intendencia más de 160.000 pesos al año, en tiempos que los precios cran los más subidos por la guerra, apenas llega el consumo actual a 70.000 pesos, en medio de la increíble redundancia del comercio europeo y de la exorbitante baja de los precios.

Esta es una resulta forzosa de la poca posibilidad de los indios; porque si el comercio turiera en sus pueblos algún atractivo, veríamos a los mercaderes hacer sus expediciones por el interés de los cambios y de las permutas. Pero sólo se ve que los capitales y demás establecimientos de los españoles son los que tienen surtimientos, sin embargo de su poco despacho.

La nisma naturaleza del paîs y de sus habitadores ha añadido otros muchos obstáculos al comercio, y estos mismos apartan o a lo menos dísminuyen el beneficio de la libertad. Todos nuestros pueblos se hallan situados en serianías estériles; sus caminos son los más molestos y peligrosos; por todas partes se descubren precjpicios; los ríos se multiplican al número de las quebradas y ninguno de ellos es útil para la navegación. Son determinadas las tierras capaces de cultivo; de suerte que en un inmenso desierto, apenas suele encontrarse la longitud de una quebrada que rompió algún río, para poder sembrar en sus orillas.

Los indios nccesitados a vivir de su escasa labranza, se esparcen por toda la extensión de las quebradas, donde viven embratecidos, sin sensibilidad de la miseria y sin inteligencia de la felicidad. Por todo el año apenas salen alguna u otra vez de aquel recinto, para visitar su Parroquia. Nada ven que despierte sus miras, y reposando en su pobreza, se olvidan de procurar otra fortuna más agradable.

Recogen las pobres cosechas en sus asquerosas cabañas y las van consumiendo poco a poco, hasta que llega el tiempo de renovar los sembrados.

En este géncro de vida, ni son capaces de hacer observaciones de lo que les falta ni de procurarlo en otra parte; $y$ aun cuando lo quisieran hacer, no tienen con qué, ni pueden transportar algún corto sobrante de los frutos, porque en los fletes de la bestia, en su manutención y en las demoras de unos caminos tan ásperos crecerían los costos de acarreo al duplo del valor de aquel empleo.

Estos mismos inconvenientes embarazan las expediciones del comercio, porque el comerciante no podría dar despacho a sus géneros (aunque tuvieran consumo), sin hacer unas peregrinaciones penosas de pueblo en pueblo y por todos los huaycos, ** recorriendo las cabañas en busca de compradores. Después sería menester aguardar el tiempo de la co- 
branza, aumentando crecidos costos en los acarreos y en otros salarios.

Con estos embarazos, ni el indio sale ni el mercader lo busca, y se queda en su miseria un año y muchos años, sin posibilidad para el deseado fomento de la industria $\mathrm{y}$ de la labranza. Y si se ve que algunos mercaderes logran empresas en los Partidos de esta Intendencia, no es por lo que venden a los indios, sino a los cholos, mestizos y españoles, de que abundan más o menos los pucblos de esta Provincia.

La peor resulta que debo temerse, quedando estos infelices sin un socorro público autorizado, es que los Subdelegados y los Curas abusen de su libertad, con pretexto de compasión. Esitc fuc cl origen de la avaricia de los Corregidores, y no es dificil que se vicien con ol mismo desorden, los que ahora tienen la misma autoridad.

No dudo que en los principios, por lats recientes advertencias de la Ordenanza, habrá en los jefes mayor celo sobre la conducta de los Subdelcgados; y éstos observarín también (aunque de mala gana) las disposiciones prohibitivas del Art. 9', $y$ de las Declaraciones 7 y 8 de la Real Cédula de 5 de agosto de 1783; pero según flicre envejeciendo este sabio establectimiento, decaerá con sil observancia el cule de los superiores $y$ el temor de los subalternos y no será extraño que todos cedan a las persuaciones agradables del interés.

Hasta ahora son obscuras y domésticas todas estas desdichas, por eso no han llegado todavia a afligir nuestra imaginacion; pero es preciso seguirlas con la idea hasta las habitacionos asquerosas de? la indigencia, para despertar nuestra compasión al oír ol ruido de las quejas; entonces veriamos que, aunque es la libertad tan respetable en sus derechos, y de quién generalmente dependen el fomento de la agricultura y todas las ventajas civiles y políticas más preciosas, no están nuestras poblaciones on estado de haceise felices con la libertad, porque la pobreza y la ignorancia de los indios, los tiene muy separados hasta ahora de la base de las instituciones sociales, que es cl bien general del Estado.

Haciéndose preciso que caminen los abusos a pasos largos, hasta insultar la miseria pública, la amenaza de este desorden debe exitar las precauciones que sólo pueden encontrarse en los socorros, bajo de unas reglas inteligentes que tengan por término el fomento del trabajo nacional y la conservación de la población.

Querer mudar repentinamente la condición del indio, acostumbrado a vivir por mano ajena cerca de medio siglo, sería desnaturalizarlo y abandonar a su insensata libertad los intereses de la felicidad pública.

Aquellos que pretenden hacer respetable la libertad hasta en los abusos, dirán descle luego, que el someter los cambios a leyes, es querer llenar con una ojeada insensata, las miras activas y celosas del interés personal; y sería quercr señalar a nuestros ciudadanos un camino que ellos pudieran hallar muy bien por sí mismos. Ni puede pertenecer al Gobierno hacer la elcción de semejante camino, dependiendo de tanta multitud de combinaciones; pues, el legislador debe poner barrevas en las orillas de los principios conocidos; pero dejar que después se pasce cada uno a su gusto por el cercado que es común a todos.

Pero verdaderamente, estas palabras generales nada más hacen que esforzar la teórica y dominar la opinión sin tener fuerza para hacer felices en la práctica; porque si se reflexiona acerca de los socorros que se van a establecer para apoyo de la libertad, descubriremos que uno $y$ 
otro se derivan de un mismo principio, así la precaución del socorro tiene por tórmino el fomento del trabajo, a que también se dirige la libertad; y lejos de quebrantar sus leyes, pone límites al abuso, para el bien general, asegurando la abundancia, la población y la felicidad, con prevenir las miscrias y el infortunio del puebio.

Llevando con esta guía al incilo por la mano, para que no se precipite en el abuso, jrá conociendo poco a poco las orillas del precipicio y los limites de su fortuma, para sacar provecho de su libertad.

Al contrario, si caminamos mity de prisa en busca de la dicha, sería mayor al liesgo de tropezar, y la misma impaciencia vana de sacudir el polvo en que nació, daría con él en los ojos para acabarlo cle cegar.

Todo consiste acertar con in sistema que sea inteligente para moderar los abusos del socorro respecto de la indigencia, y los de la fuerza respecto de la debilidad.

Yo compieso que es supcrior a mis talentos la linea que debe de marcar los límites de una libertad débil (como la del indio miserable) para que la mano que ha de fomentarla no abuse de la fuerza contra su debilidad.

Son infinitas las combinaciones que se deben someter a las ideas de este gian proyecto. Eil es verdaderamente àduo, pero al mismo tiempo el más importante para restablecer la suerte abatida de nuestros pueblos.

W'ste dictamen que mi corazón había formado muy en secreto, después de muy serias observaciones sobre el estado de estos paises, ha sublevarlo con violencia mi amor al Rey y a la patria, para que lo publique apesar de las resistencias de mi propio conocimiento. Si acaso se sacrificare mi reputation a la censura de los sabios, sabré que pago con la mejor moneda que tengo lo mucho que debo a mi amado Sobcrano, y no me congratularé poco si otros políticos dispensasen toda energía para prescribir documentos capaces de imprimir en el indio sentimientos más nobles de los que ticne de costumbre, para que fijando el nido de su felicidad más allá del día de mañana, anhele por un interés más remoto de que está privado por su miseria.

Ya hemos visto que las necesidades de nuestros pueblos según la actual constitución no se pueden socorler por la acción natural del comercio, porque su movimiento aunque más general se halla interrumpido por la incertidumbre de una recompensa en las Provincias, que por su pobreza suma, no son capaces de comprar al precio que el comerciante vende, ni de pagarlo al contado. Así no pueden refluír los socorros de una parte a otra, con prontitud para poder remediar la miseria, ni el desengaño de tantos siglos permitc que nos expongamos a nuevos ensayos, confiando la felicidad pública al poder de la libertad y a sólo la fuerza del interés personal del indio.

En este caso ya pextenece al cuidado del Gobierno acudir con sabiduría al socorro de Ios pueblos, pucs, mientras el Soberano vigila sobre los más pequeños encuentros de intereses entre los ciudadanos, no puede rehusar entre sus obligaciones la vigilancia mayor de todas, que es la guarda sagrada de los derechos imprescriptibles de la humanidad.

Pero como los grandes principios de la cuestión de socorros, tienen consecuencias de tal sucrte esparcidas y multiplicadas, que es infinitamente fácil separar las ideas principales de sus relaciones, y suscitar en 
cierto modo los efectos contra sus causas, son demasiaclo inciertos los medios de ejecutarlos sin abuso, y tal vez los mismos recursos que se buscan para remediax la miseria, apenas pueden servir para completar la ruina.

En ninguna materia es más sencillo convertir las yerdades en errores y encontrar con el dario en vez de hallar ei remedio; por lo mismo, es menester no seguir senda alguna servilmente, ni recurrir a las ideas de los demás como a una guía imperiosa, sino como a un objeto de comparación útil, después de las observaciones de cada uno.

Deseando yo acertar con un sistema, que despuês do quitar nuestra timidez, asegure probablemente sus buenas consecuencias, he meditado el que me parece único en su género; pero, antes de proponerlo, juzgo conveniente explicar los demás sistemas, para que comparando sus instituciones, se descubra con más claridad sul importancia.

Algunos han creído que el medio más seguro es la intervención inmediata del Gobiemo, en hacer las ventas y compras de su euenta, para socorrer a los pueblos. Otros juzgan más conveniente eneargarlas con privilegio exclusivo a una Compañía de comelciuntes, que cuiden de hacer los suministros. Otros, finalmente creen más benéfico confiarlo todo al mismo comercio, exitando sus miras con gratificaciones. Ninguna de estas opiniones considero saludable a nuestros pucblos, y paso a demostrar sus inconvenientes, para que se vea que procedo de buena fe.

Bien meditadas las combinaciones del primer proyecto, con el estado y carácter do estos países, vendría a ser en breve tiempo dañoso al Gobierno y a la Real Hacienda, perjudicial al indio y destructivo del comercio. Pues, aumentándose sucesivamente las funciones dol Gobierno, de un socorro moderado a que únicamente aspiro en los principios, presto se vería obligado a emprender operaciones tan extensas, que liegarian a exceder a sus medios, y cuando verdaderamiente perdía en sus empresas, se sospecharía, falsamente, que entonces era el tiempo en que ganaba, y atribuyendo a miras interesadas los socorros que el pueblo recibía de su beneficencia, se vendría a destruír aquella preciosa opinión y tierna confianza que deben unirlo con su Soborano.

Lós mismos comisionados de quienes sería preciso valcrse el Gobierno para los suministros, causarían otros daños efectivos en la Real Hacienda, porque si estos factores habian de tirar la comisión de m tanto $\%$, no pondrian reparo en comprar surtimientos inmensos, sin necesídad, con pretexto de evitar alguna carestía con el recurso anticipado de estos acopios; y muy lejos de economizar los presios, solicitarian comprar lo más caro que pudiesen, porque habiendo de crecer el tanto \%, a proprción de las negociaciones, tendrían grande inter'és en comprar mucho y muy caro, para sacar mayor provecho.

Todos los que tengan alguna experiencia sobre la conducta de los comisionados o factores de Real Hacionda, confesarán que este desorden ha sido siempre $y$ sexá inevitable en cualquier sistema, porque regularmente se hacen las compras sin economía y a veces con infidelidad, pues de otro modo no era posible que pudieran enriquecer tantos factores como vemos medrados, después que los conocimos pobres en sus casas.

Pero si estos comisionados hubiesen de administrar con sueldos fijos, todavía considero más nocivo su manejo, porque necesitarían tener muchas tiendas y almacenes en cuantas partos formasen estableci- 
mientos, además de las casas acomodadas a su vanidad; muchos criados para cuidar y custodiar las mercaderías; otros tantos correspondientes y asociados en todas partes, comisionistas para las compras, y en cierto modo trajincros en todos los caminos, para facilitar las conducciones. Cuanto más extenso fuese este comercio, hay más especulaciones que hacen mayores los liesgos, y es también más incierto el éxito de las empresas, Sobre los gastos ordinarios, es preciso que se experimenten otros muy crecidos, por malversaciones, negligencias e incapacidad de los empleados.

Vićndose los administradores obligados a pagar los yerros de sus oficiales asalariados, y los suyos propios por haber formado empresas mal combinadas por falta de conocimientos y de experiencia, necesariamente recargarán a la Real Hacienda todos estos desembolsos, con título de "gastos precisos", que no hallan otra salida que darles, y tal vez con el temor de cstos desperdicios y quicbras, procurarán grandes ganancias, valióndose de arbitios fraudulentos, que dejando el mismo vacío en las areas reales, aflijan más la miserịa del indio, en lugar de remediarla.

Entonces el Gobierilo se vería obligado a adelantar todos los caudales para las complaas, $y$ sufric todas les pérdidas de la administración, costándole muchos centenares de miles en cada año; y lo peor es que, para contimuar las empresas, sería menester echar nuevos trlbutos o tomar dineros a lédito, tal vez de los mismos administradores, para pagarles sus alcances, y por este medio rendría a arruinarse la Real Hacienda, al mismo tiempo que se enviqueciesen los administradores.

Cuando ellos viesen, por una parte, abonada por los superiores Ia autoridad que tenían por el Gobierno para repartir; y por otra, el poco consumo de las mercancías por la lentitud o disminución de las compras, es consiguiente que, para dar valor a este comercio, se obligase a cada individuo, con pretexto de adelantal su pereza, a que tomase una cierta cantidad de efectos para fomento de la labranza y de la industria, aunque realmente no los necesitase o, a la menos, no los hubiese pedido. $Y$ por este régimen vicioso se abriría necesariamente el paso para el abuso de los socoryos respecto de la indigencia, de este modo se convertiría en opresión lo que se había inventado para alivio de la miseria.

De aquí resultarían innumerables pesquisas, para averiguar si todos habían compiado la cantidad que les estaba impuesta, y otras indecibles vejaciones y apremios contra los que se resistiesen a estos repartimientos. De forma que, después de molestar a todos los pueblos, quedarían muchas familias reducidas a pedir limosna; manteniendo siempre un mismo rigor el poder abusivo de los administradores, para otros muchos actos todavia más perjudiciales, que no se pueden explicar por no conocidos. Pero verdaderamente, sería este el momento infeliz en que nacía el abuso de la fuerza, respecte de la debilidad del indio, y vendría a ser cada vez más desdichado por los mismos medios discurridos para su descanso y defensa.

Fuera de que no hallándose indicado por la ley el uso de la autoridad de estos empleados, erecería su poder de grado en grado, según la fuerza de protección que mereciesen a los Ministros de Hacienda y demás Magistradios de quirenes depende el permiso de este tráfico y según fuesen más protegidos, bien sea por pura dicha o porque pagaron el favor o porque dieron parte de las ganancias; al cabo, extenderían sus miras 
para abarcar el comercio universal do todas las Provincias y excluir a los demás comerciantes, para usurparles las ganancias e imponcr a los indios una ley más imperiosa con la necesidad de ser ellos los únicos vendedores.

El medio no puede ser más fácil, pues, para arruinar el comercio de las Provincias y ahuyentar de ellas a todos los comerciantes, tendrian a la mano denuncias falsas de haberse excedido a render los materiales que debian repartir los comisionados de Real Hacienda; en fuerza de ellas se mandarían hacer pesquisas; set buscartan declaraciones infieles y serian tantas las violencias con que se practicasen semejantes averiguaciones, que ese abuso bastaría para desterrax de las Provincias ol comercio de los particulares.

Para asegurar mejor el monopolio enviarian por las Provincias mucha gente armada y espias asalariaclus para impodir la venta de los efectos de su reparto, Unas veces con verdad y las más veces falsamente, se practicarian denuncias, apremios, prisiones, multas y confíscaciones, con el único fin de que los nercaderes comprasen su libertad.

Es imposible que a poco tiempo no viniese a recaet todo el comercio en los administradores y comisionistas; porque no obrando los mercaderes más que por ganar, temerian concurrir con el Tesoro l’iblico, a costo de tantas pérdidas y vojacioness.

La Real Hacienda liegaria ch extenuarse con estos gastos, hasta el extremo de exceder ya las empresas a sus medios, y viendo cada vez más necesitadas las Provincias, después de haberse entriquecido los comisionistas a su costa, sin fuerzas en el comercio para confiarle los socorios, al cabo los encargaría a una Compañía privilegiada, que diese por su cuenta los avíos.

Este segundo sistema, inspira, con poca diferencia, los abusos que el antecedente, pero es más proporcionado para arruinar el comercio y establecer un monopolio más imperioso; porque si los comerciantes particulares no han de traficar sino en tiendas públicas y en almacenes manifiestos con las mercaderías que son fuera del reparto, era muy fácil hacer abortar todos sus proyectos, con sólo presentarse los comisionados a pujar el precio en cuantas partes ocurriesen los demás para comprar y rebajarle en cuantas podian vender. No pudiendo entonces los co- merciantes mantener la concurvencia sin arruinarse, renunciarían unos después de otros el comercio de los pueblos, y lograrían comprar y vender los comisionados por sí solos.

$Y$ aunque en la venta fuese menor el beneficio a los principios, por la baja de precios, no por eso tendrian menos interés en vender barato, así vendrían a ser ellos solos los comerciantes de las Provincias, asegurando para después exorbitantes ganancias por los medios de este inicuo monopolio.

La resulta sería acabarse de alruinar el comercio, con lo que se pensaba fomentar su libertad y, necesariamente, vendría a refluir este perjuicio en los miserables indios, poniéndoles mayores obstáculos quc antes para solicitar su bienestar donde más les acomode; no teniendo en sus pueblos otros a quienes comprar sino los monopolistas, se verían precisados a recibir de ellos una ley arbitraria, sin poder'se valer de la libertad que nuevamente se les ha declarado.

Si por huir estos inconvenientes se pensase exitar el comercio de 
los materiales necesarios para la labranza, y principalmente el de las mulas, con la gratificación do un $4 \%$, que los vendedores hubiesen de pagar menos del 6 ; cor'uspondiente al derecho de Alcabala, fijando a este fin algunos pucblos en el distrito de las lrovincias, no tiene duda que la publicidad de estas recompensas atraería muchisimos concur'rentes; pero, por otra parte, esta aistribución de recompensas en lo interior del Reino presenta dos glaves incomrenientes, el uno para el comercio y el otro par'a Real Hacienda.

Todas acyuellas personas que hubiesen formado algunas especulaciones, con la esperanza de que podía subir el precio de las mulas, concurrirían de golpe a los parajes de la feria, discurriendo desquitar sus quiebras con la retribución prometida en la baja de alcabalas; pero llegaría a aumentarse con tal exceso el número de los vendedores, que los más o casi todos quelarían perjudicados, ya por falta de salida, ya por haber vendido perdiendo el principal, ya por haber fiado los valores que después no se pueden cobrar', ya por los costos crecidos en pastos, conducciones, potjero, y por mortandad del ganado ocasionada por la demora; de suerte que, no pudiendo costearse semejante comercio, lo abandonarian enteramente, con perjuicio notorio del trajín de mulas y de los ganaderos del Tucumán.

Los mismos comerciantes tomarían entonces el arbitrio de que una misma tropa de mulas, gozase muchas veces de la gratificación concedida, pues, hallándose estas lrovincias sin barreras, fácilmente extraerían del mercado las mulas que habían introducido para la feria, y sin verificar su venta, dejarían a los pueblos en la misma neesidad, al paso que se defraudase la Alcabala en el ganado, que hubiese entrado muchas veces solamente para volver a salir.

Respecto a no poderse restablecer el buen orden y la felicidad de nucstros pueblos, por medio de los tres sistemas antecedentes, sin tener fucrza bastante el interés del indio para poder disfrutar del valor de la libertad devueita al comercio; porque una palabra del Monarca pudo destruirla desde el instante, pero no podia reproducirla sin el auxilio del tiempo y de un sinnúmero de precauciones sabias que requiere su estado lastimoso; entremos ya a la empresa de romper otra senda por donde se pueda socorrer la indigencia de una libertad débil, sin abusos de parte de la mano repartjdora y sin obstáculos que detengan la acción natural del comercio en su movimiento necesario para el reflujo de las riquezas en Io intelior de nuestras Provincias.

Pero expliquemos antes algunas advertencias que deben servir de precauciones para el buen régimen de nuestro sistema. Primera: que los suministros se hagan siempre por uno sólo y por ningún caso se pueda formar para ellos ni establecer cofradía, gremio o compañía con pretexto alguno, para que así se eviten los monopolios; pues, uno sólo no puede extender sus ideas a muy grandes empresas, ni es capaz de adquirix tanta fuerza que pueda esparcir por todas partes obstáculos a la líbertad de comercio.

Segunda: que cada Partido se socorra separadamente por su respcctivo proveedor, para que cada uno reparta los socorros a un mismo tiempo; y divididos, por otra parte, los intereses de cada Provincia, puedan ser más activas y celosas Ias miras del Gobierno sobre la conducta de los cmpleados y nunca se pueda aumentar la fuerza de éstos hasta el 
grado de introducir algún abuso inremediable, respecto de la debilidad de los indios.

Tercera: que cada proveedor haya de tener precisamente libros bien ordenados, en que consten todas las porciones de efectos, así de tarifa como cle Castilla, que hubiesen comprado o vendido a los pueblos por vía de socorro, expresando con la debida distinción las clases de géneros y las personas a quien se compraren o vendieren.

Cuarta: que los abastos y provisiones de los materiales precisos para la industria y la lałranza, se rematen en pública stibasta, por el término preciso de dos años, en quien se obligase a hacer mayor baja en el precio de los socorros, para que la incertidumbre del rematador evite todo concierto secreto con los Magistrados de la Provincia, y el calor de la subasta pública pronueva la emulación de los concurrentes a la puja de las rebajas. Que reduciéndose los suministros al corto período de dos años, se aprovechará el primero para repartir y el segundo para cobrar, sin darse lugar al proveedor para grandes uspeculaciones, pues estas no se pueden formax sin conocimientos bien combinados, que provienen necesariamente de la experiencia, que siemple es lenta.

Quinta: que por ninguin caso se suninistren socorros a quien no los pidiere por medio de los Gobernadores y Caciques de sus respectivas parcialidades, para que con esta precaución use cada uno de su libertarl en pedir solamente aquello que necesitare; $y$ la intervención de los indios principales, reprima el abuso de repartir a los particulares mayor cantidad de materiales de los que hayan pedido y ellos necesiten; aunque se puede recelar de algún modo quc, los mismos Gobernadores sobornados por el proveedor sean sus agentes para aumentar los socorros que se deben suministrar a cada Comunidad, será siempre más fácil para el indio entablar recurso contra el Cacique que lo gravó, y según la codicia de estas gentes, ninguno se excusará de denunciar el exceso, interesándolo en el perdimiento del socorro en que debe ser condenado el proveedor.

Por otra parte, como los Gobernadores y Caciques han de quedar obligados al entero de los productos de los suministros hechos a sus parcialidades, no es creíble, para quien conoce el carácter de los indios, que quieran sujetarse al riesgo de ser descubiertos en su iniquidad; $y$ cuando liegaren a cometerla, sería una sola vez, porque acostumbrado el indio a ser infiel a las obligaciones más claras (principalmente en materia de interés), faltaría más bien a la primera confianza que se le hiciese en secreto, y piesto quedaría escarmentado el proveedor para no volver a confiar en indios; $y$ véase aquí, detenido el curso del abuso a sus primeros pasos.

Combinemos ahora estas precauciones y se verá formado nuestro sistema. Una vez que no se ha de socorrer sino al indio verdaderamente necesitado, en aquella cantidad precisa que pidiere, y no más, no debe servir de regla la gruesa que se halla tasada para cada Provincia por los reglamentos antiguos del reparto; y así, el proveedor que rematare los socorros de cada Partido, quedará obligado, sin límite cierto, a suministrar las porciones de materiales que se le ordenaren por el Intendente de la Provincia, en la forma siguiente:

El Gobernador de cada Comunidad formará una planilla de los indios necesitados, que pidiesen socorros, expresando sus nombres, el de 
su Aillu o parcialidad, el de la Doctrina a que corresponde, y el de su respectivo Caciquc, con anotación específica de los materiales y efectos que cada uno necesite; y pasando estas planillas al Subdelegado, las ratificará en su presencia, para que poniendo a continuación su "visto bueno", con el Cura de la Doctrina respectiva, y jurando que los indios no han sido apremiados ni seducidos en sus per'sonas, ni en las de su Gobernador, y de ser aquellos mismos los efectivos y cantidad que piden por socorros, las remitirán cerradas y selladas al Intendente, para que, oyendo antes, instructivamente, al protcctor de naturales, expida su decreto ordenando al provecdor, suxta para determinado tiempo a cada Comunidad, de las porciones de materiales que constaren de la planilla.

Al pie de ellas se ajustará, por el Oficial Mayor de la Caja, con intervención del Proveedor y del Protector, el monto de los socorros conforme a los precios del remate, distinguiendo estas partidas con numeraciones puestas a la derccha y sumando a la izquierda los mismos valores con el aumento de su $20 \%$, para que la primera columna sirva de abono al provecdor, y la scgunda de cargo al Subdelegado, para el entero de Ios productos de socorros.

Fl modio de lograr csta empresa, es que el indio pague los socorros con el aumento de un $20 \%$ sobre los precios del remate, para que depositándose este exceso, se forme después, de todos los caudales acumulados, un Baneo para aviarlos de su cuenta; por ejemplo, si cn el remate de suministros se contrató cada mula puesta en el pueblo cabecera de la Doctrina, a trece pesos, se le repartirá al indio al precio de 15 pesos y cuatro reales, que corresponde al $20 \%$, y enterando en Cajas Reales el total de este producto, serán de abono para el proveedor los trece pesos de su contrata, y los dos restantes, que serán depositados por razón de utilirlades, para el objeto expresado.

Tomándose razón a la letra de las planillas en el libro de este ramo, que dcbe correr a cargo del Oficial Mayor, con alguna gratificación, se devolverén los originales al Subdelegado, para que congregando en Ia cabecera de la Doctrina Jos Gobernadores de la Comunidad y los Caciques de los respectivos Aillus y parcialidades, sc Ies haga la distribución de los socorros en mano propia, con especial advertencia de que los repartan entre aquellos que los pidieron, con arreglo a las mismas planillas y de quedar ellos responsables a enterar este producto en la misma forma que los tributos, al plazo de un año desde su recibo, el cual deberá autorizarse por el Subdelegado y por el Cura, con la solemnidad y formalidades expresadas arriba, entregando luego las planillas al interesado, para que ocurra con ellas a solicitar del Intendente, el respectivo libramiento al tiempo que corresponda hacer el pago.

Según el número de las Doctrinas, se habrá de señalar el tiempo necesario para las distribuciones de socorros en cada Partido y contemplándose suficiente el término de un año, correrán los plazos para la cobranza, con la desigualdad proporcionada al repartimiento; pero uno y otro nunca pasarán de dos años.

$Y$ para que el proveedor no sufra perjuicios, se deberán despachar los libramicntos en dos pagas: la primera a los seis meses del segundo año, y la últimá al fin de él, reteniéndose en Cajas Reales esta mitad de productos, por vía de fianza para la seguridad del remate $\mathrm{y}$ de cuales- 
quiera otras resultas que se le formen por recurso de los indios o por otros excesos calificados.

Para que sea efectiva la cobranza debe estar anexa al cmpleo de los Subdelegados esta imporiante obligación, bajo de la misma responsabilidad y riesgo que los tributos reales, en la forma dispuesta por el artículo 116 de la Nueva Ordenanza, $y$ con el premio del $4 \%$ del total que enterasen en la Tesorería, del producto de los socorros, a ejemplo de lo prevenido por el artículo 117 de la citada Ordenanza, deduciéndose de las utilidades este abono y la gratificación del Oficial Mayor, con los demás gastos que se arreglasen por instrucción separada, para la buena cuenta y razón de este ramo; cuyo punto omito detallar, porque me he propuesto delinear un sistema sencillo de hacer los socorros sin abuso, dejando las particularidades que tocan a la buena cuenta de los productos, a las sabias disposiciones de nuestro Gobiemo.

Según las constituciones de este sistema, no debe entender el proveedor ni en las distribuciones ni cn la cobranza, paxa excusar los actos de poder que tal vez ejerceria en los indios, teniendo alguna intervención 0 ingerencia con ellos; $y$ de esta sucrte se fija una linea de demarcación visible, entre la fuerza del proveedor y la debilidad del indio, para que no se abuse de ella.

Los principales de su nisma casta son aquí los oradores de sus necesidades y los agentes de sus negocios; por mano de ellos piden y reciben los avíos que necesitan, sinı ver la cara al proveedor, al Cura ni al Subdelegado. $Y$ es consiguiente que obren con plena libertad cuando no se miran bajo del brazo imperioso del que manda. Aunque las persuaciones de los de su propia nación son casi siempre dulces y halagüeñas para inducir, nunca son bastantes para obligar cuando no es palpable el beneficio, ni es capaz de fortificar el poder de un indio contra otro, para el abuso de su libertad y de su interés, porque no hay en ellos la fuerza de autoridad, que es la única que se teme, sino solamente la fuerza secreta de la sangre que siempre cede al interés.

Los Subdelegados y los Curas, pueden, dosde luego, entablar sus pretensiones ambiciosas, pero sin progreso, porque labiendo de correr tras de la ganancia, así ellos como el proveedor, chocarán recíprocamente sus intereses y unos a otros se destruirán las fuerzas necesarias para la empresa. La corta sustancia de los pucblos, no es capaz do hartar a todos; si se divide el provecho, quedarán todos hambrientos y mal contentos; pero como sólo el proveedor tiene derecho para suministrar los socorros, resistirá con ímpetu a los obstáculos de su facultad y cuando no alcance a remediarlo el impulso de su acción natural, clamará a la fuevza soberana que le debe protejer, descubriéndose cl abuso sobre el campo, para aniquilarlo en su origen.

Si por el contrario formasen la idea de oprimir al indio, con repartimientos clandestinos, sin quitarle al proveedor sus ganancias, sucederá forzosamente una de dos cosas: o que nunca cobren sus productos, por no salir descubiertos en el cntero de Ios socorros, o que estrujen con tanta violencia a los pueblos, hasta brotar sangre en vez de sacar subsistencias. En cualquiera de estos dos casos, debe tener una pronta enmienda el exceso, pues, si no cobrasen, es preciso que el desengaño los aparte de exponer sus intereses a nuevos ensayos desgraciados, y si lo interesaren, clamarán los indios y el proveedor, contra la violencia que 
priva a Ios primeros de su libertad y despoja al segundo de sus utilidades, y de este modo el mismo daño vendrá a ser paso para el remedio.

Ahora si es más difícil desarraigar y aun conocer los abusos de los Subdelegados, porque habiendo fjjado su principal estudio en inspirar las mismas ideas del antigno poder de los Corregidores, intitulándose en muchas partes Subdelegados Intendentes, para equivocar y confundir en el poco discernimiento del indio las facultades superiores de los jefes, han logrado dominar toda Ia opinión de estas pobres gentes, hasta reducirlas a un abatimiento todavía mayor que en el que antes vivían.

Estos infelices, al verse sometidos a una misma autoridad y en mayor miseria que antes, reproducen la memoria de los auxilios que recibian de los Corregidores; y lo que entonces toleraban como carga, solicitan en el día como favor, sobre la experiencia de no encontrar quien quiera fiarles los avíos quc necesitasen.

Con este incentivo para la avaricia de los Subdelegados, no tienen reparo en venderlos el favor lo más caro que pueden, sobrc cl seguro que el indio callará con el temor de perderlo en su Juez y de no hallarlo después en otro ninguno y, lo que es más, que lejos de reputarse agraviado, reconoce por giande beneficio el recibir por 18 o 20 pesos una mula que antiguamente repartían los Corregidores por 24 y a este tenor la bayeta, el fierro y otros materiales.

Si acaso ya no tuviesen estc manejo algunos de nuestros Subdelegados (como lo dicen por ahí), bien se pucde asegurar que lo ejecutarán dentro de pocos años, sólo con esta idea solicitan a porfía semejantes empleos, en medio de no estar dotados y de ser tan grande la responsabilidad a que se hallan sujetós.

Fin nuestro sistema se suministrará al indio por quince pesos una mula, que antes le costaba venticuatro; por dos reales un cuchillo que compraban por un peso, y sobse este pie los demás efectos de tarifa. Conoceŕ́ con evidencia las utilidades usurarias de aquellas antiguas negociaciones; mirará con odio cuanto le pueda venir por mano de sus Jueces, recclando el mismo engaño que había padecido anteriormente; y cuando los Subdelegados pudiesen allanar la resistencia del indio, nunca podrán hacer empresas ni aun sufrir la concurrencia del proveedor, no pudiendo vender a los precios que él suministra.

Las pujas del remate bajarám los valores a un punto tan ínfimo, que sólo al proveedor le puede hacer cuenta, por las gruesas porciones que despachará en los avios y por la ventaja de reducirlos a dinero para darle giro empleándolo en otras empresas más lucrativas; pero el Subdelegado estudia las ganancias, para recurso de los acontecimientos contrarios, y donde no las encontrare a su gusto, estará quieto, por no peligrar la confianza ajena y el empleo.

El Gobicrno reasumixá precisamente la opinión de su beneficencia y al mismo tiempo ahorrará las providencias y tasas mudables de Aranceles, y de otros medios de justificar los precios, sin exponerse al inconveniente de renovai en la imaginación del indio el odioso establecimiento de la tarifa, y de que siendo preciso alguna vez levantar los Aranceles por causa de guerra o por otro accidente del tiempo, se atribuye este recurso a miras puramente interesadas, que hagan desconfiar al indio, desuniéndolo de su amado Soberano.

Después dé ser menos y más irremediables los inconvenientes de 
este sistema, son también notorias sus grandes ventajas para el indio, para el Gobiemo, para el comercio y para la Real Hacienda. El indio recibirá de contado el beneficio de adquirir cuanto necesite, aun cuando no tenga dinero, y fomentará con avíos su industria y su labranza, para pagar cómodamente al cabo de un año la mitad menos de lo que antes le costaban los mismos efectos. En un solo año adquirirá el mismo valor que antes apenas conseguía con la fatiga de cinco, y de paso irá acumulando caudales efectivos para su propio provecho.

Su libertad no padecerá violencia, porque sólo recibirá lo que pidiere, y cuando llegase el momento de la prosperidad, tendrá en su mano suspender la ley con no pedir. Entonces ol Gobierno aquietará sus cuidados con una sencilla observación de la felicidad, porque la misma fuerza del interés personal del indio y el tiempo, irán conteniendo las empresas que la protección soberana inspiró y principió con este sistema.

El comercio tambićn recibirá beneficio, haciendo nuevos progresos más allá de los límites que ahnora tiene. Entonces se consirmirian en la provincia de Potosí, closcientos cincuenta mil pesos al año, por la parte más corta, y en todo el Perú, más de tres millones, en los efectos de fierro, acero, bayctas, paños, cuchilios y mulas, los cuales se hallan casi sin despacho desde que cesaron los repartimientos.

Todos estos caudales estancados ahora, circularían, desde luego, y por medio de una acción repetida de empleos, se producirán las immensas riquezas de que estamos privados. Este mismo impulso del comercio en América, será un fomento muy activo para nuestras manufacturas de España y para alentar el giro de la Metrópoli por estas colonias, por el continuo desaguie que tendrán las producciones de su industria y de las artes, en el mayor consumo.

Este punto es el más digno de atención para nuestra política. Porque todos los minerales del reino del Perú, no producen arriba de once millones y medio, según las cartas-cuentas de los reales quintos y la gruesa de plata y oro que labran las Casas de Moneda de Lima, Chile y Potosí. Más de cinco millones se jnvierten cada año en las Provincias del Perú, en pagamentos de salarios de los Excmos. Virreyes, Presidentes, Intendentes, Gobernadores Militares, Ministros de las Audiencias de Charcas, Lima, Chile y Bucnos Aires, Sala de Alcaldes del Crimen, Tribunal de Cuentas, Oficiales Mayores y Menores de las Cajas Reales, Ministros de Cruzadas, Juzgados de Bienes de Difuntos, Misiones de Propaganda. Situados de Valdjvia, Malvinas y Patagones, Censos y Capellanías de las Cajas de Lima y Potosí, Gastos de Proveeduría y Teneduría de Bastimentos, Sueldos del Presidio del Callao, de Montevideo y demás establecimientos militares, antiguos y modernos, en ambos Virreinatos, Mineraje de Guancavelica, costo de Fundiciones, gastos de la conducción de azogues y otros desembolsos notorios, los cuales, aunque vuelvan en mucha parte por un incomprensible cf́rculo a incorporarse a la masa general destinada a los empleos de nuestro libre comercio, la mayor debe reputarse consumida en el sustento y vestuario de los habitantes de este Reino, fuera de los caudales atesorados, que no giran por el estado o por la ambición de sus dueños.

También sale del Perú, todos los años, al reino de Quito, crecida cantidad para el tráfico de paños, pañetes, bayctas y tocuyos, pasando todos sus productos a Cartajena por el nuevo reino de Granada y Río 
Grande de la Magdalena, a la feria particular de aquel puerto, con mercaderes de Quito, Popayán y Santa Fe; todo lo cual, unido a las porciones que se conducen a España por cuenta de Real Hacienda y otras pertenecientes a los Santos Lugares de Jerusalén, para la redención de cautivos, al culto Divino y obras pías, se calcula por un cómputo prudente seiscientos cincuenta millones de pesos (\$650.000.000).

Desfalcando de los once millones referidos, estos cinco millones y medio más que hemos excluído en el concepto de consumidos o extraídos fuera del Reino, apenas quedan libres de cinco a seis millones para los empleos del comercio, que es lo mismo en que debe reputarse el consumo anual del Perú, por las reglas comunes que dicra la Economía Política.

Considérese ahora, que en sólo este año de 1786, se han introducido más de treinta miliones en manufacturas, por los puertos habilitados en los dos Virreinatos de Lima y Buenos Aires; hágase un cotejo muy sencillo entre estas producciones de industria y su consumo, y desde luego conocerá cualquicia que los veinticinco millones restantes deben quedar estancados en ol reino por cinco años, que necesitan para tener despacho, y si quisicren fiarlos, con la impaciencia de hacer negocio y salir de géneros, no por eso mejorarán su causa los comerciantes de España, porque habiendo de quedar en un pie el consumo y las producciones del reino, será siempre uno mismo el estado del comercio, y de consiguiente sc experimentarán muchas quiebras en las casas de Europa, si no detienen el curso de sus expediciones.

El único medio de aliviar esta fatiga, es aumentar el consumo entre los indios. Al prineipio subirá solamente a tres millones más en lós efectos de primera necesidad; pero según fuere haciendo progreso su libertad ayudada de las fueryas del interés personal, ellos llegarán a mudar sus hábitos, multiplicarán las necesidades que provienen de ellos y desenvolviendo por grados su inteligencia y su sensibilidad, tendrán adhesión a vestidos de mejor gusto y comidas de más regalo. Entonces despertarán sus miras en busca de la prosperidad, viendo delante aquellos beneficios de que gozan los demás y que ellos no disfrutan, por causa de su decadencia ocasionada de la pereza.

Darán acción a los brazos pala trabajar más, por vestir y comer mejor, y al cabo vendrán a conformarse con nosotros en sus trajes y costumbres, consumiendo en objetos de lujo a proporción de su número, y estos cuatro o cinco millones más que se distribuyan entre los indios, harán valer la industrija y la labranza, para producir otra tanta parte de riquezas, que después de dar impulso al comereio, servirán de regla para que sus expediciones no excedan los consumos de estos habitantes.

El método de conseguirio, es no poner limitaciones al comèrcio de los efectos de la segunda necesidad en los pueblos de indios, pues sólo así podrán estimularse a comprar los objetos agradables de nuestras manufacturas, que tanto importa para la civilización. No concibo perjuicio en que venda el mercader los efectos de Castilla en tienda pública o fuera de ella y al contado o en fiado, siempre que en este último caso no se permita hacer cobranza antes de estar pagados los socorros de primera necesidad.

Esta libertad atraerá mayor concuirencia de comerciantes, y la Rcal Hacienda conseguirá un notable aumento en el ramo de Alcabalas de efectos de Castilla, y en los de provisiones asegurará la cobranza sin 
ningún riesgo, recogiendo el importe de este derecho en las mismas arcas, según se fueren enterando los productos, sin necesidad de otra diligencia.

Lo mejor del proyecto, consiste en dos cosas: La primera, que para ser proveedor, no se necesita tener riqueza efectiva, pucs una multitud de mercaderes que tienen estancados los efectos en sus almacenes, se reputarán dichosos en fiarlos, sobre el seguro de poder recobrar su ìmporte en las mismas arcas donde se deben hacer los enteros de los suministros; cliando vemos que antes solicitaban a los Corregidores para habilitarlos, siendo más pobres que lo puede ser ahora un mercader proveedor, y con mayores contingencias de pedir al fiado, por estar más expuesto a disiparse los caudales que los mismos Corregidores recaudaban y guardaban.

La segunda, es que en cada Provincia quedarán cinco o seis vecinos, cuando no ricos, muy bien acomodados, al cabo de dos años con las utilidades de la provisión, y aunque no lograren más que el crédito, se pondrían en aptitud de emprender otras negociaciones sobre este apoyo; de suerte que, si antes un Corregidor se llevaba fuera del reino todas sus ganancias, por el contrario, las atraerá el proveedor para la felicidad de nuestras poblaciones y fomento del comercio interior y ultramarino.

En conclusión, será menester que antes de entablar este sistema, lo haga entender a los indios el mismo Intendente, visitando a este fin personalmente todos los pueblos de su Provincia; y si cumpliere con esta obligación anual que impone nuestra sabia Ordenanza, será un remedio eficacísimo para destruír cualquier abuso que suscitare la avaricia de los subalternos.

Necesariamente lo aclamarán los indios, por reparador de sus miserías, y. tanto más agradecidos quedarán a la beneficencia del Soberano, si se les advierte que al cabo de diez años debe crecer cerca de 150.000 pesos el aumento que deben pagar sobre los precios del remate, haciendo la cuenta solamente de un $12 \%$ sobre la grucsa de 200.000 pesos anuales, por deberse descontar un $8 \%$ para gastos de recaudación y demás que fuere indispensable.

Este fondo, con lo que redituare al año, scrvirá para aviarlos de su cuenta, como ahora se ejecuta con el caudal de censos. AI cabo de tiempos, si se administrare con fidelidad, puede alcanzar también para dotar Alcaldes Mayores, fundar cscuelas y otros establecimientos de industria, en que puedan emplearse para siempre los talentos de estos naturales, logrando el Gobierno una permanente gratitud del pneblo; pues, no viéndose clara y distintamente la mano que fomenta, que retiene $y$ que remedia, se olvidan luego sus servicios y se atribuye al acaso o a la resulta indispensable de las circunstancias aquel reposo a que una dilatada habitud nos ha hecho insensibles.

Si fuera yo tan feliz que llegase a establecer este sistema, también tendría la dicha de hacer felices a estos naturales $y$ haber servido con la pobreza de mi talento al Rey más amante del bienestar de sus vasallos. Este ha sido y es todo el objeto de mis tareas, sin más fin que acreditar mi amor, mi lealtad y mi gratitud a la mano soberana que me ha puesto en estado de ser útil a su real servicio.

Bien sé que otros Ministros sabios y respetables del reino, han sentido de otra forma; pero como el tiempo no les permitió observar todo lo 
que yo he notado después, con el dictamen general de los hombres más prácticos de estas Provincias, no me ha podido contener mi celo para dejar de decir lo que siento en beneficio del Estado y de la patria, por no ser desleal, ni aun en secreto, a las obligaciones con que nací para mi amado Soberano.

\section{NOT I C I A S EX TA}

De los objetos de la causa de Justicia; en que se resuelven varias chestiones importantes.
$\mathbf{E}_{1}$ colico Rey Carlos II, previno a todos los Gobernadores de América, por una Codula llena de piedad, 11 que para solicitar los efectos de la Divina misericordia a

favor de sus dominios, pusielan sumo cuidado en el remedio de los danos, por corrección de pecados, administración de Justicia y amparo de los pobres. ${ }^{12}$ Estos objetos comprenden en su extensión todo cuanto debe despertar las miras de un Magistrado celoso en la causa de la Justicia, nuevamente encargada a los Intendentes de Provincia, por su particular ordenanza, desde ol Art. 12 hasta el 52. En los diferentes cuerpos de nuestra legislación so hallan dictadas muchas y muy sabias leyes al mismo propósito. Sería una fatiga impertinente y molesta querer particularizar los casos en que so debe emplear el Ministerio de Justicia, pudiendo cualquier Intendente vencer este trabajo, muy fácil para los sabios asesores, con sólo leer los títulos de nuestro Derecho, que tratan de la Justicia, con relación a los privilegios de pobres, daños públicos y a Ios delitos y sus pcnas.

Con esta consideración me contraeré únicamente a ciertos puntos, aunque generales, muy dignos de especial advertencia, para evitar los graves inconvenientes que pueden seguix'se de la omisión o de su contraria inteligencia.

Párrafo primero. - Apelación $\mathbb{W}_{\mathrm{L}}$ Art. 14 de la Nueva Ordenanza, puede los Tenientes. do ofrecer alguna contienda en lo sucesivo, sin embargo de su contexto terminante. Previene (es verdad) que de los autos y sentencias que dictaren los Tenien. tes como Jueces ordinarios, deben admitir las apelaciones y recursos de las partes, para la Audiencia del Distrito; pero como no explica ni distingue los autos interlocutorios de los definitivos, ni tampoco los comprende en su sonido por no haber usado de la palabra universal "todos", puede algún Gobernador ambicioso intentar que se apele ante él de Ios autos interlocutorios, según la opinión del célebre Bobadilla, 18 dando por cumplida la Ordenanza en cuanto a los definitivos.

Narbona ${ }^{14}$ reflexionó con mucha prudencia y discernimiento sobre la razón en que se fundaron los autores antiguos, que autorizaban a los Corsegidores para avocarse las causas pendientes ante sus Tenientes y enmendar sus providencias; y decide que hablaron en el supuesto de haberios nombrado los mismos Corregidores; pues, teniendo en su mano revocar los nombramientos según aquel antiguo sistema, también podrían traer a sí las causas y revocar los juzgamientos; pero cuando los hubiere nombrado el Rey, como ahora se ejecuta, no debe tener lugar la 
doctrina de Bobadilla. Con el que se convence que en ningún caso se debe apelar del Teniente para el Gobernador, ${ }^{15}$ ni son admísibles los recursos sino para la Audiencia del Distrito.

Nada prueban en contrario los artículos 17 y 18, con encargar a los Intendentes la vigilancia sobre las Justicias ordinarias y de que interpongan su autoridad y remedien los daños que resultaren de las enemistades, parcialidad, pasión o venganza de las Justicias, porque estos procedimientos deben ser de puro hecho y sin figura de juicio.

Por esto, cuando sucediere acudir al Gobernador algún quejoso castigado o condenado por el Teniente, para evadirse de sus mandamientos, no debe avocarse el conocimiento de la causa, ni proceder por vía judicial a la averiguación del perjuicio.

Pero si entendiere que se obró con parcialidad o pasión y quisiese reconocer los autos, puede pedirlos a este efecto a las Justicias, y éstas se los deben entregar y estar a las determinaciones que tomare por vía sumaria, económica o gubernativa en que debc proceder, entendiéndose esto en el único caso de ser la causa afectada para desahogo de pasiones y de poca sustancia, devolviendo los autos con aviso de lo resuelto; sin que deba extender esta facultad a los demás pleitos en que su gravedad, interés o motivos requieren que sigan su curso a los tribunales donde tocan; y aunque en los primeros casos intentan maliciosamente los Jueces subalternos en continuar los pleitos, solamente podrá llamarlos para advertirles su obligación y exhortarlos a cumplir con ella, dando cuenta al tribunal superior (si no bastase la advertencia) para que se les corrija, sin excederse a multarlos ni apercibirlos como antes lo ejecutaban conforme al Art. 2 de la Real Ordenanza de 4 de julio de 1718, y por el Art. 9 de la de 13 de octubre de 1749, que tácitamente se han revocado en los Arts. 17 y 18 de nuestra Nueva Ordenanza, por el mismo hecho de haber suprimido aquellas cláusulas imperiosas de multa y de apercibimiento.

Párrafo segundo. - Información contra Eclesiásticos.
$\mathbf{P}$ los agravios que regularmente reciben de los Doctrineros y de otros eclesiásticos, se

previno por el señor Duque de la Palata, en el Capítulo 23 de la Ordenanza de 20 de febrero de 1684, recopilada al folio 311 de las Generales del Perú, que los Gobernadores, Corregidores o sus Tenientes puedan. y deban hacer Informaciones del hecho, sumaria y cxtrajudicialmente, con todo secreto y recato, examinando algunos testigos que lo sepan y se hayan hallado presentes; y después de examinados, sin pasar a otra diligen. cia alguna (porque ésta no tiene forma ni naturaleza de juicio ni proceso, sino de un testimonio auténtico, como lo puede dar un Escribano y testigos), hagan sacar dos traslados, y con carta que los acompañe, los remitan e informen al Superior Gobierno, y con otra al Iltmo. Arzobispo u Obispo.

Esta práctica se observó generaĺmente en el Perú, y se halla autorizada por la ley 13, título 14, libro 3 de la Recopilación de Indias; sin embargo de la implacable contradicción que puso al cumplimiento de aquella Ordenanza el Ilmo. Arzobispo de Lima.

Después se meditaron con más conocimiento los graves inconve- 
nientes que podían seguirse de su obscrvancia, y se ordenó al Gobernador de Potosí, por el Señor Virrey, Conde de Superunda, en carta de 4 de febrero de 1754 , que para evitar las alteraciones escandalosas, como ocasionó en Lima su promulgación en tiempo del Ilmo. Arzobispo, el Señor Liñán, se suspendiese la práctica de la citada Ordenanza, y que en las quejas contra eclesiásticos y otros casos escandalosos, pasase noticia al Arzobispo para que pusiera remedio, y no surtiendo efecto estas extrajudiciales interpelaciones, diera cuenta a la Audiencia y al Superior Gobierno, por el medio prevenido en las leyes. ${ }^{16}$ Párrafo tercero. - Castigo de
falsos testigos.
$\mathbf{E}_{\mathrm{N}}$ yor cuich que un lntondente debe poner ma(n) defender la incia contra falsos testi

gos y delatores, que son tan comunes en estos países, y tan insolentes, que sostichen en los carens la calumnia como si fuera verdad deI Evangelio. Si se castigara uste delito con el rigor adecuado a su malicia, vivirían los hombres de bien más deseuidados sobre la seguridad de su buena conciencia, y no habrian tantos Jueces y Ministros como hay, sacrificados a la infamia de estos malévolos.

Ia facilidad con que se procesa en el Perú al hombre más justificado y la desvergüenza con que se retractan los testigos, alegando temores falsos, apremios afectados y otros pretextos maliciosos, es un convencimiento del poco respeto con que se insulta la religión del juramento. El primer móvil de las operaciones de estas gentes es el interés; de alli nace la adulación servil, la intriga y la infidelidad; no miran lo lícito sino lo útil, $y$ siempre gue les acomoda aruinar al vecino, bien sea para hacer su fortuna o par'a complacer al que manda, se arrojan sacrílegamente a la temeridad de una denuncia falsa o de una deposición maliciosa, y después truecan la verdad sobre el círculo del tiempo, porque no temen ser castigados. Al fin, ellos se quedan riendo y el infeliz acusado con una cicatriz eterna en el honor, aunque haya sanado la herida que le abrieron los atropellamientos de una persecución injusta.

Nuestro invicto Rey Felipe $V$, conoció, con indignación de su real ánimo, que todos estos daños procedían de no guardarse las penas impuestas por las leyes contra falsos testigos $\mathrm{y}$ delatores, y mandó promulgar aquel celebêrimo Auto acordado del título 17, libro 8' de los de Castilla, para gue nunca sc dispensase el castigo de semejante delito; y no ocultándose a su piadoso corazón las desgraciadas experiencias de este crimen en las Américas, despachó Real Cédula de Madrid, a 10 de agosto de 1705 , para que se ejecutara inviolablemente la disposición de aquel Auto acordado de Castilla, reencargando al mismo tiempo a los tribunales la puntual observancia de las leyes del reino. ${ }^{17}$

El único merlio de contener tales excesos, es que los demás Gobernadores $\mathrm{y}$ Jueces, hagan por sus personas las sumarias en los delitos graves, examinando también por sí mismos a los testigos en causas arduas, civiles o criminales, sin dar comisión al escribano, receptor ni alguacil para esto, como lo dispone la ley 5 , título 16 , libro $2^{\circ}$ de Indias, y la ley 7 ,

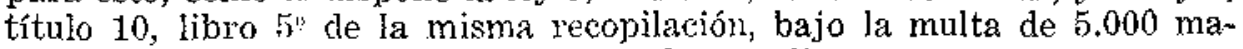
ravedies impuesta contra el Juez que no la cumpliere.

La presencia de los Jueces infunde tales impresiones de respeto 
a la verdad, que al instante se conoce al que miente, en el titubear, en la palidez y en otras vitalidades del semblantc. Entonces un Juez astuto y prudente se vale de los careos y de la amenaza y de otros medios legales para que conste la verdad y se le dé satisfacción a la causa pública y particular.

Esta cautela se hace indispensable cuando fueren indios los testigos o los reos (como sucede regularmente), porque esta miserable gente, por lo común, se abate a la fuerza de quien lo juzga, y sólo declara lo que percibe que agradará al que le pregunta, sin reparar en lo vcrdadero ni en lo falso; y así conviene que las averiguaciones se hagan por un Juez imparcial, que no les manifieste interés y que con la humanidad les quite su timidez congénita.

Párrafo cuarto. - Consulta de las sentencias criminales con la Real Audiencia.
$P$ Gobrimo deoen tener muy presente los que las sentencias pronunciadas sobre delitos de falsedad y de otras especies semejantes, deben consultar antes de su ejecución, con la Real Audiencia del Distrito, remitiendo el proceso íntegro, para que allí se examine y fenezca sumariamente; y la consulta se hace al tenor siguiente: ${ }^{18}$ - "M.P.S.:

"Por la causa adjunta se servirá V. A. mandar ver la sentencia "que contra N. N., vecino de esta Villa, he pronunciado en ella; la que, "siendo de superior agrado, se servirá canfirmar o mandar lo que sea de "su arbitrio.

"Dios güe. a V. A. los años que sus Reinos le necesitan." -

Hago esta advertencia para que los Gobemadores nuevos no equivoquen el espíritu de las leyes del Reino, antes de enterarse de las repetidas providencias con que se han explicado posteriormente.

La ley 9 , título 10 , libro $5^{\circ}$, y la 16 , título 8 , libro $7^{\circ}$ de Indias, previenen a las Audiencias que no impidan a las Justicias ordinarias la ejecución de las sentencias, que la pudieren y debieren tener conforme a derecho, en los casos que no se deben admitix las apelaciones para el efecto de suspenderla. Algunos Jueces han procedido a ejecutar sus sentencias, sin embargo de apelación, en delitos exceptuados, alegando por fundamento estas leyes y el pretexto de ser el único medio de ser respetados debidamente en sus personas y órdenes.

Pero no se han hecho cargo que por las Ordenanzas 17 y 18, títu1o 17 , libro $2^{\circ}$ de las Generales del Perú, mandadas guardar por la ley 37 , título $1^{\circ}$, libro $2^{\circ}$ de Indias, se halla ordenado que no se ejecute sentencia alguna, capital o aflictiva del cuerpo, sin precedente consulta de la Real Audiencia del Distrito, para evitar los gravísimos inconvenientes que pudieran seguirse de lo contrario.

En efecto, tal cual abuso experimentado en esta importante materia, motivó la expedición de varias Cédulas Reales y providencias del Superior Gobierno de Lima, ${ }^{19}$ para que el Gobernador de Potosí no ejecute pena capital o aflictiva de cuerpo, sin aprobación de la Real Audiencia de Charcas, ordenándole que admita para élla las apelaciones que se interpusieren.

En virtud de tode lo cual, lo que se debe de practicar y practica, 
es que cuando los Jueces inferiores pronuncian sentencia sobre delitos graves y exceptuados en que se debe negar la apelación suspensiva, entonces remiten los autos a la Sala del Crimen o Audiencia del territorio, por vía de consulta, para que examinada y fenecida la causa por la superioridad, breve y sumariamente, no se dilate su ejecución en perjucio del escarmiento público y buen ejemplo. Y esto es lo mismo que se dispone en las leyes citadas de la Recopilación de Indias.

Mas, no siendo exceptuado el crimen, ni denegada la apelación por derecho, en tal caso se publica la sentencia y dáse noticia a las partes, admitiéndoles el recurso que interpusieren. En esta diferencia de casos, procede la diversidad de decretos de que suelen usar las Audiencias, cuando los negocios criminales no se dirigen como es debido; unas veces se decreta: "Venga por su orden", cuando la sentencia de los inferiores no se reputa suficientemente justificada, bien sea por defecto de pruebas o por no juzgarse el crimen en el número de los exceptuados para negar la apelación; $y$ es cono si dijera que debe admitirse la apelación, para quc la caust conozca y decida en segunda instancia plenariamente. Otras veces se reticne en el tribunal el proceso, cuando el inferior omitió alguna actuación necesaria o no la instruyó debidamente, privándolo de conocer más cn ella, por su mal procedimiento.

Pero hallándose por todas partes justificada la sentencia, y el crimen de naturaleza que no admite apelación, se cxamina la causa muy breve y sumariamente por la Audiencia, y se devuelve al Juez que pronunció la sentencia, para que la mande cjecutar sin demora, como lo advierte nuestro criminalista Matheu; ${ }^{20}$ y de este modo asisten las Audiencias al castigo de los delitos, con el particular cuidado, ejemplo y buen gobierno que les encarga la ley 9 citada, título 10 , libro $5^{\circ}$ de Indias, y se administra justicia con libertad y sin dilación, para mantener la obediencia y el respeto de los superiores.

Párrafo quinto. - Proceđimiento contra los perturbadores de 1a paz $y$ culpados en motines.
TRO caso digno de explicación se propone en el Art. 17 de la Nueva Ordenanza, declarando entre los cuidados de los Intendentes, como principales, establecer y mantener la paz en Ios pueblos de sus Provincias, encargándoles a este fin, por el artículo 55, que soliciten saber las inclinaciones, vida $y$ costumbres de los vecinos, para couregir y castigar a los que causan inquietud $\mathrm{y}$ escándalo con trastornos del buen orden $\mathrm{y}$ policía de los pueblos.

Con este objeto se autorizó a los Gobernadores de América, por las leyes 19 y 20 , título 8 , libro $7^{\circ}$ de Indias, para echar de la tierra, si les pareciere conveniente, a algunos hombres inquietos, sin embargo de apelación, remitiendo la causa al Rey, para que en el Consejo se examine su justificación. I o mismo dispone la ley 18 del citado título y libro, con otras de la misma recopilación.

Al principio usaron los Gobernadores de esta facultad, que hasta ahora viene por cláusula en sus instrucciones y títulos, extrañando en virtud de ella a los que tenían por conveniente, por meras informaciones secretas formadas sobre los cargos que motivaban el destierro, sin oírles los descargos y disculpas; de lo que se siguieron grandes injusticias y 
atropellos de muchos hombres inocentes, falsamente acusados o perseguidos temerariamente por los Jueces desafectos.

Entonces se mandó expedir en 1568 otra Real Cédula, de que se recopiló la ley 61 , título 3 , libro $3^{\circ}$ de Indias, ordenando que, cuando pareciere conveniente a los señores Virreyes, desterrar de estos reinos y remitir a los de España algunas personas, las hagan salir luego habiendo procedido judicialmente y remitiendo la causa fulminada, para que se vea si tuvieron bastantes motivos para la resolución, por cuyo medio se vino a disponer que antes de ejccutar el destierro, se formase proceso, oyendo al reo, hasta ser convencido según fuero y derecho por el orden judicial.

Todos estos pasos se explicaron con más menudencia por otra Real Cédula de Valladolid, en fecha 4 de septiembre de 1551, dirigida al Gobernador de la Provincia del Paraguay y Río de La Plata (donde eran más frecuentes los abusos), ordenando que, cuando hubiere de desterrar a alguno fuera de la Provincia, conforme a sus instrucciones, no baste solamente la información formada sobre los cargos que motivan el destierro, sino también les oiga los descargos y disculpas que tuvieren y quisieren dar y se los reciba, enviándolo todo junto al Consejo de Indias. Pues habiendo de resultar de la exculpación una grave novedad y escándalo, con perjuicio irreparable en la persona o en los bienes del extrañado, pasa el negocio a ser materia de justicia, ${ }^{21}$ la cual exige esencialmente la observancia del orden judicial y un exacto conocimiento de causa, con audiencia formal de partes en juicio riguroso.

Así, deben proceder los Intendentes con arreglo a estas modificaciones, cuando por mantener la paz de sus Provincias quieren expulsar de ellas a algunos vecinos inquietos, para castigar su inobediencia, rebeldías y otros vicios opuestos a la pública tranquilidad, teniendo muy a la vista las disposiciones de la ley $3^{3}$, título 18 , libro $8^{\prime}$ de Castilla, donde se manda oír jurídiamente aun a aquellos que, por traidores a la Corona, se hallan despojados de sus bienes, puestos u oficios.

Lo más, es que aun en los casos de levantamientos y asonadas de gentes con armas y máscaras y otras parcialidades (contra quienes antes se procedía sin audiencia ni citación, sin proceso y sin tela ni orden de juicio), se ha ordenado últimamente, por una Real Cédula novísima, recopilada en la ley $8 *$, título 15 , libro 8 de Castilla, ${ }^{22}$ que se instruyan estas causas por las Justicias ordinarias según las reglas de derecho, admitiendo a los reos sus pruebas $y$ legítimas defensas, y consultando las sentencias con las Salas del Crimen de sus respectivos distritos, o en el Consejo, si la gravedad lo exige, para que más autorizada de este modo la opinión venerable de la justicia, quede el pueblo con mayor escarmiento en el castigo de los delincuentes, y la humanidad más honrada, sin riesgo de violarse sus respetables derechos, y sin peligrar la reputación de Ios vecinos honrados, los cuales suelen mezclarse muchas veces entre los vecinos culpados, con la confusión de un castigo violento y poco discernido por las miras circunspectas del derecho y de la justicia.

Con todo, hay caso en que se puede decretar la expulsión de una Provincia a otra, o de las Américas a España, sin necesidad de audiencia ni formación de proceso. Esto suele ejecutarse por vía de mero gobierno económico y político, cuando la permanencia de alguna persona poderosa amenaza inquietud en la tierra. Entonces, si no se trata de cas- 
tigarlo por término de justicia, basta una averiguación reservada por donde se haga constar al hey, que es sospechoso a la paz pública y en su virtud lo puede sacar de su Provincia el Gobernador, pasándolo a otras partes seguras donde pueda vivir acomodado con sus hijos y parientes, con la cercanía de algún Magistrado del superior respeto; pero se debe obrar en la ejecución con tal recato que no se cause nota, ni escándalo, ni peljuicio a la persona ni a sus bienes, según lo dispone la famosa ley 7, título 4 , libro $3^{\circ}$ de nuestra Recopilación de Indias.

Párrafo sexto. - Remoción $\mathbf{R}$ EPUTANDOSE pues tan sagrados los de los Subdelgados. fueros del honor, deben cuidar también los Intendentes de no revocar sin causa legítima, justa y probada, los nombramientos de los Subdelegados, por ia infame nota y grave desdoro que forzosamente debe resultar de la remoción, atendiendo la estimación de semejantes empleos y el decoro de las personas destinadas a este servicio.

Es verdad que el Art. 9" de la Nueva Ordenanza, autoriza a los Intendentes para que nombren por el tiempo de su voluntad, Subdelgados que administren justicia en los pueblos de sus respectivos Partidos. En virtud de esta cláusula, entiendo que se consideran con facultad bastante para ponex y quitar Subdelegados a su arbitrio, sin más causa que su mera voluntad. Confieso que no faltan algunos autores que apoyan esta pretensión, y sobran consejos de muchos interesados que influyen a esta libertad, para poder'se colocar sobre la ruina del prójimo; pero también aseguro que más de una vez han sido repuestos por el: Consejo los Tenientes removidos por los Corregidores, en aquellos tiempos que ellos los nombraban a su arbitrio, como ahora sc ejecuta con los Subdelegados.

$Y$ siendo mi fin guiar a los Intendentes de Potosí, por los caminos de la rectitud y del acierto, debo advertirles que, sin justa causa, no pueden removerlos, sin embargo de haber hecho sus nombramientos con la cláusula de amovibles por el tiempo de su voluntad.

Así lo dispuso el Rey Don Alfonso el Sabio, en la ley 2", título 10, parte $2^{a}$, y en la ley 23 , título $7^{\prime \prime}$, parte $1^{\mathrm{R}}$, ordenando que, cuando el Rey pusiere " $a$ cada uno en su lugar, cual le conviene por su linaje, por su bondad o por sus servicios, debe mantenerle con él, non faciendo por qué lo debiere perder". De cuyo texto y de otros concordantes, deducen Gregorio López y Graziano, ${ }^{23}$ que, con mayor razón, no pueden los demás superiores remover los Oficiales que hubieren diputado para la administración de algún oficio público, aunque sea amovible por el tiempo de su voluntad, siempre que no intervenge tal delito o causa que los haga indignos del primer. beneficio en que se les confió el honor y la dignidad.

Lo mismo sienten los sapientísimos Doctores Solórzano, Larrea, Antúnez, Valenzuela, Crespo de Baldaura, Zeballos y otros muchos con Jerónimo González, 21 hablando de las provisiones de los Notarios y de otros oficios que se nombran con cláusula de amovibles por el tiempo de la voluntad de los Obispos, y refieren varios casos y ejemplares de haber sido mantenidos por el Supremo Consejo y cancillerias, muchos Oficiales removidos sin causa justa y probada; de tal forma que el célebre Larrea extiende esta prohibición aun en el privilegiado juicio de visita 
siempre que los cargos no comprendan delitos comctidos in oficio oficiando. ${ }^{25}$

La razón es, por reputarse injuriosa a la estimación del removido, la privación del empleo a que le dio derecho el nombramiento y la posesión, respecto a que todos presumen culpa contra su honor por el mismo hecho de separarle del oficio. Al mismo tiempo es agravio para el mismo superior que hace la remoción, porque este procedimiento indica que halió al súbdito tan capaz para la afrenta, como le encontró para la honra.

Por esto es que aquella cláusula: "por el tiempo de su voluntad", no significa un arbitrio libre, absoluto $\mathrm{y}$ despótico para quitar o mantener al Subdelegado, según más le agradare al Intendente, sino una voluntad circunscrita dentro de los límites de la cquidad, reducido su beneplácito a arbitrio de buen varón, según la interpretación de Larrea. ${ }^{28}$ $\mathrm{Y}$ como ningún hombre prudente debe variar sus resoluciones, ni es decente a un juicio sazonado desagradarse sin causa de lo mismo que antes quiso, ${ }^{27}$ se debe concluír que el espíritu de la Ordenanza es que los Subdelegados sean mantenidos en los empleos, por todo el tiempo de la voluntad de los Intendentes, como es de una voluntad justa y bien arreglada, que nunca debe variar sin justa causa; siempre que los empleados conservaren el primer cstado de su honor y conductra.

Esta interpretación se halla bien persuadida en dos leyes del Reino, ${ }^{28}$ que hablando la primera de los Tenientes nombrados por los oficiales Reales propietarios, dispone que no sean removidos si no fuere por justas causas, comunicadas y aprobadas por el Presidente Gobernador del distrito; $y$ la segunda encarga que a los interinarios que nombraren los Excmos. Virreyes, se procure conservar y no se les separe sir causa legitima.

Unos y otros empleados se eligen a bencplácito de los superiores; pero aunque sea libre la voluntad de éstos para nombrar, no lo es para remover y privar, por la nota que causan las caídas de los empleos; luego, por la misma razón, no pueden Ios Intendentes separar a los Subdelegados, mientras duren los motivos de su primera voluntad; es decir, cuando no dieren causa contraria con algún delito, que los haga indignos del oficio.

Pues, no siendo así, los mismos servicios serían camino para la infamia, y viendo el Subdelegado que con obrar bien no merece más seguridad que el que obra mal, se haré insensible a la felicidad pública y solamente mirará en el empleo, un medio de negociar la fortuna con que se ha de sostener después de la desgracia que teme por instantes. Y véase aquí trastornado el bien general de la república, al golpe de una interpretación más o menos libre y extensa de sola una palabra de nuestra Ordenanza.

Sin embargo, cuando los Intendentes procedieren sin dolo ni malicia a la remoción de los Subdelegados, no hay razón en éstos para la queja, porque según regla de jısticia, ${ }^{29}$ no hace injuria a otro, quien usa de su derecho.

Pero es preciso prescribir ciertos términos, que sirvan como declaración de la bondad y sencillez del ánimo con que se procede, pues, si hubiera de estarse solamente a la palabra de los removentes, llegaría muchas veces a caracterizarse el dolo por buena fe. 
Según esto, no se deberá presumir malicia si la remoción se hiciere después de tres años, porque repatándose en derecho, por tiempo largo el trienio, ${ }^{30}$ basta para prueba de la buena fe de los Intendentes, el haber mantenido en sus empleos a los Subdelegados por otro tanto término, quedándoles desdc entonces libre la facultad de nombrar otro, para repartir entre todos los vecinos honrados, el honor y la comodidad, y al mismo tiempo procurar por este arbitrio equitativo el mejor servicio al Rey, a que se dirige la mutación cle Subdelegados permitida por la Ordenanza.

Párrafo séptimo. - Expulsión de extranjeros.- Se hace comentario histórico del título 27, libro $9^{\circ}$ de Indias.
$\mathbf{N}$ en extrema vigilancia sobre los extranjeros que comenzaron a pasar a estos reinos, clandestinamente, desde los primeros tiempos de la conquista, con el fin de limpiar la tierra de algunos que se había experimentado ser sospechosos y poco seguros en la fe, " y juntamente para impedir el trato ilícito tan perjudicial al comercio ${ }^{32}$ de España y destruír las correspondencias por donde adquirian las naciones enemigas, noticias muy individuales del estado de estas Provincias, mediante los extranjeros que vivían en ellas. ${ }^{33}$ Pero no pudiéndose evitar las reprobadas inteligencias de que se valían para pasar a muestros puertos, se decretó últimamente, por varias Cédulas en el título 27 , libro $9^{\circ}$ de Indias, 34 la expulsión general y absoluta de todos los extranjeros que hubieren pasado y pasaren en las Américas, sin estar habilitados con carta de naturaleza y licencia del Rey.

Sin embargo, pretendieron ser empadronados en justicia muchos extranjeros casados en España y otros avecindados en tierra firme, y fueron tan eficaces sus instancias, que aquel Gobernador hizo consulta al Rey, por quien se le despachó un capítulo de carta, inserto en Real Cédula fecha en Madrid, a 21 de febrero de 1562, declarando lo siguiente:

"Cuanto a lo que decís, que hay otro género de extranjeros que dicen ule "están casados en Sevilla, y otros que ha diez años y veinte años que están en esa "tierra, y se agravian de que tratéis de que se execute con ellos lo por nos manda"do; y suplicáis se os envíe a mandar lo que en caso semejante se hará; los extran"jeros que están en estos reinos y han vivido en ellos diez años, con casa y bienes "de asiento, y son casados en ellos con mujeres naiurales de ellos, por naturales son "habidos y tenidos, y así tendréis por tales a los que de esta calidad hubiere en esa "tierra y pasaren a ella; y los extranjeros que estuvieren en esa Provincia por diez "años y más tiempo sin licencia nuestra, sjendo casados y teniendo sus mujeres en "ellas, asi mismo los tendréis por naturales. Y los que hubieren pasado sin licencia "y fueren mercaderes, y no casados, los echaréis aunque hayan estado más tiem"po de diez años; y al extranjero que no fuere mercader y hubiere estado diez años "o más en esas partes, teniendo recindad y hacienda, como tal tenerle héis por na"tural, aunque no sea casado".

Con estas limitaciones de la primitiva prohibición hecha en Cédula de 7 de julio de $1592,{ }^{35}$ se fueron quedando en Indias muchos extranjeros, por cuyo motivo representó al Rey el Consulado de Sevilla, no haberse cumplido el Capítulo del asiento contratado con sus comisarios, sobre el sustento y conservación de la Armada destinada a la carrera de Indias, por cuenta de averías, para traer con seguridad las flotas que van. $\mathrm{y}$ vienen a ellas; y habiendo pedido que se pusiese remedio, se despachó entonces Real Cédula, de 2 de octubre de 1608, ${ }^{36}$ declarando que ningún 
extranjero, aunque sea de los que habitan en las Indias, no pucda tratar ni contratar, sin particular y expresa licencia del Rey, bajo la pena de perdimiento de bienes, impuesta igualmente a las personas supuestas por ellos, que contrataren en su cabeza.

$\mathrm{Y}$ porque cada día se iban introducicndo de nuevo extranjeros naturalizados por vecindad, con arreglo a la citada Cédula de 21 de febrero de 1561, mezclándose en los tratos y contratos, so color de estas naturalezas, en perjuicio de los vasallos, sc revocaron las referidas Cédulas en la citada de 1608, para el efecto de tratar y contratar en las Indias, previniendo que, para poderlo hacer, es necesario que hayan vivido en ellas por espacio de veinte años continuos, y los diez de ellos con casa y bienes raíces de valor de 4.000 ducados; y estando casados con natural o hija de extranjero nacida en estos reinos, con tal que no puedan gozar ni usar de este privilegio, sin que primero haya declarado el Consejo haber cumplido con estos requisitos, en vista de las informaciones y de las diligencias con que se debe instruír el recurso, según las prevenciones de las leyes 31 y 32 , título 27 , libro $9^{*}$ de Indias.

Ultimamente, en vìrtud de lepresentaciones que hizo el Marqués de Mancera, Virrey de México, sobre las lazones que alegaron para no ser expelidos los extranjeros, en una Junta de tres Oidores, que formó para oír sus expresiones, sc declaró por Real Cédula de Madrid, su fecha a 26 de enero de 1674,que se debian guardar en todo las Cédulas mencionadas, de 14 de julio de 1561 y 21 de febrero de 1562, y que aun no se hiciera novedad cn cl género de extranjeros que en ellas se refieren, advirtiendo que esto se entiende para en cuanto poder continuar su asis tencia y habitación en las Indias; $y$ lo mismo se entienda con los que hum biesen sido bautizados en ellas; pero, cn cuanto a tratar y contratar con los de España, sólo Io pudieran hacer los que tuviercn los requisitos dispuestos en la Real Cédula de 8 de octubre de 1608, recopilada en la ley 31 , título 27 , libro $9^{\circ}$ de Indias.

Aunque estas Cédulas no se recopilavon literalmente en las leyes del título 27 citado del libro $9^{\circ}$ de Indias, se encucntran en varias de ellas muchas prescripciones que sostienen la naturaleza adquirida por vecint dad y habitación, como título de excepción en los extranjeros para no ser expulsados de las Indias. Examinando el contexto de la ley $1^{a}$ del citado título y libro, que se reduce a tres partes, se ve que dospués de disponer en la primera que ningún extranjero pueda tratar ni contratar en las Indias ni pasar a ellas, si no estivierc habilitado con naturaleza y licencia del Rey, bajo de pena de perdimicnto de las mercaderías y demás bienes. para la Cámara de S. M., determina, en la segunda parte, la misma pena contra los extranjeros que habitaren en las Indias y en ellas trataren y contrataren sin real licencia, induciendo coz esta diversidad de capítulos, que hay extranjeros que pueden habitar en las fndias, aunque estén prohibidos de comerciar en ellas.

Esto no se debe entender de los extranjeros naturalizados por rescripto del Príncipe. Lo primero, porque de esta clase de personas trata separadamente la ley 31 del expresado título y libro; $y$ debiendo ser distinta esta ley de la piimera, es preciso que sean también distintos los casos proptestos en clias. Lo segundo, porque eì extratijero habilitado con carta de naturaleza y licencia del Rey, puede tratar y contratar en las Indias, conforme a las leyes $1^{\text {y }} 31$ ya citadas: luego, cuando se habla 
de extranjeros que habitan en las Indias con prohibición de comerciar, se entiende de aquellos que han adquirido naturaleza por vecindad; los cuales, aunque pueden vivir en las Indias, no tienen facultad para comerciar en ellas, en perjuicio de los vasallos españoles, según las Cédulas referidas de 1561 y 1562, despachadas para el Gobierno de tierra firme y Canarias.

Ia misma interpretación se deduce del tenor de la ley 31 susodicha, pues, previniendo las diligencias con que los extranjeros deben instruíf la pretensión de naturaleza para obtener la Rcal Cédula de su concesión, declara que este requisito y las demás calidades expresadas en la ley 31 citada, son necesarias pala que un extranjero pueda ser tenido por natural para efecto de tratar y contratar en las Indias, que es suponer tácitamente que hay otio género de naturaleza que sc adquiere por diferente título y para distinto efecto de lo que es tratar y contratar; y por consiguiente, que un extranjero puede ser tenido por natural en las Indias, para efecto de habitar y vivir en ellas, aunque no lo pueda ser para tratar y contratar sin expresa Real Cedula de habilitación, que es lo mismo que se resolvió para tierra firme y Canarias.

Aquí se ve claramente que el espiritu de nuestra legislación no fue oponerse a las anteriores Cédulas, que se recopilaron después en el título 27 , de los extranjeros, sino más bien que, juntando lo sabio con lo tím mido, dejó en su vigor la tolerancia de los extranjeros naturalizados por vecindad; pero, al mismo tiempo quiso contener el progreso abusivo de la habitación de estas gentes, con suprimir las cláusulas expresadas de permisión, por no darles ansa para pasar a las Américas con la esperanza de no ser expulsados de ellas después de haber vivido diez años o más en estas partes, con vecindad y hacienda. Esto, ya se ve, desanima a los extranjcros; pero al mismo paso debe exitar a los Magistrados sabios para hacer justicia, disponiendo la materia en tal forma que, los particulares en quien cesa la razón prohibitiva, no padezcan.

Porque, como se explica en la ley 10 del citado título y libro, la principal prohibición comprende a los tratantes y a los que viven de vecindad marítimos, para evitar correspondencia con los enenigos de la Corona; pero también encarga que se conserven las personas que fueren útiles y necesarias, guardando la integridad de nuestra santa fe católica.

Bajo de estas sabias precauciones, se exceptúan de expulsión los Oficiales mecánicos y los demás artistas útiles a la república ${ }^{37}$ y juntamente los extranjeros compuestos legítimamente; ${ }^{38}$ pero para que en ningún tiempo se haga peligrosa su residencia, se debe tomar conforme a otra ley, 39 la providencia inteligente de retirarios tierra adentro, con cargo a los superiorcs a cuyo mando estuviere el Gobierno, para que celen la conducta, ocupaciones, empleos. y manejo de semejantes personas, para remediar oportunamonte con estas noticias, cualesquiera excesos.

Ejecutando esto mismo cop los demás extranjeros católicos y amigos de la Corona, naturalizados por vecindad en el reino, habría cumplido con todas las leyes un Gobernador sabio y prudente. Porque este género de gentes se debe reputar útil, conveniente y necesario para el aumento de la pobiación de estos reinos; y por consiguiente deben ser conservados como personas en quicnes cesa lo principal de la prohibición de nuestras leyes.

$\mathrm{Y}$ aun cuando su espíritu no estuviera tan claro, debiamos seguix 
esta interpretación, por ser la más conforme a la ley 66 , Cap. $5^{\circ}$, título 4\%, libro $2^{\circ}$ de Castilla; pues, hallándose ordenado en la ley 2 , título ${ }^{\circ}$, libro 2 de Indias, que se guarden las leyes de Castilla en lo que no estuviere decidido por las de estos dominios, es preciso tolerar conforme a la ley 66 citada a los extranjeros que hubiesen adquirido naturaleza de vecindad, con arreglo a la ley 2 , título 24 , Partida $4{ }^{*}, \mathrm{y}$ a las leyes $14 \mathrm{y}$ 19, título 3, libro $1^{1}$ de Castilla.

Que esta inteligencia sea la más conforme a la benéfica intención de nuestros Reyes, se prueba convincentemente con la resolución que se tomó a instancia de la ciudad de Buenos Aires, en la súplica que interpuso de la Real Cédula de 25 de abril de 1736, en que se mandó expulsar y remitir a España los extranjeros que residiesen y comerciasen en la América, sin el requisito de licencia y carta de naturaleza. Fue cl caso que, por Cédula anterior de 27 de marzo de 1727, se mandó hacer represalia y embargo de las personas y bienes de los ingleses e irlandeses, exceptuando los católicos avecindados en las Indias, como no hubiesen estado ni estuviesen sujetos a ingleses; con cuyo ejemplar pidió dicha ciudad el mismo indulto para los demás extranjeros, alegando la necesidad de poblar estas tierras, por la poca gente que hay en ellas y las malas consecuencias que se seguirían de dejar abandonadas sus mujeres y familias, mayormente cuando de echarlos ticrra adentro, no se cumplía el literal contexto de la Cédula del año 1736 y ser imposible su remisión a España.

En vista de todo, se despachó Real Cédula de San Ildefonso, a 11 de octubre de 1742 , resolviendo:

"Que a los portugueses casados y radicados con hijos, de algún tiempo ade"lante, se les disimule la permanencia sin molestarlos en su vecindad; a los labr:"dores y artesanos que sirven oficios mecánicos y precisos a la república, se les man"tenga, siendo en aquel número que prudencialmente se considere conveniente; $y$ "que, a los recién venidos, no radicados todavía, los solteros y vagabundos, se ha"gan avecindar tierra adentro haciendo retirar e internar también a los que tuvie"xan chacras a la lengua del agua."

Luego, el no haberse tomado providencia con los extranjeros ya radicados de mucho tiempo con vecindad y hacienda, fue no querer hacer novedad con ellos, reputándolos por naturales de estos reinos, para efecto de vivir y habitar en ellos, con arreǵlo a las Cédulas anteriores sobre que he fundado mi interpretación.

Posteriormente, se despachó, entre varias Cédulas, una de Buen Retiro, fecha $1^{\circ}$ de febrero de 1750 , y otra de San Lorenzo, a 17 de octubre de 1767, mandando guardar la primera las leyes 31 y 32 del título 27, libro $9^{\circ}$ de Indias, con la Real Cédula del Sr. Don Carlos Ir, de 30 de septiembre de 1670, recopilada en la ley 35 del mismo título y libro, para que no se permita ni tolere con motivo ni pretexto alguno, que los extranjeros de cualquiera calidad que fueren, residan, traten, comercien ni se avecinden en las provincias, ciudades o lugares de Indias; y la segunda ordenó la expulsión y envío a España de los clérigos y religiosos extranjeros habitantes en América.

Pero, la Cédula de 1750 , se debe entender solamente con los extranjeros que no estuviesen naturalizados por vecindad y habitación, según queda explicado arriba; y la otra Cédula de 1767, se debe ejecutar absolutamente, respecto que los religiosos extranjeros no pueden servir para aumentar la población, cuyo interés hace reputar útiles y necesarios a los demás. 
Sin embargo, yo considero más conveniente y más legal, que no se aplique este indulto a todos los extranjeros indistintamente, sino únicamente a aquellos que por la probidad de sus costumbres o por su industria, se consideren útiles para el adelanto y honor de nuestras poblaciones; pero aun con éstos, será menester usar del arbitrio de conminarlos con la expulsión, si, dentro del término de cinco años, no presentasen ReaI Cédula de naturaleza y habilitación, o al menos la que llaman de tolerancia; par'a que atemorizados los demás con este rigor, no se detengan en las Américas. $Y$ si contintaren residiendo, no se les hará injusticia en expulsarlos, porque rigurosamente hablando, la naturaleza por vecindad, amparada por las Cédulas antiguas que hemos referido, sólo debe aprovechar a los extranjeros que ya estuvieron radicados al tiempo de su despacho, $\mathrm{y}$ de ningún modo a los que hubieren pasado después contra las prohibiciones de las leyes, respecto de ceñirse el indulto a los primeros, sin hablar de estos últimos.

Si usando de esta precaución consiguieren carta de naturaleza o de tolerancia algunos extranjeros, quedando habilitados para los efectos de residir y comerciar en las Américas; no por eso deben ser admitídos a los honores y oficios de la república, a menos que en la Real Cédula se les conceda expresamente la facultad para obtenerlos, por no ser bastante la naturaleza por privilegio, y fundarse estas dignidades y em pleos en la naturaleza por origen.

Así lo sienten el doeto Gregorio López, Salcedo y Antúnez, ${ }^{40}$ fundados en que los Reyes han concedido el honor y privilegios de Alcaldías y Regimientos a los vasallos de sus reinos, no por razón de la persona, sino por respeto de la tierra en que nacieron y de donde son naturales. Y como el extranjero no consigute la naturaleza del origen por el rescripto, no puede la naturaleza fingida obrar los mismos efectos que la realidad del origen; por eso el privilegio de la naturaleza verdadera, en que consiste el "goce de Alealdías y Regimientos, no es extensible a los extranjeros, a menos que se les habilite expresamente para obtenerlos. Más de una vez he visto suscitar pleitos muy reñidos sobre este punto, y deben tenerlo muy a la vista los Intendentes, para cortar discordias que acaso se pudieran ofrecer en los Cabildos, en las elecciones de oficios concejiles.

Párrafo octavo. - Sobre la guarda do la inmunidad local y personal.- Se refieren los casos exceptuados y se explica el nuevo método de extraer a los reos.
$\mathbf{I}$ niosa en defender a los reos, que a fuerza de disputas consiguieron extender la inmunidad a casi todos los delitos; pero era tan reñida la variedad con que hablaban sobre esos pocos casos exceptuados, 41 que cuando llegaba a disputarse un pleito de inmunidad, se confundian los derechos de tal forma, que o no se acababa el pleito jamás, ${ }^{42}$ o se fenecía siempre a favor del delincuente, ${ }^{43}$ con muchas escandalosas incidencias sobre censuras, sobre fuerzas y sobre otros puntos perturbadores de la paz entre las potestades públicas.

Esta amplísima benignidad extendida sin límites a todo género de crímenes y a todas las Iglesias de cualesquiera pueblos y ciudades, dio con el tiempo tanta ansa a la malicia, que habiendo multiplicado hasta lo infinito sus delincuentes invenciones, ya fue preciso ocurrir a la San- 
ta Sede, para que declarase otros nucvos casos en que tampoco valiese a los reos el sagrado asilo de los templos, y al mismo tiempo disminuyese el número de éstos, para contener la insolencia de los criminosos.

En efecto, después de muchas juntas, congregaciones, consultas y súplicas, despacharon sus Bulas en diferentes tiempos, los Sumos Pontífices Gregorio XIV, 44 Benedicto XIII, 45 Clemente XII, 46 Benedicto XIV ${ }^{47}$ y Clemente XIV, ${ }^{48}$ minorando en ellas el privilegio de la inmunidad y el número antiguo de los asilos, para contener a los pueblos en sus deberes y reprimir a los hombres malévolos.

Casos exceptuados de la in- DEGUN estas ruevas providencias se han munidad local. decidido muchas dudas y cuestiones antiguas, que conforme a ellas y a nuestras leyes, resultan exceptuados y excluídos del beneficio de asilo sagrado los casos siguientes:

Los ladrones públicos; 49 los salteadores de caminos; los que talaren campos; los que se atrevieren a cometer homicidios y mutilaciones de miembros en las Iglesias públicas y sus cementerios; los que hicieren muerte a traición; los ascsinos y reos de herejía o lesa Majestad; 50 los homicidas de caso pensado y deliberado; los falsificadores de Letras Apostólicas; los superiores y empleados en los Montes de Piedad, u otros fondos públicos o Bancos, que cometieren hurto o falsedad; los monederos falsos; los que cercenan monedas de oro o plata; los que fingiéndose Ministros de Justicia se entran en las casas ajenas y cometen en ellas robos con muerte o mutilación de miembros; ${ }^{51}$ los indicados, procesados o en rebeldía llamados por edictos y pregones y condenados por causa de homicidio, aunque sea hecho en pendencia, con armas cortantes o de fuego, o con palo o piedra, siempre que el homicidio no sca casual o por la propia defensa; los que hubieran vulnerado a otro mortalmente, constando el peligro de la herida por certificación del cirujano; ${ }^{\$ 2}$ los cambiadores, mercaderes y sus factores, quebrados por su culpa y aizados dolosamente cor bienes ajcnos; ${ }^{53}$ los deudores fiscales por causa de tributos; fallidos por su culpa; 54 los soldados, pilotos, marineros y artilleros desertores de las Armadas y Flotas de América; 55 los siervos fugitivos; ${ }^{56}$ los ladrones, aunque sean de un simple hurto; ${ }^{57}$ los salteadores o asesinos de caminos, aunque sea de un solo hurto, siguiéndose muerte o mutilación de miembros; los que cometen en la Iglesia, cementerio o en parte oculta de ella el pecado nefando y el estupro violento; ${ }^{\circ 8}$ los que sabiendo o teniendo noticia del intento o delito de lesa Majestad, no lo revelan e impiden por esto medio; 59 los que se juntan en asonada y conspiran a robar o quitar las regalías de Su Majestad, en todo o en parte; ${ }^{6}$ los que atentaren en cualquiera forma contra la persona de Su Majestad; ${ }^{61}$ los que violan Iglesias rompiendo sus puertas 0 quemándolas; ${ }^{62}$ Ios refugiados extraídos con engaño, ${ }^{63}$ respecto de no sufragarles ninguna extracción hecha con positiva violencia; 64 los aprehendidos fuera del lugar sagrado, que en otro tiempo hubiesen sido extraídos de él, que es lo que llaman en práctica: Iglesias frías; 65 el fugitivo de la Cárcel, cuya prisión se hizo por delito exceptuado; los infractores de Cárceles; los que por accidente tocaren en lugar inmune al tiempo de ser conducidos a las Cárceles; los ya sentenciados; los blasfe- 
mos, sortílegos y sacrílegos; los apóstatas de la fe o renegados; 66 los herejes; ${ }^{67}$ los condenados a galeras, presidios y arsenales; ${ }^{68}$ los soldados desertores; ${ }^{69}$ los adúlteros; ${ }^{70}$ con otros muchos casos que explican Socucva, Martínez y Don Francisco María Cirino. ${ }^{71}$

A estos se pueden añadir por notables, que no gozan de inmunidad, los reos que merccen pena corporal, ${ }^{2}$ y los que mataren a su enemigo a sangre fíía, pues, aunque éstos no eran tenidos antiguamente por alevosos ni se les excluía de la lglesia, según Acevedo y Narbona, is ya no tiene lugar este privilegio, después de la Bula citada de Clemente XII.

Personas que gozan deI pri- $\mathbb{W N}_{\text {cuanto a la inmunidad personal o pri- }}$ vilegio de Fuero, vilegio del Fuero, no lo goza el clérigo de prima tonsura que no tenga beneficio eclesiástico, aunque haya observado las condiciones del Tridentino, siempre que se le justifique haber cometido dos homicidios con ánimo premeditado y deliberado; 74 lo mismo el de órdenes menores y tonsura, que no hubiese observado las condiciones prescritas por el Tridentino, y por consiguiente sólo puede aprovecharle la inmunidad local, en los casos que a los legos; "ii pero la declaración de la observancia de dichas condiciones, toca al ectesiástico. is Tampoco goza del fuero el que después de cometido el delito de homicidio, consiguiesc hacerse clérigo de órdenes menores, $i$ ni todos los demás que numera por menor Martínez, en su Librería de Jueces. 78

Los seculares culpados en motines y traiciones, que por evadirse del castigo se hicieren clérigos o entraren en religión (estando ya antes procesados), quedan sujetos a las Justicias Reales, por la ley 10, títuto 12 , libro $1^{\text {de }}$ Indias, y aunque sean libres y exentas sus personas, como resuelve Carleval, explicando varias Bulas Pontificias, ${ }^{79}$ pero quedan sujetos al Juez laico en cuanto al conocimiento de sus causas y disposición de sus bienes, para poder entender y seguir Ios procesos formados antes del ingreso a la religión, e imponerles pena pecuniaria, procediendo a la confiscación de sus bienes, sin tocar a las per'sonas, que deben dejarse al eclesiástico, para que después de castigados según la gravedad del delito, los echen de la tierra, conforme a la prevención que se hace en la segunda parte de la ley citada.

Asimismo está declarado por la Real Cédula de Buen Retiro, a 29 de julio de 1716 , ${ }^{81}$ que no gozan ni deben gozar en adelante, por ninguna razón, de las inmunidades y fuero eclesiástico, personas que no sean eclesiásticos o regulares, aunque sean criados y familiares de todo género de Prelados, y aunque vivan y conmoren intra claustra, pues, estas deber y han de estar sujetas a la jurisdicción real en todas las causas civiles y criminales, reservando sólo los templos, lugares sagrados, Prelados eclesiásticos, religiosos y personas regulares; aunque por esta razón se exceptúen las estancias, chacras y haciendas de estos, respecto de que no deben gozar de inmunidad eclesiástica por ninguna causa, por no ser lugares dedicados a Dios, sino profanos.

Tampoco gozan de fuero alguno, en lo perteneciente a Real Hacienda, los familiares del Santo Oficio, Tesoreros de Cruzada y otros cualesquier Ministros que no scan eclesiásticos; y así está ordenado por Real 
Cédula dada en Barcelona, a 16 de febrero de 1702, (declarando la ley 15 , título 19 , libro $1^{n}$ de Indias) que se apremie por todo rigor de derecho, con prisión y embargo de bienes a todos los susodichos, a la satisfacción de los derechos reales y demás que toque a la Real Hacienda. ${ }^{82}$

\section{Reducción de Asilos. $\mathrm{H}_{\text {ABIENDO acreditado la experiencia, }}$ las multiplicadas excepciones de la inmuni-} dad no ser suficientes para contener y reprimir a los hombres malvados, se consideró por único medio el de minorar el número do los refugios y asilos en todas las ciudades y lugares del reino; y bajo de este concepto, se impetró por el Rey, Nuestro Señor Don Carlos III, del Sumo Pontífice Clemente XIV, la Bula que comienza: "Ea semper..." dada en Roma a 12 de septiembre de 1772 , por la cual se redujo la inmunidad local de cada pueblo, a sola una Iglesia, y a lo más a dos, según su respectivo vecindario, encargando a los Ordinarios de cada Diócesis, por el párrafo 14 de dicha Bula, el señalamiento de las Iglesias o lugares sagrados destinados para el asilo, declarandó que en las Iglesias señaladas solamente se debía guardar y observar la inmunidad eclesiástica y el sagrado asilo, según la forma de los sagrados cánones y de las Apostólicas Constituciones, y ninguna otra Iglesia o lugar sagrado, santo o religioso se deberá tener por inmune, aunque por: derecho o costumbre lo haya sido antes y en adelante debicra scrlo.

En virtud de esta Bula comunicada a las Américas por Real Cédula de El Pardo, a 14 de enero de 1773, están señaladas por asilo en esta Villa, las Iglesias de San Pernardo y San Juan, muy distantes una de la otra y situadas en los cantos (extremos) opuestos de la población; desde cuyo señalamiento quedó quitado el beneficio de la jımunidad local a todas las demás Iglesias, Monasterios, Oratorios y lugares santos de la Villa; y desde este mismo tiempo deben entenderse limitadas a los dos lugares citados de refugio, todas las doctrinas que hablan de immunidad local, debiendo valernos de las que con tanto pulso y discernimiento refiere Don Francisco María Cirino, ss en cuanto a la inmunidad de los cementerios, de los atrios, pórticos, claustros, portales y la circunferencia de las mismas Iglesias a distancia de cuarenta pasos.

El mismo autor 84 trata extensamente sobre la inmunidad del que se refugia al Santísimo Sacramento o al sacerdote que lo lleva por viático, o a la casa donde está de tránsito; y después de varias opiniones, resuelve, que se debe guardar la costumbre que se observare en cada lugar, y con esta misma distinción debe entenderse la resolución de Martínez ${ }^{85}$ sobre el propio caso.

Modo práctico de extraer a los reos refugiados en las Iglesias sin asilo, y de las que lo debieran gozar.
$\mathbf{P}$ ArA que se guarde la reverencia debida a los templos, al tiempo de extraer a los refugiados, de los que no gozan de inmunidad, deben los Ministros de la Curia secular practicar el oficio de ruego de urbanidad, pero sin usar de ninguna forma de escrito y sin exponer Ia causa de la extracción pedida al eclesiástico que, con cualesquiera títulos, en la ciudad o Villa, ejercierc la jurisdicción episcopal o eclesiástica, y por 
su falta, ausencia o repugnancia, se debe entender este ruego con otro eclesiástico de edad provecta que sca el más visible del pueblo.

Luego que fueren amonestados por el Juez, el Vicario eclesiástico, cl Rector o el Párroco de la Iglesia o el superior local, siendo Iglesia de regulares, deben en este instante, sin la más mínima detención y sin conocimiento alguno de causa, permitir la extracción del reo, la cual se debe cjecutar inmediatamente por los Ministros del tribunal eclesiástico si se hallaren prontos, y si no, por los del brazo secular, pero siempre con presencia e intervención de per'sona eclesiástica. ${ }^{86} \mathrm{Y}$ para evitar estos lances, sería muy conveniente que los Prelados de las Iglesias o Monasterios, cumpliesen exactamente con el tenor de la ley 2, título 5\%, libro 1 de Indias, en no admitir a los delincuentes que a ellos se acogieren; pero cuancio ya los tuvieren recogidos, no se debe impedir a las Justicias usar de su jurisdicción confome a la misma ley, bajo la responsabilidad y demás penas establecidas por derecho.

En cuanto a las Iglesias señaladas para el asilo, previene la misma Bula de Clemente XIV, ¿7 que se guarden inviolablemente las disposiciones de los sagrados cánones y las demás constituciones apostólicas, para no poder ser extraídos de allí sino en los casos permitidos por derecho y observando diligentemente las reglas prescritas por los mismos cánones.

Fn virtud de las disposiciones Apostólicas anteriores a que se refiere esta Bula, se hall suscitado en diversos tiempos cuestiones muy graves sobre la autoridad que debe formar el proceso acerca del caso exceptuado y reato del reo, y la calidad de las pruebas del delito para prenunciarse por exceptuado y hacer la entrega del reo a su Juez.

En una de las célebres pastorales ${ }^{\prime} \nsucceq$ de N. M. S. P. Benedicto XIV, se refiere individualmente la historia de todas las controversias y las resoluciones que se tomaron sobre los indicados puntos. La interpretación que hizo Farinacio de la Bula gregoriana, negando la entrega del delincuente de caso exceptuado por sólo indicios y presunciones, sin pruebas directas y concluyentes, aumentó nuevas dudas que motivaron las congregaciones tenidas en tiempo de Clemente II, y al cabo se resolvió que para la consignación del delincuente a la justicia secular, bastaba que del proceso formado por la Curia eclesiástica, resultasen pruebas verosímiles, indicios fuertes y urgentes, reservándose al tribunal secular instrúr mejor el proceso, aumentando las probanzas que falten al proceso eclesiástico, para constituír al reo confeso o convicto, aunque sea por la vía del tormento.

Inmediatamente siguió la nueva disputa, sobre si antes de la consignación del reo, debería oirsele su defensa, y después de muchos debates decidió Benedicto XIII, declarando que el reo podía extraerse del asilo a las Cárceles del Obispo por meros indicios, siempre que éstos fuesen bastantes para decretar la captura; y que resultando del proceso que en este estado debe formar el eclesiástico sin entrar en el punto de defensa, tales presunciones, cuales llaman los criminalistas ultra torturam se entregará entonces el reo al Juez secular, bajo la caución de restituírlo en el caso de purgar los indicios, después de oído el juicio riguroso, pero al mismo tiempo sin perjuicio de procedor a su castigo, no exculpándose el reo en sus defensas, de los cargos indiciados. 
Con esta constitución se conformó en todo la Bula de Clemente XII, confirmada posteriormente por otra de Benedicto XIV, ${ }^{89}$ con sola la diferencia de que los indicios con que se debe proceder para entregar el reo a la Curia secular, basta que sean los suficientes para la tortura, sin ser menester los de ultra torturam, como dispuso Benedicto XIII.

Para mejor inteligencia de las citadas Bulas, debo advertir aquí, que la entrega de los reos al Juez Real, se puede considerar en dos maneras: Es la primera, una entrega puramente provisional, para el preciso cfecto de asegurarlo en las Cárceles reales, con el fin de evitar su fuga y otros excesos que pudiera cometer saliendo de la Iglesia por la noche, para volver a refugiarse de día. La otra, es und entrega o consignación formal que se hace del reo a la Curia seculat como a su propio Juez, declarando constar en bastante forma el delito exceptuado y reato del reo, para que usando de su jurisdicción pucda proceder a castigarlo, si el reo no purgase los indicios en el juicio riguroso de sus defcusas.

Esta segunda entrega y consignación formal, es de la que hablan las constituciones Apostólicas de Gregorio XIV, Benedicto XIII, Clomente XII y Benedicto XIV. Y así, para extracr al reo de la Iglesia, con el fin de asegurarlo on las Cárceles reales, nio es necesario que preceda proceso jurídico, ni otra justificación por escrito del delito, porque sucedicndo cometerse algunos enormos y gravísimos, de la clase de los que por su notoriedad y circunstancias se concibe que son exceptuados de la inmunidad, entonces pueden y deben las Justicias, usando de la potestad económica y policía que ejercen en nombre del Rey, perseguir los roos en cualquier parte y extraerlos del sagrado lugar donde se refugien ( $\sin$ porjuicio de lo que a su tiempo y con conocimiento de causa se declarase por Juez competente sobre el goce del asilo), no para castigarlos, sino únicamente para asegurarlos; pidiendo para la cxtracción del reo, licencia al eclesiástico, por escrito o verbalmente si lo exigiese la necesidad y riesgo inminente de su fuga, pero sin la precisión de manifestarle la sumaria ni otra formalidad que la caución juratoria, que debe ofrecerse y darse, de no causar daño al delincuente, hasta que por el mismo eclesiástico se declare si debe o no gozar de la inmunidad de la iglesia; y negándose contra toda razón el Jucz cclesiástico a dar la licencia que se le pida, deben proceder las Justicias reales a la extracción de los rcos, ${ }^{90}$ asegurándolos en sus Cárceles, bajo las mismas precauciones de la caución juratoria, según se halla prevenido por método seguro para este gémero de negocios, en Real Cédula fecha en El Pardo, a 5 de abril de 1764, mandada guardar por otra, de San Ildefonso, a 1" de agosto de 1768.

Para los dependientes del fuero de Guerra, se comunicó, posteriormente, a todos los Juzgados y cuerpos militares, a consulta del Consejo de Guerra, por su Secretario Don Tomás Portugués, la resolución de Su Majestad, de 7 de octubre de 1775 , para que todos los reos militares refugiados o que sc refugiaren en la Iglesia, y según ordenanza estén o deban ser procesados, se les extraigan inmediatamente, con la caución de no ofender; que se les ponga en prision segura; que se les forme el correspondiente sumario y que tomada su confesión, con las citas que de ellas resultaren, en el preciso término de tres días, cuando no haya motivo urgente que exija alguna dilación, se remitan los autos al Consejo de Guerra, para que en su vista y según las calidades del delito, providencie el destino del reo o que se pida la consignación formal de su per- 
sona, o que se forme la competencia con la jurisdicción cclesiástica, som bre el goce de inmunidad.

Esta Real Orden, que ratifica en todas sus partes lo dispuesto en las dos Reales Cédulas antecedentes, se comunicó a la Capitanía General de Bucnos Aires, por el Excmo. Sr. Don José de Gálvez, con fecha 10 de septiembre de 1776 , y en conformidad de lo resuelto en ella, se ordenó nuevamente en la Ordenanza de Intendentes de América, ${ }^{91}$ por punto general, que la remisión del sumario que en España se hace al Consejo, se haga en Indias a los Virreyes, Capitanes Generales, Comandantes o Gobernadores independientes, siendo los reos militares, previniendo que si no lo fuesen, se han de hacer las remisiones a las Audiencias respectivas. Con lo que se acabaron de aclarav las dudas antiguas de este importantísimo punto, sin que a los Grobernadores y demás Jueces reales les quede otra cosa que hacer con los refugiados, más que extraerlos de la Iglesia, con la caución cle no ofender, en los términos referidos arriba, $y$ después remitir el sumario al respectivo tribunal, según la clase de los reos, para que providencie su destino o su consignación formal a la competencia con el eclesiástico.

Tas Justicias deben arreglarse en todo a las providencias que tomare la superioridad $y$ porque procediendo a su cumplimiento, puede ocurrirles la precisión de introducir, preparar y practicar los recursos de fuerza en conocer y proceder por medio de los defensores de la real jurisdicción, sin incidir en los decretos medios que se dan por las Audiencias, proveyendo: "Por ahora no hace fuerza el eclesiástico", o "No viene en estado el proceso", se estableció nueva forma, por Real Cédula fecha en San Lorenzo, a 18 de octubre de 1770, declarando el método con que deben proceder los defensores de la jurisdieción real. ${ }^{92}$

Esto es, que se instruya la sumaria, verificando por ella el agresor del delito y su cuerpo, y se proceda adelante en la causa según corresponda por derecho, intorin que el Juez Eclesiástico no se lo impida ni perturbe con exhortos comminatorios ofuminación de censura.

En este caso, debe el Juez real despachar cxhorto a aquél para que se abstenga de impedirle o perturbarle su jurisdicción, por no competerle al conocimiento sobre una persona lega y un delito exceptuado, protestando, de lo contrario, el recurso de fuerza, remitiéndole para su instrucción un testimonio de la sumaria formada, por donde le haga ver la notoria calidad de la persona del reo y del delito, ${ }^{93} \circ$ que en su defecto tome el mismo Juez real el modo más lácil y expedito de comparecer por sí o por Procurador ante el eclesiástico, declinando de jurisdicción, formando artículo sobre ella y presentando testimonio íntegro de los autos, y siguiendo la declinatoria por sus trámites, protestando desde el principio el Real auxilio de la fuerza.

Si verificada la extracción bajo la caución juratoria expresada, estrechase el eclesiástico a los Jueces reales, abreviándoles los términos sin darles lugar a que formalicen las diligencias del sumario, en esta ocuriencia deben estos insistir en la declinatoria y pedir al Eclesiástico que sobre clla reciba la causa a prueba, por tiempo limitado y suficiente a que el defonsor de la jurisdicción real pueda concluir la justificación de aquellas calidacles en que funda su conocimiento, con exclusión del tribunal eclesiástico, y éste y el reo sus defensas; reiterando, de lo contrario, la apelación y el recurso de fuerza, pór cuyo medio es preciso que se 
consiga la admisión de la prueba, o que lievados los autos a la Audiencia, se dé en ella el decreto de tercer gémero correspondiente por su denegación, y ordene reponga lo obrado, después de la petición de prueba.

Si aun después de evacuado este paso, y resultando por él sel el delito de los exceptuados, procedieren los Diocesanos a declarar la inmunidad del reo, entonces, conociendo el fuez real lo exceptuado de delito, debe abstenerse de apelar del auto declaratorio, instruyendo cn derechura el recurso de fuerza, en conocer y proceder.

Con estas diligencias, se evacúa cnteramonte la causa de inmunidad y no es necesario hacer mérito de la apelación, ni seguir la fuerza en no otorgar; pues por esta se aventura y dilata la causa, y por aquella se acorta, abrevia y decide. Y como quiera que es el fundamento do ambas jurisdicciones (respectivamente hablando), la calidad de la persona, si es o no lega; la del lugar donde se acogió el delincuente, si es o no sagrado; y la del delito, si es o no de los cxceptuados; necesariamente debe prepararse e instruírse la sumaria a verificar estos extremos, porque así como es inconcuso que el Juez Eclesiástico hace fuerza en conocer y proceder en causa de inmunjdad local, cuando el sitio de donde se extrajo al reo, no es sagrado; también es indudable, que violenta la jurisclicción real, cuando el delito es de los exceptuados, respecto que para uno y para otro caso, son iguales los fundamentos y motivos legales.

Reos con goce de immunidad. S en las Iglesias de asilo se refugiaren algunos reos de delitos no exceptuados, que sean de costumbres pervertidas, quimeristas, uscandalosos, malentretenidos, vagos, sin más destino que la embriaguez y los robos, y por otro cualquier género de excesos perjudiciales a la quietud pública y buen ejemplo, resolvió el Nuncio Arzobispo de Nacianzo, en su Breve de 30 de junio de 1748 , 95 que manifestando al eclesiástico la prueba de la mala vida, perversión y delitos de los xeos, y pucsta su respuesta por le auténtica, se trasladen con su licencia a uno de los Prosidios de Africa, para que en aquellas Iglesias gocen de inmunidad, prestando los Jueces reales la caución de guardársela allí en cuanto a la vida y micmbros, y no en otra forma. Y si se negare a ello, se debe suspender todo procedimiento y dar cuenta al Rey, con testimonio. ${ }^{96}$ Pero esto se ha de entender en las Américas con las Audiencias y Virreyes, según la clase de los reos, dejando a su disposición el señalamiento de Presidios, respecto de estar prohibido ${ }^{97}$ que se remitan reos de América a los Presidios de Europa.

Se tiró a evitar con esta providencia el desorden y maldades que cometían los reos, saliendo clandestinamente de las Iglesias para pervertir a otros ciudadanos y escandalizar los pueblos, sobre el seguro de su impunidad con sólo volver a su refugio. $Y$ este mismo motivo dio mérito para prevenirse a los Jueces Eclesiásticos, en la ley 2, título 5, libro $1^{\circ}$ de Indias, que a los que pueden y deben gozar de inmunidad, no consientan ni den lugar a que estén en las Iglesias y Monasterios por mucho tiempo; y aunque por entouces no se declaró el destino que debería darse a estos reos, lo explicó últimamente el Breve del Nuncio, conformándose con el espíritu de nuestras leyes en mandarlos sacar de las Iglesias y Monasterios en que se refugiaren, para trasladarlos a las de los Presidios, 
donde nunca pueden tener tanta oportunidad para interrumpir el sosiego público.

Si bien por este merlio se ha de imponer al delincuente la pena de presidio, no por eso se viola la inmunidad eclesiástica, ni se contraviene a las disposiciones canónicas. Porque el destierro no es pena corporal, ${ }^{3}$ sino más bien una precaución civil, política y económica, para separar de la sociedad los individuos inquietos y perturbativos del buen gobierno y del sosicgo público. En ol mismo presidio se conserva el reo con la indemnidad de su vida y micmbros, según se le prometió en la caución. Nada más sufre que la scparación de las ocasiones de escándalo y mal ejemplo, para que su mala vida no inficione a los vecinos de probidad, que es lo mismo a que aspira la Iglesia, y por esto es que Caponi ${ }^{99}$ resuclve intrépidamente, que el reo extraído de la Iglesia con caución de impunidad de pena corporal, puede ser desterrado por el Juez real, respecto que la inmunidad, según Marta, 100 no aprovecha cuando no se ha de imponer al reo pena aflictiva del cuerpo.

La Iglesia siempre ha estado tan distante de patrocinar a los malévolos, que cuancio los reos se refugiaban en las Iglesias y Monasterios para salvar la vida, tomaban a su cargo los eclesiásticos el que hicieran graves ponitencias por sus delitos, sin dejarlos salir de ellas hasta haber satisfecho a la Divina Justicia, y Eenedicto XIV, ${ }^{101}$ después de alegar en comparación de esta disciplina, un célebro caso de San Bernardo con cierto ladrón famoso, ascgura por su parte, que muy lejos de apadrinar y defender maldades, solicitara la autoridad del Sumo Pontífice, para sacar do la lglesia a los reos de delitos no exceptuados, si fuesen enormes y repetidos, y hecho el proceso, condenarlos a una pena extraordinaria.

Fl célebre canonista Próspero Fagnano, con González y otros, ${ }^{102}$ siguiendo el mismo espíritu de la lglesia, acusan por delincuentes a los Prelados que se cmpeñan por salvar de toda pena a los reos, por muy graves que sean sus crímenes y excesos. Y concluye, que es contra justicia libertarlos de los cargos correctivos y satisfactorios de la parte ofendida. En cuya conformidad aconsejan que semejantes reos deben ser condenados a pena pecuniaria o a desticrro, trasladándolos a este efecto en las Iglesias de los presidios, para que al nismo tiempo de acreditarse el respeto a los lugares sagrados, queden corregidos los flelincuentes y purgada la república del contagio de sus micmbros perniciosos y podridos.

Párrafo noveno. - Matrimonios clandestinos. Se explica la ley $1^{\text {a }}$, título 10 , libro $5^{\text {n }}$ de Castilla, y la Pragmática Real fecha en El Pardo, a 7 de abríl de 1778 .

nio sin Párroco y testigos.
M tres maneras. Es la primera, cuando se celebra sin publicación de las proclamas y denunciaciones, dispuestas por la Iglesia, sin haber obtenido clispensación de ellas por legítima autoridad. La segunda, cuando premisas las proclamas, se contrae el matrimo103 I a tercera, chando se hace el casamiento sin precedente consejo o consentimiento de los padres. ${ }^{104}$ Todas tres clases de matrimonios se hallan estrechamente prohibidas por las leyes $y$ por los cánones, para contener con las penas a los que por no guardar las solemnidades de la Iglesia, en vez de matrimonios contraigan delincuentes concubinatos. 
La pena del matrimonio clandestino ha sido varia, según los tiempos. La ley $4^{*}$, título $3^{\circ}$, parte $4^{*}$, y un capítulo canónico, 105 impone tres años de suspensión de oficio al clérigo que asistiere a semejantes matrimonios. El Concilio toledano, el zenonerise, el coloniense y otros, imponen excomunión mayor late sentencie, contra el clérigo, contrayentes y testigos, como refieren varios autores; ${ }^{106}$ pero, en sentir de Salcedo, 107 una vez que los Sumos Pontífices y el Concilio de Trento no han fulminado otras censuras, debe creerse que en subsidio más bien que por intimidar a las almas, las han impuesto los Sínodos citados, añadiendo que los ignorantes no incurren en ellas, aunque la ignorancia de las censuras sea por culpa vencible, como no sea supina.

El Concilio Tridentino ${ }^{1 n s}$ deja el castigo al arbitrio del Ordinario, en virtud de cuyo precepto, dice Salcedo, ${ }^{109}$ que peca el Obispo, o su Vicario, que omitiere castigar a semejantes transgresores.

La ley 49 de Toro, que es la ley $1^{2}$, título $1^{10}$ del Lib. $5^{2}$ de Castilla, impone a los contrayentes, mediadores y testigos, la pena ipso jure concurrenda, de confiscación de todos sus bienes para la Cámara y fisco, y destierro perpétuo del Reino, declarando por justa causa de exheredación en los hijos, con la diferencia única de que, según Antonio Gómez, 110 sólo el padre y la madre pueden acusar y ningún otro del pueblo, ni aún el Juez, de oficio; pero, lo contrario sienten Acevedo, Sánchez y Zeballos; ${ }^{t 11}$ de forma que según este autor, puede el Juez real condenar de oficio a tales delincuentes, después de haberios castigado el cclesiástico en su fuero.

La mayor dificultad es, si para incurrir en estas penas, se diga matrimonio clandestino el que se celebra ante el Párroco y testigos, omitiendo injustamente las denunciaciones canónicas. Gómez ${ }^{112}$ cita muchos autores que sostienen la negativa, pero él defiende la afirmativa con muy fuertes razones ${ }^{113}$ y autoridades, que también pueden verse en Zenedo y Gutiérrez, 114 cuando ocurriere el caso para dar cumplimiento a la ley $1^{3}$ citada, título $1^{\circ}$, libro $5^{\circ}$ de Castilla, observando las doctrinas que quedan explicadas en su comentario.

La tercera clase de matrimonios clandestinos, que son los que se celebran sin consejo o sin consentimionto de los padres, fue siempre detestada y prohibida por la Iglesia, del mismo modo que las dos anteriores, como explica el Tridentino, en la sección 24 , capítulo $1^{\circ}$, de Reformatione matrimonial, para evitar Ia ingratitud, vituperio y menosprecio de la honra debida a los padres, impedir la transgresión de la ley divina que la ordena, y la vulneración de la honestidad pública, a más de la discordia y otros malos sucesos que resultan entre las familias de los matrimonios que se contraen por los jóvenes arrebatados de una ciega pasión, sin el consejo y circunspección que les falta a su edad.

En consideración a estos infaustos matrimonios $\mathrm{y}$ al respeto soberano de que son acreedores los padres, las madres y otros mayores de cada familia, no hay duda que pecan mortalmente los hijos que se casan sin consentimiento de sus padres, según la opinión más bien fundada de los canonistas y teólogos; $115 \mathrm{y}$ aunque semejantes matrimonios no son Irritos ni inválidos en razón de Sacramento, como juzgaron algunos autores antiguos, 116 contra lo que últimamente tiene declarado el Tridentino; ${ }^{117}$ pero es punto muy disputado, principalmente entre nuestros canonistas; si los Príncipes seculares pueden prohibir legítimamente estos 
casamientos e imponer penas a los contrayentes.

El Ilmo. Sr. Di. Fermosino, mueve esta cuestión sobre el ejemplar de Enrique II y Enrique 1lI, Reyes de Francia, que anularon en culanto a los efectos civiles, los matrimonios celebrados por los hijos de familia, sin consentimiento de sus padres; $y$ después de promover varios artículos, resuelve que no son válidos los estatutos laicales que prohiben la celebración de matrimonios sin consentimiento de los padres y que las leyes que imponen la pena de exheredación y otras, no tienen fuerza alguna. ${ }^{118}$

Pero, en realidad, se engañó manifiestamente este sabio autor, pues muy lejos de oponerse al espíritu de la Iglesia, las leyes de los Príncipes que prohiben y castigan estos matrimonios, privándoles de los efectos civiles, más bien obedecen a la Iglesia y coadyuvan las sanciones canónicas, como lo resuclve fundándose en ellas mismas, el célebre moderno Van Espen, ${ }^{11 "}$ citando difsentes Edictos de Enrique II, Enrique III, Carlos III y Felipe IV. Y no hay duda que esto es lo cierto, a vista del constante uso que han hecho siompre de esta autoridad los Príncipes católicos, con especialidad en nuestra España, por la Pragmática recientísima de 23 de marzo de 1776, comunicada a estos Reinos en Real Cédula de 7 de abrij de 1778 , que es la gue voy a explicar sobre algunos puntos en que pudieran tropezar los Intendentes.

A los que celebraren matrimonio, sin consentimiento o consejo del padre, madre, abuelos y llemás parientes, por el orden que explica al artículo 1 , como también a los hijos y descendientes que provinieren de tal matrimonio, inhabilita y priva cl artículo $3^{\circ}$ de la Pragmática de 23 de marzo de 1726, de todos los eficctos civiles, como son, el derecho a pedir dote o legítimas y de suceder como herederos forzosos y necesarios, en los bicnes que pudieran corresponderles por herencia de sus padres - abuelos, a cuyo respeto y obediencia faltaron; declarando por justa causa de su exhercdación, la expresada ingratitud, para que no puedan pedír en juicio, ni alegar el inoficioso o nulo el testamento de sus padres a ascendientes, extendiéndose esta privación, por el Art. 4\%, a los vínculos, patronatos y demás derechos perpetios de la familia, en la forma que se previene allí y en el artículo $5^{\text {p }}$.

Los mayores de 25 años, cumplen con pedir el consejo paterno, según el artículo $6^{\circ}$; pero, si contravienen dejándolo de pedir, incurren en las mismas penas, así en cuanto a los bienes libres como en los vinculados. Y porque se movieron varias dudas sobre si bastaba pedir el consejo, sin necesidad de obtenerlo, para contraer matrimomo, como lo indica el sentido del citado artículo 6", se declaró, a consulta de la Audiencia de México, en Real Cédula dada en Aranjuez, a 31 de mayo de 1783, que Ios hijos de familia mayores de 25 años, para contraer matrimonio, deben pedir y obtener el consejo paterno, y por su denegación, el suplemento judicial prevenido en el artículo $9^{9}$ de la Pragmática referida, bajo las penas establecidas en ella.

Siempre que los hijos o hijas de familia, mayores o menores de 25 años, celebraren matrimonio sin el consentimiento o consejo paterno, $\mathrm{y}$ después de contraido el casamiento, alegaren que sus padres no tuvieron justa y racional cansa para negarlo, pero sin hacer constar que precedió al matrimonio el suplemento judicial, debe considerarse también en este caso, subsistente la disposición de la Pragmática, en cuan- 
to a los efectos civiles, según la decisión del docto Van Espen, ${ }^{120}$ explicando los edictos publicados por los Reyes de Francia, sobre esta materia.

Esta privación de herencias comprende, no solamente a los bienes del padre, a cuya obediencia faltaren los hijos contraventores, sino también a los de la madre; de suerte que, si después de examinado en justicia el matrimonio que intentaren contraer los hijos de familia, quedase ejecutado ser racional y justo el disenso del padro, viviendo éste y permaneciendo en su disenso, no puede la madre instituir por heredero al hijo o hija inobediente, ni hacerle donación alguna, como se declaró por punto general en otra Real Cédula, fecha en Aranjuez, a 26 de mayo de 1783, sin que en cualquiera de estos dos casos tengan los hijos más derecho que para pedir los precisos y correspondientes alimentos, conforme al artículo 3 .

En cuanto a los matrimonios desiguales que se contraen en artículo de muerte con las concubinas, para descargo de la conciencia y para legitimar la prole habida en el concubinato, se declaró igualmente su validación para los efectos civiles, por edicto de Luis XIII, Roy de Francia, que cita Van Espen; ${ }^{121}$ pero nuestra Pragmática lo limitó a las personas que están objigadas a pedir el real permiso, como son los grandes y los títulos de Castîla, conforme a Ios artículos 12 y 13 . Y aśí, no se debe entender haber incurrido en las penas que establece cl artículo $12 \mathrm{ci}-$ tado, aquellas personas particulares que en artículo de muerte celebra ren matrimonios desiguales, por descargo de sus conciencias; porque habiéndose limitado en determinadas personas la pena establecida para los matrimonios desiguales que se contracn en artículo de muerte, debe comprender a solas esas personas, y no a las otras que por lo mismo de no haberlas nominado la Pragmática, es visto que las quiso exceptuar de la pena.

La Real Cédula de 7 de abril de 1778, en que se insertó la Pragmática susodicha, declara, en el artículo $2 \%$, estar obligados a su observancia todos los demás habitantes en las Indias, exceptuando únicamente el artículo $1^{\circ}$, a los mulatos, negros, coyotes e individuos de castas y razas semejantes, salvo aquelios que sirvieren de olicialos en las milicias, o se distinguieren de los demás por su reputación, bucnas operaciones y servicios, porque éstos deben así mismó comprenderse en ella.

También deben considerarse exceptuados de pedir y obtener el consejo y consentimiento de sus padres, los hijos naturales, pues, aunque la disposición de la Pragmática de 1776, se funda, según el artículo $2^{\circ}$, en la obligación natural del respeto y reverencia a los padres; y la naturaleza no hace diferencia entre los hijos legitimos y naturales; antes bien, la prole natural se reputa por legítima para todos los efectos naturales ${ }^{122}$ y se comprende bajo el nombre de padres y de hijos, asi los legítimos como los naturales, por ser apelación de la naturaleza y no del derecho la de padre o de parentelas; ${ }^{123}$ con todo, los hijos ilegítimos no están en la potestad de sus padres, ${ }^{124}$ no tienen derecho a pedir dote o legitimar ni de suceder como herederos forzosos y necesarios, ni los padres tienen más obligación que la de precisos y correspondientes alimentos. ${ }^{125}$ De suerte que, siendo la privación de estos derechos toda la pena de los hijos inobedientes, los legítimos que lo fueren, vendrían a quedar impunes, porque en todos eventos sería una misma su condición.

De esto se deduce que la Pragmática no quiso comprenderlos, pues 
en el caso contrario, hubiera establecido pena especial contra los contraventores, para que no fuera frustratoria su disposición, así como lo ejecutó con los legítimos, privándoles de todos los derechos que les conceden las leyes del reino. Y si así, no fuese, sería por otra parte, más favorable la suerte de los ilegítimos, quedándose con el mismo y único derecho que tenían de pedir alimentos, después de su contravención al respeto de los padres y cumplimiento de la Pragmática; cuando los hijos legítimos deben perder, por igual delito, las honrosas acciones de sus herencias y legítimas.

Por esto, deberán obtenex los ilegitimos el consentimiento de la madre solamente, porque siendo sus herederos forzosos y necesarios, por testamento y ab-intestato, ${ }^{2 z}$ vendrán a quedar privados de este derecho, en contraviniendo a lo dispuesto en la Pragmática, y como que entonces tiene lugar en ellos la pena prevenida contra los inobedientes, y está visto que también se deben ineluír en la disposición del artículo $2^{\circ}$ de la Cédula de 1778 .

En medio de la rigidez de estas providencias, se mitigaron con varios suplementos, por lo respectivo a las Américas. Y así, en cuanto a los indios tributarios, se halla prevenido por el artículo 2 , que el consejo, permiso o licencia que hayan de obtener para sus matrimonios, sea de sus padres, si son conocidos y pronta y fácilmente puedan obtener de ellos; $y$ en su defecto, do sus respectivos Curas o doctrineros, usando en esta providencia de la dieción "pero", que es adversativa, 127 para denotar la diversidad de derecho glue debe observarse con esta casta de gentes, en atención a su rudeza.

Ios Curas quedan subrogados en lugar de los padres, con exclusión de las madres y demás personas nominadas en el capítulo último del artículo $1^{\circ}$ de la Pragmática de 23 de marzo de 1776 , con el fin de asegurar en su mejor discernimiento las buenas resultas de los matrimonios de estos infelices; pues aunque los indios se pueden casar con quien quisieren, conforme a la ley $2^{\prime}$, título $1^{\prime}$, libro $6^{\prime}$ de Indias, sin excluírse de estas alianzas los negros o negras, libres o esclavos, según la ley 8, título 5 , libro $6^{\prime \prime}$, y ley 2 , título 5 , libro $7^{\circ}$ de la misma recopilación; pero se debe procurar que habiendo de casarse los negros, sea el matrimonio con negras, ${ }^{125}$ cvitando en lo posible que lo ejecuten con indias, para que no les enseñen sus malas costumbres, ociosidad, errores y vicios, que podrían estragar y pervertir el fruto que se desea en orden a su salvación, aumento y quietud. ${ }^{12 t}$ Por euyas consideraciones, muy difíciles de ponderarse dignamente por los indios, están encargados los Curas de suplir el consentimiento de los padres, y aun cuado estos sean conocidos deben los párrocos estar a la mira de su consentimiento, para que siempre recaíga en personas convenientes.

Para con los españoles, euxopeos y americanos ausentes de las Provincias donde habitan sus padres, abuelos, parientes, tutores o curadores, de quienes sea dificil obtener su consejo o licencia, o con muy notable retardación por la distancia, previenen los artículos 4 y 5 de la Real Cédula de 1778, que pidan uno u otro, según cor'responda, ante el Juez del Distrito que hubiere señalado la Audiencia de él, usando de las facultades que concede el artículo $6^{\circ}$ de la citada Cédula. De suerte que prestando su consentimiento cl respectivo Juez subrogado por la Audiencia, en los casos que elia hubiese declarado no ser necesario solicitar el de sus padres $y$ 
parientes, cumplen los hijos de familia con la obligación establecida en la Pragmática.

Con este objeto declaró la Real Audiencia de Charcas, con audiencia fiscal, en Auto de $1^{\circ}$ de marzo de 1779, inserto en Provisión Real dada en 8 del citado mes y año, que cuando los padres, abuelos y demás parientes se hallaren ausentes, fuera del Distrito de ella o en los reinos de España, o en otras Provincias muy distantes, en tal caso los hijos de familia deben pedir el consentimiento de la Justicia del lugar donde habitaren, nombrando para este efecto por Jueces a los Gobernadores y Corregidores de las Provincias, y en su defecto, a los Alcaldes ordinarios en las ciudades y villas donde los hubieren, y a las demás personas que para el mismo fin diputaren los Gobernadores en cada pueblo de su jurisdicción donde aquellos no existieren. Y cuando la ausencia de los parientes no excediere del territorio de la Audiencia, se señaló a los hijos el término citatorio de la Ordenanza de las Provincias, para que dentro de él soliciten el consentimiento o permiso de sus padres; pero en este caso, nunca podrá la Justicia suplir la autoridad de los padres, ni los $\mathrm{Cu}-$ ras podrán presenciar semejantes matrimonios, cuando no se les presentare por los interesados la licencia de los mayores, ausentes, conforme a los artículos 18 y 19 de la Pragmática de 23 de marzo de 1776.

Para el caso de negarse el consentimiento, sin justicia y racional causa, permite el artículo $9^{\circ}$ de la Pragmática a los hijos de familia, introducir recurso sumario ante los expresados Jueces, contra el irracional disenso de sus padres, para que examinando en justicia, en el preciso y perentorio término de ocho dias, en la primera instancia, y por recurso ante la Audiencia del territorio, en el de treinta días, se declare por justo o por irracional el disenso de los padres, sin revista, alzada ni otro recurso de la declaración que se hiciese, por deberse finalizar con un solo auto, ora confirme o revoque la providencia del inferior, para que no se dilate la celebración de los matrimonios justos y racionales.

La Real Audiencia, usando de las facultades expresadas en el Cap. 7 de la Cédula de 7 de abril, para el señalamiento de término en la primera y segunda instancia, no hizo novedad en los cstablecidos por el citado artículo $9^{\circ}$ y sólo declaró en la provisión referida, dos puntos: es el $1^{\circ}$, que se apele dentro de tercero día, de las providencias de los Jucces inferiores; y el 2 que para la prosecución del recurso, se conceda al apelante la mitad del término citatorio de la Ordenanza de la providencia, con la calidad que cumplido éste, se determine el recurso precisamente en el término de treinta días, por el proceso cerrado y sellado; y los Jueces inferiores deben remitir original a la Audiencia, sin dejar testimonio; y ésto es aunque no se apele, para que cori arreglo al artículo 10 de la Pragmática de 23 de marzo, se custodien los procesos en el archivo secreto y separado, en la forma que allí se previene, para evitar difamación de las familias.

Hasta aquí son tan claras las citaciones prevenidas en la Pragmática antecedente, que no es fácil tropezarse en su observancia. Pero, como este género de recurso es nuevo en nuestra jurisprudencia y no enseñan el modo de sustanciarlo nuestras cartillas prácticas, ni hay en ellas modelo para los Jueces que nunca hubieren formado tales procesos, juzgo por conveniente explicar este punto brevemente, para evitar que se ocasionen difamaciones a las familias, por la falta de observancia de la 
práctica correspondiente a este juicio.

En el artículo 9 de la Pragmática, se admite libremente a la Justicia real ordinaria, recurso sumario contra el irracional disenso de los padres con prevención de que se haya de determinar y resolver en el preciso término de ocho dís. Aquí se of rece la duda, si en semejantes procesos sc deberá hacer contestación del pleito, recibir la causa a prueba y admitir tachas de testigos. Yo he visto hacerlo así a algunos Jueces, y no ha parecido disonantc esta práctica a muchos letrados de buena reputación.

Y una vez que la Pragmática no declara cl estilo de substanciar estos Procesus, es de creer que se hayan gobernado por el modelo de otras causas sumarias, en que se admiten sin escrúpulo contestaciones, probanzas y tachas.

En el remedio Posesorio de la ley de Soria, que es la $3^{7}$, título 13,

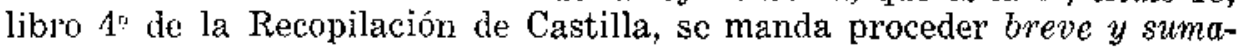
riamente, sin figura de juicio; con todo, advierte Villadiego, 180 que se requicre plena probanza y que se debe hacer contestación del pleito y admitirse tachas de testigos, entendiéndose la brevedad en cuanto al orden judicial solamente y no cuanto a la prueba.

La Ordenanza l'rimera, título $9^{\circ}$, libro $3^{\circ}$ de las Generales del Perú, ordena también que todos los pleitos y causas de minas, se traten, conozcan y reterminen sumariamente. No obstante lo cual, se reciben probanzas con citación de la parte; hay contestación del pleito, y se admiten tachas de testigos, como lo indican las ordenanzas siguientes del citado título y libro, $y^{y}$ se califica por la práctica constante de los tribunales. $Y$ así concluye Fvia Bolaños 181 con otros varios que cita Fermosino, ${ }^{132}$ ser de substancia del juicio habcr contestación, aunque la causa sea sumaria.

Pero examinando con más reflexión las cláusulas del artículo 1" siguiente, sc colige debersc seguir otra práctica más estrecha pero también más favorable a la buena reputación de las familias. Allś son de notar dos cosas. Es la primera, el prohibirse absolutamente dar certificación de las objeciones y excepciones que propusieren las partes, para evitar difamaciones; declay'ando que sea puramente extrajudicial e informativo semejante proceso. La scgunda es, que no se puede mandar dar copia simple o certificada de los procesos que se formaren sobre suplir. el irracional disenso de los padres, bajo la pena de perpetua privación. de oficio a los Jueces y Escribanos que to contraviniesen, debiendo custodiarse con tal secreto, de modo que por ninguna persona se puedan registrar, ni reconocer, ni darse tampoco segunda certificación del auto prevenido en el artículo 9", sin expresa orden y mandato de la Real Audiencia.

De estas prevenciones extraordinarias, resulta, en primer lugar, que debiendo ser este género de proceso puramente extrajudicial e informativo, se puede comenzar por artículos, según Barbosa, ${ }^{139}$ y producir testigos antes de la contestación del pleito, con excepción especial de la regla general que lo prohibe en las causas y demandas ordinarias. ${ }^{134} \mathrm{En}$ segundo lugar, que no es menester citar a la parte para ver jurar y reconocer a los testigos, por ser éste uno de los requisitos que observa la práctica en toda especie de informaciones, ya sean sobre delitos, ya sobre cualquier otro género de causas. En tercer lugar, que en este recur- 
so no se debe dar trasiado a las partes, de los dichos de los testigos, ni publicarse sus nombres y deposiciones, porque estando prohibido aun el dar certificación de las objeciones que de ellos resultaren, y negada absolutamente la copia del proccso, tampoco se puede permitir el traslado que se pidiere de los capítulos de desigualdad y atestaciones producidas sobre ellos, pues que siempre se seguirían las certificaciones de familias, que quiso evitar la Pragmática con tal prohibición de certificaciones y copias de lo actuado.

A ésto es consiguiente no admitirse tachas de los testigos, ni las demás citaciones que advirtió Villadiego, explicancio la ley de Soria. Porque semejantes informaciones no hacen cosa juzgada ni sirven para otro efecto que para suplir el irracional disenso de los padres; nunca se pueden compulsar para distinto fin, ni son capaces de perjudicar las familias, por el secreto con que se tratan y por la ignorancia que por este medio se tiene de las objeciones.

Según estos principios, sólo sirven semejantes informaciones para instruír el ánimo del Juez sobre si es justo o jxracional el disenso de los padres; y vienen a reducirse en el pic que se siguen las informaciones de pureza de sangre para el ingreso a los colegios, comunidades y órdenes militares, que la requieren por sus Estatutos.

La práctica de formar tales procesos y recibir testigos, ya sea de oficio ya sea por presentación del pretendiente, con las calidades expresadas de no ser necesaria la citación, contestación, y demás referido arriba, se puede ver lata y eruditamente en el docto Pareja, ${ }^{135}$ y yo juzgo que este es el verdadero modelo que se debe seguir en la formación de procesos sobre desigualdad.

Y así, luego que se presentaren los padres contradiciendo el matrimonio por título de desigualdad o por otra calsa que acredite de racional y justo su disenso, debe el Juez recibir los artículos y testigos que produjere para su probanza, procediendo desde luego a una averiguación reservada, bastante para cerciorarse de la verdad de los motivos por medio de una información sumaria secreta, a la ckal se cleben agregar cuantos documentos y noticias pliedan conducir para seguridad del suplemento judicial del consentimiento paterno; pero, según la regla establecida, se debc ejecutar la compulsa y la comprobación de los instrumentos que presente el mismo pretendiente, sin citación y por puro oficio del Juez, así en la primera instancia, como en la segunda de apelación, en la forma prevenida por Pareja. ${ }^{136}$

Si en este estado ocurre el interesado contrario, se le oye, no por vía de contestación o en forma de juicio, sino por un modo puramente informativo, por donde reconozea el Jucz, si se ha indemnizado de todas las objeciones; y siempre que en vista de todo formare juicio moralmente seguro y cierto de la desigualdad o de los motivos que fundaren la contradicción del padre, entonces se provee auto, declarando por justo y racional el disenso paterno, y se le manda dar certíficación de él, para que presentándolo ante el Eclesiástico se rescindan los esponsales y suspenda el matrimonio; pero, si por el contrario, se hubieran desvanecido las objeciones, se declarará en tal caso por irracional el disenso, en los mismos términos y para los mismos efectos antecedentemente explicados; y si se apelare, se sigue la causa en la Audiencia, con la misma reserva y método, en el término y plazos que quedan señalados. 
Párrafo tlécimo. - Días feriados. - Se explica la ley 4 , Tít. $9^{\circ}$, Lib. $3^{\circ}$; la ley 4 , Tít. $1^{\circ}$,

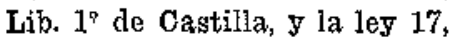
Tít. $1^{\circ}$, Lib. $1^{\prime \prime}$ de Indias.

L en honor de Dios, deben santificarse religiosamente, por precepto de la Iglesia, vacando de los negocios temporales igualmente que de todo estrépito judicial, para dar cuito a Dios en la oración y en otros actos espirituales. El Sumo Pontífice Gregorio IX, señaló en una famosa Decretal 137 todos los días feriados de precepto, en que deben cesar las actuaciones judiciales; y después, Urbano VIIl aumentố algunos más, đue pueden verse en una de sus Constituciones. ${ }^{13 \mathrm{~S}}$ Ultimamente, el Papa Clemente XIII, hizo fiesta solemne de riguroso preccpto, la Concepción de Nuestra Señora, a instancia de nuestro Soberano Reinante Don Carlos III, 139 añadiendo en honor de Mar'a Santísima csta festividad más, sobre las cuatro que señácó Urbano VIJI, bajo del título de: la Purificación, Anunciación, Asunción y Natividad.

La ley 34 , título 2 , partida 3 , recopiló los mismos días de fiesta que menciona la Decretal citada de Gregorio IX, agregando las vacaciones que mandó guardar el Rey Flavio Recesvinto, desde la Dómínica de Palmas hasta Cuasimodo, y desde la Natividad del Señor hasta la Epifanía, ${ }^{140}$ todas las cuales ferias están mandadas guardar generalmente en la ley 4, título 9, Y.ib. $3^{\circ}$ de la Recopilación de Castilla. En este Arzobispado de Charcas se guardan algunos otros días, por decreto de sus Ilmos. Arzobispos, fuera do los domingos y demás festividades establecidas por derecho común. De suerte que los feriados deben dividirse en tres clases: unos, de riguroso precepto; otros con obligación de oir misa solamente; y otros para los tribunales, que se Ilaman "feriados de Corte", par'a comodidad de los Rclatores y Abogados; para cuya mejor inteligencia, se pone la tabla siguiente:

\section{T A B I A}

De los días feriados que se guardan en esta Villa, por disposición de la Iglesia y Decreto de los Arzobispos de Charcas: Los de riguroso precepto van señalados con estas dos $i_{f}$; las de misa solamente con una $\dagger$; y sin ningún signo los feriados de Corte, últinamente establecidos en la Real Cédula de Buen Retiro, a 3 de marzo de 1750. ${ }^{141}$

T. $N \mathrm{ERO}$

t† 1 La Circuncisión del Señor.

ti 6 La Epifanía del Señor.

17 S. Antonio, Abad.

+ 20 S. Sebastián.

24 N. Sra. de La Paz.

29 S. Francisco de Sales.

$F E B R R O$

中े 2 La Purificación de N. Sra.

3 S. Blas.

8 S. Juan de Mata

†† 24 S. Matías y si es bisiesto el 25 .
$\mathrm{M} A \mathrm{R} \mathrm{Z}$

8 s. Juan de Dios.

+19 s. José.

21 s. Benito, Abad.

t† 25 La Encarnación del Señor.

\section{A B R I L}

竍 El lunes de Pascua de Resurrección.

$+\quad$ El martes de Pascua.

2 S. Francisco de Paula.

$+25 \mathrm{~S}$. Marcos Evangelista. 


$$
\text { M A Y O }
$$

† 1 Stos. Felipe y Santiago.

+ 3 La Invención de la Sta. Cruz.

$+5 \mathrm{La}$ conversión de $\mathrm{S}$. Agustín.

$8 \mathrm{La}$ aparición de S. Miguel.

$\dagger 15$ S. Isidro Labrador.

+30 S. Fernando, rey de España. (a)

\section{J U N I O}

11 S. Bernabé, Apostol.

+13 S. Antonio de Padua.

小. 24 La Natividad de San Juan Bautista.

†† 29 S. Pedro y S. Pablo.

$$
\text { J U L I O }
$$

2 La Visitación de N. Sra.

16 Ntra. Sra. del Carmen.

22 Sta. María Magdalena.

$\dagger+25$ Santiago, Apostol.

$\dagger 26$ Sta. Ana.

31 S. Ignacio de Loyola.

\section{A $G O S \mathrm{~T} O$}

2 Ntra. Sra. de los Angeles.

4 Sto. Domingo.

5 Ntra. Sra. de las Nieves.

$6 \mathrm{La}$ Transfiguración del Señor.

* 10 S. Lorenzo.

tit 15 La Asunción de Ntra. Sra.

$\dagger 16$ S. Roque.

20 S. Bernardo, Abad.

† 24 S. Bartolomé, Apostol.

25 S. Luis Rey de Francia.

+ 28 S. Agustín, Obispo.

$\$ 30$ Sta. Rosa de Lima.
S E P T I E M B R E

t广 8 La Natividad de Ntra. Sra.

$\div 21$ S. Mateo, Apostol.

24 Ntra. Sra. de las Mexcedes.

+ 29 S. Miguel Arcángel.

30 S. Jerónimo.

\section{O C T U R R}

2 wis Sto. Angel de la Guarda.

4 S. lirancisco de Asis.

† 15 Sta. Teresa de Jesús.

18 S. Lucas, Evagelísta.

$28 \cdot \mathrm{S}$. Simón y S. Judas.

\section{N O V I E M B R E}

† 1 La Fiesta de Todos los Santos.

2 La conmemoración de los difuntos.

21 La Presentación de N. Sra.

\$30 S. Andrés $\Lambda$ póstol.

\section{I C I E $M B R \mathrm{~K}$}

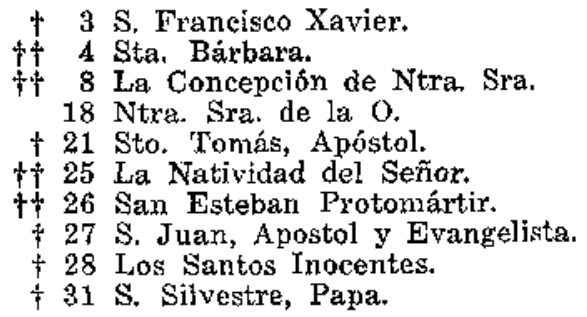

(a) Cayendo, (coma regularmente sucede) en este mes la Ascención y Pentecostés, se debe observar lo dicho para la Pascua de Resurrección.

De las tres clases de feriados que hemos distinguido, las dos primeras son pertenecientes al honor de Dios, con sola la diferencia de incluír en las primeras, dos preceptos, a saber: el de oír misa y no trabajar, y la segunda únicamente la misa. Por eso se llaman de riguroso precepto los feriados de la primera clase. La tercera, en que no interviene obligación de misa ni vacación de trabajo, se introdujo precisamente en alivio y comodidad de los hombres, esto es, de los Jueces, Relatores, Abogados y pleiteantes, para que todos estos tengan tiempo de leer los procesos, instruír los alegatos y formar las relaciones, sin atrasarse con rezagos por falta de momentos para el trabajo.

En los feriados de las dos primeras clases, generalmente está prohibido todo procedimiento judicial, bajo la pena de nulidad, ${ }^{142}$ y esto es aunque las partes pacten lo contrario, como lo decide la Ley real de Partida, ${ }^{143}$ respecto de ser éste un derecho público, espiritual y eclesiástico, que no se puede renunciar. ${ }^{144}$

Algunos han querido exceptuar de esta regla general, a las causas sumarias, fundándose en que se procede en ellas simplemente de pla- 
no, sin estrépito ni figura de juicio; pero el célebre Scacia, ${ }^{145}$ defiende lo contrario, aconsejando esta opinión por más común y observada en la práctica; pues de lo contrario, jamás vacarían los tribunales de Justicia, con espeecialidad en el reino de Nápoles, donde todas las causas son sumarias.

Sin embargo, ponen los autores muchas falencias a la referida regla, y pueden verse en Fagnano y Raynaldi, 116 con otras muchas cuestiones relativas a este asunto, muy importantes en la práctica. Más particularmente declaran las leyes 35 y 28 , título 2 , partida $3^{\text {t }}$ los casos exceptuados un que se puede oír, y demandar en los días feriados, aunque sean los ustablecidos para hon'a de Dios; debiendo de consiguiente, establecerse una excepción general de que no se comprenden en la prohibieión de los feriados, todos los casos en que se interesa el bien común do la tierva, la paz o tregua y la concordia de los hombres; establecimiento de caballería para guarda de la tierra, y el escarmiento de ladrones públicos o traidores. ${ }^{14}$ En suma, es falencia de la regla cuando urge la necesidad o lo persuade la piedad, cono lo explica la Decretal a que se refiere Fagnano y otros canonistas. ${ }^{1 / 8}$

Por eso se ha introducido cn la práctica el estilo de examinar indistintamente testigos en las causas crinumales, dar tortura a los reos, etc. De suerte que a un ladrón insigne, a un homicida de caso penado, a un sacrílego, a un raptor $\mathrm{y}$ a un envenenador, se puede dar tortura y también ajusticiar, aunque sea en el día de Pascua, como resuelve una célebre ley del código ${ }^{149}$ a que hace referencia la ley 35 citada, título 2, partida $3^{3}$, con la Glosa 12 de la ley 15 , título 6, partida 7 ; y sobre todo Raynaldi y Scacia, ${ }^{1}$ in con advertencia muy particular y curiosa.

Conforme al mismo principio, se puede arrestar al reo sospechoso de fuga ${ }^{151} \mathrm{y}$, por el contrario, también se puede excarcelar, estipular fianzas para el mismo fin, y admitir apelaciones, con otras cosas que exceptúan Raynaldi, Scacia y Fagnano, ${ }^{152}$ por ser obra de piedad la consolación de los tristes encarcelados.

Todo esto se entiende para lo judicial, y así lo declaró la nueva Ordenanza de Intendentes, en el Art. 217, que para lo que es trabajo de oficinas, sólo deben exceptuarse los días feriados de riguroso precepto, es decir, aquellos que incluyen las dos obligaciones, de oír misa y no trabajar.

Y cn cuanto a Jos días feriados establecidos por comodidad de los hoimbres, tampoco deben cesar las causas fiscales, según Alfaro, ${ }^{158}$ ni otras sumarias cuya expedición urge en beneficio de los mismos hombres; de suerte que si ellos quisieran renunciar este favor, bien lo pueden hacer, sin vicio de nulidad.

También toca al oficio de los Príncipes y respectivamente a los demás Jueces seculares, celar el cumplimiento de las Constituciones Eclesiásticas, auxiliando y fortificando el derecho de la Iglesia, con la imposición de penas contra los violadores de los días feriados, para que de este modo se guarde el culto debido a Dios. Con este objeto se prohibe todo trabajo y obra servil en los domingos y demás fiestas de guarda, imponiendo la ley $4^{a}$, título $1^{\circ}$, libro $1^{\circ}$ de Castilla, la pena de 300 maravedíes al que lo quebrantare, aplicados por tercias partes, para el acusador, Iglesia y Cámara, cuya multa duplicada en estos países, según las leyes del Reino, monta a 600 maravedies, que son 18 reales de plata. 
Esto es en cuanto a los españoles; pero en euanto a los indios, negros y mulatos que no guardaren las ficstas, se deja por la ley 17, título $1^{\circ}$, libro $1^{\circ}$ de Indias al arbitrio de los gobernadores la pena que juzgasen conveniente, es decir, o la pecuniaria o la personal de cárcel, según las circunstancias del sujeto, y de la contravención. ${ }^{15 \cdot 1}$

Si bien, para no equivocarse el magistrado secular en las obras prohibidas, que se indican en la pena de ley, deberán tener presente la Carta Pastoral del Sapientísimo Benedicto XIV, 1.: donde se refieren muy por menor todos los casos permitidos por derecho o por costumbre.

Al mismo tiempo se dobe tener presente, que en algunos lugares ha introducido el abuso una relajación tan cscandalosa en materia de fiestas, que sin quiebra ni distinción de días, se violan hasta los domingos, vendiendo impunemente todo género de mercaderías en mercados públicos. Contra este exceso exclamó con justicia el cólebre canonista Van Espen, ${ }^{156}$ exhortando a los Jucues que cuiden de restablecer la observancia de los días de fiesta, para no hacerse responsables ante Dios y el Rey, de su violación.

En efecto, sería muy grande el cargo de los Jueces de Potosí, por el descuido de este importantísimo punto. Rarísimo es el día que no se quebranta, pues los más solemnes y aun los domingos, están puestas en la calle de la Moneda, las tiendas que llaman de las gateras, y allí venden bayetas y otras mil chinchillerías a los indios y españoles, con pretexto de contribuíx al año cierta limosna para la festividad de Nuestra Señora de la Nieva.

Si por cada vez se las multara en los 600 maravedíes, o en los mil y doscientos que impone la ley $4^{\prime \prime}$ al fin, título $1^{\prime \prime}$, libro $1^{\prime \prime}$ de Castilla a los Jueces omisos, ciertamente tendrían que pagar una suma muy considerable al fin de muchos años.

Ello es que no hay pretexto que los disculpe, porque la ley 4 citada, prohibe toda dispensación en esta materia, siguiendo la opinión de varios autores clásicos que inhibieron al Juez laico de poder dar licencia de trabajar en días de precepto.

Pero si el Eclesiástico la diere por justas causas, que debe expresar, no puede el Juez laico entrometerse a calificarlas ni a exigir la multa de la ley, porque este es un negocio espiritual, oomo lo decidió la sagrada Congregación del Concilio, según Riccio, citado por Raynaldi, ${ }^{157}$ debiendo advertirse que, al contrario, puede cxigir el Eclesiástico la pena, si se procedió a trabajar sin licencia suya, aunque la hubiese dado el Juez laico.

$$
\text { N O T I C I A S E P T I M A }
$$

De las causas de Guerra.- En que se propone arbitrio para mantener las tropas del Reino en vigor de la disciplina militar, con mayor ahorro de la Real Hacienda y más subordinación de estos naturales.
$\mathbf{E}$ Art. 220 , hasta el 276 de la Nueva Ordenanza, cxplica con el mejor método, claridad $\mathrm{y}$ orden los objetivos a que deben contr'aer su atención y celo los Intendentes de Provincia, en todo lo perteneciente a la subsistencia, económica y policía en gencral de las tropas que se hallaren en sus respectivos territorios. Todos los puntos de esta impor-

tante materia, se ven allí discernidos con la mayor exactitud, y basta su 
lectura para comento.

Aunque esta causa se refiere principalmente a lo económico de Gueria, cu cuanto tiene conexión con la Real Hacienda, también corresponcle a los Intendentes lo jurisdiccional, como Comandantes Subdelegados militares de sus Provincias, a cuyo fin dispone el Art. 272, que los Excmos. Virreyes les deleguen su jurisdiceión militar, para que sean más autorizadas, expeditas $y$ respetables las providencias que tomaren en todas las dependencias de su mando.

Por el contrario, se aventuraria más de una vez el buen exito de las disposiciones de los intendentes, por la lalta de prontos auxilios, y frecuentemonte se experimentarian competencias odiosas y perturbativas de la paz de los vecindarios. Con cuya consideración se reunieron, por el Art. 6", en una sola persona los nuchos empleos políticos que antiguamente estaban separados en distintos jefes. $Y$ es igualmente poderoso este mismo motivo, para incorporar en los Inteudentes la jurisdicción militar, por el importante fin de evitar los embarazos y desavenencias que resultarian ontre ellos y los Comandantes militares de cada Provincia.

Párrafo primero, - Destacamento de tropas en los pueblos capitales,
A ticmpo de erigir las Intendencias, fue muy conveniente para establecer el respetable decoro de esta nueva autorjdad, destacar en cada cabecera de Provincia, una o dos companías por cuyo auxilio se hiciesen efectivas las primeras disposiciones del nuevo Gobicrno, hasta que la misma fuerza superior de la opinión pública pudiese sostener el sistema.

La sublevación de los años próximos anteriores, hizo con seex que la felicidad sin defensa es un soplo pasajero, que sólo se goza por instantes para aprender a sentir su lalta. la experiencia enseña a todo el Reino, que sin la fuerza pública, nunca hubiera recobrado su reposo, y que si venció la razón, fue por verse sostenida del poder de las armas; pero aunque cesó el desastre y la calamidad, quedó la triste memoria de la desdicha pasada y era preciso que nucstro sabio Gobierno no se contentara solamente con haber defendido a estos pueblos del mal que los afligió, sino también el miedo que pudieron tencr.

A este fín, esparció tropas por todas las Provincias; estableció destacamentos en las capitales y puso guardias a los Jefes, para que a la vista de los vencedores se aterxasen los alzados, se animaran'los leam les y se hiciesen más respetables los derechos del Sobcrano y las personas de sus nuevos Magistrados.

Desde la conquista hasta la rebelión no se habían vuelto a ver soldados en el Perú, y convería mantener sobre el indio por algún tiempo la mano que lo hirió, para acabar de rendir su obediencia y desterrar los funestos errores de su prevaricación.

Los indios primitivos de las Américas, reputaron a los conquistadores por unos monstruos invencibles, como hijos del sol a quien adoraban por deidad. Los de nuestros tiempos, aunque ya más civilizados, conservan en la tradición la superioridad honxosa del soldado español, y juntándose esta idea con los estragos experimentados nucvamente, han acabado de creer que la gorra, el uniforme y el bigote son compañeros de la inmortalidad. ${ }^{158}$ 
Pero es forzoso que el mismo tiempo despinte este concepto, porque según fueren tratando a los soldados, conocer'́n sus flaquezas y sus vicios; perderán el terror cuando viercn que un soldado acosado, teme, huye $y$ se rinde, $y$ al cabo se vendrá a destruír aquella poderosa opinión de la superioridad en que principalmente se ha sostenido hasta ahora la obediencia. Al contrario, crecerá siempre el miedo, al ruido lento de la fama del vencedor oculto pero prevenido, porque con saber únicamente que hay soldados en el Reino, se imaginará el indio que estân preparados innumerables ejércitos para su ruina, a la menor deslealtad; y vivirá tan sometido en esta idea, que sólo un Batallón de infantería en el centro del Virreinato, bastar'á para segurar la quietud y prosperidad de todo el Reino.

Por otra parte, estos destacamentos repartidos por Provincias, van perdiendo insensiblemente la disciplina militar. Son pocos los soldados de cada Partido, y fácilmente se ponen de acnerdo para disimularse todas las contravenciones de la ordenanza.

Ellos viven casi todos en continuos concubinatos, en que estragan, se enferman y se pierden y cuando menos se casan, que es lo mismo que afeminarse el soldado. Con esto se octupan en granjerías para mantener a la mujer; ya los domina la pasión amorosa y la ambición; no son capaces de hacer una fatiga con constancia y con fortaleza; y ponen tales esfuerzos en dejar la casaca, que no consiguiendo su reforma, ellos mismos se la toman con desertar por aquel tiempo que se ha de relevar la compañía, para volver ya en traje de paisano.

Estas alianzas que, por lo rcgular, se eontraen con gente popular, inspiran en los soldados cierta condescendencia que detiene su acción en los lances más críticos del servicio, viendo atravesarse el interés de sus cuñados, de sus parientes y de los demás que ya ellos miran como paisanos y amigos. Al paso que se multiplican las relaciones, también se van multiplicando las pretensiones y las necesidades, que siéndoles preciso remediar, se debe temer el riesgo de que tomen partido con el pueblo, en las ocasiones de carestía y otras crisis imprevistas del comercio. De suerte que, en vez de contener la inquietud, sería un nuevo motivo para aumentarla la concurrencia del soldado.

Sin haber liegado este caso, ya se está experimentando los funestos efectos del espiritu de ambición, pues que muchos de los soldados sa len a los cantos (extramuros) con pretexto de comprair bastimentos para el Cuartel, y allí quitan por fuerza al pobre indio los frutos que conduce a la Villa, por la mitad menos de su justo precio, para regatonearlos después, o para mantener a costa del infeliz a la mujer propia o la amiga y a sus parientes; causando indecibles vejaciones con estas demasías en el pobre labrador, en el trajincro miserable y en los demás ciudadanos de la comarea.

Con la relajación del soldado también se van estragando las costumbres del pueblo: ya se ven puñaladas, que antes eran tan raras, entre la gente vulgar como el Fénix entre las aves. De este modo van perdicndo el miedo a las armas; conocen por la experiencia el imperio del cuchillo sobre la vida del hombre; y si no se contiene este abuso, debomos temer que se convertirán en breve tiempo en bandidos que infesten los caminos y conductos, los ociosos gue en el día duermen en la ociosidad y la pereza, por hallarse todavía poseídos de una malicia brutal, propia del 
carácter del indio, pero que después se hará ingeniosa a costa de ejemplares desgraciados.

Los vagabundos que viven de las granjerías del juego y de la disipación, hallan en las capitales un albergue muy proporcionado a los vicios, con la facilidad de los muchos competidores que encuentran diariamente jugando en las tabernas. $Y$ lo peor es que en esta escuela se van forman. do excelentes discípulos, que con el tiempo corromperán la mayor parte de los vecindarios; y si ahora se puede mantener la paz al nivel de unas fuerzas medianas, después scrán menester fuerzas mayores para mantener en quietud los espíritus díscolos y malentretenidos.

Además de esto, se causan a la Real Hacienda muchos gastos con los destacamentos de las capitales, porque es menester que cada compañía tenga su Cuartel, su Hospital y sus Armacenes. En todas las ciudades tiene que costcar el Rey estos edificios por una yez y continuar sucesivos desembolsos en su repartición o en pagar los alquileres de las casas que sirvieron este destino.

Sobre esta nultitud de objetos de economia, se agrega que los costos crecen según la divorsidad de los lugares, como en cuanto casas y otros materiales de que es preciso surtir los destacamentos; y como en todos los pueblos no hay iguales proporciones, puede suceder el descontento de la tropa después de tan crecidas expensas de la Real Hacienda, no obstante la atención que pongan los Intendentes a esta policía, substrayéndose de otras miras más importantes a la buena administración de la Justicia y del Gobiemo, porque es moralmente imposible que un hombre solo concurra a tantas partes con la actividad debida.

Es otro inconveniente que la tropa dividida en compañias por las Provincias, se expone a cada paso a los ultrajes de los pileblos, porque viéndolos pocos en número ocasionarían el desprecio y el aborrecimiento mortal que les ticnen; armaría los ánimos y las manos para injuriarlos. Ya se ha visto por acá más de una desgracia nacida de este principio, prineipalmente en la ciudad de La Plata, donde la antipatía recíproca del pucblo con la milicia, ha revuelto varias pendemcias, en que por haber muerto uno u otro cholo, se insinuó en toda esta casta cierta fermentación peligrosa, de muy malas resultas para lo gencral de la población.

Este motivo en pura consideración, se reputó por tan grave en el Gobierno de Flandes, cuando se trató de restituír a lo interior de aquellos Estados la milicia española detenida en las fronteras; y al cabo de muchas y largas conferencias, no se llegó todavía a tomar una resolución decisiva y permanente acerca del alojamiemio de las tropas. En estas partes vemos que el suceso tiene calificados estos inconvenientes, $y$ una vez que no se puede dotar cada pueblo con guarnición competente a su vecindario, para castigar cualquiera demasía sin necesitar socorros de ấuera, parece mejor quitar de los ojos de la plebe las ocasiones de encuentros y disgustos, que tal vez pueden parar a extremo de no poderse remediar sin ruina de otros vecinos inculpables.

Porque ello es cierto que los soldados, en acabando la corta fatiga del Cuartel, como no tienen más oficio que pasear y jugar, ya se entran a esta casa, ya a la otra, tomándose de ordinario más licencia que la que conviene con mujeres solteras o casadas. Como en el pueblo los aborrecen y no hay razón ni prudencia en el artesano o el gañán que mira sus 
acciones, luego se atraviesan palabras, pasándose después a las manos, de donde nacen las riñas, las gavillas y tal vez una conmoción imprevista, que es menester aplacar con la sangre de muchos.

Por otra parte, debemos reflexionar que nuestros pueblos se hallan distantes unos de otros, los más o casi todos entre serranías escabrosas, de mil tropiezos y malísimos caminos. A la distancia de un tiro de fusil se pueden ocultar no sólo espías, sino también emboscadas numerosas que embaracen el paso de unos lugares a otros. $Y$ si sucediera (lo que no se debe esperar) alguna conmoción estudiada de parte de los indios, casi se inutilizaría el socorro recíproco de los pueblos, porque una sola compañía acaso no pudiera vencer los obstáculos puestos a su tránsito. Y así, o llegarían tarde los recur'sos o se malograrían muchas partidas, o por lo menos nunca podríamos calcular con exactitud una empresa para asegurar el suceso.

Debemos pues procurar que el soliado no viva en el ocio, para evitar los vicios a que regularmente se entrega la tropa sin fatiga. No es menester estudiar mucho para saber los estragos que causó la holgazanería en el Ejército portugués dentro de Maririd, ${ }^{150}$ y en el de Aníbal en Capua. Con este cuidado se conservaría una porción numerosa, que naturalmente debieran consumir los vicios y el odio de los pueblos.

Pero como tampoco no es justo fiarse de la razón desarmada, por eso es menester guardarnos las espaldas con la misma tropa que tenemos en este Virreinato, y si es posible, con más, combinando nuestra seguridad con el beneficio de los pueblos y con la conservación de la disciplina militar.

Párrafo segundo. - Aloja- WiN reuniendo las compañías dividirlas por miento de la tropa en los las Provincias, se lograría el mismo fin y se Cuarteles Generales. evitaría todos los inconvenientes. Toda la tropa estaría entonces a la vista de sus Jefes naturales y la costumbre de obedecerles conservará la subordinación y la disciplina, en el pie de la ordenanza. Se tendrá consideración a que variándose estos dos objetos no entrará la corrupción en la masa principal de la milicia, y como que los Jefes no haltarian disculpa a su omisión, cuidarían con más celo de mantener bien arreglada la tropa de su cargo. Y es evidente que todo cuerpo vive mejor ordenado, cuanto estuvieren más juntos y unidos sus miembros. Son demasiado notorios los ejemplos que tenemos en las comunidades religiosas y en otras congregaciones aun de seculares.

Cualquiera desasosiego del pueblo donde se halle alojada la tropa, se podrá apaciguar inmediatamente con la superioridad de las fuerzas; y cuando la alteración sucediere en otros lugares afuera, cs fácil detener los ímpetus y despejar los obstáculos, marchando un destacamento fuerte hacia donde se fijase la raíz de la sedición. Entonces se hará dueño de todos los puestos; se podrá también calcular el suceso previniendo las avenidas de la sedición, y no habrá embarazo capaz de resistir las empresas.

EI inconveniente que ahora se experimenta en los contintos excesos de quitar los soldados al labrador y al trajinero los víveres que conducen a los pueblos, cesará también enteramente; porque reunidas las tropas en uno o dos Cuarteles generales, es fácil celebrar asientos para 
las suministraciones de los abastos que necesitaren; lo cual es imposible en el sistema actual, pues ninguno se querrá obligar al surtimiento de víveres para una sola companiía, respecto a la poca utilidad que le quedaría de semejante contrato, al paso que la obligación y la responsabilidad sería igual a la suministración de torlo un cjército. En este caso nunca habría carestía para el soldado, porque el asentista sacaría de las piedras los abastos neccsarios, sin alterar el precio contratado; y de este modo, aunque el pueblo se halle mal contento con la crisis del comercio de granos, no habrá motivo para mezclar'se el soldado en la opinión del pueblo, ni deberá temerse ruido que al intentarse no pueda sosegarse.

A un golpe de ojo se reconoce la gran ventaja de este proyecto. Jo único que pudiera dudarse es, qué pueblos sean más a propósito para el alojamiento de las tropas. Unos dirán que el Tucumán o Salta, por la abundancia de carnes y bastimentos; otros tal vez que Cochabamba, porque a más de tener las mismas proporciones, se halla en el corazón de esta tierra, para aprontar a menos tiempo y costo los recursos que se necesitaren. No faltará tanıpoco quien vote por Oruro, por la facilidad de conducir allí los víveres desde Cochabamba y por evitar los encuentros indispensables de la tropa con los cochabambinos.

Yo no me conformo con ninguno de estos pareceres, y juzgo que Potosí y Tarija son los lugares más acomodados al plan del intento. Nadie ignora que en Potosí se guarda el tesoro de todo el Reino: aquí es donde vacían sus gruesos caudales las demás Cajas del Virreinato. En esta Casa de Moneda bajan casi todas las producciones de los minerales más ricos, tanto, que al fin del año de 1786 , hemos visto traer platas desde Pasco, que está a cuarenta leguas de Lima. Fucra de esto, es el pueblo más numeroso de la sierra, por ha concurrencia de la Mita, y debemos mirar siempre a toda esta gente forastera, cuando no con sospecha, a lo menos con temor. En suma, aquí donde está nuestro Tesoro, debemos poner todo nuestro corazón en el esmero y en el cuidado de su conservación por medio de precauciones sabias y anticipadas a todo riesgo, guarneciendo la Villa de un destacamento compuesto de la mitad de toda la tropa repartida en las demás Provincias.

Este es un punto de medianía para todas partes. Su grande concrcio facilita arrieros, caballerías y todos los menesteres para un transporte repentino. Yo pucdo asegurar que sólo con las mulas de las panaderías, habilité el año de 1785 más de 200 soldados que pasaron por aquí a Salta y a Chuquisaca. Véase pues cuánta es la proporción para socorrer a los demás pueblos desde Potosí, más bien que de otra cualquiera parte. Sobre todo, la grande importancia de Potosí, despierta todas nuestras miras hacia sí, y sólo este motivo basta para inclinarme a la necesidad de guarneccrla como he dicho; pues, asegurando el Tesoro del Reino, no tenemos qué temer, fuera de ser muy conforme a la buena política, que al interćs acompañe el respeto de nuestro Gobierno. Ejemplo tenemos en el prudentísimo conquistador Hernán Cortés, que dejó en México 80 españoles a cargo de Pedro de Alvarado, para guardar el Tesoro del Rey $y$ de los particulares, 160 y es de razón que imitemos las cautelas inteligentes de aquel tan valeroso General, como político Gobernador en materias de tanta consecuencia.

Tarija, perteneciente también a la Provincia de Potosí, es un país bastante poblado de gente española; de torrenos muy fértiles para toda 
especie de granos, muy semejantes a los campos de Tucumán, de donde al parecer quiso la naturaleza prolongar con estudio una faja de tierras pinguies, a la falda de estas grandes y estériles sierras del Perú.

Estas comodidades para alojarse allí, con preferencia de los indios del Paraguay, y en la última expedición que hicieron contra los indios de Charcas por los años de 1528, y desde entonces se quedaron acantonados en aquella frontera con el nombre de Chiriguanos. Bien sea la proporción de las cordilleras intermedias, o mús bien la poca disciplina militar de los tarijeños, ha dado tanta ansa a los indios, que después de tener ocupada la mejor porción de aquella tierra, se han hocho enemigos formidables para aquel vecindario; y no obstante haber fundado algunas reducciones con la predicación de los Padres Misioneros de San Francisco, todavía son frecuentes las invaciones, los robos y las muertes, con no poco daño y mayor terror de todas esas gentes.

Regularmente, se han frustrado las entradas de aquellas milicias a tierras de los indios, por falta de subordinación y por demasiada ambición. Sus Jefes han sido, por lo general, unos hombres criados como todos y elevados por el favor (comprado o gratuito) al mando superior. El desacomodo de sus casas los ha obligado a reducir a granjería cl cmpleo, aprovechándose unas veces de! botín de los enemigos saqueados, y otras veces de los mismos avíos destinados del fondo público para la guerra.

Luego que se han advertido estas negociaciones, o se han vuelto los tarijeños desamparando el campo, o han armado tales enredos con sus mandones, que la guerra ha sido más entrc ellos que con los indios. De aquí se han originado enemistades, disensiones, parcialidades y otros mil encuentros que casi han arruinado todo aquel vecindario. $\mathrm{Y}$ lo peor es que, entregados todos o los más a la fajina del papel sellado, han perdido la fuerza del espíritu, cediendo eternamente sus derechos al enemigo; de suerte que por sí solos ya no son capaces de recobrarlos, sino que se les eduque de nuevo en otra escuela menos viciosa.

Véase aquí una población importante por la calidad de su vecindario; digna de fomento por la fertilidad de sus tierras; y acreedora de la protección y tutela de nuestro Gobierno, por las miserables circunstancias que hemos indicado. Al mismo tiempo es la única tierra donde la tropa se puede mantener ejercitada en alardes $y$ en otras fatigas propias para la conservación de la disciplina militar: con que, por conveniencia de unos y de otros, parece cvidenciada la preferencia de Tarija para alojamiento de la tropa.

En tal caso, pudiera instruír y gobernar todas aquellas milicias, el Comandante de la tropa, ahorrando la Real Hacienda el sueldo que tiraría otro cualquier Gobernado: militar. Este es un empleo necesario y casi indispensable en Tarija; pero, establecido allí el alojamiento y Cuartel, cesa la necesidad y se suple muy congruentemente con la Comandancia, que equivale a lo mismo.

En las avenidas principales de los enemigos infieles, se pueden formar reductos, cercados con un foso y su trinchera de palo a pique, con un cañón de campaña de los muchos que aquí están amojosándose por falta de uso; repartiendo en ellos veinte o treinta hombres de guar. nición con su cabo u oficial. 
El Comandante debería residir en la misma Villa, con la obligación indispensable de hacer su alarde y correrías, cada dos meses, 15 o 20 leguas más adentro de los fuertes, para despejar el campo, reconocer los pasos y castigar a los enemigos que encontrare; avanzando siempre los fuertes o reductos sobre el terreno que fuese pacificando, para que el vecindario adelantara también sus poblaciones $y$ estancias a la sombra de esta defensa. Ya se vería, al cabo de dos o tres años, pedir a porfía las tierras desembargadas; poblarse de mucha gente y ganados los lugares desiertos; y por último, se ahuyentaría el enemigo hacia lo interior del Chaco, o solicitaría reducciones para no ser perseguido.

Repartiendo con equidad la fatiga entre los milicianos y veteranos, para estas correrias, trabajarían todos por igual, y al mismo tiempo se jrían disciplinando los unos y ejercitando los otros, para no viciarse en la ociosidad. X para que la tropa de Potosí no cayese en semejante inconveniente, sería bien alternarla con la de Tarija, cada seis meses; de suerte que, al fin de año, quedare toda ella actuada en las mismas camparaas y servicios.

Si acaso se ocupase en ambas guarniciones un Regimiento de Infantería, por el menos sueldo (que es muy suficiente), es seguro que, relevándolo dentro de tres años, ya sería un Regimiento de Caballería, porque el servicio de campaña en las corverías y alardes, forzosamente los instruiría en el manejo del cabalio, sin el cual nunca se da un paso en estos países; y con ésto vendría a valer por dos cada Regimiento que se emplease en estos dos Cuarteles gencrales; bien que para empeñarlos, sería conveniente guardar para el premio este mérito, en el mismo pie que están las tropas de las fronteras de Chile, pues no se encuentra diferencia en las fatigas ni en el riesgo. ${ }^{161}$

Y debemos convenir que entabladas las cosas en esta forma, en vez de inutilizarse (como ahora) la tropa veterana, se haría más aguerrida para todo género de empresas. Se lograría también instruír en caballerías casi todos los Regimientos de Infantería, después de algunos años de alternativa y con suello de soldado de a pie, podrían desempeñar en ocasiones las funciones de a caballo.

Al goce de las nuevas tierras, que iría descubriendo y pacificando la población y la fuerza, correrían todos para cultivarlas; el Chaco se desalojaría de tanto gentil que redunda en nuestro daño; por último se abrir'ía otra vez el camino al Paraguay, Corricntes y Santa $F e$ y florecería el comercio de aquellas Provincias, con la nueva alianza de estas del Perú.

En cada capital de Intendencia, basta ocupar dos hombres: uno de ordenanza y atro con título de Ayudante, para los menesteres del Jefe. $Y$ cuando fuere preciso pedir auxilio a Potosí, de alguna tropa para conducir reos o ejecutar algún castigo, puede hacer esta diligencia el ordenanza mejor que nadie, quedando el Ayudante para cumplir las órdenes superiores en lo que necesiten do semejante ministro.

Debiendo mirarse como una máxima muy importante de nuestra política, no instruír jamás al pueblo en el ejercicio de la guerra, con título de milicias, porque siendo indispensable ocupar a los artesanos y otros menestrales (que son los hombres de más razón en estos países), dejarían sus oficios y trabajos, para andar armados; se harían holgazanes y escandalosos, y después de revolver mil pendencias con peligro de la quie- 
tud pública, al cabo no servirían sino para causar cuidados a nuestro Gobierno. Ello es peligroso ejereitar a la plebe en las armas y peor el armarlas, porque en sabiendo lo que es la pica, el arcabuz, el tambor, la vela y las demás cosas de la disciplina militar, se hace insolente $y$ sospechosa. Lo cierto es, que este motivo sólo bastó para que en Castilla se mandara cesar la ordenanza de la gente que levantó el Cardenal Cisneros, con el fin de contener a los grandes, y todos nuestros políticos contextan que a no ser así, se hubiera hecho el Reino inexpugnable el el levantamiento de las comunidades, en los años de 1519 hasta 1522 , o a lo menos hubiesen sido mucho mayores y más sangrientas las alternaciones de los pueblos.

1.- El año de 1723 , se permitió la entrada de granos de fuera, por las razones que apunta Ustáriz, en su Teórica de Comereio, Cap. 92, fol, 203.

2.-De esta Pragmática y de sus notivos, hace relación el Ilmo. Fermosino: "Ad rubricam", in Cap. 10 de Constilutionibus; Cuest. 6, Nos. 12 y 13 , tomo 1", fol. 143.

3.-- El gobierno de los Pósitos se regló por la sabia instrucción dada en Buen Retiro, el 30 de mayo de 1753 , y que la transcribe Martinez, en su-Librería de Jueces, tomo $7^{\circ}$, pág. 243 , No. 1344 en el $\$ 3^{n}$, sobre el título 25 , libro $5^{\circ}$ de Castilla.

* En la actualidad este oficio de actparadores lo ejercen exclusivamente nujeres. (N. de E.).

4.-Carrasco: Cap. 2 de Diferis, No. 28 , fol. 19. E1 P. Calancha, en el libro $1^{\circ}$ de su Crónica, Cap. 10, No. 3, fol. 65, establece las estaciones del año en el Perú, poniendo el principio de la primavera a 6 de septiembre hasta el 10 de enero; el estío desde el 10 de enero hasta el 15 de marzo; el otoño, desde este día hasta el 15 de junio; y el invierno, desde este día hasta el 6 de septiembre.

5.- I eyes 13 y 14, título 28 , Jibro $8^{\circ}$. Escalona: Lib. $1^{\circ}$, Cap. 5 , No. 10 . Vide Par-

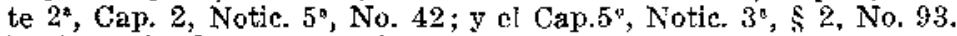

6.- El Art. 267 de Ia Nueva Ordenanza, es argumento eficaz para esta decisión.

7.-Ley 15, Cap. 9, título 25, libro 5 de Castilla.

8.- Escalona: en su Gazophil.; libro 1', Cap. 23, Cas. 20, No. 4, fol. 86.

9.-Valenzuela: En Ilustración a la Polít. del Sr. Solórzano. Lib. 5\%, Cap. $1^{\circ}$, No. 14, tomo 2 , fol. 257.

10.- Ordenanza novena y $45^{\circ}$, título 17 , libro $2^{\circ}$ del Pcrú.

** Huayeos: voz quichua que significa quebradas. (N. de E.).

11.- Real Cédula de Madrid, $\dot{a} 30$ de mayo de $167^{7}$.

12.- Ley $1^{\circ}$, título 8 , libro $7^{\circ}$ de Indias. Ley 82 , título 15 , libro $2^{\circ}$ de Indias. Ley 26 , título 3 , libro $3^{\circ}$ de la misma recopilación.

13.- Bobadilla: en su "Politic"; Lib. 1", Cap. 12, Nos. 35 y 37 al fir, fol. 187.

14.- Narbona: en la ley 59, título 4. Ley $2^{\circ}$ de Castilla, Glosa $1^{\circ}$, No. 203, fol. 183.

15.- Los Virreyes, Audiencias, Gobernadores y Alcaldes Mayores, no deben sacar de los tribunales donde pertenecen, ni avocárseles a sí, impidiendo la $1^{\prime \prime}$ y demás instancias a quien toca por derecho; ni consentir en sacar los presos de los lugares donde se hubiere dado causa a la prisión, para llevarlos a otros donde residen. Ley 35 , título 3 , libro $3^{\prime \prime}$. Ley 70 , título 15 , libro $2^{\circ}$. Ley 14 , título 2 , libro $5^{\circ}$ de Indias.

16.- Este modo últinamente preserito por el Superior Gobierno, se halla arreglado a las leyes 11,12 y 44 , título 7 . Leyes 11 y 28 , título 13 , libro $1^{\circ}$ de Indias. Leyes 5,8 y 9 , título 11 . Leyes 33 y 70 , título 14 , libro $1^{\circ}$ de la misma recopilación.

17. - Ley 7 , título 17 de Castilla. Ley 3 , título 8 , libro $7^{\circ}$ de Indias, Ley 83 de Toro, Arts. $1^{\circ}$ y $2^{\circ}$, título 4, libro $8^{\circ}$ de los Acordados de Castilla. Leyes 6 y 7 , titulo 4 , libro $8^{\circ}$, ley 10 , título $1^{\circ}$, libro $1^{\circ}$; ley 57 , título 5 , libro $2^{\circ}$ de la misma recopilación. Ley 26 , título 11 , Parte $2^{8}$, ley 11 , título 8, p. $^{4}$.

18. - Véase en Elisond. tomo $1^{\circ}$, Pract. Crim. fol. 317, No. 5 al fin.

19.- El Sr. Virrey Conde de Superunda: en 5 de junio de 1751.

20.- Matheu: De Re Criminali; controrers. $3^{4}$, Nos. 1 y 32 hasta 46. 
21.- Cuando resulta daño de tercero o el negocio es entre partes, se lama materia de justicia, en la ley 34 , título 15, libro $2^{2}$. I eyes $38,41,58$ y 59 , título 2 , libro 2 . Ley 25 , título 3 , libro $3^{4}$. Ley 60 , título 15 , libro 20 de Indias. Ley 11 , título 4 , libro 2 de Castilla.

22. - Real Cédula de Carlos 1II, dada en Aranjuez, a 17 de abril de 1774, recopilada en la ley $8^{3}$, titulo 15 , libro 8 de Castilla, de la impresión novísima de 1775 .

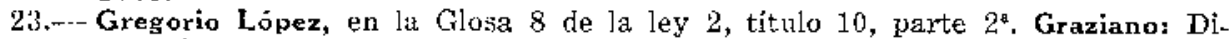
sertaciones Forenses; tonso $1^{\circ}$, Cap. 167, Nos. 41 y 23, fols. 403 y 404 .

24.- Solórzano: jlı Holit., Lib. 4\%, Cap. 8, Nio. 24. Larrea: de cie. Granatenses Disput. $2^{a}$, l'yecipue No. 8 y 1 6. Antúnez: De donationibus; Lib. 2, Cap. 13 al No. 121. Valenz.: Concil. 43, No. 14. Crespo de Baldaura: parte $1^{\text {\% }}$, obser: 7 a Fo. 33 y siguientes. Zeballos: Q. 768 , No. 21 . Jerónimo González: in Régula 8. Chancelaria, Edos. 5\%, $\$ 6^{\circ}$, No. 40 hasta 45 , fol. 131.

25. - Larrea: Dreis. 98, Nos. 57, 58 y 62.

26. - Larrea: Disp. 2", No. 16.

27.- Gregorio López: ley 5 , título 19 , parte $66^{4}$.

28.- Iey 27, lítulo 4, libro $S^{\circ}$ de Indias. Ley 47, título 2, libro $3^{\circ}$, mismo Cod.

29.- Regla 14 , título 34 , partida $7{ }^{\circ}$.

30. Leyes 9 y 14 , título 29 , Partida 3

31.- Ley 9, título 27 , libro 9" de Indias. Vide Solórzano, in Polit., libro 39, Cap. 6, No. 33 ; y libro $6^{\circ}$, Cap. 14, No. 14.

32.- El año 1614 se prohibió con pera de muerte y confiscación de bienes, el comercio clandestino, principiando en la Bahía de Bastimentos, que después se exiendió a otras costas y puertos; y se recopiló esta prohibición en la ley 7 , título 27 , libro $9^{\circ}$; ley 8 , título 13 , libro $3^{\circ}$ de Indias.

33.- Ley 8 , título 27 , libro $9^{\circ}$ citado.

34 - Leyes $1,8,9,12$ y 35 , título 27 , libro $9^{\circ}$ citado.

35.- Esta Cédula se recopiló en la Iey $1^{*}$, título 27 , libro $9^{\circ}$ de Indias.

36. - Fsta Cédula se jecopiló en la ley $1^{\circ}$ citada, título 27 , libro $9^{\circ}$, y en la ley 31 del mismo titulo y libro, partiendo sus capítulos.

37. - Ley 10 , título 27 , libro 9 ?.

38. - Ley 19, título y libro citados.

39. - Ley 21 del mismo título y libro.

40.- Gregorio López: en la Glosa 14 de la ley 2, título 24, parte $4^{4}$ de Salcedo: "De lege políticu", libro 2, Cap. 18, No. 33. Antúnez de Portugal: De Donationibus regis, libro 2 , Cap. 15, No. 38.

41.- Benedicto XIV, en la Instrucción pastoral 41, \$3, numera los casos exceptuados por derecho común y Bulas antiguas.

42.- "Si te quieres hacer inmortal, hazte pleito eclesiástico" dice nuestro Solórzano, in Polit., libro $4^{\prime \prime}$, Cap. 9, No. 2, fol. 65, tomo $2^{\circ}$.

43. - Los Jueces celesiásticos jamás declaran contra la immunidad en los casos más notorios, como lo notó con admiración nuestro Frazo, en "De regio Patron." Cap. 36, No. 42 y 43 , tomo $1^{\circ}$, fol. 237.

44,-. En su Bula que comienza: "Cum alias non nulli"; dada en Roma, año de 1591.

45.- En su Bula: "Ex quo Divina”; de 1726.

46.- En la Bula: "In supremo justitie solio"; año de 1734.

47.- En su Bula: "Ofici nostri", de 15 de marzo de 1750 , que es la 29 entre las suyas; tomo 3 de su Bulario, fol. 126.

48.- En su Bula: "Ea semper", de 12 de septiembre de 1772 .

49. - Ladrón público se llama el que con osadía y publicidad roba lo ajeno, según Benedicto XIV, en su Pastoral 41, § 3 , tomo $1^{\circ}$, fol. 182 , cuya autoridad excluye las muchas opiniones antiguas, dimanadas de la Bula Gregoriana, que no fué admitida en España, según Matheu, en "De re criminali"; controv. 7, No. 14.

50.- Estos son los casos exceptuados por Gregorio XIV, en la citada Bula, que es la séptima entre las suyas; tomo $2^{\circ}$ del Bulario Romano.

51.- Son casos exceptuados por la Bula de Benedicto XIII.

52.- Clemente XII, en la Bula de 29 de enero de 1734 , extendida a los reinos de España, por otra de 14 de noviembre de 1737, que refiere Martinez en su "Libreria", T. III, fol, 211. Benedicto XIV, en los párrafos 9, 10 y 11 de la citada Bula de 15 de marro de 1750 . 
53.- Ley 13, título 2, libro $1^{9}$. Ley 2 , titulo 19 , libro $5^{\circ}$ de Castilla. Curia Filip., libro $2^{\circ}$, Cap. 11, No. 18.

54.-- Ley 5, título 11, P. 13. Bolero de Decocr., título 1, Q. 12, No. 10, fol. 113.

55.-Ley 3 , título 5 , libro $5^{\circ}$ de Indias.

56.- Ley 3, título 11, Parte $1^{\text {. }}$.

57.- Covarrubins: Lib. $2^{\circ}$, Cap. 20, N0 14. Bobadilla: Lib. $2^{\circ}$, Cap. 14 , No. 8.

58.- Mario Curteli: Lib. $1^{\circ}$, cuestión $2^{\prime}$.

59.- Mario Curteli: Lib. 19, Q. 7, No. 40.

60.- La Bula "Alias nos", párafo 7.

61.- Benedicto XIV: en la Pastoral $47 \$ 4^{\circ}$.

62.- Mario Curteli: Lib. 1", Q. 21.

63.- En las remisiones del título 2, Lib. $1^{\circ}$ de los Acordados de Castilla, No. 3.

64.- Benedicto XIV: Pastoral 41, \$ 9.

65.- Artículo $3^{\circ}$ del Concordato, declarado por Clemente XII, en la BuJa "Venerabilis".

66.-Cirino: "Nexus rerum ecclesiástica": Cap. 1: "De inmunitate", Ces. 1", No. 16.

67.- Id. id. No. 18.

68.- Ley 9 , título 24, libro $8 *$ de Castilla.

69.- Auto acordado, remiso al título 2 , libro $1^{\circ}$.

70.-- Ley 6, título 2 , libro $1^{\circ}$ del Ordenamiento.

71. - Socueba: en el Tratado de Asilos, sobre los casos exceptuados.- Martínez en su "Librería", tomo 19, Cap. 3, No. 127, fol, 249. Cirino: "Nexus rerum ecclesiástica", Cap. 7, sec. $1^{\text {" hasta }} 4^{4}$, fol. 561 .

72.- Martínez: De jurisdictione; 2a. Parte, Cap. 51, No. 15. González, en el caso "inter alia", $6^{\circ}$ de Inmunit, $5^{\circ}$ y $6^{\circ}$, tomo 3 , fol. 643 .

73.- Acevedo, en lat ley 11, título $8^{\prime \prime}$, libro $5^{\circ}$ de Castilla. Narbona, en la ley 20 , título 1, libro 4 , glosa 12 , No. 32 .

74.-- Clemente XII, en la BuIa "Alias nos".

75.-Ley 1 , título 4 , libro $1^{\circ}$ de Castillia.

76. - Citada Bula: "Alias nos".

77. - Socueba, con muchos Drs., fol. 194 , No. 28.

78.- Martinez: tomo $1^{\prime \prime}$, Cap. 3, fol. 250 , Na. 128.

79.- Carlev.: De Judicis; título 1, Disp. 2, sec. 3, No. 448, fol. 104.

80.- Esta interpretación es de Carlev., en el lugar citado, Montealegre: in "Praxịs civili"; Lib. 14, Cap. 9, No. 150, fol. 146.- Vide Fermosino, in Cap. 10, "De Judicis"; cuest. 16, No. 5, tomo $4^{\circ}$, fol. 211 .

81.- Es conforme al No. 15 de las remisiones del título $1^{\circ}$, libro $4^{\circ}$ de Castilla y a todas las doctrinas que cita Cirino, en "Nexut rerum eclesiasticarum", Cap. 3, fol.126.

82.- A estos casos se pueden añadir los que refiere Martínez: De juris dict., 2a, p., Cap. 51, fol. 285 .

83.- Cirino: Ir nexu rex Ecelesiast. Cap. 7, de Inmunitat. Secc. $1^{\text {* }}$ desde el No. 20 hasta el $8^{\circ}$.

84 .- Id. id. No. 80

85.- Martínez; en su "Libreria", tomo 2", Cap. 6, No, 6, fol, 185.

86.- La Bula "Ea semper", de Clemente XIV, $\$ 17$.

$87 .-\$ 18$ de id.

88.- Pastoral 41,87 , tomo $1^{\circ}$, fol. 288.

89.— Bula: "Oficiî" nostri", de 1750 .

90.- Don Fernado Arias de Socueba, en su Tratado de Asilos; fol. 276 desde el No. 26 hasta el 44, cuestionó largamente la facultad de extraer a los reos las Justicias, por sí mismas y aunque se inclina en contrario, se debe observar la citada Real Cédula, que es de años posteriores a los escritos del autor.

91.- Real Orden circular, fecha en Aranjuez, a 15 de mayo de 1779, colocada bajo el No. 38, que corresponde al Art. 254 de la Ordenanza de Intendentes.

92. - Se pone el método, porque no será fácil en todas partes encontrar la Cédula citada. En las Audiencias, toca a los Fiscales la defensa de la real jurisdicción, por la ley 30 , título 18 , libro $2^{\circ}$ de Indias.

93.- Socueba: en el Tratado de Asilos; $\S 3^{\circ}$, fol. 244, y prineipatmente fol. 260, desde el No. 14, prueba que, para dejarse el reo a disposición del Juez real, basta el proceso formado por la Curia secular. Pero yo he visto a Prelados muy doctos, hacer por separado su sumaria, para descargar mejor su conciencia, y así lo indica la Bula de Clemente XIV, de 1772 , porque, si para extraer 
a los refugiados en Ias Iglesias que no gozan asilo, debe dar el eclesiástico licencia, sin ningún conocimiento de causa, se induce, por el contrario, que debe tomarlo, cuando los templos de donde se extrajeren, sean do los destinados para el refugio.

94.- El Auto 4, título $1^{\circ}$, libro $4^{\circ}$ de los Acordados de Castilla, había declarado mucho antes, que en este caso corresponde el Auto de legos, de que se hace fuerza en conocer y proceder. Jo mismo opinó nuestro Matheu y otros; y aunque disiente Socueba en su Tratado de Asilos, fol. 313, a No. 21 y siguientes se debe estar a lạs Reales disposiciones. - El modo de poner en prúctica estos recursos, vide en Socueba, fol. $295,4^{\circ}$ desde el No. $1^{\circ} \mathrm{y}$ siguientes

95. - Se refiere este Breve por: Socueba, en el Tratado de Asilos, § 2, No. 2, fol. 227 .

96.- Socueba: fol. 306 , No. 12 y siguientes.

97.- Esta prohibición se entiende con los indios, por la ley 10, título 8, libro 7 de Indias, $y$ también con los extranjeros, por Real Cédula de 31 de diciembre de 1672; pero con otros delincuentes se deben guardar las leyes del citado título 8, libro $7^{\circ}$; con especialidad las 11 y 12 que hablan sobre destierros.

98. - Es terminante la ley 2, titulo 19, libro $8^{\circ}$ de Castilla; et ibi Acevedo y Salgado, "De regia protert"., 2a. parte, Cap. 4, No, 167.- Gutiérrez: "Pract. Crim.", Q. 70, No. 6.- Salcedo: "De lege política"; libro 1", Cap. 10, No. 89, fol. 118.

99.- Caponi: tomo 4, Disert. forense 265, No. 18 , fol. 156

100....... Marta: De jurisdictione; 2a. parte, Cap. 51, No. 15, fol. 287.

101.- Benedicto XIV, en la I'astoral 41 ; $\$ 9$, fol. 293.

102. - Fagnano: in Cepp. 6 de Inmunitati; No. 14, vig. 21, tomo 2, fol. 838.- González, in Eodem, Caps. Nos. 5 y 6, tomo 3, fol. 643.

103.-Cardenal de Luca: De Matrimon,; discurso 2, tomo 14, fol. 143; glos. in Cap. Cum inhibitio 3 de claudestina desposat.- Diego Pérez, in leg. 1, título $1^{\circ}$, libro $5^{\circ}$ Ordinam. Regal, vers. pluratamen.- Salcedo et Bernardo Díaz, Cap. 73, litera A, fol. 233.- González, in Cap. Cum inhibitio, citato; No. 6, tomo 4 , fol. 65 .

104.- Lcy $1^{4}$, título 3, parte 4a.- Concil. Trident, sec. 24: De reformatione impuberum; No. 11, tomo 4 , fol. 49 .

105.-... In Cap. final de Clandestina desposatione.

106. - Salcedo: en la práctica a Bernardo Diaz; Cap. 7, vers. $6^{\circ}$, fol. 238.— González, in Relato, Cap. Cum inhivit, No. 5.

107.- Salcedo: en el lugar citado: vers. Non tamen; fol. 239.

108. - Concilio Tridentino; sec. 24, De reformat., Cap. $1^{\circ}$.

109.- Salcedo: vers. 7 , pág. 239.

110.- Antonio Gómez: in Lér. 49.

111.- Acevedo: in ley $1^{\ddagger}$, título 1, libro $5^{\circ}$, R. C.; No. 54.-. Sánchez: Del Matrimonio, $1^{4}$ parte, libro $3^{4}$, dis. p. 54, No. 6.- Zeballos, cuest. 897, Nos. 669 y 670 , tomo 4", fol. 55 .

112.-Gómez: in Predicto; Cap. Cum inhibit., No. 6, tomo 4", fol. 65.

113. - Ibiden.

114.- Zenedo: Cuest. pract. 30 , a Ǹo. $101 \mathrm{y}$ siguientes, fol. 292.- Gutiérrez: lỉ. bro $2^{\circ}$, Pract. Cuest. viv, Q. 4 a No. 8, tomo $1^{\circ}$, fol. 9.

115. - Sánchez: libro 4, De] matrimonio, Disp, 23, No, 10.- Zeballos: Constit. Q. 604, No. 33, con otros que citá Don Man. Gómez, en el Cap. $1^{\circ}$ de Desponsatione impúber, No. 12 , tomo 4 , fol. 50.

116.- Duareno Fortáculo, y otros que cita Goriz, en el Cap. citado, No. 10, fol. 49.

117. - Tridentino, sec, 24 , Cap. $1^{\circ}$.

118. - Femosino: in Cap. 10, de Constitutionibus; cuest. 27, Nos. 48 y 61 , tomo $1^{\circ}$, fols. 353 y 354 .

119. - Van Espen: De jure Eclesiast, parte 1", titulo 12, Cap. 4, al No. 20 y siguientes, fol. 47.

120.- Van Espen: De jure Eclesiast., tomo 1", título 12, de Exponsalibus; Cap. 4, No. 26 , fol. 471 .

121.-Van Espen: tomo $1^{\circ}$ citado, título 12, Cap. 5, No. 28, fol. 474.

122. - Tiraquelo: tomo 6, glos. in Verbo donatione largitus; No. 288, fol. 139.

123. - Tiraquelo: tomo $3^{4}$ : De retractis, $\$ 1^{\circ}$, glos. 8 , Nos. 3,4 y 5 , fol. 54 .

124. - Ley 2, título 17, Partida 4. 
125.- Ley 10, título 13, Partida 6; Leyes $2^{a}$ y $5^{*}$, título 19, Partida $4^{\circ}$; Ley 7, títu* lo 8, libro $5^{\prime}$.- Ley 8, del mismo título y libro de Castilla.

126.- - Ley 7, título 8, libro 5' R. C.

127.-Zenedo: Singulares; 35 , fol, 456 , No. 1 y siguientes.

128.- Ley 5, título 5, libro $7^{\circ}$ de Indias.

129.- Ley 21 , título 3 , libro 6 " de la misma recopilación.

130.-Villadiego, en su Politic. Cap. 8, No. 91, \$ "Y advierta el Juez", fol. 331.

131.-Curia Philip. $1^{\mathrm{D}} \mathrm{P}^{\text {P. }}$, 14 , Nos. 3 y 4 .

132.-Fermosino: in Cap. "Dilecti de judieiis; cuest. 17, No. 27 y siguientes, tomo $4^{\circ}$, fol. 139 .

133.- Barbosa: Cláusula 162 , No. 26, fol, 482.

134.- Cap. Quomam $5^{\circ}$ vt. lie non contestata; ibi. Barbosa y González Téllez, con Salgado y otros que cita la Curia Philip, $1^{*}$ parte, $\$ 14$, No. 14, libro $8^{\circ}$, título 10 - Ley 2, título 16, parte $3^{\mathrm{A}}$.

135.- Pareja: De universa instrumentorum, edit, título 10 , resolución $4^{*}$, per totum, fol. 240.

136.- - Pareja, en lugar citado, Nos. 2 y 3.

137.- Cap. Conquestus, final de feriis et ibi.- Fagnano, tomo $1^{\circ}$, fol. 91.

138.- Constitución universa, de 1642.

139.- Vide la Real Cédula de 19 de septiembre de 1771.

140.- Concilio Provineial $1^{*}$ Limense, en la acción $4^{*}$, Cap. 9, señaló por menor los día de fiesta para españoles, distinguiendo los que son de precepto para los indios.

141.- El lunes y martes de Carnestolendas, debe haber despacho; $y$ de las vacaciones antiguas de Pascua, sólo son feriados los días desde el de la Navidad hasta $1^{*}$ de Linero, y desde el domingo de Ramos, hasta cl otro de Pascua, inclusive conforme al auto 75 , título $4^{\circ}$, libro $2^{\circ}$ de los Acordados de Castilla; pexo por acá, se guardan hasta el lunes de Cuasimodo. En esta TABLA no se incluyen todos los Patriarcas, sin embargo de hacerlos feriados el auto 104, título $4^{\circ}$, libro 2 de los Acordados de Castilla.

142.- Cap. fin De Feriis.

143.- - Libro 34, título 2, Partida $3^{\text {* }}$.

144.- L. Jus publicum 39 ; $\$$ De practiis. Ley 11 , título 28 , part. 2 ; L. 32 , título 9 , Part. 6, in princip. Gregorio López: Glosa $2^{2}$, circa medis in Lege 2, título 16, Partid. $7^{4}$. - Scacia: De judiciso t tomo $1^{\circ}$, Cap. 46 hasta el medio, fol. 101.Fagnano, en el Cap. Concuesta 5, De feriis, No. 12, tomo $1^{\circ}$, fol. 92 .

145.- Scacia: De judiciis; Cap. 53, No. 23, foJ. 135.

146. - Fagnano, en el Cap. Conquestus 5 de feriis, per totum, tomo $1^{\circ}$, fol. 91 Raynaldi: tomo $2^{\circ}$ : Observaciones criminales; Cap. $1^{\circ}$, No. 1 , al 9 , desde el No. 25 hasta el 70 ; fol. 103 hasta el 107.

147.- Ley 35 citada; título 2, Part. $3^{2}$.

148.- Conquestus 5 De feriis, et ibi Fagnano, No. 13, título 1", fol. 93.

149.- Ley Provinciarum, C. De feriis.

I50.--Raynaldi: Observns. Crimimnls.; Cap. 1, No. 1 at 9, Nos. 50 y 51, tomo $1^{9}$, fol. 105.- Scacia: De judicis, Lib. 2, Cap. 6, Nos. 13 y 25 , tomo $2^{\circ}$, fol. 163 .

151.- Scacia: Lib. $1^{\circ}$ De judicís, Cap. 46 , Nó. $13 \mathrm{y}$ siguientes, tomo $1^{\circ}$, fol. 100.

152.- Raynaldi: Cap. 1", No. 62, tomo 1", fol. 106. Fagnano: tomo 19, fol. 93, No. 21.- Scacia: Lub. 2, De judicils, Cap. 6 , No. 8 , tomo 24 , fol. 163 . etc.

153.- Alfaro: De oficio Fiscalis; glosa 16 ; privileg. 57 , No. 199, fol. 85 .

154.- Tor el Sínodo 3 Limense del año 1585, Cap. 61, se impone la pena de dos lbrs. de cera para la Iglesia, a español que viola la fiesta, y al indio veinte azotes, por el Cap. 82 del mismo sínodo.

155.- - Benedicto XIV, en la Carta Pastoral 43, tomo $1^{\circ}$, fol. 304.

156.- Van Espen: De jure eclesiast.; part. 2, Cap. 4, título 17, No. 20, tomo 1, fol, 543 .

157.-- Raynaldi: Observ, Criminls.; tomo $1^{\circ}$, Cap. 1, $\& 1$ al 9 ; No. 84, fol. 109.

158.- Los indios creían inmortales a los soldados españoles, y rayos, las armas de fuego, - dice- Solís en la Historia de México; Lib. 1', Cap. 13, fol. 123.

159.- Marqués de San Felipe: en los comentarios de Felipe V.; Lib. 7, tomo 1", fol. 243.

160.- Solís: Historia de México; Lib. 4", Cap. 7, tomo 2, fols. 324 y 325.

161.- Auto Acordado de 2 de jumio de 1678 , a consulta del Consejo de Intendentes; al fin del título $4^{\circ}$, Lib. $3^{\circ}$ de la Recopilación. 


\title{
CAPITULO SEPTIMO
}

\section{Del Vice Patronato de los Intendentes}

Se refiere el número de las Iglesias de esta Provincia; los objetos principales a que se debe atender $y$ se proponen arbitrios para mejorar el estado Eclesiástico en cuanto a los Párrocos.

\author{
NOTI C I A P I M E R A
}

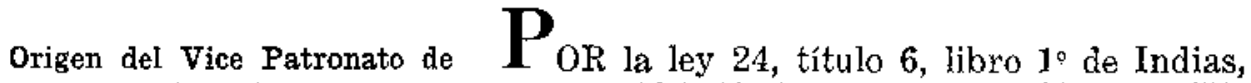
los Intendentes. se cometió indistintamente a los Excmos. Virreyes, Presidentes o Gobernadores, el ejercicio del Real Patronazgo; y después, por varias controversias que se suscitaron entre estas tres autoridades, se declaró en Real Cédula dada en San Iorenzo, a 13 de octubre de 1719, a instancia del Presidente de Chile, que la presentación de los beneficios de aquel Reino, le tocaba a él, y no al Gobernador de Valdivia, como lo había intentado; de suerte que, habiendo algumos Gobernadores subalternos en el Distrito de las Provincias, no deben ejercer el Real Patronazgo, sin expresa concesión.

Esto mismo se ve declarado en la ley 26 del propio título y libro, para con los Presidentes de La Plata, prohibiendo absolutamente a los Corregidores, Alcaldes mayores y demás Justicias, presentar Curas Doctrineros cn pueblos de indios de su mando. De tal forma, que aun después de haberse erigido en Gobierno el Corregimiento antiguo de esta Villa, nunca hicieron presentaciones sus Gobernadores, no obstante que la ley 27 del título $6^{\circ}$, libro $1^{\circ}$ citado, permite a los Gobernadores que presenten en sus distritos sacerdotes beneméritos para las Doctrinas y beneficios. 
De ésto resultó que siendo tan extenso el territorio del Arzobispado de Charcas, y numerosísima la multitud de Curas que instituye aquel Prelado, no podía el Presidente informarse de todos los propuestos con arreglo a la ley 28, título 6, libro $1^{\circ}$ del Patronazgo de Indias, y era preciso presentarse muchos sacterdotes que no eran a proposito, ni aun suficientes para Curas de almas.

De este desorden nacieron otros innumerables que calificó después el tiempo y la experiencia, no solamente en perjuicio de las costumbres de los indios, sino también en 'l de su doctrina y enseñanza. Por último, conoció a fondo estos inconverientes nuestro ilustrado Gobierno actual y trató de reformar con sabiduria el antiguo sisteria del Patronato.

A este fin se concedió a los Inlondentes de Provincia, el ejercicio del Vice Patronato Real, conforme a las leyes, por el Art. $6^{\circ}$ de la Ordenanza de 28 de enero de 1782 , con la justa esperanza de que en las visitas anuales encargadas a estos nuevos magistrados entré sus más indispensables obligaciones, reconocerían los Distritos de las Doctrinas, las proporciones para la buena enseñanza de los indios y los embarazos de ríos inmediatos, esteros, pantanos, quebradas $\mathrm{y}$ otros impedimentos capaces de estorbar el cumplimiento de los preceptos de la Iglesia a los indios esparcidos fuera de sus pueblos cabeceras. Pues, en todos casos conviene reflexionar sobre el celo del Párroco para tratar la desmembración de los beneficios, o a lo menos escoger para ello a los eclusiásticos más celosos, que sepan vencer los embarazos con su vigilaneia, ejemplo y conducta.

No se debe dudar que cesarán enteramente los desgraciados perjuicios que motivaron las sabias providencias referidas, si los nuevos Intendentes miran el Patronato, no sólo como una de las regalías más estimables de la Corona, sino también como una autoridad delegada de la Silla Apostólica, para atender el bien espiritual de los indios, procurando su enseñanza bajó la dirección de buenos Pastores. Antes era casi imposible acertar con este importante objcto, porque los Presidentes Vicepatronos de todo el Distrito del Ar'zobisnado de Chareas, no tenían conocimiento de les territorios, ni podian tenerlo de todos los eclesiásticos propuestos para las Doctrinas, y cuanclo acertaren en uno u otro, era forzoso que con los demás sucediese lo mismo que a un geómetra que tira compases en país no conocido.

La felicidad consiste en que los Intendentes y el Ilmo. Arzobispo vayan de acucrdo en las propuestas y presentaciones, que sobre los conocimientos de la tierra y de los lugares, se forme un escrúpulo muy serio acerca de no proveer los beneficios en un cualquiera, para evitar lo que ha sucedido tantas veces, de elegir en vez do Pastores, lobos, y en lugar de maestros, unos hombres ciegos que arrastren con su ignorancia todo el pueblo al precipicio.

(Es interesante recomendar la lectura de la "Vida y escritos de Victorián de Villava" que publicó Don Ricardo Levene, en Buenos Aires, donde se examina la actitud de muchos Párrocos que se opusieron a reunir indios para la mita. A raiz de esto, Villava, Protector le naturales, polemiź con el Gobernador Paula Sanz, de quién fue Ascsor don Pedro Vicente Cañete y Dominguez. - Nota de A. Alba). 


\section{NOT I I I S E G U N D A}

De las Iglesias fundadas en
esta Provincia, y de otras que
conviene establecer. Se propo-
ne arbitrio para verificar es-
tas erecciones, sin gravamen
de la Real Hacienda y sin des-
membración de los beneficios
actuales,- Párrafo primero.
Iglesias establecidas en esta
Provincia. sacristie; en ripez, tres Curato, rueve Curatos y una sacristía; en Lípez, tres Cuxatos; y en Atacama dos; los cuales, sumados entre si, forman los 66 Curatos expresados, tres sacristias y una capeHlanía.

Todus estos Curatos, a excepción de los dos fundados en la Iglesia Matriz cle Iotosi, Aullagas y Guayeona del Partido de Chayanta, se hallair dotarios con wils respectivos sírodos, que se pagan a los Curas, por tercios del año, del ratmo de tributos donde tienen su situación por las leyes; y aunque sólo siete de todos ellos purciben el sínodo entero de 1.250 pesos, correspondientes a los 800 pesos ensayados, que el Sr. Virrey Don Francisco de Toledo señaló a cada Cura, en providencia de 1572, a que se refiere otra de 25 de abril de 1574 , con todo, importa 49.781 pesos 2 y $1 / 2$ reales, el total de sínodos que paga la Caja Real de Potosí a los Curas de su jurisdicción; cuando, por otra parte, apenas sube a 8.886 pusos y medio real, el cargo de mesadas que enteran los Curas, por una ve\% en su vida.

Lo mús sensible es, que despnés de tantos gastos y cuidados con que minora su patrimorio y desvela su celo nuestro piadosísimo Monarca, todavía no sc logra el importantísimo fin de doctrinar a los indios en vida y socorrerlos en la muerte con el auxilio de los Sacramentos de la Iglesia; porque son tan grandes las distancias de unos a otros lugares, y tan impracticable reunir en los pueblos a los indios, acostumbrados a vivir en sus cabañas solitarias, desde su gentilidad, que los más de ellos no oyen misa entre año; de consiguiente, no saben la doctrina cristiana y lo peor es de todo, que mueren sill sacramentos, bien sea porque se descuidan de llamar al Cura, o porque los Curas no se quieren incomodar pasando quebradas y ríos peligrosos, por caminos llenos de fragosidad.

Por otra parte, tiene esta Provincia muchísimos asientos de minas, obrajes de pañetes $\mathrm{y}$ hacienrlas de ganado $\mathrm{y}$ labranza donde sirven los indios yanaconas o forasteros, regularmente sin domicilio ni Doctrina fija. Estos establecimientos están bastante distantes de los Curatos matrices, y aunque los dueños pagan a los Párrocos el sínodo predial, por razón de Doctrina, es tan grande el desamparo de los infelices indios, que descuidando recíprocamente los hacendados y los Curas, unos en otros, se quedun los pobres yanaconas sin enseñanza, y tal vez mueren los más sin sacramentos, si en la hacienda no se halla por casualidad algún Capellán, de los que suelen iv a decix misa los domingos.

Con motivo de estas capellanías manuales, jamás se ve la cara del 
Cura; no oyen de su boca la Doctrina y apenas reciben una ruda enseñanza de los Fiscales destinados para ello, que son también indios como todos. Este pasto que mendigan en campos no sólo ajenos sino también estériles, lejos de instruírlos, tal vez los enferma, y de este modo se vienen a invertir todas las leyes y constituciones sinodales cstablecidas con tanto escrúpulo para la institución cristiana de estas gentes, quedándose en la ignorancia y fuera del robaño de su verdadero y propio Pastor.

Yo he concurrido más de una vez en haciendas numerosas de caballeros, al parecer, muy cristianos; pero nunca he oido que cl Capellán explique un punto de catecismo, conforme al Concilio. Así se pasa un año tras de otro; los Capellanes tiran su salario, y apenas dicen misa mientras el dueño está presente, y en su ausercia, Dios sabe lo que sucede en las chacras, donde no hay Vicario ni subordinación de parte de los regulares que son generalmente ocupados en tales capallanías.

Distancia de longitud y latitud de esta Provincia de Potos, incluyendo los de aquí. tosí, que comprende 66 Cura-

$\mathbf{E}$ Curatos nada debemos extrañar, porque si miramos el mapa de esta Provincia, on Ia parte primera, hallaremos que su distancia Norte-Sur, desde Sucusuma hasta el arroyo de la Quiaca, son ciento diecisiete leguas; y desde los llanos de Manso, Este-Oeste, hasta el puerto de Cobija, doscientas treinta y cinco loguas. De suerte que bojeando todo el territorio de esta Intendencia, comprende novecientas sesenta leguas. Ahora, repártase estas distancias cntre sesenta y seis Curatos, (a) y saldrá el distrito de cada uno por catorce leguas y media, y hasta dieciocho, si las novecientas sesenta leguas se distribuyen entre cincuenta y tres Curatos, que son los de campaña, excluyendo los trece de la Villa y su jurisdicción.

El que tuviere idea de la sierra del Perú, también compren lerá que los caminos son los más fragosos y casi inaccesibles, muy arriesgados muchos de ellos, que es preciso andarlos con pausa y grande cuidado. Hay profundísimas quobradas, donde se forman ríos caudalosísimos a las avenidas llovedizas de verano, que atajan el paso tres y cuatro días, por no haber puentes ni barcos en que pasar. Los arroyos y esteros permanentes, suelen salir de madre por la misma causa, llegándose a cerrar la comunicación entre los lugares más cercanos.

Si el comercio detiene su curso y la codicia no puede ingoniar pasos en semejantes ocasiones, ¿cuán poderosa no será la excusa de los Curas para no moverse de sus casas en busca del infeliz indio, en quien sólo va a hallar miseria, asco y gxandes incomodidades? Desengañémonos, que aun en los tiempos más serenos nunca faltan motivos que retardan o imposibilitan los recursos a estos pobrecitos. No por eso digo que no hay algunos Curas ejemplares, capaces de exponer su vida por salvar la menor oveja de su rebaño; no hablo de ćstos, antes los venero y hallo muy dignos de los mayores elogios; pero, también hay otros, de quienes debo decir tanto como pudiera.

(a) El detalle de los Curatos distribuidos en la extensa jurisulicción de la Provincia de Potosí, está inserto en los cuadros finales de la Parte Primera de este libro. Véase páginas 312 y $313 .-N$. de $E$. 
Párraco segundo. - Iglesias
que conviene fundar en Ia
Provincia.

$\mathrm{N}$ ignola que hallándose las Iglesias matrices en tales distancias que los Párrocos no puedan atuxiliar debidamente a sus feligreses, se deben exigir otras nuevas, que sean proporcionadas para el indispensable recurso de los Sacramentos. Las circunstancias que acabamos de explicax, parece que exigen por fuerza este remedio; pero todavia encuentro otro motivo más legal que obliga a ejecutarlo.

Los Concilios Provinciales Limenses 1 " y 2 , ${ }^{1}$ a que se refiere la ley 46 , título $6^{\circ}$, libro $]^{\circ}$ de la Recopilación de Indias, ordena que a cada 400 indios se erija Curato; y lo mismo en aquellos pueblos que tengan 300 o 200 indios, con la prevención, que no llegando a este último número, se procuré reducirlos donde puedan ser doctrinados cómodamente. El Sr. Frazo, hacióndose cargo de estas disposiciones conciliares y reales, explica que el P'ovincial 2 " T,imense, declaró que los 400 indios deben ser casados, entranto con ellos los clemás que les pertenecen, como muchachos, viejos, huérfanos y forasteros; de suerte que, numerando a Ios 400 indios, por otras tantas lamilias de a cinco personas cada ana, (que es lo sumo a que debe subir el cómputo), resulta que un Curato a lo más debe comprender dos mil persomas, de todas clases, scxos y edades.

Sobre esta suposición, entremos al Partido de Chayanta. Allí se ve por último empadvonamiento, 54.638 personas, indios por su origen, sin contar mestizos, cholos $y$ españoles que no pagan tributo y que, por lo menos, componen una vigésima parte del número matriculado. Repártanse todos estos pobladores entro veinte Curatos, y se verá que a cada uno colresponde 2.731 indios, excediendo en 731 el número determinado por nuestras leyes y Concilios.

Reúnase ahora el cxceso, y salen sobrantes 14.620 indios, correspondientes a otros ocho Curatos que Chayanta debiera tener de más, para que sus gentes fuesen bien doctrinadas, o por lo menos, para que así se presumiera, conforme al espiritu del Concilio y leyes reales. Con lo que se viene a concluír, que este sólo Partido necesita ocho Iglesias nuevas, para que los indios logren la enseñanza y educación cristiana, tan recomendada por nuestra legislación; esto es, atendiendo únicamente a la población, sin considerar los demás motivos que hemos enunciado.

En los otros Partidos de Chichas, Porco, Tarija, Lípez y Atacama, sucede casi lo mismo, con la circunstancia agravante de que los indios viven más repartidos, para gozar de los pocos terrenos que hay en los valles con proporción para la siembra, y de esto nace el grande inconveniente que ausentándose de sus pueblos en las estaciones de la labran$z a$, viven sin Curas, sin doctrina, sin misa, $y$ si enferman, mueren también sin Sacramentos, por no haber Iglesia de donde socorrerse en aquellos parajes.

Fin cuanto a los lugares de repartimiento de indios, asientos de minas, obrajes y haciendas de ganado, dispone expresamente el Concilio $1^{\text {a Limense, }}{ }^{3}$ que se pongan sacerdotes para evitar el desgraciado suceso de morir sin Sacramentos los infelices indios. Las leyes 10 y 11, título $1^{\circ}$, libro $1^{*}$, y la ley 66 , título 16 , libro $6^{\circ}$ de la Recopilación de Indias, están de acuerdo con el Concilio y previenen, que pareciendo necesario a los Vice Patronos, pongan desde luego los doctrineros convenien- 
tes, a costa de los mismos dueños de obrajes y cncomenderos. En cuyo caso, se deberá guardar la advertencia de Rivadineira, ${ }^{4}$ proponiéndose en terna el nuevo doctrinero que se haya de instituír donde no hubiere beneficio eclesiástico; y para las oficinas y obrajes, nombrarse por el Prelado a un eclesiástico, con consentimiento del Vice-Patrono.

Contra este proyecto, ya parece que oigo reparar que, scgún la situación de estas tienras, no es posible exigir de nuevo todas las Iglesias necesarias, a menos que sc costeen otras tantas o tal vez más de las que hay fundadas, pues, de lo contrario, se aliviarán algunos pueblos y quedarán los más en la misma necesidad que se ha ponderado.

Pero aun esto, dirán, que es inverificable, porque si se desmembran y dividen los Curatos actuales para fundar otros nuevos, se llegarán a disminuir estos benelicios sobre tal pie, que por tenues y pobres, no haya sujeto de mérito que quiera servirlos, y entonces, entrando en los concursos eclesiásticos, sin letras ni virtud, vendrán a ser para los indios estos nuevos pastores tan perjudiciales como ahora es el no tenerlos.

A más de esto, sería menester dotar con igual cantidad de sínodos, pues, habiéndose de repartir entre todos los Curas nuevos y antiguos, el mismo númcro de indios prefinido por las leyes y constituciones, corresponde también el propio salario, a menos que se dispensase con las estrechas disposiciones prohibitivas de llevar derechos a los indios, ${ }^{5}$ lo cual por ningún título es convenientic a presencia de los gravísimos motivos que explican los Concilios y las leyes del Reino. Tampoco hay oportunidad de hacer nuevas dotaciones de sínodos, porque si hubiera de situarse todos estos salarios en el ramo de tributos al respecto de 1.250 pesos por cada Cura, vendría a consumirse toda la gruesa en sola esta consignación y tal vez no alcanzaría.

Ello es indispensable fundar nuevas Iglesias para alivio espiritual de los indios; y por consiguiente, nos vemos ejecutados para verificarlo, a salvar los inconvenientes propuestos, y si no me engaño, contemplo fácil el expediente, sin gravamen de los Curatos ni de la Real Hacienda.

Párrafo tercero. - Arbitrio fácil para fundar nuevas IgleBias, sin dividir las antiguas ni gravar la Real Hacienda.

$\mathbf{E}_{\mathrm{L}}$ manifiesto ol error de los que acatados servimente a la letra de algunas declaraciones de la sagrada Congregación, y de varias disposiciones de la nota, sostienen la necesidad de dividir los beneficios, sin reflexionar que en tales cuestiones, como de hecho se deben ponderar las circunstancias de los pueblos, su índole y la dotación de los beneficios, de suerte que, concuxriendo unas mismas causas, como son: distancia del territorio, el número de los parroquianos y otras semejantes, conviene unas veces hacer desmembraciones, y otras veces negarlas, según la diferencia de los lugares, costumbres de la Religión y decoro o majestad de la Parroquia.

Van Espen, T haciéndose cargo de la citada disposición del Tridentino, opina por más conforme a derecho dividir los beneficios, cuando el Párroco de la Iglesia antigua no puede asistir cómodamente a toda su feligresía, por alguna de las causas que numera la Decretal de Alejandro 
III ; ${ }^{\&}$ y no juzga conveniente erigir Capillas o vice Parroquias, al cuidado de Vicarios coadjutores o Tenientes, que administren por cl Cura los Sacramentos al resto del pueblo; fundado este dictamen en dos motivos principales: el primero es que, en las Capillas, regularmente, no se practican todos los deberes que imponc el derecho común y el Tridentino a los parroquianos, ni los Vicarios instruyen al pucblo con la doctrina necesaria, por mirarlo como a rebaño ajeno; la segunda causa es, que descuidando los Curas en sus Tenientes, jamás procuran visitar a los feligrescs encargados a su dirección, $\mathrm{y}$ con esto sucede que casi nunca ven ni conocen a su verdadero Pastor.

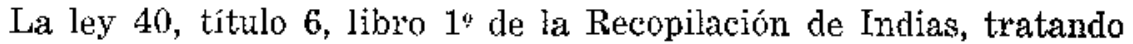
de los medios de socorrer a los pueblos necesitados de Doctrina, menciona la división, la unión y la supresión de los beneficios, sin recordar el arbitrio de fundar Capillas o vice Parroquias. Lo cual (al parecer de muchos) persuade que también nuestra legisiación miró por menos canónico este recurso.

Pero, verdaderamente, es el mejor, el monos gravoso y el más adecuado al espíritu del Tridentino. El Cardenal de Iuca ${ }^{9}$ escribió al propósito un sublime discurso, por comentario de la sección 21, capítulo $4^{\prime}$ de Reformatione; y despućs de advertir las muchas Declaraciones de la sagrada Congregación, decisiones de la Nota y tradiciones de los Doctores, concluye que consultándose suficientemente el bien espiritual de las feligresías, con destinar una o más vice Parroquias, a ciertas distancias para administrarles los Sacramentos $y$ actuar en otros ejercicios religiosos, no hay para qué llegar a la desmembración de la Iglesia matriz (que por lo regular es prohibida, en cuanto suena enajenación), pues, con este remedio se logra el mismo fin y viene a resultar un mismo efecto, sin disolver la unjdad de la Iglesia Parroquial, conservando en ella la antigua majestad y decoro, el concurso de la feligresía y el de todos los Vicarios que, con su asistencia en ciertas solemnidades del año, forman una respetable figura de colegiata en la Matriz.

El moderno Juan Jacobo Scarfantoni, ${ }^{10}$ citando a los autores más clásicos, sigue la opinión de Luca, canonizada por una decisión de la Rota, del año de 1712, y se afirma en que jamás se debe echar mano de un remedio extraordinario, exorbitante, subsidiario y odioso, como es la desmembración, y cuando resultan los mismos efectos del ordinario, de la diputación de Vicarios en vice Parroquias sujetas a la Iglesia matriz.

En efecto, se adoptó este arbitrio en Reales Cédulas circulares, dirigidas a los Exmos. scñores Virreyes del Perú, Santa Fe y México, sus fechas en San Ildefonso, a 18 de octubre de 1764, y en Aranjuez, a 25 de junio de 1765 , ordenándoles lo siguiente: Que en estos dominios de América, se erigiesen Tenientes de Curas rectores, a distancia de cuatro leguas, por los inconvenientes que resultaban de que hallándose los Curas Párrocos en los pueblos cabeceras de sus beneficios, y de no tener los necesarios Tenientes en otros, que suele haber distancia de diez, doce, catorce y más leguas, carecen de todo pasto espiritual Ios feligreses, quedando expuestos a no poder recibir los santos Sacramentos en sus últimas enfermedades, con cuya consecuencia se les ordenó estrechamente a los citados Virreyes, que poniéndose de acuerdo con los Arzobispos, dispusiesen sin pérdida de tiempo se proveyeren de idóneos sacerdotes, seculares o regulares, los pueblos que a mayor distancia de cuatro leguas del 
que fuese cabecera, careciesen de este tan preciso auxilio; tratando igualmentc con dichos Prelados, la cantidad que, a proporción de los países, se podrá señalar para la dotación de Ios propios Tenientes, y que para ella concurriesen los Curas propietarios con la suma que fuese proporcionada al ingreso de sus Curatos y al menor trabajo que les resultaba; y que el resto para completar las asignaciones que se hiciesen, se pagase del ramo de "vacantes mayox'es", y que, no alcanzando, se supliese de cualesquiera fondos de la Real Hacienda lo que faltare.

La ley 4, título 3 , y la ley 65, título 16, libro 6" de Indias, con que se conformaron las citadas Cédulas, también previenen que, en las Doctrinas que tuvieren estancias muy distantes, se pongan dos o más Iglesias, donde se pueda decir misa con decencia; y aunque no dispone el nombramiento de Vicarios coadjutores que r'esidan en estas vice Parroquias, antes bicn ordena que los Curas rectores de las Iglesias matrices, asistan por tiempos fijos del año en cada coadjutoría, para que allí acudan los indios a oír misa y Doctrina. Esto último se entiende cuando los Párrocos de los pueblos cabeceras, pueden asistir por sí solos, debidamente a la instrucción de todos; pues, en el caso contrario, impone el Tridentino, 11 expljcado por Benedicto XIV, ${ }^{12}$ la iudispensable obligación de que soliciten y pongan tantos Vicarios cuantos basten para la asistencia espiritual de las feligresías,

Pero habiéndoso considerado el riesgo a que se exponía la educación de los indios, con dejar al arbitrio de los Curas la ejecución del Tridentino y de las sabias providencias de nuestrus leyes, se mandó últimamente ${ }^{13}$ que los mismos Prelados, de acuerdo con los Vice Patronos, nombrasen sacerdotes iróneos, en calidad de Tenientes de los Curas propietarios, en todos los pueblos que a mayor distancia de cuatro leguas de la cabecera, careciesen de este tan preciso auxilio.

En lo que sc diferencian estas fundaciones, de las Iglesias matrices, es que estas últimas se deben costear de los tributos, ${ }^{14}$ y las primeras deben edificarse del fondo de "vacantes mayores" y "menores", que aplican para este efecto las citadas Cédulas de 1764 y 1765 , guardando la forma, intervención y justificaciones que para el libramiento de las mercedes hechas en este ramo, requierc la ley 13 , título 2 , libro $1^{\prime}$ de Indias, sin perjuicio del servicio personal qie deben prestar en su fábrica, como también en los de las casas de los 'Tenientes, los indios de cara pueblo, barrio o vice Parroquia, con arreglo a la ley 19, tílulo 2, líbro 1", y a la ley 67 , título 16 , libro $6^{\circ}$ de Indias.

De este mismo ramo deben salij las dotaciones de los Vicarios coadjutores, en aquella cantidad que tasaren los Prelados y Vive Patronos, teniendo presente que estas asignaciones no deben hacer por vía de congrua, sino como por salario medido al servicio mercenario que hubiesen de prestar en ayuda de los Curas rectores; $\sin$ observar en su cómputo las condiciones establecidas en la Constitución Piana, por tratarse en ellas solamente de los Vicarios perpetuos, y no de Ios temporales, como son los Tenientes de que hablamos, según Scarfantoni. ${ }^{15}$

Principal y réditos de la Caja de Censos.
$\mathbf{P}$ tes mayores y menores" " ro alcance para esta situación, respecto de no poder concurrir 
los Curas propieturios a la dotación de los Tenientes, por infinitos motivos que no ignoran los que tienen idea de estas tierras. Fn este caso, contemplo conveniente echar mano de la Caja General de Censos, entrando $5.85 \overline{0}$ pesos 7 reaies que paga la Administración de la Real Hacienda de Potosí, por el peincipal de 117.119 pesos $7 \mathrm{y} \% / 2$ reales, impuestos sobre estas Cajas, a favor de veintidús comunidades de indios del Distrito de la Alidicncia de Charcas; $y$ agregando estas cantidades a las "vacantes mayores y menores", no hay duda que se puede acumular suficiente fondo para la creación y dotación de vice Parroquias, asi en esta Provincia, como en todo el Reino; con especialidad si se hace la cuenta también sobre los estipendios que actualmente pagan los Párrocos a otros sacerdotes que les ayudan por todo el año o por ciertas festividades de él, pues, tan poco menos habrá que costear de los ramos referidos.

Yo considiro clesde luego, que a los Cay'as se ies debe obligar a contribuír con todo el sobrante de emolumentos, después de deducida su congrua y decente manutención; porque debiendo invertir en beneficio de sus feligresías los crutos residnos de las Iglosias, no hay objeto más útil ni más pío que la dotación de los Tenientes, que se dirige al alivio espiritual de los fieles.

Al mismo tieropo, juzgo que en este cómputo no deben comprenderse los sínodos porque no son frutos de los beneficios, sino estipendios y salarios temporales, según la denominación de muchas leyes del Reino; ${ }^{16}$ y cono tales, tampoco se incluyen en las prohibiciones canónicas ${ }^{1 ?}$ de disponer de ellos a su arbitrio, por reputarse eximidas de la razón de frutos eclesiásticos todas las distribuciones cotidianas, ${ }^{38}$ de cuya naturaleza son los sinodos. ${ }^{14}$

A fines del siglo pasado, hacia el año de 1680 , se tomó este mismo recurso en el reino do Chile, aplicando los censos de la Caja General de indios, para la dotación de diecinueve Curatos que en aquel tiempo se fundaron de nuevo, con aprobación y consulta del Conde de Castel-dos Rius Virrey del Perú, referida en Real Cédula fecha en Madrid, a 5 de diciembre de $167 \overline{5}$, con la calidad de que los Curas digan por los indios difuntos las misas correspondientes a la porción asignada, regulando la limosna de cada una por tres pesos de a ocho reales; por cuyo medio gozarían los difuntos de estos sufragios, y los vivos, de la eduoación y enseñanza necesarias.

Fn efecto, no se puede dar destino más a propósito a los Censos de los indios, pues, a más de la utilidad que resulta a los vivos y a los muertos, se logrará la conservación y ammento de este caudal.

En estas Provincias suele gastarse algunas cantidades de este ramo para socorro de los indios en la paga de tributos y de otras necesidades de los pueblos. Fl objeto es verdaderamente pío y recomendable; pero, no será difícil que intervengan fraudes, según el modo establecido para justificar la necesidad de los socorros.

No por esto es mi ánimo querer que se suspendan semejantes auxilios; y sí, solamente, recordar el riesgo, para que se pongan más caute. las, que ahorrándose de cste modo una gran parte de los desembolsos actuales, habrá más fondo para dotar a los Tenientes de Curas después de fundar las vice Parroquias que hemos expresado.

Y en tal caso se deberá hacer la paga en la Caja de Censos por los Oficiales Reales, en virtud del libramiento del Juzgado Mayor, al mis- 
mo tiempo y bajo las mismas justificaciones prevenidas por las leyes para la satisfacción de sínodos; señalándose por los Ilmos. Arzobispos, las misas que hayan de decir estos coadjutores, y su respectiva limosna, según la circunstancia del país.

Pero en cuanto a las Capillas que se edificaren en los asientos de minas, obrajes de paños, pagos, valles o chacras de vecinos que tuvieren yanaconas, se deberá observar lo dispuesto en la Ordenanza del Virrey Don Francisco de Toledo, referida por nuestro Frazo, ${ }^{20}$ esto es, que se hagan a costa de los dueños de dichas chacras, ayudando Ios yanaconas y los demás indios que hubieren de ser doctrinados en ellas, y S. M. dará el socorro que pareciere al Virrey.

Lo mismo se halla resuelto al fin de la ley 66 , título 16 , libro $6^{\circ}$ de Indias; y en la ley 11, títuro 1 , libro $1^{4}$ de la misma Recopilación; entendiéndose que todos estos sacerdutes deben ser proveídos por presentación de los Vice Patronos, conforme a las citadas Cédulas de 1764 y 1765, y a la ley 10 , título 1, libro $1^{\circ}$ citado de Indias.

Siendo yo Asesor de la Capitanía General del Paraguay en el año de 1783, se formalizaron las fundaciones de vice Parroquias y los nombramientos de Tenientes de Curas, conforme a las leyes del Real Patronazgo, y aunque los Canónigos hicieron su oposición, aprobó después el Rey todo lo obrado por aquel Gobierno, en Real Cédula de San Ildefonso, a 23 de agosto de 1784 , declarando: que así como en la erección de vice Parroquias y nombramiento de Tenientes, debe procederse con los prelados con acuerdo del Vice Patrono, debe también intervenir precisamente éste en todas las elecciones y nombramientos que indistintamente se hagan de Vicarios, coadjutores o Tenientes de las vice Parroquias del campo.

Si en estos países también promueve el celo de los Interldentes tan importante asunto, no dudo que se logrará el acrecentamiento de la enseñanza de los indios y se mejorará el estado de la fe católica entre ellos, sin empobrecer los beneficios con su desmembración, y sin gravar la Real Hacienda en dotar las nuevas Iglesias.

Mediante estos establecimientos se evitarán aquellas emulaciones faccionarias que suele causar la división, no solamente entre el pueblo, sino también entre cl clero. Yo he visto recur'sos muy graves con motivo de haberse erigido la nueva Parroquia de Otavi, en el territorio desmembrado a la de Miculpaya, en la jurisdicción de Porco, sin otro principio que la repugnancia de los parroquianos a sujetarse al nuevo Cura; y ello es cierto que en estas desmembraciones jamás se dejá de quitar alguna parte de sínodos al Párroco antiguo; para dotar al nuevo; con lo que se miran desde el principio como contrarios, en perjuicio del buen ejemplo que las feligresías deben tomar de sus Pastores.

Después de esto, apenas se consigue con las divisiones erigir una Iglesia más, en territorios que por su extensióin necesitan cuatro o seis, y concursando en el Cura nuevo mayor imposibilidad todavía que el antiguo, para costear muchos ayudantes respecto a su menon congrua, resulta forzosamente que el pueblo quedará tan destituído como antes; los beneficios menos apetecibles para personas de mérito, y los Curas enemistados entre sí, para que no cuiden del alivio espiritual de los pueblos.

$\mathrm{Al}$ contrario sucede donde hay vice Parroquias erigidas; pues, $\mathrm{n}$ más del consuelo que reciben los pueblos, de la asistencia de los Capellanes, mantendrán siempre un sumiso reconocimiento a la superioridad de 
los Curas rectores, viéndoles visitar dos veces cada año sus distritos, enseñar la Doctrina y empadronar a los que no la supieren, según la prevención del Concilio Provincial Mexicano ${ }^{21}$ y de una ley de Indias.

\section{NOTIOIA T F R C E R A}

Objetos que deben atender
principalmente los Intenden-
tes Vice Patronos de estos
países. son tres causas tan esenciales para la folicidad de las Iglesias y buena enseñanza de los indios, que no pudiéndose lograr sin ellas la conservación y aumento de la santa fe católica en estos países, son también otros tantos objetos a que deben contraer su atención los Intendentes Vice $\mathrm{Pa}$ tronos.

Párrafo primero. - Residen
cia de los curas.

$\mathbf{L}$ mucho que en todos los tiempos se ha faltado contra la obligación estrechísima de residir en los beneficios, se indica suficientemente por las repetidas providencias canónicas y Reales 22 que se han tomado contra el abuso de los Curas. El Concilio Tridentino ${ }^{23}$ impuso gravísimas penas a los que no residieren, encargando a los ordinarios que los compeliesen a residir por los medios y remedios más oportunos.

El Concilio Provincial $1^{\circ}$ Limense, ${ }^{24}$ había ordenado anteriormente que los Curas no desamparen sus Parroquias, aunque se celebraran en las capitales festividades muy solemnes; y el Sínodo $3^{\circ}$ impuso la pena de 4 pesos ensayados y perdimiento del sínodo respectivo a cada día de ausencia de los Curas que se ausentaren sin licencia del Obispo in scriptis: ${ }^{25}$ declarando el Sínodo $5^{\circ}$, también Limense, ${ }^{26}$ que aun teniendo licencia el Cura, no debe desamparar la parroquia, sin dejar en ella antes de su salida, un sacerdote idóneo para la administración de los Santos Sacramentos.

De acuerdo con estas canónicas disposiciones, exigen las Leyes Reales ${ }^{27}$ la misma residencia, bajo la pena de no pagarse estipendio alguno a los Curas ausentes, por todo el tiempo que no residieren, aplicando los salarios para gastos en obras de las Iglesias donde hicieren las faltas, y en ornamentos de ellas; todo con parecer del Obispo de la Provincia.

Y para evitar los continuos fraudes que se cometían contra estas terminantes prohibiciones, se despachó, después de la recopilación de nuestras lcyes la Real Cédula fecha en Madrid a 21 de julio de 1685, declarando que: "a los Curas Doctrineros no se les pague ningún.maravedî del tercio de sus estipendios o sínodos, si no manifestaren testimonio y certificaciones del Cacique (si no hubiere Escribano), de cómo han residido por sus personas en los lugares de sus Distritos"; y añade que, "ausentándose de sus Curatos, se puedan poner edictos con término competente para su residencia, con apercibimiento que pasado él, no se les pagará el estipendio; añadiendo severos apercibimientos de vacante, y que 
pasado el término del cdicto, envien los Obispos (a stien corresponde fijarlo) y el Gobernador sus visitadores, para que al Cura que hallaren no residir' en su Curato o Doctrina, le suspendan la paga del estipendio".

Pero si con licencia del ordinario, se ausentaren por los meses clue permite el Tridentino, ${ }^{2 s}$ en tal caso, bien pueden tirar por entero ol sínodo correspondiente al tercio del tienpo en que hubiosen dejado de residir, manifestando a este fin, por comprobante la licencia del Obispo y la certificación del Cacique o Fscribano, con arreglo a la Roal Cédula citada.

Y si sucediese que el Prelado conceda licencia a los Curas para ausentarse de sus feligresias, por más ticmpo dol permiticto por el Santo Concilio de Trento, sin excederse de cuatro meses, no doben los Intendentes pretender que se los pasen los autos oblados para justificación de las causas de la licencia, como antes se protondió más de una vez, antes de proveer la satisfacción del sínodo respectivo al tiempo de la ausencia, porque de resultas de tales pretensiones, se resolvió en Real Cédula dada en San Ildefonso, a 25 de agosto de 1768: "que los Ar\%obispos y Obispos cumplen con sólo participar simplemente a los Vice Patronos, así las expresadas licencias, como los nombramientos de Vicarios y coadjutores que hagan para que sirvan durante el timpo do su concesion, las Doctrinas y Curatos".

Por el contrario, cuardo por las justas cuusas hubiese de ausentarse el Cura por más tiempo de cuatro meses, no le basta la licencia sola del ordinario, y es menester que la tonga expresa del Vice Patrono, como se declaró en Real Códula de 6 de ma1zo de 1770, 29

Por la inobservancia de cstos indisponsables requisitos, vemos tan abandonados los Curatos, que, generalmente se van y vienen los Pastores, sin cuidar de pedir licencia al ordinario, $y$ tal vez sin su noticia. I os feligreses quedan como ovejas sin Pastor, al cargo de un Ayudante que apenas dice la misa, y se muda, dejando al pueblo sin doctrina $y$, lo que es peor, sin Sacramentos. De aquí procede la increíble ignorancia en que vive el mayor númeto de estos infelices, pudiéndose decir sin escándalo, que casi todos explican la poca Doctrirla que saben, como el loro, sin entenderla; y no es otra la causa que el no enseñarla los mismos Curas, sino unos indios ignorantes, llamados Fiscales, que después de no entender a fondo los misterios de nuestra santa fe católica, no pueden tampoco explicarlos bien y con propiedad en la lengua de los indios, sin cometer grandes disonancias e jmperfecciones, como decide la ley 18 , título $1^{\circ}$, libro $6^{\circ}$ de Indias. De suerte que, ignorando el verdadero sentido de la Doctrina, por falta de inteligencia del idioma castellano, ${ }^{30}$ vienen a ser estos maestros como aquellos ciegos que en vez de guiar por el camino verdadero, conducen al precipicio y a la ruina.

Por esto deben esmerar todo cuidado los intendertes, en no permitir las ausencias voluntarias de los Párrocos, celando este punto hasta el extremo de no pagar jamás cantidad alguna de sínodos, sin haberse acreditado la residencia personal del Cura, por certificación del Cacique - principal del pueblo cabecera, comprobada por el "visto bueno" del Subdelegrado del Partido.

$\mathrm{Y}$ una vez que nuestros Reyes son protectores de los Concilios, deben también los Vice Patronos procurar su cumplimiento a beneficio de los indios, incitando a los Prelados para que ooliguen a los Párrocos, vi- 
sitar anualmente todos sus Distritos, enseñar la Doctrina y empadronar a los que no la supieren, para que se la chseñen. ${ }^{31}$

Y por ser cl punto más recomendado en los Concilios, la explicación que deben hacer los I'árrocos de la doctrina cristiana, al tiempo de la misa, se debe poner igual esmero on que los Curas verifiquen la disposición del Sinodo Limense, ${ }^{32}$ formando matrículas de todos los indios, para llamarlos a misa por sus nombres y obligar a los que no asistieren por ausentes, que presenten certificado del respectivo Cura en cuya Iglesia alegaren haberla oído; pues este es el único medio de cumplir con la residencia formal; y si así no se hiciere, vivirán siempre los indios como ovejas descurriddas y los Curas serán unos Pastores negligentes del pasto de sil rebaño; qledando a todo responsables los Vice Patronos, como encargados de la proteceión temporal y espiritual de estos infelices indios.

Sobre tocio, debeiz tener prcsente los Vice Patronos, aquella famosa Real Cédula dada en Aranjucz, a 12 de junio de 1752, estrechando de tal manera la residencia de los Párrocos, que para mejor observancia del Tridentino, declaró lo siguiente: "Que no se tolere que ningún Cura falte a la indispensable obligarción de su residencia en su feligresía, ni se le dispense en ella con el motivo de necesitarlo el Obispo o Arzobispo para servir algún empleo de su Dignidad, y mucho menos de su persona, y que aun cn el irregular caso de no hallar otro sujeto capaz, de quien valerse para Vicario, Visitador, Fiscal a otro ministerio de la propia Dignidad, y considerar indispensablemente preciso haber de nombrar para él algún Curá, con consentimiento del Vise Patrono de la respectiva Diócesis". de los frutos y rentas de los Beneficios Eclesiásticos.
Párrafo segundo. - Buen uso

$\mathbf{N}$ periben mi animo hablar de los frutos que perciben los Curas por razón de congrua, supuesto que las leyes del Reino, 38 ilustradas por D. D. muy clásicos, "3 les conceden facultad para disponcr libremente de todos sus bienes, aunque sean adquiridos por razón de alguna Iglesia, beneficios o rentas eclesiásticas. Trataré solamente de los biencs pertenecientes a las fábricas de las Iglesias y Hospitales, como también a los Conventos de regulares, por los muchos abusos que se cometen en esta materia, en perjuicio de las feligresías.

Todas las que hay erigidas en estos países tienen crecidos ingresos por razón de Fábrica, y no menos los Hospitales fundados para eujación de indios y españoles ya sea del noveno y medio destinado para su renta, o ya de réditos cedidos de limosna para el mismo efecto.

Sin embargo, se ven estas Iglesias tan pobres de adorno y aun de culto, que quien no supierc cstas entradas, creerá que los Curas suplen de limosna para la cera y demás menesteres del culto divino. Todo esto procede de entrar en poder de los Párrocos las rentas de la Fábrica, y de no tomárseles las cuentas de este ramo con el rigor conveniente. Así es que, siendo de la Fábrica la mitad o algo más de las rentas crecidas que producen los Curatos que se reputan por los más ricos en la sierra, vemos que al cabo de años, se retiran a sus casas los Párrocos, haciendo renuncia o permuta de sus beneficios, con unas vajillas, que quisieran tenerlas los Pontífices, fuera de la bolsa que llevan como si fueran poten- 
tados, después que entraron a servir los Curatos tal vez sin más caudal que el Breviario y el manteo; cuando, por otra parte, quedan las Iglesias, no solamente pobres, sino también casi ruinosas, que es menester apuntalarlas para decir misa en ellas sin riesgo de desplomarse.

Es cosa bien notoria que sólo la Iglesia de San Cristobal de Lípez, perteneciente a esta Intendencia, tenía cuarenta mil marcos de plata labrada, que los azogueros de aquella ribera donaron de una vez para el servicio del culto; $y$ antes de un siglo, apenas han quedado como tres mil marcos, sin poderse averiguar el sustractor de tan ingente caudal, aunque se sabe que mucha parte se ha trasladado a la Iglesia Catcdral de Chuquisaca, por disposición de sus Prelados.

En esta misma Intendencia hay otros Curatos, como Puna, Tomave, San Pedro de Buena Vista, Tinguipaya y otros, que producen de ocho a diez mil pesos anuales, cuya mitad, o a lo menos una tercera parte, corresponde a la Fábrica; pero todos advierten la pobreza de dichas Iglesias, cuando saben que sus Curas se enriquecen y se regalan más que los Obispos.

Lo mismo sucede con Ias Iglesias de esta Villa, porque apenas tienen cálices de plata para decir misa, componiéndose el resto de su ajuar, de candeleros de madera y vinajexas de barro o vidrio ordinario. Cosa a la verdad muy reparable en un pueblo donde han rodado las barras de plata en tanta abundancia como las piedras, y por lo mismo, no puede atribuírse esta miseria a otro principio que a la malversación de los bienes pertenecientes a la Fábrica.

No es menos notable el desarreglo que ha habido en el manejo de los Monasterios, y contrayéndome solamente al Convento de San Agustín de Potosí, espanta oír que en veintisiete años corridos desde 1584, en que se fundó, hasta 1611, había recibido por partidas de libros según refiere Calancha, ${ }^{35}$ fuera de blandones, lámparas y cálices, 535 pesos (?). Pero aun es más de admirar que ahora no tiene casi el pico; la Iglesia se ve arruinada, sus paredes sin enlucir, los frailes sin refectorio, y últimamente, todo al parecer en estado de la mayor pobreza, no por otra causa que por haber puesto mano en sus bienes y rentas los Prelados locales o Provinciales, sin embarazo de parte de los magistrados seculares.

En los demás conventos se experimenta la misma decadencia, porque los Prelados sólo tiran a sacar provecho de sus rentas, para después obtener empleos maybres. Todo esto es demasiado notorio para producir nuevos convencimientos, ni conviene extender la pluma en este asunto, por respeto a la dignidad de los sujetos que se citan. Bastará haber apuntado los inconvenientes, para proponer el remedio oportuno.

Administración para las Fábricas de las Iglesias y su depósito en las Cajas Reales. las Iglesias y Hospitales de los indios, con arreglo a las leyes del Real $\mathrm{Pa}-$ tronato, ${ }^{36}$ obligándoles otra Cédula recopilada en la ley 22 , tîtulo 2 , libro $1^{\circ}$ de la misma recopilación, a que den y presenten anualmente cuenta instruída a los Obispos y Vice Patronos, de todos los bienes pertenecientes a las Fábricas de las Iglesias y Hospitales de indios, hasta cobrar- 
les los alcances y ponerlos on las Cajas donde tocaren, para distribuírlos en cosas útiles y necesarjas.

Posteriormente, se despachó Real Cédula de Madrid, a 18 de diciembre de 1768, mandando guardar otra anter'jor Cédula inserta de 31 de diciembie de 1695 , 11 las cuales, extendiendo la ley 22 citada, título 2 ,

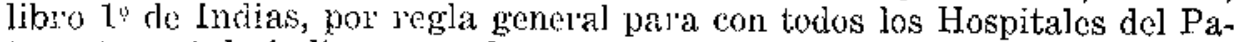
tronato, así de indios como de españoles, se declaró "Que los Obispos del respectivo territorio, o por sí o por los Visitadores que nombraren, visiten todos los Hospitales dol Real l'atronato, siempre que les parezca que conviene tomar cuentas a los Hayordomos, las veces que sea necesario, de las ientas, bienes y hacionda que en cualquiera manera les pertenezcan, con la precisa calidid de que haya de intervenir y asistir por el Real Patronato, la pelsona que nombrare el Virrey, o él mismo, si quisiere o pudiere ejccutarlo, y también con la de anotarse en los mismos autos de la visita, por el que se provea para su principio, que todo esto lo practican los Obispos por particular comisión y encargo del Rey".

Esto no obstante, bien pueden los Gobelnadores Vice Patronos, hacer y repetir entre año otras visitas, por sí o por comisarios, en caso que por fraude o por otra mala versación to estimaren necesario, concurriendo con algunos Diputados de sus Cabilios para mayor solemnidad, aunque segín la Ley Real, is deben procurar siempre que se hagan a un mismo ticmpo por el Lclesiástico y seglar, para excusar embarazos.

Si en Potosí se hubier'an cumplido las leyes con los dos Hospitales, de Belén y San Juan de Dios, que tiene la Villa, no hubieran bajado las rentas del primero a sólo cinco mil pesos, de treinta y cinco mil anuales que antes producía; y el segundo no manejara con tanta independencia de no saberso hasta ahora ol monto del cargo y data de sus rentas.

El de Belen, sabemos que pertenece inmediatamente al Patronazgo Real; pero yo no he oído ni he visto ejemplar de haberse tomado cuenta a los Administradores, por los Vice Patronos, ni jamás se ha cuidado de que no se excedan los Prêlados en las fábricas do claustros o celdas, y en usar los religiosos de las rentas o limosnas destinadas para los pobres, más de lo que hubieren mencster para su sustento y vestuario y honesta pasadia, conforme a su estado y profesión, que es lo único que se les debe pasar en cuenta. ${ }^{38}$

El otro Hospital, de San Juan de Dios, auncue no se halla dotado por el Rey, está fundado con remas, limosnas y contribuciones hechas por esta Villa, en común o en particular; y también debe cstar sujeto a las visitas de los Obispos y Gobernadores, con asistoncia de los Diputados de la Villa, para poder representar lo quo hubiera contra las cuentas. ${ }^{39}$

Pero no se debe extender a los Cabildos en sede vacante, la facultad concedida a los Obispos para visitar Hospitales, como delegados regios, por no ser ordinaria esta jurisdicción, sino delegada, en cuanto no sucede la sede vacante, según Frazo, citado por Rivadineira. ${ }^{40}$ La cual doctrina se comprueba por el argumento de una ley de Castilla, ${ }^{41}$ que niega a la sede vacante Ia autoridad otorgada a los ordinarios Diocesanos, como delegados regios, para el reconocimiento de los rescriptos pontificios tocantes a materias espirituales.

En cuanto a Fábricas de las Iglesias de Indias, se halla mandado con más estrechez ej la Cédula circular de 23 de mayo de 1769 , recopilada en el Art. 165 de la Real Ordenanza de Intendentes, que la cuenta de 
lo que resultare a favor de ellas y de los demás productos que les pertenecen, como los de censos, entierros, y otros, se deben presentar a los Vice Patronos, para que vistas y reconocidas por ellos o por las personas que diputaren, aprobadas que sean, den cuenta con testimonio en relación al Consejo, para que so halle instruido y se evite el extravio que se ha experimentado de estos caudales, en perjuicio de las santas Iglesias.

No hay duda que las Iglesias del Arzobispado de Charcas, no gozan de la parte aplicada en los diezmos, para la Fúbrica, como se ha dicho en otro lugar; pero son tan pingües los productos de esto ramo, que si se administrasen con fidelidac, alcanzaría no solamente para reedificar y adornar suntuosamente las lglesias Matrices, sino también para fundar de nuevo otras muchas en alivio de las feligresias. Así, es este punto el que más debe interesar el celo de los Intendentes, para presentar Mayordomos abonados que recauden y den cuenta de estos caudales, como único medio de quitar a los Curas la ocasión de invertirlos fuer"a de sus legítimos destinos, en contravención de los cánones y de las leyes.

'Todavía es mayor la necesidad de impedi\} los extravios escandalosos de los caudales de los Conventos regulares; pues, no contentos los Prelados con extraer de las Provincias los expolios de los reigiosos, se propasan de continuo a sacar las alhajas y otros bienes destinados bien sea al culto divino o al uso ordinario de los Conventos. Y este ha sido el infeliz camino por donde casi todas las fundaciones regulares han corrido al miserable punto de pobreza en que se hallan. Lo peor es que por ahorrar el gasto de la comida, vestuario y otros menesteres de las comunidades, toman los Prelados el arbitrio de disimular la relajación de la clausura monástica, dispensando a los religiosos el que cada uno viva donde quisiere y negocie lo necesario a su decente pasadía, con el contento de granjear algo más por otras pretensiones indebiclas procediendo de este principio la poca o ninguna residencia de los regulares en sus Conventos, la falta de culto en los templos y, sobr'c todo, las particularidades, facciones y ambición por el mando.

Nuestro sabio Gobierno, conocio mucho antes de ahora el origen de estos excesos, y quexiendo restablecer el derecho que compete a los Conventos, en los expolios que dejan los regulares difuntos, aunque sean vacantes sin licencia de sus superiores y hayan muerto en la corte Apostólica, ni los Generales puedan aprehenderlos, según lo fundado por el Sr. Solórzano; ${ }^{42}$ se despachó Real Cédula de Madrid, a 21 de noviembre de 1707, mandando a los Virreyes, Audiencias y Gobernadores de las Indias, lo siguiente:

"Que no permitan que, con pretexto alguno, se lieven ni transporten a Espa"h̃a, caudales algunos procedidos de expolios de los religiosos, ni que por los Vica"rios o Visitadores Generales de cualescuiera de las religiones de estos dominios, "se pueda poner mano en ellos, por ser como son bienes concedidos ad usum tan so"lamente de los religiosos, y fallecidos que sean, deberse reintegrar y volver a la "casa, Convento o Provineia de donde fueron dichos relimiosos; a cuyos Prelados to"ca privativamente poner el cobro y resguardo en dichos bienes. Que así mismo, no "consientan que puedan sacar bienes ni alhajas algunas de los Conventos de esas Pro"vincias, así de los destinados al culto divino, como al uso ordinnio de los Conven-

"tos; procediendo rigurosamente contra los seculares en cuya cabeza se pusieren "los referidos bienes y alhajas, teniendo muy presente las leyes reales, principalmen-

"te la 5 ", título 14, libro $1^{\circ}$ de la Recopilación de Indias, sin embargo de cualesquie-

"ra constituciones u ordenanzas que para lo contrario alegaren tener", pues no es-

"tando pasadas y vistas por el Consejo de Indias, deben entenderse perjudicia-

"les a las regalias $\mathrm{y}$ en contravención a la legal prohibición para el expresado trans- 
"porte de religiosos a España; contra las cuales regalias no pueden los Generales ni "Superiores de las religiones establecer ordenanzas o estatutos algunos, ni tampo"co ejecutarse en estos dominios, sin que primero se haya consultado al Colsejo de "Indias y por él se hava mandado darles el pase, como se acostumbra en todo cuan" "to toca al lieal Fatronato que roza en las Indias; bien entendido que los Corregi. "dores y Justicias, no deben pasar a otra diligencia que al embargo de la saca y "transporte de los caudales, bienes y alhajas que llaman expolios de religiosos, y "dar cuenta inmediatamente a la Audiencia del territorio donde correspondiere".

Todos estos daños se pueden remediar con el celo inteligente de los Vice Patronos, siempre que cuiden con vigilancia que todas las Iglesias de sus distritos tengan mayordomos ficles y abonados, a quienes tomar cuenta rigurosa de los productos de Fábricas. Fntonces tendrán los Curas monos arbitrios para enriquecerse en perjuicio de sus Iglesias; los Páxrocos celosos y timoratos, se alegrarán viénclose exentos de llevar y rendir cuenta de negocio que no les quita poco tiempo y añade grandes cuidados; y los que fueren malos, tendrán atadas las manos, para no mezclarse en bienes de ajeno manejo.

Los Prelados regulares se abstendrán también de esquilmar en sus conventos, viendo sobre sí levantada la mano poderosa de los Intendentes, para embarazarles la saca de los bienes propios de sus comunidades, con la resuita de lo que proveyeren las Audiencias, después de noticiadas do estos sucesos.

Sobre el arreglo de los Religiosos y de sus leyes canónicas.
$\mathrm{S}$ remedio sería quitarles toda la ocasión, reduciendo las rentas al número preciso de ocho religiosos que debe mantener cada Convento, conforme a las constitnciones Apostólicas, ${ }^{43}$ para que ni falte la asistencia necesaria al culto Divino, ni los Prelados tengan arbitrio para usurpar las rentas respectivas al numero que minorasen voluntariamente, concediéndose a este fin facultad a los Vice Patronos, para que, entre año, visiten con el oxdinario, las veces que juzgaren convenicnte, las comunidades religiosas, informándose de los faltos y de los motivos de su irresidencia, para dar euenta a los Excmos. Virieyes y Audiencias del territorio, con el objeto de que estas superioridades tomen providencia contra los Prelados omisos por la inobservancia de las constituciones canónicas; pues, de lo contrario, se continuará el desgraciado abuso de verse la mayor parte del año, casi vacíos los Conventos regulares, bien sea por no haberse asignado el númcro competente de religiosos, o por que estos no residen ni guardan la clausura monástica, en perjuicio del servicio de sus comunidades y del eulto de los templos.

Pero era menester averiguar escrupulosamente el importe efectivo de las rentas anuales de cada Convento, para arreglar el gasto correspondiente al sustento y decente pasadía de los religiosos, a la cera y demás cosas del culto Dirino y a las reparaciones del Monasterio, Iglesia y demás fincas, dejando algún sobrante para obras extraordinarias. Que después de todas estas defalcaciones, me presumo que sobraría otro tanto más, que en el día no luce ni parece, no obstante la suma riqueza de la mayor parte de los Conventos; pues según lo que hemos visto, sólo San Agustín adquirió, al cabo de veinte años de su fundación, más de medio millón de pesos en limosnas, fuera de vasos sagrados y menaje tocante 
al servicio de su Iglesia.

Arreglando en esta forma las cosas de los Conventos regulares del Reino, se lograrán dos ventajas muy considerables. Es la primera, que los religiosos guarden vida común, sin la propiedad en particular, que tanto reprueban nuestras leyes, ${ }^{14}$ como contraria a la perfección del estado monástico. La segunda ventaja es, que con autoridad de la Silla Apostólica, se pueden aplicar los sobrantes de estas rentas para erección de Colegios Seminarios, en aquellos donde estuvieren situadas las fincas, parà enscñanza de primeras letras y de Gramática, según la sabia propuesta del doctísimo y eminentísimo Luca. $4 \mathrm{Y}$ cuando por alguna razón más política no se juzgare conveniente desmembrar de los Colegios regulares las rentas de que vamos hablando, entonces scría bien dejárselas, con la pensión de fundar y mantener ei sus Conventos Escuelas de Gramática y de otras Facultades que doberían enseñarse en los Seminarios, a beneficio de los seculares, según el mismo eminentísimo Luca. ${ }^{46}$ Pues no hay razón para que las comunidalles regulares no recompensen al público, siquiera de este modo, las contribuciones liberalísimas que se les ha hecho en sus fundacioncs, mucho más allá de lo necesario y tal vez en perjuicio de muchas familias que hoy se hallan pereciendo, por la indiscreta generosidad y mal entendida piedad de șus autores.

Párrafo tercero. - Suficien- \I tercét objeto -y el principal- de los cia de los sacerdotes destinados para cura de Almas.

Intendentes Vice Patronos, debe ser la elección de sacerdotes idóneos para curas de Almas. Este es el primer cuidado de nuestros

Reyes, tan recomendado en las leyes, ${ }^{47}$ que declaran ser el ánimo de $\mathrm{Su}$ Majestad, que los más virtuosos, los mejores, los más útiles y convenientes para los Ministerios públicos, se le propongan con precisa obligación de conciencia. No debe repararse que se calle la calidad de Letras; porque en estos Estados, como exentos de la herejía, se requiere más la simplicidad de costumbres que la doctrina. La sufjeicncia no se debe medir por la erudición, sino por la utilidad y conveniencia de los indios. El celo y la virtud son útiles para los feligreses $\mathrm{y}$ par'a los mismos Curas; $y$ así, las prendas dignas de preferencia deben ser principalmente el celo, el valor, la vigilancia, la piedad, la caridad y la actividad, todo junto, aunque no concurra tanta ciencia que exceda o iguale estas dotes.

Sobre todo, se debe procurar el buen nacimiento en los que hubieren de obtener empleos eclesiásticos, sin permitir el trastorno de las condiciones, tan ofensivo como tolerado en estos países. Cada uno sé atreve a salir fuera de sí mismo y lo consigue abrazando el estado a su gusto, no sólo sobre su mérito, sino también sobre su esfera. De aquí resulta que el plebeyo, el ilegítimo y otras personas irregulares, quieren ser sacerdotes, Curas, Canónigos y hasta Obispos. Siendo el peor mal que conociendo estos vacíos, pretenden llenarlos con la adulación, con el cortejo y con el dinero, para conseguir por estos reprobados medios lo que no pueden esperar de su mérito.

La bajeza, a más de influír secretamente la avaricia, el engreimiento $y$ otxos vicios en todo contrarios al feliz expediente de nuestros Curatos, también inspira a los súbditos el menosprecio de sus pastores, contra su aprovechamiento espiritual. 
La autoricad, las más veces, es compañera de la calidad, porque Ios nobles son de ordinario liberales, suntiosos y decentes en su porte y aunque no tengan virtud, timen frecuentemente en el corazón los latidos de honra y de gloria, que producen los mismos efectos que el celo causado del amor de Dios. Por lo regular, aborrecen todas las acciones indignas, y cuando por falta de virtud no se mueven a dejarlas por temor de Dios, las omiten por lespeto humano.

Al contrario, el plebeyo se desvanece en la altura, sonroja a sus iguales para ahuycntarlos de la familiauidad a que los ata su nisma condieión. Saliendo fiuera de sí nismos con la inhumanidad, con el rigor, con la avaricia y con el despotismo con sus iguales $y$ tal rez con sus mismos parientes, protenden hacer desconocible la fortina en que nacieron, y borrando ya las apariencias de humildad que manifestaron en la miseria, descubren los vicios, se hacen aborrecibles, esquilman los Curatos y dospués de usurpar con sus intrigas el lugar a los bcneméritos, corrompen los pueblos y siembran tal cizaña de abusos y desórdenes, que sofocan la semilla del Evangelio que deben cultivar por su ministerio.

De este principio nacen tantos excesos como llora infelizmente la sierra del E'erí. No es decente referilos, pero apuntaré uno u otro, para hacer ver la necosidad del remedio; advirtiendo antes, que no es mi ánimo tratar de los muchos Curas que hay virtnosísimos, humildes, ejemplares, doctos, celosos y timoratos; porque estos dignos pastores, conocidos en los pueblos y venerados por los Prelados, son los operarios que mantienen la viña de la religión en estos paises, y se debe a sus fatigas evangélicas mucha parte de la unidad y sujeción de estos dominios. A todos estos verdaderos eclesiásticos elogio y venero pecho por tierra; mas, cllos mismos me dispensarán la relación de los desórdenes que ejecutan los malos, para que la maledicencia no escupa indistintamente sobre todos su veneno.

Hay pucs algunos Curas tan relajados y ambiciosos, que después de no guardar los Aranceles en cobrar derechos indebidos a los indios, les quitan por fucl'za a las viudas y herederos sus ganados y otros bienes, al precio que quieren, hasta dejarlos en estado de mendigar, sin que estos infelices se atrevan a icclamar, temerosos del castigo que esperan y del poco fruto que sacan en sus lecursos, por la facilidad con que los Curas desvanecen los cargos más graves, por medio de los mismos indios, a la persuación o amenaza de ausentarse, que de cien acusaciones, apenas suele castigarse una, y esto es cuado interviene el Corregidor, el Subdelegado a otro español poderoso, para vengar sus particulares resentimientos con Ios Curas; pero sí, ios pobres indios no encuentran tales coyunturas, o salen mal o callan o se retractan, dejando a los Párrocos más satisfechos y prepotentes que lo eran antes de procesados.

En otros Curatos se sabe que los indios, niños, majeres y hombres, llamados en su lengua "imillas y yocallas", cuando concurren a la Doctrina, llevan al Párroco, por vía de gratificación, unas veces costales, otras, sogas, y otras, unas raíces que llaman airampo, muy estimadas para tinturas, precisando con tanto rigor a estos infelices, que cuando no entregan estas tareas, los castigan públicamente como si hubieran cometido algún grande delito; y así viven estos pobrecitos, tan cuidadosos de complacer a sus Curas, abasteciéndoles de todas estas especies de mercancía, fuera de la leña y otros menesteres, que emplean toda la semana en hi- 
lados $y$ otwos servicios particulares, sin pagarles nada por su trabajo y sin que puedan asistir a sus padrcs, contra las estrechisimas prohibiciones anticipadas sobre este abuso, en la ley 11 , título 13 , libro $1^{\circ}$ de la Recopilación de Indias.

Lo más espantoso es, que no falta Cura que para obligar a los indios herederos a que mander decir muchas misas cantadas o rczadas, unas veces mandan enterrar el difunto boca abajo, persuadićndoles que no podrá salvarse hasta volver la cara al cielo, por medio de diez o doce misas.

Otras veces publican apariciones fingidas, alegando necesidad de misas. Los pobres indios, como tan superficiales en puntos de religión y que, si saben la Doctrina, son como lovo que la dicen de boca, sin entenderla, creen por de fe, que el cura les amonesta y clamoreando la infelicidad del mucrto, son capaces de vender hasta los hijos, para pagar cuantas misas se le antojare al Cura, que necesita el difunto para salvarse.

Concluiré por referir, lo que me ha contado un Juez, visitador fidedigno, de estas Provincias, de cierto Curato digno de compasión. Este sujeto, pues, me aseguró, que para amontonar muchos derechos de casamientos, mandaba (el Cura) depositar a esta o a otra india, de las más bien parecidas, con el pretexto de estar amancobadas con Pedro o Juan, feligreses del mismo Curato. Entonces, o bien, instigados los indios a remediar el daño que se les acusa, o bien las mismas indias, o sus padres por sacarlas de la reclusión, andan activos en solicitar cl matrimonjo; y de este modo consigue el Cura cuantos casamientos quiere; no siendo lo peor que asi agencien el acrecentamiento do sus rentas, com el que, casándose sin vocación y tal vez sin inclinación, resultan al poco ticmpo enenistades ${ }_{1}$ disenciones, adulterios y otros excesos i $1^{4} r^{\prime}$ mediables ya, entre estos infelices casados.

Por decencia paso en silencio otros desórdenes más escandalosos, que casi son increíbles de personas dedicadas a Dios por su estado. Reservo estas noticias a los Vice Patronos celosos que pueden adquirirlas con poco trabajo, sólo con dar una vuelta por sus Provincias.

Pero, sí, aseguro que ja causa principal, es cntrar los más al importantísimo ministerio de Curas, sin haberlo aprendido, cuando vemos que los oficios más viles y mecánicos no se ejercitan sin haber gastado muchos años siendo aprendices.

Una mitad menos de inconvenjentes experimentaríamos en nuestras Provincias, si en los Seminarios Conciliares fundados para estudios eclesiásticos, aprendieran la Gramática, la Moral, la Liturgia, el Canto, . la Oratoria, y otras facultades determinadas por los Concilios. ${ }^{48}$ Saliendo de estas casas bien instruídos con la obligación de Curas y ensayándose antes en otras Iglesias Catedrales o Parroquiales, para acreditar la suficiencia, la humildad y las buenas costumbres, no hay temor que después sean malos Párrocos.

Asimismo, admitiéndose en los Seminarios solamente hijos y descendientes de los primeros descubridores, pacificadores y pobladores de esta Provincia, gente honrada, de buenas esperanzas y respetos, con exclusión de los ilegítimos y de hijos de oficiales mecánicos, conforme a la Ley Real, "9 tendrían los Vice Patronos muchas personas beneméritas en qué escoger, con la graduación y preferencia prevenida en la ley $6^{\text {* }}$, título 23, libro $1^{\circ}$ de Indias. Y los infelices naturales tendrían buenos pastores que les suministrasen Doctrina pura y sólida, conservándose en es- 
tos países la túnica inconsútil y nunca rota de Jesucristo, como ponderá el ilustrísimo Palafox, "jo para asegurar la sociedad civil de este poderoso Imperio.

Lo que esto importa, nadie ignora; pues, ningún Estado se ha perdido hasta ahora mientras la religión se ha conservado en su pureza; $y$ debemos asegurar que estos dominios se perpetúan bajo el dichoso gobiezno de nuestros Reyes, siempre y continuamente en la unidad de la fe y religión que profesan sus felices pobladores.

Ya quisiera concluír este discur'so, pero referiré por apéndice dos abusos muy perjudiciales, nacidos tambión de la abundancia de los Curas. Muchos de ellos, por una especie de economía reprobada, hacen grandes sembrados, fundan chacras y crian ganados, a costa de los pobres indios, sin pagarles sil salario, con pretexto de ser para ol sustento de sus personas, familias y caballos. Y hay Párroco que, bajo de esta excusa, mantiene manadas de costosas mulas y caballos, cultivando inmensos alfalfares y crecidas siembias de cebada, en lugares que debieron aprovechar los infelices indios.

El Concilio Limense condenó este arbitrio, prohibiendo estrechamente a los Curas la labranza de chacras y cria de ganados, salvo que sea to preciso para alimentarse, como declaró la sagrada congregación, ${ }^{51}$ y en la forma y casos que explica el Ilustrísimo Obispo de Quito. 52

Las leyos reales is tambión reprueban estos excesos, como el de beneficiar minas (que no es poco frecuente) y otras granjerías, declarando por justa causa para remover por concordia a los Curas contraventores. Y una ve\% que van de acuerdo con los Coneilios, deben los Vice Patronos, por su parte, celar con vigilancia tales procedimientos, para que los Párrocos se arreglen a tan santas disposiciones, aprendiendo en ellas el método de conducirse en sus ministerios.

El otro abuso más perjididicial, es la facilidad con que los Curas castigan con azotes a indios e indias, indistintamente, validos de la doctrina de Montenegro, is que los favorece con la facultad para imponerles la pena hasta de cincuenta azotes.

Este es el origen fecundo del despotismo de los Curas y del terror de los indios; pues con el pretexto de corregirlos por la doctrina, desahogan sus resentimientos y los maltratan miserablemente, al paso que los Corregidores y demás Jueces no pueden hacerlo sin proceder en términos del derecho, con arreglo al auto acordado del Superior Gobierno de Lima, recopilado a fojas 202 del título 17 , libro $2^{n}$ de las Ordenanzas Generales del Perú.

Con esto, temen más un simple disgusto del Cura, que las amenazas serias de los Subdelegados, y se invierten todas las reglas de la subordinación civil, en perjuicio del buen gobierno. Se facilita cuantos arbitrios intenta el Párroco; se fomentan das parcialidades y se transtorna el orden político de la real autoridad, haciéndose los Curas tan absolutos, que casi no hay poder bastante en los Magistrados más superiores, no digo para castigar, pero ni aun para averiguarles el exceso más reparable.

Verdaderamente, nace todo ello de la mala inteligencia de las leyes. Así se vio en un Cura del pueblo de Itapé de la Provincia del Paraguay, que habiendo castigado a unos indios, con el colorido de doctrina, se despachó Real Cédula de Madrid, a 9 de octubre de 1728, ordenando al Gobernador, lo siguiente: 
"Y para en adelante os ameglarcis a lo dispuesto por' las leyes, no permitien"do se cxecuten semejantes castigos en indios y mucho menos en indias; porque sólo "con el hecho de executarlo en ellas, se debe pasar a renover al Cura; pues sólo "puede ser admisible este castigo en los niños, para su corrección y enmienda."

Mandando guardar las leyes 5 y 6 , título 13 , libro $1 \%$ de Indias, que los Virreyes, Gobernadores y Justicias, no permitan ni consientan a los Curas, clérigos ni religiosos, que tengan cárceles, prisiones, grillos y cepos, para prender ni detener a los indios, ni les quiten el cabello, ni azoten, ni impongan condenaciones, si no fueren en aquellos casos que tuvieren comisión de los Obispos.

Con lo cual se concluye, que la doctrina del Ilmo. Montencgro se debe entender cuando los Párrocos procedieren comisionados, por delitos graves, después de haberles oído sus defensas por los términos de derecho. $\mathrm{Y}$ siempre que cjecutaren pena de azotes y otros castigos, sin guardar estas formalidades, deberán los Intendentes hacerles entender su obligación, libertando a los infclices indios del insoportable yugo que hasta ahora han lievado sobre la cerviz.

Después de todo, el remedio será no presentay para Curas a hombres insuficientes, guardando por la mejor regla, no tener en estas elecciones la general, como dice el sapientísimo Richelieu en su Testamento Político: 55 "mas, elegir unas veces hombres cruditos; otras, personas menos letradas y más nobles; mozos, en algunas ocasiones, y ancianos en otras, según los sujetos de diversas condiciones que se hallaren a propósito para el Gobierno".

\section{NOTIOIA OUAETA}

Arbitrio útil, según la condición de estos países, para mejorar el estado Eclesiástico en cuanto a los Curas.

L LuS Doctísimos Padres del sagrado Concilio de Trento, conocieron muy bien que el lastimoso estado de las Iglesias, sujetas con especialidad a los Patronos particulares, provenía de que los herederos de los fundadores, siéndolo de sus bienes, pero no de su celo ni de su virtud, ponían sacerdotes a su voluntad, sin atender a la utilidad de las Iglesias; y no puldiendo remediar el mal, quitando totalmente la causa, propusieron por remedio ${ }^{36}$ que el Sínodo elija examinadores, que examinen a todos los opositores a beneficios curados, para que conocida su capacidad, propongan dos o tres de los más beneméritos a los patronatos del curato vacante, con obligación de presentar al Obispo el que más le agrada'e.

No hay duda, que este expediente quita mucha libertad a los Patronos, porque no eligen a quien quieren, sino a uno de los tres que le propone el Diocesano, y los Obispos mismos tienen coartada la facultad para proponer solamente a los examinados y aprobados en el concurso.

Pero lo cierto es que se observa muy poco el orden del Concilio; porque si se cumpliera con su espíritu, no hubieran tan malos Curas como vemos. Unas veces, aprueban con compasión los Obispos, a unos hombres reprobados en otros Obispados, por ignorantes o por viciosos, que con maña han sabido merecer la gracia o la piedad, ocultando sus defectos. Otras veces, principalmente en sede vacante, que suele ser muy frecuente y dilatada en estas Provincias, atienden los Cabildos, por lo regular, sólo al fin de sus causas y negocios particulares, admitiendo a exa- 
men $\mathrm{y}$ aprobando a personas que carecen de los requisitos y partes necesarias de letras, virtud, nacimiento y utilidad de las Iglesias.

Los Vice Patronos, que no todos imitan el celo y el fervor de nuestros muy Católicos Reyes, encuentran tambićn la puerta abierta para condescender con el favor, con el respeto o con la pasión, y sirviéndose reciprocamente de ellos y de los Cabildos, no queda ahijado sin acomodo, aunque no sea capaz ni aun para una sacristía, siendo lo más malo, que se abandona con injusticia y las más veces con escándalo, el verdadero mérito de otros opositores más dignos.

De esto resulta que nadie cuida de estudios ni de vistudes, sino de procurarse buenos padrinos. Aprenden la adulación y el cortejo; se abaten a cstos entretenimientos ruínes, en vez de cursar los Colegios, y como enviciados ya con la ociosidad y con la ambición, no perdonan atajo a que no se atrevan para conseguir un Curato, pudiendo avanzarse a decir arrebatado de celo (no sé si indiscreto) que en el Perú casi todas las Iglesias son feudales para recompensar el favor de los padrinos.

Aquí vemos que la distancia en que se hallan las Iglesias del verdadero Patrono, da Iugar a no cumplirse las buenas y santas intenciones de S. M. Tampoco el remedio del Tridentino alcanza a precaver para con Ios Vice Patronos, todos los daños que conoció al tiempo de dictar sus sabios decretos; $y$, o es preciso abandonarnos a la desdicha o procurar otro arbitrio que siendo legal sea más útil para nejorar el Estado Eclesiástico.

Yo no encuentro otro medio, como reducir todos los Curatos a la provisión del Rey, en la forma que están hoy las Canonjías. Me sugiere esta persuasión el ver siempre mejores Canónigos que Curas, y no puedo atribuír a otra cosa sino a que jamás se atreven a ocurrir al Rey personas indignas, sin nacimiento, virtud ni estudios, $\mathrm{Ni}$ se logra el intento, aunque alguno atropelle estos atajos; porque la justificación inexorable de la Cámara siempre consulta al más benemérito, en quien concurren todas las calidades que requieren las leyes rcales.

Lo cierto es, que al principio de la pacificación de estos dominios, se presentaban por el mismo Rey todos los beneficios curados de las Indias, hasta que, habiéndose aumentado el Estado Eclesiástico de éllas por los años de 1609, se despachó Real Cédula de Madrid, a 4 de abril del mismo año, delegando el Sr. Don Felipe IIT, a los Excmos. Virreyes, Presidentes y Gobernadores, la presentación de todos los beneficios curados, así de españoles como de indios, sin necesidad de impetrar la Real confirmación como antes se ejecutaba, según refieren los sabios regnícolas Solórzano y Frazo. ${ }^{57}$

La ley 24 , título 6 , libro $1^{\circ}$ de Indias, abraza todo el contexto de la citada Real Cédula, y aunque no expresa el motivo de la comisión para estas presentaciones, lo declaran muy bien los citados autores y se colige de la ley 16 del mismo título y libro, a saber: por la mucha distancia que hay de estos reinos a los de Castilla y el inconveniente que podrá resultar de que los Curatos vacantes estén sin proveer hasta que el Rey presente quien los sirva. Pues, hallándose ordenado en las leyes 35 y 48 , título 6 , libro $1^{\text {D }}$ de nuestra Recopilación, que no pasen de cuatro meses las vacantes de los Curatos y Doctrinas, era indispensable delegar su presen tación a los Gobernadores de las Indias, para evitar la precisa y larga lación de ocurrir al Rey. 
Pero, sobre todo, es cosa muy notoria que en estas Provincias jamás se proveen las vacantes dentro de cuatro meses, porque regularmente se espera que vacuen ocho o dicz y tal vez más Curatos, para fijar los Edictos, quedando después el arbitrio de prorrogar uno o dos términos; de suerte que ha llegado vez de estar suspendido el concurso en dos y hasta tres años, sin cumplirse los soberanos y justificados motivos que consideró la piedad del Rey, para cometer a los Gobernadores las presentaciones.

En este intervalo, es tan imponderable la batería que ponen los pretendientes, que es imposible no l'endir la plaza más fuerte, saliéndose con su intento después que Jos interinos que trabajan como mercenarios, han esquilmado los Curatos, dejando cntre los feligreses solamente el clamor, el disgusto y el mal ejemplo.

Los Vice Patronos también disimulan bien contentos estas moratorias, por la mal entendida economía de lo que el Rey ahorla en los sínodos, sin advertir que se pierde la porción más estimable, que es la enseñanza de los pueblos. Al cabo lo vienen a pagar estos infelices, porque, unas veces por las vacantes $y$ otras por las traslaciones de sus verdaderos Párrocos, rara es la población que los disfruta media docena de años; pues, si el Curato es bueno, pretenden otro mejor, y si por al contrario, procuran dejarlo cuanto antes, arrancando de este modo infelizmente del corazón de los indios, la semilla mal sembrada del Evangelio, con la tempestad continua de mutaciones.

Ya pues, que según lo visto, no se cumple el fin de las leyes en cuanto al modo de estas presentaciones, sera lo mejor reformarlas, reduciéndolas a su primitivo modelo; esto es, que a la manera de las Canonjias, según fueren vacando los Curatos se fijen Edictos para concurso, y remitan al Rey las nóminas para su real presentación, sin admitir personas que carezcan de los requisitos que disponen las leyes, y en el ínterin, puede servir un interino, como ahora se practica; que no debe dudarse estarán las Iglesias vacantes por menos tiempo y las feligresías mucho mejor asistidas, si se manda guardar el sínodo Limense, is en no admitir traslaciones de Curas, no habiendo servido las Doctrinas siquiera seis años.

Con esta cautela y con la de proponerse bajo estrecha obligación de conciencia a la Real designación los más beneméritos, por el orden, lugar y grado que detallan nuestras leyes municipales 59 y sus intérpretes, ${ }^{60}$ considero remediar en mucha parte, cuando no en todo, los espantosos abusos que hemos referido sin la menor ponderación, y al cabo de pocos años se verá mejorado el Estado Eclesiástico, más instruídos los indios y con mayores víneulos nuestra sociedad política, para su eterna duración.

1.- Concilio Limense $1^{\circ}$ : Cap. 11, acet. $3 ; \mathrm{y}$ el $2^{\circ}$ Concilio, Ces. 3, Cap. 76 y 78.

2.- Frazo: De Patronat. tomo $2^{\circ}$, Cap. 69, No. 11.

3.- Concilio $1^{\circ}$ Limense : acction, 3, Cap. 12.

4.- Rivadineira: De Patronat. Cap. 11, No. 76, fol. 225.

5.- Conc. $1^{\circ}$ Limense Provincial, Cap. 38. - Ley 13, título 13, libro $1^{\circ}$ de Indias.Ordenanza 31, título 13, libro 2, de las Generales del Perú... Prov. del Duque de la Palata, a 20 de febrero de 1684; Nos. 3 y 4, fol. 1311 vlta. de las Ordenanzas impresas en el año de 1752 . 
6.-Luca: Disc. 16, en las anotaciones del Concil. Tridentino sec. 21, de Reformat. Cap. 4, No. 2, p. 5", tomo 14 , fol. 365 , Nos. 3,4 y 5.

7.- Van Espen: De jure Eelesiast. título 16, part. 2, Nos. 33 y 34 , tomo $1^{\circ}$, fol. 523.

8.-Cap. ad. Audient. 3 , de kdificand. Fclet.- Ley 3 , título 5, Partid. $1^{9}$.

9.-- Luca: en cl lugar citado.

10.- Scarfantoni: Deeis. 21 , a No. 17 y siguientes, fol. 222.

11.- Ses. 21 de Reformatio.; Cap. $4^{4}$.

12.- Introduc. l'astoral 94 , tomo 2 , fol. 266.

13. - Real Cédula focha en Aranjuez, a 23 de abril de 1767.

14,- Leyes: $6,7,19$ y 23 , título 2 , libro $1 "$ de Indias. Ley 5 , título 3 , libro $6 "$ de la misnia Recopilación.

15.- Scarfantoni: en las Animadversiones et Lucubraciones canonicales de San Francisco Cecoperio, Lib. $3^{\circ}$, No. 4 , fol. 21.

16.- Ley 48, título 6 , ley 18 , título 7 ; ley 14, título 11 ; leyes $8,13,15,16,17,18$, $19,21,22,24$ y 26 , título 13 ; leyes 13,16 y 35 , título 6 ; leyes 16 y 17 , título 7 ; leycs 4,14 y 25 , título 15 ; leyes 23 y 29 , titulo 6 , Lib. $1^{\circ}$ de Indias.

17.-- Scarfantoni: Lib. 2", Luculurat. Canonic.; título 10, No. 12, fol. 119; con Fagnano y otros unuchos.

18.- Fagnano: en el Cap. Gravis de restitutione espoliator; No. 7, tomo 1, fol. 119.

10 - L L 13, título 11 ; Tey 24 , título 13 , libro $1^{*}$ de Indias.

20.- Frazo: De 1'atronat. Cap. 83, Nos. (' y 7 .- Concil. 1" Limense. Cap. 12 action 3, fol, 38 de la Colección Aguirre, tomo $6^{\circ}$.

21.--- Concilio Mexicano de 1585; título 2, Lib. 3, Noo, 12.

22. - Ley 65 , titulo 16, Lib. $6^{\prime \prime}$ de Indlias.

23. - Tridentino, Sect. 6, de Reformatione, Cap. $2^{4}$.

24.- Concil. Provel. 1" Limense; Cap. 18, action 4.

25. - Sínodo 3 , Limense de 1585 , Cap. 333.

26 . - Sinorlo 5" Limense de 1588 , Cap. $1^{\circ}$, fol. 215 , en el tomo $6^{\circ}$ de la colección del Cardenal Aguirre.

27. - Leyes 1 (i y 18 , título $1: 3$; Lcy 16 , título 7 ; Ley 6 , título 15 ; Ley 48 , título 6 ; Ley 26 , título 13 ; Lib. 1" de Indias.

28.-- Trident. Ces. 23, de Reformatione; Cap. $1^{\circ}$, vers. 10.

29.- No se debe reparar ni justifiear las licencias quc los Prelados dieren a los Doctrineros dentro de cuatro meses. Ley 16 , título 7.- Ley 17, título 13.- Ley 16, titulo 15.-- Lib. $1^{\circ}$ do Indias.

30.- l'ara evitar estos inconvenientes, dispuso el Si'. Duque de la Palata, en provisión de 20 de febrero de 1624 , Cap. 6 , a f. 311 , de la Ordenanza del Perú, que los Curas enseñen la Doctrima en lengua castellana.

31.-. Concil. Prov. Mexicano de 1585, título 2, libro $3^{4}$, No. 13.

32. - Sírodo 4", de 1586; Cap. 4, todo 61 Tít. 8, Lib. $2^{\prime}$ de las Ordenanzas Generales del l'erú, trata de la enseñanza y doctrina de los indios; principalmente las Ordenarizas $5,7,8,9,12$.

33.- Ley 13, título 8, Lib. 5" de Castilla. Ley 6, título 12, Lib. 1" dé Indias.

34.- Barbosa: Lib. 3, de jure Lelesiast.; Cap. 17, No. 67, contra Molina, De jus et jure trat. 2 , dispot. 147. Conclus. $7^{\mathrm{y}}$. Senedo en la colección $12^{\mathrm{s}}$ de las Decretales.- Salcedo: De leg. Polit.; Lib. 19, Cap. 15, No. 16.- Antúnez: De donationib.; Lib. 1, prelud. 2, § 7, No. 78.- Molina: De primogeniis; libro 2, Cap. 1, No. 54.- Gregorio López: en la Ley 53, título 6, Part. 1, glos. 1.- Barbosa en el Cap. Relatum 12, de tcstamentis, No. 5. González ib. No. 2.

35.--Calancha: en la Crónica de San Agustín, del Perú; Lib. $3^{\circ}$, Cap. 40, No. 6 . tomo $1^{\circ}$, fol. 749 .

36.- Concil. Limense $1^{\prime \prime}$, Cap. 31 , act. 3 , fol. 42, en el tomo 6 de la colece. del Cardenal Aguirre, requiere que estos nayordomos afiancen el caudal que administran, para su mejor cuenta y razón.

37.- Ley 5, Cap. 21 al fin, título 4 , libro $1^{\circ}$ de Indias.

38.- Ley 5, Cap. 25, y 26 , título 4 , libro $1^{\circ}$ de Indias.

39.- Ley 5, Cap. 21 y 22 , título 4 , Lib. $1^{\circ}$ de Indias.

40.- Frazo: Cap. 60, No. 50,- Rivadineira: Cap. 12, § 2 al fin, fol. 238.

41. - Ley 37 , Cap. 8, título 3, Lib. $1^{\prime \prime}$ de Castilla, impresión en Madrid, año de 1775.

42.-- Solorzano: en la Polit, Indin.; libro $4^{\circ}$, Cap. 11, No. 52.

43.-. Bulas de Paulo V., Gregorio XV y Urbano VIII, mandadas guardar en Reales Cédulas de 7 de noviembre de 1693 y 7 de marzo de 1698 , referidas con particular orden de su cumpliniento, en otra de Madrid, a 16 de febrero de 1703, 
con advertencia que en el número de los 8 religiosos de actual y precisa asistencia, no se incluyen los que se hallan instruyendo las Doctrinas y Curatos de sus territorios; y si a falta de este número se incorporasen a los Conventos cabeceras, quedan sujetos al Diocesano.- Vide Solórzano, in Polit.; Lib. 4', Cap. 23, y allí Ramiro Valenzuela, desde el No. 58 hasta el 81 , tomo $2 \%$, fol, $20^{\circ}$

44. - Leyes 45 y 50 , título 14 , libro $1^{\circ}$ de Indias.

45. - Cardenal De Luca: en las anotaciones al Concil. de Trento. Disc. 25, a la sec. 23 de Reformatione; Cap. 18, Nos. 4 y 5, Part. 5*, tomo 14, fol. 379.

46.-Luca: en el lugar citado, No. 6.

47. - Auto 127 al fin, título 2 , Jibro $2^{\circ}$ de Indias.

48.- San Carlos Borromeo: en sus instrucciones para el réginen de Ios Seminarios: part. 1, Cap. 1 hasta el $5^{\circ}$, tomo 2, fol. 819. Concil. $1^{\text {P }}$ [imense, Cap. 22, act. 3, fol. 40, en el tomo 6, del Cardenal Aguirre.

$49,-$ Ley 3 , título 23 , libro $1^{\prime}$ de Indias.

50.- Ilmo. Palafox: tomo 1", Cap. 1: De la Naturaleza del Indio. No. 3 al fin, fol. 454.

51.- Aguirre: en el tomo $6^{*}$ de su colección, fol. 54.

52.- Montenegro: en su Itinerario de Párrocos; Lib. 1, tract. 13, No. 1, fol. 132; y secn. 6 , Nos. 11 y 12 , fol. 136 .

53.- Leyes 2, 4, 5, título 12, Lib. $1^{4}$; Leyes 11 y 23 , título 13 , libro $1^{\circ}$ de la misma recopilación.

54.-- Montenegro: en su Itinerar; Lib. $1^{\circ}$, tract. 40 , secns. 2 y 3 , fols. 63 y 64 .

55.- Testamento Político; Cap. 2, ces. 1, fol. 74.

56.- Tridentino: ces. 2, Cap. 18, de Reformat.; y ces. 24, Cap. 18. Concuerda la ley 24, título 6, libro $1^{\circ}$ de Indias.

57.- Solórzano: De jure indiarum; Lib. $3^{\circ}$, Cap. 15, desde el No. 1. hasta el 15; tomo 2, fol. 661.- Frazo: De regio patronat.; Cap. $1^{\circ}$, desde el No. 22, tomo $1^{\circ}$, tol. 61 .

58.- Sínod. 5. Diocesana Limense de 1588; Cap. $2^{\circ}$, en el tomo 6 de la colec. de Aguirre, fol. 218 .

59.- Leyes $24,28,29$ y 30, título $6^{\circ}$, Jey 4, titulo 13, libro $1^{\text {y }}$ de Indias.- Leyes 32 y 38 , título 2 , libro $2^{\circ}$ de la misna Recopilación.-. Ley 3 , título 15, Part. $1^{8}$.

60.- Solórzano: De jure indiarum; libro $3^{\circ}$, Cap. 19.- Salcedo: Leg. Polít. libro $2^{\circ}$, Caps. 15 y 18.- Frazo: Cap. 33, No. 17.- Gutiérrez: libro 2 "Canonicarum; Cap. 11.- Abendaño: Tesauro Indico, tomo 1\%, título 1, Cap. 7, a No. 62 . 


\title{
CAPITULO OCTAVO
}

\section{De la Superintendencia de Minas.}

Se explica su origen, distrito y jurisdicción, con la de todos sus Oficiales Reales y dependientes, según el actual sistema de Mineria.

\author{
NOTICIA PRIMERA
}

Origen de esta Superinten- $\mathrm{WN}_{\mathrm{N}}$ otro lugar ${ }^{1}$ hemos referido que desde dencia. los primeros tiempos del descubrimiento de este imponderable mineral, no tenía el Corregidor de Potosí en el Cerro, otra autoridad que la de un Visitador subdelegado, para inquirir si cumplian sus respectivas obligaciones el AIcalde Mayor y los tres Veedores, si los indios recibian agravios en sus jornales o algún daño en las labores, si la mita se distribuja con arreglo a su repartimiento, si las minas se trabajaban según ordenanza, si se ejecutaban robos u otros excesos contrarios a las leyes y al buen gobierno de la minería y, por úitimo, para procurar y entender todos los demás casos y negocios que declara la Ordenanza 17, título $9^{9}$, libro $3^{\circ}$ de las Generales del Perú, tratando de las visitas que el Corregidor debía hacer en el Cerro, dos días cada mes; señalándole seiscientos pesos de plata ensayada, en la Caja de Granos, por razón de salario de su trabajo; aunque después, hacia el año de 1632 , cesó esta situación y se mandaron abolír todas las demás, por Real Cédula de 1618, recopilada en la ley 14, título 15 , libro $6^{\circ}$ de Indias. De modo que siendo por esta causa muy limitada la jurisdicción del Corregidor de Potosí, en materia de minas, se suscitaron entre el Alcalde Mayor y él, varias muy reñidas competencias, que dieron mérito para formar en su declaración la Ordenanza 19, título 9, libro 3 citado del Perí. 
La Superintendencia corría entonces a cargo de los Presidentes de Charcas, y con este carácter bajaban a esta Villa, en ciertos tiempos del año, a visitar las minas e ingenios de su Ribera, con todo lo incidente a la distribución de azogues, reparos de labores y repartimientos de mita, según refiere Escalona. '2 Pero siempre estaba reservado al alto Gobiemo de los Excmos. Virreyes, el conocimiento de cuanto inspeccionaban los Superintendentes, para aprobar o modificar sus providencias.

Se mandó después, por Real Cédula de 1578, recopilada en la ley 22 , título 31 , libro $2 \%$ de Indias, que los Oidores de Charcas, vinieran por turno, cada año, a esta Imperial Villa, a tomar cuentas a los Oficiales Reales y, de camino, visitar la Casa de Moneda ; con cuyo motivo se ordenó en otra Cédula posterior, de 1605 , 1ecopilada en la ley 29, título 1, libro $8^{\prime \prime}$ de nuestras Municipales, que también visitasen las minas e ingenios de esta Ribera, con la gente de Mita, conetiéndoseles de esta suerte la Superintendencia que antiguamente ejercian los Presidentes.

Pero habiendo insistido éstos en venir a Potosí, con pretexto de cerrar las cartas cucntas, entrometiéndose en otras dependencias, so color de su antigua jurisdicción, con muchas faltas de sus personas en el Tribunal de la Audiencia, se despachó Real Cédula de Madrid, a 23 de rebrero de 1713, mandando cumpliz el turno de los Ministros conforme a la ley citada, con absoluta prohibición de hacerlo los Presidentes y de demorar aquí los Oidores comisionados luego después de cerrada la carta cuenta, bajo la pena de no pagárscles el sueldo.

Con el tiempo se experimentó la poca utilidad de estas comisiones, por falta de inteligencia de los Ministros en materia de cuentas, que eran el primer objeto; y se libró nueva Cedula de Madrid, a 31 de enero de 1720 , para que por turno pasase a Potosí un Contador Mayor de cuentas, de Lima, de tres en tres años, y residiesc aquí continuamente, para tomar y fenecer las cuentas de los Oficiales Reales, con la ayuda de costa de 1.335 pesos, sobre los 3.615 de su sueldo; mandando que en esta virtud cesasen de venir los Oidores al tanteo de cuentas y visita de minas, como lo habian ejecutado antes.

A Ia sazón se estaban tratando varios altículos muy graves de la Cédula expedida en 1698, sobre la Mita de este Cerro y sus ingenios, y al cabo de pocos años de suspensión, se despachó aquella famosa Cédula de Sevilla, a 23 de octubre de 1732 , concediendo a los Excelentísimos Virreyes de Lima, la facultad de nombrar, cada dos años, un Ministro de la Audiencia de Charcas o Lima, por Superintendente de las Minas y Mita de Potosí, con el sobresueldo de 4.000 pesos anuales. Con lo que se restableció aquella antigua comisión que tenían por la misma ley, para inspeccionar y visitar estas minas y su gente mitaria.

Con este favorable suceso para los Ministros de Charcas, entraron a ejercer su nueva autoridad, con notable deslucimiento de los Corregidores, causando esta multiplicidad de mandos no pocas parcialidades y facciones en extremo perturbativas de la paz pública. El ruido llegó hasta el Trono, y los mismos efetos dieron a conocer el mal estado de este Gobierno, no menos que el remedio único de reunir los negocios en una sola mano que fuese diestra y fuerte en su manejo.

En efecto, fue nombrado por Corregidor de esta Villa, en el año de 1750, Don Ventura de Santelices y Veneyo, Oidor de Cádiz, y teniendo este Ministro bien acreditada su capacidad y juicio, se le concedió el Go- 
bicrno con todas las supcrintendencias y encargos anteriormente repartidos en diversas personas, fijándose en este dichoso punto la morosa época del origen de la Superintendencia on los jefes naturales de esta portentosa Villa.

Parece que todavía respiró, entre intervalos, de cuando en cuando, aqquel antiguo sistema, dejando como el relámpago deslumbramiento para cegar, en vez de luces para ver. Se amontonaron muchos desaciertos y no pocas desgracias, causadas las más do las veces por la emulación de los mandones competidores; y resuclto al cabo nuestro Gobierno, sabio a poner la mano en este enfermo, publicó la nueva Ordenanza de Intendentes, y por el Art. 1" de ella, unió al de esta Villa la Superintendencia de la heal Casa de Moneda, la de sus Minas y Mita, y la del Banco de Rescates, para uniformar el Gobierno y evitar los frecuentes embarazos y competencias que resuitaban, quedando separados estos empleos. Con cuya providencia, pasaron los Gobernadores de esta Villa, de meros visitadores del Cerro, at ser confirmados por verdaderos Superintendentes de todas sus minas e ingenios.

$$
\text { NOTIOIA SEGUNDA }
$$

Distrito de la Superintenden- $\mathbf{D}_{\mathrm{ESDE}}$ que se dividieron los dominios en cia de Minas. el mimdo, por convención general de las gentes, también se demarcaron los campos, 3 las posiciones y los dercehos, para evilar confusiones. Con este fin se fundaron las ciudades y se tueron distinguiendo las jurisdicciones de los reinos, hasta los más ínfímos magistrados. X como el mando es la porción más estimable del dominio bumano, por eso se ha puesto siempre mayor cuidado en contener la ambición, señalándole limites invariables.

Este desórden se notó muy pronto en Potosí, y fue igual su remedio para conservar el buen Gobicrno en las Provincias confinantes. Luego que Don Ventura Santelices fue nombrado Superintendente de las minas de Potosí, el año 1750, bajo de instrucción formal para administrarlas, pretendió extender esta jurisdicción a todas las del Tucumán, expidiendo providencias para el fomento del mineral de Catamarea.

E] Gobernador de aquella Provincia se resistió, norque la Superintendencia de Santelices no podía alcanzar a aquel territorio. De lo que avisado cl Rey, despachó Real Cédula de San Ildefonso, a $1^{\circ}$ de septiembre de 1761 , declarando que las facultades que se le concedieron, eran limitadas para las minas e ingenios del distrito de esta Villa de Potosí. Y desde entonces quedó domareado el territorio de ella en el ámbito de las cinco leguas por Distrito formal de la Superintendencia de Minas.

Ultimamente se unió a la Intendencia de Potosí, por el Art. $1^{\circ}$ de la nueva Ordenanza, la Superintendencia de sus minas en la extensión de los Partidos de Chayanta, Atacama, Lípez, Chichas, Tarija y Porco, que abraza este Gobierno, quedando por deslinde de la jưisdicción la misma Provincia de Potosí, y para los demás Intendentes respectivamente la strya, según el Art. 133 de la citada Ordenanza de 28 de enero de 1782.

Pero llegándose a entablar el nuevo sistema de minería que anuncia el Art. 135, y la declaración 11, de 5 de agosto de 1783, se viene a los ojos que entonces deberá ser el Distrito de la Superintendencia de Poto- 
sí, todo el del Virreinato de Buenos Aires; de suerte que, manteniendo cada Intendente la particular de su Provincia, para velar inmediatamente el fomento de las respectivas minerías, vendrá a ser el Gobernador de Potosí, un Superintendente General de todas ellas juntas, como antes lo eran los Excmos. Virreyes, respecto de las minas y de las Casas de Moneda del Reino, sin perjuicio de las Superintendencias particulares de estos ramos.

Ello es que si se trata de fomentar con solidez las minas del Perú, es forzoso exigir una Dirección General de Minería, que lleve la voz de todo el cuerpo de ella, para representar lo justo y lo útil, con autoridad competente y en tiempo oportuno.

También conviene conservar el Banco de Rescates y Avíos fundado en Potosí, dándole una nueva forma, ${ }^{4}$ para que estos dos efectos sean generales en todo el Reino; porque pensar en nuevas fundaciones, es querer que queden para siempre en el papel, como aquellas repúblicas estoicas en las ideas de Platón.

Siendo pues regular que la Dirección se plantee donde residiere el Banco, para pedir sin retardación las certificaciones y demás documentos relativos a rescates, avíos de azogues, consumos y productos de platas, es consiguiente que asista allí mismo el Superintendente que ha de despachar todas las expediciones, como el que éste sea el Goberrlador de Potosí; porque si cada Intendente hubiese de librar auxilios contra el fondo del Banco, o lo ejecutarían sin oír la voz de la Dirección y sin el debido conocimiento, o cuando se sujetaren a este órgano a tan largas distancias, llegarían tan de tarde en tarde los socorros, que ya no fuesen de provecho en una materia regularmente ejecutiva, como es la de las Minas.

Por último, una vez que ha de haber un solo Banco, que será como un corazón sólo, de donde han de circular los avíos y los fomentos a todos los miembros del cuerpo de minería, así también, no debe haber más que una sola cabeza, representada en el Superintendente, para evitar monstruosidades. $Y$ véase cómo, por unos pasos contados vendrá a ser Superintendente General de las minas del Virreinato, un Gobernador que, en un principio, fue apenas visitador del Cerro; después, en su mayor progreso, Superintendente del Distrito de la Villa, y últimamente el de su nueva Provincia.

\section{NOT I I A T E R C E R A}

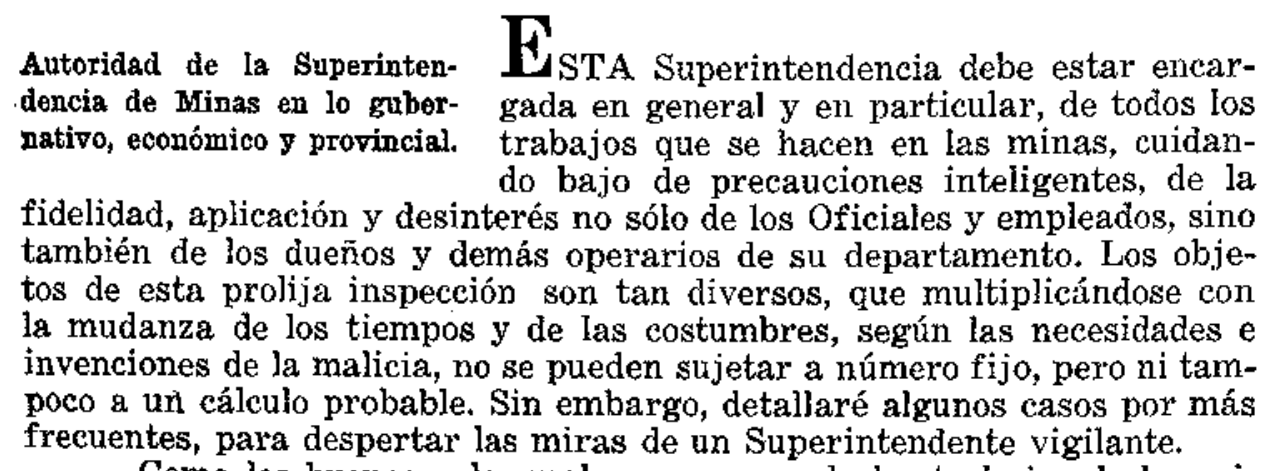
Como los buenos o los malos progresos de los trabajos de las mi- 
nas, dependen del convoniente empleo de los indios en las Mitas de sus respectivos repartimientos, debe ser, entre los cuidados del Superintendente, el principal que los dueños de minas e Ingenios no abusen de los operarios que les ha concedido el Gobierno para el fomento de su industria, celando muy particularmente que los apliquen a la labor de las minas, sin permitir que vendan, cobren, recibar o truequen en plata o en cualquiera otra especie, el trabajo de los indios que les están señalados, bajo las ponas inpuestas on diferentes Cédulas, Ordenanzas y Leyes del Reino. ${ }^{5}$ A este propósito, debe estar advertido el Superintendente, que el abuso de recibir en plata semanalmente el trabajo que habrá de hacer el indio en las minas de su repartimiento (que aqui llaman "rezago"), ha tenido su origen de moler en los Ingenios la broza de metal arrojada en las canchas, que es lo que llaman desmontes o pallacos; porque no hevando labor de barreta, no tienen en quć emplearse los indios del Cerro; y entonces los deja libres el azoguero, cobrando siete pesos semanales de los rezagos, en plata; sin alcanzar la vigilancia más escrupulosa a poner remedio a daño tan grave, por las ingeniosas invenciones con que se encubre este desorclen; y así, el único arbitrio es quitar la causa totalmente prohibiendo con rigor que los dueños de minas o ingenios se aprovechen de los desmontes que estuviezen fuera de elfas, y que los dejen al aprovechamiento comun de los que no tienen minas, por el orden dispuesto en las Ordenanzas, ley 2", título 1', libjo 3 ' del Perú.

Como no es posible que el Superintendente General, que ha de residir en Potosi, tome conocimiento de todas las minas de su Departamento, y del estado de prosperidad o decadencia en que se hallan, para proporcionar los anxilios convenientes y mandarlas cultivar con progresos, para sacar de cllas un partido ventajoso a favor de la causa pública, es indispensable que procure noticias seguras de los mismos Intendentes y de los Jueces reales subdelegados, accrca de estos importantes objetos. El medio ordinario es visitar personalmente cada Jue\% las minas de su distrito, reconocer las labores corrientes, despobladas y nuevamente descubiertas; los mojones y todo lo perteneciente al estado de las minas; enviando estas noticias, con Jos registros que ante ellos deben hacerse, con arreglo a las Ordenanzas del Reino. ${ }^{6}$

Pero la precanción más inteligente para adquirir la noticia cabal que se requicre, de todos los mineralcs e ingenios del Departamento y de su cstado, es que anualmente sc envíe a la Superintendencia General, una relación instruida de los cerros de oro o plata de cada Partido, 7 especificando las vetas descubiertas y corrientes los pumbos hacia donde corren, el caudal que rindieren o que se espera de ellas (con separación del metal rico al de las brozas y de los guijos sobre que arman), la naturaleza y diversidad de los metales, entre pacos, negrillos y mulatos, la ley que cada uno rinde, el beneficio a que se sujetan con más propiedad, entre el azogue y la fundición, los dueños de las minas e ingenios, los intereses que cada uno posee, las labores que se traen corrientes, la profundidad y estado en que se hallan, las imposibilidades por agua, y la disposición de poderse habilitar por socavón, según la altura y forma de los cerros, informando con justificación la riqueza en que quedaron al tiempo de aguarse, y acompañando a la relación expresada, mapas delineados o pintados, de cada mincral o cerro de por sí; de modo que instruyan a la vista de todo lo que en sí contienen, para que además de poderse to- 
mar un expediente favorable en todas estas dependencias, se hagan más inteligibles y justificadas las diligencias de visitas sobre que han de rodar las providencias generales de la Superintendencia.

Reaimente conducen todos estos conocimientos para dirigir el cultivo de minas, con progresos de parte de los dueños y de la Real Hacienda; pero ellos solos no son bastantes para reprimir los funestos efectos de la desaplicación, de la falta de inteligencia y del fraude. Son muchas las experiencias desgraciadas de los atrasos que ha producido en este ramo industrioso del Estado, cualquiera de los tres desórdenes referidos. Por lo general, están abandonados los minerales del Reino a la dirección de un minero o mayordomo ignorante y desidioso, que a espaldas del amo, no tira a más que a pasar la vida alegremente, a costa de los crecidos salarios que goza, sin cuidar del trabajo con la actividad que requiere su importancia. $Y$ cuando interviene alguno celoso y trabajador para el dueno, suele no poseer toda la fidelidad necesaria para el Rey en la paga justa de Ios Reales quintos.

El Gobierno ha aspirado siempre a remediar estos daños, alentando y promoviendo el espíritu nacional hacia la minería; y al mismo tiempo ha dictado providencias bien premeditadas para contener los abusos del dominio y asegurar los intereses del Rey.

El Excmo. Príncipe de Esquilache, \& mandó que en todos los ingenios se llevaran libros de los beneficios de metales, para asegurar anualmente la ley de ellos y el costo del beneficio, así en los jornales y materiales, como en pérdida de azogue. El Excmo. Marqués de Castelfuerte, ${ }^{9}$ adelantó algunas precauciones más y ordenó a los Jucces de Minas que, por juramento de los mayordomos de ellas, averiguien los cajones de metal que en cada mes puede sacar a sus canchas cada minero; con distinción de sus difercncias de pacos, mulatos y negrillos; y según este cálculo, examinar en la visita de los Ingenios, si los cajones beneficiados corresponden a la saca de los frutos del cerro y labores del mineral, haciendo este cotejo por los libros de beneficio y juramento del beneficiador; para dar cuenta al Superior Gobierno de los cajones de metal que mensualmente pudo lavar y beneficiar cada ingenio, con arreglo a las salcas, y de los que efectivamente lavó y bencfició, con especificación de la ley de cada uno y del importe total.

Si de estas diligencias resultare que no se ha sacado el metal que corresponde a la gente y labores del mineral, o que no se ha bencficiado y lavado mensualmente, a proporción del que se haya sacado o se debió sacar, entonces deben averiguar los Jueces la causa de la decadencia, y si procediere de negligencia o poca aplicación de los dueños, estimularlos al trabajo, hasta reducirlos a un corriente regular de marcos que todos los meses puede fructificar cada ingenio; o si fuere por falta de auxilios, proveer todos los necesarios en plata, azogues y en otras especies, para evitar por medio de oportunos fomentos las interrupciones que atrasan el ejercicio.

Y porque suele contribuír de ordinario a estas decadencias, la falta de recuas para la baja de los metales, dispuso también el Excmo. Castelfuerte, que ocurriendo los mineros a Ios Jueces, compeliesen éstos a los arrieros más inmediatos, a que se ocupen en las bajas, sin permitirles que, pagándoles el precio regular, dejen este trajín por el privilegio de la minería. 
Por el contrario, descubriendose por las visitas que se ha beneficiado mayor número de marcos de los que se han fundido y quintado en las Cajas respectivas, quoda averiguado el extravío y se debe exigir el quinto a corruspondencia del beneficio; de manera que, celando el Superintendente el cumplimiento de estas sabias precauciones, es indispensable que se acreciente el ramo de minería, o al menos que no decaiga en tanto perjuicio del Estado, como se ha visto en este Reino.

Hay otro daño que no se ve, todavía más perjudicial, que l'eclama toda la atención clel Superintendente. Consiste en el desperdicio de una gran parte de la ley que tienen los metales, desapareciéndose con la plata que se les deja sacar, otro tanto peso de azogue, por la mala fe e insuficiencia de los beneficiadores, en perjuicio del dueño, del Rey y del Estado.

Nuestro mineralogista Barba, citado en otro lugar, "ponderó sobro muchas pruebas experimentales, las incroibles sumas que ha despedido rio abajo la ignorancia tan lastimosa como notoria de los beneficiadores. Nadie iguora que este es el origen más funcsto de ruestra mhería, y nuestio Gubierno mismo lo tiene conocide; pero bien sea por el poco celo o por la preocupación de los azogueros, no hemos visto hasta aquí ejecutadas las serias piovidencias expediclas por los Excmos. Virreyes, principalmente por el Sr. Marqués de Castelfucrte, acerca do este importante asunto.

Para remedial este daño propiamente intenso, se halla mandado que los Juexes, acompañados de personas do conocida práctica en el beneficio de los metales, examiner a los bencficiadores, por medio de repetidos ensayes menores de fundición, antes de aprobarlos y dar la licencia que necesitan para ejercer el magisterio; multando, así a éstos como a los azogueros que se valieren de ellos sin precedente aprobación y título de la Superintendencia, por haberse reconocido que muchos mineros ocupay a unos indios ignorantes, que apenas tiench conocimiento del azogue, por ahorrar on ellos el salarjo que habia de ganar otra persona más inteligente.

Y para mayor calificación de la idoneidad, será bien que, antes de entrar al ministerio, evachen un acto solemne de beneficio por mayor, examinando precisamente por la prueba infalible del fuego la última ley de los metales, para apurarlos después (gobernándose por ella) en el corriente y común beneficio de azogue.

És verdad que cuando vinieren a Potosí los maestros beneficiadores, que se esperan de Alemania, cesará el cuidado de aprobarlos, porque los primeros traerán sus títulos correspondientes, y los sucesivos ya serán examinados en el Seminarie de Metalurgia y Mineralogía. Pero, en el entretanto, conviene no retaldar por más tiempo tan importante precaución; además, que aun después de llegados los maestros para Potosí, scrá preciso que estos mismos examinen, para los minerales de afuera, a aquellos sujetos peritos que actualmente ejercen de beneficiadores, despachándoles su licencia respectiva el Superintendente General; y si acaso no se prepara con este rigor la nueva planta de minería, es de temer que después siga el mismo disimulo para ruina irreparable de todo el Reino.

Aun toca al Superintendente celar que las minas e ingenios se trabajen con actividad, inteligencia y desvelo, como se acaba de decir; no 
debe compeler a los ducños que residan personalmente en los asientos de los minerales, como lo intentó Don Ventura Santelices, Gobernador de Potosí, sobre el ejemplar de lo que se practica en Huancavelica; porque atendiendo a la gran diversidad de circunstancias, se declaró en Real Cédula de Aranjuez, a 21 de mayo de 1765, que los azogueros bien pucden ausentarse de donde tienen sus minas, sin ineurrir en su perdimiento, siempre que, estando ellos ausentes, queden en administración o arrendamiento de personas inteligentes y activas para el trabajo.

También corresponde al Superintendente General, nombrar los facultativos de minas y peritos beneficiadores, y despacharles títulos a propuesta de la Dirección; admitir al grentio los individuns que soliciten ocuparse en la azoguería, calificando su idoneidad, limpicza, utilidad y probidad de costumbres, con advertencia de la Dirección en Junta de diputados; arreglar el arrendamiento anual de los ingenios, con acuerdo de la misma Dirección, citación de los dueños e interesados, con intervención del Procurador General de la Villa, ajustando los arrendamientos al respecto de los cajones o quintales de molienda al año, para remediar el precio excesivo y arbitrario que exigen los ducños, con notorio atraso de los arrendadores que son vasallos verdaderamente ítiles al Fstado; convocar a Junta general a los consultores de la azoguería; presidir las que se hicieren para elecciones y para otros fines; oír las propuestas de la Dirección y hacer por sí todos los nombranientos a que se refíceren los Arts. 14, 25, 26 y 27, título $1^{\circ}$ de la Ordenanza de México; librar en el Banco los avíos y auxilios extraordinarios que pidieren los mincros del Departamento, por mano de la Dirección, despues de examinàda y bien calificada la necesidad o utilidad, en Junta de diputados. Practicar por sí y remitir cada año al Rey, las visitas de minas e ingenios de esta $R i-$ bera, cumpliendo estrechamente la obligación que le impone una Real Cédula de 31 de enero de 1762, y otra de Aranjuez, a 13 de mayo de 1765. $\mathrm{Y}$ aunque los recursos que i'esultaren de la visita en punto del manejo y administración de las minas e ingenios, ya no deben ir al Virrey y a la Audiencia, según la distineión de casos de Gobierno y Justicia, como se previno en las citadas Reales Cédulas, por hallarse en el día inhibiclas ambas superioridades del conocimiento de minería; pero siendo preciso que haya en el Reino algún tribunal para estas alzadas, se deberán admitir para la Junta Superior de Buenos Aires, a quien toca atender todos los negocios agregados al Departamento de Hacienda, cntendiéndose esta regla igualmente con los Intendentes y demás Jueces reales subdelegados sobre materias de justicia, a excepción de las de Gobierno, que deben venir por recurso a la Superintendencia General.

Por ejemplo: si algún minero se agraviase de lo proveído acerca del mayor adelantamiento de la ley de los metales y de su beneficio por fundición o azogue, o en orden a evitar derrumbamientos, muertes, inundaciones de planes, y cuanto concierne al mejor método y habilitación de las minas o de los ingenios.

Lo mismo será tratándose de exceder las dos varas y media de ancho y otro tanto de alto, que permite en el hueco de Ios socavones, la Ordenanza $2^{3}$ al fin, título 8, libro $3^{n}$ del Perú; o el de vara y media de ancho y dos y media de alto, que dispone para los barrenos la Ordenanza $6^{*}$ del citado título y libro; porque en todos estos casos y otros semejantes de Gobierno, están sujetos al conocimiento del Superintendente General de 
Minería, por la autoridad que le concede la ley 3, títuio 1, libro $2^{\circ}$ de la Recopilación re Indias, para disponer en materia de minas, Io que hallare más conveniente.

Y sí, bien prede el Superintendente no pasar por el juicio y experiencia de los demás Jueces, no to solían los Virreyes prudentes y experimentados (cuando tenían a su cargo este ramo), proceder a nombre de visitadores, sino en caso rarísimo e indispensable, por los graves inconvenientes que tocan tales comisiones, a menos que se mezcle algún punto en que se interese el Gobierno gener'al de la minería o la dispensación de algún artículo de la Ordenanza, en notable perjuicio de partes; porque entonces, además de justo, es conveniente despachar comisiones en personas de mérito y experiencia, para consultar el mejor Gobierno y contener perjuicios de tan grave consecuencia. ${ }^{11}$

No debe ser menor el cuidado y la buena cuenta en mandar labrar. las minas desclbiertas y buscar otras nuevas, ${ }^{12}$ aplicando de los repartimientos más ccreanos dentro de las reinte leguas, los seis indios que concoden las Ordenanzas al descubridor; ${ }^{1.3}$ proveer' los asientos de minas de buenos bastimentos y materiales, a precios justos; ${ }^{14}$ hacer guardar a los mineros sus privilegios; ${ }^{16}$ y limpiar los minerales de jugadores, vagabundos, amancebarlos y reicatirits. "is Todos estos puntos tocan a lo gubernativo, do que pueden entender tanibién los Alcaldes Mayores, gobernadorcs y sublelegados, en sus respectivos Distritos, según el tenor de las leyes. ${ }^{2}$ Sin enbargo, se prede Inczclar en todos ellos el Superintendente (soncral, con prudencia y buenas cautelas, si juzgare conveniente dispensin, corregir o alterar algo.

Como las minas e ingenios suelen pasar a otros poseedores, por venta, airendamiento o hercncia, es preciso advertir que cada Intendente, inciuso el de Potosí, puede conceder licencia para verificarlo según ordenanza. ${ }^{1 / 8}$

El estilo corriente es que cl que quiere vender o arrendar sus minas e ingenios, comparece ante el Gobernador haciendo reiación dcl contrato que intenta cclebrar, y de su precio, causa y condiciones, $\mathrm{y}$ pide se le reciba información de utilitad así a la Real Hacienda como a la causa pública, e igualmente de scr legítimo el precio, hábil y suficiente el comprador o arrendador, para llevar la labor, concluyendo que, en vista de todo, se le otorguc la licencia.

Mandada recibir la información que disponen las Ordenanzas, resultando de ella comprobada la utilidad y el precio en que se concextó la venta, se provee auto concediendo la licencia que se pide, con la calidad expresa de traer confirmación dentro de un año siguiente; añadiendo en los arrendamientos la obligación y fianza de ocupar los indios en las tales minas e ingenios con que se arrendaron, y no en otras, $y$ de dejar las mismas minas seguras y reparadas a vista de veedores, y los ingenios molientes y corvientes al tiempo de acabarse el arrendamiento.

Notificado el permiso a lasi partes, se otorga la escritura por el Escribano de minas, con citación del Protector de naturales, por el interés que tienen los indios en el abono de las fianzas con que se asegure su buen tratamiento y su indemnidad en la reparación de las minas.

El interesado ocurre al Superior Gobierno, con testimonio de estas diligencias, $y$ precediendo vista fiscal, provee que se libre despacho de aprobación donde se confirma la venta a arrendamiento, y el dexe- 
cho de los indios de Mita, mandando al Corregidor que se los haga acudir en los tiempos y mitas ordinarios, en virtud del despacho que sirve de mandamiento en forma.

En el entretanto se obtiene la confírmación del Superior Gobjerno, quedan, por puro depósito, en poder del comprador los indios que estuvicren repartidos o señalados para las minas a ingenios, bajo la pena de nulidad de los contratos que en otra manera se hicieren y de perdimiento del derecho y acción que pudiexan tener para repartirseles indios de mita, según el tenor do las Ordenanzas, ${ }^{19}$ siendo calidad ${ }^{20}$ que no so dé posesión de ninguna mita permutada, vendida o donada, o por cualquier otro contrato enajenada, sin que, primeramente, ambas partes parezcan ante la Justicia y declaren por juramento, que el contrato que asi hicieron es cierto y verdadero y no fingiclo ni simulado, sino con ánimo de estar y pasar por él, realmente y con efecto, bajo la pena de nulidad de la posesión y cle cien pesos de plata ensayada y marcada, al Juez que la mandare dar, y a las partes, el perdiniento de la mina, si fuere suya, y no siendo, del valor y estimación de ella.

Por eso, cuando constare que las ventas o arrendamientos de las minas e ingenios, han sido simulados y fingides, pasando únicamente la administración de ellos, en confianza secreta, al que suena comprador o arrendador, no debe repartírseles indios más adelante, aunque compren otros ingenios y minas o las abran de nuevo; y a los vendedores se les debe quitar perpetuamente los repartidos y señalados, para que con estas precauciones se embarace el gran inconveniente de vender el trabajo de los indios a trueque de plata, con el indecible perjuicio de ocuparlos estos fingidos compradores o arrendadores de minas e ingenios, en tareas excesivas, maltratándolos con azotes y haciendo en ellos otros daños gravísimos, prevenidos muy de antemano y prohibidos estrechamente en las Ordenanzas del Reino. ${ }^{21}$

Aquí se debe notar, que aunque se previene en la Ordenanza 4, título 12, libro 3 ? del Perá, y en la adición de Iapidana, título $14 \mathrm{del}$ mismo, Nos. 2, 6 y 26 , que en las ventas, donaciones o arrendamientos, no pasen ni se den a las personas que sucedieren en las minas e ingenios los indios que para ellos estuvieren señalados y repartidos, $y$ queden vacos para repartirlos a otros, señalando el Corregidor de la Villa algunos in-m dios a la persona que sucediere, hasta que el Sx. Virrey provea los que se le han de dar para ello; no por esto es contra Ordenanza la provisión ordenada de suceder y despachar los señores Virreyes, cuando aprucban tales contratos, porque en declararse la vacante del repartimiento en las Ordenanzas citadas, no hubo otro fin que mantener la naturaleza libre de los indios y la calidad de invendibles y enajenaciones, como personas exentas de ajeno dominio, según las leyes y ordenanzas del Reino, ${ }^{22}$ para que jamás se mostrase ni un indicio de que el comprador o arrendat dor tienen adquirido algún dominio y propiedad en ellos, segín la interpretación de nuestro Solórzano. ${ }^{23}$

Pero en la realidad, sucede de los indios el comprador o arrendador de las minas e ingenios, no por el traspaso o contrato panticular que tiene celebrado, sino por nuevo repartimiento que se le hace, atendida la causa de necesidad y utilidad pública que en él continúa.

Por esto concluye el citado Solórzano, ${ }^{24}$ que pareciendo el conprador de las minas e ingenios con títulos legítimos, se le deben dar los 
indios que pidiere en virtud de ellos, y que se tendrá por injusto el denegárselos, no habiendo razón explicable que a ello mueva, porque no se Ie conceden por gracia o beneficio, sino por estar ya entablado por ley y costumbre.

Fundado en este principio, anade ${ }^{2 \pi}$ que sin embargo de estar prohibido el venderlos o al'cendarios, haciendo específica mención de elios c1 Jos contratos o escrituras de ventas o ar'rendamientos de las minas, no será injusto ni reprobado que quien las vende o arrienda lleve algún mejor precio por ellas, en consideración del repartimiento de indios; porque siendo ordinario $y$ casi seguro ontrar a su nuevo goce, es precio inestimable la esperanza de su continuación. ${ }^{26}$

Fin efecto, se practica cn Potosi, con la circunstancia de ser ya entable invariable, de ammentar sobre ol valor intrínseco de la hacienda que se vende, mil pesos más por cada indio de su repartimiento, y a este mismo respecto on los aricndamientos.

Pero en sentencia dle nuestro Solórano, 27 no tiene derecho alguno el comprador o arrendados, a título de evicción o saneamiento, enor. me y enormisima lesión, si pol particulares respetos o por otras razones, se le clejaren de conceder del todo, o se le redujeren a menor número, como cada dia acontece, por no haberse podido obligar el vendedor a unos cargos que a a mismo le pudieran haber sucedido aunque no hubiera hecho la venta o traspaso.

No debe sol así, en mi juicio, cuando se quitare el repartimiento de indios al heredero a quien le tocó en partición alguna mina o ingenio, en cicita cantidad de pesos regulada al respecto de los indios, sin Ios cuales no los valiera: $\because \mathrm{g}$.: (') veinte mil pesos por otros tantos indios senialados a una hacienda, que, sin tencrtos, no valiera más que cinco mil pesos; que: en semejante caso se debe atender únicamente la igualdad entre los hijos, y no es justo que alguno de ellos reciba perjuicio tan notable, de quedar casi deshercdado pol causa de un accidente en cl que él no tuvo parte, y que si lo hubiora sucedido al padre, alcanzaría a todos los hermanos, disminuyéndose la masa común hereditaria a proporción del llúméo de indios que se le quitó a la hacienda o se le minoró.

En Potosí son muy frecuentes las herencias y adjudicaciones de esta clase, y es muy factible que algún heredero reclame cuando se forme la mita, para repartirla con mejor método a todas las minas e ingenios de esta Ribera, con arreglo a la Real Cédula dada en Buen Retiro, a 15 de julio de 1750, que hemos citado en otro lugar. ${ }^{28}$ Fntonces se debelá tener muy a la vista la adyertencia antecedente. Por ahora, ninguno debe temcr la injusticia de negársele el repartimiento que tuvo su padye, porque el Si. Marqués de Montesclaros, para quitar dudas y establecer un derecho firme, declaró, en provisión de 23 de agosto de 1609, que: "los hijos y heredcros de los dueños de minas e ingenios, que tienen repartimiento de indios, sucedan en su goce, de la misma forma que en las minas e ingenios, con el cargo de llevar confirmación dentro de cuatro meses siguientes, y que en el caso de quitarse los indios por su mal uso, se remitan los autos dentro de dos meses".

Muchos dudan si en las ventas y arrendamientos de las minas e ingenios que no tienen indios repartidos, como son todos los de este Reino a excepción de la Ribera de Potosí, (en que, sin embargo, también hay algunas sin repartimiento) deberá proceder la formalidad de la infor- 
mación y demás solemnidades expresadas arriba. Algunos letrados son de parecer que no, porque todas las cautelas de la Ordenanza se dirigen a evitar el mal uso de los indios mitarios; y una vez que se trata de haciendas quo no tienen repartimiento, debe cesar la disposicion de la Ordenanza, respecto do cesar su causa final.

Otros son de contrario sentir, porque las minas son una legalía rue el Rey concede a sus vasallos, con la pensión de contribuíle el leal derecho de quintos; y los ingenios son unos edilicios públicos destinados para el mejor expediente de la miner'áa, que subsisten con las aguas comunes de la Ribera y se surten como los otros del avio de azogues y de otros suplementos que suministra el fondo del Banco de Rescrites. Por otra parte, necesita de su corriente para el trabajo, de los indios mingados, que son los que se conchaban por conciertos foltunlarios con los duerios de minas e ingenios.

Ya se vo que se interesan el Rey y ol Estado en la buena administración y manejo de ellas y do se oculta el gravisimo perjuicio que puede menoscabar estos importantes objetos, si se cjecuta la enajenación y traspaso de tales haciendas en personas ineptas para el trabajo de la minería. No es tan universal el interés de la causa pública en la bnena administración de las pulperías, boticas y otros negocios de estat clase; $y$ con todo de que el Rey nada impende en su conservación y fomento, disponen los Arts. 70 y 132 de la Real Ordenanza de lntendentes, quo se visiten y celen las pulperías, platerías $y$ otras oficinas con quienes tiene relación el público.

En efecto, se ha estimado por más segura en la práctica esta biltima sentencia, y conforme a elia se ha procedido en la venta de uno u otro ingenio sin repartimiento. Pues, si con la intervención del Magistrado de la mineria no se cuidara de tener corrientes y molientes los ingenios, y bien seguras y reparadas las minas, se arriesgaría la vida de los trabajadores y la Real Hacienda quedaría pexjudicada en la miuoración de sus quintos, atrasándose el corriente de las minas e ingenios, como sucedería las más veces, si un negocio tan público como éste, no quodase sujeto sino a la ley particular de Ios contratantes.

Las solemnidades de esta clase de enajenaciones, entran en los puntos de buen gobiemo, cuya naturaleza comprende todos los casos de que puede venir daño a la causa pública, aunque no concurran juntos todos los motivos de la dísposición gubernativa; es decir, que no releva el defecto de indios de Mita, cuando existen otros fines y causas muy princjm pales de la Ordenanza. Luego, así como en consideración a cllas, se sujetan indistintamente todas las minas e ingenios a las visitas de los res-pectivos Jueces, del mismo nodo deben reglar'se por" la ley que de los contratos de minas, tengan o no indios de repartimiento.

Aquí se puede añadir la f́ábrica de nuevos ingenios, que es otro caso de gobierno comprendido en la autoridad del Superintendente do minas. El estilo es presentarse el interesado, haciendo relación de la cabeza (de ingenio) que quicre construír, y de la utilidad que se sigue a los reales quintos; y ofrece información acreditando la pertenencia de la Mita, con los títulos de su repartimiento.

Recibida la infoimación, con citación del Protector por parte de los indios, con la de los diputados del gremio de azogueros, y con la del Procurador General por el interés del público, no resuitando contradic- 
ción, se le concede la licencia, con la calidad de traer confirmación del Superior Gobierno, dentro del término de la Ordenanza de la Provincia, y de que pondrá y dará construído el ingenio, seguro y bien reparado, corriente y molicnte a la vista de Veedores; de manera que se puede traer el trabajo y molienda sin peligro ni riesgo de los indios. En cuyo estado se envía el expediente al Sr. Virrey, con parecer del Gobernador, para su aprobación.

En los ingenios sin Mita, se duda también si deberán practicarse para su fábrica las formalidades que acabo de referir; y aunque algunos lo niegan, por las razones apuntadas en orden a los arrendamientos, lo contrario es más seguro, con la única diferencia de no ser necesaria la citación del Protector, por no haber interés de parte de los indios.

Porque si bien algunos autores enseñaron que no es menester ni aun licencia del Gobierno, cuando los ingenios o molinos no se edifican en río páblico navegable; otros con mejores fundamentos, la requieren por indispensable, conforme a una ley Real, ${ }^{29}$ ilustrada por célebres doctores.

Ahora ya no parece revocable en duda; pues, si por el Art. 66 de la Real Ordenanza, se previene que preceda presentación de los dibujos de todo edifício público para obtener' licencia y aprobación con qué proceder a su fábrica, con más razón debe intervenir lo mismo en la construcción de los ingenjos, por ser unas máquinas y edificios públicos que tienen notoria dependeneia y conexión con la minería.

El Rey tiene interés en ellos, por reales quintos que se adeudan en el beneficio de las platas, y también el público, por los arrendamientos, ventas y demás dependencias que se han de contraer con ellos. Por otra parte, no es regular que el señor del territorio ignore las cosas públicas que en él sc ejecutan, y que se hagan sin su licencia, pudiendo resultar después notables perjuicios a la causa pública; luego, a la manera que se pide licencia del Gobicrno, con precedente información de utilidad, para la fábrica de molinos de granos, aunque no tengan repartimiento de indios, así también deben practicarse las mismas diligencias para la construcción de ingenios de moler metales.

Sobre este punto, hay que notar que según el actual sistema de minería, debe entenderse con la Junta Superior ${ }^{31}$ la aprobación que requieren del Sr. Virrey las ordenanzas del Perú, para ventas, arrendamientos, enajenaciones y fábricas de ingenios, por scr todas unas dependencias relativas a minería, que nuevamente se hallan agyegadas al Departamento de Hacienda, principalmente cuando vomos sujetos a su jurisdicción los edificios públicos, por el Art. 66 citado, con todo ce ser materia puramente política.

Por último, debe advertir cl Superintendente, que aunque la Ordenanza 22, título 11, libro $3^{\circ}$ del Perú, da per vacos desde luego los indios repartidos a los dueños de ingenios, que teniéndolos arruinados no los hayan enderezado en dos años de aguas o estándolos, no hubiesen molido metales en dicho tiempo, con expresa prohibición de acudirles con la mita de su señalamiento, nunca se ha observado esta disposición, atendiendo a la imposibilidad que ha causado el atraso de la azoguería, para construír unas fincas tan costosas. $Y$ así, cuando alguno las ha fabricado, se le ha mandado acudir con sus indios, alzando el depósito en que se hallaban; porque verdaderamente, al impedido no le corre término ni le para 
perjuicio de su atraso, además que el perdimiento que impone la Ordenanza, aunque sea con la calidad de "desde luego", siempre requiere sentencia declaratoria del hecho, sobre bastante probanza, ${ }^{23}$ cono allí mismo se previene. Conque, no habiendo precedido estos requisitos, no hay derecho para hacer ejecutar la Ordenanza.

Pero, por lo mucho que convicne poblar la Ribera, seré bien usar la cautela anunciada en la ley 11, título 12 , libro 4 de Indias, últimamente reproducido en la nueva Ordenanza de Mćxico, de 1783. Ts a saber: apercibir a los dueños con las peras que establece la 22 del Perú, con más el perdimiento del sitio, aplicado a quien quisiere poblarlo, si dentro del término de dos años ${ }^{33}$ no lo practicasen sus dueños, sin necesidad de otra declaración ni sentencia, que el simplo reconocimiento clel despucble.

$$
\text { NOTICIA C UA A T A }
$$

De los Oficiales de la Superintendencia $y$ demás dependientes de la ininería. Se explica su respectivo ministerio y jurisdicción.

I únicos Superintendentes de minas, en la antigua legislación del Perú. El Corregidor de Potosi, no tenía otro carácter que el de Visitador del Cerro, para cuidar de los objetos detallados en la Ordenanza 17, título 9 , libro $3^{\circ}$ de las Generales del Reino; y así él, como todos los Gobernadores y Alcaldes Mayores, tenían, por las leyes del Reino, $: 1$ un encargo o Intendencia subalterna, para cuidar de mandarlas descubrir, beneficiar. y labrar, y de todo lo demás concerniente a su buena administración con arreglo a Ordenanza.

Por entonces, estaban reducidos todos los Oficiales de Minería, a un Alcalde Mayor, tres Vecdores y un Jucz de Rescates, con unos sucldos bien crecidos, situados al principio en la Caja de Granos, y desde el año 1632, en la Real Hacienda.

Los dependientes eran todos los azogueros de esta Ribera y los demás comprendidos en la jurisdicción de esta Villa. Pero todo el cuerpo se representaba formalmente en los Procuradores o Diputados, que la Azoguería elegía en sus Juntas.

Posteriormente, se refundió en este siglo la Alcaldia Mayor y una de las tres Veedurías, quedando solamente dos, que subsisten en cl día. Yo comprendo que esta minoración se pretextó con la imutilidad de estos empleos, desde que se comenzó a experimentar cl absoluto atraso deI Cerro, el desorden irremediable de todas las labores y la decadencia de la Mita.

Ahora se trata de arreglar esta importante legislación según el actual aspecto de las minas y costumbres del Reino, tomando por modelo el de la nueva Ordenanza de México, en la parte que fuere adaptable, y juntamente, la antigua del Perú, con reforma de lo que por experiencia se reconociera inútil, según el estado presente de estas Provincias.

Siguiendo la nueva forma que se propuso al Rey, en informe de $\mathbf{1 6}$ de julio del año próximo pasado, aprobado novísimamente en Real Orden de este año, con la calidad de que el actual Gobernador Don Juan del Pino Manrique, lo reduzca a cuerpo de Ordenanza, arreglándose a los fundamentos propuestos, deben crearse por la Dirección y Juzgado de Mine- 
ría, otros muchos Oficiales más, convaleciendo uno de los antiguos que cstableció el Excmo. Sr. Don Francisco de Toledo, a saber: el Teniente de Gobernador, que ha de ejercer las funciones de Alcalde Mayor; dos Vcedores, un Asesor, un Director, tres Diputados, doce Consultores, un Administrador, Contador y Tesorero, con sus Oficiales para el manejo del Banco; un Solicitador, un Escribano, Portero, Alguacil; un Facultativo de Minas y dos peritos beneficiadores. Todos los cuales deben ejercer el ministerio y autoriclad que se explica en los parágrafos siguientes.

Párrafo primero. - Alcalde Como no es posible que el Corregidor soMayor de Minas. lo asistiera personalmente en el Cerro a visitar las labores, examinando menndamente los muchísimos objetos de la Ordenanza, para celar su cumplimiento así en las minas como en los ingenios, y al mismo tiempo componer diferencias y hacer justicia on general sobre todas las dependencias de minería, fue indispensable nombras: un Alealde Mayor en quien estuvieren reunidos estos importantísimos cuidados.

Con este fin disponen las loycs y Ordenanzas del Reino, ${ }^{35}$ que sea hábil y cntendido on materia de minas y práctico en el beneficio de ellas, imponiéndole entre otras obligaciones, la de entrar a ver y visitar las del Cerro, de tantos en tantos días; scrialar a los Alealdes Veedores, por autoridad de Escribano, en su presencia, las minas y vetas que cada uno ha de tener at su cargo, do suerte que, al cabo del año, cada uno esté en todas las partes del Cerro paraz cuidar de lo que es su obligación; ${ }^{36}$ desterrar los vagabundos, jugadores medidas, "asesiones "1 o propiedad, ${ }^{12}$ denuncios, ${ }^{43}$ despueble, ${ }^{14}$ desplazamicntos, ${ }^{4} \bar{y}$ y todas las demás causas civiles o criminales tocantes a minas, incirentes o dependientes de las tratadas sobre ellas, ${ }^{46}$ ventas de indios, ${ }^{17}$ mojones ${ }^{15}$ y otros de esta naturaleza.

Párrafo segundo. - veedores. $\mathbf{P}$ OR la misma razón de multiplicar celadores del buen tratamiento, satisfacción $\mathrm{y}$ paga do los indios del Cerro, y evitar las muertes, heridas y otros gravísimos daños que resultaban contra los trabajadores, a causa de que no se habían hecho las labores y reparos convenientes en las minas para su perpetuidad, y seguridad de los indios que las labran, se creó el oficio de Alcaldes Veedores, bajo la precisa obligación de asistir en el Cerro, turnando unos a otros, en todas las partes rle él, de manera que al fin del año haya asistido cada uno en todo el Cerro. ${ }^{49}$

Reconociéndose después, que continuaban los excosos, por la inobservancia de los Veedores, se renovó la Ordenanza del Excmo. Sr. Marqués de Cañete, on la adición de Iupidana, ${ }^{50}$ con la notable circunstancia de precisar a los Veedores, que duerman y asistan en el Cerro, y no en esta Villa, y que se castigará severamente al que no subiese una semana; por haberse averiguado que había Veedor, de los de aquel tiempo, que no había subido al Cerro dos veces, ni entrado en minas de riesgo.

Si se hubiera llevado con rigor el cumplimiento de la Ordenanza, no hay duda que el Cerro nunca hubiera llegado al estado increíble en que hoy se ve. Todas sus cajas están rotas, disfrutados los puentes, hundidas 
las labores, taqueados los caminos, y en suma, tan desordenado todo el Cerro, del medio para arriba, (que es lo trabajado hasta ahora), que sola su vista hace conocer el criminal descuido que han tenido los Alcaldes Veedores en el cumplimiento de sus deberes.

Ahora, ya se ve, tienen más disculpa, porque el daño ya es irremediable; pero ello es cierto que no es bastante para excusarlos de muchas muertes, $y$ desgracias que suceden en el Cerro, por la libertad en que se envía a los infelices indios, para que trabajen en minas antiguas desamparadas, sin preceder reconocimiento a vista de Veedor'es, de haberse reparado y aderezado, como conviene, para traesse labor a ellas, con seguridad y sin riesgo de los indios, según la prevención de la Ordenanza. 51

En el día, deberían celar siquiera esto. Pero no lo ejecutan; y por eso ni aun saben cuántas son las labores que ticne el Cerro. Si alguna vez suben, es solamente para dar posesiones o practicar otros actos donde perciben lucro. Conocen muy bien su responsabilidad a los daños que reciben Ios indios, y aunque no los ignoran por notorios, se muestran compasivos con los mineros, para remisión del delito, $y$ por medio de estas arbitrarias composiciones, es rarísimo el caso que llega a noticias del Superintendente, para poder castigar a Ios delincuentes.

Así, aunque la mayor parte de las Ordenanzas, tanto del Pexú como de México, ${ }^{52}$ que tratan de las labores y reparo de las minas y ruinas que suceden en ellas, no pudo ponerse en prúctica en el Cerro de Potosí, no obstante, sería muy conveniente renovar, bajo de gravísimas penas, las que disponen los reconocimientos prolijos que se deben hacer por vista de ojos de los Veedores, ${ }^{53}$ para examinar la seguridad de ellas, antes de permitir que los infelices indios entren a trabajarlas al arbitrio de los dueños, con peligro casi evidente de las vidas. $Y$ siempre que no se cuide de esta gravísima importancia, se hará cada vez más repugnante a estos miserables el trabajo del Cerro, y los Alcaldes Veedores tirarán inútimente el sueldo de sis empleos, quedando los superiores con el formidable cargo de las desgracias que sucedieren por su misión.

Si bien yo considero que todos los abusos y descuidos que se experimentan en el día, traen su principio vergonzoso de haberse conferido el empleo de Veedores a hombres ignorantes de las obligaciones principales que deben saber, lo cierto es, que deben sel muy inteligentos en las labores y reparo de minas, ${ }^{54}$ como macstros que han de aprobar a los mineros que quisieren entrar a servir en el Cerro. 5 " Pero, se puede asegurar que no entienden siquiela los nombres de "encapada" y "gabarro", que son muy comuxes entre los vocablos de nuestra minería.

De la impericia de éstos, que deben ser los maestros del Cerro, tomó oxigen también la espantosa ignorancia de los mineros o mayorơomos. Será muy raro el que entendiere el modo de levantar, fortificar o reparar un puente, y lo mismo de otros aderezos; porque cualquiera toma este oficio, sin más principios que la fama de horrados, y entran a ejercerlo sin examen ni aprobación, por no haber quien sea capaz de darle, y a no ser una clase infeliz de indios, llamados "pongos", que son los únicos que entienden de labores, es muy verosímil que se hubieran arruinado ya las más o casi todas.

No es menos perjudicial que ignoren lo que cada día están practicando con no poco provecho suyo. Ellos, como coadjutores del Juez de minería, deben hacer todas las medidas, así de las vetas como de las minas, 
cuando se dividen o cuando se piden por demasías. En efecto, las ejecutan; pero como no tienen conocimiento de los rumbos y agujón para saber los que corren las vetas, regularmente se valen para estas importantes diligencias, de algún otro, que aunque sea más inteligente, tal vez carece de la honradez y buena conciencia que tanto se requiere para obrar sin fraude y sin injusticia.

Si ellos supieran todo lo que deben saber, deberían precisamente entender algo de Geometría, para medir las minas con acierto; pues, si conforme a Ordenanza ${ }^{56}$ se han de haccr las mensuras sobre el haz de la tierra, reducidas las varas a llano por nivel y cartabón, proporcionando el exceso y faltas que pueden tener en la hondura, conforme a la caída del cerro, es necesario que quién lo haya do ejecutar sea hábil y suficiente en el arte de Geometría, como dice una Ordenanza del Sr. Toledo; ${ }^{57}$ de donde concluye el Licenciado Don Fernando de Montesinos, ${ }^{58}$ que el Veedor debe ser Geómctra, según el espíritu de nuestras Ordenanzas.

En ol caso que fueran nucstros Veedores de todas estas calidades, es claro que no sería menester el nuevo empleo de facultativo de minas, mandado crear en la Ordenanza de México; y es de creer que la deI Sr. Toledo trwo este grande fundamento para no haberlo establecido.

Pero, una vez que es indispensable que lo haya en el día, segủn el estado actual del país, no se haría injusticia en remover alguno de los Veedores que se encontrase del todo insuficiente, para colocar, con el mismo sueldo, al Perito facultativo de minas, reuniendo ambos empleos en una sola persona, por ser unas mismas las obligaciones, con cortísimas diferencias; 0 a lo menos se debería tomar esta providencia luego que vacare alguna de las dos Veedurías del Ccrro, señalándole al facultativo geómetra, un sueldo moderado, interinamente.

Con esto se excusaba la multiplicación de oficiales y se venía a conseguir, no solamente tener un Veedor perito, por el mismo sueldo que ganaban los ignolantes, sino también instruír a su compañero en las cosas esenciales del arte; de strerte que, a poco tiempo, lograríamos en lugar de un facaultativo, dos, en los Veedores que tenemos por constitución fundamental del Cerro.

Párrafo tercero. - Juez de Los Excmos. señores Virreyes nombraRescates. ban en esta Villa un Juez de Rescates, para evitar los robos y sustracciones de las minas del Cerro. Tste empleo no subsiste en el día, ni hallo por conveniente restablecerlo, por lo mismo de ser ahora más frecuentes que nunca los hurtos de metales.

El Sr. Toledo ": permitió a los indios que pudieran restablecerlos. La Villa se quejó ante el Excmo. Sr. Don García Hurtado de Mendoza, por los años de 1590 , solicitando que se les impidiese el rescate de plata en las rancherías, fuera de la calle del Gato y Plaza, porque con el color de lo que les era propio, hurtaron en el Cerro el metal más rico.

En efecto, el Excmo. Sr. Marqués de Cañete, mandó expedir varias Ordenanzas ${ }^{60}$ en 13 de noviembre de 1593; y el Excmo. Sr. Don Luis de Velasco, mandó guardar después por otras suyas, ${ }^{61}$ prohibiendo rigurosamente, con pena corporal y pecuniaria, que ningún minero pueda tratar en metales, ni los dueños de minas vendérselos ni dárselos gracio- 
samente, ni tampoco trabajarlos del Cerro a ninguna persona, aunque sea dueño de minas, desde el sábado después de medio día liasta el lunes a las mismas horas; como el que no puedan tener labor suya, ni pallacos, ni ellos ni otros españoles, ni indios, metales algunos en las rancherías, con el fin de evitar por medio de estas precauciones, los robos $y$ daños frecuentes que se experimentaban en el Cerro.

Y llegó a avanzarse a tal punto la previsión del Gobicrno, que también prohibió ${ }^{62}$ a los propios dueños de minas, of vender metales dentro de ellas, sin expresa licencia del Corregidor, haciendo antes constar que cl vendedor es verdadero dueño de la reta y que actualmente se ocupa de labrar sus metales, y con cargo de poner minero para la salca de ellos. Porque sólo así se podría contener la licencia criminal de muchos que, sin tener minas, con pretexto de haber comprado metales para sacar de ellas, robaban no solamente a los vendedores, sino también a los circunvecinos, con tanto desorden, que para atender a la mayor saca, deribaban los puentes y reparos puestos a stl seguridad, en gravísimo daño de 'os indios y con la resulta de otros abusos muy perjudiciales. 6 ::

Este rigor dio motivo a los Jueces de Rescates, para que ejecutaran muchas extorsiones, contra ol espiritu de las Ordenanzas. Entonces resolvió el Excmo. Sr. Conde de la Monclova, a fines del siglo anterior, que una vez puestos fueva de las anchas los metales que se tral'ican en el Cerro de Potosí, no se inquiete al que los comerciare, averiguando do dónde son o de dónde los sacó, respecto de ser contraíctas las prohibicionnes al comercio de metales dentro de las minas.

Como se consiguió esta induigencia en tiempos que el Cerro ya había tocado la época infeliz de su actual pobreza, y cuando por la misma causa comenzaron los azogueros a entablar el beneficio de los pallacos, huyendo de las labores de barreta, que no podian costear por su corta ley, hallaron la puerta abierta los vagabundos de la Villa para colorir sus hurtos y agregándoseles después los indios mitarios, necesitados de buscar cómo satisfacer los rezagos del tiempo que habian cnterado ya en plata, en lugar del trabajo, se fundó a poca diligencia, la criminosa cofradía de ladrones, nombrados "ckacchas", aumentándose de día en día a tallto número, que ya fue preciso tolerar los robos que hacian a vista de ojos, porque no habia fuerzas bastantes para castigarlos. De suerte, que anoticiado el Rey de semejantes desórdenes y de la imposibilidad de su remedio, no dio otra providencia sino por buenos medios se prockrase separar a los cabczas de estas cuadrillas de facinerosos.

En este estado, no solamente cesó la prohibición de rescatar metales, sino también que se les admitió públicamente al rescate de platas en el Banco de San Carlos. Por el mismo hecho se inutilizó la jurisdicción del Juez destinado para la averiguación de los robos, y fue menester extinguir este oficio. Ahora se halla nuestro Cerro en la misma situacion; con lo que debe reputarse tan inoficioso como antes el Juez de Rescates; y solamente pudiera considerarse conveniente en los nuevos asientos, siempre que se mantenga inexorable el celo para reprimir en su cuna cualquicra desorden que quiera introducir la malicia.

Párrafo cuarto. - Asesor. A $\quad$ UNQUE según el antiguo sistema de mineria, concurría en calidad de asesor del Go- 
bernador. Superintendente de Potosí, su Teniente letrado, para resolver en primera instancia todas las causas de esta línea; luego que se verifique la meva plantación, ya no podría ejercer estas funciones el Tenicnte, porque debiendo ser Juez de las primeras instancias de los pleitos que conociesen sobre minas del territorio de la capital, es menester que intervenga otro asesor imparcial en el grado de apelación, en la forma que se explica en su propio lugar.

Pei'o atendiendo a la suficiencia e idoneidad que haya de adquirir sobre minas on el manejo de su Juzgado, hallo, a más de conveniente, preciso que sirva de asesor en los pleitos que vinieren por apelación de los reales de minas do afuera, ocupándose en este despacho, sin derechos en el caso de schalársele salarios, o con ellos con arreglo a Arancel, si no los turiere.

Párrafo quinto. - Director.- TA clección de este Ministerio se debe haElecciones. cor en Junta general de mineros, al principio del año, por pluralidad de votos, congregándose un tribunal de li Superintendencia, d día que fueren convocados por pregón o citación personal, todos los que se hallaren presentes en la Villa. Yos ausentes on los mimerales de afuera en lugar de Ios diputados, que segun la Ordenaniza de México "deben elegir y enviar con poder suficiente para votar en la Junta y elecciones generales, deben entregar su voto firmado al Juez respectivo de cada asiento, en una cédula secreta, cerrada, scllada y rubricada en el sobrescrito por el Juez y el elector, para que remitiéndola al Superintendente y Junta de Dirección, se archive hasta el día de las elecciones en que hayau de abrirse y reconocerse con las demás que expresa el Art. $9^{\circ}$ del título $1^{\circ}$ de la Ordenanza de México.

El Supcrintendente es quién debe presidir estas Juntas, haciendo oficio de conciliarios el Director y los tres diputados generales, por cuya vía tambión se le deben hacer las propuestas de los empleos menores expresados en los Arts. 14, 25, 26 y 27, título 1" de la citada Ordenanza.

El Director debe ser natural de los reinos de Castilla e Indias, minero y vecino, ${ }^{65}$ que tenga casa de por sí en esta Villa ${ }^{66}$ o su jurisdicción, $y$ sea casado o viudo, mayor de 25 años, ${ }^{67}$ honrado, de buena opinión, vida y fama, 6 abonado y rico, ${ }^{69}$ que no haya ejercido ningún oficio mecánico, ni otros tratos humildes y bajos, ${ }^{70}$ para que su representación sea más rospetable, su voz más independiente y su persona del todo libue de motivos para recusaciones u otro género de notas y embarazos.

Al mismo tiempo debe ser hábil, suliciente y experimentado en materia de minas, pues, sicndo necesaria esta calidad en el Alcalde Mayor, Veedores $y$ demás Oficiales de la minería, con mayor razón debe concurrir en el Director, para que entienda la necesidad y utilidad de las obras que por su mano se representaren como precisas para el reparo y habilitación de las minas y para otras operaciones de importancia.

Madame de Beausoleil, ${ }^{71}$ persuade cuan indispensable es en el Director de Minas, el conjunto de muchas ciencias. La Astrología, para conocer los temperamentos, Arquitectura, Geometría, Aritmética, Perspectiva, Pintura, Hidráulica y otras, que largamente expresa.

Lo mismo el sabio Agrícola, ${ }^{2}$ hablando de la ciencia metálica: 
dice que debía abrazar la Física, para discernir la naturaleza de los metales y juzgar de su formación; la Medicina, para preservar de enfermedades a los que trabajan en las minas y curar a los que en ellas enferman; la Astronomía, para calcular por la calidad del clima el porte y largor de las venas o vetas metálicas; la Geometría, para modir la profundidad hasta donde se debe ahondar en las entrañas de la tierra; la Arquitectura, para construír las máquinas, bóvedas y tablados; la Pintura, para dibujar los planos de los lugares y los trabajos que se cmprenden; la Jurisprudencia, para no hacer contestación mala a propósito $\mathrm{y}$ sostener sus derechos.

Bien veo que no es posible encontrar en todo el Reino persona que posea tantas cualidades juntas; pero entretanto se forman hombres de tanta talla, con la aplicación y con la explicación en el Seminario de Metalurgia y Mineralogía que se fundare en esta Villa, en la forma que se previene en el título 18 de la Ordenanza de Múxico, es necesario ocupaz a algún sujeto de los más experimentados en negocios de minas, que al mismo tiempo sea honrado en su nacimiento, profesión y costumbres, sobre ser hábil y expedito en el manejo de asuntos graves; porque si se va a buscar solamente algún mincro acomodado o que tenga la reputación de práctico, desnudo de las demás cualidades, se lograría, desde luego, un hombre bueno y útil sólo para sí, que no es lo que sc intenta sino el beneficio común. Nunca obrará por su mano propia y valiéndose para todo de otros que sean parciales interesados, insuficientes o de mala intención, en vez de dirigir al acierto, conducirá a la confusión las operaciones más importantes.

Pero este Director no ha de componer por sí sólo la Dirección General de Ia Minería, aunque sea el Ministro principal de ella. Deben concurrir juntos con él, los tres Diputados generales y proceder todos de acuerdo para representar lo más conveniente al feliz progreso de la minería; y siempre que llegaren a discordar todos entre sí sirf tomar resolución en la Junta, entonces deberá cada uno exponer separadamente su parecer al Superintendente, para que provea lo que entendiere por más justo y útil.

Debe ser el único conducto por donde soliciten los mineros del Distrito los avíos y socorros que necesitaren, y por la misma mano se deben representar a la Superintendencia el grado y materia de las necesidades, en oficios firmados por sólo el-Dircetor, después que haya rubricalo todos los acuerdos de la Junta de que dimanaren; exceptuándose las consultas, representaciones y propuestas que se hagan de oficio, sobre empleos o sobre otros puntos de Ordenanza; porque atendida su gravedad, conviene firmarlas el Director y Diputados que intervinieron en el acuerdo. Y este mismo método debe seguirse en la correspondencia con los mineros, factores del Banco, Oficiales reales y demás Ministros dependientes de la minería.

Habiendo de correr a su cargo el celar todo lo económico de la minería, para proponer lo que hallare conveniente a la mejor administración, manejo y fomento de las minas e ingenios, también debe ser su principal cuidado enterarse del número de todas las que se hallaren en el Distrito, en corriente, nuevas o desiertas, con las puntualidades expresadas en otro lugar, ${ }^{73}$ para promover el correspondiente repuesto de azogues y moneda (en las Cajas donde estuvieren las factorias) para facilitar las 
sacas de platas, los rescates y habilitaciones que se necesitaren, bien sea para el trabajo ordinario o para otras empresas de mayor importancia y costo.

$Y$ como hay muchas Cajas muy distantes de los asientos de minas de grande saca, tal vez convendría establecer factorías separadas, en distinto paraje de la Callana, para engrosar el rescate y aviar a menor costo a los mineros; con cuya consideración, debe proponer igualmente este punto la Dirección, como el de las conducciones a esta capital, bien sea de cuenta del misno Banco o por asiento celebrado con el situadista general, según lo advicrta más útil y asegurado.

Por último, corresponde a la Dirección, proponer en terna al Superintendente, los empleos de su nombramiento, para que elija al que mejor le pareciere $y$ despache sti título; celando después, que así estos como todos los dependientes de minería, cumplan con sus oficios y ministerios, sin fraudes ni desaplicación, para dar cuenta de los culpados, a fin de que los castigue el Superintendente.

\section{Párrafo sexto. - Diputados. TUUEGO que los azogueros de Potosí obser-} varon que continuaba la decadencia de este Cerro Rico, trataron de unirse en un cuerpo con título de cofradía, para poder nombrar Diputados que llevando la voz del comán, representasen sus derechos a los scĩores Virreyes y demás tribunales del Reino. Y en efecto, obtuvieron permiso para ello del Excmo. Sr. Marqués de Montesclaros, ${ }^{\top 4}$ en el año de 1611.

Se fundó la cofradía en San Francisco, donde celebraban sus juntas para tratar de labores $y$ elegir Procuradores o Diputados. La Vilia Ste quejó al Excmo. Sr. Príncipe de Esquilache, de que los azogueros echaban deruamas y hacían sus juntas sin asistencia de las Justicias, causando al público varios perjuicios que no se podían evitar ni eran de fácil remedio, porque los Jueces ignoraban sus tratados. Fntonces ordenó el mismo $\mathrm{Sr}^{2}$. Virrey, is que de ningún modo repartieran contribuciones, ni celebrasen juntas sir concurrencia del Corlegidor o de quién hiciera sus veces.

Esta providencia moderó los abusos, pero no extinguió la cofradía de azogueros, como establecida con superior permiso. Siguieron celebrando juntas, cligiende Diputados y ejecutando lo que entendían conveniente a beneficio dle su cuerpo; de suerte que es la primera compañía de mineros que se estableció en estos Reinos.

Los Corregidores, como Presidentes de las juntas, comenzaron a mandarlas celebrar en sus casas, oyendo a los Diputados solamente por modo informativo, como Visitadores del Cerro, para resolver con pluralidad de votos de los azogueros congregados en junta. La mejor disposición del Gobierno fue autorizando después, cada vez más, a los Corregidores; $y$ aunque reaimente ela decisiva la voz de las juntas, se excusaba este paso con determinar por si solos la mayor parte de los negocios, salvo uno $u$ otro, que inmediatamente tocaba al interés particular de los azogueros.

En este estado, se incorporó a la Corona el Banco que la Compañía de mineros de Potosí fundó para el rescate de sus platas, por donación que ellos hicieron, en testimonio de su generosa lealtad, promovida 
por el celo acreditado del Sr. Don Jorge Escovedo, su Gobernador y actual benemérito Ministro en el Supremo Consejo de Indias. *

Extinguidas ya todas sus acciones al fondo del Banco y, por otra parte, cada vez más menoscabado su interés, por la pobrcza del Cerro, con total independencia del Gobierno en el expediente de avios y habilitaciones, vinieron a reducirse las juntas a muy rara vez y a ser consultivas más bien que decisivas, conservando siempre aquella antigua forma de Diputados y demás solemnidades que acabo de referir.

Ahora que se trata de alentar el cuerpo de minería, casi difunto en el Perú, no ha parecido a propósito alterar el método fundamental en que hizo oír su voz, en el origen de sus primeras necesidades, porque la novedad le haria tal vez sospechoso su mismo alivio.

Por eso, en el nuevo sistema delineado al modelo de la minería de México, al mismo tiempo de establecer su proyecto en cuanto a Diputados, ${ }^{76}$ sc intenta mantener en este Reino la primitiva ley que impuso el mismo cuerpo de Azogueros, por compromiso universal acerca de la voz, autoridad y representación de sus Diputados, con sola la diferencia de aumentar un Director hábil y experto, que siendo igual en las facultades, vivifique, como cabeza, las acciones de este órgano del común.

En conformidad de lo cual, quedando reunido en el Superintendente, todo el poder decisivo en lo gubernativo, también quedan amparados los Diputados de Potosí, en las antiguas funciones de informar y pedir, de acuerdo con el Director, en la misma forma que se ha expuesto en el párrafo antecedente. $Y$ así debe entenderse con ellos igualmente el requisito de calidades que han de concurrir en el Director. iT

* (Figura singular y preclara la de don Jorge Escovedo y Alarcón, en la historia colonial de Potosí.

Docto jurista, experto en materias de administración pública, organizador incansable como pocos, hombre probo y magnánimo, cúpole sistematizar el régimen interno de la Casa de Moneda y de las Cajas Reales; hacer cumplir muchas de las leyes y ordenanzas en el trabajo de minas; articular magistralmente el reglamenlo del Banco de Rescates de San Carlos, como instituto del Fistado, y reorganizar las dependencias de la gobernación de la Villa Imperial.

Superintendente de Minas, Mita y Hacienda a mas de Revisor de los Virreinatos de Lima y Buenos Aires, en el primer tiempo; Gobernador de Potosí, luego; fue requerido después, por sus eminentes cualidades, para Ministro del Consejo de Indias en Madrid. En todos esos cargos demostró ser un auténtico realizador, fecundo y visionario.

Hasta hace poco tiempo, América y España olvidaron la existencia de este colonizador, en el mejor sentido del vocablo; $y$ nuestros historiadores locales ignoraron la obra de Escovedo y Alarcón, hecha en servicio de Potosi, que aquilatada con justeza hace honor a su época y a su destino. Llegará día en que se escriba la biografía del ilustre español-precursor de nuestros reformistas de legislación social-con los muchisimos documentos que se conservan en los Archivos de la Casa de Moneda en Potosí, Nacional en Sucre, de la Nación Argentina en Buenos Aires, de Lima, General de Indias en Sevilla, de Simancas y en Madrid. 
Ya ha actualizado la sagat obra de Escovedo el erudito investigador don Vicente Palacio Atard, en una monografia sintética sobre "La incorporación del Banco de Rescates de Potosi a la Corona" que publicó en su II volúmen el "Anuario de Estudios Americanos" de la Escuela de Estudios HispanonAmericanos, del Consejo Superior de Investigaciones Científicas, en Sevilla, el año 1945. Don Pedro Vicente Cañete y Domínguez, al reforive a Escovedo, a través de las páginas de este libro, lo hace -como te el lector- con justa y explicable ponderación.- Nota de A. Alba).

Párrafo séptimo. - consul- Como en todos los estadlos, bien sea de tores. prosperidad o de decadencia, envuelve la minería innumerables casos que requieren nuevas experiencias para el acierto de las providencias, y tal vez no se encuentra aquel conocimiento que se necesita, en tres o cuatro mineros, es conveniente la elección de doce azogueros prácticos, inteligentes y honrados, que sirvan en calidad de consultores o consejeros, para concertar aquellos asuntos más graves en quc el Superintendente no contemplare asegurada ia resolución con sólo cl informe del Director y Diputados, entrando también estos en las juntas para su mejor expediente.

Fn los consulados, a cuyo modclo se ha proyectado este nuevo sistema, vemos observar lo mismo is para ilustrar el celo de sus priores y cónsules; y no es razón negar este auxilio a los Superintendentes de Minería, ni a los azogueros el arbitrio de consultar los negocios de su propio interés, según el dictamen de las experiencias de su arte.

Fllo es, que no debe ser decisivo el parecer de esta junta; de aquí que el Superintendente no estará obligado a ejecutar lo que se acordare, aunque sea por la mayor parte, siempre que no lo confirmare él, por ha+ llar inconvenientes en su ejecución; así como tampoco se ejecuta lo acordado en las juntas de consejeros y Diputados del consulado, cuando no precede confirmación del Sr. Virrey o persona a cuyo cargo corre el Gobierno. ${ }^{79}$ Pero, como se supone en todos estos individuos un celo inteligente por su intcrés propio, será responsable el Superintendente, si por un arbitrio gratuito no quisiere aprobar' cl acuerdo de la junta y obrare por sólo su dictamen contra el parecer del mayor número de vocales, a cuyo fin debe quedar extendido por Escribano, en el libro de los Ayuntamientos, el voto consultivo de la junta, porque en tales casos resulta contra el Superintendente, vehemente presunción de dolo, que es justo que se castigue, según la Glosa de Gothof redo. ${ }^{80}$

Párafo octavo. - Adminis- DoBRE el pie de hallarse fundado en Potrador, Contador, Tesorero y tosí el Banco de Rescates y Avíos, a benefiOficiales del Banco. cio de los azogueros de esta Ribera, también hay Administrador, Contador $y$ Tesorero, con los Oficiales respectivos para su manejo, bajo de ordenanzas bien instruías que deslindan la autoridad y funciones de cada uno, con la circunstancia de ser de la Provisión dcl Rey, y no electivos, como se expresó hablando del Banco. ${ }^{81}$ Por lo mismo, sólo debe entenderse su conocimlento en la nueva planta a todos los mineros del Virreinato, estableciendo las 
formalidades necesarias en su correspondencia con los factores particulares, y otras cautelas que, después de facilitar los rescates y los avíos, aseguran su pago y conducción a esta Tesorería General. Sobre lo cual apuntamos diferentes reglas, en el lugar que se trató del Banco. Párrafa noveno. - Solici-
tador. pone la Ordenanza de México, que haya un Solicitador: Conforme al nuevo plan, también se iba a establecer en Potosí: y su oficio es agenciar todos los negocios de la minería, judicial o extra-iudicialmente, en cualquiera de los tribunales del Reino, según se le ordenare por la Dirección. ${ }^{82}$

Párrafo décimo. - Escribano. ESTE Oficial sỉve para autorizar las elecciones y Ayuntamientos, concurrir a las Audiencias, intervenir en los autos que se despachasen en todo to judicial y demás cosas necesarias a la buena administración de la mincría, uso, ejercicio y jurisdicción de los respectivos Jueces. Debe guardar los protocolos de las escrituras, instrumentos, acciones, registros y domás papeles de su mancjo, en archivo scparado que exista en la misma casa de la Dirección, asi para su entcra seguridad como para evitar confusiones.

Párrafo undécimo. - Portero EL portero es necesario para que asista $\mathrm{y}$ ejecutor.

a las Audiencias que hiciere el tribunal, y - Jlamar las personas que le mandaren; cuidando del aderezo y limpieza de la sala del Despacho, y de cerrar sus puextas, como también de ejecutar sus mandamientos, órdenes, prisiones, embargos y demás que pueda ocurrir y se le ordenare.

Párrafo duodécimo. - Facul- WL sabio Virrey Don Francisco de Toletativo de Minas. do, confesó en una de sus Ordenanzas, ${ }^{83}$ la necesidad de ocupar para las medidas de minas, personas hábiles y suficientes en el arte de Geometría; y alega por comprobante su propia experiencia. Don Francisco Xavier Gamboa, 84 pondera con mayores convencimientos, la indispensable precisión de medir las minas por facultativos de Geometría, haciendo demostriación de los daños irreparables que causa la ignovancia a los dueños de fundos metálicos; y arreglándose a sus conocimientos, refiere por menor las cosas principales que debe saber practicar un facultativo de minas para ser útil; encarece el delito de los que siendo ignorantes, se plantean en semejante ejercicio, y anuncia el modo de establecer en los Reales de Minas, personas prácticas para Peritos de cada mineral; si bien, que no es practicable su arbitrio en Potosí, por no haber catedrático de Matemáticas (como en México), a quien remitirlos a examen.

$\mathrm{Y}$ aunque se espera dentro de breve, hombres hábiles y sabios en las ciencias conducentes a esta profesión, en cumplimiento de la real pa- 


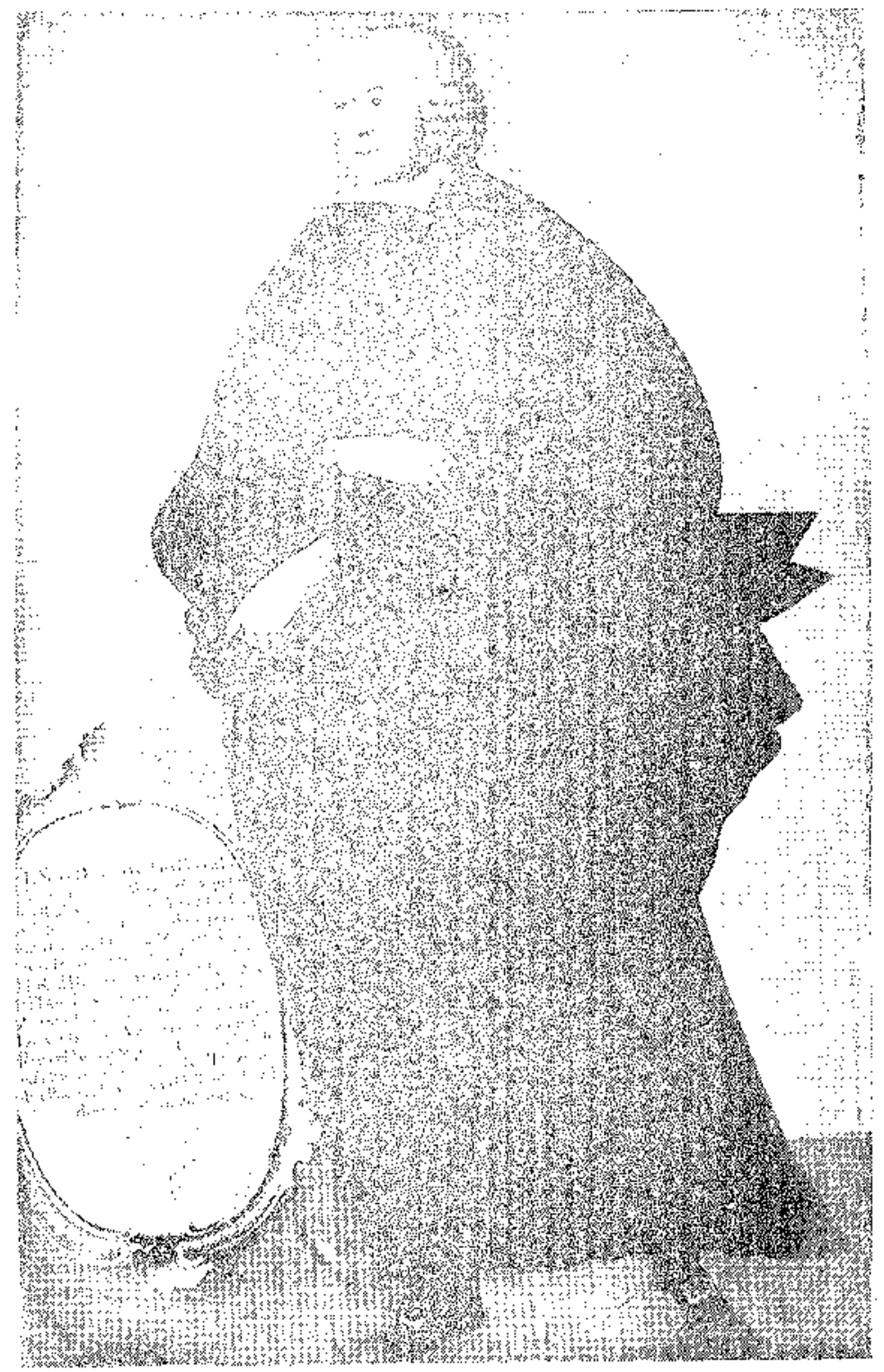

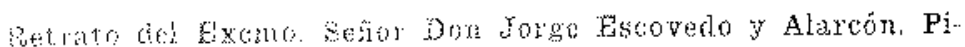

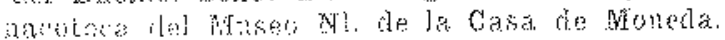

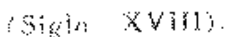


EN EL FSCUDETE DEL ANGULO IZQUIERDO INFERIOR, SE LEE:

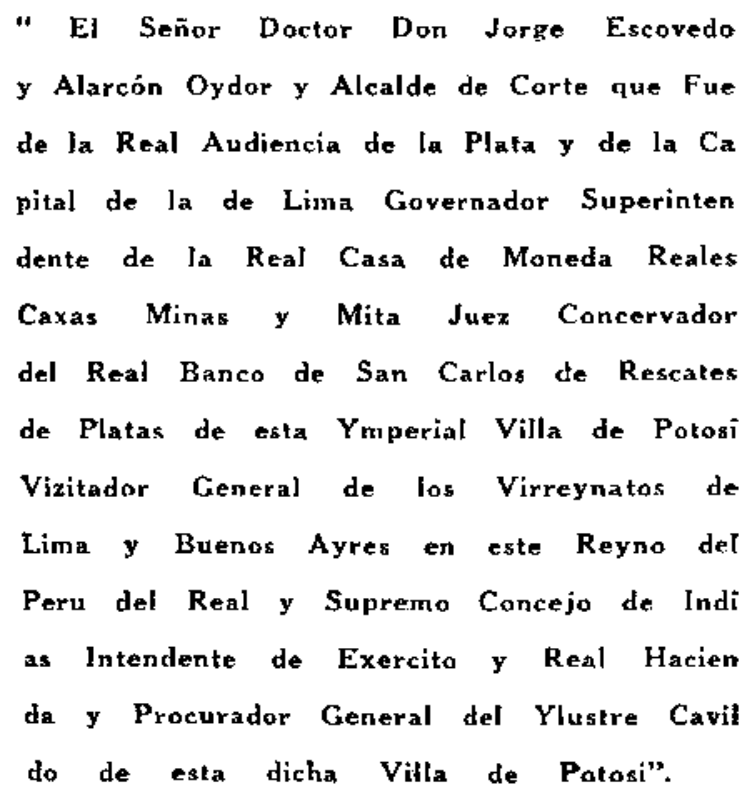


labra empeñada en la Declaración 11, de 5 de agosto 1783 ; pudiendo tal vez retardarse su envio por causas inevitables, $y$ atendiendo por otra parte el perjuicio que en el ínterin sc puede experimentar, debe considerarse ejecutiva la urgencia de buscar por acá un sujeto idóneo, a quien encargar la enseñanza de algunos jóvenes de aplicación y talento escogido, estableciéndose deste luego, el Seminario que dispone todo el título 18 de la Ordenanza de México.

En Chuquisaca es bien conocido Don Lorcnzo Lorensana, por uno de los sujetos más hábiles en matemáticas, desde el tiempo que sirvió en el cuerpo de marina; se halla retirado, sin dastino y pobre; por lo que es de creer que dotándolo cou un salario regular, haya de preferin' este empleo a todos cuantos se le propongan.

En este clima hay talentos muy sobresalientes y genios tan felices, que llegándose a perfeccionar con el tiempo, son capaces de producir los más ventajosos sucesos a beneficio del Estado; pero como no encuentran establecimientos en qué emplear su industria con progresos, ni descubren en todo este gran teatro recompensas proporcionadas a la aplicación, se abandonan a la ociosidad y ven con indiferencia las fortunas que ellos no pueden alcanzar.

Esta es la causa por qué en el Perú se dedican al estado eclesiástico los jóvenes de todas condiciones y clases: pues miran esta carrera como la única cn que se premian las tareas, ya sea con un Curato pingüe, ya en alguna Capellania, o en una prebenda de las Catedrales del Reino. Y como regularmente no se repara mucho en la condición de los pretendientes, se agolpan tantos a estudiar las ciencias por donde hacer fortunas, que casi no hay persona que busque ni aun aprecie otro destino.

Por esto será difícil encontrar jóvenes de talento, linaje y buenas costumbres, que se dediquen al nobilísimo estudio de las Matemáticas o siquiera de la Geometría, porque es preciso que consideren ellos mismos o sus padres y parientes, que nunca han de salir de facultativos de minas, que su vida ha de ser siempre penosa viviendo en la rigidez de las punas donde están situados todos los minerales; que su trato ha de estar reducido a los indios y otras gentes grosesas y viciosas, que son los únicos habitantes de los asientos de nuestras minas más famosas; $y$ por último, se harán cargo que ocupándose por primera vez las plazas de facultativos de los pocos asientos de mineral que tenemos formalizados, ya se han de quedar absolutamente privados de adquirir conveniencia para sustentarse, después de haber consumido años en el estudio de una Facultad en quién miran el bien como puramente futuro y muy lejano.

También se debe considcrar que en estos países casi no hay negocio que al cabo de algunos pasos no se envuelva en la intriga y en la supercheria, sin que se perdone medio, el más criminoso, para conseguir el intento. Esto lo saben todos y lo lloran muchos injustamente desgraciados por el poder de la maldad. Y cuando estas maquinaciones han arrebatado, en medio de los tribunales más respetables, la reputación a muchos personajes de autoridad y conducta, temerá con razón cualquier mozo de honra, emplearse en un destino subalterno, donde ha de estar expuesto a la crítica maliciosa de los interesados, a continuas recusaciones criminales, y tal vez a perderse, si se descuida, quedando para siempre reducido a la mendicidad. 
Todos estos reparos, que son muy obvios para quien tenga alguna experiencia de la sierra, sólo se pueden vencer poniendo una recompensa cierta, a la vista de estos nuevos Profesores. Las gentes de por acá son amantísimas de la distinción, aunque no le acompañe el lucro; y así, entiendo que para alentarlas, bastará condecorarlas con un grado de Alférez o Teniente de los Reales Cuerpos de Artillería o Ingenieros, a uno de los que en cada curso sobresaliese a todos los demás en su aprovechamiento, con opción declarada al mejor destino que vacase en los minerales del Reino.

Entonces sí, se empeñarán las familias más honradas a que sus hijos se dediquen a este estudio. ${ }^{2,5}$ La misma distinción y seguridad del premio, irá arreglando las proporciones de jerarquías entre la nobleza y sus empleos; cesará la confusión que en el día tiene debilitado el mérito, y llegándose por este medio a reunir en la clase de la nobleza el oficio de facultativos, desde luego, hará progresos esta ciencia y su manejo será el más puro, por el propio honor de los mismos empleados.

Pero, aun así, es menester que la Dirección de Mincría despierte incesantemente su celo contra el abuso, pues, hallándose el Seminario Conciliar y la Universidad de Chuquisaca en el centro de los Tribunales y a la vista del Preiado y Ministros reales, se experimenta tan grande relajación en los estudios, que hay hombre a quién se le confiere el Doctorado en Leyes, sin haber saludado el segundo Libro de Instituta, indultándose con certificaciones de amistad, así en cuanto a ésto comzo en lo perteneciente a la práctica. De suerte que, por este camino se ven salir innumerables Médicos y Curas tan perjudiciales por su ignoraneia, que sólo sirven para vituperar estas nobles profesiones y confundir los derechos en vez de ilustrarlos a bencficio de las partes, para quietud del Estado.

Con que siendo más fácil que se relaje la disciplina de un estudio que ha de tener menor emulación por sus pocos concurrentes, y menos celadores por el corto número de Profesores en la facultad, es menester mucha mayor vigilancia en los superiores, para contener los funestos efectos que ha de producir la ignorancia; pues, cmpleándose por facultativo un hombre mal aprovechado, serán tanto mayores, por irreparables y costosos, los desaciertos que cometieren en un socavón errado, lum. breras, tiros, contraminas y otras operaciones de esta clase; y lo peor es que tampoco podrán remediarse las muertes y desgracias de innumerables trabajadores en los derrumbamientos que se causaren en las minas, por no saber dirigir los pilares y demás reparos que se necesitan para su seguridad. ${ }^{86}$

Por último, motivarán una infinidad de enredos y discordias eternas entre los interesados, con el crror de las medidas. De manera que, un empleo destinado para beneficio de la minería y utilidad de los azogueros, será el medio para acabarse de arruinar.

Párrafo décimotercero. - Be- $\mathbf{N}$ UNCA como ahora se puede quejar el neficiadores.

Perú de la ignorancia de los beneficiadores de sus metales, porque realmente no son capaces de dar la razón de una sola operación de cuantas practican en tan importante beneficio. Ellos apenas saben leer; no entienden una regla de 
aritmètica para arreglar una cuenta trivial de la correspondencia de las leyes del metal, de un beneficio o ensaye por menor al por mayor; no conocen las afinidades de los cuerpos metálicos, ni tienen más que una práctica material, adquirida de haber visto beneficiar a otros ignorantes como ellos.

A] principio, parece que no fue así; pues, el Excmo. Sr. D. Francisco de Toledo, indica en una de sus Ordenanzas, 87 que habían beneficiadores muy hábiles y de particular industria para trabajos en el beneficio de los metales. Fuera de esta suficiencia común, también se vieron algunos Peritos excelentes, que hicieron descubrimientos admirables, con grande utilidad alel Estado.

Por los años de 1571, inventó en este Reino, el célebre Pedro Fernández de Velasco, el beneficio pol azogue por amalgame; con lo que se sacó infinita plata y fue el total remedio de nuestras minas, que ya eran casi inscrvibles por falta de los metales de fundición, como pondera el Sr. Solórzano, ${ }^{\text {s: }}$

Carlos Cor'so de Leca, descubrió después, por fines del año de 1586, el beneficio del hierro, con el cual dice D. Juan de Carvajal y Sande, ${ }^{89}$ que si antes sc perdion diez libras de azogue, se consiguió el no perder más que una.

Por último, le visto en una Provisión del Excmo. Sr. Marqués de Montesclaros, que Francisco Gómez hizo el descubrimiento del beneficio del cobre, $y$ demandó en juicio 50.000 pesos por recompensa de la invención.

A más de estos peritísimos beneficiadores, también logró Potosí facultativos muy hábiles en matemáticas, por cuya mano se hicieron muchas obras que hasta ahora permanecen. Una de ellas es la celebrada acequia de la Laguna de Chalviri o Tabaco-ñuño, fabricada por ingenieros de profesión; y cn la citada Provisión de 1611, se refiere que recibieron doce mil pesos, por último concierto de su trabajo, despaés de un largo y costoso pleito.

No es difícil averiguiar la causa de la escasez lastimosa de hombres peritos, que posteriormente lloró Potosí, en la ignorancia de sus beneficiadores. En el año de 1637, ya ponderó D. Alonso de Barba, ${ }^{91}$ los daños irreparables que sufría la causa pública, por el continuo desacierto en cl beneficio de metales. Pero esto provenia de que en ese tiempo se compadeció ya en un grado de miseria la pobreza de nuestro Cerro; con lo que salieron rápidamente a disfrutar de sus conveniencias en otro pais más delicioso, aquellos mineros que atrajo y lisonjeó su destemplado clima con el cebo de la plata.

Todavía no ha hecho su período (como debe esperarse), aquella primitiva prosperidad, ni debemos prometernos que en este intervalo se aliente la industria, faltándole el incentivo de la recompensa. Pero, nuestro sabio Gobierno ha suplido los impulsos de la codicia, con el establecimiento de un Seminario donde se enseñe la Mineralogía y Metalurgia, para dar progreso al beneficio de metales. Estableciéndose el buen uso de estas facultades, conforme a Ordenanza, ${ }^{22}$ es preciso que el Reino convalezca de su actual decadencia, con el aumento de ley que ahora se pierde por ignorancia. $Y$ en el ínterin, se puede echar mano de los beneficiadores mejor opinados, examinándolos el Sr. Superintendente, por medio de dos azogueros los más hábiles, en la forma que en otro lugar ${ }^{93}$ expu- 
se haberlo dispuesto el Excmo. Sr. Marqués de Castelfuerte, con la cautela de dividir toda la Ribera en dos, cuatro o más Cuarteles, para que cada beneficiador responda de las operaciones del suyo, como se previene en la Ordenanza del Perú, ${ }^{94}$ para con los Alcaldes Vecdores del Cerro.

\section{N O T I C I A Q U I N T A}

De los empleos electivos de
Minería y sus electores. za de México, 95 requiere tambiến un Administrador General. Pero no se ha reputado necesario en Potosí, por haberse scparado del Tribunal de Minería la jurisdicción económiea y contenciosa, quie ejerce en Nueva España; ${ }^{96}$ pues, habiéndose querido conservar allí la forma establecida en la ley de Castilla, ${ }^{97}$ (que antes hacia partc de su Ordenanza) sobre el Juez privativo de Minas, titulado Administrador General, se creó este mismo empleo en su nuevo sistema, con la diferencia de no ejercer él solo toda la jurisdicción, sino de acuerdo con el Director y Diputados juntos. Y como aquí es puramente informativa la voz de estos empleados, se ha excluído con fundamento muy legal, el oficio de Administrador, porque si Jo hubiera, no correspondería a su nombre la autoridad.

En Lima 98 se minoró a sólo dos Diputados, el número de los tres establecido en Móxico, en atención a los cortos fondos de aquella minería. Esta misma razón pudiera valer aquí, si se hubiese de asalariar a los Diputados de Minexía; pero el plan es que sirvan sin dotación alguna, como los Alcaldes ordinarios, por carga pública de su profesión, pues, aunque ésto sería intolerable habiendo de servir cada Diputado por nueve años, ${ }^{99}$ se ha evitado este motivo de queja, limitando el tiempo del empleo a sólo dos años, al modelo de lo dispuesto para los Alcaldes ordinarios en el Art. $8^{\circ}$ de la Ordenanza de Intendentes.

$\mathrm{Ni}$ por acá conviene mantener a los vecinos por tiempo tan largo en oficios de autoridad, porque de la lisonja del mando proceden de ordinario las parcialidades, bandos, facciones y discordias, que son las que siempre han alterado la armonía y quietud pública de estos países. Con esta consideración se hizo bienal el oficio de Alcaldes ordinarios, con todo de necesitarse en ellos mucha instrucción para el manejo de los propios, y suponiendo aplicación en los empleados, se reputó suficiente aquel tiempo, para que el más antiguo instruya al que entrare de nuevo. Todo lo cual milita igualmente con los demás empleados electivos de Minería.

De la misma clase son los doce Consultores que se establece ${ }^{100}$ por consejeros para los casos arduos, y debe durar su oficio el mismo tiempo que el de los Diputados; con la circunstancia de no ser necesario que todos ellos sean mineros, porque la Ordenanza habilita 101 también a los aviadores de minas, expertos, distinguidos y de la mejor reputación.

Los otros empleos, como el de Factor del Banco, 102 el de Asesor, ${ }^{103}$ el Escribano, ${ }^{104}$ el Solicitador, 105 el Portero ejecutor, 106 el Facultativo de minas y los Peritos Beneficiadores, 107 que en México nombra el Tribunal a propuesta del Director solo, por elección del mayor número de votos, con facultad de removerlo de la misma forma y sin necesidad de expresar la causa, ${ }^{108}$ se deben elegir en Potosí por el Superin- 
tendente, a propuesta en terna de la Dirección, de acuerdo con los demás vocales de la Junta. Pero en cuanto al Escribano, se debe exceptuar de esta regla, por oficio vendible y renunciable, que se ejerce en propiedad por los compradores, con arreglo a la Ordenanza $6^{*}$, título 9 , libro $3^{\circ}$ de las Gencrales del Perú; así como, aunque el Art. $9^{\circ}$ de la Ordenanza de Intendentes les da facultad para elegir Escribanos de su satisfacción, con calidad de amovibles, exceptúa el caso en que hubiere Escribanos propietarios de Real Hacienda.

En esta misma conformidad debe nombrar ol Superintendente, de cuatro mineros que le proponga la Dirección, dos que tengan su residencia más inmediata al Subdelegado o Juez del territorio, para que sirvan de Conjueces en la primera instancia, quedando los dos restantes en calidad de substitutos, para alternar en los casos de enfermedad, muerte, recusación o de otro legítimo impedimonto. X para Conjueces de alzadas con ins respectivos Intendentes de las Provincias del Departamento, se labrán de elegir otros tantos mineros por esta Superintendencia, en la forma precedente, si no se quiere encomendar esta facultad, atendiendo a la confianza y crédito de sus empleos y al mejor conocimiento de los mineros más honrados y hábiles de su distrito.

Párrafo único. - Electores. LA Ordenanza del perú dispone acerca de los clectores, porque ninguno de los empleos de minas se confería de otro modo que no fuese por nombramiento de Su Majestad o de los Señoros Virreyes. Abora que se ha planteado en este Reino la minería, según el sistema de Nueva España, es preciso observar sus reglas, con las diferencias convenientes a la diversidad de ambos Imperios.

El Art. 2 del título 2", habilita para clectores a todos los que hubieran trabajado más de un año, una o muchas minas, como dueños de ellas. Los artículos 3, 4 y 6 del mismo título, admiten también a los aviadores siendo mincros, maquileros (que aquí liaman trapicheros), dueños de ingenios y a sus administradores con poder bastante. Pero para que los lugares de minas tengan voto por medio de sus diputados, requiere otro Art. de Ia citada Ordenanza, "11" que se hallen en población formada, Iglesia con Cura o teniente de Cura, Juc\% Real y Diputados de Minería, seis minas en corriente y cuatro haciendas de beneficio.

La pobreza de cstos minerales y mala situación de ellos, no permite en los más las formalidades de población, haciendas y residencias de Jueces que acabamos de oír; y por esto, con ser un mineral tan rico este Reino, Guantajaia, que su ordinario es medio millón de pesos al año, se halla desicrto $y$ es casi inhabitable porque earece de todas las comodidades humanas, principalmente de leña y agua, que para beberla es preciso conducir de Tarapacá, distante 18 leguas, y aun también este asiento tiene tan poca agua y tan mala, que apenas alcanza para llenar las cochas de los buitrones para los días de lavas; causa por la que hay poquísimos pobladores y no se conocen ingenios algunos para moler metales que allí tienen de Guantajaia; si no es una casta de máquinas groseras, llamadas quimbaletes, que se componen de una piedra grande esférica, con un palenque metido o amarrado en la parte superior, para moler sobre una solera, también de piedra, contra el metal que le arrojan. 
De esta constitución del reino procede que en cada mineral se encuentra cuando más solamente tres o cuatro intereses formales; y aunque hay muchos mineros, son de los que por acá llaman pucheros, los cuales no tienen labor ni registros, ni otras mil cosas que pide la Ordenanza. De suerte que, al cabo de la semana, sacan cuatro o cinco marcos de plata, de los pocos metales que benefician de aquí o de allí ; pero como son tantos los de este ejéreito, componen con este ramo la gruesa más considerable de cada asiento.

Sobre todos estos conocimientos se ha planteado la minería de este Virreinato, en un pie más acomodado al estado del país. Para quitar dudas y excusar motivos de discordias, pasiones y parcialidades, que son tan frecuentes en las chacras, en teniendo algún viso de autoridad con que hacer fuerte al que manda; cstán admitidos por mineros aptos para entrar a votación, todos los que tengan trabajo corriente en minas de oro o plata, bajo de formal registro, constando este requisito en documentos auténticos que deben acompañar a los libros de Matrícula que anualmente remitieren los Jueces de cada Partido, antes de clecciones.

Si bien convendría que no fuesen electores los que, en más de un año atrás, no hubieren traído trabajo corriente, porque es de temer que muchos registren minas inservibles, con tal de hacer este papel sin ánimo de trabajarlas, y otros por hacer negocio con el voto; cuyos inconvenientes se remediarán en la mayor parte, con la cautela de la Ordenanza de México. ${ }^{111}$

Asimismo tienen voto activo y pasivo los arrenderos de ingenios y minas, con exclusión de los propietarios que no las trabajan en su cabeza; porque, según la expresión de la Ordenanza, ${ }^{112}$ el intento es favorecer únicamente a los que trabajan y gastan sus haciendas en descubrir minerales, y a los que se aplican a labrarlas. De suerte que observando esta regla, no se deben reputar por mineros los que tienen puestas sus minas o ingenios en arrendamientos (como sucede en Potosí), pues, los arrendadores y no ellos, son los que emplean su caudal, su industria y su personal diligencia a beneficio del Estado.

También quedan excluídos los naquileros, que aquí se llaman trapicheros, por ser estos unos hombres por lo regular desconocidos, que viven de fomentar el robo de los ckacchas, alquilándoles sus ingenios y el azogue, sin producir ellos por su parte ninguna utilidad para el Rey y para la causa pública.

Pero si alguno de estos trabajare mina propia o arrendada, bajo las formalidades de la Ordenanza, no tendrá impedimento para ser elector ni para ser elegido, concurriendo en su persona las calidades ${ }^{113}$ de buen americano español, limpio de toda mala raza, hijo y nieto de cristianos viejos y el haberse ejercitado en la minería por más tiempo de diez años. 114

Hemos visto la situación lastimosa de los asientos de nuestras minas y las indulgencias con que se va a ejecutar la nueva planta de minería, por considerarse que no se puede más. Desde luego, es muy justo que no se dicten providencias impracticables o dañosas, porque toda ley debe ser acomodada a las costumbres del país.

No obstante, cuando los usos del pueblo son demasiado informes, entonces no deben acomodarse a ellos las leyes, sino más bien procurar infundirles una nueva forma, aunque sea contraria, como se practica con 
tha nación bélibara a la que se va a imponer la ley. Es verdad que nuestros mireerales están despoblacios $y$, al mismo tiempo, entre sus pocos habitantes reina la emulación y la tajina, que han sido siempre los embarazos para su formación con arreglo a nuestras leyes.

Tampoco hay duda que on este estado no es posible ni conviene crear Diputados territoriales, y monos el que hagan Juntas para elecciones, sin el freno de la presoncia respetable de un Magistrado de grande autoridar. Pero sabemos también que estas gentes tienen su flaco en hacer figura, y que pai'a lograllo suelen a veces rencer las cosas más arduas.

Sobre este fundamento, permitase, en hora buena, a los mineros de afuera, que baste el serlo solamente para tener voto en uno o dos años; porque cn el dia no se puede más, y para que tomen el gusto a la golosina deI mando, sin que nada les cueste. Después ya entrarán por otro camino más áspero, para mantener aquella primera figura y entonces se introduce la ley por esta misma senda.

Con quedar privados de voto activo y pasivo todos los mineros que, dentro de dos años siguientes no tuvieren casa poblada en el respectivo asicnto de su conarca, me atrevo a decir que selá muy yaro el que no abrace este particlo, con la obligación de costear a prorrata Iglesia y sacerdote que rliga misa y enseñe la doctrina, conforme a la ley real. "15 'Todo lo cual verificado, ya sorá adaptable la Ordenanza de Móxico, en cuanto a Diputados territoriales y demás que abiaza el título $2 "$, en que si se procede con alguna sagacidar en las providencias, será medio para cumplirlas y poblar los minerales, el mismo desórden que ahora las embaraza.

EI Sr. Virrey Marqués de Castelfuerte, 116 dispuso mucho antes, que los Jueces de Minas mandasen levantar Iglesia, a costa de los interesados en los cerros y labores corrientes. La providencia se publicó, y quedaron las cosas como las estamos viendo. Para curar este mal, el remedio es tocarle al minero en la fajina (que es lo que más le duele), quitándole el voto, si no cumple la ley.

\section{NOT I C I A S E X T A}

De los Mineros y sus calidades, obligaciones y privilegios. Párrafo primero. - Mineros y sus calidades.
$\mathbf{E}$ Perú, se llanan comumente Mineros, todos: los que buscan su fortuna en el trabajo de las minas y beneficio de metales. Sólo en Potosí dejan los dueños principales aquel nombre a sus Mayordomos y criados, tomando ellos por si, el de Azogueros, según dice el Excmo. Sr. Marqués de Montesclaros, en una relación que cita Escalona. 117 Por lo mismo, hablaré siempre con esta diferencia, para no confundir las obligaciones y derechos de los Mayordomos con los amos.

Entendiendo, pues, el nombre de Mineros en el sentido común, pueden serlo todas las personas de cualquier estado, condiciôn, preeminencia o dignidad, españoles o indios, vasallos del Rey; dar catas libremente, buscar minas, y sacar todo género de metales, por sus personas, criados o esclavos, de las minas que hallaren en lugares públicos o privados, sin que los dueños de las heredades, ni otras personas que sean univer- 
sidades o consejos, lo puedan impedir, pena de mil pesos, pagando el daño a justa tasación de la heredad o con el tributo de $1 \%$ de cuanto sacaren de la mina. ${ }^{118} \mathrm{Y}$ se extiende a tanto el privilegio en esta línea, que a quien quisiere descubrir y dar catas para buscar metales en tierras de indios bravos, se le permite llevar las armas necesarias para su defensa, no excediendo el número de seis personas; ${ }^{11 y}$ provecrle (siendo pobre) de seis indios de los repartimientos más cercanos dentro de veinte leguas, cuando hicieren el descubrimiento en lugares pacificados. ${ }^{12 " 1}$

Como según esta regla, es del género de los permitidos el oficio de mineros, deben excluírse sólo aquellos que expresamente se hallan prohibidos por Ordenanza. Estos son todos los Ministros, Gobernadores, Corregidores, Alcaldes Mayores y sus Tonientes letrados, Alcaldes Veedores, el Escribano de Minas 1:1 y sus oficiales con los Escribanos Públicos y los del Cabildo de esta Villa; los euales no las pueden pedir ni tomar por estacas, despoblados, demasías, donación, ni por otro título. ${ }^{122}$

Sin embargo de esta prohibición tan absoluta, hace la Ordenanza de México la excepción ${ }^{123}$ de que pueden tenerlas en distinto territorio del de su jurisdicción. El Excmo. Si'. Marqués de Castelfuerte, 124 usando de la facultad que siempre ejercieron los demás señores Virxeyes, para declarar los puntos de Ordenanza en materia de minas, mandó cumplir la ley que prohibe a los Jueces el trabajar minas o tener iutereses en ellas, agravando la pena de perdimiento a favor de S. M., siempre que constare después de cumplidos los of icios, haber quedado con minas adquiridas en tiempo de ellos por cualquier forma, si no parcciere legítimo dueño a quien restituirlas, para evitar las confianzas criminosas y disimulos fraudulentos de que se valían para paliar durante el Gobierno el agravio y tiranía con que usurpaban el dominio ajeno con el poder y respeto del empleo.

Pero al mismo tiempo declaró, que esto no debía entenderse con aquellas minas que, por sí propio, con su industria y caudal hubiesen deseubicrto; porque siendo de esta clase, las podían haber y trabajar por sí, libremente, en cesando sus oficios. No hay duda que esta declaración sirve para fomentar y promover las labores de las minas; pues, sin ella, algunos Jueces hábiles y expertos, dejarían de hacer muchos descubrimientos poderosos, en perjuicio del Estado, por el temor de incurrir en las penas de la Ordenanza; pero fue la misma consideración que obligó a declarar expresamente la aptitud de los indios para trabajar minas, con el fin de excitarlos a su descubrimiento y de que no ocultasen los veucros de plata y oro de que tuvieren conocimiento.

Por una consecuencia forzosa, también vienen a quedar excluídos los extranjeros, por lo mismo que las leyes generales del Reino ${ }^{125}$ prohiben su entrada y permanencia en estos doninios y el que cojan y saquen de ellos oro 0 plata. ${ }^{126} \mathrm{Ni}$ se opone a estas Jeyes la Ordenanza $6^{\mathrm{a}}$, título 1, libro $3^{\prime}$ de las Generales del Perú, concediéndoles el derecho y privilegio de descubridores, con facultad de pedir estacas y demasías, sin distinción de los demás, porque esto se debe entender respecto de los extranjeros naturalizados 127 o tolerados con expresa real licencia, como opinó Gamboa ${ }^{128}$ y lo ha declarado últimamente la Ordenanza de México. 129

Tampoco pueden tener minas ni ingenios Ios clérigos, religiosos, Conventos y Hospitales, ${ }^{130}$ así por la indecencia, escándalo y mal ejem- 
plo que resultaría del laboreo de ellas, ${ }^{131}$ como también y principalmente por los inconvenientes y daños que se scguirían contra los indios, en Ias muertes, agravios y malos tratamientos y peores pagas que reciben de los Eclesiásticos, a causa de no poderse proceder contra estos como exentos de la jurisdicción real. ${ }^{132}$

Una Real Cédula moderna ${ }^{13: 3}$ mandó guardar estas mismas Ordenanzas y leyes, scñalando igualmente el término de scis meses ${ }^{134}$ para vender las minas que recayesen en tales per'sonas, por descubrimientos, donaciones, herencias, mandas, limosnas o cláusulas de testamentos; con la diferencia que los Hospitales, Iglesias, Monasterios y Cofradías, pueden aceptar y recibirlas, con tal de que con personas de abono afiancen pagar los daños, agravios y malos tratamientos que los indios recibieren de los Mayordonos. ${ }^{135}$ Pero, en cuanto a ventas, trueques o cambios, estín prohibidos indjstintamente para las comunidades y para los demás Eclesiásticos, bajo la pena de perdimiento de la mina e ingenio con más 500 pesos de oro.

Debiendo quedar on su vigencia esta Ordenanza, no es segura ni practicable la doctrina de Solórzano, ${ }^{13 i}$ acerca de poder los clérigos arrendar las minas e ingenios que hubicran heredado; porque la disposición del Sr. Tuledo, ${ }^{137}$ precisa a venderlas sin dejar arbitrio para retener su dominio; y la de México habla con tanta estrechez, ${ }^{138}$ que a más de mandarlas vender, declara a los Eclesiásticos precisamente obligados a poner en manos ile vasallos legos las minas o haciendas de molex metales; que fue proveer que no quede en venta solamente, sino que se transfiera el dominio en efecto, pasando o poniendo las fincas en manos de legos.

También están prohibidos de tener minas, en mil varas al contorno de las de sus anoos, los Administradores, Mayordomos (que en Potosí se llaman mineros), ${ }^{139}$ Veladores, Rayadores, Guarda-minas, ni otro sirviente alguno u operario de los dueños de minas, sean ordinarios o sobresalientes; pero pueden denunciarlas para sus mismos amos, aunque no tengan su poder, con tal que estos ratifiquen el denuncio dentro de sesenta días. ${ }^{140}$

Asimismo, el que no fuerc asalariado, no puede pedir mina para otro, si no tuviere su poder o carta orden, ${ }^{141}$ ni para sí solo, habiendo tratado compañía antes del denuncio, y sin nombrar sus compañeros, pena de perder su parte. ${ }^{142} \mathrm{Y}$ aunque la Ordenanza de México nada dice de ratificación acerca del registro que se hace en virtud de poder o carta orden, debe guardarse por declaración de este caso omitido la Ordenanza del Perú, ${ }^{143}$ que la requiere, con la única diferencia que los cuarenta días asignados en ésta para cjecutarlo, se prorrogaron a los sesenta de aquella.

Párrafo segundo. - Obliga- \os Mineros, entendidos por Azogueros ciones de los Mineros. o dueños de minas, están obligados por Ordenanza, a los deberes siguientes:

$1^{\circ}-$ No pueden recibir Mayordomo ni otro criado a cuyo cargo hayan de correr las minas c ingenios, sin antes pedir y recibir de ellos fianzas abonadas, en cantidad de 600 pesos, de que estarán a derecho por los daños y agravios que causaren a los indios, en lo que contra ellos se juzgare y sentenciare, bajo la pena de que, recibiéndolos en otra forma, 
quedan los dueños responsables como fiadores llamos hasta dicha cantidad, a más de satisfacer los daños que se hubieren causado a los indios, 144 Si los hosteleros, albergadores, almojarifes y otros do esta clase, están obligados a satisfacer los daños $y$ todo otro cualquier mal que ejecutaren sus sirvientes en las personas o bienes de los que se entregin a su cuidado, por razón del cuasi-delito y culpa que en ellos so presume en haberse confiado del ministerio de malos sirvientes; ${ }^{145}$ por la misma regla deben quedar responsables los dueños de minas a indeminar a los indios que se les repartieron con cargo de ser bien tratados y pagados.

$2^{\text {- }}$ - No deben ir por sus personas a la labor de las minas del Cerro, para evitar las ruinas que se experimentaban en los puentes, con daño irreparable de los indios, a causa de no cutcuder el aparojo y reparación de ellas; $y$ precisamente deben ponerlas a cargo de mineros o mayordomos hábiles, expertos, sufieientes $116 \mathrm{y}$ aprobados por los Veedores del Cerro, para el desempeño del oficio que toman, bajo la pena de perdimicnto de todos los metales y de 200 pesos de oro. ${ }^{117}$

$3^{\prime}$ - Los mineros o mayordomos que fueren nombrados para cuidar la labor de las minas, han de tener asignación de salario fijo, con la obligación de servir por lo menos el tiempo de un año, y de ningún modo ha de intervenir concierto de cuota parte de los frutos o metales que se sacaren, bajo la pena de perdimiento de todos ellos, con más 300 pesos al dueño, y al minero 200 pesos por. la primera vez; por haber resultado de la tolerancia de estos abusos, grandes molestias y maltratamientos a los indios, forzándolos a ejercer el trabajo más tiempo del que están obligados, a más de arruinar las minas cn la saca ordenada de melal para hacer más copiosa su ganancia. ${ }^{14}$.

4. - Deben proveer a los indios trabajadores de agua suficiente para beber, poniendo a su costa a las bocas de los socavones y minas, tantas botijas de agua cuantas fuesen necesarias para todos los que trabajan; y a los mitarios que se ocupasen en sacarla, se les debe pagal el mismo jornal que a los demás indios que trabajan en las minas, a proporción del tiempo de su servicio, bajo la pena de 30 pesos, para impedir la molestia y tal vez el riesgo a que se exponian por no tener agua que beber; en atención de lo cual hace la Ordenanza 149 particular encargo a los Veedores, que cuiden de saberlo cada día y averiguar si se cumple, encargándoles en esto la conciencia, con descargo de la del Rey.

$5^{\mathrm{a}}$ - No pueden vender metales ni daj graciosamente a los Mayordomos ${ }^{150}$ ni a ninguna otra persona, para que los saquen de dentro de las minas si no fuere con licencia del Corregidor, constando primero que el comprador es verdadero dueño de la misma veta y que actualmente se ocupa en labrar sus metales, bajo la pena de otros tantos pesos como se hubiexen dado o prometido en la venta. ${ }^{151} \mathrm{Ni}$ tampoco hacer bajar metales del Cerro, desde el sábado después de mediodía hasta el lunes a la misma hora, ${ }^{152}$ para que así se eviten contrataciones de metales hurtados.

6. - Para fabricar ingenios, han de pedir licencia al Gobernador y han de verificar la obra dentro de dos años, bajo la pena de perder la mita. ${ }^{153}$

$7^{\circ}$-. Deben ocupar a los indios en los destinos de su repartimiento, ${ }^{154}$ y no recibir de ellos ni de sus Caciques, plata, oro, ni otra especie 
en cambio de su trabajo, bajo la pena de perder los que estuvieren señalados y de no repartínseles otros en adelante. ${ }^{1 \text { ii }}$

$8^{\circ}$ - Bajo de estas mismas penas, no pueden vender los indios con las haciendas que enajenaren, ${ }^{136}$ ni tener sin labrar por tiempo de tres meses, las minas para que se les hubiere repartido. ${ }^{157}$

$9^{\circ}$ - No deben ocupar en su servicio a los indios señalados para labor de las minas e ingenios, ni en guardar netales los domingos y días de fiesta; 15.5 ni azotarlos y maltratarlos por si mismos sin acudir a la Justicia, bajo la pona de destierro y per'dimicnto de la mita. ${ }^{159}$

10: - De ningún modo pteden mandar alzar. ${ }^{160}$ ni echar labor en la mina de donde las Justicias le mandaron quitar, por poca seguridad, basta que se repale a vista de Vecdores, eon nueva licencia del Corregidor. ${ }^{161} \mathrm{Y}$ mucho menos mandal quitar ni labrar ningún puente de los que hubieren en sus minas, no siento más gruesos de dos estados y cuatro de largo, bajo la pena de muerte. ${ }^{162}$ Realmente, una y otra Ordenanza parecen muy justas en sus motivos; pero su demasiado rigor requiere explicazción separada, que la haré en otro lugar.

$11^{\prime}$ - Los indios enfermos o lastimados en las minas, quedam relevados del servicio hasta poder trabajar, y su falta por aquelia mita debe con'rer at cargo de los azogueros, cuidando éstos de enviarlos al Hospital y de acudirles con dos reales diarios, sin obligarlos a que den los siete pesos semanales acostumbrados para mingar otro. ${ }^{163}$ Pero, quedando Jisiados, de suerte que no puedan trabajar, les deben satisfacer la lesión conforme a la culpa, sin perjuicio de la pena que merecieren. $Y$ si al daño le siguiere muerte, la han de satisfacer a sus mujeres e hijos, en aquella cantidad que soble uno y otro caso se arbitrara por las Justicias. 101

Regularmente, no se deben pechar los menoscabos que recibe el herido en las labores que deja de trabajar, en no siendo menestral; 165 pero es opinion comin ${ }^{166}$ autorizada por nuestras Leyes de Partida, ${ }^{167}$ que si el lastimato îtere hombre que vive de su industria y trabajo personal, se le deben abonar los perjuicios del tiempo de la enfermedad según lo apreciare el Juez. A lo cual se ha acomodado nuestra Ordenanza, conformándose con las Leyes de Partida.

$\mathrm{Ni}$ debc juzgarse que se aparta de ellas, porque deja también al servicio judicial, la estimación de la muerte, cuando las Leyes de Partida ${ }^{168}$ condenan al malhechor en 50 maravedíes de oro, la mitad para los herederos del muerto y la otra mitad para la Cámara del Rey; pues esto se entiende en lo eriminal, y lo arbitrario de la Ordenanza, en lo civil, daños e intereses de la parte.

Bicn pudiera concluír las obligaciones de los azogueros, en las que acabo de referir, por ser las que principalmente necesitan alguna explicación más; pero, como mi objeto es escribir para los Gobernadores de Potosí y demás del Reino, una Guía clara y metódica, donde encuentren a golpe de ojo noticias cabales de cuanto les pertenece entender, sin necesidad de abrir otro libro, continuaré refiriendo compendiosamente las demás obligaciones repartidas en el cuexpo de nuestras Ordenanzas.

$12^{\circ}$ - Que en arruinándose alguna mina, acudan a costa de su dueño, los de otras más cercanas, con los indios necesarios para sacar a los que estuvieren encerrados o enterrados en el cerrumbamiento, hasta dejar seguras y bien reparadas las labores. ${ }^{109}$ 
$13^{\circ}$ - Que den los indios necesarios, rata por cantidad, de los que tuviere cada azoguero, para abrir las labores antiguas $y$ hacer otras de nuevo, con la debida seguridad. 1 io

14: - Que el dueño, y no los Mayordomos, peche la pena y satisfacción de las desgracias que sucedieren en minas reparadas, con aprobación de Veedores. 171

$15^{8}$ - Que asistan a las pagas de los indios on el lugar señalado o acostumbrado. ${ }^{172}$

$16^{\circ}$ - Que no hagan trabajar a los indios más tiempo que desde las 10 del día hasta las 4 de la tarde, cn los meses de mayo, junio, julio

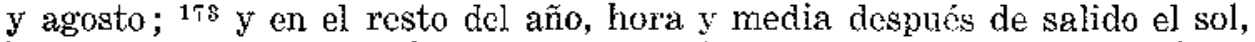
hasta ponerse, con una hora de intermedio para comer y descansar, bajo la pena de 20 pesos, aplicados por terceras partes a Cámara, Jucz y denunciador, y dos días de cárcel. ${ }^{\text {lit }} \mathrm{Y}$ porque se continuaba contraviniendo a estas Ordenanzas, se mardaron guardar a la letra, en el capítulo $7^{\circ}$ de la Real Cédula fecha en Scvilla, a 22 de octubre de 1732, con la calidad de que no se dispense en ellas por ningún caso y que, faltándose a su cumplimiento, se ponga al indio luego en libertad y se lo despache a su tierra, pagándosele lo que se le debiere, hasta llegar a su casa; y se proceda al castigo contra el que contravinicre. ${ }^{175}$ De suerte que, a más de las penas de la Ordenanza, se ve aquí agravada la del perdimiento del servicio del indio por aquella mita.

$17^{\circ}$ - Que no den tareas a los indios y los dejen trabajar lo que buenamente pudieren, pena de 10 pesos por cada uno por la primera vez, agravada hasta perdimiento de la mita, por la tercera.

18: - Que no pongan pongos para sacar los indios al trabajo, para evitar las grandes tareas y trabajos doblados que les imponen por congraciarse con los amos y no salir jamás de esta ocupación en quẻ viven reservados del servicio personal. 156

$19^{\circ}$ - Que no hagan trabajar en minas a los indios repartidos para ingenios, sino en tiempa de seca, con licencia del Gobernador; ${ }^{17 i} \mathrm{ni}$ los muden a trabajar otras minas a los señalados para las vetillas nuevas, para que descubran lo que son, pena de privación de la mita. ${ }^{1}{ }^{1 *}$

$20^{\circ}$ - Que no se aprovechen de los desmontes y los dejen para los que no tienen minas, ${ }^{179}$ porque de este modo limpiarán las labores interiores y sacarán mayor provecho en la ley que regularmente tienen.

$21^{\circ}$ - Que paguen el diezmo al ducño del socavón por donde desaguaren las minas, y el quinto los que han de recibir la entrada. ${ }^{180}$

$22^{\circ}$ - Que labrando minas por sacavón, no sea a tajo abierto, sino por pozos de a diez varas de hueco entre uno y otro a lo más, y a la boca, de dos varas de largo y una y media de ancho; y para sacar los desmontes deben tener abierta la puerta del socavón, desde el amanecer hasta una hora de noche. 181

$23^{\circ}$ - Que barrenen sus pertenencias en las vetas donde hubieren llegado los socavones, labrando por ellos las minas y pagando por la entrada y saca de metales el quinto. 182

$24^{\circ}$ - Que atravesando los intereses de otros mineros, cuando pasaren con el socavón de una veta a otra, no perjudiquen las cladras ajenas y el metal que en ellas hallaren, 183

$25^{\circ}$ - Que den paso tibre a los socavones por todos los lugares y puentes necesarios para llegar a las minas donde van dirigidos. ${ }^{154}$ 
$26^{n}$ - Que den entrada por su mina a los que la pidieren, cobrando el quinto. ${ }^{185}$

27" - Que no tengan minas indivisas, sino señaladas con estacas fijas, para que cada uno conozca su parte y se eviten los fraudes, muertes, robos y pendeneias que origina la confusión. ${ }^{1 \times G}$

$28^{\circ}-$ Que los dueños de minas en compañía, acepten la división cuando se la piclieren sus compañeros, eligiendo dentro de seis días la parte que quisieren. ${ }^{18 i}$

29" - Que en las minas adjudicadas por demasías, pongan un pozo de seis estados más de lo que estuvieren cuando se les adjudicó, y no la pueden vender ni enajenar sin este requisito, bajo la pena de perdimiento de su valor. ${ }^{188}$

$30^{\prime \prime}$ - Que no enajenen las minas que poseyeren por demasías, después de pedidas por otros; pena de mil pesos y de nulidad de la venta. ${ }^{189}$

Los mineros y mayordomos dependientes de los Azogueros están sujetos a los deberes principales que se enumeran a continuación:

$31^{\circ}$ - Que no fuercen al indio que sacare metal, a que lo quiebre bajo la pena de veinte pesos por cada vez que contraviniere. 190

$32^{\circ}$ - Que no comiencen ninguna labor nueva, ya sea para sacar tierras y metales sueltos que quedaron on las labores antiguas, ya para entrar por las cajas a buscar otros nuevos, sin que primero vea el Veedor la parte donde se va a entablar el trabajo y disponga el aderezo $y$ reparos convenientes a su scguridad, 191

3:" - No pueden echar labor nueva ni alzar la antigua, sin vista del primer Veedor, para que los indios entren con seguridad al trabajo. ${ }^{192}$

34" - Que suban al Cerro los lunes de cada semana, a horas de medio día, y no bajen hasta el sábado con ningún pretexto, para que con su asistencia se excusen desgracias y los indios trabajen el tiempo que es justo, con la instrucción y arregio debido. ${ }^{108}$

$35^{\circ}$ - Que no puedan tener a su cargo más de dos labores gruesas, o tres moderarlis solamente en una misma veta, y por una entrada, precediendo vista de ojos y declaración de los Veedores, de que las pueden tener; porque encargándose de mayor número, es preciso que algunas labores queden sin director para el trabajo, y que, por sacar metal para cumplir sus tareas, los indios derrumben los reparos antiguos, en perjuicio de sus vidas. ${ }^{194}$ Conviene muchísimo la observancia de esta Ordenanza, pues, de su contravención procede mucha parte del atraso de nuestra minería y no pocos fraudes; porque si una labor tiene más ley que otra, suelen los mineros arbitrar medios de que trabaje en pertenencias ajenas aquel que le paga más, buscando caminos ocultos, que hay muchos en el Cerro, para que no se descubra la maldad. $Y$ el único remedio cs cl de la Ordenanza, para excusar estos arbitrios delincuentes.

$36^{\circ}$ - Que no traten ni contraten en metales, ${ }^{195}$ ni tengan labar suya, ni pallacos, para evitar hurtos y fraudes. ${ }^{196}$ Párrafo tercero. - Privilegios
de los Mineros. alentado a sus profesores con premios y privilegios. La agricultura, con ser la primera y la más sana de las artes, ha necesitado con el tiempo 
varias excepciones para fomentar la aplicación de los labradores. Lo mismo sucede en el comercio, milicia, abogacía y otras profesiones liberales o mecánicas, que sostienen al Estado.

Entre todas, es la minería la más noble, por la insinuación que tiene con las ciencias más excelentes; la más útil, por los grandes tesoros que derrama en el Estado, para vivificar todos sus ramos; $\mathrm{y}$ la más penosa, por los increíbles trabajos a que sujeta el oro para buscarlo en las entrañas de la tierra, entre cavernas tenebrosas y otros peligros que sufre la experiencia, y no se pueden explicar bastantemente con sola la declaración.

Cuando se comenzaron a descubriy en este Reino las inmensas riquezas de sus minerales, fue bastante este incentivo para que los hombres de más distinción y caudales se empleasen en el ejercicio de la minería; porque con el trabajo de un año, hacian una fortuna opulenta para toda la vida. Pero luego que la codicia empobreció los cerros, ya fue preciso alentar de otro modo más ingenioso a los mineros, concediéndoles grandes privilegios.

El gran Virrey Don Franciseo de Toledo, fue el primero que promovió esta recompensa; y a su ejemplo ejecutaron lo mismo los demás Virreyes, hasta que se redujeron los privilegios al cuerpo de nuestras leyes. Supuesto que deben observarse inviolablementc, compendiaré aquí todos los que se hallan repartidos en las Ordenanzas del Perú y México, para gobierno de los Jueces.

Primero. - Como la naturaleza fabricó este gran coloso de plata del Potosí, entre serranías estériles, sin agua, leña ni maderas, que son materiales tan necesarios para el beneficio de metales, advirtió esta esencial falta el Sr. Don Francisco de Toledo, cuando vino a esta Villa a ponex en arreglo la administración de sus ricas minas, y concedió a los Azogueros el privilegio (que después confirmó el Rey), ${ }^{197}$ para que pudiesen hacer carbón, cortar y traer leña y madera en todos los términos del distrito de la Real Audiencia de La Plata, aprovechándose también de los pastos, que a este fin se declaró por comunes.

Esto no quiere decir que cada uno pueda coger y llevar libremente leña y carbón de cualesquier montes para su aprovechamiento particular, como de cosa común, según lo indican varias leyes del Reino. ${ }^{198}$ Porque el verdadero espíritu del privilegio se reduce a proveer que ningún particular interesado en los montes, impida a los Azogueros que hagan carbón y corten leña en ellos, para surtimiento de la minería; pero se debe entender, paganclo un justo precio, como lo declara la nueva Ordenan7a de México. ${ }^{199}$

Solamente se exceptúan de esta regla, aquellos montes contenidos en las mercedes hechas de señoríos en las Indias, quedando su aprovechamiento común a españoles e indios, por la ley 7 , título 17 , libro $4^{\circ}$ de la recopilación.

No obstante, es mucho.más extenso el privilegio de los mineros del Perú y los de México en esta parte, porque en Nueva España se permite únicamente ${ }^{200}$ el corte de maderas y leña en los montes y selvas próximos a las minas, cuando en el Perú pueden ejecutarlo los Azogueros de Potosí en todos los del distrito de la Real Audiencia, que también ha de ser todo el territorio de nuestra minería. 
Segundo. - Es otro privilegio bien singular el que se refiere en la Ordenanza del Perú, 201 y se halla reducido al cuerpo del Derecho común Municipal en la ley 7, título 20, libro t" de Indias, para que los mineros y Azogueros de Potosí, puedan ser proveídos en Corregimientos y Oficios públicos $y$ concejiłes, aunque sean deudores a la Real Hacienda, por razón de azogues o de otra deuda que no proceda del oficio en que pretendieran entrax; sin cmbargo de la expresa prohibición que se contiene en varias Cédulas recopiladas en las leyes 17 y 43, título 2 , libro 3 ?.

Posteriormente se despachó otia Real Cédula de Madrid, a 10 de agosto de 1689 , con inserción de la de 15 de julio de 1620, recopilada en la ley 7 , título 3 , libro 5 "de Indias, y de otra librada a 17 de diciembre de 1679 a consulta del Excmo. Virrey Conde de Castelar, declarando que la prohibición de obtcner oficios de administración de Justicia los deudores a la Real Hacienda, se entienda con todos, indistintamente, aunque proceda de otros cualesquiera ramos, que no sean de oficios vendidos, sin embargo de haber dado motivo a la antecedente el caso especial de deudores por los oficios que hubieren comprado, y hace relación que en la Isla de Santo Domingo, se suspendió su cumplimiento con motivo de haberse publicado la ley 11 , título 9 , libro $4^{\circ}$ de la nueva recopilación, que limita la prohibición solamente a los deudores de oficios; con cuya consideración derogó y amıló expresamente la ley 11 citada, título 9, libro $4^{\text {"}}$, mandando guardar las antecedentes Reales Cédulas, para que en adelante ninguna pcrsona, de cualquier calidad y condición que sea, pueda ser elegido Alcalde, ni obtener otro algún oficio público y de administración de Justicla, siendo deudor al Rey, en poca o mucha cantidad de cualesquier ramos y eíectos reales, bajo la pena de privación del oficio, perdimiento de bienes, para la Cámara, y destierro a veinte leguas en contorno del lugar donde obtuvierc el oficio. La cual resolución se comunicó después, en Real Cédula circular, fecha en El Pardo, a 1 ${ }^{\circ}$ de abril de 1779 , por haberse considerado que podría no tenerse noticia de ella en otras partes de América.

Sobre este fundamento, se puede dudar si deberá estimarse revocado el privilegio concedido a los Azogueros de Potosí. Porque habiéndose hecho la derogación con la cláusula universal de que ninguna persona, de cualquier calidad y condición que sea, pueda obtener empleo de administración de Justicia, debiendo alguna cantidad a la Real Hacienda, parece que se quiso también inclúr a los privilegiados, (como son los Azogueros de esta Villa), una vez que no se exceptuó caso, persona ni calidad.

Otra razón legal más apoya este dictamen. Este privilegio se halla inserto en el cuerpo de nuestras leyes, con todas las demás que constituyen las generales del Reino; y así como éstas son el Dexecho común de la nación, aquél también lo es para los Azogueros. ${ }^{202}$ Para que dos leyes generales se deroguen, la una por la otra, basta que la posterior sea contraria a ka más antigua, aunque no se haga especial mención de ella; ${ }^{203}$ luego, también debe quedar revocado el privilegio, por la citada Cédula Real, que le es en todo contraria, no obstante que no se haya traído a consideración en ella, por ser constante ${ }^{204}$ que de un privilegio, incluso en el cuerpo del Derecho, se debe juzgar to mismo que del Derecho común, en cuanto al efecto de la derogación. 
Se puede alegar a favor de la azoguería la doctrina de Jerónimo González; ${ }^{205}$ pero todos sus fundamentos están bien desvanecidos en los lugares citados de Fagnano. Con todo, no me atrevo a dirimir la duda, y creo, cuando no necesario, al menos conveniente que el Rey la aclare.

Si bien debe tenerse presente que según los reglanentos del Banco donde se reparten los azogues, son fijos e indefectibles los plazos en que se han de pagar sus valores, el azoguero los paga por semanas; de modo que en la última del año, satisface el último resto, y entra debiendo para el año siguiente, sin que, por más que se esmere, pueda salir de esta deuda. El espíritu de la Cédula de 1689, es apurar a los deudores fiscales para que no dilaten la paga por el interés de quedar habilitado para obtener empleos; con que, hallándose fuera de este caso los Azogueros de Potosí, parece que no deben reputarse comprendidos, pues de lo contrario, no podrían ejercerlos jamás, porque nunca dejarán de ser deudores mientras fueren Azogueros, ${ }^{206}$

Tercero. - Las leycs reales y las ordenanzas del Perú, ${ }^{207}$ concedieron a los Azogueros el privilegio de no poder ser presos fuera de la Villa, asiento y Cerro donde labraren las minas, y siendo demandados en otra jurisdicción, aunque sea por deudas de Real Hacienda, eumplen con afianzar que se presentarán ante los Jueces de su territorio, en el término que se les señalare. Pero cuando llegue el caso de ser presos en la Villa, asiento y Cerro de su labor, deben dar fianza del haz, de que tendrán por cárcel dichos lugares. La Ordenanza de México, 208 concede el mismo privilegio a los dueños de minas, sus administradores, veladores, rayadores y demás sirvientes de minas y haciendas; con la diferencia de señalar solamente a estos últimos por carcclería en su respectivo caso, la misma mina o hacienda donde sirvieren, exceptuando absolutamente de prisión a los dueños principales. No declara si los sirvientes la han de sufrir dando la fianza que disponen las Ordenanzas del Perú, y por lo mismo que los privilegios deben interpretarse del modo menos vulnerativo del derecho común, ${ }^{209}$ parece que se habrá de guardar el suyo a los operarios, con la calidad de fianza, para que al mismo tiempo de no atrasarse en el trabajo de las minas por su falta, asegure el acreedor su derecho e intereses, sin el riesgo de perderlos haciendo fuga del asiento, como es de temer del ningún arvaigo y poca vergüenza de las gentes que de ordinario se emplean en este ejercicio.

Pero, como la Ordenanza citada, de México, impone a los amos la obligación de ir pagando sus deudas con la tercera parte de sus salarios, entretanto que los tuvieren, 210 es claro que no necesitan dar tal fianza del haz, porque los mismos amos quedan constituídos como fiadores de saneamiento de los salarios que se devengaren en el tiempo de su servicio; y una vez que, saliendo de aquella mina, sin entrar en otra, pierden el privilegio y pueden ser llevados a la cárcel, no deben los acreedores solicitar más seguridad que su propia vigilancia para estorbar que hagan fuga en su perjuicio.

No se debe juzgar por esto, que haya alguna oposición con otro artículo de la misma Ordenanza, ${ }^{211}$ que sólo manda retener la cuarta parte de lo que importaren las rayas de los operarios, para pagar a sus amos. Pues, aunque según la naturaleza de los créditos, parece más privilegiado el de estos últimos, para que fueren atendidos a lo menos con igual cantidad, a fin de evitar el atraso de las pagas, yo considero que en esta 


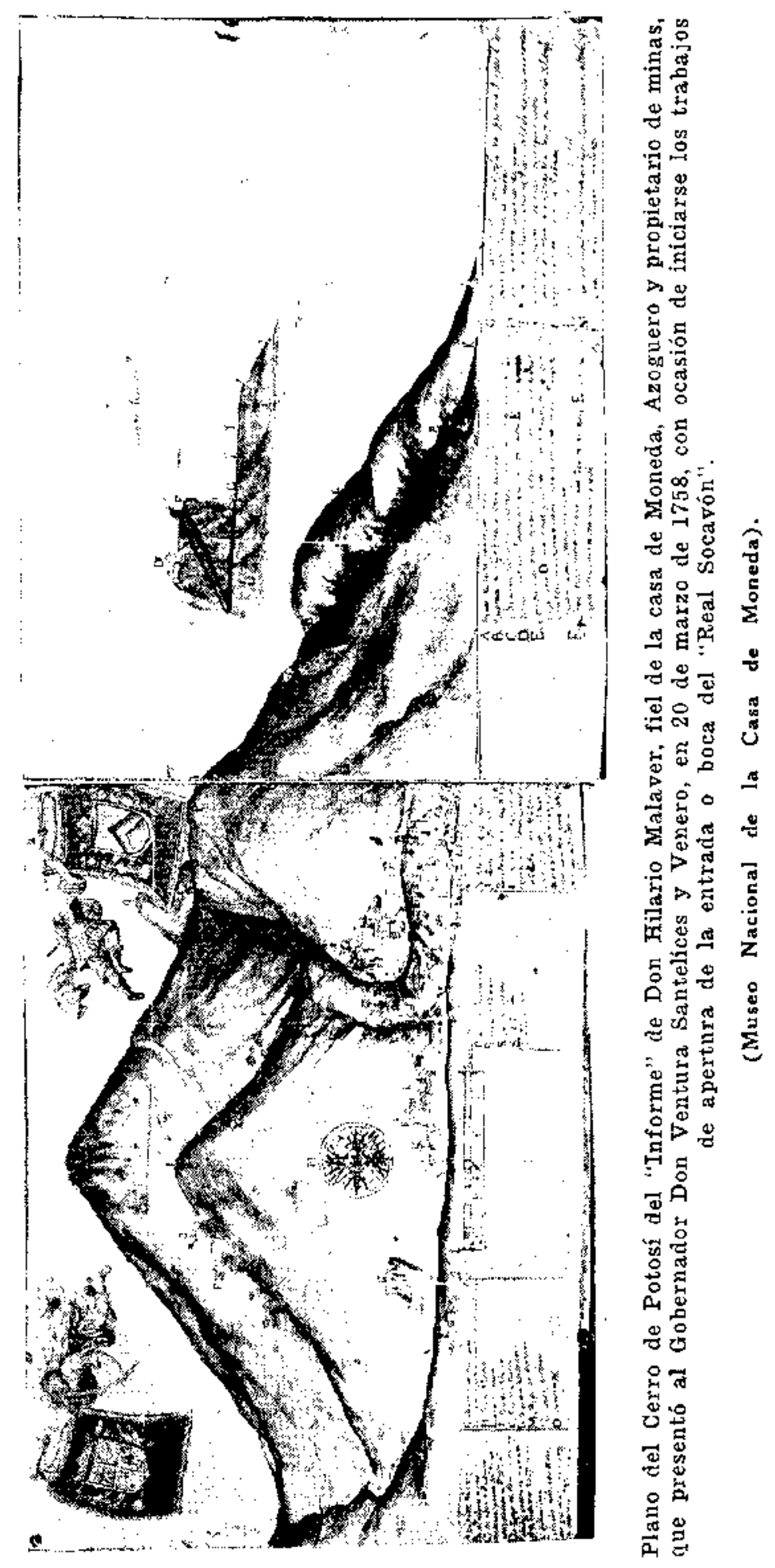




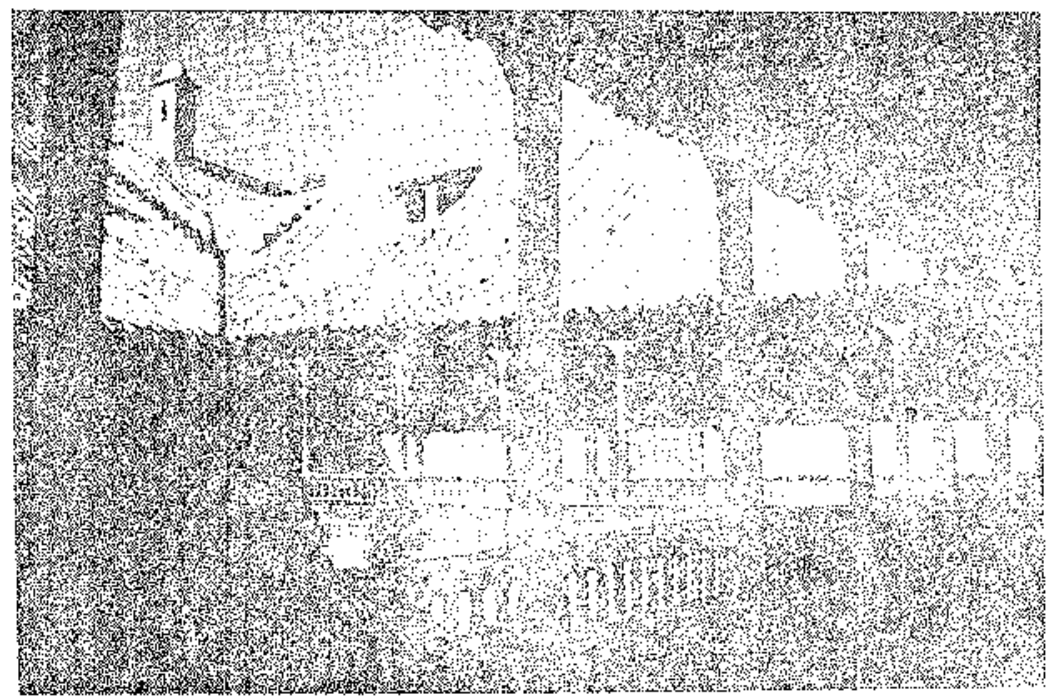

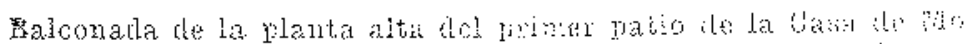

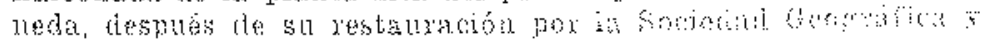
de Hustown "Pron". 
misma desigualdad consiste el mayor privilegio de los amos y de los mismos sirvientes a quienes se procur'a favolecer, principalmente para fomonto de la minería.

Porque cuanto más tiempo quedaren debiendo los sirvientes de minas, otro tanto más han de cstar empleados en trabajar', en beneficio de sus amos. La poca poblacion del Reino hace escasear los operarios, de tal suerte que es grande privilugio el tenerlos, como se experimenta con la mita de Potosí. De aquí proccke, que habiendo de durar más el servicio, mientras más se dilataue la paga, dispuso la Ordchan\%a, con esta misma consideracion, que los amos sólo descontaren la cuarta parte de los salarios, para gue, por una consccuencia natural, gozasen del privilegio de ocupar a estos trabajadores por tiempo más largo en el empleo rle las labores.

loos mismos sinvientes gozan lambién de notorio privilegio respecto de los demás aeredores; pues, con todo de ser conforme a Derecho, "uz que a los operarios viles y cualesquiera otros artífices mecáni$\cos$, se les sectestre la mitad de sus estipendios y salarios, para componer en to posible la paga con la subsistencia del deudor, rebaja la Ordenanza a una tercera parté, rlejándoles un tercio más de salarios de qué poder aprovechar, para incitarjos mas al trabajo de la minería.

1.o que se puede dudar con más lundamento, es la exención absoluta que franquea la Ordemanza citada de México, 213 para que los dueños de minus no puedun ser presos por deudas, se entiende únicamente de las dendas de particularces, o también de las de Real Hacienda.

Cuarto. - El no ser presos por deudas, es consiguiente a la declaración del privilegio de nobleza, que la misma Ordenanza hace en otro lugar, 214 a favor de la profesión científica de minería; porque las leyes 4 y 5 , título 2, libro 6" de Castilla, oddenan expresamente, que ningún hijodalgo pueda ser preso ni encarcelado por deudas.

l'ero, en la misma ley 4 , se exceptúa el caso de ser deudor por arrendamiento o receptoria de los Pechos y Derechos Reales. De aquí forman los Doctores la disputa si conforme a la ley deberá entenderse exceptuada igualmente que cualq̧uier otra deuda la de Real Hacienda.

Todos resuelven que, el privilegio de la nobleza se derogó por la ley, solamente en el caso de arreudamiento o receptoxía de rentas, y por consiguiente, que no puede ser preso al hombre noble, por cantidad que deba a la Real Hacienda, por otros ramos que no sean de arrendamiento de rentas. Nogucrol, "21. cita por esta opinión a Lazarte y a otros muchos célebres autores, y concluye con ellos, que el deudor de alcabalas por su propio contrato, o de otros efectos reales, no debe ser preso siende noble, por no ser estos casos de los comprendidos en la ley.

Con lo cual se comprueba que los Azogueros que debieren al Rey, por deudas de azogues o de otros ramos reales, conservan ileso el privilegio de nobleza en este caso y no pueden ser presos ni encarcelados por ello. Bajo de cuya inteligencia se debe interpretar la Ordenanza mexicana, entendiéndola como suena en cuanto a los sirvientes y operarios, en los términos que queda explicado arriba.

Quinto. - Sólo sus bienes se han de ejecutar, entrando las ropas preciosas, adornos, joyas y alhajas de valor, sin reservarles más que un caballo enfrenado y ensillado, una mula de carga, las armas, la cama y la ropa de uso, y el de sus mujeres e hijos, en lo absolutamente indispen- 
sable para su precisa decencia, según dispone la Ordenanza, ${ }^{216}$ de conformidad con las leyes del Reino. 217

Con arreglo a esto, no se debe observar la ley 23, título 21, Partida 2 , que no permite dejar libre más de aquella ropa que baste para no quedar desnudo, como única cosa que prescribe la humanidad; pues, fuera de proveer lo contrario la Ordenanza, también enseñan los Doctores, con Parladorio, ${ }^{218}$ que al ejecutado se debe dejar franca toda la ropa de su uso.

Sexto. - Asimismo están exceptuados de ejecución los ingenios y minas, las máquinas, herramientas, aperos, esclavos, bestias, bastimentos, materiales y demás provisiones necesarias a su labor; ${ }^{219}$ y en los casos que corresponda en justicia la ejecución, se puede verificar solamente en los metales de plata, oro y demís productos, salvos los alímentos y avios. ${ }^{220}$

La. Ordenanza de México 221 no señala cantidad fija para estos dos efectos, y deja al arbitrio de los Jueces lo que se juzgue precisamente bastante para sustentarse el deudor según las circunstancias do su familia $y$ de la negociación embargada, mandando graduar estos descuentos con tal tino, que el acreedor no se haga de peor condición que antes del secuestro.

El Sr. Don Francisco de Toledo, también dejó arbitraria la asignación de las costas necesarias en una de sus Ordenanzas; ${ }^{222}$ pero habiendo resultado después muchas sinxazones, quejas y agravios en el modo de hacer los señalamientos, rebajando a unos indebidamente y aumentando a otros, según el grado de amistad y favor, más bien que el de las circunstancias del deudor y de sus necesidades, publicó otra Ordenanza posterior, 223 mandando sacar la mitad de todos los frutos para costas, avios y para alimentos, y declaró que los deudores no podían renunciar al beneficio de esta Ordenanza, porque dirigiéndose a favor de la causa pública, ningún particular puede pactar su inobservancia. 224

Desde luego, será el único medio de evitar injusticias y disgustos el cumplimiento exacto de la Ordenanza del Sr. Toledo, declarándose por ella, en los casos ocurrentes, la cantidad que se debe reservar al deudor: pues habiendo graduado este gran Virrey, por suficiente la mitad de los frutos que regúlarmente rinden las minas $\mathrm{y}$ los ingenios de este Reino, para avios y alimentos, se debe juzgar que esta misma es la que precisamente basta para ambos efectos, según el espíritu de la Ordenanza de México. Sólo será justo exceptuarse el caso extraordinario de alguna mina tan rica, que la mitad de sus frutos sea notoriamente superabundante para llevar su labor y mantener al deudor, según las circunstancias de una y otro; porque entonces se deberá arbitrar la asignación a juicio prudente del Juez, para no perjudicar al acreedor.

La Ordenanza de México omite aquí dos casos muy notables, en que la del Perú y una ley de Indias derogan este privilegio, los cuales son dignos de advertencia. El uno es el privilegio de no ejecutarse las minas e ingenios por razón de deudas, se entiende solamente en aquellas que fueren contraídas después de compradas dichas minas e ingenios, o en las que los deudores registraren como descubridores, o tomaren por vía de estacas o en otra cualquier manera, como no sea por compra; quedando sujetas a ejecución para poderse vender como los demás bienes, las 
que se hubieren comprado posteriormente a las deudas, según lo declara la Ordenanza 9, título 9, libro 3" del Perú. Para evitar que los deudores hagan compras fraudulentas, con la esperanza de ayudarse de los privilegios de la minería, en perjuicio de sus acreedores.

Esta justísima providencia se ve claranente fundada en aquel superior privilegio que conceden al acreedor las leyes civiles y reales, 225 en castigo del engaño, para que por' medio de la acción pretoria, revoquen y rescinclan cuanto se hubiere obrado en su pexjuicio, y lo repongan a su primitivo estado, cono si nada se hubiera hecho; porque si en este caso le importa al acrecdor restituír a su primer ses: la heredad que se enajenó maliciosamente, para que no fuera pagado con ella o con su precio. Del mismo modo se interesan los acrecdores del comprador de una mina o ingenio, on que por una fingida rovocación se reputen como restituidas ustas fincas a la materia del precio con que se compraron, para poder usar de su derecho contra ellas, como si fuerau los demás bienes no privilegiados; pues sólo así no le resultará provecho al deudor de la iniquidad de haber subrogado mints e ingenios a otros bienes ejecutables, con el depravado tin de no dejar' a sus acreedores con qué pagarse.

En cfecto, se muesträln tan escrupulosas las leyes en este punto, que persiguen al fraude hasta en lo más sagrado. Así se advierte, que la ley 10, título 11, libro $1^{\circ}$ de Indias, manda a las Justicias reales, procedan contra los seculares culpados en motines y traiciones, que para evadirse del castigo se hicicren clírigos o entraren en religión después de procesados; no por otra causa sino por presumirse que su ingreso a la religión se hizo on fraude de la jurisdicción secular; y por ésto quiere la ley que no goen cel privilegio del fuero y queden sujetos al Juez laico, como estaban antes de ser religiosos, en cuanto al conocimiento de sus causas y disposición de sus bienes.

Del mismo modo deroga nuestra Ordenanza ef privilegio de la minería en el caso de que hablamos, porque quiere que las minas compraclas después de contraílas las deudas, queden como antes eran los demás bienes con que las compró el deudor, para poder hacer ejecución en ellas y ser pagados con su precio los arrenderos.

Si bicn deberán antes hacer ejecución en los bienes del deudor, y hallándolo insolvente, intentar entonces esta acción dentro de un año útil, ${ }^{226}$ computado desde el día en que se verificó la comprobación de la quiebra; 227 porque pasado este término, perderán ya ế remedio de Ja Ordenanza, y el deudor reasumirá el privilegio de no ser ejecutado en sus minas.

El otro caso exceptuado, se propone en la Ley 5, título 14, libro $5^{\circ}$ de la recopilación de Indias, y es cuando las deudas montan tanto como el valor del ingenio. Porque entonces, no teniendo e] deudor otros bienes con qué pagar, se puede hacer cjecución en todo el ingenio, esclavos y pertrechos, dando la persona en cuanto se rematare, fianzas de conservarlo entero, bien reparado, moliente y corriente, como lo tenía el dueño.

Por último, se exceptúan las deudas de Real Hacienda, por cuyo pago se pueden ejecutar las minas c ingenios, según dos leyes de Indias $\mathrm{y}$ la Provisión del Sr. Conde de Chinchón. ${ }^{228}$ A este efecto está mandado practicar arrendamiento con la calidad de enterar en Cajas reales, todos los frutos y los productos de las haciendas, y hacer de su monto seis partes: la primera, para los alimentos del dueño, no teniendo otra hacien- 
da de quó sustentarse; la segunda, para los reparos necesarios, excepto el caso de necesitar rueda o eje, porque entonces debe librarse su costo, aunque exceda la sexta parte; las otras dos electivas, para Su Majestad, sin concurso de acreedores; $y$ en las otras dos restantes, deben entrar éstos, en el lugar que les tocare; $y$ no habiéndolos, ha de quedar todo por cuenta de la deuda de la Caja, con más lo que sobrare de la parte aplicada para obras mayores, no gastándose en cllas. De cste modo se asegura la Real Macienda, se proteje la mineria y se consulta al deudor en lo más preciso, como los alimentos, según consideración de mustro Escalona. 229

Séptimo. - En el repartimiento de solares para fabricar casas, también deben ser atendidos con preferencia, $2: 0$ y aunque se les concede el mismo privilegio en alquilarlas, osto se debe entonder con arreglo a la ley 78 , título 16 , libio 2 "de Indias, para el eiecto de mandarles dar las que se alquilan comunmente, pagando el precio que los demás particulares, sin molestia ni agravio de los dueños, cuando no hallaren quien con libre voluntad se las quiera dar en arrendamiento; pero on ningún caso pueden ocupar ni retener casas ajenas, queriéndolas vivir su dueños.

Octavo. -- El Art. 4", título 13 de la Ordenanza de México, permite transitar libremente con bestias de carga, do unos a otros lugares de minas, por todos los caminos, prados, ejidos públicos y comunes y de particulares, sin pagar ninguna contribución. Fil estos países, a ninguno se le impide caminar por donde quisierc, ni se le exige la menor nensión, conforme a lo dispuesto en la ley 2 , título 17 , libro $4^{\circ}$ de Indias; por lo que no es privilegio, sino derecho común.

En conclusión: es tanto el empeño de nuestras Ordenanzas en promover los progresos de la minería, que se promete a los más idóneos en esta profesión y a sus hijos, los efectos de la Real piedad ${ }^{231}$ y se encarga muy particularmente a los Jueces que velen sobie ellos, para que no disipen sus caudales en faustos inutiles, juegos prohibidos o excesivos y otros desórdenes, ${ }^{232}$ hasta lkegar al punto de poner curador a los incorregibles, como a veldaderos pródigos, ${ }^{23}$ para conservar el decoro $y$ el buen orden, entre unas gentes tan benélicas al Rey y al Estado.

Noveno. - Además de los casos explicados, en que los Azogueros gozan de privilegios personales, también los tienen en cuanto á sus causas, así civiles como criminales; a saber: sobre descubrimientos, denumcios, pertenencias, medidas, desagües, diserciones, despilaramientos, avios de minas, rescates de metales, $y$ todo to que se hiciese en perjuicio de su labor; en todos los cuales casos, es privativo al conocimiento del Juzgado de minas, 234 como igualmente en los crímenes de hurtos de metales, herramientas y demás cosas pertenecientes a las minas y a su bereficio; sobre delitos cometidos en ellas o en los ingenios, entre los mismos operarios; sobre falta de subordinación de éstos a los mayordomos, o de unos y otros a sus amos; y sobre agravios, injusticias y desacato a los Juzgados de minas. Bien que si los delitos merecieren, por' su gravedad, la imposición de pena ordinaria, mutilación de miembros u otra corporis aflictiva, solamente podrá el Juzgado de minas aprehender los reos, tomar la sumaria y remitirla con ellos a los Jueces reales respectivos, para que a su tiempo den cuenta a la Audiencia del distrito. ${ }^{235}$

Pero quedan sujetos a la jurisdicción real ordinaria, en todas las causas criminales por delitos de alevosía, moneda faisa, resistencia, in- 
sidencia de tumulto o motín, toda conmoción o desorden popular, desacato a los Magistrados, quebrantamiento de Bandos de Policía y de las Ordenanzas municipales de los pueblos, contrabando y fraudes contra rentas y por los demás delitos comunes.

Sin embargo, acapciendo estos crimenes y excesos sobre cumplimiento de cjecutorias o providencias emanadas del Juzgado de minas, le pertenece su areriguación y castigo, por ser dependientes de causas tratadas ante él, segín se halla decidido par'd caso equivalente, en la ley 118, título 15, libro 2 " de la recopilación de Intlas.

En cuanto a causas civiles, son exceptuadas todas las demandas de bienes raices, pleitos de cuentas, juicios de inventarios, sucesiones hereditarias, particiones, concursos do acrechores, cesión de bienes, compras universales, todos los juicios posesorios de bienes pertenecientes a vínculos, aniversarios, patronatos de legos, mayorazgos y otras disposiciones tocantes a tratos y negocios particulares sobre las mismas minas, como sua por título de coinpra, venta, donación a otro semejante, de que no se trata en las Ordenanzas de miner'a. ${ }^{230}$

Pero en toilas estas causas y casos en que los dependientes de la minería quedan sujetos a la jurisdicción real ordinaria, no podrán ser presos por ella, sino cin las mismas minas o haciendas donde sirvieren, siendo la causa civil; ":i y en las crimiriales, sin dar parte antes o respućs, según la calidad del dejito, ${ }^{2: 9}$ al Juzgado de Minas, para que mande poner otro sujeto en su lugar, de modo que no se atrase el importante trabajo y labor de las minas. ${ }^{2: 3}$

\section{NOTI IA S EF T I M A} De las Minas y sus diferentes
especies. Se explica el dominio
de éllas y el modo de adquirir-
las, medirlas, labrarlas, repa-
rarlas y ampararlas.- Párra-
fo prinero. - De las Minas y
sus diferencias.
$\mathrm{T}$ convienen on que las poderosas riquezas del Perń, depositó la naturalcza principalmente en lat comarea de Charcas, donde se halla situado Potosí y su Provincia. En otro lugar 241 refor' por monor las riquisimas minas de oro y plata que se han trabajado $y$ trabajan todavía en el distrito de Potosi y sus Partidos. Ahora extenderé las noticias a todo el territorio de la Real Audiencia de Ia Plata, para que la Dirección General de la minería, tenga a golpe de ojo el conocimiento necesario de las minas más importantes de su departamento, para proveer lo conveniente a los progresos de su labor.

Pấrrafo segundo. - Minas de $\mathrm{W}_{\mathrm{N}}$ Garci-lvendoza, Pevenguela y Sicasiplata.

ca, se trabajaron antiguamente minas de plata muy ricas y caudalosas, que por considerarse do grande importancia para el Estado, tuvieron asignación de 729 indios de Mita, en los Corregimientos de Lípez, Pacajes, Chayanta, Cochabamba, Paria, Omasuyos y Sicasica.

El Sr. Virrey Marqués de Montesclaros, ${ }^{242}$ revocó estos repartimientos, a causa de haberse pasado a las minas de Oruro, nuevamente 
descubiertas en la Provincia de Paria, los dueños de las de Berenguela y Garci-Mendoza de las Salinas dejändolas muy derrumbadas, maltratadas y peligrosas de trabajar.

El Sr. Virrey Príncipe de Esquilache, ${ }^{24.3}$ con noticia de las grandes riquezas de las minas de Oruro, repartió entonces para su labor los indios de Mita suprimidos a Berenguela y Garci-Mendora. Y aunque después revocó este repartimiento, ${ }^{24}$ dejándolo como antes para entero de la Mita de Potosí, siempre se continuó el trabajo de ellas con indios mingados, y hasta el día tiene una saca bien regular de platas; no debiendo dudarse que, si tuvieran fomento así éstas como aquellas, rendirían otro tanto más de su corriente actual.

Cerca de la Villa de Puno, on la Provincia de Chucuito, está la céleby'e mina de Layka-cota, conocida por la de Salcedo, tan rica y caudalosa de plata hasta el año de 1669 , que lo más del tiempo se cortaba a cincel de la misma veta. Esta prodigiosa abundancia, junto con la generosidad de su dueño, Don José Salcedo, atrajo un concurso innumerable de gentes, que causaron grande tumulto en Puno.

Ambos motivos obligaron al Sr. Virrey Conde de Lemus, a pasar personalmente al mineral de Layka-cota, donde la envidia y la malicia convenció de culpa al infeliz Salcedo, no teniendo en realidad otra que su misma riqueza.

Todo lo perdió al cabo con su vida, muriendo ajusticiado en Lima. Al mismo punto se llenó la mina de tanta agua, que no bastaron los mayores esfuerzos para habilitarla, cuando el Virrey mandó que la volviesen a trabajar.

Muchos lo atribuyeron a castigo de Dios, como refiere nuestro viajero Don Antonio UlIoa; ${ }^{245}$ otros juzgaron que era efecto purarnente natural, y eñ este concepto la tomó a su cargo, el año de 1740, Don Diego Baena, minero rico de aquellos parajes, gastando inmenso caudal en la empresa del desagüe.

Aunque el suceso no fue como se esperaba, no se debe creer que procediese de no hallar la veta o de hallarla exhausta (como suele suceder en los desaguies), porque todo el Reino contesta que al tiempo de aguarse esta mina, estaba en la mayor riqueza. Esto persuade que los directores de la obra erraron sus medidas, $y$ ningún otro minero rico se ha atrevido a entrar después al mismo designio, con el escarmicnto desgraciado de Baena; ni los demás se han vuelto a acordar de ella, con la abundancia de plata de otras minas que tiene el Perú, y se van descubriendo cada día.

Pero lo cierto es, que esta mina no podía estar más aguada ni en peor estado que la de Guadalcanal, en España, cuando la arrendaron aque1los dos hermanos Fúcares, * mineros alemanes habilísimos de su siglo. No solamente lograron estos hombres el desaguarla por medio de admirables máquinas y de otros artificios, sino que también sacaron tantos centenares de miles, que después de haber gastado inmensas sumas de dinero para evadirse de los graves cargos que les hicieron, por haber inundado y abandonado maliciosamente la mina, en el año de 1635, con motivo de haber querido el Ministerio subir el arriendo, se llevaron a Alemania un caudal tan crecido, que les bastó para hacerse grandes Condes en su tierra. 246 
* (Fúcar, apellido castellanizado que corresponde al de los capitalistas alemanes Fügoer, que en el siglo XVI, impalsaron el sistema de casas bancarires on mnchas ciudades de Europa. Monopolizaron la producción de cobre de Hungria y mantuvieron estrecha relación con la Monarquia española, concedićndole empréstitos para sostener los cuantiosos gastos en las campañas de Italia y Africa. En compensación, se hicicron cargo en condiciones pritilegiadas de las minas de Guadalcanal y de azogne del Almadén, gue suministró su producto, por dilatado espacio de tiempo, al yremio de Azoglleros de Potosí. Finalmente, fueron autorizados para acuñar monedas en el territorio españal.

Recibieron muchas distinciones honorificas $y$ acumalaron enorme rifueza. La prestigiosa editorial mexicana "Fondo de Cultura Economice". publicó en su importante colección una bien locumentada biografia, baio el lítulo de "Los Fúcar". Nota de A. Alba).

Es probable que se lograran iguales progresos en la mina de Laykacota, si por nuestra dicha vinicse al Reino algún excelente facultativo de minas, para el establecimiento del nuevo sistema de minería. Desde luego, sería esta una de las empresas más útiles que se proyectase en el Reino, pues, llegándose a dirigir con acierto este gxan designio, nos valdría sólo este mineral de Taylua-cota, por casi toclos los demás minerales que se trabajan en el Perú.

Fn el Pastido de Irípe\%, jurisdicción de la Provincia de Potosí, hay otra mina, distintà de la del Cerro de San Cristóbal que refiere Ulloa, ${ }^{247}$ y pertencce al Curato de San Antorio, en el pueblo nombrado Jaquegua. Este mineral fue muy caudaloso $y$ rindio muchos millones hasta principios de este siglo, en que se acabó de inhabilitar con las inundaciones del agua. No está situado sobre cerros altos, en que regularmente se hallan las demás minas, sino sobre una loma pelada. Esta irregular situación, ha hecho mucho más difícil su desagüe, porque el socavón por donde se debe vaciar la inundación, es preciso que comience de muy lejos, para buscar el pie de la loma.

En efecto, se ve trabajado un socavón muy costoso, al parecer con buenas medidas, y según dicen los que lo han reconocido, faltará como veintc varas para concluírlo; siendo tradición general, que se desamparó esta empresa por falta de medios, no obstante de considerarse muy próxima la veta que se intentaba cortar.

Despućs aquí, nadie ha proyectado seguir la obra; así porque la decadencia de los minerales del Reino ha desalentado a los hombres, como por la falta de gente y caudales. A lo que se agrega la suma rigidez de aquel clima, que es odioso aún para los indios, por cuyo motivo no se encuentra quien quiera fletarse para ir a Lípez. Si la falta de agua fuera la única causa que impide trabajarlas (como se persuadió Ulloa), ${ }^{248}$ sería fácil al Gobierno vencer csta dificultad, asignándole mita, del modo que se practicó para las minas de Berenguela, Garci-Mendoza y Oruro; pero siendo los obstáculos mucho más graves, contemplo reservado este - grande designio para el nuevo Tribunal de Minería, después que multiplicando los laboratorios, academias y tareas, llegase a poseer las experiencias necesarias para intentar y concluír felizmente, empresas de esta gravedad. 
$\mathrm{Y}$ cuando algún minero particular no quisiere aventurar su caudal al riesgo de un suceso contingente, no contemplo temerario el empeño de concluír el socavón, a costa de los fondos del Banco de la Azoguería; porque a más de ser probable la utilidad, es conveniente que el mismo cuerpo de mineros incite a los particulares con su ejemplo, para que no desconfíen en la práctica del acierto de las especulaciones con que se promueve su felicidad.

En Carangas, Lampa y otros lugares de este mismo Virreinato, hay otros muchos minerales de plata, que pueden rendir inmensos caudales, si se fomenta su trabajo con el arbitrio inteligente que introdujo en Nueva España, Don Sebastián Ramirez, de establecer las crianzas y labranzas; 249 porque entonces las tierras desiertas en que regularmente se hallan las minas, se poblarán de gentes que las trabajen, y la misma necesidad de subsistir los plecisará a buscar obras nuevas.

$\mathrm{Si}$ acaso se agregase al Virreinato de Buenos Aires el mineral de Guantajaia, sería mucho más fácil su fomento, por la mayor inmediación en que está con la Casa de Moneda y Banco de Potosí, para sus rescates y avios.

Lo cierto es que dividiendo el Virreinato de Lima, por el río de Camarones, como conviene, por ser esta una demarcación inmutable y permanente, quedaría todo el distrito de Buenos Aires dentro de una línea casi recta hacia el Norte, y consiguientemente se incluiría en su territorio el de Tarapacá y Guantajaia.

EI corriente ordinario de este mineral, es ahora cerca de medio millón de pesos, por'que no le permite más saca su poca población, ni se puede aprovechar sus ricos desmontes, por los crecidos costos del acarreo hasta el asiento de Tarapacá, a dístancia de diez y ocho Ieguas, desiertas y sin agua.

E) Tribunal de Minería de Potosí, pudiera emprender la grande obra de dar agua a todo el valle de Tarapacá, conduciéndola desde las cabeceras de aquellas serunías inmediatas. Entonces era fácil formar una hermosa población, a las siete leguas de Guantajaia, en la falda de la cordillera que corta el valle Norte-Sur, fabricando una ribera de muchos ingenios grandes como los de Potosí.

En la cercanía se molerían todos los desmontes, que rinden de 14 a 15 mareos por cajón los más pobres, porque serían mucho menores los costos de acarreo; de suerte que si la saca actual sube a medio millón al año, después alcanzaría o tal vez excedería de un millón de pesos, aumentándose Jos quintos a favor del Rey, y la circulación numerosa a beneficio del Estado. Párrafo tercero. - Minas
de Oro. $\triangle$ A abundancia de oro en este Reino, se convence de las grandes vajillas que tuvo de este rico metal el Inca Mayta-Cápac, ${ }^{250}$ y de

las estatuas y otras obras que se encontraron en el templo del Cuzco, al tiempo de la conquista.

En la parte agregada a este Virreinato, hay riquísimos minerales y lavaderos de oro. Choquecamata, en la Provincia de Cochabamba, fue riquísimo del oro de más ley del Reino; al principio rindió porción muy considerable de este metal: ahora se halla decaído, pero puede ser 
efecto de que estas gentes abandonan más pronto cuanto son más ricos los minerales, luego que van a menos, porque, por una fajina nacional, sólo apetecen aquel trabajo cn que pueden enriquecer en una semana.

Entre todos, es el más célebrado el cerro de Illimani, cércano a la ciudad de La Paz, que estando nevado todo el año, descubrió una veta riquisima de oro en el derrumbe que abrió un rayo. En este cerro tiene sus vertientes la quebrada de Tipuani, tan fértil de oro, que allí recogen copia muy considerable de pajas y pepitas entre las arenas. 251 Es de creer que corriendo la humedad con lentitud, filtra y depone las partículas metálicas en ol terreno dispuesto a recibirlas; y es probable que mudando la caja del arroyo, so encontrarían inmensos tesoros en las capas inferiores de Ias ticrex del fondo. ${ }^{2.2}$

Hin Carabaya, Larecaja, Chichas, Chayanta y casi en todos los demás Particios de las Intendencias del Virreinato de Buenos Aires, hay muchos veneros de oro, que fructilican grandes cantidades al año. Son pocos los mineros ricos que so emplean en su labor, porque no hay vetas donde se corte of metal a cincel; siempre que se fornente esta profesión, rendiríam el duplo que ahora nuestros minerales.

No obstante, estoy bien cerciorado que antes de dividirse el Vixreinato, conducía a Lima cada correo de los 18 anuales que corrían la posta, de doce a catorce arrobas de oro, cuyo valor intrínseco, regulado por 128 pesos, importa más de un millón-de pesos, fuera de las porciones que sc llevan a España, en pasta.

En este nuevo distrito cae la mayor parte de los minerales de oro, ${ }^{253}$ y aunque computamos solamente la mitad de los productos que acabo de refexir, corresponde a más de medio millón de pesos. De manera que, llegándose a fomentar con buen tino nuestras minas, debe creerse que montarán las sacas a cercea de un millón de pesos, y si se tiran buenas medidas para los rescates, según el actual estado del Reino, rendirá seguramente la Casa de Moncda de Potosí, cerca de treinta mil pesos de utilidades al año en la labor del oro.

En suma, cuando el Tribunal de Mineria arreglase el trabajo con economía, libre de violencia, premiando a los que se aventurasen en esta profesiôn, se descubriría seguramente las riquísimas minas de oro y plata que los indios tienen encubiertas por huír del trabajo y por reservarlas para la venida del Inca, a quien esperan por una superstición criminal nacida de su ignorancia y de la falta de trato en los desiertos nonde viven, según Solórzano y Herrera. ${ }^{254}$

Párrafo cuarto. - Minas de
Cobre. $\begin{aligned} & \text { Wa, que es de finísimo cóbre } 255 \text { y el único } \\ & \text { que sirve para las aleaciones de platas en }\end{aligned}$ esta Casa de Moneda. Hay fundición, pero no se saca cuanto puede producir la mina; porque solamente se dedican a su labor algunos pobres que no tienen otro empleo.

En el mismo Partido se halla también otro mineral de cobre, llamado Conchi, aunque no es $\tan$ abundante ni tan bueno como el antecedente. 
El mejor de todos los cobres de este Departamento, es el de Zarvicoya, en el territorio de Oruro. Es metal muy puro y muy fino, de que se valen en esta Casa para las ligas de oro, porque el de Escapa sólo sirve para la plata. Su costo en las minas es acomodado; pero como es preciso afinarlo para las aleaciones, viene a importarle al Rey, cerca de 40 pesos el quintal, después de todas las operaciones.

En otros lugares también se encuentran minas de cobre, que pudieran fructificar mucho si se trabajasen; pero, las de arriba son las más celebradas y las más útiles.

Párrafo quinto. - Estaño y U $_{\text {I }}$ cerro de Huanuni, en el distrito de Plomo. Oruro, produce el estaño más lico y el más estimable, no solamente en estos Reinos, sino también por las naciones extranjeras; de suerte que entre ellas es tan conocido Huanuni, por su estaño finísimo, como Potosí por su plata.

Lo que tiene de particular es que sale la pasta purisima de la simple fundición de los metales, sin necesidad de magistrales ni de otros materiales más que el carbón para las quemas.

El cerro es muy empinado; tiene las bocaminas en lo superior y sacando allí las botas de metal, las arrojan para abajo, de suerte que rodando van a parar a las mismas cuadras de la hacienda, sin impender gastos de acarreo.

Don Alonso Barba, ${ }^{256}$ testifica de otros dos minerales de estaño: uno, cerca de Chayanta; y el otro, un cuarto de legua de San Bernardo. No sé el estado del primero; pero el segundo, me consta que no existe en el día. 257

También hay en otros lugares no muy lejanos, de donde lo traen a esta Villa, para la Casa de Moneda, por el ínfimo precio de veinte reales el quintal.

Cualquiera que tenga algún conocimiento de los inmensos gastos que ocasionan los trabajos de minas de plata y oro, y lo expuestas que son a perderse las vetas, con absoluta ruina del minero, conf́esará de buena fe que nos haría mejor cuenta labrar las de estaño, cobre y plomo, así porque rinden más por su mayor abundancia, como por sus menores costos.

Lástima es que, por un alucinamiento inapeable, nadie que tenga alguna conveniencia quiere fomentar estas labores; porque están criados en el error de que valiendo un quintal de plata por doscientos de estaño, importa más trabajar en la plata que en el estaño; sin advertír que, con la mitad de lo que gastan en un quintal de plata, sacan trescientos de estan̄o, y ganarán a más de su valor la otra mitad del costo que ahorraren.

El nuevo establecimiento nacional que se va a hacer de las minas de este Reino, debe velar en destruír esta perjudicial preocupación, entablando algún comercio fructuoso del estaño y cobre, en cambio del hierro y acero, o de otros metales que necesita traer de Europa, para las operaciones de la minería. Entonces tendrán más salida estos metales, y con el provecho a la vista, se emplear'á en su labor otro tanto más número de gentes, que ahora reposan en la ociosidad o viven de robar en las minas de oro y plata, viendo que son las únicas que se estiman en el país. 
Párrafo sexto. - Azufre, sa- Articulo 1". Azufre. - En San Juan litre, Caparrosa, Alumbre, Sal, de Tagua, anexo del Curato de Llica en el Bol Arménico, Mármol y A- Partido dé Lípez, hay un cerro mineral de zogue. azufre, de donde lo sacan en tanta abundancia los indios, que de allí sólo surten las Provincias inmediatas, a tan bajo precio, que por una carga de cuatro arrobas, of recen en Potosí, de ordinario, doce reales y a lo sumo dos pesos.

El cerro de Collu-michi, (que significa Cerro del Gato) también es abundantísimo de vetas de azufre, de dos calidades: el uno amarillo, y el otro color de caña, que es el mejor para la pólvora.

Fn el mismo lípez, hay cuatro volcanes en el paraje que llaman Caisa, los cuales producen también algún azufre entre sus erupciones. $Y$ de todos estos minerales se ha de entender que habla Barba, 258 que dice que hay mucha abundancia en Lipez, sin citar parajes.

Articulo 2:. Salitre. - En un lugar llamado San Juan de Chujcha, ${ }^{25}$ anexo de San Cristóbal de Lipez, y en otro paraje nombrado Calcha, del mismo Particlo, hay tanta abundancia de salitre, que con la pólvora que allí fabrican todos los indios, surten a todos los minerales de Chichas, Porco y Guantajaia. Venden de dos calidades, y la superior es excelente para la cana, y stl precio no excede dos reales la libra.

Articulo 3". Caparrosa. - En Atacama hay un cerro rico de caparrosa, que se divide deste Calama, 29 leguas de Cobija. También la hay en Lípez, muy azul, y la Ilaman picdra-Lípez, por el nombre de su Provincia, a diferencia de la de Atacama, que es algo verdosa. ${ }^{260}$

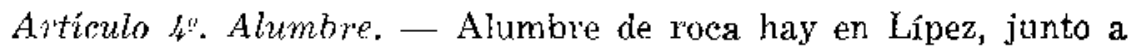
Colcha $y$ cerca de la Ventilla, camino de Oruro para Chayanta. También hay en la Provincia de Porco. Pero sólo se chcuentra en la Ventilla el seisile o alumbre de pluma, que se tiene por tal en las boticas. ${ }^{261}$

Articulo 5p. Sal. - En Lípez y en Salinas que llaman de GarciMendoza, hay una llanura de sal cristalina, cuya travesía, por lo más corto, tiene 16 leguas de ancho y 40 o más de largo. Cuatro leguas de las minas de San Cristóbal de Achocalla, en los Lípez, hay una laguna pequeña ctyya agua se convierte en sal colorada. A siete leguas de Potosi, están las minas de Yocalla, tan abundantes de sal, que gastándose inmensas porciones desde su descubrimicnto, se conservan hasta ahora. ${ }^{262}$

Artículo $6^{\prime \prime}$. Bol Arménico. - En el Cerro de Potosí, hay diferentes vetas abundantísimas de Bol Arménico, más fino y más excelente qưe el de Armenia. Las boticas de esta Villa se surten a tan bajo precio, que una arroba apenas les cuesta 7 reales; y los que no quieren comprarlo, envían dos o tres indios al Cerro y traen otras tantas botas de esta preciosa tierra, por 4 reales de la conducción. También hay en Oruro, pero no sé si será de tan buena calidad. ${ }^{263}$

Si estas gentes no vivieran tan ciegas con la plata y el oro, falsamente persuadidas de que en el mundo no se hace aprecio de otra cosa, se dedicarian a extender este material entre las demás materias de comercio del Reino, y sin duda estorbarian la concurrencia del bol que traen de Armenia, así por su menor costo como por su mejor calidad. 
Es claro to que ahora pierde el Rey en los derechos que adeudaría la contratación de este género, y esta Provincia también se priva de los productos que le acarrearía este cambio. Sólo el Gobierno pudiera promover en el día semejante comercio, aunque llegará tiempo en que hagan empleo de bol arménico, cuando estos reinos se pueblen más de lo que hoy están y no puedan subsistir todos de las minas.

Artículo $7^{\circ}$. Mármoles o jaspes. - En Atacama los hay en abundancia, hermosísimos, en grandor admirable, matizados de bellos celajes, salpicados de verde, verde-amarillo y blanco. En los años pasados se han llevado a España, donde han hecho grande estima por su particular belleza.

En Berenguela de Pacajes, hay otra clase de mármoles muy transparentes, que aquí se conocen por piedra de Berenguela. ${ }^{264}$ Antiguamente se servian de elias en lugar de vidrieras para las ventanas, que por su mucho consumo eran muy aprcciadas. En las claraboyas de las Iglesias, se ven hasta ahora estas piedras, como monumentos de la falta de policía del siglo pasado, y según el tamaño que se divisa, la mayor no excede de una vara en cuadro.

Si en estos países hubiera gusto, veríamos bellas fábricas de mesas y otros utensilios de esta materia. Entonccs tuviéramos artesanos hábiles que se emplearan en este ramo de industria, y muchos infelices que ahora perecen de miseria por no tener destino, hallarían más proporciones para buscar la vida.

Artículo 89. Azogues. - En otro lugar ${ }^{265}$ referí por menor los parajes en que se han descubierto varias muestras de azogue, con fundadas esperanzas de encontrar otro mineral como Guancavelica. Pero todo se ha quedado en relación y en deseo.

Párrafo séptimo. - Del domi-
nio de las Minas.

$\mathbf{E}_{\mathrm{I}}$

moderno Gamboa 266 dispufa largamente sobre el dominio de las minas, alega todas las leyes del Reino ${ }^{267}$ que deciden su incorporación a la Corona, y después de fundar que no se enajenaron de elias, por haberse declarado común en la ley de Indias, ${ }^{268}$ como opinó Lagúnez, ${ }^{269}$ concluye, que aunque Su Majestad las concedió a todos sus vasallos para que pudieran descubrirlas, labrarlas y beneficiarlas, no fue por traslación absoluta de dominio, sino por participación, quedando el alto dominio en el Rey.

Para absolver las dudas que suscitaron estas opiniones, declaró últimamente la nueva Ordenanza de México, ${ }^{270}$ que todas las minas eran propiedad de la Real Corona, así por su naturaleza y origen, como por su reunión dispuesta en la ley 4 , título 13 , libro $6^{\circ}$ de la nueva recopilaciôn. $\mathrm{Y}$ sin separar las del Real patrimonio, ni abdicar el dominio radical de ellas, las concede a los vasallos que las descubriesen, en propiedad y posesión, 271 bajo las condiciones de pagar los derechos establecidos y de labrarlas conforme a Ordenanza, pena de su perdimiento. ${ }^{272}$

Dos siglos antes había declarado ya la Ordenanza Primera, título $1^{\circ}$, libro $3^{\circ}$ del Perú, ${ }^{273}$ que todos los minerales son propiedad de Su Majestad y le pertenecen como derechos realengos. Por lo que en este Reino jamás se ha dudado de esta regalía, sin embargo de la doctrina de Lagúnez. 
Pues, amuque la ley 1 , título 19 , libro $4^{\circ}$ de Indias, recopilata de dos Cédulas de 1526 y 1568 , permite a los vasallos de estos dominios, descubrir $y$ beneficiar las minas, con la expresión de que sean comunes a todos, esto no quiere decir que se hayan separado del patrimonio Real, quedando sujetas a la adquisición particular del que las descubriere, como las marguritas, corales, perlas y otras cosas que se las apropia absolutamente el descubridor que las encuentra en las orillas de los mares. ${ }^{274}$ Sólo significa que cualquiera tiene libertad de buscarlas, sin exclusión de ninguno; porque según refieve Herrera, $2: 5$ so motivó esta ley de que los Oficiales Reales prohibían que descubriesen minas, dando licencia únicamente a quienes ellos querían.

Conforme a esta interpretación en nada se opone a nuestra Ordenanza el verdadero espíritu de la ley, ni ha declarado cosa nueva la Ordenanza de México, si no es la denominación de "dominio radical" al derecho realengo que simpre se le reservó a Su Majestad en las minas de este Reino.

Pero, como por otra parte se conceden los minerales en propiedad y posesión, con tacultad de enajenarlos por cualquiera de los modos conocidos en Derecho Civil, conviene explicar las funciones de este dominio reservado al Rey, quc Gambaa Jama "alto dominio", para que no se juzgue que es regalía de puro nombre.

Este artículo quedasá suficientemente absuelto con el ejemplo de la concesión que suelen hacer los Reyes de algunas tierras, transfiriendo en el vasallo toda sa propiedad y jurisdicción, con mero y mixto impejio. En este caso no hay duda que en las tiemas enfeutadas, no puede el Sobclano poner mano en todo lo pertencciente a utilidades pecuniarias, como son gabelas, multas, penas, confíscaciones y otras de esta clase, porque el reudatario tieno adquirido el dominio y posesión útil en todas las condiciones respectivas, 2 it

Sin embargo, queda siempre reservada al Soberano la propiedad superior $y$ ol clerecho dol alto y supremo dominio en las tierras enfeutadas, 'ii por poder él sólo, y no el feudatario, acuñar moneda, legitimar los bastardos, ocupar los bienes vacantes, imponer nuevos tributos, y asi de las demas regalias tocantes al supremo dominio. ${ }^{278}$

Del mismo modo, el descubridor de minas adquiere la propiedad subalterna y la poscsión útil, en virtud del registro, para disfrutar él sólo todas las utilidades y provechos, sin quc el Rey pueda percibirlos, ni prohibir que los ceda a otro, por venta y por los demás títulos del derecho.

Pcro el Rey, que es el dueño absoluto de todos los minerales de sus Estados, retiene en sí la propiedad superior o el alto y supremo dominio, que llama radical la Ordenanza, ${ }^{279}$ para imponer las condiciones convenientes al buen uso de las minas, para suceder en las que vacasen por defecto de sucesor dentro del grado asignado por ley; para caducar las que no se trabajaren según los reglamentos de minería, para adjudicarlas a otro; para establecer sobre sus frutos los derechos que parecieren justos; para aumentar o disminuír las pertenencias; y para otras mil cosas que serír molesto cl peferiu. De donde se viene a concluír, que la propiedad $y$ la posesión que la Ordenanza concede en las minas del Reino, es una propiedad subalterna y se entiende de la posesión útil, sin perjuicio de la superior propiedad o aito dominio del Rey, que es propiamente radical, como lo intitula la Ordenanza. 


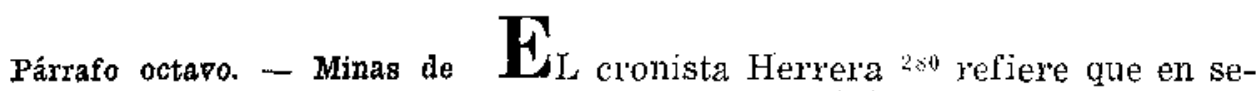
$\mathrm{Su}$ Majestad. nal de superior dominio (que se acaba de explicar), mandaron los Reyes Católicos, por los años de 1507, que todos los vecinos españoles que hallasen veneros, gozasen de ellos por un año, sin que en este término se les pudiera quitar, y que después los tuviesen por el tiempo de la voluntad del Rey, salvo tres cerros ricos de aquella Isla, (?) que debían quedar reservados para el real patrimonio.

En las Ordenanzas posteriores del Sr. Don Felipe 11 , se perpetuó esta concesión a beneficio de los descubridores, con la cláusula de que, por parte del Rey, ni por otra persona alguna, se les pueda ocupar, embarazar ni impedir Jas labores, exceptuando ${ }^{281}$ las minas del Guadalcanal, Casalla, Aracena y Galarroca, para aprovechamiento de la Real Hacienda. $Y$ en efecto, se han arrendado de cuenta de ella, en todos tiempos, principalmente la del Guadalcanal, ${ }^{28}$ que por ser la más rica, ha tenido siempre más interesados. Se sabe que los Fúcares la dejaron inundada de agua, en el año de $1635 ;{ }^{233}$ mas no por eso se ha abandonado su labor, pues, Antonio Pons 284 certifica que al tiempo de escribir su Viaje, se trabajaba con utilidad; y Don José Nicolás de Arana, en las sabias notas con que ilustró la Ilistoria Natural de Bowles, ${ }^{2} \times 5$ asegura que hasta el año de 1782, se hallaba empeñada er su beneficio, con permiso del Rey, una compañía de extranjeros, aunque por entonces todavía no habían podido dar con la veta.

Sin perjuicio de estas reservas, se ordena en la ley 5 , capitulos 22 y 75, título 13 , libro $6^{\circ}$ de Castilla, y en su conformidad, en las Ordenanzas del Perú, 286 que en cada descubrimiento se señale para Su Majestad, una mina de 60 varas, en las de plata, y en las de oro, de 50 varas de largo y 25 de ancho. ${ }^{287}$

Este derecho pertence a S. M., fuera de los quintos, y es tan considerable, según Escalona, ${ }^{288}$ que de sólo la mina de Conchuco, administrada por Don Francisco Tello de Guzmán, se enviaron a España en los galeones, el año de 1644, seis mil trece marcos de plata en piña, que importaron cerca de 50.000 pesos fuertes.

También estoy enterado que en estos últimos años se vendió una estaca-mina del Rey, en el mineral de Pasco, en 14.000 pesos; otra del asiento de Aullagas, en la Provincia de Chayanta, se remató, ahora 10 o 12 años, en un vecino llamado Don Antonio Almandos, en 600 pesos; y otra más por 1.000 pesos en el Capitán Don José de Andrés Sanz, de cuya boca sé, que después de haberla disfrutado sacando más de 30.000 pesos, la vendió muy rogado en 21.000 pesos fuertes.

Mucha mayor admiración causaría el sumar las cantidades que han entrado en Cajas Reales, por cuenta del Rey, de las estacas-minas señaladas a Su Majestad en este Cerro de Potosí, en las vetas principaJes del Estaño, Antora, Ciegos, Zenteno, Zúñiga, Veta-Rica, Flamen$\cos$ y Corpus-Cristi; ${ }^{289}$ porque siendo cierto que en los primeros años del descubrimiento, cada quintal de tierra rendía medio quintal de plata, debemos creer que las estacas de Su Majestad (que deben ser las mejores), producirían otro tanto, o que, en el caso de no administrarse, se vendiesen a proporción de esta inmensa riqueza.

Es verdad que, en el día, son muy raras las estacas que se ava- 
lúan en más de 50 pesos; pero esto procede de dos causas. Es. la primera, que los descubrimicntos se hacen, de ordinario, en veneros de corta ley; y la segunda y principal es, que no se procede en cstos remates con toda la escrupulosidad necosaria, pues, no se encontrará en ninguno de cuantos se han practicado hasta ahora, que antes de sacarlas al pregón para venta o para arrendamiento, se haya examinado y reconocido por perjtos la calidad, naturaleza y ley de los metales, para admitir en este conocimiento las posturas y pujas, como se ordenó en Real Orden de Madrid, a 13 de marzo de 1762, explicando el método en que debía observarse la ley $2^{\prime}$, título 11 , libro $8^{\circ}$ de Indias, que trata de las minas de Su Majestad.

Según Ia creencia en que vivimos sobre fundamentos muy graves de experiencia, se debe esperar que con el tiempo se hagan descubrimientos portentosos de otras minas más ricas que las que actualmente so benefician, como lo vemos verificado en el caudaloso mineral de Guantajaia, muy posteriox' a P'otosí.

En tal caso, serún muy pinguies los productos de este ramo, si se observan con exactitud las reglas de la antecedente Real Ordenanza; y pudiera afirmar sin temeridad, que no serian cortas las entradas, en Ia actual decadencia de las minas si se manejara este asunto con el celo debido.

Lo cierto es que yo no encuentro razón para este descuido, a vista de que, habiendo reservado Su Majestad para sí, la mina más rica de España, que es o fuc la del Guadalcanal, 290 con una legua al rededor, ha querido mostrarse más liberal con sus vasallos de América, contentándose con una sola estaca en cada descubrimiento, con absoluta cesión de las sucesivas a beneficio gratuilo de los que quisieren registrarlas.

No ignoro que en Nueva España no tiene el Rey semejantes estacas, 2y! y que a este ejemplo se pretenda por acá establecer lo mismo, olvidando por medio del descuido, una regalía tan justa como antigua; pero como las leyes de uste Reino se hallan en su vigor en este punto, no alcanzo la razón en que se quiera apoyar la necesidad o la conveniencia de su derogación.

Nada prueba en contrario el ejemplo de México, porque allí ha tolcrado el Rey la inobservancia de esta regalía, tal vez por motivos muy justificados que aquí no militan. Sólo puedo decir, que es sobre manera notoxio aquel caso de la riquísima mina de Morcillo, en Michoacán, que Ios Oficiales Reales no contentos con los quintos, se la quitaron al dueño y adjudicaron toda al Rey; ${ }^{242}$ y no estoy lejos de persuadirme que por evitar otras mayores usurpaciones con mejores pretextos, habrá querido privarse el Rey de las rentas de este opulento ramo.

Artículo Unico.- Situwción, privilegio y medida de la EstacaMina del Rey. - En la Ordenanza 37 del Presidente Gasca, se mandó que el descubridor señalase mina para Su Majestad, en la mejor parte de la veta, y que se pudiera mejorar dentro de dos meses, sin fijar sitio ni determinar otras particularidades condrcentes a quitar dudas.

Por este motivo, declaró el Sr. Don Francisco de Toledo, ${ }^{293}$ que cuando se hiciere el descubrimiento en cerro nuevo, se señale la mina de S. M., entre la descubridora y la salteada, para que por este medio se coloque la del Rey en el mejor lugar, pues habiendo de sucederle inmediata- 
mente la salteada, es regular que, por su propio interés, escoja el descubridor el paraje ventajoso para colocar la mina de Su Majestad.

Pero cuando el descubrimiento fuere dentro de la legua donde el descubridor no puede tomar más que una mina de 60 raras, y por lo mismo, no tiene interés que le mueva a escoger la mejor parte para Su Majestad, dispone otra Ordenanza, ${ }^{294}$ que en este caso, se le señale mina hasta el lugar donde escogiere el primero de los registrados; de modo que quede entre la descubridora y la del primero que hubiere pedido y registrado mina en aquella veta. $Y$ si esto no se hubicra verificado, entonces debe jurar el descubridor que la mina que señala para Su Majestad, es la mejor que le parece después de la que elige para sí, para evitar fraudes; porque nadie como el descubridor entenderá cual es lo mejor dè la veta, y se debe presumir que elige para si el lugar más caudaloso.

Es muy fácil defraudar esta Ordenanza, sin embargo de las penas impuestas contra los estacadores que entre sí tuvieren algún concierto para que la mina de Su Majestad no esté en el mojor lugar; ${ }^{295}$ porque a más de fundarse todo sobre fe humana, cs impracticable el denuncio del engaño, habiendo intervenido compromiso de los misnos interesados; y así aconseja el Licenciado Montesinos, ${ }^{296}$ que es más provechoso y útil a Su Majestad, y suave a los mineros, que se pueda mejorar dentro de dos meses la estaca-mina del Rey, según la Ordenanza del Presidente Gasca.

Lo dicko de la mina de Su Majestad, que se hiciere dentro de la legua, se entiende en tantas, cuantas vetas se descubricren, de suerte que, en cada una se debe señalai estaca de 60 varas para Su Majestad, como Jo insinúa la Ordenanza 13, título $1^{\circ}$, libro $3^{\circ}$ de las Generales del Perú. $Y$ lo mismo se debe ejecutar en las minas antiguas ciegas, que nuevamente se descubrieren, según la Ordenanza 10, del propio título y libro.

Este derecho reajengo participa del mismo privilegio que gozan todas las regalías, para no perderse por tiempo, siguiendo la regla general de que la omisión de los Ministros no debe perjudicar al Rey. ${ }^{297}$ Por cuya razón, aunque no se labren, beneficien o pueblen las minas de Su Majestad, nunea se puede pedir por despoblados, como lo dispuso la Ordenanza 37 de Gasca, y la 15 del Sr. Toledo, en el título $7^{\circ}$ de los despoblados, libro $3^{\circ}$ del Perti. ${ }^{298}$

Aunque las Ordenanzas del Reino sólo hablan de las minas de plata, se deben guardar también con las de oro, en cuanto al modo y forma de señalar mina a $\mathrm{Su}$ Majestad, ${ }^{299}$ con da diferencia do que, cn lugar de 60 varas que debe tener la mina de plata, ha de ser 50 de largo y 25 de ancho en las de oro, conforme a la ley real de Castilla. 300

Acerea de las minas de azogute, se permite igualmente a todos el descubrimiento libre de ellas, concediendo al descubridor una de ochenta varas, como en las de plata, por el término de 30 años, con absoluta incorporación de todas las demás en la Corona real, bajo la calidad de vender al Rey todo el azogue que sacare de su mina. ${ }^{\text {s01 }}$

La Nueva Ordenanza de México, ${ }^{302}$ concede Ia misma libertad, pero no declara menudamente la incorporación y demás circunstancias en la del Perú. Sólo previene que ha de quedar a disposición de los superiores, el trabajarlas de cuenta del descubridor particular o por la del Rey, dándose en cambio algún premio equitativo. Por cuyo motivo, se deberá explicar una Ordenanza por otra, sin omitir jamás la adjudicación 
al Rey, de todas las demás minas de azogue que se hallaren en la veta o cerro, salvo la descubridora.

No obstante que se deben guardar cstas mismas reglas en todos los minerales referidos en los artículos del Párrafo $5^{n}$ precedente, en e] Reino sc observan solamente en los de plata, oro, azogue, cobre, plomo y estaño, quedando absolutamente franco el trabajo de las demás minas de sal, salitre, azufre, etc., sin formalidad de Registros, ni obligación de señalar estaca-minas a Su Majestad.

Párrafo noveno. - Modos de adquirir las Minas,-- Sección 1": De los nuevos descubrimientos. Del número de minas permitido a los primeras descubridores, De los Registros. De los Pozos de Ordenanza. De las estacas y su mejora.
A A vos. - Los nuevos descubrimientos son en tres maneras. La primera, de cerro absolutamente nuevo, en que no hay ninguna mina ni cata abierta, 303 o de aquellos que habiendo sido antes registrados, los hubieran desamparado del todo por término de tres meses. ${ }^{304}$ La segunda, de veta nueva en cerro conocido y ya trabajado en otras partes. ${ }^{305}$

La tercera, de metal fijo en minas antiguas, ciegas y ocultas con los desmontes. ${ }^{306}$

Aunque en todos estos casos compete el derecho de descubridor, ${ }^{307}$ no están conformes en cuanto al número y medidas de las minas, las Ordenanzas del Perú con las antiguas de Castilla y la nueva formada para México en 1783. Así, explicaré los casos distintamente, por las tres maneras referidas de nuevos descubrimientos por el orden de cada Ordenanza, declarando los puntos dudosos, para que no se of rezcan dudas en su inteligencia.

Artículo 2. Número permitido de Minas. - El primer descubridor no ha gozado jamás en el Perú más que de dos minas en una misma veta. La primera, de $8 \theta$ varas de largo con 40 de ancho, y otra que llaman la salteada, de 60 varas de longitud y 30 de latitud, 308 moderando a las 100 varas de largo y 50 de ancho, que concedían las Ordenanzas antiguas de Castilla, ${ }^{309}$ y mucho más las 120 varas de longitud y 60 de latitud, que asignan las modernas. 310

Pero, últimamente, aumentó la nueva Ordenanza de México, ${ }^{111}$ 200 varas todas las medidas, concediendo en la veta principal de cerros absolutamente nuevos, tres pertenencias continuas o interrumpidas, con más una pertenencia en cada veta de cuantas se descubrieren en el mismo cerro, ${ }^{312}$ y en la veta nueva de cerro conocido, dos pertenencias en la misma forma que las antecedentes. ${ }^{313}$ Con lo que corrigió las Ordenanzas antiguas de Castilla, ${ }^{314}$ que limitaban el privilegio del primer descubridor a solas dos minas en una veta, como también las modernas, que le concedieron 315 tener cuantas minas quisiera; quedando sin efecto desde la publicación de esta nueva Ordenanza, la doctrina de Gamboa, ${ }^{316}$ que extendía el derecho de descubridor, para poder tomar y disfrutar toda la veta, haciendo estacas en cada mina, con tal que tuviere en todas ellas el pueble necesario.

Aquí no distingue la distancia en que debe hallarse el cerro conocido donde se hubiera descubierto veta nueva, para que competa el privilegio de descubridor, como lo ejecutó la Ordenanza del Perú, ${ }^{317}$ seña- 
lando el espacio de una legua, con reforma de otra anterior del Presidente Gasca, que no admitía el derecho de nuevo descubrimiento, en el término de legua y media.

Tampoco determina número cierto de las minas que puede poseer el descubxidor, ni dispone cosa alguna sobre las demasías en este punto. 318 Conformándose con las Ordenanzas del nuevo cuaderno, 319 que permitieron cuantas quisiere labrar el descubridor, para promover los nuevos descubrimientos, sacar de ellos los partidos posibles a beneficio del Fistado y precavez que los vasallos desengañados de no poder gozar las que excedieren el número señalado, se abstengan de hacer otros nuevos y tal vez oculten algunas minas de las más ricas.

La Ordenanza del Perú anduvo más prolija en todas estas incidencias, pero necesitan de explicación para aclarar cicrtas apariencias de analogía que se notan en ellas. En el título de las demasías ${ }^{320}$ se ordena que el descubridor del cerro nuevo o de veta nueva dentro de la legua, teniendo las minas que concede la Ordenanza, 321 disponga de las demasías, dentro de dos meses contados desde que hiciere estaca fija. Al mismo tiempo, previene en el título de los Descubridores, ${ }^{222}$ que a quien debiere pagar el derecho de tal, no se le cuenten las minas que tomarc, en el número de las que señala la Ordenanza, ${ }^{323}$ como si dijora que al descubridor no se le tasa número de minas y que puede tener todas cuantas descubriere, para que no se impidan ni estorben los descubrimientos, según la expresión gencrosa de otra Ordenanza "ž. del Pcrú. Con que, siendo cierto que no hay demasias sino donde hubiere número fijo, cntenderá desde luego cualquier Gobernador laico, que se contradicen las Ordenanzas precedentes en proveer sobre demasías, en los casos de nuevo descubrimiento, cuando entonces no se limila el número de las minas que puede tener el descubridor.

Realmente, no hay contradicción: porque la Ordenanza que trata sobre demasías, habla de las minas que el descubridor pucde poseer; y la que dispone sobre el privilegio de los descubridores, se contrae a las que éstos pueden adquirir. Io uno mira al provecho del descubridor, y lo otro al beneficio del Rey y del Estado. El fín de la Ordenanza no es quitar lo que puede adquirir uno, y cada uno puede tener y poseer lo que cómodamente pueda labrar; ${ }^{825}$ y así, cuando se dice, que al descubridor no se le deben contar las minas que hallare, ni señalarle número en ellas, se entiende por lo que es poder adquirit cuantas descubriere; pero no siendo posible poblar todas juntas, se les conceden sólo doce minas, (que son las que cómodamente, se presume, puede labrar), para que posea cste número y no más, con facultad de vender dentro de dos meses las que sobraren, pena de adjudicarse al que las pidicre por demasf́as; de suerte que el señalamiento de número, es únicamente para la posesión o goce, y la libertad de tener cuantas minas se descubrieren, toca a la adquisición.

Desde luego, tuvo motivo justísimo la Ordenanza, para quitar aI descubridor las minas que no pudiere labrar, porque el fin principal de haberlas concedido Su Majestad, fue el aprovechamiento de sus reinos $\mathrm{y}$ vasallos $\mathrm{y}$ el acrecentamiento del real patrimonio con los quintos y derechos que resultan de la labor'; ${ }^{326}$ pero la razón en que se funda el senalamiento de número, es meramente presuntiva, y como tal no puede ser universal ni permanente para todos los casos; pues, aunque en lo ge- 
neral, no se puedan labrar cómodamente más minas que las doce asignadas en la Oxdenanza, es innegable que podrá poblar duplicado número un hombre poderoso, inteligente y sabio en materia de minas, si quisiere emplear todo su caudal en trabajarlas.

En esta Villa tuvimos el ejemplar en el célebre Quiroga, que tuvo minas en el Cerro Rico, in Andacaba, en Lípez, Chocaya y Aullagas, donde gasto muchos millones, y a no ser así, no es creible que pudiese haber pagado al Rey reintinueve y medio millones de quintos. De suerte que este vasalio sólo, fue para el Rey y el Estado, más útil que treinta o cuarenta de otros menos acomodados.

Sin duda, esta fue la razón porierosa de no haber querido deterninar número de minas a los descubridores la nueva Ordenanza de México: es verdad que asi en aquel Reino como en este, se concedieron las minas para labiarlas; mas, como la extensión de las labores depende de la posibilidad de los descubridores, dejó sabiamente que el suceso del trabajo reterminase el númrero; esto es, que al descubridor se le quite por título de despoblado, y no por demasías, todas las minas que abandonale $y$, por falta de labor, quedarch desiertas y despobladas el tiempo de un año y un cía. ${ }^{32}$ De manera que, al mismo paso de promover los descubrimientos con la libertad y alentar empleo de hombres acaudalados en la labor de minas, también sostiene el fin de las concesiones, no permitiendo que se posean más que aquellas que se trabajaren real y efectivamente.

Conforme a este nuevo sistema, no se debe atender que los nuevos descubrimientos se hagan dentro o fuera de la legua, porque verificándose a cualquiera distancia del asiento principal, siempre que sea de cer'ro nuevo o de veta nueva en cerro conocido, o de minas antiguas ciegas, ${ }^{32 s}$ competa el derecho de descubridor.

Esto se prueba de la generalidad con que se explica la Ordenanza, siendo regla de dexechó, que donde la ley no distingue, tampoco debemos distinguir nosotros. ${ }^{329}$ Persuade lo mismo el artículo 4, título 7, donde, después de prohibir a los mayordomos o sirvientes de minas, que denuncien otras para sí, en mil varas en contorno de las de sus amos, concede el registro de cualesquiera, en siendo para éstos; que fue habilitarlos para poder tener como descubridores todas las que encontrasen, aunque diste sólo un paso la una veta de la otra, según explica Gamboa, ${ }^{330}$ quedando reformada la Ordenanza del Sr. Toledo, ${ }^{381}$ que no concede el derecho de descubridor sino en los descubrimientos fuera de la legua.

De todo lo cual, procede que no se debe observar la Ordenanza $1^{\text {a }}$, título 10, libro $3^{\circ}$ del Perú, 332 en cuanto a la obligación de vender la mina salteada en los descubrimientos que se hicieren de algunas antiguas y ciegas, dentro de la legua; porque en este caso, compete el derecho de verdadero descubridor ${ }^{333}$ y no se debe atender la distancia sino el privilegio.

Las mismas disposiciones referidas para con las minas de veta, en cuanto a número y medidas, se deben guardar también 334 con los mantos, ${ }^{335}$ placeres, criaderos, rebosaderos, ${ }^{336}$ sombreros ${ }^{337}$ y lavaderos, ${ }^{338}$ sin distinción de espeñoles a indios, por considerarse de igual condición todos los vasallos para los privilegios y efectos de los descubridores.

Así lo induce la Ordenanza de México en su generalidad, ${ }^{339}$ y por más que la Ordenanza $5^{2}$, título 1 , libro $3^{\circ}$ del Perú, haga diferencia en- 
tre unos y otros, $y$ aun entre los mismos, la clase de principales, mandones, indios comunes, se debe seguir la nueva legislación para alentar con el premio el espíritu nacional del indio, convertir su pereza en diligencia y contener los funestos efectos que ahora produce su malicia, ocultando de propósito minas ricas, para que los españoles no las disfruten, una vez que ellos no las pueden gozar; con lo cual se cebará también su genio codicioso y por el interés propio olvidarán aquella supersticiosa y ridicula manía que refiere nuestro Solórzano, ${ }^{30}$ de guardar para cuando resucite el Inca, todas las minas caudalosas de que tienen noticia los indios del Perú. ${ }^{341}$

1.-- Parte $2^{*}$, Cap, 1 , Noticia 1".

2.- Escalona: en su Gazophilacio, libro 1", Cap. 46, No. 65, fol. 196.

3.-Ley 2, título 1, Parte 1".

4.-E] título 16 de la Ordenanza de México, puede ser modelo para extender los avios del Banco de Potosí.

5.- Cédula Real de 25 de dicjembre de 1594, dirigida al Marqués de Cañete; otra de 11 de agosto de 1596, cometida a Don Luis de Velasco, mandada guardar por el Sr. Virrey Marqqués de Guadalcázar, en provisión de 28 de septiembre de 1624. Ordenanzas $1^{\text {a y }} 2^{2}$, título 11.- Ordenanzas $1,2,3,11$, título 13 , libro $3^{\circ}$ del Perú.- Ley 30 , título 12 ; ley 18, título 13; leyes 5 y 7 , título 15 , libro $6^{\circ}$ de Indias. - Solórzano: in Politica; libro 2", Cap. 18... Véase capítulo de la Mita, en la parte 1 .

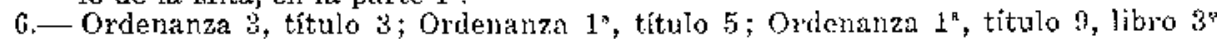
del Perú.

7.- Si la riqueza del mineral merece atención, debe disponer el Superintendente el mejor método para su asiento, provisión de víveres $\$$ materiales, y cobranza de los reales derechos, conforme a las leyes $1,2,9$ y 10 , título 1 , y ley 4 , títuio 20 , libro $4^{\circ}$ de Indias. Pero, en cuarto al establecimiento de Caja Real, ensaye y callana, toca a la Junta Superior, según la nueva Ordenanza de Intendentes.

8.- En Provisión de 15 de septiembre de 1617.

9.- En Provisión fechada en Lima, a 9 de agosto de 1726.

10.- Parte $1^{7}$ de este libro, Cap. 3, Noticia $1^{*}$, fol. 63 ; y Noticia $2^{4}$, fol. 69.

11.- Los casos que varios Virreyes han nolubrado Visitadores en materia de ninas, se pueden ver en el comentario de Don Xavier de Gamboa: Cap. 25, sobre la Ordenanza 67 , No. 7 y siguientes.

12.-Ley 1 , título 11 , libro $8^{\circ}$ de Indias.

13.- Ley 9 , título 19 , libro $4^{\circ}$ de Indias.

14.- Ley 8, título 19 , libro $4^{\circ}$; título 20 , libro $4^{\circ}$ de Indias. Ordenanza 8 , título 11 , libro $3^{\circ}$ de las Generales del Pertí-- Fl Sr. Principe de Esquilache, mandó que el Cabildo ponga tasa y precio en los efectos de comercio con moderación, ya sean de indios o de españoles; y en otra providencia ordenó, que a los regatones de madera se les tome el tercio de la que tuvieren por el tanto a que la compraron en el término de 20 días.

15.- Ley 1, título 2 , libro $4^{\prime \prime}$ de Indias. Ley 3 , titulo 14 , Iibro $5^{\circ}$ de la misma Recopilación.

16.- Ordenanzas 15 y 20, título 11; Ordenanza 12, título 9, libro $3^{\circ}$; Ordenanza 30 , título 17, libro $2^{\circ}$ del Perú. Ley 12, título 19, libro $4^{\circ}$; Leyes 1 y 2, título 4, libro $7^{\circ}$ de Indias.

17.- Véase las leyes citadas en los Nos. anteriores.

18. - Ordenanzas 4, 5, 6, título 12; Ordenanza 5, título $13, y$ la adición de Lupidana, título 14, libro $3^{4}$ del Perú, Nos. 26 y 27.

19.- Ordenanza 4, título 12; Ordenanza 5, título 13, y la adición de Lupidana, título 14, libro $3^{\circ}$ del Perú, No. 6.

20 .- Ordenanza 5 , título 12 , libro 3 .

21.- Ordenanzas $1,2,3,8$, titulo 12, libro $3^{\circ}$ de las Generales del Perú.

22.-Ley 11, título 2 , Jibro $6^{\circ}$ de Indias. Ordenanzas $1,2,3,4,6$ y 8 , título 13 , libro $3^{\circ}$ de las Generales del Perú.- Reales Cédulas dirigidas a los Excmos. 
Virreyes, Don Luis de Velasco y Marqués de Mantesclaros, que están recopiladas en el título 18 , Jibro $2^{4}$ de dichas Ordenanzas; fols. 208 y 211 , Nos. 4 , $15 \mathrm{y} 18$.

23.- Solórzano: en su Política; libro 2", Cap. 18, No, 20, tomo 1", fol. 145.

24.- Solórzano: en el lugar citado; Nos. 21 y 22.

25.- Solórzano: ídem. Nos, 25 hasta 28.

26.- El mismo Solórzano: en ídem.

27.-- Solórzano: libro 2", Cap. 18, No, 29, fol. 146.

28.- Parte 1*, Cap. 5", Noticia 14.

29.- Ley 18 , título 32 , Parte $3^{2}$

30.- Gómez: in ley 46; Fauri No. 11.- Antúnez: De Donationib.; libro 3^, Cap. 4, tomo 2, No. 34.- Franchis.: Desien. 183 in adition. Mendiole, No. 6, fol. 216, tomo 1.... Cardenal de Luca: De regalibus; disc. 167, Nos, 5, 6, 7, tomo 2, fol. 287 .

31.- Fste nuevo sistema de minería proyectado en la Ordenanza de México, del año de 1783 , ha recibido su forma del Cap. 77 de la ley 9 , título 13 , libro $6^{\circ}$ de la recopilación de Castilla, en que se creó un Administrador General de Minas, con otros particulares en cada Partido, concediéndoles jurisdicción privativa, dependiente del supremo Consejo de Hacienda para entender en todos los negocios de esta clase, con inhibición de los demás tribunales y Justicias. Por lo que nos hallamos en el mismo caso, y así se ha visto comunicar las órdenes para la nueva planta de mineria, por vía de la Superinterdencia de Real Hacienda. I'or otra parte, los Fxcmos. Virreyes conocian de los negocios de minas, como Superintendentes de Real Hacienda y en este sentido entendió la ley 2, tít.ulo 1, Jibro $2^{\prime}$ de Indias. El Sr. Virrey, Arzobispo de México, Don Juan de Vizarrón, según Gamboa, dice en su comentario de minas, Cap. 25 , No. 13 , fol. 470 , con que habiendo cesado en esta jurisdicción, se debe reumir a la Junta Superior, la que antes ejercía en materia de minas.

32.- Antúnez: libro $2^{\circ}$, Cap. 29 , a No. 48, vers. 53 , tomo $1^{\circ}$, fol. 340.

33.- Aunque la ley 11 citada, señala tres meses, y la Ordenanza de México, seis, no es posible verificarto en tan poco tiempo y para no hacer injusticia, convienc conceder el mismo tórmino de la Ordenanza 22 , como bien fundada; sobra el conocimiento experimental de la posibilidad del país.

34.- Ley 9, título 19 , libro $4^{\circ}$. Ley $1^{\circ}$, título 11 , libro $8^{\circ}$ de Indias.

35.- Ley 1 , título 21 , libro $4^{\circ}$ de Indias. - Ordenanza 13, título 9 , libro $3^{\circ}$ de las Generales deI Perú.

36 - Ordenanza 16 , título 9, libro $3^{*}$.

37.- Ordenanza 12 , título 9 , libro $3^{\circ}$.

38.- Ordenanza 30, título 17 , Jibro $2^{\circ}$ del Perú.- Ley 12 , título 19 , libro $4^{*}$ de Indias. Lo dicho de rescatadores, se entiende de los que compran metales robados; pero no de aquellos que los contratan con sus dueños, a precios razonables y justos, como lo indica la ley 4, título $1^{\circ}$, libro $8^{\circ}$ de Indias; obligándolos a manifestar las platas y pagar su diezmo; en cuyo sentido interpreta las antecedentes leyes Gamboa, en su comentario de minas, Cap. 24, Nos, 11 y 12 , fol. 463 ; y es muy conforme a las Ordenanzas 15 y 16 , título 11 , libro $3^{\circ}$.

39.- Oxdenanza 1 , título 9 ; Ordenanzas $8,10,11,12$, título $1^{\circ}$, libro $3^{\circ}$.

40.- Ordenanza 2 , título 9 ; Ordenanza 2 , título 3 , libro $33^{\circ}$.

41.- Ordenanza 4, título 9 , libro $3^{\circ}$. Ordenanza $14 \mathrm{Cod}$.

42.- Ordenanza 4 al fin, título 9 , libro $3^{\circ}$.

43.- Ordenanza 3 , título 7 , libro 3 ".

44.- Ordenanzas 4,5 y 17 , título 7 ; Ordenanza 4, título 9 , Iibro $3^{\circ}$.

45.- Ordenanzas $2,3,7,9,11$ y 18 , título 5 ; Ordenanza 18 , título 9 ; Ordenanza 10 , título 11 , libro $3^{\circ}$.

46.- Ordenanzas 1 y 19 , título 9, libro $3^{\nu}$. Ley 118 , títuto 15 , libro $2^{\circ}$ de Indias.

47.- - Ordenanza 1 , título 13 , libro $3^{\circ}$.

48.- Ordenanza 3, título 3 , libro $3^{\circ}$ del Perú.

49.- Ordenanza 13 , al principio; Ordenanza 16 , título 9 , libro $3 "$.

50. - Título 14, libro $3^{\circ}, \mathrm{No} .24$.

51. - Ordenanzas $4,5,6,8,9,12$ y 13 , título 5 , libro $3^{\circ}$ de las Generales del Perú.

52. - En los 18 artículos del título 9, de la Ordenanza de México, y en el título 5 . libro $3^{\circ}$ del Perú.

53.-. También serfa convenjente que se ejecutase la Ordenanza 19, título 11, li- 
bro $3^{\circ}$ del Perú, en cuanto a obligar a los Veedores que aprueben a los mineros antes de entrar al ejercicio, de que son hábiles $y$ suficientes para el efecto.

54 - Ordenanza 13 , título 9 , libro 34.

55.- Ordenanza 5, título 11, jibro $33^{\circ}$. La adición de Lupidana No, 17, título 14, libro $3^{\circ}$. Ordenanza 16 , título 9 , del mismo libro.

56.- Ordenanzas 1 y 2 , título 3, libro $3^{\circ}$. Ordenanza 2, título 9, libro 3 .

57.- Ordenanza 4, título 8 , libro $3^{\circ}$ del l'erú.

58.- Don Fernando de Montesinos: en su Política de Minería, escrita el año de 1698 ; Cap. 3, No, 1 , fol. 27.

59.- Provisión de 5 de mayo de 1579.

60.- Ordenanzas 15, 16, 18 ; título 11, libro $3^{\circ}$ del Perú.

61.- Ordenanza 17, título 11, libro $3^{\circ}$.

62.- Ordenanza 18 citada, título 11 , libro $3^{\circ}$.

63.- Ordenanzas 18 y 19 , titulo 11, libro $3^{\circ}$ del Perú.

64.- Artículo 5, título $1^{4}$.

65.- Ley 8, título 3 , libro $5^{4}$ de Indias.

66. - Ley 6, título 10 , libro $4^{4}$ de Indias.

67.- Ley 2, título 9, ljbro $3^{\circ}$ de Castilla.

68.- Ley 3 , título 4, Parte $3^{*}$. Ieyes 1 y 7 , título 9 , libro $3^{\circ}$ de Castilla. Leyes 18 , 20 y 22 , título 9 , Parte 2 .

69.- - 玉l pobre es repelido de ser testigo, en la ley 8, título 16 , Parte $3^{\natural}$, y por la misma razón no puede ser Juez.

70.- Ley 12, título 10 , libro $4^{\circ}$ de Indias, al fin.

71. - Én la Restitución de Plutón, dirigida al Cardenal de Richelieu, que cita Gamboa, en el Cap. 12 de su Coment. fol. 232 Ňo. 17, interlin. 16.

72.- Agricola: 1) re methálica; libro $1^{\circ}$.

73.- Parte $2^{7}$, Cap. $8^{\circ}$, Noticia 3 , al principio.

74. - En provisión de 20 de febrero de 1611.

75. - Fl Sr. Principe de Esquilache, en Provisión de 6 de abril de 1621.

76. - En Potosí, no se han de nombrar los diputados territoriales, que debe haber en cada Asiento de Minas, por la mala djsposición de estos países y la despoblación de los Asientos; y la elección ha de ser solamente de los Dipntados generales, de que tratan los artículos 1, 5 y 8 del titulo $1^{2}$.

77.- El artículo 3, tílulo 1, de la Ordenanza de México, requiere que el Director y Diputados hayan ejercido la minería por sí mismos el espacio de 10 años, y que sean españoles, limpios y de legítimo matrimonio.

78. - Leyes 14 y 15 , título $46^{6}$, ]ibro $9^{\circ}$ de Indias._. Ordenanzas 4 y 5 , título 42 , libro $1^{\circ}$ de las Generales del Perú.... Ordenarza 20 del mismo título y libro.

79.- Ordenanza 24, título 42 , libro $1^{\circ}$ de las Generales del l'erú.

80.- Glosa de Gothofredo, citando a Cujacio, sobre la Ley de edicto, 2 ff. de Jurisdictione.

81.- Parte $1^{7}$, Cap. $7^{\circ}$, Noticia 8, Pârrafo 10 , fol. 151.

82. - También puede nombrar solicitor o Agente que agite sus negocios en la Corte de Madrid, según la Ordenanza 20 , título 1 , de la de México, concordante con la 12 del consulado de Lima, título 42 , libro $1^{\circ}$ de las Generales de] Pexú, y Ley 24, título 46 , libro $3^{\circ}$, de la Recopilación de Indias. Pero para poder pasar a España algún Agente de las de América, debe calificar la causa y obterier la aprobación del Superintendente, y con ella el permiso del Sr. Virrey, según la declartación 10 hecha pos Don Jorge Escovedo, atendiendo al gasto, que se ha de hacer del fondo de la minería para salarios; con cuyo respecto requieien el mismo requisito para el transporte de los religiosos indianos, las leyes 29 y 30 , título 14 , libro $1^{\circ}$ de Indias.

83.- Ordenanza 4, título 8, libro $3^{\circ}$ de las Generales del Perí.

84.-- Gamboa: En su Comentazio de Minas; Cap. 12, Párrafo 2 y siguientes, principalmente desde el No, 18, fol. 291.

85.- Ẽl artículo 11, título 17 de la Ordenanza de México, admite por facultativos a españoles, mestizos de éstos o indios nobles, declarando este oficio por honroso, noble y meritorio. $Y$ aunque la ley 12 , título $1^{\circ}$, libro $3^{\circ}$ de Indias prohibe a los mestizos sentur plaza de soldados, la ley $40^{\circ}$, título 8 , libro $5^{*}$, el de ser eclesiasticos, y la ley 6 , titula 7 , libro $6^{\circ}$ de la misma recopilación, el ser Protectores, contradiciendo a la Ordenanza mexicana, debe concordarse entendiendo que estas leyes hablan de los mestizos ilegítimos, y la Ordenanza 
citada, de los legítimos, según la interpretación de Ramiro Valenzuela, para caso equivalente, en el Cap. 30, libro $2 "$ de la Política de Solórzano, No. 55, tomo $1^{\circ}$, fol. 220 .

86. - Atendiendo a la escasez que hay en estos Reinos de facultativos de profesión, para dirigir el aderezo y la seguridad de las minas, dispone la Ordenanza 19, lítulo 11 , libro $3 "$ del Perú, que suplan los mineros, y a este efecto sean probados por los Alcaldes Veedores, de ser hábiles y suficientes para el tuabajo de minas; $y$ no hay duda que se puede remediar mucho observándose esta Ordenanza si en el ínterin hay Peritos facultativos de profesión. Todo cl título 5, libro $3^{\circ}$ del Perí, requierc inteligencia en los Veedores sobre materias de minas, y asi, deben suplir las reces de los facultativos.

87.-Ordenanza 6 , título 1 , libro $3^{\circ}$ de las Generales del Peri.

88.- Vide Solórzano, en su l'olitica; libro 6 ${ }^{\circ}$, Cap. 2, No. 17, tomo $2^{\circ}$, fol. 433.

89.- En una carta escrita al Excmo. Conde de Chinchón, que refiere Escalona, en su Gazophilacio, libro $1^{\circ}$, Cap. 45, No. 29, fol. 177.

90.- l'rovisión de 20 de febrero de 1611.

91 - En e] Arte de Metales.

92.- Artículos 9 y 10, titulo 17 ; artículo 10 , título 9, de la Ordenanza de México.

93.- Tomo 2", Cap. $8^{\circ}$, Noticia $3^{\circ}$.

94.- Ordenz, 16, Tít. 9, y la Adjuión de Lupidana, No. 24, Tít. 14, Iib. $3^{\circ}$ del Perú.

95.- Artículo 2, título $1^{\circ}$.

96.- Artículos 1 y 2 , título 3 .

97.-- Ley 9, Cap. 77, título 13, libro 6" de Castilla.

98. - Dil la Declaración $2^{4}$, de 7 de octubre de 1786 , publicada por el Superintendente D. Jorge Escovedo.

99.- Artículo 8 ", título 1, de la Ordenanza de México.

100.- Artículo 15, lítulo $1^{\circ}$.

101.- Artículo 15, título 1 de Mćxico. Declaración 8, de 7 de octubre de 1786 .

102.- Artículo 14, título 1.- Articulo 4, título 16 de la Ordenanza de México.

103.- Artículo 14, título 1; artículo 1, título 3 .

$104,-$ Articulos 14, 21, 24 y 25 , título 1 ".

105.- Artículo 20, título $1^{\circ}$.

106.- Artículo 26, título 1.

107.- Artículo 7, título 18.

108.- Artículo 4, título 16 , concordante con la Ordenanza 11, título 42 , libro $1^{\circ}$ de las Generales del Perú.

109.- El artículo 9 , título 2 de la Ordenanza de México, trata sobre la elección de Ios substitutos; y la Declaración 24, de 7 de octubre de 1786, hecha por el Virreinato de Lima, los asipna por Conjueces de alzadas con los Intendentes. Porque según la diversidad de reformas que se ha proyectado en Potosí, juzgo que lo más seguro es dejar el nombramiento a los Jefes de cada Provincia, una vez que en los asientos de Minas no se han de celebrar elecciones ni se deben elegir los Diputados y substitutos territoriales que previenen los artículos 8 y 9 , título 2 de dicha Ordenanza de México.

110.- Artículo 6, título 1 , et vide las declaraciones 6 y la 12 hasta 20 , de la mis ma Ordenanza.

111.- Artículo 2, del título 2 : ibi los que no hubieran trabajado más dr un año, otc.

$112 .-$ Ordenanza 6 , título 2 , libro $3^{\circ}$ del Perú.

113.- Artículo 3, título $1^{\circ}$ de la Ordenanza de México.

114.- Estos diez años se entiende gue han de sex los inmediatos precedentes.

115.-.- Ley 10, título 15 , libro $6^{\circ}$ de Indias.- Ordenanza 1, título 10 , Iibro $2^{\circ}$ del Perúl.

116. - Prov. de 3 de agosto de 1726, artículo 18, titulo 13 de la Ordenanza de México, ordena que sea obligado el Azoguero a fabricar casa en aquel lugar donde pertenezca su mina.

117.-- Se refiere esta relación por Escalona, en su Gazophil, libro 1\%, Cap, 45, No. 57 , fol. 189 .

118.- Ordenanzas 1,2 y 5 , título $1^{\diamond}$, libro $3^{\circ}$ de las Generales del Perú. Leyes 1 y 14 , título 19 , libro $4^{\circ}$ de Indias.- Ley 9, Cap. 16 , título 13 , líbro $6^{\circ}$ de Castilla.- Artículo 1, título 7 de la Ordenanza de México.

1.19.-Ordenanza 4, título 1, libro $3^{9}$ del Perú.- El artículo 4, título 13, de México, permite a los cateadores de minas, llevar una bestia de silla cada uno $y$ otra de carga. 
120. - Ordenanza 3, título 1, libro $3^{\circ}$ del Perú, mandada guardar por el Excmo. Marqués de Castelfuerte, en la instrucción que forruó para Minas, en 8 de agosto de 1726 , artículo $6^{\circ}$.

121. - Ley 1, título 19. Libro 4 de Indias. Ordenanza 15 , título 9, libro $3^{\circ}$ del Perú. Artículo 3, título 7 , de la Orden de México. Leyes 46 y 48 , título 4 , libro $8^{\circ}$.

122. - La Adición de Lupidana, número 18, título 14, libro $3^{\circ}$, de las Generales del Perú. Leyes 46 y 48 , título 4, libro 8, No. 7.

123.- Art. 3 al fin. Título 7.

124.- En la instrueción que formó para Minas en 3 de agosto de 1726 .

125. - Todo el título 27 , libro $9^{\circ}$ de Indias.

126.- Ley 1 , título 10 , libro $8^{\circ}$; ley 6 , título 2 , libro $9^{\circ}$ de Indias.

127.- Aquí se debe entender, no solamente los naturalizados por Rescripto del Príncipe, sino también por fuero de vecindad, en los términos que expliqué en el Cap. $6^{\circ}$, Noticia $6^{\circ}$, Púrrafo $7^{\circ}$, de esta $2^{n}$ Parte. También se puede decir que la misma profesión de minería habilita a los extranjeros mineros para residir en la Amćrica, y los exceptúa del Decreto general de expulsión, porque ésta no se entiende en cuanto a los que sirvieren oficios útiles a la república, según la ley 10 , título 27 , Iibro $9^{\circ}$ de Indias $Y$ desde luego, no hay arte como el de la minería, que sea más benéfico ni más necesario en estos países.

128.- Gamboa: en su Comentario; Cap. 2, Nos. 27 y 28 , fol. 21.

129. - Artículo 1 al fin, título 7.

130.- Ley 4, título 12, libro $1^{\circ}$ de Indias. Ordenanza 21, título 11, libro $3^{\circ}$ del Perú.- Artículo 2, título 7 de la Ordenanza de México.

131.- Son expresiones de la ley 4 , título 12 , libro $1^{\circ}$ de Indias.

132.- Esta causa se expresa literalmente de la citada Ordenanza 21, título 11, libro $3^{\circ}$.

133.- Real Cédula de Euen Retiro, a 15 de febrero de 1750 .

134.- Aunque el semestre es término muy suficiente, dejó al arbitrio de cada Intendente la asigruación del competente, la declaración 36 hecha por el Virreinato de Lima.

135.- El artículo 2, título 7 de la Ordenanza de México omite este caso, y asi se debe decidir por la del Perú.

136.-. Solórzano: in Política, libro 2, Cap. 18, No. 58, tomo 1\%, fol. 148.

137.- Ordenanza 21 , titulo 11, libro $3^{\circ}$.

138.- Artículo 2, título 1, de México.

139.- Ordenanza 17, título 11 , libro $3^{\circ}$ del Perú.

140.-- Artículo 4, título 7 de México.

141.- Artículo 5, título 17.

142.- Artículo 6, título 7 ; Ordenanza 11, título 1, libro $3^{\circ}$ del Perú.

143.- - Ordenanza 11 citada, título 1 , libro $3^{\circ}$.

144.- Ordenanza 3, título 11, libro $3^{\circ}$ del Perín.

145. - Ley 5, Párrafo último, de Obligat. Párrafo ítem. 3, Inst., de Obligationibus que quasi ex delito. Ley 26, título 8, Partida 5. Ley 7, titulo 14, Partida 7 .

146.- Ordenanza 5, título 11 , libro $3^{\circ}$ del Perú.

147.- La Adición de Lupidana, título 14 , libro $3^{\circ}$, No. 17.

148.-. Ordenanzas 4 y 14; título 11, libro 3 del Perú. Ley 29, título 1 ; ley 25, títula 13, libro $6^{\circ}$ de la Recopilación de Indias, mandadas guardar novísimamente en Real Cédula despachada al Goberrador del Paraguay, prohibiendo los conciertos que allí se hacfan con los mayordomos de bienes de comunidad sobre un $10 \%$ de los frutos de las cosechas.

149.- Ordenanza $8^{\circ}$, título 11 , libro $3^{\circ}$ del Perú.

150.- Ordenanza 15 , título 11, libro $3^{\circ}$.

151.- Ordenanza 18, título 11 , libro $3^{\circ}$ citado.

152.- Ordenanza 16, del mismo títuło y libro.

153.- Ordenanza 22, del citado título y libro.

154.-. Ordenanza 31 , título $1^{\circ}$, libro $3^{\natural}$.

155.- Ordenanzas 1 y 2 , título 11, libro $3^{\circ}$.

156..- Ordenanza 1 hasta 8 , título 13, Iibro $3^{\circ}$ del Perú.

157.- Ordenanza 11 del mismo título y libro.

$158,-$ Ordenanza 7 , título 11, libro $3^{\circ}$ del Perú.

159.- Ordenanza 6 , del mismo título y libro.

160 - Ordenanza 6 , título 5 , libro $3^{\circ}$.

161. - Ordenanza 13, título 5 , libro $3^{\circ}$ del Perú. 
162.- Ordenanza 3, del mismo título y libro. La pena de muerte impuesta en esta Ordenanza se conmutó en la de destierro y multa, por la Adición de Lupidana, No. 15, título 14, libro $3^{\circ}$ del Perú.

163.- Provisión del Sr. Virrey Marqués de Guadalcázar, de 9 de febrero de 1626.Ordenanza 10, título 11, libro $3^{\circ}$ del Perú.

164.- Ordenanza 9 , título 11 , libro $3^{\circ}$

165.- Jur. Andz. citado por Gutiérrez, Concil. 36, No. 46.

166.-Gómez: 3 var, Cap. 3, No. 37, y Cap. 6, No. 9.- González: in Cap. 10 de Injuris et danno dato; No, 3 , tomo 5 , fol. 356 . Cobarrubias, libro 3 , var, Cap. 1 Carl. De judiciis; disp. 25, título 3, No. 16, al medio, fol. 192.

167.- Leyes 6, 18 y I9, título 15, l’artida 7, Párrafo 3 ; etc.

168.- Leyes 25 y 26 , título 16 , Partida $7^{\circ}$.

169.- Ordenanza 11, título 5 , libro $3{ }^{\circ}$.

170.- Ordenanza 7 , título 5 , jibro $3^{\circ}$.

171.-Ordenanza 12 , título 5 , libro $3^{\circ}$.

172.- Ordenanza 20, título 10, libro 3\%. Esta Ordenanza está mandada guardar en el Cap. 6, de la Real Cedula, fecha en Sevilla, a 22 de octubre de 1732 , y por el Sup. Gobierno de Lima, en 28 de febrero y 20 de agosto de $1755, y$ 17 de agosto de 1756.

173.- Ordenanza 6, título 10, libro $3^{\circ}$ del Perú.

$174,-$ Ordenanzas 3 y 6 , título 1.0 , libro $3^{\circ}$.

175. - Ordenanzas 4,10 y 11 , título 10 , libro $33^{\circ}$.

176.- Ordenanza 9, título 10, libro $3{ }^{\prime}$. La Adición de Lupidana, No. 12, título 14, libro 3 .

177.- Ordenanza 27 , título 10 , libro $3^{9}$.

178.- Ordenanzas 30 y 32 , del misno título y libro.

179... Ordenanza 2 , título 10 , libxo $3^{\circ}$.

180 - Or ilenanza 10 , titulo 8 , libro 8.

181.- Ordenanza 7, título 8, libro $3^{\circ}$.

182.-Ordenanza 6 , titulo 8 , libro $3^{\circ}$.

183.- Ordenanza 7, título 8, jibro $3^{\circ}$.

184 - - Ordenanza 2 , título 8 , libro $3^{\circ}$.

185.- Ordenanza 1 , título 6 , libro $3^{\circ}$.

186.-Ordenanza 8, título 7, libro $3 "$.

187 - - Ordenanza 7 , í́tulo 7 , Jibro $3^{\circ}$.

188. - Ordenanza 6, título 2, libro $3^{\circ}$.

189.-- Ordenanza 1 , títılo 2 , libro $3^{*}$.

190.- Ordenanza 12, título 10 , libro $3^{\circ}$.

191. - Ordenanza 4, título 5, libro $3 "$.

192.- Ordenanza 5 del mismo título y libro.

193.- Ordenanzas 11 y 12 , título 11 , libro $3^{\circ}$.

194.- Ordenanza 13 del mísmo titulo y libro.

195.- Ordenanzas 14, 15, 38 y 19 , título 11, libro $3^{\circ}$.

196. - Ordenanza 17, del mismo título y libro. Esta Ordenanza prohibe al minero, ulue pueda tener minas a labores suyas, pero no declara si la prohibición es solarrente por título de Registro y denuncio, o por todos los demás modos de adquirir conocidos en el derecho; ni tampoco si la prohibición ha de durax en todo el tiempo que usare el oficio y no nás, o también por algunos años después; ni especifica si el no poder tener minas, se ha de entender en sólo el asiento donde asiste $y$ sirve, y cuánta sea la distancia permitida fuera de allí. El artículo 4, título 7 de la Ordenanza nueva de México, ha decretado la misma prohibición, sin declarar más punto que el de poder adquirix uninas en mil varas de contorno de las de sus amos. Por csto se deben declarar las dudas que ocurrieren, por la ley $5^{*}$, título 13 , libro $6^{\circ}$, Cap. 34 de la recopilación de Castilla, que comprende todos los casos propuestos, respecto de estar mandada guardar expresamente en la ley $5^{4}$, titulo 19 , libro $4^{\circ}$ de Indias, con la única diferencia que la legua en contorno que señala la ley de Castilla, se debe linitar a las mil varas de la Ordenanza de México; quedando en su vigor de que no puedan tenerlas, por sí ni por interpósita persona, directa ni indijectamente, por compra ni otra cualquier manera todo el tiempo que sirvieren, ni dos años después, bajo la pena de tres años de destierro a tres leguas en contomo del asiento, y perdimiento de las rrinas para su amo, con reagravación de galeras al remo, si quebrantase el destie- 
rro. Gamboa, en su Comentario, Cap, 15, No. 3, fol. 304 , refiere dos casos en que se amplió esta ley de Castilla; Montesinos, en la P’olítica de Minería, Cap. 10, No. 8, fol. 139, propone la misma ley, por de rigurosa observancia. (Cada vara de las mil que pone la Ordenanza de México, se debe componer de tres tercias, $y$ todo su largo dividido en 48 dedos, como es la que el Consejo de Castilla entrega al Fiel Almotacen, según Don Jorge Inn. en el tomo de sus observaciones, libro 4", fol. 100, y libro 7, sección $3^{x}$, Cap. 5, fol. 302. Vide Don Mateo Sánchez Villajos, en su Estadal de medir tierras, Cap. 8, Párrafo 2, fol. 110.

197.- Provisión de Don Francisco de Toledo, fecha en Arequipa, a 2 de agosto de 1575 , inscrta en Real Cédula de Madrid, a 7 de julio de 1656 , que corre testimoniada al fol. 349 del libro del Cabildo, que comenzó el año de 1701.

198.- Leyes 5, 6,7 y 14 , título 17 , libro $4^{\circ}$ de Indias.

199.- Artículo 12, título 13.

200.- Artículo 12, título 19. El artículo 9 , título 19, concede lambién el corte de madera en los ejidos $y$ demás lugares comunes.

201. - Real Cédula de 15 de octubre de 1635 , que corre al fol. 301 de las Ordenanzas Crenerales del Perú, en el título 16, del libro $3^{\circ}$.

202. - Fagnano: in Cap. in His. de privilegiis; No. 11, tomo $3^{\circ}$, fol. 279 .

203.- Fagnano: in Cap. Son nulli de rescrintis; No. 41, tomo $1^{\circ}$, fol. 171.

204.- Una Glosa con muchos DD. que cita Fagnano, in Cap. Non nulli de rescriptis; No. 4 , tomo 1 , fol. 170 .

205.- González: in Regula 8, Cancellar 36, No. 31 hasta 35, fol. 399.

206. - El artículo $8^{\circ}$, título 19, de la Ordenanza de México, peinite a los mineros y sus Administradores, que puedan obtener empleos de Justicia en los pueblos de minas, y aunque nada decide para cl caso de ser deudores al Rey, da bastante fundamento para suponer que no les obsta esta calidar.

207. - Leyes 2 y 3, título 20, libro 4 de Indias. Provisión del Viyrey Toledo de 20 de mayo de 1571, manda guardar para el Sr. Conde Alba de Líste, en 22 de octubre de 1655 y Real Cédula de 9 de oetubre de 1635 que corren en el título 16, libro 3 , fol. 299 hasta 302 de las Ordenes Genera]es del Perí.

208.-- Artículo 3, tílulo 19.

209.- Jerónimo González: in Régula 8\%, Cancellar glos. 35 , número 17, fol. 393.

210.-... Artículo $3^{\circ}$ al fín, titulo 19 de México.

211.- Artículo 4\%, título 12.

212. - Carlev: De judiciis; título 3, disposición 18, Nos. 3 y 4, fol. 161. De Salariis, cuest. 18 a 22 y siguientes, fol. 402

213.- Artículo 3, título 19.

214.- Artículo 2, título 19.

215.- Noguerol: Alegat. 33, No. 70 hasta 73, fol. 572.

216.- Artículo 5, título 19.

217.- Ley 6, título 14, libro $5^{\circ}$ de Indias. Ley 5, título 13; ley 1, título 15, Partida $5^{\mathrm{k}}$.

218.-Parladorio; libro 2, Rerum quotidianam, Cap, final. Partida 5, Párrafo 3, No. 24.

219.- Artículo 13, título 3 de la Ordenanza de México y artículo 4, título 19 de la misma. Ordenanzas 7 y 8 , título 9 , libro $3^{\circ}$ del Perú. Ley 1 , título 20 , libro $4^{\circ}$. Ley 3 , título 14 , libro $5^{\circ}$ de la recopilación de Indias.

220.- Artículo 23 citado, título 3. Artículo 4, título 19. Ordenanza 8, título 9, libro $3^{\circ}$ del Perú. Provisión del Sr. Toledo, de 20 de mayo de 1571 , en el títtulo 16 , libro $3^{\circ}$ de las Ordenanzas del l'erú, al fol. 299.

221.- En los Iugares citados.

222,- Ordenanza 7, título 9, libro $3^{\circ}$ del P’erú.

223.- Ordenanza 8 , título 9 , libro $3^{\circ}$.

224.- Ley: Jurig gentium, 7, Párrafo si pasisear. Ley Jus publicurn 31, ff, de pactis.- Carlev.: título $1^{\circ}$, Dispos, 2, número 916, fol, 201. Ley 11, título 28, Partida 2. Ley 32, título 9, parte $6^{\circ}$, al principio. Gregorio López, en la glosa 2. Ley 2 , título 16 , partida 7 . Ordenanzas 7 y 8 , título 9 , Jibro $3^{y}$ del Perú. Ley 4 al fin, títula 14 , libro $5^{\circ}$ de Indias.

225.- Párrafo Non tamen in principio, etc.- Pázrafo In fraudem, $3^{\circ}$ instit. título 6 , libro $1^{\circ}$, et Párrafo 7 , ítem $6^{\circ}$ infr, título 6 , libro $4^{\circ}$. Ley 7 , títuło 15 , Partida 5, et glosa 1, hasta el medio, sobre la ley 50, título 5. Parte 5, las leyes del título 19 , libro $5^{\circ}$ de Castilla. 
226.- Ley 7, título 15, Partida 5. Pax in praxi, tomo 3. Párrafo 3, No. 15, fol. 25. Villadiega: en su Politica, Cap. 8, No. 15, fol. 319.

$227 .-$ Vinnio: en el Párrafo ítem 6, inst. titulo 6, libro 4, No. 10 al fin, tomo $2^{\circ}$, lol. 340. Gregorio López: en Ja ley 7, titulo 15, Partida 5, Glosa $6^{\circ}$.

228.- Ley 1 , título 20 , libro $4^{\circ}$; ley 4, título 14 , libro $5^{\circ}$ de Indias. Provisión de 2 de octubre de 1629 , al fol. 318 vta. de las Ordenanzas Generales del Peŕá.

229.- Escalona, en el Gazophilacio, libro 1, Cap. 17, caso 14, No. 3, al fin, fol. 65.

230 - Artículo 3, título 19.

231.- Artículos 6 y 7, título 19 de México.

232. - Artículos 10 y 11 , título 19 .

233 - Artículo 10, título 19.

234. - Artículo 2, título 3.

235.- Artículo 29 , título 3 .

296.- Ordenarıa $1^{\circ}$, título 9 , libro $3^{\circ}$ del Perú.

237.- - Artículo 3, título 19.

238. - Ei artículo 85 de la Ordenanza de Intendentes, sixve de regla para esta diferencia de casos.

239.- El artículo 86 de la misma Ordenanza es argumento con que se prueba este método.

240.- Herrera, en Ja Descripción de las Indias Occidentales; Cap. 13, tomo 1\%, fol. 29, colum. 2 ai fín. Década 5 , libro 3, cap. 15, tomo 2, fol. 77, colum. 2. Década 6 , libro 6 , tomo 3 , fol. 141 , colum. $1^{t}$.

241.-Cap. 2 ${ }^{\circ}$, Noticia 2, Parte $1^{*}$.

242. - En Prov. de 30 de octubre de 1611.

243.- En Provisión de 14 de junio de 1618.

244. - En Provisión de 17 de febrero de 1621 .

245.- En el Resumen Histórico, tomo 4, de su Viaje; fol. 128, No. 194 y fol. 131, No. 198.

246.- Bowles: en su Historia Natural de España; fol. 66 ; y fol. 7 en la descripción de la mina de Cinabrio en Almadén.

247.- Tomo 3 , de su Viaje; Jibro 1, Cap. 13, fol. 200, No. 345.

248.- Ulloa: Tomo 3, fol. 200, y fol. 34 ã al fin.

249. - Herrera: en la Descripción de las Indias Occidentales. Tomo 1, Cap. 9, fol. 17, colum. $1^{\mathrm{g}}$.

250.- Herrera: Década 5", libro $3^{\circ}$, Cap. 8, tomo 2, fol, 65.

25.1. Los prácticos de los lavaderos de oro, hacen unos pozos en las playas de Tipuani, en el paraje que mejor les parece, y al cabo de 4 o 5 varas, se encuentra una capa de tierra gredosa, dura, que es la señal del oro. Profundizan la excavación y todas las arenas de abkjo lavan en bateaś y de allí escogen el oro en pepita.

252.- Mudar las cajas del lío, es empresa muy árdua, por ser caudaloso y navegable en canoa; como que por ćl se escaparon sjete personas en tiempo de la sublevación, navegando desde Sorata hasta Moxos.

253,- Don Alonso Barba en su Arte de Metales, libro 1, Cap. 26, refiere por menor las vetas de oro que se encuentran en Chayanta y otras Provincias. En Atacama no se habia descubierto en aquel tiempo; y Ulloa también da a entender en el tomo $3^{*}$ de su Viaje, fol. 208, No. 358 , que no las hay; pero en el día están descubiertos Ios minerales de oro en Ingahuasi, Olaros, Susquiz, San Antonio del Cobre; y de plata el de Chatipos.

254, - Solórzano: in Política; lihro 2 ; Cap. 17, No. 19, tomo 1, fol. 189. Herrera: Década $5^{8}$, libro $3^{\circ}$, Cap. 15 , tomo 2 , fol. 77 , colum. $1^{4}$.

255.- Barba: libro $1^{\circ}$, Cap. 29.

256.-Barba: libro 1\%, Cap. 32.

257.- Barba: libro 1\%, Cap. 31. En Chichas todos los minerales están mezclados de plomo; $y$ en Potosí, hacia el sombrio, en el paraje que Ilaman Cívicos, hay muchas vetas del propio metal, según el mismo Barba.

258.- Barba: libro $1^{\circ}$, Cap. $1^{\circ}$.

259.- Chujcha, voz quichua que quiere decir cabello. (N. de E.).

260.- Barba: Jíbro $1^{\circ}$, Cap. 6.

261. Barba: libro $1^{\circ}$, Cap. 5, párrafo último.

262,- Barba: libro $1^{\circ}$, Cap. 9 .

263.- Barba: en su Árte de Metales; libro 1." Cap. 4\%.

264.- Barba: libro $1 \%$, Cap. 16. 
265.-- Parte Primera, Cap. $4^{\circ}$, Noticia $4^{\circ}$.

266. - Gamboa, en su Comentario de Minas, Cap. 2, fol. 12, desule el No. 5 hasta 21.

267.- Ley 5, título 15, Partida 2; ley 11, título 28, Partida 3; ley 4, Cap. 1, título 13 , libro $6^{\circ}$ de Castilla.

268. - Ley 1 , título 19 , libro $4^{\circ}$ de Indias.

269.-- Lagúnez: De juris; $1^{*}$ P'arte. Cap. 1", Nos. 63, 64 y 65.

$270 .-$ Artículo $1^{\circ}$, título $5^{\circ}$.

271.- Artículo 2, título 5\%.

272.- Artículo 3, título 5".

273 - En 1574. Ordenanza $1^{\circ}$, al principio, título 7 , libro $3^{\circ}$ del Perú.

274.- Párrafo Item 18, Instit. de Rerum Dirin. Ley 5, título 28, Partida 3.

275.- Herrera: Década 3, Cap. 7 , tomo 2, fol. 288 , colum. 1 al fin.

276.- Peregrino: De jure fiscii ; libro $1^{\circ}$, título 3 , No. 55 , fol. 30 , vta.

277.- Idem, No. 75 al princip. fol, 30 .

278.- Peregrino: De jure físcii ; libro $1^{\circ}$, título 2 , No. 97, fol. 14 vta.

279. - Fn el epígrafe del título $5^{\circ}$ de la Ordenanza de Mrixico.

280.- Herrera: Década $1^{*}$, libro 7 , Cap. 1, tomo $1^{\circ}$, fol. 177 , colum $1^{\circ}$.

281.- Iey 4, Cap. 2, título 13. Ley 5, Cap. 14, título 13, libro $6^{\circ}$ de Castilla.

282.- Bowles, en el Discurso Prelininar de la Historia Natural de Fspaña; No. 7, [ol. 34 .

283. - El nismo, en el cueppo de la obra, fol. 66 .

284.- En el tomo $8^{\circ}$ del Viaje en España, carta 6, No. 7, fol. 218.

285. - Nota bajo dol No. 1, jntertineal a la Fistoria de Bowles, fol. 167, en el Cap. donde continúa el viaje desde el Almadén.

286.- Ordenanza 13, 16 y 19, título 1 , libro $3^{*}$ del Perú. Escalona, en su Gazophilacio, libro $1^{*}$, Cap. 15, No. $1^{\circ}$, fol. 56 ; y libro 2 , parte $2^{\text {? }}$, Cap. 1, l'árrafo de Minas de S. M., Nos. 1 y 2, fol. 99.

287.- Esta medida que cila Escalona, es conforme a la Ordenanza 75 , de las antiguas de Castilla, comprendidas en la ley 5 , título 18, libro $6^{\circ}$ de la recopilación.

288.- Escalona: libro $2^{\circ}$, Partida 2, Cap. $1^{\circ}$, Nos. $1^{\circ}$ y $4^{\circ}$ al fin, fol. 100.

289.- La Ordenanza 5, título 7 , libro $3^{\circ}$ del Perú, las refiere por principales.

290. - Bowles: en el Discurso preliminar de su Historia Naiural; fol. 34.

291.-Gamboa: Cap. 2, No, 18, fol. 16.- Aunque todo el título $6^{\circ}$ de la Ordenanza de Mćxico, que habla sobre descubrimientos; nada dispone accra de la mina para S. M., se mandó guardar en Iima la Ordenanza 19, título $1^{\circ}$, libro $3^{\circ}$ del Ferú, por la declaración 32 hecha para aquél Virreinato, entre otras, a 7 de octubre de 1786 , con la prevención de que se coloque la estaca del Rey, después de todas las pertenencias del descubidor, si acaso las escogiere continuas; pero siendo intermumpidas, donde él señalare, hasta que hayan l'eritos, pues éstos son los que ]a deben escoger cntonces. Yo me persuado que son más inteligentes las cautelas de la Ordenanza del Perú, por las razones explicadas desde el No. 17 hasta el 20 de este párrafo $7^{\circ}$, y que se debe poeferir la situación que señaló el Sx. Toledo.

292,-m Torquemada, Inda. libro $3^{\circ}$, Cap. 42, tomo 1\%, fol. 336, colum. 2 ,

293.- Ordenanza 13 , título $1^{\circ}$, libro $3^{\circ}$ del Perú y Ordenariza 19 , del mismo título y libro.

294. - Ordenanza 19, título $1^{8}$, libro 3.

295.-Id. id, id.

296.- Montesinos: en su Política de mineros, Cap. 7, No. 5, fol. 55.

297. - Kes fiscii 4 institut. de usucapionibus. Leyes 6 y 7 ; título 29 , Partida 3.Ley 1 , título 1.6, libro $4^{\circ}$ de Castilla. Vide Salgado, De regia protect.; partida 3 , Cap. 10, desde el No. 17, fol. 418 .

298. - La Ordenanza 23, tílulo 1, libro $3^{\circ}$, también dispone que la mina de $\mathrm{S}$. $M$., nunca reciba perjuicio.

299.- Ley 5, Cap. 74, título 13 , libro $6^{\circ}$ de la recopilación.

$300 .-$ Ley 5, Cap. 75 , título 13 , libro $6^{\circ}$. Una vez que las minas de todos los particulares deben tener 200 varas, por el artículo 2, título 8 de la Ordenanza de México, por la misma razón debe gozar otras tantas la mina que se señalare a S. M., bien sea de plata o de oro, según se previno en la declaración 32 , de 7 de octubre de 1786, de las hechas para el Virreinato de Lima, innovándose en esta parte de la Ordenanza de Gastilla y la antigua del Perú.

301... Ordenanza 17, título 1 , libro $3^{\circ}$ del Perú. 
302.- Artículo 22, título 6.

303.- Artículo 1, título 6, de la Ordenanza de México.— Ordenanzas 13 y 19, título 1 , libro $3^{\circ}$ del Perú.

304.- Ordenanzas 9 y 12 , título 1 , libro $3^{7}$ del Perú.

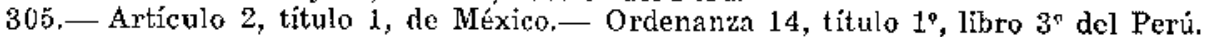

306.- Ordenanza 1, título 1 ", Jibro " del F'erú.

307.- En todo nuevo descubrimiento se debe serialar mina para $\mathbf{S}$. M, conforme a las Ordenanzas 10, 13, 14 y 19, título 1, libro $3^{\circ}$ del Perá, y a la declaración 32 de las del Virreinato de Lima.

308.- Ordenanza 13, título 1 ", Jibro $3 "$.

309.- Ley 4, Cap. 5", título 13 , libro $6^{\circ}$ de Castilla.

310.- Ley 5, Cap. 22 , título 13 , libro $6^{\circ}$ de Castilla.

311.- Artículo 2, título 8".

312.- Artículo 1, título 6".

313.- Artítulo 2, título 6 . Hallando el mismo descubridor de veta nueva en cerro conocido, otras vetas más, adquiere en cada una su respectiva pertenencia o mina, porque no debe gozar nás privilegio que el descubridor de cerro nuevo, ni se le debe privar de la adquisición que compete por los descubrimientos. La Ordenanza 14, título 1 , libro $3^{\circ}$ del Perú, sólo concede una mina en celda veta nueva, $y$ se ha ampliado esta concesión a otra mina más, por la de México, en la forma que acabo de referir.

314.- La ley 5, Cap. 31 , título 13 , libro $6^{\circ}$.

315. - Ley 9, Caps. 22 y 31 del mismo título y libro.

316.-Gamboa: Cap. 8, No. 13, fol. 188 .

$317 .-$ Ordenarza 14, título $1^{\circ}$, Jibro $3^{*}$.

318.- Art. 13, título 6; Aits. 13 y 16, tílulo 8, de la Ordenanza de México, prueban que sólo en las medidas, y no en el número de minas, se admiten demasías.

319. - Ley 9 citada, Capitulos 22 y 31 , título 13 , libro $6^{\circ}$, Nueva Compilación.

320.- Ordenanza 5, título 2, libro 3 .

321.- El descubridor puede tener hasta 12 minas, según el Licenciado Monteginos en su l'olítica de Minerales, Cap. 8, $\mathrm{No}^{\circ} 1$, fol. 57 vta.- Siempre que baya descubierto dos cerros nuevos y cuatro vetas dentro de la legua conforme a la Ordenanza 14, título $1^{\circ}$, libro $3^{n}$ del Perú.

322.-- Ordenanza 14, al fin, título 1, libro 3 .

323. - Vide el No. 45 antecedente.

324.- Ordenanza 5 , título 2 , Jibro $3 \%$

325 - Ordemanza 3 , título 2 , libro $3^{\circ}$ del Perú.

326. - Orderanza 1, título 2, libro $3^{\circ}$ del Perú.-.. Ordenanza 4, título 7 , libro $3^{\circ}$, al principio.

327.- Ordenanzes 4 y 5 , título 7 , libro $3^{\circ}$ del Peev́, Los artículos 13 y 14 de la Ordenanza de México, señalan cuatro meses continuos de abandono, u ocho interumpidos por algunos dits de trabajo, para poderse admitix denuncia de despoblado; pero se há mandado guardar la Ordenanza del Peíú.

328.- Artículos 1 y 2, título 6, de México; Ordenanza 10, título 1, libro $3^{\circ}$ del Pertí.

329. - Lege prevaricationis, l'árrafo final, Prevaricationibus, con otros textos que cita Valenzuela, en el Concil. 79 , No. 112, tomo $1^{\circ}$, fol. 472 .

330.-Gamboa: en su Coment. de Minas; Cap. 9, Nos, 23 y 25, fols. 206 y 207.

331.- Ordenanza 14, título $1^{\circ}$, libro $3^{\prime \prime}$ del Perú.

332.- Fl Jicenciado Montesinos explica esta Ordenarza en su Pofítica de Minerales, Cap. 5, No. 7 , fol. 40 rta.

333.- Ordenanza 10, título $1^{\circ}$, libro $3^{\circ}$, del Perú.

334. - En el siguiente Apéndice se explica este lugar.

$335 .-$ En la Ordenanz 16, titulo $1^{\prime}$, libro $3^{*}$ del Ferú, se hace mención del descubrimiento de los mantos. Gamboa: en el Indice de las roces de la minería, le. tra $M$, fol. 496, dice que "riantos" son vetas de metal, tendidas en el monte, sin profundidad. Barba, en su Arte de Metales, libro 1․, Cap. 25, fol. 24 vtr. lama manto, a la veta yue se extiende y alarga hacia los flaneos sin decaida considerable hacia el centro de la tierra.

336.- "Criadero", según Gamboa, en el Indice citado, letra C, fol. 493, es una bolsa o bóveda en que está el metal suelto.

337.- "Sombrero", según Barba, libro 10, Cap. 25, fol, 24 vta, es una mina amontonada en donde se halla junto el metal, en más o menos cantidad y distancia, que no descienda abajo ni se dilate por los tados. 
338.- "Lavaderos", según Barba, Jibro 1", Cap. 22, fol. 22 vta., son las arenas de algunos róos, donde rodó con el agua el oro criado en las vetas.

339.- Títulos 6,7 y 8.

340.- Solórzano: en su Política Indiana, libro $2^{\circ}$, Cap. 17, No. 12, tomo $1^{\circ}$, fol. 139 , concuerda con la relación de la ley 15 , título 19 , libro $4^{\circ}$ de Indias.

341,- Esta igualdad de condición se previene en la ley 16 , título 19 , libro $4^{\circ}$ de Indias y en la ley 4, título 12 , libro $8^{9}$ de la misma recopilación. 


\section{$\begin{array}{lllllllllllll}\text { A } & P & \mathbf{E} & \mathbf{N} & \mathbf{D} & \mathrm{I} & \mathrm{C} & \mathbf{E}\end{array}$}

\section{A los artículos primero y segundo precedentes.}

Cuáles son los que deben gozar el privilegio de primeros descubridores y cuántas las minas que deben poseer los demás mineros que no lo fueren.

D do metal en el cerro, aunque otro haya empezado a dar catas. 1 Porque no se puede liamar mina, aquella donde no se ha encontrado metal, según expresión de la Ordenanza. ${ }^{2}$

El nuevo descubrimiento de minas, se diferencia aquí de la invención del oro, margaritas y otras piedras preciosas halladas en las orillas del mar, en que para gozar la preeminencia de descubridor, basta haber hallado primero metal en alguna veta; pero el inventor no adquiere dominio con verlas, encontrarlas o descubrirlas solamente, si al mismo tiempo no aprehendiere las cosas que halló, según la Ley de Partida; ${ }^{3}$ porque el Rey, que es el único dueño de las minas, las concede a sus vasallos y súbditos, sin otra condición que por' descubrirlas y hallarlas; ${ }^{1}$ al contrario, las piedras preciosas criadas en las playas de los mares, no pertenecen a nadie, y el derecho no las concede al que las descubre, sino al que las ocupa, y así afirman los intérpretes, ${ }^{5}$ que es menester tomar posesión de ellas para apropiarselas; aunque otros hayan opinado que se adquiere desde el instante que se comenzaron a ver y descubrir.

Conforme a este principio, resuelve Vinnio, ${ }^{6}$ que si alguno encontrare a otro tomando ya la cosa que halló y le ayudare, debe ser preferido el inventor; y Mancio ${ }^{7}$ dice, que si los dos a un mismo tiempo vieren piedras, oro $\mathrm{u}$ otro metal en las orillas del mar, $\mathrm{y}$ uno lo tomare primero, que éste tiene mejor derecho, porque la posesión no se adquiere con sólo el ánimo, sin que preceda la aprehensión material. 
Antúnez, ${ }^{8}$ concuerda con la misma opinión, hablando de la invención de algún tesoro, y afirma cue, de dos que Io hubieran visto, debe tener preferencia el que primero lo aprehendiere.

Todas las cuales reglas son muy adecuadas para resolver otros casos semejantes en materia de minas y muy frecuentes en la práctica, en el concepto de que la ocupación en las invenciones de piedras preciosas, corresponde al descubrimiento, y éste debe obrar en su caso los mismos efectos que aquélla en el suyo, guardando la debicla proporción.

Pero, si sucediere que no se puede averiguar cual fue el primero que halló metal en la veta, debe gozar por Ordenanza del privilegio de descubridor, el que primero hiciere manifestación y registro juridico; y al segundo, que encontró también metal en el mismo día y no lo registró, se le debe señalar estaca, junto a la mina cle Su Majestad, siendo la diferencia en una misma veta, y si fucre en otra distinta, ticne derecho de elegir, como descubridor de ella; de sucrto que según la legislación antigua del Perú, debía partirse la mina entre aquél que manifestó primero el metal y el otro que la halłó en el mismo día, para que los dos viniesen a poseer las que debería gozar un solo desoubridor.

A este respecto, corresponde ahora que entre ambos disfruten las tres pertenencias que la nueva Ordenanza de minería, concede a los descubridores de cerros absolutamente nuevos, o las dos, al que descubriere veta nueva en cerro eonocido; es a saber para cada uno la suya bien entendido, que si los que tienen la disputa hubieran descubierto metal en diferentes vetas nuevas, cada cual gozaría las dos pertenencias que permite la Ordenanza, ${ }^{10}$ por el orden y lugar de sus respectivos registros.

Suponiendo gue puedan discordar entre si, en la eleceión de pertenencias, aconseja Gamboa, 11 que el Juez debe componerlos por medio de la suerte: en efecto, es muy factible la desavenencia, según al método prevenido para estas particiones, en las leyes de Castilla a que se contrae dicho autor. Pero no es asî en las Ordenanzas del Perú, jiz y el primero que registrare, debe conforme a cllas, elegir mina con la misma preferencia, y sucesivamente el otro: de modo que, segúm este orden, Jamás puede motivarse contienda.

En lo que más se conocen las grandes preeminencias de las priméros descubridores, es el caso propuesto en la Ordenanza 23 , título $1^{\circ}$, li-

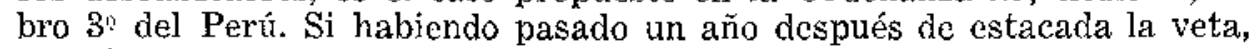
sucediere (como es factible) que los dueños de ella la perdicsen, no acertando más con el metal, y otros la tomaren fuera de cuadras, y la registraren, éstos bien pueden labrarla por suya y aprovecharse de ella, cxceptuando el dexecho del primer descubridor, a quien deben dejar que tome enteramente su mina donde la eligiere, en toda la veta, y la salteada, donde cayere, después de nembrada la mina de Su Majestad. De sucrte que, por haberse perdido la veta, no han de recibir perjuicio las pertenencias de Su Majestad, ni las del descubridor; pero los demés estacados, no deben ser oídos, por no haberse mejorado por la parte y lugar hacia donde corría la veta, en todo el año que les está concedido para este fin.

Son justísimos los motivos de esta providencia: se fundan, por una parte, en otro privilegio que gozan los mismos descubridores, para mejorar dentro de dos años, ${ }^{13}$ contados desde el día de su registro, por lo que, estando todavía dentro de este término, en cl caso de la Ordenanza, nadie puede agraviarse de que ellos usen de su derecho ${ }^{14}$ eligiendo 
en la misma veta que descubrieron a su costa e industria, las minas que pucden tener en ella.

También se funda cn equidad; porque si la incertidumbre muy natural en todo lo que no se ve, les hizo errar las estacas, sin aprovecharles las diligencias practicadas en solicitud de la veta, así en barrenarla por la mina descubridora, en dar pozos por la derecera que muestran las cajas, $y$ en poner estacas por el haz de la tierra por donde va la veta, descncapándola por de fuera y descubriéndola por de dentro; no es justo que los otros la usurpen absolutamente, siendo notoriamente la misma que ellos registraron $y$ tomaron en la cata principal, pues, continuando el empeño en buscarla por donde quiera que llevare su rumbo (como lo puedon hacer), de necesidad hubicran llegado otra vez a tomar la veta $y$ encontrar con el metal.

FI que habiendo perdido una alhaja hace diligencia de buscarla, nunca se presume que su ánimo sea desampararla pro derelicto, y está tan lejos de privatse de su dominio, que queda obligado a restituírsela cualquier otro que la encontrare. ${ }^{15}$ Por esta regla conserva el descubridor' su derecho, una vez que la misma empresa de solicitar la veta perdida, declara la voluntad que tiene de aprovecharse de ella.

Lo contrario sería, si habiéndose escondido la veta no practicase las diligencias indicadas arriba, dejando pasar los dos años concedidos para mejorarse, porque siendo muy suficiente este plazo para concluír la busca con buen suceso, se debe creer que en haberla abandonado, quiso abdicar tácitamente el derecho adquirido por el descubrimiento, y por consiguiente, quedó la veta $p r^{\circ}$ derelicto para otros que la encontrasen después. 36

En la Ordenanza de México no se propone este caso; pero se determina que las estacas o mojones que se fijaren en los términos de las minas, sean invariables $y$ se guarden perpetuamente sin mudarlos jamâs, aunque se alegue que la veta varió de rumbo o de recuesto; ${ }^{13}$ porque debiendo reconocer los facultativos de minas, su dirección, anchura o inclinación al horizonte, y conforme a csto medir las pertenencias y amojonarse, ${ }^{18}$ se debe contentar cada uno con la suerte que le hubiere deparado la Providencia; y así parece que en esta nueva legislación no debe tener lugar la mejora dispuesta cn la antigua del Perú.

Con todo, la misma Ordenanza de México ${ }^{29}$ permite que se haga mejora de estacas o mudanza de términos, en variando la veta de rumbo, siempre que no se pueda argüir malicia a quien la solicita, ni ceda en perjuicio de tercero. Aquí no le hay verdaderamente, respecto que en la parte donde se ha tomado nuevamente la veta perdida, no hay vecinos a quienes poder inquietar. Y como tampoco señala término perentorio en qué verificar las mejoras en semejantes circunstancias, parece que no hay motivo para dejar de conciliar ambas Ordenanzas, sujetando la de Mếxico al plazo asignado en la del Perú, a fin de evitar dudas y contiendas.

Con el fil de promover descubrimientos y alentar a los que quieren gastar su hacienda en hacerlo, concede la Ordenanza ${ }^{20}$ el derecho de primer descubridor al que se propusiese tornar a buscar metales en algún cerro enteramente despoblado, por tres meses, por aquellos que lo habían registrado primero y habían dado catas en él, si después de pasado el trimestro hallare metal y lo registrare en cualesquiera vetas que 
descubriere, ya sean nuevas o en las que antes hubieren sido manifestadas, como si nunca fuera descubierto ni registrado.

El Sr. Toledo se conformó en esta Ordenanza con una antigua, de 1536, recopilada en la Ley 11, título 12, libro $4^{\circ}$ de Indias, donde se mandó, con el fin de fomentar el descubrimiento y población de cllas, que no poblándose dentro de tres meses los solares y tierras que se hubicran repartido, o dejado de aprovecharse de ellos, ${ }^{21}$ se quiten para que se pueda proveer y dar a otro cualquiera poblador.

Sin duda tuvo presente que los baldíos, suelos y tierras de los indios (así como las minas), pertenecen al Patrimonio y Corona Real, 22 y por eso quiso sujetar ambos ramos a una misma disposición.

Por lo mismo, el descubridor, en el caso propuesto, puede tomar tres pertenencias en la veta principal, conforme al artículo $1^{\circ}$, título 6 , de la Ordenanza de México, porque el cerro del todo despoblado, se reputa absolutamente nuevo para este efecto; pero si hubiere quedado labrando en él, aunque ne sea más de nna persona, debe tener sólo dos pertenencias, por el artículo 2 del mismo título, en la veta nueva que registrare; y los demás, el derecho de despoblados en las viejas, scgún la Ordenanza del Perú. ${ }^{23}$

Del mismo modo, goza la preeminencia de primer descubridor, el que lo fuere de minas antiguas, ciegas, que emprende limpiar a costa de su hacienda; pero no adquiere dominio hasta haberlas registrado después de tomar metal fijo en ellas. ${ }^{24}$

Siendo constante que ninguno tiene derecho a labrar ni disponer de los minerales, sin la licencia que se concede por los registros, 25 declaró el Sr. Toledo: ${ }^{26}$ que si desde que halló el metal, hasta que lo registrare el descubridor, se probase haber hecho algún contrato de venta, pierda la mina que después registrare y todas las demás que le cabian en la veta, quedando vacas para el primero que las pidiere.

Gravísimas dudas se pueden altercar sobre la inteligencia de esta Ordenanza, por más que parezca sobremanera clara y sencilla. Según lo que suena aquella cláusula desnuda; "si se probase haber hecho algún contrato de venta", "pierda la mina". Entenderá cualquiera que aquí nada más se prohibe que la venta, y no será extraño que intente donar, permutar, ceder, legar, hipotecar, arrendar y dar en pago de sus deudas, las minas que hubiere descubierto, y inucho más promover venderlas después que las registrare.

Cada Capítulo de estos es una cuestión intrincadísima, que puede acarrear muchas confusiones, y necesita por su gravedad un comentario separado. Mi instituto no es otro que escribir una Gúa abreviada, para dirección del Gobierno de Potosí ; y así se me dispensará el tratar ligeramente esta materia, indicando con brevedad las resoluciones que, en mi concepto, son las más bien fundadas.

Es opinión contextada por innumerables Doctores, de los más clásicos, que en la apelación de venta, vienen comprendidas todas las especies de enajenación que son hábiles para transferir dominio, y conforme a este principio resuelven que, cuando la ley o estatuto prohibe la venta, se entienden igualmente prohibidos todos los demás contratos traslativos de dominio.

El erudito Barbosa, Pedro. Surdo y Narbona, ${ }^{27}$ refieren por menor los textos de uno y otro derecho, con los intérpretes de mejor nota, 
que sostienen y prueban esta opinión, y omitiendo las razones que alegan sobre sutilezas civiles, me limito a preferir la que expone el sapientísimo Solórzano, ${ }^{28}$ en comprobación de lo mismo y es que, en prohibiendo la ley, la venta o enajenación, es visto haber querido también prohibir todo aquello por donde se camina a ella; porque, como dice Molina ${ }^{29}$ apurando csta regla, cuando se prolsibe algún acto específicamente, se prohibe también otros cualesquiera semejantos, que pueden surtir aquel efecto que dio mérito para prohibir la venta.

En la Ordenanza del Perú, que voy explicando, se motivó la prohibición, porque ninguno tiene derecho a lablar ni a disponer de los minerales sin la licencia que para registrarlos se le concede por la persona que en nombre de Su Majestad tiene facultad para darla; luego, interviniendo la misma falta de licencia en otras cualesquiera especies de contratos que se celebraren antes del registro, todos cllos se deben entender prohibidos del propio modo que la venta; y por eso, queriendo significar. esto mismo, la Ordenanza cuando explicó la causa de su promulgación, no repitió otra vez la palabra "venta", sino que usó de la de "disponer", que es mucho más universal y se extiende a clantos géneros hay de contrataciones; de suerte que, entrando en clase de disposición, no solamente la venta, sino tambión las cesiones, legados, pagandentos; compromisos, traspasos, hipotecas, arrendamientos y otros actos del mismo género, es consiguiente que todos queden igualmente prohibidos, una vez que la Ordenanza declara que ninguno tiene derecho para disponer de las minas antes de haberlas registriado.

Con más claridad que ninguno, trato este asunto el docto teólogo Luis de Molina, "oxplicando las diversas significaciones de la palabra "enajenación". Distingue dos modos en que regularmentc se toma y entiende la enajenación: el uno, propio rigurosamente, y tentonces indica algún acto traslativo de dominio, como es el cambio, la donación o la venta, según la ley $1^{a}$, título 11 , Partida $1^{4}$; cl otro modo es más lato y extenso, y siempre que se prohibe enajenar o disponer, que vale tanto como arbitrar, distribuír o dar alguna cosa; en este caso, concluye el citado Molina, 31 alegando por su parte la ley 10, título 33, Partida 7n, que a quién se le prohibe la cnajenación en el scntido lato, no solamente se le inhibe transferiz el dominio directo, vendiendo, cambiando o donando, sino también el útil, para que no pueda empeñar, hipotecar, dar a censo, ni poner en la cosa servidumbre alguna.

Por consecuencia, tampoco puede el descubridor hacer contrato alguno de arrendamiento, porque a más de las razones expuestas, funda el docto Avilez, s2 que la venta y la locación caminan a un mismo paso, y por eso, según Barbosa, ${ }^{33}$ es válido el argumento de la venta al arrendamiento.

Lo más disputable es, ¿si en la prohibición de vender, también se comprende la promesa o pacto de la venta, bajo la mienia pena de perdimiento de la mina, si se contratase antes del registro?

Los autores clásicos eș́án discordes entre sí: pues, según refiere el Cardenal de Luca, ${ }^{34}$ unos son de la opinión absolutamente afirmativa y reputan la promesa de hacer alguna cosa, por el mismo hecho, con especialidad en materia de renunciaciones de dote $y$ de elecciones.

Otros defienden la negativa; y los demás distinguen dos clases de promesas: una con juramento, y otra sin él; y se conforman con la opi- 
nión afirmativa, en el caso de ser jurada la promesa, y no siéndolo, con la negativa.

El célebre Alvaro Velasco propone en una de sus consultas, ${ }^{35}$ el caso de haber prometido el marido, sin consentimiento de la mujer, la venta de una finca, recibiendo una parte de precio, con la cláusula de que pagándoscle el resto, se otorgaría la escritura y la mujer prestaría su consentimiento.

Se hace cargo de la prohibición que en el Reino de Portugal ticnen los maridos para enajenar los bienes raices dotales, sin expreso consentimiento de la mujer; del mismo modo que está prohibido entre nosotros, por la ley 7, título 11, Partida 4"; cnumera muchas autoridades que prueban la diferencia que tienen entre sí, el vender y prometer la venta, y después de todo, absolviendo los argumentos contrarios, concluye que es nula la promesa que el marido hizo de vender, como lo hubiera sido la misma venta efectiva, no habiendo prestado consentimiento la mujer; porque en tal caso no se diferencia de la venta la promesa de hacerla, para que no se defraude la ley prohibitiva.

Tiraquelo, ${ }^{36}$ fue del mismo parecer hablando de la mujer que promete alguna cosa, en el supuesto de haber estatuto o ley que lo prohibe contratar sin el marido; y después de citar algunas decisiones, fuera de las que refiere Velasco, dice que la inhibición hecha a las mujeres por el Estatuto florentino, para enajenar sus bienes sin el consentimiento del marido, se extiende igualmente a la promesa de enajenar, una vez que éste ha de ser el medio de verificarlo.

Francisco de Sousa, jurisconsulto lusitano, ${ }^{37}$ sigue la misma opinión, alegando como terminantes una glosa y varios textos del Derecho Civil.

Sobre todos, es más respetable la autoridad del sapientísimo Doctor Don Juan de Solórzano, 88 el cual, hablando de la total prohibición que hay de enajenar las encomiendas, refiere una decisión en que se declaró que, por sola la promesa de venderlas, se incurría en todas las penas impuestas por las leyes, alegando a este intento muchas y muy fundadas razones.

Pedro Surdo ${ }^{39}$ fue de la opinión media, sobre que siendo juxada la promesa, tenía la misma fuerza que el hecho, para los efectos del derecho.

La negativa defienden, con grandísimos fundamentos, el célebre Cancerio, Don Juan del Castillo y el insigne Olea, ${ }^{40}$ citando a Zeballos, Avendaño, Calda, Pereira, César Barsi y otros muchos Doctores; y después de hacerse cargo Don Alfonso de Olea, de la venerable doctrina de Don Juan de Solórzano, resuelve por más verdadero y recibido en práctica, que son cosas diversas la promesa y el hecho, y por consiguiente, que no es venta la promesa de vender, ni por haber prometido solamente se incurre en las penas impuestas por la venta.

En medio de ser tan sólidas las razones, como respetable el nombre de los autores que acabo de citar, es a mi parecer de grande recomendación la opinión de Don Alfonso Narbona, por equivalencia del caso que refiere y por el empeño con que se explana y funda su doctrina.

Propone ${ }^{41}$ que uno que prometió de vender libros extranjeros, antes de haberlos tasado el consejo, y resuelve que, aunque el verdadero vendedor incurre en la pena de mil maravedíes y perdimiento de los libros, 
de ningún modo se entiende incurso el que sólo prometió enajenarlos.

Yo me inclino de buena fe a esta opinión, y discurro que no incurrió en la pena de la Ordenanza, el descubridor que antes de registrar la veta hubiera prometido o pactado vender su mina, arrendarla o hipotecarla; y así de las demás especies de contrato, por las mismas razones alegadas por los Doctores, principalmente por Narbona.

$\mathrm{Y}$ conformándome también con su dictamen, ${ }^{42}$ digo que tampoco debe caer en perdimiento de la mina, aunque realmente la hubiera vendido antes del registro, siempre que arrepentido de la venta, recupere y reasuma el dominio de la misma mina, antes de la sentencia del Juez; porque no se debe reputar venta efectiva la que se retractó a poco tiempo después de hecha, ni se presume infractor de la ley, rigurosamente, el que pesaroso de su contravencion, la retracta y repone la observancia que había violado.

En la misma Ordenanza del Perú, ${ }^{43}$ se pone otra prohibieión para después del registro, a saber: que los descubridores no puedan ceder ni traspasar el derecho de tales, y que ellos solos le gocen, y de ningún modo el que sucediere en la veta registrada, ya sea por venta, donación o despoblado, y annque sea su hijo o heredero.

Según la antigua legislación del Perú, es de fácil inteligencia la Ordenanza citada, porque como sólo el primer descubridor puedo tener dos minas en una propia veta, ${ }^{14}$ y entre todas hasta doce, ${ }^{45}$ con la facultad de mejorarse dentro de dos años contados desde el día de su registro, ${ }^{26}$ y de disponer de las demasías dentro de dos meses desde el día que hiciere estaca fija; ${ }^{47}$ por todo esto se ordenó justísimamente, que el derecho de descubridor goce únicamente la persona que hizo el registro, y no sus sucesores particulares, ni aun los universales, para evitar la inquietud y daño de los cireunvecinos.

Ahora se ha variado este sistema por la nueva Ordenanza de México, concediéndose a cualquiela que pueda poseer sobre una misma veta, una mina por registro, y otra por denuncio, y muchas más por venta, donación, herencia, u otro oualquier título; ${ }^{4 \times}$ de manera que ya no hay demasías en cuanto al número de pertenencias, sino únicamente en orden a las medidas; ni hay tiempo prefijado para mejora de estacas o mudanza de términos, pues, aunque está prohibida por lo regular semejante variación, se puede permitir por justísimas causas, cuando no hubiere vecinos a quienes inquictar o perjudicar. ${ }^{4{ }^{\prime}}$

Por todo lo cual, si sc mrocurase combinar ambas Ordenanzas, sería empresa que jamás pudiera tener desempeño; y así, debe reputarse tácitamente revocada la del Perú, en cuanto son incompatibles con ella los efectos del todo contrarios que permite y abona la Ordenanza de México para el mismo caso.

La prohibición que hay bien contestada por una y otra legișlación, es la respectiva a Eclesiásticos descubridores, ${ }^{50}$ para que no puedan tener el laboreo de las minas que registraren, pues, según expuse en otro lugar, ${ }^{51}$ están obligados precisamente a vender y poner en manos de vasallos legos las tales minas, dentro del término de seis meses, pena de aplicarse a quien las denunciare. ${ }^{52}$

De àquí resultan cuatro dudas dignas de explicación. La primera es, si durante este plazo, podrá el Eclesiástico descubridor trabajar la mina y aprovecharse de sus frutos, mientras encontrare comprador de ellas. 
La segunda, si el término del semestre es continuo o uitil. La tercera es, si para proveer la adjudicación que otro pidiere después de pasado dicho término, será preciso oírlos en justicia, o sólo averiguado el tiempo por el registro, se procederá a la aplicación de ella, sin admitir pleitos sobre este asunto. La cuarta, si los parientes que pueden sucederle ab intestato, tienen alguna preferencia sobre la adjudicación de la mina.

Es tan apreciable el caso de Ia primera duda y $\tan$ palpables los razonamientos que alegan por su parte los clérigos descubridores, y aun también los seculares de su partido, que sería muy conveniente hacer una expresa declaración, principalmente habiendo Ilegado en estos tiempos el abuso de los eclesiásticos a tanto grado, que no hacen escrúpulo en trabajar minas con más codicia (o llamemos aplicación) que los seculares.

Dicen que las Ordenanzas ${ }^{53}$ repiten a cada paso no haber sido Ia intención de Su Majestad, el permitir les descubrimientos de minas, sino porque se labren a beneficio particular de los vasallos y para prosperidad universal del Estado, no menos que para acrecentamiento de la Real Hacienda.

En impidiéndose al clérigo el trabajo de las que registrare, de consiguiente, no se cumple con la voluntad del Rey, ni se pueden conseguir los efectos favorables que despertaron sus soberanas miras. Lo más es, que después del atraso consecutivo a la suspensión de la labor, puede suceder que no rinda la mitad de frutos después de vendida a algún sujeto sin caudal ni experiencia, la misma mina que principiaba a labrarse por el clérigo descubridor, con empeño y con inteligencia y que le hubiera dejado muchas utilidades en su venta, y al público la riqueza de que necesita para vivifiear todos los ramos del Estado.

Sin embargo, yo opino sin vacilar, que lejos de conformarse con el espiritu de la Ordenanza 21, título 11, libro 3" del Perú, la facultad que pretenden los clérigos para trabajar las minas que descubrieren durante el semestre, se opone directamente a la intención del legislador, que por ella se descubre.

Fundan mi propósito, tres argunentos graves: el primero, de razón; el segundo, de inconveniente; y el tercero, de autoridad.

El fín por qué la Ordenanza manda que el clérigo venda las minas que descubriere, concediéndole seis meses para que en ellos se pueda deshacer de ellas, es porque no las trabaje distrayéndose de si sagrado instituto, en un negocio puramente temporal, opuesto a la santidad del sacerdocio, y justamente para evitar las muertes, agravios, malos tratamientos y peores pagas que recibían de los eclesiásticos los indios repartidos en sus haciendas, en la confianza de no poderse proceder contra ellos, como exceptos de la Real jurisdicción; luego, de ningún modo se puede entender permitido el trabajo de las minas durante los seis meses, porque entonces se incurriría en lo mismo que se intentaba impedir con obligarlos a la venta, y al propio tiempo, de procurar separarlos de la labor $y$ beneficio de minerales; el mismo medio adoptado para lograrlo,vendría a producir efectos contrarios.

De aquí se siguen dos inconvenientes muy considerables: el primero, que los indios recibirán los mismos agravios que dieron misito para prohibir absolutamente a los eclesiásticos el poder labrar minas; y el segundo, que con la codicia de aprovecharse de sus frutos, y aunque no sea sino por el demasiado apego del corazón humano a las riquezas, cuan- 
do hay esperanza de conseguirlas, pretextarían una infinidad de excusas e impedimentos para hallar comprador; $y$ dilatando la venta de día en día, con pedir un plazo tras de otro plazo, con otras mil invenciones que sugiere el interés, al cabo conseguirán disfrutar toda la mina, habiéndola trabajado con fraude de la Ordenanza, en perjuicio de los indios y contra el decoro de su estado.

Además de esto, es trivial que lo que se permite bajo de cierto modo a cierto géncro de personas, para un caso y por un determinado tiempo, no se entiende ni se extiende fucra de ellos; antes, se supone prohibido en todos los demás casos, según Lar'rea y Graciano, ${ }^{54}$ porque la concesión nunca se debe extender a cosas diversas, como resuelve este último.

Hablando el sabio Tiraquelo 5 cle lo que se promete por cierto tiempo limitado, por cjemplo, cuando el comprador estipula la retroventa dentro de seis mescs, dice que so entiende no haber querido obligarse para después de aquel tiempo, y alega aquella regla vulgar, que lo que se permite por cierto plazo, se juzga prohibido para después, como se ve en el retracto concedido dentro de nueve días, que ya no compete si se deja pasar el término; lo mismo en el Procurador constituído por determinado tiempo y para cierta clisse de negocios, que después de evacuados, ya expira su oficio; y por íltimo, en el Estatuto, que permite inquirir dentro de plazo limitado, en que entienden todos prohibida la inquisición después de l'enecido el término; porque, como funda el sabio Salgado, ${ }^{5}$ una causa jimitada sólo puede producir efectoślimitados.

Cuando se concede una cosa (principalmente en lo facultativo) sicnta. Fontancla, sis fublado en la nota, que se entiende denegada la facultad que no se lee, ni se expresa en la concesión. Según aquella regla, pacientemente explanada por Barbosa: "in "inclusio unius, ets exclusio et resenatio allerius."

Explicando este prólogo, el célebre jurisconsulto español, Jerónimo González, ${ }^{60}$ pone muchos ejemplos, reducidos a que permitiéndose el uso, se prohibe el abuso; concedida la administración, parece prohibida la disposición; y así otras cosas que vienen a conchuír en que la concesión jamás se extiende fuera del caso expresado, y por el contrario, se entienden prohibidos todos los demás.

Conforme a estos principios, comentando Acevedo ${ }^{61}$ la ley $3^{n}$, título 10, libro 4" de Castilla, en aquellas palabras: "muriendo el acusado dentro del año, estando ausente, en los casos que el delito no se extingue por la muerte, sean oidos los herederos del acusado, sobre las dichas penas de dineros o de bienes", dice que en aquellos delitos que se extinguen por la muerte, no deben ser oídos los herederos del acusado ausente y contumaz, porque los delitos de que habla la citada ley, se expresaron limitativamente y por vía de excopción, para afirmar la regla en contrario en los casos no excepcionados.

Con lo cual se prueba, que habićndose concedido el término de seis meses para que los clérigos descubridores, se puedan deshacer en ellos de las minas que registraren, de ningún modo pueden trabajarlas durante este plazo, porque la renta se fijó en la Ordenanza, por vía de excepción, para afirmar la regla prohibitiva en todos los demás casos no exceptuados; es decir, que por el mismo hecho de permitir limitadamente la venta dentro de seis meses, prohibió tácitamente durante ellos el 
trabajo $y$ beneficio de las minas, como caso no comprendido en el tenor de la concesión.

$\mathrm{Y}$ aunque se quisiera decir con Fontanela y Pareja, ${ }^{62}$ que más bien se debe reputar omitido el caso de nuestra duda, quedando como tal, sujeto a las disposiciones del derecho común, también se debe concluír, que el clérigo descubridor no puede trabajar la mina que registrare, pendiente el semestre, porque componiéndose el derecho común real y el ectesiástico de las Indias, de las leyes xecopiladas y Concilios provinciales, es claro que el clérigo descubridor no puede labrar sus minas, una vez que las leyes de Indias y el Concilio provincial Limense ${ }^{6}$ is le prohiben absolutamente el trabajo de minerales, sin excepción ni linitación de tiempo.

$\mathrm{Y}$ porque puede suceder, que por sus fines particulares, haga estas ventas el clérigo descubridor, lingida y simuladamente, sin que en realidad de verdad sea su intención pasar el scñorío de las minas, ni enajenarlas, trabajándolas él en cabeza ajena por este medio, contra las prohibiciones de la Ordenanza, es menester observar la sabia cautela pre-

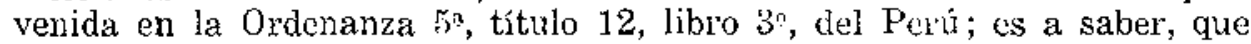
ocurran el comprador y el vendedor ante el Juez que ha de dar la posesión, declarando ambos con juramento, que la dicha venta, permuta, donación o contrato que así hiciesen, es cierto, verdadero y no fingioo ni simulado, sino con ánimo e intención de estar y pasar por ćl realmente y con efecto permanente, bajo la pena de ser: nula la posesión que cn contrario se diere y de perder la mina o su estimación; pues, por difícil que sea la averiguación de semejantes ficciones, por hacerse regularmente en secreto, se evita en lo posible el fraude, $y$ se debe esperar que las partes se abstengan de cometerlo, por el temor de la pena.

Por último, juzgo conveniente advertir una incidencia muy practicable en esta materia, y es, que permitiéndose al clérigo descubridor, deshacerse de las minas, ya sea vendiéndolas o enajenándolas por cualquier otro contrato traslativo de dominio, puede tal vez pretender hipotecarlas durante el semestre o arrendarlas por cl mismo término.

Estando al rigor de derecho, no encuentro razón para que no se le conceda esta facultad, porque siendo válido y trivial el argumento que se toma afirmativamente, de lo más a lo menos, conforme a los textos que refiere $y$ explica Barbosa, "BA se debe entender permitido el arrendamiento o la hipoteca, una vez que la Ordenanza pelmite la venta, que es más, según resuelve Molina, ${ }^{65}$ de los bienes de Mayorazgo, que tienen licencia para enajenarse.

Con arreglo al argumento antecedente, deducido de aquelia regla civil y canónica, 66 que no se debe prohibir lo menos a quien es lícito lo más, se leen en el Derecho varios ejemplos que lo comprueban. A saber: el padre matar a la hija adúltera, en adulterio infraganti delicto, tiene con mayor razón facultad para azotarlos o causarles otra molestia contumeliosa; ${ }^{67}$ del mismo modo que la mujer que entregó su cuerpo al marido, debe mucho más bien confiarle la dote, que es menos. 68 Así como el hijo de familia que puede testar del peculio castrense, también puede hacer donación por causa de muerte, por ser mucho más testar que donar. ${ }^{69}$ Luego, según esta misma regla, le será permitido al clérigo descubridor arrendar o hipotecar su mina, respecto que puede venderla, siendo mucho más.

Pero todo esto se debe entender sin perjuicio de la venta, traspaso 
o enajenación mandada hacer dentro de los seis meses, y a lo sumo, se podrá per'mitir lá continuación del arrendamiento o hipoteca, con licencia del Superintendente de Minas, hasta hallar acomodada venta.

Esto, que mira directamente al clérigo descubridor, es trascendental al que hubiese adquirido minas por donación, herencia o por cláusula de testamento; de sucrte que se debe proceder de un mismo modo, así en uno como en otro caso, absteniéndose de seguir la doctrina del sabio Solorzano, referida en otro lugar, i" pues, por respetable que sea su autoridad, son de más veneración las Ordenanzas posteriores al tiempo en que escribió su docta obra.

Para resolver la seguncla duda, se debe tener presente que se llama tiempo continuo, aquel que corre siempre y sin intermisión contra cualquicr"a, aunque sea menor, impedido, ignorante o ausente; ${ }^{11}$ de cuya naturaleza os el término de nueve días concedido por la ley $8^{n}$, título 11 , libro $\tilde{b}^{n}$ de Castilla, para retraer las cosas vendidas de abolengo, según Jerónimo González, Tiraquelo y otros, que traen copiosos ejemplos de esta materia: por lo mismo, corre de momento a momento y comprende todos los días, aunque scan de vacaciones y feriados, según Cortiada y la común opinión de los Doctores. :":

Por el contrario, se llama tiempo útil, aquel que no corre al ignorante, ni al impedido, según Vela y Cortiada. ${ }^{74}$ Pudiera alegar muchos ejemplos que hicieran palpable su demostración; pero basta asignar el cuatrienio constituído por ley para pedir la restitución in integrum, según la forma de aquella ley del Código a que se refiere la ley 47 , título 12, Partida $5 *$ :

Matienzo, 75 hablando do este término, afirma que es útil al principio: de esta misma clase contomplo a nuestro semestre, y desde luego no se debe poner la menor duda en resolver que el tiempo es útil, reflexionando el espíritu de las Ordenanzas de minería.

Los artículos $5^{\circ}$ y $6^{\circ}$ de la de México, ordenan que en las materias de minas se determinen la verdad sabida y la buena fe guardada, concediendo a los Jueces el arbitrio de examinar de oficio los testigos que hallaren por conveniente, $y$ tomar los juramentos de las partes, para mejor averiguar la verdad.

Todo debe ser equitativo en este género de negocios; y así cuando ocurrieren accidentes que impidan el cumplimiento de alguna Ordenanza, es preciso que el Juez socorra al impedido, con nuevo término', según lo dijo Tiraquelo, í tratando de la prórroga del tiempo prescrito al apelante para proseguir su recurso, en caso de no haberlo podido verificar por algún justo embarazo.

La misma Ordenanza de México ${ }^{77}$ adoptó este partido, permitiendo que al denunciante de minas abandonadas, que no hubiere podido habilitar el pozo de ordenanza, ni tomar la posesión dentro de los 60 días señalados en el artículo $8^{\circ}$, título $6^{\circ}$, bajo la pena de perder el derecho a la mina, se le pueda ampliar el término en cuanto fuese suficiente; de manera que aquella regla generalmente recibida, de ser improrrogables los plazos establecidos por ley o por estatuto, se viene a exceptuar en negocios de minería, por deberse observar en cllos, sólo por equidad y por arbitrio de buena fe.

Por último, se comprueba por la Ordenanza del Perú, que el tiempo del semestre no es continuo, sino útil; porque hallándose determinado 
por la $8^{\prime \prime}$, título $1^{\circ}$, libro $3^{\circ}$, que el transcurso de los treinta días prescritos para manifestar y hacer registro de la mina, no debe perjudicar al descubridor que se hubiese detenido más tiemipo por algún legitimo inpedimento, es consiguiente que no sea continuo este término, pues segín las reglas que dejamos sentadas, es útil aquel tiempo que no se le corre ni perjudica al impedido. is

De aquí resulta la resolución de la tercera duda, a saber, que el descubrictor clérigo, debe ser oído antes de adjudicarse a otro que pidiere la mina cuya venta no hubiese él verificado dentro de los seis meses de la Ordenanza, porque siendo axioma vulgar deducido de las leyes, 79 y universalmente contestado por los Doctores, so que al impedido no le corre término ni perjudica su transcurso, a menos que haya sido por su dolo y culpa lata, ${ }^{81}$ antes bien le excusa de la pena el impedimento justo y embaraza el curso del tiempo establecido por la ley, o por el hombre, ${ }^{82}$ es menester oír y citarlo, antes de proceder a la privación de la mina, para que alegue y pruebe el impedimento, que tal vez pudo haberle estorbado la venta dentro del semestre de la ordenanza.

Ei Eminentísimo Cardenal de Luca, ${ }^{\circ .3}$ propone un caso muy adccuado para comprobación de nuestra sentencia: se refiere a que una $\mathrm{Ba}-$ ronesa de Mondovi o Mondevi, (ciudad episcopal del Piamonte), instituyó por heredero universal a su marido, bajo la condición de ordenarse sacerdote dentro de un año desde el día de su muerte, pena de caducidad, substituyendo en su lugar a una congregación pía.

Este heredero no cumplió la condición, por el impedimento de bigamia que le resultaba por la viudedad de la testadora, y habiendo pasado a Roma a solicitar la dispensación del Sumo Pontífice, sobrevino una dilatada vacancia de la silla Papal, por muerte de Clemente IX; y habiendo obtenido después de mucho tiempo la conmutación del sacerdocio en el hábito militar de San Juan de Jerusalén, con la obligación de profesar a su debido tiempo, se dudó por los Oficiales de la dataria, al tiempo de despachar el Breve de gracia, si ésta, como concedida después de transcurrido el año prefinido por la testadora, podría ser perjudicial a la congregación y privarla del derecho adquirido a la herencia en virtur de la substitución.

Sobre to cual, consultado el Eminentísimo Luca, respondió, que mediando las justas y legítimas causas que impidieron al heredero para cumplir la voluntad de la testadora, dentro del año prescrito, no le debía perjudicar su transcurso para incurrir en la caducidad; ni la congregación substituta había adquirido derecho a la herencia por la misma razón.

Añade, que el precepto de ordenarse dentro del año, se impuso por vía de modo a parte post, y no por vía de condición a parte ante. y como al mismo tiempo de la inobservancia del precepto induciría privación de derecho ya adquirido (lo que se asemeja a una pena formal, en que nunca se incurre sin dolo y sin malicia), debía èstimarse el impedimento muy suficiente para excusar al heredero del lapso del término, y por consiguiente, de la caducidad.

Conforme a esta doctrina, parece muy segura y bien fundada la resolución propuesta, una vez que sólo el transcurso del tiempo no basta para privar el derecho ya adquirido, y menos para aplicarlo a otro. $Y$ es así, porque como dice el mismo Luca, 84 el tiempo no es tan preciso que de él dependa toda la fuerza y el efecto de la Ordenanza; el fin es vender 
la mina; luego, siempre que éste se cumpla, con verificarse la venta, aunque sea después del tiempo prefinido, principalmente estando la cosa íntegra, y antes de declavarse la caducidad del registro, se debe mirar el ticmpo como si todavía durase el primer plazo, según la más benigna y recibida sentencia de los Doctores.

El sabio Solórzano, trató más de intento otra cuestión idéntica con la nuestra, que quita toda duda en la resolución: supone el caso de haberse ausentado un Encomendero, por más tiempo del que se le concedió, sin volver a residir en el lugar de la enconienda, como está obligado por las leyes, bajo la pena de privación ipso jure incurrenda.

Compara las encomiendas a los feudos y a los beneficios eclesiásticos, y haciéndose cargo de las graves autoridades que requieren citación, ya sca personal, ya por edictos y proclamas de los beneficiados o feudatarios auscntes más tiempo del asignado en la licencia, resuelve, 85 en cuanto a los encomenderos, que deben ser oídos y citados, formándoseles proceso para dax y pronunciar la sentencia declaratoria de la incursa privación.

Para todo esto, alega ${ }^{86}$ por principal funclamento, los impedimentos que pueden haber ocurrido para que el encomendero no compareciese a residir dentro del término prescrito: luego, observando las mismas reglas y principios, debe ser ódo y citado el clérigo descubridor, para que pueda hacerse la privación de la mina en términos de justicia.

Ello es cierto, que para poderse adjudicar semejante mina, es menester que se denuncie; pero no basta hacer constar solamente el transcurso del tiempo, por el reconocimiento del registro; pues, fuera de todos los fundamentos que acabo de referix, previenen las Ordenanzas del Pelú y de México, ${ }^{87}$ que se debe citar al poseedor, oír a las partes y adjudicar la mina al que mejor probare su intención.

Si la sentencia saliere a favor del denunciante, se sigue la cuarta resolución, de no tener preferencia alguna los parientes del eclesiástico. Porque cuando se adjudica a otro su mina, por no haberla vendido a tiempo, ha precedido declaración de la caducidad del registro, incorporándose de nuevo a la Corona; entonces recupera la primitiva naturaleza de bien realengo $y$ es como cualquiera otra mina que nunca se hubicra registrado: ś́to el Rey es su dueño; el clérigo nada tiene en ella, ni se estima por de su patrimonio; lucgo, así como ninguno puede pretender preferencia en la adjudicación de una mina enteramente nueva, tampoco lo pueden intentar los parientes del eclesiástico en la mina que se le haya quitado por la caducidad de su registro, pues ya salió de entre sus bienes y. se reputa como nueva por su reversión a la Corona.

Pasemos ya a examinar el número de minas permitidas a los mineros regulares, que no gozan privilegio de primeros descubridores. En este punto, será preciso referir las Ordenanzas del Perú que tratan de ello y de las demasías, para que entendida brevemente la grande diferencia de la Ordenanza de México, no se vacile después en el verdadero derecho que debe regir, según el actual sistema de minería.

En varias Ordenanzas del Perú se advierte cierta aparente distinción de las minas estacadas a las compradas y a las adquiridas por herencia u otro cualquier título lucrativo, pero ésto no conduce a la determinación del número, sino al plazo en que se deben vender las demasías. Así se ve, que la Ordenanza $3^{n}$, título 2 , libro $3^{\circ}$, concede cuatro meses al 
que hallándose en las minas que puede poseer, adquiexe otras por herencia, donación, legado o cláusula de testamento, para que disponga de lo demasiado, sin que nadie se lo pueda demandar en el entretanto; y al mismo tiempo se lee en la Ordenanza 15, al fin, título 1", $y$ en las Ordenanzas 1 y 3 , título 2, libro 3", que al posecdor de más minas de las que están permitidas, se le puedan pedir las demasias luego que las hubiere adquirido por compra o por contrato, quedando obligado a dárselas al demandador, dentro de tercero día, con prohibición de no ajenarlas desde entonces, pena de nulidad y de mil pesos.

La razón de esta diversidad consiste, a mi juicio, en que el comprador obra con la codicia de abarcar muchas minas (tal vez por un precio ínfimo), para aprovecharse de sus frutos sin contemplación de más utilidad que la suya. Y ya que la Ordenanza no refrena esta codicia en cuanto a prohibir la adquisición, ha querido estrechar los términos en que se deben vender las demasías.

Al contrario, favorece las adquisiciones que provienen de algún título lucrativo porque en tal caso todo lo hace la fortuna $y$ no se advierte vicio que castigar ni reprimir de parte del poseedor. Por esto indulta la Ordenanza el plazo de cuatro meses para deshacerse de las demasías, con el fin de que se haga con más libertad la enajenación de lo que se adquirió por disposición de la ley en las heroncias y por mera liberalidad de los hombres en las donaciones y legados.

Con esta diforencia de plazos, se deben vender las minas que excedieren de las cinco que puede poscer un minero regular en difeventes vetas: a saber, tres minas de metal rico ss y dos de soroches, así compradas, como por estacas, conforme a la Ordenanza 15 , título $1^{\circ}$, libro $3^{\circ}$ del Perú, entendiéndose sin perjuicio de las otras cinco que permite la Ordenanza 14 del mismo título y libro, al que descubriere vetas nuevas, aunque no sea descubridor dol cerro en que se hallaren; de sucrte que, si el mismo que tuviere por compra o por estacas las cinco minas de que habla la Ordenanza 15 , descubriere otras vetas nucvas, puede tener en carla una de ellas una mina cntera hasta completal cl número de otras cinco minas más, como dispone la Ordenanza 14 citada, título 1 ", Iibro $3^{\circ}$ del Perú.

La nueva Ordenanza de México, mandada guardar en este Reino, en nada concuerda con nuestra antigua legislación de minería, en orden a los puntos propuestos. Primeramente, sin limitar número, permite la tenencia de cuantas minas se quisiezen poseer por títulos de registro, donuncio, venta, donación o herencia; ss en segundo lugar, no prohibe la adquisición de dos o más minas sobre una propia veta, sicmpre que proceda de títulos diferentes, es a saber, una por registro y otra o más por denuncio, venta, donación, herencia o legado.

En esto se conforma con la ley $5^{n}$, Cap. 31 , titulo 3 , libro $6^{\circ}$ de la recopilación de Castilla, que al mismo tiempo de prohibir la adquisición de dos minas contiguas en una veta, por registro o por denuncio, exceptúa do esta regla las que se hubieren comprado, aunque sean muchas y estén todas juntas. De manera que, según este nuevo sistema, quedan del todo abolidas las antiguas restricciones, y cualquiera que tuviere una mina registrada por estaca, puede denunciar otra por despucble, y adquirir muchas más, todas ellas juntas, por compra o por título lucrativo. ${ }^{90}$

Sólo se reserva el caso de pretender alguno la habilitación de mu- 
chas minas inundadas o ruinosas, u otra empresa de notable importancia; porque entonces, bien puede poseer muchas minas juntas en una veta, por título de denuncio, preccdiendo per'miso del Superintendente General de Minas, a consuita del tribunal, después de calificado el mérito y circunstancias de la operación, con arreglo al artículo 17, título 6\%. Por los mismos fines de utilidad pública, también queda exceptuado ${ }^{\$ 1}$ el caso de haber sido algún minero con sus labores subtexráneas, fucra de los términos de sus preeminencias, bien sea por longitud o por primera cuadra, que hubiera avanzado sobre teryeno virgen o de mina desamparada porque, no debiendo presumir'se aqui animo codicioso de abarcar toda la veta en pexjuicio de otros (que fue el motivo de prohibir muchas pertenencias juntiss), no se le debe impedir el trabajo a continuación de las minas sobre la misma vcta, siempre que denunciare la nueva pertenencia; cle manera que si hubiera adquirido por registro la mina de donde avanzó sus labores sobre ter'eno virgen, vendrá a poseer dos pertenencias contiguas por un mismo título do registro; y si hubieren sido minas desamparadas, la que comonzó a laborar y la otra donde se introdujere de nuevo, las dos corresponden a un mismo título de denunclo; pero se advierte que cada concesión no debe pasar de otro tanto más de las medidas que anteriormente se le concedieron y se han de renovar las estacas hasta los nuevos térninos, para que lo sepan todos.

En teicer lugar, no admite demasias en cuanto a número, porque permitiendo cue cualquicra posea cuantas minas pudiere labrax, es consigujento que no hayan demasias en este sentido, si bien, aunque no se puedan pedir por este título al que las ocupare, se pueden denunciar por despobladas las que no tuvicre en actual trabajo, o a lo menos amparadas con arreglo a Ordenanza.

Así, cuando la Ordenanza de México ${ }^{92}$ habla de demasías, se entiende precisamente del terreno que sobra entre dos minas, ya sea por haber mejorado estacas de un xumbo hasta otro, ${ }^{93}$ o por haber excedido a las medidas primeras.

La cuarta y última diferencia consiste, en que por la legislación del Perú, ${ }^{94}$ el poseedor de las demasías es incapaz de tenerlas por cualquier título que sea, cuando, por el contrario, la Ordenanza de México ${ }^{95}$ no solamente sc las concede, sino que tambićn le declara preferencia, aunque sea en concurso de otros que las hayan pedido primero. ${ }^{96}$

(Aquí concluye el Apendice a los artículos $1^{\circ}$ y $2^{\circ}$ del párrafo noveno, noticia séptima del Cayitulo $8^{n},-\boldsymbol{N}$. de $\boldsymbol{E}$.).

Artículo $3^{\circ}$. Registros.- Se explica el método práctico de hacerlos. - Registro, no es otra cosa que la manifestación o denuncia de algunos bienes, para evitar fraudes, o para otros fincs que declaran las leyes. ${ }^{97}$ Esta voz trae su origen, según el sabio Solórzano, ${ }^{98}$ de la palabra latina res-gesta, que significa cualesquiera autos judiciales en que se da fe y testimonio de lo que se hace o va haciendo; pongo por ejemplo, en el comercio naval, de todo lo que llevan o embarcan o cargan en la nave, así de mercaderías como oro, plata, perlas, sueldos y hasta las cédulas de cambio. 99 
Conforme a este principio, se mandan registrar por las leyes de Castilla, 100 los caballos, potros, yeguas y demás bestias que se mantienen fuera del Reino, dentro de las doce leguas de los puertos, y juntamente los que nacieron dentro de este mismo distrito.

En materia de minas, es tan indispensable el Registro de todas las que se descubrieren, que comenzando a trabajarlas antes de hacerlo, se incurre en la pena de su perdimiento y más la mitad de los otros bienes, ${ }^{101}$ El docto Fiscal Don Franeisco de Alfaro, ${ }^{102}$ funda la necesidad del registro en el interés del fisco a la cobranza de los quintos, y en el propio derecho del descubridor para conservar claras y especificas sus pertenencias.

A fin de mantener el buen orden entre los interesados, se ha prescrito por las Ordenanzas cierto término y forma en que se deben hacer los registros.

En el Perú ${ }^{103}$ están señalados 30 días desde que se hubiere descubierto metal, para manifestarlo y hacer registro ante la respectiva Justicia, ampliando a diez días más los 20 que para este mismo efecto concede la ley 4, Cap. $4^{\circ}$, título 13 , libro $6^{\circ}$ de Castilla, en consideración a las grandes distancias y a los embarazos de los caminos; así como se halla prorrogado por el propio motivo, a tres o cuatro meses el término de los Edictos para concursos en el Perú, 101 con todo de haber prefijado sólo diez días o a lo más 20, la Bula de Pío V, explicada clegantemente por Salgado. ${ }^{105}$

$\mathrm{Y}$ en cuanto a los indios, se atendió tambièn su incapacidad, a más de las razones referidas, y por tanto se les triplico este tímino, permitiéndoles el registro dentro de tres meses, ${ }^{106}$ pues, verdaderamente, son mayores para ellos las dificultades, según su pobreza y la fragosidad de los lugares donde viven de ordinario.

Todos los vasallos del Rey pueden descubrir y registrar minas en el plazo referido, exceptuando únicamente aquellos que por expresa Ordenanza se hallaren prohibidos de poderlo hacer. thi

Pero deben los que registraren, presentarse por sí mismos, trayendo personalmente la muestra de plata que sacaron, $\mathrm{y}$ jurando que es la misma que salió del metal manifestado y descubierto en la veta que registran. ${ }^{108}$

El requisito de esta personalidad ocasionó innumerables pleitos y calumnias, porque se solicitaba privar a los descubridores del derecho al registro, cuando no lo habían hecho personalmente, pretextando no ser practicable por Procurador este acto y mucho menos el juramento, como personal, según opinión de varios Doctores, 109 tratando del juramento de fidelidad que deben prestar al Papa los obispos electos o translatos.

Entonces resolvió el Sr. Toledo, ${ }^{110}$ para evitar dudas y diferencias, que los justamente impedidos de poder cumplir con los requisitos necesarios de juramento y manifestación personal, pudiesen hacer por un poder especial 111 para dichos efectos, verificándolo por carta, en caso de no haber Escribano en el lugar donde se halló la veta, ni en las inmediaciones. ${ }^{112}$ De suerte que, conformándose con el Derecho Canónico, ${ }^{119}$ autorizó con fuerza de ley las doctrinas ${ }^{114}$ que defienden practicable por Procurador el juramento, cortando con esta sabia providencia las tenaces altercaciones que, sobre el mismo punto, se ven reñidas por los autores más clásicos. 
De aquí resulta una cuestión muy digna de explicarse, por su gravedad y frectencia, a saber: si aunque el deseubridor no se halle impedido, podrá registrar libremente por Procurador.

De la lectura de la Ordenanza 11 , título 19 , libro $3^{n}$, se deduce, al parecer con evidencia, la negativa; porque después de haber prevenido en la $8^{\text {a }}$ del mismo título y libro, la compareceneia personal del descubridor, resuclve que puede registrar y hacer juramento por Procurador con poder especial, cuando no pudiere venir en persona a cumplir con estos requisitos, por vejez, por enfermedades, por ríos crecidos, por ausencia necesaria, por destierro, por cautiverio, por su Dignidad, 115 por su sexo, ${ }^{116}$ o por otros impedimentos justos que referí en otro lugar ${ }^{117} \mathrm{y}$ numera el docto Harprector: ${ }^{118}$ que fue lo mismo que admitir cl uso de Procuradores solamente on caso de neccsidad.

En ésto se conformó cl gran Toledo, con la resolución que tomó el Emperador Justiniano, ${ }^{119}$ permitiendo que pudiesen apersonarse uno por otro, judicial o extrajudicialmente, cuando estuvieren impedidos de hacerlo per'sonalmente, por enfermedad, vejez o peregrinación. De suerte que, discurriendo por los principios vulgares de Derecho, parece no haberse aprobado la intervención de Procurador en los demás casos libres de impedimento, porqque conceptuándose solamente los de necesidad, debe afirmarse la regla en contrario, en los otros que no se reservaron expresamente.

No obstante, soy de opinión que la afirmativa es más probable y dcbe seguirse en la práctica. Dice una ley del Digesto, ${ }^{2} 20$ que "es muy nccesario el uso de Procuradores, para que los que no quieran o no puedan asistir a la intervención de sus negocios, puedan reconvenir o ser reconvenidos po: medio de otros". Según esta disposición, no es menester que uno se halle impedido, para obrar por Procurador, pues para poderlo nombrar, basta que no quiera intervenir por sí mismo; luego, aunque el descubridor no tenga impedimento para registrar personalmente, puede practicarlo por apoderađo, siempre que él así lo quisiere.

La ley 68 del Derecho Canónico comprueba esta opinión, porque si en lo general cualquiera pucde por otro, lo puede hacer por sí mismo, exceptuando los casos que allí anota Andrés de Alciato: se debe concluír que quién puede registrar por sí mismo, también lo puede hacer por Procurador, según derecho.

Para fundar mejor esta resolución, veamos como resuelven los intérpretes institutarios, el argumento deducido del texto de Justiniano, y de ahí descenderá la inteligencia verdadera de nuestra Ordenanza peruana.

El sapientísimo Vinnjo dice ${ }^{121}$ que los impedimentos expresados en el texto y otros semejantes, introdujeron al principio el uso de Procuradores, pero que una vez recibidos, continuaron su ejercicio aunque no hubiese necesidad o impedimento. Asimismo sucedió en materia de registros: pues, habiendo admitido el Sr. Toledo la intervención de Procuradores, por varios embarazos que impedían a los descubridores para hacerlos por sus propias personas, se ha conservado esta facultad indistintamente fuera de los casos de necesidad; de suerte que, según explica Pichardo, ${ }_{22}$ los impedimentos fueron la causa impulsiva para admitir Procuradores, pero el final de la Ordenanza (como expresa ella misma), fue evitar los pleitos y calumnias, que de ordinario se seguían, como de 
guardarse la libertad que cada uno tiene de usar de su derecho, por sí mismo o por otro con su poder.

Por esto, faltando la causa impulsiva, no debilita ni destituye el valor de Ia ley subsistiendo la causa final como advierten y notan los Doctores con Acurcio, citado por Cobarrubias, ${ }^{128}$ hablando de Calfurnia, la cual aunque dio ocasión con su insolencia y procacidact, al Edicto en que se prohibió a las mujeres el oficio de abogar, con todo, no fue ella la causa final. Y así quedan, generalmente, prohibidas todas las mujeres, también aquellas que no fueren insolentes ni procaces; porque subsiste la causa final, que fue evitar perjuicios del pudor y honestidad del sexo, como lo indica la ley $3^{\mathrm{a}}$, título 6 , Partida $3^{3}$. Con que ebservando la misma regla, pueden valerse de Procuradores los descubridores sin impedimento, del mismo modo que los impedidos, respecto de concurrip en unos y otros la causa final de la Ordenanza.

$\mathrm{Ni}$ porque se exceptuaron los impedidos, se debe presumir prohibido a los demás que no lo fueren, el indulto de Apoderados, porque según Pareja, ${ }^{124}$ se debe suponev más bien omitidos los otros casos que no expresó la Ordenanza, dejándolos a la disposición del Derecho común. Por lo que se deberá guardar la regla ya citada: que cualquiera puede hacer por otro, lo que puede por sí mismo. ${ }^{125}$

Aquí se puede tener po* exceptuado el que registrare estacas o las pidiere, porque debe pedirlas por su persona y no por poder ni carta, si no es que fuere dado a persona asalariada, según la Ordenanza $4^{a}$ del Presidente Gasca, y la 11 al final, título $1^{\circ}$, libro $3^{\circ}$ de las del Sr. Toledo.

No es extraña la reservación de este easo por el gravamen que imponen las Ordenanzas a los estacados, ${ }^{126}$ de que entre todos dopositen cien pesos antes de concedérseles estacas, para que con ellos se pueda dar un pozo o dos en el paraje de la veta que mejor le pareciere al descubridor, pena que no queriendo pasar por la condición de contribuír, ninguno sea admitido a estacarse en la veta.

Sin tanto motivo, se ve exceptuado de la regla antecedente el caso de la impetración de venia en los menores varones, obligándoseles ${ }^{12 \pi}$ a que por sí mismos y no por Procurador, aleguen el beneficio imperial y prueben su edad y costumbres; fuera de otras muchas falencias que requiere Alciato sobre la regla 68 expresada.

Según el sentido de la Ordenanza del Perú, se requiere dos calidades en el que pidiere estacas por otro: a saber, que tenga poder especial, y que sea criado asalariado. Casi lo mismo determina la de Méxi$c 0$, ${ }^{128}$ pues, aunque permite a los criados que registren para sus mismos amos, sin tener su poder, previene al mismo tiempo, que ratifiquen el denuncio o registro dentro de 60 días, 129 y es como si se hubiera procedido con poder bastante, porque la ratificación se equipara al mandato, por la ley 10 , título 34, Partida $7^{\mathrm{n}}$.

No distingue el Registro de nuevos descubrimientos del de las estacas, como lo ejecutó la Ordenanza del Perú; pero, debiéndose conciliar las leyes para evitar toda corrección, se debe también declarar la una por la otra, y concluír lo primero, que cuando el artículo 5\%, título 7, permite absolutamente registrar mina por otro con su poder, o carta orden, se entiende de los nuevos descubridores, con las circunstancias y distinciones que he explicado comentando la Ordenanza 11 , título $1^{\circ}$, libro $3^{\circ}$ del Perú; lo segundo, que para el registro de estacas, no basta el poder 
solo, ni que sea criado quien las pidiere, sino que sobre esta última calidad, debe concurir el poder o la ratificación que es su equivalente.

Según la antecedente advertencia, se han practicado siempre los registros de minas en el Perú y en México, casi por el mismo método. La corta diforencia que se nota entre ambos estilos, consiste en circunstancias que por el nuevo sistema de minería se pueden uniformar. Por esto explicaré el método práctico de registrar, siguiendo las disposiciones de una y otra legislación, combinadas ya en este Reino, distinguiendo las clases de descubrimientos que dejamos explicado para su mayor claridad.

El que fuer'e nuevo descubridor, exhibe ante la Justicia y Escribano de Minas el metal y pella que halló, 180 expresando su nombre y los de sus compañeros "3i si los tuviere; el lugar de su nacimiento; su vecindad, profesión y ejercicio, con todas las señales individuales y distingui"das del sitio, cerro o veta cuya adjudicación pretendiere, ${ }^{132}$ y jura que sacó realmente mno y otro de la misna veta que registra, por tal veta, manto, bolsa, aspa, crucera, criadero, ramo, o cualquiera que sea, ${ }^{133}$ pidiendo mina entera de 200 varas, y señalando la de Su Majestad, 134 denunciando al mismo tiempo la veta a mayor abundamiento, por defecto de pozo de cualquier persona que la haya pedido o alegare derecho para que se le adjudique en nombre de S. M.

El Jiez decreta: "Por fecho el registro, exhibido el metal y pella y por nombrada la mina de Su Majestad, en su Real nombre se concede mina de 200 varas en el lugar y parte y para el efecto que se pide, en conformidad de las Reales Ordenanzas, y cumpla con su tenor, so Ia pena de ellas".

Cuando se pide por derecho de limpia alguna mina o veta ciega y oculta, para repararla y habilitarla, con protesta de presentar el metal fijo quc descubriere y hacer registro en forma, señalando mina para $\mathrm{Su}$ Majestad, el decreto es: "Sin perjuicio de tercero que mejor derecho tenga, se concede la veta que refiere, por derecho de limpia, bajo las protestas expresadas; y en el interin ${ }^{135}$ no se le inquiete ni impida la labor". ${ }^{136}$

Los demás que quisieren estacarse en la mina descubierta, piden sencillamente mina de 200 varas, sin la distinción de medidas que hacía la Ordenanza antigua del Perú, ${ }^{137}$ y la providencia de estilo es: "Concedida sin perjuicio de tercero que tenga mejor derecho, en la parte y lugar, y para el efecto que se pide, on conformidad de lo dispuesto por ordenanzas, y so la pena de ellas".

El Escribano autoriza cl proveido y allí mismo da fe del día y hora en que se presentó el descubridor, tomando de todo razón exacta en un Libro de Registros, que debe tener por abecedario, conforme a las Ordenanzas del Per'ú y de México. ${ }^{13 \$}$

La formalidad de registro, prevenida para las minas nuevas, es igualmente indispensable para las baldías y despobladas, porque el registro en que se comprende licencia para Iabrarlas, es todo el fundamento y el único título de su adquisición y dominio. ${ }^{139}$ Por eso dice Gamboa, ${ }^{140}$ que quien denuncia el despueble, no sucede al anterior poseedor, antes lo delata pol contravención de las Ordenanzas, que entra como poseedor nuevo por potestad de la ley, y se le hace nueva concesión y nueva investidura, y se le da nuevo título, y por consiguiente una mina que, aunque en realidad no es nueva, se reputa por tal y como si nunca hubiera sido registrada. De suerte que hasta las medidas es menester renovarlas, se- 
gún el nuevo registro, sin considerar para nada las antiguas como procedentes de un título ya extinguido y de una merced enteramente caduca.

El único caso que se exceptúa de registro en materia de despoblados, es cuando alguno labra públicamente una mina que otro había registrado, ora sea por socavón, o sobre el haz de la tierra, por espacio de dos años, sin contradicción alguna; porque según la Ordenanza 15, título $1^{\circ}$, libro $3^{\circ}$ del Perú, le vale por título bastante esta posesión, y sobre ella no se puede mover pleito ni admitirlo por ninguna causa.

El Rey es el dueño absoluto y privativo de las minas, y puede proveer su adquísición como mejor le pareciere: por lo mismo, así como en el modo regular el registro es el título esencial para el dominio, en este caso surte los mismos efectos la posesión de dos años, y sirve para transferir la propiedad, como si realmente se hubieta r'egistrado la mina.

Pero, como la prescripción, según Modestino, ${ }^{14}$ y una ley de Partida, ${ }^{142}$ es la adquisición del dominio, por continuada posesión de cierto tiempo señalado por ley; debe entenderse contimuos $\mathrm{y} \sin$ interrupción los dos años de labor que prescribe la Ordenanza citada del Perú, para adquirir sin título ni registro una mina que otro había registrado.

- La duda sólo puede estar en el modo de probar esta posesión continuada; pues, tal vez se quisicra intentar que el poseedor lo probare por testigos que depusieran haberio visto trabajando continuamente y sin intermisión en todo el bienio.

Esto, realmente, es imposible, conforme a los textos del Derecho Civil, ${ }^{143}$ y así resuelve el docto Tiraquelo, ${ }^{144}$ que basta para certificar (la posesión continua), haber percibido los frutos de cada año, o, al menos, que puso trabajadores para que sacaren metales, aunque nada le hubiesen fructificado en realidad. Y por último añade, que se estima suficientemente calificada la continuación del tiempo, si se probare que poseyó al principio del primer año y al fin del segundo; porque probándose los extremos, se tiene por justificados los medios, que presúmense de una misma calidad.

Volviendo a los Registros, se puede dudar, lo primero, si. cuando el Escribano de Minas no tomare razón de los autos formados por parte del descubridor, conforme a ordenanzas, quedará siemple firme su derecho, para todos los efectos que producen los demás registros protocolados, de sucrte que sea preferido a otro que presentare registro de la misma mina, con el requisito de hallarse asentado en los Libros de razón o Protocolo.

Los Doctores movieron esta cuestión sobre la necesidad del registro, que impone la ley 13 , título 25 , libro $4^{\prime \prime}$ de Castilla, en todos los instrumentos públicos, y también puede suscitarse en nuestro caso, por la obligación que induce a este propio fin, la Ordenanza 6, título 9, libro $3^{\circ}$ del Perú.

La negativa se puede fundar en una Novella de Justiniano, ${ }^{145}$ donde se lee haber declarado este Emperador, por nulo todo instrumento que $n 0$ hubiese quedado anotado en los libros de registro o en los Protocolos.

Pero, absolviendo esta duda, cl insigne Cobarrubias, ${ }^{116}$ responde que la citada constitución fue especial para la ciudad de Constantinopla, y así nunca estableció ley general. Fuera de que, según Nicolás de Martarellis (a quien él se refiere), allí sólo sc trató de la forma y solemnidad del Protocolo, para que éste nada pruebe sin aquella; pero no se de- 
terminó que no mereciese fe un instrumento otorgado solemnemente, cuando no se hubiere reducido a Protocolo; por lo que concluiré, que es tan bien recibida esta opinión, que no tiene contradictor en la práctica.

Don Francisco Carrasco formó un dilatado diseurso sobre el mismo caso, y después de alegar muchas autoridades para probar la fe de los instrumentos auténticos que no se hubieran protocolizado, refiere ${ }^{147}$ que abogando él, por Garci López de Morales, fue preferido en más de 25.000 ducados, por una escritura signada, de la que no quedó registro.

Todo lo cual convence de que el pedimento firmado por el descubridor, decretado por el Juez y autorizado pox Escribano, hace entera fe $\mathrm{y}$ se debe tencr por título matriz y original, aunque no se haya tomado razón de él ni anotado en el jibro de registros.

Bien que deberá ser castigado el Escribano, con la pena de un año de suspensión del oficio y los 10.000 maravedíes para la Cámara, que impone la ley 16, título 8, libro 5" de la recopilación de Indias; sin embargo de que las partes lubiesen consentido que no quedase registro.

Se puede dudar lo segundo, si, pasados los treinta días asignados para registro, conserva todavía su derecho el descubridor, para poder registrar después.

La Ordenanza 8", título 1", libro $3^{\circ}$ del Perú, distingue entre los descubridores morosos, al impedido, de aquel que se hubiera detenido sin justa causa, y declara que no goce del derecho de descubridor, si se detuviese más tiempo de los treinta días, sin causa muy legitima; como si dijera que aunque otro no venga a registrar, no puede ya hacerlo el descubridor que no estando impedido dejó pasar por omisión voluntaria el plazo de la ley.

El Sr. Toledo siguió aquí las disposiciones generales del derecho, porque como enseñan Baldo, Koppen, Saliceto, y otros que cita Martín Magero, ${ }^{148}$ el transcurso del tiempo señalado por ley, induce tácita renunciación, y el que lo deja pasar, se juzga haber renunciado su derecho. Al mismo tiempo se presume fatal, preciso y perentorio, y no admite purgación de la demora, aunque la cosa permanezca íntegra; porque en este caso, no se establece el término por vía de prescripto, según Surdo, Fontanela y Tiraquelo, ${ }^{249}$ con otros muchos; de manera que no debiendo ser más oído en adelante, como resuelve Salgado, ${ }^{150}$ es consiguiente que no sea admitido a registrar como descubridor, después de fenecidos los treinta días de la Ordenanza.

La ley $5^{n}$, título 9, Partida 4 , puede servir de nuevo fundamento y confirmación de esta sentencia. Allí se previene que, habiêndose amonestado por edicto público, que los que supieren algún impedimento del matrimonio que se proclama, lo denuncien hasta cierto día que determinare el Párroco; si alguno de los que estuvieren delante cuando esto fuere dicho, se callare entonces sabiendo que entre ellos había tal embara$\mathrm{zo}, \mathrm{y}$ los quisiese acusar después de casados, para separar el matrimonio, que no debe sex oído. Luego, tampoco debe serio el deseubridor que quisiere registrar después de pasado el término fatal de la ley, si durante su curso se estuvo callado sin querer usar de su derecho, sabiendo que por su detención debía perder el de descubridor.

Sin embargo, yo considero que siempre se debe tomar algún temperamento equitativo con el descubridor, estando todavía la cosa íntegra. Es un bello ejemplo el del enphiteuta que ha demorado la paga del 
censo, por dos años, a la Iglesia, o por tres años al lego. No hay duda que pasando estos plazos sin haber pagado la renta o el censo, cae la heredad en comiso y los señores de ella la pueden tomar sin mandato del Juez, ${ }^{151}$ aun cuando no lo hubieran reconvenido por sí, ni otro por ellos, porque el día mismo del plazo a que debe pagar la renta, lo demanda y emplaza a que le pague. ${ }^{152}$ Así como queda obligado a la pena que prometió, aquél que afianzó a otro, en juicio de ayudarle a estar y a cumplir de derecho, a quién hiciese querella de él, si no lo verificare al plazo que le pusieren. ${ }^{153}$

Y con todo, la misma ley liberta de pena al fiador, aunque no presente al deudor en juicio dentro del plazo que le fuere puesto, si lo llega a practicar a dos días, o a tres o a cinco o más, scgún arbitrio del Juez, atendidas las circunstancias de las personas y de los lugares, como nota la Glosa de Gregorio López. ${ }^{134}$ Porque, no resultando perjuicio de tercero, siempre se admite purgación de la demora, si fuere corto y no considerable el tiempo transcurrido. 155 Por cuya misma regla, después de cumplidos los tres años, permite la ley 28 , título 8 , Partida $5^{n}$, que el enfiteuta purgue la demora pagando la renta o el censo, dentro de diez días siguientes.

Respecto del descubridor, son mucho más graves estos principios de equidad; porque el plazo de los treinta días se asignó principalmente a su beneficio; y como por otra parte, el exceso de algumos días más no resulta en daño de ningún otro, es muy justo que no se le tenga por incurso en la pena de perder el derecho de tal descubridor, después de transcurrido el término de la Ordenanza, en verificando el registro dentro do dos días siguientes, o de algunos más, según lo arbitrare el Juez, teniendo consideración a las personas y lugares de donde vinieren. ${ }^{156}$

Pero en cl caso de haberse retenido el registro por algún impedimento justo, entonces no tiene duda que el descubridor conserva íntegro su derecho para registrar después de los treinta días de la Ordenanza. ${ }^{157}$

Esta conclusión se deduce manifiestamente de la misma Ordenanza que estamos explicando. En ella se declara que, si más tiempo se detuviere (no siendo por causa muy legitima) que no goce del derecho de descubridor. Luego, si la detención fuerc por causa legítima, lo debe conservar para poder hacer el registro, como si estuviera en el plazo.

Ilustremos más este punto. Hablando de los términos establecidos por ley, había dicho el docto Tiraquelo, que feneciéndose sin habel cjecutado en ellos la obra para que se concedieron, nada mís se puede hacer en adelante, según aquella regla: que lo que se permite por cicrto tiempo, se entiende prohibido para después. 1 is Pero este mismo ilustre jurisconsulto exceptuó después el caso de haber sobrevenido algún impedimento que prohibiese obrar dentro del tiempo señalado por la ley, poniendo varios excelentes ejemplos, para calificación de su doctrina. ${ }^{1 ; s i}$

Aquí entra oportunamente la aplicación de aquel célebre axioma, latamente explicado por Barbosa y Salgado, 1to de que "al impedido, no le corre término ni le perjudica su transcurso"; por lo que, concluye Valenzuela, ${ }^{161}$ que el impedimento justo excusa la pena e impide el curso de los plazos, legales o convencionales. Fúndanse en el mismo principio Salgado y García, para afirmar: ${ }^{162}$ que no le corren al impedido los seis meses destinados por derecho ${ }^{163}$ para la provisión de Ios beneficios vacantes; y por consiguiente, que se excusa de la pena de contumacia, deser- 
ción, paga y del de la obligación de concurrir al Concilio general o provincial, con otros muchos ejemplos, en que se remite a Flaminio Paricio.

Lo mismo determinan nuestras leyes de Partida, ${ }^{164}$ excusando de pena a los que por justos impedimentos no pudieren comparecer al plazo que les fuere puesto, y haciendo enumeración puntual de los embargos derechos que los pueden excusar, refiere los siguientes: la vejez, las enfermedades, las heridas, la carcelería, los casamientos, los funerales y entierros del padre o parientes, de amigo o vecino conocido; el emplazamiento para tribunal superior; la menor edad; la ausencia justa o necesaria por causa de estudios o por servicio del Rey, de la Iglesia o de la república; la romería, el destierro, el cautiverio; las avenidas de ríos, las grandes nieves, tempestades y lluvias; los ladrones o enemigos conocidos que le hubieran desafiado o estuvieren acchando en los caminos; ol peligro de mucrte, el temor, la peste; la suma pobreza; el riesgo del deshonor en saliendo a público, u otras razones semejantes a estas como dice la ley 11, título 7, Partida $3^{*}$, y que puedan verse en Savelli, Solórzano y Valenzuela. ${ }^{165}$

Después de todo lo cual, resuelve a nucstro propósito la ley 37, título 11, Partida 5", que no cumpliéndose lo que se mandó hacer en cierto día y bajo de cierta pena, por haberle sobrevenido algún embargo derecho que impidiese su ejecución, no cac en la pena, queriéndolo hacer lo más presto que pudicre; es decir, que el descubridor legítimamente impedido para registrar dentro de treinta días, no incurve en perdimiento del derecho de descubridor, en aprontándose a verificar el registro cuamo antes pudiere, o enviando apoderado que lo haga por él, cuando el impedimento hubiese de durar mucho, como lo previene la ley 11, título 7, Partida $3^{\mathrm{a}}$

$Y$ en este sentido, se debe entender la Ordenanza 11, título $1^{\circ}$, libro $3^{\circ}$ del Perú; pues aunque permite registrar por Procurador para vencer los impedimentos que pueden embarazar hacerlo personalmente, no por eso impone obligación de nombrar apoderado para este fin, antes de hallarse impedido el principal, ni en aquel mismo purito que le sobreviniere el impedimento; porque debiéndose explicar nuestra Ordenanza según el espíritu de las leyes generales del Reino, no debemos inducir necesidad de elegir apoderados, si no es cuando el impedinento se fuere dilatando, de modo quo cl descubridor pueda creer justamente que ya no podrá hacer el registro por si propio en el tórmino de la ley, según lo determina la ley 11 citada de Partida.

En cuya consideración se debe mirar destituída de fundamento en la práctica la roctrina de Gamboa, ${ }^{166}$ que quiso persuadir de lo contrario, sin producir apoyo alguno convincente.

Por último, pneden ocurrir como incidencias de las anteriores resoluciones, las dudas siguientes: I a primera, si relevará de pena el impedimento a que diere ocasión el mismo descubridor, imposibilitándose, por culpa propia, de poder verificar el registro dentro de los 30 días. La segunda, si antes de cumplir el término, será preciso protestar el impedimento o enviar un excusador que lo haga notorio al Juez. La tercera, si compareciendo el descubridor después de pasado el plazo (pero estando todavía la cosa integra), deberá probar el impedimento, para ser admitido, o le bastará adegarlo. La cuarta, si deberá ser oído el descubridor, y de qué manera, cuando ya otro hubiere registrado la mina. La quin- 
ta, si excusará de pena el impedimento que le sobrevino al descubridor, después de la demora, esto es, después de cumplido el plazo de los treinta días.

En cuanto a la primera duda, son muchísimos los autores que defienden la negativa, fundándose en aquellas dos reglas de Derecho Canónico y Civil, 167 adoptadas por el Real de Partida, ${ }^{168}$ que el daño ocasionado por culpa de alguno, a él solo y no a otro, le perjudica. De donde deducen que no debiendo aprovecharle a nadie su propia culpa, para que el delincuente no se haga de mejor condición por su malicia, que el inculpable por su inocencia, tampoco debe relevarlo de pena el impedimento con que él mismo se imposibilitó para obrar.

Se hacen cargo de estos y de otros más graves argumentos, Savelli, Velasco, Cobarrubias, ${ }^{169}$ y principalmente el sabio Solórzano, ${ }^{170}$ tratando de un Encomendero a quien se intentaba privar de la encomienda, a causa de hallarse imposibilitado de desidir en la Provincia, por sentencia de destierro en que había sido condenado por șus delitos.

No obstante lo cual, satisfaciendo uno por uno los textos contrarios, sostiene que cuando la cuipa no fuere afectada, ni ordenado directamente para caer en el impedimento, siempre debe excusarse el impedido, aunque haya dado è mismo la ocasión al impedimento; y luego procede a fundar difusamente esta opinión, por haberse preferido a favor del condenado, por el Supremo Consejo de las Indias, en el pleito que acabo de citar.

Considero por demás referir en detalle los fundamentos de nuestro sabio jurisconsulto, porque siendo todo el fin de esta obra el que sirva de guía para los Gobernadores, es muy suficiente apuntar las doctrinas y algunas resoluciones que pueden valer por ejemplos.

Así se ve que el matrimonio celebrado por temor, es nulo, aunque el amedrentado haya dado causa a la coacción. Las distribuciones cotidianas se deben al beneficiado enfermo, no obstante de haber caído en la enfermedad por su culpa. Las esperas se conceden también por deudas que descienden de culpa y de delito; y finalmente, los Jueces son recusados con justicia, por título de enemistad, por más que el recusante la hubiere motivado por sus excesos: luego, siguiendo estos mismos principios, se debe concluír que el impedimento superviniente dentro del término de la ley, excusa de la pena al descubridor, aunque él se haya imposibilitado por su culpa propia, dando ocasión a la enfermedad, al destierro, o a otro cualquier impedimento de Ios muchísimos que dejamos numerados.

$Y$ no importa que el impedimento venga al principio, al medio o al fin del plazo, porque teniendo facultad el descubridor, para no registrar hasta el último momento de los 30 días, según la doctrina de Tiraquelo en caso equivalente, ${ }^{171}$ no le debe constituír en demora el embarazo que le ocurrió en tiempo hábil.

La segunda duda se absuelve convenientemente por la ley 37, título 11, Partida $5^{\text {a }}$. Hablando esta ley real, del que por su impedimento no presentó al deudor por quien había afianzado de estar a derecho en cierto plazo y bajo de cierta pena, dice que lo debe aducir a derecho, luego que fuera libre de aquel embargo. De lo que se infiere, que durante el impedimento, no está obligado el descubridor a protestarlo, ni tampoco anoticiarlo al Juez, porque la ley nada más exige que el cumplimien- 
to de la promesa en el caso de que trata; y esto, después que cesare el impedimento; con que en cumpliendo con el registro después que se librare del embarazo, habrá hecho lo bastante para satisfacer a la ley, pues no haciéndose en ésta, distinción de protestas ni de noticias, tampoco debemos distinguir nosotros.

Es verdad que algunos autores ${ }^{122}$ tienen por previo protestar el impedimento para que no perjudique; $y$ según otros, con Solórzano, 173 aunque no es necesario, tal vez suele ser útil; pero según Antonio Gómez, ${ }^{174}$ en aquellas cosas que no penden de sola nuestra voluntad, sino que, por ley, tienen establecida cierta forma (como son Registros), entonces, no solamente no es necesaria la protesta, sino también es de ningún momento; $y$ Cortiada 175 dice absolutamente, que el impedimento se ha de acreditar a su tiempo, y no es menester protestarlo, citando a Cancerio, Fontanella y otros autores clásicos.

Mucho menos necesario es el envío de excusador que noticie el impedimento; pues, siendo de mayor gravamen excusarse por procurador, que el protestar, claro está que quien no estuviere obligado a esto último, con más razón debe estar libre de lo primero, según aquel principio vulgar de que: no debe obligarse a lo más, el que estuviere absuelto de lo menos.

Así lo siente expresamente el Dr. Gregorio López, ${ }^{176}$ recomendando muy particularmente la ley 11 , título $7^{\circ}$, Partida $3^{\text {a }}$, que no requiere misión de tal excusador de impedimentos, sino en el caso de que procedan de enemigos; y concluye, que aunque no se envíe en las demás ocurpencias, debe socorrerse al impedido.

Pero, para lograr este efecto, debe probarse el impedimento, y no basta el alegarlo solamente, cuando el descubridor compareciere a registrar después del plazo (que es la resolución de la tercera duda). Así lo declara la ley 11 citada, título 7, Partida 3a, por aquellas terminantes palabras: "en probándolo e mostrándolo al Juagador (aquí habla del impedimento), debe valer, de manera que pena ni daño non reciba, por razón que no vino al plazo".

Lo mismo había resuelto Bartholo, 17i a quien siguen Alejandro Decio, Vancio y otros muehos, conformándose con aquella regla trivial de que, quien alega el impedimento como cosa de hecho, queda obligado a probarlo.

Lo que no se expresa es, si sexá bastante prueba el juramento del impedido, o serán menester otras justificaciones. El Derecho Canónico 178 decide absolutamente por la afirmativa, $y$ aunque Juan Andrés Grido, Papa, y otros, con Vancio, 79 lo dejan al arbitrio del Juez, para que según la gravedad del perjuicio, calidad del impedimento y circunstancias de la persona, determine el género más conveniente de prueha; los mismos autores, con Gregorio López, ${ }^{180}$ se inclinan al juramento, cuando no resulta daño de tercero, como sucede en nuestro caso, donde no puede haberlo estando la cosa íntegra.

Pero advierten Bartholo y Rebufo, ${ }^{181}$ que el impedido debe esperar que el Juez le defiera el juramento, para que haga prueba, porque en practicándolo antes, de nada le aprovechará.

La cuarta duda (de que voy a hablar), contiene materias esparcidas en diferentes Ordenanzas, así del Perú como de México, que bien 
entendida, será lo bastante para resulver perfectamente todo el artículo de Registros.

Para entrar en el punto, es menester distinguir dos tiempos, según la diferencia que tienen entre sí las Ordenanzas del Perú y de nueva España, acerca del que se debe hacer el registro; $y$ al mismo tiempo explicar la naturaleza de los juicios metálicos, según el sistema actual de minería y la clase de acción que debe seguir en ella el descubridor, cuando comparece a contradecir el registro que otro hubiera hecho anteriormente.

La Ordenanza de México también impuso la nceesidad del Registro, pero no quiso scñalar plazo, ${ }^{1 \mathrm{~s} 2}$ sin duda considerando que en los nuevos descubrimientos sólo el descubridor tiene derecho a la veta, y no puede resultar daño de tercero, no habiéndose adquirido todavía ninguna pertenencia en ella.

$Y$ aunque previene que se anote la hora on que se presentare el descubridor, no llevó más fín que precaver el caso de dudarse quien fuc el primero que halló metal en la veta, para que se profiera como a descubridor, al que por la nota del Fscribano constare haber sido el que primero registró, según se colige del artículo 7, título 6. De suerte que liegándose a probar que fue el que primero halló metal en la veta, éste es el que goza del derecho de descubridor, no obstante que otro haya anticipado el registro.

A este fin se mandan fijar carteles, luego después de haberse verificado el registro, para inteligeneia de todos, concediendo el término de noventa días, ${ }^{183}$ para que dentro de ellos comparezca a deducir su derecho el que pretendiese tenerlo a aquel descubrimiento, pena de no ser oído si ocurre después. ${ }^{184}$

El contradictor ha de ser oído en justicia, brevemente, y se debe adjudicar la mina al que mejor probare su intcnción ${ }^{185}$ sobre la anterioridad del descubrimiento o hallazgo del metal.

Y como quiexa que no se puede hacer la adjudicación al que la pretenda en virtud del descubrimiento, sino cuando resultare ser verdadero y legítimo descubridor, es consiguiente que se admitan todas las excepciones que se opusieren contra este intento, por más que sean concernientes a la causa de propiedad, pues aunque son posesorios los juicios metálicos (como lo son todos los interdictos), siempre se deben oír las excepciones de propiedad, cuando por ellas queda excluída la posesión.

Esto se ve claramente en los remedios posesorios de mayorazgos, en los que, pidiendo una mujer mísión en posesión como sucesora inmediata del difunto, si comparecen otros parientes varones transversales, queriéndola excluír de la sucesión, bien sea por mayor inmediación de la línea y grado de llamamiento, ya sea por la naturaleza y calidad de los bienes, bien sea por otras circunstancias de la institución del mayorazgo, en tal caso se admite la contradicción y se suspende la posesión para la mujer, mientras se disputa y averigua cual de ellos sea el legítimo y verdadero sucesor. 186

La razón, según el docto Molina; ${ }^{187}$ es que por este remedio nacido del interdicto adipicende, al paso que es posesorio, trae al mismo tiempo mezclada la causa de propiedad, como muchos otros interdictos, cuyos ejemplos refiere dicho autor y Salgado. ${ }^{88}$ Sirve de prueba el que, para poner en posesión al pretendiente del mayorazgo, es preciso discernir su 
derecho sobre la sucesión, para lo cual se debe tratar quien de ellos es el verdadero succsor, y así viene el asunto a caer de necesidad en la causa de propiedad.

La Oxdenanza de México consideró igualmente que, para adjudicar una mina por título de descubrimiento, era indispensable incidir en la causa de propiedad, o en el petitorio clesde aquel mismo punto que se comenzasc a disputar quien fue el primero que descubrió el metal, y por ese poderoso fundamento determinó ${ }^{1: 9}$ que se hayan de tratar juntas las causas de posesión y propiedad en todas las materias de minas.

Acumulándose pues el posesorio con el petitorio, se sigue: lo primero, que puesta la contradicción en tiempo (esto es, dentro de los 90 días), debe suspenderse la posesión pedida en virtud del registro, hasta que scguida la causa por sus términos, se defina y sentencie, adjudicando la mina al que hubiere producido mejores pruebas, al mismo modo que se practica en los interdietos de mayorazgos. Lo segundo, que si compareciere otro tercero más a contradecir el legistro, cuando entre los dos primeros se hallare ya la causa conclusa o en lo último del término probatorio (pero todavía dentro do los 90 días), se debe suspender la primera causa y señalar al nuevo contradictor término competente para probar su acción. ${ }^{190}$ Lo tercero, que las partes deben prohar plenamente su derecho, sin embargo de que el juicio sea sumario y se haya de proceder, pero no en cuanto al modo de probar, según Cristóforo de Paz, Salgado y Villadiego. Poi cuya razón resuelven estos mismos, ${ }^{191}$ que se debe hacer contestación del pleito y admitir tachas de testigos, reduciendo precisamente la brevedad respecto de las solemnidades del juicio y de las dilaciones, ${ }^{192}$ sin menguar de ningin modo la prueba, porque debe ser plenaria como en los juicios sumarios.

Ia cuarta, que con dos testigos, aunque sean sirvientes, que hayan ayudado en dar las catas, se prueba suficientemente el descubrimiento, como lo determina la ley 4 , Cap. 21 , título 14 , libro $3^{\circ}$ de la recopilación de Castilla, explicada por Rodríguez, ${ }^{19}$ ? hablando de los pastores de rebanos de mesta, perturbados de sus pastos, para que pudiesen ser testigos y hagan fe plena dos de ellos juramentados.

Lo quinto, que deben seguir el fuero de minería, aunque sca Eclesiástico el contradictor; porque habiendo recibido de la potestad secular la calidad de mincro, se reputa como laico, según Paz y Rodríguez. ${ }^{194}$ Lo otro, porque comparece como actor, por el mismo caso de entrar proponiendo acción. ${ }^{10:}$ Lltimamente, porque las minas son un derecho realengo de que hace merced ol Rey, con la calidad de que las demandas se sigan ante la jurisdicción real, según la ley 17 , título 7 , libro $1^{\circ}$ de la recopilación de Indias.

Lo sexto, que si algún tercer opositor sobreviniere al juicio, después de transcurridos los 90 días, pero antes de haberse recibido la causa a prueba entre los principales litigantes, o estando todavía muy al principio el término probatorio, no debe ser oído, según Molina el Teólogo, a quien sigue Don Cristóbal de $\mathrm{Paz},{ }^{196}$ impugnando a Molina el jurista, fundado en que cl lapso del término legal, prescribe y extingue el derecho del opositor moroso, de manera que nunca puede recibir de los demás que propusieron sus acciones en tiempo hábil y oportuno; la cual sentencia autorizó el artículo 4, título 6, de la Ordenanza de México, ordenando que no se le oiga al que ocurriere después de los 90 dias. 
Lo séptimo, que cuando la ley $1^{7}$, título 16 , libro $4^{\circ}$ de Castilla, permite las dilaciones probatorias hasta 80 dias, el Juez de minas puede $y$ aun debe abreviar estos términos en las causas que se trataren sobre ellas, como sumarias, cual advierte Maranta, citado por Fermosino. ${ }^{195}$ En cuya conformidad, certifica Gonzalo de Paz, 198 ser práctica común y frecuente de nuestros tribunales, conceder los términos de tales causas, de tres en tres días, o recibir a prueba con término de cuatro o seis días, con todo cargo de publicación, conclusión y citación para sentencia.

La Ordenanza 17, título 7 , libro 3 ' del Per'ú, adoptó absolutamente esta práctica y ordenó que en las causas de despoblados, no pase de seis días el término de prueba, aun cuando nada dispone en cuanto a las demás sobre minas, se debe entender to mismo, por ser todas de igual naturaleza. Es verdad que, según Rodríguez, ${ }^{199}$ esto es reservado al arbitrio del Juez; con todo, discurro yo, que no habiendo determinado la Ordenanza de México, cuanto haya de ser el término probatorio en causa de minas, se debe entender que quiso conformarse con el estilo que se observa en los tribunales del Reino; y cuando así no fuera, debemos reducirlo a la disposición de la Ordenanza peruana, sin perjuicio del arbitrio que le compete al Juez en ciertos casos, para prolongar con prudencia las dilaciones probatorias, según las circunstancias de las personas y distancia de los lugares.

No se puede dudar que el espíritu de la nueva Ordenanza sea este mismo, cuando por una espccial excepción de las leyes generales del Reino, ha limitado a sólo tres días el término para apelar, abreviando por privilegio de la minería los cinco días concedidos para el efecto en todo género de causas, aun las más privilegiadas, como son las militares. ${ }^{200}$

Lo octavo, que apelándose de la sentencia que se pronunciare, debe otorgarse el recurso en ambos efectos, según Paz, Molina y Salgado; ${ }^{201}$ porque siendo la causa mezclada de posesión y de propiedad, juntamente la sentencia fenece el negocio y es rigurosamente definitiva, como en cualquier otro juicio ordinario en que se admite la apelación. Por consecuencia de la acumulación del posesorio con el petitorio, prevenida en el citado artículo 20, título 3 , siguió la misma Ordenanza de México ${ }^{202}$ las doctrinas anteriores, ordenando que, no siendo apeladas y pasándose en autoridad de cosa juzgada, las sentencias del Juzgado de Minas se ejecuten breve y sumariamente; como si dijera, que en apelândose de ellas, se admitan y no se ejecuten, según aquel principio: contrariorum contraria est ratio.

Pero aunque no hubiese una resolución tan clara, bastaría la que se repite desde el artículo 13 del mismo título hasta el artículo 15 , mandando que en las causas que excedieren de 400 pesos, se admitan las apelaciones, sin hacer distinción de efectos; porque según el docto Scacia, 203 cuando la ley permite absolutamente la apelación, se entiende concedida en los dos efectos, suspensivo y devolutivo, del mismo modo que se juzgan prohibidos ambos efectos cuando el derecho prohibe la apelación, como resuelve Salgado, con muchos doctores. 204

Por los cuales fundamentos, debe el Juez de Minería abstenerse de seguir la Ordenanza 4, título 9, libro $3^{\circ}$ del Perú, en cuanto manda ejecutar luego las sentencias, otorgando las apelaciones para el Tribunal de alzadas, porque esto sólo podía tener lugar según el sistema antiguo, en 
que debían tratarse divididas, cada una de por si, las causas de posesión y de propiedad, como se advierte en la misma Ordenanza 4, al fin. Ahora son inadaptables estas reglas, por haberse acumulado ambos juicios posesorio $y$ petitorio, $y$ desde luego sería un error craso negar la apelación en lo suspensivo, después de haber tratado juntas las causas de posesión y de propiedad.

Aquí occr'le, por incidencia, una cuestión gravísima que puede traer grandes dificultades en la práctica. La Ordenanza 8, título 19, libro $3^{\circ}$ del Perú, señala 30 días desde que se hubiere descubierto el metal, para hacer registro de la veta, bajo la pena de perder el derecho de descubridor, si más tiempo se detuviere, si no fuere por causa legítima. En el supuesto de haberse adoptado nuevamente esta Ordenanza, pongamos el caso que otro registró primero la mina, y después de transcurridos los 30 días, pero durante los 90 de la Ordenanza de México, ocurre a contradecir el registro el que se supone verdadero descubridor, alegando no haber comparecido antes por algún impedimento justo.

Ya se sabe que para ser oído, debe pedir in integrum del término de la Ordenanza contra el registro que otro verificó en su perjuicio, por causa del impedimento. Ahora se duda si esta acción restitutoria deberá seguir y propender separadamente ante todas cosas, o si podrá acumular con el remedio posesorio el interdicto ad dipiscende.

El Juez de Vizcaya, Don Cristóbal de Paz, trata doctamente esta cuestión en un caso muy semejante, relativo a mayorazgos, y después de haber propuesto la duda y expendido las autoridades que sostienen la parte negativa, resuelve ${ }^{\prime}$ con muchos fundamentos, que bien se puede acumular en el juicio de teruta el remedio residente con el rescisorio; pone el ejemplo del contrato que se dice nulo y al mismo tiempo se pide restitución in integrum contra él, en el caso de sel válido, para evitar los circuitos de los pleitos y sus costosas dilaciones; lo mismo enseña en cuanto a la reivindicación que se puede proponer sucesiva y condicionalmente, junto con la restitución; por último, alega una ley del Código, ${ }^{206}$ con la cual prueba que si procedió algún obstáculo contra el dominio, no es menester proponer acción separada para rescindirlo, porque basta intentar la reivindicación directa, en que se incluye aquel antecedente.

Sobre las cuales pruebas concluyc, que no es necesario intentar anticipada y separadamente la acción restitutoria o rescindente del obstáculo, y que basta alegar que el primero que registró es un descubridor intruso, que trató de perjudicarlo practicando esta diligencia, cuando él se hallaba impedido. En esta acción se incluye implícitamente la restitución, porque sin rescindir el obstáculo, no debe ser admitido al derecho de descubridor, no habiendo verificado el registro dentro de los 30 días.

Por lo mismo, deberá producir en el término de prueba las justificaciones relativas, así al descubrimiento, como al obstáculo que impidió hacer el registro en tiempo; y el Juez resolverá en vista de ellas, lo que hallare de justicia. De suerte que, adjudicando la mina al descubridor, aunque nada expresa sobre el impedimento, se juzgará tácitamente rescindido. 207

Porque no siendo así, era muy factible que mientras seguía juicio sobre la restitución in integrum, se pasasen los 30 días que señala la Ordenanza para contradecir el registro, quedando privado de intentar este remedio después de haber costeado un pleito penoso, en preparar su ac- 
ción; lo que es contra toda equidad; y si acaso fuese admitido a proponerla, sería menester seguir nuevo juicio restitutorio, contra el término de los noventa días de la Ordenanza, formando un círculo vicioso en esta parte, no se cumplía lo que tan claramente se halla mandado en cuanto a no oir al que ocurriere después de este plazo. Reflexión verdaderamente poderosa y por si sola suficiente para seguir en la práctica la conclusión que dejamos asentada.

Resulta de aquí, que si constase en el discur'so del juicio, no haber' comparecido a registrar, por algún impedimento que le hubiera sobrevenido después de los 30 días como se propuso en la quinta y última duda, no se le debe adjudicar la mina, aunque probase, por otra parte, ser verdadero y legitimo descubridor; porque los obstáculos que sobrevienen después de causada la demora, por aquél que se halla obligado a dar o hacer una cosa, no excusan de la pena, según doctrina expresa del Sr. Gregorio López, ${ }^{208}$ fundado en la ley 20 , título 14 , Partida $3^{*}$.

Artículo $4^{\circ}$. De los Pozos de Ordenanza. - Es bien notable la diferencia de la Ordenanza del Perú con la de México, en cuanto a este punto. La primera, ${ }^{209}$ manda dar en la pertenencia del descubicior un pozo de seis varas de hondo y tres de largo, dentro de los sesenta dias contados desde que se estacare y amojonare la veta; de suerte que el pozo viene a ser posterior a todas estas diligencias, y la práctica antigua era, que luego después de dada la posesión, pasaba, el Alcalde Veedor a señalar el pozo de Ordenanza, y volviendo a reconocerlo al cabo de los 60 días, comparecía ante el Escribano y testigos, a declarar que habiendo visto y medido el pozo con el cordel acostumbrado, habia hallado que tenía más de los cuatro estados dispuestos por Ordenanza. Todo lo cual asentado por fe del Escribano, se entregaba al interesado para su resguardo.

Por el contrario, precede el pozo a la posesión, medidas y amojonamiento, según la Ordenanza de México, 210 reduciéndose su nuevo método a que, dentro de noventa días desde que se hubiera proveído el registro, debe tener hecho en la veta un pozo de vara y media de ancho o diámetro en la boca, y de diez varas de hondo o profundidad, dejando para después el amojonamiento y medidas, de que hablaré en su lugar.

En cuanto a las minas despobladas, previene otra Ordenanza del Perú, ${ }^{211}$ que se de un pozo de cuatro estados on la mina que se adjudicare, dentro de los 60 días desde el de la adjudicación, declarando que para poderla vender, haya de haber profundizado dicho pozo hasta diez estados por lo menos. Ia de México, ${ }^{212}$ señala para este caso los mismos 90 días ya expresados, en esta forma: diez días desde la citación del denuncio; otros veintiuno para los pregones; y sesenta más para que en ellos habilite una labor o pozo, de diez varas a plomo dentro de los respaldos de la veta.

Nada determina acerca de la pena de perdimiento que impone la legislación del Perú, 213 a los que no hubieren abierto el pozo de Ordenan$\mathrm{za}$, sin otra diligencia que la vista de ojos del Juez; ni declara si el demunciante podrá vender la mina, antes de haber ahondado las diez varas, y si habiéndolo verificado sin este requisito, la deberá perder el comprador, aunque la esté labrando.

Tampoco resuelve que depositen cien pesos para el costo del pozo, los que pidieren estacas al descubierto, como se halla dispuesto en el Perú; ${ }^{214}$ pero aunque se debiera continuar esta práctica, entiendo que 
sólo puede tener lugar en el caso de no haberlo abierto todavía el descubridor, en la profundidad de las diez varas, porque entonces no corre ya el riesgo de abandonarla, que es lo único que se tiró a precaver con esta providencia.

Fuera de estos pozos, que se llaman de Ordenanza, por la obligación que ella impone para abrillos, ${ }^{215}$ puede el dueño de la mina hacer otros más en el haz de la tierra para poder barrenar la veta por ellos a un cabo y otro; pero al fin de mantener las labores con la debida seguridad, deben dejar entre pozo y pozo diez varas de tierra virgen y por labrar, y por lo menos ahondándolos hasta seis estados, y no menos, antes de dar los barrenos, pena de cien pesos y de tornarse a cegar a su costa. ${ }^{216}$

La misma facultad tiene cuando descubriere en sus cuadras alguna veta por el haz de la tierra, porque no pudiéndola abrir a tajo abierto, puede dar un pozo de tres varas de largo y cinco estados de hondo, para alumbrar y ver el rumbo que lleva, con la obligación de cegarle dentro de 60 días y de emprender la labor por dentro de su mina, por socavón y no de otra manera. ${ }^{217}$ Posteriormente se prohibieron los barrenos, con la orden de que siempre labren los dueños de minas por sus vetas en la mano, ${ }^{218}$ para impedir los derrumbamientos, muertes de indios, pleitos y diferencias que se seguían de la primera permisión; pero la Ordenanza de México, ${ }^{219}$ ha declarado por último a favor del minero, el dominio, no sólo del trecho de la veta que principalmente denunció, sino también de todas las que cn cualquiera forma, figura y situación se hallaren dentro de su pertenencia; de manera que puede labrar como mina propia, todas las que encontrare en sus respectivos términos y cuadras, aunque se hayan descubierto en las ajenas o tengan su cabeza en ellas; por cuya razón podrá abrir los pozos que quisiere, a los trechos y distancias que díspone la Ordenanza citada del Perú, como caso omitido en la de México; bien que deberá ahondarlo diez varas conforme a este nuevo sistema, y labrar por ellos la veta, una ver. que es suya en todo rigor, sin necesidad de hacerlo precisamente por dentro de su mina, por socarón, como antiguamente se habia resuelto.

En las minas que se han de labrar por socavón, está obligado cada uno a dar en su pertenencia, un pozo de veinte varas de hueco entre uno y otro, con dos varas de boca de largo y una media de ancho, para que puedan tener labor distinta los unos y los otros, $y$ se conserven las minas con la firmeza correspondiente. ${ }^{220}$

Artículo 5?. De la posesión, medidas y estacas. - Después de abierto el pozo de Ordcnanza en los expresados noventa días (si no hubiere contradicción), debe pasar personalmente uno de los Jueces de Minas con el Escribano, o por su falta, con dos testigos, y con el perito facultativo, 221 a reconocer el rumbo y dirección de la veta, su echado o recuesto, su dureza o blandura, su firmeza $y$ pintas del metal, ${ }^{222}$ en cuyo acto se pide y se da posesión de la mina en aquclias mismas pertenencias que el descubridor hubiere determinado y señalado, dentro de diez días desde el registro, como lo previene la mueva Ordenanza de México, en los artículos $1^{\circ}$ y $2{ }^{\circ}$, título $6^{\circ}$, conformándose con la ley 9, Cap. 22, título 13, libro $6^{\circ}$ de Castilla, explicada por Gamboa. ${ }^{223}$

Puede suceder que el minero no haya podido, en los noventa días, profundizar su mina las diez varas dispuestas por Ordenanza; bien sea por hallarla durísima o por otro grave y justo inconveniente; en tal caso, 
opina Gamboa, ${ }^{224}$ que se le debe dar la posesión, quedando obligado al ahonde en la forma posible; pero, lo contrario se debe decir estando al tenor del artículo 10 , título $6^{\circ}$ de la Ordenanza de México, porque en ella se suponen unidos los dos casos, de no habilitarse el pozo, ni tomarse la posesión, como consecuencia uno de otro, y previniendo el accidente de dureza, dispone que se ocurra al Juez respectivo, para que, averiguado y calificado el motivo, le amplíe el término en cuanto fuere suficiente, no por otro fin sino por preparar la mina para el reconocimiento del rumbo, anchura, echado y demás circunstancias de la veta, en la forma prescrita por el artículo 4 , titulo 6 ; luego, no pudiendo verificar esta diligencia, sin las diez varas de profundidad, según lo indica el artículo $3^{\circ}$, título 8;, tampoco debe darse la posesión; por ser este un acto posterior y subsecuente a la inspección del perito faculativo.

Debe pues suspenderse la posesión, las medidas y el amojonamiento, hasta que se halle perfectamente concluído el pozo con la profundidad de diez varas, ya sean perpendiculares las vetas o ya de recuesto. Gamboa ${ }^{225}$ no es de esta opinión, porque si acaso fuesen de la segunda calidad, dice que el minero gastará infructuosamente su dinero en seguir una tierra muerta por aquella profundjdad perpendicular, sin sacar metales, que es todo cl fin de la ordenanza. Sólo en las vetas profundas o clavadas se puede trabajar a pique, y entonces es útil dar dercchamente el pozo, pues según fuere ganando más profundidad se descubre mejor la veta y se manifiesta la ley del metal con más certidumbre.

En efecto, es muy natural la ref́lexión; pero la Ordenanza ${ }^{226}$ requiere el ahonde absolutamente, sin embargo del recuesto de las vetas, que también lo considero, pues aunque parece inútil y vano el trabajo y gasto que impenden en el pozo, por la razón de no sacarse metal, es por otra parte muy importante, respecto de manifestarse en él, muy suficiente la inclinación de la veta, para emprender después con cabal conocimiento el modo y medio más proporcionado a trabajarla con ventaja, bien sea por chiflón o de otra cualquiera manera que arbitrare el Juzgado de Minas, con parecer del facultativo.

Párrafo segundo. - Medidas. $\mathbb{W}_{\mathrm{N}}$ el mismo tiempo que se diere la posesión, se han de medir y amojonar las minas, ${ }^{227}$ para evitar los pleitos y diferencias interminables, que antiguamente resultaban de la separación de estas diligencias, como ponderó Gamboa ${ }^{228}$ encareciendo la necesidad de mandarse practicar juntas, al modo que ahora se ve dispuesto. 229

Las medidas se entienden en dos maneras: o en cuanto a las varas que debe tener cada pertenencia, o en cuanto al modo de medirlas. Diré separadamente de uno y otro, para debida claridad.

Por la ley 4, Cap. 5, título 13, libro 6 de Castilla, tenían las minas cien varas de largo y cincuenta de ancho, sin distinción ni privilegio del descubridor, respecto de los demás estados. Después, señaló la ley 5*, Cap. 22 del mismo título y libro, 120 varas de longitud y 60 de ancho al descubridor, sin hacer novedad para con los otros por la anterior medida de 100 de largo y 50 de ancho. Por último, la ley 9, Cap. 23, título 13 , libro $6^{\circ}$ citado, extendió las pertenencias del descubridor a 160 
varas de largo y 80 de ancho, dejando para los demás las 120 de longitud y 60 de latitud, que antes gozaba solamente el primero.

El Sr. Toledo tuvo presente todas estas providencias, pero según sus conocimientos prácticos del país, estrechó las pertenencias, reduciendo las del descubridor a 80 varas de largo y 40 de ancho, y las demás a 60 de longitud y 30 de latitud, sin distinción de las minas de plata a las de azogue. 230 Nada determinó acerca de las minas de oro; por lo que se ha guardado siempre en el Perú la ley 5, Cap. 75, título 13 , libro $6^{\circ}$ de Castilla, concediendo al descubridor 50 varas de largo y 25 de ancho, y a los demás, 40 de longitud y 20 de latitud, como testifican Escalona y Montesinos. ${ }^{231}$

La nueva Ordenanza de México, aprobada por el Rey en 1783, estimó por' estrechos los términos anteriores, a proporción de la multitud de las vetas metálicas de aquel Reino, y estableció otras reglas más benéficas a los vasallos, sobre principios inteligentes y prácticos.

Sin hacer distinción entre descubridores y estacados, concedió a todos absolutamente, doscientas varas castellanas por el hilo y dirección de la veta, sea de oro, plata o cualquier otro metal, ${ }^{232}$ y sólo en cuanto a cuadras redujo en las vetas perpendiculares a cien varas promediadas o todas al lado que quisiere el minero, ${ }^{233}$ dejando en las de echado o recuesto, las mismas doscientas varas que deben tener por longitud, ${ }^{234}$ sin facultad de exceder jamás esta medida, aunque sea mayor que lo regular el echado de la veta. 235

En el Perú también se podrá practicas miy bien esta providencia sin agravio de particulares, en guardándose las medidas antiguas, con las minas actualmente abicrtas y trabajadas, según lo previene el artícuIo 12 , título 8 ; pero, en lo general, entiendo que se puede perjudicar el progreso de la minería, y tal vez resultar algunas gravísimas dudas, que necesiten nuevas declaraciones antes de secarse la tinta de las Ordenanzas acabadas de formularse.

Por el conocimiento que tengo de este Reino y porque lo he of do a los mineros más experimentados, no dudo en afirmar que las venas metálicas son aquí incomparablemente menos extensas que en Nueva Espana, y las vetas corren tan cercanas unas de otras, que en este famoso Cerro de Potosí, casi no distan 60 varas entre sí. El sabio Virrey Don Francisco de Toledo, inspeccionó por si mismo estos minerales, los visitó personaimente muchas veces, conferenciando con otros sujetos científicos en la profesión mineralógica, las observaciones que él tenía hechas sobre los rumbos, anchuras e inmediación de las vetas, y al cabo de tantos exámenes y vistas de ojos propios, no hallo por conveniente mandar observar las leyes ya citadas del nuevo cuaderno de minas, y en sus Ordenanzas limitó a una mitad por longitud y latitud las medidas determinadas para Castilia.

Su objeto fue evital, lo primero, que se ocupase toda una veta por tres o cuatro personas solamente, quedando excluidos los demás vasallos de este beneficio, por no extenderse a más la fecundidad de las venas metálicas, como efectivamente se ha observado en Potosí y en otros minerales, donde no se dilatan las riquezas fuera de 600 u 800 varas. En comprobación de ello, pudiera citar varios ejemplares de haber enriquecido los seis u ocho primeros estacados en las vetas, sin encontrar los subsecuentes sino miseria y desengaños. Omito explicar sujetos y casos, por- 
que nadie deja de confesar esta verdad por acá.

Lo segundo, que un solo interesado no abarcase en su pertenencia dos o tres vetas ricas, como es factible hallándose en tanta cercanía las unas de las otras, y con todo de haber estrechado las cuadras en la angostura de 30 varas, se califica por las mismas ordenanzas, que ni esto fue bastante para impedir las grandes diferencias que, poco tiempo después, se suscitaron por causa de la entrada de muchas vetas por cuadras ajenas; lo cual sirve de argumento incontestable de la mucha inmediación con que corren, por lo general, las vetas metálicas en este Reino, y al mismo tiempo anuncia que a largos pasos se harán sentir los inconvenientes que acabo de referir.

Será por consiguiente un obstáculo poderosísimo para los progresos de la minería; porque en una veta que no prolonga su riqueza sino por 800 varas, trabajarán solamente cuatro mineros, en otras tantas pertenencias de a 200 varas cada una, ocupando las que debían labrar de contínuo doce azogueros de igual número de nuinas de a 60 varas, conforme a las Ordenanzas antiguas del Perú. Lo que va de cuatro a doce, es la diferencia en que por precisión se han de disminuir la saca de los metales y su beneficio al mismo respecto. De suerte que si ahora fructifican doce millones, debe temerse que después no pasarán de cuatro.

Ello es claro, que en dos minas diferentes deben haber a un propio tiempo otros tantos puebles de a cuatro trabajadores continuos, para que el minero no pierda su derecho; con que, manteniendo el suyo con sólo cuatro pueblos de igual número de gente, los que tengan cuatro pertenencias de a 200 varas, es forzoso que reduzca la saca a correspondencia del menor pueble, de la menos gente y del menor trabajo.

En México hay hombres muy acaudalados, que cada uno de por sí puede empeñarse en empresas de importancia; las minas son mucho más ricas, como lo acredita el cuño de aquel Reino, y la industria penosa de la minería de halla sostenida de auxilios cuantiosos, con que es fácil vencer las mayores y más árduas borrascas de las minas. Por eso, allí un solo minero trabaja tal vez por diez o más azogueros de los nuestros, y ayudado de la inmensa población del país, se le hace todavía corto el distrito de 200 varas.

Aquí es al contrario: no hay minero que tenga cien pesos en su casa; es poquísima la gente jornalera, y ésta se ve tan resabiada y renuente para el trabajo, que dos hombres apenas hacen lo que uno que fuese honrado; de donule procede que cada cual se contenta en poblar su mina con la gente muy precisa para que otro no se la denuncie, y tira a pasarlo como puede.

Por su misma pobreza, emplea los cortos auxilios del Banco en otros menesteres más precisos, sin verse lucir jamás los socorros benéficos del Soberano; y pues, no han de mudar de condición porque ahora tengan 200 varas, recelo mucho que suceda con nuestros mineros, lo que hace un hombre pobre metido en un gran palacio, que escoge un rincón para vivir y abandona todo lo demás por farta de menaje.

No es menor el inconveniente de que en las cuadras de una pertenencia sola, se abarquen dos o tres vetas, pues, aunque no son de temer las cuestiones que tiró a cortar el Sr. Toledo, en las Ordenanzas del título 4, libro $3^{\circ}$, por la propiedad absoluta que concede el artículo 17 , título $8^{\circ}$ de México, en todo do que encontrare dentro de sus términos ca- 
da minero. Se plaede seguir por otra parte, que en un cerro nuevamente descubierto, casi nunca puede verificarse algún otro descubrimiento de veta nueva; porque en el caso de encontrarla alguno más arriba o más abajo de la que hubicre registrado el primer descubridor, es muy disputable si deberá reputarse por nueva aquella veta, hallándose comprendida en pertenencia ya registrada por otro. Lo cual es suficiente para desalentar el empeño de nuevos descubrimientos, que son de tanto interés para el Rey, por la multiplicación de estacas, y para el vasallo, por los privilegios que goza como descubridor. 236

Son iguales con su importancia, las dificultades de medir bien las pertenencias de cada mina. En todos tiempos ha sido este el objeto principal de Ios cuidados de los señores Virreyes y Gobernadores del Reino del Perti. El Presidente Gasca dispuso cierto método en una de sus Ordenanzas antiguas, para asegurar el acierto de esta clase de mensuras; pero luego se conoció que la figura y situación de los cerros mensurables, continuaba venciendo toda diligencia.

Con este conocimiento, se valió el Sr. Toledo de geómetras prácticos que lo dirigiesen en sus providencias relativas a medidas; y en efecto, se ve en las Ordenanzas $1^{i !}$ y $2^{*}$, título 3 , libro $3^{\circ}$, que ninguno avanzé tanto sobre la materia, como este sabio Virrey.

Mandó que todas las medidas de minas se hagan sobre el haz de la tierra, reduciendo a llano por nivel y cartabón las diferencias de aquelia parte, de modo que entre mojón y mojón quede la cantidad que se mide proporeionada con la hondura, conforme a la recaída del cerro. Que es el modo que hasta ahora se ha practicado en todas las medidas de minas. Gamboa 237 trató extensamente sobre medidas, explicando las reglas más ajustadas a principios de buena Geometría. Mucho puede servir para instrucción de los peritos medidores, y porque anda su libro en manos de todos, omito dar idea de lo que escribió sobre esta materia. Sólo advierto, que para medir las vetas perpendiculares, casi no es menester echar mano de otro maestro ni valorse de otras advertencias, que las que dejó el Sr. Toledo.

Pero, en cuanto a las vetas manteadas, esto es, de inclinación o de recuesto, es necesario mayor cuidado, por el más o menos echado que suele reconocerse en ellas. La Ordenanza de México, 228 apuró con admirable inteligencia este punto, y reduce sus prevenciones a Io siguiente.

Dejando caer una vara de plomo por el pozo de Ordenanza (que ha de ser perpendicular y abierto sobre la misma veta), si acaso se retira de ella, desde tres dedos hasta dos palmos, se deben medir por la superficie cien varas solamente, dándosele por cuadra esta medida y no más; de suerte que estas vetas, aunquo sean recostadas, vienen a tener la misma longitud y latitud que las perpendiculares. ${ }^{239}$

Si por ser mucho mayor el recuesto o echado de la veta, se retirase de ella el plomo más de dos palmos, se ha de ir aumentando la medida, proporcionalmente, hasta el complemento de cuatro palmos de retiro, que corresponden a 200 varas de cuadra; de forma que jamás se ha de aumentar esta pertenencia, aunquc sea nayor el recuesto, esto es, aunque el plomo se retire de la veta más de cuatro palmos; 240 ni tampoco se ha de disminuir la medida de las 100 varas, por más que se diga haberse retirado el plomo menos de los dos palmos, porque de este punto para arriba, se equiparan las vetas inclinadas con las perpendiculares. 
Deduciéndose de estos principios, que conforme a la Ordenanza, es variable el distrito de las cuadras, según el más o el menos retiro del plomo, desde dos palmos hasta cuatro; $y$ así, aunque las medidas no deban bajar de cien varas, ni subir de doscientas, bien se pueden variar entre estos dos guarismos, según la escala que formare el retiro del plomo, desde los dos palmos hasta los cuatro por el ejemplo que pone la misma Or. denanza. ${ }^{241}$

De aquí resulta, que en las vetas perpendiculares, y también en las de recuesto donde el plomo se retipare desde tros dedos hasta tres palmos y nueve dedos, forman las medidas la figura de un cuadrilátero o paralelogramo, porque siendo sus cuatro ángulos rectos, sólo sus lados opuestos son iguales.

Pero en aquellas vetas cuyo recuesto llegare al punto de retirarse de ellas el plorno hasta 4 o más palmos, se manifestará la pertenencia, después de medida en figura de un perfecto cuadrado, cuya diagonal será la veta, y los dos triángulos que hacen a uno y otro lado, serán las cuadras permitidas por Ordenanza.

De esta manera queda medida dentro de las cuadras toda la veta, aunque sea muy manteada, y no puede sulrir perjuicio alguno el minero, porque disfruta de doscientas varas por cada ángulo de ella, y cien varas desde el centro de la diagonal hacia los cuatro costados de su pertenencia. 242

En los placcres, rebosaderos y cualesquiera otros criaderos irregulares de cualquiera especie de metal, deja la Ordenanza 243 al arbitrio de los Jueces de Minas, el señalamiento de varas según el tamaño y riqueza del sitio, y número de concurrentes, con jarticular recomendación de distinguir solamente a los descubriclores, sin hacer la menor novedad en cuanto al modo de hacer medidas.

Pero a fin de evitar toda colusión de parte del Juez que hubiere de proveer el registro, debe dar cuenta precisamente a la Superintendencia General de Minas, para que resuelva lo que arbitrare más justo, en vista del informe que se le enviase, con relación de las medidas que se hubieren arreglado atendidas todas las circunstancias expresadas en la Ordenanza; ${ }^{244} \mathrm{y}$ en el entretanto que toma providencia, debe suspender toda diligencia la diputación respectiva; porque en el caso de no aprobar la Superintendencia, las medidas que hubiese arreglado, sería menester reformar las antiguas, hacer otras de nuevo y alterar los mojones, causando gravísimos perjuicios a las partes, así por la demora como por los costos.

Párrafó tercero. - Estacas. A RREGLADAS y medidas las pertenencias en la forma expuesta, se deben fijar en sus términos, estacas y mojones firmes, bien distingtidos e inmutables, que deslinden perpetuamente unos intereses de otros. 245

Hay dos clases de estacas y mojones: unas se llaman "estacas terminales", y son las que se fijan en los linderos de cada pertenencia por los cuatro rumbos o vientos principales, para distinguir por todas partes el derecho de los circunvecinos. ${ }^{246}$ La otra especie de estaca (que es la más esencial), se ilama "estaca fija", ${ }^{247}$ por ser un centro invariable de donde se tiran las medidas para arreglar los fondos metálicos. 
Este centro o estaca fija no es otra cosa que aquella boca primitiva que se abrió en la mina al tiempo de su registro y donde se dio el ahonde de las diez varas. Sirve de centro, porque es el fundamento y base de la mina, y la puerta por donde se ha de entrar y salir para su manejo; y es invariable, porque según sus señales, es la única estaca que tiene las pruebas más ciertas, mâs seguras y más durables de identidad, para que nunca se confunda. Por eso se debe guardar perpetuamente, sin mudanza ni alteración, pues, de lo contrario, se estarían inquietando de continuo los dueños de minas; y si no hubiera centro fijo para las medidas, carla uno las mudaría a medida de su codicia, $y$ en breve se confundirían los dueños, contra el buen orden de la justicia. ${ }^{248}$

Pol todos estos fines, dispuso el Presidente Gasca, que para mayor claridad y duración de los mojones, fuesen hechos de piedra y lodo, de un estado de alto. El Sr. Toledo ordenó lo mismo, añadiendo, que tuviese por lo menos una vara de bojeo, mitad en una pertenencia y mitad en otra, cuando fuese mojón terminal. 249

El estilo en que se hacen estos amojonamientos primordiales, con arreglo a una Ordenanza de Gasca, se reduce a juntarse con el Juez de Minas todos los interesados que van a estacar en la veta. Luego se manda abrir un hoyo, donde se ha de poner el mojón, y antes de fijarlo, provee auto, haciendo relación de la persona a quien pertenece, del día en que se va a poner (que es el mismo en que se estaca la veta), de los vecinos con quienes linda, y de las varas en que se estacó por lo largo. ${ }^{250}$ Practicada esta diligencia, se fija el mojón, se da fe de la posesión por el Escribano y queda el auto en registro, entregándose al interesado testimonio de todo, por título bastante. 251

Al propio modo de la primera medida se han de hacer las demás, para dividir entre muchos la mina que se amojona entera; pero estos nuevos mojones no han de tener sino medio estado de alto con el amojonamiento en forma debajo de tierra, signado del Escribano, con tres testigos, para que diferencien de los que se pusieron al principio cuando se estacó la veta, y se conozca también cuál fue la mina descubridora. ${ }^{252}$

Por lo profundo de las minas se han de fijar igualmente otros mojones, de cinco en cinco estados, poniéndoles por señal una cruz en las cajas de un cabo, y de otra en presencia de las partes interesadas, $y$ se han de medir desde la última señal que se hubiera puesto, por ser la que sirve de estaca fija. ${ }^{253}$

Y para que no se omita una diligencia tan precisa, es obligación de los Jueces de Minas, que al tiempo de sus visitas anuales, reconozcan la puntualidad de las señales y mojones, y hallando que las minas no están señaladas, ni adobados y reparados los mojones, lo manden remediar antes de acabar la visita, ${ }^{254}$ exigiendo a los omisos la multa de tres mar$\cos$ de plata, para sí y sus oficiales. ${ }^{255}$

Pero si alguno se atreviese a quitar o mudar los mojones ya puestos y aderezados, debe caer en pena de perdimiento de la mina donde estaban, aplicando su valor ${ }^{256}$ por tercias partes a la Cámara, Juez y denunciador, quedando además obligado al castigo correspondiente a su delito, 257 no solamente el mismo que hubiere mudado los mojones, sino también el que los mandó mudar, según la Ordenanza 12, del Presidente Gasca, la cual aunque está anticuada acerca de otros puntos, tiene competente fuerza para declarar el de nuestro caso. 
El Sr. Toledo arregló su Ordenanza a la disposición de la ley 30 , título 14, Partida 7?, en la que el sabio Rey Don Alfonso, impone a los que varían los límites, la pena de 50 maravedíes de oro para el Fisco, y perdimiento de la heredad, si fuese propia, o de su valor, siendo ajena. La ley 6, título 4, libro 4 del Fuero, determina lo mismo, con la diferencia de rebajar la pena a diez matavedíes y de 'áplicarlos al dueño de la finca. Todo lo cual se entiende cuando se hubiera hecho la mudanza de límites por la ambición de ocupar lo ajeno; en cuyo caso queda también excluído el goce de la inmunidad eclesiástica, por la ley 3 , título 2 , libro $1^{\circ}$ de Castilla, en odio particular de este delito. Pero habiendo sido otra la causa, se debe dejar el castigo al arbitrio del Juez, como notó el Sr. Gregorio López. ${ }^{25 \&}$

Articnlo 6. Mejora de estacas. - Mejora de estacas no es utra cosa que mudar los mojones terminales a otro lugar donde se juzga más caudalosa la veta, para disfrutar de ella con mayor provecho, en su hilo o en su echado, pero sin alterar la situación do la estaca fija; de suerte que quedando ésta inmutable, se mueve sobre clla toda la pertenencia, como sobre su propio polo, hasta aquel rumbo en que se suponc haber variado la inclinación de la veta; ya sea tomando todas las 200 varas por un viento, ya promediadas entre dos rumbos, siempre ha de ser la estaca fija el centro de las medidas, $y$ se debe guardar en cllas la misma figura que tuvieron las primeras.

Por la Ordenanza antigua del Perú, tenía el descubridor dos años ${ }^{25 \%}$ y los primeros estacados uno, 260 para mejorarse por la parte $y$ lugar por donde la veta fuere; y lo mismo jermiten las leyes del títu. lo 13 , libro 6 ? de Castilla, con tres calidades: de guardar la estaca fija, de hacerlo sin perjuicio de tercero, y que ésto sca por cuadra derecera y ángulos rectos, como la primer medida, sin determinar tiempo.

El espiritu de una y otra legislación, fue la conveniencia que le lesulta al Estado y al minero, de mudar el trabajo al paraje donde hubiere de sacar más fiuto.

La novísima Ordenanza de México, mandada guardar en el Perú, previno sabiamente estos motivos dictando reglas inteligentes, para que desde las primeras medidas quedase bien aclarado el rumbo de la veta, y por este medio se evitasen los pretextos que antes alegaban los mineros para pedir mejora de estacas. Por la inspección del perito facultativo, queda una fijeza moral de no llevar la veta otro lumbo que aquel señalado por él, y se debe creer que si al minero no se contentare, debe quejarse de su suerte y no de otra cosa.

Por todo esto, determinan los artículos 11 y 13 del título 8 , la inmutabilidad de las estacas o mojones terminales, ordenando que se guarden perpetuamente en los sitios y rumbos donde se fijaron, sin que se puedan mudar aunque el interesado alegue que su veta varió de rumbo o de recuesto. La razón en que se funda es, por ser estas unas cosas irregulares que aun cuando sucedan, no deben perjudicar al vecino, sino al mismo que tuvo la mala suerte deparada por la Providencia.

No obstante esto, permite la misma Ordenanza, en los artículos citados, la mejora de estacas o mudanza de términos, cuando no hubjeren vecinos a quienes inquietar, o habiéndolos, no resultare perjuicio contra ellos, ni se descubra malicia en quien lo solicita; pero es preciso que se otorgue la licencia con conocimiento de causa y con intervención y au- 
toridad del respectivo Juez de Minas, citando y oyendo en justicia a las que fucren partes legítimas. Entonces se examina la justilicación del motivo, y calificándose justo, sin malicia en el pretendiente, ni agravio de otro tercero, tiene arbitrio la equidad para hacer conveniencia al minero y utilizar a la causa pública.

Sección $2^{*}$ : De la labor y amparo de las minas y de los despoblados, - Se explica el método práctico de seguir estos juicios.

\begin{abstract}
A MPARAR una mina, no es otra cosa que labrarla con cierto número de opcrarios determinado por Ordenanza, por el pozo abierto sobre la veta, en profundidad proporcionada, para descubrix y aprovechar sus riquezas; y como este es el fin principal por-
\end{abstract} que ha concedido Su Majestad esta regalía de su Corona, por eso al que no cumple las condiciones con que se le hizo la merced, se le priva de la mina, adjudicándola a otro, que la pide para trabajarla conforme a Ordenanza.

De aquí resulta que la primel'a obligación del minero, es dar un pozo en la pertenencia que le cupiere, de diez varas de hondo por vara y media de boca, dentro de 90 días desde que hubiere hecho el registro, 261 pena de perder el derecho ${ }^{262}$ y adjudicarse a otro que denunciare la mina, sin más diligencia que la vista deI Juez, con el testimonio del día en que se legistío, 26. entendiéndose lo mismo con las que se adjudicaren por despucble, ${ }^{264}$ respecto de ser en unas y en otras igualmente necesario el requisito del pozo, sin diferencia en la profundidad. ${ }^{265}$

$\mathrm{Y}$ es de advertir, que así como los descubridores y demás estacados pueden vender sus minas, con sólo el ahoude de las diez varas, tampoco tienen embarazo para hacerlo los denuncientes; pues, aunque la Ordenanza 2, título 7, ljbro $3^{\circ}$ del Perú, exige que para vender vâlidamente la mina adjudicada por despeblada, se dupliquen en el pozo las varas de profundidad que se le hubiere dado al tiempo de la adjudicación, esto procede porque según la legislación antigua del Perú, cranıde diferente calidad los pozos de las minas desamparadas, por los que debían abrirse en las nuevamente registradas. Con que, si en aquel sistema no tenía prohibición el que registró una mina, para venderla con la hondura primitiva que abrió en el pozo de Ordenanza, ahnra debe militar la misma razón, por haberse determinado una misma profundidad en las minas de denuncio. 266

Los compradores de minas ya ahondadas conforme a Ordenanza, tampoco están obligados a darles nuevo ahonde, y pueden labrarlas por el mismo pozo o enajenarlas en aquel mismo estado en que ellos las hubieren comprado, sin incurrir en pella alguna; porque continuando ol propio derecho del vendedor bajo de un mismo registro, no se le debe gravar con responsabilidad que no tuvo su causante, a distinción del denunciante, por ser nuevo poseedor que adquiere todo su derecho del título que le confiere la Ordenanza, debe observar purtualmente las condiciones de pozo, amparo y otras semejantes, con que se adjudican las minas. ${ }^{267}$

Pero si no tuviesen la profundidad de Ordenanza al tiempo que las compraren, es nulo el contrato, y cualquiera otro la puede denunciar, porque habiendo perdido el vendedor su derecho, por falta de pozo, no puede transferir dominio que él no tenía; y como por la misma razón no es 
justo el título del comprador, por eso, aunque las esté labrando, se debe adjudicar al primero que las pidiere. ${ }^{26}$

Sin embargo, hay varios casos en que no se incurre en la pena de perdimiento, aunque no esté abierto el pozo de Ordenanza en el término de ella, como si la veta estuviere dentro de caja de piedra durísima, cuyo ahonde es materialmente impracticable en 90 días con el trabajo de sólo cuatro personas; o si reventasen veneros de agua; o se hundicsen las labores; o si las minas hubiesen sido adjudicadas en Porco, por los meses de diciembre, enero, lebrero y marzo, porque imposibilitándose el trabajo por las muchísimas liuvias que se experimenta en la estación de dicho tiempo, no se pueden pedir por despobladas, ya sea por falta de pozo o de otra especie de amparo, 264 o si se imposibilitare la labor por otro cualquiera justo y grave inconveniente, 270 como la guerra, mortandad o hambre en el lugar o veinte leguas en contorno, y otros semejantes que sean fortuitos e inevitables de parte clel minero. 27

Si bien, es preciso que él ocurra a calificar estos motivos ante el Juez respectivo, y a pedir la ampliación del término suficiente para cumplir la condición del ahonde; " ${ }^{\top 2}$ mas, no deja por eso de sex denunciable la mina, luego que se haya pasado el plazo destinado para abrir o habilitar el pozo; ${ }^{273}$ y por lo mismo, en pidiéndola alguno por falta de este requisito, se le debe admitir la denuncia, oyendo al poseedor que se opusiera en tiempo, ${ }^{274}$ con las causas que alegue de impedimento para no haber ahondado el pozo; ${ }^{275}$ pero si compareciese después de transcurridos los 90 días que señalan los artículos $5^{\circ}$ y $8^{*}$, título 6 , no ha de ser admitida ninguna contradicción, ${ }^{276}$ a menos que pida y obtenga restitución in integrum contra algún otro obstáculo que le hubiera imposibilitado contradecir el denuncio en tiempo hábil, por el oxden y forma que queda explicado en otro lugar. ${ }^{2 i}$ i

Verificado el pozo, se deben destinar cuatro operarios, un rayador ${ }^{278}$ y un minero o mayordomo, ${ }^{279}$ para que estén continuamente ockipados trabajando alguna obra interios o exterior, verdaderamente útil y conducente al beneficio de la mina, ${ }^{28}$ lo cual se entiende al respecto de cada pertenencia y no al número de los dueños; de suerte que aunque sean muchos (en siendo una sola la mina, bien sea entera de 200 varas, o menos), cumplen con traer unu labor con los cuatro sirvientes, ${ }^{2 s 1}$ al modo que cuando se concede a muchos un mismo plazo, no se deben multiplicar los términos según el número de los agraciados, porque la dilación no se otorga distributivamente para que cada uno goce de su respectivo plazo, sino colectivamente para que todos participen de un solo término, como lo prueba el doctor Tiraquelo ${ }^{25^{2}}$ y se practica en el caso de haber hallado metal en una sola mina muchos descubridores juntos.

Aunque según esta regla, el que poseyere muchas minas, o una partida por varias en diferentes partes del cerro, debla tener labor en cada pertenencia con el pueble de cuatro operarios ${ }^{283}$ para no perder su derecho, exceptuó el Excmo. Sr. Don Luîs de Velasco, ${ }^{2 * 4}$ las vetas principales del Cerro de Potosí, que son las de Estaño, Antona, Ciegos, Centeno, Zúniga, Veta-rica, Flamencos y Corpus-Christi, ordenando que las personas que en una parte de cllas trajere labor, amparen todas las demás minas que hubieren en las mismas vetas, sin que en ningún tiempo se les pueda quitar por despobladas. $Y$ porque todavía pareció muy tímida esta excepción, la amplió después generalmente a todos los mimerales y vetas 
metálicas del Reino, el Licenciado Lupidana, en su Adición; ${ }^{285}$ y declaró, que quien tuviere muchas minas y trajere una o dos labores, ampara todas las demás.

La razón es muy equitativa, porque trabajando a un tiempo en todas partes, serían por lo regular más los costos que el provecho, y lejos de beneficiar al minero la labor, le sería dañosa, contra los fines de la Ordenanza. ${ }^{2}$ Lo común es emplear todas las facultades en la mina que se reconoce más poderosa y muchas veces el tesón logra grandes ventajas para el vasallo, para el Rey y par'a el Estado; así, no es justo que una aplicación mejor esperada, sea motivo para que se pierdan otras minas reservadas para tiempo más oportuno; porque sin este indulto, repartirían desde luego las fuerzas hacia todas las pertenencias, por no perderlas; peio el fruto de este trabajo lento y casi forzado, no sería otro que la ruina del particular y el horror a la minería.

Con todo, no se entiende el amparo con las vetas vírgenes (cuya hondura no pasa de cuatro estados), ${ }^{2} s$ sino únicamente con las que ya estuvieren poceadas y abiertas conforme a Ordenanza, porque las primeras se pierden por falta de pozo, cuyo requisito no se puede cumplir de otro modo que abriéndoto on la profundiclad dispuesta por Ordenanza, por ser la condición con que se adquiere el dominio de las minas, y por esto es que el despueble de unas y otxas se gobierna por tiempo y reglas diferentes, aunque sea uno mismo el orden de stus pleitos.

El quc teniendo una o muchas minas en alguna veta, le diere socavón empleando en su trabajo toda la gente con que poblaba dichas minas, también las ampara a todas (aunque no las beneficie) con sólo el pueble y labor del socavón; porque no se entiende despoblar, el que sin sacar provecho gasta su hacienda para disponer labor que se pueda aprovechar en adelante, como declaró en una Ordenanza 288 el Virrey Don Francisco de Toledo; guardándose lo mismo cuando se ocupan los jornaleros en desaguat alguna mina, segun otra Ordenanza del Sr. Duque de la Palata ${ }^{2 s 9}$ por ser éstas las obras exteriores útiles que indica el artículo 13 , título 9, de México, por suficientes para el amparo de las minas, según explica Gamboa. ${ }^{200}$ De manera que nientras el minero tuviere ocupados cuatro operarios en cortar metal, formar pilares, en dar lumbreras $y$ en hacer otras faenas interiores, o en dar socavones y tiros, en correr cañón, dar contramina, desaguar por medio de máquinas, en extraer el humo y sofocación de las labores, o en otro cualquier acto conducente a la habilitación del beneficio de la mina, se entiende legítimamente poblada para conservar su derecho y amparar las labores, según el espíritu de la Ordenanza.

Por el contrario, faltando el número referido de personas o las especies de trabajo que constituyen pueble, se estiman por desamparadas; y por el mismo caso de tenerlas despobladas más tiempo del permitido por la Ordenanza, se incurre en su perdimiento, y no se puede volver a adquirir su dominio sino por nuevo registro.

El Sr. Don Francisco de Toledo, estrechó tanto los términos, que dió ${ }^{291}$ por verificado el despueble en dejándose de labrar la mina 20 días, siempre que en seis continuos del mismo tiempo no trabajasen en ella los cuatro sirvientes juntos. El Sr. Conde del Villar, declaró que esta disposición debía entenderse solamente con los dueños de minas a quienes están repartidos indios, y no de otros; pero, el Sr. Virrey Marqués de Ca- 
ñete, tirando a precaver el daño que resultaba a la causa pública, de tener los más, desiertas y despobladas sus minas, con el pretexto de no habérseles repartido indios para sti labor', sujetó a todos, indistintamente, a la pena de los despoblados, y para quitar toda ocasión de queja, amplió el plazo anterior a un año y un día, "s’ ordenando que se adjudiquen al que las pidiere, si probase haber estado desiertas $y^{r}$ despobladas, sin traer labor en ellas por dicho tiempo, entendiéndose duplicario, esto es, de dos años y dos días, para el despoblado de socavones y minas aguadas, según otra declaración moderna del Si. Duque de la Palata. ${ }^{243}$

De todas estas ordenanzas, se puede deducip varias resoluciones, que sirvan de comentario; las propondré por: su ordeu.

La primera, es que el tiempo de año y día señalados para el despueble de las minas, y el de dos años y dos días par'a los socavones, no es precisamente continuo; y así, aunque el poseedor de la mina haya interrumpido por algunos días o semanas de trabajo, el desamparo de las labores, incurre por el mismo hecho on la pena do su perdimiento. De sucrte que no debe aprovechar ol fraude ingenioso de que suelen valerse por to regular los mineros, entablando alguna faena antes de cumplirse el año, para evitar la denuncia por entonces. Antiguamente, era muy notable el desolden que había en este punto, porque no encontrándose en las Ordenanzas del Perú, declaración expresa sobre si este tiempo debía ser continuo o bastase el interrumpido, todos entienden lo primero, gobernándose por las leyes de Castilla ${ }^{294}$ quc asi lo previenen: pox hallarse mandado en la ley 30 , título 10 , libro $2 "$ de Indias, que en estos Reinos se guarden las de Castilla, en lo tocante a minas.

En la nueva Ordenanza de Móxico, se tuviepon muy a la vista los inconvenientes que de esto resultaban, $y$ se declaró en el artículo 14 del título 9, que se pierda la mina por despucble, aun cuando se haya intcrrumpido por algunas semanas de trabajo el tiempo prescrito por la ley; cuya providencia, sobre ser conveniente por las razones que pondera Gamboa, 295 debe guardarse en el reino del Perú, con preferencia a las leves de Castilla, por otras que apunta para caso equivalente el Eminentísimo Cardenal de Luca. ${ }^{296}$

La segunda es, que en cumpliéndose el término sobredicho, se pierde poz' el mismo hecho la mina, y aunque después continúc detentándola por largo tiempo cl minero, de nada le aprovecha su primer registro, porque habiéndose revocado por el despueble, cualquiera otro la puede denunciar válidamente. ${ }^{297}$

La cuestión que aquí puede ocurrir más difícil, es: si la pena do hecho se deberá ejccutar sin necesidad de citación, sentencia ni previa monición alguna. $\mathrm{Y}$ si, desde el tiempo en que se incurró en perdimiento de la mina, se deben perder sus frutos, con obligación de restituirlos.

Jerónimo González y García, ${ }^{208}$ resuelven afirmativamente la primera parte de la cuestión, hablando de los beneficios eclesiásticos, y concluyen con muchos Doctores y textos, que vacan desde el día en que el clérigo hubiere cometido algún crimen que tiene pena de privación ipso jure; de tal manera que el patrono puede conferirlos a otro, sin esperar pronunciamiento de sentencia; así como el Obispo que abusó de la alternativa proveyendo los beneficios vacantes en los seis meses apostólicos, queda privado de usarla en adelante, por el mismo hecho de su contravención, sin necesidad de sentencia. 
Yo tengo por más verdadera la negativa, como más común en la práctica, según el sabio Solórzano y Antúncz; ${ }^{299}$ y recordando cl estilo que se observa en privar a los eclesiásticos irresidentes en sus Iglesias, advierto que nunca son desposeídos de ellas sin ser primero citados, oídos y condenados definitivamonte; por lo cual afirma nuestro político, contrayéndose a las encomiendas, que para quitarlas al encomendero ausente, que no haya cumplido las condiciones con que se confieren tales mercedes, es menester Lormación de proceso, citación, probanza y a lo menos sentencia declaratoria de la incursa privacion, por ser este el verdadero espiritu de los Estatutos que la imponen ipso jure, ipso facto. ${ }^{800}$

La mueva Ordenanza de México 301 apoya esta opinión con haber ordenado que denunciante justificue la descrción y desamparo de la mina; porque en admitićndose probanzas, es indispensable el proceso, la citación y, por consiguiente, la sentencia.

1)e aqui mismo se deduce la resolución de la segunda parte, esto es: que el poseedor antiguo de la mina no debe perder los frutos, sino desdo el dia de la privación judicial, y por consecuencia, que no está obigado a restituíl lo que hubieve percibido, después que se resolvió su título en fuerza del desamparo de las labores, porque mientras el Juez de Mineria lo tolera en el trabajo y en el aprovechamiento de los metales, reputa por algún modo vílido el primer registro y lo mantiene on un estado implicito para el efecto de recoger los frutos y para hacerlos suyos.

Con este mismo fiundamento determinó la Sagrada Rota, otro equivalente que sirve para comprobar nuestra sentencia. Refiere Jerónimo González, 302 que el Cabildo de la Colegiata de San Celso, puso pleito de nulidad contra un censo que había vendido bajo de obligación de los bienes de su Iglesia, fundando la subsistencia en el defecto de solemnidades dispuestas por los cánones para la enajenación de los bienes eclesiásticos, y pidió que los réditos satisfechos en más de veinte años, se compensasen con la suerte principal y se Io mandaren restituír los sobrantes. La Rota declaró nulo el contrato censual, por los vicios que concurrieron en su imposición; pero, al mismo tiempo, proveyó que no debían compensarse los réditos pagados antes del juicio de nulidad, ni tampoco restituírse los sobrantes.

Con lo cual confirma González, ${ }^{308}$ que los estatutos penales y los decretos irritantes, nada obran, si la parte interesada no reclama ni pide, como se ve en los atestados, que aunque sean nulos ipso jure, se entiendo en pidiéndolo la parte, $y$ lo mismo en la compensación y en otros ejemplos que pone el citado autor, ${ }^{304}$ después de haber sostenido lo contrar rio por regla general.

El docto Tixaquelo ${ }^{30}$ dió la misma inteligencia a la glosa de una ley del Código, sur tratando de la donación que se revoca y resuelve por superabundancia de los hijos, y para satisfacer a los diferentes argumentos con que había probado la obligación de restituf́r los frutos percibidos desde el día que se resolvió la enfiteusis, la donación o el título de benoficio, responde que, aúnque el donatario sepa haberle nacido hijos al donante, no por eso se constituye en mala fe, para quedar obligado a restituír los frutos, porque esta responsabilidad sólo comienza a correr desde que el donante declare que su voluntad es revocar la donación, al modo que el enfiteuta 10 se priva de los frutos, hasta que el señor de la cosa declara el comiso, según se colige sin obscuridad, de la glosa de una Ley 
de Partida. ${ }^{308}$ Luego, observando estas mismas reglas, no debe perder los frutos el minero que desamparó la mina, sino desde aquel día en que, por sentencia definitiva, se declarase ei despueble.

La tercera resolución es, que aunque por la ley 44, título 28, Partida $3^{*}$, se deben descontar on las expensas útiles y necesarias, los frutos esquilmados de la heredad ajena (como lo es la pérdida por desamparo), con todo, bien puede reclamar el antiguo poseedor de ella, todas las obras movedizas $y$ exteriores hechas a su costa, como cubiertas de galera, o cuartos para guardar los metales, y otras cualesquiera máquinas de que se puede servir útilmente el denunciante, $y$ éste quedará obligado a pagarlas, por lo que las avaluaron los peritos; ${ }^{309}$ porque la disposición citada de Partida, se debe entender solamente con aquellas expcnsas y mejoras que se hubieren hecho por dentro de las minas, para su beneficio y saca de metales, como enseña Tiraquelo, "10 probando que semejantes obras se han de compensar con los frutos; pexo de ningun modo las que se hayan fabricado para perpetua utilidad de la finca, como son los ingenios, las herramientas, los negros, los aperos, y otras cosas que se usan en los trabajos de la mineria. ${ }^{311}$

La cuarta es, que si uno de los dneños que poseyeron la mina proindiviso, no quisiere poblarla sino con la cantidad de gente respectiva a su parte, y el otro compañero no concurriese a labrar la suya, el primero cumple con lo que a él le tocá, y la pertenencia del omiso se puede denunciar por cualquiera; pero el que labraba tiene derecho para clegir dentro de diez días, si quiere continuar en compañía o partir los intereses; $y$ en este último caso, él mismo puede escoger la parte que mejor le pareciere, ${ }^{312}$ y después de hecha la elección no puede retractar, ni alegar engaño, ni pretender otro remedio. ${ }^{313}$

La quinta es, que deben exceptuarse de caer en pena de perdimiento, todos aquellos que no hubiesen poblado sus minas por impedimentos justos e inevitables, según dejo fundado en otro lugar, 314 sobre el principio general de que al impedido no le corro término ni para perjuicio su transcurso.

La misma Ordenanza ${ }^{315}$ exceptúa los casos de justo impedimento; pero sólo hace mención de la peste, hambr'c y guerra en el mismo lugar de las minas o dentro de 20 leguas en contorno. De aquí toma asunto Don Francisco Xavier Gamboa, ${ }^{316}$ para afirmar que los tres casos propuestos se asignaron por modo taxativo y limitativo, y no por vía de ejemplo o demostración; y por consiguiente, que deben quedar cxcluídas otras cualesquiera especies de impedimentos, como son la edad pupilar, la ausencia necesaria, el destierro, la pobreza y otros semejantes; 31 i de manera que no concurriendo los tres impedinentos referidos, todos los demás no son bastantes para mantener el dominio de las minas sin pueble.

Yo venero todas las opiniones de nuestro sabio autor, tanto por la ingeniosa solidez $y$ fecundidad de su doctrina, como por su magisterio en materia de minas; pero me arrastra a sentir lo contrario cierto peso de razón que a golpe de vista veo trasluciv en la misma Ordenanza.

Aunque en ella se hace especial mención de los tres casos particulares, de peste, hambre y gucrra, callando los demás, yo entiendo que el ánimo del legislador no fue excluírlos, como discurre Gamboa, sino más bien demostrar los impedimentos más calificados entre los que puedan embarazar el amparo de las minas, para que así viesen mejor justificados 
los motivos de la ordenanza en excusar de la pena al impedido.

Dos textos muy terminantes me costearán la prueba, sin necesidad de multiplicar argumentos. E.l Sumo Pontífice Inocencio III, haciendo memoria de las quejas que había producido a la silla apostólica Gaufrido, Arzobispo de Eroba, por haberse introducido algunos a conferir ciertas prebendas que a él le tocaban proveer mientras estuvo suspenso del ejercicio de su jurisdicción, rescribió a Pedro Capuense, su Cardenal Legado, que en el semestre señalado para la provisión de las Prebendas, no se debía computar el tiempo de la suspensión del Arzobispo, ni tampoco el que residió en Roma, desterrado de su Iglesia por Ricardo, Rey de Inglater'ra, porque la constitución del Concilio Lateranense se promulgó solamente contra los negligentes y de ningún nodo contra los impedidos, como lo era el Arzobispo. ${ }^{318}$

En esta Decretal, según la nota del célebre Fagnano, ${ }^{119}$ se refieren con especialidad dos impedimentos: el uno de derecho, que es la suspensión; y el otro de hecho, que es la ausencia necesaria. Y con todo de haber omitido el Pontífice la expresión de otros casos, resuelven todos los canonistas ${ }^{320}$ que en demorándose la colación, no por negligencia del Prelado, sino por cualquier impedimento justo, de hecho o de derecho (aunque no sean los dos de que hace mención el Papa), no debe tener lugar la pena de devolver la provisión a la silla apostólica, como determinó el Concilio Lateranense. Luego también, aunque la Ordenanza haya expresado únicamente los tres casos de peste, hambre y guerra, no se deben tener por excluídos todos los demás en que concurra la misma razón de justo impedimento, para el efecto de que así unos como otros excusen la pena de perdimiento de mina.

El Derecho Canónico asignó el semestre, para conferix dentro de él los beneficios eclesiásticos, bajo la pena de quedar privado de proveer el negligente y devolverse la elección al superior, por evitar de este modo las vacantes dilatadas, que son tan dañosas a la Iglesia; ${ }^{321}$ así como la Ordenanza dispone que las minas no se dejen de poblar por el tiempo de un año y un día, bajo la pena de perderlas el minero, volviéndose a incorporar en la Corona, con el fin de que se excusen los desamparos prolongados, $\tan$ perjudiciales a la prosperidad del Estado y de la Real Hacienda. Todo es igual en estas dos disposiciones, con la única diferencia de la materia en que recaen.

Con que, si el semestre para elegir no le corre al impedido, por cualquiera causa legítimamente inevitable, aunque no sea de suspensión ni ausencia, tampoco debe correr al minero el año determinado para el pueble, mientras hayan obstáculos inexcusables, aunque no sean de hambre, guerra o peste.

También se deduce de la ley 25 , título 3 , libro 1 i de la recopilación de Castilla, otra prueba muy eficaz para el asunto. El Reino congregado en Cortes, representó al Sr. Emperador D. Carlos V, las fuerzas, agravios y otros inconvenientes que sufrían los vasallos en la expedición de muchas Bulas Apostólicas, con perjuicio del derecho de las partes y de lás regalias de la Corona; y pidió que se aplicase el debido remedio. Entonces, dispuso el Emperador, que se continuase la práctica de los recursos de fuerza, y para ello mandó promulgar la citada ley, expresando en ella seis casos especiales, derogatorios de las preeminencias reales.

Con este motivo dudaron los Doctores, si fuera de ellos podrá te- 
ner lugar el remedio de la retención. Algunos sostuvieron la negativa, fundándose en que la disposición genérica del derecho o de la ley, se debe restringir precisamente a los casos expresados en ella, porque el género se limita y se individualiza por las especies a que se contrae.

Sin embargo, deficnde la afirmativa nuestro Salgado, en un capítulo cntero de sus doctos escritos: ${ }^{322}$ alega por su opinión un número crecido de clásicos autores, y haciéndosc cargo de la enumeración especial de los seis casos referidos, concluye que, cuando concurre una misma razón en los demás casos omitidos, se debe estimar que los primeros se expresaron por vía de ejemplo, y no por modo taxativo; porque siendo imposible promulgar una ley para cada caso, acostumbran los legisladores aclarar uno u otro, para que por su ejemplo se examinen, juzguen y decidan los otros que ocurricsen, según las reglas genéricas de la ley.

Sólo que ésta haga la enunciación de ellos, por las dicciones declarativas: "a saber", "tales como", y otras semejantes; entonces admite nuestro autor la restricción de la ley a los casos especialmente expresados en ella; ${ }^{328}$ luego, no encontrándose en el artículo 14 , título 9 , de México, semejantes dicciones al ticmpo de referir los tres casos, de peste, guerra y hambre, se debe concluír que se pusieron por modo demostrativo y no para excluír otros semejantes en que milite la misma lazón de impedimento.

Esto convence que la nueva Ordenanzì no quiso conformarse en

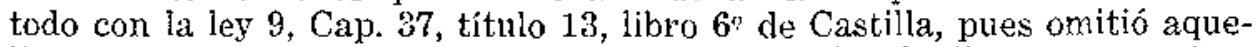
lla cláusula: "se entiende guerra, mortandad o hambre" (que es equivalente a la dicción: "a sabco") para que, según la observación de Salgado, no se dudase que su ánimo no er'a restringir la disposición a estos tros casos solamente.

Por eso, aunque fuese muy segura la doctrina de Gamboa $3: 1$ según el sistema antiguo, en el día se debe entender al contrario, por corrección hecha en la nueva Ordenanza.

De todo lo que se deduce, que en calificandose haber provenido el desamparo de las minas por cualquiera impedimento justo inevitable, de hecho o de derecho, aunque no sea hambre, guelra o peste, se cxcusa el minero de perder su mina, como enseñal los canonistas 325 respecto del Prelado que no proveyó los bereficios vacantes dentro del semestre; porque habiéndose impuesto esta pena solamento contra los negligentes, de ningún modo se debe verificar en los impedidos.

La diferencia es, que en los impedimentos de derecho, y siendo de hecho en aquellos solamente que sean a todos comumes $y$ notorios, como peste, guerra o cisma y hambrc, no le corre tiempo al impedido, según la observación del docto Crespi, ${ }^{82}$ de manera que si por ley o estatuto, se excluyese al que no practicase algún hecho dentro de cierto y determinado término, siempre queda exceptuado el que no pudiere verificarlo por algún impedimento de derecho, como es la edad pupilar y por eso no corre la prescripción contra el menor de 25 años, como asegura Matienzo haberlo visto decidir; ${ }^{327}$ porque en tal caso, quedan los plazos en suspenso y se reputa por no corrido el tiempo que ya pasó; caya regia extiende también Pinelo, citado por Martínez, a los impedimentos de hecho, comunes y notorios, que quedan referidos.

En consideración a todo esto, exceptuó la Ordenanza de México ${ }^{328}$ los mismos tres casos de peste, hambre y guerra, declarando que si la de- 
serción resultase por la ocurrencia de cualquiera de ellos, no se debía dar por perdida la mina; porque no habiéndole corrido al minero el tiempo del despueble, conserva ileso su derecho y debe ser amparado en alegando alguno de los tres impedimentos, que por notorios y comunes, no necesitan de pruebas.

Pero, como nada dispuso en cuanto a los demás impedimentos particulares de ausencia, destierro, pobreza y otros semejantes, siempre tiene su lugar el remedio de la restitución in integrum contra el lapso del año y día de desamparo, por la cláusula general: "si quia allia mini justa causa", ${ }^{329}$ que compete a los mayores de edad, porque según Cancerio con Mieres, ${ }^{330}$ nunca se entiende excluída la restitución in íntegrum, por ninguna disposición general.

No puede ser más claro el motivo, porque la Ordenanza hizo especial mención de los tres impedimentos: de peste, hambre y guerra, y calló los demás. Todos convienen que aquel axioma vulgar de que al "impedido no le corre tiempo", se entiende de los impedimentos de derecho; $\mathrm{y}$ es igualmente incontestable que en los de hecho inevitables, concede el Derecho Civil el auxilio de la restitución a cuantos lo imploran, indistintamente. Sólo se disputaba si aquellos tres impedimentos debían comprenderse en el axioma, o más bien en la cláusula: "si quia allia mini". Por eso entró la Ordenanza en el partido de resolver Ia duda, dándole la misma fuerza y privilegio que tienen los impedimentos do derecho, para que unos y otros suspendan los efectos del tiempo en lo perjudicial al minero; y por el mismo hecho de haber pasado en silencio las demás casos, quiso dejarios a la disposición gencral del Derecho Civil, para que según su clase, los unos impidan el transcurso del térnimp, y los otros demanden por medio de la restitución el suplemento del que hubiere pasado en perjuicio del minero.

De aquí resulta, que si éste desampara las labores, por haber consumido su caudal en ellas mismas, y otro hubiere denunciado la mina en el intermedio de andar solicitando habilitación, puede pedir restitución contra el transcurso del tiempo, para que, recibida información de las obras que hubiese costeado y de la pobreza ocasionada por ellas, ${ }^{33}$ se declare pertenecerle la mina, mandando reponerla en el mismo estado que la tenía antes de la deserción y despueble.

Gamboa ${ }^{332}$ sintió lo contrario, según- las leyes del antigoo gobierno de la minería de México; pero el artículo 15, título 9 de la nueva Ordenanza de aquel Reino, amplió el auxilio restitutorio al caso de pobreza, y por una atención equitativa, lo concedió también por otros justos motivos, que no habiéndolos especificado, se debe entender de toda clase de impedimentos, así como el edicto pretorio no reservó ningún caso del beneficio de la cláusula "si quia allia mihi justa causa", por lo mismo de haberlo establecido en la equidad.

De esta regla se debe comprender por exceptuado el que no teniendo para alquilar cuatro operarios, él sólo por su persona labrare su minaa, sin desampararla (como hay muchos en todas estas Provincias del Perú), porque atendiendo a la poca población del país y al mérito de la aplicación de tales mineros, declaró el Presidente Gasca, en la Ordenanza 54, que se debía tener por poblada una mina, para el efecto de mantener su dominio. Si bien, yo juzgo que para evitar fraudes, es conveniente hacerles entender por declaración expresa, que debe preceder especial 
permiso del Superintendente de Minas, con informe de las respectivas diputaciones, como está mandado practicar por punto general, para todo lo que es moderar o dispensar en puntos de Ordenanza.

Es consiguiente a lo dicho, que en todos los demás impedimentos particulares, de hecho, se haya de intentar el remedio de la restitución, del mismo modo que dejo expuesto en cuanto a la pobreza. Pero en los otros tres, comunes a todos y notorios, como son la peste, hambre y guerra, y juntamente en los impedimentos de derecho, no corresponde el auxilio restitutorio, porque, como entonces no corre el tiempo, tampoco puede alegarse lesión de su transcurso. Ia defensa se hace en tales casos por la acción primitiva y es bastante pedir su ampario contra el denunciante, probando el impedimento y su calidad.

Lo que hay, es que si el dueño de la mina despoblada fuere menor de edad, debe recurrir primexamente ante el Albacea, Tutor o Curador, por cuya omisión se desamparó, y sólo por su insolvencia, puede intentar la restitución, por ser un remedio puramente subsidiario ${ }^{333}$ para este caso.

No sc debe temer que venga a adquirír logro en daño del denunciante, aprovechándose de su trabajo, como ponderó Gamboa; ${ }^{334}$ pues, para precaver este inconveniente, determinó sabiamente el artículo 9, título 6 de la Ordenanza de México, que el dueño antiguo de la mina sea oído solamente en la causa de propiedad, y si obtuviere éxito en ella, satisfaga al denunciante los costos que hubiera hecho.

Desde luego, se excusarían estas cuestiones, si se cumpliese la Ordenanza 11, título 7, libro $3^{\circ}$ del Perú, vendiendo los Albaceas dentro de cinco meses las minas mortuorias; pero ya se ha visto que no puede tener lugar en esta Villa, porque las haciendas o ingenios a que se hallan anexas las labores, son tan costosas, que valiendo cada una 50 y tal vez hasta 100.000 pesos, es imposible encontrar comprador.

$\mathrm{Y}$ aunque en defecto de venta, sea obligación del Albacea tener poblada la mina, bajo la responsabilidad de resarcir el daño que resultare de su omisión, lo que ésto prueba únicamente es que el menor debe dirigir su recurso, ante todas cosas, contra el Tutor; pero no hay prohibición para que, en no aprovechándole este remedio ordinario, entonces no la competa, en subsidio, la restitución in integrum contra el denunciante.

Según los estados del tiempo en que se pusiere la contradicción al denuncio, así será la diferencia en cl método de seguir el juicio. No contemplo impertinente exponerlo con prolijidad porque la práctica referida por Gamboa, ${ }^{335}$ ha sufrido sus novedades por la nueva Ordenanza de México.

Comencemos por el libelo de denuncfo. Debe expresarse en él, el nombre del denunciante, el lugar de sła nacimiento, su vecindad, profesión y ejercicio; la ubicación individual de la mina, su último poseedor si hubiera noticia de él, y los de las minas vecinas si estuvieren ocupadas; ${ }^{336}$ y concluye por denunciar el despueble, of reciendo información de ello, para que en su vista se le ađjuđique la mina desamparada, bajo de nuevo registro.

El decreto es: "Por fecho el denuncio: recíbase la información que se ofrece, con citación del antiguo poseedor (si hubiere noticia de él) y de los dueños de las minas circunvecinas". En estanclo presente el denunciado, se le ha de citar en su persona; ${ }^{337}$ y si no pudiere ser habido, por 
hallarse ausente del lugar o por haberse escondido, entonces puede ser citado en su casa, haciéndolo saber a su mujer e hijos o criados (si los tuviere) y si no a los vecinos más cercanos. "38 Pero en los despuebles de los socavones, cuyo dueño no estuviere en el Reíno, o no se supiere donde está, es menester nombrarle defensor para seguir los autos con él, según la forma establecida por el Sr. Duque de la Palata, ${ }^{859}$ conformándose con una ley de Partida. ${ }^{340}$ Pues la Ordenanza de México ${ }^{341}$ sólo dispone la citación de los dueños de minas, sin tratar de los socavones; y asî, como caso omitido en ella, se debe resolver por la del Perú, en atención al mayor perjuicio que resulta de semejantes causas, por los grandísimos costos que acarrea la empresa de socavones.

Si en virtud de la citación, compareciere dentro de 10 días, ha de ser oído en justicia, brevemente, " $" 12$ sin esperar el término de los pregones, por el método explicado en otro lugar, ${ }^{343}$ admitiéndose todas las probanzas y justificaciones que of recieren las partes, como en cualquiera otra causa sumaria; ${ }^{344}$ con advertencia que el término de prueba no debe pasar de seis días, conforme a la Ordenanza 17, título 7, libro $3^{\circ}$ del Perú, a que nos debemos arreglar, por no hallarse on la de México disposición alguna sobre este punto; bien que siendo arbitrarias todas las dilaciones probatorias, ${ }^{445}$ podrá prolongarlas el Juez, según las circunstancias del caso.

Lo que se puede dudar con más fundamento es, hasta qué número de testigos se puede recibir. La Ley Real de Castilla, ${ }^{340}$ admite hasta treinta en una causa; y e1. Derecho Canónico, ${ }^{847}$ hasta cuarenta; aunque Paz ${ }^{848}$ advierte que en los tribunales inferiores sólo se reciben hasta doce testigos en cualquier causa y sobre cualquier artículo; cuya práctica la hallo fumdada en una Decretal ${ }^{349}$ concordante con una Ley de Partida. ${ }^{350}$ Pero yo discurro que en pleitos de despoblados, no se debe admitir arriba de cuatro testigos, según la Ordenanza 5, título 7, libro $3^{\circ}$ del Perú, por aquellas palabras: " $Y$ las demás vetas que se probare, con cuatro testigos, que han estado un año despobladas..." por esta cláusula no se puede entender del número suficiente para probanza, cuando sabemos que por derecho divino la hacen plena dos testigos de excepción; ${ }^{851}$ luego, es preciso decidir que con ella quiso la Ordenanza limitar el número hasta cuatro testigos, para que fuera de ellos no se reciban más, con el fin de evitar demoras y cavilaciones.

En no compareciendo el denunciado, en el término de diez días, se debe pregonar luego el denuncio en los tres domingos siguientes, en las puertas del Oficio de Minas, fijando carteles en las de la Iglesia, Cajas Reales y otros lugares de la población, para la debida inteligencia. ${ }^{352} \mathrm{Si}$ no se presentare contradictor alguno, se le notifica al denunciante, que dé la justificación del despueble ${ }^{353}$ y tenga limpia y habilitada dentro de sesenta días, ${ }^{354}$ alguna labor de considerable profundidad, o a lo menos de diez varas a plomo y dentro de los respaldos de la veta, para que el facultativo de minas reconozea el rumbo y demás circunstancias de ella, en la misma forma que se practica en los registros, 355 inspeccionando al propio tiempo los pozos, labores, obras y máquinas que allí se encontraren, bajo de formal razón y asiento que se debe tomar en nn libro separado de denuncios.

Todo lo cual verificado, se procede a medir las pertenencias, señalar estacas y dar posesión por el orden explicado anteriormente; ${ }^{356}$ de 
manera que según el método prescrito en la nueva Ordenanza, se reciben estas causas a prueba ${ }^{357}$ en no habiendo contradicción, o cuando se ignore el dueño, o no se sabe de su paradero; ${ }^{558}$ y porque en estos dos últimos casos tampoco hay sujeto a quien citar, se debe pregonar el denuncio inmediatamente, sin aguardar el transcurso de los diez días ${ }^{359}$ prevenidos para cuando haya habido citación efectiva.

Según el tiempo en que se propone la oposición, son muy diversos sus efectos: porque si el denunciado la verifica dentro de los días primeros de la citación o de los 21 siguientes de los pregones, entonces se le debe oír en la causa de posesión juntamente con la de propiedad, y por la acumulación del posesorio con el petitorio, se suspende dar la posesión al denunciante; y en apelándose de la sentencia, se ha de admitir el recurso en ambos efectos, del mismo modo que se practica cuando se contradicen los registros, según lo dejo fundado latamente en otra parte. ${ }^{260}$

Pero si el anterior dueño de la mina comparece a contradecir el denuncio en los últimos 60 días asignados para habilitar la labor o pozo de Ordenanza, no debe ser oído en cuanto a la posesión, sino en la causa de propiedad; ${ }^{361}$ el denunciante goza eu: tal caso todos los efectos de la posesión, como si realmente la hubiera obtenido en este juicio seguido con separación; y por consiguiente se le debe dar posesión, sin admitir más que en lo devolutivo la apelación que interpusiere el denunciado, en la causa de propiedad, porque no debiéndose innovar pendiente la apelación, ${ }^{362}$ justamente se continúa la posesión y goza de las comodidades de ella el poseedor, mientras se sigtte el recur'so, según dos capítulos canónicos. ${ }^{368}$

Pasados todos estos términos, queda cerrada la puerta, para no ser oído el dueño de la mina. ${ }^{864}$ Porque, como dice Flaminio Cartario, citado por Cancerio, 366 alegando a Paulo de Castro y Angelo, por el mismo hecho de haber dejado pasar todo el tiempo en que debió poner su contradicción, adquirió el contrario un derecho perfecto, que ya no se le puede quitar. ${ }^{366}$

Se deben exceptuar de esta regla los que no hubieren comparecido a contradecir en tiempo, por algún impedimento legítimo; porque mediante el auxilio de la restitución in integrum, nunca se juzga excluído por ninguna disposición general, como resuelve Cancerio con Miers, ${ }^{367}$ en un caso casi idéntico.

Si bien entonces se deberá reducir la audiencia a la causa de propiedad solamente; porque el beneficio extraordinario de la ley, se debe interpretar siempre del modo menos dañoso al derecho adquirido de tercero.

Es consiguiente que ganando sentencia favorable el denunciante, no debe dar en este nuevo sistema la fianza que requiere Gamboa, ${ }^{368}$ aumque apele el denunciado, porque teniendo declarado por su parte el dominio de la mina, a más de su posesión, le corresponden inseparablemente todos los frutos de ella, sin obligación alguna de restitución, aun cuando el Juez de alzadas llegase a revocar la sentencia de la primera instancia, con que dirigiéndose las fianzas a la seguridad y abono de los frutos percibidos, es claro no estar obligado a afianzar lo que nunca ha de devolver.

Y no prueba lo contrario el artículo 21, título 3 de la Ordenanza de México, con proveer que en las minas litigiosas se ponga interventor o se afiance, en pidiéndolo alguna de las partes; porque en este caso la po- 
sesión es de mero hecho y se ignora a quien corresponda el verdadero dominio, por lo que es justo que para cuando vengan a declararse estos puntos, queden afianzados los frutos.

Todo lo contrario debe ser si el anterior dueño de la mina, que comparcció después de largo tiempo y fue oído por beneficio de la restitución in integrum, obtuviese contra el denunciante, en la causa de propiedad, porque en apelando éste, debe otorgar las fianzas que le pidiere el contrario, para inclemnizarje los frutos que fuese percibiendo in integrum; pues debiendo esperarse que será condenado a restituírlos, es conveniente Ia precaución de afianzar este caso, para que no salga después inútil y frustratoria la sentencia en cuanto a este efecto. Por eso resuelven Scacia, Castillo y otros, con una Ley de Partida, ${ }^{269}$ que, apelando el poseedor de la sentencia dada contra él, se le debe obligar a llevar cuenta de los frutos o a dar fianza y seguro de ellos, aun cuando no se tema dilapidación, por dirigirse esta diligencia únicamente al mejor expediente de la sentencia de apclación.

Artículo 1". Del modo de labrar y reparar las minas. - Como las minas no pueden fructificar en no haciendo economía en sus labores, no es posible la permanencia de ellas sin trabajadores; por eso ha sido siempre la materia de este artículo, como el compendio de toda la legisiación de minería.

Al principio, cada uno trabajaba como le parecía; nadie se avergonzaba de las demasías de su ambición, creyendo que la tierra las cubría, y caminando sin más regla que el amor desordenado del oro y de la plata, era el principal empeño hacer en un día (si era posible) la anatomía de los cerros para descubrir sus ricas entrañns.

Los puentes, que son tan necesarios para la primera de las labores, no menos que para la seguridad de las vidas de los operarios, se derribaban sin reparo, por' el interés de los metales, y otros partían las montañas labrando sus minas a tajo abierto, para ver con la luz del sol lo que sabiamente ocultó la naturaleza on la obscuridad de las cavernas.

Pero lejos de conseguir el intento, resultó del desorden que, imposibilitándose las labores con los derrumbamientos y sepuitados en las ruinas los operarios, se venía a perder una inmensidad de riquezas en lo que ya no se podía sacar, o en los gastos de habilitar los caminos, después de no encontrar sirvientes para las minas por el terror con que las miraban, como a la desolación de la humanidad.

Entre otros motivos, éste fue el principal que obligó al sabio Virrey Don Francisco de Toledo, para que viniese a visitar el mineral de Potosí y a darle reglas para su gobicrno. En efecto, remedió infinitos inconvenientes, metodizando la labor y reparo de las minas, por las Ordenanzas de todo el título 5 ${ }^{\circ}$, libro $3^{\circ}$ del Perú. 870

Lo primero que dispuso, fue mandar guardar la Ordenanza 79 del Presidente Gasca, para que todos labrasen por socavnnes y pozos y de ninguna manera a tajo abierto; 371 formando después una admirable legislación, con que se aseguró la prosperidad del Estado, la perpetuidad de las minas y la conservación de los indios trabajadores.

Los Virreyes sucesores continuaron sus desvelos para perfeccionar tan grande objeto. Las experiencias fueron facilitando nuevas providencias, pero tan sabias y tan eopiosas, que casi no dejan qué desear en cuanto a labores y reparos. 
Allí se halla proveído que, para mayor firmeza de los pozos y su labor, se sondeen los cerros por lo alto, separando toda la ticrra y piedras movedizas, hasta llegar a lo fijo, con cargo de limpiar 80 varas de cada parte de la veta, para abrir el pozo donde mejor pareciere. $3: 2$

Que en toda veta nueva, se traiga siempre una labor a pique, aunque sea con barretero solo. ${ }^{373}$ Que no se derriben ni se adelgacen los puentes y pilares, con pretexto de ser más gruesos de lo necesario para la seguridad y fijeza de las minas. ${ }^{3}$ if Por último, que las minas tengan escaleras, que estén limpias y desahogadas con buenos reparos y aderezos, y que nadie eche ni alce labores sin reconocimiento de los Veedores, para que como inteligentes eviten todo perjuicio; con otras mil menudencias muy importantes, que ya hemos referido en otro lugar, tratando de las obligaciones de los dueños de minas y mayordomos, ${ }^{375}$ que allí se puede ver completamente.

La nueva Ordenanza de México, consideró lo difícil que es sujetar a reglas permanentes una multitud de empresas, que suelen of recerse en materia de minas, así por la variedad de circunstancias, como por la variedad de los cerros en su blandura o dureza, o en la mayor o menor firmeza de los respaldos de las vetas; por cuyos motivos reservó sabiamente a la perspicacia de los facultativos titulados, la dirección de todas las obras, ${ }^{376}$ ya sean tiros, contraminas, socavones, cañones, lumbreras $\mathrm{u}$ otras semejantes, para que dirigiendo el laboreo con conocimicnto experimental y práctica bien inteligente, trabajen los operarios con salvoconducto de su vida, y se eviten las frecuentes ruinas de las minas, cn costos infructuosos de empresas muy grandes, erladas en su trazo y ejeeución.

Como por todo esto se ha hecho arbitzario ya el modo de labrar y reparar las minas, juzgo por demás demorarme en este artículo; pues, en el día se deben mirar como puramente instructivas las prolijas providencias de la legislación del Perú, en cuanto a la distancia de los pozos, longitud y espesor de los puentes, calidad de los socavones y barrenos, con una infinidad de otras menudencias que se discurrieron muy importantes en el siglo pasado; porque, verdaderamente, hay cerros como el de Guantajaia y otros varios, tan sólidos por la piedra viva que compone la sustancia interior de ellos, que un puente de una vara de espesor, será may suficiente para sostener la firmeza de las minas; cuando en Porco, Potosí y otros minerales de más blandura, no basta el macizo de tres o cuatro varas, $\mathrm{y}$ habrá lugares donde sea preciso fortificar las labores con mampostería de madera o de cal y canto, por la insubsistencia de los respaldos, según lo indica el artículo 4 , del título $9^{\circ}$.

Conforme a esta diversidad de circunstancias, se deberá negar en unas partes el cercén de los puentes, y permitirlo en otras por la mayor solidez del terreno en menor macizo. ${ }^{377}$ Lo mismo digo de las paredes intermedias a dos labores vecinas, que una está aguada y superior a la otra, porque según fuere la sustancia del mineral, se deberá aumentar o disminuír el grueso de ellas, para que las aguas, por sí mismas, no las venzan y revienten. $Y$ tal vez será necesario prohibir enteramente los barrenos, obligando al minero a que emprenda el desaguie de sus labores con máquinas, para que no perjudique al vecino. 378

En procediendo los facultativos con honradez y con inteligencia, cada uno se contentará con su suerte; pero siendo tan fácil viciarse los 
hombres con el interés, conviene que los Jueces de Minas y con especialidad el Superintendente, no aparten los ojos de cuanto obraren en su oficio, principalmente en los principios, porque en la confianza de no haber otros peritos que puedan juzgar sus operaciones, no será extraño que cometan abusos.

$Y$ cuando alguna de las partes se agraviare de la diligencia del far cultativo de su departamento, debe tener la libertad de pedir que la practique otro, de alguno de los mineros más cercanos; y siempre que resultare convencida su culpa o su impericia, tampoco se puede embarazar el recurso del interesado contra él, por el daño que hubiera experimentado, quedando el Juez con la mano alzada para castigarlo, aunque no se haya seguido perjuicio.

Con los ensayadores se ejecuta lo mismo, sin que obste la aprobación y título que tienen, paya que los dueños de las platas pidan reensaye $: 77^{\prime}$ y les demanden por los yerros culpables que cometieren, hasta procederse contra ellos criminalmente, según la calidad de la culpa. ${ }^{880} \mathrm{Y}$ por que no se quede sin electo cualquiera resulta, manda la Ordenanza ${ }^{381}$ que afiancen en la cantidad que pareciere a los señores Virreyes,

Verdaderamente, es una excolente cautcla para que cumplan con su obligación, y no sería poco conveniente que los facultativos afianzasen del mismo modo cl buen uso de sus oficios, una vez que pende de su arbitrio, no solamsnte la fortuna del particular, sino también el gran interés del Estado.

Siendo la inundación de las minas uno de los mayores obstáculos de su labor, se hallan expedidas muchas providencias, para que la omisión de los dueños de las más altas, no perjudique a las más bajas con el agua que corre y cae de aquellas, o con la que se comunica de unas a otras.

Las Ordenanzas del Perú y de México tratan este punto; pero cada una se contrae a su particular y distinto caso; por lo que es menester supliy con una, lo que se omite en la otra.

Ta de México as' determina que, aguándose las más bajas, por habérseles comunicado las aguas de otras más altas, a causa de que sus dueños no mantienen todo el desagüe que cllas demandan o que necesitan por su excesiva inundación, se satisfaga por estos el perjuicio que hicicren a los otros, tasados por peritos.

La Ordenanza del Perú ${ }^{383}$ sólo dispone que unos y otros concurran a los gastos, sin resolver el abono de perjuicios; pero esto mismo indica que allí se supone haber practicado los dueños de las minas más altas, las diligencias posibles para el desagtie, y que no han podido evitar la comunicación a las más bajas. Inmediatamente que esto procede, por consecuencia inevitable de la misma vecindad, es muy equitativo que no se les obligue más que a la concuriencia de los gastos, debiéndose explicar en este sentido la Ordenanza de México, y por ésta la del Perú, cuando se notare descuido.

Pero si la inundación sucediere cayendo el agua de una mina a otra, es indisculpable la omisión; y entonces es justo no sólo que desagien y reparen las minas más bajas, a costa de los dueños de las más altas, como determinó el Sr. Duque de la Palata, ${ }^{384}$ sino también que paguen el perjuicio, con arreglo a la Ordenanza de México. ${ }^{385}$

Respecto a que las minas suelen labrarse por muchos, de mancomún o en compañía, también sc han contraído a este caso las Ordenanzas de 
ambos Reinos. ${ }^{386}$ A primera vista, parece que se oponen algunas entre sí, y otras necesitan explicación en lo dispositivo del modo de hacer las labores.

En México, no solamente se mandan mantener las compañías de minas, sino también que se procure se promuevan y protejan, por considerarse más convenientes al progreso de su trabajo y a la prosperidad del Estado.

En el Perú, se experimentaron grandes inconvenientes de robos, muertes y discordias, por la indivisión de las minas; por lo que pareció necesario el mandarlas partir y señalar estacas, para que conociendo cada uno su parte cuidara de su labor y reparo, como de hacienda suya.

Sin embargo, yo no hallo contradicción; porque en aquel Reino se trata de los contratos de compañía, y en éste de la comunidad de derechos que tienen muchos en una mina, por sucesión hereditaria. No hay duda que es muy útil lo primero, porque cada interesado entra a la compañía bajo de ciertis estipulaciones que le aseguran su dercho, siendo lo principal que el fin es trabajar pro indiviso, por las ventajas que espera de la concurrencia de muchas fuerzas unidas. Entre los herederos no es así, porque habiéndolos reunido el acaso, ninguno se quiere sujetar al dictamen de otro, y sucede que cada cual malbarata el trabajo donde se le antoja, o se originan discordias inextinguibles, o por temor de ellas se abandona la labor, en perjuicio del Rey y del Estado.

Para evitar todo esto, mandó el Sr. Toledo, que no hubiese minas indivisas. Contrayéndose a las que pertenecen a muchos por sucesión hereditaria, sin alterar las leyes generales, se permiten y protejen los contratos de compañía. La Ordenanza de México habla de estas últimas, y nada dispone de las primeras; con que siendo justo lo proveido en ambos casos, también parece serlo que, lo omitido en una legislación, se declare por la otra.

Lo que realmente tiene oposición, es que en el Perú se permite ${ }^{397}$ que un compañero labre por' sí solo su parte, con la cantidad de gente que le corresponda, cuando el socio no quisiere concurrir a los gastos de toda la labor; de suerte que la pertenencia desampàrada, se puede pedir por despueble, amparando el otro la suya, aunque sea una misma la mina; por el contrario, en México, ${ }^{\text {} в 8 ~ n i n g u ́ n ~ c o m p a n ̃ e r o ~ p u e d e ~ p o n e r ~ d e t e r m i n a d o ~}$ número de operarios por su parte, ni trabajar en determinado paraje de la mina, sino en común todo lo que ella permitiere; y para evitar disenciones, está prevenido ${ }^{389}$ que cuanto fuere concerniente al laboreo, se decida por el mayor número de votos, con intervención del Juez de Minas.

En efecto, es mucho más reflexiva esta providencia y también más útil al adelantamiento de las labores; por lo que, no pudiendo combinar las dos Ordenanzas en este punto, soy de sentir que ninguno cumple, si no puebla la mina con el número completo de los cuatro operarios; y por consiguiente, que se puede denunciar el todo de ella. Y aunque dije lo contrario en otro lugar, fue hablando puramente con la Ordenanza del Perú; pero, según el nuevo sistema, no debemos separamos de la regla que acabo de asentar.

Artículo $2^{\circ}$. De las entradas de las minas y los socavones. - En otro lugar 390 se dijo la obligación que tienen los dueños de minas abiertas, para dar entrada por la puerta a los que la pidieren, y la de éstos para pagar a la boca de la mina el quinto de los metales y llampus, o el de 
la plata de su precio, si quisieren vender todos los que hubieren sacado; y asimismo para contribuír con la mitad de la escalera principal de que se aprovechan para la entrada.

Esta es una servidumbre rústica ${ }^{3: 1}$ constituída por precepto de la ley y que el Rey, que es el dueño de las minas, la concede a sus vasallos, imponiendo en todas ellas la servidumbre de entrada, como lo puede hacer cualquier dueño de heredad, según la ley 10, título 31, Partida $3^{n}$; pero no quiso invertir la naturaleza de las servidumbres, que nunca se constituyen sin utilidad del predio o de la persona; ${ }^{392}$ por cuyo motivo señaló que pagasen el quinto todos los que recibieren la entrada ${ }^{393}$ para que unos y otros gocen igual utilidad.

Con respecto también al bencficio que resulta a la causa pública, del desaguie y evacuación de las labores inundadas o sofocadas, están obligados por Ordenanza 39 sus dueños, a dar socavones, 'a juicio del facultativo del Distrito, con cl cargo de concurrir a los costos los demás mineros, a proporción del beneficio que deba seguírseles; ${ }^{395}$ pero si ellos no quisieren acudir con los gastos, deben pagar el diezmo de todo el metal que sacaren, puesto a las bocas de sus minas, según la Ordenanza del Perú; ${ }^{395}$ debiéndose tener entendido que para lograr los efectos de Ordenanza, debe preceder licencia de la Justicia, sobre el proyecto del Perito facultativo del sespectivo departamento. ${ }^{397}$

En las Ordenanzas "as se ven decididos todos los demás puntos relativos a la economía de los socavones, casi sin diferencia en el Perú y México. Sólo en cuanto a la altura y ancho, se advierte que en este Reino no debe exceder de dos varas y media; ${ }^{399}$ hallándose dispuesto para México, ${ }^{409}$ que no pase de dos varas de ancho y tres de alto. Sobre lo cual yo entiendo que el Superintendente General, puede dispensar cuando lo juzgare conveniente, bien sea aumentando o disminuyendo dichas medidas, según dejamos dicho en otro lugar. ${ }^{401}$

Ya que he incidido, por consecuencia del tratado, en materia de socavones, no será extraño que diga algo del Socavón Real que se está dando en este Cerro Rico.

En la primera parte expuse los fundamentos que hay para desconfiar del buen éxito de la empresa; pero, como nadie sabe lo que oculta la tierra, y no es temeridad seguir el testimonio de los prácticos, añado ahora que fue prudentísima la resolución que se tomó para darlo, por la gravísima autoridad del Sr. Don Francisco de Toledo, el cual afirma en la Ordenanza 3 , título 4 , Iibro $3^{\circ}$ del Perí, que según dictamen de los mineros más científicos, en alcanzando la humedad bajo el Cerro, se encontrará la misma riqueza que tuvo en el haz de la tierra.

Es verdad que, por más de 30 años, se suspendió esta empresa, sin haberse atrevido los señores Virreyes a mandarla poner en ejecución, sin embargo de las instancias que hizo la Azoguería de Potosí, principalmente en el Gobierno del Sr. Conde de Chinchón. Tampoco hay duda que se tuvo por motivo la incertidumbre de lograr las riquezas que se iban buscando; y yo discurro que la causa principal fue que entonces todavía no apuraba la necesidad, pues, cada cajón rendía arriba de 80 marcos, y no es difícil comprender que se creyera no bajaría en adelante de esta ley.

En el dia, ha llegado la pobreza a tal extremo, que se tiene por afortunado el que lava de 6 a 7 marcos por cajón; y por más que se desvelan en los escudriños del Cerro, no vemos que se adelante cosa alguna. 
A excepción de uno u otro, todos los demás apenas logran tres o cuatio marcos por cada 50 quintales de metal (que aquí llaman "cajon"), sin alcanzarles este producto siquiera para el costeo de sus faenas, a causa de los excesivos arrendamientos y subido precio de los materiales. De donde procede, que no hay azoguero que pueda contau con cien pesos libres al cabo del mes. Sólo la esperanza alegre de las minas, o más bien llamémosla fátua, puede entretener un ejercicio tan poco útil al par que penoso. Todas las labores conocidas ya están disfrutadas, y no se oye que se haya descubierto alguna veta nueva. De suerte que, si no se mejora esta minería, se puede temer que la experiencia dilatada de tantos desengaños, obligue a dejar el trabajo, como ya lo pensaron en el siglo pasado y se verificó en la Gran Chocaya, Lipez y otros lugares del Rcino.

Pero debiéndose creer, por otra parte, que aquellas vetas antiguas inundadas en la riqueza (según testimonio de los ancianos), la conservan hasta ahora, y que se encucntran por el hilo de su dirección, es por haberse repartido en ramillos muy menudos, ahondados hasta los planes, para volver a formar en la humedad el tronco de la veta, en figura de cepa, como afirma el sabio Virrey Don Francisco de Toledo, 402 hubiera sido cobardía lastimosa no empeñarnos a buscar el corazón de este gran coloso de plata, y después de incurrir en el desprecio de todas las naciones, nos hubiéramos abandonado a los últimos extremos de la ruina que se está temiendo ha más de un siglo.

Según ha figurado la situación de nuestras vetas, opinan todos, que fuera del Socavón: Real debían darse otros particulares para el desagie de las minas que se sabe haber sido caudalosas al tiempo de su inundación; porque es muy dudoso que se acierte a cortar por el mismo sitio donde van a encabezar todas las venas metálicas de nuestro Cezro; y aunque se toque con ellas cortando la montaña por su travesía, nunca se logrará la empresa del desaguie, si por aquél paraje no se han reunido todavía los ramos en que se estrelló la veta; cuando por el contrario es infaliblë el suceso por medio de los socavones particulares.

Sin más fin que facilitar la saca de los metales, por la excesiva profundidad de las vetas llamadas de Centeno y Ia Rica, asegura Juan de Laert, ${ }^{403}$ con la autoridad de Acosta, que el año de 1590 se hallaban ya abiertos en el Cerro de Potosí, nueve socavones, fuera de otros que se iban comenzando a abrir, y que uno de ellos nombrado el Benino, dirigido a la Veta Rica, se concluyó al cabo de 29 años, a costa de imponderable trabajo, con todo que su boca no distaba del crucero sino 250 varas.

En esta misma Provincia se han dado otros socavones en el mineral de Aullagas, en el Partido de Chayanta, y en Ubina, del de Porco, los cuales han tardado de 15 a 20 años; y hablando don Antonio de Rivadineira ${ }^{404}$ del Real y minas del Monte, distante 18 leguas de México, afirma que al tiempo en que escribía, se habían pasado más de doce años desde que se dió un socavón para desaguarla, a expensas de mucha gente y de millares de pesos que hasta entonces iban gastados.

Nuestro Socavón Real apenas lleva siete años, y ya se halla avanzado más de 800 varas en lo interior de la montaña, sin haberse gastado - más de 120.000 pesos, con todo que la altura del canal es de dos y media varas $\mathrm{y}$ su ancho de otro tanto, cuando el socavón del Benino apenas tenía la estatura de $\mathrm{m}$ hombre, con ocho pies de longitud, según el citado Laert. ${ }^{40 \overline{5}}$ 
Sin embargo de estos progresos, no falta quien se aflija al ver todavía que no se han descubierto pozos de plata más poderosos que los de Aníbal; pero si recordasen la historia del mismo Cerro que acabo de refevir, tendrían mucho que admirar, en vez de entristecerse.

Lo que al parecer de muchos hace desconfiar del buen suceso del Socavón, es haberse emprendido al Este del Cerro, cuyo sitio se manifiesta a la vista más elevado que al Poniente; y creen que hacia este lado se debio abrir en un paraje que llaman Santiago, o en otro que llaman Lipij-Orko.

El mismo Director confiesa la mayor elevación de aquel sitio; pero al mismo tiempo asegura que el plan del Socavón corresponde al punto de la falda del Cerro en los citados parajes de Santiago Y Lipij-Orko; y en este caso tanto importa por un lado como por otro la abertura del canal, porque todo al fin es buscar el pie de la montafia; para el desagüe de las inundaciones más altas.

Sicndo así, es mucho unás conveniente que el Socavón se haya dado por donde hoy se ve, porque por allí están mucho más cercanas las vetas del Cerro, como advierten todos, en la que llaman de Polo; de suerte que si por esta parte había de durar la faena en obras muertas diez o doce años, hasta hacer el primer corte, es necesario que durase triplicado término por la parte contraria, según la distancia que se extiende la falda del Cerro antes de tocar el cuerpo de él. Los gastos se multiplicarían también proporcionalmente, y éstos tal vez subirían a un guarismo espantoso, si se quisiera llevar la línea por el centro de la montaña, pues, abierta la puerta del Socavón a un tercio de ella, sería menester buscar después, a fuerza de trabajo y de dinero, la dirección correspondiente para atravesarla por su mitad; $y$ no que ahora corre el canal por la derecera de la cumbre, ahorrando camino y cesto, con la ventaja que si fuera cierto el pronóstico del Sr. Toledo, debemos esperar que al cabo encontraremos con esa cepa de riquezas que tanto se necesitan para remedio de las urgencias de la Corona.

Por último, yo no juzgo digno de aprecio el rumor que oigo sobre los errores del Socavón, pues, no he hablado aquí con ninguno que sea capaz de decidir una materia de esta clase, ni juzgo que se pueda alzar la mano de ella, mientras no nos desengañe un geómetra científico, que tenga acreditados sus aciertos por la práctica de otras operaciones. No es la primera vez que se ha oído en el Perú censuras muy tenaces sobre la mala dirección de socavones y al cabo se ha palpado su arreglo con los efectos; con que, no será extraño que suceda lo mismo en Potosí.

Bien que se debe tratar de economizar los gastos, cercenando los sueldos crecidos de mayordomos, sobreestantes, segundos directores, $\mathrm{y}$ otros semejantes, con que suben los costos semanales a más de 300 pesos, cuando sólo trabajan dos barreteros por frontón y cuatro apiris (acarreadores), para el acarreo de los desmontes. En quedando el Director principal que comenzó la obra, y un mayordomo que cele el trabajo de los operarios, con al mismo salario que tienen los mayordomos o mineros del Cerro, es muy suficiente para que se pueda encargar al Administrador del Banco la contribución de los avios mecesarios, en pólvora y otros materiales, como también el pago de jornales y sueldos, en presencia de los Diputados de la Azoguería; $y$ entonces se vendría a ahorrar más de la mitad de lo que actualmente se gasta; de manera que, con otro tanto de 
lo impendido en siete años, alcanza para trabajar otros catorce y concluír el taladro del Cerro, aunque fuera mucho más grande.

Para los socavones particulares, discurro que no habrá quien se anime a darlos, por el grande atraso de esta Azoguería, ni creo que se puedan facilitar semejantes empresas por medio de remates, mediante el horror que tienen a minas los que no están ciegos con su trabajo, y porque no hay sujetos acaudalados que quieran emplear si dinero en tales destinos. Sólo el Gobierno puede adelantar el espíritu de cstas gentes, con premios que sean capaces de tentar la ambición, como sería: prometer mina al que no la tuviere, en verificado el desaguie; o minorarle el derecho de quintos, u otra recompensa que puede discurrir la sabiduría de nuestro Gobierno.

\section{NOTI C I A O C T A V A}

De los Jueces, pleitos, sentencias $\mathbf{y}$ ejecuciones de minas.-Párrafo primero, - Jueces.
D Oxdenanza de México, de los Jueces de Minería, así en las capitales como en las provincias $y$ asientos de afuera, con todas las disposiciones relativas al uso y manejo de la jurisdicción contenciosa, que es trascendental a todos los Juzgados y a la economía gubernativa reservada al tribunal.

Se debe componer de un Administrador General, un Director General y tres Diputados Generales; pero el Director no debe hacer de Juez, sino de Fiscal y Promotor en el tribunal, para representarle, advertir y proponer todo lo que juzgare conveniente a los progresos, buena conservación y mayor felicidad del cuerpo. de minería. $Y$ en los asientos de fue$\mathrm{ra}$, son Jueces las respectivas Juntas de los Partidos, en consorcio de las Diputaciones territoriales, sin ninguna autoridad económica ni gubernativa, con sujeción en las alzadas, al Juzgado que debe entender de ellas en la Provincia.

Este sistema, que en Nueva España debía producir grandes progresos, según el carácter, calidades, costumbres, riquezas y pericia do aquellos mineros, se estimó no conveniente en estos países, con especialidad en Potosí, por sus contraxias circunstancias; porque, en efecto, se iba a exponer todo el manejo de los gruesos caudales del Banco y demás dependencias de la minería, si se concediese su privativo conocimiento a unos azogueros que, cuando tuvieron en sus manos el Banco, lo disiparon con dos quiebras escandalosas, sin haber dado jamás las pruebas necesarias de suficiencia, por la prohibición que les impone la Ordenanza fundamental del Perú ${ }^{406}$ para que ningún azoguero pueda tener, ni tenga, a su cargo las labores de] Cerro, sino por medio de mineros o mayordomos experimentados.

Por todo esto, junto con los poquísimos pleitos que hay en Potosí ${ }^{407}$ se representó por el celoso Gobernador de esta Villa, a consecuencia de un dictamen que yo produje en fecha $1^{\circ}$ de junio de 1786 , deberse continuar al Gobernador con el lieno de facultades que maneja en el día sobre lo gubernativo y económico del Banco, Mita y Minería, con el agregado de la Superintendencia General de este último ramo, en todo el Distrito del Virreinato de Buenos Aires, reduciendo el Juzgado de la capital (que 
es Potosí para lo respectivo a Minas) al Teniente Asesor, acompañado de los Diputados Generales, para que haciendo las veces de los antiguos Alcaldes Mayores con estos conjueces, determinara las causas con acierto, por la inteligencia que debe tener de la Ordenanza; y al mismo tiempo se hiciera a favor de la minería el ahorro de todos los sueldos que se han asignado en México y en Lima, con respecto ${ }^{408}$ a los muchos asuntos gubernativos y contenciosos que debe conocer el Tribunal, según el sistema fundamental de la nueva Ordenanza.

El Administrador y los tres Diputados Generales, que son los que componen el Tribunal de minería *w según la Ordenanza de México, deben juntarse diariamente desde las 8 a las $11, y$ no pueden tratar ningún negocio contencioso, sin la precisa asistencia de tres de ellos, ${ }^{410}$ y en can so de no poderse completar este número, por muerte de alguno de ellos, deben nombrar los demás un interino, hasta la Junta General subsiguiente; ${ }^{411}$ pero si procediere la falta por impedimento legitimo de enfermedad, ausencia, recusación u otra causa semejante, debe enviar a excusarse el impedido, ${ }^{412}$ y entonces entra a sustituír por el que falte, alguno de los cuatro consultores más antiguos, ${ }^{413}$ de los doce que se deben elegir en cada trienio. ${ }^{114}$

En los asientos de afuera deben concurrir los dos Diputados territoriales, ${ }^{415}$ con el Juez real subdelegado del Partido, ${ }^{416}$ y los tres juntos componen el Juzgado de mineria ; y faitando alguno de ellos, por cualquiera de las causas susodichas, se subroga uno de los euatro substitutos, que en cada Junta general se deben elegir con este destino. ${ }^{417}$

Del mismo modo deben asistir indispensablemente tres Jueces en el Juzgado de alzadas, 118 compuesto en Potosí del Intendente de la Provincia, con el Director General y otro minero que eligiese la Junta de Minería en cada trienio, de entre los que anteriormente hubieren sido Administradores, Directores y Diputados Generales o consultores de los cuatro más antiguos; ${ }^{413}$ y en caso de faltar alguno de los dichos conjueces, por cualquier impedimento o por haberse suplicado de la sentencia primera que se pronunció con sus votos, ${ }^{420}$ debe entrar a substituírle uno de los cuatro consultores que han de residir en Potosí. ${ }^{421}$

En las demás Provincias, también han de ser Jucces los respectivos Intendentes, ${ }^{422}$ y sus conjueces, dos substitutos de los cuatro que se hubieren elegido ${ }^{423} \mathrm{en}$ el asiento más inmediato, ${ }^{424}$ entrando los siguientes por su orden, por impedimento de los dos primeros; ${ }^{425}$ y a falta de todos ellos, otros mineros de las cualidades convenicntes. ${ }^{226}$

Estos Jueces pueden ser recusados por la regla general que a todos exceptua, si no a los Príncipes soberanos, al Papa y a los Coneilios; ${ }^{427}$ pero no son recusables juntos todos los del Tribunal y los de alzadas, y Sí, únicamente uno o dos, en particular, dando causas y fianzas; ;28 en cuanto a los Diputados, está prevenido ${ }^{429}$ que sólo uno puede ser recusado; lo cual se debe entender en el sistema de no concurrir con ellos el Subdelegado del Partido, porque si asistiese (como se propuso), ya eran recusables dos de ellos, por ser entonces tres los Jueces, según lo dispuesto para los del Tribunal y los de alzadas.

Una vez que estas recusaciones no se deben admitir sin causas y fianzas, será menester que el recusante deposite cien pesos ensayados, para el caso de no probarlas, por ser esta la pena que imponen las Leyes y Ordenanzas del Consulado de Lima ${ }^{430}$ a que nos debemos arreglar, ${ }^{431}$ 
respecto de no encontrarse en las de minería disposición terminante sobre la materia.

Tampoco se halla declarado ante quien se haya de probar las recusaciones de los Jueces del Tribunal y de los de alzadas, ni quicn deba substituix al Intendente recusado legitimamente. El primer punto, no contemplo que sea difícil, porque siguiendo la regla precedente, se deberá observar las Ordenanzas 16 y 18 , título 42 , libro $1^{\circ}$ cle las Generales del Pertí y las leyes 31 y 39 , título 49 , libro $9^{\circ}$ de la recopilación de Indias, resolviendo en su conformidad, que las probanzas de recusación de alguno de los Jueces de primera instancia, se deben hacer ante el mismo tribunal; como también las del Juez de apelación, que es el Intendente; pero las recusaciones de algunos de los conjueces de alzadas, se deberán determinar por el mismo Intendente, con el otro acompañado; $y$ en el caso de ser recusados los dos, nombrará para decidir el artículo, dos consultores de los que se siguieren por cl orden de antiguiedad que se ha propuesto atrás.

El segundo punto, aunque parece más grave, está decidido determinadamente por el artículo 12 de la Ordenanza de Intendentes, subrogando a los Tenientes Asesores, en todo lo que corresponde a los Gobernadores Intendentes, en los casos de enfermedad, ausencia, falta u otro impedimento legítimo; con que siendo ahora la apelación de minería, una de las materias de su conocimiento, no se puede dudar que los Asesores deben substituírles, cuando la recusación fuere justa y probada.

Tampoco hay duda en que, por el mismo artículo deben asesorar las causas de minas en grado de apelación, respecto que son Asesores ordinarios de todos los negocios que conocieren los Intendentes. Lo mismo se deduce de los artículos 10 y 13 , al fin, título $3 "$ de la Ordenanza de México; debiendo arvertirse que, aunque sea letrado el Juez de apelación, debe intervenir el Teniente en calidad de Asesor', como ahora sucede en Potosí, porque ambos empleos deben guardar su constitución esencial en cualquier género de causas; y si no fuera así, quedarían a perecer los Tenientes, quitándoles los derechos de la minería, que es tano de los ramos más pingües de sus actuaciones en estos países.

Párrafo segundo. - Pleitos, II ABLANDO de los privilegios de los mineros, ${ }^{432}$ especifiqué las causas de que conocen los Jueces de Minas y las que son exentas de su jurisdicción privativa: ahora resta saber la naturaleza de los pleitos y el orden de seguirlos.

Cuando la materia en cuestión no excediere de 200 pesos se ha de seguir y determinar los pleitos verbalmente, aunque las partes lo resistan, ${ }^{438}$ admitiendo las excepciones legítimas y probamzas necesarias, de palabra y no por escrito; de suerte que sobre esta cantidad no se han de hacer procesos, del mismo modo que se halla prevenido por las leyes generales del Reino ${ }^{434}$ para los demás pleitos que no pasaren de 20 pesos, con el fin de evitar gastos y dilaciones, an causas que, sobre ser leves, exigen brevedad por su naturaleza; y así se debe proceder solamente a verdad sabida y buena fe guardada, según dos Auténticas de Justiniano, 43; concordantes con una ley de Partida, ${ }^{436}$ en cuya conformidad concluye Avendaño, ${ }^{437}$ que en estos casos están absueltos los Jueces de la obligación que les impone la ley 27 , título 6 , libro $3^{\circ}$ de la recopilación de Cas- 
tilla, para que todos los autos de Justicia que hicieren y mandaren hacer sean en escrito, porque en todo tiempo se halle razón de ello.

Pero aunque no se admitan escritos y alegaciones de abogados, ni se haya de formar proceso, se ha de asentar siempre por escrito la conde. nación o absolución, conforme a la ley 19 , título 9 , libro $3^{\circ}$ de Castilla, con quien parece haberse conformado en todo la Ordenanza de México. ${ }^{438}$

Pox consiguiente, no debe haber en tales causas apelación ni restítución ni otro remedio, según la ley 19 citada, ya sea por capítulo de menor' edad o por la cláusula general concedida a los mayores, según CaIrasco; $4: 39$ y lo que es más, tampoco se puede retractar la sentencia, con pretexto de instrumentos recientenente hallados, aunque se contenga en ellos paga, transacción o cancelacion de la deuda, a cuya satisfacción hubiere sido alguno condenado, polque nada debe obstar a ejecución de la sentencia, como l'esuelve el mismo Car'Tasco, ${ }^{400}$ y el único remedio es entablar nueva demanda para recobrar lo mal pagado por la conditio indebiti, conforme a una sabia advertencia del citado autor. ${ }^{4 t}$

Lo que se puede dudar es, si en este género de causas hará plena probanza un solo testigo que depone el hecho con todas sus circunstancias. Valenzuela, Velásquez, con muchos Doctores y textos, defendieron la contraria; ${ }^{412}$ sin embargo de lo cual sostiene la afirmativa nuestro Acevedo, ${ }^{443}$ con el célebre Dicgo Pérez, ${ }^{44}$ cuya doctrina no juzgo exorbitante de las leyes de Justicia, atendiendo a los poderosos motivos con que se ha procurado evitar demoras y circuitos en causas de poca importancia.

Pero nada de esto se debe entender con las causas criminales de miner'́a, aunque sean de menor cuantía, así por las excepciones que alega el referido Alonso de Acevedo, ${ }^{45}$ como porque la misma Ordenanza de México 146 manda que se sustancien en justicia, y apelando las partes, se admitan estos remedios legales para los Juzgados de alzadas, guardando el orden correspondiente a su naturaleza, y el modo y forma preserito en las causas civiles.

Todos los demás pleitos se pueden seguir por escrito, breve y sumariamente, la verdad sabida y la buena fe guardada, por el estilo del Comentario, ${ }^{447}$ sin tener atención a defectos de formalidades escrupulosas, ineptitud del libelo y otras semejantes; por lo que se puede determinar y sentenciar en cualesquiera estados que se sepa la verdad, tomando para ello juramento a las partes y examinando a los testigos que pareciere conveniente, hasta el número de diez, ${ }^{489}$ pues, aunque se dijo en otro lugar, ${ }^{40}$ que en pleitos de despoblados de minas, no se debían recibir arriba de cuatro testigos, esto se entiende según el espiritu de la Ordenanza del Perú.

El procedimjento breve y sumario de estas causas, no quita la contestación del pleito, las tachas de testigos y las probanzas necesarias para una justificación; porque la brevedad se entiende solamente en cuanto al modo de proceder y no en cuanto al modo de probar, según Paz, Salgado y Villadiego; 450 de tal forma que la contestación es de sustancia del juicio, aunque la causa sea sumaria, en opinión de Evia Bolaños, con otros varios que cita Fermosino; ${ }^{451}$ y así, nunca se podrán dispensar las tales estaciones en las demandas ordinarias de minas, por más sumarias que sean, a diferencia de las ejecutivas, en que se ha de proceder según su naturaleza, en cuanto al orden del proceso, distingtiendo la misma Or- 
denanza ${ }^{452}$ lo ejecutivo de lo ordinario, en materia de minas, aunque sea común a uno y otro la calidad del sumario, por deber guardarse siempre en ambas especies de demandas la buena fe y la verdad, sin dar lugar a dilaciones.

Con el mismo fin de cuidar circuitos en los pleitos, se deben tratar juntas las causas de posesión y propiedad, ${ }^{4: 3}$ en la manera que se ha explicado anteriormente, ${ }^{454}$ pues sólo de este modo se pueden reprimir las cavilaciones con que antes se dilataban los juicios metálicos, por la separación en que corrían el posesorio del petitorio, según el régimen primitivo de la minería de Nueva España y del Perú.

$\mathrm{X}$ porque estas providencias se invertirian fácilmonte, si al mismo tiempo no se pusiese término a la duración de cada instancia, se propuso en el Gobierno, en el plan aprobado por el Rey para la formación de nuevas Ordenanzas, que el recurso de apelación se sustanciara ante el Juez de la primera instancia, con arreglo a la Ordenanza 4, título 9, libro $3^{\circ}$ del Perú, concluyendo con sólo el término de veinte días en segunda instancia para definitiva; de manera que el proceso haya de pasar enteramente substanciado al Juez de alzadas, para que lo vea $y$ detcrmine sin necesidad de hacer más autos, ni abrir nuevos términos para dilatorias $y$ probanzas, $y$ sin admitir escrito alguno, ni aun el de expresión de agravios del apelante y respuesta del contrario, que permite el artículo 14 , título $3^{\circ}$ de México; imponiéndosele al que apeló la obligación perentoria de presentar al inferior, dentro de noventa dias, la determinación en dicho grado, bajo la pena de ejecutar su sentencia el Juez que la pronunció, para que con este temor solicite con actividad que el pleito se concluya y tenga fin.

De aquí procede que nunca se manda cerrar ninguna mina litigiosa, ni suspender su labor, para que no sea motivo de prolongar los pleitos; y lo único que permite la Ordenanza, 4iri es que el poseedor sea obligado a dar fianza o a costear. Interventor, para el mejor expediente del cargo futuro de sus frutos.

$\mathrm{Y}$ como de mantener corrientes las labores depende el progreso de las minas y la felicidad del Estado, se concede absoluta preferencia al que siendo acreedor con otros a una mina desamparada, of reciere habilitarla con su caudal, por resistirse los demás a concurrir a prorrata, para que, con lo que fuere fructificando la mina, sea pagado primero que todos, no solamente del importe de su habilitación, sino también de su antiguo crédito, aunque no proceda de igual causa. ${ }^{456}$

Cuyo medio es verdaderamente el más inteligente que pudo meditarse para promover los adelantamientos de la minería; porque si la prelación hubiere de recacr únicamente sobre el débito de refecciones, conforme al privilegio general que concede la ley 28, título 13, Partida 5", a todo acreedor refeccionario, es seguro que ninguno querría habilitar una mina pobre, respecto que en vez de ganar, sólo iba a emplear el dinero en una negociación, sobre morosa, muy contingente; y por falta de auxilios dejarían de fructificar muchas labores, que teniéndolos, tal vez rendirían muchos productos.

Atendiendo también al privilegiado beneficio de las minas, se ha declarado ${ }^{45 \tau}$ novisimamente, que en pleitos sobre compañía (cuantas veces se han reñido en las Audiencias de ambos Reinos), no se entienda dividida por muerte de algunos de los compañeros, y antes queden obliga- 
dos los herederos a seguirla con ellos, haciendo en esta materia una especial excepción de las leyes generales ${ }^{458}$ que constituyen por regla la disolución de la Compañía, por muerte de cualquiera de los socios y su intransmisibilidad a los herederos, ${ }^{25} y$ aun cuando se hubiere pactado lo contrario con juramento, como sostienen muchos Doctores, ${ }^{460}$

Pero en queriendo vender su parte cualquiera de ellos, bien lo pueden hacer libremente a favor de otro tercero, sin estay precisados a vender ni a comprar unos a otros (como se intentaba frecuentemente antes de la publicación de las nuevas Ordenanzas), y sólo tienen el derecho de ser preferidos por el tanto, ${ }^{461}$ con arreglo a las leyes 13 y 14, título 11 , libro $5^{\prime}$ de Castilia.

Esto mismo se halla resuelto en Hermosilla, 462 el cual hablando del caso de haberse vendido o cedido su parte a otro extraño, aiguno de muchos arrenderos de un fundo o de diezmos o de otros réditos, afirma que los demás consocios la pueden retraer por el derecho del tanto, y sin duda siguió esta doctrina la Ordenanza, en la decisión que queda referida.

No será extraño que se dude con este motivo, si cuando no quieren intentar el retracto los compañeros del vendedor, podrían precisar al comprador que continúe en la compañía como lo tenian con el otro, y prohibirle la partición de la mina, porque no siendo la venta aiguno de los modos expresados en el Derecho ${ }^{463}$ para disolver la Compañía, ni ser facultativo, por otra parte, a ningún compañero el dirimirla en perjuicio de los demás antes del tiempo estipulado, parece claro que pueden sostener la antigua sociedad con el comprador, eligiéndolo por compañero en lugar del otro, por nueva convención. $Y$ en efecto, lo indica así con bastante claridad la Ordenanza 9, título 7, ilbro $3^{\circ}$ del Perú, en un caso equivalente, que decide afirmativamente.

Es verdad quie ninguno puede entrar en compañía ajena, por donación, venta o traspaso que otro le haga, como sienta Olea, ${ }^{464}$ alegando muchos textos y Doctores; pero esto se entiende cuando los socios se resistieren a mantener la mina por indivisa como antes, porque en perseverando en el primer consentimiento, tambiên debe subsistir el antiguo contrato; ${ }^{465}$ y sólo que el comprador o donatario se niegue a ello, queriendo más bien que se parta la mina, entonces podría recibir y trabajar separadamente su respectiva parte, pagando a los demás los daños y menoscabos que experimentaren por causa de la división, 466 siempre que ellos no quisieren quitársela por el derecho del tanto; pues tienen a su arbitrio poder usar del uno o del otro privilegio, como más les acomodare.

Párrafo tercero. - Sentencias. $14 \mathrm{~N}$ pronunciándose sentencia definitiva o auto interlocutorio que contenga gravamen irreparable, se puede interponer la apelación ante el respectivo Juez de alzadas de la Provincia; ${ }^{467}$ y no siendo apeladas y pasándose en autoridad de cosa juzgada, se han de ejecutar breve y sumariamente por el Juez que las hubiese pronunciado, o bien sea el Tribunal o las Diputaciones territoriales; 468 pero para que sean admisibles los recursos, se deben interponer dentro de tercero día de notifieado el auto o la sentencia, y no de otra manera, ${ }^{469}$ quedando moderado en materia de minas el término de los cinco días que concede la ley de Castilla para otro género de 
pleitos, ${ }^{470}$ y en el todo equiparado su plazo al concedido por otra ley ${ }^{471}$ para apelar de los autos interlocutorios.

Aunque Acevedo, ${ }^{472}$ con casi todos los autoles del Reino, disputa largamente sobre si el día de la notificación se debe computar en el término concedido para apelar, todos ellos, después de tanta riña, dejan la materia siempre disputable. Confieso que nunca pude aquietar mi juicio con cuanto he leído en ellos, hasta que encontré la Real Orden, fecha en Madrid a 19 de marzo de 1756 , referida por Dn. José Antonio Portugués, en su Colección General de Ordenanzas Militaros. ${ }^{473}$ En ella se resolvió cierto punto grave sobre consultas de las sentencias, y se ordenó que, cuando usaren del recurso de apelación, ocuryan en derechura a Su Majestad, dentro del término preciso de cinco dias, no comprendido el de la notificación.

Como esta real déclaración tiene fuel'za de ley por lo respectivo a este punto, o por lo menos, de doctrina magistral, ya se puede afirmar sin riesgo de contradicción que el déa de la notificación de las sentencias de minas, no se debe contar entre los tres dias asignados para interponer el recurso.

Debiendo advertirse que, aunque la Ordenanza permite 174 introducir la apelación en el Juzgado de alzarlas, por carta del apelante, no debe tener efecto esta indulgencia, siempre que sustancie el grado ante el Juez de primera instancia, como queda dicho en el páruafo antecedente haberse propuesto en el plan aprobado por el Rey.

Todas las apelaciones se deben admitir en anbos efectos, según he fundado en otro lugar, ${ }^{4 i}$ alegando muchos textos y gravísimas autoridades; por lo que, recordaré aquí solamente la poderosísima razón de que, por la Ordenanza q $^{\top} 6$ se manda seguir y tratar juntas las causas de posesión y propiedad; en euyo caso conviene la común opinión de los Doctores, en que las sentencias pronunciadas en estos juicios mixtos, se estiman, en cuanto a la apelación, como las demás de los juicios ordinarios, y por consiguiente, surten de un mismo modo los dos efectos, suspensivo y devolutivo, diferenciándose esencialmente en ésto el nuevo sistema dè minería del antiguo del Perú, en que los recursos sólo eran admisibles en lo devolutivo, tit a causa de que por aquella antigua legisla $2 i o ́ n$, se trataba separadamente el posesorio del petitorio.

El caso verdaderamente dudoso es, si cuando la cantidad de la disputa no excediere de 400 pesos, se podrá interponer apelación sin embargo de haber declarado la Ordenanza ${ }^{47 s}$ que no ha de ser admisible, y que haya de causar ejecutoria la providencia final que se tomare por los Jueces del Real tribunal o Diputaciones territoriales.

Bien pudiera producir un largo discurso sobre este punto, que en mi concepto ha de ser muy frecuente, por la pobreza de estos minerales; pero el tiempo ya me ejecuta $y$, por otra parte, considero suficiente la autoridad del sabio Scacia, para dejar del todo dirimida la cuestión.

Explicando los efectos de las cláusulas apelatione remota sententia firma remaneat et executione mitatum lata sententia sortiatur efectum, que son equivalentes a la de nuestra Ordenanza, resuelve ${ }^{479}$ que, aunque quitan la apelación suspensiva y en su virtud no se debe retardar un momento la ejecución de la sentencia, no prohiben el recurso en cuanto al efecto devolutivo; y añade; que desde luego no está precisado el Juez a admitir la apelación, ni comete atentado negándola absolutamente, porque 
queda libre y salvo el efecto de devolver al superior el negocio, para que pueda revocar y enmendar el gravamen, por vía de la apelación que ante él se introdujere.

Sin duda, siguiendo esta célebre opinión, la Nueva Ordenanza no quíso declarar que la apelación no debia tener lugar, sino ünicamente, que no ha de ser admisible; como si dijera que el Juez inferior no está obligado a otorgar el recurso y que ha de mandar cumplir la providencia final, llevándola a su ejecución y efecto, sin privar al agraviado del arbitrio de ocurrir al superior, ni a éste de la facultad de pedir los autos y según su mórito administrar justicia, sin mandar suspender la ejecución de la sentencia. Y véase aquí, cómo en medio de no ser admísibles tales apelaciones, son apelables las sentencias de parte del interesado y del superior.

Las que se confirmaren en segunda instancia o en revista, se deben ${ }^{400}$ devolver al inferior para su cumplimiento y ejecución, sin perjujcio del grado de segunda suplicación que puede verificarse aunque la cantidad litigiosa no llegue a 20.000 pesos, con tal que el valor de la propiedad sea de 60.000 pesos ensayados, de 450 maravedíes cada uno, según el plan a que se ha mandado arreglar la Ordenanza, conformándose en este punto con la ley 1, título 13, libro 5’ de la recopilación de Indias. Y cuando no hubiere lugar a este remedio, debe quedar libre y salvo a las partes este recurso de injusticia notoria, al Consejo, según un auto acordado, ${ }^{481}$ por el estilo y práctica que explica Elizondo. ${ }^{\$ 82}$

Por último debo anotar, que no es justo negar la apelación de las sentencias en que se impusiere alguna pena de Ordenanza, pues aunque varios autores lo han creído así, tratando de las leyes penales, fundados en que la ley 2 , título $7^{\circ}$, libro $4^{\circ}$ de Castilla, resuelve que, del mandamiento o imposición de pena, no se admita apelación, ni otro remedio, ni recurso alguno, Fermosino ${ }^{483}$ dice que bien se puede apelar del pronunciamiento o auto declaratorio de la incursión en la pena, alegando al Panormitano Gutiérrez y Diego Pérez, lo cual es digno de recuerdo para los casos ocurrentes.

$$
\begin{aligned}
& \text { Párrafo cuarto. - Ejecu- } \\
& \text { ciones. }
\end{aligned}
$$

\section{libro $4^{\circ}$ de la recopilación de}

L ejecutoriadas, se deben ejecutar por el orden y forma que prescriben las leyes del título 21 , y Castilia, y las del títuio 14 , libro $5^{\circ}$ de Indias, guardando en cuanto al secuestro de minas, lo que se dejó dicho extensamente en este comentario. ${ }^{484}$

Sin embargo de ésto, anotaré aquí algunas resoluciones curiosas, que pueden ahorrar a los Jueces un estudio prolijo en muchas causas de su manejo.

Sea la primera, que la sentencia dada en rebeldía, debe notificarse personalmente, para que sea justa y legítima su ejecución; pero si el condenado se hallare en partes muy remotas, se puede proceder sin notificación personal, como opina el Sr. Solórzano, ${ }^{485}$ alegando la práctica de nuestros tribunales.

$\mathrm{La}$ segunda, que ninguna sentencia ni instrumento guarentigio se puede ejecutar contra ios herederos del deudor difunto, sin que primero pruebe el acreedor con citación de ellos, que son tales herederos, y así 
se declare por el Juez; de suerte que la probanza de esta calidad es necesaria, aunque sean hijos del difunto, según Rodríguez, Parladorio y otros que cita y sigue Fermosino. ${ }^{486}$

La tercera, que el instrumento ejecutivo de deuda hipotecaria, se puede ejecutar contra el deudor del deudor principal, sin oír antes, citar ni condenar a éste; y aunque no se haga ejecución, ni sea insolvente, como lo pensó Olea y otros citados por Cirino, ${ }^{48}$ porque la hipoteca tiene fuerza de cesión; y así, incluyéndose en la hipoteca, general o especialmente, los nombres de los deudores del deudor, bien se puede demandarlos legítimamente, aun en el caso de ser clérigo el deudor principal, y no debe ser oído aunque comparezca a alegar excepciones.

La cuarta es, que el contrato jurado se puede ejccutar por el Juez de Minas, aunque alguna de las partes lo haya reclamado ante el Eclesiástico. 488

La quinta, que el mismo Juez laico de minería, puede relajar la obligación del contrato jurado ad efectum agendi, sin necesidad de ocurrir al Eclesiástico, según Molina y otros, ${ }^{189}$ aunque sientan lo contrario Gutiérrez, Bobadilla y Larrea. ${ }^{490}$

La sexta, que la vía ejecutiva no prescribe, aunque en los instrumentos se ponga la cláusula: "siempre que quisiere y sea su voluntad", según Guzmân con Tiraquelo. ${ }^{491}$

La séptima, que la prescripción decenal en la vía ejecutiva, se puede renunciar como derecho privado, según Avilez, Gómez y Salgado, 492 y así se podrán ejecutar en todo tiempo los instrumentos donde se hubiere pactado la renuncia referida.

La octava, que en las causas criminales de minería, no se puede hacer ejecución y embargo de bienes, por dclitos en que no se incurre en perdimiento de tođos o parte de ellos, según Gutiérrez y otros textos, con muchos Doctores. ${ }^{493}$

Omito otros casos, porque para guía bastan los referidos, que son los más frecuentes, al paso de ser loș más singulares.

\section{NOTIOIA NOVENA}

De las Ordenanzas Penales de Mineria.- Párrafo primero. Casos en que se incurre en pena pecuniaria.

manera siguiente.

Los que impidieren nuevos descubrimientos de minas; 494 los que consertaren que no se coloque en el mejor lugar la estaca-mina del Rey; ${ }^{485}$ los que no estacaren sus minas por lo hondo de las Iabores; ${ }^{496}$ los que no adobaren, fortificaren y aderezaren cada año los mojones de sus pertenencias; ${ }^{497}$ los que no cegaren los pozos abiertos paxa alumbrar las vetas halladas en cuadras; ${ }^{498}$ los que no labraren con sus vetas en la mano; ${ }^{199}$ los que entraren por las cajas a buscar metales y comenzaren nuevas labores sin noticia y reconocimiento de los Alcaldes Veedores; ${ }^{500}$ los que no tuvieren escaleras largas y seguras, sobre buenos palos; ${ }^{501}$ los que 
no repararen las minas a satisfacción de los Veedores; ${ }^{502}$ los Albaceas que no vendieren las minas mortuorias, dentro de cinco meses; ${ }^{503}$ los que cada sábado no limpiaren sus pertenencias, echando fuera los desmontes o los dejaren en las ajenas; ${ }^{504}$ los socavoneros que no manifestaren el metal descubierto en las minas por donde pasaren; 505 los que impidieren Ia entrada en sus minas; ${ }^{406}$ los que labrando su mina por otra o por socavón ajeno, no sacaren los metales por la puerta o por la escalera común; jor los azogiteros que aprovecharen los desmontes que hay fuera de sus minas; ${ }^{5}$ los que cobraren por sa mano, quitándole al indio minero los metales de sus minas o ingenios; ${ }^{509}$ los Jueces que no desterraren vagabundos de los asientos de minas; 510 los Jueces y demás personas prohibidas, que tuvieren minas contra Ordenanza; $\$ 11$ los que apremiaren indios que trabajen más horas de las que deben; $\$ 12$ los que no pagaren el jornal entero al indio que no hubiere enterado la tarea; ${ }^{513}$ los que ocuparen a los indios obligándoles a trabajar en dias de fiesta; ${ }^{614}$ los que tuvieren pongos señalados para capataces de los demás indios; ${ }^{115}$ los que cargaren a los indios en llevar metales para otras partes; ${ }^{516}$ los que rebajaren salarios, por no haberles entregado las tareas; ${ }^{517}$ los que obligaren que quiebre metales al indio que trabaja en minas; ${ }^{518}$ los que no mudaren de cuatro en cuatro serviduras de metal y carbón a los indios empleados en la desazogadora. $\$ 10$

Ios que consintieren a los indios que destapen las ollas de fundición de metal de azogute, después que dejaren de darles fuego. 520 Los que no pagaren en la forma dispuesta al indio trabajador en guairas. ${ }^{621}$ Los que no dieren las velas necesarias a los indios apiris y barreteros. ${ }^{522}$ Los que no dieren mantas y quepiñas (a) a los indios sacadores de metales, o un cuartillo cada semana para ello. ${ }^{23}$ Los que no pagaren a los indios de su repartimiento. ${ }^{524}$ Los que ocuparen indios de ingenios, en labores de minas, sin precedente licencia del Corregidor y reconocimiento de Veedores. "525 Jos que consertaren con los indios tomar en plata su servicio. ${ }^{52 B}$ Los que recibieren mayordomos sin fianzas. ${ }^{527}$ Los que recibieren minero por menos tiempo de un año concertando en parte de los metales. 528 Los que siendo azogueros tuvieren a su cargo las labores del Cerro. ${ }^{529}$ Los que azotaren o maltrataren a los indios. ${ }^{530}$ Los que ocuparen en su servicio indios de mita y les obligaren a guardar metales en días de fiesta. 531 Los que no surtieren de agua las bocas de los socavones y minas. ${ }^{532}$ Los que siendo mayordomos no subieren al Cerro, desde el lunes de cada semana, después de siesta. ${ }^{533}$ Los mayordomos que bajaren del Cerro antes del sábado. ${ }^{534}$ Los mineros que tuvieren minas suyas o $p a-$ llacos. ${ }^{585}$ Los que vendieren metales dentro de las minas, sin licencia del Corregidor. ${ }^{536}$ Los que jugaren y vieren jugar naipes en el Cerro. ${ }^{537}$ Los que vendieren minas o ingenios a personas eclesiásticas. ${ }^{538}$ Los que hicieren arrendamientos y compras fingidas, para servicio de los indios de repartimiento. ${ }^{539}$ Los que vendieren minas o ingenios, sin licencia del Corregidor, con las calidades dispuestas por Ordenanza. ${ }^{540}$ Los que vendieren indios con las minas o ingenios, o los fletaren para sacar metales. ${ }^{54 t}$ Los Jueces que mandaren dar indios de repartimiento, a personas que no los tienen. ${ }^{542}$

En cualquiera de los casos referidos, en que los incursos no tuvieren con qué satisfacer la pena pecuniaria, se les debe conmutar en la pena corporal, siendo seculares, ${ }^{513}$ y en destierro a los eclesiásticos. ${ }^{544}$ 
Párrafo segundo. - Casos en que se incurre en perdimiento de indios.
$\mathbf{E}_{\mathrm{L}}$ Gobcrnador de la Villa debe quitar los indios y depositarlos en las personas más necesitadas, luego que cesaren los motivos y causas de su repartimiento, dando pronto aviso al Sr. Virrey; ${ }^{55}$ debe ejecutar lo mismo con noticia del Protector, con los que emplearen los indios en trabajar otras minas fuera de las de su repartimiento, a menos que estén en las vetas principales. ${ }^{546}$ También incurren en esta pena los que ocuparen los indios en guardar ganados y en otros servicios particulares, hallandose repartidos para el de los ingenios y minas. ${ }^{547}$ Los que dejaren de trabajax tres meses con los indios repartidos para la labor de las vetas nuevas. $54 \times$ Tos que recibieren de los indios que les van señalados, dineros u otras cosas en lugar de sus servicios, o los alquilaren a otros. ${ }^{54 y}$ Los que azotaren o mandaren azotar a los indios y los maltrataren de otra cualquier manera. ${ }^{550}$ Los que no molieren, por dos años, en los ingenios que tienen repartimiento de indios. Los quo hicieren ventas simuladas de ingenios o minas, en fraude de las Ordenanzas. ${ }^{552}$ Los que compraren o vendieren el trabajo de los indios, bajo de contrato o arrendamiento fingido. ${ }^{608}$ Los que vendieren minas o ingenios, sin licencia del Corregidor, confirmación y aprobación del Superior Gobierno, y demás diligencias prevenidas por Ordenanza. "5na Los que por adquixir indios usaren de ventas $y$ donaciones fingidas. sirvieren de indios mitarios, en destino diferente de su repartimiento. 5.66

Se ha mirado siempre con tanto escrúpulo la ocupación extraordinaria de los indios, en servicio donde no estân repartidos, porque si algún Cura se propusiera a servirse de más indios que los permitidos por Ordenanza, sin pagarles sus jornales, debe el Gobierno de la Villa no pagarle en adelante el salario o sínodo, y privarle de la Doctrina, presentando otro sacerdote en su lugar. 557

La autoridad de dar o quitar, pone' y remover indios de repartimiento, toca privativamente a los señoles Virreyes, como Gobernadores y Capitanes Generales de estos Reinos y Provincias del Perú. "5is Por ésto reservaron a sí mismos los Excmos. Virteyes Don Franciseo de Toledo y Conde del Villar, la privación de los indios; 569 pero habiéndose advertido después los gravísimos inconvenientes que resultaban de la falta de cumplimiento de dichas Ordenailzas, concedió facultad a los Corregidores o Gobernadores de Potosí, el Virrey Marqués de Cañete, "i60 para que en todos los casos en que por. Ordenanza se pone pena de privación de indios, los quiten y formen causa a los contraventores, enviando copia de los procesos al Superior Gobierno, en la primera ocasión, a costa de las partes; $y$ en el ínterin, deben depositarlos 581 en las personas que más necesidad tuvieren de ellos, para el "aviamiento" de sus haciendas.

$\mathrm{Y}$ es de advertir, que basta sólo la declaración de cuatro indios que depongan haber alquilado otros por ellos o dado dinero para este fin a los dueños de minas, o a sus mineros, o a los pongos por su mandato, para que se les pueda quitar sin necesidad de otra información y averiguación; debiéndose entender para otros casos y causas menos privilegiadas, la doctrina del Sr. Solórzano y de Matheu, 562 sobre la precisión de examinar seis indios por lo menos, para que hagan fe. Pero atendida la gravedad de tales causas, deberán declarar con juramento los cuatro indios de que habla nuestra Ordenanza, encargándoles antes la conciencia, en los 
términos que aconseja el Concilio Provincial $1^{\text {n }}$ Limense, ${ }^{563}$ y nuestro sabio Político Solórzano. 5ó

Párrafo tercero. - Casos en que se incurre en pena corporal y en la de destierro.
H mismos indios son los peores enemigos unos de otros, cuando advierten que con ello complacen a los amos, quiso la Ordenanza horrorizarlos con el rigor de las penas, ya de azotes, ya de marca en las espaldas, o ya de muerte natural; pero como no hay proporción entre la pena y los delitos, no se puede creer que haya sido de intención tanta severidad, con unas personas por otra parte llenas de privilegios por su condición miscrable, rusticidad e ignorancia. Desde luego, me atrevo a decir que la pena de marcar" en las espaldas a los indios "pongos" que se ocuparen ch sacar del trabajo a los demás mitarios, o concurriesen en los trueques del servicio en plata, fue impuesta por la Ordenanza, 5 s.5 ad terrorem solamente, y de ningún modo se puede ejecutar, respecto de haberse prohibido toda sevicia por las leyes posteriores de nuestro Gobierno sabio, ilustrado y cquitativo; conviniendo todos los intérpretes regnícolas por esta misma razón, en que se deben tener por anticuadas todas las leyes de la Hermandad, que disponen la pena de saeta y otras semejantes, por ser, a más de odiosa la sevicia en cuerpo humano, prohibida también con bastante claridad en la ley 46 , título 13 , libro $8^{\circ}$ de Castilla.

Sólo contemplo exigible la pena de azotes que imponen dichas Ordenanzas, ${ }^{660}$ guardando la forma de todos los juicios criminales, en cuanto a formación de proceso, citación, audiencia y defensa de los reos, pronunciamiento de senteneia con dictamen de Asesor, y consulta de la Audiencia para su cjecución, con arreglo al auto acordado del Superior Gobiexno de estos Reinos, su fecha 1 de mayo de 1671, inserto al folio 202 del título 17, libro 2 de las Ordenanzas Generales del Perú.

Del mismo modo deberá cumplirse la pena de destierro en los que, contra Ordenanza tuvieren pallacos, siendo mineros, ${ }^{567}$ o por cchar trabajo en ellos sin licencia, sucediere alguna desgracia, ${ }^{5}$ fi o trocaren el servicio de los indios en plata, sin Iicencia del Corregidor, 570 o trataren en ellas con los mineros o mayordomos, 571 o jugaren o vieren jugar naipes, dados y otros juegos vedados en el Cerro, ${ }^{572}$ y los que vendiesen minas sin manifestar sus escrituras. ${ }^{573}$ Bien entendido que si fueren indios los contraventores, se debe guardar la ley 10 , título 8 , libro 7 " de la recopilación de Indias, imponiéndoles el destierro dentro del distrito de la ciudad cabecera de Provincia.

Continua la Ordenanza agravando su severidad, hasta el extremo de imponer pena de muerte natural, a los que derribaren o labraren en puentes, 574 en los cruceros, ${ }^{575}$ o echaren labores sin permiso del Corregidor ${ }^{576}$ y por esta causa resultaren algunos daños o muertes, o reincidieren por tercera vez en el trueque de indios por plata. ${ }^{577}$ Pero yo discurro que en todos estos casos se debe entender también que los señores Virreyes no tuvieron intención del cumplimiento de semejante castigo y sólo decretaron para terror de los mineros. Porque siendo de creer que hubiesen querido conformarse con las leyes generales, no es regular que, imponiendo las de Partida ${ }^{578}$ la pena de destierro por cinco años, a más 
de la satisfacción del daño, se hayan propasado intencionalmente hasta la de muerte.

$Y$ cuando se insistiere en su ejecución, será menester probar que el derribador de puentes, no sólo ocasionó las muertes por su culpa, sino también por dolo malo, que es lo único que sujeta al último suplicio.

Por todas estas consideraciones, innovó la Ordenanza de México las penas prescritas por la del Perú, y determinó $5 \%$ que quién quitare, debilitare o cercenare los puentes, sea castigado con diez años de presidio, y el dueño de la mina quede privado de ella y del ejercicio de la minería perpetuamente, con la mitad de sus bienes. Todo lo cual es muy conforme a derecho y debe practicarse en los casos ocurrentes.

1.- Ordenanza 13, título $1^{\circ}$. Libro $3^{\circ}$ del Perú. Articulo $\tau$, título 6 de la Ordenanza de México. Cata, se llama la boca que se abre en solicitud de la vena. Gamboa, Cap. 8, No. 2, fol. 184 .

2.- Ordenanza 13 citada, hasta el medio, título $1^{\circ}$, libro $3^{\circ}$. Gamboa en su Comentario, Cap. 8, No. 2, fol. 114, se funda en la misma razón, aunque no con tanta claridad. Y en el propio Cap., No. 16, resuelve expresamente, que no puede haber minas, estacas, ni mejora, si no está descubierto el metal.

3.- Ley 5, título 28, Partida 3.

4.- Ordenanza 1, título 1 , libro $3{ }^{\circ}$.

5.- Vinnio, con varios Doctores, sobre el \$ Idem. Cap. 18, Instit. de Rerum divitione, libro 2, título $1 \%$.

6.- Vinnio, en el Iugar citado.

7.- Mancio, en el mismo § Idem, 18, No. 6, fol. 115.

8.- Antúnez: De donationibus; libro $3^{\circ}$, Cap. 13, No. 79 , tomo $2^{\circ}$, fol. 85 ; con Gustavo Barbosa y Zebullos.

9.-- Ordenanza 13, título $1^{\circ}$, libro $3^{\circ}$ del Perú. Artículo 7, título 6, de la de México.

10.- Artículo 2, título 6.

11.- Gamboa: Cap. 8, No. 9.

12.- Ordenanza 13, título 1, libro $3 "$ ".

13. - Ordenanza 20, título $1^{\circ}$, libro $3^{\circ}$ del Perú.

14.-.- Ley 14, título 34, Partida $7^{\circ}$.

15.- $\$$ Allia 47. Instit. de Rerum divitione, título $1^{\circ}$, libro $2^{\circ}$; et ibi Vinnius, Nos. 2 y 3 , tomo $1^{\circ}$, fol. 234 . Ley 7, título 9, Partida $5^{*}$, título 12 , libro $6^{\circ}$ del Ordenamiento Real. Ley 17 , título 19 , libro 8 del mismo. Ley 7 , título 13 , libro $6^{\circ}$ de Castilla. Ley 18 , título 20 , libro $1^{\circ}$. Ley 7 , título 12 , Libro $8^{\circ}$ de Indias. Antúnez: De donationibus, libro $3^{\circ}$, Cap. 13 , No. $93 \mathrm{y}$ siguientes, tomo $2^{\circ}$, fol 86 .

16.- Ley 50, título 28, Partida $3^{\circ}$.

17.- Articulo 11, título $8^{\circ}$.

18.- Artículo 4, titulo 6:

19.- Artículos 9 y 11 , título 8 .

20.- Ordenanza 12, título $1^{\circ}$, jibro $3^{\circ}$ del Perú.

21.- Ley 2, título 12, libro $4^{\circ}$, Real Cédula.

22.- Ley 14, título 12, libro $4^{\circ}$ Real Cédula.

23.- Ordenanza 12 , título $1^{\circ}$, libro $3^{\circ}$.

24.- Ordenana 10, título $1^{\circ}$, libro $3^{\circ}$ del Perú. Estos descubridores, son realmente los restauradores de antiguos minerales decaídos y abandonados, de que habla el articulo 6, título $6^{\prime \prime}$ de México, y como que tienen el privilegio de primeros descubridores, también gozan las mismas preminencias.

25. - Ordenanza 8 , al fin, título $1^{\circ}$, libro $3^{\circ}$ del Perú.

26.- Ordenanza citada.

27.- Barbosa: De apelat. Verborum juris significatione; apelativo 267, Nos. 1 y 2. Surdo: Concil. 394, No. 26 y siguientes tomo 2 , fol $364 .-$ Narbona, con más de doce Doctores, sobre la ley 29 , título 7 , libro $1^{*}$ de Castilla; glosa $3^{*}$, Nos. 1 y 2 , fol. 70.

28. - Solórzano: en la Política Indiana; libro $3^{\circ}$, Cap. 15, No. 8, tomo $1^{\circ}$, fol. 305 ; y en el libro $2^{\circ}$ de Jure Indiarum; Cap. 14, No. 16, tomo $2^{\circ}$, fol. 330 . 
29. - Molina: De primoreniis. Libro 4", Cap. F, Nos, 19 y 21, fol. 538 ; con la Adición de Maldonado sobre el $\mathrm{N}^{*}$. 15 hasta el ?:?.

30.- Molina: Tratado $2 \%$, Disput. 464 , tomo 2", fol. 542 .

31.- Molina: en el lugar próximo citado.

32.-Avilez: in Cap. 33, P'retorum, No, 5, fol. 239.

33.- Barbosa: loc 120, T'actatus valia fol. 319. Lo mismo sientá Velasco, en De jure Enphiteut, 1' Parte, Quest. 29, No. 7, fol. 156.

34.-Card. de Luca: Timptione et venditione; Disc. 48, No. 3, tomo 7", fol. 195.

35.- Alvaro Velasco: Consulation 83 y 77, principalmente el No. $6^{\circ}$.

36.... Tiraquelo; Libro 16, Iegur connubalium, palabra contracta; glosa 5, Nos. 186 y 220, tomo 2\%, fol. 207 y 303 . El mismo Tiraquelo: De retractus linagier; 1'áxrafo 1, Glosa 2, No. 55, tomo $3 \%$, fol. 27.

37.- Sousa: De regulis jurisis; fol. 95, No. 37 .

38.- Solórzano: en la polítima Indiana; libro $3^{\circ}$, Cap. 15, No. 5, fol. 304, tomo $1^{\circ}$.

39.- Surdo: Concil. 457, No. 14, tomo $2^{4}$, fol. 633 .

40.- Cancerio: Parte $3{ }^{\circ}$, Cap. 7 , No. 124 y simuientes, 1ol. 105 - Castilo: libro $2^{\circ}$, Controv. Cap. 3 , No. 21, tomo 2, fol. 16. Olea: De cetione jurium, título 10, cuest. 6 , Nos, 33 y 43 , fol. 32 y 33 .

41.- Narbona: en la ley 29 , título 7 , libro $1^{\circ}$ de Castilla. Calosá $3^{x}$, Nos. 13 hasta 15, fol, 72 .

42.-- Narbona: en la ley eitada, Nos. 16 y 20 hasta 61.

43...- Ordenanza 7 , título 14 , libro :"

44.- Ordenanza 13, título 1", libro $3{ }^{\circ}$.

45.-- Montesinos: Polit. de Minas; Caps. 8 , No. 1 , fol. 57.

46. - Ordenanza 20 , título $1^{\circ}$, libro $3^{\circ}$. Fisto se entifinde si los interesados on la veta, no lo hubieren reguerido que haga estaci fija, porque entonces debe hiscerla el mismo día del dequeriniento, cogún esta misma Ordenanaa.

47.- Ojdenauki 5", Lítulo 2 , libro $3^{\prime \prime}$ del l'erú.

48.- Ordenanza 17 , título $6^{*}$ de Móxico.

49.-- Ordemanza 11, titulo 8 , de id.

50.... Gamboa, en su Comenturio, Cap. 2\%, No. 29, fol. 21, interlineal 51. Refiere los Fclesiásticos que han escrito libros sabios sobre minas, y esto prueba lo úti que es dejarles libertad para hacer descubrimientos $y$ aprovecharse de su precio.

51.-- Cap. 8*, Noticia $6^{*}$, l'arte $2^{*}$, T'úrafo $^{*}$, l'ág. 635 de esta obra.

52.-- Articulo $2^{\circ}$, título 7 , de Míxico.

53.-. Ordemanza 1 , título $x^{\circ}$. Ordenanza 1 , título 2 , kibro $3^{\circ}$ del Perí.

54.-- Larrea: Aleg. 9, No. 30, fol. 44.- Graciano: Disertaciones icrenses; Cap. 33, tomo $6^{*}$, fol. 466 .

55.- Graciano: Jyecis. 14, No. 20, tomo $3^{\circ}$, fol. 53.

56.- Tiraquelo: De retract. Conventionali; Párafo 1?, glosa 1, Nos. 46 y 47 , to. mo 3 , fol. 389 .

57.- Salgado, en la Partida 4 de Irave. Acreedores. Cap. 5\%, Nos. 7 y 8, fol. 41.

58.- Fontanela: Decis. 289, No. 22, tomo $1^{\circ}$, fol. 722 .

50.- Barbosa: en el Axioma 120, Nos. 1 y siguientes, foi. 73 de sus Tratados varios.

60.- Jerónimo González: en la regra $8^{\circ}$ Cancolaria, Glosa 54 per totum, fol. 494. Fste autor mereció elogio de nuestro Salgado, en la $3^{*}$ parte de Regia protectione, Cap. $4^{\circ}$, No. 5.3 , con el renombre de Aborado famoso y diligentisimo, de frande y claro entendimiento.

61.- Acevedo: sobre la dicha ley, No. $17 \%$, tomo 2 , fol. 258.

62.-. Fontanela: Decisn. 289, No. 22 , tomo 1", fol. 722. Pareja: De instrumentorum editione; título 6 , resol. 7, No. 61 , fol, 56.

63.- Ley 4, título 12 , libro $1^{4}$ de Indias. Concil Limense $1^{\circ}$ Provincial, acción $3^{*}$, celebrada en 1008 , Cap. 5 , al fol. 37 del tomo 6 de la colec. del Cardenal Aguirre.

64.- Barbosa: en el tomo de sus Tratados varios, locot. 67, No. 1, fol. 317.

65.- Molina: Jo primogeniis; libro $4^{\circ}$, Cap. 5, Nos, 17 y 18, fol. 538 .

66.- L. Non debet. 21 , Párrafo De regulis juris; Cap. Evi licet. de regulis juris.

67.-. L. Nec in ea 22 , Párrafos $2^{\circ}$ y $3^{\circ}$, ad Y. Jul. de adult.

68.- L. L. $1^{\mathfrak{a}}$ y 2" C. Nefidei juss dot. dent Cap. per vestras ext. de Donat, inter virum et uxorem.

69.- L. filut familias 7, Párrafo fin al de Donat. 
70.- Cap. $8^{\circ}$ de la Parte $2^{\circ}$, Noticia $6^{\circ}$, Pág. 635, Párrafo $1^{\circ}$ de esta obra.

71.- Vela: Disertación 18, No. 15, tomo 1, fol. 230.

72.- Jerónimo González: in regula $8^{2}$ Cancelaria 27, No. 51, fol, 364.

73. Cortiada: Decis. 16 , Nos. $90,92 \mathrm{y} 95$, tomo $1^{\circ}$, fol. 170 ; con otros que él cita. Vide Antonio Gómez in L. 70; Fauri, No. 25, fol. 670 .

74.-Vela: Disertación 18, No. 15, fol. 230. Cortiada: Decisn. 17, No. 43, tomo 1, fol. 176 .

75.- Matienzo, en la Ley 8, título 11, libro 5" de Castilla; gilosa 12, No. 9, fol, 380.

76.- Tiraquelo: in Lege Bobes hoc sermone, Pärrafo De verborum significatione limit. 23, No. 7, tomo 4, fol. 206.

77.- Artículo 10, título 60.

78.-.- La ley 1. Párrafo De diversis et temporalibus, es la niejor prueba de ser útil este tiempo.

79.- Ley 1, Párrafo final Cod. De annali exceptione; latamente explicado por Barbosa, Axioma 116, fol. 71 , en sus Tratados varios.

80.- Garcia. De benef.; Part. 1, Cap. 2, No. 17, tomo 2, fol. 210, con Gutiérrez, Cerola, Flores, Plasentino Abad y otros.-- Salgado: De reg. protectione; Part. 1, Cap. 7, fol. 125, No. 65 husta 68 , donde cita media planilla de autoridades y textos, poniendo varios ejemplos, un que se remite a Flaminio Paricio.

81.- Sabelli: Párrafo Impedimentum; num, 2, tono 2, fol. $2: 7$; con Graciano, Fusco y otros.

82.-Valenzuela: Concil. 4, No. 70 hasta 77 , tomo $1^{\circ}$, fol. 31.

83. - Cardenal de luca: disc. 72, De testament.; Nos. 6 y 7 , tomo 9, fol. 112.

84. - Luca: ibid, No. 7.

85. - Solórzano: en la Política; libro $3^{*}$, Cay. 27 , desde el No. 18 hasta 25 , teia $1^{4}$, 1ol. 385 .

86.- Solórzano: De jure Indian; libro 2, Cap. 25, No. 65 y sigujentes, tomo 2", fol, 442 .

87.- Artícello 8", título bi de Mćxico. Ordenanzos 3, 5, 17, título 7, libro 30. Ordenanza 14, título 9, del mismo libro.

88. - Mina rica se llama a la que rinde dos mareos de plata por quintal de metal, según la Ordenanza 1 , título $7^{\circ}$, libro $3^{\circ}$ del Perú.

89.- Artículo 17, título $6^{n}$ de México.

90.- Artículo 17, título $6^{7}$ de México.

91.- Artículo 16, título $8^{\circ}$ de México.

92.- Artículo 13, título 6" y articulo 13, título 8 de México.

93. - Si las varas que se tomarcn al oriente, se mejorasen hacia el poniente, se llama demasía lo que quedase vacío al oriente. Gamboa, Cap. 13, Nos. 10 y 14, fol. 279 .

94,- Ordenanza 2 , título 2, libro $3 "$.

$95 .-$ Artículo 13 , título $6^{\circ}$.

96.- La Jey $5^{\circ}$, Cap. 28 , título 13 , libro $6^{7}$ de Castilla, niega las demasías al poseedor de ellas, del mismo modo que la Ordenanza del Perú; y así se debe tener por derogada una y otra según el nuevo sistema de minería, que es mucho más proficuo para el minero, quedando enteramente sin fuerza lo que dijo Camboa acerca de este punto, en su Comentar. Cap. 13, Nos, 14, 15 y 16 , fols. 280 y 281 .

97.- Ley $1^{*}$ y siguientes, título 33 , libro 90 de Indias.

98. - Solórzano: en la Política Indiana; libro $6^{\circ}$, Cap. 10 , No. 6, tomo 2, fol. 162.

99.- Leyes $10,15,26,28,29,30,31,32$; título 33 , libro $9^{v}$ de Indias. Vide a Evia Bolaños, libro $3 \%$, Cap. 8, al principio.

100.-- Leyes 13,21 y 57 , título 8 , libro 6 .

101.-- Ordenanzas 8 y 11 , título $1^{\circ}$; Ordenanza 6 , títula 9 , libro $3^{\circ}$ del Perí. Ley 1 , título 13 , libro $6^{\circ}$ de Castilla. Ieyes 2 y 3 , título 32 , libro $8^{\circ}$ de Indias. Artículos 4 y 22 , título $6^{\circ}$ de México.

102.- Alfaro: De ofic. Fiscalis; glosa 20, Párrafo 6, No. 109, fol. 141.

103. - Ordenanza 8, título $1^{\circ}$, Jibro $3^{\circ}$. Ordenanza 1 , título 9 del mismo libro.

104.-- Rivadineira: Del Real Patronato; Cap. 13, Párrafo 5\%, fol. 259.

105. - Salgado: De regia protect.; Partida $3^{\star}$, Cap. 9 , Nos. 53 y 57.

106. - Ordenanza 9, título $1^{\circ}$, libro $3^{\circ}$ del Perú.

107.- En el Cap. 8०. Noticia 6*, Párrafo ptimero, Parte $2^{\natural}$, Pág. 635 de esta obra se refieren por menor las personas prohibidas de descubrir y registrar minas.

108.- Ordenanzas 8 y 11 , título $1^{\circ}$, libro $3^{\circ}$. 
109._. Garcia: De beneficii; 3 p., No. 74, tomo 1", fol. 120. Graciano: Disp. Forense (ap. 166 , No. 22, tomo 1\%, fol. 400 ; con Barbosa, Cobarrubias y otros Doctores que cita Rivadineira, en su Compend. del P'atronato, Cap. 11, Párrafo 53 y siguientes, fol. 213 .

110,- Ordenanza 11, titulo $1^{\text {n, libro }} 3^{\circ}$.

11. - Se pide poder especial, porque sin ál nakla puede hacer el l'rocurador, en negocio en que puede caer en yena el principal, según Pareja: título 6, resol. 3, ㅅo. 51 .

112.-... Ordenanza 11 citada.

113.-. Cum tibi Domino 31, distinen. 63; Cap. optaxum 3, distincn. 100, Cap. Atenienses 25 , cans 17 , cuest. 4, Cap. Periculoso.

114.-Graciano: Jisput. Forense, Cap. 97, No. 18, tomo $1^{\circ}$, fol. 221. - Fermosino: in Cap. Ego enim. 4. De jure jurando; cuest. 4, No. 51 , tomo 6 , fol. 254.Solórzano: in Politic, ; libro 4, Cap. 6, No. 2 y siguientes, tomo 2 , fol, 33. Suárez: De religione; libro $2^{\circ}$, Cap. 31, tomo 13 , fol. 340 .

115. - Leyes 8 y 11 , título 5, Pariida '3.

116.- Ley 5, título 5, Jartida ; ley $:$, titulo 6, l'artida 3.

117.- in el Apéndice juesto a los antecedentes Arts. 1" y 2\%, Fág. 675 de esta obra.

118.-- Harprector: en el Párráo Nunc admonendi in princip. Institut, título 10, libro 4, No. 10.

119. - En el l'áritio Nume admonend in princip. Institut. título 10, libro 4, vers. fin. sed quia. En este Párrafo se hace mención de la ley Hostilia, que fue la primera que permitió apersonarse por los cautivos y por los ausentes para perseguir los robo:; y dice Heinecio, en la Historia del Derecho Civil, libro $1^{\circ}$, Cap. 3, Prijafo 95, que no se hace mención de ella en ningún otro lugar del Derecho.

120.- Ley l'rocurarum in Párrafo usus de Procurationizus L. $3^{\text {a }}$, título 3.

121.... Vinnio: in F́rrafo Nume: in princip. Instit. título 10 , libro $4^{\circ}$.

122... Pichardo: sobre el mismo texto; No. 32, fol. 527, tomo 2.

123.- Cobarrubias: libro $1^{\prime \prime}$, ver. Cap. 20 , Nos. $1^{\circ}$ y $2^{\circ}$ explieado en la ley 1 , Párafo sexto De Postulando.

124. - Pareja: Resol. $6^{\circ}$, título $7^{\circ}$, No. 61 , fol. 56.

125.- Aunque el artículo 4, título $6^{*}$ de México, nada dice sobre poderes, antes indica que los mismos descubridores hayan de hacer el registro, todo se debe entender en el temperamento explicado.

126. - Ordenanzas 21 y 22, título 1 , libro $3^{\circ}$ del Perú.

127. - L. Omnes Adolescentes, $2^{\circ}$ cod. de hist quj ven et imptd. 45 , libro $2^{\circ}$, concord. a ka glosa 1 , título 19 , Partida $3 "$.

128..... Artículo 4", título 7 ,

129.- La Ordenanza 11, título 1, libro $3^{4}$ del Perú, coneede sólo 40 dias para la ratificación, pero como la de México ha ampliado todos los demás términos, se prorrogó también ćste, muy justanente, a 60 días, conformándose con la Ordenanza 6 , título 1 , libro $6^{\circ}$ del Perti, que concede el mismo plazo, aunque en diferente caso.

130.- Ordenanza 8, título $1^{\circ}$; Ordenanza $\mathrm{G}_{1}$ título 9, libro $3^{\circ}$ del Perú.- Artículo 4, título 6, de México. La pella que se presentare, debe ser ensayada, según la Ordenanza 3 , titulo $1^{\circ}$, libro $3^{\circ}$ del Perú.

131. - Ordenanzas 8 y 18 , título $1^{\circ}$, libro $3^{\circ}$.

132.- Artículo 4, título 6 .

133. - Ordenanza 8, título $1^{\circ}$, libro $3^{\circ}$.

134.- Odenanzas 13 y 19 , título $1^{\circ}$, hibro $3^{\circ}$.

135.- En la Sección $2^{\sharp}$ de este Párrafo 9, Pág. 713 que vamos explicando, se dirá el tiempo que basta para pedir por despoblada la nina concedida por derecho de limpia.

136.- Es conforme a la Ordenanza 10, título $1^{\circ}$, libro $3^{\circ}$.

137.- Las Ordenanzas 13,14 y 19 , título $1^{\circ}$, libro $3^{\circ}$ concedian al descubridor de mina, 80 varas; $y$ a los demás 60 varas.

138. - Ordenanza 6, título 9 , jibro $3^{\circ}$, artículo 21 , título $1 ; y$ artículo 4 , título 6 , de México.

139.-Ordenanza 8, al fir, título 1, libro $3^{n}$ del Perú.

140.- Gamboa: Cap. 11, No. 12, fol. 219.

141. - In L. 3, Párrafo De usucapionibus, título 3, libro 41.

142.- Ley 1, título 2, Partida 1". 
143. - L. Servitutes. L. Quoties, Párrafo De servitutibus.

144.- Tiraquelo: De prescriptione; I'árrafo 1, glosa 5 , tomo 5, fol., 68 .

145.- Autentic. De Tabellonibus, Párrafo Illud Novella 44, título 7 , collastione 8 .

146.-Cobarrubias: Praet.; Cap. 19, No. 3, I'árralo Nec quidquam; tomo 2, fol. 581.

147.- Carrasco, sobre la interpretación de la ley 41, título 4, libro $3^{3}$ de Castilla; Cap. 11, Nos. 7, $10 \mathrm{y}$ signientes, fol. 245 .

148. Magero: De advocatia armata; Cap. 16, No. 360, fol. 698.

149.- Surdo: Concil. $8^{4}$, Nos. 8 y 9, tomo $1^{1}$, fol. 39 ; y Concil. 97, Nos. 16 hasta 35 , tomo 1", fol. 316. Fontanella: Decisión 166, Nos. 6 y 7, tomo 1", fol. 409 . Tiraquelo: De retract. lignagier. P'árrafo 3 , glosa 4 , No. 2 hasta 7 , tomo 3 , fol. $194 ;$ y De retraci. convention.; Parrafo 1 , glosa 2 , No. 42 hasta 54 , tomo 3, fol. 388. Fontanella: Decien. 406, No. 14, tomo 2, fol. 315.

150.-- Salgado: De regia protect.; Part. 2, Can. 8, No. 101, fol. 235.

151.- Ley 28, título 8, Partida 5". Ley 1, título 1.5 , libro $5^{4}$ de Castilla.

152.- Ley 28, título 8, Parta. 5*. Ley 8, título 14 de la misma l'artida.

153.- Ley 36, título 11, Partida $5^{\text {}}$.

154.- Glosa $3^{4}$. L. 36, título 11, Partida 5".

155.- Glosa 9, in L. 35, y Glosa 4 in L. 36, título 11, Partida $5^{9}$.

156,- Ley 13, título 11, Partida 5"; y Glosa 3 in L. 36 , del mismo título y Partida.

157.- Gamboa: en el Cap. 5", No. 16, fol. 107, resolvió abs:"lutamente que, no habiendo venido otro a registrar la mina, puede hacerlo el descubridor, sin distinguir la demora voluntaria, de la forzosa; y así debe entenderse su doctrina en este último caso, y no en el primero, si no es que con el tenjperamento que se acaba de explicar en el $\mathrm{No}$. antecedente.

158.- Tiraquelo: De retracta conventionali; Párrafo 1, Glosa 2, No. 46, to:10 3, fol. 383 .

159.- Tiraquelo: De retract. lignagier, Párrafo 3, Glosa 4, No. 5, fol. 195, y De retract. convention. Párrafo 1 , glosa 2 , No. 58 y siguientes, tomo 3 , fol. 391 .

160.- Barbosa: en el Axioma 116, fol. 71 de sus Tratad. varios. Salgado: De regia protest., P. 1 , Cap. 7 , No. 65 hasta 68 , fol. 125 .

161.- Valenzuela: Concil. 4, No. 70 , hasta 77 , tomo 1., fol. 31.

162. - Salgado: Ubi proxime. García: De beneficiis; P. 10, Cap. 2, tomo 2, fol. 21 , No. 17 y siguientes.

163. - En Indias se deben proveer los beneficios, dentro de cuatro meses, por las leyes 35 y 48 , título 6 , y ley 16 , título 13 , libro $1^{\circ}$ de la recopilación.

164.- Leyes 2, 11, 12, título 7, Partida 3; Ley 12, título 23 mism. Partida. Ley 37 , título 11 , Partida 5 , Lcy 5 , título 9 , I’artida 4 . Ordenanza 8 , título $1^{\circ}$, libro $3^{\circ}$ del Perú.

165. - Sabelli: Párrafo Impedimentum, No. 2 al fin, tomo 2, fol, 318. Solórzano: in Política: libro 3, Cap. 27 , Nos. 32 y 33 , tomo $1^{\circ}$, fol. 387 , Valenzuela: Concil. 184, articulo 2, No. 38 hasta 42 , fol, 451 .

166.-Gamboa: Cap. 5, No. 18 y siguientes, fol. 108 .

167. - Cap. Damnum 86, De regulis juris, in $6 \mathrm{~L}$. quod quis 203, Párrafo De regulis juris.

168. - Ley 22, título 34, Partida 7".

169.- Sabelli: Ymposibilitas; No. 2, tomo 2, fol. 319. Velasco: De privilegis paupertum. $P$. 1, cuest. 54, fol. 215. Cobarrubias: In Epitome de Sponsalibus; 2" P. Cap. 3, Párrafo 5 , No. 7 , tomo 1 , fol, 183 ; y libro 3 var, Cap. 3 , No. 8 , vers. 7 , tomo $2 "$, fol. 345 .

170.- Solórzano: De jure indian.; libro 2, Cap. 25, desde el No. 70 , tomo 2, fol. 443; con muchos autores de grande nota.

171.- Tiraquelo: De retract. convention.: Párrafo 1, glosa 2, No. 67, tomo 3, fol. 992.

172.- - Puede verse en los alfabetos de Castejón y Sabelli.

173. - Solórzano: De jure indiarum; libro 2, Cap. 25, No. 65, tomo 2, fol. 442.

174.- Gómez: in ley 61, No. 5, fol. 638 .

175.- Cortiada: Decisn, 17, No. 46, tomo $1^{0}$, fol. 177, con Graciane, Cancerio y otros muchos Doctores. Valenzuela: Concil. 4, No. 78, es de la misma opinión.

176.- Gregorio López: en la ley 11, título 7, Partida $3{ }^{4}$, glosa 11.

177. - Bartholo: in L. Qui comeatus; Párrafo De re militari.

178. - Cap. Quia propter, 42, Párrafo Illud autem de clection; título 6, libro $1^{\circ}$; et ibi Barbosa, No. 38, Cap. Statutum de reseriptis, in 6, et ibi glosa: verbo prop. juramento; Cap. 1 , párrafo 22 ; cuest. 1.

179.- Juan Andrés: in Cap. I De Dolo et conturn in 6. Guido Papa, q. 64. Vancio: 
De nulit ex defect jus orden., No. 166 , in fine.

180.- Gregorio López: in Jey 11, título 7 , Partida $3^{\mathrm{a}}$, glosa 7.

181.- Bartholo: in Concil. 72. Rebufo: in 'T ractat de excusationib. No. 66, tomo 39. Supercontitut leg. Sebastian.

182.- Artículo 4, título 6.

183.- Artículo 4, título 6 .

184.- Artículo 5, título 6 .

185.-- Artículo 5, título 6.

186.- Molina: De primogenits; libro 3, Cap. 4, Nos. 43 y 44, fol. 407 ; y en al libro 3, Cap. 13 , No. 23, fol. 475.

187. - Libro 3 , Cap. 13 , No. 9 , fol. 474.

188. - Ibidem, No. 10 y siguientes. Pichardo: título i5 De Interdictus, libro 4, Párrafo Summa autem, 1", No. 30, tomo 2, fol, 630. Salgado: De regia protect.; P. 2, Cap. 7, No. 88, fol. $219 ;$ y 1.3 , Cap. 12, No. 84, fol. 452.

189. - Artículo 20, título 3 de México.

190.- Paz: De tenuta tractad, 1, Cap. 31 desde el No. 14, fol. 101. Salgado: De regia protect.; P. 2, Cap. 12, desde el No, 10 hasta 27 , fol. 447 . Villadiego: Cap. 8 de su Polit., No, 91, Vers. Y advierta, fol. 381.

191.- Villadiego, en el lugar citado. Bolaños, en la Curia filipp. 1." J.' Párrafo 14, Nos. $3 \mathrm{y}$ 4. Fermosino, en el Cap. Dilecti 0 De judicio; Q. 17, No. 27, tomo 4, fol. 139.

192.- Paz: Do Tenut. 1" P., (ap. 31, No. 35, fol. 102, y en ol Cap. 15, No. 11, fol. 55.

193.- Rodríguez: De posesione mixte, Cap. 5, No. 41, fol, 89 .

194.- Paz, De 'lenut. Cap. 64, No. 7. Rodríguez: De posesione mixte, Cap. 11, No. 11, tiol. 111 .

195.- Paz, Cap. 24, No. 2, fol. 74.

196.- Paz, De Terut, tract. 1, Cap. 22, No. 17 hasta 26, fol. 73, al No. 35 y siguientes, admite la doctrina de Molina, por equidad, y refiere que conforme a ella ha jurgado el Supremo Consejo alguna vez. Con todo se debe guardar la Ordenanza nueva de minería.

197.-Fermosino, in Cap. $1^{\circ}$ De Dilationibus; Q. 5*, No. 12 al fin, tomo 5", fol. 246.

198.- Pax: In Praxi. tomo 1", Part. 1, tomo 8, No. 30, fol. 88.

199.- Rodríguez: De ordinarid. proces.; Cap. 7, Nos. 23, 26 y 28.

200.- Real Ordenanza de 19 de mar\%o de 1756, copiada por Don José Portuguez, en el tomo $5^{p}$ de la Colección general de Ordenanzas; fol. 564.

201.- Paz, De Tenut. tract. 1, Cap, 15, Nos. 11 y 12, fol. 55. Molina: De primoseniis, libro 3, Cap. 13, Nos. 17, 18 y 19, fol. 474. Salgado: De regia protect.; P. 3, Cap. 12, No. 67 y siguientes, fol. 450 .

202.-. Artjeulo 12, título 3 .

203.- Scacia: De apelationibus; q. 17, limit. 6, memblo. 3, No. 26, fol. 300.

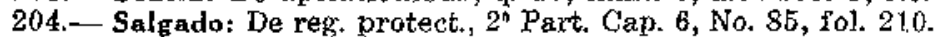

205.- Paz, De Tenut. tract. 2, Cap. 41, No. 4 y siguientes, fol. 171.

206.- Leg. nullo cod. De revindicatione.

207.- Paz: en el lugar citado, No. 7. El mismo en la Ley 1" del Estilo; Escol. 2*, No. 36, fol. 40. Vimnio: in I’árralo Xursus 5, De action. Libro 4, título 6, a No. 5 , tomo 2 , fol. 344 .

208.- Gregorio López: en la ley 37, título 1.1, Partida 5, glosa 4.

209.- Ordenanza 1*, título 7, libro $3^{*}$. Ordenanza $1^{*}$, título 5 , del mismo libro.

210.- Artículo 4, título 6.

211.- Ordenanza 2, título 7 , jibro $3^{\circ}$.

212.- Articulo 8", título 6.

213.- Ordenanzas 1 y 2 , título 7 , libro $3^{\circ}$.

214.- Las Ordenanzas 21 y 22 , título $1^{\circ}$, libro $3^{\circ}$ del Perú, previenen esta contribución.

215.- Gamboa: en su Comentar. Cap. 16, No. 4, fol. 313, expone la causa por qué la Ordenanza previene el uhonde de las minas.

216.- Ordenanza 1, título 5, libro 3". Estos pozos que se llaman boca-mejoras, para alumbrar la veta $\mathrm{y}$ trabajarla con más comodidad y provecho, no se pueden abrir sin licencia del $J u e \%$ de Minas y asistencia del Veedor o facultativo, como Io indica la Ordenanza citada y lo cnseña Gamboa, Cap, 13, desde el No. 4 y siguientes, fol. 276 .

217:- Ordenanza 6, título 4, libro $3^{9}$ del Perú.

218. - Ordenanza 7, título 4, libro $3^{\circ}$ del P'erú. 
219.- Artículo 17, título 8.

220.-- Ordenanza 8, título 8, libro 39 del Perú.

221.- En el Perú se entiende con uno de los Alcaldes Veedores, hasta que hayan peritos facultativos.

222.- Por el artículo 4, título 6, se debe tomar razón de todo esto y añadirse la correspondiente partida de registro, con las demás diligencias đe posesión, medidas y estacas, entregándose a la parte una copia autorizada de ellas, como título bastante.

223.- Gamboa: en su Comentario, Cap. 8, No. 11, fol. 187.

224.-Gamboa: en su Comentario, Cap. 16, No. 11, fol. 316 , y en los Nos. 9 y 10 , refiere tres casos fortuitos gue pueden impedir el ahonde.

225.- Gamboa: Cap. 16, No. 5, fol. 114.

226.-Artículo 3, título 8.

227.-Artículos 4 y 8 , titulo $6^{\circ}$.

228.- Cap. 13 , No. 12 , fol. 280.

229.- Artículos 4 y 8 , título $6^{\circ}$ de la Ordenanza de México.

230 .- Ordenanzas $13,14,16$ y 17 , título $1^{\circ}$, libro $3^{\circ}$ del Perú.

231.- Escalona, in Gazophil., libro 2, Part. 2, Cap. $1^{\circ}$.- Verb. mins de S. M., No. 2, fol. 99. - Montesinos: in Polit. de Min., Cap. 22, No. 2, fol. 151, vlta.

232.- Articulo 2, título 8.

233. - Articulo 4, título 8.

234.- Artículo 7, título 8.

235.- Artículo 8, título 8.

236.- Por todas estas consideraciones, creen algunos deberse reducir las medidas gereralmente a 150 varas de longitud y 75 de ancho; pero siempre rivedan en pie los inconvenientes que tiró a evitar el Sr. Toledo, acortando las pertenencias a 60 varas de largo y 30 de anchura, por el conocirniento práctico que tenía de la situación y figura de las vetas de estos mincrales.

237. - Gamboa escribió doctamente sobre medidas, en todo el Cap. 12 de su Comentario, fol. 231.

238.- Artículo 6 hasta 9, título 8.

239.- Artículo 6, título 8 .

240.- Artículo 8, título 8.

241.- Artículo 7, título 8.

242.- Reduciendo todas las medidas a 150 varas de largo y 75 de ancho, como se dijo en este misino artículo y párrufo, sin distinguir las vetas perpendiculares de las inclinadas o de recuesto, ni urreglar en estas la mensura según lo echado a proporción del retiro del plomo, contemplo dificil hacer una medida sin pleitos; y lo más es, que no logran igual beneficio tndos los vasallos, porqne cuando alguno gozaice de todas las riquezas de una veta perpendicular por la naturaleza de su situación, otro perderá una mitad de saca en las manteadas, porque con el recuesto de ellas a pertenencia ajena, se quedará sin tener qué disfrutar después de los mayores costos que haya impendido en los trabajos por chiflón; pues, no es difícil que al cabo de las 75 varıs, venga en menor riqueza la veta y entonces queda tnútil el trabajo preparado, para que el vecino se haga rico.

243.- Artículo 10, título 8.

244.- Artículo 10, título 8. Según Ordenanzá se debe dar cuenta al Tribunal; pero como aquí no entiende en lo gubernativo sino el Superintendente, debe entenderse con él y no con otro, la disposición citada.

245.- Artículo 11, título 8.

246.-- Esto es lo que la Ordenanza 4, título 4, libro $3^{n}$, llama anojonar las cuadras, después de haber estacado las vetas por lo largo.

247.-Gamboa: Cap. 8, No. 11; Cap.9, No, 19 y Cap. 12, No. 4, habla de la estaca. fija y dice que es propiamente sólo la boca en que se registró la veta.

248. - Vide Gamboa, Cap. 9, Nos. 20 \& 21, fol. 205.

249.- Ordenanza 1, título 3 , libro $3^{\circ}$ del Perú.

250.- Desde la estaca fija se pueden tomar al rumbo que se quiera todas las varas de Ordenanza o su mitad; por eso es menester que conste en cuántas varas se estac $\delta$ por lo largo.

251.- En este método se debe practicar los artículos 4 y 8 , título 6 de México.

252.- - Ordenanza 2, título 3 , libro $3^{\circ}$ del Perú.

253.- Ordenanza 2 al fín, título 3 , libro $3^{\circ}$ del Perú, 
254.- Artículo 10, tílulo 9.

255. - Ordenanzas $2^{*}$ y $33^{\circ}$, título 3 , libro $3^{\circ}$.

256.-- Esto es, aurque sca ajena la mina, porque si se incurre en pena de perdimiento, se ejecuta en su estimación, según la Ordenanza 5 , lítulo 12, libro $3^{\circ}$.

257.- Ordenanza 3, título 3, Jibro $3^{\circ}$.

258.- Gregorio López: en la ley 30, título 14, Partida 7, glosa verb, 50 mrs.

259.- Ordenanza 20 al fin, título $1^{\circ}$, libro $3^{\circ}$.

$260 .-$ Ordenanza 23 al fin, título $1^{6}$, libro $3 \%$.

261.- Vide el Articulo 4\%, Noticia VIII, Cap. VIII de esta Yarte Segunda, Pág. 704, donde se citan las Ordenanzas del Peru y de México y la diferencia que tienen entre sí, en cuanto a pozos.

262,- Artículo 10 , título 6 de México.

263.- Ordenanza 1 , titulo 7 , libro $3 \%$. Lo mismo se debe practicar cuajdo el pozo no pasare de la hondura de cuatro estados, porque entonces se supone la veta virgen y bastu la vista de ojos le sólo el Juez de Minis, sin otra averiguación, para darla por despoblada, scgún la Ordenanza $5^{*}$ al fin, título 7 , libro $3^{\circ}$.

264.- I á Ordenanza 14, título 7 , libro 3" del Perú, dispone que, no teniendo más de dos estados de hondo la mina que se poseyere por cualesquiera títulos, se adjadique a quien la pidiese, sin más averiguación que la vista de ojos del Juez; lo cual entiende Montesinos en su Política de Minería, Cap. 14, No. 16, fol. 96, despuŕs de que se haya pasado el término legal en que se debe abrir el pozo.

265.- Artículo 8, título 6 de México. Según esta Ordenanza, no es menester abrir pozo nuevo y basta habiliter el antiguo o alguna otra labor que tenga diez varas de hondura a lo menos. Tero si se hubiere decretado el despueble, por falta de pozo, es preciso abrirlo, con la profundidad de las diez varas, enten. díndose lo primero con las minas abandonadas, después de dado el pozo.

266. - Las Ordenanzas: 1 y 2 , título 7 , libro $3^{\circ}$, califican la diferencia de pedir en distinta profundidad en unas minas que en otras.

267.- Gamboa: Cap. 16, No. 14, fol. 317 .

268.- Artículo 8, título 6, y Ordenanza 2, título 7, libro $3^{\circ}$ citado.

269.- Ordenanza 13 , título 7 , libro $3^{\circ}$ del Perú.

270 - Artículo 10 , título 6.

271.- Gamboa: Cap. 16, No. 10, fol. 315 .

272 . - Artículo 10, título 6 .

273. - Artículo 15, título 9.

274.-Artículos 5 y 8 , título 6.

275.- Artículo 4 al fin, título 9.

276. - Artículos 5,8 y 10 al fin, título 6 .

277. - Vide el Apéndice a $\operatorname{los}$ artículos $1^{\text {\% }}$ y $2^{\circ}$ de la sección $1^{4}$, Noticia 7, Cap. 8, Pág. 675 y artículo $3^{\circ}$ id, Pág. 689 de esta Parte Segunda.

278. - Artículo 13, título 9. La Ordenanza 3, título 7 , libro $3^{\circ}$ del Perá, pide 8 indios o 4 negros para el pueble; pero se ha mandado guardar el número determinado en la Ordenanza de México.

279. - Ordenanza 3, título 7, libro $3^{\circ}$; Ordenanza 5, título 11 del mismo libro.

280.- Vide Gamboa, Cap. 17, No. 4, fol. 326.

281.- Ordenanza 6, título 7, líbro $3^{\circ}$ del Perú.

282.- Tiraquelo: De retract. Convention. Párrafo 2, glosa 1, No. 66, tomo $3^{\circ}$, fol. 421.

283.- Ordenanza 3 al principio y Ordenanza 5 al fin, título 7, libro $3^{\circ}$.

284. - Fn su Ordenanza 19 , recopilada en la 5 , título 7 , libro $3^{\circ}$ del Perá.

285.- Título 4, libro $3^{\circ}$, No. 22 . De esta Adición de Lupidana se deduce, que aunque la mina en que se trae labor no sea rica (que es cuando rinde 2 marcos por quintal), se amparan las demás minas; y asi la disposición de la Ordenanza 10 , título 7 , libro $3^{\circ}$ del Perí, se debe entender según la Adición citada; pues de lo contrario, casi ninguno pudiera poseer arriba de dos minas, por la imposibilidad que hay en estos países para poblarlas, y quedaría sin efecto la libertad que concede este nuevo sistema para poseer muchas minas en una o diferentes vetas; por lo que se debe guardar la Adición de Lupidana, declarando por ella todas las ordenanzas que hablan de amparo de minas.

286. - Ordenanza 1, titulo 7, Libro $3^{\circ}$.

$287 .-$ Ordenanza 5 al fin, título 7 , Libro $3^{\circ}$.

288. - Ordenanza 12, título $\mathrm{i}$, Libro $3^{\circ}$. 
289.- Ordenanza 18, Caps. 2 y 3 , título 7 , libro $3^{\circ}$.

290.- Gamboa: Cap. 17, No. 4 y siguientes, fol. 326 .

291. - Ordenanza 3, título 7 , libro $3^{\circ}$.

292.- - Ordenanza 4, título 7 , libro $3^{\circ}$.

293.- Ordenanza 18 , Caps. $1^{\circ}$ y $3^{\circ}$, título 7 , libro $3^{\circ}$.

294.- Ley 5, Cap. 40; Ley 9, Cap. 37, título 13 , libro $2^{9}$ de Castilla. Vide Gamboa: Cap. 11 y siguientes, fol. 330 .

295.- Gamboa: Cap. 17, No. 13 .

296.- Luca, tomo 15, De judiciss; disc. 35.

297.-- Solórzano: in Polit.; libro 3", Cap. 27, No. 24, tomo $1^{7}$, fol. 385.- Antúnez: De donationibus, libro $2^{\circ}$, Cap. 29.

298.- Garcia: De Beneficii; 13. II, Cap. 10, Nos. 23 y 36, tomo 2, fol. 377,- Gonzáleż: in Reg. 8 Carcell.; glosa 56 , Nos. 29 y 43 , fol. 501 .

299.- Solórzano: in Polit., libro 3", Cap. 27, Nos. 24 y 25, tomo 1, fol. 385.- Antúnez: de Donationib. libro $2^{\prime \prime}$, Cap. 29, No. 49 hasta 52 , tomo $1^{\circ}$, fol. 340.

300.- Tanto vale la privación ipso jure, como jpso facto, según Barbosa, en la Dic. 178 de Trat. var., fol. 576 .

301.- Artículo 14 , títujo 9.

302.-González: in Reg. 8, Carcell., glosa 56, No. 97, fol. 505.

303.- González: id, No. 48 , fol. 502.

$304 .-$ Id, id, No. 52 hasta 108, fol. 102 hasta 105.

305.- Id, id, No. 43, fol, 501 .

306.- Tiraquelo: in Verbo revertatur de revoc. donationibus, No. 273 , tomo 6, fol. 245 ; y en la misma glosa, No. 10, tomo 6, fol. 208.

307.- L. Si unquam codic. de revert. donationibus.

308. - Ley 28, título 8, Partida 5, glosa 16 hasta 20.

309.- Artículo 12, título 6.

310.- Tiraquelo: in glosa Revertatur; No. 190 , tomo 6, fol. 247.

311. - También son denunciables los ingenios desamparados, los terrenos junto con las minas, en la forma dispuesta por los artículos 16,19 y 20 , título 6 ; Ordenanzas 1 y 2 , título 10 ; Ordenanza 22 , título 11 , libro $3^{\circ}$ del Perú.

312.- Ordenanzas 9 y 6 , título 7 , libro $3^{\circ}$.

313.- Ordenanza 9 al fin, título 7 , libro $3^{\circ}$; y Ordenanza 9 , título 11 , libro $3^{\circ}$ del Perú.

314. - Parte Segunda, Cap. 8, Noticia 7*, l’ágs. 696 y 697 de esta obra.

315.- - Artículo 14, título 9.

316.-- Gamboa: Cap. 17, No. 17 y siguientes, fol. 333.

317 .- Vide los casos referidos en la Parte Scgunda, Cap. $8^{\circ}$, Noticia 7', P'ág. 697 de esta obra.

318. - Cap. Quja diversitatem, 5 De concesn. prebende; título 8, libro $3^{9}$. Decret. concuerda la ley 8 , título 16 , Partida $1^{*}$.

319.- Fagnano: in Cap. citado, Nos. 7 y 8, tomo 2, fol. 192.

320.- Fagnano: Ibid, in Nulla, 2 cod., título No. 33 , tomo $3^{\circ}$, fol. 184.

321. - Gonzálex Téllez: in Cap. Quia diversitatem $5^{\text {n }}$ De conces. prebende, No. 7, tomo 3, fol. 134.

322.- Salgado: De retent. Cap, 9, partida $\mathbf{1}^{4}$, desde el No. 13 y siguientes, fol. 108.

323. - Salyado: De retent. P. 1, Cap. 9, No. 62, fol. 114.

324.-Gamboa: Cap. 17, No. 17 y siguientes, fol. 333.

325. - Fagnano, González y todos los demás, en el Cap. $5^{4}$ de Conces. prebende.

326.- Crespi: Observaciones Nos. 1 y 2.

327.- Matienzo: in ley 8, título 11 , libro $5^{\circ}$, glosa 9, No. 4, fol. 378.

328.- Artículo 14, titulo $9^{9}$.

329.- La $1^{4}$. Exquib, causa major. Glosa in L. Conimeatur. Párrafo De re militari.

330.- Cancerio: Parte $3^{\circ}$, Cap. 13 , No. 29 hasta 34 , fol. 145.

331. - La pobreza se prueba pox la fama y común opinión muy suficiente, según cardl. concil. 77 , No. 6.- Bartholo: in Si const. in princip.; in $2^{2}$ q. Párrafo Soluto matrim.-.- Vide Villadiego, sobre el remedio decisivo en la forma de liberar; No. 64 y siguientes, fol. 370 .

332.- Gambon: Cap. 17, No, 24, fol, 336.

333 . - Per regulam in L final, párrafo De Eo perquem, fact. crit., L. plane $2^{*}$, Párrafo $1^{\circ}$. De legatis $1^{\circ}$.

334.- Gamboa: Cap. 17, No. 21.

335.- Gamboa: en todo el Cap. 18 de su Comentario. 
336.- Artículo 8, título 6 de México.

$337 .-$ Ordenanzá 3 y 17 , título 7 ; Ordenanza 14, título 9, libro $3^{\circ}$ del Perú. Ley 19 , título 21, libro 4 de Castilla.

338.- Ley 15 , título 21 , fibro $4^{\circ}$ de Cescilla. Ley 1, título 7 , Paridia 3.- Vide Carlev.: De judiciin, título 8, disp. $1^{\mathrm{n}}$, Nos. 28 y 29 , fol. 66.

339... Ordenanza 18, Cap. 1", título 7 , libro $3^{\prime}$ del Perú. Ordenanza 14, título 9 , libro $3^{\circ}$ al fin.

340.- Ley 12, título 2, Partida $3^{3}$.

341.-- Altículo 8, título $6^{v}$.

342 - Artículo 5, tílulo $6^{4}$.

343.-.. l'arte 27, Cap. 8, Noticia 7, Párrafo 9, Sec. 1", Articulo 3, en la resolución

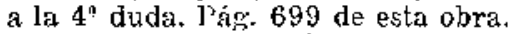

344.- - Ibid en la $3^{\mathrm{A}}$ resolución al tratar la cuarta duda. Pág. 701.

345. - 1bid, en la ‘a resolución. Pág. 702.

346 . - Ley 7 , título 6, libro $4^{\text {? }}$.

347.- Cap. Ciun cans. 37 , de Testibus.

348.- Paz: In praxi; tomo $1, \mathrm{H}$. 1 , temp. 8, No. 14 , fol. 87 .

349.- Cap. Accipinius 4, De fide instrumentum.

35 (1. Ley 32 , título $16, \mathrm{l}^{2}$. 3.

$351 .-$ in Ure duormit.

$352 . \cdots$ Artículos 4 y 8 , titulo $6^{\circ}$.

353.-- Gamboa: Cap. 18, No. 3, fol. 344.

354.- La justificación se debe dar dentro de los mismos 60 días.

355.- Articulo 4, titulo 6 .

356.- Parte Segunda, Cap. 8, Noticia 7, Párrafo 9, sección 1", articulo 5. Pág. 705 de esta obrid.

357.- For la Ordenanza 17 , título 7, libro $3^{\circ}$ del l'erú, se deben recibir las causas de despoblados, a prueba, annque no haya contradicción.

358.- Gamboa: Cap. 18, No. 3, fol. 334.

359 - Ordenanza 17 , titulo 7 , libro $33^{\circ}$ del I'erú.

360.- Parte Segundil, Cap. 8", Noticia $7^{*}$, I'arrafo 9, sección $1^{8}$, articulo 3, desde la resolución $1 "$ y siguientes a la $4 *$ duda. l'ág. 699 de esta obra.

361.- Artículo 9, tílulo 6 .

362.-- Iux úmica. I’úrafo Nihil innovari apelation interposit.

363.- Cap. 1 ${ }^{\circ}$, Ut lite penderite. Juan Menacho, in Cap. Cupientes 138. De election. in $6^{\circ}$.

364.- Artículos 5 y 8 , títuio 6 .

365.-Cancerio: P. 3, Cap. 13, No. 25, fol. 145.

366.-. Artículos 5 y 8 , título 6 cítado.

367.--Cancerio: P. 3, Cap. 13, No. 30, fol. 145.

868.-- Cap. 18, No. 8.

369.- Scacia: De apelatio.; q. 3, No. 31, fol. 12,-.. Castillo: Controvers.; tomo 8, libro $8^{4}$, Cap. 13, No. 23, pár. 93. Ley 1, título 9, Parti. 3".

$370 .-$ Concuerda con el título 9 de México.

371.- Ordenanza $1^{\circ}$, título $5^{\circ}$, libro $3^{\circ}$

372.- Ordenanza 45 de Gasca.

373,- Ordenanza 11, del Virrey Marqués de Cañete.

374.- Ordenanzas 2 y 3 , título 5 , libro $3^{\circ}$. Artículo 7 , título 9 de México.

375 .- Parte Segunda, Cap. $8^{\circ}$, Noticia $6^{\mathrm{s}}$, Párrafos $1^{\circ}$ y $2^{\circ}$. Págs. 635 y 637 de esta obra.

376.- Artículo 2, título 9.

377.- Artículo 6, título 9. La prohibición de cercenar que impone el artículo 7, siguiente, se entiende, sin autoridad del Juez de Minas y aprobación del facultativo. Jero concurriendo su permiso, se debe guardar el artículo 6 citado.

378.- Artículo 11, título 9,

379.- Ordenanza 9, de la Cása de Moneda.

380.- Ordenanzas 14, 19 y 20 , título 17 , libro $3^{\circ}$ del Perú.

381.- Ordénanza 3, título 17, libro $3^{\circ}$ del Perú.

882.- Artículo 16, título 10.

383.- Ordenanza 18, Cap. 3 , título 7 , libro $3^{\circ}$.

384.- Ordenanza 18 , título 7 , libro $3^{\circ}$.

385.- Artículo 16 , títufo 10 citado.

386.- Ordenanzas 6 hasta 9 , título 7 , libro $3^{\circ}$ del Perú; y todo el título 11, de la Ordenanza de México. 
387.- Así se colige de la Ordenanza 9, título 7, libro $3^{\circ}$.

388. - Articulo 4, título 11.

389 - Artículo 5, título 11 .

390.- Parte Segunda, Cap. 8\%, Noticia 6, Párxafo 2, en las obligs. 21 y 26. Págs. 635, 640 y 641 de esta obra.

391.- Ley 3, título 31, Partida $3{ }^{\circ}$.

392.- Castillo: De usufruct.; libro $1^{\circ}$, Cap, 49, No, 17, tomo $1^{\circ}$, fol. 192

393.- Ordenanza 1 , título 6 ; Ordenanza 10, título 8 , libro $3^{\circ}$ del Perú.

394.- Artículo 10, titulo 2, de México.

395.-. Artículo 3, título 10:

396.- Ordenanza 10, título 8, libro $3^{\circ}$.

397.- Ordenanza $1^{*}$, título 8 , libro $3^{\circ}$ del 1'erú; título 10 de México.

398.- Título 8, libro $3^{\circ}$ del F'erú; título 10 de México.

399.- Ordenanza 2, título 8, libro $3^{4}$.

400.- Artículo 8, título 10.

401.- En la Noticja Tercera, que trata de la autoridad del Superintendente. Pág. 608 de esta obra.

402,-- Ordenanza $5^{\circ}$, título 4 , libro $3^{\circ}$.

403.- Laert: en la Descripción de las Indias Occidentales; libro 11, Cap. 3, No. 50, fol. 464 .

404-- Rivadineira, en su Pasatíempo; canto $3^{\prime \prime}$, época 3 , tomó 1 , letra $Z$; año de 1759 ; fol. 52 .

405. - Laert: loco citato.

406.- Ordenanza 5, título 11, libro $3^{9}$ del Perú; y la Actición de Lupidana, título 14, No. 17.

407. - En tres años no he determinado arriba de diez pleitos de minas, ni he visto alguno que importe 500 pesos.

408. - El fundamento principal de haberse propuesto no dar sueldo a los Jueces del Tribunal de Potosí, es porque sólo entienden en lo contenciosor, respecto de negárseles por ígual razón a los Diputados territoriales, en el artículo 15, título 2.

409. - Donde no se eligiesen más que dos Diputados, según la facultad que concede el artículo 2, título $1^{4}$ de la Ordenanza de Mćxico, se compondrá el Tribunal de sólo tres: a saber, los dos Diputados y el Administrador, todos tres de precisa asistencia.

410.- Artículo $1^{\circ}$, título 4.

411.- Artículo 12, título 1".

412.- Ley 27, título 46, libro 9* de Indias.

413. - Se dicen más antiguos los que en la elección sacaren mayor número de votos, segûn el artículo 9 , título 2 .

414.- Artículo 15, título $1^{1}$.

415.- Artículo 8, título 2 ; artículo 4, título 3.

416.- El Subdelegado concurre, según el plan que se propuso por este Gobierno de Potosi, para evitar pasiones tan frecuentes en las chacras.

417.- Artículo 9 , título 2 ; astículo 13 al fin, título $3^{\circ}$.

418. - Artículo $1^{\circ}$ al fin, título $4^{\circ}$.

419. - Vide la nota inmediata al No. 3 .

420.- Artículo 17, título 3.

421.-. Artículo 17 citado, título 3.

422.- Artículo 13, título 3, y la declaración 24, de las hechas en Lima.

423.- - Se deben guardar con estos el orden de antigüedad prevenido para los consultores en el artículo $9^{\circ}$, título $2^{\circ}$.

424.-- Artículo 9, título 2 ; artículo 13, título 3 .

425.- Articulo 17, título 3; artículo 4.

426.- Artículo 17 al fin, título $3^{\circ}$.

427. - Vide Carrasco: De causis recusationes; No, 3, fol. 174.-. Solórzano: in Polit., libro 5\%, Cap. 6, No. 15, tomo 2, fol. 303; libro 5\%, Cap. 18, No. 10. fol. 417. Libro 5, Cap. 10, No. 38 , fol. 349 .

428.-. Artículo 2, título 4.

429.- Artículo 3, título 4.

430.- Leyes 32 y 33 , título 46 , ibro $9^{\circ}$ de Indias; Ordenanza 16, título 42, libro $1^{\circ}$ del Perú.

431.- Artfeulo 5, título 3 . 
432.- Parte Segunda, Can. 8". Noticia 6" Párrafo 3․ Pág. 641, de esta obra.

433.-Artículo 5, titulo 3.

434.- Isey 1 , título 10 , libro $5^{\circ}$ de lndias.

435.- Autentic. nisi brevis codice de sententits expericulo resitandis; libro $7^{\circ}$, título $44 ; y$ la Autêntica De mandatis principum; Párrafo Sit tibi colatione 3 , título 4, Constit. 17.

436.- Ley 6, título 22, P. 3; y allí Gregorio López, glosa 19.

$437 .-$ Avendaño: De secuendis mandatis; $2^{*}$ Part. Cap. 16, No. 23.

438. - Artículo 5 citado, título 3.

439.- Carrasco: Tratado $2{ }^{\circ}$, Anhabeat locun restitutio contra sententiam revitionis; Nos. 33 y 48 , fols. 50 y 53.

440.- Ibid.

441.- Id, loco citato.

442.- Valenzuela: Concil. 77, No. 47, tomo 14, fol. 455; y Concil, 78, No. 45, fol 460.

443.- Acevedo: en la ley 19, título 9, libro $3^{\circ}$ de Castilla; No. 3, tomo $1^{\circ}$, fol. 293.

444.- Diego Pérez: en la rúbrica del título $1^{\circ}$, libro 3 del Ordenamiento Real; vers. Esto quest quotidiana; colum. $1^{4}$, tomo $1^{*}$, fol, 437 de la impres. de Madrid, año de 1779 .

$445 .-$ Id, No. 10.

446.- Artículos 29 y 30 , título 3".

447.- Artículo 5", título $3^{*}$.

448.- Artículo 6, título 3.

449.- Parte Segurda, Cap. 8, Noticia 7*, Párrafo $9^{\circ}$, Pág. 661 de esta obra.

450. - Paz: De tenut. Trat. 1", Cap. 31, desde el No. 14, fol. 101. Salgado: De Regia protectione, Partida $3^{*}$, Cap. 12, desde el No. 10 hasta 27, fol. 447.-Villadiego: Cap. 8 de su Polít., No. 91, vers. 7, fol. 331.

451.- Cur. Philip. P. 1, Párrafo 14, Nos, 3 y 4.- Fermosino: en el Cap. Dilecti. 6 De judiciis; Q. 17, desde el No. 27 , tomo 4, fol. 133 .

452,- Artículo 22, título 3 .

453.- Artículo $2^{\circ}$, título $3^{\circ}$.

454.-. Parte Segunda, Cap. $8^{*}$, Noticia $7^{*}$. Sección Primera, artículo $3^{\circ}$ sobre la $4^{*}$ duda, fol. 699 de esta obra.

455.- Artículo 21, título $3^{\circ}$.

456.- Artículo 26, título $3^{\circ}$. Ordenanza 6, título 15.

457.- Artículo 11, título 11 .

458.- Párrafo Solvitur, $5^{*}$, Institut de societat, título 26 , libro $3^{\circ}$; Ley 10, título 10 , Parte 5.- Vide Sousa: De regulis juriis; P. 4, articulo 7, No. 56, fol. 218.

459. - Ley 1 , título 10; Partd. 5'.

460.- Vide Sabelli: De societat, No. 24.n- Oloa: título 3, Q. 5, per totum, Casa regis del coment.; Disc. 144, Nos. 6 y 26 ; y Disc. 145, No. 20.- Estéfano: Tratad. De principiis regulis juris; libro $2^{\circ}$, Cap. 77 , No. 3. - Oñate: De contrat.; tomo 4, tratad. 28 , dispsc. 100 , Párrafo 1 , Nos. 6 y 12, fol. 63.- Vide Gamboa: Cap. 7, No. 37.

461.- Artículos 10 y 11, título 11.

462.- Hermosilla: en la ley 55 , título $5^{\circ}$, glosa 4, P. 5, No. 12, fol. 645 .

463.- Las leyes del título 10, Partd. 5,- Sousa: De regulis juris; part. 4, artícu. lo $7 "$ per totum, desde el No. 54, fol. 218.

464.- Olea: Cesion, título 3, Q. 5, No. 1 hasta 5, fol. 108.

$465 .-$ Id, No. 15 hasta 17.

466.- Ley 11, título 10 , Partd. 5.

467.-- Artículos 7 y 13, título 3 .

468. - Artículo 12, título 3.

469. - Artículo 15, título 3.

470.- Ley 1 , título 18 , libro $4^{\circ}$, de Castilla.

471. - Ley 1 , título 19 , libro $4^{\circ}$ citado.

472.- Acevedo, en la ley 1 , título 18 , libro $4^{\circ}$, No. 49 , tomo 2 , fol. 435 .

473.- Tomo 5\%, pág. 564 .

474.- Axtículo 15, título 3.

475 . - Parte Segunda, Cap. $8^{\circ}$, Noticia $7^{*}$, artículo $3^{\circ}$, en la $8^{\circ}$ resolución sobre la $4^{*}$ duda. Pág. 699 de esta obra.

476.-. Artículo 20, titulo 3\%.

477 .- Ordenanzas 4 y 5 , título 9 , libro $\mathfrak{z}^{\circ}$.

478.-2 Artículo 13, título $3^{\circ}$. 
479.- Scacia: De apelat.; Q. 16, limit. $1^{*}$ No. 29 , fol. 227 ; y No. 98 , fol. 233 ; et No. 105, vers. Declarac, 15, fol. 234.

480.- Artículos 17 y 18 , título $3^{3}$.

481.- Artíeulo 10, título 2, Jibro $4^{\circ}$ de los Acordados de Castilla.

482.- Elizondo: De pract. univers. forense; Juicio ordin.; tomo 1", fol. 253 hasta 255 , Nos, 1 y siguientes.

483.- Fermosino: Ad rubricam de Litis contestat.; $Q$. 13, Nos 4 y 5 , tomo 5 , fol. 114.

484, - Parte Segunda, Cap. $8^{\circ}$ Noticia $6^{n}$, arlículo único, P’árafo $3^{\circ}$, de los privilegios de los mineros. Pág. 641 de esta obra.

485.- Solórzano: in Polit. ; libro 5॰, Cap. 3, No. 16, tomo 2, fol. 272.

486.- Rodríguez: De ejecutione; Cap. 4, No. 2, per totuni. Parladorio: Rerum quotidjanorum, 4 P., Párrafo 1 , libro $2^{\circ}$, Nos. 1 y $2 . \cdots$... Fermosino: in Cap. Quia de judiciis. Q. 19 , Nos. 6 y 7 , tomo 4, fol. 277.

487.- Cirino: in Nexu rerum Eclesiastic.; Cap. 7, sección 4:, Nos. 134 y 143, fol. 735 hasta 743 .

488.-Cancerio: P. 2", Cap. 8, No. 75 , fol. 108 .

489.- Molina: De just. et jure; tomo 1", Tract. 2, Disp. 149; Allud y Párrafo De inde ; et tomo $2^{\nu}$, disp. 281 , Párrafo Dubium.- Sánchez y otros citados por Carleval: De Jud., título 1, Disp. 2, q. 4, Nos. 206 y 212. - Fermosino: De judiciis, tomo $44^{\wedge}$, fol. 319 , No. 16 ; et in Cup. $1^{\circ}$, De jure jurando, No. 56 , tomo 6 , fol. 216 .

490.- Gutiérrez: in Autem sacram puber, No. 96.- Bobadilla, in Polit., Jibro 2", Caip. 17, No. 52; y Cap. 18, No. 173.-.-Larrea: Alegat. 119, No. 12, fol. 217.

491.-Guzmán: Veritat. 333.

492.- Avilez: in Cap. 11), l'retor plos execucion. No. uiltimo.- Gregorio López: in L. $1^{n}$, título 29, P. 3, glos. ] ; ley 14, título 2, libro $6^{\circ}$ de Castilla.- Gómez: $1^{8}$ variar, Cap. 11, No. 14.- Salgado: De retention, P. 1, Cap. 13, No. $33 \mathrm{y}$ sig'uientes.

493.- Ley 3, título 10; ley 7, título 23, libro 49 de Castilla; et ibi Acevedo, No. 11 y siguientes... - Ley 22, título 34, libro a" de Iraias. Libro 5, del título del libro Gutiérrez. Alleg. 12.- Gómez is var. No. 14.- Fermosino: Ad rubric. de secuest.; q. 1, título 15 , tomo $5^{2}$ fol. 628 .

494,- Ordenanza 1 , título 1 , libro $3^{\circ}$.

495. - Ordenanza 2, libro $3 "$ ".

496.- Ordenanza 2, título 3 , libro $3 \%$.

497.- Ordenanza 3 , título 3 , cod.

498.- Ordenanza 6, título 4, cod.

499.- Ordenanza 7 , título 4 , cod.

500. - Ordenanzas 4 y 5 , Tít. 5 .

501.- Ordenanza 9, título 5, cod.

502.- Ordenanza 12, título 5 , cod.

503.- Ordenanza 3, t5tulo 6, cod.

504.- - Ordenanza 11, título 7, cod.

505.- Ordenanza 2, título 8, cod.

506.- Ordenanza 9, título 8, cod.

507.- Ordenanza 12, título 8, cod.

508.- Ordenanzas 1 y 2 , Tít. 10.

509.- Ordenanza 10, título 9, cod.

510.- Ordenanza 12, título 9, cod.

511.- Ordenanza 15, título 9 , cod.

612.- Ordenanzas 3, 6 y 7 , Tít. 10.

513.- Ordenanza 4, título 10 , cod.

514.- Ordenanza 5, título 10, cod.

515.- Ordenanza 9, título 10, cod.

516. - Ordenanza 10, título 10 , cod.

517.- Ordenanza 11, título 10 , cod.

518.- Ordenanza 12, título 10, cod.

519.- Ordenanza 13, título 10, cod.

520.- Ordenanza 14, título 10, cod.

521.- Ordenanzas 15, 16 y 18, Tit. 10, cod-Guairas o guairachinas, eran unos hornos donde fundian el metal rico del cerro. En el día no se conocen en Potosí, por haber cesado la fundición de metales. N. de E. 
522.- Ordenanza 24, título 10, cod.

523.-- Ordenanzia 25, título 10 , cod.

524.- Ordenanza 26 , tílulo 10 , cod.

$525 .-$ Ordenanzas 27 y 30 , título 10 , cod.

526.-.- Ordenanzas 1 y 2 , título 11 , cod.

(a) Ckepiña: Especic de poncho ceñido a la cintura que sirye para cargar bultos a la espalda. $\mathbf{N}$. de $\mathbf{E}$.

527,- Ordenánza 11, título 3, cori.

528.-Ordenanza 4, titulo 11, cod. Y Ordenanza 14, titulo 11, cod.

529.- - Oxdenariza 5, título 11 , cod.

530. - Ordenanza 6, título 11, cod.

531.- Ordenanza 7 , título 11 , cod.

532.- O1denanza 8 , tilulo 11, cod.

533. - Ordenanza 11, titulo 11, cod.

534 - Oddenanza 12, titulo 11 , cod.

$5: 35$ - O Odenanza 17 , título 11 , cod.

536.-Orderianza 18, título 11, cod.

537.-- Ordenanza 20, título 11, cod.

$538 .-$ Ordenanza 21 , título 11 , cod.

539.- Oddenanza 3 , títu] o 12 , cod.

540 - Ondenanzas 4,5 y 6 , título 12 , cod.

541.- Ordenamzas 1,4 y 5 , título 13 , cod., y Ordenanzas 7 y 8 del mismo título y libro.

$542,-$ Ordonanza 10, titulo 13, cod.

$543,-1, c y$ if al lim, título 1 , liblo $6 \%$ de Indias-Gutiérrez: Del juramento confirnatorio; I'. 1* Can. 17 , desde el No. 24, pág. 86.- Cobarrubias: Varian. C.ap. 1", No. 8.-. Gregorio Lopez: en la ley 4, glosa $4^{*}$, título 15, Partida 54.

544,--- Salcedo a Bernardo Diaz, Cap. 142, No. 4, letra D., fol. 482 y 484 ; con Bacza, De inope debitore, Cap. 11, No. 3, fol. 166 vuelta.

545.- Orenanza 29, título 10 , liblo 39 .

$546 .-0)$ denanza 30 , título 10 , cod.

547.- Ordenanza 31 , título 16 , cod.

$548 .-$. Ordenanza 32 , titulo 10 , cod. Ordenanza 11, título 13 , cod.

549.- Ordenanza 1 , t.tulo 11 , cod.

550 . Ordenanza 6 , título 11 , cod.

551 ... Ordenanza 22, título 11 , cod. Vide sobre este punto la Noticia $3^{\circ}$, al fin, Cap. 8* de esta Parte Serunda, Ṕá. 608 de esta obra.

$552 .-$ Ordenanza 1 , título 12 .

$553 .-$ Ordenanza 3 , título 12 , cod.

554. - Ordenankis 4, 5, y 6, título 12 , cod.

555 . - Ordenanza 8, título 12 , cod.

556.- Ley 30 , título 12 , libro $6^{\circ}$ de Indias.

557.-- Ordenanza 33, título 10, libro $3^{\circ}$ del Perú.

558.- Ordenanza 14, título 13, libro $3^{\circ}$.

559.- Ordenanzas 12 y 14 , título 13 , libro $3^{\circ}$ del Perú.

$560 .-$ Ordenanza 28 , título 10 , libro $3^{\circ}$.

561 - Ordenarza 1, título 11, libro $3^{\circ}$. Por la Adición de Lupidana, título 14, No. 28, sobre la Ordenanza 2 , título 13 , libro $3^{\circ}$, hace probanza el dicho del que comprare el servicio de indios por plata.

562.- Solórzano: in Polit, ; libro $2^{\circ}$, Cap. 28, No. 35, tomo $1^{\circ}$, fol. 208.- Matheu: De re criminali; controv, 61 , Nos. 27 y 28 .

563.- Acta 4, Cap. 6; vide el Cardenal Aguirre, en el tomo 6 de su colec. de Concils, fol. 44.

564. - Solórzano: loco citato, No. 34.

565 - Ordenanza 9, título 10 ; Ordenanza 1 , título 11 , libro $3^{\circ}$.

566. - Ordenanza 9 , título 10 ; Ordenanza 1 , título 11 , libro $3^{\circ}$. Ordenanza 17 , título 11 , cod.

$567,-$ Ordenanza 17 , título 11, libro $3^{9}$.

568 - Ordenanza 13 , título 5 , cod.

569.- Ordenanza 2, título 11, cod.

570 - Ordenanza 18, título 11 .

571.- Ordenanza 15, titulo 11, cod.

572 . Ordenanza 20, título 11 , cod. 
573.- Ordenanza 7, título 9, cod.

574.- Ordenanza 3, título 5, cod.

575.- Adición de Lupidana, título 14, libro $3^{\circ}$, No. 15.

576. - Ordenanza 3, título 5, cod.

577.- Ordenanza 1, título 11, cod.

578.- Ley 5, título 8; ley 6, título 15, Partida $7^{\sharp}$, Párrafo $1^{\circ}$ y siguientes, Instit, de Lege aquilia.

579.-- Artículo 7, título 9. 


\section{CAPITULO NOVENO}

\section{De la Superintendencia de Mita}

$\mathbf{E}$ Exmos la Superinoñes Virreyes, cometieron a los Gobernadores de esta Villa los indios de repartimiento, puedan enviar por ellos a hasta de los Corre gidores, con facultad de suspenderlos de sus empleos, en caso de hallarlos culpables de omisión. Siempre han usado los Gobernadores de Potosí de esta autoridad, como delegados del Superior Gobierno, librando despachos conminatorios para el entero de los indios faitos en el padrón de su envío o de los fugitivos; pero sólo se ha insertado un Auto acordado del Sr. Virrey Marqués de Villa-García, por no hallarse entre los papeles comunes de la Escribanía de Minas y Mita las Provisiones del Sr. Marqués de Montesclaros, ${ }^{2}$ Príncipe de Esquilache ${ }^{3}$ y Marqués de Guadalcázar. ${ }^{4} \mathrm{Y}$ no hay duda que por el temor de ser suspendidos y entrar otro en su lugar para la administración de Justicia, han obedecido en todo tiempo Ios Corregidores de las Provincias los despachos del Superintendente de Potosí; siendo de crcer que si no se ejerce la misma autoridad con los Subdelegados, se trastornará la economía de la mita, porque disculparán sus faltas unas veces con los Intendentes y otras veces con los Gobernadores; de manera que confundida la culpa, vendrá a ser irreparable el daño para las minas e ingenios de Potosí, cuando aun ahora se experimentan tantas omisiones, con todo de estar vivas las facultades para privarlos de sus empleos.

En no proviniendo de la omisión de los Corregidores o Subdelegados la falta de mitarios, se debe hacer el entero a costa de los azogueros que reciben el beneficio de repartimiento, según el Cap. $6^{\circ}$ de la Real Cédula del servicio personal, del año 1609 , recopilada en la ley 46 , títu- 
lo 12 , libro $6^{\circ}$ de Indias, y en el título 18 , libro $2 "$ de las Ordentanzas Cenerales clel Perú, al folio 212; pero en el caso de darse comisión a alguno, para traer a P'otosí los indios faltos, debe ser sujeto de mucha verdad, muy pío y de grande satisfacción, para que los conduzca con el regalo, buen tratamiento y gobierno que conviene.

Con este mismo fin prohibió el Sr. Toledo, ś que los indios ladinos y hábiles (que llaman "pongos"), fuesen a sacar los mitarios de sus rancherios, para evitar los daños y perjuicios que les calsaban, y que los sacasen precisamente los dueños de las minas o sus mineros; cuya orden renovó después el Sr. Don Luis de Velasco, por la Adición 12 del ticenciado Lupidana, Visitador General nombrado para las minas e ingenios de Potosí.

Los azogueros reclamaron esta obligación y solicitaron con instancia que se volviese a crear algunos Alcaldes Cañaris, que ayudaren al Capitán de la Mita en el arreglo de los indios y su efectiva asistencia, como lo tenía mandado el Sr. Duque de la Palata, en una de sus Ordenanzas aprobadas posteriormente en la $17 \mathrm{del} \mathrm{Sr}$. Conde de la Monclova, en cuanto al punto de que los mismos Capitanes enteradores que condujesen la mita, cuiden de recoger los indios en las rancherías y asistir con ellos en el "Guaina". (a)

En efecto, se hallan establecidos cuatro Alcaldes Cañaris, que sirven como Alguaciles ordinarios del Capitán mayor de la Real Mita, para el cumplimiento de to que provee en orden a su buena economía, y se les paga un peso semanal, deducido de dos reales que cada scmana contribuyen los azogueros, por cabeza de ingenio. Pero siempre son obligados los Capitanes enteradores al recojo de los indios en las ranchcrías, para la asistencia en el Guaina el día lunes por la mañana, de cada scmana, y cuando no lo verifican por descuido, se les castiga moderadamente por el Gobernador.

1.-- Parte Primera, Cap. 6 ${ }^{\circ}$, Párrafo 6 ; página 105, I’arte Segunda, Cap. 1ْ, Noticia $1^{\circ}$, página 327 , hasta el fin de esta obra.

2.- Provisión de 23 de enero de 1609.

3.- Provisión de 6 de julio de 1617.

4.- Provisión de 22 de diciembre de 1622 .

5.- Ordenanza 9, título 10 , libro $3 "$.

(a) "Guaina", plaza y barrio adyucentes al río del mismo nonbre, que corre al pie del Cerro de Potosí. N. de E. 


\section{CAPITULO DECIMO}

\section{De la Superintendencia del Banco}

$\mathrm{W}_{\mathrm{N} \text { la Parte Primera }{ }^{1} \text { expliqué suficientemente la autoridad }}$ del Superintendente, con todo lo relativo a la buena economía de esta oficina. Si los fondos del Baneo quedan como siempre incorporados a la Real Hacienda, no tengo qué añadir, porque en lo respectivo a la azoguería de Potosí, siempre debe tener el Rey las utilidades, en fuerza de la incorporación que hizo a la Corona, por cesión voluntaria de ella misma. Pero, habiéndose de confundir en una masa todos los caudales que fuere produciendo la nueva Compañía, para avíos de las minas de todo el Virreinato, juzgo muy de razốn que, conformándose una compañía general, tenga parte en ella el Rey, a proporción del fondo actual del Banco, para que arreglado su giro con el progreso del ticmpo, perciba como ahora las ganancias de su capital, del modo que los mineros han de aprovechar las suyas, en las habilitaciones sucesivas de sus haciendas.

Lo que contemplo más digno de advertencia, es que a los mineros de afuera se les fían los auxilios con el plazo de un año, concediéndoles todo este intervalo para que inviertan en avfos de sus propias minas los productos que ellas f'ueren rindiendo, Este es un grande beneficio, porque con dos mil pesos, por ejemplo, que recibieron a principios del año, sacan diez o doce mil pesos que vuelven a invertir en avíos, para aumentar proporcionalmente la gruesa de sacas de metal y su beneficio. En Potosí estarían sumamente contentos, si gozaren otra tanta espera porque pagando ahora los auxilios para descuentos semanales del valor de un piñón, vienen a privarse de una mitad de avíos para los que necesitan las minas en los últimos meses del año. Con mucho mayor gusto pagarían un seis y tal vez hasta diez por ciento, por lograr esta demora, en que yo no considero riesgo, mediante la mancomunidad de todos los azogueros, y si 
hubiese alguno todavía, es mucho mayor en los auxilios a los de afuera, y con todo, gozan el plazo de un año, siendo mucho menos solventes las seguridades de su cobro.

Entablándose en Potosí este plazo, percibiría el Rey, anualmente, 15 a 20.000 pesos, correspondientes a los 200.000 pesos del fondo del Banco, y con ellos se puede continuar con gran desahogo la empresa del Socavón Real y de otros que conviniere dar en este mismo Cerro o en otros del distrito.

1.- Parte Primera; Cap. $7^{\circ}$, Noticia $8^{\circ}$, Párrafo $9^{\circ}$. Pág. 150 de esta obra. 


\section{CAPITULO UNDECIMO Y ULTIMO}

\section{De la Superintendencia de la Real Casa de Moneda}

L.

A Ordenanza 22 de la Real Casa de Moneda, que se ha explicado detalladamente en otro lugar, ${ }^{I}$ trata del Superintendente de ella $\mathrm{y}$ de sus principales facultades, funciones, manejo, jurisdicción $y$ obligaciones. Antiguamente corría este encargo, separado del Gobierno. La multiplicidad de mandos fue un origen fecundo de discordias, desavenencias y parcialidades, con notable perjuicio del servicio del Rey. Se estuvo estudiando el remedio, por muchos años, aunque no tuvo efecto en el antiguo sistema de Gobierno, por la diversidad de sus combinaciones. Ultimamente se reunieron en sólo el Intendente, todas las Superintendencias de esta Villa, incluso la de su Casa Real de Moneda, por el artículo $1^{\circ}$ de la Real Ordenanza de Intendentes, quedando desde entonces inseparables estos Ministerios, que aunque de tiempo atrás habian corrido juntos, sólo era por comisión.

La experiencia ha acreditado el acierto en la reunión de estos empleos y cl público lo contesta con su imparcialidad y mayor subordinación, sin los encuentros que antiguamente ocasionaba la multitud de jurisdicciones independientes.

Sin embargo, recargando en una sóla persona el peso de una infinidad de negocios en que debe entender por sí mismo, casi es imposible su cabal desempeño, principalmente cuando uno sólo no es capaz de poseer juntas las muchas y diferentes cualidades que requiere la naturaleza de cada empleo, de por sí; porque un sujeto dotado de la ciencia civil, que constituye un buen gobernador político, si carece de los conocimientos económicos del manejo de Hacienda, no será apto para Intendente y lo será menos para Superintendente del Banco y Moneda, si no posee la ciencia industriosa del Comercio. 
Por esto parece conveniente que la Superintendencia de estos dos últimos ramos, se encargue a una persona bien instruída sobre materias de comercio, asi por la íntima unión de este objeto con el cambio, el crédito público y los Bancos, como también porque se agencie las verdaderas utilidades de la Casa por medio de aquellas combinaciones y cálculos profundos, que no se pueden adquirir perfectamente sino por un exacto y hábil comerciante o por algún otro que haya bebido sus máximas en las Juntas de Moneda y Comercio.

Pero no pudiéndosc verificar este plan, sin separar los empleos con las anteriores consecuencias, discurro que el único medio es erigir en esta Villa una Intendencia General de Ejército, de quién tuviesen dependencia todos los demás Ministerios.

Bien lo sufre la entidad de esta Provincia y con crearse un Contador Mayor de Cuentas, con dos oficiales, como se ejecutó en Buenos Aires pocos años antes del establecimiento del Virreinato, quedará fundado el sistema sin exponer los negocios a las demoras que en el día sufren por la distancia de los recursos; creando al mismo tiempo para las apelaciones, una Junta Superior, compuesta de cuatro sujetos, bien sea de hos mismos empleados en la Villa (para ahorrar los sueldos), o de otros que el Rey quisiera destinar.

Seguramente tomaría este pueblo y su Provincia un incremento considerabie, que ai cabo de pocos años sería la cmulación de todo el Reino. Yo así lo contemplo, según los conocimientos que he adquirido en el tiempo que lo habito, pues aunque no es muy largo, nada he cuidado más que instruirme del estado y circunstancias del país, para procurar en el modo posible, la utilidad del Rey y la felicidad del Reino.

Si tuvjera la gran dicha de haber acertado siquiera en la parte más pequeña de esta obra, será también el holocausto más aceptable que podré ofrecer a la piedad de mi amado Soberano. Desde luego, puedo asegurar que el celo del real servicio es el único fin que me ha conducido a impender este trabajo, sujetándome en todo a su Real voluntad y a su sapientísimo Consejo y Ministerio.

Con lo cual, ceso en esta obra, en la Imperial Villa de Potosí, a 1: de octubre de 1787 .

1.- Parte Primera, Capitulo $8^{\circ}$, per totum. Pág. 157 y siguientes de esta obra.

FIN DE LA PARTE SEGUNDA Y ULTIMA. 
Epilogo

BREVE COMENTARIO DE LA BIBLIOGRAFIA DE PEDRO VICENTE CAÑETE Y DOMINGUEZ 

SI la vida de cañete fue intensa en acontecimientos de singular dramaticidad, su obra erudita y polémica se caracteriza por su ealidad y extensión.

Por este motivo, es del caso anotar sus particularidades esenciales, sin invadir los campos de una critica severa o de un juicio complaciente, procurando, eso sí, ajustar el comentario a las circunstancias que concurrieron al proceso de la elaboración de sus escritos, sin perder de vista el medio circundante que orientó sus ideas así como las metas que se propuso alcanzar.

El polígrafo don Gabriel René Moreno, clasifica en tres órdenes predominantes la producción de nuestro personaje: administrativo, forense y político. Olvidó o no quiso referirse al histórico, que sin mayores dubitaciones es de trascendente valor. El presente libro lo está pregonando. Señala seguidamente, que los escritos del célebre Asesor, no son pocos y tan sólo han sido publicados seis. De mi parte, estoy en condición de asegurar que los trabajos de Cañete son numerosos, habiéndose editado mayor número del que indicara el minucioso autor de "Los Ultimos Días Coloniales".

El punto de partida de la obra de Cañete, bien pudiera fijarse en Ia época en que inicia su carrera de funcionario, como Asesor y Auditor de Guerra del Primer Virrey de Buenos Aires, donde a poco tiempo se consagra perito en el conocimiento de las ciencias jurídicas, diestro en el decir y hábil escritor. Infelizmente, parece que ni él mismo se preocupó de conservar copias de sus informes, alegatos y discursos producidos ante los tribunales superiores, especialmente las Audiencias Coloniales, donde se debatían asuntos atañaderos a las cuatro ramas principales de la administración pública: de Gobierno, Hacienda, Policía y Guerra; involucrándose en elias las cuestiones canónicas, mineras, industriales, misionarias o colonizadoras, de acuerdo a las disposiciones que regían el funcionamiento de la maquinaria administrativa del gobierno español en sus dominios del Nuevo Mundo.

La tarea del Asesor sobre ser compleja no era liviana, sino de 
grande responsabilidad, como pocas de las habidas en aquelios tiempos, distantes de poder ser llamados patriarcales.

Colocado en ese sitio de prueba, frente a un alto tribunal de que eran vocales jurisconsultos de nota, prolijos en el mejor conocimiento de la jurisprudencia y de las leyes do Castilla, que incluía el de las Leyes de Toro, las Pandectas de Justiniano, las Siete Partidas, los Cedularios Reales, fuer'a de las Provisiones de las propias Audiencias, Ordenes, Decretos, Autos acordados, Rescriptos y tantas otras disposiciones de las numerosas autoridades coloniales, el Asesor se obligaba a mostrar los frutos de su talento y de su experiencia, si quexía salir triunfante en ese ámbito donde se suscitaron las contenciones más enconaras a través de los diálogos agresivos, inspirados en la pugna de intereses contrapuestos. Y esto no era todo. Sí, que también, los Asesores tomaban a su cargo la administración de justicia, y tenían por cllo que conocer a fondo multitud de autores de renombre universal. Bajo este aspecto, preciso es confesar que Cañete, si no fue posecdor de una nutrida y seleccionada biblioteca, debió realizar esfuerzos grandes paira tener a mano múltiples obras, que sólo podía obtener en las bien provistas estanterías do los conventos.

De sus lecturas y conocimientos dan clocuente testimonio sus varios escritos, en cuyas páginas resalta su admirable ilustración, con el acopio proficuo do notas marginales de que estín exormados.

Vistos estos antecedentes, cabe ingresar a la catalogación de sus obras.

¿Cuál fue la primera? No es fécil la respuesta, por la falta do dátos. Apenas es posible asegurar, con relativa certidumbre, que está constituída por sus numerosos dictámenes en la Asesoría del primer Virrey de Buenos Aires, don Pedro de Zeballos. He dicho que de ellos ni el propio autor conservó copias.

Igualmente puede afirmarse de los dictámenes cuando Asesor del Gobierno del Paraguay, que no se conservan en su bien cuidado y ordenado Archivo Nl., como lo atestiguan don Fulgencio R. Moreno, al doctor Garay y don Juan E. O'Ieary, paraguayos todos ellos.

Muy al contrario ocurrió durante su Asesoría en la Gobernación de la Intendencia de Potosí, ciudad donde residió muchos años, con lustre y sin él; donde dedicó sus mayores desvelos y dio stus mejortes luces al estudio de los asuntos que llegaban a su olicina u otros de inobjetable importancia que había de tratar extraoficialmente, como la presente Historia de Potosí, sus estudios políticos, ctc. Dichos dictámenes y discursos, como él los denomina, se han conservado en copias autorizadas con la firma y rúbrica de su autor, reputándose por consiguiente como auténticos de toda autenticidad, y peritenecen al acervo de mi Archivo particular. Eilos son los siguientes por orden cronológico:

El mâs antiguo es el dictámen referente a otro producido sobre el Real Patronato de presentaciones eclesiásticas. Al margen, dice textualmente: "Don Pedto Vicente Cañete Oidor" honor"' de la Rl. Auda. de Charcas y Asosor de Potosí, dirije a V. M. el adjunto discurso que es copia del que ha remitido original a vstr Vimey de Bs. Ays., para q, lo acompañe con otro antr. qe. escribió sobre el Real Patronato, mejorando ahora las precedencias interpretaciones al intento de qe. vniéndose al informe de dicho Virvey, sobre los efectos que tanto convienen pa. el mejor ser- 
ricio de Dios y el d? Y. M. en estas remotos provincias". Lleva fecha 31 de diciembre de 1796. Trátase más que de un alegato sobre el tema enunciado, de una nota de remisión de un otro dictamen y consta solamente de siete páginas.

El Dictamen o Discurso principal, lleva el siguiente encabezamiento que pudiera servir de titulo al trabajo, a que habro de referirme en la parte pertinente de los comentarios: "Don Pedro Vicente Cañete. Oidor" honorario de la Real Audiencia de Charas: aclara y mejora por pste Discurso las inteipretaciones que hizo, como Asesoi de Potosí en el mes de setiembre de so, sobre la inteligencia de la Rl. Cúdula de 9 de mayo del mismo año, en cuanlo a preschlariones eclesiasticas, $y$ a que $V$. $E$. y ningun ofro tiene la preminencia ho Vistepatrono propietario en todo el Tirreynato; apologizando su aterior Dirtamen con demostraciones incontestables contra las invectives acres do low SS. Fiscales de Charcas y Buenos Ayres part que en anchto de dirigive ch derechura al Sumemo Conceio conia de este biscurso, se digne Y. E. acompañalo con el

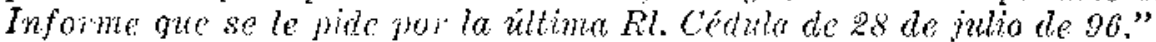

La picza de esta l'eferencia tiene 64 páginas de letra clara y lleva la misma fecha que la anterior. Su contenido puede decirso que está extractado on la nota matginal reproducida. En realidad es una réplica a refutaciones que Victorián Villava, fiscal de Charcas, habia lanzado contra Cañete, no sólo impugnando los trabajos de esto bajo el aspecto juridico, sino que habia avanzado lasta expresiones de subido tono personal. Cañete, ch la exposición del mamuscrito que se comenta, no es cl brioso jurista ni el polemista cálido de las innumerables contiendas en que intervino; sc muestra medido hasta la prudencia. Lo quc no quiere decir que no luzca su característica exudición, por mucho que algunos sospechen que sus escritos sobre el Patronato se asienten en el Tratado de Pedro Frisso "Del Pegio Patronato", impreso en dos tomos en 1677.

Con todo, su dominio del tema era tah antiguo como profundo; pues, en 1790 ya se había esforzado en publicar otro trabajo intitulado "Sinagma" o "Sintagena", conteniendo las resoluciones prácticas cotidianas del detecho del Real Patronazgo de Judias.

$\mathrm{Ni}$ don Gabriel René Moreno ni don Toribio Mcdina, mencionan este trabajo en las bibliografías referentes al doctor paraguayo. Lo registraron los investigadores argentinos en sus catálogos de documentos extractados para el Ministerio de Relaciones Exteriores de su pais, bajo el número 74 de "Papeies de Iistado de la Audiencia de Charcas, Axchivo General de Indias". Don Fulgencio R. Moreno, anota: "Obra inédita hasta hoy (1.900)".

Cañete pidió licencia para su impresión, la que le fuc concedida cxtemporáneamente, motivo por el que no se conoce edición alguna y sólo se sabe con certeza el trámite efectuado ante el Consejo de Indias.

De la misma ćpoca que la anterior es la siguiente obra: "Dictamen jurídico producido en la Villa Imperial de Potosí, sobre la causa célebre de tres ladrones, que forzaron la casa de un mercader para robarle a prima noche. Por el Dr. Don Pedro Vicente Cañete, Asesor General y Auditor de Guerra que fue del primer Virrey de Buenos Ayres el Excelentisimo Señor Don Pedro Zoballos: después de la Capitanía General del Paraguay, y actual Teniente de Gobernador, y Asesor General del Govicrno e Intendente de Potosí. Con licencia. En la calle de Juan Medina." 
Al respecto, don Gabriel René Moreno, anota lo que sigue: "Folio de $256 \times 152$; cincuenta y tres páginas. Fechado en Potosí a 17 de junio. Impresión de Lima. Cañete había pronunciado sentencia en esta causa. Determinó extender este dictamen motivado de ella y publicarlo, ello acaso-para dar a conocer sus luces y talento". Cabría simplemente, con el debido respeto al ilustre bibliografo, aclarar que Cañete no dictó sentencia. Los fiscales dictaminan o requieren, formulando opinión con los datos del proceso, pero no sentencian, dejando esa atribución a los jueces.

Luego publicó -dato de don Toribio Medina- la "Relación de la Literatura, grados y méritos del Doctor Don Pedro Vicente Cañete $y$ Dominguez, Asesor General del Firreynato de Buenos Ayres." Es un folio de 6 páginas, una en blanco y la final para la suma. Madrid 18 de junio de 1779 .

El año 1795 redactó otro dictamen en una gestión incoada por María Josefa Pérez de la Reynaga, solicitando confirmación de unas diligencias practicadas sobre heridos de molinos, opinando porque se respeten las leyes de la materia y las costumbres mantenidas. La cuestión debía considerar y determinar el Sr. Virrey Melo de Portugal y Villena. Aunque el dictamen no está firmado por Cañete, el estilo, la variedad de citas, el vigor jurídico y hasta la letra del amanuense, denuncian sin temor a equivocación, a su autor.

Asimismo y mostrando lucida erudición dentro de un breve texto, se expidió en un dictamen sobre deberes y derechos de un albaceazgo, en 19 de abril de 1809 , en cuatro escasas páginas.

Inédita también permanece en el fondo documental de la Biblioteca de la Academia de la Historia de Madrid, un "Informe sobre las Ordenanzas de Minería e intervención en ellas del Protector de Naturales". Manuscrito en copia constante en 20 hojas, folio. Está dirigido al Gobernador Intendente de Potosí don Francisco de Paula Sanz, en 19 de agosto de 1794. "Escrito notable por su estilo y erudición", dice un experto en conocimientos científicos y bibliográficos, al ocuparse de dicha pieza, y concluye: "Se extiende en consideraciones sobre la Mita, justificándola".

Vale la pena de dejar sentada la explicación de la actitud de Canete, con referencia al servicio de la Mita. En ciertos documentos mostróse contrario a la subsistencia de esta institución, poniéndose a tono con numerosos juristas, historiadores y recinos notables que habían liegado a conclusiones francamente vehementes y condenatorias de esa servidumbre cruel para con los indígenas. En otros escritos, se constituyó en abogado apasionado, intolerante y sofista, de la Mita.

Conducta contradictoria que ocasionó una famosa polémica de muchos años, con el Sr. Fiscal de la Audiencia de Charcas y Protector de Naturales don Victorián de Villava, cuya probidad y luces encomia uliestro René Moreno, en sus "Ultimos Días Coloniales". El docto paraguayo tuvo que habérselas con el no menos inteligente y apasionado abogado aragonés, titulado en Huesca y que entre otros cargos había desempeñado con brillo el Corregimiento de Tarragona de la Mancha. Con admirable sentido moral, Villava impugnó la Mita y atacó con rudeza a Cañete y Domínguez y al Gobernador de Potosí don Francisco de Paula Sanz.

La disputa aludida, puede sumariarse en la breve catalogación que se anota en seguida, incluyendo en ella los Informes de Paula Sanz, que 
seguramente fueron rudatidos en su maror parte por la pluma del Asesor, esto sin menoscabo de los talentos y experiencia administrativa de sul Jefe:

"Discuriso sobre la Mita", por Victorién Villava, a que me he referido líneas ariba, cue se publićr an Buenos Aires.

"Contestacion al Discuro sobre la Mita en Potosi", escrito en La Plata a 9 de marzo de 1793, que lleva al final fecha de Potosi, en 19 de novienbre de 1791 , sin legistrar el nombre del autor. Tiene 46 fojas y 9 estados. Debe atribuírse este trabajo, sin vacilaciones, a Cañete.

"Papel del Señor Villava defendiendo su Discurso contra la Mita" impugnando el escrito contrario. Manuscrito en 20 fojas, folio tiene fecha en La Plata, a 3 de encro de 1795 . Fil bibliốtilo comentarista de estos trabajos, anota al respecto, yo siguiente: "El Sr. Villava no cede a su impugnador en pureza de estilo, erudicción y formas corteses, excediéndole en concisión, en lógica y argumentación ell contra de los beneficios que la Mita produce al Estario $\because$ a los indios y que Sanz trató de encomiar".

"Oficio del Gobemador de Potosi, respondiendo al Papel del Fiscal Villata de 3 de enero de $179{ }^{\prime \prime}$. Manuscrito original de 40 fojas en folio, firmado en Potosí, a 24 de abril de 1795, por el Gobernador Paula Sanz.

"Representación del Gobernador Intendente de Potosi..." en que hace presente ol deplorable estado de la Azoguería de aquella Villa y la decadencia de los trabajos mineros en el Cerro. Copia en 30 fojas. Está dirigida a don Diego Gordoqui desde Potosí, el 26 de septiembre de 1796. Entre otras cosas se refiere el autor a la historia de la Villa y concretamente al servicio de la Mita; prevee la próxima ruina de la Azoguería y del pueblo, concluyendo con amenazar con su retiro del alto cargo que desempeña si no se pone pronto remedio a la situación "una vez que sus tareas, fatigas y esmeros no han de ser bastantes a evitarla".

"Representación del mismo Gobernador..." indioando los medios que juzga oportunos para evitar Ia ruina absoluta del gremio de Azogtueros y darle el fomento que necesita, con expresion de los artículos de la Ordenanza del Banco de San Carlos a que se oponen, y de los demás que necesitan declajación para evitar dudas en lo sucesivo. De igual fecha que la anterior. Copia de 19 fojas, folio.

Un cotejo atento del estilo, citas y juicios jurídicos de ambos trabajos nos llevarian a descubrir a Cañete y Domínguez como al autor verdadero; al partidario irreductible de la Mita. Muy al contrario, al Cañete y Domínguez magnánimo y generoso con los indios, denostador de esa servidumbre, le veremos a través de las palabras de un hombre eminente que lo conoció y cultivó su amistad en Potosí y Chuquisaca: don Vicente Pazos Kanki. En uno de sus libros, diee el celebrado humanista: "... Como tributo debido a la memoria de este grande hombre debo re. cordar que muchas veces hallándome en Potosí, le oí decir, lamentando la suerte de Ios mitayos: "que si le fuera permitido llegar a los pies del Rey y narrarle las miserias de los indios y la falsa política en forzarlos a caminar a un trabajo que no es ventajoso para el Azoguero, ni provechoso al Estado, porque sólo el trabajo iibre es el que rinde utilidad, atravesaría desde luego el Océano aunque fuera con peligro cierto de mi vida'. Estas expresiones quedaron grabadas desde entonces en mi corazón, como que tenían en sí el sello de la filantropía y del amor a la jus- 
ticia, sentimientos a la verdad propios de aquel digno y justificado magistrado que habló siempre en el idioma de la verdad a las primeras autoridades del reino, y que murió víctima de su celo al principio de la re. volución del Río de la Plata; no porque fuese enemigo de ella, mas si por las vejaciones que sufrióp por la precipitación con que se le declaró en Buenos Aires hostil al nuevo orden que se abrazé an aquella capital". Y luego prosigue Pazos Tranki: "Es igualmente justicia el consignar" en este lagar el aprecio que el doctor don Mariano Moreno hacia do la capacidad del señor Cañete; pues antes de embarcarso para Lond'es, en cuyo viaje murió, me encargó muy especialmente para que signifjcase a éste, la estima y consideración que tenía a sus talentos, y aunque había disentido de él en su carictè ministerial, esto no aminoraba en manera alguna el alto concepto que tenía formado de su previsión y vistas elevadas. Yo tuve el gusto de thasmitir estos sentimientos del doctor $\mathrm{Ma}$ riano Moreno al señor Calinetr. Me será permitirla esta digresión que es sugerida por la memoria de cstos dos greandes letrados, ciertamente los luminares del foro americano, y que hombarian cualquicra de los estrados de los triburales supremos de justicia de Europa; ambos se formaron sin salir de América".

Paréceme que toda historia de Potosi deberá tratar con detenimiento la cuestión de la Mita, que durante siglos so impuso como atroz servidumbre sobre la desgraciada raza indígena. El renombre de Potosí, que cautivó el universo y causó la envidia tanto de las Contes europeas como la do sus pueblos; que sostuvo guerras, livantó industrias, improvisó cuantiosas fortunas, movilizó el concrcio; que creó en su contorno la abundancia y la prospexidad, está unido a ese subfondo de miserias, vejámenes y crueldades, que como trágica sccucla, dejó la Mita.

Mucho se ha dicho sobre la terrible institución desde su establecimiento en Potosí y Guancavelica por el Vir'rey Don Francisco de Toledo, y todo lo publicado no alcanza a registrar los detalles y condiciones con que se aplicó esta servidumbre.

Numerosos son los bistoriadores que han condenado la Mita y los trabajos de obligación que se impuso para los inclígenas en América. Desfe ol Padre las Casas hasta Victorián Villava, pasando por F'rancisco de Alfaro, Messía Alonso, ete., que lleguron a levar hasta el trono español, representaciones y protestas, con resultados satisfactorios en la Corte, pero sin posible ejecución porcrue mediaba en ello cl interés $y$ la codicia de los mineros. No faltaron tampoco los que después de defender la Mita como beneficio del Estado, ante la realidad vista y comprobada de los hechos, tuvieron que medificar su criterio. Así el Padre Miguel de Agia, citaclo por don Armando Alba, en la nota (a) del Capétulo Vr página 122 , de este libro. I

Fintre los mucstros, don Gabriel Rene Moreno, al referirse al trabajo de las minas de Potosí, en aquellos tiempos, escribe: "En los ingenios de mincría él (mayordomo) era el mayoral que daba la voz de movimiento al gran trapiche de la mita, entre cuyo engranaje cra triturada y exprimida con sudor y sangre la libertad humana". Y prosigue en su libro "Bolivia y Perú. Notas Históricas y Bibliográficas", pág. 316 de la segunda edicion: "La mita es materia fecuncla y luminosa de estudio para explicar la socialidad alloperuana. Su forma prinitiva e implantación constan de las ordeuanzas de Toledo y en legajos que no 
han visto la luz. Las principales de dicho Virrey forman casi todo el volúmen $I$ de las Relaciones de los Vivreyes y Audiencias. Una memoria del libro III de las provisiones $y$ despachos del Licenciado Matienzo, inserta en el volúmen $X X$ de la Colección de Documentos inéditos, relativos a las antiguas posesiones españolas, contiene el inventario del Virrey en Charcas al organizar el repartimiento y encomiendas, como ramos de la administración. En la Recopilación de las leyes V, VII, XIV, XVI y XVII del título XV, del libro 6", se establece la mita moderna, según la había reglamentado y modificado el cedulario de Charcas. Allí aparece medianamente inicua y pasaderamente abominable, bien así como todos los servicios personales. El candor sinjestro de la verdad histórica, no está en las leyes sino en cualquier expediente sobre mita. Con sólo dejar constancia del suceso, denigran esos papeles sin saberlo, las formas de aquella ante la conciencia humana".

$Y$ ahor paso a exponer la grave actividad del Dr. Cañete y Domíngıez en materia polítion.

Las revoluciones libertarias del 25 de mayo y 16 de julio de 1809 , operadas en Chuquisaca y La Paz, sucesiva y complementariamente, habían conmovido la sensibilidad social de la capital del Virreinato, Buenos Aires, cuyas personalidades más descollantes habían aprendido y pexfeccionado sus conocimientos profesionales en la ya continentalmente famosa Universidad de San Francisco Xavier de Charcas.

Sintieron en su país tantas exacciones y contemplaron más crueles en el Alto Perú, que lógicamente se creó la necesidad de tentar todos los recursos posibles, para alcanzay la emancipación de los pueblos sometidos al dominio español. Si a ello se agrega la ferocidad desbordada de Goyeneche que inmoló en La Paz preciosas vidas y las violencias de Nieto, Presidente de la Audiencia de Charcas, se justificará el ardor patriótico que envolvía a todas las poblaciones que no retrocederían por nin- ... gún motivo de la firme resolución de luchar por su libertad.

El Virrey de Lima, vió el peligro en su magnitud. "Pensó entonces en detener la corriente z'colucionaria que lo amenazaba, apoderándose del Alto Perú y estableció allí los reales de su ejército - dice el historiador J. Ramón Muñoz Cabrera- no obstante pertenecer este territorio al Vir'reinato de Buenos Aires".

A su vez, simultáneamente, el Virrey de esta última capital, se: . dirjgía al Dr. Pedro Vicente Cañete, Asesor de la Intendencia de Potosí, requiriéndole un dictamen sobre la situación agitada que vivían las colonias españolas en América.

"El doctor" Cañete -prosigue Muñoz Cabrera- hombre de una vasta erudicción pero de una moral nada austera, expidió en efecto su dictamen, el día 26 de mayo, en que se consumaba la revolución de Buenos Aires. Por un azar de las cosas, dicho dictamen llegó a poder del gom bierno revolucionario, el que lo mandó publicar en la "Gaceta Oficial", correspondiente al 3 de julio de 1810.

Empieza su escrito el señor Cañete, con esta franca y desconsoladora descripción del estado político y moral de los pueblos sudamericanos: "Excmo. Señor: En unos pueblos sin ilustración. sin disciplina y sin costumbres, como son la mayor parte de los de América, es imposible establecer un sistema de seguridad, no teniendo un apoyo de protección sobre quien fijen sus esfuerzos los ciudadanos. Hasta ahora las re- 
compensas han venido a tres mil leguas de distancia, explestas a otras tantas equivocaciones y engaños: Nuestro gobierno de Amédica puramente derivativo ha subsistido solamente por Ia opinión de lo que podía influír a las fortunas de los particulares con sus recomendaciones a la metrópoli y un temor aunque lejano del poder armado del Soberano, ha detenido la osadía de algunas manos rebeldes para dejar de obiar a pesar suyo".

Más adelante, midiendo la gravedad del peligro, Cañete continúa: "Si faltase el muelle real que daba impulso a esta máquina, al momento se desconcertará todo su movimiento, y las pasiones que se han reprimido como los torrentes que corren, entre dos montañas encerrados dentro de sus bordes, se derramarán fuera de este dique, desolando no sólo su propio terreno, es dect. la felicidad de csos hombues aturdidos y ambiciosos, sino también acusando estragos por de luera para destruír el orden, la armonía social y la seguridad general de este dichoso continente".

Luego, prosiguc: "No ostá la Anrérica en estado de organizar una politica sutil que pudiera scrvir de matriz para un sistema de gobierno. Ya se ha dejado presentrir que la independencia es el proyecto favorito por los dechados de Fuladelfial Se puede afianzax con la cabeza que on cuanto se aparezea este cometa funesto, y tienda su cauda sanguinolenta sobre la América, todos estos pueblos por un espíritu de imitación habrán de ejecutar idem por idem lo que se practicó en España desde êl momento que se disolvió la Junta de Gobjerno. Quiero decir que en las capitales de los virreinatos formarán una junta suprema tumultuariamente, y todas las demás cabeceras de provincias haran lo propio con el pretexto de armar sus territorios, y ponerse en observación sobre la fidelidad de los jefes y empleados públicos: matricularán milicias, nombrarán jefes quedas manden. Pel'o antes de esta crisis vergonzosa por donde vendría La América a quedar esclavizada a otro ajeno dueño contra tantos pactos y juramentos nacionales, no es capaz de ponderar'se los escámdatos que en cada pueblo, y en cada barrio se levantarán como columnas de llamas devoradoras entre los mismos americanos por ocupar fasiento en las juntas, por obtener mandos y grados, por celos y desconfianza recíprocos, por ambición y por odio para arrebatarse la fortuna los unos a los otros".

“...En la Carta Apologética de los procedimientos del Excmo. señor don Santiago Liniers contra la Junta de Montevideo ---escribe en otro parágrafo el apasionado Asesor- tengo demostrado que los señores virreyes son los vicarios del príncipe en estas remotas regiones, que pueden hacer y obrar lo mismo que haría y obraría cl Soberano; y por estar revestidos de su viva imagen representan a Su Majcstad, con todo el lleno de su soberano poder mientras ejercitan esta altísima autoridad, con la regalía de que subsiste y permanece en todo su vigor, aunque se halle ausente o prisionero el rey que lo hubiese elegido".

Obligado a concretar en el dictamen sus opiniones para encontrar remedio a la insurgencia, Cañete en el documento que trascribo en sus partes esenciales, redacta así sus pensamientos: "No se debe dudar que por las regalías expresadas, cada virrey como gobernador del reino de su distrito, conservará la misma constitución aunque suceda la hipótesis de que se pierda la España. Este gobierno provisional absoluto debe subsistir mientras los cuatro virreyes de ambás Anréricas acuerden entre sí a 
la mayor brevedad posible la convocación de Cortes en un punto promedio a tan grandes distancias que sea accesible a todos los diputados; a fin de que organizada la forma menos expuesta a la impostura y a la sorpresa sobre cl modo de elegir a estos respetables representantes, se proceda al nombramiento de una regencia soberana que represente los derechos, la autoridad y la persona del señor don Fernando VIl y en él, la sucesión de la real casa de Borbón scgún los llamamientos de nuestras leyes fundamentales... Y para el caso no expresado aunque posible de sojuzgar a la España el excomulgado Napoleón, indigno por este solo título para poder dominar a una nación tan catolica como la Améxica española, la misma junta (formada por los cuatro virreyes en forma secreta) debe ceder y trasmitir interinamente en el Señor Vixrey a nombre y voz de todas las clases sociales que representa, toda la autoridad que fuera necesaria para mayor validación y firmeza clel alto poder que tiene a su cargo, lo mismo que practicó la ciudad de México con su virrey el Excmo. señor Iturrigaria, en las primeras convulsiones de la España, cuando se creyó que subsistía la monarquía sin gobierno legítimamente organizado. Es consiguiente verificar la propia diligencia en todas las ciudades cabeceras de provincias y cabildos subalternos, remitiendo a los respectivos jefes y cuerpos municipales copia auténtica de la resolución de la junta general de autoridades del virreinato, encargando a los prelados y por su medio a los vicarios y jueces eclesiásticos foráneos que, congregando al clero secular, curas, prelados, regulares, les exhorten y ordenen bajo de penas espirituales que en el púlpito y confesonario enseñen y prediquen la estrechísima obligación que tienen en conciencia todos los vasallos de cualquier conclición, estado, sexo y clase, de sostener la concordia recíproca en la defensa de los derechos del señor don Fernando VII y de obedecer a su vicario virrey, imagen y cabeza del reino como supremo gobernador de su distrito, hasta tanto que esta América proceda a elegir una regencia soberana para su gobiesno legítimo... Si conseguimos fijar anticipadamente la alitoridad del virrey bajo resguardos, ya podemos esperar con menos inquietud la accesión que se sospecha de que una escuadra inglesa a la vista de Buenos Aires nos traerá repentinamente la nöticia de la pérdicla de España y debemos presumir que entonces nos habrán de proponer tuno de dos partidos: $O$ bien su protección para provocamos a la independencia; 0 bien el gobiemo de regencta- $a$-cargo de la Serenísina Señora Infanta de España, princesa del Brasil. . . a falta de los señoves Infantes suss hermanos. Lo primero es infinitamente más perjudicial; porque daría principio a la anarquía, y se daría el origen a la pérdida de toda la Améxica... Lo segundo tiene el gravísimo inconveniente de que la Corona de Portugal tal vez quiera apropiarse de estos establecimientos con el mismo derecho que contrataron hacer un repartimiento Portugal, Francia y España, en el Tratado secreto de Fontainebleau el 27 de octubre de $1807^{\prime \prime}$.

Concluye el documento, con estas sugerentes cláusulas: "En la extremidad de estos dos grandes peligros, parece mucho menos expuesto el último, siempre que adoptándolo con sagacidad continúe el gobierno de América al mando de sus actuales magistrados, jefes y ministros confesores a muestra constitución y códigos legislativos, jurando la Señora no inmovar nuestro sistema, ni introducir tropas, ni elegir jefes ni magistrados extranjeros, sino auxiliarnos con armas y artillería para nues- 
tra defensa interior y maritima, bajo Ia protección de la Gił Bietaña",

"Ya se ve que con el tiempo casi es imposible que no sobreviviese el abuso del poder, pero como en tanto pudiera España sacudir la douinación del tirallo, y éste precipitarse como un cometa inlausto para la libertad general de Europa, deberíamos contar como católicos con esta crisis dichosa para sostenex con energía y unión los pactos que quedasen concertados. Siendo muy probable que la Señora entrase por cualquiera de estos conciertos para asegurar su derecho de sucesion; bien que todo debería entenderse bajo del consentimionto general de ambas Américas, después de requeridos los virreyes, convocadas las Cortes según queda dicho. $\mathrm{Y}$ en a interin no rebería establecerse en Buenos Aires la Señora Princesa ni hacer otra novedad más que sonar el título de su regencia bajo del mismo sistema gie nos fije el presente".

"Si continuamos en el letargo que nos tiene adormecidos, la sorpresa desconcertará todas las medidas que quisiéramos tener en la misma acción de la desgracia; y a la manera que al asalto repentino de abandonarlos contra una casa no hay pies con cabeza para provenir los daños, asimismo sucederá con nosotros, armándose la inritación de los pueblos contra los jefes, con el protexto de haberlos tenido cngañados bajo de una falsa y estudiada seguridad".

"Todos estos pueblos so mantienen en una fespcctación asombrosa, como quien espera el gotpe de ana tempestad deshecha ta tista de las negras nubes que se miran colgadas sobre las cabezas. Al fin son pueblos anc se irán tras de viento que los moviese".

Tiene este documento lecha 26 de maro de 1810 y esti dirigido al Excmo. Señor Virrey Don Paltazar Hidalgo de Cisneros.

Recopilación de las Ordonanzas Reales y Providencias tomadas por el Gobierno de Potosí sobve al Gobierno y Dirección del interesantísimo ramo de la Mita en él. Es una enumeración prolija, dividida en capítulos en vez de artículos. Se remonta al siglo XVI para recordar las disposiciones del Virrey Toledo y de Isuis de Velasco, deteniéndose en el Coude de Ia Monclova. Después del capítulo XVII concluye con razonadas anotaciones sobre infraccionos a las Ordenanzas por parte de los Azogueros, pormenorizando aspectos del trabajo de minas, que demuestra conocer en todas sus fases.

No lleva firma el manuscrito, pero por la letra del copista así como por las citas de leyes, se denuncia el trabajo como propio de Cañete. Consta de 14 páginas.

Mitario del Cerro. Es un estado manuscrito en el que se enumera a los destinados al servicio de la mita durante su tanda, con detalle de los días de trabajo señalados y los que están fuera de la obligatoriedad. Trae datos minuciosos como el número de velas que se distribuye para cada faena, con otras particularidades de interés.

Informe sobre articulos de la Ordenanza para la minga do lotosí a las minas de Ubina. Informe e incidencias sobre ol mismo asunto, dice el anotador de este escrito, que parece continuación por la materia de que se trata y la fecha, del Informe sobre las Ordenanzas de Minería de que se ha hecho referencia lineas arriba.

Corresponde a los años 1795 y 96 y señala las ebligaciones a que debía sujetarse el concesionario de las mingas o sean los servicios y jornales de los indios alquilados. 
Instrueciones part al manejo de las Caxas Reales de La Paz. E1 manuscrito fue remitido al Perú, de donde ha sido enviado nuevamente al pais. Se encuentra inédito en una biblioteca particular.

Escribió este trabajo el Sr. Cañete, por su condición de Visitador de las citadas Cajas Reales, en 1805. Sus observaciones ahincaron en las mismas raices del funcionamiento de la compleja repartición oficial, sobre la qtue sc folmó etr ese tiempo un proceso cuyo expediente está en el Archivo General de Indias, en 122, 1,16 , bajo el epígrafe de "Expediente por el que se prescribe al Virrey de Buenos Aires las reglas que ha de observar el arieglo de las Caxas de la Paz y administradores provinciales, para evitar los escrindalos descubiertos... para la mejor administración de la Hacienda Real". Baruuto que tales "justrucciones" provinieron inicialmonte de lo observado por Cañete on su visita.

No estár demás decir aquí, que el alto funcionario, se mostró complacido con la ciudad de Ia Paz. Cierta vez estuvo empeñado en fijar su residencia, propontenle octpar su Asesoría como en Potosí.

Respecto de las "instrucciones" queda por hacer algunos esclarecimientos más: en la biblioteca de José Rosendo Gutiérrez que hoy forma parte de la que pertence a la Universidad, en su catálogo antiguo, correspondía al número 1558 un "Reglamento económico para el manejo y buena cuenta de la administración de la Real Audiencia de La Paz". Juzgo que se trata de una equivocación rotularia y que es una copia del documento motivo de este parágrafio.

Más todaria: en un catálogo peruano formado por el investigador Jorge Corpanchu, sc registra bajo el número 267, esta insoripción: "Año 1797. - Copia de la carta de instrucción que dejó al señor Gobernador Intendente de la Provincia y Ciudad de La Paz Don Pedro Vicente Cañete, en 21 de agrosto de 1797, de orden del Excmo. señor Virrey de. Buenos Aires, al tiempo que por $S . E$. se le mandó en la visita de aquellas Reales Cajas"._ "Es copia de otra igual de su tenor y de la misma que su propio autor el señor Cañete me remitió desde la ciudad de Fa Paz, al tiempo de cerrar la visita de acuellas Reales Cajas y antes de su restitución al Potosí; con el lin de que me impusiese de sus tareas, o con la idea de que las aprobase, a que me remito $y$ certifico. Ut supra.Lamberto de Sierré". Contisne 306 articulos de instruccjón.

El señor Lamberto de Sicrra, español, desempeñó el delicado cargo de Tesorero de Real Hacienda. Sus descendientes viven en Oruro.

En este aspecto de variación de títulos en las obras de Cañete, escribe don Fulgencio R. Noreno, el biógrafo mejor documentado de los historiadores paraguayos que se ocuparon de su compatriota, bajo el epígrafe "Discurso sobre el manejo de la Real Hacienda en América, concordado con la Teoloffía y Jurispmudencia Civil", éstas líneas: "Obra inédita, dada a conocer por el Dr. Medina. En la historia de este erudito escritor, ya citada, se lee el siguiente pedimento de Cañete dirigido al Virrey Marqués de Avilés, sobre la impresión de dicho trabajo: "El manejo dilatado de los negocios públicos y la experiencia de los desórdenes, principalmente en los países del Perú, por el tiempo de quince años, en que casi no hay espacio que no haya corrido por mi mano, me han hecho conocer que el desareglo general de la economía política de la Real Hacienda de estas provincias, proviene de ciertos principios relajados de la morai, que sustrayendo del corazón de los Ministros Reales el temor se- 
creto de la religión, los hacen abandonar también a la solicitud de riquezas, cuya adquisición se persuade como lícita por una teología disonante a las reglas canónicas y civiles de ambos derechos. - No puedo menos que atribuir estos males a la omisión de no haber tratado ningún autor la materia del adjunto discurso con cl magisterio que corresponde a su importancia y dignidad... Deseoso pues, de conocer la concordia de la teología y de la jurisprudencia civil en este punto, he ereído meritorio para ambas majestades escribir la Disertación que dirijo a las superiores manos de V. E., para que si lo hallare digno de atención, permitirme su impresión en los Niños Expósitos, a expensas suyas". sultó tardío.

Es presumible que el permiso no fule otorgado, o de existir, re-

El clamor de la lealtad americana en defensa de la legitimidad del Supremo Consejo de Regencia, contra los atentados de la Junta Gubernativa de Buenos Ayres. Dedicado al Excmo. Señor Don Fernando de Abascal y Sousa. Lima, año 1810. Imprenta del Real Colegio de San Fernando. Dictamen oficioso suscrito en Potosi a 25 de agosto de dicho año.

El más eminente de nuestros bibliógrafos (G. R. Moreno) califica como "importante" y "rara" esta pieza.

Carta consultiva de los procedimientos del Excmo. Señor Virrey Don Santiago Liniers, sobre las ocurrencias de la Junta de Gobierno establecida en la ciudad de Montevideo, con varias reflexiones que apoyan la sabia vista fiscal. A 15 de octubre de 1808. De orden superior, impresa en 1809 en la Real Imprenta de Niños Fxpósitos, en 20 páginas y suscrita en Potosí el 25 de entero.

El mismo bibliógrafo después de referirse al proceso de formación de la Junta Gubernativa de Montevideo para derrocar a Liniers, se pronuncia así: "...vino a fines de 1809 Cañete con su Carta consultiva y apologética. Pero es alegato que está formulado en defensa, no sólo del honor de dicho jefe sino también de la dominación colonial. Cañete se declara abiertamente contra las tendencias revolucionarias que ya asoman dentro del virreinato. Mueve todo a creer que aqucl dictamen fuera enteramente oficioso. Pendía en esos instantes del conocimiento de aquel magistrado una queja de Cañete contra la Real Audiencia de Chuquisaca, la que había proveído decretos de proscripción, de la ciudad, contra dicho letrado; decretos según el estatuto del nuevo virreinato, enteramente inícuos y arbitrarios".

Carta consultiva sobre la obligación que tienen los eclesiásticos de denunciar a los traidores, y exhortar en el confesonario y púlpito su descubrimiento y captura, sin temor de incurrir en irregularidades los que asistieren armados en los combates contra los insurgentes, ni los que promovieren y concurrieren a la prisión de sus caudillos prófugos. Que sirve de apéndice a la Pastoral del Iltmo. Arzobispo Don Benito María Moxó. Lima, imprenta de los Huérfanos, 1812. Por. D. Bernardino Ruiz. Con 91 páginas, hasta la 28 el texto de la Pastoral. Está fechada el 22 de agosto en La Plata.

Este cuaderno está calificado de rarísimo y el erudito y admirable don René Moreno, no logró conocer a tiempo que escribía sus anotaciones a la Biblioteca Peruana. Es un elegante ejemplar que contiene las proposiciones y conclusiones sustentadas por el mitrado y el togado, 
ya que a su hora $y$ en su lugar se impusieron a los pobladores del Alto Perú, objetivándose en realidades las prédicas en ellas sostenidas, visto que provenían de tan altas autoridades, foronse la una y eclesiástica la otra.

Comienza el Arzobispo Moxó respondiendo a cicrto interrogato. rio fingido que el clero do su diocesis le habría formulado en aquelios días turbios de agosto de 1812. El quid de la cuestion era si los curas "podrian licitamente denunciar ante los magistrados o jefes militares a aquellas personas de quienes se supiese o tuviese vehemente sospecha que eran enemigos del Rey o que matuinaban turbar la quietud pública y romper el freno de la obedicneia". Y si con tal delación se expondrían a incurrir on irregularidad, caso gue los reos sufriesen efectivamente la pena de la ley. Asimismo, "si cuando sus feligmeses saljesen a contener las gavillas de insurgentes que huyendo de los invencibles batallones del ejéreito real, talaban los campos, robaban, forzaban y amenazaban lo profano y lo sagrado, poclian éllos acompañarlos en tan santa expedición; y, finalmente, en ese caso, sin peligro de irregularidad, armarse, hacerles fuego, destruirlos o prenclerkos".

Su criterio, teologizante como el de todos los clérigos, se mostraba claramente decidido por Ia causa del Soberano, en las tres proposiciones, para concluir con esta recomencheión rotunda: "El que así no lo hiciere, no merecería el nombre de ciudadano; la ley lo declararía infame y lo trataría como a vil cómplice de Ios verdaderos insurgentes. Los enemigos del rey, del estado o de la nación que tantos males causan a una $y$ otrca América, deben ser prontamente delatados. La rebelión es una ponzoña que si luego que es dada no se acude al enformo, va derechamente al corazón y lo mata. Es un fuego que conviene apagar luego que se descubre humo, o salta la primera centella, si se quiere que no se consuma todo el edificio. Se me dirá -concluye cl párrafo- que el reo de alta traición merece pena capital: que naturaimente la sufriría; y que así el eclesiástico delator contribuyendo eficaz aunqne indirectamente a esa muerte, inclurira en irregularidad. Pero a este reparo se debe decir, que este riesgo debe evitarse con sólo hacer la acostumbrada y sincera protesta de no pretender ni querer el castigo del reo, sino el bien y la seguidad pública". Para concluir, recuerda a los curas "no tomar más arma que las insignias de la religión; en lugar de la espada el crucifijo".

Cañete, a su vez, con voz do barítono se une al exquisito acento de tiple del mitrado, en este duo de incondicional defensa del absolutismo borbónico, discurriendo por los meandros del sofisma, para sentenciar que "no descubrir al traidor es culpa grave, que cualquiera que supiese de cualquiera manera y no lo descubriera, es traidor y debe morir por ello, según varias leyes de Alfonso el Sabio. Luego, el denunciar al traidor es obligación del vasallo". El abogado asunçeno, no emitía sus opíniones de mutuo proprio, sino a petición de Goyeneche -maestro de capilla en el caso- que se valió de la intervención del ilustrado fraile Juan J. Matraya.

Si bien nuestro autor sostiene y defiende la delación con citas de autores célebres, entre ellos Santo Tomás, el Auterpiense, es irrefragable que estuvo en aquellos nomentos como cegado por su fanatismo político. Su intemperancia llega hasta el cinismo nocivo. Porque es oportuno hacer saber que hubo gente o gentuza que lievada de esas pernicio- 
sas prédicas, no trepidó en cumplir los consejos, cono si se tratase de un versículo del Evangelio. Y, los culas fanatizados, estimulados por las incitaciones de un prelado de la religión y por un prócer de la judicatura, originaron la prisión de los "inicuos" revolucionarios. Ordenaron a los jefes de las poblaciones indígenas per'seguir a los caudilios por los más escondidos rincones del teritorio para prenderlos y entrogarlos a la justicia, bajo la amenaza de incendiar sus easas si les dejaban huír o los amparaban.

Por lo comentado se puede tener idea completa del contenido del panfleto que abarca casi un centenar de páginas. Texto que a ser conocido por nuestro René Moreno o por don Toribio Medina, en toda su extensión, habría suscitado mayores y extensos juicios analíticos, poco favorables por cierto al batallador Arzobispo y al sutil y enredado Oidor Honorario. Con todo, no está demás decir que el autor de los "Ultimos Días Coloniales", no juzga con rigurosa severiclad la conducta de Cañete, o mejor, la falta de ética en los críticos trances en que intervino, si bien con indiscutido talento, lamentalsloniente sin ningún respeto a la moral; ya que todo escritor está obligado a respetarse y respetar la opinión de los demás, sin dejarse arrastrar por sus violentas pasiones ni por sus intereses personalísimos; mucho menos, dando ancho cauce a sus vedados impulsos, unas veces arteros, otras dolosos, quizá escondiendo en su propia intimidad, inclinaciones irreprimibles hacia la sangxe $\mathrm{y}$ el crimen.

Intendencia de Potosí. Este trabajo corresponde a la iniciación del siglo XIX; pues, cuando se publicó por primera y única vez en Buenos Aires en la séptima decena de aquel siglo, se estampó su fecha original de 17 de diciembre de 1802. Es trabajo histórico de buenos quilates, sobre todo si se tiene en cuenta que en aquellos ticmpos eran rarísimos los escritos que abundaran en datos de los anales de la Villa Imperial y casi ninguno que fuese información numérica y fidedigna del movimiento general administrativo o industrial. I a copia tiene 27 páginas.

Don Gabriel René Moreno, lo encomia sobremanera, cual lo merecía; aunque cree que en materia de mita es lo mejor y más completo - que se ha producido, lo que en nuestra opinión no es exacto. Menos puede considerarse como una simple síntesis de la obra que yo llamo fundamental de Cañete, o sea la presente GULA. Si bien se consignan en este libro datos contenidos en aquella editada el siglo pasado, abarcan aspectos y fases distintos, que establecen su individualidad inconfundible.

Guía histórica, geografica, fisicr, etc. de Potosí. Para dar conclusión a este breve comentario bibliográfico de la obra de Cañete, tiempo es de expresar que el excelente libro con que sc inicia la COLECCION DE LA CULTURA BOLIVIANA, contiens temas de indiscutible trascendencia para numerosas actividades mentales, cual Io anota el propio autor en sus Dedicatorias y Prospecto. Nada hay, en consecuencia, que añadir a lo dicho por el propio Cañete, sino recomendar al lector boliviano, detenga su atención en la iniciativa del Capítulo previo en que se expone el "Proyecto sobre la conveniencia que debe esperarse a beneficio del Rey y del Estado, si se agrega al Virreipato de Buenos Aires el Partido de Tarapacá, con el cerro de Guantajaia y su territorio, tirando la línea de demarcación por la Quebradì de Camarones", para admirar la 
supervision del autor por completar la estructura geográfica del Alto Per'ú, en aquellos días en que nadie paraba mientes en este factor determinante del progreso regular e ininterrumpido de los pueblos y de las naciones.

Don Pedro Vicente Cancte, on su GLit no ha tocado la historia política y militar de Potosi, pero ha dedicado sus empeños y su talento al estudio de los aspectos industrial y legal de aquella vida, cuyo elogio y comentrio corresponden a otro lugar. Resulta incuestionablemente un libro de consulta minucioso que junto con otras obras sobre Potosí, a poco conocidas por su impresión limitada o que se conservan en manuscritos, servirá como fuente de futuros estudios para que se cscriba la Gran Historia de la Villa, desde los díts iniciales de su esplendor pasando por los huctuosos de su recadencia $y$ los actiales de su renacimjento, acaso mús que en cl orden material, en sus proyecciones espirituales y morales. Pues, en este camino, debe soñalarse por honrosa y loable, su constante actitud patriótica clesde la spoca de la guerra de Independencia en cl curso de la vida rẹpublicana, en que la estrella potosina aparece refulgente en medio de las tempestades, en las que ha brillado con propia y pura luz, señalando las normas de la ley y de la justicia. Pero esto es historia contemporánea que no toca los lindes de los trabajos de Canete. Solamente se ha hecho la digresión en cumplido homenaje a ese pueblo de limpias tradiciones $y$ de portentosa vitalidad.

Para dar por concluídas estas apuntaciones bibliográficas, juzgo necesario referirme a los datos yic poseo de la vida del autor.

Hasta no hace mucho tiempo, los antecedentes genealógicos del doctor Cañete, se mantuvieron dcsconocidos. Su más acucioso biógrafo y más insigne admiradox, el internacionalista e historiógrafo don Fulgencio $R$. Moreno, logró coordinar algunos detalles que hicieron adelantar no pocos pasos en el conocimiento de la vida de su compatriota, aunque sin descorrer los espesos velos que cubrían su pasado familiar.

Cupo al incansable investigador de papeles antiguos y empolvados don Juan E. O'Leary, cumplir la fatigosa tarea de verificar aquellas informaciones y of recer noticias documentadas de la vida de Cañete, por muchos de sus aspectos y peripecias, emotiva a la par que disclitida ardientemente.

Su más lejano origen o antecedente fue mostrado a la luz pública en forma indirecta, mediante los estudios de Paul Groussac y Enrique de Gandía, en sus ilustrados comentarios y reproducciones de "La Argentina, estudio del descubrimiento, conquista y población del Río de La Plata", que escribió Ruy Díaz do Guzmán, y que en opinión del segundo de los nombrados es "la obra argentina, clásica por excelencia". Olvidó decir que era también alto-peruana.

¿Quién cra Ruy Díaz de Guzmán? Gandía, nos lo presenta con esm tas palabras: “. . Debió nacer entre los años 1558 y 1560 . Su abuelo era 
el célebre Gobernador Domingo de Irala, originario de la villa guipuzcoana de Vergara, y su abuela, una india de nombre Leonor. En cuanto a su madre era una joven mestiza paraguaya llamada Ursula, casada con un hidalgo andaluz: Antonio Riquelme de Guzmán. Este hiclalgo se casó con doña Ursula, de unos trece años de edad, para que lrala no le cortase la cabeza, a raíz de una conspiración. Historia extraña y dramática. El matrimonio así formado fue feliz. Ruy de Guzmán sentía orgullo de sus antepasados. No olvidaba que Alvar Cabeza de Vaca había sido tío de su padre... Lo indudable es que nuestro historiador hallóse ligallo a las familias más linajulas de Éspaña...".

Tratándose de ascendencia, el mismo Ruy Díaz, expresa al cedicar su historia a don Alonso Pérez de Guzmán, Duque de Medina-Sidonia, Conde de Niebla, Marqués de Gibraltar, etc., "aunque el discurso de largos años suele causar las más reces en la memoria ke los hombres, mudanzas y olvido de las obligaciones pasadas, no se podrá decir asi de Alonso Riquelme, mi padre, hijo ric Ruy Diaz de Guzmán, mi abuelo, vecino de Jerez de la Frontera, antigno servidor de esta antigua casa tan ilustrísima, en la cual habiéndose criado mi padre desde su niñez hasta los veinte años, sirvió de paje y secretario al Excmo, don Juan Alarcón".

Pero lo que más atañe a las letras bolivianas, es el origen y trabajo de la obra calificada "como la más clésica de la Argentina". Dice Gandia: ". . críticos han querido afirmar que Díaz de Cruzmin se vio en dificultades y aletró la historia, para explicar las luchas entre su abueIo Irala y el tío de su padre Alvar. Núnez. L'n examen atento de los hechos y de la obra de Díaz de Guzmán, demuestra que el historiador paraguayo no cometió ni injusticias ni tergiversaciones. Su obra es un modelo de sinceridad. Si cometió errores fue porque sus informantes le llevaron a ellos. Tomó la pluma inspirado por un fin noble. En las bibliotecas del Alto Perú leyó a los cronistas del tiempo y comprobó que en sus obras poco o nada se decia de nuestra tierra. El quiso reparar este olvido, esta omisión que hacía tanta injusticia a los esfuerzos de los Conquistadores del Río de la Plata, y empezó la redacción de su historia para que no se perdiese el recuerdo de la conquista...".

Después de algunas correrías colonizando, guerreando, gobernando, el año 1605 "se hallaba en la ciudad de La Plata para hacer constar. sus méritos y servicios. En Santiago del Estero tuvo unas diferencias con el gobernador Alonso de Ribera y se vio obligado a volver a La Plata. Allí comenzó a trabajar con intensidad en sus anales del descubrimiento, población y conquista de las provincias del Río de La Plata. Ia parte del libro que ha llegado hasta nuestro tiempo estaba terminada en el año 1612. A los dos años, el Virrey Marqués de Montesclaros lo antorizó a emprender la conquista de los indios chiriguanos. Era una empresa superior a cualquier fuerza en aquel entonces. En ella habian fracasado virreyes y capitanes. Los indios eran de los más indómitos de América. Díaz de Guzmán realizó prodigios. Con poco más de cien hombres fundó un fuerte y se sostuvo cinco años entre los salvajes. Su fin era unir el Alto Perú con el Atlántico a través del Chaco y del Guajirà . Ésa empresa pára aquet tiempo era cast menos que imposible y en nuestros días no se ha realizado completamente. Adenás, los virreyes del Perú no quevían gastar dinero en combatir a los feroces chiriguanos. "La empresa fracasó -continúa Gandía - y el autor de "La Argentina" decepcionado, volvió 
al Paraguay con el manuscrito de su obra cn la mano: única riqueza que había salvado para él y para su patria de todas sus andanzas y aventuras". Habia muerto en junio de 1629. "Con él se apagó el primer historiador natiro del Río de La Plata; el primer soplo de cultura argentina y paraguaya, y el último resplandor de la conquista heroica".

Sin entrar en mayores consideraciones, sostengo que la obra nombrada es de neto origen alto-peruano y está comprendida no sólo como "obra clásica de la Argentina" sino como elemento valioso de la cultura boliviana, porque fue concebida, encarnada, alumbrada y formada en suclo y cielo de este territor'io. Lo está diciendo el propio Gandía.

Pero volvamos a Cañete, este otro escritor nacido en Paraguay y que da su obra inspirada en acontecimientos de Charcas, en tierras altoperuanas igualmente. Por lo anotado y porque alguna vez lo expresó Cañete en sus escritos, Ruy Díaz de Guzmán, fue directo antecesor suyo.

Conlirmando datos consignados por' don $J$. Toribio Medina, en el tomo tercero de su Biblioteca Hispano-chilena, don Juan E. O'Leary, proporciona nuevos detalles documentados $y$ dice: "En el volumen 129, números 22-25, letras A-Z del Archivo de Asunción, puede leerse el testamento de un hermano del doctor Pedro Vicente Cañete. De este documento resuita que José Ignacio Cañek, vecino de la capital, era también doctor e hijo legítimo del sargento mayor José Cañete, Regidor propietario de Asunción, y de doña Juana Catalina Domínguez de Obelar. Y con ésto queda aclarado el origen de nuestro compatriota. Sabemos dónde nació y quienes fueron sus padres. $Y$ hasta sabemos que no fue el único doctor en su familia".

Prosigue: “...ambos hermanos nacieron en Asunción; poseían una tierra en condominio en Paraguay; Pedro Vicente tuvo a su cargo la librería del Colegio Carolino hasta el 10 de febrero de 1783".

Había emigrado joven de su patria, para completar su educación. "Estudió tres años en la Universidad de Córdoba del Tucumán, y se graduó de licenciado en Teología en la Tinversidad de San Felipe de Santiago de Chile, en la que regentó la Cátedra de Teología como sustituto durante los años 1773 y 74 . En 1776 recibió el nombramiento para la Cátedra de Artes. Cañete y Domínguez se recibió también de Abogado en Santiago, donde sirvió de Asesor en algunas causas al Presidente Jáuregui, y de Protector de indígenas. En 1777 pasó a Buenos Aires, desempeñando los cargos de Auditor y Asesor del Virrey", informa don Toribio Medina.

A su vez, don Gabriel René Moreno, anota: "No sé por cuales eventos pasó muy joven Cañete a seguir estudios universitarios en Santiago, o más bien a proseguirlos. Según el libro de "Matriculas de estudiantes en la Universidad de San Felipe (Biblioteca Nacional, departamento de manuscritos, volumen 6-C) el 9 de dicjembre de $177 \%$ se inscribió para concluír Teología y comenzar Leyes. El $1^{\circ}$ de octubre de 1776, Cañete se recibió aquí de abogado con la suficiencia que para ello le daban sus diplomas de bachiller en Cánones y en Leyes (junio 11), y con el título de licenciado y doctor en Teología que había obtenido en 13 de febrero de 1773; esto último no $\sin$ haberse recibido previamente, como era regular, de bachiller en dicha asignatura el 8 de enero y 5 de febrero de dicho año. El 2 de octubre de 1776, al día siguiente de haberse recibido de abogado, obtuvo la Cátedra de Artes a que se había opuesto unos tres y medio me- 
ses antes en concurrencia con otros. Vêase la Biblioteca Niacional, volumen 493 entre los pertenecientes al Alchivo de la Real Audiencia". (Moreno: Biblioteca Peruana, pág. 572).

Su permanencia en Chile, fue después, por pocos meses. Pasó de allí a Buenos Aires, donde se iniciaban las labores del Virreinito. Ingresó de lleno a la vida pública como Asesor General y Auditor de Guerra del Primer Virrey, don Pedro Zeballos. Sustituído éste por' el Virrey Vertiz, abandonó la capital dirigiéndose al Paraguay con igual cargo de Asesor. El Cabildo de Asunción dio información al Virrey de Fuenos Aires, en 13 de enero de 1782, del siguiente modo: "D. Pedro Vicnte Caniete, nuevo Asesor de este gobierno, se presentó an este despacho el $7 \mathrm{de}$ diciembre $\mathrm{pp}$, de cuyo empleo tonó posesión el mismo día, habiendo procedido al juramento de fidelidad relativo al buen procedimiento de su $\mathrm{Mij}$ nisterio en los casos que ocurran...".

Todos los documentos hasta ahora conociclos, con singular uniformidad, nos hacen saber que el comportamiento, accion y vida de Caniete en el pais de su nacimiento, en aquella época de su Asesoría, fue lucido, austero, ejemplar, captando a favor suyo el respeto $\mathrm{y}$ la estimación generales.

Natalicio González, ex-Presiciente del Paraguay y cultísimo escritor de la historia de su patria, trae a colación a esta etapa de la vida de Cañete un testimonio del Gobernador de la provincia, concebido en estos términos: "...habiendo Cañete despachado muchísimos y giaves negocios, en que tenían parte algunos parientes suyos, ha prevalecido la justicia de los extraños, portándose con tanto ejemplo en su vida y costumbres, que con estar en su patria, nadie le la recusado legitimamente, ni se ha interpuesto más que seis recursos de lo sentenciado con su parecer".

Pero como nadic es profeta en su tici'la, dejó el 'araguay en 1784, con ocasión de desempeñar otras funciones públicas a que se le invitara un año antes. Formada su personalidad, maduro de juicio, pleno de experiencias, conocedor de las pasiones humanas, diestro on la hermencutica administrativa, se alejó de su solar nativo, para no volver nunca más.

Llegó a la Villa potosina para asesorar al Goberuador Francisco de Paula Sanz. Su estancia se prolongó por años. De su actividad son elon cuente demostración los numerosos escritos, extensos y variados, que hubo de elaborar, casi en lucha abierta con letrados, vecinos, industriales de la minería y toda clase de gente $\mathrm{y}$ en todo género de asuntos. Socialmente ocupó sitial honroso y respetable, fundando un hogar a base de un casorio con dama de alcurnia, poseedora de holgada fortuna. Tuvo tres hijos: dos mujeres, una de las cuales desposó con un encumbrado funcionarjo español de apellido Ibarnegaray; la otra vivió soltera hasta avanzada edad, en que falleció en Chuquisaca, según dato de don Gabricl René Moreno. Del hijo varón, existen estas noticias: Cañete, en un memorial de remisión de cierto dictamen elevado el 31 de diciembre de 1796 al Snberano, a propósito del Patronato Real, escribía: "Entiendo que sin revocar muchas leyes reales, no es sostenible el caráctel' a que aspira el Presidente (de la Audiencia de Charcas). Yo nada intento que no sea de vuestro soberano agrado, por más conducente al Real seivicio de V. M. No tengo en la causa más interés que el de un criado honrado pos la felicidad de los países de su amo. Mi úmico hijo se halla por gracia de V. M. 
sirviendo de cadete del Regimicnto de Dragones de Buenos Aires, sin pretensión de curatos (esto a propósito del Patronato), ni otros beneficios eclesiásticos. El Reyno cntero es testigo también, que jamás me he ingevido en cstas crapulosas colocaciones; sabe la pureza de mi manejo; y ha visto consumir: mis sueldos y mi patrimonio on el trato decoroso de mi empleo, y de mi fanilia, sin tocar on lo ajeno, sino para mejorar su fortuna, con la Administración de justicia". Este explicito y fidedigno documento suscrito en La Paz, aclara sin lugar a dudas, lo referente al hjjo de Cañete.

Pasado al tiempo, los enconos crecieron contra el Ascsor y se hizo insoportable su vivir en Potosí. No cran suficientes su actividad y su talento para contrarrestar la campaña pertinaz que sus enemigos descargaban contra el funcionario, el abogado, el escritor: y el irreductible adicto a la causa del Rey. Optó por trasladarse a Chuquisaca cuya Audiencia presidia D. Ramón García Pizarro, varón de luengos años, que ni en su vida militar demostı́́ entereza y coraje. Entre la Corporación y su jefe se había roto toda armonía, porque la prepotencia audiencial pretendía erguirse por sobre las determinaciones de su Presidente, aun en çuestiones de menor importancia o de simple lormulismo. Cañete llegó a la ciudad, en tal coyuntura, para descmpenar sucesivamente dos cargos de responsabilidad e influjo: la Asesoría y luego la Secretaria de la Presidencia. Comenzó por ganar a favor suyo la voluntad de Pizarro y su estimación. Sus consejos estaban enderezados a levantar el ánimo de su jefe, menoscabado en su autoridad y en sus prestigios. Lógicamente el espíritu turbulento de Cañete produjo el enojo y la animadversión de los engreidos Oidores, a extremo de pronunciarse en un voto expreso de extrañamicnto contra el audaz conscjero foráneo. El Virrey Liniers, amparó en esta emorgencia a Cañiete y pudo restituírse a la sede de sus funciones, para provocar con distintos motivos y por caminos diferentes que su intransigencia solía encontrar, justificativos al ardoroso fermento revolucionario de los nativos que projiraron la gesta del 25 de mayo de 1809.

Envuelto en las brasas del actirismo, salido de Chuquisaca, acompañó y colaboró a Goyeneche en su trágico paso por cl Alto Perú. No solamento fue su secretario, sino su consejero. En Cochabamba formó el nefasto Comité de Pacificación, donde en compañía de aquel perverso Mendizábal e Imas, aconsejó los saqucos, persecuciones y matanzas de los patriotas. Esta es una mancha en la conducta de Cañete, denunciada en la prensa de la época y nada hay que arguiir en su favor.

Cambiaron después los acontecimienos en el Alto Perú. Las fuerzas organizadas al servicio de la emancipación triunfaban. Cañete, al arribo de Juan José Castelli, Delegado de la Junta de Buenos Aires, anduvo fugitivo. Pero el jefe argentino había tomado buena nota de la conducta del antiguo Asesor y lo condenó a destierro con la pena de confíscación de sus bienes. Medida nominal porque Cañete ya no tenía bienes y no pudo ser apresado.

Rastreando cicrtas referencias, se sabe que después se refugió en la región de Copacabana, fronteriza con el Bajo Perú, dada su situación cacla vez más azarandeada. Falto de recursos económicos ambulaba sin rumbo y $\sin$ esperanzas. Ocasión hubo que pidió auxilio al Brigadier Ramírez, quien conociendo la habilidad intelectual del paraguayo letrado, 
le encomendó redactar la crônica de sus campañas militares y las de su pariente Goyeneche; sin haberse llevado a término, por oposición del Virrey.

Y aquí, conviene pensar que el fanático "lealismo" de Cañete acaso se debio sobre toda otra razón a su estado económico precario y hasta desesperante. Sus petitorios al Virrey de Lima como a los jefes realistas, pecan por su tono humilde y sumiso que lastima su personalidad. Sus dificultades materiales no daban lugar a rubores.

En 1814 logro retornar a Chuquisaca, cuando las fuerzas de la dominación hispánica parecían reaccionar. Allá desempeñó el cargo de Rector de la Universidad Carolina, con severidad desmesurada antes que eficacia. Luego, sobrevino su decadencia. Llegaba al ocaso de su vidia. Las contingencias de la campaña libertaria le obligaron a retracrse, tanto que no existen noticias sobre sus últimas actuaciones. Fallecio el 21 de Enero de 1816 , repentinamente.

Cañete ha de ser discutido todavía en los campos de nuestra historia. No faltarán plumas que lo defiendan y escritores que lo condenen inflexiblemente. En definitiva, es de presumir, que brillará en el recuerdo de nuestros estudiosos por su talento más que por su vida contradictoria y borrascosa.

Ia Paz, septiembre dz 1952.

León M. LOZA

\footnotetext{
1.- Para complementer lo anotado por el Sr. Alba, y confirmar el dato del investigador Lohmann Villena sobre el arrepentimionto del Padre Miguel de Agia, do haber tacrito a favar de la mita en sus "Tres Pareceres" editados por primera vez en Lima en 1604, juzgo interesanfé trascribir un comentario bibliográfico to le época, que dice textualmente:

"Imprimióse este tratado (Los tres Pareceres) con licencia del V. y aprobฉción del lic. Joan Ximenes de Montalvo, y Dr. Arias de Ugarte, oydores de Lima y Fray Benito de Huerta, Guardián de $S$. Francisco por comisión del Virrey. También dió su licencia a Fray Joan Benido, comisario de Sant Francisco en el Piru. Juntáronse en confirmación de los pareceres del padre Agia el lic. Francisco Núñez de Bonilla, D. Francisco Fernández de Córdova, el lic. don Diego de Avila Falcón, el maestro Antonio León de Garavito, el lic. don Luis de Córdova, el lic. Acuăa Otivera, el lic. don Juan de Zúñiga, el bachillex Andrés de Poso Maseote, el bachiller Joan de Vergara Zamudio, el bachiller Miguel Cornejo, todos los del colegio de San Marcos y San Phelipe de Lina. De eclesiásticos el Dr. Muñiz, Dean de Lima, Fr. Joan de Montemayor, comisario que ha sido de San Francisco; el d. d. Joan de Velásquez, Arcediano y comisario general de la cruzada, Fr. Diego de Pineda, provinciak que ha sido de San Francisco; el Dr. Matheo González de Paz, Maese de escuela, el dr. Miguel de Salinas, provisor; el dr. Carlos Marcelo, canónigo de ia Magistral y catedrático de visperas de theología; de los seglares el Dr. D. Francisco de Sosa,
} 
cathedrático de prima de cánones; el Dr. Feliciano de Vega, ubogado y cathedrático de vísperas de leyes; el Dr. Cipriano de Medina, abogado, el lic. Delgado, abogado y el lic. I'ardo del Castillo, abogado".

Dase cuenta de esta impresión, en los siguientes términos, en el manuscrito citado: "Defensa de los Indios en la causa y labor de las Minas consagrado a intpugnar estos "Pareceres", haciendo ver la inconsecuencia del P. Agia, que sostenía ser Jegitima y natural la compulsión de los indios a la labor de las minas, con excepción de las de azogue, fundándose el citado Agia, en lo siguiente: 'Después de aver dado ha los lareceres de su uso, por descargo de la real conciencia de su Magestad y mía, por el mes de mayo del año pasado de 1603 , fú a la villa de Gugncavelica y entré en el dicho sockavón grande en compañía del licenciado Pedro García, clérigo, presvítero y de Marcos García su hermano, mineros antiguos de aquel cerro, $y$ del veedor, hasta bajar al plan en profundidad de ciento cincuenta estados poco más o menos, y vi por vista de ojos la labor de dicha mina y de Sant Jacinto, $\mathrm{y}$ en el modo cono trabajaban los indios y considerando el lugar y su gran profundidad, y la malicia y viscosidad de los metales y el humo espesisimo de las velas de sebo, la angostura del lugax, la corrupción del aire catusada por el sudor de los cherpos y otras inmundicias y viscosidades, e] polvillo rque sale de los metales con los golpes de las barretas, la falta de respiración que allí tienen los indios, por no poder colar el aire, la subida inmensa hasta la boca del socavón, con la carga de metales por tan prolixas y empinadas escalas, el aire delgadisimo $\mathrm{y}$ frio, quando salen cargados y sudando, el agua frigidisima que beben con el grande calor que traen, la comida que toman de tan poca sustancia, el peso de tan gran trabajo, el peligro de despeñarse, la poca y casi ninguna seguridad de puentes $y$ estribos que tiene el dicho socavón, y finalmente los muchos millares de indios que tienen muertos y sepultados, sin otros muchos que están para morir, y todos los demás daños que a los dichos podria acumular, los cuales constan por infornaciones jurídicas que están hechas, digo y es mi parecer por lo que he visto por vista de ojos que tiene obligación el Rey, nuestro señor, y el señor Virrey en su númbre, de mandar cerrar el dicho socavón o quitar las primeras escalas, para que no se pueda entrar dentro de él, para de esta manera evitar tan gran destrozo y daño de muertes inevitables, como se les siguen a estos miserabics y desventurados indios, ansi por tener S. M. al presente azogue en bastante cantidad para algunos años, como por haber otras minas junto al socavón en cuya labor se ptedan ocupar los indios, como también por la ocasión que hay de echar indios al desmonte, para que descubran alguna gran riqueza de metales, los cuales puedan labrar a tajo abierto o de otra manera que no sea de daño tan grande e inevitable para los indios como el dicho socavón y siendo en Dios y en mi conciencia que no tiene bristante núnero de indios el Rey, nuestro señor, en todas las provincias del Piru y Nueva España para los que consumirá y acabará en brevísimo tiempo el dicho socavón, pues de algunos años a esta parte se ha visto y se ve por experiencia que todos los indios que entran a hacer la mita en el y andan en su labor, salen irremisiblemente condenados a muerte, y aunque algunos mueren luego otros tardan más tiempo, es cosa cierta que ninguno llega a los tres años de vida y en los cuales es tan cruel la enfermexlad que padecen, que quisieran los indios morirse antes que padecerla con tan graves dolores y congojas, y esto me parece salvo la censura, \&. Fr. MIGULL DE AGIA",

2.- l'or lo general se tiene la creencia de que el universalmente conocido Potosí, no tiene escrita su historia, no obstante haber asombrado al mundo con el prodigio de sus inmensas riquezas. Si hien es cierto que ninguna historia de los países americanos ha dejado de tomar en cuenta la abundancia de los tesoros del Cerro Ríco y la largueza de su reparto en el Nuevo Mundo y en Lspaña, es verdad que no se ha escrito una obra que abarque el estudio detallado de todas las actividades y vicisitudes de su intensa vida económica, industrial, social y política. Las historias publicadas $\mathrm{y}$ sobre todo las inéditas, son numerosas, pero fragmentarias o parciales. No dejará de ser interesante, por esto, hacer una enumeración bibliográfica, de todos modos incompleta, pero que dará una idea de Io que se ha escrito sobre la existencia potosina:

"Historia de Potosi", por Bartholomé de Dueñas, citado por Orzua y Vela.

"Grandezas de Potosi", por Bernardo de la Vega.

"Relación de las inquietudes y alborotos de la Villa de Potosi", desde el 8 de junio de 1620 hasta el 20 de marzo de 1625 .

"Relación de las Guerras Civiles de Potosi", dirigida a S. M. Felipe IV, por Juan de Medina. 
"Historia de Potosi", por el Capitán Pedro Méndes.

"Felipe de Godoy a Felipe III: Cuenta del estado de las minas de Potosi".

"Cantos" sobre la historia de Potosí, por el poeta Juan Sobrinc.

"Historia de Potosí", por Juan de Pasquier.

Se han referido en sus libros, en foma extensa, a Potosi, los siguientes autores: José y Antonio Acosta, Garcilaso de la Vera, Ramos Gavilán, Zírate, Gomara, Illescas, Herrera, Cieza de León, Calancha, Argensola, Las Casas y muchos otros.

Los Virreyes y las altas autoridades de la colonia: oidores, visiludoros, corregidores, intendentes, consejeros, ete., cuando informaban sobre asuntos relacionados a sus funciones oficiales, se obligaban a tocar las actividades de Potosí, centro importante como el que más en esa ćpoca. Muchos de esos documentos conticnen noticias de primera nano, como la "Relación" del Marqués de Montcsclaros glue reristra el relato integro de Anbrosio Maldonado, mereedario, visitador de su Ordon, gue está euajado de datos sobre el estado de la Villa, sobre todo en el aspecto social, constituyendo una especie de álbum biográfico del vecindario prineipa]. Otros como el General Miller dan cabida en sus "Memorias" a relaciones sobue hechos y episodios de Potosí o sobre su estado industrial y su erecimiento urbano.

Los archivos de España y de América, ofrecen len caudal emorme de documentos sobre l'otosí. La revisión que he hecho de catálogos me lleva a calcular en cerca de dos milares de títulos referentes a dicha Villa, a lo largo de su existencia. He aquí, algunas citas, por vía de ejemplo: Los hermanos Salazar Cabrera, uno de ellos descubridor de Guancavelica, presentaron hacia 1551 un memorial a nombre de los mineros. Pinelo los cita sin detalles así como Fexuando Montesinos en sus: "Momorias antiguas y modernas del Perú". El florentino Nicolás Benino, dueño del socavón de su nombre, en el último cuarto del siglo XVI, hace ung relación mu particular del Cerro y minas. En otro manuserito elevado al hey se ocupa de "las cosas más convenientes a Potosín. El Harqués de Casa l'izar'o habia es cito una obra sobre las posesiones de España en América, en que se refiere a Potosí. l's sabiilo rive ese manuscrito está en poder de los herederos. Don Juan Davila, Corregidor y Visitador de Charcas y Potosí, en encro de 1573, dejó una "Relación de las minas que hay en el Cerro Rico de Potosí.

Nada habrá que decix, por esta rez, de libros importantes y cimeros como la Historia de la Villa de Patosí por Bartholomé Arran\% Orsua Y Vela; El Arte de Metaleg del Padre Alvaro Aloriso "Barbä; Tos escritos sobre metaluria de Velasco y los informes, disposiciones, sistemas de organización adninistrativa de don Jorge Escovedo y Alarcón y del Intendente Goberrador Ventura Santelices y Venero.

Como acotación final ofrecenos los siguientes datos que nuestras últimas investigaciones nos han dado, referentes a la familia $\mathrm{y}$ descendientes de don Pedro Vicente Cañete:

La hija casada en Potosí, resulta ser la señora Josefa Cañete, que al fina. lizar el siglo XIX estaba cerca de alcanzar cien años de vida. Dejó la prole gue a continuación se apunta: Juana Baez Puch Cañete de Ibarnegaray; Josefa Baez Puch Cañete de Urriolagoitia; Remedios Baez Puch de Prudencio; Francisco Baez l'uch Cañete y Ranón Baez Puch Cañete.

Hijo de la señora Renedios fue el poeta Almanzor Prudencio. El Arzobis. po Don Peciro Puch, perteneció a otra rama de la misma familia. Posiblemente era hexmario de doña Josefa Cañete; dícese que llevaba como apellido ruaterno el de "Cañete".

La señora Juana Baez Puch Cañete tuvo la siguiente descendencia: la hija mayor se llamaba Virginia, casada con un español que viajó a la Península para establecerse. Los dos hijos de ese matrimonio se trasiariaron también a España. Otro hijo suyo llamado Pedro, casó con Doña Zoila Reyes Ortiz, hija del conocido escritor Félix Reyes Ortiz. Murió hace varios años. La viuda vive en La Paz. Hermano de Pedro, fue Felipe, casado por tres veces. La primera esposa de apellido Quesada, le dio una hija de nombre María, que se crió en la casa de la señora Juana; la segunda esposa del indicado Felipe era doña María Urquidi Linares, majer de singular belleza. Falleció dejando tres hijos: el mayor, Enrique, que se matrimonió en Santiago de Chile; ahora vive en Sucre; la segunda, Graciela, que acompaña a su anciano tío Don Julio Urquidi; Ia tereera, llamada María, que no conoció a su madre -que fallecio al dar a $\mathrm{luz}_{\text {- ha }}$ hrofesado de monja en las Adoratrices; vive en el Convento de esta ciudad con el nombre de Madre Sofía. La tercera, esposa de Felipe, fue una señorita de Fotosí, apollidada Heredia. Dejó descendencia. 
Un otro hijo de la señora Juana, es Miguel, matrimoniado con la señora María Gutićrrez Guerra, hermana de don José Gutiómez Guerra, que fue Presidente de la República.

La euarta deseendiente cra la señora Angela, casada con Don Imilio BoneI, gerente de ull Banco. Ambos fallecidos. Dejaron dos hijas: una, llamada Angela, que casó con ur señor Ballivín, cuya hija se llarja Maria Teresa; la segunda hija es doña Blanca $v$ de Bosanic, hesidente en Londres, con tres hijos jôrenes.

Til quinto hijo se llamó Alfiedo. Casó con la señora Angélica Aramayo Arrieta; ambos han fallecido. Hijos del matrimonio fueron Afredo, muerto hace poco tiempo; Raul, casado en Oruro, ralleció en la gruerra dol Chaco.

El scxto hijo era Juan, casado con la señora Judith l'eraja (peruana), sobrina dol Du. Vaca Guzmán. Juan falleció dejando los siguientes hijos: Juana, soltera; Judith, casada con el Dr. Quintanilla (Eduardo), residente en esta ciudad. Otro de los hijos de nombre Fdundo, matrimoniado con la hija de un diplomático.

La séptina hija de doria Juaria se llamó María, casada con Don Roberto Tavolara; ambos fallecidos. Son hijos de este matrimonio: Robcrto, casado con la senora lisena Montes, hija de don Ismael Montes; René, casado con la señora Arana; Elviua, unida er matrimonio con Don Gastón Mujía, y Aida, casuda con el Sr. J. Llovet. - L. M. L.

Nota do Edición. - I'osiblemente por no hacer más extensa su enumeración el señor Loza no ha tomado en cuenta los siguientes escritos de Cañete que figuran on las listas de su interesante Archivo:

"Bando de proseripción dictado por" la Junta Provisional Gubernativa de Buenos Aires,- Castelli.- En el Cuartel General de La Plata, a is de enero de 1811". Copia del original que se conserva on el Archivo General de Indias. El expediente del proceso se encuentra en el Archivo del señor Loza.

"Doeumentos" en siete piezas distintas relacionadas a asuntos de la Audiencia de Chareas. Copias de originales que pertenecen al Archivo de Sevilla. No están publicadas sus 33 páginas.

"Proclamas" dirigidas por Cañete a los pueblos del Alto Perú, en defensa de la Corona de España. Copias, como las anteriores, procedentes del Archivo General de Indias, en número de 40.

"Bio-bibliografía de I'. Vicente Cañete y Dominguez", copia en 27 párinas, folio. Los originales se conservan en el Archivo General de Indias.

"Otros Documentos varios". Copias de documentos varios referentes a Cañete, adcuiridos especialmente por el señor Loza y cuyos originales están en la Biblioteca Nacional en Lima.

Con datos recogidos de otros escritores podemos añadir a la bibliografía de Cañete, los siguientes títulos que no están comprendidos en la colección documentai del señor Loza:

"El Clamor do la Lealtad Americana en defensa del Consejo de la Regencia contra los actos revolucionarios de la Junta de Buenos Aires". Cita de don Gustavo Adolfo Otoro, en "Potosí Colonial", libro antológico de la "Biblioteca Boliviana", La Paz, 1939.

"Espectáculo de la Verdad". Importantísimo documento que contiene provechosos datos y detalles para el enjuiciamiento del fenómeno 
emancipador en Chuquisaca. Don Gabricl René Moreno, que ha comentado el escrito en sus libros, dice: "Respecto de las querellas de $1808 \mathrm{y}$ a noticias sobre las anteriores desde la venida de Cañete a Chuquisa. ca, la mejor guia es el ESPECTACULO DE LA VERDAD, que vale por una confesión de parte, si, como parece indudable, es folleto escrito por el mismo Cañete". "Ultimos Días Coloniales", página 142. Edición: Imprenta Cervantes, Santiago de Chile, 1896.

"Proscriptores". Papel polémico del año 1809, del que escribe en su meritísimo libro "Uitimos Días Coloniales" (Pág. 212 de la edición chilena (le 1896) don Gabriel René Moreno, lo que sigue: "MS. varias veces citado, y acerca del cual es tiempo de dar breve noticia. Es un fo. lleto escrito con el mismo carácter de letra del FSPECTACULO DE LA VERDAD, letra que veo también en algunos borradores de la secretaría de Pizarro. Es debida su composición indadablemente a la plama vigorosa de Cañete, como que se ocupa lo más en el asunto del destierro de dicho letrado por los Oidores, aquel destierro de Chuquisaca suspendido por Liniers y reiterado por aquellos, etc. Contiene algunas referencias, por desgracia demasiado incidentales, a la gran querella de las autoridades de la ciudad en 1808. Paréceme que este folleto ha debido de aparecer poco antes del 25 de Mayo".

"Ensayo sobre la conducta del Gencral Boliza" $y$ "Disenrso Histórico Cronológico sobre la Fundacion de Puenos Airs", publicaciones mencionadas por don Gustavo Adolfo Otero.

Tenemos el convencimiento de que muchísimos escritos más de Pedro Vicente Cañete quedan por descubrir en los archivos de Potosí (Casa Nl. de Moneda), Sucre (Nacional), Buenos Aires (General de la Nación), Santiago y Lima (Nacionales), en nuestro continente; y en Sevilla, Madrid y París, en el viejo mundo, como nos ha demostrado Marie Helmer. Por otra parte, el probo investigador don Humberto Vázquez Machicado, nos decía recientemente, que tiene muchos datos e informaciones sobre los últimos años de Cañete, que servirán para un estudio biográfico que el distinguido hombre de letras se propone escribir.

Se han ocupado de Cañete, de su actuación pública y de sus abras, entre los más notorios escritores y pensadores: Gabriel René Moreno, en sus "Ultimos Días Coloniales", "Catálogos" y "Notas Históricas"; Nataniel Aguirre, en su novela "Juan de la Rosa"; Luis Paz, en "Historia de la Universidad de San Francisco Xavier"; Juan Ram̃ón Muñoz Cabrera, * en su "Historia de la Guerra de 15 años"; Valentín Abecia, en "Hístoria de Chuquisaca"; Gustavo Adolfo Otero, en "Potosí Colonial"; todos ellos escritores bolivianos. Del Paraguay: Fulgencio R. Moreno, en su estudio biográfico de Cañete; Juan O'Leary, en sus comentarios históricos y Natalicio González, en varias de sus obras biográficas. En la Argentina: Mariano Moreno en sus réplicas en defensa de la causa patriota y en sus estudios sobre el trabajo minero; Ricardo Levene, en "Vida y escritos de Victorián de Villava" y Pedro Juan Vignale en "Estudio de los historiadores coloniales de Potosi", Rev, de la Universidad de Buenos Aires. En Chile José Toribio Medina, on sus libros cie historia. En el Perú el R. P. Rubén Vargas Ugarte en "Manuscritos peruanos en las bibliotecas del extranjero" y Jorge Basadre, en "El régimen de la mita"; En Francia: Louis Baudin, en su "Imperio socialista de los Incas"; Raoul d'Harcourt, en "Platería peruana en la época colonial" y Marie 
Helmer, en "Historia de un manuserito". Esta última, distinguida y paciente investigadora que el pasado año ha publicado una referencia puntual y admirable de Potosí y de Cañete, en el tomo XL de "Journal de la Societé des Americanistes", que sc edita en París.-A. Albr.

la Argentina.

* A Muñoz Gabrera, lo consideramos como escritor nuestro aunque nació en

A continuación, como complemento indispensable a este libro, reproducimos las partes esenciales del expediente inédito formado con motivo de las gestiones que hizo Doña Melchora Pérez Prudencio, viuda de Don Pedro Vicente Cañete, solicitando un montepío en vista del estado de indigencia en que quedó y a mérito de los muchos servicios y.lealtad de su esposo a la causa del Rey.

Este documento que contiene el certificado de óbito de Cañete, las instancias de la viuda requiriendo ayuda monetaria y los pronunciamientos de las autoridades, nos informa claramente sobre la suerte lamentable del celebrado escritor y funcionario en los días de su madurez hasta su fallecimiento $\mathrm{y}$, luego de sus deudos, caídos en desgracia. (Nota de A. Alba). 


\title{
INFORME DEL VIRREY
}

\author{
(Archivo General de Indias en Sevilla) \\ Audiencia de Lima. - Signatura antigua $110-7-22$ \\ " moderma: Legajo 762 .
}

/F. 1 ,

/Numo, 1:?,

El Virrey del Perú, informa la deplorable constitn. en que bá quedado la familia de Dn. Pedro Vicente Cañete, uno de los Ministros, q. mas se ha distinguido en el Servo, de la Nación, $p^{a}, q^{e}$, se digne $S$. M. aprobar la pensión interinaria qe. le señaló el Gral. del Alto Perú.
ACOML'AÑO a F, F. la instancir Jocumentada de b:t. Melchora l'erez I'rudencio, Viuda tle Dr. Tedro Vicente Cancte, antiguo Asesor de Jotosi, Oidor honomario de la Audiencia de Charcas, Fiscat intizerino de ella aprobado por S. M., y trastarlato de Oidor a Quito, para que la boneficencia de $\$$. M. se digne confirmar la pensión de norenta pesos nensuales, lane le scñaló el Geneval bu. roaguín de la l'ezuela interingumente para auxilio de su subsistencia, y la de una hije lexitina infatuada llanada Dolores, que háa quedado huérfana, $y$ sin mas armparo que de una hernana suya Vilifla tam pobre cono ella.

Es muy digna del Real amparo, la familia de ur Ministro, tan esclarecido por su sabiduria, sus luminasos Escritos $y$ sus mohos servicios a la Nación, $y \sin$ mis esperanze pue este caritatio socorro de la IReal mano. No habiendo sido mas que un Fiscal interino de la Audiencia de Chareas, y que no entró en la posesión de ella cono propietario, aungue esta fué una de las gracias y limpleos que contirió el Gart. Inn. José Manuel de Goyeneche, $y$ se dignó S. M. aprobar en resulta de la recuperación de aquella Provincia, se le ha consiclerado excluida de los beneficios del montepio de Ministros; mas se cree no menos digna de una pension que el Soberano ha dispensado muchas veces a la Viuda e hijos de huenos servidores a la Nacion, gue no han hecho ventaja a Cañete; y mas cuando en el mismo Iueblo en $q^{*}$. ha brillado por sus meritos, se be mendigar su familia, especialmente la hija fatua, que no ha disfrutado, sino una pequeñisima parte del auxilio herogado hasta ahora / a lo Viuda su Madrastra. Digneze V. F. elevar a la consideracion de S. M. las eireunstancias de ella, para la dispensación que sc solicita.

Dios gue. a V. E. me, as. Cuzco Sever. 15 de 1822.

$$
\text { Exmo: Sor. }
$$

José de la Serna (Rubricado). 


\section{CERTIFICADO DE OBITO}

Yo el infraseripto Escrivano, cumpliendo con lo pedido, y mandado, hice sacar, y saqué los testimonios del Expediente que se indica, cuyo tenor a la letra, es el siguiente.-

Certifico, Yó el Doctór Don José de Oliveros, Cura Rector de esta Santa Iglecia Matriz de esta Villu, Comisionado del Ilustrisimo se-

/F. 2. nor / Doctor Don Benito Maria Moxo y Francoli, Dignisimo Arzobispo de la Plata, del Consejo de su Magestad: como er un libro forrado con badana colorada, donde se sientan las partidas de entierros mayores de Españoles, que empesó á correr el seis de Septiembre de mil ochocientos tres, a foxas doscientas quarenta, y siete se halla entre otras la partida firmada por el Doctor Mon Mariano Vasquez, Teniente de Cura de aquel tiempo, aue sacada á la lẹtra es del tenor siguiente.-

S. D. D. Pedro Vicente EN el año del Señor, mil ochocientos diez y Cañete de 60 años. seis, a veinte y tres del mes de Enero, murió en su casa, y en la Comunion de Nuestra San-

ta Madre la Iglecia, el Señor Doctor Don Pedro Vicente Cañete, Oydor honorario, $y$ Fiseal de la Audiencia de Chareas, al parecer de edad de secenta años. Casado que fué con la Sefiora Doña Melchora Perez Prudencio, no tubo lugax para testar, ni hacer otra alguna disposición, por

/F. 2 v. que muríó repentinamente: su Cuerpo fué sepultado el dia / siguiente con Oficio solemne en la Iglecia de Nuestra Señora de las Mercedes de esta Villa. $Y$ para que conste lo siento, y firmo.- Doctor Mariano Vasquez.- Concuerda con el original de su contesto, á que en caso necesario me remito. $Y$ á pedimento verbal de la parte, di esta en Potosí a nuebe de Febrero de mil ochocientos diez y seis años.- Doctor José de Oliveros.-

\section{CUOTA DEL MONTEPIO EN FAVOR DE UNA DE LAS HIJAS DE CAÑETE}

\section{Carta.}

POTOSI, y Octubre diez, y siete de mil ochocientos diez, $y$ siete.- Muy Señor mio: De los noventa pesos que me debe suministrar mensualmente la Real Caxa de su cargo, se servirá separar diez, y seis pesos mensuales para Doña Dolores Cañete, mi Hijastra, y cada seis meses cinquenta pesos para su vestuario; de modo que del total que al año me corresponde, le resulte trescientos pesos de alimentos. $Y$ como quiera que este dinero le tengo afianzado hasta las resultas de Su Magestad por lo respectivo á la Cantidad asignada á dicha Doña Dolores son fiadores sus hermanas, y por ellas

/F. 30. sus naridos, lo que se expresa para / evitar enrredos en lo futuro.- Dichos diez, y seis pesos mensuales, se dignará Usted entregarlos á su hermana Doña Catalina desde el mes que se me debe, para que le pueda suministrar sus semanas, $\mathrm{y}$ lo mismo en sus respectivos tiempos los cien pesos que al año se le destinan para su vestuario. Para constancia le paso á Usted esta Carta firmada por mi, y por su Cuñado el Señor Don Manuel Antonio Baez.- Deceo que Usted se halle sin novedad, y de que me mande como á su afectísina servidora que Besa sus Manos.- Manuel An- 
tonio Baez.- Melchora Perez Prudencio.- Señor Ninistio Contador Don José Maria Sanchez Chaves, - Asi consta de la referida Carta original de su contesto, con la que ba cierto, y verdadero, corregido, y conceriato, á

/F. $30 \mathrm{v}$. que me remito. Y para gue conste autoriso, y firmo en Potosi, y / Enero diez, y nuebe de mil ochocientos veinte y un años, siendo testigos Don Evaristo Barroso, Don Jośa Simón Fonseca, y Patrieio Callejas presentes.- José Estevan Fonseca.-- Fscrivano de I Iacienda l'ublica.

\section{FIANZA PRESTADA POR LA CONDESA DE CASA REAL DE MONEDA, PARA}

\section{LAS RESULTAS DEL MONTEPIO SOLICITADO}

Decreto loTOSI, Diciembre veinte $y$ flos de mil ochocientos veinte.- Informe el Ministerio prin-

eipal de Hacienda Publica.-.- Huarte.-.

Informe. SENOL Governador Politico._L La fializa presentada por la Suplicante con la Hacienda de Conapaya, es buena, y to hay embargo parta gute se admita en seguridad, y resultas del pago de la pencion asignada á esta Señora por el Exelentisimo Señor Virrey del Reyno; cn esta virtud puede procederse á el otor-

/F. 32 v. gamiento de la ES / critura, que debe estaz concevida en clausulas faciles, é inteligibles, y que no adritan interpretacion en lo sucesivo, para evitar dudas, y Jitigios: es decir que dicha finca afianza lo dado hasta el dia á dicha Señora, y lo gue huviere de percivit en adelante, y resultare de partidas de los Libros de esta Caxa; entendiendose la accion de la Hacienda Publica con dicha Señora, y no contra ninguna ofra persona interesada en la pencion, ni su Magestad no la aprovare: en tales terminos que son los que se indican en este Escrito, puede desde luego entrar la interesada en el goze de dicha pencion integra, como es de Justicia; desaforandose del Expediente la Carta original que en el corre del Señor Intendente del Exercito, Don Manuel Antorio Baez, la que deverá debolversele á ella para los fines que le convengan: con lo que es fenecido este F. 33. asunto, y asegurada / la Hacienda. Contadiuria Nacional, y Principal de Potosí, y Diciembre veinte, y tres de mil ochocientos veinte.-- José Sanchez Chaves.- Mariano de Sierra.-

Decreto PoTosi, Diciembre veinte, y ties de mil ochocientos reinte. - Hagase saver á la Señora Interesada, el anterior Informe del Ministerio; y en caso de conformidad, extiendase la Escritura en los terminos indicados.- Huarte.-

Provto. EL Señor Don Francisco Huarte Jauregui, Teniente Coronel del Cuerpo de Ingenieros de Exercito, actual Comandante general de su arma en este de Operaciones del alto Perú, Governador Intendente interino de esta Villa, y su Provincia, Superintendente de la Casa Nacional de Moneda, Minas, Banco Nacional de San Carlos, con otras Comiciones del servicio: Proveyó, y fir-

F. 33 v. mó lo de suso en Potosi en el dia de su fecha.- Ante mi.-- José Este / van Fonseca.- Escrivano de Hacienda Publica.- 
Diliga.

EN Potosi en dicho dia. Yo el Escrivano hice notorio el Decreto antecedente á los Señores Ministros dé Itacienda labblica, de que doy fé.- Fonseca.-

Otra. EN el mismo dia. Yo el Escrivano hice saver el Decreto precedente á la Señora Doña Melchora Perez l'rudencio, en su persona, de que doy fé-- Fonseca.-

Prosigue.

EN cuya conformidud, bien inteligenciada de todo la Señora Compareciente, otorga en la mas bastante forma, que asegura, y afianza las Cantidades que ha percivido de la Caxa Nacional de esta dicha Villa, y las que en adelante pereiviere de ella, la dicha Doña Melchora l'erez Prudencio por via de la expresada pencion que se le tiene asignada, con su Hacienda nombrada Conapaya, cita en el I'artido de Porco, suya propia sin pencion ninguna, y abaluada en la Cartidad de veinte, y nuebe mil pesos, la que está su-

/F. 34. geta á las resultas, si / su Magestad no tubiere á bien aprobar la referifa asignacion. A cuya firmeza, y cumplimiento obliga la expresada finca en toda forma de derecho, para que los Ser̃ores Ministros Principales en el caso de la no aprovacion del Rey, tengan accion de reclamar contra ella por la Cantidad que haya percivido la expresuda Doña Melchora, con sumicion á las Justicias, y Jueces de Su Magestad, á cuyo fuero y juris dicción se sontete, y renuncia el suyo propio domicilio, y vecindad, y la ley sit cum venerit de jurisdictione omnium judicum, con la que dice que el Actor debe seguir el fucro del reo, para que á todo lo que dicho es, la executen, compelan, y aprenien por todo rigor, como si el tenor de esta Escritura fuese Sentencia definitiva de Juez competente, consentida, y /F. 34 v. no apelada, pasada en autoridad de cosa jusgada, y como tal mandada / llevar á pura, y devida execucion su cumplimiento. Cerca de Io qual renuncia todas las Leyes de su favor, y defensa; y especialmente renuncia el auxilio de Beleyano, aprovado por el Emperador Justiniano, Leyes de Toro, Fuero, Madrid, y lartida, y las demas que son, y hablan á favor de las Mugeres; y como cerciorada de sus efectos por mi dicho Escrivano, las aparta de su favor. En cuyo testimonio, asi lo otorga, y firma, siendo testigos Don Everisto de León Barroso, y Don Patricio Callejas presentes.- La Condeza de Casa Real de Moneda.- Melchora Perez Prudencio de Cañete.- Ante mi.- José Estevan Fonseca.- Escrivano de Hacienda Publica.- Concuerda con la Escritura matriz de sa contesto, que pasó, y se otorgó ante $\mathrm{mi}, \mathrm{y}$ en mi registro de Contratos publicos, con la qual ba cierto, y verdadero, corregido, y concertado, á que en lo necesa-

/F. 35. rio me remito. Y para resguardo de / los Señores Ministros de la Caxa Nacional de Provincia, autoriso, y firmo el presente, en Potosí, fecha, y testigos ut supra.- José Estevan Fonseca- Escrivano de Hacienda Publica.-

\section{REClAMACION DE PAGO DEL MONTEPIO SUSCRITA POR LA VIUDA DE CAÑETE}

Oficio

EXELENTISMO SENOR.- La indigencia, la miseria, y el ultimo termino á que puede llegar la desgracia de una Señora Viuda; hace que desde el centro de mis 
abrumantes penalidades comparesca ante la inalterable bondad de Vuesencia mediante este memorial, para pedir, confiada en su generosa herojca justificacion, que continue el Montepio, que el digno Señor Pezuela me havia asignado en las Caxas Nacionales, como en compensacion de los trabajos, é imponderables perdidas que ha sufrido mi persona, mi finado Espozo, y mi triste Casa. ¿Será presiso que detalle nucbamente ante Vue/F. 35 v. sencia que está orientado del más minimo/ suceso de lat Cuerra Civil que nos consume, y devora, las fatales consequencias que han perseguido, y circundado mi Casa? Ique onirinosos han sido los pasos con que se ha conducido la rebolucion para mi ruina, y para reducime casi á pedir limosna! Los saqueos que he sufrido constart a Vuesencia, $y$ al mundo entero. Los servicios de mi finado Marido, han sido practicados á la presencia de Vuesencia: nada tengo que exponer á su consideracion, pues está sumamente interiorisado en los meritos que le hicieron digno del premio, y de la recompenza: estos mismos dieron ligar á que se me declarase el Montepio, como a Viuda de un Ministro que havia muerto en actual servicio de la Nación, y del Rey, y a que me havia hecho acreedora por mi fidelidad, como lo declaró el Txelentisimo Señor Pezuela, como General

/F. 36. del Rey, / y a nombre de su Magestad, á quien se le dió cuenta para la aprovacion.- Los Ministros de estas Caxas Nacionales, intentaron suspender lo que por Ley, y declaracion del Exelentisino Señor l'czuela, devian contribuir para mis alimentos: consuitaron al Exelentisimo Señor Virrey, y este resolvió continuarun dandome la pencion asignada hasta la aprovacion Soverana, afianzando como to he hecho, no solo por lo que he percivido; mas tambien todas las resultas. Sin embargo de estar asegurado el credito, me veo nuevamente privada del haber que me corresponde: hacen ocho meses que no me contribuyen lo presiso á mi subsistencia: me veo cercada de penalidades, careciendo de todo humano recurso. Este es el motibo por que ocurro á Vuesencia, para que atendiendome en justi-

F. 36 v. cia, mande á los Señores Minis / tros de estas Caxas Nacionales, que sin embargo de cualquiex consuita, ó duda que les ocurra, continuen contribuyendome la pencion asignada, supuestas las seguridades con que he afianzado las resultas. - El estado de los negocios de la I'eninsula, no pueden privarme de los alimentos presisos, ni ger causa para que estos Señores Ministros suspendan lo que por Ley me corresponde, no haviendo resolucion soberana que contradiga lo mandado por el Señor Virrey, que lo hiso á nombre de la Nación, y del Rey.- Dios guarde á Vuesencia muchos años para alivio, $y$ consuelo de infelices. Potosi, veinte, y siete de Agosto de mil ochocientos veinte, y uno.- Fxelentisimo Señor.Melchora Percz Prudencio de Cañete.- Exelentisimo Señor General. Don Juan Ramirez-

\section{OTORGAMIENTO CONDICIONAL DE LA PENSION}

Auto supor. Quartel General en Potosí, catorce de Marzo de mil ochocientos diez, y seis.- Visto este recurso con lo expuesto por los Señores Ministros Principales de Real Hacienda, teniendo en concideracion los relevantes distinguidos servicios con que el finado Señor Fiscal interino de Charcas, Don Pedro Vicente Cañete, se prestó en obsequio de los derechos del Rey; el indigente estado á que su Señora Viuda há quedado reducida, por el publico saqueo, y pér- 
/F. $38 \mathrm{v}$. dida total de sus quantiosos bienes, que les infirieron los insurgentes / en odio de su acrisolada lealtad; la tacita Real confirmacion que obtubo de su Magestad en su Real Decreto de quatro de Octubre del pasado año de mil ochocientos catorce, comprensivo á todas las gracias, y empleos conferidos por mi difno Antecesor el Excelentisimo Señor Don José Manuel de Goyeneche, en resulta de la recuperacion de estas Provincias, en cuya clase se halla incluso el Empleo de Fiscal interino de la Real Audiencia de la f'lata, que sirvió hasta su nuerte; los inculpables motivos que por las circunstancias del tiempo habrian retardado seguramente el arribo del Real Despacho de Fiscal propieturio, con que se save por el mismo Señor Goyeneche, ha remunerado el Soverano los meritos de este zeloso Ministro la horfandad en que ha dejado constituida á toda su benemerita fa-

/F. 39. milia, y especialmente á su legitima hija Doña Dolores / Cañete sin otro recuno para su subsistencia, que el que la piedad del Rey se digne proporcionarle; y ultimamente todas las demas razones de equidad, que se interesan en favol de esta dekgraciada Niña y en los alivios que solicita la Señora Viuda Ocurrente; rengo en asignarles, cono desde luego les asigno por via de socorro, y aucilio para su subsistencia, noventa pesos mensuales sobre las Reales Caxas principales de esta Villa, á buena cuenta de la pencion del Montepio que hayan de gozar luego que se les declare su goce, que deberan impetiar con la manifestacion del precitado Real Despacho, y demas recaudos necesarios, sir perjuicio de la presentasion que we harán del de el primero entro del termino de la Ordenanza de tyltrumar, y de los restantes en el correspondiente á la Ciudad de la Pla-

/F. 39 v. ta, baxo de / condicion de que hasta las resultas de Su Magestad, á quien se dará cuenta de esta gracia, con el Expediente original, y el oportuno informe, y para que la Señora Viuda disfrute de la asignacion de los noventa pesos mensuales indicados, ha de afianzar su debolucion, y reintegro á satisfaccion de los Señores Ministros principales de Real Hacienda; entendiendose esta gracia desde la fecha que pide la Señora Suplicante- Pezuela.- Concuerda con el Superior Auto de su contesto, que se halla á foxas quarenta, y siete del Libro de Proviciones corriente, que se inició en dos de Febrero del pasado año de ochocientos diez, y seis, que existe en estas Caxas Principales de Hacienda Publica archivado. $\mathrm{Y}$ para que conste, de orden de sus Señores Ministros, autoriso, y firmo el pre-

/F. 40. sente en Potosí, Octubre dos de mil ochocientos veinte, / y un años.Apolinar Figueras- Escrivano I'ublico, y de Hacienda.-

\section{MEMORIA DE LA AUDIENCIA DE CHARCAS RECOMENDANDO \\ LA CONCESION DEL MONTEPIO}

/F. 53.

\section{/ Señor}

La Audiencia de Charcas, recomienda a V. M. los meritos del finado Oydor Dn. Pedro Vicente Cañete $p^{\mathrm{a}}$. $q^{\mathrm{e}}$. se le asigne a su Viuda Da. Melchora Prudencio una pencion por no obtener el Montepio.
Con fecha 15 de Febrero de 1816 informó a V. M. este Tribunal haber fallecido Dn. Pedro Vicente Cañete dejando a su Viuda, y familia en la mayor insolvencia despues de haber servido la Asesoria de Potosi, y otras Comiciones de importancia como la de Fiscal interino de esta Audiencia, $y$ obtenido los honores de ella cuyas recomendaciones eran dig. nas de la Consideracion de V. M. pa. que le asignase á aquelia una pencion ú otra gracia equivalente con que pudie- 
/F, 53 v. se Subvenir á sus necesidades. Mas entonces ignorando haber / sido confirmado en esta Fiscalia, y consiguiente promocion á la Audiencia de Quito se omitió esforsar la suplica con esta recomendacion como lo hace al presente, á fin de que el accidente de falta de pocesion que ha impedido se le acuda á la Viuda con el respectivo Montepio le sixba al menos de un motivo mas a la Consideracion que se merece la memoxia de un Ministro que consumio sus bienes, y aun su vida en sostener los derechos del Estado en la actual revolucion, y por consequencia se le asigne á su Viuda una pencion equivalente con que pueda mantenerse con la decencia que reclama su Clase. Que es lo çue puede, y deve informar este Tribunal á V. M., en virtud de la peticion que se le hase por la interesada, $\mathrm{y}$ testimonio que se acompaña.

/F. Ba. Dios guarde la / Catolica Real Persona de V. M. los muchos, y felices años que la Christiandad ha menester en aumento de mayores Reynos, y Señorios. Plata Noviembre 23 de 1820.

\section{Señor}

A. L. R. P. de Vtra. Magd.

Mañ. José de Reyes

(Rubricado)
José Felix de Campoblanco

(Rubricado) 
I N D I C E S 



\section{INDICE Y NOTICIA DE LOS PRINCIPALES AUTORES CITADOS EN LA OBRA}

\begin{abstract}
Acevedo, Alfonso de
(p. 436, línea 34). Jurisconsulto español nacido en 1518. Murió en 1598. Obras más conocidas: Comentarium juris civilis in Hispania, impresa en Salamanca en 1583 y Additiones ad curiam pisanam, en la misma ciudad, en 1593.
\end{abstract}

Acosta, P. Joseph de

Agia, P. Miguel de

Agricola, Jorge

(p. 47, linea 32). Historiador, cosmógrafo y autor de poesias. Nació en Medina del Campo el año 1539. Falleció el 15 de fobrero de 1600. Obras importantes: De promulgatione Evangelii apud Barbaros, sive de Procuranda Indorum Salute, impresa en Salamanca en 1588; Historia Natural y Moral de las Indias, editada en Sevilia en 1590. Se le consideró en Roma como el más sabio de los jesuítas. Consejero de Felipe II. Provincial del Pcrú. Se han hecho numerosos estudios de la obra de Acoste. En la época moderna, en México, A. Crónez Robledo há escrito un comentario sobre sus ideas jurídicas; L. Lopetegui S. J., es autor de una biogrufia $y$ el notable investigador Silvio Zavala, en su libro Servidumbre Natural y Libertad Cristiana, dedica al $P$. Acosta, un denso análisis. En la Revista de Indian, de Madrid, E. Alvarez López, publicó un ensayo sobre la filosofía natural en la obra del eminente jesuita.

(p. 100, linea 49). Obras: De exhibendis auxiliis sive de invocatione utriusque brachii tractatus, Madrid, 1600 , y Tratado y consulta sobre el servicio de los indios, Lima, 1604. Para más datos véase la nota (a) de la página 122, línea 12, y la igual $N^{\circ} 1$, del Comentario bibliográfico del Sr. Loza.

(p. 60, línea 40). Médico y químico. Fundador de la Metalurgia y Mineralogía modernas. Nació en 1494 en Glauchau (Sajonia). Marió en 1555. Se dice que su verđadero nombre era Bauer o Landmann. En 1528 editó el pximer tratado de mineralogía que se conoce: Bermannus sive de ro metallica dialogus. Como historiador compuso su Dominatores Saxonici a prima origine ad hanc oetatem. Clasificó los minerales en simples y compuestos y estableció sus caracteres físicos. Otras obras suyas son: De ortu et causis subterraneorum; De natura fossilium; De natura rerum quae eflunt a terra; De veteribus et novis metallis; De bello Turcis iferento philosophica. 
Aguila, P. Juan de (p. 124, línea 32). Arcediano de Areuguipa. Escribió sobre reducciones de indios,

Aguirre, José Saenz de (p. 302, linea 14). Cardenal español nacido en Logroño en 1630. De la Orden de San Benito. Abad en Salamanca y Secretario del Santo Oficio. Por su libro Defensio Cathedrae Sancti Petri adversus declarationes clerigallici, en 1683, mereció ser nombrado Cardenal por el l'apa Inocencio XI. Otras obras notables: Ludi Salmanticensis sive Theologia floralenta (1668); Collectio maxima conciliorum Hispaniae (1694) y Teología de San Anselmo.

Agustín, San

(p. 258, línea 3). Muy conocido.

Cañete fue asiauo lector de Civitate Dei.

Alejandro Vl.

(p. 62, linea 29). Huy conocido.

Alcedo Ugarte y Herrera, Dionisio

(p. 124, línea 37), Nació el Madrid en 1690. Murió en 1777. Obras: Aviso Histórico, político, geográfico, con las noticias más particulares de la América Meridional, Madrid 1740. Memorial informativo sobre el comercio del Perú, impresa en la capital española.

Su hijo Antonio, nació en Quito en 1735 y murió en Madrid en 1812. Escribió: Diccionario geográfico-histórico de las Inclias Occidentales o América; es a saber: de los reinos del Perú, Nueva España, Tierra Firme, Chile y al Nuevo reyno de Granada (1786 al 1789). Biblioteca Americana - Catálogo de los autores que ban escrita de la América en diferentes idiomas, y noticia de su vida y patria, años en que vivieron $y$ obras que escribieron.

Alfaro, Francisco de (p. 432, línea 9). Fiscul de las Audiencias de Panamá y Charcas. Ministro del Consejo de Indias, en el ramo de Hacienda. Escribio: Del Oficio Fiscal y sus privilegios, que editó en Valladolid en 1606.

Alfonso el Sabio.

(p. 541, línea 31). Muy conocido.

Alvarez de Abreu, Antonio

(p. 421, línea 32). Español. Jurisconsulto famaso del siglo XV1. Autor de numeiosos libros, entre ellos: Tratado de Vacantes on Indias y Tratado sobre la ley de Partida do los que son obligados a hacer los Alcaldes que tienen a su caxgo furtalezas y castillos. 1558.

Antúnez y Acovedo, Rafael

(p. 414, línea 7). Célebre economista español que alcanzó la Vocalía en el Consejo Supremo de Indias. Autor de Mémorias históricas sobre la legislación y gobierno del comercio de los españoles con sus colonias en las Indias. Con un apéndice documental interesante. 


\author{
Aristótele: \\ Avendaño, P. Andrés \\ de
}

Azara, José Nicolás

Baeza, Gaspar de

Barba, P. Alvaro

Alonso

Barbosa, Agustín

Baumé, Antonio

Beausoleil, Juan del Chátelet, Barón de (p. 46, Jínea 16). Muy conocido.

(1) 280, línea 2). Religioso español de la Orden de San Francisco. Fjlólogo, escribió Diccionario sobre la lengua de Yucatán.

(p. 46, línea 38). Escribió Adiciones a la Historia Natural de España de Bowles.

(p. 757, línea 23). Nació en Baeza (Jaén) a mediados del siglo XVI. Abogudo en la Cancillería de Granada. Escribió muchas obras, siendo las principales: Historia del Reyno de Italia; De non melioradis rationi dotis filizbus; $D$ e inope debitore creditore adicendo; Elogios a vidas broves do los caballeros antiguos $y$ modernos $y$ Decima tutori hispanico jure praestanda, de edición póstuma.

(p. 50, línea 35). Muy citado en el libro. Sacerdote español que residió muchos años en Potosí, como Cura del templo de San Bernardo. Famoso on su tiempo y muy admirado ahora por su libro Arte de Metales. (Será reeditadio en la Colección de la Cultura Boliviana, con extenso estudio biográfico).

(p. 394, línea 33). l'relado y jurisconsulto portugués (15901649). Por su adhesión a España en 1640 ocupó el Obispado de Urgento, en Nápoles. Escribió: Dictionarium Lusitanico-Latinum, que editó en Braga en 1611; De officio ot Potestate Parochi; Repertorium juris civilis et canonici; Formularium epiacopale $y$ Variae juris tractationis. Sus obras completas publicadas en Lyon en 1712, alcanzan a 16 tomos.

(p. 46, línea 43). Francés nacido en 1728. Murió en París el año 1804. Químico famoso. Dueño de fábricas de productos químicos. Miembro de la Academia de Ciencias en 1772. Escribió sobre el procedimiento para teñir telas, mojorar la porcelana, etc.

(p. 52, línea 36). Alquimista alemán, nacido en Brabante en 1578. Murió en París en 1645. Con su esposa viajó a América y de vuelta a Europa fue acusado de hechiceria, guardando prisión en la Bastilla y Madame Beausoleil - ilamada Martina de Berthereau, de noble familia de mineros,encerrada en Vincennes. Escribió obras científicas, siendo la más importante La Restitution de Pluton á l'Eminentissime Cardinal duc de Richelien, en 1640.

Benedictix, Juan Bautísta de (p. 340, línea 38). Italiano. Nació en 1620. Murió el año 1706. Jesuita, fue Profesor de Teología y Filosofía. Combatió vehementemente las doctrinas de Descartes y de Jan- 
senio, como afiliado a la filosofía aristotélica. Escribió obras en latin e italiano. Su escrito principal es Filosofia Peripatética, editado en 1723.

Berrio de Montalvo, Luis

(p. 60, línea 35), Abogado español del siglo XVII. Ocupó cargos notorios: Alcalde de Crimen, Oidor de la Audiencia de Nueva España, Auditor de guerra y Administrador de las minas en esa jurisdicción. Trabajos innportantes: Informe sobre el nuevo beneficio dado a los metales ardinarios por azogue. Informe al Virrey Conde de Liste, so. bre beneficio de plata, conservación de azogues, mezcla de antimonio, que se publicó en México en 1650.

Bobadilla, Lic. Jeró(p. 536, linea 2), Abogado espanol. Nació en 1547 cn Menimo Castillo (Cos. tielo) de dina del Campo. Tuvo larga actuación en la política. Murió en Valladolid à principios del siglo XVII. Fstudió en Salamanca. Autor de Política para Regidores y Señores de vasallos en tiempos de paz y guerra y para Prelados, que se editó en Madrid en 1597. Su nombre está registrado en el Catálogo de autoridades de la Lengua.

Bolaños, Juan Evia de (p. 222, línea 9). Natural de la ciudad de Oviedo, en Astu. rias. Autor de la célebre Curia Philipica, escrita en Indias, en 1615. La bibitioteca del Museo de la Moneda, posee la edición hecha por Ramón Ruiz, bajo el cuidado del Lic. Juan Martín de Villanueva, en la Imp. de Uloa, en tres tomos, en 1790 .

Borromeo, San Carlor (p. 604, línea 11). Alto prelado de Ia lglesia en el siglo XVI. Cardenal. Nació en el Castillo de Aroma, en 1538. Entre sus muchas obras, la conocida por Cañete se titula Instrucciones para el régimen de los Seminarios.

Bowles, Guillermo

(p. 44, linea 40). Nació en Irianda. Falleció en la cápital española en 1780. Amplió en Paxís sus conocimientos en Ciencias Naturales. A iniciativa del gobierno español, con intervención de Antonio Ulloa, viajó a estudiar la riqueza natural y las industrias del país. Fruto de sus observaciones es su obra Introducción a la Historia Natural y a la Geografía fisica de España, redactada con la colaboración de José Nicolás de Azara, en 1775. Escribió otras obras de su materia como la Memoria sobre minas de Alemania.

Buffon, Jorge Luis

Loclerc, Conde de

(p. 229, línea 53). Sabio naturalista muy conocido.

Caluncha, Antonio de la

(p. 12, línea 5). Religioso agustino nacido en Chuquisaca. Murí en Lima. (1584-1654). Su padre era capitán del ejército español. Estudió en Lima. Cronista de su Orden, fue Prior en Trujillo. Escribió: De Immaculatae Virginis Conceptionis Certitudine, publicada en Lima en 1653. De los 
varones ilustres de la $O$. de San Agustín y la comentada Crónica moralizada de la Provincia del Porú, editada en su primera parte en I3arcelona elı 1639, y la segunda en 1853. Durante su estancia en Potosí, construyó la actual Iglesia de Copacabalua.

Caracciolo, don Carmino Nicolás

\section{Cárdenas Cano,} Cabriel

Carleval, Tomás

Carranza, Alfonso

Carrillo y Aitamirar no, Hernando

\section{Castejón, El}

Castillo, Juan del

Cenedo, Pedro Jerónimo (p. 321 , linea 19). Grande de Espana, Principe de Santo Buono, Duque de Castel de Sagro, Conde de Esquiavi, de Santo Vido, Barón de Monferzato, etc. Virrey del Perú, desde octubre de 1716 a 1720 . Durante este período se prohibió marear con hierro a los esclavos negros. Intentó suprimir la institución de la Mita, pero no fue escuchado por la Corte, que desatendió el pedido.

(Simple error o muliciost confusión, en el MS. del A. G. de $\mathrm{I}$, de Sevilla, en la página citada que consigna la nómina de Virreyes, aparece escrito "Santo Mono" en lugar de Santo Buono. Hemos conservado la escritura original, haciendo la lespectiva enmienda en estas líneas).

(p. 21, línea 54). Publicó en 1722 un Ensayo Cronológico para la Historia de la Florida.

(p. 549, línea 28), Abogado y filósofo de prestigio. Nació en Jaén en 1576 y murió en Nápoles en 1645. Sus principales obras: Naturalem philosophiam. Disputationum Juris variarum ad interpretationem Regiarum Legum Regni Castellae.

(p. 53, línea 9). Jurisconsulto y escritor nacido en España de fines del simlo XVI. Fscribió: De partu naturaji et legitimo, editada en Madrid en 1628 y El ajustamiento $\mathbf{y}$ proporción de las monedas de oro, plata y cobre, el año 1629.

(p. 116, línea 4). Colonizador español en Centro América, en el siglo XVI. Dirigio un memorial al Rey sobre la población de la Nueva España.

(p. 748, línca 53). Autor de varios escritos. Su obra más conocida es Alfabeto Juridico Canónico.

(p. 680, línea 38). Historiador español nacido en Burgos en el siglo XVI. Cronista del Rey Felipe III. Obra importante: Historia de los reyes godos que vinieron de la Scitia de Europa contra el Imperio Romano, y a España.

(p. 222, linea 49). Ficritor de mediados del siglo XVI. Autor de Singulare quinto. 
Cicerón

Cisnero*, Cardenal

Jiménez do

Corso de Leca, Carlos

Claro, Julio

Claudiano

Clelio

Cortiada, Miguel de

Covarrubia y Leiva, Diego

Crespo de Buldaura, Cristóbal

Curcio, Quinto

Daniel, Pedro

Demócrito

Disdoro Siculo (p. 299, línea 34). Muy conocido.

(p. 489, línea 31). Eminente político y religioso de España. Muy conocido.

(p. 631, línea 17). Descubrió el beneficio de hierro. Escribió informes sobre la materia.

(p. 222, línea 27). Abogado italiano nacido en el Piamonte en 1525. Murió en España en 1575. Su nonbre original era Chiaro, que se españolizó. Alcanzó a ser. Consejero de Estuda en tiempos de Felipe Ii. Fue muy consultado por estudiantes de Derecho y magistrados su libro Sive practica civilis et criminalis, impreso en 1672 .

(p. 4, línea 9). Poeta latino muy conocido.

(p. 335, línea 44). Rey de Albalonga, muerto por 'Tulio Hostilio. Muy conocido.

(p. 222, linea 24). Abogado español nacido en Lérida a principios del siglo XVIJ. Murió en 1691. Autor de numerosos libros: Decisiones Rev. Cancel!arii Sacri regit senatus Cathaloniac sive pars prima pro praxi contentionum, et competentiarum Regnorum inclytae Coronae Aragnorum, editado en Barcelona en 1661 y Desisiorum pars 2 pro recto uso contentionum et competentiarum Regnorum inclytao Coronae Aragoninae super immunitate ecclesiae, aparecido en Barcelona en 1665 , etc.

(p. 416, línea 8). Fumoso jurisconsulto y teólogo nacido en Toledo en 1512. Murió en Madrid en 1577. Escribió muchas obras sobre temas eclesiásticos y juridicos, entre ellas Practicarum Quaestionum librum singulares, editada en 1556; De regulis juris y Primo variar. Figura en el Catálogo de autoridades de la Academia de la Lengua.

(p. 541, línea 42). Llamado originariamente Cristóbal Crespi de Valldauri y Parizuela. Escritor y abogado español. Funcionario de la Corona en América. Nació en Valencia en 1599 y murió en Madrid en 1671. Entre sus obras, la más difundida es: Observationes illustratae dessicionibus Sacri Supremi Regi Aragonum Concilii.

(p. 258, línea 29). Rufo, Conocido historiador latino.

(p. 6t, línea 64). Autor de Historia de Francia.

(p, 46, linea 16). Muy conocido.

(p. 46, línea 14). Famoso historiador muy conocido. 
Elizondo y Alvarez, Fco. Antonio de

\section{Escalona Aguero, Gaspar}

Eucobar y Loayza, Alfonso de

Escovedo y Alarcón, Jorge

Fagnano, Próspero

Farinacio

Fermosino, Nicolás Rodriguez

Fernández, Juan del Castillo

Fernández de Velasco, Pedro

Feyjóo y Montenegro, Benito Jerónimo

Flegón (p. 222, línea 46). De la Orden de Carlos III. Fiscal de Ia Real Cancillería de Grarialdi. Obra conocida: Práctica Universal forense de los tribunales de España y de las Indias.

(p. 8, línca 17). Con Solórzano y el Padre Barba, es el autor más cilato por Cañete. El lugar de sla nacimiento ha sido discutido. Alcedo dice ser oriundo de Riobamba (Ecuador) $\dot{y}$ Antonio León Pinelo, sostiene el dato de que nació en Lima. Toribio Medina y Gabriel René Moreno, creen que vió la luz en Chưuisuca. Itijo del Lic. del mismo nombre $y$ de Isidora de la Torre, estudió en la capital virrejnal. Fue Corregidor en Tarija; Gobernador en CastroVirreina: Procurador General en Cuzco, y Visitador de las Caxas Reales. Se hizo famoso por su gran obra Gaxophilacium Regium Perubicum, cựa primera edición apareció en Madrid en 1647 , el texto en latín en la parte primera y en casteflano la segundia. Posteriormente se hicieron ediciones de su libjo en 1675 y 1775 . En la Biblioteca Boliviana dirigida por G. A. Otero y L. M. Loza, apareció en 1939, una reciente edición antológica.

(p. 436, linca 11). Nacido en Guareña (Badajoz). Colegial en la Mayor de Cuenca; de la Universidad de Salamanca. Figuran entre sus libros: De pontificia et regia Jurisdictione in estudiis generalibus; et de Judicibus et foro studiosorum. (1643) y Comentarin in Tryphonium.

(p. 5, línea 22). Véase nota especial de A. A. en las pán ginas 626 a 627 . Muy citado por Cañete.

(p. 420, línea 12). Clebre canonista. Autor de numerosos libros: Indice; Postulatione Prelatorum; Preterea decu., etc.

(p. 222, línea 30). Citado en las obras de Raynaldo. Aparece como autor de Apendice de Immunitate Ecclesiae, que escribió en 1518, y pocos años después: De Haeresi.

(p. 114, línea 50). Obispo de Astorga, autor de Tratado de Leyes Eclesiásticas; De Feriis. Consta de 14 tomos su Opera Omnia Canonica.

(p. 60, Innea 38). Autor de la Relación histórica de la Misión de Chiquitos.

(p. 75, línea 7). Escribió sobre el Beneficio de la plata por amalg ama de azogue.

(p. 46, línea 41). Conocido polígrafo español cuyas obras, especialmente su Teatro Critico Universal, en sus primeras ediciones, fue muy leído en el Alto Perú.

(p. 262, línea 32). Historiador griego, nacido en Lidia. Escribió De mirabilibus (De las cosas maravillosas) y otras obras. 
Fleury, M. Claudo de (p. 229, línea 22). Autor francés de numerosas obras sobre temas religiosos $\mathrm{y}$ de Moral. Nació en 1640 y murió en 1723. Escribió Historia Eclesiástica, Discursos, Las Instituciones Canónicas, Tratado de elección y Método de los estudios; traducida ésta última al español por Ventura Villegas.

Focher, Juan

(p. 114, linea 13). Subemos que escribió la Explicación de la Bula de Paulo Ill, referente a servidumbres indígenth.

Fontanella, Juan Pedro (p. 683, línea 26). Tspañol. Abogado sobressiliente. Nació en 1576 y murió en 1680 . Entre sus libros principales, figuran: Las decisiones; De pactis nuptialibus, sive capitulis matrimonialibus tractatus.

Frazzo, Pedro

(p. 417, línea 29). Muy conocido. Autor de Regio Patro. nato Indiar. edición de 1775 . Dicese que Cañete estuvo muy influenciado por sus obras $y$ sus ideas.

Frézier, Amadeo Francisco

(p. 62, línea 24). Nació en Chambéry en 1682 y falleció en 1773 en Luest. Ingeniero ordinario del Rey de Francia. Jiscribió la famosa obráa Relación del viaje a la Mar del Sux y a las costas de Chile, Perú y Brasil, durante los años de 1712,13 y 14. Lá edición francesa se hizo en Amsterdam, en 1717, en dos vol, y la inglesa en Londres, a los diez años.

Függer, Los

(p. 650, línea 42). Véuse la nota especial de A. A. en las páginas 650 a 661 - I a obra "Los Fúcar" editada en México es del eseritor Lrnesto Hering.

Gálver, José de

Gamboa, Francisco Javier

Garcilaso, Inca

Gil, Francisco (p. 492, Hnea 21). Autor del escrito sabre lnstrucciones para sustanciar las causas de fraude de tabacos.

(p. 86, línea 13). Ilustre jurisconsulto nacido en Guadalajara (México) en 1717. Falleció en 1794. Viajó a España. Estudió con preferencia la legislación de la minería y los problemas de esta industria. Escribió entre otras, las siguientes obras: Geometría subterránea; Código Negro para gobierno de los esclavos de Santo Domingo; Ordenanzas de dicha Audiencia y el Comentario a las Ordenanzas de Minas, editado en Madrid, en 1761, por Jonquín Ibarra.

(p. 47, línea 33). Muy conocido por sus Comentarios Reales.

(p. 40, línea 20). Afumado médico español de fines del siglo XVIII. Cirujano ell el Monasterio de ki Escorial. La obra a que se refiere Cañete en sus citas de este autor, se titula: Disertación filosófica, en la cual se prescribe un método seguro para preservar a los pueblos de viruelas, hasta lograr su completa extinción de ellas en todo el reino. Ma. drid, 1784 . 
Gómez, Antonio

Gothofredo, Dionysii

Graciano,

Gutiérrez, Juan

Guzmán, Ruy Díaz de

Heinecio

Heródoto

Herrera, Antonio de

Homberg, Guillermo

Horacio, Quinto

Isidoro, San (p. 2222, líneat 25), Juriscorsulto español del siglo XVI. Nació en Talavera de la Reina. Citase entre sus principales obras: Variarum Resolutionum Juris Civilis Comunis et Regii, libri llI; Ad legis Tauri Commentaricis absolutissimun; Recopilac. Castell.; De accion.

(p. 666, línea 41). De este celebrado tratadista existe la edición de Iugduni, en 1612, de: Infortiatum sev Pandectarum Juris Civilis, Volumen Legum, Corpus Juris Civilis, Codicis Sacratissimi, ete, en la Biblioteca de la Soc. Geográfica "l'olosí".

(p. 302, línea 16). Canonista italiano de] siglo XIY. Natural de Toscana. Su obra principal es la Historia del Derecho Eclesiástico. Lé Biblioteca de la Soc. Geográfica $\mathrm{y}$ de Historia "Potosi" tiene la edición de Iugduni, de 1584, de: Decretum Gratiani Emendatumet Notalionibus.

(p. 222, linea 52). No tenemos nás noticia de este autor que la de haber cserito Cuestionario Criminal $y$ un estudio sobre tauromaquia.

(p. 250, línea 42). Nacido en Paraguay posiblemente en 1563, Falleció en Asunción en 1629. Escribió su obra sobre Argentina y Paraguay, en Chuquisaca, según comentario de don León M. Loza (p. 781) en este libro. Cañete, dijo en documento serio que conocí Fulgencio R. Moreno, ser bisnieto del azañoso $y$ tesonero colonizador.

(p. 747, línea 24). Autor de Historia del Derecho Civil.

(p. 47, línea 46). Historiador muy conocido.

(p. 61, línea 35). Nuy conocido escritor de la Colonia. Cronista Mayor de S. M. en las Indias y de Castilla. Se han hecho muchas ediciones de sus Décadas y de la Descripción de las Indias Occidentales.

(p. 56, línea 20). Holandés. Nació en 1652. Fallecio en París en 1715. Hizo estudios de Derecho en Leipzig; luego se dedicó a la Medicina y a la Química, escribiendo sobre sus observaciones $y$ experimentos.

(p. 352, línea 39). Poeta latino, muy conocido por sus Odas $y$ otras obras.

(p. 302, línea 10). Arzobispo de Sevilla. Nació en 560 y Murió en 636. Escribió muchos libros. Los más conocidos son:

Etímologías y Origenes. Libri duo diferentiarum. Sinónimos - Liber Lamentatiorum, etc.

(p. 62, línea 5). Profeta muy conocido. 
Josefo, Flevio

Juatiniano, Emperador

Kirchor, Atanatio

Krebe, F.

Laet, Juan de

Lagúnez, Matins

Larrex, Juan Bautista

León, Franciaco Jorónimo de

López, Gregorio

Lozano, Padre Pedro (p. 258, línea 1). Conocido historiador nacido en Jerusalem. Obras nuás difundidas: Antigüedades judias. Guerra de los judios y el tratado Del Imperio de la Razón.

(p. 691, línea 15). Muy conocido entre los historiadores y legistas. Nació en Tauresium de Iliria hacia 483. Célebre por su Código.

(p. 60, línea 41). Nació en Alemania en 1601 y murió en Roma en 1680. Irofesor jesuita de Matemáticas, Filosofia y Lenguas orientales. Hizo grandes estudios sobre Arqueologia. Obras importantes: Specula meliatentis encyclica. Musurgia universalis. Mundus subterraneus.

(p. 60, línea 41). Escribió De ligno et lapide de metalibus et mineralibus y De la fuente de las minas.

(p. 229, línea 30). Nació en Bétgica en 1593 y murió en 1649. Famoso filólogo, geográfo y viajante. Autor de El Nuevo Mundo o descripción de las Indias Occidentales; de Notse addissertationem $\mathbf{H}$ Grotii de origine gentium americanarum, en la que sustenta la teoría de que los americanos constituyen una nueva raza.

(p. 418, línea 23). Fiscal en Lima, que se hizo notorio en el Virreinato por su escrito contra la institución dé la Mite y su necesaria abolición.

(p. 431, linea 60), Abogado español. Vivió en Madrid en la primera mitad del siglo XVII. Fue Vocal del Consejo Supremo de Castilla. Escribió nuchos libros. Entre ellos, los más difundidos son: Decisionos Granatensis Senutus; Alegaciones fícales, que se editó en León de Francia en 1651; De Auctoritate Magistratorum seu Misiatrorum publicorum; De Fooderibus Principis Christiani; De revela. tionibus; De Factis of Virtutibu. Hispenorum, etc.

(p. 433, línea 44). Jurisconsulto nacido en Valencia, en el siglo XVII. Hizo estudios de Derecho en Salamanca. Entre sus escritos más interesantes, se cuentan: Decisiones saurae Audientiae salentinae y Celebración de Cortes en los reinos de la Corona de Aragón.

(p. 457, linea 29). Español y jurisconsulto notable. Perteneció al Consejo Real de las Indias. Escribió Glosas a Las Siete Partidas del Rey Don Alforso el Sabio. La Biblioteca de la Sociedad Geográfica y de Historia, tiene la edición de 1767, en Valencia, en la Imprenta de Berito Monfort.

(p. 252, línea 12). Sacerdote de la Cía. de Jesús. Madrileño, nació el año 1697. Murió en Humaguapa, en 1752. Muy 
Luca, Cardenal Juan Bautista

\section{Lupidana, Juan Diaz de}

Llano y Zapata, José Eusebio

\section{Maggero, Martín}

Mairan, Juan Jacobo Dorotus de

Maranta, Bartolomé

Marta, Jaime Antonio joven partió al Paraguay siendo novicio. Escribió obras de singular interés. Algunas se publicaron durante su vida. Otras se han editado con posterioridad a su muerte. Se puede citar: Descripción chorográfica del terreno, ríos, árboles y animales de las dilatadísimas Provincias del Gran Chaco, Gualamba, y de Ios ritos y costumbres de Ias innumerables Naciones bárbaras e infieles que le habitan, editada en Córdoba, 1733. Historia de la Conquista del Paraguay, Río de La Plata y Tucumán. Edieión póstuma de 1873. Historia de las Revaluciones de la Provincia del Paraguay en la América Meridional, deste el año 1721 hasta el de 1735, publicada por prinuera vez el año 1905.

(p. 584, línea 34). Nació en Italia en 1614. Murió en 1683. Dejó la abogacia para dedicarse a la Inglesia. Inocencio XI le hizo Cardenal hacia el año 1.681. Ha escrito entre otras obras: Theafrum veritatis et justitiae; Annotationes ad Concilium Tridentinum; Tractatus de officiis venalibus romanae Curiae.

(p. 123, línea 23). Oidor de la Audiencia de Charcas, desde 1583. Es posible que en 1597 , hubiese escrito sus Adicionos.

(p. 61, línea 49). Humanista limeño de mítad del siglo XVIII, Enseñó griego en Lima. Famoso en su tiempo, viajó a Furopa, residiendo luego en Cádiz. Sus libros principales: Resolución físicomatemática sobre los comekas, editado en Lima en 1744; Memorias físicas-apologéticas de la、 América Meridional y Memorias hịtóricas.

(p. 695, línea 28). Autor de De advocatia armate.

(p. 259, línea 36). Nació en 1678. Murió en París en 1771. Preferentemente estudió Ciencias Fxactas. Sus obras más conocidas: Dissertation sur les variations du barométro $y$ Traité physique et historique de l'aurore boréale.

(p. 702, línea 4). De profesión médico. Hizo estudios de Botánica. Italiano, Murió a fines del siglo XVI. Libros importantes que escríbió: De aqua Neapoli in Luculliano scaturientes, quan ferrean vocant metallica natura ac viribus y Methodi cognoscendor um medicamentorum simplicium libri 11 I.

(p. 577, línea 22). Doctor en derecho. Nació en 1559 en Nápoles y murió el año 1623 en. Padua. Erudito en Derecho Canónico, sostuvo la idea de que el poder religioso exa superior al poder civil. Autor de Tractatus de tribunalibus urbis et corum proeventionibus $\mathrm{y}$ Tractatus de jurisdictione per et inter judicen ecclesiaticum ef saecularem exercenda. 
Martinez, Lic. Mantuel

Silvestre

Matienzo, Juan de

Mendoxa, Fray Diego

de

Madestino, Herennio

Molina, Luis do

Montecinos, Fernando
de

Mieres, Tomás (p. 429, linea 2), Famoso abogado de los reales Consejos y del Colegio de los de ja Corte. Escribió desue 1763 a 1774. Cañete consultó con asiduidad la Librería de jueces, utilisima y universal para Alcaldes, Corregidores, Intendentes, etc. Se editó en 1771 en la Imp. de Blas Román.

Gélebre jurisconsulto nacido en Valladolid en el sigto XVI. Primer Oidor de la Audiencia de Charcas, l'asco a Lima. Vol. vió a Charcas, donde falleció en 158\%. Asesor del Virrey Francisco de Foledo, trabajo juntamente con el I'adre jesuita Joseph de Acosta. En 1580 se hizo la primera edición de su famosa obra Comentaria Joannis Matienzo. Existe abundante bibliografím sobre los Matienzo.

(p. 12, línea 5). Muy conocido en el Alto Perú. Por su importancia será reimpresa en la "Colección de la Cultura Boliviana" la Crónica Franciscana de la Provincia de San Antonio de Charcas.

(1. 694, linea 1.t). Jurisconsulto romano, con el que conduye la serie de grandes hombres de Derecho Cláisico de esa cultura. Sus opiniones y escritos se los consideró como indiscutibles.

(p. 684, linea 37). Téólorro y escritor. Nació ell 1535, murió en 1600.- Obra principal: Del Derecho y de la justicia. Sostiene la tesis de ser justos los monopolios cuando los erige el Estado en interés común. (Quando videlicet publica auctoritate fiunt, bono communi id efflagitante).

(p. 666, línea 9). Autox de Política de Minexía. Posible autor de Memorias antiguas, históricas $y$ políticas del Perú.

(p. 721, línea 11). Sobresaliente abogado del siglo XV. Sirvió como Fiscal y Consejero de Alfonso V. Escribió un Comentario completo sobre la Iegrislación indígena.

Murillo, Pedro Volarde (p. 35, línea 9). Nació en 1696 y murió en 1753 . De la Cía. de Jesús. Enseñó Derecho Canónico. Notable abogado y geógrafo singular, escribió Goografía histárica, en diez tomos, editados en Madrid en 1752.

Nardín, Famiano (p. 259 , línea 3). Célebre arquéologo italiano, nacido en Capri en el siglo XVII. Autor de Roma antica.

Nordenflicht, Barón de (p. 210, línea 10). Véase nota *:* de A. Alba en lá pág. 221 , linea 28 .

Nuix, Abate

(p. 124, línea 39). Muy conocido por su obra Reflexiones imparciales sobre los españoles en las Indias.

Poña Montenegro, Alfonso de Ia (p. 114, línea 16). Célebre prelado y canonista. Fue Obispo de San Francisco de Qtito y Vocal del Consejo de S. M. 
Novar, Melchor de

Olea, N.

Ordóñez de Montalvo, Juan García de

Ovidio Nasón, Publio

Palafox y Mendoza, Juan de

Paz, Cristóbal

Peregrino, Alexandro

Pereyra de Castro, Gabriel

Pérez, Diego
Su obra más consultada en América ha sido Itinerario para Párrocos de Indios, editada en León de Francia por Juan Antonio Huguetan, en 1978 .

(p. 340, línea 36). Sacerdote espafiol de la Cía. de Jesús. Nació en puente de la Reina en 1629 y murió en Pamplona en 1707. Catedrático de Filosofía y Teología. Tradujo del latín al castellano Las Décadas de las Guerras de Flandes, escritas las dos primeras por el P. Famiano Estrada y la tereera por el P. Guillermo Dondino, ambos jesuitas.

(p. 418, linea 23). l'oseen:os el único dato de ser autor de De cetione juris.

(p. 60, línea 36). Fiscritor español del siglo XV. Autor de los afamados hibros de caballerías Amadis de Gaula y La: sergas de Esplandián.

(p. 262, línea 27). Muy conocido poeta latino, autor de las Metamorfosic, Arte de Amar, etc.

(p. 493, linea 20). Sacerdote español. Obispo de Puebla, administrador del Arzobispado de México. Por breve tiempo fue Virrey de Nueva España. Autor de numerosas obras, entre ellas: Historia de Ia Conquista de China por el tártaro. Nació en Navarra en 1600 y fulleció siendo Obispo en Osma, España, en ei mes de octubre de 1659.

(p. 701, limea 22). Celebrado abogado español, nacido en Salamanca. Fue letrado notable en tiempos de Felipe III. Regidor en Salamanca, juez mayor en Vizcaya en la Chancillería de Valladolid y oydor de ese tribunat. Autor de varios escritos, Su obra principal: De tenuta, seu interdicto et remedio possessorio summarissimo tam mero quam mixto super Hispaniae primogeniis.

(p. 414, linea 8). Conocido autor de tratados jurídicos como De Immunitate $y$ De jure fisci. El primero editado en 1621 .

(p. 80, Júnea 39). Nacido en Praga en 1571, falleció en Lisboa en 1632. Famoso en las letras portuguesas. Doctor en Cánones, fue Catedrático en ia Universidad de Coimbra. Publicó muchos libros, siendo los principales: Tractatus do manu regia, in quo omnium Legum Regiarum, quibus Regis Portugalliae in causis ecclesianticis cognitio eat jure, etc.

(p. 755, línea 10). Escritor español conocido por su obra Ordenamiento Real. 
Pérez de Lara, Alfonso

Pérez de Vargas, Bernardo

Platón

Plinio, (el Antiguo)

Plutarco

Pomponio, Mola

Pons, Antonio

Portugués y Monente, José Antonio

Quevedo, Juan (p. 396, línea 49). Abogado español de fines del siglo XVI. Toledano. Juez de causas criminales en Lima. Éscribió muchas obras, siendo las más consultadas: Compendio de las tres gracias de la Santa Cruzada; De Anniversariis et capellaniis, $y$ Compendium Vitae Homoris in Jure Fori et Poli, etc.

(p. 60, linea 37). Naturalista $y$ ustrótromo español macido a principios del siglo XVI. De distinguida familia y elevada posición: llamado "el magnífico". Obras importantes: Repertorio perpetuo o Fábrica del Universo, (en dos partes); De re metalica, consultada por muchos mineros del viejo y nuevo mundo, por los datos que contiene. Se lo atribuye el libro De los edificios y máquinas del arte de ela. borar metales.

(p. 262, línea 52). Celebririmo filósofo griego muy conocido.

(p. 61, línea 50). Naturalista, nacido en Como en 23 de J. C., miliciano y gobernador, luego, en lispaña, prefccto de la escuadra de Miseno; amigo de Vespasiano y Tito. Eseribió: Historia de Roma; ocho libros de Dubbi sermones; Historia Natural, en 87 libros.

(p. 258, linea 18). Muy conocido historiador por sus obras biográficas, de política, historia, moral, ete.

(p. 258, línea 27). Geógrafo romano, parece que permaneció en España, en tiempo de Tiberio y Claudio. Escribió un interesante tratado de Gcografía bajo el título De situ orbis, muy conocido.

(p. 272, líneu 49). Famoso y conocido autor español de Viaje de España; libro del que se han hecho hemosas y comentadas ediciones en el último tiempo, por las editoria. les madriteñas.

(p. 738, linea 8). Escritor español, nacido en Egea de los Caballeros (Zaragoza) en 1708. Murió en la capital española en 1781. De familia ilustre. Autor de la Colección general de las Ordenanzas Militares del Ejército de España desde 1551 hasta 1758. Fue editada en Madrid, entre los años 1746 al 1765 , en diez rolúmenes.

(p. 100, Ínea 9). Franciscano español, nació en Bejoris (Santander). Fue el mimer Obispo de Tierra Firme. Viajó con redro Arias Dávila, en la expedición denominada de las "Banderas". El Cardenal Cisnetos to distinguió con su amistad. Con poderes del Papa Ieón $X$ y las instruccio- 


\section{Raynal, Guillermo Tomás Francisco}

Rebufo

Richelieu, Armand Juan du Plessis, Cardenal y Duque de

Rivadeneira y Barrientos, Antonio Jonquín de

Roberston Guillermo

Rodríguez Campomanes, Pedro

Rollin, Carlos

Sage, Baltasar Jorge nes de Jermando el Católico, hizo una labor singular en facor de la civilización, defendiendo la libertad y atacando el sistema de encomiendas de indios. Como el Padre de Las Casas, luchó contra la esclavitud y la servidumbre en Anjérica. Falleció en la capital catalana en 1519.

(p. 222, línea 20). Nació en Frameia en 1713. Falleció en l'arís el año 1796. Ilustre profesor y predicador, abandonó e] hábito de jesuita para incorpararse en la Redacción de el Mercurio de Francia. Fscribió muchas obras que se hicieron famosas, eonio Historia del Estatuterato; Historia del Parlamento de Inglaterra; Anécdotas Históricas; Anécdotas Literarias; Memorias politicas de Eurapa; El divorcio de Enrique VIII. Siu Historia Filosáfica y Política del Comercio de los europeos en los dos mundos, editada en Gémova en 1780, fue condenada al ano de su aparición por el Parlamento. Después de la condena emigró y no volvió a su patria hasta 1788.

(p. 699, línca 46). Autor de Immunitate Ecclesiastica, editada en 1567. J'osteriormente escribió su obra Práctica Beneficial.

(p. 600 , línea 20). Eminente y muy conocido político de su tiempo (1585-1642). Ministro de Luis XIIT. Protegió las artes y las ciencias. Fundó la Academia Francesa. Existe amplia bibliografia sobre la vida del extraordinario prelado.

(p. 584, línea 2). Jurisconsuito y hombre de letras nacido en Puebla, México, en 1710. Murió en 1771. Abogado de la Real Audiencia. Sus obras principales son: Manual compendio del regio patronato indiano, editada en Madrid el año 1755. Disertación sobre la inmunidad local eclesiástica.

(p. 115, línei 44). Historiador y orador escosés que nació en 1721 y falleció en 1793. Entre sus numerosas obras, se distinguen: Historia de Escocia, Historia de Carlas V. e Historia de América.

(p. 482, línea 22). Literato, economista y político español. Nació en 1723 y murió en 1803. Escribió obras sobre Economia Iolitica y la Apologia de los Conquistadores. Carlos III lo nombró Fiscal del Consejo Real y Supremo de Castilla.

(p. 301, línea 44). Humanista e historiador francés. Nació en 1661 y murió en 1741. Escribió su famosa Historia Antigua.

(p. 55, línea 33). Químico y mineralogista francés, nacido en Paris en 1740, murió en 1825. Sus obras más conocidas 
en su época, son: Elementos do Docimástica o Arte de Eneayes; Arte de Ensayar oro y platn, traducidas al castellano por Casimiro Gómez de Ortega, y Expérences relatives á l'alcali volatil fluor, etc.

Salcedo, Francisco

Salgado de Somoza, Francisco

Salinas, Buenaventura de

Sandoval, Prudencio de (p. 32, línea 1). Prelado y escritor nacido en Valladolid hacia 1550 y fallecido en Estella (Navarra) en 1621. Escribió muchas obras sobre historia, siendo la más difundida: Vida y hechos del Emperador Carlos V., editada en su primera parte en Valladolid el año $1604 \mathrm{y}$ la segunda parte el año 1606, en la misma ciudad.

Sanz, Joté

Scarfantoni, Juan Jacobo

Sénoca, lnucio Annoo

Sepúlveda, Juan

Cinés de

Socuéba Arias Fustero,

Fernando González de (p. 549, línea 4). Escritor y jurisconsulto español del siglo XVIII. Natural de Sevilla. Fue Relator de Audiencia, Corregidor y Capitán a guerra de la Villa de Puerto Real. Autor de Estado actual de los censos más frecuentes en exte reyno; $y$ aquel a que deben reglarse sus réditos y condiciones, editado en Sevilla en 1759. Instrucción manual para la más breve expedición de los casos prácticos y disputas de inmunidad local. Memorial ajustado en el pleito que siguen el Conde de Benazuza y el de Altamira cobre jurisdicción. Leyes y costumbres del Reyno. Se apunta la 
Solino, C. Julius

Soliz,

Solórzano Pereyra (o Perea), Juan de

Souza, Francisco do

Stilicón, Flavio

Strabon

Suárez, Francisco forma en que deben hacer las extracciones de los Reos y describe el método de las instancias ante los jueces eclesiusticos y los recursos más frecuentes que pueden ofrecerse. Datos de la Bibl. Méndez Bejarano: Dicc. de maestros, escritores $y$. oradores naturales de Sevilia. Tom. 1.

(p. 257, línea 44). Escribió, según se presume, este pensador latino, una recopilación titulada Polyhistor. publjcada también con el nombre de Situ et mirabilibus orbis, imitación resumida del libro de plinio el viejo.

(p. 301, línea 49). Muy conocido por su Historia de la Conquista de Móxico.

(p. 61, linea 48). Cañete cita a este autor innumerables veces. Muy conocido por los actuales estudiosos de Derecho Indiano e Historia de América. Nació en Madrid en 1575. Falleció en 1654. Doctor en ambos Derechos. Felipe III lo designó en 1609, Oidor de la Rl. Audiencia de Lima. Inpulsó las minas de azogue de Guancavelica. En 1628 fue nombrado Fiscal del Consejo de Facienda y Iuego Fiscal del de Indias. For su afección al oído no quiso aceptar el nombrumiento de Fiscal del Consejo de Castilla, que el Rey insistentemente le ofreció. Autor de obras muy inportantes en materia jurílica e histórica. Disputationes de Indiarum Jure, editada en dos volúnenes en Madrid, de 1629 a 1639. Su Politica Indiana, corregida e ilustrada con notas por el Lic. don Francisco Ramiro de Valenzuela, editada en Madrid el año 1776, ha circulado profusamente en América.

(p. 470, línea 12). Abogado portugués famoso. Nació a fines del siglo XVI. En 1618 publicó Repetitiones ad L. Ferminam de Regulis Juris. Ad Actionum Instit. Aphorismos Inquisitorium, etc.

(p. 4, línea 10). Muy conocido en la historia de Roma. Fue cantado por Claudiano en un poema De Laudibus Stiliconis.

(p. 46, línea 16). Célebre filósofo griego, muy conocido por sus libros de Geografia que en gran parte se conservan. No asi sus Memorias Hitóricas.

(p. 124, línea 19). Sobresaliente jesuita español, nacido en Granada en 1548. Falleció en Lisboa en 1617. Profesor de Filosofía y Teologia. Su nombre y su obra se han actualizado en la misma medida que la obra y el pensamiento del Padre Francisco de Vitoria, en el Derecho Internacional. Los libros de Suárez, se difundieron en América. Muchas bibliotecas como la Nacional en Sucre, poseen ejemplares interesantes. La Biblioteca de la Soc. Geográfica 
de Potosi, en el Museo de la Moneda, ticne la edición de Lugduni, de 1615 de la obra Disputationem Decensuris in Communi. Otras obras notables: Varia Opurcula Theologica: De Poenitentia; De Deo uno et trino; De Religione; De Legibus; Defensis fidei; De la Cosmogonía; del Alma; De las Virtudes Teologales; Del fin último del hombre; De la Gracia, etc.

Tácito, Cayo Cornelio (p. 340, línea 32). Uno de los más grandes historiadores de Roma. Muy conocido por sus Anales; Historias, y Diálogo de los Oradores.

Techo, Padre Nicolás del

(p. 250, linea 46). Autor de Historia Paraguaya.

Teofrasto

Tortuliano

(p. 86, linea 22). Filósofo griego, muy conocido. Discípulo de Platón y luego de Aristóteles. Entre sus obras, se señalan como principales: Historia de las plantas. Causas de la vegetación, de las piedras, vientos, etc.

(p. 229, línea 47). Muy conocido como fecundo y original escritor eclesiástico. Escribió De pallio, apología personal para defenderse de sus detractores.

Tomás de Aquino, Santo

(p. 262, línea 42). Sabio té́logo de su tiempo. Escribió muchos libros interesantes. Su Summa theológica fue estudiada como ningún otro libro en la Universidad Mayor de San Francisco Xavier.

Torquemada, Juan de (p. 221, línea 44). Cardenal nacido en Fispaña en 1388. Falleció en 1468. Autor đe obras importantes, entre ellas Monarquía Indiana.

Tevillo, Padre Luis de (p. 268, línea 29). Escritor y viajante ilustrado. Fn 1712, apareció una de sus más celebradas obras: Diario de observaciones en las costas orientales de la América Meridional.

Ulloa, Antonio de

(p. 12, línea 5). Nació en Sevilla el año 1716. Murió en la ciudad de León en 1795. Llegó a ser Teniente General de la Armada. La Academia de Ciencias de París to designó socio correspondiente. Escribió numerosos trabajos de carácter eientífico y sus Noticias Americanas.

Con Jorge Juan y Santacilia, marino español oriundo de Nobleda, fueron elegidos para la comisión de medir la magnitud de un arco del meridiano, por el Rey Felipe V. En 1735 salieron de Cádiz y visitaron Cartagena de Indias, Portobello, Panamá, Guayaguil y Quito. Los resultados de su trabajo fueron perfectos suscitando la admiración de los sabios y corporaciones científicas de Francia, España $\mathrm{y}$ otros países. Publicaron las Observaciones astron nómicas y fisicas hechao on los reinos del Perú; la Rela- 
Ustariz, Jerónimo

Valenzuela, Francisco Ramiro de

Valero Diaz y Asengio de Pradas, Pedro

Van Espen, Bernardo Zegero

Varela y Ulloa, Pedro

Vela, José

Velasca, Alvaro

Villadiego Vascuñana, Alonso ción histórica del Viaje a la América Meridional hecha por orden de 5. Mag., para medir algunos gxados del meridiano terrestre, etc.; Resumen histórico de los Incas, impro. sa en 4 vol. en Madrid el año 1748 y las farnosas Noticias Secretas de América sobre el Estado Naval, Militar y Político de los Reynos del Perú y Provincias de Quito, Costas de Nueva Granada y Chile: gobierno y régimen particular de los pueblos de indios; cruel opresión y extorsiones de sus Corregidores y Curas, etc.

(p. 155, línea 15). Celebrado economista español que vivió en el siglo XVI\}t. Fue difundido en América su libro Teoría y práctica del Comercio y de la marina. Murió en 1760 .

(p. \&6, línea 20). Hspaỉol eminente. Relator del Consejo de Indias en 1736. Comentó e ilustró la Política Indiana de Solórzano. En la tercera edición de la misma, escrita en 1646, hizo una coordinación con la Recopilación de las Loyes do Indias (que data de 1680 .

(p. 433, línea 52). Jurisconsulto espariol, de Ja primera mitad del siglo XVII. Nació en Teruel y murió en Zaragoza en 1700 , Entre sus obras se cita: Comentario al jurisconsulto Tertuliano.

(p. 302, línea 5). (Se ha escrito también Wan Spen y Van Spen). Profesor de Derecho Canónico en Lovaina, de 1702 a 1709. Auter distinguido, escribió la conoctda Jus Eclesiasticum Universum.

(p. 409, linea 34). Gran bailio de la Orden de Malta. Carlos IV le nombró Ministro de Marina $\mathrm{y}$ después fue de $\mathrm{Ha}$ cienda. Murió en 1797. Dejó importantes escritos.

(p. 433, línea 45). Abogado y canonista célebre, nacido en Palencia en 1588 y fallecido en Granada en 1643. Dejo gran número de obras, entre ellas las más notables: Tratado del poder de los obispos para la pesquisa y castigo de los crímenes cometidos on su diócesis, y la apelación al brazo secular; De epíscopo; Matrimonio contraído por procurador y Disertación de Derecho.

(p. 352, línea 44). Muy conocido autor de De jure enphiteutic.

(p. 561, línea 16). Nació en Toledo este famoso abogado y tratadista español, a fines del siglo XVI. Abogado en Ios Consejos de S. M. Tscribió libros importantes como Instrucción Política y Práctica Judicial, utilísima para gobernadores, etc., editada en Madrid, por Antonio Marín, en 
1766. Forum antiquum Gothorum Regum Hispaniae, olim Librum Judicum, hodie Fuera Juzgo nuncupatum; etc.

Villars de Haustin

Villarroel, Gaspar

Vinio, Arnoldo

Vitruvio, Pollio

Zedillo y Rujaque, Pedro Manuel (p. 52, linea 35). Sabio frances, autor del conocido libro Tratado de Arte Metálica.

(p. 493, línea 40). De la Orden de San Agustin. Sus obras son numerosas y es notable la que se titula: El gobierno eclesiástico y pacífico. Nació en Quito en 1587.

(p. 671, línea 3). Llamado en latin Vinnius, Abogado holandés, nacido en 1588. Murió en 1657, Catedrático. Es. cribió: lnstitutionum imperialium commentarius.

(p. 86, Ifiea 22). Famoso arquitecto romano, nacido en Verona. Dejó un Tratado de Arquitectura, en 10 volúmenes, dedicado a Augusto.

(p. 268, línea 26). Marino y matemático nacido en AndaJuciá en 1676, fallecí en Puerto de Santa María en 1761. Realizó tres viajes hasta el Caribe, visitando Caracas y Nueva España, l'jloto mayor de la carrera de Indius. Escribió: Arte náutica; Tratado de trigonometria aplicada a la navegación; Tratado de Cosmografia y Náutica y VocabuIario marítimo.

NOTA. - Muchos de los autores snotados en este indice, han sido citados roiteradamente por Cañote en su libro. Hemos señalado. solamente la página y linea de la primera referencia. Los datos han sido recogidoa en Bibliotecas particulares y se ha consultado kambién algunos Diccionarios y Enciclopedias.- A. Alba.

\section{INDICE ANALITICO DE LAS LAMINAS CON- TENIDAS EN ESTA EDICION}

Carta Geográfica de la Provincia de Potosí con sus Partidos de Porco, Chayanta, Lípez, Chichas, Tarija y Atacama, mandada hacer por el autor de esta obra. Firma Don Hilario Malaver, Fiel interino de la Casa de Moneda. Julio de 1787. El dibujo correspondiente al Ms. del A. G. I. en Sevilla, Jleva el No. "Charcas 697", En cuanto al del Ms. de Potosí, no se conserva. Empero se hizo una cuidadosa reproducción litográfica ampliada en tamaño, a dos tintas, por cuenta del escritor Dn. Juan W. Chacón, el año 1910 , y se distribuyó profusamente en homenaje a las fiestas civicas de aquel año. $\ldots \ldots \ldots \ldots \ldots \ldots \ldots \ldots \ldots$ 
Facsímil del testinonio del certificado otoryado por Don Vicente Joaquín de Maturami, Secretario del Supremo Consejo de Indias, por el que consta que Don Pcdro Vicente Cañete y Domínguez, solicitó licencia "para imprimir y publicar" su obra sobre l'otosí. Contiene, en la parte final, el texto del dictamer de Don Jorge Escovedo y Alarcón, comisionado del Consejo, favorable a la instancia. Fl testimonio está rubricálo es $I$ a $P_{a l z}$, por Don Antonio Gabriel Quiñones, Escribano de Su MIajestad. Año

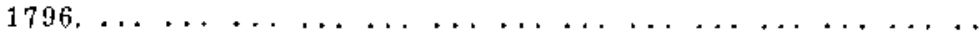

Facsínil de la Dedicatoria de lá obra al "Muy Ilustre Gremio de Azogueros" de la Villa de lotosí. Tiene tres páginas, la firma autógrafia de Don l'edro Vicente Cañete : Domínguez y corresponde al mono $1796 \ldots \ldots \ldots \ldots$

Reproducción fotogríricia de la lápida existente en el Mercado Páblico de Abastos de lá Villa, colocada cuando se acabó de construir el edificio siemio Gobernador Intendente Don Francisco de Paula Sanz $y$ su Teniente Asesor Don redro Vicente Cañete y Domínguez, en 20 de enero de $1793 . \ldots \ldots \ldots \ldots \ldots$

Flano incidito del Cerro de Totosí y parte de la Villa, del "Informe de Don Jouchim Antonio de Guendien, Marqués de Aro, Maestre de Campo, General Capitán a Guerra y Superintendente de las armas de las reales y cathólicus concuititas cle las rastas provincias del Gran Caupolicán, azoyuero, dueño de minas e ingenios, etc.", clcvado al Superintendente de Minas, Gobernador Don Ventura Santelices y Venero, con motivo de los estudios para la apertura del "Real Socavón", de orden del Rey. Lleva fecha 30 de abril de 1758, En el centro de las referencias' se lee: "Corta parte del Plan de la Imperial y rica Villa de Potosí y de su famoso cero a 17 de Abril de 1758 años". Museo Nl. de la Casa de Moneda. $\ldots \ldots \ldots \ldots \ldots \ldots \ldots$

Reproducción de un dibujo en la plaza de "Ll Regocijo" de Potosí. A1 fondo la actual Iglesia Matriz. Las figuras del primer plano parecen representar las jerarquías o "clases sociales" del vecindario al concluir el sigio XVIII. De izquierda a derecha: indios, mestizos o "cholos", criollos de la clase media y "españoles de Europa". Publicó este grabado Mr. Edmound Temple, en su obra "Travels in various parts of Perú", en $1830 \ldots \ldots \ldots \ldots \ldots$

Plano del Cerro de Potosí con las primeras edificaciones de la futura Villa Inperial. Se imprimió por primera vez en el famoso ATLAS de Pedro Bertius (1565-1629), con la siguiente leyenda: "Descriptio Argentifodinarum Potusi". El grabado es de Jodocus Hondius (1563-1611). Posteriomente ha sido reproducido varias veces en estudios como "Imagen del mundo hacia 1570", de Don Gonzalo Menéndez Pidal, Fd. Madrid, 1944, y en la "Revista de Geografia", dirigida por el Sr. Anesi, en Buenos Aires, año $1942 \ldots \ldots \ldots \ldots \ldots \ldots \ldots$ 
"Breve y verdadero retrato de la Villa Imperial de este Ríco Cerro, Arrabales y Lagunas". Dibujo original del siglo XVII.

Fotocopia de una de las páginas (54) del Manuscrito de esta obra, existente en el Archivo General de Indias, Sevilla. Tstante 121, cajón $7^{\circ}$, Iegajo 25, según la antigua catalogación. . .

Facsímil de una de las priginas (170) del primer volumen del Manuscrito de este libro, que lleva fecha de 1787 , pertcreciente a la Sección de "Archivos Coloniales" del Museo Nl. de la Casa de Moneda de Potosi, por cesión del Ayuntamiento. ... ...

Retrato del afortunado azoguero Maestro de Campo Don Antonio López de Quiroga, en 1666 . Oleo de autor anónimo, perteneciente a la Pinacoteca del Museo Nl, de la Casa de Moneda.

Vista de uno de los corredores'con arcos de ladrillo que comunica el segundo patio con el tercero, de la Casa de Moneda, des-

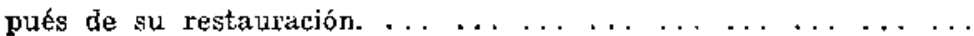

Facsimil de la copia del nombramiento de Ministro Honorario de la Audiencia de Charcas expedido por el Rey en favor de Don Pedro Vicente Cañete y Dominguez, en 1791. Fil documento tiene sello de catalogación del Archivo General de Simancas. ...

Vista de un ángulo del princr patio de la Casa de Moneda, edificio restaurado desde $1938 . \ldots \ldots \ldots \ldots$

Dibujo del Cerro de Potosí, con la dirección de las retas de plata "topadas", firmado por Don Nicolás Benino, natural de Florencia propietario de minas en el siglo XVI ... . . . . . . .

Retrato de S. M. el Rey Don Carlos III, pintado en Fotosí por autor desconocido, para las solemnes ceremonias de jura $y$ aclamación del Soberano en la Villa. Oleo de la Pinacoteca del Museo Nl. de la Casa de Moneda. Año de 1760. ..........

Retrato del Excmo. \$r. Don Jorge Escovedo y Alarcón, por pintor anónimo, perteneciente a la Pinacoteca del Museo Nl. de la

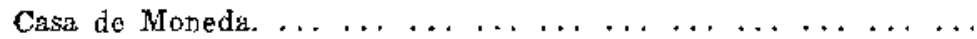

Plano inćdito del Cerro de Potosí, del "Informe" de Don Hilario Malaver, azoguero y propietario de minas, que presentó al Gobernador Superintendente de Minas Don Ventura Santelices y Venero, en 20 de rarzo de 1758 , con ocasión de iniciarse los trabajos de apertura de la entrada o boca del "Real Socavón". Museo Nl. de la Casa de Moneda. ... . . . . . . . . . . . . . .

Vista del corredor de la planta alta del primer patio de la Casa de Moneda, después de su restuuración. ... ......... 


\section{I $\quad \mathbf{N}$ D}

\section{DE LOS CAPITULOS, NOTICIAS Y PARRAFOS CON'TENIDOS EN ESTA OBRA}

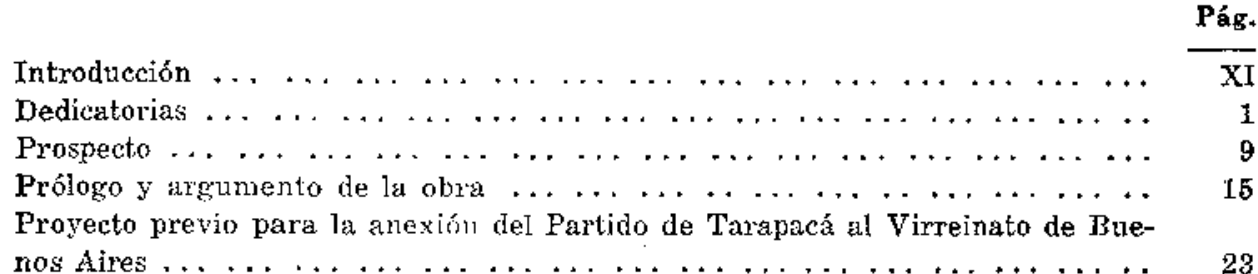

\section{P A R T E $\quad$ P R I M E R A}

\section{CAPITULO PRIMERO}

\section{De la fundación de la Villa Imperial de Potosí}

Se describe su situación, planta y altura del Polo.- Su antigua magnificencia.- El número de sus pobladores, iglesias y oficinas.- La calidad de su temperamento; el aspecto y naturaleza de su terreno, y de las aguas minerales de su territorio.

Noticia 1a.- De la fundación de la Villa, con todo lo tocante a la descrip. ción de su casco $\ldots \ldots \ldots \ldots \ldots \ldots$

"2a.-Del aspecto y naturaleza del terreno de Potosí ... ... ... 44

$" \quad 3 a .-$ De las aguas minerales del territorio de Potosí $\ldots \ldots \ldots .45$

\section{CAPITULO SEGUNDO}

\section{Del rico mineral de Potosi}

De su descubrimiento y riquezas. - De las minas del Cerro Rico y de otras de sus contornos.

Noticia 1a.-Descubrimiento y riquezas del Cerro de Potosí ... ... ...

" 2a.-- Párrafo primero: De otras minas de sus contornos y permanencia de las del Cerro $\ldots \ldots \ldots \ldots \ldots \ldots \ldots \ldots$ Párrafo segundo: De la reproducción de los metales del Cerro Rico de Potosí $\ldots \ldots \ldots \ldots \ldots \ldots$ Párrafo tercero: De las diversas clases de metales del Cerro y dirección de sus vetas $\ldots \ldots \ldots \ldots \ldots \ldots \ldots$ 


\section{CAPITULO TERCERO}

\section{Beneficio de metales y uso del azogue}

Del beneficio de las minas de Potosí y de la variedad que en ésto ha habido.

Noticia la.- De las diferentes maneras de beneficios que se han practicado hasta ahora en las muchas elases de metales de este Cerro $y$ en las escorias y tierras $\ldots \ldots \ldots \ldots \ldots \ldots$

2a.-Del desperdicio de azogue $\ldots \ldots \ldots \ldots \ldots \ldots \ldots$

3a.- Del correspondido de azogues $\ldots \ldots \ldots \ldots \ldots$

4a.- Arbitrios para mejorar el beneficio y evitar el desperdicio de azogue $\ldots, \ldots, \ldots, \ldots, \ldots, \ldots, \ldots \ldots \ldots$

\section{CAPITULO CUARTO}

\section{Minerales de azogue y su comercio}

\section{Del azogue, de la diversidad de sus precios y de la mano y método de su distribución.}

Noticia 1a.-De la invención del beneficio por azogue ... . . . . . .

"2a.- Descubrimiento de las minas de Guancavelica . . . . . . . . .

"3a.- Minerales que han proveido de azogue a Potosi . . . . . . . . .

4a... De varios minerales de azogue en el l’erú ... . . . . . . . .

5a.- Se refiere históricarnente los diversos precios del azogue y otras graves contestaciores sobre este asunto ...........

7a.- Del asiento, del Trajín y conducción de azogues . . . . . . .

8a. - Medios de mejorar el Trajín de los azozues ... ... . . .

\section{CAPITULO QUINTO}

\section{Lagunas e Ingenios de Potosi}

\section{De las Lagunas y de los Ingenios que forman la Ribera.}

Noticia 1a.- Motivos por qué se fabricaron Ingenios y Lagunas en Potosí.

2a.- Número antiguo de Lagunas $\ldots \ldots \ldots \ldots \ldots$

" 3a.. Número actual de Lagunas ... . . . . . . . . . . . .

4a.-Distribución de la Ribera de Potosí $\ldots \ldots \ldots \ldots \ldots$

5a.—Custodia y reparo de las Lagunas . . . . . . . . . . . . . 91

6a.-Número de ingenios y el tiempo que comenzaron a moler ... 91

7 a.. Ruina de la Ribera por la reventazón de una Laguna . . . . . 91

" 8a.- Nueva forma en que se repararon las Lagunas; impuestos establecidos para este fin y premios concedidos para la reedificación de tos ingenios $\ldots \ldots \ldots \ldots \ldots \ldots$

9a.- Producto de la sisa para reparos de Lagunas y nombramiento del Lagunero ... . . . . . . . . . . . . . .

" 10a. - Sueldo del Lagunero Mayor . . . . . . . . . . . . . . . . 93

$" 11$ a. - Restablecimiento de la Ribera $\ldots \ldots \ldots \ldots \ldots \ldots$ 
Noticia 12a.- Demolicion de algunos ingenios $\ldots \ldots \ldots \ldots \ldots \ldots$

" 13a.-Número de ingenios que señaló el Sr. Toledo y el Sr. Velasco.

Pig.

" 14a.- Proridencias modernas sobre fábrica de ingenios ... .....

" 15a.- Arbitzio para conservar las Lagunas surtidas de agua en tiempo de seca $\ldots \ldots \ldots \ldots \ldots \ldots \ldots \ldots \ldots \ldots \ldots \ldots$

\section{CAPITULO SEXTO}

\section{De la Mita}

Se refiere el origen, progresos, novedades y actual estado de la Mita, con los empadronamientos hechos desde el año 1578 hasta 1690.

Párrafo primero: Datos generules sobre ta Mita en Potosi ... . . . . . .

" segundo: Fundación del Hospital para indios mitarios ... . . . . .

$"$ tercero: Potación del Hospital . . . . ................

" cuarto: Exención del derecho de granos que pagaban al Hospital los indios mitarios $\ldots \ldots \ldots \ldots \ldots \ldots \ldots \ldots$

$"$ quinto: Continuación del asunto de la Mita .............

" sexto: De los leguajes que se deben pagar a los mitarios ........

" séptimo: Formalidades que se deben observar en el envío y recibo de la Mita y facultades del Superintendente para verificar su entero ...

" octavo: Del trueque del servicio personal en plata $y$ sus penas .....

" noveno: Lugar destinado para la paga semanal de jornales y personas que deben concurrir a este acto $\ldots \ldots \ldots \ldots \ldots$

$n$ décimo: Abusos introducidos en perjuicio de la Mita ..........

" undécimo: Días de fiesta de guarda para los indios ... . . . . . . .

" duodécimo: La decadencia de la Mita y otras fatales consecuencias que han procedido de los abusos tolerados contra ella ... . . . . .

" décimotercero: Estado actaal de la Mita ................

" décimocuarto: Necesidad de hacer nuevo repartimiento general y medios para verificario $\ldots \ldots \ldots \ldots \ldots \ldots \ldots \ldots \ldots$

" décimoquinto: La grande importancia de poblar los Asientos de minas, para conservación de la Mita $\ldots \ldots \ldots \ldots \ldots \ldots$

\section{CAPITULO SEPTIMO}

\section{Del Real Banco de Rescates}

Del Real Banco de San Carlos de la Villa de Patosí; su establacimiento, progresos $y$ demás incidencias.

Noticia 1a.- Del origen y motivos de los rescates de platas en Potosí y la forma en que se hacían antiguamente .............

" 2a.- Párrafo primero: Establecimiento de la Compañía de Azoguegueros de Potosí, para avíos de sus minas. Se refiere el núme: ro de acciones y capitales con que comenzó .......... Párrafo segundo: Establecimiento del Banco por los Azogueros. Párrafo tercero: Rescate del Banco, por establecimiento de 
los Azogueros, el uño de $1752 \ldots \ldots \ldots \ldots \ldots \ldots$

Párrafo cuarto: Epoca en que se empezó a pagar al azoguero a 7 y 1,2 pesos el marco de pina, en lugar de 7 pesos que antes se le pagaba $\ldots \ldots \ldots \ldots \ldots \ldots \ldots$

Noticia 3a.- Quiebra del Banco de P'otosí; sus causas y resultas ... . . . .

" 4a.- Incorporación del Banco de Potosi a la Real Corona, con el título de "San Carlos" ... . . . . . . . . . . . . . . . . . .

5a.- Utilidades del Banco en un quinquenio siguiente a la incorporación y gastos que sufre su fondo. Se pone al fin de este Capítulo un estado comprensivo hasta fin del año $1786 \ldots \ldots$

6a.- Formación del Reglamento aprobado por el Rey, para el gobierno del Banco ... ........................

7a.-Párrafo primero: Economía del Banco en los principales em-

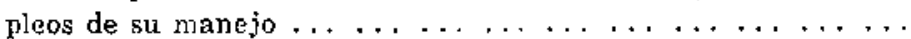
p’árrafo segundo: Inciso I. --- Administrador del Banco ... .. Inciso II. - Tesorero. . . $\ldots \ldots \ldots \ldots \ldots$ Inciso IHI. - Contador. $\ldots \ldots \ldots \ldots \ldots \ldots$ Inciso IV. - Sueldos. . . . . . . . . . . . . . . . .

8a.- Banco General de Avios para todas las minas del Virreinato: Párrafo primero: Se propone los medios más proporcionados a su conservación y alivio de los mineros . . . . . . . . . . . Párrafo segundo: Cautelas para prosperar en el trabajo de minería y evitar fraudes $\ldots \ldots \ldots \ldots \ldots \ldots$ J'árrafo tercero: Método, lugar y forma de repartir los auxilios en plata y azogues a los mineros de fuera de esta Provincia de Potosí $\ldots \ldots \ldots \ldots \ldots \ldots \ldots$ Párrafo cuarto: Aviadores particulares de minas. Se refieren varios inconvenientes $\mathrm{y}$ los medios de evitarlos ......... Párrafo quinto: Ganancias del Banco en las demás Provincias del Virreinato $\ldots \ldots \ldots \ldots \ldots \ldots \ldots \ldots \ldots$ Párrafo sexto: Desezentos del valor de las platas ........ Párrafo séptimo: Precaución para amonedar las barras que no

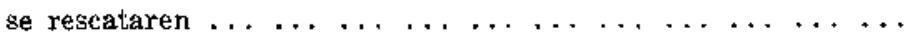
Párrafo octavo: Fondo que se computa para el Banco de Avíos Generales para la Minería del Virreinato ............ Párrafo noveno: Superintendente. Su responsabilidad, jurisdicción, causas a que se extiende y sus facultades ... . . . . Párrafo décimo: Provisión de los empleos del Banco ....... Párrafo undécimo: Indultos de los empleados en el Banco. ... 139

Párrafo duodécimo: Advertencia muy importante ... . . . . .

\section{CAPITULO OCTAVO}

\section{De la Real Casa de Moneda de Potosi}

Se refiars el tiompo y motivos de su fundación; ol método antiguo y moderno de su labor; las quiebras que antes sufrió y lo demás tocante a sus oficinas.

Noticia 1a $\ldots$ De los metales considerados como mercadería ......... 
Noticia 2a. - De los metales contempiados como moneda . . . . . . . . .

" 3a.- Fistablecimiento de la Casa de Moneda de Potosí ... . . . . .

4a,... Historia circunstanciada del origen de la Casa de Moneda de Potosí; de su costo $y$ de la fábrica de las cuatro hornazas an-

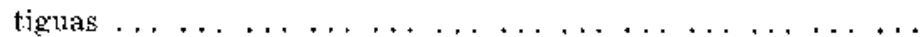

5a.- l'árrafo primero: (antidades de labor en la Casa de Moneda, de cuenta del Rey y de los partidarios, en la proporción de diez mil mareos . . . . . . . . . . . . . . . . . . . . P'árrafo segundo: Se romata la amonedación de la plata en 27 de abril de 1575 años, para facilitar la circulación en Potosí.

6a.--De los delitos de falsetad on lia fábrictición de moneda en esta Casa de Frotosí $\ldots \ldots \ldots \ldots \ldots \ldots$ tera pureza $\ldots \ldots \ldots \ldots \ldots \ldots \ldots \ldots$

10a.-Fundación de Casns de Moneda en las ciudades de Lima y del Cuzco; la primera para labor de plata y la segunda para oro.

11a.- Privación de las hormazas, de resultas de la visita del Sr. Negtares $\ldots \ldots \ldots \ldots \ldots \ldots \ldots \ldots \ldots$

12a.- Reintegración del Real Derecho de Cobos ............

13a.-.- Irimeras rendicioness con la reducción de la ley a 11 dineros justo $\ldots \ldots \ldots \ldots \ldots \ldots \ldots \ldots \ldots$

14a.- Aplicación de los cuatro granos de baja en la ley, a favor de los ducños de los metales . . . . . . . . . . . . . . .

15a.- - Nueva Ordenanza para labrar moneda de cordoncillo ......

16:- Número de empleos y sus dotaciones, con arreglo al Capítulo $1^{\circ}$ y $40^{\circ}$ de la Ordenanza y de un Auto acordado del Superior Gobierno $\ldots \ldots \ldots \ldots \ldots \ldots$

17a.- Jurisdicción de los Sres. Virreyes en lo criminal de las causaa

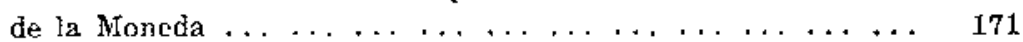

18 a... La vía donde se debe proponer los empleas de la Moneda ...

19a.- Empleos que recesitan Real confírmación ... . . . ..... 173

20a. - Sueldos de los interinos . . . . . . . . . . . . . . . . . . . 173

$21 a$. - Montepío y media anata . . . . . . . . . . . . . . 174

22a.-Medios políticos de nejorar el servicio de los empleados ... 174

23a.- Cierta declaración en chanto a la excepción de los dependientes de la Moneda, de la jurisdicción ordinaria ...........

24a.- Apelaciones en causas criminales de la Moneda ... ... . .

25a- Fxplicación de varias Reales Ordenes acerca de la pena contra ladrones $\ldots \ldots \ldots \ldots \ldots \ldots \ldots \ldots$

26a.-Subrogación de la Superintendencia $\ldots \ldots \ldots \ldots \ldots \ldots$

$27 a$ - I abor de cuenta de S. M. . . . . . . . . . . .

28a.- Nueva fábrica de la Casa de Moneda, en la esquina de la Plaza $\ldots \ldots \ldots \ldots \ldots \ldots \ldots$

$29 a$ - Historia de las cuatro hornazas $\ldots \ldots \ldots \ldots \ldots \ldots$

30a.- Novedades en los Oficios de la Moneda en tiempo del Gobernador Santelices $\ldots \ldots \ldots \ldots \ldots \ldots \ldots$ 
la Casa de Moneda ... ......................

Pág.

Noticia 32a. - Principio de la moneda de cordoncillo y laurel . . . . . . . .

" $33 a$. Fondo destinado para el giro de la Casa . . . . . . . . . .

" 34a.- Método en el giro de la Casa, desde la compra de metales hasta su reducción a moneda .....................

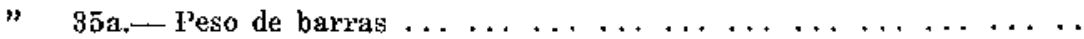

" 36a.- Formalidades con que se despachan las libranzas y se puisan las platas a las oficinas respectivas .................

37a.- Deducción de 17 maravedies en cada marco, para gastos de afinación $\ldots \ldots \ldots \ldots \ldots \ldots \ldots \ldots$

38a.-- Intervención del Guardamateriales on los caudales que pasan al Tesoro de Fundición .....................

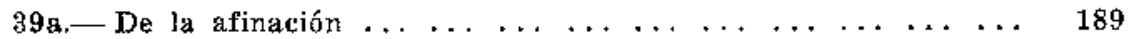

" 40a... De la fundición $\ldots \ldots \ldots \ldots \ldots \ldots \ldots \ldots$

"41a.- Establecimiento de la labor del olo y el método que se observa en su afinación .......................

42a.- Errores y pérdidas experimentadas en la afinación del oro ...

43a. - De las cuentas del Fundidor; tiempo y método de rendirlas . .

44a.-De la Fielatura. Se explican las diferentes operaciones de esta Oficina; se refieren los utensilios de la labor; con varias reflexiones importantes para el aumerito de utilidades ......

45a.- Causa de la escasez de moneda menuda ... . . . . . . . . .

46a.-Cantidad que se debe labrar por Ordenanza ... . . . . . .

47a.- Medios de aumentar la circulación de moneda en el Reino y perjuicios que se expeximentar de la falta de su giro ......

48a. - Sobre el feble de la moneda . . . . . . . . . . . .

49a.- Formalidades en las Libranzas ... . . . . . . . . . .

50a-Método de formar los cargos y datas al Fiel y Tesorero, en las rendiciones $\ldots \ldots \ldots \ldots \ldots \ldots \ldots \ldots$

51a. Sobre las mermas de la Fielatura . . . . . . . . . . .

52a.- De las causas a que se atribuyen las mermas de la Fielatura.

$53 a \ldots$ De la verdadera economía de la Casa ... . . . . . . . .

54a. Medios para aumentar la labor del oro ... . . . . . . . .

55a.- De 19 gruesa de marcos de plata y oro amonedados desde que empezó la lảor de cuenta del Rey; sus precios, utilidades y gastos $\ldots \ldots \ldots \ldots, \ldots, \ldots, \ldots, \ldots, \ldots, \ldots, \ldots, \ldots, \ldots$

TABLA I. - Para ajustar el valor de los marcos de oro de 22 quilates, después de verificadas las reducciones de esta ley; y también para deducir el Real derecho de 3 por ciento, perteneciente a $S . M . \ldots \ldots \ldots \ldots \ldots$ TABLA II. - Valor de la plata de 11 dineros justos, a 8 pesos 2 maravedíes

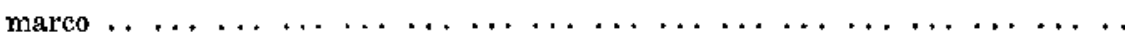

\section{APENDICE}

\section{Al Capitulo 89 , desde la noticia XXXVI}

Contiene los artículos más dignos de reforma en esta Real Casa de Moneda, con varios discursos económicos y químicos que manifiestan los medios proporcionados para lograr este fin $\ldots \ldots \ldots \ldots \ldots \ldots \ldots \ldots \ldots$ 


\section{CAPITULO NOVENO}

\section{Del Partido de Porco}

Su descripción física y geográfica

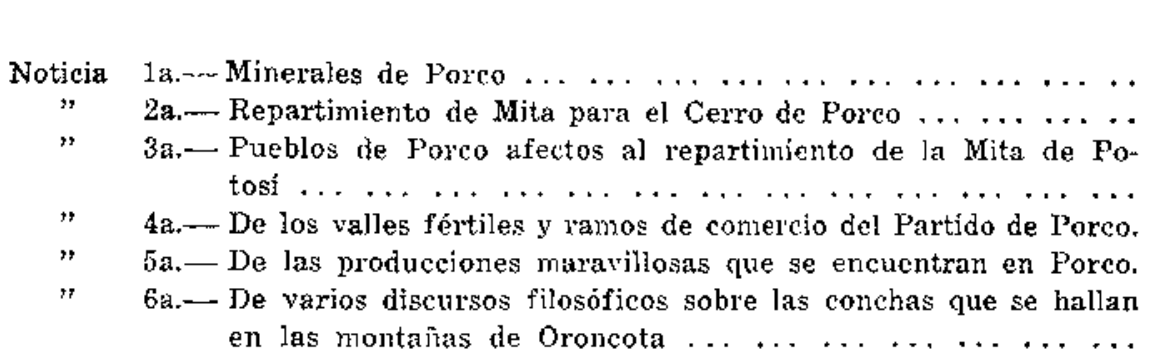

Pás.

225

226

226

227

227

228

\section{CAPITULO DECIMO}

\section{Del Partido de Chichas}

Se describe sus principalos poblaciones, con los minoralos de oro y plata, Ingenios y Doctrinas.-- Su extensión y demás circunstancias.

Noticia 1a.- De la extensión y naturaleza del terreno de Chichas ......

" 2a.- De la Capital Tupiza, y de otros pueblos principales con sus respectivos minerales $\ldots \ldots \ldots \ldots \ldots \ldots \ldots \ldots$

" 3a... Reflexiones para aumentar las sacas de plata ... . . . . . .

" 4a.-Comunidades Mitarias para el servicio de Potosi ... ... ...

$" \quad 5 a .-$ Discurso político para hacer feliz al Partido de Chichas ... . .

\section{CAPITULO UNDECIMO}

\section{Del Partido de Lípez}

Se informa sobre las riquezas de su suelo, extensión, sales y otros productos.

Su descripción circunstanciada y la de sus principales minerales, con varios discursos sobre algunas particularidades extrañas $\ldots \ldots \ldots \ldots \ldots \ldots$ Noticia 1a.-De la mina llamada "La Hedionda"; y sobre ella se discurre ffsicamente $\ldots, \ldots, \ldots, \ldots \ldots \ldots \ldots \ldots$

" 2a.- De las vicuñas y progreso que puede lograrse con el comercio de sus pieles; aplicando en la crianza de animales la economía que se apunta $\ldots \ldots \ldots \ldots \ldots \ldots$

\section{CAPITULO DUODECIMO}

\section{Del Partido de Chayanta}

Se explica por noticias su situación, extensión, pueblos principales, su temperamento, minerales, rios y producciones.

Noticia 1a.- De la situación, extensión y confines de Chayants con sus principales pueblos $\ldots \ldots \ldots \ldots \ldots \ldots \ldots$ 


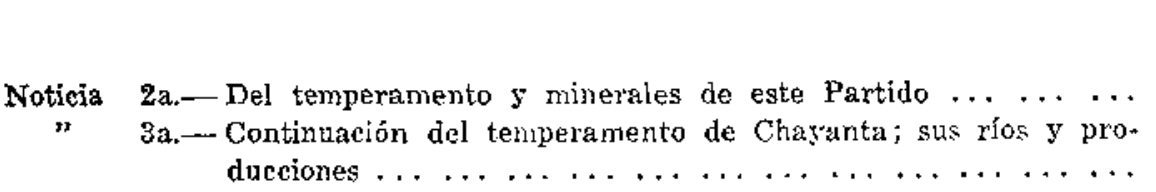

Pág.

244

\section{CAPITULO DECIMOTERCERO}

\section{Del Partido de Tarija}

Se refiere su historia, calidad de sus aguas, aspecto de su valle $y$ origen de los chiriguanos y otras noticias.

Noticia 1a_- De la fundación de la Villa de San Bernardo, su Capital; altura, distancia de Potosi y su fertilidad ... . . . . . . . .

$" \quad 2 a$. De la mala calidad de las aguas de Tarija . . . . . . . .

" 3a.- De los daños que causan los infieles Chiriguanos; medios de contener sus irrupciones y de adelantar la población. ...... Historia y ferocidad de los Chiriguanos ............

" 4a.- Del aspecto admirable del valle de Tarija, mirado desde la

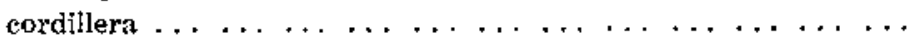

" 5a.-De los huesos de extremado tamaño que se encuentran en este Partido, atribuidos a gigantes. Se expore un discurso físico sobre esta curiosa materia ... . . . . . . . . . . . .

" 6a.- Se contradice la historia de haber sido fabricada por Santo Tomás, apóstol, una Cruz que se vonera en Tarija ... ......

$"$

7a.- De los indios tributarios de Tarija y sus tasas .........

\section{CAPITULO DECIMOCUARTO}

\section{Del Partido de Atacama}

So detalla su extensión, riqueza de su suelo, producciones y otras particularidader de la comarca.

Noticia ta.-De su extensión; de sus pueblos y de la naturaleza y fertilidad del terreno $\ldots \ldots \ldots \ldots \ldots \ldots \ldots$

" 2a.- De los minerales y demás producciones de este Partido. ...

" 3a.- Del Puerto de la Magdalena de Cobija. Se describe su situación y su comarca .......................

\section{PARRAFO UNICO}

Avisas y reflexiones políticos sobre los destinos y medios con que deben apro. vecharse las preciosas materias y producciones que ha creado la Naturaleza en los Partidos que se acaba de describir.

Artículo 10. - Varias advertencias económicas para reformar los abusos dominantes en lo general de la Provincia contra el bucn régimen de Policía ... Artículo 2o. - Conclusión del artículo anterior con una extensa explicación sobre el estado urbano de la Villa, la necesidad de su major aseo, refecciones urgentes que hacer; la mejora de su servicio de agua y arreglo de las lagunas; ruinosa condición de sus iglesias; cuidado de los caminos principales 
para beneficio del transporte comercial; servicio de correos y atención de mesones para viajantes $y$, finalmente, sobre el pésino sistema de enterratorios que se acostumbra, a más de otros importantes discursos para los servicios públicos de Potosí $\ldots \ldots \ldots \ldots \ldots \ldots$

\title{
APENDICE
}

A los últimos seis capitulos precedentes.

Observaciones sobre los medios más importantes para el mejor servicio del Rey y para la felicidad de los indios, habitantes en los Partidos campestres de la Intendencia $\ldots \ldots \ldots \ldots \ldots \ldots \ldots \ldots \ldots \ldots$

\section{P A R T E S E G U N D A}

\section{DISCURSO PLELIMINAR O CAPITULO PRIMEKO}

\author{
Del Gobierno antiguo de la Villa Imperial de Potosi
}

\footnotetext{
Se explica el estado político y civil de su población y de las cinco Provincias agregadas a esta Intendencia, durante el mando de los Corregidores.
}

Algunas advertencias importantes para el sistema del Gobierno reformado ... Noticia la.-Del estado político y civil de esta Villa durante el Gobierno de los Corregidores .........................

"2a.-De los Corregidores de Jas cinco Provincias: Chayanta, Porco, Chichas, Lipez y Atacama, agregidas a esta Intendencia; se explica su autoridad y principales objetos de su manejo y se apuntan algunas reflexiones sobre la importancia de su extinción $\ldots \ldots \ldots \ldots \ldots \ldots$

\section{CAPITULO SEGUNDO}

\section{De la Tesorevia de la Real Hacienda de Potosí}

So refiere la erección de estas Cajas Reales y la dotación de ellas; su territorio; la autoridad de sus Ministros, con las novedades ejecutadas en su Admipistración y los ramos de su manejo.

Noticia 1a.- De la fundación de estas Cajas Reales ... . . . . . . . . Período primero. Varios recursos fiscales ... ........

" segundo. Incorporación de la Real Hacienda al Sucuarto. Embarazos e intervención del Legado Apos- 
Noticia 2a. - Del sueldo de los Oficiales Reales ... . . . . . . . . . 357

" 3a.- Del territorio antiguo y moderno de estas Cajas . . . . . . 358

" 4a.. De ja autoridad de los Ofjeiales Reales ... . . . . . . . . 359

Asiento de los Oficiales Reales en el Cabildo . . . . . . . . $\quad 360$

" 5a.- De las novedades ejecutadas en los Oficinles Reales ... . . . .

" 6a._- De los Ramos de Real Hacienda, del cargo de estas Cajas de

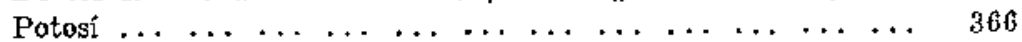

Párrafo primero, - Diezmos y Cobos de plata en pasta . . . . . . . . 367

" segundo. - Diezmo de plata labrada ... . . . . . . . . . 370

" tercero. - Tres por ciento del oro ... . . . . . . . . . . . 372

" cuarto, - Oficios vendibles y renunciables . . . . . . . . . . . 374

" quinto. - Tributos de los Cinco l'artidos de Chayanta, P'oreo, Chichas, Lípez y Atacama, incluso los Yanaconas .............

" sexto. - Yanaconas de fa Real Corona, de la jurisdicción de la Villa a saber: Chulchucani, Salinas, Tarapava, Cantuniarea, la Matriz y $\operatorname{San}$ Roque $\ldots \ldots \ldots \ldots \ldots \ldots \ldots \ldots \ldots \ldots$

" séptimo, - Indios criollos de las Parroquias de Potosí . . . . . . . .

" octavo. — Minas Estacas de Su Majestad ... . . . . . . . . . .

$" \quad$ noveno. $\ldots$ Sitios solares $\ldots \ldots \ldots \ldots \ldots \ldots \ldots \ldots \ldots$

"décimo. - Media Anata y Larzas ... . . . . . . . . . . .

" undécimo y duodécimo. - Papel seliado y Naipes . . . . . . . .

" décimotercere. - Bulas de Cruzada . . . . . . . . . . .....

" décimoczarto $y$ décimoquinto. - Casa de Moneda y Real Banco ...

" décinnosexto. - Real Aduana .....................

Noticia única, - Ramos que administra la Villa do Potosi:

Artículo primero. - Alcabalas ... . . . . . . . . . . . . . .

Artícula segundo. - Sisa y nuevo impuesto sobre el efecto del aguardiente y

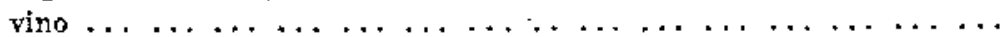

Párrafo décimoséptimo. - Las Cajas de afuera $\ldots \ldots \ldots \ldots \ldots$

\section{Ramos de Hacienda de segunda clase.}

Parrafo primero. - Penas de Cámara $\ldots \ldots \ldots \ldots \ldots \ldots \ldots$

" segundo. - Novenos $\ldots \ldots \ldots \ldots \ldots \ldots \ldots \ldots \ldots$

tercero. - Mesadas Eclesiásticas ... ...............

cuarto. - Medias anatas eclesiásticas ... . . . . . . . . . . . 420

quinto. - Vacantes menores $\ldots \ldots \ldots \ldots \ldots \ldots$

sexto - Donativos $\ldots \ldots \ldots \ldots \ldots \ldots$

séptimo. - Alcances de Cuentas ................... 422

octavo. - Vacantes Mayores ... . . . . . . . . . . . . . . . . . . . 423

Ramos de tercera clase.

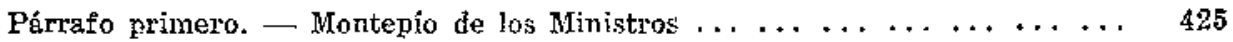

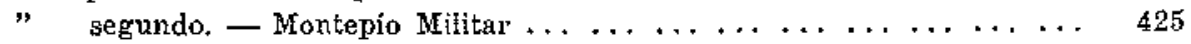

$" \quad$ tercero, - Cinco por ciento de Sínodos $\ldots \ldots \ldots \ldots \ldots \ldots$ 


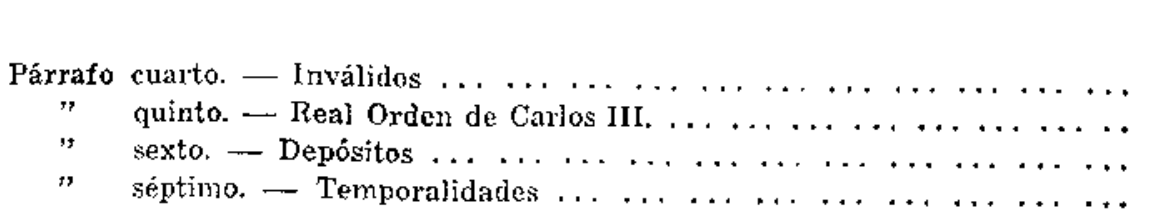

Pág.

\section{CAPITULO TERCERO}

\section{De las estaciones de la Real Hacienda}

Distinción de las estaciones en su orden y clases $\ldots \ldots \ldots \ldots \ldots \ldots \ldots$

\section{CAPITULO CUARTO}

\section{De los libros do la Razón Gonoral de la Real Hacienda}

Noticia 1a.- De los gastos, sueldos y pensiones de la Real Caja de Potosí..

" 2a.-.- Resumen general de los sueldos y pensiones que sufren Ias ofjcinas de la keal Hacienda de esta Villa .............

\section{CAPITULO QUINTO}

Del envio anual del Real Tesoro de las Cajas de estas Provincias, a la Tesoreria General de Buenos Aires.

Formas, detalles y condieiones de los envíos $\ldots \ldots \ldots \ldots \ldots$

\section{CAPITULO SEXTO}

Del nuevo sistema de Intendentes y :eforma de la Ordenanza de Real Hacienda

Se explica las facultades de estos nuevos Magistrados y los casos en que versa su autoridad en materia de Hacienda, Policia, Justicia y Guerra. Con numoración de los objetos principales de estas cuatro causas.

Noticia 1a.- Del establecimiento de la Intendencia ... . . . . . . . .

" 2a,-De la reforma de la Administración de la Real Hacienda ...

" 3a.- Varios casos de la Administración por mayor en que versa la autoridad de los Interdentes; con distinción de los que necesitan consulta de la Junta Superior de Buenos Aires:

Párrafo primero. - Juntas de Hacienda ... . . . . . . . . . . .

" segundo. - Libramientos sobre Real Hacienda . . . . . . . . . .

tercero. - Transacción de negocios fiscales . . . . . . . . . .

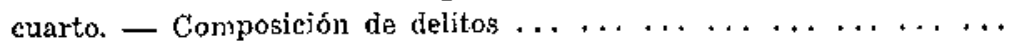

quinto. - Expensas de Misioneros ... . . . . . . . . . 450

sexto. - Costeo de Iglesias $\ldots \ldots \ldots \ldots \ldots \ldots$

séptimo, - Esperas de deudores fiscales ... . . . . . . . . 451

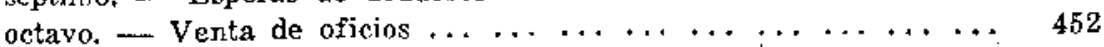

$"$ noveno. $\ldots$ Dudas en materias de Hacienda $\ldots \ldots \ldots \ldots \ldots \ldots \ldots \ldots$ 
Párrafo décimo. - Manejo deł ramo de Alcabalas . . . . . . . . . . . undecimo, - Administración de Tstacas-Minas del Rey . . . . . . . 458 duodécimo. -. Repartimiento de Mita ... . . . . . . . . . . . . 453 décimotercero. - Arrendamietlo de minas por deudas fiscales . . . . 454 décimocuarto. —. Cobranzas de Real Hacienda . . . . . . . . 455 décimoquinto. - Fianzas de Oficiales Reales ... . . . . . . . 455 décimosexto. - Nombramiento interino de Oficiales licales . . . . 455

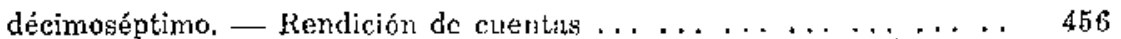

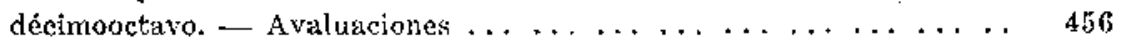

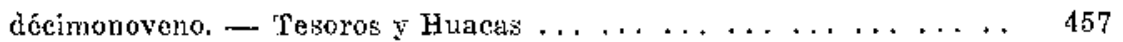
vigésimo. - Venta y composición de ticrras . . . . . . . . . . . 458

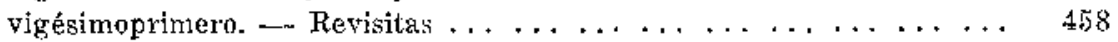

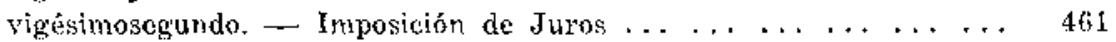

vigésimotercero, -- Erección de Cajas Reales . . . . . . . . . . . . 461 vigésimocunrto. - Arbitrio para aumento de la Rea] Ilatcienda ... 462 vigésimoquinto. Apéndice. -- De los objetos de la Direceión por mayor de Real flacienda $\ldots \ldots \ldots \ldots \ldots \ldots \ldots \ldots$

Seccion primera. - Impuestos sobro las tierrus $\ldots \ldots \ldots \ldots \ldots \ldots \ldots$

" segundel. — Alcabala de arrendamifentos de Die\%mos . . . . . . . .

$"$ tercera. - Siembra de Tabaco $\ldots \ldots \ldots \ldots \ldots \ldots$

Noticia 4a.- De lo jurisdiccional de Iuxticia en las liependencias de Rentas. Párrafo primero. - De las apelaciones y conpetencias en las casas de Haciend $a \ldots \ldots \ldots \ldots \ldots \ldots \ldots \ldots \ldots \ldots$

" segundo. - De las personas y Ministros comprendidos en el goce de fuero militar $y$ del pasivo de Hacienda $\ldots \ldots \ldots \ldots \ldots \ldots$

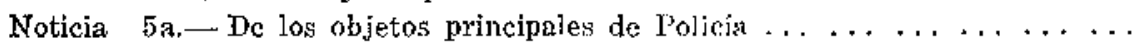
Artíctulo primero $\ldots$ Seguridad $\ldots \ldots \ldots \ldots \ldots \ldots \ldots$

\section{APENDICE A LA NOTICIA QUNNTA}

Consideraciones más delicadas que pueden tocarse en toda la obra

Abraza los abastos, los oficios mecánicos, los materiales para obras y los surti-
mientos de morcaderias que necesitamos para subsistir con comodidad, respecto
de incluírse todos estos tnenesteres bajo el nombre de alimentos, según la decla-
ración de la Ley 2, Título 19 , Partida 4 a.; para no confundir estos objetos se
trata do por sí cada uno de ellos, según el por menor de sus circunstancias.

Párafo primero, - Alimentos $\ldots \ldots \ldots \ldots \ldots \ldots \ldots \ldots$

" segundo. - Oficios Mecánicos ...................

$"$ tercero. - Materiales para obras. (Nota) ...............

" cuarto. - Suxtimientos de mercaderías para provisiones de Jos pueblos; se explica la Declarnción 7a. de la Nueva Ordenanza y se propone un arbitrio fácil y libre de inconvenientes en su ejecución ...

Noticia 6a.m. De los objetos de la causa de Justicia en que se resuelven varias cuestiones importantes $\ldots \ldots \ldots \ldots \ldots \ldots \ldots$

Párrafo primero, - Apelación de los Tenientes . . . . . . . . . . . .

" segundo. — Información contrá Eclesiásticos ... . . . . . .

" tercero. . . Castigo de falsos testigos . . . . . . . . . . . .

" cuarto. - Consulta de las sentencias criminales con la Real Audien- 


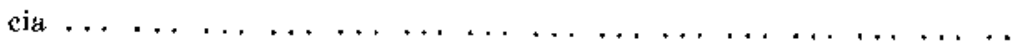

Párrafo quinto. - Irocedimiento contra los perturbadores de la paz y culpados en motines $\ldots \ldots \ldots \ldots \ldots \ldots \ldots \ldots \ldots \ldots \ldots \ldots \ldots$

" sexto, — Remoción de los Subdelegados $\ldots \ldots \ldots \ldots \ldots \ldots$

" séptimo. - Fxpulsión de extranjeros. - Se hace comentario histórico del título 27 , libro 90 de lndias .................

" octavo. - Sobre Ia guarda de !r inmunidad local y personal.- Se refieren los casos exceptuados y se explica el nuevo método de ex-

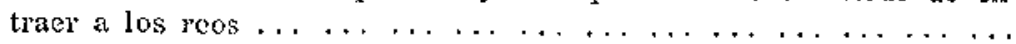

Casos exceptuados de la inmmidad local ... ... . . ......... l'ersonas que gozan del privilegio de Fuero $\ldots \ldots \ldots \ldots \ldots \ldots$ Reducción de asilos $\ldots \ldots \ldots \ldots \ldots$ Modo práctico de extrace a los reos refugiados en las Iglesias sin asiTo y de las que 10 debieran gozal $\ldots \ldots \ldots \ldots \ldots \ldots \ldots$ Jeos con goce de inmunidad $\ldots \ldots \ldots \ldots \ldots$

" noveno. -- Matrimonios clundestinos.-... Se explica la ley 1a., título 10, libro 5o. de Castilla y la Praquática Real fecha en EI Pardo, a 7 de abril de $1778 \ldots \ldots \ldots \ldots \ldots \ldots \ldots \ldots$

" décimo. - Dias ferialos. - Se expliea la Jey 4, título 90, libro 3o.; la ley 4, título 10, libro 1.o. de Castilla, y la ley 17, título 1o., libro 10. de Indias $\ldots \ldots \ldots \ldots \ldots \ldots \ldots$

Noticia Ta.- De las causas de guerra. Fn que se propone arbitrio para mantener las tropas del Reino en vigor de la disciplina militar, con mayor ahorro de la lieal Hacienda y más subordinación de estos natuxales.

Párrafo primero. - Destacamentos de tropas en los pueblos capitales ... . " segundo. -- Alojamiento de las tropas en los Cuarteles Generales. . .

\section{CAPITULO SEPTIMO}

\section{Del Vice Patronato de los Intendentes}

Se refiere el número de Iglesias de esta Provincia; los objetos principales a que debe atender y se proponen arbitrios para mejorar el estado Eclesiástico on cuanto a los Párrocos.

Noticia 1a.- Origen del Vice Patronato de los Intendentes ... . . . . .

" 2a.-De las Iglesias fundadas en esta Provincia y de otras que conviene establecer. Se propone arbitrio para verificar estas erecciones, sin gravamen de la Real Hacienda y $\sin$ desmembración de $\operatorname{los}$ beneficios actuales. . . . . . . . . . . . .

Párafo primero. - Iglesias establecidas en esta Provincia . . . . . . . . Distancia de longitud y Jatitud de esta Provincia de Potosí, que comprende 66 Curatos, incluyendo los de aquí ... . . . . . . . .

" segundo. - Iglesias que conviene fundar en la Provincia . . . . . .

" tercero. - Arbitrio fácil para fundar nuevas Iglesias, sin dividir las antiguas nj gravar la Real Hacienda $\ldots \ldots \ldots \ldots \ldots \ldots$

Noticia 3a.-Objetos que deben atendex principalmente los Intendentes VicePatromos de estos países $\ldots \ldots \ldots \ldots \ldots \ldots \ldots \ldots \ldots$

Párrafo primero. - Residencia de los Curas ... . . . . . . . . . . 
siásticos $\ldots \ldots \ldots \ldots \ldots \ldots \ldots \ldots \ldots \ldots \ldots \ldots$

Administración para las Fábricas de las Iglesias y su depósito en las Cajas Reales $\ldots \ldots \ldots \ldots \ldots \ldots \ldots \ldots \ldots$ Sobre el arreglo de los Reliriosos y de sus leyes canónicas . . . . .

Párrafo tercero. - Suficiencia de los sacerdotes destinados para Cura de Al$\operatorname{mas} \ldots \ldots \ldots \ldots, \ldots, \ldots, \ldots, \ldots, \ldots, \ldots, \ldots \ldots \ldots$

Noticía 4a.- Arbitrio útil, según la condición de estos paises, para mejorar el estado Eclesiástico en cuanto at los Curas . . . . . . . . .

\section{CAPITULO OCTAVO}

\section{De la Superintendencia de Minas}

Se explica su origen, distrito y jurisdicción, con la de todos sus Oficiales Reales $y$ dependientes, según el actual sistema de Mineria.

Noticia 1a.-. Origen de esta Superintendencia ................ 605

"2a.-Distrito de la Superintendencia de Minas ... . . . . . . . .

" 3a.- Autoridad de la Superintendencia de Minas en lo gubernativo, económico y provincial $\ldots \ldots \ldots \ldots \ldots$

" 4a.- De Ios Oficiales de la Superintendencia y demás dependientes de la Minería. Se explica su respectivo ministerio y jurisdic-

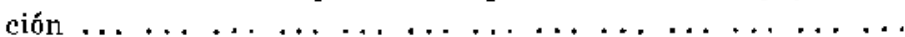

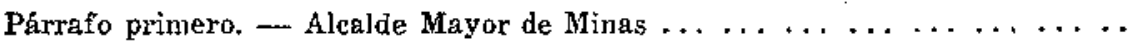

segundo. - Veedores $\ldots \ldots \ldots \ldots \ldots \ldots \ldots \ldots \ldots$

tereero. - Juez de Rescates $\ldots \ldots \ldots \ldots \ldots \ldots \ldots \ldots \ldots \ldots \ldots$

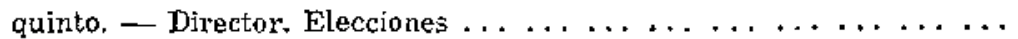

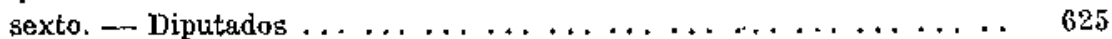

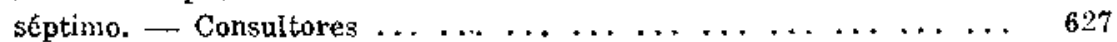

octavo. - Administrador, Contador, Tesorero y Oficiales del Banco. 627

noveno, $\ldots$ Solicitador ....................... 628

décimo. - Escribano ....................... 628

undécino, - Portero ejecutor ................... 628

duodécimo. - Facultativo de Minas $\ldots \ldots \ldots \ldots \ldots \ldots$

décimotercero. - Beneficiadores $\ldots \ldots \ldots \ldots, \ldots \ldots$

Noticia 5a.- De los Empleos electivos de Minería y sus electeres ... ... 632

Párrafo unico. - Electores $\ldots \ldots \ldots \ldots \ldots \ldots$

Noticia 6a.-De los Mineros y sus calidades, oblinaciones y privilegios:

Párrafo primero. $\ldots$ Mineros $\mathbf{y}$ sus calidades $\ldots \ldots \ldots \ldots \ldots \ldots$ segundo. - Obligaciones de los Mineros ............. tercero. - Privilerios de $\operatorname{los}$ Mineros ... .............. 64.1

Noticia 7a. - De las Minas y sus diferentes especies.- Se explica el dominio de ellas, $y$ el modo de adquirirlas, medirias, labrarlas, repararlas $y$ ampararlas:

Párafo primero. — De las Minas y sus diferencias $\ldots \ldots \ldots \ldots \ldots \ldots$ segundo, - Minas de plata . . . . . . . . . . . . . . . . . 649

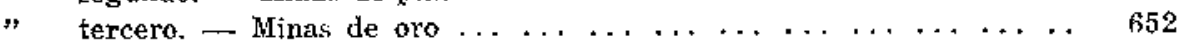

" cuarto. - Minas de cobre $\ldots \ldots \ldots \ldots \ldots \ldots \ldots \ldots \ldots$ 
Pág.

654

655

656

658

659

661

661

\section{APENDICE}

\section{A los articulos primero y segundo precedentes}

Cuáles son los que deben gozar el privilegio de primeros descubridores y cuántas las minas que deben poseer los demás mineros que no lo fueren.

Dónde se compulsa las leyes vigentes para los descubridores de minas, su posesión y explotación $\ldots \ldots \ldots \ldots \ldots \ldots \ldots \ldots \ldots$ Articulo tercero. - Registros.- Se explica el método práctico de hacerlos ..

$" \quad$ cuarto. - De los Pozos de Ordenanza ... . . . . . . . . .

$"$ quinto. - De la Posesión, medidas y estacas: ... . . . . . .

Párrafo primero. - Posesión $\ldots \ldots \ldots \ldots \ldots \ldots \ldots \ldots \ldots$

$" \quad$ segundo - Medidas $\ldots \ldots \ldots \ldots \ldots \ldots \ldots \ldots \ldots \ldots$

$" \quad$ tercero. - Estacas $\ldots \ldots \ldots \ldots \ldots \ldots$

Artículo sexto. - Mejora de estacas . . . . . . . . . . . . . . . Sección scgunda. - De la labor y amparo de las Minas y de los despoblados.Se explica el método práctico de seguir estos juicios . . . . . . . . . . Artículo primero. - Del modo de labrar y reparar las Minas ... . . . . . .

" segundo. - De las entradas de las minas y los socavones ... . . . .

Noticia 8a.-De los Jueces, pleitos, sentencias y ejecueiones de Minas:

Párrafo primero. - Jueces $\ldots \ldots \ldots \ldots \ldots \ldots \ldots \ldots \ldots$

$" \quad$ segundo. - Pleitos $\ldots \ldots \ldots \ldots \ldots \ldots \ldots \ldots \ldots$

" tercero. - Sentencias . . . . . . . . . . . . . . . .

$" \quad$ cuarto. - Ejecuciones $\ldots \ldots \ldots \ldots \ldots \ldots \ldots \ldots \ldots \ldots \ldots$

Noticia 9a.- De las Ordenanzas Penales de Minería:

Párrafo primero. - Casos en que se incurre en pena pecuniaria .......

" segundo. - Casos en que se incurre en perdimiento de indios ...

destierro $\ldots \ldots \ldots \ldots \ldots \ldots$

\section{CAPITULO NOVENO}

De la Superintendencia de Mita $\ldots \ldots \ldots \ldots \ldots \ldots \ldots$ 


\section{CAPITILO DECIMO}

Pág.

De la Superintendencia del Banco $\ldots \ldots \ldots \ldots \ldots \ldots \ldots \ldots \ldots$

\section{CAPITULO UNDECMMO Y ULTIMO}

De la Superintendencia do la Real Casa de Moneda ... . . . . . . . . . 763

\section{EPILOGO}

Breve comentario de la bibliografía de Pedro Vicente Cañete y Domínguez

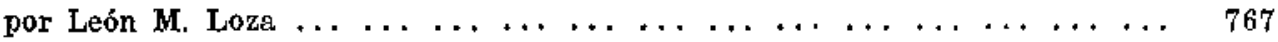

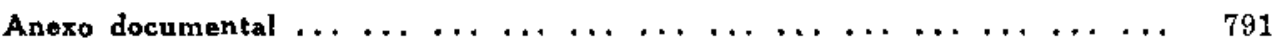

\section{N D I C E S}

Indice y noticia de los principales autores citados $\ldots \ldots \ldots \ldots$. . . . . . 801

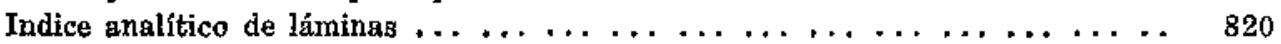

Indice General de los Capítulos, Noticias y Párrafos de la obra ... . . . . 823 